\title{
Zin in poezie : een interpretatief en empirisch onderzoek naar de pragmatiek van het kinderlied
}

Citation for published version (APA):

de Bruijn, M. A. (2015). Zin in poezie : een interpretatief en empirisch onderzoek naar de pragmatiek van het kinderlied. [, Maastricht University]. Datawyse / Universitaire Pers Maastricht.

https://doi.org/10.26481/dis.20151221 mb

Document status and date:

Published: 01/01/2015

DOI:

$10.26481 / \mathrm{dis} .20151221 \mathrm{mb}$

Document Version:

Publisher's PDF, also known as Version of record

\section{Please check the document version of this publication:}

- A submitted manuscript is the version of the article upon submission and before peer-review. There can be important differences between the submitted version and the official published version of record.

People interested in the research are advised to contact the author for the final version of the publication, or visit the DOI to the publisher's website.

- The final author version and the galley proof are versions of the publication after peer review.

- The final published version features the final layout of the paper including the volume, issue and page numbers.

Link to publication

\footnotetext{
General rights rights.

- You may freely distribute the URL identifying the publication in the public portal. please follow below link for the End User Agreement:

www.umlib.nl/taverne-license

Take down policy

If you believe that this document breaches copyright please contact us at:

repository@maastrichtuniversity.nl

providing details and we will investigate your claim.
}

Copyright and moral rights for the publications made accessible in the public portal are retained by the authors and/or other copyright owners and it is a condition of accessing publications that users recognise and abide by the legal requirements associated with these

- Users may download and print one copy of any publication from the public portal for the purpose of private study or research.

- You may not further distribute the material or use it for any profit-making activity or commercial gain

If the publication is distributed under the terms of Article $25 \mathrm{fa}$ of the Dutch Copyright Act, indicated by the "Taverne" license above, 


\section{Zin in poëzie}

Een interpretatief en empirisch onderzoek naar de pragmatiek van het kinderlied 
Copyright (C) Annette de Bruijn 2015

Omslag illustratie getekend door Elie Schakel Omslag design uitgevoerd door Dana Paslaru

Lay-out binnenwerk en drukwerk door Datawyse / Universitaire Pers Maastricht ISBN 9789090294391 


\title{
Zin in poëzie
}

\section{Een interpretatief en empirisch onderzoek naar de pragmatiek van het kinderlied}

\author{
PROEFSCHRIFT \\ ter verkrijging van de graad van doctor aan de Universiteit Maastricht, \\ op gezag van de Rector Magnificus, Prof. dr. L.L.G. Soete \\ volgens het besluit van het College van Decanen, \\ in het openbaar te verdedigen \\ op maandag 21 december 2015 om 16.00 uur
}

door

Mildred Annette de Bruijn 


\section{PROMOTORES}

Prof. dr. M.J.H. Meijer

Prof. dr. E. Wesseling

\section{BEOORDELINGSCOMMISSIE}

Prof. dr. J.H.W. Kusters (voorzitter)

Prof. dr. A.G. Bus (Universiteit van Leiden)

Prof. dr. J. Van Coillie (KU Leuven)

Prof. dr. L.M.E.A. Cornips

Dit onderzoek maakt deel uit van het project Emergent Cultural Literacy: Assimilating Children's Literature dat (mede)gefinancierd is door de Nederlandse Organisatie voor Wetenschappenlijk Onderzoek (NWO) (projectnummer 360-30-210). 


\section{Een woord vooraf}

Nonsens neemt een vlucht in haar eigen universum. Hoewel verder verwijderd van de alledaagse realiteit dan categorieën als realisme, mythe of ironie, stelt Susan Stewart in Nonsense: aspects of intertextuality in folklore and literature (1989), staat nonsens toch nooit volledig los van de werkelijkheid. Nonsens, als speciale soort onzin, is altijd een spiegel van de 'zin', van wat we zinvol, betekenisvol, 'normaal' vinden. Een lachspiegel wellicht, maar voor de effecten die ze kan produceren altijd afhankelijk van wat er voor de spiegel staat (Anderson \& Apseloff, 1989, pp. 4-5). Nonsens is kunstzinnig op geheel eigen wijze: ze is verwarrend, de omgekeerde wereld, of de wereld, maar dan een beetje scheef, of door elkaar gehusseld. Alle puzzelstukjes zijn er, maar ze liggen niet allemaal op de 'juiste' plaats. De afbeelding komt niet overeen met het plaatje op de doos, maar het is ook geen volledige chaos. Een nieuwe verbeelding van de werkelijkheid ontstaat. Een verbeelding waarin vissen in bomen zitten en vogels in de zee zwemmen, waarin we vliegen in een schoen of varen in een hoed, waarin appels vierkant zijn, waarin iedereen op z'n kop staat, waarin twee plus twee vijf is, waarin we 's avonds ontbijten, in januari opstaan om in december weer naar bed te gaan, en ga zo maar door. Een verbeelding met een geheel eigen logica, met een speelse humor. Een verbeelding waar een sterk relativerende, en wellicht ook emanciperende, werking vanuit gaat. Want nonsens laat ons zien dat we allemaal in staat zijn om de werkelijkheid te 'herscheppen'. Alles wat daar voor nodig is, is verbeeldingskracht, en liefst met een gezonde dosis speelse humor.

Ik ben bijzonder dankbaar dat ik de kans heb gekregen om me, na mijn Master scriptie, nog eens vier jaar te mogen bezighouden met nonsens, met taalmuziek, met kinderpoëzie en met wat kinderen daar zelf nu eigenlijk van vinden. Het is een geweldig universum waarin nog veel meer sterren en planeten te ontdekken zijn. Een universum waar ik maar al te graag een (toe)vlucht in neem, maar wat zou dat waard zijn zonder in verbinding te blijven staan met de aarde, de werkelijkheid? Ik ben dan ook minstens zo dankbaar voor iedereen die de vlucht, de verbinding en de landing mede mogelijk heeft gemaakt en in goede banen heeft geleid. Allereerst natuurlijk mijn promotoren Maaike Meijer en Lies Wesseling. Maaike, dank voor je eindeloze geduld! Dank dat je me de zet(ten) gaf die ik nodig had om de vlucht überhaupt te durven nemen. Je gaf me het vertrouwen om door te gaan met de exploratie van het universum, en de vrijheid om daarin mijn eigen weg te volgen. Zonder jouw inspirerende en motiverende begeleiding weet ik niet wat er van dit proefschrift geworden was. Ik prijs me gelukkig dat ik dit onderzoek onder jouw begeleiding heb mogen doen. En Lies, eerst als projectleider en vervolgens ook als mijn tweede promotor, dank dat je ons als projectgroep door tij en ontij hebt geloodst. Dank voor je doortastendheid, je ideeën, je inhoudelijke commentaren, je initiatieven en goede raad. Je hebt ons steeds gestimuleerd om het project op internationale, nationale en lokale podia te presenteren. Ons 'uitstapje' naar Brisbane was onvergetelijk, evenals de indrukwekkende wijze waarop je het IRSCL-congres in Maastricht hebt neergezet. Bedankt voor alle mogelijkheden die je me hebt geboden. 
Een van de aspecten die dit onderzoek voor mij zo plezierig hebben gemaakt, is het feit dat het onderdeel uitmaakt van een groter geheel. Ik heb me bijzonder thuis gevoeld in het ECL-projectteam vanwege de prettige en motiverende sfeer wanneer we elkaar ontmoetten, de inhoudelijke besprekingen, en de meligheid waarin we na drie uur overleg onvermijdelijk belandden. Lieve mede-aio's Inge en Karen: gedeelde smart is halve smart, en gedeeld plezier is dubbel plezier. Ik ben zo blij dat ik niet in mijn eentje in die doordenderende trein heb gezeten, maar samen met jullie. Dank voor jullie kritische en nauwkeurige commentaren, dank voor jullie steun en relativeringsvermogen, dank voor de samenwerking en de kletspraatjes. Ik had het niet in mijn eentje willen doen. Karen, in het bijzonder dank ook voor al het lekkers waarvan je ons voorzag en voor je morele steun. Bedankt allebei: na onze aio-overleg-sessies kon ik er weer tegenaan! Ingeborg en Elma, onze scholencoördinator en methodoloog, dank voor jullie drijvende kracht en expertise. Ingeborg, ik heb enorme bewondering voor al het werk dat jij verzet hebt, niet alleen in de werving van scholen, maar ook in de organisatie en uitvoering van expertraadplegingen en pilots, je bijdrage aan de ontwikkeling van de interventiematerialen en alles wat je in het kader van de interventie hebt georganiseerd en gedaan. Je bent van onschatbare waarde geweest en ik ben je dankbaar voor de goedgeplaatste 'schoppen-onder-de-kont' die je af en toe hebt uitgedeeld. Elma, jouw methodologische expertise, geduldige statistiek-bijspijker-sessies en je 'u-vraagt-wij-draaien-service' zijn onmisbaar geweest in de ontwikkeling en verwerking van het empirisch deel van dit onderzoek. Je nuchterheid en rust waren daarbij een welkome aarding te midden van de onzekerheid en stress die dit project regelmatig teweegbracht. Beste Herman, dank voor je hartelijkheid, je humor en altijd constructieve bijdragen in de begeleidingsbijeenkomsten. Tussen al die vrouwen zorgde je voor de nodige balans. En natuurlijk Julie, als stagiair heb je ons enorm geholpen met de ontwikkeling en uitvoering van de interventie. Je handigheid in de vormgeving van de Leeskalenders was geweldig, je enthousiasme was aanstekelijk en ik heb met veel plezier met je samengewerkt.

Speciale dank gaat uit naar Piet Mooren en Jeanne Kurvers. Beste Piet, dank dat je me vanuit je tomeloze enthousiasme op het pad van de kinderpoëzie en de nonsens hebt gebracht, dat je me na mijn afstuderen uitzicht hebt geboden op een terugkeer naar dat prachtige universum, waar ik in dit onderzoeksproject mijn eigen vlucht in heb genomen. Beste Jeanne, dank voor de interesse die je als docent in me hebt gewekt voor taalwetenschap en onderzoek naar geletterdheid, en dank voor de prettige samenwerking in de beginfase van dit onderzoeksproject.

Niets van dit alles was echter mogelijk geweest zonder alle scholen, leerkrachten en kinderen die hebben meegedaan aan het Leeskalenderproject. We zijn jullie grote dank verschuldigd voor de tijd en energie die jullie in het project hebben geïnvesteerd bovenop de toch al volle onderwijsprogramma's. In het bijzonder wil ik de leerkrachten van groep 2 en groep 4 op ‘mijn' observatieschool bedanken. Tiny en Karen, het feit dat ik wekelijks bij jullie mocht meekijken in de klas heeft een schat aan inzichten opgeleverd voor dit onderzoek. Dank voor jullie inzet en openheid! Daarbij heb ik genoten van het (overwegende) enthousiasme van de kinderen en mis ik die wekelijkse bezoekjes nog steeds. Dank aan alle experts die ons in een vroeg stadium van dit onderzoek van waardevolle feedback hebben voorzien, en aan de pilotscholen in Weert en 's-Hertogenbosch voor jullie medewerking in de ontwikkeling van de Leeskalender en de toets. Dank ook aan de bibliotheken in Heer- 
len, Maastricht, Tilburg en Venlo voor het leveren van al die boeken aan de scholen. En niet te vergeten: dank aan alle vrijwilligers die hebben meegewerkt aan de toetsafnames tijdens de voormeting en/of tijdens de nameting. Zonder jullie hadden we het nooit gered!

Ik had nooit gedacht dat ik nog eens in Maastricht zou belanden, maar dankzij de Graduate School kwam ik al snel in contact met de veelzijdige aio-gemeenschap die de Faculty of Arts and Social Sciences rijk is. In de AMC-onderzoekscolloquia en summer harvests kreeg ik een beeld van vele interessante onderzoeksgebieden die in deze multidisciplinaire groep vertegenwoordigd zijn. Beste collega's van het Centrum voor Gender en Diversiteit, dank voor de interessante onderzoekslunches (zeker de speciale varianten met pizza en prosecco), en voor de persoonlijke benadering en interesse! My dearest GG86 office-mates, bunch of attic-dwellers, Andreas, Annelies, Annika, Johanna, Philip, and Sarah, and across the hall Aalok and Oriane (I'm sure I am forgetting people, several have come and gone): thank you for being or having been there, for sharing good times and bad times, frustration and elation, lots of 'bier en bitterballen', for your advice and friendship, in whatever combination. Andrea, Daniel, Ties, not attic-dwellers per se but regularly part of the 'bier en bitterballen' sessions, and many other colleagues: thank you all for reminding me that there is life outside of work. Dear Codruta and Constance, I am so happy to form a kind of 'buddy triangle' with you. Cody, although I officially became your buddy, you have supported me in so many ways I'm not even going to sum them up. Know that your friendship is priceless! Constance, thank you for having been my buddy and giving me some much needed direction when I just arrived. I thoroughly enjoy our hallway chats, having seen you getting married, bumping into you and the family on your evening strolls, and your good sense of humor in general. I am honored that, after our marvelous performance of 'It's the hard knock life', you two will be my paranymphs as well.

Lieve ouders, bedankt voor het leggen van de vroege basis van mijn interesse in de kinderliteratuur en een brede culturele socialisatie waarin zowel de Bijbelverhalen als Roald Dahl's Rotbeesten, liedjes, rijmpjes, heel veel verhalen en (soms vieze) moppen een plaats hadden. Bedankt voor jullie steun door de jaren, met alle ups-and-downs die bij het leven horen, heen. Lieve grote zus en grote broer, ik vind het heerlijk om jullie 'kleine zus' te zijn (een bevoorrechte positie, ik weet het). Lieve schoonzus, naast dat ik je een hele leuke schoonzus vind, bedankt dat je me het Nijmeegse Vierdaagse virus hebt gegeven! Ooit komt het er weer eens van ... En lieve kleine Tijn, bij voorbaat mijn excuses als ik die tante ben die steeds maar met boeken aan komt zetten terwijl je daar niet om had gevraagd. Last but not least, lieve Elie, bedankt dat je er voor me bent als het nodig is, voor de ruimte die je me geeft, voor je begrip en geduld. En bedankt voor je mooie tekening voor de omslag: ik ben trots dat 'ie erop staat. We mogen dan regelmatig allebei in ons eigen universum zijn, maar de momenten die we samen op dezelfde planeet doorbrengen, vind ik nog steeds heel leuk!

Mijn hoop is dat iedereen zo op zijn tijd de zin van de onzin kan inzien, en (dus) ook de onzin van de zin. Dat iedereen af en toe mag zijn zoals de makers van nonsens: 'dames en heren die met een vlindernetje achter paradoxen aan huppelen, als een soort filosofen zonder filosofie, en die niet bereid zijn welk verschil dan ook op de spits te drijven, zeker niet dat tussen zin en onzin, of ernst en humor' (Boelens \& Komrij, 2007, p. 12). 



\section{Inhoudsopgave}

Een woord vooraf

HOOFDSTUK 1 Kinderliteratuur en ontluikende culturele geletterdheid 13

$\begin{array}{lll}1.1 & \text { Introductie } & 15\end{array}$

$\begin{array}{ll}1.2 & \text { Opvattingen van culturele geletterdheid } \\ 1.3\end{array}$

$\begin{array}{lll}1.3 & \text { Kritiek op culturele geletterdheid } & 18\end{array}$

1.4 Ontluikende culturele geletterdheid: de cultuur van het dagelijks leven 21

1.5 Kinderliteratuur en ontluikende culturele geletterdheid 26

1.6 De tijd waarin we le(v/z)en ... Culturele diversiteit en meervoudige geletterdheid 30

1.7 Ontluikende culturele geletterdheid, kinderliteratuur en canonvorming 36

1.8 Conclusie: een onderzoek naar de verwerving van kinderliteratuur 41

HOOFDSTUK 2 Kinderpoëzie: naar een pragmatische benadering 47

2.1 Introductie 49

2.2 Opvattingen van 'poëzie': de cultuur van het innerlijk? 50

2.3 Opvattingen van 'kinderpoëzie': bestaat er wel zo iets als kinderpoëzie? 54

2.4 Het taalspel poëzie in de cultuur van het dagelijks leven 60

2.5 Er schemert een duidelijke tekst achter, naar het lijkt ... 65

2.6 Kinderpoëzie: naar een pragmatische benadering in ontwikkelingsperspectief $\quad 70$

2.7 Conclusie en de eerste deelvragen voor de kinderpoëzie $\quad 74$

HOOFDSTUK 3 Kinderpoëzie in pragmatische contexten van tekstgebruik $\quad 77$

$\begin{array}{lll}3.1 & \text { Introductie } & 79\end{array}$

3.2 Het begin: 'Het spel van moeder en kind' 80

3.3 Functies van het bakerrijm 83

3.4 Het kindervers in de context van de vieringen in het jaar en in het leven 86

3.5 Functies van het feestrijm 89

3.6 Het kindervers in de context van spel 93

3.7 Spelfuncties van het kindervers 96

3.8 Poëtische ritualisering aan de bakermat van culturele geletterdheid 102

3.9 Conclusie: 'de directe evocatie van poëtisch geritualiseerde handelingspatronen' een eerste indicator van canoniciteit in kinderpoëzie 107 
HOOFDSTUK 4 Kinderpoëzie en het muzikale spel met de taal

4.1 Introductie

4.2 De muzikaliteit van het kindervers

4.3 Muzikaal taalspel en taalontwikkeling

4.4 Metrum en ritme in het muzikale kindervers $\quad 122$

4.5 Rijm in het muzikale kindervers $\quad 125$

4.6 Muzikale segmenten in het kindervers 129

4.7 Tongbrekers en struikelzinnen 131

4.8 Kettingen, cirkels en slingers: ruimtelijke spelstructuren in taal gevat 134

4.9 Conclusie: 'muzikaal taalspel' een tweede indicator van canoniciteit in kinderpoëzie 139

HOOFDSTUK 5 Kinderpoëzie en het spel met de wereld 141

5.1 Introductie 143

5.2 Subversiviteit als raakvlak tussen volkscultuur, kindercultuur en kinderpoëzie 144

5.3 Het subversieve kindervers als carnavaleske nonsensicaliteit begrepen 149

$\begin{array}{lll}5.4 & \text { De omgekeerde wereld } & 154\end{array}$

5.5 Liegen, dromen en wensen 158

5.6 Een koe en een kalf en een heel paard half, en ja, er kan nog meer bij... 162

5.7 Varen in een hoed en het breken van narratologische conventies 165

5.8 De carnavaleske lach die onderbuik en intellect verbindt: de zin van de onzin in ontwikkelingsperspectief 167

5.9 Conclusie: '(carnavaleske) nonsensicaliteit' een derde indicator van canoniciteit in kinderpoëzie

HOOFDSTUK 6 Het Leeskalenderproject: de opzet en uitvoering van een empirisch onderzoek $\quad 175$

$\begin{array}{lll}6.1 & \text { Introductie } & 176\end{array}$

6.2 De empirische onderzoeksvragen 176

6.3 De opzet van het Leeskalenderproject: het onderzoeksdesign 178

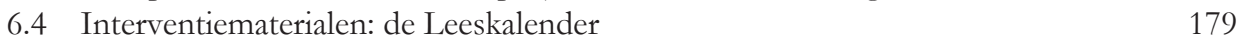

6.5 De Leeskalender: het ontwikkelingstraject 183

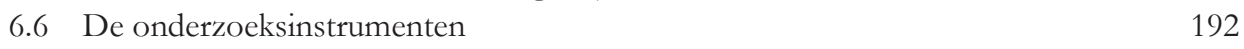

HOOFDSTUK 7 Kinderpoëzie in Leeskalender en Toets 213

$\begin{array}{lll}7.1 & \text { Introductie } & 215\end{array}$

7.2 De Leeskalender: de ontwikkeling van een interventie 215

7.3 Kinderpoëzie in de Leeskalender 222

7.4 Het meten van ontluikende culturele geletterdheid 230

7.5 Operationalisering van de relatie poëzie - ontluikende culturele geletterdheid 235

$\begin{array}{ll}\text { 7.6 Toetsontwikkeling } & 237\end{array}$

7.7 Kinderpoëzie: de items in de Toets Ontluikende Culturele Geletterdheid 242 
HOOFDSTUK 8 Experimenteel onderzoek naar de bijdrage van kinderliteratuur aan ontluikende culturele geletterdheid (Of: Het Mysterie van het Lokaliseren van Effecten van Kinderpoëzie)

8.1 Introductie

8.2 Kwantitatieve onderzoeksvragen 260

8.3 Betrouwbaarheid en validiteit 262

8.4 Effecten van de Leeskalender op ontluikende culturele geletterdheid 277

8.5 De deeltoets Kinderpoëzie: resultaten groep 2 en groep $4 \quad 287$

8.6 De deeltoets Kinderpoëzie ter discussie: betrouwbaarheid en validiteit 294

8.7 Conclusies en discussie 311

HOOFDSTUK 9 Het taalspel poëzie in groep 2: Het belang van de waarneembare pragmatische context 319

9.1 Introductie 321

9.2 Een globaal beeld van de Leeskalender en poëzie in de kleuterklas 322

9.3 Poëzieverwerving in de kleuterklas 329

9.4 Conclusies 361

HOOFDSTUK 10 Het taalspel poëzie in groep 4: De verinnerlijking van de $\begin{array}{ll}\text { pragmatische context } & 371\end{array}$

10.1 Introductie 373

10.2 Een globaal beeld van de Leeskalender en poëzie in groep 4

10.3 Poëzieverwerving in groep $4 \quad 378$

$\begin{array}{ll}10.4 \text { Conclusies } & 415\end{array}$

HOOFDSTUK 11 Tegen de verwachtingen in ... (conclusies en discussie) 425

11.1 Het belang van (onderzoek naar) culturele geletterdheid in het basisonderwijs $\quad 427$

11.2 Pluriforme canonvorming vanuit de cultuur van het dagelijks leven 431

11.3 'Confronting the Snark' (of: Bestaat er wel zoiets als kinderpoëzie?) 435

11.4 Subversiviteit: een 'neo-Romantisch kindbeeld'? 442

11.5 'Confronting the other Snark' (of: Het Mysterie van het Lokaliseren van Effecten van Kinderpoëzie) 446

11.6 De vertaling van de resultaten naar de praktijk van het basisonderwijs $\quad 452$

Bijlages $\quad 457$

Bijlage $1 \quad$ Geraadpleegde primaire bronnen 458

Bijlage 2___ Overzicht van het volledige Leeskalenderaanbod 461

Bijlage 3 Leeskalenderproject: overzicht van deelnemende scholen 466

Bijlage $4 \quad$ Protocol voor afname Toets Ontluikende Culturele Geletterdheid 467

Bijlage $5 \quad$ Logboekgegevens $\quad 471$

Bijlage $6 \quad$ Oudervragenlijsten: poëtische socialisatie in het gezin 475

Bijlage $7 \quad$ Een alternatieve benadering van 'effectiviteit' 481

Bijlage $8 \quad$ Zeilexpertise nodig bij onderzoek naar nonsens 484 
Valorisatie addendum

Verantwoording

Over de auteur

505

Bibliografie 


\section{HOOFDSTUK 1}

Kinderliteratuur en ontluikende culturele geletterdheid 



\subsection{Introductie}

"Literatuur een toegang tot de cultuur? Lezen maakt deel uit van wat men in het Duits 'Enkulturationsprozess' noemt, in het Engels 'cultural literacy' (= culturele geletterdheid)," schrijft Rita Ghesquière in Jengdliteratuur in perspectief (2009a, p. 112). Via kinderliteratuur kunnen jonge kinderen geïntroduceerd worden in gedeelde uitingsvormen en de daarin gerepresenteerde normen, waarden, kennis en gebruiken die aan de basis liggen van de culturele gemeenschap(pen) waarin ze opgroeien. Naast het feit dat dergelijke culturele geletterdheid een voorwaarde vormt voor begrijpend lezen, faciliteert het ook cultureel burgerschap (Heath, 1982; Hirsch, 1983; Dickinson \& Smith, 1994). Dit zijn belangrijke vermogens voor een volwaardige deelname aan de hedendaagse Nederlandse samenleving en cultuur. Voorwaarde voor de bijdrage van kinderliteratuur aan de ontwikkeling van culturele geletterdheid bij jonge kinderen is echter dat kinderen deze teksten verwerven, zich eigen maken. Het ligt voor de hand dat die verwerving wordt gefaciliteerd door aansluiting van teksten op de kennis, vaardigheden, leef- en belevingswereld, i.e. de culturele competentie van kinderen, maar hoe ziet die culturele competentie eruit? Deze vraag wordt enkel dringender wanneer we ons realiseren dat de Nederlandse samenleving in velerlei opzichten multicultureel is. Zijn er genres en tekstsoorten die opeenvolgende generaties van kinderen met verschillende culturele achtergronden aanspreken? Wat kenmerkt deze transculturele en langdurig geliefde genres? En hoe maken jonge kinderen zich deze vitale genres en tekstsoorten eigen? Met andere woorden: waar liggen de raakvlakken tussen kenmerken van 'canonieke' (transcultureel langdurig geliefde) tekstsoorten en genres en de factoren die een cruciale rol spelen in processen van tekstverwerving bij jonge kinderen? Wanneer we begrijpen welke eigenschappen bepaalde soorten teksten duurzaam geliefd maken bij jonge kinderen, dan kunnen we deze 'indicatoren van canoniciteit' vertalen naar criteria voor de selectie van kinderliteratuur die effectief bijdraagt aan de ontluikende culturele geletterdheid van vijf- tot achtjarige kinderen in het basisonderwijs.

Dit is het uitgangspunt van het onderzoeksproject Emergent Cultural Literacy: Assimilating Children's Literature dat drie deelprojecten omvat die gelijktijdig zijn uitgevoerd: 'Deugden \& Dilemma's', 'Narratieve Genres', en 'Kinderpoëzie'. In dit boek staat het deelproject 'Kinderpoëzie' centraal. In dit eerste hoofdstuk introduceer ik het conceptueel kader en de uitgangspunten en doelstellingen van het onderzoeksproject als geheel. Allereerst bespreek ik kort bestaande opvattingen van culturele geletterdheid (\$1.2) en de belangrijkste kritieken daarop (\$1.3). Van daaruit introduceer ik onze opvatting van 'ontluikende culturele geletterdheid' (\$1.4), gevolgd door een bespreking van de relatie tussen ontluikende culturele geletterdheid en kinderliteratuur (\$1.5). Ik ga in op wat we verstaan onder 'cultuur' en 'geletterdheid' tegen de achtergrond van de multiculturele en multimediale Nederlandse samenleving (\$1.6) en bespreek de opvatting van 'canoniciteit' die we hanteren binnen dit onderzoeksproject tegen de achtergrond van canonvormingsdebatten in Nederland (\$1.7). Ten slotte breng ik de verschillende overwegingen en uitgangspunten samen in de rationale en het doel van dit onderzoeksproject (\$1.8). 


\subsection{Opvattingen van culturele geletterdheid}

De term 'culturele geletterdheid', die het conceptueel kader van dit onderzoeksproject vormt, kreeg voor het eerst bekendheid in de Verenigde Staten door het werk van E.D. (Donald) Hirsch Jr. Hij bracht de term in 1987 bij een breed publiek onder de aandacht met de spraakmakende bestseller Cultural Literacy: What Every American Needs to Know, gevolgd door verschillende uitgaven van The Dictionary of Cultural Literacy. Dolph Kohnstamm en Elly Cassee vertaalden het werk van Hirsch niet veel later naar de Nederlandse context met Het Cultureel Woordenboek: Encyclopedie van de algemene ontwikkeling (vanaf 1992), gevolgd door het Nieuw Cultureel Woordenboek en later omgezet naar de website 'Cultureel Woordenboek' (www.cultureelwoordenboek.nl). Zowel in de uitgaven van Hirsch als in de adaptaties van Kohnstamm en Cassee is het concept 'culturele geletterdheid' geoperationaliseerd in encyclopedisch weergegeven lemmata die een weerslag zijn van algemene kennis van 'cultuur-in-brede-zin'. Op de website van het Cultureel Woordenboek schrijft de redactie over de onderliggende opvatting van cultuur:

"In de brede betekenis verwijst het woord [cultuur] naar alles wat een samenleving van mensen heeft voortgebracht en eigen is; naar alle in de taal van die samenleving beschreven en geschreven producten, de geschiedenis zowel als de wetten, de rituelen zowel als de leerboeken, naar dijkbouw zowel als muziek." (Kohnstamm, Everdingen, Rümke \& Stelt, 'Waarom deze site?')

De algemene kennis van 'cultuur-in-brede-zin' plaatsen Hirsch en ook Kohnstamm en Cassee tussen het niveau van de 'praktijkkennis', de functionele kennis die iedereen met minimale scholing en taalvaardigheid wel opdoet in het dagelijks leven, en het niveau van de 'specialistische kennis', de diepgaande kennis van experts. Daartussenin ligt het niveau van de algemene ontwikkeling, de 'culturele geletterdheid': het is de brede kennis die relevant is om in het publieke domein mee te kunnen praten en te begrijpen waar anderen het over hebben. In Jengdliteratuur in perspectief vat Rita Ghesquière de opvatting van Hirsch, en ook Kohnstamm en Cassee, als volgt samen: "Culturele geletterdheid is het resultaat van een brede intellectuele opvoeding. ... Het gaat om de hoofdstroom van informatie die de doorsneelezer nodig heeft om een krant of een tijdschrift te lezen en het nieuws op radio en televisie te duiden." (2009a, p. 113) De redactie van het online Cultureel Woordenboek licht toe dat bijvoorbeeld in kranten over een veelheid aan onderwerpen wordt bericht "... zonder dat eerst wordt uitgelegd wie the King of Pop was, wat inflatie is of wie Jard van Nes.” (Kohnstamm et al, 'Waarom deze site?') Berichtgeving in publieke media vooronderstelt dat lezers (of kijkers of luisteraars) over voldoende algemene kennis beschikken om dergelijke verwijzingen te begrijpen. 'Canonieke kennis' noemt Hirsch de algemene kennis waarover de doorsneelezer van kranten en tijdschriften geacht wordt te beschikken. Wie niet over die algemene kennis beschikt, zal moeite hebben om te begrijpen waar het over gaat in het 'nationale discours' zoals dat bijvoorbeeld in de publieke media gevoerd wordt. Deze kennis vormt volgens Hirsch de basis voor 'community and communication' op nationaal niveau in een geletterde democratie. 
De 'woordenboeken', of encyclopedische naslagwerken, waarin Hirsch die canonieke culturele kennis ontsloot, zijn door hem en collega's samengesteld op basis van analyses van veelvoorkomende allusies in Amerikaanse kranten, tijdschriften en boeken (Warnock, 1987, p. 488). Het gaat om cultuurspecifieke verwijzingen naar historische gebeurtenissen, uitdrukkingen en gezegden, vormen van humor, namen van bekende figuren uit politiek, kunsten, wetenschap, plaatsen met een bepaalde symbolische betekenis, titels van 'klassieke' muziekalbums, kunstwerken, literatuur, et cetera. Hirsch benadrukt dat deze canon van culturele geletterdheid niet voorschrijft, maar beschrijft welke kennis ten grondslag ligt aan het nationale discours binnen de geletterde Amerikaanse democratie (Warnock, 1987, p. 487; Whitman Hertzberg, 1988, p. 146). Tegelijk stelt hij dat het diezelfde kennis is die Amerikaanse scholieren bijgebracht moet worden op school. Enerzijds omdat het onderwijs de aangewezen plaats is om een 'democratisering van culturele kennis' te verwezenlijken, ook voor leerlingen die die kennis van huis uit niet (kunnen) meekrijgen. Anderzijds omdat het onderwijs volgens Hirsch ook verantwoordelijk is voor de afnemende culturele geletterdheid onder scholieren. In een eerder artikel zette Hirsch uiteen hoe hij via empirisch onderzoek tot het inzicht kwam dat leessnelheid en tekstbegrip sterker afhankelijk zijn van de achtergrondkennis die scholieren hebben van het onderwerp van een tekst dan van de structuur en stijl van een tekst. Wanneer hij in dezelfde periode vaststelt dat er een gestage achteruitgang is waar te nemen in de uitslagen van Amerikaanse scholieren op de leesvaardigheidssectie van de Scholarly Aptitude Test (SAT), ziet Hirsch directe aanleiding om het belang van inhoudelijke achtergrondkennis onder de aandacht te brengen. Waar het leerlingen aan ontbreekt, zo concludeert Hirsch op basis van aanvullende onderzoeken die in die tijd verschenen over de oorzaak van de achterblijvende leesvaardigheid, is culturele geletterdheid: de gedeelde 'meta-talige' kennis waarvan geletterdheid afhankelijk is (Hirsch, 1983, p. 165). Waar Hirsch op wijst is dat teksten niet alleen alfabetisch, maar ook cultureel 'gecodeerd' zijn: "We have learned that successful reading also requires a knowledge of shared, taken-for-granted information that is not set down on the page." (Hirsch, 2002, p. xiii) Volgens Hirsch wordt er in het onderwijs, juist doordat de samenleving in toenemende mate multicultureel is, nauwelijks nog aandacht besteed aan het overdragen van culturele kennis en waarden uit angst bepaalde groepen leerlingen buiten te sluiten. Dit heeft het tegenovergestelde resultaat, zo stelt hij. Het is juist de inhoudelijke terughoudendheid van de cultuurrelativistische houding en het daaruit voortgekomen educatief formalisme waardoor veel kinderen de kans niet krijgen om volwaardig te participeren in de geletterde democratie omdat ze de nodige kennis van 'het nationale discours' niet van huis uit wordt bijgebracht (1983, p. 161). De effecten hiervan zijn al zichtbaar in het fenomeen van 'The Fourth Grade Slump': een term van Jeanne Chall die verwijst naar het achterblijven (en zelfs afnemen) van de scores op begrijpend lezen van kinderen uit lagere sociaaleconomische milieus ten opzichte van die uit de hogere sociaaleconomische milieus vanaf groep 6. Hirsch stelt dat het onderwijs teveel is gericht op technische vaardigheden, op 'formal comprehension skills' en de herhaling daarvan, terwijl er volgens empirisch onderzoek een plafond is in het effect dat je daarmee kunt bereiken (2003, p. 22). Is dit plafond eenmaal bereikt dan blijven kinderen die niet over de nodige inhoudelijke kennis van woorden (woordenschat) en kennis van de wereld (domeinkennis) beschikken, in de ontwikkeling van hun tekstbegrip én in de uitbreiding van hun kennis steken. "Verschillende onderzoe- 
kers zien ook een duidelijk verband tussen lezen en culturele geletterdheid," schrijft ook Ghesquière: "Kinderen die veel lezen, breiden hun woordenschat snel uit, waardoor ze weer vlotter kunnen lezen. Zo ontstaat een mattheüseffect ${ }^{1} . "(2009 a$, p. 113)

Culturele geletterdheid, als de kennis en ook waarden waarover leden van een culturele gemeenschap voorondersteld worden te beschikken, is dus op twee niveaus van belang. Enerzijds is het een voorwaarde voor begrijpend lezen en daarmee zeer belangrijk voor leerlingen om optimaal te functioneren in (en profiteren van) het onderwijs; anderzijds draagt het bij aan burgerschapsvorming omdat het leerlingen inwijdt in de nationale samenleving en cultuur zodat ze optimaal kunnen functioneren binnen de geletterde democratie. Wanneer er in het onderwijs geen aandacht is voor culturele geletterdheid, zo benadrukt Hirsch, dan is dat vooral in het nadeel van leerlingen uit lagere sociaaleconomische klassen en leerlingen uit minderheidsculturen omdat zij de nodige kennis niet van huis uit (kunnen) meekrijgen. Hirsch verwijst in zijn publicaties veelvuldig naar het werk van onderzoekers die het belang van culturele kennis voor lezen, en voor leren, bevestigen (o.a. Iser, 1978; Reynolds et al, 1982; Chall, 1983a, 1983b). Toch zijn er verschillende vraagtekens bij het werk van Hirsch te zetten en werden zijn opvattingen, mede door het verkoopsucces van zijn boeken, internationaal onderwerp van kritisch debat.

\subsection{Kritiek op culturele geletterdheid}

In de kritiek op Hirsch' werk werd niet zozeer het belang van 'algemene ontwikkeling' of 'culturele geletterdheid' in twijfel getrokken; de kritiek richtte zich vooral op de inhoud van zijn lijst van 'canonieke kennis', op de vorm waarin hij die kennis ontsloot, en op de onderliggende opvatting van 'cultuur'. Verschillende critici wezen op het hoge Trivial Pursuit gehalte van Hirsch' lijst: droge, alfabetisch geordende, gedecontextualiseerde feitenkennis die men tijdelijk uit het hoofd kan leren en waarmee men indruk kan maken in gezelschap. Het type oppervlakkige kennis dus, dat niet werkelijk wordt opgenomen in de diepere kennisstructuren en daarmee niet werkelijk wordt verworven, zo waarschuwden de critici. Hirsch erkende dit probleem, maar liet het verder voor wat het was: hij hield zich aanvankelijk ${ }^{2}$ niet bezig met het hóe van culturele geletterdheid, enkel met het wát (Whitman Hertzberg, 1988, p. 146). Hirsch' canon kreeg ook kritiek vanwege het statisch karakter en mono-cultureel perspectief. Deze kritiek is volgens Paul Lauter, zoals hij schrijft in Canons and Contexts, echter niet het meest fundamentele probleem; de lijst kan namelijk, zoals Hirsch zelf aanvoerde in reactie op de kritiek, uitgebreid en aangepast worden. Een volgens Lauter fundamenteler probleem is de simpliciteit van de achterliggende idee van cultuur als

\footnotetext{
${ }^{1}$ Voor de cultureel geletterde lezer zal de verwijzing duidelijk zijn. Dit 'mattheüseffect' van lezen, zoals Stanovich het noemde (1986), verwijst naar de parabel van de talenten zoals beschreven in het evangelie naar Mattheüs (25:29): "Want wie heeft zal nog meer krijgen, en wel in overvloed, maar wie niets heeft, hem zal zelfs wat hij heeft nog worden ontnomen.” (De Nieuwe Bijbelvertaling, 2004/2007, Nederlands Bijbelgenootschap)

${ }^{2}$ In 1986 richtte Hirsch de Core Knowledge Foundation op van waaruit hij ook Cultural Literacy: What Every American Needs to Know (1987) publiceerde. Deze stichting is zich later gaan richten op het ontwikkelen van een hele serie werken vanaf What Your Preschooler Needs to Know tot en met What Your Sixth Grader Needs to Know, inclusief allerlei instrumenten voor de implementatie van het materiaal in het onderwijs, zoals handleidingen voor leerkrachten, inpassing van het materiaal in het bestaande curriculum en evaluatie-instrumentarium.
} 
'een soort koopwaar', als 'een lijst met items' waarvan je er zoveel mogelijk moet proberen aan te schaffen in de 'cultuurwinkel' ofwel school:

"From this perspective, those who own more of these certifiably cultural items are more 'cultured' than those who have fewer, or whose stock consists of articles not marked in our society - or in Hirsch's dictionary - as items of 'culture.' Furthermore, these cultural items have been produced by people other than yourself; your role is simply to obtain as many as you can by purchase or perhaps by some form of labor (...) performed in the culture store. The nirvana of culture thus becomes the demonstrated ability of an individual to own the whole 64-page set!" (Lauter, 1991, pp. 264-265)

Lauter wijst erop dat Hirsch' lijst een 'exclusief' nationaal discours (re)produceert dat slechts beperkt representatief is voor de cultuur waarin mensen daadwerkelijk functioneren, met de vele eigenaardigheden van klasse, etniciteit, gender, seksualiteit of regionaliteit ( $\mathrm{p}$. 264). 'Leeftijd' kunnen we ook zeker aan dit rijtje toevoegen. Tegenover de cultureel relativistische houding waarvan hij het onderwijs betichtte, zet Hirsch zelf een zeker cultuurabsolutisme: er bestaat één nationale cultuur die iedereen zich eigen moet maken om aan die cultuur deel te kunnen nemen. Lauter stelt de vraag of er andere concepties van 'cultuur' en van 'geletterdheid' zijn die effectiever bijdragen aan de realisatie van democratie dan het exclusieve, historisch en Westers georiënteerde, concept van 'nationale cultuur' dat aan Hirsch' opvatting ten grondslag ligt (p. 263). Lauter is voorstander van een vergelijkende strategie waarin meerderheids- en minderheidsculturen gelijkwaardig worden meegenomen in kritische overwegingen van wat wel en niet waardevol of wenselijk wordt geacht. En deze kritische overweging is dan niet voorbehouden aan de culturele elite, maar zou door de hele samenleving heen moeten worden gestimuleerd, en zeker in het onderwijs. Dit biedt volgens Lauter niet de 'valse kalmte van gevestigde tradities', maar de opwinding en passie van de worsteling “. .. over what shall be honored by calling it 'culture' or 'literature' or 'history'; what shall be esteemed by describing it as canonical; what shall be dignified by including it in college curricula, reading lists, and cultural catalogues." (p. 269) Geen door de elite bepaalde 'top-down' culturele-kennis-canon dus, maar culturele-canonvorming als mensenwerk waar iedereen deel aan heeft, als pluriform construct dat continu 'onder constructie' is, i.e. een cultureel pluralistische benadering.

Ook in de Nederlandse context bleef het begrip 'culturele geletterdheid', zoals door Hirsch gemunt en voor de Nederlandse context uitgewerkt door Kohnstamm en Cassee, niet onbesproken. In de inleiding op Een beeld van belezenheid: Over culturele geletterdheid ${ }^{3}$ stellen Ronald Soetaert en Luc Top vast dat het debat over culturele geletterdheid in Amerika voortkwam uit de angst dat deze vorm van geletterdheid aan het verdwijnen was. De term dook volgens hen op in "een aanzwellende lastercampagne waarin de onwetendheid van de massa in het algemeen en de jeugd in het bijzonder, bron van ergernis en vermaak werd." (Soetaert \& Top, 1996, p. 7) Niet alleen Hirsch werd toonaangevend auteur in het debat, maar ook auteurs als Neil Postman met zijn Amusing Ourselves to Death (1985), en Allan

\footnotetext{
${ }^{3}$ De Nederlandse Taalunie wijdde in 1993 en 1994 twee opeenvolgende conferenties aan 'culturele geletterdheid', gehouden in Nederland en Vlaanderen. Lezingen van beide conferenties werden gebundeld in Een beeld van belezenbeid: Over culturele geletterdheid (1996).
} 
Bloom met The Closing of the American Mind (1987). Soetaert en Top wijzen erop dat deze auteurs deel uitmaken van een 'back-to-basics' beweging die in de jaren 1980 de kop opstak in de Verenigde Staten: een beweging “... terug naar de oude waarden of in elk geval weg van het moderne waardenrelativisme.” (1996, p. 8) Naast een conservatieve en zelfs nationalistische argumentatie die bij auteurs als Hirsch en Bloom aanwezig is, zien Soetaert en Top in hun werk toch ook een progressief ideaal, namelijk dat van gedeelde kennis “. ... als een basisvoorwaarde voor democratie en communicatie, zelfs voor multiculturele confrontatie." (p. 8) Soetaert en Top stellen een benadering van culturele geletterdheid voor die vergelijkbaar is met die van Paul Lauter. Een benadering waarin erkend wordt dat 'culturele geletterdheid' een aan cultuurhistorische veranderingen onderhevige sociale constructie is. In navolging van Richard Rorty (1989) bepleiten de auteurs dat het in pluriforme democratische samenlevingen van belang is " ... om te leren leven met waarheden i.p.v. Waarheid, met vocabulaires i.p.v. één Vocabulaire.” (Soetaert \& Top, 1996, p. 10) Cultuur is net zozeer een 'forum' (Bruner, 1986) waarop betekenissen en handelswijzen in een continu proces worden onderhandeld en heronderhandeld als dat het een vaste set van regels of specificaties voor ons handelen is. Literatuur speelt een belangrijke rol in het onderhouden van dit 'forum-karakter' van cultuur, stellen de auteurs: "Het gaat immers bij literatuur om inleidingen in wat anderen denken en doen, aan de hand van levendige voorbeelden uit verschillende tijden en culturen." (Soetaert \& Top, 1996, p. 10) Literatuur als uitgelezen podium voor 'cultuur als confrontatie': een opvatting van literatuur als middel dat bijdraagt aan een dynamisch cultuurmodel, maar - om die functie te kunnen vervullen - tegelijk ook afhankelijk is van een dynamisch cultuurmodel. Want een statische opvatting van cultuur en de daarbij horende statische opvatting van canonvorming, zoals we in Hirsch' uitwerking van culturele geletterdheid herkennen, "is ... gericht op wat er dominant is in een samenleving en op wie er de gecanoniseerde posities innemen." (Mooren, 2001, p. 14) Wil literatuur bijdragen aan cultuur als forum dan moet er ook aandacht en ruimte zijn voor het niet-canonieke. Althans, dan is er ook een andere, pluriforme en dynamische, canonopvatting nodig.

In dit onderzoeksproject zetten we, in navolging van verschillende van de hierboven aangehaalde critici, vraagtekens bij de achterliggende idee en uitwerking van culturele geletterdheid zoals door Hirsch gehanteerd. Culturele geletterdheid is ook in onze optiek geen 'informatiepakket' dat je al dan niet op enig moment aanschaft, maar een ontwikkelingsproces waarin iedereen van jongs af aan culturele kennis én vaardigheden opbouwt. De scheiding tussen formele vaardigheden en inhoudelijke kennis is, in onze optiek, een artificiële scheiding die in de praktijk niet steekhoudend is. Want zowel het verwerven van culturele kennis als het gebruiken van die kennis vergt allerlei vaardigheden. Kinderen in het basisonderwijs vertegenwoordigen daarbij de pluriformiteit - op basis van klasse, etniciteit, religie, gender, et cetera - die de Nederlandse samenleving kenmerkt, en daarmee ook een verscheidenheid aan culturele kennis, vaardigheden en voorkeuren. Het onderwijs kan een belangrijke rol spelen in het bij elkaar brengen, uitwisselen en uitbreiden van de culturele geletterdheid van leerlingen en literatuur kan daarin een belangrijk middel zijn. Zeker bij jonge kinderen, die nog maar net zijn begonnen met het leren kennen en begrijpen van literatuur, is het echter van belang dat teksten nauw aansluiten op de ontluikende culturele kennis en vaardigheden waarover ze beschikken (zie ook Mooren, 2000a). De eerste en 
meest cruciale vraag die zich aandient, is dan: waar begint de ontwikkeling van culturele geletterdheid bij jonge kinderen?

\subsection{Ontluikende culturele geletterdheid: de cultuur van het dagelijks leven}

De eerste fase van de ontwikkeling van culturele geletterdheid duiden we binnen dit onderzoeksproject aan als de fase van de 'ontluikende culturele geletterdheid'. We moeten de ontwikkeling van culturele geletterdheid bij jonge kinderen begrijpen in de brede context van processen van culturele socialisatie en cultuurverwerving: de inwijding van kinderen in de 'cultuur-in-brede-zin' van de samenleving waarin ze leven. Die inwijding begint zodra kinderen geboren worden en binnen het gezin worden opgenomen in de 'cultuur van het dagelijks leven'. Daar, binnen het gezin, worden de primaire culturele referentiekaders van kinderen vorm en inhoud gegeven. Het zijn die eerste culturele referentiekaders waarmee kinderen vervolgens de wereld instappen: ze vormen de voedingsbodem voor de verdere culturele ontwikkeling van kinderen in bijvoorbeeld het onderwijs. We kunnen de term 'ontluikende culturele geletterdheid' in die zin vergelijken met het begrip 'ontluikende geletterdheid': de eerste fase op de weg naar alfabetisering, naar leren lezen en schrijven. Dit begrip wordt gebruikt om de voor- en vroegschoolse periode aan te duiden waarin kinderen, naast het zich eigen maken van de meeste basisprincipes van ons taalsysteem door mondeling taalgebruik, allerlei alledaagse toepassingen van geschreven taal ontdekken:

"Ze zien een ouder boodschappen opschrijven, een televisiegids inkijken, ze herkennen het logo van hun lievelingsrestaurant (bijvoorbeeld de M van McDonald's) en ze ervaren dat het voorlezen van een boek nieuwe werelden kan openen. Kinderen ontdekken door voorlezen dat er een verband bestaat tussen gesproken en geschreven taal. Ideeën over geletterdheid ontstaan dus in uiteenlopende situaties zowel thuis, op straat als op de peuterspeelzaal, in interacties tussen volwassenen en kinderen en kinderen onderling." (Verhoeven \& Aarnoutse, 2008, p. 23)

In die eerste fase op weg naar alfabetisering draait het dus om het al doende ontdekken van geschreven taal ${ }^{4}$ via de waarneming en ervaring van allerlei ogenschijnlijk triviale toepassingen (zoals boodschappenlijstjes) en allerlei ongeschreven 'regels' met betrekking tot lezen en schrijven (zoals dat een geschreven woord, als teken, correspondeert met iets in de werkelijkheid, iets betekent). In vergelijking zien wij de fase van de ontluikende culturele gelet-

\footnotetext{
${ }^{4}$ Ook de eerste kennismaking van kinderen met 'boekconventies' wordt tot de ontluikende geletterdheid gerekend: conventies die betrekking hebben op de eigenschappen van een boek en wat je met boeken kunt doen. We kunnen het lezen van boeken als een specifieke vorm van communicatie zien die gebaseerd is op een hele set aan ongeschreven regels, of 'contracten', die kinderen al op jonge leeftijd door ervaring leren kennen en gebruiken (Snow \& Ninio, 1986). Het gaat onder meer om het besef dat boeken anders zijn dan andere objecten, dat het boek de interactie tussen de voorlezer en de luisteraar (mede) bepaalt, dat verhalen zich buiten de werkelijke tijd afspelen en op zichzelf staande fictionele werelden zijn, dat illustraties representaties van dingen zijn, en dat ze moeten worden 'gelezen', net als woorden. In het huidige multimediale tijdperk, waarin gesproken wordt van meervoudige geletterdheid, kunnen we ons soortgelijke 'contracten' voor de communicatie met andere media goed voorstellen (zie ook Snow \& Ninio, 1986).
} 
terdheid als de fase waarin kinderen al doende kennismaken met de culturele wereld waarin verschillende soorten teksten een vaste plaats hebben en betekenis krijgen. Het gaat dus niet om het ontdekken van de relatie tussen gesproken en geschreven taal, maar om het ontdekken van de relatie tussen allerlei soorten teksten en de wereld. Die ontdekking is aanvankelijk ingebed in de 'cultuur van het dagelijks leven' binnen het gezin, maar is op verschillende manieren ook al verbonden met de tradities en overtuigingen van grotere culturele groepen. Die verbindingen worden gemaakt via de 'gezinscultuur'.

De kennismaking met of inwijding in de cultuur van het dagelijks leven bestaat eruit dat kinderen worden opgenomen in de gezinscultuur. Zoals ook bij culturen in het groot, bestaat die gezinscultuur uit een dynamisch netwerk van gedeelde overtuigingen, waarden, kennis, kunde, gestructureerde relaties, gebruiken, socialisatiepraktijken en symboolsystemen (Miller, 2002, p. 374). Dit netwerk vormt de basis van de gezinsidentiteit die omschreven kan worden als een gedeeld systeem van overtuigingen op basis waarvan de gezinsleden zichzelf als groep, als gezin, ervaren en profileren. Aan deze gezinsidentiteit wordt uiting gegeven in allerlei 'gezinsrituelen' (Juchtmans, 2008; Spagnola \& Fiese, 2007; Dickstein, 2002; Fiese et al, 2002, 1993; Bennet, Wolin \& McAvity, 1988). Deze gezinsrituelen kunnen in verschillende categorieën worden ingedeeld op basis van het type relatie dat ermee bestendigd wordt. Allereerst zijn er de vieringen, i.e. de feestdagen en ceremonies die binnen grotere culturele gemeenschappen als zodanig worden erkend en waar het gezin aan deelneemt. Hiertoe behoren overgangsrituelen zoals huwelijken, begrafenissen en religieuze sacramenten en jaarlijks terugkerende religieuze en seculiere feestdagen zoals Kerst, Suikerfeest en Koningsdag. Via deze vieringen identificeert een gezin zich met bredere etnische, politieke of religieuze gemeenschappen en de daarin geldende overtuigingen en rituele praktijken. Ten tweede zijn er de familietradities, waaronder de gezins- of familiespecifieke invulling die wordt gegeven aan bijvoorbeeld zomervakanties, familiebezoek, jubilea, verjaardagen, of speciale maaltijden. Met familietradities wordt vooral uitdrukking gegeven aan het belang dat wordt gehecht aan het in stand houden en doorgeven van specifieke familiewaarden en de bevestiging van familierelaties. Ten slotte zijn er gestructureerde routines: de meest voorkomende, maar minst bewust geplande gezinsrituelen, zoals de vaste gebruiken bij dagelijkse maaltijden, bij het naar bed brengen van de kinderen, de omgang met gasten, of gezamenlijke vrijetijdsbestedingen. Deze vaste routines hebben de functie om het dagelijks gezinsleven te structureren via gedrags- en rolpatronen en om de onderlinge relaties te onderhouden (Bennet, Wolin \& McAvity, 1988, pp. 215-217). Op al deze niveaus zijn de gezinsrituelen belangrijke contexten waarin cultuuroverdracht plaatsvindt. Binnen deze rituele contexten kunnen allerlei soorten teksten een vaste plaats hebben, van de formulaire uitingen waarmee een huwelijk wordt bevestigd of ingezegend, de verhalen, gebeden en/of liederen die een vaste plaats hebben in de liturgie van een religieuze gemeenschap of in de viering van feestdagen, de moppen van oom Kees bij elk familiefeest, tot aan een verhaaltje, gebed of liedje voor het slapen gaan. De routines en rituelen uit de cultuur van het dagelijks leven vormen dus belangrijke contexten waarin de basis van de ontluikende culturele geletterdheid wordt gelegd. 


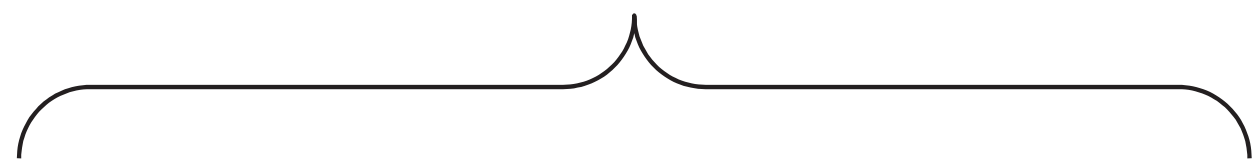

Micha Wertheim, cabaretier van Joodse komaf, vertelde in het avondvullende programma Zomergasten (VPRO, 29 juli 2012) dat hij als kind opgroeide in een klein dorpje waar zij het enige Joodse gezin waren. Dit opvallende verschil tussen zijn familie en alle andere families in het dorp maakte dat hij lange tijd in de overtuiging leefde dat alles waarvan hij dacht 'dit doen wij alleen thuis', ook specifiek Joods was. Hij dacht niet alleen dat het ontsteken van de chanoekia met Chanoeka voortkwam uit de Joodse identiteit van het gezin, maar ook de manier waarop zijn vader hem 's avonds instopte en zelfs het feit dat zij thuis 'sinaasappelsap' zeiden en niet, zoals de buren, 'jus d'orange'. Pas toen hij na de middelbare school een jaar in Israël verbleef en omringd was door andere Joodse mensen, werd hem duidelijk welke gebruiken die hij van huis uit had meegekregen tot de Joodse traditie behoren en welke een andere oorsprong hebben.
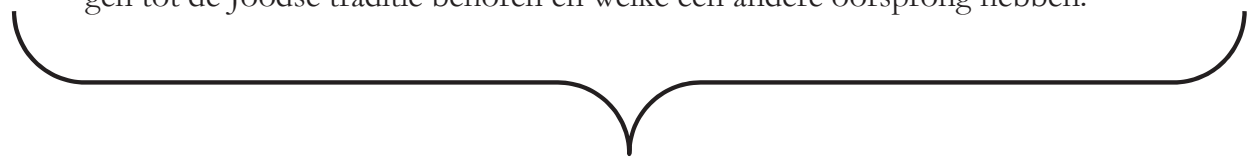

Sommige zaken worden binnen gezinnen heel expliciet en bewust overgedragen op kinderen en sommige zaken impliciet en onbewust: alles bij elkaar vormen deze praktijken de primaire culturele socialisatie (Kraaykamp, 2009, p. 5). Deze primaire culturele socialisatie geeft vorm aan de culturele referentiekaders, de kennis en vaardigheden, maar ook de normen, waarden, gebruiken en voorkeuren waarmee kinderen aan hun schoolloopbaan beginnen. De culturele socialisatie binnen het gezin is zeer relevant "... omdat de persoonlijke hulpbronnen die men gedurende de socialisatie in het ouderlijk gezin opbouwt, kunnen worden ingezet in het onderwijs, op de arbeidsmarkt, en in het dagelijkse sociale leven," schrijft cultuursocioloog Gerbert Kraaykamp: "Kinderen waarvan de ouders over kwalitatief hoogwaardige culturele hulpbronnen beschikken, hebben daardoor een voorsprong op kinderen waarvan de ouders over minder bruikbare culturele hulpbronnen beschikken." (p. 7) Dat de ene of de andere hulpbron meer of minder 'waardevol' of 'bruikbaar' is in het onderwijs, in het dagelijkse sociale leven en later ook op de arbeidsmarkt, heeft volgens cultuur- en onderwijssociologen alles te maken met het principe dat de maatschappelijke bovenlaag de grootste belangen, de middelen en de invloed heeft om de eigen positie en die van hun kinderen te beschermen, door deze als 'maatgevend' te stellen voor de samenleving als geheel. In cultuur- en onderwijssociologisch onderzoek wordt keer op keer bewijs gevonden voor wat 'sociale reproductie' wordt genoemd. Dat houdt in "dat kinderen van hoog opgeleide ouders een veel grotere kans hebben om een hoog opleidingsniveau en een hoge beroepspositie te bereiken, dan kinderen van laag opgeleide ouders (...).” (p. 6) Wanneer in het onderwijs de dominante cultuur als uitgangspunt wordt genomen, dan hebben kinderen die die cultuur van huis uit meekrijgen direct een streepje voor en heeft het Mattheüseffect vrij spel. 
De cultuur- en onderwijssociologische inzichten wijzen er op dat het 'cultureel kapitaal' dat kinderen van huis uit meekrijgen sterk kan variëren, afhankelijk van het sociale milieu van het gezin, en dat bestaande verschillen moeilijk te overbruggen zijn. Maar, zoals ook Kraaykamp benadrukt, in de cultuur- en onderwijssociologie wordt 'cultureel kapitaal' vooral afgemeten aan aangelegenheden als theater- en museumbezoek, het lezen van literaire boeken, het luisteren naar klassieke muziek of het bezitten van kunst. Dit zijn exclusieve (sterk milieu- en leeftijdsafhankelijke) culturele praktijken die, wanneer ze als graadmeter voor 'cultureel kapitaal' worden genomen, slechts een beperkt beeld geven van wat er nu werkelijk aan 'cultureel kapitaal' in de samenleving als geheel vertegenwoordigd is. Uitgaan van wat dominant is, zo is ook in de vorige paragraaf al aan bod gekomen, sluit bij voorbaat al groepen in de samenleving uit omdat zij die specifieke 'artikelen uit de cultuurwinkel' niet bezitten, of anders gezegd, omdat zij artikelen bezitten die niet als 'cultuur' zijn aangemerkt. Binnen het kader van dit onderzoeksproject willen we niet zozeer uitgaan van de verschillen tussen kinderen, maar van de overeenkomsten. Daarom lijkt een ander perspectief op 'culturele praktijken' ons vruchtbaarder om aansluiting te vinden op de ontluikende culturele kennis, vaardigheden en voorkeuren van pluriforme groepen van jonge kinderen dan het perspectief zoals dat door cultuur- en onderwijssociologen vaak gehanteerd wordt. We kiezen voor een perspectief dat gebaseerd is op de notie van 'volkscultuur', "als aanduiding van de brede, alledaagse cultuur, waar iedereen, elite of volk, vreemd of eigen, in participeert." (Dekker, Roodenburg \& Rooijakkers, 2000b, p. 10) We laten ons in die zin informeren door de etnologie waar de bestudering van 'het schijnbaar triviale van onze dagelijkse cultuur ${ }^{5}$, ofwel breed gedragen cultuurverschijnselen, centraal staat (p. 10). Gezinscultuur en volkscultuur raken elkaar binnen thema's als feesten, rituelen, geloofsvoorstellingen, kleding, voeding, wooncultuur, omgangsvormen, vertelcultuur en zangcultuur. Die breed gedragen, alledaagse culturele praktijken vormen, in al hun pluriformiteit, voor alle kinderen de basis van waaruit hun ontluikende culturele geletterdheid verder kan worden ontwikkeld. Cultuur- en godsdienstpsycholoog Ina ter Avest wijst er dan ook op dat het 'tweede opvoedingsmilieu' (dagopvang, peutergroep en school) juist haar voordeel kan doen met de culturele kennis en ervaringen die de verschillende kinderen van thuis uit meebrengen door ze als uitgangspunt te nemen voor de gezamenlijke verkenning van woorden, objecten en praktijken in de klas. Op deze manier kan in het 'tweede opvoedingsmilieu' de culturele geletterdheid van alle kinderen worden gestimuleerd, stelt Ter Avest: "een belangrijke factor die bijdraagt aan het leren samenleven in de multiculturele Nederlandse samenleving." (Avest, 2010, p. 59)

Culturele socialisatie bestaat niet alleen uit de overdracht van cultuur door volwassenen op kinderen; voor geslaagde socialisatie moeten kinderen die cultuur ook verwerven. Hoe maken jonge kinderen zich de alledaagse cultuur in het gezin eigen en wat leert dit ons over processen van (tekst- en) cultuurverwerving bij jonge kinderen? Net zoals dat het geval is bij taalverwerving en ontluikende geletterdheid, is ook cultuurverwerving bij jonge kinderen voor een belangrijk deel een reproductief proces dat wordt gevoed door de directe omgeving. Hoe jonge kinderen aspecten van de gezinscultuur verwerven, is volgens Ter Avest in eerste instantie via 'nadoen en meedoen':

\footnotetext{
${ }^{5}$ In deze bewoording kenschetsen de redacteuren het onderwerp van het boek Volkscultuur: Een inleiding in de Nederlandse etnologie (Dekker, Roodenburg \& Rooijakkers, 2000b, p. 7).
} 
"Dat geldt voor het nadoen van de moeder bij het verschonen van de baby (met de pop), maar evenzeer ook bij het stofzuigen, ramen lappen en inruimen van de afwasmachine; en ook voor het samen 'lezen' van een boek. Dat geldt voor het nadoen in het bestraffend toespreken van zichzelf (als hij iets heeft gedaan waarvan hij wéét dat het niet mag), net zoals voor het meedoen in het samen zingen van een slaapliedje bij het naar bed gaan." (Avest, 2010, p. 59)

'Nadoen en meedoen' vormen basale modellen voor de wijze waarop jonge kinderen zich aspecten van de cultuur van het dagelijks leven eigen maken, inclusief de teksten die in die cultuur zijn ingebed, zoals het slaapliedje bij het naar bed gaan of de verhalen die ieder jaar in het kader van een viering verteld worden, maar ook de rijmen, liedjes en verhalen die vast onderdeel uitmaken van kinderprogramma's op televisie, of de Disney-films die regelmatig gekeken worden. De eerder beschreven gezinsrituelen, van vieringen tot en met gestructureerde routines, vormen dan concrete contexten van tekstverwerving die de ontwikkeling van ontluikende culturele geletterdheid in gang zetten. Naast het meedoen en nadoen in specifieke terugkerende contexten, verwerken kinderen hun ervaringen en opgedane kennis in allerlei vormen van (symbolisch) spel waarin ze gedragspatronen en taaluitingen uit hun directe omgeving imiteren, maar ook adapteren naar eigen kunnen, behoefte en plezier. Spel vormt, naast de routines en rituelen van de alledaagse cultuur, een belangrijk middel voor jonge kinderen om nieuwe praktijken toe te eigenen en op te nemen in de diepere kennisstructuren, in hun mentale 'schemata'6 (Piaget, 1952, 1977). Hieruit kunnen we afleiden dat cultuurverwerving, en tekstverwerving als onderdeel daarvan, bij jonge kinderen in hoge mate ervarings- en handelingsgericht verloopt, en concrete vorm krijgt in routines, rituelen en spel in de 'cultuur van het dagelijks leven'.

Het is van cruciaal belang dat het tekstaanbod voor jonge kinderen aan het begin van het basisonderwijs zorgvuldig wordt afgestemd op hun prille cognitieve en culturele competentie, om de ontwikkeling van hun ontluikende culturele geletterdheid ${ }^{7}$ vervolgens optimaal te kunnen stimuleren. Voor kinderen aan het begin van het basisonderwijs begint de ontwikkeling van culturele geletterdheid echter niet met 'hoogwaardig cultureel kapitaal', zoals in de cultuursociologie veelal centraal staat, en ook niet met kennis van 'alle in de taal van die samenleving beschreven en geschreven producten', zoals de makers van Het Cultureel Woordenboek in navolging van Hirsch als uitgangspunt gebruiken. Het is onze opvatting

\footnotetext{
${ }^{6}$ Jean Piaget $(1952,1977)$ noemde schemata de basale bouwstenen van intelligent gedrag: het middel om ervaringen om te zetten in georganiseerde kennis en op te slaan in het geheugen. Schemata zijn een soort kenniseenheden, sets van aan elkaar verbonden mentale representaties die betrekking hebben op specifieke aspecten van de wereld, inclusief objecten, handelingspatronen en concepten met bijbehorende taal en betekenissen. Deze schemata gebruiken we om de wereld te begrijpen: ze liggen ten grondslag aan ons denken en handelen. Volgens Piaget wordt de intellectuele ontwikkeling, als de uitbreiding van het aantal en de complexiteit van schemata, voortgedreven door een continu streven naar 'equilibrium', de staat waarin de aanwezige schemata toereikend zijn om met nieuwe ervaringen om te kunnen gaan ('assimilatie'). Wanneer de schemata waarover een kind beschikt in een bepaalde situatie echter niet werken (er ontstaat geen herkenning en begrip, of handelen leidt onbedoeld tot falen), dan ontstaat er 'disequilibrium' en moeten bestaande schemata worden aangepast of uitgebreid ('accommodatie'). Een simpel voorbeeld is dat jonge kinderen hun schema voor 'opa', gebaseerd op hun eigen opa, toepassen op alle oudere mannen met grijs haar en een baard en hen allemaal 'opa' noemen, totdat iemand uitlegt wat het verschil is tussen 'eigen opa', 'opa van een ander' en 'oudere man'.

7 'Ontluikende culturele competentie' heeft betrekking op wat kinderen aan cultuur kunnen verwerven; 'ontluikende culturele geletterdheid heeft betrekking op wat kinderen aan cultuur bebben verworven.
} 
dat de ontluikende culturele geletterdheid van jonge kinderen ontspruit in de voedingsbodem van de 'cultuur van het dagelijks leven' zoals ze die binnen het primaire opvoedingsmilieu leren kennen. Ingebed in allerlei soorten vaste en regelmatig herhaalde praktijken maken kinderen (in meer of mindere mate) kennis met allerlei soorten teksten, van verhalen in de context van religieuze vieringen tot en met een liedje voor het slapen gaan. In die contexten van routines en rituelen dienen 'meedoen' en 'nadoen' zich aan als primaire modellen voor processen van cultuur- en tekstverwerving bij jonge kinderen, en nieuwe kennis en ervaringen worden door kinderen vaak geconsolideerd in vormen van spel. De inwijding in de cultuur van het dagelijks leven thuis geeft vorm aan de ontluikende culturele geletterdheid waarmee kinderen op school komen en op school kan van daaruit worden bijgedragen aan de verdere uitbreiding van die ontluikende culturele geletterdheid. Willen we een aanbod van kinderliteratuur samenstellen en aanbieden dat de ontluikende culturele geletterdheid die pluriforme groepen kinderen van huis uit meekrijgen effectief verder helpt ontwikkelen, dan moeten we, zo is ons uitgangspunt, aansluiting maken bij "de brede, alledaagse cultuur, waar iedereen, elite of volk, vreemd of eigen, in participeert." (Dekker, Roodenburg \& Rooijakkers, 2000b, p. 10) Die aansluiting kan, ons inziens, enerzijds gemaakt worden door de aanbieding van kinderliteratuur op school in te bedden in alledaagse, culturele en religieuze rituele contexten, zoals de vieringen in het jaar en in het leven; anderzijds kan die aansluiting gemaakt worden door uit te gaan van genres en tekstsoorten die van oudsher een vaste plaats hebben in de 'brede alledaagse cultuur', i.e. de orale volkscultuur.

\subsection{Kinderliteratuur en ontluikende culturele geletterdheid}

Literatuur kan een belangrijke bijdrage leveren aan de ontwikkeling van culturele geletterdheid. In 2005 nog benadrukte de Raad voor Cultuur dat lezen als sleutel tot informatie en cultuur essentieel is om volwaardig te kunnen deelnemen aan een geletterde samenleving (2005b, p. 2). Naast de oproep voor het instellen van een 'culturele-kennis-canon' legt de Raad het primaat in het verwerven van kennis van onze cultuur zelfs bij het lezen van literatuur. Ze spreekt van het belang van 'het culturele lezen', waarover ze stelt:

"Het culturele lezen, het lezen van cultureel waardevolle en literaire teksten, draagt bij aan de cognitieve ontwikkeling, vergroot de literaire competentie, verschaft leesplezier, en is te beschouwen als sociaal kapitaal. Het lezen van literaire en culturele teksten verschaft ook toegang tot het culturele erfgoed. Het kweekt historisch besef aan en draagt bij aan cultureel relativisme en onderhoud van een collectief geheugen." (Raad voor Cultuur, 2005b, p. 3)

Hoewel het stimuleren van dit 'culturele lezen' al lange tijd een hoofddoelstelling van het leesbevorderingsbeleid was, wijst de Raad voor Cultuur erop dat de kennis en vaardigheden die nodig zijn voor het culturele lezen in de samenleving en in het onderwijs minder vanzelfsprekend zijn geworden: "Het accent is in de afgelopen periode verschoven van literatuur naar leesvaardigheid en leesplezier in het algemeen.” (p. 6) Ondanks dat leesbevordering officieel onderdeel uitmaakt van het cultuurbeleid en gericht was op de bevordering 
van 'het culturele lezen', wordt het in de praktijk van het basisonderwijs vaak impliciet of expliciet gekoppeld aan taalontwikkeling en het leren lezen en schrijven. Cultuurnetwerk Nederland en Stichting Lezen bevestigen dit beeld in een publicatie uit hetzelfde jaar. In het artikel 'Wat gaat voor: literaire canon of leesplezier?' wordt gesteld dat leesbevordering en literatuureducatie, voor zover die laatste term al (of nog) wordt gebruikt in het basisonderwijs, hoofdzakelijk vallen onder het taal- en leesonderwijs. De mate waarin aandacht aan het lezen van kinderliteratuur wordt besteed, is daarbij vaak sterk afhankelijk van de gebruikte taal- en leesmethoden en de houding van de leerkracht ten aanzien van (voor)lezen en literatuur (Nicolaas, 2005, p. 8). De expliciete en vroege aandacht voor literatuur als toegang tot brede cultuur en het aanbieden van 'cultureel waardevolle' teksten als middel voor de ontwikkeling van culturele geletterdheid, of algemene ontwikkeling, heeft geen expliciete en structurele plaats in het Nederlandse basisonderwijs ${ }^{8}$. Dit is vooral in het nadeel van kinderen die de brede culturele kennis en vaardigheden die nodig zijn in het onderwijs en later voor deelname aan de Nederlandse cultuur en samenleving van huis uit niet (kunnen) meekrijgen (Bourdieu, 1979; Bourdieu \& Passeron, 1981; Mooren, 2000a).

In dit onderzoeksproject stellen we de rol die kinderliteratuur kan spelen in het ontwikkelen van de ontluikende culturele geletterdheid bij kinderen van vijf tot en met acht jaar, verdeeld over groep 2 en groep $4^{9}$ van het basisonderwijs, centraal. Dat betekent dat wij uitgaan van een 'culturele benadering' van kinderliteratuur, dat we kinderliteratuur dus zien als opstap naar brede culturele geletterdheid. De bijdrage die kinderliteratuur kan leveren aan de ontluikende culturele geletterdheid van jonge kinderen krijgt vorm in de brede context van processen van culturele socialisatie en cultuurverwerving. "Dit proces van cultuurverwerving kunnen we inhoudelijk en formeel benaderen," stelt Rita Ghesquière. "Formeel is het de competentie ontwikkelen om in contact te treden met de cultuur; inhoudelijk is het een overdracht van cultuurinhouden." (2009a, p. 112) Formeel kan kinderliteratuur bijdragen aan culturele geletterdheid door kinderen stapsgewijs kennis en begrip te laten opbouwen van de taal van verhalen en poëzie en van allerlei tekstsoorten en -kenmerken die een belangrijk onderdeel uitmaken van de cultuur waarin ze opgroeien. Door al van jongs af aan te luisteren naar een breed scala aan tekstsoorten ontwikkelen kinderen een genuanceerde taalvaardigheid waarmee ze zichzelf beter kunnen uitdrukken en anderen beter kunnen begrijpen, leren ze verhaalpatronen (her)kennen en typerende openings- en

\footnotetext{
${ }^{8}$ Dit geldt voor cultuureducatie in het algemeen en heeft, zo stellen Onderwijsraad en Raad voor Cultuur vast in een gezamenlijk advies uit 2012, alles te maken met de moeilijkheid om 'culturele ontwikkeling' van leerlingen te vertalen naar meetbare resultaten. De Raden schrijven: "De vraag is steeds in hoeverre meetinstrumenten die uitgaan van rationaliteit, objectiviteit en vergelijkbaarheid, bruikbaar zijn voor kunstzinnige processen die sterk verbonden zijn met emoties, subjectiviteit en individuele kwaliteiten (...). Hoewel in de afgelopen jaren diverse instrumenten en methoden zijn ontwikkeld om de beoordeling van kunstproducten betrouwbaarder te maken, blijven betrouwbaarheids- en validiteitsaspecten onderwerp van discussie (Haanstra \& Schönau, 2006)." (Onderwijsraad \& Raad voor Cultuur, Cultuureducatie: leren, crëren, inspireren!, 2012, p. 15) Doordat de opbrengsten van cultuureducatie moeilijk zijn om te zetten in meetbare resultaten, is er voor scholen ook nauwelijks een prikkel om hier structureel tijd en ruimte voor te creëren. Tijd en ruimte 'ten koste van' tijd en ruimte die wordt besteed in directe aansluiting op geformuleerde kerndoelen en leerlijnen voor het basisonderwijs waar wel meetinstrumenten voor bestaan waarmee de opbrengsten in kaart worden gebracht. Scholen worden beoordeeld op meetbare resultaten en 'opbrengstgericht werken' staat dan ook al lange tijd hoog in het vaandel.

${ }_{9}$ Dit onderzoeksproject omvat een interventie in het basisonderwijs: we richten ons op groep 2 en groep 4 omdat groep 3 voor zowel leerkrachten als kinderen een bijzonder intensief jaar is waarin de overgang vanuit het kleuteronderwijs gemakkt moet worden, kinderen leren lezen en schrijven, enzovoort. Vanuit deze overweging is besloten groep 3 buiten beschouwing te laten.
} 
slotformules, maken ze kennis met verschillende soorten personages en de rollen die zij spelen, leren ze genres en subgenres (her)kennen en bouwen daar verwachtingspatronen over op (Ghesquière, 2009b, z.p.). Deze formele kant van culturele geletterdheid kan stapsgewijs worden opgebouwd met kinderliteratuur en is nodig om uiteindelijk een brede waaier van tekstsoorten vlot en duidend te kunnen lezen. Dit draagt niet alleen bij aan begrijpend lezen en leesplezier, maar is ook belangrijk voor de algemene ontwikkeling. Want naast het opbouwen van kennis en begrip van allerlei formele kenmerken van verschillende genres of tekstsoorten, bieden die genres en tekstsoorten ook toegang tot een brede waaier aan cultuurinhouden. Hierbij valt te denken aan algemene kennis van (allerlei aspecten van) de wereld, maar ook van wereldbeelden, van tradities en gebruiken, van normen en waarden (zie ook Avest, 2010; Ghesquière, 2009a). De mogelijkheden voor beleving, identificatie en verbeelding die teksten en de wijze waarop ze worden aangeboden aan kinderen bieden, spelen daarbij een cruciale rol als voorwaarden voor leesplezier en betrokkenheid bij verhalen en poëzie (zie o.a. Nicolaas, 2005, p.7). Sinds een aantal jaar klinkt er in Nederland een hernieuwde roep om aandacht voor culturele vorming in het onderwijs. In 2011 stelde de Onderwijsraad vast dat vorming van kinderen en jongeren complexer en minder vanzelfsprekend is geworden onder invloed van een veelheid aan sociaal-culturele ontwikkelingen, zoals afnemende invloed van traditionele levensbeschouwelijke instituties, toenemende culturele pluriformiteit in de samenleving, de toenemende dynamiek van de huidige netwerksamenleving, en het toegenomen belang dat aan economisch nut en rendement wordt gehecht, ook op het gebied van kennis, cultuur en wetenschap. Juist vanwege de toegenomen complexiteit en de afgenomen vanzelfsprekendheid acht de Onderwijsraad het van belang dat in het onderwijs aandacht wordt besteed aan brede culturele vorming:

"Kinderen en jongeren hebben behoefte aan brede cultuuroverdracht, waaronder kennis van tradities en moraal. Ze zullen deze kennis niet gauw meer op andere plekken kunnen opdoen. Scholen en leraren hebben de taak kinderen en jongeren in te leiden in de opgebouwde kennis en (morele) tradities, zowel door kennisoverdracht als door voorbeeldgedrag en regels." (Onderwijsraad, 2011, p. 12)

Het gaat dan niet om een eenzijdig opleggen van normen en waarden, benadrukt de Raad, maar om het zorgen "dat kinderen en jongeren zaken meekrijgen waarmee zij in dialoog kunnen gaan, zodat zij zelf kunnen ontdekken wat zij richtinggevend en van waarde vinden." (p. 12) In 2013 benadrukt de Onderwijsraad opnieuw: "De raad constateert dat in de afgelopen periode de aandacht eenzijdig gericht was op meetbare doelen, in het bijzonder op taal- en rekenprestaties. Er was veel minder beleidsaandacht voor het bredere vakkenaanbod en voor algemene vorming ...." (Onderwijsraad, 2013, p.7) Aandacht voor vorming is zo oud als het onderwijzen zelf, schrijft Bert Roebben: "Wie kinderen wil thuisbrengen in een cultuur, maakt hen ook vertrouwd met de waarden en normen die daar heersen en met een positie die men zelf als burger kan innemen." (Roebben, 'Waarden: de moeite waard?', z.p.) De aandacht die aan vorming en aan de overdracht van cultuurinhouden (waaronder waarden en normen, tradities en gebruiken) besteed wordt in het onderwijs wordt echter, afhankelijk van het maatschappelijk debat, meer of minder belangrijk gevonden. Op dit moment staat burgerschapsvorming opnieuw hoog op de onderwijsagenda, 
maar de Onderwijsinspectie stelt in haar meest recente rapport De staat van het onderwijs: Onderwijsverslag 2013/2014: "De inspectie schenkt in het toezicht al geruime tijd aandacht aan de manier waarop scholen de bevordering van burgerschap en integratie invullen. Hoewel de meeste scholen voldoen aan de minimale wettelijke eisen, verloopt de ontwikkeling van dit onderwijs langzaam." (Inspectie van het Onderwijs, 2015, p. 66) Voor het basisonderwijs ligt een koppeling met leesbevordering voor de hand, want aandacht voor vorming is evengoed zo oud als de kinderliteratuur zelf, hoewel er onder invloed van veranderende literatuuropvattingen op dit moment minder (expliciete) aandacht voor de maatschappelijke functies van kinderliteratuur is (Ghesquière, Joosen \& Lierop-Debrauwer, 2014).

We kunnen de overdracht van formele en inhoudelijke aspecten van culturele geletterdheid via kinderliteratuur overigens niet los van elkaar zien, "want inhoudelijke opties worden door formele keuzes ondersteund." (Ghesquière, 2009a, p. 114) Voor het stapsgewijs opdoen van kennis en vaardigheden met betrekking tot cultureel relevante uitingsvormen én inhouden via kinderliteratuur is een structurele aanbieding van een verscheidenheid aan genres een zeer geëigend middel. Lies Wesseling stelt dat genres een specifieke oplossing voorstellen voor het esthetisch probleem van het samenbrengen van vorm en inhoud. Op die manier kunnen genres enerzijds het proces van literaire compositie leiden; anderzijds vormen genres voor lezers sets van verwachtingen die het leesproces sturen. Genre repertoires kunnen dan gezien worden als 'bodies of shared knowledge' die zijn afgeleid van waargenomen regelmatigheden in individuele teksten. Als sets van normen die schrijvers en lezers met elkaar delen, vervullen genres een belangrijke rol in processen van literaire communicatie (Wesseling, 1991, in: Van Gorp en Musarra-Schroeder, 2000, p. i). Hendrik van Gorp en Ulla Musarra-Schroeder voegen hieraan toe dat genres "ons culturele geheugen” activeren (p. i). Voordat genres op die manier 'werken' in processen van literaire communicatie, zal de kennis van de vormen en inhouden die in genres samenkomen echter opgebouwd moeten worden en zullen de vaardigheden om die kennis op te doen en te gebruiken ontwikkeld moeten worden. Pas als lezers delen in de 'bodies of shared knowledge' die processen van literaire communicatie ondersteunen, kan er sprake zijn van herkenning en wordt 'het culturele geheugen' van lezers geactiveerd. Jonge kinderen hebben door hun beperkte leeservaring echter nog nauwelijks kans gehad om dat 'culturele geheugen' van de vormen en inhouden die samenkomen in genres op te bouwen. We moeten er dan ook rekening mee houden dat jonge kinderen teksten anders begrijpen en waarderen dan volwassen lezers:

"Volwassen lezers hebben door hun jarenlange lectuur een bredere verwachtingshorizon opgebouwd. Daardoor kan er bij de evaluatie van teksten kortsluiting ontstaan tussen volwassenen en kinderen. Stereotypie en herhaling maken voor de volwassenen een verhaal vlug doorzichtig, vervelend en saai, terwijl dezelfde kenmerken een kind juist plezier verschaffen." (Ghesquière, 2009a, p. 137)

Jonge kinderen beschikken nog niet over uitgebreide genrekennis en een brede verwachtingshorizon; ze beschikken wel over ontluikende culturele schemata op basis van de primaire culturele socialisatie in de 'cultuur van het dagelijks leven'. Daar komt bij dat ze zich 
in een overgangsfase van oraliteit naar geletterdheid bevinden en volop in ontwikkeling zijn. Het is dus niet vanzelfsprekend dat wat volwassenen 'cultureel waardevol' vinden ook bij kinderen in de smaak valt. Als we willen komen tot de identificatie van criteria voor de selectie van kinderliteratuur die effectief bijdraagt aan de ontluikende culturele geletterdheid van jonge kinderen dan zullen we op zoek moeten naar aansluiting op hun ontluikende 'culturele geheugen'.

Genres en verhalen die aan de basis van een cultuur liggen, dragen in vorm en inhoud meer bij aan culturele geletterdheid dan verhalen die niet dieper reiken dan de alledaagse werkelijkheid, stelde Hirsch in zijn latere uitwerkingen van culturele geletterdheid voor jonge kinderen (2002, p. xv). In de vorige paragraaf hebben we gezien dat het de 'cultuur van het dagelijks leven' is, met de vele alledaagse rituelen en routines en de tekstsoorten die daar van oudsher onderdeel van uitmaken, die de basis vormt voor de ontwikkeling van ontluikende culturele geletterdheid bij jonge kinderen. In die volkscultuur vormen genres ${ }^{10}$ en tekstsoorten als het sprookje, het schelmenverhaal, de fabel, verhalen uit religieuze tradities, moppen en raadsels, het bakerlied en het nonsensrijm van oudsher de 'canon van de alledaagse cultuur'. Dit zijn genres of tekstsoorten die al eeuwenlang meegaan en diep geworteld zijn in de orale volkscultuur. Ze hebben bovendien een vaste plaats verworven binnen het domein van de kinderliteratuur en vallen ook bij huidige generaties van kinderen nog altijd in de smaak. Deze teksten voeden het culturele geheugen van kinderen met basale genrekennis die toegang biedt tot een veelheid aan literaire uitingen, want niet alleen auteurs van kinderliteratuur, maar ook auteurs van literatuur voor volwassenen laten hun waardering van deze genres via allerlei vormen van intertekstualiteit doorklinken in hun eigen werk (zie o.a. Mooren, 2002). Daarbij bevatten deze genres en tekstsoorten een veelheid aan cultuurinhouden die kinderen laten kennismaken met allerlei aspecten van de wereld, met wereldbeelden, met tradities en gebruiken, met normen en waarden. Hoe komt het dat deze in de orale volkscultuur gewortelde tekstsoorten, als specifieke 'cultural frames' die een diepe en brede culturele waarde vertegenwoordigen, nog altijd aansluiten op de culturele schemata van kinderen van nu? Als we begrijpen wat deze klassiekers uit de 'volksculturele canon' zo vitaal maakt, dan kunnen we deze inzichten vertalen naar criteria voor de selectie van kinderliteratuur die effectief kan bijdragen aan de ontwikkeling van de ontluikende culturele geletterdheid van jonge kinderen.

\subsection{De tijd waarin we le(v/z)en ... Culturele diversiteit en meervoudige geletterdheid}

In het kader van dit onderzoek hanteren we het begrip '(ontluikende) culturele geletterdheid' als conceptueel kader vanuit het bewustzijn dat deze term in de huidige Nederlandse samenleving en het huidige Nederlandse basisonderwijs aan beide kanten, zowel de 'cultuur'-kant als de 'geletterdheid'-kant, vraagt om explicitering. Zoals ook Ronald Soetaert

\footnotetext{
${ }_{10}$ In het algemeen kan binnen de literatuurbeschouwing onder 'genre' verstaan worden: aanduiding voor de inhoudelijk en formeel bepaalde soorten of klassen van literaire teksten. Daarbij moet worden opgemerkt dat voor het begrip 'genre' geldt dat de term nauwelijks valt vast te pinnen omdat hij in de praktijk steeds afhankelijk blijkt van de cultuurhistorische verschuivingen in het literaire veld (Bork et al, 2012).
} 
vaststelde in zijn essay 'De cultuur van het lezen' leven we in een complexe en dynamische wereld: "Een wereld waarin we geconfronteerd worden met de verschuiving van een enkelvoudige geletterdheid naar meervoudige geletterdheden, van één cultuur naar het multiculturele." (2006, p. 9) Belangrijke vragen in het kader van dit onderzoek zijn dan ook hoe de bijdrage van kinderliteratuur aan de ontluikende culturele geletterdheid van kinderen zich verhoudt tot een multiculturele samenleving en dito schoolpopulaties enerzijds en tot de veelheid aan 'geletterdheden' die worden onderscheiden in het hedendaagse multimedialandschap en -onderwijs anderzijds. Wat verstaan we binnen dit onderzoeksproject, in die complexe omgeving, precies onder 'ontluikende culturele geletterdheid'?

Schoolklassen gevuld met leerlingen die verschillende sociaaleconomische, etnische en religieuze achtergronden vertegenwoordigen, stellen naar onze opvatting specifieke eisen aan de invulling en operationalisering van het begrip 'culturele geletterdheid'. Onderwijspedagoog Wilna Meijer gaat in haar artikel 'Het boek en de school: Over geletterdheid en algemene vorming' (1996) in op Hirsch' opvatting van culturele geletterdheid en stelt kritische vragen over wat de diversiteit in leerlingenpopulatie betekent in relatie tot een canon van algemene vorming die het onderwijs zou moeten aanbieden:

"Een van de actuele ontwikkelingen die tegenwoordig de vaststelling van een canon van algemene vorming compliceert, is de toegenomen culturele diversiteit van de bevolking van onze landen en onze scholen. Kunnen we vasthouden aan een canon, aan een gedeelde cultuur, zoals in de idee van culturele geletterdheid (met haar 'common reader') en in de idee van algemene vorming (de vorming van allen gemeenschappelijk) is voorondersteld? Of zou dat een ontkenning van culturele pluriformiteit inhouden die we ons niet kunnen permitteren?” (Meijer, 1996, pp. 25-26)

De vragen die Meijer stelt, zijn binnen het kader van dit onderzoek zeer relevant. Hoe stellen we ons een 'common reader' voor in een cultureel pluriforme samenleving? De onderwijspsycholoog Richard Anderson toonde, samen met collega's, in verschillende experimentele onderzoeken aan dat lezers eenzelfde tekst zeer verschillend kunnen onthouden en interpreteren, enkel vanwege het wel of niet aansluiten van de cultuurspecifieke inhoud van de tekst op de etnische achtergrond van die lezers. Omdat de schemata waarover elke individuele lezer beschikt mede bepaald worden door sociaal milieu, etniciteit, gender, leeftijd, et cetera, spreken deze onderzoekers dan ook van 'culturele schemata'11 (Reynolds et al, 1982). Deze onderzoekers waarschuwen dat in de selectie en ontwikkeling van materialen voor het onderwijs rekening moet worden gehouden met het feit dat kinderen uit minderheidsgroepen minder kansen hebben gehad om de schemata van de meerderheids- of dominante cultuur te verwerven omdat, voor jonge kinderen, de meest toegankelijke schemata die van hun ouders en leeftijdsgenoten zijn. Daar komt bij dat jonge kinderen vaak moeite hebben om gebeurtenissen te interpreteren vanuit perspectieven die hen niet eigen zijn. We mogen er dan ook niet zomaar van uit gaan dat bij het lezen van eenzelfde tekst verschillende kinderen dezelfde mate van ervaring hebben met de setting, dezelfde doelen en motieven toeschrijven aan personages, hetzelfde belang hechten aan

${ }^{11}$ De term 'culturele schemata' is dus feitelijk een pleonasme, net als 'culturele socialisatie'. De term benadrukt in deze vorm echter het belang van de culturele categorieën die van invloed zijn op de formatie van mentale schemata. 
gebeurtenissen, dezelfde emotionele reacties verwachten of dezelfde uitkomst voorspellen (p. 356). In het aanbod van teksten met het doel de ontluikende culturele geletterdheid van alle kinderen te vergroten, is het daarom van groot belang dat er gezocht wordt naar aansluiting op de culturele schemata waarover ze beschikken en om ruimte te laten voor verschillende interpretaties en het daarover in dialoog treden.

Enerzijds hebben we dus te maken met een cultureel pluriforme populatie van kinderen die beschikken over ontluikende culturele schemata die ze voor een belangrijk deel thuis opbouwen; anderzijds hebben we te maken met tekstsoorten en genres die als 'cultural frames' (Kamberelis \& Bovino, 1999) of 'repositories of cultural memory' (Van Gorp en Musarra-Schroeder, 2000) eveneens praktijken, normen en waarden van bepaalde culturele gemeenschappen vertegenwoordigen. Binnen het domein van de kinderliteratuur is al sprake van de nodige inzichten in differentiatie op basis van leeftijd en (deels ook) gender van lezers. We richten ons binnen dit onderzoek daarom meer expliciet op culturele pluriformiteit in de zin van etniciteit en levensbeschouwelijke categorieën. Helma van LieropDebrauwer en Piet Mooren schrijven met het oog op canonvorming voor kinderen in de multiculturele samenleving: "Putten uit de canon van de volkscultuur ligt voor de hand, omdat rijmpjes en versjes, sprookjes en fabels, raadsels en spreuken, moppen en grappen deel uitmaken van een internationale traditie." (2004, p. 11) Welke kenmerken maken dat deze '(trans)cultural frames' zo goed aansluiten op de ontluikende culturele schemata van een pluriform publiek van jonge kinderen? Deze inzichten kunnen dienen als criteria voor de selectie van kinderliteratuur die kinderen, ongeacht hun herkomst, aanspreekt en de mogelijkheid biedt om betekenisvol te participeren in activiteiten die gericht zijn op de verdere ontwikkeling van hun culturele geletterdheid. Hierdoor kunnen kinderen vanuit de culturele kennis en vaardigheden die ze al hebben deze kennis en vaardigheden via de interactie met de teksten, de leerkracht en elkaar verder uitbreiden. Hiermee sluiten we aan op wat Wilna Meijer als volgt formuleerde:

"Om kinderen op de pluriforme samenleving voor te bereiden, is bijvoorbeeld - naast een gedeelde taal - ook kennis nodig van de verschillende culturen die de collage van onze samenleving uitmaken. Dan dient de pluriformiteit in zekere zin in het leerplan van algemene vorming gerepresenteerd te worden. Wel gaat het nog steeds om gedeelde kennis die allen, ongeacht hun culturele achtergrond, moeten verwerven, maar het is kennis van culturele verscheidenheid.” (Meijer, 1996, pp. 25-26)

Omdat wij specifiek kijken naar de relatie tussen kinderliteratuur en ontluikende culturele geletterdheid bij jonge kinderen, verstaan we in het kader van dit onderzoeksproject onder 'cultuur' dus breed gedragen (transculturele en langdurig geliefde) genres, als 'cultural frames' waarin specifieke formele en inhoudelijke tekstkenmerken samenkomen, die de pluriformiteit van de Nederlandse samenleving representeren. Dit komt bijvoorbeeld tot uitdrukking in het feit dat we onder 'schelmenverhalen' niet alleen Tijl Uilenspiegel verstaan, maar ook Anansi of Kompa Nansi, Hodja en Djoha. En dat verhalen uit religieuze tradities niet alleen de Christelijke traditie, maar ook de Islamitische traditie beslaan, en dat het bakerlied niet alleen 'Slaap kindje slaap', maar ook 'Nini ya moemoe' en 'Dandinidan' om- 
vat. 'Culturele relevantie' heeft dan betrekking op transculturele kenmerken die verhalende en poëtische vormen uit verschillende tradities en/of taalgebieden met elkaar delen.

Aan de andere kant van de term 'culturele geletterdheid' hebben we tegenwoordig te maken met een veelvoud aan 'geletterdheden' die in het huidige multimediale tijdperk van elkaar worden onderscheiden. Naast de gebruikelijke termen 'geletterdheid' en 'literaire competentie'12 zijn termen als 'mediageletterdheid'13 of 'mediawijsheid' en 'digitale geletterdheid'14 in de afgelopen jaren sterk in opkomst. 'Mediawijsheid' heeft in Nederland de meest concrete uitwerking gekregen in het kader van het onderwijs. De Raad voor Cultuur definieert dit concept als volgt: "Mediawijsheid is alle kennis en vaardigheden en de mentaliteit die mensen nodig hebben om bewust, kritisch en actief mee te doen in de wereld van vandaag en morgen, waarin media een bepalende hoofdrol spelen." (2008) Vanuit het advies van de Raad ontwikkelde de Stichting Leerplan Ontwikkeling [SLO] in samenwerking met scholen een 'leerlijn mediawijsheid' op basis van begrippen als 'mediageletterdheid' en 'visuele geletterdheid"15, waarbij het begrip 'media' een smalle invulling krijgt: "Mediageletterdheid is begrijpen hoe beelden (met geluid en tekst) betekenissen krijgen en hoe die betekenissen invloed hebben op jezelf en op de groep, gemeenschap of maatschappij waarin ze voorkomen. Een leerling die mediageletterd is, kan op een kritische en actieve manier naar beelden kijken, beelden gebruiken en beelden produceren." 16 De versmalling van 'mediageletterdheid' tot de omgang met beelden is binnen de context van het onderwijs te begrijpen als een aanvulling op de al bestaande aandacht voor 'geletterdheid' als de omgang met geschreven (en gesproken) tekst. Definities van media-specifieke vormen van geletterdheid hebben met elkaar gemeen dat 'geletterdheid' wordt ingevuld als 'kennis', 'vaardigheden', 'begrijpen', 'vermogen', 'mentaliteit', 'bewustzijn', 'houding', met andere woorden: dat 'geletterdheid' steeds betrekking heeft op de formele competentie die nodig is om op de (door de bedenkers van de definities) gewenste manier met bepaalde media en inhouden om te gaan. Voor onze opvatting van ontluikende culturele geletterdheid geldt dat we de competentie die nodig is om in contact te treden met de cultuur en om cultuurinhouden te

\footnotetext{
12 "Gesproken wordt van literaire competentie als iemand de weg weet in het brede aanbod van boeken en organisaties (wegwijs raken), kennis heeft van kenmerken van literaire teksten en daarmee waardering kan ontwikkelen (tekstgerichte vaardigheden) en vervolgens die waardering beargumenteerd kan formuleren (lezersgerichte vaardigheden)." (Nicolaas, 2005, p.7)

${ }^{13}$ In 2007 voerde de Europese Commissie in de aanbeveling 'Een Europese aanpak van mediageletterdheid in een digitale omgeving' het begrip 'mediageletterdheid' ('media literacy') in. Het wordt gedefinieerd als: “The ability to access, analyse and evaluate the power of images, sounds and messages which we are now being confronted with on a daily basis and and are an important part of our contemporary culture, as well as to communicate competently in media available on a personal basis." (zoals geciteerd in Raad voor Cultuur, 2008, p. 90) Een Europese aanpak van mediageletterdheid moet volgens de Commissie betrekking hebben op alle media, van kranten tot digitale televisie tot virtuele internetgemeenschappen, en op allerlei vormen van omgang met de media, zoals consultatie, interactie, amusement, creatief gebruik en kritische reflectie.

${ }^{14}$ In het KNAW-rapport Digitale geletterdheid in het voortgezet onderwijs (KNAW, 2012) wordt digitale geletterdheid omschreven als het vermogen digitale informatie en communicatie verstandig te gebruiken en de gevolgen daarvan kritisch te beoordelen. Een digitaal geletterde moet daartoe informatie kunnen begrijpen en doelgericht kunnen gebruiken (Thijs, Fisser \& Hoeven, 2014, p. 15).

15 Zie bijvoorbeeld het lesmateriaal dat SLO ontwikkelde in relatie tot de leerlijn Mediageletterdheid (zie: http://mediageletterdheid.slo.nl/lessen/slo/). Hier wordt het leren omgaan met beelden vergeleken met het leren omgaan met taal en wordt eveneens een verdeling gemaakt in drie niveaus: beginnend, gevorderd en expert (zie: mediageletterdheid.slo.nl/leerlijn/).

${ }^{16}$ Deze definitie en de uitwerking in een leerlijn zijn terug te vinden op de website van SLO: mediageletterdheid.slo.nl/leerlijn/ (geraadpleegd op 8 januari 2015).
} 
begrijpen en te verwerven (vgl. Ghesquière, 2009a, p. 112), als voorwaarde zien voor de ontwikkeling van culturele geletterdheid, i.e. kennis en begrip van specifieke langdurig geliefde en (trans)cultureel diepgewortelde genres en tekstsoorten. De competentie waaraan ik refereer, wordt wel 'culturele competentie' genoemd, waarbij competentie een combinatie van kennis, vaardigheden en houdingen omvat (Nispen \& Stralen, 2010). Wij gaan ervan uit dat kinderliteratuur alleen effectief verworven wordt en daarmee bijdraagt aan de ontwikkeling van culturele geletterdheid bij jonge kinderen wanneer teksten aansluiten op de ontluikende culturele competentie waarover die kinderen beschikken. Geletterdheid en competentie steunen daarbij op cognitie: de wijze waarop jonge kinderen (kunnen) denken, kennen en begrijpen. De cognitieve basisvaardigheden die ten grondslag liggen aan ons denken, kennen en begrijpen, ontwikkelen zich in de kindertijd van concreet naar abstract: van waarnemen (met alle zintuigen), naar verbeelden (iets kunnen voorstellen, ook iets dat niet direct is waargenomen), naar conceptualiseren (omzetten in taal en symbolen) naar analyseren (patronen en verbanden ontdekken) (Heusden, 2010, pp. 13-16). Eenmaal verworven, blijven al deze cognitieve basisvaardigheden aanwezig en vormen ook steeds de basis voor het (metacognitieve) bewustzijn van en het denken óver hoe wij en anderen waarnemen, verbeelden, conceptualiseren en analyseren. In dit onderzoek staan kinderen van vijf tot en met acht jaar centraal, verdeeld over groep 2 (vijf- en zesjarigen) en groep 4 (zeven- en achtjarigen). Volgens de cognitieve ontwikkelingstheorie van Jean Piaget bevinden deze kinderen zich deels nog in de pre-operationele fase ${ }^{17}$ (van twee tot en met zes jaar) en deels in de concreet operationele fase ${ }^{18}$ (van zeven tot en met 11 jaar) van cognitieve ontwikkeling. De theorie van Piaget ligt ten grondslag aan veel aanvullende ontwikkelingstheorieën met betrekking tot specifieke domeinen als taalontwikkeling, humorontwikkeling, de ontwikkeling van tijdbesef en morele ontwikkeling. Al deze gebieden spelen een rol in de wijze waarop kinderen van verschillende leeftijden met teksten omgaan, hoe zij deze verwerken en begrijpen. In alle gevallen geldt echter ook dat de theorie vooral een richtlijn is. De cognitieve ontwikkeling van kinderen verloopt in de realiteit lang niet altijd vloeiend, maar fluctueert en hangt samen met specifieke ontwikkelingsgebieden (Verhulst, 2008). Daar komt bij dat de cognitieve ontwikkeling interacteert met de sociaal-culturele omgeving waarin kinderen opgroeien (Vygotsky, 1978). De fasen van Piaget zijn dus geen wet van meden en perzen, maar zeker bij jonge kinderen is het van belang te beseffen dat de ontwikkeling van hun culturele schemata niet alleen door culturele, maar deels ook door biologische ontwikkelingskenmerken wordt vormgegeven.

Samenvattend verstaan we binnen dit onderzoeksproject onder 'ontluikende culturele geletterdheid': kennis en vaardigheden met betrekking tot alomtegenwoordige formele en

\footnotetext{
17 In de pre-operationele fase, die volgens Piaget de boventoon voert in de periode van twee tot en met zes jaar, doen kinderen hun kennis van de wereld vooral op via de zintuiglijke waarneming. De 'semiotische functie' ontwikkelt zich in deze periode sterk (mentale representaties maken van objecten en gebeurtenissen), maar kinderen zijn nog heel statisch en sterk egocentrisch in hun denken en verbeelden. Ze kunnen zich nog niet goed verplaatsen in het (letterlijke of figuurlijke) standpunt van een ander, al zijn kleuters daar al wat beter in dan peuters.

${ }^{18}$ In de concreet operationele fase, vanaf een jaar of zeven (tot en met einde basisschool), speelt de waarneming nog steeds een belangrijke rol, maar kunnen kinderen in toenemende mate logisch en operationeel denken. Ze kunnen nu niet alleen voorstellingen maken in hun hoofd, maar deze ook mentaal manipuleren, hoewel hun voorstellingsvermogen nog sterk berust op (eerdere) waarnemingen. Ze kunnen zich verplaatsen in het standpunt van een ander en denken categorisch: objecten hebben categorische eigenschappen en die blijven hetzelfde ondanks bepaalde manipulaties. Logica kan alleen op concrete waarneembare of voorstelbare objecten worden toegepast, nog niet abstract of hypothetisch.
} 
inhoudelijke kenmerken van breed gedragen (transculturele en langdurig geliefde) genres en tekstsoorten. De ontluikende culturele geletterdheid waarover kinderen al beschikken vormt de voedingsbodem van waaruit die ontluikende culturele geletterdheid verder kan worden uitgebreid. In de fase van de ontluikende culturele geletterdheid gaan we er van uit dat de verwerving van culturele geletterdheid via kinderliteratuur in het bijzonder in gang wordt gezet door de inbedding van teksten in concrete contexten van tekstgebruik (de routines en rituelen uit de 'cultuur van het dagelijks leven'). Daarin hebben media, als 'the material means of expression' die wij ter beschikking hebben (Hutcheon, 2006/2013, p. 34 ), ontegenzeglijk een belangrijke plaats ${ }^{19}$. Cultuur noch enige vorm van -overdracht of verwerving kan plaatsvinden zonder media en de verscheidenheid aan media die vandaag de dag kunnen worden ingezet in deze processen is groot. Aandacht voor en onderzoek naar dergelijke ontwikkelingen is dan ook van groot belang. In het kader van dit onderzoek kijken we specifiek naar kinderliteratuur omdat teksten nog altijd een belangrijk middel voor cultuuroverdracht en -verwerving zijn en de kinderliteratuur (in print) tot nu toe het meest uitgebreide en beproefde aanbod van teksten - inclusief de tekstsoorten en genres die in dit onderzoek centraal staan - voor kinderen te bieden heeft. In zijn studie naar de leeswereld van kinderen van zeven tot vijftien jaar, 'Van woordjes naar wereldliteratuur', noemt Frank Huysmans twee centrale argumenten voor het blijvende belang van tekstuele geletterdheid in het digitale tijdperk waarin vele (audiovisuele) alternatieven voor informatieoverdracht voor handen zijn. Allereerst is er het argument van cultuurhistorici die erop wijzen "dat cultuuroverdracht in de voorbije eeuwen vooral via tekst, geschreven en gedrukt, is geschied." (2013, p. 7) Kennis van dat verleden ligt grotendeels opgeslagen in tekstuele bronnen en tekstuele geletterdheid blijft van belang om die bronnen te begrijpen. Belangrijke toevoeging is echter dat veel van de tekstsoorten die aan de basis van onze cultuur liggen niet zozeer teruggaan op geschreven of gedrukte tekst, maar op de orale volkscultuur. "Folklore is the birthplace of literature," schrijft Betsy Hearne: "Historically, oral texts preceded written, print, or electronic texts and were rooted in communal memory and performance." (2011, p. 210) De blijvende culturele waarde van genres als het sprookje, het schelmenverhaal, de fabel, het bakerlied en het nonsensrijm worden enkel bevestigd door de veelvuldige adaptatie en remediëring van deze tekstsoorten in lokale en globale media (zie ook Grijp, 1991; Kurvers, 2004).

Als tweede argument voor het blijvende belang van tekstuele geletterdheid wijst Huysmans op de vele empirische studies die uitwijzen dat een goede taalbeheersing en leesvaardigheid nog altijd belangrijke voorspellers zijn van succes in het onderwijs en later ook op de arbeidsmarkt, met als bijzondere aandachtspunten het 'Mattheüseffect' van lezen en het feit dat taalbeheersing en leesvaardigheid ook na school onderhouden moeten worden (2013, p. 7). Huysmans voegt toe: "Leesbevordering lijkt voor de periode daarna de beste resultaten te sorteren wanneer de nadruk in het onderwijs ligt op leesplezier. Een doceerstijl gericht op het bijbrengen van de literaire canon blijkt te leiden tot minder lezen in het latere leven.” (p. 7) Opnieuw kan daar een kritische kanttekening bij gemaakt worden, want de scheiding tussen leesplezier en literaire canon is afhankelijk van de canonconceptie die

19 Overigens is het van belang te realiseren dat het begrip 'media' in feite alle dragers van cultuur omvat. Niet alleen publieke media, maar ook het menselijk lichaam en allerlei (andere) alledaagse gebruiksvoorwerpen vallen daaronder (Heusden, 2010, p. 22). 
gehanteerd wordt en de wijze waarop die canon wordt aangeboden. Terecht schrijft Martijn Nicolaas in 'Wat gaat voor: literaire canon of leesplezier?': “Aandacht voor de literaire canon hoeft het leesplezier niet in de weg te staan, zolang ze samen opgaan. Sterker nog: door leesplezier vanaf jonge leeftijd te stimuleren, zullen jongeren eerder geneigd zijn kennis te maken met de literaire canon en te genieten van de boeken die ertoe behoren." (2005, p. 12) Maar wat verstaan we, gezien de hierboven geschetste dynamische en pluriforme samenleving, onder 'de literaire canon'? In onze optiek bevatten langdurig en transcultureel geliefde ('canonieke') genres, geworteld in de orale volkscultuur, cruciale kenmerken die zorgen voor nauwe aansluiting op de culturele competentie en voorkeuren van jonge kinderen. Belangrijk onderliggend uitgangspunt in dit onderzoeksproject is dan ook dat het aanbieden van 'cultureel waardevolle' tekstsoorten en het plezier dat kinderen aan dergelijke 'canonieke' teksten beleven, elkaar niet hoeven uitsluiten wanneer we uitgaan van een meer etnologische opvatting van 'canoniciteit' dan in de literaire kritiek gebruikelijk is. We willen laten zien dat een 'bottom-up' benadering van canonvorming een vruchtbare en cruciale aanvulling is op 'top-down' benaderingen waarin wordt uitgegaan van een culturele elite die vaststelt 'wat alle kinderen gelezen zouden moeten hebben'. In de multiculturele en multimediale wereld waarin we le $(\mathrm{v} / \mathrm{z}) \mathrm{en}$ is de idee van een van bovenaf vastgestelde Canon die geldig is voor de samenleving als geheel een achterhaald concept gebleken. Met een 'bottom-up' benadering geven we tegelijk gehoor aan een toenemende roep om 'pluriforme en descriptieve canonvorming'.

\subsection{Ontluikende culturele geletterdheid, kinderliteratuur en canonvorming}

De kwestie van canonvorming in een pluriforme samenleving is een centrale kwestie wanneer we het hebben over culturele geletterdheid. Zoals al uit de eerder geciteerde woorden van Wilna Meijer bleek, is het maar de vraag of we in een pluriforme en dynamische samenleving kunnen vasthouden aan "een canon, aan een gedeelde cultuur, zoals in de idee van culturele geletterdheid (met haar 'common reader') en in de idee van algemene vorming (de vorming van allen gemeenschappelijk) is voorondersteld” (Meijer, 1996, pp. 25-26). Meijer staat hierin niet alleen. Sinds de jaren 1980 is er in Nederland een toenemend besef dat cultuuroverdracht in de zin van 'ingevoerd worden in de canon' problematisch is geworden (zie o.a. Vriend, 2004; Moerbeek, 1998; Peer \& Soetaert, 1993). Het onderwijs heeft zich, al sinds de jaren 1960, ontwikkeld naar een leerlinggerichte aanpak met een grote nadruk op individuele vaardigheden en competenties; de informatiemaatschappij en nieuwe media maken dat inhoudelijke kennis steeds sneller veroudert; de onderwijspopulatie is breder en meer divers geworden (Vriend, 2004, pp. 22-23). Maar er kwam ook een tegengeluid, niet zozeer vanuit "een aanzwellende lastercampagne waarin de onwetendheid van de massa in het algemeen en de jeugd in het bijzonder, bron van ergernis en vermaak werd" (Soetaert \& Top, 1996, p. 7), zoals in het Amerika van de jaren 1980, maar vanuit een groeiende dreiging van het ontstaan van een nieuwe onderklasse in de Nederlandse samenleving. Op 29 januari 2000 verscheen in het NRC het essay 'Het multiculturele drama' van Paul Scheffer. In dat essay benadrukte hij dat de multiculturalistische houding ten 
aanzien van het toenemend aantal migranten in de Nederlandse samenleving op gespannen voet staat met het streven naar "verheffing van de verschillende bevolkingsgroepen, opdat eenieder volwaardig burger zou kunnen zijn". Een streven van waaruit in de 19de eeuw de sociale ongelijkheid in de samenleving was teruggedrongen. Waarom wordt er in diezelfde samenleving - die eerder 'zo energiek de 'sociale kwestie' van weleer te lijf ging' - nauwelijks gereageerd "op het ontstaan van een nieuwe, veel venijniger tweedeling", zo vroeg Scheffer zich af: "waarom wordt er niet in veel dwingender termen gesproken over het achterblijven van hele generaties allochtonen en over de vorming van een etnische onderklasse?" Scheffer spreekt in zijn essay van een 'multicultureel drama' dat gekenmerkt wordt door ontwikkelings- en taalachterstanden, werkloosheid, armoede, schooluitval en criminaliteit die zich 'ophopen' bij niet-Westerse etnische minderheden, in combinatie met gettovorming in de grote steden en segregatie in het onderwijs door de vorming van witte en zwarte scholen waardoor de verschillen enkel worden gereproduceerd.

"Een gemakzuchtig multiculturalisme maakt school omdat we onvoldoende onder woorden brengen wat onze samenleving bijeenhoudt. We zeggen te weinig over onze grenzen, koesteren geen verhouding tegenover het eigen verleden en bejegenen de taal op een nonchalante manier." (Scheffer, 2000, z.p.)

Volgens Scheffer leven de verschillende etnische groepen in Nederland langs elkaar heen en weten ze weinig tot niets van elkaar. Hij roept vanuit die gedachte op om de Nederlandse taal en cultuur, de liberale democratie en de geschiedenis die daaraan ten grondslag ligt, hoog op de agenda te zetten. Hij neemt niet alleen het immigratie- en integratiebeleid onder vuur. Ook "[d]e richting van het huidige onderwijs- en cultuurbeleid staat haaks op wat nodig is," schrijft Scheffer die zou willen zien dat de politieke bovenlaag opnieuw over een duidelijke beschavingsmissie zou beschikken, zoals dat in de tweede helft van de $19^{\text {de eeuw }}$ het geval was. Scheffer bereikt met zijn essay precies wat hij voor ogen had: niet alleen maakte het een breed maatschappelijk debat los, ook de politiek reageerde met een debat in de Tweede Kamer en daarmee werd de vermijding van de multiculturele vraagstukken (deels) doorbroken ${ }^{20}$. Echter, vanwege politieke verschillen van mening over of en hoe het multiculturele gestalte zou kunnen krijgen in onderwijs en samenleving, richtte het debat zich vooral op de vraagstukken van "inburgering en onderwijs in het Nederlands als tweede taal, en werd met geen woord gesproken over wat cultuurvakken als geschiedenis, aardrijkskunde, biologie of literatuuronderwijs kunnen bijdragen aan de multiculturele samenleving." (Mooren, 2001, pp. 11-12) Toch had het proces dat met Scheffers 'multiculturele drama' in gang was gezet, haar uitwerking. Zijn roep om het 'onder woorden brengen wat onze samenleving bijeen houdt', vormde voor sommigen aanleiding om opnieuw aandacht te vragen voor het belang van een Canon als richtsnoer of maatstaf voor samenleving en onderwijs. Tegelijk kon ieder initiatief ook op felle kritiek rekenen. "De canon-kritiek komt vooral voort uit de groeiende twijfel over het bestaansrecht van 'een canon van de samenleving', een lijst met boeken die ... 'functionele geldigheid heeft voor de maatschappij als geheel',"

${ }^{20}$ De NRC heeft het dossier rond Paul Scheffers essay 'Het multiculturele drama' online beschikbaar gemaakt, inclusief de vele schriftelijke reacties die op de publicatie van het essay volgden en verslagen van het tweedaagse Kamerdebat, op: http://retro.nrc.nl/W2/Lab/Multicultureel/inhoud.html 
stellen Helma van Lierop-Debrauwer en Piet Mooren vast: "Pogingen om een dergelijke canon vast te leggen, leiden keer op keer tot verhitte discussies." (2004, p. 8).

Toch gaf de Raad voor Cultuur in 2005 het advies dat er meer nadruk zou moeten komen te liggen op culturele 'kernkennis' en bepleitte het instellen van een culturelekenniscanon (2005a). Niet als 'historisch gefixeerd complex van te lezen werken', maar als "een modern, zich ontwikkelend begrippenkader van chronologische literaire, culturele en historische kennis die kan fungeren als collectief geheugen.” (2005b, p. 7) Dit advies kreeg concrete vorm in de historische Canon van Nederland, in 2006 gepresenteerd door de commissie Ontwikkeling Nederlandse Canon (de commissie Van Oostrom) en sinds 2010 opgenomen in de kerndoelen voor de midden- en bovenbouw van het basisonderwijs en de onderbouw van het voortgezet onderwijs. De presentatie van de historische Canon leidde echter tot ware 'canonitis', schrijft de redactie van Canon met de kleine c: 50 verhalen en liederen bij de Canon van Nederland: "Niet alleen werd de inhoud van de canon druk bediscussieerd, er ontstonden talloze alternatieve canons. Regionale en locale [sic] canons, de canon van de muziek, de canon van de film, de canon van de wiskunde, de religieuze canon, de sportcanon... Er was geen houden meer aan, en zo ongeveer elke potentiële doelgroep kreeg een eigen canon.”21 (Meder, Koman \& Rooijakkers, 2008, p. 6) Hieruit blijkt eens te meer dat een andere canon-conceptie zich langzaam maar zeker heeft afgetekend; een canonconceptie waarin canonvorming niet langer als enkelvoudig, inhoudelijk eenduidig en prescriptief product, maar als pluriform en descriptief groepsgebonden proces wordt voorgesteld (Moerbeek, 1998; zie ook Vriend, 2004, p. 26). Ook in het jeugdliteraire veld zijn allerlei processen van canonvorming werkzaam ${ }^{22}$, maar de stem van de doelgroep, kinderen, wordt daarin nog altijd nauwelijks gehoord. Doorgaans verloopt canonvorming in de kinder- en jeugdliteratuur, zoals dat ook bij literatuur voor volwassenen gaat, via de selectiekanalen van journalistieke, essayistische en academische kritiek die een werk tot een meesterwerk en potentiële klassieker kunnen bestempelen (Lierop-Debrauwer, 2004; Rees, 1983). Canonvorming in kinder- en jeugdliteratuur wordt daarbij altijd getekend door grote verschillen in leef- en leeservaring tussen de volwassen critici en de daadwerkelijke doelgroep (Vries, 1990). Dat dit deels leidt tot verschillende literaire voorkeuren, blijkt onder meer uit vergelijkingen van bekroningen door de volwassen jury's en bekroningen door de Kinderjury (Vries, 2003). Overigens zijn er ook overeenkomsten in door kinderjury's en volwassen jury's geselecteerde werken, maar de keuzes zijn vaak wel vanuit andere criteria

${ }^{21}$ Naast de veelheid aan groepsgebonden 'sub-canons' verscheen er "naast de voorname en een beetje deftige Canon ... de 'canon met de kleine c', waarin uitingen en erfgoed uit de alledaagse cultuur voorkomen." (Meder et al, 2008, p. 6) Die volksculturele canon bestaat uit een selectie van vijftig volksverhalen, liederen en getuigenissen uit de mondelinge overlevering en onderdeel van de dagelijkse cultuur, gekoppeld aan de vijftig vensters op de historische Canon. Het belangrijkste argument voor deze aanvulling is, zo stelt de redactie, "[dat] verhalen makkelijker in de herinnering blijven hangen dan feiten", een ervaring die tegenwoordig niet meer vanzelfsprekend wordt benut in het onderwijs (p. 6).

${ }^{22}$ Nieuwe kinder- en jeugdliteratuur wordt geselecteerd voor bespreking door recensenten in dag-, week- en maandbladen; werken en auteurs worden uitgelicht in vakbladen voor bibliotheken en het onderwijs; werken worden geselecteerd voor aankoop door bibliotheken en (kinder)boekhandels; ontwikkelingen in de jeugdliteratuur worden beschreven in professionele en academische vaktijdschriften op nationaal en internationaal niveau. Het Nederlandse jeugdliteraire veld kent haar eigen smaakmakende prijzen, zoals de Theo Thijssenprijs, de Woutertje Pieterse Prijs, de Griffels en Penselen, en haar eigen smaak-beschouwende geschiedschrijving, eerst in $D e$ hele Bibelebontse berg (1989), aangevuld met Tot volle waschdom. Bijdragen aan de geschiedenis van de kinder-en jeugdliteratuur (2000) en recentelijk opnieuw bekeken en in kaart gebracht in Een land van waan en wijs. Geschiedenis van de Nederlandse jengdliteratuur (2014). 
onderbouwd. Canonvorming in de kinder- en jeugdliteratuur heeft niet alleen te maken met verschillen in leef- en leeservaring tussen literaire kritiek en beoogde doelgroep; het heeft ook te maken met heersende kindbeelden en opvoedingsidealen. In het domein van de volwassenenliteratuur voltrok zich vanaf de tweede helft van de negentiende eeuw al een beweging van een gerichtheid op 'de emancipatie van de burger' naar een gerichtheid op 'de emancipatie van de literatuur', i.e. de autonomistische literatuuropvatting. "Dat geldt niet voor de jeugdliteratuur, waar het burgerlijk verbond tussen literatuur en opvoeding in de canon stand houdt," lezen we in het inleidend hoofdstuk op Een land van waan en wijs: "Precies die pedagogische bekommernis bepaalt de inhoud en oefent de controle uit over distributie en receptie. Op een eigenzinnige en autonome kinderliteratuur is het wachten tot de jaren 1980." (Ghesquière, Joosen \& Lierop-Debrauwer, 2014, p. 27) Anne de Vries schetste dit beeld ook (1989, 1990), maar relativeert de effecten van deze late ontwikkeling op de verhouding tussen kritiek en beoogde doelgroep: "Eigenlijk is er ... niets veranderd: alleen werd vroeger de Moraal aan kinderen opgedrongen en nu de Literatuur." (Vries, 1990, p. 68)

De gesloten cirkel van de normbepalende literaire kritiek vormt in het domein van de kinder- en jeugdliteratuur een ware, bijna onontkoombare, 'catch-22' omdat de smaak van kinderen als 'ongevormd' wordt gezien en dus niet als maatgevend. Met betrekking tot kinderpoëzie geeft Peter Hunt de mening die vele critici is toegedaan als volgt weer: "In short, when it comes to deciding what poetry is, adults are better judges, and a child's opinion does not count; after all, 'It is necessary to read a great many poems and read them attentively in order to develop a discriminating taste' (Hill, 1983: 200).” (Hunt, 2010, p. 18) Ditzelfde geldt voor de kinder- en jeugdliteratuur als geheel. Omdát kinderen een beperktere leeservaring hebben dan volwassenen, kúnnen zij geen geldig oordeel over de kwaliteit van literatuur vormen; alleen ervaren (en geschoolde) lezers kunnen dat, dus aan hen de taak om voor te schrijven wat kinderen zouden moeten lezen. Als die literatuur niet bij de doelgroep in de smaak valt, dan komt dat dus doordat de smaak van die doelgroep nog niet ontwikkeld is, zo zouden we de houding van de literaire kritiek enigszins kort-door-debocht kunnen samenvatten ${ }^{23}$. Aan de andere kant van die 'catch-22' staat de educatieve kritiek die rechtstreeks te maken heeft met de uiteenlopende interesses, talenten, ervaringen en voorkeuren van de jonge lezers. Omdat hun primaire doel leesbevordering en het stimuleren van leesplezier is, kunnen zij niet anders dan (ook) afgaan op de voorkeuren van de doelgroep. Dit heeft ertoe geleid dat in de context van het onderwijs een veelheid aan 'subcanons' is ontstaan, afgestemd op een breed en in vele opzichten gevarieerd lezerspubliek (Mooren, 2004, p. 41). Om de tekstgerichte aanpak van de literaire kritiek en de lezersgerichte aanpak van de educatieve kritiek bij elkaar te brengen, is een belangrijke rol weggelegd voor wat de 'literair-educatieve kritiek' genoemd kan worden. Idealiter, zo stelt Piet Mooren, probeert de literair-educatieve kritiek bruggen te slaan tussen de smaak van het (heterogene) publiek en die van de literaire kritiek om zo een 'derde canon' te vormen (p. 39). Daarbij heeft de literair-educatieve kritiek ook te maken met het feit dat in het onder-

\footnotetext{
${ }^{23}$ Deze hele discussie is enigszins gepolariseerd weergegeven omdat canon-discussies zich over het algemeen ook juist op de polen richten. Er zijn genoeg titels die zowel door kinderen als door volwassen critici worden gewaardeerd; er is echter bij iedere poging tot canonvorming ook een aantal titels dat de verschillen tussen volwassen beoordelaars en jeugdig publiek duidelijk maakt, volgens andere volwassen critici...
} 
wijs andere belangen en doelen spelen dan in de literaire kritiek, zoals inpassing van kinderliteratuur in de context van de schoolvakken. In de inleiding op de bundel Dat moet je gelezen bebben vragen Van Lierop-Debrauwer en Mooren zich af op welke wijze de literaireducatieve kritiek tegen die complexe achtergrond nu met de grootste kans op succes kan bijdragen aan het proces van pluriforme canonvorming. Ze stellen een model van canonvorming langs drie wegen voor, waarbij zowel lezer, context als tekst worden meegewogen. Ten eerste een route in de lengte "door canonvorming te beschouwen als de keerzijde van longitudinale literaire socialisatie"; ten tweede een route in de breedte, "door canonvorming op te vatten als latudinale [sic] literaire socialisatie door het literaire aanbod te verankeren in zoveel mogelijk schoolvakken"; ten derde een route in de diepte, "door op teksten te wijzen die als uitgangspunt dienen voor het spel van de intertekstualiteit en die deze teksten daarmee als het ware voordragen voor canonvorming." (Lierop-Debrauwer \& Mooren, 2004, pp. 12-13) Dit theoretisch model biedt een interessant uitgangspunt voor de conceptualisering van canonvorming als proces waarin aansluiting op de voorkeuren van kinderen, inbedding in het onderwijs en aansluiting op wat vanuit de literaire kritiek van belang wordt geacht, bij elkaar worden gebracht. Een dergelijk model wijst echter ook op de noodzaak van aanvullend onderzoek waarin tekstgerichte en lezersgerichte benaderingen van kinderliteratuur worden gecombineerd en waarin theoretische verwachtingen worden getoetst aan de empirische praktijk van het onderwijs.

Onderzoek naar canonvorming heeft zich veelal gericht op het in kaart brengen van top-down processen door te kijken naar de manier waarop een nieuw werk een plaats verwerft in de traditie van grote werken via de drievoudige selectie door de literaire kritiek, door na te gaan welke criteria de literaire kritiek hanteert, of door te bestuderen welke kenmerken 'grote werken' uit bepaalde perioden typeren. Hoewel dergelijke benaderingen ook binnen het domein van de kinderliteratuur van toepassing zijn en belangrijk inzicht bieden in veranderende literatuuropvattingen, wordt hiermee niet geheel verklaard waarom sommige (soorten) teksten, ongeacht die veranderende literatuuropvattingen, een vaste plaats in het cultureel erfgoed hebben verworven, zowel binnen als buiten de nationale grenzen. Ook wordt hiermee niet verklaard waarom sommige (soorten) teksten, ongeacht multimedialisering en culturele pluriformiteit, in de smaak blijven vallen bij opeenvolgende generaties van jonge kinderen. Gezien vanuit volkscultureel perspectief is canonvorming (ook) het resultaat van langdurige en breed gedragen processen van tekstoverdracht én verwerving. Inzichten in de kenmerken die een cruciale rol spelen in de langdurige en transculturele geliefdheid (i.e. 'canoniciteit') van bepaalde tekstsoorten bij jonge kinderen, vormen een cruciale aanvulling op 'top-down' benaderingen van canonvorming in de kinderliteratuur. Literatuurtheoretische en hermeneutische benaderingen kunnen inzicht bieden in vitale kenmerken van langdurig en transcultureel geliefde genres en tekstsoorten, maar inzicht krijgen in de rol die dergelijke kenmerken spelen in processen van overdracht en verwerving vraagt om empirische beproeving. Door zowel theoretisch en hermeneutisch als empirisch in kaart te brengen waar de raakvlakken liggen tussen specifieke kenmerken van langdurig en transcultureel geliefde (i.e. 'canonieke') genres en tekstsoorten en factoren die een belangrijke rol spelen in processen van tekstverwerving bij jonge kinderen, kunnen we cruciale 'indicatoren van canoniciteit' identificeren die cultureel relevante teksten en jonge 'lezers' bij elkaar brengen. Deze inzichten hebben de potentie om maatschappelijke 
instellingen die rechtstreeks moeten bemiddelen tussen literaire kritiek en reële lezers, zoals scholen en bibliotheken, te voorzien van concrete theoretisch en empirisch onderbouwde kaders voor de selectie van kinderliteratuur die effectief bijdraagt aan de ontluikende culturele geletterdheid van jonge kinderen in de pluriforme Nederlandse samenleving.

\subsection{Conclusie: een onderzoek naar de verwerving van kinderliteratuur}

Er bestaat een wijdverbreide consensus dat het van belang is jonge kinderen kennis te laten maken met teksten die hen introduceren in gedeelde uitingsvormen, maar ook in normen, waarden, kennis en gebruiken die aan de basis liggen van de culturele gemeenschap(pen) waarin ze opgroeien. Het opdoen van culturele geletterdheid maakt dan ook een belangrijk deel uit van de culturele socialisatie van kinderen in een geletterde samenleving. Niet alleen vormt brede culturele geletterdheid een noodzakelijke voorwaarde voor het duidend kunnen lezen van een grote variatie aan teksten (Heath, 1982; Dickinson \& Smith, 1994; Ghesquière, 2009a); het kan ook culturele burgerschapsvorming faciliteren. In dit hoofdstuk heb ik het brede kader uiteengezet waarbinnen we ons met dit onderzoeksproject positioneren. In verschillende debatten die onderdeel uitmaken van dat kader komt duidelijk naar voren dat het concept 'culturele geletterdheid' - en de onderliggende concepten van cultuur, van 'het culturele lezen' en culturele vorming en ook van culturele en/of literaire canonvorming - complexer en minder vanzelfsprekend is geworden onder invloed van een veelheid aan sociaal-culturele ontwikkelingen. Daarbij moet gedacht worden aan afnemende invloed van traditionele levensbeschouwelijke instituties, toenemende culturele pluriformiteit in de samenleving, de toenemende dynamiek van de huidige netwerksamenleving, en het toegenomen belang dat aan economisch nut en rendement wordt gehecht, ook op het gebied van kennis, cultuur en wetenschap (vgl. Onderwijsraad, 2011). Tegelijk zijn deze zelfde sociaal-culturele ontwikkelingen in de afgelopen jaren aanleiding geweest om cultuureducatie, brede culturele vorming en literaire canonvorming opnieuw te agenderen en de druk op het onderwijs om hier structurele vorm en inhoud aan te geven neemt toe (Onderwijsraad, 2013; Onderwijsraad \& Raad voor Cultuur, 2012; Onderwijsraad, 2011). Het aanpakken van de achterstanden van Nederlandse leerlingen op het gebied van taal en rekenen die lange tijd in internationale vergelijkingen werden waargenomen heeft haar vruchten afgeworpen, maar de eenzijdige aandacht voor de basisvaardigheden noemt de Onderwijsraad een 'verschraling van het onderwijs' ten koste van de zaakvakken, maar ook van (onder meer) burgerschapsvorming: "Meetbare doelen zijn de maatstaf geworden voor de kwaliteit van het onderwijs. De raad roept op discussie te voeren over wat het Nederlandse onderwijs leerlingen en studenten moet meegeven.” (2013, pp. 4-5)

\section{Doel van het onderzoek.}

In dit onderzoeksproject staat de bijdrage van kinderliteratuur aan de ontluikende culturele geletterdheid van kinderen in groep 2 en in groep 4 van het basisonderwijs centraal. Leesbevordering is de belangrijkste peiler waarop de inbedding van kinderliteratuur in het ba- 
sisonderwijs rust en valt in de praktijk vooral onder het taal- en leesonderwijs; structurele aandacht voor kinderliteratuur als brede toegang tot cultuur is daar geen onderdeel van. Voorwaarde voor de bijdragen die kinderliteratuur kan leveren aan de ontwikkeling van de ontluikende culturele geletterdheid van jonge kinderen is echter dat kinderen zich deze teksten eigen maken, dat ze de specifieke cultureel relevante vormen en inhouden die in die teksten samenkomen, opnemen in hun culturele schemata en hun ontluikende culturele geletterdheid op die manier uitbreiden. We weten echter nog heel weinig over hoe de verwerving van cultureel waardevolle tekstsoorten bij jonge kinderen in zijn werk gaat (Sipe, 2008), hoewel dergelijke kennis cruciaal is voor het selecteren van werken die kinderen van diverse culturele afkomst aanspreken. Het doel van dit onderzoeksproject is dan ook: De ontwikkeling van evidence-based criteria voor de selectie van kinderliteratuur die effectief bijdraagt aan de ontwikkeling van de ontluikende culturele geletterdheid van kinderen in groep 2 en groep 4 van het basisonderwijs. Daarbij vatten we (ontluikende) culturele geletterdheid op als kennis en begrip van breed gedragen (transculturele en langdurig geliefde) genres, als 'cultural frames' waarin specifieke formele en inhoudelijke tekstkenmerken samenkomen. Op basis van de in dit hoofdstuk besproken inzichten, moeten we in dit onderzoeksproject rekening houden met het feit dat tekstverwerving bij jonge kinderen steunt op een andersoortige competentie dan bij meer ervaren lezers. Jonge kinderen verwerven teksten vooral in contexten van tekstgebruik waarin ze van alles met teksten doen, zoals navertellen, zingen, dansen, of verwerken in symbolische handelingen en spel. Die contexten van tekstgebruik worden aanvankelijk gevormd door de terugkerende routines en rituelen uit de 'cultuur van het dagelijks leven' binnen het gezin, maar overlappen voor een belangrijk deel met de 'volkscultuur' als 'de brede, alledaagse cultuur, waar iedereen, elite of volk, vreemd of eigen, in participeert." (Dekker et al, 2000b, p. 10) We verwachten dan ook dat inbedding in regelmatig terugkerende routines en rituelen of vieringen makkt dat teksten effectiever worden verworven en meer worden gewaardeerd door jonge kinderen dan wanneer ze niet zijn ingebed in terugkerende contexten van tekstgebruik. Deze pragmatische contexten waarin kinderen voor het eerst kennismaken met langdurig en transcultureel geliefde (i.e. 'canonieke') tekstsoorten vormen een belangrijk onderdeel van de inwijding van jonge kinderen in 'cultuur-in-bredezin'. We moeten er wel rekening mee houden dat die contexten in de hedendaagse Nederlandse samenleving multicultureel en multireligieus zijn. Tekstverwerving bij jonge kinderen wordt naar verwachting verder gefaciliteerd door specifieke (inter)tekstuele kenmerken die enerzijds de contexten van tekstgebruik oproepen en anderzijds aanshiten op de cognitieve (biologisch en cultureel gevormde) ontwikkeling van die beoogde doelgroep. Voor de identificatie van de specifieke (inter)tekstuele kenmerken die een cruciale rol spelen in processen van tekstverwerving bij jonge kinderen, laten we ons eveneens informeren door de volkscultuur. Als we weten wat maakt dat langdurig en transcultureel geliefde genres uit de volksculturele canon, zoals het sprookje, het schelmenverhaal, de fabel, het bakerlied en het nonsensrijm, zo nauw aansluiten op de ontluikende culturele competentie en voorkeuren van jonge kinderen, dan kunnen we deze inzichten vertalen naar criteria voor de selectie van kinderliteratuur die effectief bijdraagt aan de ontwikkeling van de ontluikende culturele geletterdheid van kinderen aan het begin van het basisonderwijs. Kort samengevat gaan we er in dit onderzoeksproject van uit dat tekstverwerving bij jonge kinderen gefaciliteerd wordt door een dyna- 
misch samenspel tussen: (a) pragmatische contexten van tekstgebruik, (b) specifieke formele en inhoudelijke tekstkenmerken, en (c) de ontwikkelingskenmerken van kinderen.

\section{De opzet van het onderzoek}

In elk van de drie deelprojecten binnen dit onderzoeksproject is dit dynamisch samenspel tussen pragmatische, tekstuele en ontwikkelingsfactoren die vorm geven aan processen van tekstverwerving bij jonge kinderen onderzocht voor een selectie van tekstsoorten: in het deelproject Deugden \& Dilemma's staan fabels en verhalen uit religieuze tradities centraal, in het deelproject Kinderpoëzie staan gedichten, rijmen en liedjes centraal, en in het deelproject Narratieve Genres staan sprookjes, schelmenverhalen, griezelverhalen en moppen centraal. Voor al deze tekstsoorten is, verdeeld over de drie deelprojecten, op basis van bovengenoemd samenspel van factoren onderzocht wat de cruciale 'indicatoren van canoniciteit' zijn die ten grondslag liggen aan de langdurige en (trans)culturele geliefdheid van genoemde tekstsoorten enerzijds en aan de verwerving en waardering van genoemde tekstsoorten door kinderen in groep 2 en groep 4 van het basisonderwijs anderzijds. Omdat de pragmatische, tekstuele en ontwikkelingsfactoren die vorm geven aan processen van tekstverwerving in de fase van de ontluikende culturele geletterdheid in samenspel moeten worden bestudeerd, volstaat het niet enkel uit te gaan van theoretische inzichten en tekstuele analyses. Een adequate bestudering van het samenspel tussen de factoren vraagt om aanvulling van (literatuur)theoretische en tekstgerichte benaderingen met empirische benaderingen van de verwerving van ontluikende culturele geletterdheid via kinderliteratuur. Op basis van theoretische inzichten en hermeneutische analyses van teksten zijn daarom eerst verwachte 'indicatoren van canoniciteit' geformuleerd. Vervolgens zijn deze verwachte indicatoren gebruikt om een selectie van kinderliteratuur in een gezamenlijk interventieprogramma in groepen 2 en groepen 4 van het basisonderwijs te implementeren en zijn zowel kwantitatieve als kwalitatieve empirische methoden ${ }^{24}$ toegepast om de verwachtingen te toetsen aan de praktijk. In het interventieprogramma, het 'Leeskalenderproject' getiteld, zijn leerkrachten en kinderen aan de slag gegaan met een selectie van religieus en moreel georiënteerde verhalen, van gedichten en versjes en van verhalende genres zoals sprookjes en schelmenverhalen, gekoppeld aan de rituelen en feesten van de verschillende culturele groepen die de Nederlandse samenleving rijk is en aan alledaagse gebruiken door het jaar heen. Met deze selectie - vormgegeven als een kalender, de 'Leeskalender' - is dertig weken lang gewerkt in bestaande groepen 2 en groepen 4 van het basisonderwijs op basis van door ons ontwikkelde aanbiedings- en verwerkingsinstructies. In een experimenteel onderzoeksdesign is met een eveneens door ons ontwikkelde 'Toets Ontluikende Culturele Geletterdheid' nagegaan of het aanbod van teksten in de Leeskalender inderdaad, zoals voorondersteld werd, heeft bijgedragen aan de ontwikkeling van de culturele geletterdheid van kinderen. Bovendien is in de drie deelprojecten onderzocht hoe kinderen de betreffende tekstsoorten verwerken en verwerven, hoe ze op teksten reageren en wat ze ervan vinden. Op deze manier willen we op empirisch onderbouwde wijze criteria formuleren die de selectie van teksten voor transculturele programma's in de eerste klassen van het basison-

\footnotetext{
${ }^{24}$ Een nauwkeurige beschrijving en verantwoording van de ontwikkeling, opzet en implementatie van het interventieprogramma, inclusief de gebruikte empirische methoden, zijn te lezen in Hoofdstuk 6 en 7.
} 
derwijs kunnen sturen. Zulke programma's kunnen een belangrijke en structurele aanvulling vormen op de sterke maar relatief eenzijdige nadruk op taal en rekenen, en zijn van belang voor de ontwikkeling van de culturele geletterdheid van leerlingen als voorwaarde voor begrijpend lezen en als belangrijke bijdrage aan burgerschapsvorming in de hedendaagse pluriforme en globaliserende Nederlandse samenleving en cultuur.

\section{Het theoretisch en methodologisch kader: een interdisciplinair onderzoek}

We achten het van groot belang dat er al vanaf het begin van het basisonderwijs aandacht is voor ontluikende culturele geletterdheid. Niet alleen omdat culturele geletterdheid voorwaarde is voor het duidend kunnen lezen van een brede waaier aan tekstsoorten en genres om daarmee de culturele geletterdheid verder te ontplooien, maar ook omdat dit van groot belang is voor een brede sociaal-culturele ontwikkeling die kinderen introduceert in gedeelde uitingsvormen (genres of tekstsoorten) en gedeelde cultuurinhouden (normen, waarden, gebruiken, etc.) in de pluriforme Nederlandse samenleving. Het concept 'ontluikende culturele geletterdheid' is relatief nieuw voor het Nederlandse basisonderwijs en we weten feitelijk nog maar heel weinig over hoe kinderen verschillende genres en tekstsoorten verwerven. Daarom beoogt dit onderzoek evidence-based criteria te formuleren voor de selectie en aanbieding van kinderliteratuur die effectief bijdraagt aan de ontwikkeling van de ontluikende culturele geletterdheid van kinderen aan het begin van het basisonderwijs. Om erachter te komen welke (kenmerken van) langdurig geliefde en (trans)cultureel diepgewortelde tekstsoorten en genres een krachtige impuls geven aan de ontwikkeling van ontluikende culturele geletterdheid bij kinderen in groep 2 en in groep 4 en hoe kinderen zich deze teksten eigen maken, zijn we stapsgewijs te werk gegaan. Allereerst hebben we verwachte 'indicatoren van canoniciteit' in verschillende langdurig geliefde en (trans)cultureel diepgewortelde tekstsoorten en genres geïdentificeerd op basis van literatuuronderzoek en analyse van primaire teksten. Vervolgens hebben we teksten die gekenmerkt worden door deze indicatoren geïmplementeerd in de praktijk van het basisonderwijs. Ten slotte zijn we empirisch nagegaan of de ontluikende culturele geletterdheid, i.e. de kennis en het begrip met betrekking tot (specifieke kenmerken van) langdurig geliefde en (trans)cultureel diepgewortelde tekstsoorten en genres, van kinderen in groep 2 en in groep 4 is vergroot onder invloed van het tekstaanbod. Daarnaast zijn we in de praktijk van de schoolklas nagegaan welke factoren nu daadwerkelijk cruciaal zijn voor de verwerving van verschillende genres en tekstsoorten bij kinderen in groep 2 en in groep 4. De onderzoeksvragen die het onderzoeksproject Emergent Cultural Literacy als geheel beoogt te beantwoorden, zijn: 
PROJECTBREDE ONDERZOEKSVRAGEN

1. Welke langdurig geliefde en (trans)cultureel diepgewortelde tekstsoorten en/of genres sluiten naar verwachting nauw aan op de ontluikende culturele competentie van kinderen in groep 2 en kinderen in groep 4 ?

2. Welke contextuele, tekstuele en ontwikkelingskenmerken van deze langdurig geliefde en (trans)cultureel diepgewortelde tekstsoorten en/of genres dragen naar verwachting het meest effectief bij aan bottom-up canonvorming, i.e. 'natuurlijke' processen van tekstverwerving, bij kinderen in groep 2 en kinderen in groep 4 (verwachte 'indicatoren van canoniciteit')?

3. Wat zijn de effecten van de structurele aanbieding van teksten die gekenmerkt worden door de geformuleerde indicatoren van canoniciteit op de ontluikende culturele geletterdheid van kinderen in groep 2 en kinderen in groep 4 ?

4. Welke contextuele, tekstuele en ontwikkelingskenmerken zijn cruciaal te noemen in processen van de verwerving van langdurig geliefde en (trans)cultureel diepgewortelde genres en tekstsoorten bij kinderen in groep 2 en in groep 4 op basis van observaties, logboekaantekeningen en gesprekken met leerkrachten met betrekking tot de presentatie van het tekstaanbod in de klas, de reacties van de kinderen op deze teksten en hun waardering daarvan?

De eerste twee onderzoeksvragen hebben betrekking op de formulering van verwachte 'indicatoren van canoniciteit'; de laatste twee onderzoeksvragen hebben betrekking op de beproeving van deze verwachte 'indicatoren van canoniciteit' in de onderwijspraktijk. Zowel in de formulering als in de implementatie en beproeving van 'indicatoren van canoniciteit' in de onderwijspraktijk is dit een interdisciplinair onderzoeksproject. De gehanteerde interdisciplinaire aanpak kan als volgt worden samengevat:

INTERDISCIPLINAIR THEORETISCH EN METHODOLOGISCH KADER (projectbreed)

Beantwoording onder- Theoretisch en methodologisch kader, opgebouwd uit: zoeksvraag 1 en 2

- Literatuurtheoretische inzichten in tekstsoorten en/of genres;

- Etnologische inzichten in tekstsoorten en/of genres;

- Ontwikkelingspsychologische inzichten in de doelgroep;

- Analyse van primaire teksten.

Beantwoording onder- Methodologisch kader, opgebouwd uit: zoeksvraag 3 en 4

- Experimenteel onderzoeksdesign (voormeting/nameting en controlegroepen) voor de implementatie van het interventieprogramma;

- Ontwikkeling en gebruik van kwantitatieve en kwalitatieve instrumenten en methoden voor dataverzameling en -analyse.

Dit onderzoek draagt met deze interdisciplinaire aanpak niet alleen bij aan de ontwikkeling van bruikbare kennis voor de onderwijspraktijk, maar ook aan de ontwikkeling van een - 
nog in hoge mate innovatieve - methodologie voor empirisch onderbouwde 'bottom-up' canonvorming in de kinder- en jeugdliteratuur.

In dit proefschrift staat het deelproject Kinderpoëzie centraal dat ik in Hoofdstuk 2 introduceer. De formulering van verwachte 'indicatoren van canoniciteit' volgt in Hoofdstuk 3 $\mathrm{t} / \mathrm{m}$ 5. De ontwikkeling, opzet en uitvoering van het experimenteel onderzoek en de daarin gebruikte interventiematerialen en onderzoeksinstrumenten staan beschreven in Hoofdstuk 6 en 7. De beantwoording van onderzoeksvraag 3 volgt in Hoofdstuk 8 en de beantwoording van onderzoeksvraag 4 in Hoofdstuk 9 (groep 2) en Hoofdstuk 10 (groep 4). Hoofdstuk 11 presenteert de conclusies en discussie, en geeft aan hoe de resultaten vertaald kunnen worden naar bruikbare kennis en materialen voor het basisonderwijs. 


\section{HOOFDSTUK 2}

Kinderpoëzie: naar een pragmatische benadering 



\subsection{Introductie}

$\mathrm{Na}$ de introductie van het brede onderzoekskader voor het Emergent Cultural Literacy project als geheel in het vorige hoofdstuk, duiken we nu de wereld van de kinderpoëzie in: het deelproject dat in dit boek centraal staat. Dit deelproject heeft tot doel cruciale indicatoren van canoniciteit' in kinderpoëzie te formuleren, implementeren en beproeven in de praktijk van het basisonderwijs voor kinderen in groep 2 en groep 4. Die indicatoren van canoniciteit' moeten een nauwe aansluiting van kinderpoëzie op de ontluikende culturele competen$t_{i} e^{25}$ van de kinderen waarborgen en daarmee processen van poëzieverwerving in de schoolklas stimuleren. Die poëzieverwerving is op haar beurt onderdeel van de ontwikkeling van de ontluikende culturele geletterdheid van kinderen, hier opgevat als kennis en begrip van langdurig geliefde en (trans)cultureel diepgewortelde tekstsoorten en genres als '(trans)cultural frames' waarin specifieke vormen en inhouden samenkomen. Wanneer we weten welke kenmerken een cruciale rol spelen in de verwerving van (trans)cultureel relevante poëzie bij kinderen in groep 2 en in groep 4, dan kunnen deze inzichten gebruikt worden voor de ontwikkeling van methoden (transculturele geletterdheidsprogramma's) voor het basisonderwijs die niet zozeer gericht zijn op de basisvaardigheden taal en rekenen, maar gehoor geven aan de roep om brede cultuuroverdracht en culturele vorming in het onderwijs (zie Hoofdstuk 1). Zo ver zijn we echter nog niet: in dit hoofdstuk en de volgende hoofdstukken staat de beantwoording van onderzoeksvraag 1 en 2 centraal. Voordat ik inga op de specifieke verwachte 'indicatoren van canoniciteit' die ik voor de kinderpoëzie heb geformuleerd (Hoofdstuk $3 \mathrm{t} / \mathrm{m}$ 5), stel ik in dit hoofdstuk eerst de vraag: welke langdurig geliefde en (trans)cultureel diepgewortelde soorten poëzie sluiten naar verwachting nauw aan op de ontluikende culturele competentie van jonge kinderen? Om die vraag te beantwoorden, is het zinvol eerst stil te staan bij een aantal overwegingen. 'Kinderpoëzie' is, net als 'kinderliteratuur', een term die de nodige moeilijkheden met zich meebrengt. Zo schrijft Peter Hunt in 'Confronting the Snark: The Non-Theory of Children's Poetry':

"As a term, children's poetry offers the same problem as children's literature - it consists of two complex terms and a possessive. Children denotes a broad and highly variable construct, often bearing little relation to reality - although its use is often unavoidable. By the possessive, do we mean belonging to, written by, written for, adopted by, of childhood .... and so on. (...) Poetry is equally problematic; the judgement that something is poetry or good poetry is nothing to do with what is on the page - it is nothing do to with form: it is a cultural value-judgement, exactly equivalent to the decision as to what literature is." (Hunt, 2010, p. 20)

We zijn er nauwelijks over uit wat poëzie eigenlijk is, laat staan wat kinderpoëzie is. Omdat we hier te maken hebben met 'culturele waardeoordelen' zijn opvattingen over wat (goede)

\footnotetext{
25 'Ontluikende culturele competentie' heeft betrekking op wat kinderen aan cultuur kunnen verwerven; 'ontluikende culturele geletterdheid heeft betrekking op wat kinderen aan cultuur bebben verworven. Binnen het kader van dit onderzoeksproject bedoelen we met 'cultuur' specifieke (kenmerken van) langdurig geliefde en (trans)cultureel diepgewortelde tekstsoorten en genres (soorten kinderpoëzie binnen dit deelproject).
} 
kinderpoëzie is bovendien aan veranderingen onderhevig, net zoals opvattingen over wat (goede) (kinder)literatuur is. Toch moet daar enige helderheid in aangebracht worden binnen het kader van een onderzoek dat beoogt cruciale 'indicatoren van canoniciteit' te formuleren, implementeren en valideren voor kinderpoëzie. Waar heb ik het dan eigenlijk over? Of: wat is het cultureel waardeoordeel dat ik hanteer in mijn benadering van het construct 'kinderpoëzie'?

Om die onderliggende vraag te beantwoorden, kijk ik in dit hoofdstuk eerst naar bestaande opvattingen van wat 'poëzie' is en hoe deze zich verhouden tot opvattingen over wat 'kinderpoëzie' is, waar opvattingen van wat 'het kind' is onlosmakelijk mee verbonden zijn (\$2.3 en \$2.4). Daarna plaats ik 'het taalspel poëzie' in de context van de cultuur van het dagelijks leven van jonge kinderen om te zien wat poëzie daar eigenlijk doet (\$2.5) en vervolgens ga ik in op wat voor soort poëzie dat dan is (\$2.6). Ten slotte zet ik de benadering van kinderpoëzie uiteen die ik binnen dit onderzoek hanteer voor de identificatie van verwachte 'indicatoren van canoniciteit' $(\$ 2.7)$ en trek ik de nodige conclusies (\$2.8) die antwoord geven op de eerste onderzoeksvraag en de basis vormen voor de formulering van verwachte 'indicatoren van canoniciteit' in kinderpoëzie voor kinderen in groep 2 en groep 4.

\subsection{Opvattingen van 'poëzie': de cultuur van het innerlijk?}

$\mathrm{Nu}$ we de blik richten op poëzie voor kinderen dient de vraag zich aan: wat maakt poëzie nu eigenlijk tot poëzie of, anders gesteld, wat kenmerkt nu eigenlijk 'het poëtische'? Is dat hetzelfde voor alle poëzie, of zijn er verschillen tussen poëzie voor volwassenen en voor kinderen? De vraag wat poëzie is, of waaraan we 'het poëtische' herkennen, heeft al vele filosofen, literatuurwetenschappers en taalkundigen beziggehouden ${ }^{26}$. In den beginne, dat wil zeggen in de Griekse oudheid, makkte men onderscheid tussen epiek, dramatiek en lyriek. In epische teksten werden heldenverhalen verteld, in dramatische teksten werden conflictueuze relaties tussen personages in dialogen uiteengezet, en in lyrische teksten stonden persoonlijke gevoelsuitstortingen centraal. En dat gebeurde doorgaans allemaal op rijm: dergelijke teksten waren grotendeels toegesneden op mondelinge performance en overdracht, dus moesten goed te onthouden zijn. Deze indeling op basis van een thematisch onderscheid tussen genres of tekstsoorten gaat echter al lang niet meer op. Van recenter datum is de benadering van poëzie en het poëtische als een bijzondere manier van taalgebruik waarin betekenis tot stand komt door middel van een onalledaagse ordening van taal via allerlei stijlfiguren, zoals parallellisme, klankeffecten, enjambementen, inversies, et cetera. Echter, we kennen tegenwoordig ook vormen van poëzie waarin de formele stijlfiguren niet (structureel) aanwezig zijn, zoals in vrije versvormen die niet gebonden zijn aan metrum, rijm of regel- en strofelengte. Ondanks dat is poëzie, als globale aanduiding voor bepaalde soorten teksten, voor de meeste mensen wel duidelijk herkenbaar aan hoe het eruit ziet op papier. Bij gedichten is het de dichter die de lengte van de regels bepaalt, en niet, zoals bij proza meestal het geval is, de instellingen van een tekstverwerkingsprogramma of een drukpers. "Maar zo makkelijk als het is om poëzie te herkennen, zo moeilijk is het om poëzie te defi-

${ }^{26}$ De beknopte vogelvlucht over verschillende opvattingen van poëzie in deze eerste alinea is deels gebaseerd op 'Poëzie en de cultuur van het innerlijk' (Meijer, 1997). 
niëren of er algemene kenmerken van te bepalen," lezen we in Op poëtische wijze: Handleiding voor het ležen van poërie (Alphen, Duyvendak, Meijer \& Peperkamp, 2010/1996, p. 14).

In Op poëtische wijze stellen de auteurs dat wat poëzie poëtisch maakt, gezien moet worden als het resultaat van de specifieke communicatiesituatie waarin poëzie als poëzie functioneert. Allereerst is het in die communicatiesituatie de lezer die het 'taalspel poëzie' moet meespelen door een 'poëtische leeshouding' aan te nemen. Vanuit die poëtische leeshouding accepteert de lezer dat betekenis in poëzie anders tot stand komt dan in bijvoorbeeld verhalende of informatieve teksten: "Al poëzie-lezend volgen en analyseren we daarom hoe het vers 'gewone' referentiële betekenis ondermijnt en door middel van herhalingen van allerlei aard poëtische betekenis tot stand brengt.” (p. 9) Hoe dit in zijn werk gaat, wordt duidelijk wanneer we naar een concreet voorbeeld kijken:

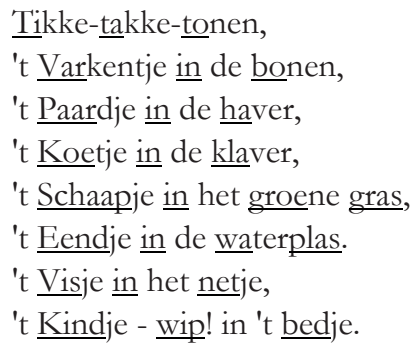

Op tekstueel niveau zien we dat dit bakerrijm (Vloten, 1874, pp. 4-5), met uitzondering van de eerste regel, bestaat uit opeenvolgende regels die allemaal dezelfde zinsstructuur hebben ('onderwerp - plaatsbepaling'). Dit wordt 'parallellisme' genoemd: een bekende poëtische stijlfiguur. De samenhang tussen de regels wordt, naast parallellisme in de opbouw, versterkt door het gebruik van gepaard eindrijm (tonen-bonen; haver-klaver; gras-plas; netjebedje) en trocheïsch trimeter als basismetrum ${ }^{27}$ dat de maat van het vers bepaalt (de beklemtoonde lettergrepen zijn in het bovenstaande voorbeeld onderstreept). We zien ook dat de regels over het schaapje en het eendje elk een extra beklemtoonde lettergreep tellen: een variatie op het metrum, de basismaat van het vers, waardoor ritme ontstaat. De equivalentie van de regels op basis van structuur en klank laat zich binnen het taalspel poëzie vertalen naar equivalentie in betekenis: de regels kunnen we opvatten als verschillende manieren om hetzelfde uit te drukken. We begrijpen de tekst bijvoorbeeld als: 'Zoals 't varkentje in de bonen hoort, / zoals 't paardje in de haver hoort,/ zoals 't koetje in de klaver hoort, / et cetera,/ Zo hoort 't kindje in het bedje.' Er is dus sprake van betekenisoverdracht tussen de regels waardoor een 'surplus aan betekenis' ontstaat omdat elke regel tegelijk de betekenis van alle regels draagt (vgl. Bronzwaer, 1993, p. 14). Elke regel staat dan voor iets groters dan alleen de eigen mededeling: 't varkentje in de bonen staat voor het idee dat alle dieren en ook het kindje een aangewezen plaats hebben, ergens thuishoren. Zoals Maaike Meijer heeft geschreven over dit vers: “Alle dieren krijgen hun plek en hun juiste voedsel,

\footnotetext{
${ }^{27}$ Met metrum wordt de specifieke afwisseling tussen beklemtoonde en onbeklemtoonde lettergrepen in de regels van een gedicht bedoeld. Of, in de nauwkeurige definitie: “... een regelmatige afwisseling van beklemtoonde en onbeklemtoonde posities in een begrensde structuur, die onderverdeeld is in perioden welke elk afzonderlijk ook een regelmatige afwisseling van beklemtoonde en onbeklemtoonde posities bezitten." (Bronzwaer, 1993, p. 53)
} 
het kindje gaat naar bed. Zo wordt dat naar bed gaan ingevoegd in een natuurlijke en maatschappelijke orde." (Meijer, 1997, p. 152)

Vanuit een poëtische leeshouding accepteert de lezer de omslachtige manier waarop poëtisch taalgebruik betekenis tot stand kan brengen en verwacht dat juist de elementen die afwijken van ons alledaags taalgebruik betekenisvol zijn. De 'poëtische functie' van taal, zoals Roman Jakobson dit aspect vanuit taalkundig perspectief aanduidt, komt naar voren wanneer in het gebruik van taal de aandacht primair op de vorm en vormgeving van de boodschap zelf is gericht (1987, p. 69). Deze, in referentieel opzicht, 'redundante' manier van communiceren is een belangrijk kenmerk van poëzie, maar die poëtische functie is niet exclusief voorbehouden aan gedichten en in gedichten kunnen ook andere functies van taal ${ }^{28}$ een rol spelen. De poëtische functie van taal staat in poëzie doorgaans wel op de voorgrond, maar is strikt genomen niet toereikend om poëzie, als literair genre of als tekstsoort, af te bakenen van andere genres en vormen van taalgebruik waarin de poëtische functie van taal evengoed aanwezig kan zijn. Om 'het poëtische' af te bakenen is meer nodig dan alleen een bijzondere vormgeving van de tekst en het als betekenisvol interpreteren van het onalledaagse taalgebruik door de lezer. In Op poëtische wijze wijzen de auteurs er daarom op dat in de poëtische communicatiesituatie ook een bijzondere spreekhouding van de woordvoerder in de tekst kenmerkend is. De woordvoerder die de poëtische communicatiesituatie typeert, stellen ze, is het lyrisch subject of 'lyrisch ik'. In tegenstelling tot een narratieve woordvoerder die tot de lezer spreekt, de lezer iets vertelt en hem ergens deelgenoot van makkt, is de poëtische woordvoerder een spreker die van de lezer afgekeerd is. Het 'lyrisch ik' creëert al 'sprekend' (in de tekst) een ik-jij relatie met een object, idee, of afwezige ander ${ }^{29}$. Deze poëtische taalsituatie, die typerend is voor veel literaire gedichten voor volwassenen, maar ook voor veel liederen - van de middeleeuwen tot en met de hedendaagse popmuziek -, sluit de lezer als het ware buiten. De lezer mag meeluisteren, of afluisteren, met het 'lyrisch ik' die in een intieme monoloog de eigen gevoelens of gedachten tot uiting brengt in relatie tot iets of iemand anders (Alphen et al, 2010/1996, p. 10). Dit maakt dat we het poëtische kunnen identificeren als ".. de culturele vorm die onze cultuur heeft gereserveerd voor de exploratie van het innerlijk leven,” stelt Maaike Meijer (1997, p. 144) Daarbij wijzen de auteurs er wel op dat de poëtische communicatiesituatie, 'het poëtische', niet exclusief is voorbehouden aan wat we herkennen als poëzie, net zoals

\footnotetext{
${ }^{28}$ In Lessen in lyriek vat Bronzwaer de overige functies van taal, zoals onderscheiden door Roman Jakobson, als volgt samen:

“... ze is expressief in zoverre ze iets tot uiting wil brengen dat de spreker of schrijver 'kwijt wil'; ze is referentieel in zoverre ze iets over de wereld meedeelt; ze is conatief in zoverre ze zich altijd tot een hoorder of lezer richt; ze is fatisch in zoverre ze altijd een kanaal (geluidsgolven bij het spreken bijvoorbeeld) nodig heeft om het contact tot stand te brengen tussen degene die de uiting voortbrengt en degene die haar ontvangt; ze is ten slotte metalinguaal in zoverre ze zich over zichzelf kan uitlaten ...." (Bronzwaer, 1993, p. 32)

Het bakerrijm 'Tikke-takke-tonen' is ontegenzeglijk poëtisch opgebouwd, maar is tegelijk ook expressief omdat het een wens of doel tot uitdrukking brengt van degene die het zegt of zingt, het is referentieel omdat het mededelingen doet over de dieren en hun slaapplek en voedsel en over het kindje, het is fatisch omdat het gezegd of gezongen moet worden om contact tussen bijvoorbeeld een moeder en haar nog onmondig kind tot stand te brengen.

${ }^{29}$ De meest expliciete vorm van deze communicatiesituatie in de tekst is de apostrof of aanspreking, vaak gemarkeerd door het gebruik van 'o' als aanroep, zoals in 'O dennenboom, o dennenboom'.
} 
de narratieve communicatiesituatie niet beperkt is tot wat we herkennen als proza (Alphen et al, 2010/1996, p. 10).

In kinderpoëzie uit de afgelopen decennia is het lyrisch subject in toenemende mate aanwezig. De introductie van de innerlijke wereld van het kind in de kinderpoëzie plaatst Jan Van Coillie in de jaren 1970 met het verschijnen van, onder meer, de bundel Dat overkomt iedereen wel van Willem Wilmink (Van Coillie, 1982, p. 88). Zagen we het van de lezer afgewende lyrisch subject bij Annie M.G. Schmidt slechts bij hoge uitzondering, in 'Ik ben lekker stout' (Ziezo, p. 166) en 'Zomeravond' (Zięo, p. 200), bij dichters als Willem Wilmink, Ted van Lieshout, Ienne Biemans, Edward van de Vendel, Hans en Monique Hagen, Nannie Kuiper en Hans Kuyper is het steeds vaker een lyrisch 'ik' dat de eigen innerlijke gedachten en gevoelens in relatie tot een ander (niet de lezer) tot uiting brengt. Dat gebeurt bijvoorbeeld op heel basaal niveau al in het gedicht 'Ik en jij' van Hans en Monique Hagen: "ik ben ik/ en jij bent jij// als ik jou was/ was jij mij// we wassen samen/ in het bad// ik was droog/ en jij was nat" (Hagen \& Hagen, 2007). Naast dat hier een subtiel spel gespeeld wordt met de dubbele betekenis van 'was', wordt er ook een ik-jij relatie geëxploreerd waar de lezer buiten staat, hoewel in dit gedicht nog heel concreet. Ted van Lieshout heeft veel gedichten voor jongeren geschreven waarin de lezer eveneens 'luistervink' speelt en al duidelijk een exploratie van het innerlijk leven centraal staat, zoals in 'Ik dek onze tafel': "Ik dek onze tafel/ met stilte, schuif/ voor de ramen// het donker dicht/ en ik denk niet/ dat je thuiskomt// om te eten, te slapen,/ te zeggen dat je ons/ verlaat. Blijf maar// weg en doe dat/ zo stil dat zelfs/ je naam niet valt." (Lieshout, 2005) Kijken we echter naar baker- en kinderrijmen, zoals 'Tikke-takke-tonen', dan blijkt dat daarin wel alle formele stijlfiguren voorkomen die doorgaans met poëzie worden geassocieerd - rijm, metrum, parallellisme en alle andere vormen van herhaling -, maar dat de hierboven beschreven van de lezer afgewende spreekhouding van een lyrisch subject als tekstaspect ontbreekt. In traditionele baker- en kinderrijmen wordt vooral over het kind gesproken ('Toen 't kindje op de wereld kwam'), wordt het kind direct aangesproken ('Klap eens in je handjes'), wordt het aangesproken kind in een rol geplaatst ('Zeg, Roodkapje, waar je henen?'), of wordt het een klein verhaaltje verteld ('Daar zaten zeven kikkertjes al in een boerensloot'), maar: "[k]inderliederen zijn nooit monologische teksten, met de rug naar de lezer toe," stelt Meijer vast (Meijer, 1997, p. 156). Hoewel het bakerrijm en kinderlied kinderen een basis aan 'poëtische socialisatie' meegeven in de kennismaking met het poëtisch taalspel in klank, in herhalingen en metaforen, aldus Meijer, is de spreekhouding van de woordvoerder in die teksten eerder narratief dan poëtisch. De exploratie van het innerlijk leven door mee te luisteren met of als het ware in de schoenen te stappen van een 'lyrisch ik' komt pas later in de ontwikkeling, zo rond de puberteit, stelt ze (p. 156).

"Das Thema der Kinderlyrik ist die Welt," lezen we nog bij Ruth Lorbe (1984, p. 200) en Jan Van Coillie voegde daar in zijn overzichtsstudie van dertig jaar kinderpoëzie (19501980) begin jaren 1980 aan toe: "Het is dan ook vooral de omgeving rondom het kind die in de kinderpoëzie primeert. Kinderverzen hebben een hoofdzakelijk extravert karakter." (1982, p. 21) Samen met de verschuiving naar een autonome literatuuropvatting in de kinder- en jeugdliteraire kritiek die vooral vanaf de jaren 1980 haar intrede deed, zien we dus een 'verinnerlijking' van de kinderpoëzie die er voor die tijd nog niet was. Kijken we naar de volksculturele kinderrijmen en -liedjes, dan lijkt het er echter sterk op dat de kindertijd 
wordt gekenmerkt door een overheersende behoefte aan verhalen, of 'het verhalende', zoals ook invloedrijke theorieën over de literair-esthetische ontwikkeling van jonge kinderen suggereren (Bühler \& Bilz, 1977, 1922; Schliebe-Lippert, 1950; zie ook Mooren, 2000a). In ieder geval door een overheersende behoefte aan kennismaking met de buitenwereld. "In die zin is er zeker sprake van 'stadia in geletterdheid'," schrijft Meijer: "de kinderliedjes zijn er voor de intrede in de sociale orde, om de taal te leren, het eigen lichaam te verkennen, je te oriënteren op de regels van de buitenwereld. Pas als je dat allemaal hebt gehad is de binnenwereld aan de beurt, en het hebben van emoties en een individuele denken verbeeldingskracht wordt dan voorgedaan in het lyrische, in poëzie." (1997, pp. 156157) Annie M.G. Schmidt schreef niet voor niets: "Dit is het begin van alle literatuur: Zagen zagen, wiedewiedewagen... Misschien mag het ook zijn: Schuitje Varen, Theetje Drinken..., maar de bakerrijmpjes zijn het begin. Het onontbeerlijke begin." (1954, p. 32, cursief $\mathrm{AdB}$ ) En ook Bregje Boonstra stelde dat de aloude bakerrijmen ervoor zorgen dat bij jonge kinderen "... al spelend, zingend en wiegend de smaakpapillen voor de literatuur ontwikkeld raken.” (1989, cursief AdB) Niet specifiek de smaakpapillen voor poëzie of 'het poëtische' dus, maar voor de literatuur in het algemeen. Dit roept de vraag op wat kinderpoëzie dan precies is.

\subsection{Opvattingen van 'kinderpoëzie': bestaat er wel zo iets als kinderpoëzie?}

In De hele Bibelebontse berg: De geschiedenis van het kinderboek in Nederland \& Vlaanderen van de Middeleeuwen tot heden is het eerste dat we over kinderpoëzie lezen:

"Bestaat er eigenlijk wel zo iets als kinderpoëzie, met de nadruk op poëzie? Is er niet alleen maar poëzie, even begrijpelijk (of onbegrijpelijk, in de zin van mysterieus) voor kinderen als voor volwassenen? Is het niet zo, dat gedichten voor kinderen meestal als 'versjes' betiteld worden en niet als poëzie?” (Bekkering, 1989, p. 341)

Deze vraag, of er wel zoiets als kinderpoëzie bestaat, is direct gerelateerd aan de literatuurof poëzieopvatting waarmee kinderpoëzie vanaf de jaren 1970 en vooral sinds 1980 in de jeugdliteraire kritiek benaderd wordt, met de maatstaven van een autonome literatuuropvatting "waarin het gaat om een abstracte Literaire Waarde" (Vries, 1990, p. 65). Het ideaal van de emancipatie van de kinderliteratuur dat hieraan ten grondslag lag, betekende in de context van de jaren 1980 concreet dat kinderliteratuur volgens de jeugdliteraire kritiek moest worden losgemaakt van pedagogische perspectieven die op dat moment overheersten en moest worden gezien en beoordeeld als kunst, als Literatuur (zie ook Ghesquière, Joosen \& Lierop-Debrauwer, 2014, p. 27). Voor de kinderpoëzie heeft dit tot gevolg gehad dat er, zoals de tweede vraag in het citaat van Bekkering impliceert, in de kritiek vaak maar een soort poëzie wordt erkend op basis van de literaire eisen van volwassen critici: 'poëzie die even begrijpelijk of onbegrijpelijk is voor kinderen als voor volwassenen'. In de meest recente 'geschiedenis van de Nederlandse jeugdliteratuur', Een land van waan en wijs, schrijft ook Jan Van Coillie in het hoofdstuk over kinderpoëzie: "Na 1980 kwam het esthetische op 
de voorgrond, vanuit een poëtica die een andere kijk op de werkelijkheid wilde bieden. Het was dezelfde visie die centraal stond in de poëzie voor volwassenen en daardoor werd de kloof met de kinderpoëzie kleiner." (2014, p. 246) Een kloof tussen poëzie voor volwassenen en voor kinderen, overigens, die volgens Van Coillie pas eind 19de eeuw was ontstaan. Voor die tijd werd poëzie voor kinderen meestal geschreven vanuit "een rationalistisch, verlicht kindbeeld, dat van kinderen goede burgers wilde maken" en dat was bij poëzie voor volwassenen al niet anders (p. 246). Toen rond 1850 het romantisch kindbeeld in opkomst kwam en in kinderpoëzie - nog altijd vanuit een opvoedende strekking - het geromantiseerde (lieflijke, onschuldige en spelende) kind centraal kwam te staan, een kind dat als zodanig beschermd en gekoesterd moest worden, begonnen poëzie voor kinderen en voor volwassenen uit elkaar te groeien. Dat gebeurde mede onder invloed van bewegingen in de poëzie voor volwassenen als de Tachtigers die niets moesten hebben van de pedagogische moraal of van poëzie gericht op kinderen. Na de Tweede Wereldoorlog ${ }^{30}$ verdween de romantische idealisering van het onschuldige en natuurlijke kind grotendeels uit de kinderpoëzie, en ook de pedagogische moraal: dichters kozen de leef- en belevingswereld van het kind als uitgangspunt, gaven kinderen een eigen stem, eerst door veel humor en fantasie ('50-'80) en vervolgens ook door eigen gedachten en gevoelens ('80-heden). Het kind in de poëzie kreeg een eigen 'binnenwereld'. De kloof met de poëzie voor volwassenen bleef tot de jaren 1980 bestaan, schrijft Van Coillie, waarna de twee domeinen weer nader tot elkaar kwamen, nu vanuit een gedeelde esthetische poëtica: "Meer dichters dan voorheen publiceerden voor beide doelgroepen. De gedichten hadden een vrijere vorm en een complexere beeldspraak. Centrale thema's uit de poëzie voor volwassenen, zoals tijd, vergankelijkheid en veranderlijkheid, drongen binnen in de kinderpoëzie, eerst voor tieners, daarna voor jongere kinderen en kleuters." (pp. 246-247)

In lijn met deze ontwikkeling stellen steeds meer hedendaagse dichters van (kinder)poëzie dat zij niet specifiek voor kinderen, maar primair voor zichzelf schrijven. Claire Polders wijst op de geïmpliceerde consequentie van de autonome poëzieopvatting die door de jeugdliteraire kritiek gehanteerd wordt: "Gedichten die speciaal voor kinderen geschreven zijn, zouden dan geen poëzie, maar eenvoudige versjes zijn.” (1997, p. 248) En zo komen we terug bij de vraag die Bekkering stelde: "Bestaat er eigenlijk wel zo iets als kinderpoëzie, met de nadruk op poëzie?” (1989, p. 341) De internationale kinderpoëziekritiek draait in dezelfde vicieuze cirkel rond, hoewel er steeds meer critici zijn die zich daar ongemakkelijk bij beginnen te voelen (zie Thomas, 2004; Hunt, 2010; Coats, 2013). "It is an uncomfortable - possibly blasphemous - thought that very many people fundamentally do not believe that children's poetry exists," schrijft Peter Hunt (2010, p. 17). Hij koppelt dit aan het feit dat keer op keer wordt vastgesteld dat kinderpoëzie niet is wat 'echte' poëzie, althans vanaf de Romantiek, volgens de literatuurkritiek wel is. Kinderpoëzie is daarmee een negatieve categorie geworden, een vorm van niet-poëzie. Hoewel deze opvatting retorisch

\footnotetext{
${ }^{30}$ Het mag duidelijk zijn dat ik hier met zevenmijlslaarzen door de kinderpoëzie-geschiedenis ga: het is niet zo dat kinderpoëzie in de periode tussen het einde van de $19^{\text {de }}$ eeuw en de Tweede Wereldoorlog van hetzelfde laken een pak is. Er is in die periode bij sommige dichters al een verandering zichtbaar die de weg bereidt voor de postWOII periode. Echter, een indeling van de literatuurgeschiedenis is noodzakelijkerwijze gebaseerd op een zekere simplificering en dat is voor de kinderliteratuur en daarbinnen de kinderpoëzie al niet anders. Het is hier ook niet mijn bedoeling een nauwkeurige beschrijving van de ontwikkelingen in de kinderpoëzie(beschouwing) te geven: alleen de belangrijkste 'omslagpunten' zijn hier relevant.
} 
gezien waarneembaar is in de (inter)nationale kinderpoëziekritiek, is de praktijk minder eenduidig, want er was en is nog altijd poëzie die speciaal voor kinderen wordt geschreven en uitgegeven en die als zodanig ook door de kinder- en jeugdliteraire kritiek wordt gewaardeerd en bekroond. Het gaat er vooral om dat in die waarderingen en bekroningen de relatie tot de beoogde doelgroep - 'het kind' - niet langer als beoordelingscriterium wordt meegewogen, maar alleen de esthetische 'criteria' zoals die ook aan de literaire poëzie voor volwassenen worden opgelegd. Zo is het label 'poëzie zonder leeftijd' binnen de kinderpoezie-kritiek tot motto verheven en bevatten succesvolle bloemlezingen als Als je goed om je heen kijkt zie je dat alles gekleurd is (Buul \& Stigter, 2006/1990) 'gedichten voor kinderen van alle leeftijden'. Dat zijn gedichten die voor kinderen geschreven zijn en ook door volwassenen (kunnen) worden gewaardeerd en gedichten die voor volwassenen geschreven zijn en ook door kinderen (kunnen) worden gewaardeerd. Tegelijk zien we dat verschillende critici - Kees Fens, Bregje Boonstra, Anne de Vries - de blik ook richtten op dat andere grensvlak van de kinderpoëzie: de rijmen en liedjes uit het volksculturele domein waar alle poëzie van oudsher 'poëzie zonder leeftijd' was (zie o.a. Bekkering, 1989, p. 342). Al doen ze dat vaak vanuit hun volwassen lees- en leefervaring juist vanwege de 'abstracte Literaire Waarde' die ze in dit volksculturele materiaal herkennen ${ }^{31}$. In ieder geval lijken beide strategieën - zowel de verkenning van de grens met de literaire poëzie voor volwassenen als de verkenning van de grens met de orale poëzie uit het volksculturele domein - erop gericht de waardering van kinderpoëzie te bevrijden van 'het juk' van de beoogde doelgroep.

Als we kijken naar de context van het basisonderwijs, waar men toch niet aan de doelgroep van kinderen kan ontkomen, dan blijkt de inbedding van kinderpoëzie in de onderwijspraktijk niet zo vanzelfsprekend. Het nationaal expertisecentrum SLO schrijft over kinderpoëzie in hun lexicon voor het primair onderwijs:

"De drempel voor het lezen van poëzie met kinderen, blijft in het basisonderwijs hoog. In de kleutergroepen wordt vaak wel regelmatig gewerkt met rijmpjes en (opzeg-)versjes, maar in hogere groepen komen gedichten meestal alleen aan de orde als ze in de taalmethode zijn opgenomen en dan nog betreft het hier vaak niet de favoriete lessen van leerkrachten.” (SLO, online lexicon, lemma 'kinderpoëzie')

Het beeld dat uit deze beschrijving naar voren komt, is dat poëzie in het basisonderwijs het sterkst is ingebed in de kleutergroepen ${ }^{32}$. Daar, in de onderbouw, gaat het dan vooral om

\footnotetext{
31 Bloemlezingen als Goedemorgen, welterusten van Kees Fens (vanaf 1975), Ik geef je niet voor een kaperschip met tweehonderd witte zeilen van Tine van Buul en Bianca Stigter (vanaf 1993), Voor de kleine Poppedeine en de grote Bimbam van Anne de Vries jr. (2002), De Nederlandse kinderpoëzie in 1000 en enige gedichten van Gerrit Komrij (vanaf 2007 meerdere malen herdrukt), en populaire uitgaven van kinderliedjes als Liedjes met een boepeltje erom van Joke Linders en Toin Duijx (vanaf 1994 vele malen herdrukt) en Een mandje vol amandelen van Mien Stam-van der Staay (vanaf 2003 vele malen herdrukt) putten allemaal volledig of deels uit de bronnen van de mondelinge overlevering. Alhoewel, om nauwkeuriger te zijn, moet ik stellen dat voor de selectie van baker- en kinderrijmen in genoemde bloemlezingen niet zozeer uit de mondelinge overlevering is geput, maar uit vroege uitgaven van verzamelingen van baker- en kinderrijmen en dan met name Van Vlotens Nederlandsche baker-en kinderrijmen (vanaf 1871 vele malen herdrukt) en Abramsz' Rijmpjes en versjes uit de oude doos (vanaf 1910 vele malen herdrukt).

32 SLO stelt wel dat het om allerlei redenen belangrijk is om op school met poëzie te werken. Veel in aanraking komen met rijm stimuleert de fonologische ontwikkeling van jonge kinderen; een belangrijke graadmeter voor latere leesvaardigheid (zie ook Bryant en Bradley, 1989; Bryant et al, 1990). Dagelijks voorlezen van een gedicht leert kinderen woordstructuren herkennen die hetzelfde klinken en het stimuleert kinderen om zelf rijm te gaan
} 
het gebruik van oude en nieuwe kinderrijmen en -liedjes, of 'opzegversjes' zoals ze in het lexicon van SLO worden aangeduid ${ }^{33}$. Daarbij wordt opgemerkt dat niet alle poëzie geschikt is als opzegvers: "De versjes moeten niet te lang zijn en een duidelijke structuur hebben. Ook moeten ze aansluiten op de belevingswereld van kinderen." (SLO, online lexicon, lemma 'opzegversjes') Er wordt echter niet nader ingegaan op de aansluiting op de belevingswereld van kinderen; wel wordt gesteld dat opzegversjes te vinden zijn in taalmethodes en programma's voor kleuters en dat onder leerkrachten van de kleuterklassen vaak allerlei versjes in omloop zijn. Dit type (gebruik van) poëzie in kleutergroepen sluit aan op de situatie in kinderdagverblijven en peuterspeelzalen, waar een sterke traditie bestaat in het gebruik van rijmen en liedjes, vaak rechtstreeks gekoppeld aan speciale gelegenheden als vieringen en aan speelse en routinematige activiteiten als springen, dansen, lopen, handen wassen en knutselen (Weterings, 2004). Na de voor- en vroegschoolse fase, wanneer kinderen 'Zagen zagen, wiedewiedewagen' ontgroeid zijn, lijkt het er echter sterk op dat de poëtische smaakpapillen van kinderen steeds minder structureel gevoed worden in het onderwijs. Als er al aan poëzie gedaan wordt, dan is dat veelal het zelf schrijven van gedichten door kinderen, mede gestimuleerd door de jaarlijks georganiseerde landelijke dichtwedstrijden 'Kinderen \& Poëzie' (6 t/m 12 jaar) en 'Doe maar dicht maar' (12 t/m 18 jaar) van Stichting Poëziepaleis. De jaarlijkse Poëzieweek, ingeleid met de nationale Gedichtendag, stimuleert het werken met poëzie in basis-, voortgezet en secundair onderwijs met uitgewerkte poëzielessen (door Stichting Lezen Vlaanderen \& Nederland en Stichting Collectieve Propaganda van het Nederlandse Boek). Handleidingen voor het werken met poëzie in het (basis)onderwijs zijn er ook (onder meer Mooren \& Kurvers, 2012; Kemmeren, Markesteijn \& Verhallen, 2001; Van Coillie, 1999; Eerhart, 1998; Vos, 1996). Toch stokt de potentiële doorlopende leeslijn voor poëzie in het basisonderwijs vaak na 'schuitje varen'34: pas op de middelbare school heeft poëzie lezen weer een vaste plaats als onderdeel van het

produceren. Door te werken met poëzie maken kinderen kennis met beeldspraak en symboliek en leren ze dat je gedachten en gevoelens op allerlei manieren kunt uitdrukken. Al snel wordt een overgang gemaakt van poëzie lezen naar zelf poëzie schrijven: bestaande gedichten kunnen als uitgangspunt worden genomen om kinderen vervolgens zelf een gedicht te laten maken, bijvoorbeeld door te associëren op een begrip uit een gedicht, of door gebruik te maken van de standaardvorm van een gedicht, zoals een 'elfje' (SLO, online lexicon, lemma 'kinderpoezie').

33 Opzegversjes worden gedefinieerd als 'korte versjes die met name in de onderbouw worden gebruikt om hardop op te zeggen door de kinderen'. Deze versjes zijn vaak gekoppeld aan speciale gelegenheden als Moederdag, Vaderdag, Sinterklaas, Kerstmis, et cetera, maar er wordt aan toegevoegd dat kleuters korte opzegversjes ook vaak leren omdat ze toevallig bij een thema passen of 'zomaar tussendoor' (SLO online lexicon, lemma 'opzegversjes').

${ }^{34}$ Het is niet zo dat poëzie volledig afwezig is in de bestaande leerlijnen voor het basisonderwijs, maar het genre heeft nauwelijks een eigen plaats. Zo omvat Kerndoel 9 ('De leerlingen krijgen plezier in het lezen en schrijven van voor hen bestemde verhalen, gedichten en informatieve teksten') van de leerlijn Nederlands in het aanbod voor groep 1/2 nog expliciet 'boeken met rijmpjes, versjes, dichtbundels', maar lezen we bij groep $3 / 4$ onder de doelstellingen van 'plezier in lezen': "belangstelling voor verhalende (waaronder poëzie) en informatieve teksten" (TULE, leerlijn Nederlands). Hier wordt alleen nog een grove scheiding gemaakt tussen verhalende en informatieve teksten en wordt poëzie dus onder de eerste categorie geschoven. In 2014 schreef Nina Wassink haar Masterscriptie Poëzie en taal in het basisonderwijs aan de Rijksuniversiteit Groningen over de verbinding tussen poëzieonderwijs en taalvaardigheidsonderwijs op de basisschool. Daarin analyseerde ze twee taalmethoden op de plaats die poëzie daarin inneemt, hield ze interviews met leerkrachten en deskundigen en zette een enquete uit onder leerkrachten uit de database van Stichting Poëziepaleis. Zij concludeerde onder meer dat poëzie af en toe in taalmethoden voorkomt en soms onderdeel is van taallessen, maar dat leerkrachten grote behoefte hebben aan lesvoorbeelden, -ideeën en -suggesties voor het werken met poëzie. 
literatuuronderwijs $\mathrm{s}^{35}$. Voor de overbrugging van de voor- en vroegschoolse periode tot aan het voortgezet onderwijs komt het gebruik van poëzie voor kinderen in het basisonderwijs, als we SLO mogen geloven, aan op de gebruikte taal- en leesmethode en de houding van de leerkracht. Tegelijk heeft het genre het in algemene zin moeilijk in een vercommercialiseerde, jachtige wereld', schrijft Van Coillie: "Enkele bundels (vooral voor kleuters) halen weliswaar enorme oplagen, maar het aantal bundels daalt en er verschijnen nauwelijks nog debuten.” (2014, p. 247) Van Coillie betitelt de kinderpoëzie in de laatste paragraaf van zijn historisch overzicht dan ook als 'Een bedreigde soort'.

In de meest recente jeugdliteratuurgeschiedenis van 2014 lezen we dat kinderpoëzie je dwingt "om stil te staan, om in je hoofd te kijken en van daaruit de wereld anders te zien" (p. 247). Deze karakterisering weerspiegelt de poëzieopvatting zoals gehanteerd in de hedendaagse (jeugd)literaire kritiek en laat duidelijk de verandering in de heersende poëtica zien ten opzichte van dertig jaar eerder. Begin jaren 1980 werd aan de kinderpoëzie tot dan toe nog een hoofdzakelijk extravert karakter toegedicht waarin de omgeving rondom het kind primeert (Van Coillie, 1982, p. 21). Zijn kinderen in dertig jaar tijd zo sterk veranderd? De kinderpoëzie? Of alleen het discours rond kinderen en poëzie? In een tijd waarin de jeugdliteraire kritiek veelal vanuit literaire waardeoordelen haar stempel op nieuwe werken drukt, kan er nog wel eens sprake zijn van 'kortsluiting' of zelfs een 'ongezonde discrepantie' tussen wat door volwassenen enerzijds en door kinderen zelf anderzijds wordt gewaardeerd in de kinder- en jeugdliteratuur, waarschuwde Rita Ghesquière (2009a, p. 137). Maar was dat niet zo toen de pedagogische waardeoordelen overheersten? In internationaal perspectief stelt Karen Coats vast:

"The problem is that, due to muddled and often contradictory perspectives about who we want children to be, do, and mean, and what we want poetry to be, do, and mean, we don't yet have a clear understanding of what children's poetry is, does, and means." (Coats, 2013, p. 132)

Zij stelt zelfs dat literaire interpretatie, vanuit de leesconventies waar ervaren lezers in gesocialiseerd zijn, in zichzelf een uitwissen van de ware betekenis van kinderpoëzie is (p. 133). De vraag is dan welk perspectief nodig is om poëzie voor kinderen op waarde te kunnen schatten. De eerste uitingen van ongemakkelijkheid en verwarring in de internationale kinderpoëziekritiek wijzen erop dat ook hier behoefte begint te ontstaan aan een nieuwe 'canon-conceptie': een canon-conceptie waarin canonvorming niet langer als enkelvoudig, inhoudelijk eenduidig en prescriptief, maar als een pluriform en descriptief groepsgebonden proces wordt voorgesteld (vgl. Moerbeek, 1998; zie ook Vriend, 2004, p. 26). Als we willen weten wat kinderen in poëzie aanspreekt, dan zijn vragen als 'Bestaat er eigenlijk wel zo iets als kinderpoëzie, met de nadruk op poëzie?' (Bekkering, 1989) niet de juiste, of meest relevante, vragen. Dit type vraag komt voort uit wat we, in navolging van Maria Nikolajeva, 'aetonormativiteit' kunnen noemen, i.e. de "adult normativity that governs the way children's literature has been patterned from its emergence until the present day." (2010, p. 8; zie ook Beauvais, 2012) Hoewel Nikolajeva die volwassen normativiteit vooral binnen de

\footnotetext{
${ }^{35} \mathrm{Er}$ is voor het voortgezet onderwijs een specifieke 'leerlijn poëzie schrijven en lezen' ontwikkeld (Ebbers \& Steeghs, 2007).
} 
tekst analyseert en aanwijst in de representaties van de rol van kinderen en volwassenen en de machtsverhoudingen tussen hen, kunnen we de term ook toepassen op de kinderliteratuur- en daarbinnen de kinderpoëziekritiek (Coats, 2013). Om het aetonormatieve perspectief - dat in de kinderpoëziekritiek overigens haar eigen functies heeft - van de nodige doelgroepgerichte aanvulling te voorzien, is het belangrijker om te vragen: 'Wat waarderen kinderen in poëzie, met de nadruk op kinderen?' Daarvoor is doelgroeponderzoek nodig.

$\mathrm{Er}$ is in het Nederlands taalgebied, voor zover ik heb kunnen nagaan, weinig tot geen structureel en/of grootschalig empirisch onderzoek verricht naar de poëtische voorkeuren van kinderen in het basisonderwijs. In de Verenigde Staten zijn wel verschillende grootschalige survey-onderzoeken gedaan naar de soorten poëzie die kinderen in het primair onderwijs het meest waarderen, en naar de inhoudelijke en formele kenmerken die daar een belangrijke rol in spelen. Toonaangevende onderzoeken zijn die van Terry (1974) en Fisher en Natarella (1982). Deze landelijk opgezette onderzoeken bestonden uit het gestandaardiseerd inventariseren van de poëtische voorkeuren van kinderen in groep 6, 7 en 8 (Terry, 1974) en van kinderen in groep 3, 4 en 5 (Fisher \& Natarella, 1982) door grote aantallen schoolklassen op scholen verspreid door het hele land, ingedeeld in verschillende categorieën naar mate van verstedelijking, naar een groot aantal voorgelezen gedichten te laten luisteren $^{36}$ en op een drie-punts-schaal te laten aangeven wat ze van elk gedicht vonden. Voor groep 3 tot en met 5, het meest relevant binnen het kader van dit onderzoeksproject, kwam uit het onderzoek van Natarella en Fisher dat kinderen van de aangeboden kinderpoëzie de narratieve gedichten en limericks het meest waardeerden, gevolgd door rijmende verzen; vrije versvormen, lyrische gedichten en haiku, daarentegen, werden het minst gewaardeerd (1982, p. 346). Inhoudelijke voorkeuren gingen uit naar vreemde en fantastische voorstellingen, gevolgd door gedichten over dieren en over kinderen en herkenbare ervaringen, op de derde plaats gevolgd door gedichten over dingen en als laatste gedichten over de natuur (p. 348). Van de poëtische elementen, ten slotte, viel figuratief taalgebruik niet bij de kinderen in de smaak: in het algemeen sprak er weinig waardering voor metaforische poëzie uit de resultaten. Kinderen in groep 3 tot en met 5 waardeerden vooral het gebruik van rijm, evenals andere klankeffecten als alliteratie en onomatopeeën (p. 349). De poëtische vorm (narratief, limerick, etc.) verklaart daarbij een groter deel van de voorkeuren van de kinderen dan de inhoudelijke kenmerken (het onderwerp). Het eerdere onderzoek van Terry (1974) onder kinderen in groep 6 tot en met 8 liet grotendeels dezelfde voorkeuren zien: kinderen waardeerden poëzie met rijm, ritme en andere klankeffecten, gaven daarbij de voorkeur aan narratieve gedichten, vooral die met humor, over herkenbare ervaringen en over dieren. Haiku en vrije versvormen werden ook hier het minst gewaardeerd (zie Patrick, 2012, p. 116). Zowel eerdere als latere onderzoeken naar de poëtische voorkeuren bevestigen dit beeld en laten zien dat kinderen in de basisschoolleeftijd weinig waardering tonen voor poëzie die wordt gekenmerkt door rust en meditatieve kwaliteiten (Sloan, 2003b; Kutiper \& Wilson, 1993; McClure, 1993; Nelson, 1966; Avegno, 1956; Kyte, 1947;

\footnotetext{
${ }^{36}$ In beide survey-onderzoeken waren alle gedichten opgenomen op cassettebandjes zodat alle kinderen dezelfde uitvoering te horen kregen. Verspreid over meerdere dagen kregen de kinderen meerdere gedichten per dag te horen. Natarella en Fisher, bijvoorbeeld, lieten kinderen acht gedichten per dag horen en waarderen verspreid over acht dagen (een totaal van 64 gedichten dus). Het luisteren naar en waarderen van de gedichten gebeurde in de klas onder leiding van de leerkracht die instructies had ontvangen en tegelijk ook gevraagd was zelf reacties van kinderen te noteren en aan te geven welke gedichten al bij de kinderen bekend waren.
} 
Bradshaw, 1937; Mackintosh, 1924; King, 1922). Deze grootschalige survey-onderzoeken geven slechts een globaal beeld van de poëtische voorkeuren van kinderen. Hoewel er wel indicaties uit naar voren komen dat kinderen andere voorkeuren hebben dan volwassen critici, bieden de survey-onderzoeken geen nauwkeurig inzicht in eventuele ontwikkelingen in de poëtische voorkeuren van kinderen naarmate ze ouder worden. Ook vertellen ze niets over de rol die de pragmatische context en de wijze van aanbieding en verwerking van poëzie in de klas spelen in de waardering van kinderen. Ze dragen daarmee niet bij aan het begrijpen waarom kinderen de genoemde voorkeuren hebben en hoe kinderen poëzie verwerken en verwerven.

Wanneer 'het poëtische' voor ervaren en geschoolde lezers tot stand komt in een specifieke communicatiesituatie, een interactie tussen lezer en tekst waarin zowel de leeshouding van de lezer als de spreekhouding van de woordvoerder in de tekst van belang zijn, zoals uiteengezet in Op poëtische wijze, hoe valt de communicatiesituatie die vorm geeft aan 'het taalspel poëzie' voor jonge kinderen dan te typeren? Inzichten in de kenmerken die een cruciale rol spelen in de langdurige en transculturele geliefdheid (i.e. 'canoniciteit') van bepaalde poëziesoorten bij jonge kinderen, vormen een cruciale aanvulling op 'top-down' canonvormingsprocessen in de kinderliteratuur (zie Hoofdstuk 1). Het construct 'poëzie' kan in 'kinderpoëzie' niet los gezien worden van 'kinder(en)' als we rekening houden met het feit dat 'lezers' in het literaire communicatieproces een minstens zo belangrijke rol spelen als de tekst. Tegelijk mag duidelijk zijn dat jonge kinderen niet de 'lezers' zijn zoals we ons die doorgaans voorstellen in het proces van literaire communicatie. De eerste vraag is dan: wat kenmerkt de communicatiesituatie waarin 'het taalspel poëzie' voor jonge kinderen vorm en betekenis krijgt?

\subsection{Het taalspel poëzie in de cultuur van het dagelijks leven}

In dit onderzoek richten we ons op een doelgroep van kinderen aan het begin van hun schoolloopbaan. Om inzicht te krijgen in de ontluikende culturele competentie van cultureel pluriforme groepen van jonge kinderen laten we ons binnen dit onderzoek informeren door de 'volkscultuur', "als aanduiding van de brede, alledaagse cultuur, waar iedereen, elite of volk, vreemd of eigen, in participeert." (Dekker et al, 2000b, p. 10) We sluiten ons in die zin aan bij de etnologie waar de bestudering van 'het schijnbaar triviale van onze dagelijkse cultuur', i.e. van breed gedragen cultuurverschijnselen, centraal staat (p. 10). Vanuit een etnologisch perspectief is kinderpoëzie niet zozeer een autonoom literair verschijnsel als wel een cultureel verschijnsel dat gezien wordt als onderdeel van een levende traditie die geworteld is in culturele gemeenschappen. Kijken we specifiek naar vormen van 'het taalspel poëzie' die in de brede alledaagse cultuur een vaste plaats hebben verworven in het leven van jonge kinderen en daarmee mede vorm geven aan hun 'poëtische socialisatie', dan zijn het wiegelied of slaaplied, het speelrijm en het feestlied van oudsher basisingrediënten van de primaire culturele socialisatie (zie ook Mooren, 2000, pp. 112-116; Vries, 2000, p. 1). Baker- en kinderrijmen, als onderdeel van de orale volkscultuur, introduceren jonge kinderen in allerlei belangrijke culturele categorieën van de gemeenschap(pen) waarin ze opgroeien als onderdeel van de taalcultuur: 
“Certainly cradle songs, nursery rhymes, and children's poems anchor us in our particular language groups as they replicate the rhythms, sound patterns, and material concerns of our culture. They form an enduring thread of tradition that binds us to our cultural and linguistic past. They introduce language as a site of play and often humour." (Coats, 2013, p. 134)

In het kader van dit onderzoek is het echter minstens zo belangrijk ons te realiseren dat die overdracht van culturele categorieën, die inwijding in culturele gemeenschappen, alleen effectief kan plaatsvinden wanneer de rijmen en liedjes nauwkeurig zijn afgestemd op de culturele competentie van kinderen zodat ze ze ook verwerven.

De aloude baker- en kinderrijmen zijn exemplarisch voor het soort poëzie dat jonge kinderen aanspreekt en nodig hebben, zo stelde een van Ruslands populairste kinderdichters Kornei Chukovsky in zijn boek From Two to Five. De langdurige populariteit en vitaliteit van rijmen en liedjes uit de mondelinge overlevering wordt volgens hem gewaarborgd doordat jonge kinderen alleen de rijmen en liedjes die hen het meest aanspreken hun leven lang onthouden en doorgeven aan hun eigen (klein)kinderen, die dat op hun beurt ook weer doen. Dit mondelinge canonvormingsproces leidt tot repertoires van rijmen en liedjes die iedere dichter als voorbeeld zou moeten nemen om aansluiting te vinden op de doelgroep van jonge kinderen, meent Chukovsky, want: "What was unsuitable for them perished along a thousand-year-old road. In this way an exemplary children's folklore has come into existence - exemplary in its language and rhythm, as well as ideally suited to the intellectual needs of the young child." (1971/1925, p. 94) Het zou volgens hem dan ook verspilling zijn als dichters die ervaring van duizend jaar en meer niet zouden benutten ( $\mathrm{p}$. 144). Vele anderen hebben opgemerkt dat rijmen en liedjes uit de orale volkscultuur, gezien hun vitaliteit en langdurige populariteit, kenmerken moeten bezitten die ze bijzonder aantrekkelijk maken voor kinderen (zie ook Vloten, 1874/1871; Kes, Pollmann \& Tiggers, 1948; Enzensberger, 1969; Opie \& Opie, 1952, 1959, 1968, 1988; Lurie, 1990; Eiselin, 1996). Iona en Peter Opie stellen in The Oxford Dictionary of Nursery Rhymes vast: "[T]hese trivial verses have endured where newer and more ambitious compositions have become dated and forgotten. They have endured often for nine or ten generations, sometimes for considerably more, and scarcely altered in their journey." (Opie \& Opie, 1973, p. 1) Anne Marie Schaerlaekens merkte in het kader van de taalontwikkeling van jonge kinderen iets soortgelijks op:

"Elke kleuterleidster en ouder van jonge kinderen kent het fenomeen dat nieuwe, pedagogisch opgestelde liedjes door het kind weliswaar gedwee worden meegezongen in de klas, maar daarbuiten meestal slechts een kort bestaan beschoren zijn. Eeuwenoude bakerrijmen, die soms een mengeling zijn van de meest triviale en absurde thema's, zijn daarentegen bijzonder geliefd en worden, eens gekend, nooit meer vergeten." (Schaerlaekens, 1977, p. 181) ${ }^{37}$

\footnotetext{
${ }^{37}$ Hier en daar zien we aanvulling van het traditionele repertoire met 'nieuwe klassiekers' als 'Elsje Fiederelsje' en 'Opa Bakkebaard' - beide geschreven door Herman Broekhuizen (1922-2012), maar ondertussen al losgezongen van hun geestelijk vader. Of 'De wielen van de bus gaan rond en rond' en 'Op een houten bruggetje liep een
} 
Baker- en kinderrijmen vervullen als onderdeel van de orale volkscultuur voor jonge kinderen belangrijke functies in de exploratie van de buitenwereld (Meijer, 1997, pp. 156-157). Het is deze exploratie van de buitenwereld die voor jonge kinderen tegelijk essentiële functies vervult voor de binnenwereld. Allison Lurie schrijft over volksculturele teksten in het leven van kinderen: "One function of folklore is to help its users to understand and if possible to control the world - or at least to feel that they are controlling it - and one way to control the world, of course, is with words." (Lurie, 1990, p. 196) In dezelfde trant karakteriseert ook Hans Magnus Enzensberger het mondeling overgeleverde (baker- en) kinderrijm in zijn bloemlezing Allerleiraub: Viele schöne Kinderreime:

"Het kinderrijm is vandaag de dag de enige poëtische vorm, waarvan het directe nut voor de hand ligt. Het wordt gebruikt. Alles is nog onontdekt: het eigen gezicht, de eigen vingers, de dieren, de seizoenen, het weer, de beroepen. Het rijm helpt het kind zich in deze wereld te oriënteren en er meester over te worden. Eten en inslapen, spreken en vragen, gaan en tellen, schommelen en spelen zijn kunsten die het rijm hem kunstzinnig toevertrouwd. Daaraan ontleent het zijn aanzien als gebruiksvoorwerp; daaraan heeft het zijn hardheid, zijn standvastigheid, zijn eigenzinnigheid, zijn vitaliteit te danken.” (Enzensberger, 1962, p. 353; vertaling overgenomen uit Mooren, 2000a, p. 113)

In de inleiding op de bundel Oude Kinderrijmen voor Jonge Ouders: Het Spel van Moeder en Kind lezen we: "Het kinderrijm is boven alles een nuttigheidsding, dat ontstond uit de behoefte om bepaalde veelvuldig terugkerende handelingen door rhythme en melodie te binden." (Pollmann, 1948, p. XV) Deze beschrijvingen geven inzicht in de concrete communicatiesituatie waarin de 'poëzie van het dagelijks leven' voor jonge kinderen haar functies vervult. Die communicatiesituatie omvat aanvankelijk, zeker in de voor- en vroegschoolse fase, meerdere tekstexterne partijen die met elkaar en met de tekst interacteren. Bakerrijmen en kinderliedjes bemiddelen allerlei soorten terugkerende interacties tussen (zeer) jonge kinderen en ouders, grootouders, leid(st)ers op kinderdagverblijven en peuterspeelzalen en leerkrachten in kleutergroepen, en dat alles ingebed in concrete gebruikscontexten. Jop Pollmann geeft als voorbeeld: "Er is een kindje, dat niet kan slapen of nog op wil blijven, dat een slechte zin heeft of stout is, dat gewassen moet worden en gekleed. ... Met dat kindje moet wat gedaan worden, opdat het zelf zal leren doen. Dan is het echte [baker] rijm het arbeidslied, dat aan dat werk de nodige rhythmische regelmaat en melodische draging geeft." (p. IX) Bakerrijmen omvatten van oudsher de allereerste poëtische vormen waarmee kinderen in aanraking komen, zoals het wiegelied, kietelliedjes, vinger- en schootspelle-

krokodilletje' (ook wel 'In de Haagse stadsbus daar zat een krokodil') die ondertussen tot het vaste repertoire van peuters en kleuters behoren, maar niet precies te herleiden zijn tot een bron. Het internet heeft een deel van de orale overlevering overgenomen: websites en blogs, fora en YouTube zijn tegenwoordig belangrijke plaatsen waar ouders en leerkrachten rijmen en liedjes voor met name peuters en kleuters uitwisselen. Het precies in kaart brengen van deze digitale ontmoetingsplaatsen en de wijzen waarop canonvorming daar plaatsvindt, is een onderzoek op zich waard. Voorbeelden zijn: www.kindertube.nl, www.kinderliedjes.nu, www.pinkelotje.nl/kinderliedjes, www.oudersvannu.nl (forumdiscussie 'wat-voor-liedjes-zingen-jullie-voor-de-kleine'), www.maroc.nl (forum 'wieschrijft-blijft', discussie 'arabische-kinderliedjes'). En natuurlijk doen kinderprogramma's op televisie ook een duit in het zakje: liedjes uit De Film van Ome Willem, Sesamstraat, de Fabeltjeskrant, de Teletubbies, Kinderen voor Kinderen, enzovoort, willen nog weleens tot het mondelinge gemeengoed van kinderen gaan behoren, al is niet bekend hoe lang dergelijke liedjes blijven voortbestaan nadat een programma is gestopt. 
tjes, handklap- en uitbeeldrijmen, de eerste vraag- en antwoordspelletjes, en niet te vergeten de dansliedjes. Zonder uitzondering geven ze 'ritmische regelmaat en melodische draging' aan terugkerende en sterk geformaliseerde fysieke activiteiten.

Naarmate kinderen ouder worden, valt een deel van het vroegste repertoire weer af in het alledaags gebruik (want is niet meer nodig) en komen er nieuwe vormen bij. De rol van kinderen zelf wordt in de poëtische communicatiesituatie steeds actiever naarmate ze ouder worden en het initiatief komt in toenemende mate bij hen zelf te liggen. Ook voor schoolgaande kinderen blijven kinderrijmen van oudsher verbonden aan concrete gebruikscontexten. In de inleiding op de drie bundeltjes Kinderzang en Kinderspel lezen we: "De zang van het kind is vrijwel nooit abstract. De zang is gebonden aan de feesten van het jaar en vooral aan het spel. Het lied heeft een functie in het kinderlijke leven.” (Kes, Pollmann \& Tiggers, 1947, p. 7, cursief in origineel) Vanaf groep 3 komen kinderen steeds meer in aanraking met groepen van oudere kinderen, bijvoorbeeld op het schoolplein ${ }^{38}$ waar repertoires van rijmen en liedjes door kinderen aan elkaar worden overdragen, vaak gekoppeld aan specifieke spelvormen (Fine, 1980; Grijp, 2000a; zie ook Hoofdstuk 3). Kinderen gebruiken rijmen en liedjes daarnaast om de beurt te verdelen, om hun positie in de groep te bepalen, om 'het Gerechtelijk Wetboek van de speelplaats' te handhaven en om allerlei gevoelens die ze zelf nog niet goed onder woorden kunnen brengen, uitdrukking te geven (Opie \& Opie, 1970, p. v). Daarnaast leren en gebruiken kinderen allerlei liedjes en rijmen gebonden aan de vieringen in het jaar en in het leven. Al die rijmen en liedjes vervullen concrete gebruiksfuncties in de alledaagse cultuur. 'De enige poëtische vorm waarvan het directe nut voor de hand ligt', 'gebruiksvoorwerp', 'nuttigheidsding', 'arbeidslied', 'vrijwel nooit abstract' en 'gebonden aan de feesten van het jaar en vooral aan het spel': deze beschrijvende termen bieden een nuchtere kijk op de concrete communicatiesituatie, en handelingscontext, waarin baker- en kinderrijmen als 'poëzie van het dagelijks leven' functioneren. Er wordt iets gedaan met deze poëzie. Als onderdeel van de orale volkscultuur zijn baker- en kinderrijmen nauwkeurig afgestemd op toepassingen in concrete alledaagse situaties waarin niet vanuit een poëtische leeshouding, maar vanuit een 'poëtische gebruikshouding' met de tekst wordt omgegaan. Jonge kinderen zijn in deze fase geen gevormde literaire lezers, ze kunnen zelfs nog helemaal niet lezen, of nog maar net. Voor de verwerving van poëzie zijn jonge kinderen noodzakelijkerwijze afhankelijk van mondelinge performance en die performance van 'het taalspel poëzie' is van oudsher een fysieke, sociale en interactieve aangelegenheid, ingebed in concrete tekstexterne gebruikscontexten waarin de rijmen en liedjes instrumentele en communicatieve functies vervullen. Het is inherent aan de orale traditie dat gebruikers van rijmen en liederen veelal tegelijk 'woordvoerder' en 'lezer' zijn, dat performer en publiek samenvallen (zie ook Grijp \& Willaert, 2008, pp. 12-13). En als gebruikers gaan jonge kinderen met poëzie om zoals dat in de orale volkscultuur gebruikelijk is:

"Developmentally, folklore is born with a child. Children begin their pre-literate lives as part of the oral tradition, hearing and remembering rhymes, songs, games, images, and stories, incorporating them into play and daily activities, and retelling or referring to what they've heard told or read aloud with peers as they socialize." (Hearne, 2011, p. 211)

\footnotetext{
${ }^{38}$ Op veel scholen is er een apart 'kleuterplein' en/of hebben de kleuters op andere tijden pauze dan de oudere kinderen. Vanaf groep 3 gaan ze een schoolplein en pauzetijden delen met hogere groepen.
} 
Vanuit een 'poëtische gebruikshouding' dienen meedoen en nadoen zich aan als de eerste modellen van poëzieverwerving: jonge kinderen leren rijmen en liedjes van (groot)ouders, leerkrachten, broers en zussen, oudere schoolkinderen en audio-/visuele media door meeof nazingen/-zeggen en mee- of nadansen, -stampen en -klappen. Eenmaal verworven, vormen deze rijmen en liedjes materiaal voor reproductie, adaptatie, selectie en verwerking in nieuwe contexten en vormen (van spel bijvoorbeeld). Al deze vormen van poëzieverwerving en -verwerking door jonge kinderen zijn te typeren als handelingsgerichte modellen. Poëzieverwerving door jonge kinderen is in die zin altijd verbonden aan actieve participatie in en reproductie van vormen van 'het taalspel poëzie' waarin conservatie en adaptatie beide een belangrijke rol spelen (zie ook Fine, 1980): processen van productieve receptie dus. Alleen die rijmen en liedjes die in een specifieke context aansluiten op de behoeften, vaardigheden en voorkeuren van (groepen) kinderen, lenen zich voor dit (re-)productieve verwervingsproces.

Kinderpoëzie bestaat vanuit het gebruiksperspectief, ingebed in de cultuur van het dagelijks leven van kinderen, niet uit in print gefixeerde 'artefacten' die kinderen dwingen 'om stil te staan, om in hun hoofd te kijken en van daaruit de wereld anders te zien' en kinderpoëzie vertegenwoordigt voor kinderen ook geen 'abstracte Literaire Waarde'. Ze zijn zich van die literaire waardeoordelen tenslotte nog niet bewust: ze zijn nog niet gesocialiseerd in de geïnstitutionaliseerde poëziebeschouwing. Het zijn voor hen concrete gebruiksvoorwerpen, talige instrumenten, die ze verwerven door ze actief te gebruiken. Orale poëzie is per definitie belichaamde poëzie en biedt kinderen, eenmaal verworven, de mogelijkheid zich actief te verhouden tot en - ten minste het gevoel van - controle te hebben over allerlei aspecten van de hen omringende wereld via poëtisch taalgebruik. Kinderpoëzie die het meest nauwkeurig op de functionele behoeften van kinderen aansluit, ze het instrumentarium biedt om de voor hen relevante aspecten van de omringende werkelijkheid te controleren, heeft dan naar verwachting de grootste kans om bij kinderen in de smaak te vallen. Die functionele behoeften van kinderen veranderen door de tijd heen en houden verband met de ontwikkelingsfasen waarin ze zich bevinden. Welke domeinen van ontwikkeling daar in relatie tot poëzie de belangrijkste rol in spelen, komt in de volgende hoofdstukken aan bod. Te denken valt aan hun taalontwikkeling, maar ook de ontwikkeling van tijdbesef, van humor, en van moraliteit. Hier is het vooral van belang te benadrukken dat poëzie voor jonge kinderen dus niet zozeer moet worden benaderd als literatuur om te lezen, te analyseren en interpreteren, maar als “een daad, een handeling, een doen” (Pollmann, 1948, p. IX) ingebed in 'de cultuur van het dagelijks leven'. Het is daarbij de koppeling aan specifieke terugkerende contexten van tekstgebruik - i.e. de inbedding in concrete terugkerende gebruikssituaties zoals de dagelijkse routines van opstaan tot naar bed gaan, de vieringen in het jaar en in het leven en vele vormen van spel - die de 'poëzie van het dagelijks leven' zo sterk verankert in de alledaagse cultuur en daarmee een belangrijke bijdrage levert aan de duurzaamheid en vitaliteit van deze belichaamde gebruikspoëzie. 


\subsection{Er schemert een duidelijke tekst achter, naar het lijkt ...}

De autonome literatuuropvatting die door de jeugdliteraire kritiek al een aantal decennia op de kinderpoëzie is toegepast, brengt een sterk tekstgerichte blik met zich mee waarin tekstanalyse en interpretatie centraal staan. Vanuit die blik wordt regelmatig ook naar het eeuwenoude cultuurgoed uit 'de oude doos' gekeken. Kees Fens heeft meer dan eens zijn liefde voor het traditionele kindervers uitgesproken en heeft ook meer dan eens onder woorden gebracht wat hij nu, in tekstueel opzicht, zo intrigerend vindt aan 'Witte zwanen, zwarte zwanen' of 'Hoe laat is het? Twaalf uren'. Zo schrijft hij:

"Wat maakt de bekoring van die gedichtjes uit? Hun schijnbare helderheid; maar de onderdelen ervan rijmen vaak op elkaar als gebeurtenissen in dromen. Er schemert een duidelijke tekst achter, naar het lijkt. Dan zijn er soms regels als uitgesleten plekken of stenen, met alle charme daarvan. De versjes zijn niet gemaakt, de woorden lijken zichzelf vermenigvuldigd te hebben of vanzelf in elkaar gegroeid te zijn. Bakerversjes, zoals ze soms in het Nederlands genoemd worden, zijn de gevonden voorwerpen in de literatuur, en weer en wind hebben hun sporen nagelaten." (Fens, 1985, zoals opgenomen in Bekkering, 2002, p. 357)

Wat opvalt, is dat de notie van 'gebruikers' en de sociale context waarin die teksten hun functies van oudsher vervullen geheel afwezig is in deze beschrijving: het is een beschouwing op het bakervers als autonoom artefact, als 'gevonden voorwerp' dat blijkbaar lange tijd was blootgesteld aan de elementen, maar nu van straat opgeraapt, afgeveegd, en eens nauwkeurig bekeken. Bekijken we de baker- en kinderrijmen echter in de communicatiesituatie waarin ze van oudsher als poëzie functioneren, dan is het juister te zeggen dat niet 'weer en wind', maar opeenvolgende generaties van gebruikers hun sporen hebben nagelaten. Waar Fens het heeft over een duidelijke tekst die achter de rijmen lijkt te schemeren, moet worden opgemerkt dat een groot deel van de baker- en kinderrijmen te herleiden is tot literaire poëzie en liederen voor kinderen en volwassenen uit een ver verleden. En over de charme van die regels als uitgesleten plekken, over de woorden die zichzelf vermenigvuldigd lijken te hebben, kunnen we ook stellen dat dat het resultaat is van decennia van verbasteren, misverstaan, vergeten, improviseren en adapteren. Alleen dat wat praktisch én esthetisch het beste werk.t in de gebruikscontext - wat het gewenste effect bewerkstelligt en daarmee de gewenste functie vervult én wat het best onthouden wordt - blijft overeind. En dat is mensenwerk: dat gaat niet door 'weer en wind'. Dat wil overigens niet zeggen dat literaire analyse niet op het traditionele kindervers kan worden toegepast of dat de rijmen en liedjes tekstueel gezien geen zekere charme en bekoring hebben. Integendeel, maar wat geschoolde en belezen literaire critici zo aantrekkelijk vinden aan baker- en kinderrijmen is in het kader van dit onderzoek, kort gezegd, niet werkelijk van belang. Hun oordeel verklaart namelijk niet waarom juist deze 'gevonden voorwerpen in de literatuur' ook voor hedendaagse kinderen nog van betekenis zijn. Daarvoor is een perspectief op poëzie nodig waarmee tekst en 'lezer' (gebruiker) in hun sociale context worden bekeken.

Het gebruikskarakter van baker- en kinderrijmen neem ik binnen dit onderzoek als uitgangspunt voor de identificatie van verwachte 'indicatoren van canoniciteit' in kinderpo- 
ezie, ook die uit de literaire overlevering. Baker- en kinderrijmen zijn vaak heel oude gebruiksvormen van poëzie uit de orale volkscultuur, maar niet wezenlijk gescheiden van literaire kinderpoëzie. Veel dichters van kinderpoëzie laten zich niet alleen door literaire poëzieopvattingen, maar ook door de volksculturele poëzie beïnvloeden (zie Bekkering et al, 2002; Mooren, Kurvers \& Lierop-Debrauwer, 2004). Die tweezijdige beïnvloeding biedt aanknopingspunten om ook kinderpoëzie uit de literaire overlevering te 'toetsen' op aansluiting bij concrete mondelinge gebruikscontexten. Die benadering van kinderpoëzie houdt rekening met de positie van jonge kinderen tussen oraliteit en geletterdheid en de gebruikshouding van waaruit zij 'het taalspel poëzie' aanvankelijk leren kennen en (mee)spelen. Natuurlijk heeft die benadering ook gevolgen voor de tekstuele kenmerken die ik aanwijs als de kenmerken die, naar verwachting, het sterkst bijdragen aan de langdurige geliefdheid van dit materiaal bij jonge kinderen. De vraag is vooral welke tekstuele kenmerken voor kinderen het meest effectief bijdragen aan de verwerving van poëzie. Jop Pollmann wijst er echter in zijn inleiding op de bundel Oude Kinderrijmen voor Jonge Ouders: Het spel van moeder en kind in de jaren 1940 al op dat er een duidelijk onderscheid is tussen de volksculturele rijmen en liedjes voor jonge kinderen en de maatstaven die in de literatuur gelden:

"Het spel van moeder en kind wordt beheerst door geheel andere normen dan die van de schoonheid en ook wanneer niemand, die deze rijmen kent, zich aan de eigenaardige bekoring er van kan onttrekken, kan er hier geen sprake zijn van de gewone eisen der litteraire of muzikale aesthetica." (Pollmann, 1948, p. IX)

Tekstuele kenmerken kunnen we formeel en inhoudelijk benaderen, waarbij de inhoud, de 'betekenis' in referentiële zin, voor kinderen zelf pas een rol gaat spelen wanneer ze over voldoende taalvaardigheid beschikken. "Eerst is het alleen maar klank en ritme, waarmee we worden gesust en in slaap gewiegd, 'suja, suja, kindje'," schrijft Anne de Vries terecht (2000, p. 1). En ook na die vroegste fase geldt nog een tijd lang dat kinderen, zolang ze niet zelf kunnen lezen, voor de verwerving van poëzie afhankelijk zijn van wat ze horen - of dat nu van (groot)ouders, leerkrachten, andere kinderen of via elektronische media is - en van wat ze kunnen onthouden. Rita Ghesquière stelt vanuit dat perspectief: "Bij gevormde lezers, zeker in onze dagen, wordt complexiteit als een positief evaluatiecriterium gehanteerd. Dit is ... bij kinderen niet zo." (2009a, p. 133) Het ligt in de lijn der verwachting dat juist tekstuele redundantie en stereotypie jonge kinderen houvast bieden voor het opbouwen van mentale representaties en daarmee ook voor het onthouden van teksten (p. 137). En dat onthouden betekent ook gebruik, herhaling en actieve verwerking: dat vereist participatieve omgang met teksten. Betsy Hearne schrijft: "Children reclaim stories from family and cultural traditions -whether delivered in person, print, or electronic media - and make them their own, selecting, adapting, and appropriating various elements as needed in a process that reflects the oral formation of folktales." (Hearne, 2011, p. 211) Wat er dan door de tijd heen overeind blijft, voldoet inderdaad niet aan de 'gewone eisen der litteraire of muzikale aesthetica', zoals Pollmann al stelde. Ruth Lorbe, die in haar beschrijving van 'Kinderlyrik' de tekstuele kenmerken van kinderrijmen en -liedjes uit de mondelinge overlevering (de 'kindervolkslyriek') als maatstaf voor de kinderpoëzie als geheel aanwijst, benoemt verschillende eigenschappen die in populaire kinderrijmen en -liedjes de boventoon voeren: 
"Diese Eigenschaften sind vor allem das Ausstoßen aller lehrhaft moralisierenden oder streng verstandesmäßigen Tendenzen; das Umwandeln von Erwachsenenmotiven; der Verzicht auf Sinnzusammenhang innerhalb eines Textes, statt dessen immer wieder Sprunghaftigkeit; eine ausgesprochene Freude am Un-Sinn; das Vorherrschen von kurzen Zeilen, von Rhythmus, Reim, Wiederholungen und Assoziationen."39 (Lorbe, 1984, p. 345)

Wie door uitgaven van baker- en kinderrijmen uit de orale volkscultuur heen bladert (zie Vloten, 1874/1871; Abramsz, 1984/1910; Troelstra-Bokma de Boer, 1947; Kes, Pollmann \& Tiggers, 1948; Vries, 2000) en kijkt naar terugkerende tekstkenmerken, ziet al snel dat volkomen betekenisloze klankreeksen veelvuldig voorkomen, als in 'Epompee, poedenee, poedenaska' of 'Arabine koeterine', en dat allerlei objecten, personages, handelingen en locaties die normaal gesproken niets met elkaar van doen hebben aan elkaar worden gesmeed door ritme en rijm, zoals in 'Eén, twee - kopje thee' of 'Zwarte zwanen, witte zwanen -/ wie wil er mee naar Engeland varen?'. De verhaaltjes die we er aantreffen, zoals 'Berend Botje ging uit varen' of 'Er zaten zeven kikkertjes', worden wel gekenmerkt door een narratieve woordvoerder, maar volgen niet een gebruikelijk narratologisch stramien en vervullen daarmee nauwelijks een narratieve functie. Berend Botje verdwijnt op zijn weg die recht én krom was - naar Zuidlaren om nooit meer terug te komen (Abramsz, 1984/1910, p. 142) en de zeven kikkertjes zitten aan het eind van het liedje nog steeds bijna dood te wezen in een bevroren sloot (p. 69). Het zijn vooral vreemde mededelingen of zeer beeldende en vaak grappige situatieschetsen met onverwachte wendingen: 'Jan-oom/ zat op een boom/ te wachten./ Toen brak de boom,/ en viel Jan-oom,/ en al de koetjes/ lachten.' (p. 107)

Het 'nonsensicale' karakter van dergelijke klankrijmen en vreemde situatieschetsen wordt beschouwd als structureel tekstkenmerk van volksculturele baker- en kinderrijmen (zie o.a. Cammaerts, 1925; Chukovsky, 1971/1925; Anderson \& Apseloff, 1989; Mooren, 2000b; Bruijn \& Mooren, 2013). In de orale volkscultuur is nonsens, of nonsensicaliteit, een zo diepgeworteld en wijdverbreid fenomeen dat het niet tot een specifieke bron te herleiden valt: "We cannot trace those strands to their first spinning in the case of folklore, but we know that tall tales, and riddles, and nonce phrases in refrains have existed from the earliest recorded days of most cultures." (Anderson \& Apseloff, 1989, p. 9) En het feit dát 'betekenisloosheid' (in referentiële zin) een structureel tekstkenmerk is van volksculturele baker- en kinderrijmen wijst erop dat dit kenmerk functioneel is. Het 'werkt' op de een of andere manier in de communicatiesituatie waarin 'het taalspel poëzie' voor jonge kinderen gestalte krijgt. Ook schrijvers van kinderpoëzie hebben opgemerkt dat die nonsensicaliteit bij kinderen in de smaak valt: "Die oude deuntjes zijn pure poëzie. Ze dansen en zingen vanzelf en ze hebben een eigen logica, ook al bevatten ze louter nonsens. Diezelfde nonsens-logica moet de schrijver van moderne kinderversjes in zich hebben," schrijft Annie M.G. Schmidt (1954, p. 33). Het feit dat die nonsensicale logica van baker- en kinderrijmen

\footnotetext{
${ }^{39}$ Lorbe stelt hier vast dat we expliciet didactisch moraliserende of strikt rationele tendensen in kinderrijmen uit de mondelinge overlevering niet aantreffen; wel allerlei omzettingen van volwassenenmotieven. Betekenis-samenhang binnen de tekst is ver te zoeken; in plaats daarvan worden de teksten gekenmerkt door een zekere vluchtigheid. We vinden er een uitgesproken plezier in onzin en de overheersing van korte regels, van ritme, rijm, herhalingen en associaties.
} 
een breed gedragen en diepgeworteld cultuurverschijnsel vertegenwoordigt, dwingt ons te vragen wat het is dat die nonsensicaliteit in de vorm van baker- en kinderrijmen doet voor kinderen. Met andere woorden: wat is de 'betekenis' van verschillende vormen van 'betekenisloosheid' als tekstaspect in de communicatiesituatie waarin jonge kinderen 'het taalspel poëzie' van oudsher leren kennen en spelen in de cultuur van het dagelijks leven? Vanuit functioneel perspectief maak ik onderscheid tussen twee globale soorten 'betekenisloosheid' die we in baker- en kinderrijmen aantreffen. Allereerst zijn er de rijmen en liedjes waarin 'betekenisloosheid' voortkomt uit een bijna exclusieve foregrounding van de prosodische aspecten van taal in 'het taalspel poëzie', dat wil zeggen een sterke tekstuele nadruk op vormgevingselementen in klank en structuur (Bork et al: lemma 'prosodie'). Denk aan 'Ozewiezewoze' of 'Iene miene mutte'. In dergelijke verzen is sprake van een poëtische klanktaal die betekenisvol is in een niet-symbolisch taalsysteem, door Julia Kristeva aangeduid als het semiotisch taalsysteem: “... de taallaag waarin taal geen betekenis is, maar pure klank, ritme en muziek.” (Meijer, 1997, pp. 150-151) Dit type tekstuele ‘betekenisloosheid' duid ik aan als 'muzikaal taalspel' en werk ik verder uit in Hoofdstuk 4. Daarnaast zijn er de rijmen en liedjes waarin 'betekenisloosheid' betrekking heeft op de voorstelling van aspecten van de werkelijkheid. In deze verzen kunnen we de woorden wel van betekenis voorzien, maar wat die woorden samen vertellen, wijkt af van wat we als 'betekenisvol' ervaren op basis van onze kennis van de wereld. Deze verzen beschrijven aspecten van de werkelijkheid zoals we die kennen, "but shaped according to a certain pattern of play." (Bakhtin, 1984, p. 7) Dit type tekstuele 'betekenisloosheid' duid ik aan als '(carnavaleske) nonsensicaliteit' en werk ik verder uit in Hoofdstuk 5.

Wat de verschillende soorten 'betekenisloosheid' in baker- en kinderrijmen met elkaar gemeen hebben, is dat ze weerstand bieden aan interpretatie en erop duiden dat 'betekenis' niet primair in de tekst gezocht moet worden. Om de betekenis van nonsensicale baker- en kinderrijmen te achterhalen, moeten we mijns inziens niet zozeer naar de tekst als tekst kijken, maar naar de tekst als een vorm van 'materiële cultuur', i.e. de tekst als gebruiksobject. En "objecten kunnen alleen begrepen worden in hun maatschappelijke context: wie gebruikt het (sociaal) op welke manier (technisch) voor welk doel (functie), waar (ruimte), wanneer (tijd) en op welke wijze markeert men zich daarmee ten opzichte van anderen (betekenis)?"40 (vgl. Rooijakkers, 2000a, pp. 110-111) De vormen van nonsensicaliteit die we in baker- en kinderrijmen veelvuldig aantreffen, sluiten dan op de een of andere manier aan op de poëtische gebruikshouding, gebaseerd op specifieke poëtische gebruiksconventies, van waaruit jonge kinderen 'het taalspel poëzie' leren spelen. Sterker nog, als alomtegenwoordig tekstaspect van het volksculturele baker- en kinderrijm mogen we er van uit gaan dat vormen van 'betekenisloosheid' kinderen helpen de wereld te begrijpen en, ten minste gevoelsmatig, te controleren (Chukovsky, 1971/1925; Lurie, 1990). Om te begrijpen wat poëzie voor jonge kinderen is, hoe zij ermee in aanraking komen en er betekenisvol mee om (leren) gaan, moeten literatuurtheoretische perspectieven dus aangevuld worden met etnologische perspectieven op de tekst in zijn sociaal-culturele gebruikscontext. In de he-

\footnotetext{
${ }^{40}$ Hoewel er in de etnologische benadering in de praktijk niet zoveel verschil is in de wijze waarop de materiële cultuur van groepen mensen wordt benaderd en de wijze waarop de orale cultuur wordt benaderd, kies ik er hier bewust voor om een citaat op te nemen dat afkomstig is uit het hoofdstuk getiteld: 'Mensen en dingen. Materiële cultuur' en niet uit bijvoorbeeld het hoofdstuk 'Zangcultuur'. Dit om de 'materialiteit' van het kindervers te benadrukken.
} 
dendaagse etnologie ${ }^{41}$ worden objecten niet meer als opzichzelfstaande artefacten verzameld en beschouwd, maar juist bekeken in context. "Door middel van nauwkeurig onderzoek van de context waarin een gebruiksvoorwerp gehanteerd wordt kan de communicatieve betekenis ervan in een bepaalde groepscultuur achterhaald worden." (Rooijakkers, 2000a, p. 110) Ook musicologen die zich bezighouden met het kinder- en volkslied bieden belangrijke aanvullende inzichten (Grijp, 2000a, 2000b; Mithen, 2005). Net als antropologen die zich bezighouden met rijmen en liedjes als onderdeel van de kindercultuur (Fine, 1980; Sutton-Smith, 1999; Hirschfeld, 2002). In zijn inleiding op Children's Folklore: A Source Book schrijft vooraanstaand onderzoeker van kinderspel en bijbehorende kinderfolklore Brian Sutton-Smith: "Folklorists today are more concerned with the actual living performance of these traditional materials (dance, song, tale) in their particular settings, with their functional or aesthetic character in particular contexts." (Sutton-Smith, 1999, p. 3) Het is deze blik die, mijns inziens, ook nodig is om te leren begrijpen wat poëzie voor jonge kinderen is en doet, wat het voor hen kan betekenen in het licht van de ontwikkeling van hun ontluikende culturele geletterdheid.

De overwegingen tot nu toe wijzen erop dat er, in vergelijking met literaire benaderingen van kinderpoëzie, een andere benadering nodig is om te begrijpen wat poëzie voor kinderen is en doet, wat en hoe zij (in) poëzie begrijpen en waarderen, en hoe zij poëzie verwerven. Een benadering die poëzie voor kinderen primair als waardevol begrijpt in wat het met kinderen doet en wat kinderen met poëzie doen en niet in de literaire interpretatie van haar formele en inhoudelijke eigenschappen door volwassen en ervaren lezers (zie Coats, 2013, p. 133). Gemodelleerd naar inzichten die baker- en kinderrijmen in context bieden in de aansluiting van 'het taalspel poëzie' op de ontluikende culturele competentie van de beoogde doelgroep van jonge kinderen, vraagt het identificeren van cruciale indicatoren van canoniciteit' in kinderpoëzie als het ware om een 'antropologisering van de kinderpoëziebeschouwing'. Dat wil zeggen dat ik verbindingen leg tussen literatuurwetenschappelijke benaderingen enerzijds en disciplines die zich bezighouden met de 'geleefde praktijk' van kinderrijmen, -liedjes en -gedichten in hun sociale context anderzijds (vgl. Nissen, 2000, p. 238). Dit voegt een analysekader toe aan de kinderpoëziebeschouwing: ik kijk niet alleen naar de 'tekst' of naar de interactie tussen 'lezer' en 'tekst', maar ook naar de context waarin 'het taalspel poëzie' - in de vorm van verschillende soorten rijmen, liedjes en ook gedichten - door en met kinderen gebruikt wordt. 'Het taalspel poëzie' als gebruiksobject in context. 'Het taalspel poëzie' ontleent haar communicatieve functie en daarmee ook haar waarde(n) en betekenis(sen) voor jonge kinderen naar verwachting primair aan hoe er, door

\footnotetext{
${ }^{41}$ De eerste verzamelaars van het Nederlandse baker- en kinderrijm - Johannes van Vloten die zorgde voor de eerste grote publicatie van dit materiaal in de bundel Nederlandsche baker- en kinderrijmen (1871), en Gerrit Jacob Boekenoogen die de oudste verzameling van kinderrijmen aanlegde -, waren nog voornamelijk vanuit historisch of volkskundig en oudheidkundig perspectief geïnteresseerd in de mondeling overgeleverde rijmen en liedjes (Grijp, 2000; Veurman, 1894/1994). In het voorwoord op de herdruk van zijn opstel 'Onze rijmen' schrijft Boekenoogen in 1893: "Het [opstel] verhaalt een en ander over onze rijmen en dient tot toelichting van mijn voornemen, om een Nederlandsch Rijmenboek samen te stellen en daardoor onze volksrijmen voor den ondergang te bewaren." (z.p.) Mede hierdoor, zo schrijft B.W.E. Veurman ter gelegenheid van "Honderd jaar Nederlandse baker- en kinderrijmen', “werden de teksten nog te vaak los gezien van de functie die zij - meestal als element van het spel in het kinderleven hebben." (Veurman, 1894/1994, p. 179) Latere verzamelaars hadden meer oog voor de gebruiksfuncties van baker- en kinderrijmen. Zij legden vaker verbanden tussen de gebruiksfuncties, de tekstuele eigenschappen en de behoeften van (verzorgers van) jonge kinderen (Opie \& Opie, 1959, 1970, 1985; TroelstraBokma de Boer, 1947; Kes, Pollmann \& Tiggers, 1948; Enzensberger, 1962; Chukovsky, 1971/1925).
} 
wie, waar en wanneer, op welke manier en waartoe mee gehandeld wordt. Dat is in principe niet anders dan wat de auteurs van Op poëtische wijze (Alphen et al, 2010/1996) doen: ook zij bekijken de rol van de tekst, van de lezer én van de context in het poëtisch communicatieproces, maar gaan daarbij uit van ervaren lezers die gesocialiseerd zijn in een poëtische leeshouding met de conventies die daaraan ten grondslag liggen. Hierin ligt een cruciaal verschil tussen jonge kinderen en ervaren lezers: jonge kinderen hebben die leeshouding en de bijbehorende leesconventies nog niet verworven. Willen wij poëzie voor kinderen primair als waardevol begrijpen in wat het voor kinderen is en doet, dan moeten we inzicht krijgen in de condities waaronder kinderen poëzie als zodanig begrijpen en waarderen.

\subsection{Kinderpoëzie: naar een pragmatische benadering in ontwikkelingsperspectief}

In het vorige hoofdstuk verwees ik al naar Van Lierop-Debrauwer en Mooren die met het oog op pluriforme canonvorming voor kinderen in de multiculturele samenleving schreven: "Putten uit de canon van de volkscultuur ligt voor de hand, omdat rijmpjes en versjes, sprookjes en fabels, raadsels en spreuken, moppen en grappen deel uitmaken van een internationale traditie." (2004, p. 11) Wat ik binnen het kader van dit onderzoek uit die canon van de volkscultuur put, zijn niet alleen rijmen en liedjes. Ik wil er vooral kenmerken uit afleiden die veel van die teksten met elkaar gemeen hebben en die naar verwachting zorgen voor een nauwe aansluiting op de ontluikende culturele competentie van kinderen in groep 2 en in groep 4 van het basisonderwijs. Kenmerken die aangewezen kunnen worden als 'indicatoren van canoniciteit' waarmee kinderpoëzie, ook uit het literaire domein, geselecteerd kan worden die nauwkeurig aansluit op de voorkeuren van deze kinderen. In dit hoofdstuk heb ik verwezen naar verschillende auteurs die ieder vanuit hun eigen perspectief vaststelden dat volksculturele baker- en kinderrijmen kenmerken moeten bezitten die maken dat ze zo langdurig, en transcultureel, geliefd zijn bij opeenvolgende generaties van kinderen. Als we begrijpen welke kenmerken van baker- en kinderrijmen maken dat deze '(trans)cultural frames' zo goed aansluiten op de ontluikende culturele schemata van jonge kinderen en hoe kinderen dergelijke tekstsoorten verwerven, dan kunnen deze inzichten vertaald worden in criteria voor de selectie van kinderpoëzie die effectief bijdraagt aan de ontluikende culturele geletterdheid van kinderen in groep 2 en groep 4. Om dat te achterhalen, moeten we begrijpen welke normen of conventies ten grondslag liggen aan het proces van poëtische communicatie dat met (het gebruik van) baker- en kinderrijmen vorm krijgt. Dit vormt de basis voor een beter inzicht in wat poëzie nu eigenlijk betekent voor jonge kinderen, welke poëtische voorkeuren ze hebben en hoe zij langdurig geliefde en cultureel diepgewortelde soorten poëzie verwerven.

Wat nodig is, is een benadering die kinderpoëzie - waaronder ik hier zowel poëzie uit de orale traditie als poëzie uit de literaire traditie versta, gebruikt door of met en/of geschreven voor kinderen - als betekenisvol begrijpt in het gebruik ervan door kinderen (vgl. Coats, 2013, p. 133). Poëzie voor kinderen is, kort gezegd, wat poëzie voor kinderen doet of wat kinderen met poëzie doen. De beleving van 'het taalspel poëzie' is voor jonge kinderen gekoppeld aan en komt heel expliciet tot uitdrukking in de mondelinge performance. 
Die performance is een sociale en interactieve aangelegenheid, ingebed in concrete tekstexterne pragmatische contexten waarin de rijmen en liedjes vastomlijnde instrumentele en communicatieve functies vervullen. Voor ervaren lezers is de fysieke ervaring van de ritmische verschijnselen wellicht niet het primaire niveau waarop zij betekenis aan poëzie toekennen. Zij zijn dusdanig gesocialiseerd in een wereld van taal die grotendeels is ontdaan van haar materialiteit ten voordele van haar conceptuele kracht, dat ze voorrang geven aan analyse en interpretatie, aan inhoudelijke thema's en referentiële betekenis. Voor jonge kinderen introduceren baker- en kinderrijmen echter primair regelmatige patronen (ritmische regulering) in de stortvloed van ervaringen die voortkomen uit hun lichamelijk zijn in de wereld (vgl. Coats, 2013, pp. 135-136). In alle gebruikscontexten waarin de 'poëzie van het dagelijks leven' voor jonge kinderen is ingebed dienen rijmen en liedjes om ervaringen, interacties en emoties ritmisch te reguleren in 'patronen van betekenis' op meerdere niveaus (zie Hoofdstuk 3). Dit is waar de 'lived experience' van poëzie voor kinderen begint, ingekaderd in en gebonden aan terugkerende contexten van tekstgebruik. Zij lezen geen 'gedichten', maar gebruiken slaapliedjes, klapspeliedjes, aftelrijmen, Sinterklaasliedjes en verjaardagsliedjes: dát is de poëzie van het dagelijks leven, met haar aangewezen plaats en functie, haar gebruiksconventies en fysieke effecten die dat wat niet waarneembaar en controleerbaar is, ervaarbaar en controleerbaar maken door ritmische regulering. Deze bijzondere vormen van taalgebruik helpen kinderen de wereld te begrijpen en, ten minste gevoelsmatig, te controleren (Chukovsky, 1971/1925; Lurie, 1990), niet alleen met taal, maar met het lichaam in taal. Echter, kinderen ontwikkelen zich, dus hun specifieke behoefte aan poëtische regulering zal ook veranderen naarmate ze ouder worden. In de volgende hoofdstukken, waarin ik verwachte 'indicatoren van canoniciteit' voor de kinderpoëzie uitwerk, maak ik dan ook steeds de koppeling met relevante ontwikkelingsgebieden (cognitie en tijdbesef, taal- en humorontwikkeling).

Binnen het kader van dit onderzoek ga ik uit van een 'pragmatische benadering van kinderpoëzie'. 'Het taalspel poëzie' openbaart zich aan jonge kinderen als een bijzondere vorm van taalgebruik. Zij leren 'het taalspel poëzie' kennen en gebruiken in de vorm van specifieke soorten taaluitingen, vooral gekenmerkt door ritmische (klank)patronen én ingebed in vaste, terugkerende contexten van tekstgebruik. Bij dergelijke teksten hebben we er weinig aan te analyseren wat er staat en hoe het er staat (tekst/syntaxis) om van daaruit te interpreteren wat daarmee wordt bedoeld (betekenis/semantiek). Voor jonge kinderen zijn dat niet de aspecten op basis waarvan 'het taalspel poëzie' primair betekenis krijgt. Er is echter nog een derde component die maar weinig (structureel) in aanmerking wordt genomen in de literatuur- of poëziebeschouwing: de pragmatische component van taalgebruik (Dijk, 1980, p. 5). In ons 'natuurlijke', alledaagse taalgebruik is deze pragmatische component verantwoordelijk voor een groot deel van wat we met taaluitingen bewerkstelligen, of doen. In de taaltheorie houdt de pragmatiek zich bezig met dat deel van taalgebruik dat geconcentreerd is op talig handelen, gevat in de term 'taalhandeling'42, in een specifiek soort communicatieve situatie of context (p. 3). Gezien in die context is een taalhandeling nooit

\footnotetext{
42 Deze term is vooral te danken aan taalfilosoof J.L. Austin (How to do Things with Words: The William James Lectures delivered at Harvard University in 1955, uitgegeven in 1962 onder redactie van J.O. Urmson en Marina Sbisà, Oxford: Clarendon Press) en de verdere uitwerking door Searle (Speech Acts: An Essay in the Philosophy of Language, uitgegeven in 1969, Cambridge University Press).
} 
alleen maar een 'zeggen' of een 'betekenen', maar ook - en van cruciaal belang - een daad of handeling ('actie') die een effect teweegbrengt ('reactie') die samen interactie tussen leden van een taalgemeenschap vormen (p. 5). Uiteraard spelen syntactische en semantische aspecten van 'het taalspel poëzie' daarin ook een rol, maar ik spreek van een 'pragmatische benadering van kinderpoëzie' omdat dit aangeeft dat vormen en zeker betekenissen van poëzie voor jonge kinderen naar verwachting primair gebonden zijn aan wat er met een rijm of lied gedaan wordt, waar, wanneer, hoe, door wie en waartoe (vgl. Rooijakkers, 2000a, pp. 110-111). Niet de taal, maar de taalhandeling vervult de primaire communicatieve functie en brengt betekenis tot stand. Die 'betekenis' is gebaseerd op bepaalde condities of gebruiksconventies gekoppeld aan een specifieke handelingscontext of communicatiesituatie en moet dus primair in pragmatisch perspectief begrepen worden. We gaan weer even terug naar het begin: in Op poëtische wijze stellen de auteurs dat wat 'het poëtische' tot stand brengt en karakteriseert, gezien moet worden als het resultaat van de specifieke communicatiesituatie waarin poëzie als poëzie functioneert (Alphen et al, 2010/1996). In 'het taalspel poëzie' zoals zij dat identificeren, brengen zowel de poëtische leeshouding van de lezer als de poëtische spreekhouding van de woordvoerder in de tekst - het 'lyrisch subject' - 'het poëtische' tot stand (zie ook Meijer, 1997, p. 148). De aandacht voor de communicatiesituatie die 'het poëtische' karakteriseert, vormt een bruikbaar uitgangspunt om ook kinderpoëzie als betekenisvol te begrijpen in het gebruik ervan door kinderen omdat het proces van poëtische communicatie hier wordt voorgesteld als sociale actie. Echter, de poëzietheorie zoals uiteen gezet in Op poëtische wijze gaat uit van ervaren lezers die al gesocialiseerd zijn in de poëtische leeshouding en de bijbehorende leesconventies. Zij hebben het poëtisch communicatieproces verinnerlijkt en nemen de poëtische leeshouding aan omdat ze een tekst, bijvoorbeeld op basis van het onalledaagse, redundante, taalgebruik, als poëtisch herkennen. Omdat ze lezen, hebben ze ook de tijd om het poëtisch taalgebruik op zich in te laten werken, te analyseren en te interpreteren. Jonge kinderen zijn nog niet gesocialiseerd in de literaire of specifiek poëtische leeshouding: zij kennen de poëtische leesconventies niet. Vanwege hun positie tussen oraliteit en geletterdheid is de houding van jonge kinderen ten aanzien van poëzie per definitie anders dan die van ervaren en geschoolde lezers: jonge kinderen zijn noodzakelijkerwijze aangewezen op een (fysieke en mondelinge) gebruikshouding ten aanzien van poëzie. Baker- en kinderrijmen zijn daar, door opeenvolgende generaties van gebruikers, nauwkeurig op afgestemd. Baker- en kinderrijmen zijn van oudsher onderdeel van de orale traditie waarin niet de lezing, maar de performance, de mondelinge uitvoering van poëzie en, inherent aan de performance, ook de mondelinge overdracht en verwerving van poëzie centraal staat (zie ook Grijp \& Willaert, 2008, pp. 12-13). De verschillen tussen hoe 'het poëtische' voor ervaren lezers tot stand komt en hoe 'het poëtische' voor jonge kinderen tot stand komt, hangen in mijn optiek hoofdzakelijk samen met verschillen op het niveau van de pragmatische context.

De pragmatische benadering die ik hanteer is geenszins gericht op het maken van onderscheid tussen 'literaire (kinder)poëzie' en 'kinderversjes': ik wil juist de raakvlakken tussen het literaire en volksculturele domein benadrukken, maar dan vanuit het perspectief van de beoogde doelgroep. Dat betekent ook dat de 'pragmatische benadering' die ik hanteer niet gelijk is aan de strikt taalkundige pragmatiek, want ook die gaat uit van culturele conventies en helpt dus niet begrijpen hoe jonge kinderen die conventies verwerven. Taalkundige 
Teun van Dijk concludeert in 'The Pragmatics of Literary Communication', na een zoektocht naar de pragmatische uniciteit van literatuur als specifiek soort taalhandeling, dat vanuit pragmatisch perspectief het enige verschil tussen literatuur en vormen uit de orale volkscultuur is dat literatuur geïnstitutionaliseerd is, en dat er een literaire kritiek bestaat die invloed uitoefent op de waardering van de kwaliteit van literatuur:

"It is well known that the specific notion of 'literature', as such, is not very old. Indeed, our novels have their roots in everyday stories, myths, and folktales, and our poems in songs, hymns, etc. Functionally, then, our literature still belongs in the class where we also have our jokes, wise-cracks, dirty stories, etc. The differences with these kinds of communication, then, are not so much pragmatic as rather social: literature has been ... institutionalized; it is published, authors assume a specific status, it is reviewed in specific papers and journals, it is taken up in text books, discussed, analyzed, etc." (Dijk, 1980, pp. 9-10)

Voor jonge kinderen zelf speelt dit sociale, institutionele, verschil tussen literatuur en vormen uit de orale volkscultuur nog geen rol. En functioneel, i.e. pragmatisch, gezien verschillen een vers uit een bundel kinderpoëzie en een vers uit de mondelinge overlevering niet van elkaar. De meest exclusieve eigenschap die literatuur en vormen uit de orale volkscultuur vanuit pragmatisch perspectief met elkaar delen, zo stelt Van Dijk, is dat dit 'rituele' taalhandelingen zijn. Dergelijke vormen zijn 'quasi-taalhandelingen' omdat ze niet aan bepaalde waarheidscondities hoeven voldoen. 'Er zaten zeven kikkertjes' doet een bewering over de werkelijkheid, maar we zullen het liedje niet verwerpen omdat er niet écht zeven kikkertjes in een boerensloot zitten. Literatuur en vormen uit de orale volkscultuur hebben met elkaar gemeen dat ze, zo stelt Van Dijk, ten minste de communicatieve functie vervullen dat ze de houding van de toehoorder beogen te veranderen ten aanzien van de tekst zelf (vgl. Jakobsons 'poëtische functie'). En zelfs als ze daarin niet op de gewenste manier slagen, worden ze als het type taalhandeling dat ze beogen te zijn, niet verworpen. Als we een mop vertellen dan blijft de mop een mop ook als de toehoorder de humor er niet van inziet, en als we een gedicht schrijven, dan blijft dat zo ook als de literaire kritiek het geen geslaagd gedicht vindt (p. 9). 'Rituele' taalhandelingen dus.

Echter, deze pragmatische conventies zijn, niet anders dan de geïnstitutionaliseerde literatuurkritiek, cultureel bepaald en moeten door jonge kinderen verworven worden, i.e. onderdeel worden van hun culturele schemata. Zij leren 'het taalspel poëzie' aanvankelijk kennen in vormen die veelal context- en functiegebonden zijn: het slaaplied, het klapspelied, het aftelrijm, het verjaardagslied. De concrete pragmatische gebruikscontexten vormen de 'externe schemata' waarbinnen deze teksten hun poëtische gebruiksfuncties vervullen. Het is de vraag of jonge kinderen een slaaplied nog steeds als slaaplied zien, dus als 'rituele taalhandeling' herkennen, buiten de rituele context. Over hoe het proces van 'poëtische socialisering' precies verloopt en hoe tekst, lezer (gebruiker) en pragmatische context zich in verschillende stadia van dat proces tot elkaar verhouden, weten we echter nog nauwelijks iets. Door binnen het kader van dit onderzoek uit te gaan van een pragmatische benadering van kinderpoëzie en daarin het samenspel tussen contextuele, tekstuele en ontwikkelingsfactoren als uitgangspunt te nemen voor de formulering van verwachte indicatoren van 
canoniciteit' kan dit onderzoek bijdragen aan een nauwkeuriger inzicht in wat 'het taalspel poëzie' voor jonge kinderen is en doet, hoe zij het (leren) herkennen en hoe zij het begrijpen en waarderen.

\subsection{Conclusie en de eerste deelvragen voor de kinderpoëzie}

Het doel van dit onderzoek is evidence-based criteria te ontwikkelen voor de selectie van kinderpoëzie die effectief bijdraagt aan de ontluikende culturele geletterdheid van kinderen in groep 2 en groep 4 van het basisonderwijs. Voorwaarde is dat kinderpoëzie, om die bijdrage te leveren, enerzijds een bepaalde breedgedragen culturele waarde moet vertegenwoordigen en anderzijds nauwkeurig moet aansluiten op de culturele competentie van kinderen. Kinderen zijn pas net begonnen met het leren kennen van en met het plezier beleven aan poëzie; ze zijn nog niet gesocialiseerd in de poëtische leeshouding en bijbehorende leesconventies, en ze bevinden zich tussen oraliteit en geletterdheid. Dit heeft consequenties voor de wijze waarop kinderen poëzie benaderen en verwerven. De overwegingen in dit hoofdstuk wijzen erop dat er, in vergelijking met literaire benaderingen van kinderpoezie, een nieuw perspectief nodig is dat poëzie voor kinderen primair als zinvol of betekenisvol begrijpt in het gebruik ervan door kinderen in plaats van in (het communicatieproces dat ten grondslag ligt aan) de literaire interpretaties van haar formele en inhoudelijke eigenschappen door volwassen en ervaren lezers. Dit perspectief, althans, is nodig wanneer we willen begrijpen wat kinderen aanspreekt in kinderpoëzie, waar ze plezier aan beleven, wat ze waarderen en hoe ze poëzie begrijpen. Een centraal uitgangspunt in dit onderzoek is dat ik me laat informeren door kenmerken van volksculturele baker- en kinderrijmen omdat deze poëzie, gezien haar vitaliteit en langdurige populariteit, enerzijds een breed gedragen culturele waarde vertegenwoordigt en anderzijds kenmerken moet bezitten die haar bijzonder aantrekkelijk maken voor kinderen (zie ook Vloten, 1874/1871; Kes, Pollmann \& Tiggers, 1948; Enzensberger, 1969; Opie \& Opie, 1952, 1959, 1968, 1973, 1988; Schaerlaekens, 1977; Lurie, 1990; Eiselin, 1996). Wat kenmerkt deze transculturele en langdurig geliefde vormen van poëzie? Wat voor soort poëzie is het en hoe maken jonge kinderen zich deze vitale genres en tekstsoorten eigen? Met andere woorden: waar liggen de raakvlakken tussen kenmerken van 'canonieke' (transcultureel langdurig geliefde) baker- en vooral kinderrijmen en de factoren die een cruciale rol spelen in processen van poëzieverwerving bij jonge kinderen?

Uitgangspunt is dat in de communicatiesituatie waarin bakerrijmen en kinderliedjes als poëzie functioneren feitelijk nog geen sprake is van lezers, maar van gebruikers die niet vanuit een poëtische leeshouding, maar vanuit een 'poëtische gebruikeshouding' met de tekst omgaan in concrete mondelinge en fysieke interacties. Kort samengevat: kinderen doen poëzie in context. Er gelden dan ook andere culturele conventies in dergelijke concrete en sociaal georiënteerde toepassingen van 'het taalspel poëzie': conventies die naar verwachting een cruciale rol spelen in de langdurige en transculturele geliefdheid, i.e. 'canoniciteit', van dit cultureel erfgoed bij jonge kinderen. Om inzicht te krijgen in de functie en betekenis van poëzie in het leven van jonge kinderen, de verwerving van poëzie door jonge kinderen en de specifieke eigenschappen die een cruciale rol spelen in de duurzame populari- 
teit ('canoniciteit') van bepaalde soorten poëzie bij kinderen in de leeftijd van vijf tot en met acht jaar, moeten we het kindervers niet onderwerpen aan literaire interpretatie, of meten langs de meetlat van een 'abstracte Literaire Waarde', en volstaat het ook niet om de voorkeuren van kinderen te inventariseren op basis van surveys, plankstanden of uitleenen verkoopcijfers. We moeten poëzie voor kinderen heel concreet begrijpen als gereedschap of instrument, als gebruiksobject dat haar vorm en betekenis, haar vitaliteit en populariteit primair ontleent aan toepassingen in specifieke gebruikscontexten. Om te begrijpen wat poëzie voor jonge kinderen doet en is en hoe kinderen poëzie waarderen en verwerven, hanteer ik daarom een pragmatische benadering van kinderpoëzie. Deze benadering houdt er rekening mee dat jonge kinderen rijmen en liedjes leren kennen en gebruiken als materiële gebruiksvoorwerpen, als gereedschap waarbij de functie geen afgeleide is van de vorm van het object, maar de vorm een afgeleide is van - want toegespitst op - de functie van het object in gebruikscontexten. De functie en betekenis van het kindervers voor jonge kinderen wordt, zo is mijn uitgangspunt, in de eerste plaats bepaald door de wijze waarop het waar en wanneer, met welk doel en door wie gebruikt wordt. Op tekstueel niveau worden baker- en kinderrijmen gekenmerkt door de alomtegenwoordigheid van vormen van 'betekenisloosheid' die, vanuit pragmatisch perspectief, onder te verdelen zijn in vormen van 'muzikaal taalspel' en vormen van 'nonsensicaliteit'. Vanwege de alomtegenwoordigheid van deze vormen van tekstuele 'betekenisloosheid' in volksculturele baker- en kinderrijmen, mogen we er van uit gaan dat ze functioneel zijn binnen de pragmatische contexten waarin ze van oudsher zijn ingebed en aansluiten op de culturele competentie en voorkeuren van kinderen. Deze algemene pragmatische karakterisering van volksculturele baker- en kinderrijmen vormt de basis voor de formulering van verwachte indicatoren van canoniciteit in kinderpoëzie.

Binnen dit onderzoeksproject zijn eerst verwachte indicatoren van canoniciteit geformuleerd en gespecificeerd op basis van literatuurtheoretische en etnologische inzichten in specifieke tekstsoorten of genres en de analyse van primaire teksten, gecombineerd met ontwikkelingspsychologische inzichten in de doelgroep. Om te komen tot evidence-based criteria voor de selectie van kinderpoëzie die effectief bijdraagt aan de ontluikende culturele geletterdheid van kinderen in groep 2 en groep 4 van het basisonderwijs zijn de verwachte indicatoren gebruikt om selecties van - zowel volksculturele als literaire - poëzie samen te stellen voor groep 2 en groep 4 die via een interventieprogramma, het Leeskalenderproject, zijn geïmplementeerd in de praktijk van het basisonderwijs (zie Hoofdstuk 6 en 7). Stap 1 was echter de formulering en specificatie van verwachte 'indicatoren van canoniciteit' voor de kinderpoëzie. Dit vertaalt zich in een deelprojectspecifieke herformulering van onderzoeksvraag 2 en de formulering van deelvragen (zie kader hieronder). In de volgende drie hoofdstukken zal ik achtereenvolgens ingaan op de relaties tussen poëzie voor kinderen en pragmatische contexten van tekstacquisitie en -gebruik (Hoofdstuk 3), en de twee belangrijkste (inter)tekstuele kenmerken van die rijmen en liedjes in relatie tot relevante ontwikkelingskenmerken van de beoogde doelgroep (Hoofdstuk 4 en 5). Tegelijk bekijk ik waar de raakvlakken liggen met kinderpoëzie uit het literaire domein. Deze hoofdstukken leiden tot de formulering van verwachte 'indicatoren van canoniciteit' die via een selectie van kinderpoëzie in het interventieprogramma de 'Leeskalender' zijn geïmplementeerd in groepen 2 en groepen 4 van het basisonderwijs. In Hoofdstuk 6 tot en met 10 beschrijf ik de wijze 
waarop de implementatie heeft plaatsgevonden, welke methoden en instrumenten zijn gebruikt om de geformuleerde indicatoren te 'toetsen' aan de praktijk en bespreek ik de resultaten daarvan.

KINDERPOËZIE: ONDERZOEKSVRAAG 2 EN DEELVRAGEN

KP2. Welke contextuele, tekstuele en ontwikkelingskenmerken van langdurig geliefde en (trans)cultureel diepgewortelde soorten poëzie dragen naar verwachting het meest effectief bij aan bottom-up canonvorming, i.e. processen van poëzieverwerving, bij kinderen in groep 2 en kinderen in groep 4 (verwachte 'indicatoren van canoniciteit')?

KP2.a. Wat zijn de belangrijkste pragmatische contexten waarbinnen kinderen in groep 2 en in groep 4 in aanraking komen met 'het taalspel poëzie', welke functie(s) vervult 'het taalspel poëzie' binnen deze pragmatische contexten en hoe verhoudt de inbedding van 'het taalspel poëzie' in deze pragmatische contexten zich tot ontwikkelingskenmerken van de kinderen?

KP2.b. Hoe kenmerkt 'muzikaal taalspel' zich in 'het taalspel poëzie' voor kinderen in groep 2 en in groep 4, zowel in relatie tot pragmatische contexten van tekstgebruik als in relatie tot ontwikkelingskenmerken van de kinderen?

KP2.c. Hoe kenmerkt '(carnavaleske) nonsensicaliteit' zich in 'het taalspel poëzie' voor kinderen in groep 2 en in groep 4, zowel in relatie tot pragmatische contexten van tekstgebruik als in relatie tot ontwikkelingskenmerken van de kinderen?

Omdat binnen dit onderzoek ook empirisch is nagegaan hoe de pragmatische context in samenspel met tekstuele en ontwikkelingsfactoren werkt in processen van poëzieverwerving bij jonge kinderen (zie Hoofdstuk 9 en 10) biedt dit onderzoek een cruciale aanvulling op de top-down canonvormingsprocessen in de literaire kritiek en draagt het bij aan ons begrip van poëzie voor kinderen. De evidence-based criteria kunnen gebruikt worden voor de samenstelling van transculturele geletterdheidsprogramma's voor het basisonderwijs waarin ook poëzie een structurele plaats heeft. 


\section{HOOFDSTUK 3}

Kinderpoëzie in pragmatische contexten van tekstgebruik 



\subsection{Introductie}

In dit hoofdstuk staat de relatie tussen poëzie voor jonge kinderen en pragmatische contexten van tekstgebruik centraal. Het volksculturele kindervers is van oudsher per definitie gerelateerd is aan specifieke gebruikscontexten. De verwachting is daarom dat die inbedding van volksculturele kinderrijmen en -liedjes in handelingsgerichte pragmatische contexten sterk bijdraagt aan de canoniciteit van deze teksten, i.e. hun langdurige en transculturele geliefdheid (zie Hoofdstuk 2). Hoewel de oorsprong van baker- en kinderrijmen lang niet altijd in de kinderkamer of op de speelplaats ligt (Opie \& Opie, 1959, 1973; Lorbe, 1984), zijn deze teksten al wiegend, verzorgend, zingend, dansend en spelend in deze contexten terecht gekomen en van generatie op generatie doorgegeven. Jop Pollmann schreef: "De zang van het kind is vrijwel nooit abstract. De zang is gebonden aan de feesten van het jaar en vooral aan het spel. (...) Het lied heeft een functie in het kinderlijke leven." (Kes, Pollmann \& Tiggers, 1948, p. 7, cursief in origineel) We weten alleen nog niet zoveel over de precieze rol die de inbedding van 'het taalspel poëzie' in pragmatische contexten speelt in processen van poëzieverwerving bij jonge kinderen. Daarom kijk ik niet alleen naar wat de belangrijkste gebruikscontexten zijn waarin 'het taalspel poëzie' voor jonge kinderen is ingebed, maar wil ik ook begrijpen wat 'het taalspel poëzie' in die gebruikscontexten doet en hoe dit, naar verwachting, bijdraagt aan poëzieverwerving bij jonge kinderen. De deelvraag die dit hoofdstuk beoogt te beantwoorden, is:

KINDERPOËZIE: DEELVRAAG 2.a.

Wat zijn de belangrijkste pragmatische contexten waarbinnen kinderen in groep 2 en in groep 4 in aanraking komen met 'het taalspel poëzie', welke functie(s) vervult 'het taalspel poëzie' binnen deze pragmatische contexten en hoe verhoudt de inbedding van 'het taalspel poëzie' in deze pragmatische contexten zich tot ontwikkelingskenmerken van de kinderen?

Het doel van de exploratie van de relatie tussen poëzie voor jonge kinderen en gebruikscontexten in dit hoofdstuk is de formulering van theoretisch onderbouwde verwachtingen over de rol die de inbedding van poëzie in pragmatische contexten speelt in processen van poëzieverwerving en de formulering van concrete criteria voor de selectie van kinderpoëzie in relatie tot die pragmatische contexten. Die criteria zijn in dit onderzoek gebruikt voor de samenstelling van het poëzie-aanbod zoals dat in het interventieprogramma, het 'Leeskalenderproject', voor groep 2 en groep 4 is opgenomen en beproefd in de praktijk van het basisonderwijs.

Zoals ik in Hoofdstuk 2 heb aangegeven, ga ik voor de formulering van indicatoren van canoniciteit steeds uit van repertoires van volksculturele kinderrijmen en - liedjes ${ }^{43}$. Om de

\footnotetext{
${ }^{43}$ Het is van belang te benadrukken dat ik met dit hoofdstuk noch de volgende twee hoofdstukken wil beweren dat kinderen per definitie, en ook vandaag de dag nog, structureel in aanraking komen met en gebruik maken van traditionele baker- en kinderrijmen in het primaire opvoedingsmilieu. Binnen het kader van dit onderzoek ga ik, voor de identificatie van verwachte 'indicatoren van canoniciteit', uit van baker- en kinderrijmen uit de orale volkscultuur om een aantal andere redenen, namelijk: (1) omdat dit vormen van 'het taalspel poëzie' zijn die, cultuurhistorisch gezien, een vaste plaats hebben in de brede alledaagse cultuur en het aannemelijk is dat vormen als het wiegelied of slaaplied, het aftelrijm en het feestlied nauwkeurig aansluiten op de ontluikende culturele competentie van jonge kinderen, en (2) omdat de soorten rijmen en liedjes uit de 'canon van de volkscultuur' - net
} 
deelvraag die in dit hoofdstuk centraal staat te beantwoorden voor zowel groep 2 als groep 4 is daarbij een ontwikkelingsperspectief op de relatie tussen poëzie en pragmatische contexten nodig. Daarom begin ik daar waar de poëtische socialisatie van zeer jonge kinderen van oudsher begint en volg ik de lijn tot de basisschoolleeftijd. Eerst beschrijf ik de soorten poëzie die van oudsher zijn ingebed in de context van de verzorging van het zeer jonge kind (\$3.2) en de functies die 'het taalspel poëzie' in die context vervult (\$3.3). Vervolgens volg ik de belangrijkste vertakkingen die daaruit voortkomen, te weten de contexten van de vieringen in het jaar en in het leven enerzijds en het kinderspel anderzijds. Ik beschrijf eerst de soorten poëzie voor kinderen die van oudsher zijn ingebed in de context van de vieringen in het jaar en in het leven (\$3.4) en de functies die 'het taalspel poëzie' in die contexten vervult (\$3.5), gevolgd door de soorten poëzie die van oudsher zijn ingebed in de context van het kinderspel (\$3.6) en de functies die 'het taalspel poëzie’ in die context vervult (\$3.7). Ten slotte geef ik een algemene typering van de relatie tussen 'het taalspel poëzie' voor kinderen en pragmatische contexten in de cultuur van het dagelijks leven in ontwikkelingsperspectief (\$3.8) en formuleer ik de eerste 'indicator van canoniciteit' gespecificeerd in criteria voor de selectie van kinderpoëzie voor groep 2 en groep 4 (\$3.9). De tekstuele kenmerken die naar verwachting een cruciale rol spelen in de canoniciteit van poëzie voor kinderen beschrijf ik in de volgende hoofdstukken.

\subsection{Het begin: 'Het spel van moeder en kind'44}

De bakerrijmen vormen voor veel kinderen de eerste kennismaking met poëzie (inclusief liedjes) en daarmee het begin van hun 'poëtische socialisatie'. In de Encyclopedie van de jengdliteratuur wordt het bakerrijm als volgt beschreven: "De benaming bakerrijm verwijst naar de bakers, vrouwen die tot taak hadden de kraamvrouw en de pasgeboren kinderen te verzorgen. Zij zongen voor de kinderen onder meer wiegeliedjes, knierijversjes, schootspelletjes en vingerrijmpjes." (Van Coillie, Linders, Niewold \& Staal, 2004, p. 27) Tegenwoordig worden wiegeliedjes en bakerrijmen binnen gezinnen door (groot)ouders of oudere broers of zussen gebruikt in interacties met zeer jonge kinderen ${ }^{45}$. Ook zien we dat rijmen en

zoals de sprookjes en fabels, raadsels en spreuken, moppen en grappen - deel uitmaken van een internationale traditie (Lierop-Debrauwer \& Mooren, 2004: 11) en zich daarom bij uitstek aandienen als 'poëtische modellen' die aansluiten op de ontluikende culturele competentie van cultureel pluriforme groepen kinderen. De verwachting is dan dat kinderpoëzie uit de literaire overlevering die bepaalde pragmatische en tekstuele overeenkomsten vertoont met kinderpoëzie uit de orale volkscultuur in aansluiting op de ontwikkelingskenmerken van kinderen, beter bij kinderen in de smaak valt en effectiever door hen verworven wordt dan poëzie die dat niet doet. Dat is een theoretische verwachting die ik specificeer op basis van theoretische en tekstuele verkenningen van poëzie voor jonge kinderen (Hoofdstuk $3 \mathrm{t} / \mathrm{m}$ 5) die vervolgens via het interventieprogramma in de praktijk van het basisonderwijs is getest (zie Hoofdstuk $6 \mathrm{t} / \mathrm{m} \mathrm{10)}$.

${ }^{44}$ Deze titel is een verwijzing naar de uitgave Het spel van moeder en kind. Oude kinderrijmen voor jonge ouders (TroelstraBokma de Boer \& Pollmann, 1948, De Toorts) waarin (een deel van) de collectie bakerrijmen van Sjoukje Troelstra-Bokma de Boer (bekend als Nienke van Hichtum) is uitgegeven.

${ }^{45}$ Er zijn voor het Nederlands taalgebied geen studies waarin het hedendaagse gebruik van bakerrijmen en -liedjes binnen het gezin structureel in kaart is gebracht. Waarschijnlijk bestaan er grote verschillen in de mate waarin dit gebruik nog voorkomt binnen gezinnen. Met de technologische ontwikkelingen in het achterhoofd kunnen we speculeren dat een deel van de mondelinge overdracht is vervangen door het gebruik van televisie, cd's, Dvd's, mp3-spelers, Youtube en elektronische muziekmobielen voor boven de wieg. In een kleinschalig (N=91) surveyonderzoek in Engeland naar 'Mothers' attitudes to singing to their infants' rapporteerde echter geen enkele moe- 
liedjes uit deze categorie een plaats hebben gekregen in de dagelijkse praktijk binnen kinderopvang en peuter- en kleuterschool waar repertoires van bakerrijmen worden aangevuld met kring- en rijspelliedjes en nieuwere peuter- en kleuterversjes bij terugkerende activiteiten in de betreffende context, zoals de seizoenen, dagopening en -sluiting, eten en drinken, naar buiten en naar binnen gaan (Weterings, 2004).

De wiegeliederen en bakerrijmen vormen voor veel kinderen een eerste kennismaking met poëzie, maar zijn in de volksculturele traditie strikt genomen van een andere categorie dan het kinderrijm. Wiegeliederen en bakerrijmen behoren tot het poëtisch instrumentarium van bakers, ouders en andere verzorgers in de verzorging van zeer jonge kinderen. Officieel zijn bakerrijmen dus instrumenten die door volwassenen werden en worden gebruikt en niet zozeer door kinderen zelf, behalve dan wanneer ze volwassen zijn en dezelfde rijmen en liedjes aan hun eigen kinderen overdragen (Chukovsky, 1971/1925). Dat we hier hoofdzakelijk met het poëtisch instrumentarium van volwassen gebruikers te maken hebben, wordt onder meer gereflecteerd in de inhoud van veel traditionele wiegeliederen waarin vooral de zorgen of wensen van de baker of moeder tot uiting komen ${ }^{46}$ (Meijer, 1997). Ook in de herkomst van veel bakerrijmen en -liedjes komt het gebruik door volwassenen naar voren. Kijkend naar de oorsprong van bakerrijmen wijzen Iona en Peter Opie in hun voorwoord op The Oxford Dictionary of Nursery Rhymes de rijmende alfabetten, de 'infant amusements', en de wiegeliederen aan als de enige vormen die speciaal voor het zeer jonge kind zijn gemaakt; de overige bakerrijmen zijn fragmenten van balladen en volksliedjes, drink- en straatliederen, overblijfselen van eeuwenoude gebruiken en rituelen, verhalen van historische gebeurtenissen of figuren, of herinneren aan het spel van straatspelers (1973, pp. 3-4). De Opies maken daarnaast een duidelijk onderscheid tussen de nonsensjingles, humoristische liedjes, karakterrijmen, wiegeliederen, 'infant amusements' (rijmen die een spelletje begeleiden), 'nursery counting-out formulas', babypuzzels en -raadsels, rijmende alfabetten, tongbrekers, kindergebedjes en een aantal 'singing games' die door volwassenen op het kind worden overgedragen in de voorschoolse fase (nursery age), en rijmen en liedjes die strikt genomen aan oudere kinderen toebehoren (1973, p. vii). Ondanks het feit dat bakerrijmen voorafgaan aan de leeftijdsfase van de kinderen die in dit onderzoek centraal staan, is het toch informatief om aandacht te besteden aan het gebruik van bakerrijmen en wiegeliederen omdat deze repertoires inzicht bieden in de basale relaties tussen poëtische teksten en de pragmatische contexten van tekstgebruik in het leven van het jonge kind. Zij

der dat ze nooit zingt voor haar zeer jonge kind (Street, Young, Tafuri \& Ilari, 2003, p. 4). Websites als 'Mama Lisa's World: International Music \& Culture, Kid Songs Around The World' (http://www.mamalisa.com/) en Youtube fungeren tegenwoordig als geglobaliseerde verzamelplaatsen van rijmen en liedjes voor kinderen van over de hele wereld en vormen interessante bronnen om het materiaal op transnationaal niveau te vergelijken. In Bijlage 6 zijn de resultaten van een eigen survey te vinden over de bekendheid met en het gebruik van rijmen en liedjes in het gezin, gehouden onder de ouders van kinderen die deelnamen aan dit onderzoek.

${ }^{46}$ Sommige van deze liedjes geven uiting aan wat er van het kindje gewenst wordt, van de simpele wens dat het gaat slapen tot aan de wens van de verzorger om van zijn of haar taken verlost te zijn: 'Suja, suja, kooien, / De kippetjes in de bonen, / De schaapjes in het groene gras, / Ik zou, dat 't kindje groter was.' ('Spel van moeder en kind, p. 6); sommige bevatten aanwijzingen voor de verzorger, bijvoorbeeld wat te doen als het kindje niet slapen wil: 'Roe, roe kindeke, / Hoe bende gij zo stout! / Hebt gij pijn in 't buikje, / Of zijn de voetjes koud? / Dan zult de roomske drinken / Al van die bonte koe. / Dan zullen wij pappetje koken, / Doe, kindje, uw oogjes toe!' ('Spel van moeder en kind', p. 9). Regelmatig bevatten de liedjes een uiting van moederlijke bezorgdheid om het welzijn van haar kind, maar soms ook een uiting van moederlijke bezorgdheid om haar eigen welzijn: 'Doderido, mijne Mertiko, / Patrijskes en zijn geen vinken. / Als mijn lief mij nie en wilt / Dè gon ik mij verdrinken.' (p. 17). 
vormen het begin van de poëtische socialisatie van kinderen in de cultuur van het dagelijks leven en daarmee ook de basis voor hoe jonge kinderen 'het taalspel poëzie' leren kennen, begrijpen en (mee)spelen.

Er bestaan vele verzamelingen en bloemlezingen van bakerrijmen en wiegeliedjes uit de orale volkscultuur (o.a. Van Vloten, 1874; Troelstra-Bokma de Boer \& Pollmann, 1948; Abramsz, 1984/1910; Buul \& Stigter, 1993; Vries, 2002, 2003; Komrij, 2008; Van Camp, 2011). De meeste van deze bronnen zijn samengesteld en/of geordend op basis van terugkerende handelingspraktijken in de verzorging van zeer jonge kinderen, zoals opstaan en slapengaan, eten, wassen, kleden, en ook spelen. Jop Pollman schrijft in zijn inleiding op de bundel Oude Kinderrijmen voor Jonge Ouders. Het spel van moeder en kind over de ordening van de rijmen en liedjes: "De volgorde der liedjes en rijmpjes [in deze bundel] werd bepaald door de dubbele chronologie van het ouderwordende kindje en van de normale gang van zaken op iedere dag." (Pollmann, 1948, p. XVIII) In de volgorde die deze dubbele chronologie oplevert, staan de wiegeliedjes voorop, komen dan de liedjes bij het wassen en kleden, dan de schootspelletjes en de gesprekjes, en staan de knie-rij-rijmpjes achteraan omdat die - we bevinden ons hier in 1948 -, "meestal pas aan de beurt komen als het kindje ouder is en als Vader thuiskomt" (ibidem), samen met leren lopen en de liedjes bij het naar bed toe gaan. Bij Van Vloten (1874) komen we rijmen tegen waarin de geboorte van het kind centraal staat ('Toen 't kindje op de wereld kwam'), en de eerste spelletjes met de handjes ('Draai er het wieltje nog er eens om'; 'Handje plak'; 'Torentje, torentje bussekruit') en de voetjes ('Dit voetje, dat voetje, lip, lap, lorum'; 'Dag, Jan! (linkervoetje gepakt). Dag, juffrouw! (rechtervoet)/ Kan Jan juffrouw ook een paar schoentjes maken?'). Dan volgen de rijmen waarin meer lichaamsdelen worden benoemd en aangeraakt, de eerste ABC-rijmen en rijmen met dierengeluiden, en de eerste schootspelletjes waarbij het kindje omhoog wordt gewipt ('Tante Nans/ Zat op een gans;/ 'Wip!' zeî de gans,/ En weg vloog tante Nans'; 'Jantje,/ Wide, wadde, wantje,/ Wide, wadde, winkel, tinkel, tantje;/ 'Hip!' zei Jantje'). Ook vinden we vele slaapliedjes ('Slaap, kindje, slaap'; 'Suja, suja, kindje’; 'Klaas Vaak die komt'), dialoogspelletjes met de vingers en de tenen ('Naar bed, naar bed, zeî Duimelot'; 'Duimelot is in 't water gevallen'; 'Deze man heeft een koe gekocht'). Vervolgens komt het paardje rijden op de knieën ('Danderomdeine kwam van Brugge'; 'Schok, schok, schok,/ De boer rijdt om een rok'; 'Ju ju, paardje'; 'Ziet, zoo rijen de Heeren'), het schuitje varen door tegenover elkaar te zitten en met de handen vast heen en weer te bewegen ('Roeien, roeien naar grootje toe'; 'Schuitje varen, theetje drinken'; 'Kroene kranen,/ Witte zwanen'), maar ook de eerste verhaaltjes en gesprekjes ('Ik kwam laatst in een poppekraam'; 'Goeien avond, Tante Betje,/ Goeien avond, oome Jan'; 'Hoe laat is 't?/ Twaalf uren'), de karakterrijmen ('De dominee van Urk'; 'De bisschop van Munster'; 'Prins Robbert was een sjentelman'), rijmen over de dood en het dodenrijk (Engeland = Engelland), de leugenliedjes, grappige verhaaltjes en onzinnige rijmen ('Ouwe Jan en jonge Jan,/ Die zouden samen pompen;/ Ouwe Jan, die brak zijn been,/ En jonge Jan zijn klompen'; 'Adam en Eva,/ Die zaten op een tonnetjen;/ Adam had een rokjen aan/ En Eva een japonnetjen’). Grofweg herkennen we hierin een ontwikkeling van een aanvankelijke gerichtheid op het lichaam en de lichaamsdelen via een gerichtheid op formele aspecten van taal en taalgebruik naar een gerichtheid op de wereld en het verhalende (hoe vreemd die verhaaltjes ook mogen zijn). 


\subsection{Functies van het bakerrijm}

Vanuit gebruiksperspectief vormen bakerrijmen wellicht het meest ontnuchterende poetisch gereedschap in ons cultureel erfgoed. Zeker de oudere onder de bakerrijmen zijn alles behalve lieflijk en zachtaardig. "Het echte kinderrijm is wars van alle gevoelerigheid, het is hard als een bikkel," schrijft Jop Pollmann (1948, p. X). Het gebruik ervan komt dan ook uit pure noodzaak voort, zoals Pollmann bondig samenvat in zijn inleiding op Het spel van moeder en kind:

"Er is een kind, dat niet kan slapen of nog op wil blijven, dat een slechte zin heeft of stout is, dat gewassen moet worden en gekleed. Er is een kindje, dat door moeder op de schoot en door vader op de knie wordt genomen, dat leert lopen, dat wegwijs moet worden in de rare bewegelijke dingen aan zijn handjes. Met dat kindje moet wat gedaan worden, opdat het zelf zal leren doen. Dan is het echte kinderrijm een arbeidslied, dat aan dat werk de nodige rhythmische regelmaat en melodische draging geeft." (Pollmann \& Troelstra-Bokma de Boer, 1948, p. IX)

Als arbeidslied ${ }^{47}$ kunnen we het traditionele bakerrijm en wiegelied koppelen aan alle functies die aan zingen als algemeen menselijke activiteit worden toegekend. Zo verlicht zingen fysieke arbeid door vocale en niet-vocale bewegingen te coördineren, houdt het tegenspoed (gevoelsmatig) op afstand met magische bezweringen, fungeert het als een bewaarplaats voor culturele kennis en kan het de solidariteit binnen een gemeenschap vergroten door het bevorderen van identificatie tussen zanger en publiek door het herhalen van gekoesterde waarden en idealen, en door het markeren van belangrijke overgangsrituelen (Trehub \& Trainor, 1998, p. 4788). In de koppeling tussen deze functies en volksculturele bakerrijmen en wiegeliederen lijkt het erop dat het gebruik van het bakerrijm deze functies, zoals het verlichten van de fysieke arbeid, het bewaren van culturele kennis en het markeren van overgangsrituelen, vooral voor de volwassen verzorger vervullen. Naarmate het kind ouder en mondiger wordt, gaat het echter steeds actiever participeren en zal het ook verschillende functies gaan ervaren. Daarmee vormen bakerrijmen en -liedjes het begin van de poëtische socialisatie van kinderen: ze leren kinderen niet alleen hun eigen lichaam, de taal en de wereld ontdekken, maar ook 'het taalspel poëzie'. We zien dan (a) dat de bakerrijmen en liedjes gericht op het zeer jonge kind gekoppeld zijn aan de dubbele chronologie van de dagelijkse tijd en de ontwikkeling van het ouder wordende kind, (b) dat de bakerrijmen en liedjes binnen die dubbele chronologie zonder uitzondering gekoppeld zijn aan concrete, fysieke, handelingspatronen, en (c) dat het gebruik van bakerrijmen en -liedjes een veelheid aan functies kan vervullen. In de ontwikkeling van het ouder wordende kind begint de ervaring van 'het taalspel poëzie' bij de fysieke ervaring van de vocale en niet-vocale hande-

\footnotetext{
${ }^{47}$ In The Puffin Book of Nursery Rhymes verwoorden Iona en Peter Opie de onromantische noodzaak van bakerrijmen eveneens heel beeldend: "The mother or nurse of former days did not croon her ditties because they were songs for children, but because - with her sleeves rolled up and arms in the wash-tub - they were the first verses to come into her mind when the children had to be amused." (1974, p. 7)

${ }^{48}$ Dit verbindt deze soms eeuwenoude liedjes ook nu nog met orale culturen waar zingen bijna altijd vergezeld wordt door ritmische beweging, zoals dansen, op drums slaan, het schudden van een rammelaar, het wiegen van een kind, of de repetitieve handelingen van fysieke arbeid (Trehub \& Trainor, 1998, p. 47).
} 
lingspatronen die door een ouder of andere verzorger worden gedaan met het kind (wiegen, voeden, kleden, wassen), gevolgd door rijmen en liedjes waarin de fysieke participatie van het kind wordt gestimuleerd in steeds complexere vormen (van simpele schootspelletjes waarbij bewegingen gestuurd worden door de volwassene tot complexere 'choreografieën' waarin het kind bewegingen zelfstandig nabootst). Vervolgens laten rijmen en liedjes waarin ook de talige participatie van het kind wordt gestimuleerd hen proeven van allerlei formele aspecten van taal en taalgebruik in steeds complexere vormen (van beginnende klanknabootsing in ABC-rijmen en rijmen met dierengeluiden tot uitgebreide dialoogrijmen). Ten slotte wordt de aandacht van kinderen gericht op de relatie tussen taal en de wereld (van het uitbeelden van woorden tot het spelen met de representatie van de wereld in de leugenliedjes, grappige verhaaltjes en onzinrijmen). Deze chronologie is in werkelijkheid niet zo strikt: veel van de vroege vormen blijven onderdeel van het gebruiksrepertoire naarmate het kind ouder wordt, maar globaal laten de bakerrijmen en -liedjes, naast het verloop van de dag van opstaan tot slapen gaan, ook een ontwikkeling zien die verloopt van de exploratie van het lichaam, dan van de taal en dan van de wereld.

Allereerst wijst dit verloop erop dat poëzie een communicatieve functie heeft die aanvankelijk los staat van de referentiële functie van taal: poëzie communiceert zeker voor pasgeboren kinderen als muziek, via de fysieke ervaring van klank, van melodie en ritme in de combinatie van vocale en niet-vocale handelingspatronen die sterk gestileerd en geformaliseerd zijn. Het lichamelijk effect van het horen van de stem, het zien van de moeder of vader, het voelen van het ritme en de aanraking in het wiegen, kietelen of spelen zijn daarbij van groot belang. Zij maken dat het wiegelied haar koesterende werking heeft, het kietellied haar activerende werking heeft, et cetera. Al vanaf de geboorte van een kind zoeken ouders naar betekenisvolle interacties die in eerste instantie gericht zijn op het opbouwen van een systeem van affectieve communicatie (Tronick, 1989, p. 113). Door vaste, voorspelbare patronen te ontwikkelen voor dergelijke interacties, is er grotere kans op een synchrone, gecoördineerde interactie waarin de affectieve signalen van ouder en kind op elkaar zijn afgestemd en wederzijdse behoeften vervult worden dan wanneer op willekeurige momenten en op willekeurige manieren wordt geprobeerd om dergelijk contact tot stand te brengen. Ouders en verzorgers streven daarbij naar synchrone affectieve communicatie met het kind die niet alleen wederzijds is, maar ook positief. Om dit te bereiken is het van belang dat zij zowel de emotionele staat van het kind als hun eigen emoties reguleren. Juist hierin, in de afstemming van wederzijdse positieve affectieve communicatie, vervullen de rijmen en liedjes een belangrijke functie in de vroegste levensfasen van kinderen. Repertoires van bakerrijmen en -liedjes vormen vanuit dit perspectief bewaarplaatsen van effectieve 'scripts' voor het tot stand brengen van positieve affectieve communicatie met zeer jonge kinderen in de dubbele chronologie van het verloop van de dagelijkse tijd en de ontwikkeling van het kind. In poëtisch taalgebruik speelt de specifieke, onalledaagse en vaak redundante ordening van taal daarin eveneens een belangrijke rol: die ordening wijkt zo sterk af van alledaags taalgebruik dat het de aandacht op zichzelf richt. Wat die poëtische ordening van taal doet, al voor zeer jonge kinderen, is de aandacht trekken én een directe lichamelijke ervaring teweegbrengen. Zoals Anne de Vries al schreef: "Eerst is het alleen maar klank en ritme, waarmee we worden gesust en in slaap gewiegd, 'suja, suja, kindje'.” (2000, p. 1) Het zijn de op lichamelijke ervaring gebaseerde effecten van poëtisch taalgebruik die voor jonge 
kinderen ten grondslag liggen aan hun primaire poëtische socialisatie, rechtstreeks verbonden aan de functies, gebruikstoepassingen en daarmee ook de betekenis van poëzie in terugkerende gebruikscontexten in de 'cultuur van het dagelijks leven'. De betekenis van poëzie voor jonge kinderen is dan niet primair in tekst, maar in tekstgebruik en de fysieke ervaring van teksteffecten gevat. Karen Coats stelt:

“... children's poetry accomplishes a feat even more profound than that of connecting us to a particular cultural heritage, with its unique histories, material conditions, and sense of humor. I would argue that children's poetry enables each of us, no matter what our culture, to move from being bodies in the world to being bodies in language." (Coats, 2013, p. 134)

Teksten als 'Ozewiezewoze' en 'Tene miene mutte' betekenen in referentiële zin niets, maar ze doen wel iets: hun betekenis komt voort uit hun gebruik, hun performance als toepassing in een specifieke gebruikscontext enerzijds en de fysieke ervaring van de poëtische effecten die ze teweegbrengen anderzijds. Dit is het primaire niveau waarop poëzie voor jonge kinderen werkt. Poëzie is daarin anders dan alledaags taalgebruik en ook anders dan verhalen. Taal wordt doorgaans gebruikt om aspecten van de wereld te benoemen, de wereld op te delen in categorieën, en taal biedt ons de mogelijkheden van abstrahering en conceptualisering, van verbeelding, waarmee we (onze ervaring van) de wereld ordenen en van betekenis voorzien. Naarmate kinderen ouder worden en hun cognitieve processen en taalgebruik zich ontwikkelen, komen ze verder af te staan van de lichamelijkheid, van de materialiteit van ons fysieke zijn in de wereld en in de taal. Poëzie voor kinderen behoudt die relatie doordat de ritmes en klanken van die poëzie - waarvan de metriek, de fonetiek en de structuren resoneren met het lichaam en lichamelijke processen - het lichaam behouden in taal, terwijl haar metaforen, overigens bijna altijd geworteld in zintuiglijke ervaring, kinderen helpen begrijpen wie ze zijn als subjecten en objecten in een wereld van tekens (Coats, 2013, p. 134). Dus poëzie behoudt het lichaam en de lichamelijke, zintuiglijke ervaring van de wereld in taal, ook wanneer ze via beschrijvingen en metaforen op conceptueel niveau werkt. Een rijm, lied of gedicht is vanuit dit perspectief in de basis een vertaling van een lichamelijke, zintuiglijke ervaring in metrische, klank- en structurele patronen die die ervaring op hun beurt reproduceren wanneer we dit 'taalspel poëzie' spelen. Voor zeer jonge kinderen, die de taal nog niet machtig zijn, kan poëzie niet anders dan op dit niveau 'werken'. De gerichtheid van poëzie op de fysieke ervaring van haar prosodische eigenschappen geldt echter niet alleen voor poëzie voor jonge kinderen. Zo wijst Jan de Roder in 'Het schandaal van de poëzie' ook op de ervaringsgerichtheid van poëzie voor volwassenen: poëzie is taalhandeling waarin 'betekenis' afhankelijk is van 'beleving' en die 'beleving' in hoge mate gestuurd wordt door ritmische verschijnselen die fysiek ervaren worden (Roder, 2001). Vanwege haar 'communicatieve muzikaliteit' is poëtisch taalgebruik zeer effectief in het tot stand brengen van 'betekenisvolle' interactie tussen volwassenen en zeer jonge, nog onmondige, kinderen. Vandaar ook dat met name moeders als vanzelf 'motherese' spreken tegen hun pasgeboren kinderen (zie \$3.8).

Daarbij schetsen verzamelingen van volksculturele bakerrijmen een beeld van de cruciale momenten in de dubbele chronologie van de dagelijkse tijd en het ouder wordende kind 
waarop door ouders en verzorgers gebruik werd en wordt gemaakt van die poëtische scripts. Die cruciale momenten zijn aanvankelijk vooral gekoppeld aan de gestructureerde routines in de cultuur van het dagelijks leven (zie Hoofdstuk 1, \$1.4), die de functie hebben om het dagelijks leven in gezinnen - maar ook op bijvoorbeeld kinderdagverblijven - te structureren via gedrags- en rolpatronen en om de onderlinge relaties te onderhouden (Bennet, Wolin \& McAvity, 1988, pp. 215-217). Die verankering van de rijmen en liedjes in terugkerende handelingspraktijken in de dubbele chronologie van de dagelijkse tijd en het ouder wordende kind, speelt naar verwachting een cruciale rol in de duurzame geliefdheid en vitaliteit, i.e. de canoniciteit, van volksculturele bakerrijmen en -liedjes. Zoals gezegd is dit echter slechts het allereerste begin van de poëtische socialisatie: de fase van de bakerrijmen wordt opgevolgd door de fase van de kinderrijmen die door kinderen zelf worden gebruikt. Deze rijmen doen hun intrede naarmate kinderen ouder en zelfstandiger worden en zich ook gaan verhouden tot groepen van andere kinderen. Vanuit de bakerrijmen en wiegeliederen zijn twee vertakkingen te onderscheiden in de belangrijkste pragmatische contexten waarin volksculturele kinderrijmen en -liedjes van oudsher een vaste plaats hebben: de feesten van het jaar en van het leven enerzijds, en het spel van kinderen onderling anderzijds (zie ook Kes, Pollmann \& Tiggers, 1948, p. 7).

\subsection{Het kindervers in de context van de vieringen in het jaar en in het leven}

"Poems have their origins in life, especially in the formal or informal ceremonies that occur at crucial moments or phases in a single private life - birth, adolescence, marriage, death - or at public moments when we collectively commemorate a war, a religious feast, a holiday." (Vendler, 2002, p. 3)

Er bestaat een sterke verbinding tussen poëzie en de vieringen en rituelen in het leven en door het jaar heen. Dit geldt net zo goed voor (literaire) poëzie voor volwassenen, waar bovenstaand citaat betrekking op heeft, als voor volksculturele kinderrijmen en -liedjes en kinderpoëzie uit het literaire domein. Van Vloten verzamelde verschillende kinderrijmen gebonden aan de feesten door het jaar heen ('Feestrijmen'; 1874, pp. 65-83). Bij Nieuwjaar vinden we allerlei variaties op de nieuwjaarsgroet, zoals: 'Gelukkig Nieuwjaar!/ Trek de kat bij het haar,/ Trek den hond bij de start,/ Dan heb je alle jaar wat.' Bij Driekoningen hoorde in de tijd van Van Vloten onder meer het gebruik 'kaarsje springen' dat werd vergezeld door een rijm als: 'Keuningskaarsje!/ Lik mijn aarsje!/ Keuningskaarsje, beentje!/ Al wie daar niet over en kan,/ Die gooi ik met een steentje.' Op Vastenavond werden eind negentiende eeuw nog lange liedjes gezongen bij het langs de deuren gaan voor geld of wat eten: 'Ik heb zo lang met den foekepot [ook wel 'rommelpot'] geloopen,/ 'k Heb geen geld, om brood te koopen,/ Foekepotterij, foekepotterij,/ Geef mij een oortje, dan ga ik voorbij.' Bij Palmpasen herkennen we in het volgende rijm het gebruik om met een brooddeeg haan op een houten kruis de Palmpaasoptocht te lopen: 'Palm-, palm-paschen;/ Een haantje op een stokje,/ Een gaatje door zijn rokje,/ Een stukje van zijn linkerpoot;/ Nu is 't heele haantje dood.' Met Pasen werden eieren opgehaald, maar ook wel brandbaar materiaal om een 
Paasvuur te maken: 'Heb je ook olle wanne,/ Die we Paoschmaandag kunne branne?/ Of 'n bosse riet? / Anders hewe Paoschmaandag niet.' Luilak is een gebruik dat traditioneel op de (vroege ochtend van de) zaterdag voor Pinksteren wordt uitgevoerd en bestaat uit het publiekelijk wekken en bespotten van langslapers, wat gepaard gaat met veel lawaai op straat en het scanderen van een rijm als: 'Slaapkop, doedelkop/ Staat voor negen uur niet op.' Bij Pinksteren zelf vermeldt Van Vloten slechts een rijm, dus waarschijnlijk gekoppeld aan een zeer lokaal gebonden gebruik, wat eveneens geldt voor 'Sint-Jan in den zomer'. Bij het feest van Sint Maarten, op 11 november, vermeldt Van Vloten vijftien verschillende rijmen, zoals: 'Sinte Marten is zo koud,/ Geeft een stuksken turf of hout,/ Om mij wat te verwarmen./ Geeft wat, houdt wat,/ 't Andre jaartje weêr wat./ De klok heeft twaalf geslagen,/ Mijn vrouw doet niets al klagen.' Van Vloten noemt ook '12 November (dag na St. Maarten)', maar geeft daar opnieuw slechts een rijm weer, uit 'Graft en omstreken' (NoordHolland). Bij 'Sint Nikolaas' vinden we zestien rijmen, waaronder de oude bekenden als: 'Sinterklaas, goed heilig man!/ Trek je beste tabberd an,/ Rijd er meê naar Amsterdam,/ Van Amsterdam naar Spanje,/ Appeltjes van Oranje,/ Pruimpjes van de boomen;/ Sinterklaas zal komen.' Kerstmis ging gepaard met een waar feestmaal, hoewel anders dan we tegenwoordig gewend zijn: 'Kerstavondje, kerstavondje,/ Mijn moeder kookt karnemelksbrij,/ Mijn vader slacht een haring,/ De kop die is voor mij.' En de verjaardag werd in de tijd van Van Vloten nog niet ingeluid met de overbekende liedjes van tegenwoordig, maar bijvoorbeeld met: 'Deze strik heb ik gebonden,/ Niet om kwaad en niet om zonden,/ Maar tot een gedachtenis,/ Daar 't vandaag jou jaardag is.'

De verklaring van de nauwe relatie tussen traditionele kinderrijmen en -liedjes en de context van de jaarfeesten is niet eenduidig. Een gedeeltelijke verklaring kan gezocht worden in het gebruik waarbij kinderen uit arme gezinnen langs de deuren gingen bij burgers en boeren om wat eten, brandstof of geld op te halen. Dit gebeurde zeker bij de winterfeesten uit pure noodzaak en wordt in veel volksculturele feestrijmen gereflecteerd in de tekst. Bij Nieuwjaar vinden we: 't Is Nieuwejaar, ik sta hier buiten:/ Ik heb een korfje, en 't wil niet sluiten;/ Ik heb een mesje, en 't wil niet snijen;/ Ik heb wel boter, maar hij wil niet braaien;/ Ik zie een koekje en kan 't niet koopen;/ Geef me een stuiver, en laat me loopen.' Sommige rijmen zijn nog steeds bekend, hoewel ze in de hedendaagse context niet meer overeenkomen met de werkelijkheid: 'k heb zoolang met den rommelpot geloopen,/ 'k Heb geen geld om brood te koopen;/ Rommelpotterij, rommelpotterij,/ Geef mij een oortje, dan ga ik voorbij.' Dergelijke bedelliedjes behoorden in de negentiende eeuw al tot het domein van het kinderrijm en verschenen veelvuldig in verzamelingen of bundels met kinderliedjes ${ }^{49}$. Tegenwoordig is het gebruik om zingend langs de deuren te gaan nog steeds bekend, bijvoorbeeld met Vastenavond, Driekoningen en Sint-Maarten. Overigens merkt Marie van Dijk ook op dat Sint Maartensgebruiken fluctueren, en dat geldt voor alle feesten en bijbehorende gebruiken en betekenissen: "Ze kunnen verdwijnen, voorgoed of tijdelijk, of zich verplaatsen.” (2000, p. 1) Bij Van Vloten is al zichtbaar dat er grote verschillen bestaan in de geografische spreiding van gebruiken gekoppeld aan vieringen: van een gebruik op 12 november is maar een enkel rijm bekend, wat erop duidt dat dit een zeer plaatsgebonden gebruik was, terwijl bij de viering op 11 november, Sint Maarten, in de tijd

49 Zie 'Nederlandse Liederenbank', zoekterm: 'bedellied' (http://www.liederenbank.nl/resultaatlijst.php?zoek veld=bedellied\&zoekop=trefwoord) 
van Van Vloten ten minste vijftien rijmen bekend waren, wat duidt op een wijdverbreid gebruik ${ }^{50}$. Als we kijken naar de feesten of vieringen die we in de drie bundeltjes Kinderzang en Kinderspel (Kes, Pollmann en Tiggers, 1948) tegenkomen, zeventig jaar later, dan zien we dat daar een aantal vieringen niet meer genoemd wordt en dat er enkele nieuwe feestelijke contexten zijn bijgekomen die we bij Van Vloten nog niet aantroffen. We vinden er liedjes gekoppeld aan Sinterklaas, Sint Maarten, Driekoningen, Palmpasen, Witte Donderdag, Pasen, Kerstmis en Vastenavond. Daarnaast zijn er enkele kermisliedjes, en nog steeds een liedje over de rommelpot ${ }^{51}$ waarmee ook in die tijd op Sint Maarten, oudejaarsavond, Driekoningen en/of Vastenavond langs de deuren werd gegaan. Ook staat het Wilhelmus in de eerste twee delen van de serie bundeltjes en zelfs een vakantieliedje, wat erop wijst dat langs de deuren gaan met de winterfeesten en op vakantie kunnen in de zomer elkaar in deze tijd niet meer uitsluiten ${ }^{52}$. Dat er vandaag de dag nog steeds veel rijmen en liedjes in omloop zijn in de context van de feesten van het jaar is onder meer af te leiden uit de vele bundels, cd's en Dvd's met feestliedjes en -rijmen die doorlopend op de markt worden gebracht. Daarbij is er ook steeds meer aandacht gekomen voor feestdagen en vieringen uit andere landen en culturen, al dan niet in Nederland vertegenwoordigd, met bijbehorende gebruiken en liedjes ${ }^{53}$. Bij het selecteren van kinderpoëzie gekoppeld aan de vieringen door het jaar heen moet dus altijd rekening gehouden worden met het feit dat sommige vieringen niet overal bekend zijn, dat vieringen en bijbehorende gebruiken kunnen verdwijnen of zich verplaatsen, en dat de feestkalender in de huidige Nederlandse samenleving multietnisch en multireligieus is.

In de instandhouding, revitalisering of introductie van feesten speelt, zeker daar waar het feesten of gebruiken voor kinderen betreft, het onderwijs een belangrijke rol. In 'Vieren en markeren: Feest en ritueel' stelt Gerard Rooijakkers vast:

"De kinderen leren op school bijvoorbeeld hoe ze een palmpaasstok moeten maken. In klasverband wordt ingegaan op de betekenis en achtergronden van het gebruik, waarbij

\footnotetext{
${ }^{50}$ De notie dat verschillende versies van eenzelfde rijm of lied, of verschillende rijmen of liedjes bij eenzelfde gebruik, de geografische spreiding van een gebruik weerspiegelen, hangt samen met het feit dat een bepaalde versie van een rijm en/of gebruik gekoppeld is aan een bepaalde plaats of streek.

${ }^{51}$ De rommelpot is een traditioneel muziekinstrument, ook wel de foekepot genoemd, en kon dus in feite bij alle gelegenheden waar kinderen zingend langs de deuren gingen, gebruikt worden ter begeleiding van de liedjes. Bij welke feesten dit werd gedaan, is afhankelijk van tijd en plaats.

52 Deze vergelijking tussen Van Vloten en Kes, Pollmann en Tiggers is niet betrouwbaar om daadwerkelijk te kunnen oordelen over levende gebruiken: de bundeltjes Kinderzang en kinderspel werden gebaseerd op bundels die in die tijd in omloop waren en waren bestemd voor de school- of huiskamercontext die andere eisen stelt aan de samenstelling dan Van Vlotens volkskundig perspectief. Het geeft wel een indicatie van de fluctuaties in kinderfeestlied repertoires en in de perspectieven op het volksculturele kinderlied. Kes, Pollmann en Tiggers profileren hun bundeltjes als "een protest tegen de veel te moeilijke melodieën die nog steeds veelvuldig aan onze kinderen worden voorgeschreven" en tegen "de praktijk van de teksten, die zogenaamd kinderlijk zijn en in werkelijkheid niets te maken hebben met de psyche van het kind." (p. 7)

53 Zie bijvoorbeeld de bundel Feestliedjes van ons allemaal (2006), samengesteld door Ingrid Rietveld met illustraties van Mies van Hout, waarin vieringen uit België, Bosnië, Griekenland, China, Spanje, Italië, Servië, Luxemburg, Denemarken, Duitsland, Tsjechië, Turkije, Hongarije, Noorwegen, Suriname, Groot-Brittannië, Marokko, Oostenrijk, Nederland, Frankrijk, Zwitserland, Zweden, IJsland, Finland en Polen aan bod komen, elk met een bijbehorend (kinder)lied. Ook in enkele andere bundels is aandacht voor culturele pluriformiteit, hoewel niet specifiek aan de vieringen gekoppeld, zoals in Heb je wel gehoord... Versjes en liedjes uit Opstap Opnieuw (2000) ter gelegenheid van het tienjarig bestaan van Opstap, een gezinsprogramma voor ouders en kleuters uit diverse culturen. Daarin zijn rijmen en liedjes opgenomen in het Nederlands, Turks en Marokkaans.
} 
naast een portie katechese niet zelden een Rücklauf van verouderde volkskundige inzichten gestalte krijgt. Ook bij andere kinderfeesten, zoals Driekoningen (6 januari) en Sint-Maarten (11 november), is er een wezenlijke invloed van scholen op de vorm- en betekenisgeving van het ritueel. ... Het onderwijs heeft ... een sterk socialiserende en acculturerende betekenis, die tot uitdrukking komt in het klassikaal vieren van rituelen van een andere etnische herkomst, zoals het mohammedaanse suikerfeest." (Rooijakkers, 2000b, pp. 202-203)

Tegelijk maken kinderen uit etnische minderheidsgroepen op school kennis met Sinterklaas, Kerstmis en Driekoningen en zo brengen scholen feesten en gebruiken uit verschillende religieuze en etnische tradities samen. Scholen hebben daarmee de potentie om ook bij te dragen aan de interculturele uitwisseling van repertoires van feestrijmen en -liedjes door niet alleen 'Fijne verjaardag' te zingen, maar ook 'İyi ki doğdun' of 'Sana helwa ya gameel'. We moeten er overigens in de context van feesten en vieringen rekening mee houden dat de liedjes en rijmen in officiële uitgaven zijn onderworpen aan een proces van 'domesticatie': “Ook oude sinterklaas- en kinderliedjes zijn uit de mondelinge overlevering opgetekend en via pedagogische uitgaven aan de moderne jeugd doorgegeven - in een gestandaardiseerde versie. Zelfs het kinderlied is dus niet meer 'onbedorven'." (Grijp, 2000 b, p. 350) Het aanbieden van teksten zoals ze zijn opgenomen in bundels met feestliedjes garandeert in die zin geen directe aansluiting op wat kinderen van thuis uit kennen: ruimte voor de inbreng van feestliedjes door kinderen zelf kan de herkenning en beleving versterken. Ongeacht fluctuaties in feestrepertoires vormen deze gelegenheden voor jonge kinderen een belangrijke context waarbinnen ze liedjes en rijmen verwerven en gebruiken. Kinderen worden op deze manier niet alleen opgenomen in een feestcultuur, maar tegelijk ook in een daaraan gekoppelde taalcultuur (zie o.a. Schaerlaekens, 1977). Een officiële taalcultuur, overigens, die vervolgens weer door kinderen wordt toegeëigend en onderworpen aan allerlei manipulaties die onderdeel uitmaken van de taalcultus binnen de kindercultuur ${ }^{54}$. We kunnen dus spreken van een voortdurende wisselwerking tussen de mondelinge en schriftelijke overlevering (vgl. Grijp, 2000b): een wisselwerking die in de schoolklas de betrokkenheid van kinderen bij poëzie in de context van vieringen mogelijk kan vergroten. Buiten dat de feesten als onderdeel van de cultuur van het dagelijks leven belangrijke contexten van poëzie-overdracht en -verwerving zijn voor kinderen (zie Hoofdstuk 1, \$1.4), vormen ze als concrete pragmatische (rituele) contexten ook de 'externe schemata' waarbinnen veel kinderrijmen en -liedjes hun poëtische gebruiksfuncties vervullen en daarmee ook betekenis krijgen. Wat leren deze contexten ons over de gebruiksconventies die ten grondslag liggen aan de primaire poëtische socialisatie van kinderen?

\subsection{Functies van het feestrijm}

De functies en betekenissen van rijmen en liedjes in de context van vieringen kunnen we op twee niveaus bekijken. Het eerste niveau is het niveau van het gebruik van een rijm of

${ }^{54}$ Over de tekstuele weerslag van deze wisselwerking meer in Hoofdstuk 4 en 5. 
lied binnen de rituele context: het feestrijm als ingebedde tekst. In de rituele gebruikscontext van vieringen zien we dat kinderrijmen en -liedjes altijd direct gekoppeld zijn aan een specifiek gebruik binnen die viering. Deze rijmen en liedjes zijn geen metateksten die gaan óver (de betekenis van) een feest, maar teksten in de directe rede die nog het best te typeren zijn als riten, als ceremoniële (taal)handelingen: 'Sinterklaas kapoentje,/ gooi wat in mijn schoentje,/ gooi wat in mijn laarsje,/ dank u, Sinterklaasje'. Het zijn daarbij in hoofdzaak performatieve taalhandelingen. Een rijm als ' $\mathrm{k}$ Wensch je veel geluk en zegen,/ Op dijken en wegen,/ Met krullen in 't haar; / Ik wensch je geluk en zegen in 't nieuwe jaar.' (Vloten, 1874, p. 65), is een poëtische formalisering - met parallellisme, rijm en metrum die dienen als bindmiddelen - van de nieuwjaarsgroet als cultureel gebruik. Ook de bedelliederen zijn heel duidelijk te karakteriseren als performatieve taalhandelingen. Ze hebben een pragmatische functie die voortkomt uit hun vroegere noodzaak (langs de deuren gaan om eten, geld, brandstof). Het zijn feitelijk liedjes waarin om iets gevraagd wordt, hoewel de vraag in het bedellied vaak goed verborgen is: 'Nieuwejaartje komt in 't land;/ Het varken heeft zijn gat gebrand,/ Van achter aan zijn poortje./ Moeder, geef me een oortje;/ Is 't geen oortje, dan is 't een duit,/ Morgen is 't Nieuwjaartje uit.' (p. 66) De vraag is hier gemaskeerd als eis ('Moeder, geef me een oortje;/ Is 't geen oortje, dan is 't een duit'), waar in veel bedelliedjes overigens ook een 'beloning' voor de gever aan gekoppeld is, zoals: 'Geef me een oortje,/ dan ga ik voorbij.' Een schrijver als Willem Wilmink moet dit gebruik gekend hebben, want in het gedicht 'Sint-Maarten' legt hij in de laatste strofe sterke nadruk op het 'voor-wathoort-wat' aspect: “Als we iets krijgen, loopt ons koor/ met alle lampions weer door,/ als ons niet open wordt gedaan,/ dan blijven wij gewoonweg staan,/ blijven wij vannacht hier staan." (Wilmink, 2006, p. 65)

In haar artikel over het 'Sint Maartenszingen' schrijft Marie van Dijk: "Het zingen is het onvoorwaardelijke middel om het beoogde doel te bereiken .... De te zingen (bedel)liedjes moeten op de een of andere manier gerelateerd zijn aan Sint Maarten of aan de folklore van zijn feestdag. Voor het overige lijkt het niets uit te maken wat of hoe er wordt gezongen." (2000, p. 1) De meeste teksten lijken dan ook, zo stelt Van Dijk, in hoge mate 'instant-made', terplekke verzonnen, zolang het maar (een soort van) rijmt en duidelijk maakt wat de zangers willen. De meeste hedendaagse liedjes waarmee langs de deuren wordt gegaan bevatten allerlei liedsegmenten van oudere versies, aangevuld met nieuwe regels. Ook wordt er veel gebruik gemaakt van bestaande melodieën. Zo wordt 'Elf november is de dag,/ dat mijn lichtje, dat mijn lichtje,/ elf november is de dag,/ dat mijn lichtje branden mag' gezongen op dezelfde melodie als 'O, wat zijn wij heden blij', 'Sinterklaas is op het dak' en 'Daar was laatst een meisje loos'. En zowel de 'Sinte sinte Maarten,/ de koeien hebben staarten' varianten als de 'Sinte Maarten mik mak' varianten worden op dezelfde wijs gezongen als 'Sinterklaas, kapoentje,/ gooi wat in mijn schoentje' (p. 5). Verschillende liedteksten die op bestaande melodieën worden gezongen, noemt men 'contrafacten' (Grijp, 2000b, p. 353). Deze tekenen van orale overdracht hangen sterk samen met de concrete situatie van het langs de deuren gaan: je weet niet of en wanneer er wordt opengedaan, dus improvisatie is een vereiste en daar komt bij dat korter en makkelijker liedjes sneller gezongen zijn waardoor meer huizen kunnen worden aangedaan en de buit dus groter is. Om dezelfde reden worden adressen met lange tuinpaden of opritten vermeden. Waar overigens wel tijd voor wordt vrijgemaakt is het gebruik van scheldrijmen. Van Dijk schrijft: "Er zijn mensen die 
doen alsof ze niet thuis zijn en met het licht uit zitten te wachten tot het tijdstip waarop het zingen voorbij is. ... Ze kunnen het volgende te horen krijgen: 'Hier woont een kikkerbil/ Die niks geven wil' eventueel gevolgd door 'Had ik het maar geweten/ Dan had ik op de stoep gescheten'.' (2000, p. 9) Ook bij Van Vloten treffen we een categorie 'Scheldrijmen' aan, al zijn deze niet specifiek aan de context van het langs de deuren gaan verbonden. Een verwensing is overigens, qua type taalhandeling, niet ver verwijderd van de wens. Dat wens en verwensing dicht bij elkaar liggen, blijkt ook uit het feit dat ze in verschillende volksculturele feestrijmen vermengd worden: 'Tk wens je al wat wenselijk is, / een bochel die ordentelijk is, / twee benen als een ooievaar,/ dat wens ik je voor het nieuwe jaar,/ een kop met rooie luizen,/ dan heb je wat te pluizen.' (Buul \& Stigter, 1993; Zwaagdijk, 1947) Hierin komt een fenomeen tot uitdrukking van de ogenschijnlijk paradoxale juxtapositie van pragmatische functie en semantische inhoud. De vorm (Nieuwjaarsrijm) 'sanctioneert' als het ware de ambiguiteit van de inhoud (wens/verwensing) waardoor de pragmatische functie, dus wat er bewerkstelligd wordt met het gebruik van de tekst, deels los komt te staan van de semantische inhoud, dus wat er eigenlijk gezegd wordt in de tekst. In de context van de feesten van het jaar staat de formele taalhandeling, de formele daad van het zingen of reciteren van een vers vaak boven de inhoud. Dit ondersteunt de verwachting dat het taalspel poëzie' haar betekenis voor jonge kinderen primair ontleent aan wie het waar, wanneer, hoe en waartoe gebruikt en niet zozeer aan wat er in de tekst staat, hoe het er staat en wat daarmee wordt bedoeld. Enerzijds leren dergelijke vormen van gebruikspoëzie kinderen 'how to do things with words' (vgl. Austin, 1962), de performatieve kracht van taal te gebruiken; anderzijds leren ze kinderen ook dat de poëtische vorm 'ritueel' is, in die zin dat de wens of verwensing in deze vorm in zekere zin 'virtueel' is, niet echt.

Het is hierbij echter van belang te wijzen op de mogelijke verschillen in de perceptie en beleving van rijmen en liedjes door kinderen binnen de context van feesten en vieringen. Gerard Rooijakkers schrijft: "Feesten en rituelen zijn welbeschouwd sleutels om toegang te krijgen tot de culturele categorieën van groepen mensen. Alles wat voor hen van belang, wat voor hen 'heilig' is, komt hierin tot uitdrukking." (2000b, p. 183) Kinderen worden in eerste instantie door volwassenen ingewijd in feesten, meestal door ze te laten participeren in specifieke riten binnen de context van het feest, zoals langs de deuren gaan, deelnemen aan een optocht, aan gebed, maaltijd, kerstspel, schoen zetten of eieren zoeken. Of kinderen deze riten ook als 'heilig' (zowel in seculiere als religieuze zin) beleven kan sterk variëren met de leeftijd van kinderen, maar is ook afhankelijk van de context en afhankelijk van de aansluiting op de culturele referentiekaders die kinderen van huis uit meekrijgen. Zo kunnen jonge kinderen 'heilig' geloven in het bestaan van Sinterklaas en dus ook in de reële werking van de liedjes die ze zingen bij het zetten van de schoen, ook zonder dat zij enige religieuze betekenis hechten aan de heilige figuur. Terwijl oudere kinderen het zingen van de Sinterklaasliedjes en het zetten van de schoen meer als spel beleven dat 'voor de vorm' wordt gedaan ${ }^{55}$. Dat spel en rituelen aan elkaar gerelateerd zijn, is op zichzelf geen nieuw

\footnotetext{
55 Verschillen in beleving komen deels tot uitdrukking in de teksten van feestliedjes en -rijmen. Waar jongere kinderen doorgaans de 'officiële', gedomesticeerde, versies van teksten gebruiken, zoals 'Sinte sinte Maarten,/ de koeien hebben staarten,/ de meisjes hebben rokjes aan,/ daar komt Sinte Maarten aan', gebruiken oudere kinderen vaak subversievere versies als 'Sinte Maarten mik mak,/ mijn moeder maakt een flik-flak,/ mijn vader maakt een koprol,/ middenin een hondendrol.' Dit aspect is evenwel diffuus, want ook kleuters kunnen met groot plezier subversieve versies van Sinterklaasliedjes zingen (zie ook Hoofdstuk 5).
} 
inzicht. De gezamenlijke viering van feesten wordt altijd gekenmerkt door de dynamiek tussen spel en ritueel, tussen 'communitas'56 en structuur (Rooijakkers, 2000b, p. 190). In The Ambiguity of Play noemt Brian Sutton-Smith, als toonaangevend onderzoeker van (kinder)spel, in een opsomming van vormen van spel of spelervaringen ook: "Celebrations and festivals: birthdays, Christmas, Easter, Mother's Day, Halloween, gifting, banquets, roasts, weddings, carnivals, inititations, balls, Mardi Gras, Fastnacht, Odunde.” (2001, p. 5) Hoe kinderen een viering en/of de rituele (taal)handelingen binnen die viering beleven, is van te voren moeilijk te zeggen, maar is wel een aspect om rekening mee te houden, zeker bij jonge kinderen. Variatie in beleving geldt voor alle vieringen en is ook binnen grotere culturele gemeenschappen en door de tijd heen waarneembaar, wat zichtbaar maakt dat feesten en bijbehorende rituelen complex zijn en meerdere betekenislagen hebben:

"Als gevolg van de voortschrijdende secularisatie is vaak nog maar een minderheid van feestvierend Nederland zich bewust van de christelijke betekenislaag in feesten als Kerstmis, Pasen, Hemelvaart en Pinksteren. Voor de betekenisgeving van decemberfeesten als sinterklaas en Kerstmis zijn momenteel factoren als huiselijkheid, vrijetijdscultuur, toerisme en commercie van groter belang dan de christelijke traditie rond de cultus van de heilige Nicolaas of de viering van de geboorte van Jezus. Daarmee is niet gezegd dat deze feesten daarmee hun sacrale dimensie verloren hebben. Maar de sacraliteit put wel uit andere bronnen dan (alleen) die van de christelijke traditie." (Nissen, 2000, p. 248)

Ongeacht verschillen in beleving en veranderende betekenissen, behouden feesten en de rituele handelingspatronen die daarbij horen, inclusief bijbehorende rijmen en liedjes voor kinderen, belangrijke functies. "[I]n de sociale praktijk hebben feesten juist betekenis voor de mensen die ze vieren. Ze markeren er enerzijds overgangen (statusveranderingen) mee, anderzijds bakenen ze de groep af." (Rooijakkers, 2000b, p. 184)

Vervulden de bakerrijmen nog belangrijke functies in de dubbele chronologie van de dagelijkse tijd en het ouder wordende kind en in het tot stand brengen van affectieve communicatie tussen ouder en kind; rijmen en -liedjes die onderdeel uitmaken van vieringen vervullen vergelijkbare functies, maar dan op het niveau van de jaarlijkse tijd en de levensloop en in het afbakenen van groepen mensen. De feestrijmen en -liedjes gekoppeld aan vaste handelingspatronen zijn daarbij belangrijke instrumenten waarmee kinderen actief kunnen participeren binnen de vieringen: dat is niet alleen van belang voor de verwerving, maar ook voor de instandhouding van die tradities. Want, zo benadrukt Rooijakkers, "[h]et in stand houden van tradities veronderstelt ... actief mensenwerk, waarbij de continuiteit van een ritueel wordt gegarandeerd door de voortdurende (re)productie van vormen en betekenissen.” (p. 212) Hiermee komen we meteen op het tweede niveau waarop we de functie en betekenis van rijmen en liedjes in de gebruikscontext van feesten en vieringen kunnen bekijken: het overkoepelende niveau van het verloop van de tijd. Op dit niveau kunnen we repertoires van feestliedjes en -rijmen beschouwen als een soort kalender, of

\footnotetext{
${ }^{56}$ Victor Turner gebruikte het begrip 'communitas' om “een onmiddellijke en totale momentane beleving van de groep als een homogene, niet-hiërarchische, ongestructureerde en vrije gemeenschap" (Rooijakkers, 2000: 190) aan te duiden, zoals dat bij het gezamenlijk vieren van een feest als tijdelijke toestand kan worden bereikt.
} 
beter: als markeringen op de kalender. In vergelijking met bakerrijmen gekoppeld aan "de dubbele chronologie van het ouderwordende kindje en van de normale gang van zaken op iedere dag" (Pollmann, 1948, p. XVIII), zijn feestrijmen en -liedjes voor iets oudere kinderen gekoppeld aan de dubbele chronologie van de lineaire levensloop en de circulaire jaarkalender. Specifieke feestrijmen en -liedjes horen bij specifieke rituele contexten door het jaar en het leven heen, van Nieuwjaarsdag tot Oudjaarsavond, van geboorte tot dood. De rijmen en liedjes markeren daarmee bepaalde 'cruciale momenten' op de kalender (vgl. Vendler, 2002, p. 3; Nissen, 2000, p. 244). De koppeling tussen rijmen en liedjes en de verschillende vieringen markeert daarmee terugkerende momenten in de tijd, maar ook het verschil tussen alledaagse en bijzondere tijd. Op deze manier markeert het gebruik van verschillende rijmen en liedjes in de context van verschillende feesten en vieringen voor kinderen bepaalde patronen van herhaling en afwisseling in de tijd. Tijd wordt op die manier geperiodiseerd en waarneembaar: "Periodisering heeft ... te maken met afwisseling, met terugkeer van hetzelfde na het andere, met ritme. De tijd zelf kunnen we alleen beleven als in periodes verdeeld: etmalen, seizoenen en de al veel abstractere periodes van generaties en tijdperken.” (Bronzwaer, 1993, pp. 15-16) Het verloop van tijd krijgt dan met het gebruik van rijmen en liedjes ritmische structuur en de momenten in de tijd waarbij wordt stilgestaan, worden betekenisvol.

\subsection{Het kindervers in de context van spel}

Naast de vieringen in het jaar en in het leven als belangrijke contexten waarin kinderen repertoires van rijmen en liedjes verwerven en gebruiken, is ook het kinderspel een niet te onderschatten domein waarin omvangrijke repertoires van rijmen en liedjes al generaties lang worden gebruikt en overgeleverd ${ }^{57}$ :

"Het echte kinderrijm kreeg in het spelende zingen zijn vorm: het werd spelend gedicht en gecomponeerd. ... Het kinderrijm is handeling, is spelend leren, zoals alle spel." (Pollmann, 1948, p. IX)

In de voor- en vroegschoolse fase spelen volwassenen nog een aanzienlijke rol in de overdracht van rijmen en liedjes met bijbehorende spelvormen. Hierbij valt te denken aan allerlei kring- en rijspelletjes als 'Zakdoekje leggen', 'Zeg, Roodkapje, waar ga je henen?', 'Twee

\footnotetext{
${ }^{57}$ De omvangrijke verzamelingen van kinderliederen en kinderrijmen uit de orale overlevering die door het Meertens Instituut voor onderzoek en documentatie van de Nederlandse taal en cultuur worden bewaard, vormen de cultuurhistorische getuigen van de mate waarin en de wijze waarop kinderen in Nederland sinds het einde van de negentiende eeuw gebruik hebben gemaakt van rijmen en liedjes. De laatste systematische verzameling stopt echter in 1965. Sindsdien is er nog wel kortdurend lokaal veldwerk verricht naar de rijmen en liedjes die kinderen gebruiken dat laat zien dat kinderen, zolang er plekken zijn waar ze ongestoord in groepen kunnen spelen, nog altijd gebruik maken van het orale kindervers. In zijn overzichtsartikel over de kinderliedverzamelingen van het Meertens Instituut stelt ook Louis Peter Grijp tentatief dat er 'natuurlijk nog steeds door kinderen wordt gezongen’ (Grijp, 2000a, p. 97) hoewel er geen systematisch onderzoek van recente datum is om dit voor het Nederlands taalgebied te staven. In de paragrafen over rijmen en liedjes in de context van spel heb ik, waar mogelijk, geprobeerd de oude verzamelingen aan te vullen met recenter studies waarin voorbeelden van het kinderlied en rijm als levende traditie onder kinderen te vinden zijn.
} 
emmertjes water halen', 'Jan Huigen in de ton' of 'Witte zwanen, zwarte zwanen'. Ook in de overdracht van deze vormen speelt het secundair opvoedingsmilieu een belangrijke rol: dergelijke rijmen, liedjes en spelvormen behoren vaak tot de standaardrepertoires van kinderdagverblijven, peuterspeelzalen en kleutergroepen. Zodra kinderen op schoolpleinen en speelplaatsen in contact komen met iets oudere kinderen worden de repertoires van de voor- en vroegschoolse fase verder uitgebouwd en deels vervangen. Kinderen gaan nu participeren in schoolpleinspelletjes die door kinderen onderling worden gespeeld als tikkertje en verstoppertje, touwspringen, klapspelletjes en balspelen.

Bij Van Vloten treffen we allerlei, voor een groot deel verdwenen, 'Spring- en dansrijmen' (1874, pp. 84-93) waaronder 'Wie gaat er meê naar de schermschool toe,/ Om te leeren schermen?/ Meester Schermer was niet thuis,/ Om te leeren schermen./ Stoot maar toe, stoot maar toe met jou verroesten degen,/ Driemaal om, en driemaal om,/ En driemaal drie is negen.' Maar we treffen in dezelfde categorie ook rijmen en liedjes die ook nu nog voorkomen, zoals: 'Tusschen Keulen en Parijs,/ Leit de weg naar Rome,/ Al wie met ons meê wil gaan,/ Die moet onze manieren verstaan:/ Zoo zijn onze manieren'; 'Hop, Marjannetje, stroop in 't kannetje,/ Laat de popjes dansen;/ Eertijds was de Prins in 't land/ En nu die kale Franschen.'; of 'Hedde niet gehoord van den zeuven, den zeuven,/ Hedde niet gehoord van den zeuvensprong? / et cetera.' Naast de 'Spring- en dansrijmen' vinden we bij Van Vloten ook rijmen en liedjes verbonden aan spelvormen van het type 'Zakdoekje leggen', 'Krui-wagentje', 'De koningsdochter', 'De kanonniken', 'Krijgertje', 'Blindemannetje en anderen', 'Touwtjespringen', 'Bikkelen', 'Ballen', 'Touter- of schommelrijmen', 'Pandverbeuren' en een heel aantal 'Tel- en aftelrijmpjes'. In de in totaal drie bundeltjes Kinderzang en Kinderspel (Kes, Pollmann \& Tiggers, 1948) voor kinderen in de leeftijd van zes tot tien jaar zijn liedteksten met muzieknotatie en bijbehorende spelbeschrijvingen van kringspelen, dans- en ritmische bewegingsspelletjes, rijspelen, klapspelletjes, balspelletjes, zoek- en verstopspelletjes, vang- en tikspelletjes, touwspringen, hinkelen, en ook hier het aftellen bij aanvang van een spel. Voor de uitgave Iene miene mutte: Over knik.keren, bokspringen en andere straatspelletjes verzamelde Judith Eiselin informatie over kinderspelen van 'meer dan honderd mensen van alle leeftijden uit het hele land' (1996, p. 8). Dat leverde een verzameling op van spelbeschrijvingen met bijbehorende liedjes en rijmen, soms al uit het straatbeeld verdwenen (bikkelen, hoepelen, tollen, bokspringen, pinkelen, noppelen of kaarten en klepperen), maar veelal nog altijd, of nog niet zo heel lang, gespeeld. Ze begint waar het spel begint: met de aftelrijmen. Vervolgens vinden we de kring- en rijspelletjes, hoewel de enorme variatie die uit historische bronnen valt af te lezen sterk is afgenomen, het touwtje springen en kaatsbal, tikkertje en overlopertje, hinkelen, knikkeren, het zogeheten pandverbeuren, gebaren- en geluidenspelletjes, klapspelletjes, verstoppertje, en allerlei (soms bijzonder creatieve) spelletjes tussen meisjes en jongens (Eiselin, 1996). Zo goed als elke genoemde spelvorm kenmerkt zich in de uitvoering door het gebruik van bijbehorende liedjes en rijmen. Er zijn aftelrijmen, rijmen bij het verzamelen van een groep deelnemers voor aanvang van een spel, rij- en kringspelliedjes, klapspelliedjes, liedjes bij het touwspringen en rijmen bij het elastieken en kaatsen, hinkelen en overlopertje (vaak gerelateerd aan het speltype 'pandverbeuren'). Het onderzoek van Eiselin is een relatief kleinschalig voorbeeld van de grote interesse die er bestaat in de spelletjes die kinderen op schoolplein en speelplaats spelen (zie o.a. De Cock \& Teirlinck, 1906; Opie \& Opie, 1969, 1997; Sutton- 
Smith, 1971, 1972, 1981, 1997) en de doorgaans aan spel verbonden rijmen en liedjes die kinderen op schoolplein en speelplaats gebruiken (Pollmann, Kes \& Tiggers, 1948; Opie \& Opie, 1947, 1959, 1985). We hebben hier van doen met een pervasief onderdeel van de kindercultuur: zeker voor kinderen in de leeftijd van zes tot twaalf jaar geldt dat zij beschikken over eigen repertoires van liedjes, rijmen en spelvormen (Opie \&Opie, 1969), voor een belangrijk deel aan elkaar gekoppeld, die ze van andere kinderen krijgen overgeleverd (Fine, 1980). De onderlinge taalcultus waar kinderen vanaf een jaar of vijf in toenemende mate aan deelnemen (Schaerlaekens, 1977), is voor een belangrijk deel onderdeel van een spelcultus, zeker waar het de kinderrijmen en -liedjes betreft (ook verhalen, moppen, raadsels, et cetera, maken deel uit van 'folklore' binnen de kindercultuur). De vele rijmen en liedjes die direct gerelateerd zijn aan fysieke spelvormen schetsen een beeld van hoe kinderen hun onderlinge speelse interacties reguleren. Getuige het feit dat de ritmische verschijnselen in deze 'poëzie van de speelplaats' zeer expliciet aanwezig zijn en vaak nog eens extra benadrukt door de overlapping met ritmische fysieke beweging (klappen, stampen, springen, dansen, etc.) blijft de lichamelijke ervaring voor kinderen in de basisschoolleeftijd nog lange tijd een expliciet onderdeel van 'het taalspel poëzie'.

Een belangrijk kenmerk van de specifieke soorten spel waaraan rijmen en liedjes zijn verbonden, is dat die vormen van spel altijd heel sterk gestileerd zijn. Er bestaan allerlei spelletjes op schoolpleinen en speelplaatsen waarbij kinderen in fysieke vorm stapelen, kettingen vormen, rijen of kringen maken, slingeren of draaien, precies hetzelfde of precies het tegenovergestelde bewegen. Een voorbeeld is dat kinderen een ketting vormen waarvan het voorste kind de hand op een boom (of paal) houdt. Tijdens het herhalen van de regel 'De boom, de boom,/ wordt hoe langer,/ hoe dikker,/ de boom, de boom...(etc.)' windt de rij kinderen zich als een spiraal rond de boom en als het een lange rij is dus ook om elkaar heen tot iedereen zich rond de boom heeft gedraaid. Vervolgens wikkelt de rij zich weer af onder het herhalen van de regel 'De boom, de boom,/ wordt hoe langer,/ hoe dunner,/ de boom, de boom...(etc.)' (Eiselin, 1996, p. 69). Het liedje 'Ik zou zo graag een ketting rijgen,/ maar ik kon de draad niet krijgen,/ ha, ha, victoria/ ha, ha, victoria' kan gepaard gaan met een spel waarbij kinderen een lange rij vormen waarvan de voorste met de hand tegen een muur een poortje vormt waar vervolgens de hele rij vanaf de achterste onderdoor kruipt als een lus die steeds strakker wordt getrokken totdat de voorste onder de eigen arm door moet draaien (p. 67). Er zijn kringspelen waarbij kinderen twee concentrische cirkels vormen die in tegengestelde richting ronddraaien, een enkele kring vormen die rond een kind in het midden draait of een enkele stilstaande kring vormen waar een kind omheen beweegt. Er zijn rijspelen waarbij kinderen twee rijen tegenover elkaar vormen en de rijen om de beurt vocale en niet-vocale handelingspatronen uitvoeren, of rijspelen waarbij een kind langs een rij heen en weer beweegt, et cetera. Ronddraaiende springtouwen bakenen ruimtes af waarbinnen de springer zich, op zijn of haar beurt al ronddraaiend, middenin de wetten van Newton begeeft. Al deze basisvormen bakenen de spelruimte af en delen die ruimte in. Binnen die basisvormen kunnen nog weer ingebedde patronen worden onderscheiden. Er zijn touwspringroutines waarbij in het springen wordt herhaald, omgekeerd, afgewisseld, in tempo gevarieerd; allemaal 'stijlfiguren' die ook in klapspelroutines, elastiekspringroutines, kring- en rijspelroutines herkenbaar zijn. Het stapelen, het vormen van kettingen, dubbele kringen, klap-, hinkel-, elastiek-, spring- en dansroutines zijn fysieke 
vormen van spel die sterk gestileerd en geformaliseerd zijn en waarin allerlei ritmische patronen worden gevormd. Gelijksoortige patronen komen we ook op tekstueel niveau tegen in kinderrijmen en liedjes (zie Hoofdstuk 4 en 5). We kunnen stellen dat de specifieke spelvormen waaraan kinderrijmen en -liedjes van oudsher verbonden zijn in zekere zin even 'poëtisch' zijn als de rijmen en liedjes zelf, omdat de vorm, de structuur, en de fysieke ervaring daarvan in deze spelletjes op de voorgrond staat en daarmee de aandacht op zichzelf richt. Dit in (betrekkelijke) tegenstelling tot vormen van symbolisch, of doen-alsof, spel die vaak een meer 'verhalende' structuur hebben.

\subsection{Spelfuncties van het kindervers}

In de gebruikscontext van het kinderspel kunnen rijmen en liedjes verschillende spelfuncties vervullen. Feitelijk begint dat al voordat er sprake is van spel. Zo schrijft Anne Marie Schaerlaekens in De taalontwikkeling van het kind: "Bij opkomende verveling beginnen kinderen het volgende versje in de groep te skanderen [sic]: 'Wat gaan we doen?/ kakken in onze schoen/ om morgen in de soep te doen/ Wat gaan we doen?/ kakken in onze schoen/ om overmorgen in de soep te doen." (1977, p. 182) Ook Judith Eiselin beschrijft hoe kinderen die aan het begin van een speelpauze een spel willen initiëren bijvoorbeeld met zijn tweeën of drieën over het schoolplein rennen en vragen wie er mee wil doen: 'Wie doet er mee met televisietikkertje?’ Wie zich bij de groep aansluit, moet wel toegewijd zijn: 'Wie er met ons mee wil doen,/ die krijgt een schop,/ en een klap voor zijn kop,/ en een trekkie aan zijn haar,/ en dan is het klaar!' (1996, p. 13) Met een dergelijk rijm worden deelnemers als het ware in hun functie van speler bevestigd: zo wordt een groep gevormd én wordt het spelkader opgezet. Voordat het eigenlijke spel kan beginnen, moet er ook nog iemand worden aangewezen om 'hem' (de tikker, of zoeker, of iets anders, afhankelijk van het spel) te zijn. Dit kan snel gedaan worden met poten of ploffen waarbij geen rijm wordt gebruikt, maar gebeurt ook vaak met een aftelrijm: 'Tene, miene, mutte,/ tien pond grutten,/ tien pond kaas,/ iene, miene, mutte,/ is de baas' is daar wellicht het meest bekende voorbeeld van. Aftelrijmen hebben in het gebruik vaak heel duidelijk het karakter van een rituele taalhandeling: "Het is alsof het lot iemand aanwijst," schrijft Judith Eiselin (p. 16). Overigens vormt de categorie van de aftelrijmen in verzamelingen en bundels met traditionele kinderrijmen doorgaans de meest omvangrijke. Aftelrijmen zijn er in vele soorten en maten, van een twintig regels tellend stapelvers (pp. 19-20) tot zeer efficiënte rijmen als 'Aaf, eef, af,/ meel en staf,/ koffiedik,/ af ben ik' (p. 17). Van volkomen betekenisloze klankrijmen als 'Pot,/ ingele mingele mangele mot/ kaatje vingele vangele vod/ een minuutje, apetuutje/ iet, wiet, waai, weg' (p. 17) tot rijmen met plaats- en tijdgebonden inhouden als 'Pief, paf, poef,/ Hitler is een boef,/ Göring is een zwijn,/ jij moet hem eerlijk zijn' (p. 15). Wanneer we het aftelrijm nader bekijken, dan moet geconcludeerd worden dat de rijmen in de praktijk bijna nooit voorkomen in de vorm waarin ze in bundels en bloemlezingen zijn vastgelegd. In de praktijk bestaan de rijmen vaak uit een set van segmenten die naar behoefte kunnen worden losgekoppeld en samengevoegd in verschillende composities. Neem het aftelrijm 'Iene miene mutte' dat in de basis uit de vijf regels 'Iene miene 
mutte,/ tien pond grutten,/ tien pond kaas,/ iene miene mutte/ is de baas ${ }^{58}$ bestaat, maar in de gebruikspraktijk vaak wordt aangevuld met extra coupletten zoals 'Maar de baas die is niet thuis, / want hij ligt in het ziekenhuis' waar dan vervolgens ook nog de losse regel 'Tet wiet waait is eerlijk weg' achteraan kan worden geplakt. Die laatste regel vinden we in een keur aan aftelrijmen terug, evenals regels als 'pief, poef, paf,/ jij bent af. Regels als 'af ben ik' of 'af ben jij' komen ook veelvuldig voor, in de meeste gevallen wel, maar niet altijd, door rijm aan de voorgaande regel(s) verbonden ${ }^{59}$.

In het volgende voorbeeld is te zien hoe 'Iene miene mutte' in de gebruikspraktijk kan worden aangepast door het gebruik van meerdere uitbreidingen:
Iene miene mutte
Tien pond grutten
Is de baas
Maar jij mag de baas niet zijn
Want jij bent nog veel te klein
Kikker in de sloot
Drop, drop, drop
Jij bent eerlijk op
Op de grote autoweg
Jij hebt pech $^{60}$

Hier zien we dat het basisvers ('Tene miene mutte,/ etc.') is ingekort van vijf naar slechts drie regels. De eerste uitbreiding wordt gevormd door het rijmende couplet 'Maar jij mag de baas niet zijn,/ want jij bent nog veel te klein', de tweede door het rijmende couplet 'Drop, drop, drop/ jij bent eerlijk op' en de derde door 'Op de grote autoweg/ jij hebt pech'. De tussenregel 'Kikker in de sloot' werd misschien ooit vergezeld door een rijmende regel ('Kikker in de sloot/ jij bent dood' bijvoorbeeld). Het is in ieder geval opvallend dat deze regel niet door rijm is verbonden aan andere regels in het vers, waarschijnlijk een resultaat van de mondelinge overlevering waarin nog wel eens wat verloren kan gaan. Voor de kinderen die het vers in deze vorm gebruiken, hoort deze regel echter evengoed thuis in dit aftelrijm. De daarop volgende rijmende coupletten kunnen elk worden weggelaten, worden toegevoegd, aan een ander basisvers worden geplakt, of los worden gebruikt, al naar gelang de situatie. Dezelfde onderzoeker die dit vers optekende uit de mond van een meisje noteerde op hetzelfde schoolplein, maar uit de mond van een ander kind, ook het ultrakorte aftelrijm: 'Drop, drop, drop,/ rot jij maar op' (Buchel, 2010, p. 17), een los gebruikte variant van 'Drop, drop, drop,/ jij bent eerlijk op'. Een dergelijk couplet dat aan

\footnotetext{
${ }^{58} \mathrm{Dit}$ is een bekende variant van het aftelrijm, dat overigens in de collectie van Van Vloten in vier verschillende varianten voorkomt, in de collectie van Van Hichtum (pseud. Sjoukje Troelstra-Bokma de Boer) in negentien varianten en in de collectie van Boekenogen maar liefst zevenzeventig keer voorkomt in vele varianten. (bron: Nederlandse Liederenbank, http://www.liederenbank.nl, Meertens Instituut, tekstnorm: Iene miene mutte Tien pond grutten).

${ }_{59}$ Zie voor voorbeelden onder meer de bundel Iene miene mutte. Over knikkeren, bokspringen en andere straatspelletjes van Judith Eiselin (1996), waarin het eerste hoofdstuk getiteld 'Iet wiet waait weg' verschillende aftelrijmen te vinden zijn.

${ }^{60}$ Dit aftelrijm werd opgetekend uit de mond van een zevenjarig meisje op een schoolplein in Amsterdam (Buchel, 2010).
} 
verschillende teksten kan worden geplakt, al dan niet door rijm met de rest van het vers verbonden, of los kan worden gebruikt door wie haast heeft, wordt een 'coda' genoemd, een term ontleend aan de muziek waarin 'coda' staat voor een passage die een muziekstuk tot een einde brengt. De coda in aftelrijmen is vaak te herkennen als een laatste regel of couplet afwijkend van het ritmisch en semantisch patroon van de voorgaande regels. In die coda is de inhoud vaak heel direct gericht op de spelhandeling en de functie van het rijm ('pief, poef, paf/ jij bent af') en omdat het vaak rijmende coupletten zijn, kunnen ze gemakkelijk worden getransporteerd van het ene vers naar het andere (Arleo, 1980, p. 214). We kunnen ook zeggen dat de coda de pragmatische component van het aftelrijm in zich draagt. Mede hierdoor kunnen kinderen ook met relatief gemak andere liedjes of rijmen adapteren: plak er een coda aan vast en elk rijm wordt een aftelrijm. Het stapelen van coda's geeft de afteller de mogelijkheid om door te blijven tellen tot een specifieke speler 'hem' moet zijn in het spel en hier zelfs enige invloed op uit te oefenen (p. 220). Op deze manier wordt het aftellen soms al een spel op zich waarin de afteller zijn repertoirekennis en improvisatievaardigheden kan tonen. Dit spelelement doorbreekt echter het rituele aspect van de performatieve taalhandeling van het aftellen: een afteller die speelt met zijn machtspositie, wordt plotseling ook herkenbaar als degene die het lot bepaalt en is daarmee niet meer immuun voor kritiek van de andere deelnemers. In deze situatie doorbreekt de afteller de performatieve kracht van de taalhandeling en onthult zichzelf als handelend subject door te spelen met de formele eigenschappen van het aftelrijm. De verschuiving van de focus van het ritueel uitvoeren van het aftellen als taalhandeling naar het niveau van het spelen met de formele kenmerken van het rijm, i.e. de verschuiving van een rituele naar een speelse beleving van het gebruik van poëzie in pragmatische contexten, is een terugkerend aspect in de omgang van kinderen met rijmen en liedjes naarmate ze ouder worden, zowel in de context van de feesten van het jaar als in de context van het spel. Ik kom hier aan het eind van deze paragraaf nog uitgebreider op terug.

Wanneer is bepaald wie 'hem' moet zijn of wie mag beginnen, kan het eigenlijke spel beginnen. Dat kan een spel zijn waar verder geen rijm of lied meer aan te pas komt, zoals bij tikkertje, bepaalde balspelen of knikkeren, maar het kan ook een spel zijn waarbij een rijm of liedje gebruikt wordt. Bij verstoppertje is het telrijm een middel voor degene die moet zoeken om aan te geven hoe lang de anderen nog hebben om zich te verstoppen en duidelijk aan te kondigen dat het zoeken begint: 'Eén, twee, drie, vier, vijf, zes, zeven, acht, negen, tien,/ wie niet weg is wordt gezien,/ IK KOM!' Op deze manier worden verschillende fasen van een spel van elkaar afgebakend. Bij touwspringen hebben rijmen en liedjes voor degenen die het touw draaien de functie om de maat aan te geven, maar ook om degene die springt opdrachten te laten uitvoeren. Zo moet degene die springt bij 'Beertje, beertje' al springende alle handelingen uitbeelden of uitvoeren waartoe 'beertje' de opdracht krijgt: "Beertje beertje, draai je om/ Beertje beertje, tik de grond/ Beertje beertje, poets je tanden/ Beertje beertje, was je handen/ Beertje beertje, pak je rugzak/ Beertje beertje, ga naar school/ et cetera." (Buchel, 2010, p. 12) Net zo lang tot 'beertje' de fout in gaat door een opdracht niet goed uit te voeren, of door op het touw te springen. Als 'beertje' geen fout maakt, wordt de beurt van een springer afgesloten wanneer het rijm is afgelopen. Daarna is volgende aan de beurt. De scripts die de rijmen en liedjes in dergelijke contexten vormen voor de uitvoering van het spel, zijn minimaal gebaseerd op de ritmische synchro- 
nisatie van tekst en fysieke spelhandelingen en maximaal gebaseerd op zowel de ritmische als semantische synchronisatie van tekst en handelingen. Daarbij kan, binnen het spelkader, zelfs profetische kracht aan de uitkomst van het spel worden toegekend, waarbij 'fouten' van de springer worden gekoppeld aan de toekomst (p.12):

Zaterdagavond zat ik in de bus

Toen kwam er een jongen

Die gaf me een kus

En die jongen heette

A,B,C,D,E,F,G,H,I,J,K,L,M,N,O (Omar!)

En die jongen heette Omar

Wil je met hem trouwen

Wil je van hem houden

Ja, nee, misschien ok

Ja, nee, misschien ok

Hoeveel baby's krijgen jullie?

$1,2,3,4,5,6,7,8,9,10$

De meeste touwspringliedjes worden (bijna) uitsluitend door groepen meisjes gebruikt. Als er met grote groepen gesprongen wordt, en hier willen jongens ook nog weleens aan meedoen, kan het scanderen van 'In spin, de bocht gaat in' en 'Uit spuit, de bocht gaat uit' voldoende zijn om aan te geven wanneer de deelnemers mogen inspringen en wanneer ze weer moeten uitspringen.

Een ander typisch 'meisjesspel' dat standaard verbonden is aan het gebruik van rijmen en liedjes is het klapspel. Bij klapspelletjes staan meestal twee kinderen tegenover elkaar die volgens vaststaande patronen in hun eigen handen en tegen elkaars handen klappen op de maat van een liedje of rijm. Bekende klapspelletjes zijn 'Papegaaitje, leef je nog?', 'O monnie monnie ma' en 'Er is een vrouw vermoord'. Er zijn ook klapspelletjes waarbij het rijm aanleiding is om, naast het klappen, nog andere bewegingen te maken. Bij 'Charlie Chaplin ging naar de disco' (of naar Spanje) worden er verschillende bewegingen gemaakt: 'Charlie Chaplin ging naar de disco,/ en leerde de meisjes dansen,/ de Engelse en de Franse,/ de eerste was de chachacha (met heupen heen en weer)/ de tweede was de hoelala (met heupen rond)/ de derde was de pijl en boog (met beweging)/ de vierde was de rok omhoog

(idem)/ de vijfde was de split (met voeten een eindje uit elkaar springen).' Overigens zijn veel touwspringliedjes en klapspelliedjes uitwisselbaar: 'Charlie Chaplin' kan bijvoorbeeld ook als touwspringlied worden gebruikt en 'Onder de tafel lag een briefje' ook als klapspel (zie ook Antens \& Mooren, 2002). Bij kring- en rijspelen is er in de begeleidende rijmen en liedjes vaak sprake van een 'verhaaltje', zoals bij 'Zakdoekje leggen', 'Groen is gras' en 'Er zat een klein zigeunermeisje', of er is sprake van een vraag- en antwoordstructuur, zoals bij 'Zeg, Roodkapje, waar ga je henen?', 'Ik kom uit verre landen' en 'Mariëtte Alfabette (de armen en de rijken)', of is het spel vooral gebaseerd op nabootsing of gezamenlijke uitvoering van bewegingen, zoals bij 'Ik stond laatst voor een poppenkraam' en 'Heb je wel gehoord van de zeven, de zeven'. Judith Eiselin schrijft: 'In feite zijn het een 
soort toneelstukjes. Een paar kinderen spelen de rollen, de rest staat eromheen, in een kring of een rij, en houdt nauwlettend in de gaten of het spel wel volgens de regels verloopt. Er wordt vaak bij gezongen en gedanst." (Eiselin, 1996, p. 37) Kring- en rijspelen zijn in die zin de meer dramatische spelvormen op het schoolplein waarbij de tekst van een lied of rijm de handelingen van betekenis voorziet.

Het schoolplein is een plek waar kinderen op allerlei manieren met elkaar interacteren en die interacties worden regelmatig gestructureerd door het gebruik van rijmen en liedjes met bijbehorende spelvormen. Of het schoolplein de aangewezen plaats is voor interculturele uitwisseling van liedjes en rijmen tussen kinderen van verschillende etnische achtergronden, is in een aantal lokale empirische studies onderzocht. Zo bekeken Marloes Antens en Piet Mooren de mate waarin er uitwisseling plaatsvindt in het Nederlandse en Turkse liedrepertoire van kinderen op de schoolpleinen van vier Tilburgse basisscholen. Zij stellen vast dat de kinderen van allochtone afkomst zeker delen in repertoires van Nederlandse liedjes en dat kinderen van autochtone afkomst bekend zijn met een klein aantal Turkse liedjes: "Daaruit valt enerzijds op te maken dat er enige multiculturele uitwisseling heeft plaatsgehad. ... Anderzijds laten allochtone kinderen zich meer beïnvloeden door het Nederlandstalige repertoire dan dat autochtone kinderen zich laten beïnvloeden door het Turkse repertoire ....” (2002, pp. 421-422) Jori Buchel deed onderzoek naar, onder meer, interculturele uitwisseling van klapspelversjes, aftelrijmen en springtouwliedjes op twee schoolpleinen in Amsterdam. Allereerst trof zij daar verschillende verbasterde Engelse klapspelliedjes aan, zoals 'Coca cola, coca cola/ Aluwali poesica, aluwali poesica/ Coca cola, coca cola// The boys get the netsjes/ They teach kaka/ The girls got the sexy legs/ You better wa ou// O hit me baby/ Hit me baby/ Turn around/ And fall down'61 (2010, p. 22). Daarnaast valt uit haar waarnemingen op te maken dat er wel enige interculturele uitwisseling was, maar dat deze uitwisseling hoofdzakelijk beperkt bleef tot klasgenoten en vooral bij klapspelliedjes gebeurde omdat daar de correcte uitspraak of het begrijpen van de tekst het minst van belang is (pp. 24-27, 39). De hoge mate van tekstuele 'betekenisloosheid' in met name de aftelrijmen en klapspelliedjes die op het schoolplein worden gebruikt, wijst erop dat deze rijmen vooral van belang zijn voor de ritmische afstemming van vocale en niet-vocale spelhandelingen. Daarnaast markeren de rijmen en liedjes ook specifieke spelvormen en/of spelfases met een duidelijk begin en einde. Tegelijk, zoals ik ook over bakerrijmen al opmerkte, is die betekenisloosheid slechts schijn. Zoals Anne Marie Schaerlaekens in De taalontwik.keling van het kind opmerkt: "Enerzijds kan men zeggen dat het kind door deze rijmelarij doelbewust afstand neemt van de communicatieve functie van het taalgebruik en taal aanwendt als ludiek en artistiek middel. Anderzijds heeft ook dit taalgebruik wellicht toch een zekere communicatieve functie.” (1977, p. 186) Ze doelt dan op de functie die de rijmen en liedjes op schoolplein en speelplaats vervullen in de onderlinge communicatie tussen kinderen die, zoals Iona en Peter Opie (1959) tentatief theoretiseerden, wellicht nog moeite hebben om zich in bepaalde situaties of bij bepaalde gevoelens uit te drukken in taal. De repertoires van rijmen en liedjes vormen dan als het ware 'ready-

\footnotetext{
${ }^{61}$ Buchel herleidt deze 'vernederlandste' versie tot een Britse versie: 'Coca cola, coca cola./ Alley alley pussy cat, alley alley pussy cat./ Coca cola, coca cola./ Alley alley pussy cat, alley alley pussy cat./ The boys got the muscles, the teacher can't count/ The girls got the sexy legs, you better watch out./ The boys go X X, the girls go 'Whooo' (Buchel, 2010, p. 22).
} 
made' instrumenten waarmee niet alleen handelingen worden gesynchroniseerd en dus samenwerking ontstaat, maar ook problemen kunnen worden vermeden of opgelost, of uiting kan worden gegeven aan allerlei gevoelens die meespelen in de sociale omgang. Zoals ook in de context van de feesten van het jaar het geval is, omvatten repertoires van speelrijmen eveneens rijmen waarmee kinderen hun interacties in meer algemene zin reguleren, zoals scheldrijmen of rijmen die de 'mores van het schoolplein' en het zelfregulerend vermogen van groepen kinderen vertegenwoordigen ('Klikspaan, boterspaan' bijvoorbeeld). Iona en Peter Opie beschreven de functie van het gebruik van dergelijke rijmen als het handhaven van 'the judicial code of the playground' (Opie \& Opie, 1959; 1970; 1985). De 'poëzie van de speelplaats' vervult daarmee voor groepen kinderen onderling belangrijke sociale functies.

In het kader van de functies van feestrijmen en -liedjes wees ik er al op dat er sprake kan zijn van variatie in de beleving binnen bepaalde contexten en in de uitvoering van bijbehorende poëtisch geformaliseerde handelingspatronen. Daar waar kinderen in hun onderlinge spel gebruik maken van rijmen en liedjes is ditzelfde effect waar te nemen. De uitvoering van poëtisch geformaliseerde spelhandelingen, zoals aftellen, maar ook een kring- of rijspel, klapspel of touwspringspel, kan door kinderen met uiterste precisie worden uitgevoerd. Judith Eiselin merkt hier in Iene miene mutte: Over knikkeren, bokspringen en andere straatspelletjes over op:

"Meer nog dan bij een toch overduidelijk vormgegeven spel als 'vadertje en moedertje' liggen de woorden van de dialogen en de liedjes vast. Ook de gebaren en de handelingen volgen altijd hetzelfde stramien. De spelletjes zijn in zekere zin rituelen." (Eiselin, 1996, p. 37)

Zoals dat ook geldt voor de inbedding van rijmen en liedjes in de context van vieringen, kan dit erop duiden dat jonge kinderen 'het taalspel poëzie' als rituele taalhandeling herkennen omdát het is ingebed in rituele contexten van tekstgebruik. Tegelijk is zichtbaar dat kinderen naarmate ze ouder worden de formele ritmische structuur van bestaande rijmen en liedjes steeds meer gaan benutten om op tekstueel niveau te variëren. Die variatie kan betrekking hebben op formele aspecten, zoals het uitbreiden van aftelrijmen. Schrijvers van kinderpoëzie maken soms op vergelijkbare manier gebruik van speelplaatspoëzie om via een (inter)tekstueel spel met de formele kenmerken een nieuwe versie te maken, zoals Hans Hagen (2007) doet in 'Verstoppertje': "wie niet ziet is blind/ wie niks zegt is stom/ wie niks hoort is doof/ wie niet denkt is dom/ wie niet leeft is dood/ wie niks aan heeft bloot// recht/ is niet krom/ na negen komt tien/ wie niet stil is wordt gehoord/ wie niet weg is wordt gezien// IK KOM". Het tekstuele spel van kinderen zelf heeft ook vaak betrekking op de inhoud van rijmen en liedjes waarin allerlei grenzen worden afgetast. Daar waar de spelfunctie van een rijm of lied hoofdzakelijk gekoppeld is aan de ritmische structuur en die ritmische structuur in tact blijft, kunnen kinderen intens plezier beleven aan de inhoudelijke voorstelling van lugubere gebeurtenissen (' $\mathrm{Er}$ is een vrouw vermoord,/ aan het gordijnenkoord,/ ik heb het zelf gezien,/ het was op nummer tien,/ het bloed liep langs de trap,/ het leek tomatensap,/ ik nam er een likje van,/ en kotste in de gang,/ et cetera') of van scabreus taalgebruik ('Onder de brug van Janke-Panke lag een hond./ Als hij 
schijt, dan schijt hij stront,/ als hij pist, dan pist hij wijn./ Hoeveel liter zou dat zijn?’). Net als in het geval van veel kinderrijmen en -liedjes in de context van vieringen, zien we ook hier dat vooral de formele kenmerken van de rijmen en -liedjes een cruciale rol spelen in de vervulling van de pragmatische functie in de gebruikscontext. Zolang het strikt formele, in hoofdzaak op ritme en rijm gebaseerde, stramien van de gesynchroniseerde vocale en nietvocale handelingen maar met rituele nauwkeurigheid in acht wordt genomen, 'sanctioneert' dit als het ware het spel met de inhoud van de tekst dat bij oudere kinderen haar intrede doet. Dit is een belangrijk punt met het oog op de poëtische ontwikkeling van kinderen waar ik in de volgende paragraaf nog op terugkom. Op schoolpleinen en speelplaatsen bestaat een overleveringssysteem waarin rijmen en liedjes met bijbehorende spelvormen door oudere kinderen worden doorgegeven aan jongere kinderen, op basis van leeftijdscohorten die corresponderen met de indeling van het onderwijs (zie o.a. Fine, 1980). De leeftijd van de kinderen speelt dus ook hier een belangrijke rol in de beleving en voorkeuren: jonge kinderen zijn conservatiever en strikter in de uitvoering van rijmen en bijbehorende poëtisch geformaliseerde handelingspatronen dan oudere kinderen. Daar komt bij dat de complexiteit van spel- en bijbehorende rijmvormen toeneemt naarmate kinderen ouder worden en steeds meer 'autonome' 62 poëtische vormen onderdeel worden van het gebruikte repertoire, zoals tongbrekers en andere 'taal- en uitspraakrijmen'.

Bij de selectie van poëzie voor kinderen van verschillende leeftijden is het niet alleen van belang rekening te houden met de leeftijd van de kinderen in de keuze voor teksten, maar ook in de keuze voor verwerkingsvormen. Zowel baker- als kinderrijmen wijzen erop dat jonge kinderen 'het taalspel poëzie' bijna uitsluitend (leren) spelen in combinatie met (niet-vocale) fysieke handelingspatronen. Getuige het feit dat de ritmische verschijnselen in de 'poëzie van de speelplaats' zeer expliciet aanwezig zijn en vaak nog eens extra benadrukt worden door de overlapping met ritmische fysieke beweging (klappen, stampen, springen, dansen, etc.), blijft de expliciet lichamelijke ervaring voor kinderen in de basisschoolleeftijd nog lange tijd een belangrijke rol spelen in hun voorkeuren en beleving van 'het taalspel poëzie'. Tegelijk komt dat 'taalspel poëzie' naarmate kinderen ouder worden ook steeds meer op zichzelf te staan.

\subsection{Poëtische ritualisering aan de bakermat van culturele geletterdheid}

Tot nu toe heb ik in dit hoofdstuk de belangrijkste pragmatische contexten van tekstacquisitie en -gebruik van volksculturele poëzie voor kinderen beschreven. Met het oog op de bijdrage die kinderrijmen en -liedjes leveren aan de ontluikende culturele geletterdheid van jonge kinderen is het daarbij van belang ons te realiseren dat we op zowel het ingebedde als het overkoepelende niveau ${ }^{63}$, of dat nu in de context van de gestructureerde routines, de vieringen of het spel is, te maken hebben met basale processen van betekenisgeving. Om

\footnotetext{
62 'Autonoom' wil hier zeggen: niet aan non-verbale fysieke spelvormen gekoppeld.

${ }^{63}$ Het ingebedde niveau $=$ de individuele teksten in hun gebruikscontexten; het overkoepelende niveau $=$ repertoires van liedjes en rijmen die de dubbele chronologie van klok- en kalendertijd enerzijds en leeftijd anderzijds volgen.
} 
de functie van rijmen en liedjes in processen van betekenisgeving te karakteriseren, is 'ritualisering' een bruikbaar begrip. De ontwikkelingspsycholoog E.H. Erikson stelt in het artikel 'Ontogeny of Ritualization in Man' de volgende voorwaarden om te kunnen spreken van 'ritualisering':

“... behavior to be called ritualization in man must consist of an agreed-upon interplay between at least two persons who repeat it at meaningful intervals and in recurring contexts; and that this interplay should have adaptive value for both participants. And, I would submit, these conditions are already fully met by the way in which a human mother and her baby greet each other in the morning." (Erikson, 1966, p. 337)

Op basis van het voorbeeld van de begroeting tussen moeder en baby stelt Erikson vast dat ritualisering herkenbaar is als een speciale vorm van alledaags handelen waarin het praktisch noodzakelijke en het emotionele met elkaar verenigd zijn, waarin de beleving sterk individueel is hoewel de handelingen algemeen menselijk zijn, waarin de aanleiding fysieke noodzaak is terwijl de invulling veel verder gaat dan het puur noodzakelijke (p. 338). Ellen Dissanayake legt ditzelfde proces van ritualisering in moeder-kind interacties uit als de verbijzondering van alledaagse routinematige handelingen en gedragingen door formalisering (simplificatie en stereotypering), herhaling, overdrijving, uitbreiding en toepassing in een nieuwe context om een andere, onalledaagse, boodschap te communiceren (2009, p. 154). Handelingspatronen worden door ritualisering gemarkeerd als bijzonder en daarmee onderscheiden van alledaagse activiteiten door een intensivering in beleving en daarmee ook in betekenis. De ritualisering van handelingspatronen in ouder-kind interacties bestaat los van het gebruik van bakerrijmen en -liedjes, maar hoe moeders met hun pasgeboren kind interacteren, zowel vocaal als niet-vocaal, wordt wel in poëtische termen beschreven:

“... the utterances are simplified, rhythmic, and highly repetitive. Transcripts ... reveal poetic features: talk to babies is composed of phrases, each (whether having two or nine syllables) about three and a half to five seconds in length - the temporal length of a poetic line, a musical phrase, and a phrase of speech in adults (Lynch et al. 1995; Turner 1985) - and these phrase segments are combined with others in 'stanzas' that comprise a theme with variations. Subtler poetic features such as metrics, phonetics, and foregrounding are discernible with further close analysis (Miall and Dissanayake 2002). ... Along with this special vocal behavior, adults engage and keep infants' attention by the use of rhythmic body movements (touching, patting, stroking) .... The baby responds to these peculiarly repetitive, exaggerated, and elaborated antics with wriggles, kicks, and smiles." (Dissanayake, 2009, pp. 151-152)

Zowel Erikson als Dissanayake laat het gebruik van wiegeliederen en bakerrijmen buiten beschouwing in de bespiegelingen op vormen van ritualisering in het leven van het zeer jonge kind. Dat ritualisering in ontwikkelings- of gezinspsychologische beschouwingen op ouder-kind interacties niet of nauwelijks in verband wordt gebracht met het gebruik van bakerrijmen en/of wiegeliederen is een opmerkelijk hiaat (zie ook Bennet et al, 1988; Dickstein, 2002; Fiese et al, 2002). Zeker gezien het feit dat wiegeliederen een al even universeel 
fenomeen zijn als ritualisering van handelingspatronen of het gebruik van 'motherese' (of 'parentese' zoals het ook wel genoemd wordt). Hoewel ze in evolutionair perspectief pas relatief laat hun intrede doen in ouder-kind interacties, is het opvallend hoe sterk de, soms eeuwenoude, wiegeliederen en bakerrijmen van oudsher verbonden zijn aan geritualiseerde handelingspatronen in de dubbele chronologie van de dagelijkse tijd en de ontwikkeling van het ouder wordende kind (zie Vloten, 1874; Troelstra-Bokma de Boer, 1948; Enzensberger, 1962; Opie \& Opie, 1963/1974, 1973). Dan rijst de vraag wat de toegevoegde waarde is van het gebruik van rijmen en liedjes als cultureel bepaalde vormen bovenop de toch al poëtisch geritualiseerde vocale en niet-vocale handelingspatronen in ouder-kind interacties. Zonder daarbij het gebruik van bakerrijmen en -liedjes in beschouwing te nemen, ziet Dissanayake de geritualiseerde interacties tussen moeder en onmondig kind, een fenomeen dat zich al vroeg in de evolutie van de menselijke soort heeft ontwikkeld, als 'protoesthetisch' gedrag omdat moeders dit type hechtingsritueel bijna 2 miljoen jaar geleden onbewust, instinctief, zijn gaan ontwikkelen ${ }^{64}$. Zij ziet dit type gedrag echter ook als de basis voor processen van 'artificatie' die in de loop van de menselijke evolutie vorm hebben gekregen in rituelen, religie en kunst. 'Artificatie' is, vanuit Dissanayakes evolutionaire perspectief, niets anders dan de bewuste toepassing van de kenmerken van (onbewuste) protoesthetische ritualisering in nieuwe contexten die op die manier bewust 'ritueel', 'buitengewoon' of 'artificieel' werden gemaakt. Ze spreekt daarbij expliciet van 'artificeren' omdat ze wil benadrukken dat rituelen, religie en kunst handelend tot stand komen. We kunnen de poëtische ritualisering van terugkerende fysieke en talige handelingspatronen door het gebruik van baker- en kinderrijmen dan typeren als een specifieke vorm van artificatie, of artistieke ritualisering. De rijmen en liedjes maken deel uit van een culturele traditie en er wordt vaak bewust betekenis gehecht aan het gebruik van deze poëtische vormen. Zo rapporteren moeders dat het gebruik van een vast en gevoelsmatig 'speciaal' liedje op vaste momenten in de dagelijkse verzorging van hun jonge kind een routinematige handeling verheft tot 'quality time' (Street et al, 2003, p. 630).

Dit is echter bekeken vanuit het perspectief van de volwassenen die met het zeer jonge kind interacteren: het kind is in de levensfase die Dissanayake beschrijft nog onmondig. Hoe ontwikkelt 'het taalspel poëzie' zich voor kinderen zelf? In De taalontwikkeling van het kind schrijft Anne Marie Schaerlaekens dat kinderen vanaf een jaar of vijf bewust groot plezier gaan beleven aan het componeren van rijmen en liedjes en het creëren van 'taalfantasieën', “waarvan men rustig kan zeggen dat het poëzie is. Het kind neemt immers afstand van de communicatieve bedoeling van de taal en gebruikt taal als louter ludiek en 'artistiek' middel.” (1977, pp. 177-179) Anders gezegd: vanaf een jaar of vijf, wanneer kinderen het taalsysteem zo ongeveer onder de knie hebben en dit systeem kunnen gebruiken om met anderen te communiceren, gaan ze bewust plezier beleven aan het spelen met de poëtische functie van taal die duidelijk verschilt of afwijkt van alledaags taalgebruik. Daarnaast zien we zowel in de context van vieringen als in de context van spel dat op enig moment vooral de formele kenmerken van de rijmen en -liedjes voor kinderen een cruciale rol blijven

\footnotetext{
${ }^{64}$ Dissanayake schrijft hierover: "I argue that this 'bonding ritual', as it began to evolve in early hominin motherinfant pairs -perhaps as early as 1.7 million years ago (Falk 2009, Leakey 1994) - relied upon distinctive emotionally affecting 'proto-aesthetic operations' on common vocal, facial, and kinetic expressions of friendliness or affiliation, making them attention-getting and pleasurable." (2009, p. 149)
} 
spelen in de vervulling van de pragmatische functie. Zolang het strikt formele stramien van de gebruiksvorm (bijvoorbeeld het Nieuwjaarsrijm) en de bijbehorende handeling(en) (het doen van een lied of rijm in de betreffende pragmatische context) maar met rituele nauwkeurigheid in acht wordt genomen, vervult het rijm of lied haar pragmatische functie (iemand iets toewensen). Tegelijk 'sanctioneert' dit als het ware het inhoudelijk spel met de tekst dat bij oudere kinderen haar intrede doet (het verwensen; zie ook Hoofdstuk 5). Dit zegt iets over de 'poëtische ontwikkeling' en de voorkeuren van kinderen. Op het moment dat kinderen het lied of rijm formeel als 'rituele taalhandeling' (zie Hoofdstuk 2) herkennen en de bijbehorende gebruiksconventies hebben verworven, dan verschuift de focus in het handelen met 'het taalspel poëzie' van de context naar de tekst. Daarnaast zien we dat ook 'taal- en uitspraakrijmen' zoals de tongbrekers geliefd zijn onder oudere kinderen: een teken dat de poëtische functie van taalgebruik in deze fase in relatief autonome vormen van 'het taalspel poëzie' langzaamaan op de voorgrond komt te staan (zie ook Hoofdstuk 4). De tekst, als 'rituele taalhandeling', gaat nu op zichzelf het rituele kader vormen terwijl de externe, concrete, rituele gebruikscontext die aanvankelijk nog zo belangrijk was om 'het taalspel poëzie' haar functie en betekenis te geven, steeds meer door kinderen wordt verinnerlijkt en niet langer concreet, maar conceptueel meespeelt in de poëtische communicatiesituatie. Hoewel we nog niet precies weten hoe de 'poëtische ontwikkeling' van kinderen verloopt, geeft de verschuiving van de context (van concreet en extern naar conceptueel en verinnerlijkt) een indicatie van die ontwikkeling.

Een ander criterium om van ritualisering te kunnen spreken, is dat de markering en formalisering van handelingspatronen in dezelfde vorm wordt herhaald met, zoals Erikson zegt, betekenisvolle intervallen en in terugkerende contexten (1966, p. 337). Dissanayake wijst eveneens op dit aspect: "Importantly, the [ritualized] interaction [between mother and infant] became temporally-organized, allowing for further aesthetic effects." (2009, p. 149) Zoals Pollmann al schreef, volgen bakerrijmen en -liedjes de dubbele chronologie van het verloop van de dagelijkse tijd enerzijds en de ontwikkeling van het zeer jonge kind anderzijds. Hiermee worden ritmische patronen in de tijd gecreëerd: in de circulaire dagelijkse tijd door de herhaalde markering van opstaan, voeden, spelen en slapen, en in de lineaire tijd door de markering van opeenvolgende fases in de ontwikkeling, van de eerste hapjes, naar de eerste stapjes, naar de eerste gesprekjes. Voor oudere kinderen vervullen feest- en spelrijmen een soortgelijke functie. In de lijn van de circulaire, zich herhalende, tijd worden met rijmen en liedjes gekoppeld aan vaste momenten op de dag of in het jaar zich herhalende patronen gemarkeerd; in de lijn van de lineaire, voortschrijdende, tijd worden unieke overgangsmomenten gemarkeerd in de ontwikkeling of in het leven. Dat ritme bestaat uit patronen van (jaarlijkse) herhaling en patronen van (periodieke seizoens- en feestgebonden) afwisseling. Met die ritmische patronen in de tijd wordt ook weer betekenis gecreëerd, schrijft Marli Huijer in Ritme:

"Dagritmes, weekritmes, maandritmes, jaarritmes, maar ook de ritmes van alledaagse handelingen, zijn markeringen die steeds opnieuw verschil en herhaling aanbrengen en daarmee ordening en betekenis aan het leven geven." (Huijer, 2012, p. 24) 
In de context van het spel markeren rijmen en liedjes daarbij ook ritmische patronen in de afwisseling van alledaags handelen en spelen en markeren ze ruimtelijke patronen die de afbakening van het rituele of spelkader nog eens versterken. Vanuit dit perspectief zien we dat de verbinding tussen rijmen en liedjes en pragmatische contexten van tekstgebruik op meerdere niveaus te typeren is als de poëtische ritualisering van ritmische patronen die (ten minste affectieve) betekenis dragen. Die ritmische patronen bestaan zowel in de temporele ordening van overlappende geritualiseerde taal- en handelingspatronen, als in de temporele ordening van terugkerende en opeenvolgende cruciale momenten waardoor ritme ontstaat in de dagelijkse, wekelijkse, maandelijkse en jaarlijkse tijd, als in de ruimtelijke ordening waarmee momenten in de tijd ook in de ruimte worden afgebakend van het alledaagse. Op tekstueel niveau worden die ritmische patronen nog eens extra benadrukt, zoals heel expliciet te zien is in de veelheid aan volksculturele en literaire poëzie voor kinderen waarin de dagen van de week of de maanden van het jaar als structurerend middel worden ingezet.

De betekenis van poëzie voor jonge kinderen komt dan, zowel binnen een specifieke context als over terugkerende en opeenvolgende contexten heen, voort uit het creëren van verschil: het verschil tussen alledaags en onalledaags taalgebruik, het verschil tussen alledaagse en onalledaagse handelingen, het verschil tussen alledaagse en onalledaagse tijd. Kinderpoëzie kan voor jonge kinderen op al deze niveaus 'patronen van betekenis' vormen die hen helpen de wereld te begrijpen en te controleren - of tenminste het gevoel te geven dat ze de wereld controleren - met en via het lichaam in taal (vgl. Coats, 2013; Lurie, 1990). Poëzie kan die functie echter vooral vervullen wanneer kinderen het ook herkennen als 'rituele taalhandeling', als 'niet echt'. Dat herkennen van poëzie als 'rituele taalhandeling' hangt samen met de ontwikkeling van kinderen, met hun kennis van gebruiksconventies van rijmen en liedjes, met de inbedding en afbakening in rituele contexten, en ook met de mate waarin een rijm of lied afwijkt van alledaags taalgebruik. In het gebruik van baker- en kinderrijmen en -liedjes zijn allerlei bewuste manipulaties van verwachtingspatronen, i.e. verrassingselementen, aan te wijzen, zoals in doelbewuste variaties in ritmische en prosodische patronen, gekoppeld aan (steeds opnieuw) 'onverwachte' bewegingen (zoals bij kietelliedjes, of klapspelliedjes die eindigen op 'poef?' waarbij de ander in de buik wordt gepord), in de alomtegenwoordige tekstuele vormen van 'betekenisloosheid' en in het plezier dat oudere kinderen beleven aan het creëren en gebruiken van (subversieve) variaties op bestaande teksten ${ }^{65}$. Hoe duidelijker een rijm of lied is afgebakend van ons 'natuurlijk' alledaags taalgebruik, hoe gemakkelijker het als 'buitengewoon', als 'geartificeerd' te herkennen is. Die afbakening krijgt vorm in de ritualisering, zowel op het niveau van de inbedding in terugkerende pragmatische contexten als op het niveau van de vocale en niet-vocale verbijzondering van alledaags taalgebruik door formalisering (simplificatie en stereotypering), herhaling, overdrijving en uitbreiding. In Hoofdstuk 9 en 10 waarin ik de kwalitatieve inzichten in het taalspel poëzie in groep 2 en groep 4 bespreek, kom ik hier op terug om na te gaan in hoeverre de empirische inzichten deze theoretische verwachting bevestigen.

\footnotetext{
${ }^{65} \mathrm{Op}$ dit fenomeen, dat een teken is van productieve receptie, kom ik in de volgende twee hoofdstukken terug.
} 


\subsection{Conclusie: 'de directe evocatie van poëtisch geritualiseerde handelingspatronen' een eerste indicator van canoniciteit in kinderpoëzie}

De in dit hoofdstuk beschreven exploratie van de relatie tussen volksculturele baker- en kinderrijmen en pragmatische contexten van tekstgebruik in de 'cultuur van het dagelijks leven' van jonge kinderen, vormt de basis voor de formulering van de eerste verwachte 'indicator van canoniciteit' in kinderpoëzie. De specificatie van deze indicator in concrete criteria vormde de basis voor het samenstellen van selecties van kinderpoëzie die via het interventieprogramma, het 'Leeskalenderproject', zijn geïmplementeerd in groepen 2 en groepen 4 van het basisonderwijs. Volksculturele baker- en kinderrijmen zijn, bijna zonder uitzondering, gebonden aan concrete contexten van tekstgebruik. Voor kinderen in groep 2 en in groep 4 zijn de vieringen in het jaar en in het leven en het spel de belangrijkste gebruikscontexten waarin de overdracht en verwerving van poëzie voor jonge kinderen vorm krijgt. De koppeling tussen volksculturele baker- en kinderrijmen en pragmatische contexten is op verschillende niveaus te karakteriseren als 'ritualisering'. Op het niveau van een rijm of lied als ingebedde tekst in de context van een viering of spelvorm kunnen we spreken van ritualisering omdat er sprake is van de verbijzondering van alledaagse routinematige vocale en niet-vocale handelingen door formalisering (simplificatie en stereotypering), herhaling, overdrijving, uitbreiding en toepassing in een nieuwe context om een andere, onalledaagse, boodschap te communiceren. Dat communiceren gebeurt in de contexten van de vieringen en het spel overigens nog niet zozeer tussen 'lezer' (gebruiker) en 'tekst' (gedicht), maar via poëzie tussen meerdere gebruikers of tussen een (groep van) gebruiker(s) en een (soms afwezige) (groep van) ander(en). Dat kan binnen een spel een groep kinderen zijn die een lied zingen gericht aan een andere speler (of andersom); dat kan binnen een viering ook een kind zijn dat een liedje zingt gericht aan Sinterklaas; et cetera. Liedjes en rijmen zijn in deze pragmatische contexten zeker voor jonge kinderen bijna per definitie gekoppeld aan fysieke (niet-vocale) handelingspatronen (spelvormen of riten). Getuige het feit dat de ritmische verschijnselen ook in de 'poëzie van de speelplaats' zeer expliciet aanwezig zijn en vaak nog eens extra benadrukt worden door de overlapping met ritmische fysieke beweging (klappen, stampen, springen, dansen, etc.) blijft de lichamelijke ervaring voor kinderen in de basisschoolleeftijd nog lange tijd een expliciet onderdeel van 'het taalspel poëzie'. Tegelijk komt dat 'taalspel poëzie' naarmate kinderen ouder worden ook vaker op zichzelf te staan en gaan ze relatief 'autonome' vormen van poëtisch taalspel, zoals tongbrekers, steeds meer gebruiken en komt zelf variëren op bestaande teksten vaker voor. Op het overkoepelende niveau is sprake van ritualisering omdat de markering en formalisering van handelingspatronen met het gebruik van rijmen en liedjes in de contexten van vieringen en spel in dezelfde vorm wordt herhaald met betekenisvolle intervallen en in terugkerende contexten. Die contexten creëren daarmee ritmische patronen in de tijd en de ruimte: ritmische patronen die allerlei ongrijpbare dingen die het leven beïnvloeden, waarneembaar en ervaarbaar maken en daarmee ook (gevoelsmatig) beheersbaar.

Omdat het overkoepelende niveau van de vieringen in het jaar al vertegenwoordigd is in het kalenderformat van de interventie (zie Hoofdstuk 6 en 7), formuleer ik de eerste indicator voor de kinderpoëzie op het ingebedde niveau van 'het taalspel poëzie' binnen 
pragmatische contexten: 'de directe evocatie van poëtisch geritualiseerde handelingspatronen in de context van feesten en spel'66. Ik leid uit bovenstaande analyses ook af dat die relatie tussen poëzie en gebruikscontext globaal in twee soorten geritualiseerde handelingspatronen is onder te verdelen: (i) fysieke handelingspatronen (zoals wiegen, dansen, klappen, et cetera), en (ii) performatieve taalhandelingen (zoals wensen, aftellen, verwensen, vragen, et cetera). Welke van deze twee soorten het sterkst bijdraagt aan de beleving en waardering van de kinderen hangt deels af van de specifieke pragmatische context en uiteraard ook de tekstuele eigenschappen van een rijm, lied of gedicht. Echter, ik verwacht dat de verwerving van poëzie in pragmatische contexten van tekstgebruik bij jonge kinderen (groep 2) sterker wordt gestimuleerd door de koppeling met (i) fysieke handelingspatronen (zoals dansen, klappen, maar ook uitbeelden), terwijl oudere kinderen (groep 4) daar minder sterk op steunen voor hun ervaring en waardering van 'het taalspel poëzie':

\begin{tabular}{|c|c|c|}
\hline $\begin{array}{l}\text { KINDERPOËZIE } \\
\text { Verwachte 'indicatoren van canoniciteit' }\end{array}$ & Groep 2 & Groep 4 \\
\hline $\begin{array}{l}\text { 1. 'de directe evocatie van poëtisch } \\
\text { geritualiseerde handelingspatronen in de } \\
\text { context van feesten en spel' }\end{array}$ & $\begin{array}{l}\text { 'de directe evocatie van poëtisch } \\
\text { geritualiseerde fysieke } \\
\text { handelingspatronen in de } \\
\text { context van feesten en spel' }\end{array}$ & $\begin{array}{l}\text { 'de directe evocatie van poëtisch } \\
\text { geritualiseerde talige } \\
\text { handelingspatronen in de } \\
\text { context feesten en spel' }\end{array}$ \\
\hline
\end{tabular}

Om scherper inzicht te krijgen in de rol die deze indicator speelt in processen van poëzieverwerving, zijn enkele aanvullende aspecten van de relatie tussen poëzie voor kinderen en pragmatische contexten meegewogen in de samenstelling van het aanbod kinderpoëzie dat is geïmplementeerd in de praktijk (zie Hoofdstuk 7, 9 en 10). Te denken valt aan de rol die de tijd- en plaatsgebondenheid van feesten en bijbehorende poëzie speelt in de waardering van de kinderen, de rol die de (on)bekendheid van bepaalde vieringen bij kinderen speelt evenals mogelijke verschillen in beleving, en wat effectieve manieren zijn om culturele pluriformiteit in het aanbod aan te brengen. Fysiek spel laat zich naar verwachting gemakkelijker inbedden in groep 2 - waar spelen vaak nog onderdeel is van het dagelijks onderwijs - dan in groep 4 waar 'spelen' iets is dat vooral op het schoolplein wordt gedaan. Kan fysiek spel in combinatie met poezie in groep 4 worden gedaan? Maar ook: in hoeverre draagt expliciet fysiek handelen in groep $4 \mathrm{nog}$ bij aan de beleving en waardering van poëzie in vergelijking met meer autonome vormen van 'het taalspel poëzie'? Ook hier kan nauwkeuriger inzicht in verkregen worden door verschillende vormen van poëzie en verschillende combinaties met verwerkingsvormen te implementeren in de praktijk van het basisonderwijs (zie Hoofdstuk 7, 9 en 10).

\footnotetext{
${ }^{66}$ Ook 'dagelijkse routines' zouden hier genoemd kunnen worden als belangrijke pragmatische contexten waarin 'het taalspel poëzie' voor jonge kinderen vorm en betekenis krijgt. Ik laat ze hier echter buiten beschouwing omdat ze zo sterk verbonden zijn aan de gezinscultuur. 'Naar bed gaan', bijvoorbeeld, laat zich als pragmatische context moeilijk inbedden in de schoolklas. In voor- en vroegschoolse educatie spelen de routines ook een belangrijke rol in de inbedding van poëzie in de alledaagse cultuur, maar omdat de aanbieding van poëzie in dit onderzoek is ingekaderd in het werken met de Leeskalender als dagelijks terugkerende activiteit kan de 'natuurlijke' situatie van een lied of rijm bij het knutselen, eten, naar binnen en naar buiten gaan, et cetera, niet goed worden gereproduceerd. Daarom richt ik me vooral op vieringen en spel, hoewel de routines zo hier en daar wel aan bod komen.
} 
Buiten de pragmatische contexten die vormen van 'het taalspel poëzie' verbinden met de bredere culturele gemeenschappen waarin kinderen opgroeien (de gezinscultuur, de kindercultuur en de Nederlandse samenleving met de vele culturele groepen die daarin vertegenwoordigd zijn), moeten we er ook rekening mee houden dat 'de schoolklas' in dit onderzoek eveneens een contextueel kader vormt. Ook die context brengt eigen normen, waarden en gebruiken met zich mee en zal dus van invloed zijn op de aanbieding en verwerving van kinderpoëzie. In de vertaling van de verwachte 'indicatoren van canoniciteit' naar de selectie van poëzie voor de Leeskalenders heb ik hier rekening mee gehouden (zie Hoofdstuk 7, \$7.3). Dat ik pragmatische contexten als belangrijke aanvulling op de analysekaders van 'het taalspel poëzie' beschouw om poëzie voor kinderen als betekenisvol te begrijpen in het gebruik ervan door kinderen, betekent echter niet dat de tekstuele eigenschappen van de rijmen, liedjes en gedichten verwaarloosbaar zijn. Zoals ik in Hoofdstuk 2 al heb aangegeven, vormen de pragmatische contexten waarin kinderen gebruik maken van rijmen en liedjes het culturele kader waarin de teksten zijn ingebed, maar interacteren deze gebruikscontexten ook met de tekstuele eigenschappen van de rijmen en liedjes. Poëzieverwerving wordt, naast de inbedding in pragmatische contexten, naar verwachting dan ook verder versterkt door specifieke (inter)tekstuele kenmerken die enerzijds gerelateerd zijn aan de genoemde pragmatische contexten terwijl ze anderzijds aansluiten bij relevante ontwikkelingskenmerken van de beoogde doelgroep. Deze specifieke (inter)tekstuele kenmerken komen in de nu volgende hoofdstukken aan bod. 



\section{HOOFDSTUK 4}

Kinderpoëzie en het muzikale spel met de taal 



\subsection{Introductie}

In het vorige hoofdstuk ben ik ingegaan op de relatie tussen poëzie voor kinderen en terugkerende contexten van tekstgebruik, te weten de vieringen en spel. De exploratie van die relatie heeft geleid tot de verwachting dat poëzie effectiever door kinderen wordt verworven wanneer ze specifieke, voor kinderen herkenbare en ervaarbare, 'poëtisch geritualiseerde handelingspatronen' oproept. Daarbij is de verwachting ook dat poëzie die expliciete poëtisch geritualiseerde fysieke handelingspatronen oproept - zoals klappen, dansen, stampen, uitbeelden - nauwkeurige aansluiting op de culturele competentie van kinderen in groep 2 waarborgt, terwijl bij kinderen in groep 4 poëzie die expliciete poëtisch geritualiseerde talige handelingspatronen oproept meer in de smaak zal vallen. In het vorige hoofdstuk ben ik nog niet expliciet ingegaan op de rol die de esthetische kenmerken van poëzie spelen in de relatie tussen poëzie en pramtische contexten en in de nauwkeurige aansluiting van poëzie op de competentie en voorkeuren van kinderen in groep 2 en 4. Dit hoofdstuk, en ook het volgende, is gewijd aan de exploratie en formulering van verwachte tekstuele ('esthetische') indicatoren van canoniciteit in kinderpoëzie. In Hoofdstuk 2 is 'nonsensicaliteit', of betekenisloosheid, al geïntroduceerd als structureel tekstkenmerk van baker- en kinderrijmen dat een breed gedragen en diepgeworteld cultuurverschijnsel vertegenwoordigt. Vanuit pragmatisch perspectief maak ik onderscheid tussen twee categorieën van nonsensicaliteit: in de eerste categorie wordt een poëtisch taalspel gespeeld met de prosodische, of materiële aspecten van taal en in de tweede categorie wordt een poëtisch taalspel gespeeld met de referentiële aspecten van taal. Daarmee representeren de beide typen taalspel verschillende manieren om de wereld te begrijpen en te controleren (Lurie, 1990), enerzijds gekoppeld aan verschillende gebruikscontexten en anderzijds gerelateerd aan specifieke ontwikkelingskenmerken (de culturele competentie) van jonge kinderen. In dit hoofdstuk bespreek ik poëtische vormen van spel met de materiële aspecten van taal, dus poëzie waarin rijm, ritme en allerlei vormen van herhaling de boventoon voeren, ofwel 'muzikaal taalspel'.

De veelvormigheid van 'muzikaal taalspel' in kinderpoëzie vraagt om specifieker inzicht in de aansluiting van de verschillende vormen op de poëtische voorkeuren van kinderen in groep 2 en in groep 4. In verschillende wetenschappelijke studies (Geller, 1985; Waugh, 1980; Schaerlaekens, 1977; Chukovsky, 1971/1925) wordt het spelen met de poëtische functie van taal aangewezen als 'natuurlijk fenomeen' in taalverwervingsprocessen bij jonge kinderen. Omdat deze studies uitgaan van de taalontwikkeling van kinderen bieden ze vooral inzicht in de spontane productie van vormen van taalspel met poëtische kenmerken, maar veel minder in de receptie en het gebruik van bestaande poëzie door kinderen (Geller, 1985; Waugh, 1980; Schaerlaekens, 1977) of hebben ze geen betrekking op de leeftijdscategorieën die in dit onderzoek centraal staan (Chukovsky, 1971/1925). Er is in het Nederlands taalgebied, voor zover ik heb kunnen nagaan, weinig tot geen structureel en/of grootschalig empirisch onderzoek verricht naar de poëtische voorkeuren van kinderen in het basisonderwijs (zie Hoofdstuk 2). Muzikaal taalspel wordt in de praktijk vaak gezien als kenmerk in poëzie dat vooral kinderen in de voor- en vroegschoolse fase aanspreekt, bijvoorbeeld in de vorm van 'opzegversjes' (SLO, online lexicon, lemma 'kinderpoëzie'). Grootschalige survey-onderzoeken in de Verenigde Staten lieten zien dat kinderen van 
groep 3 tot en met 8 poëzie met rijm, ritme en andere klankeffecten nog steeds sterker waarderen dan vrije versvormen (Patrick, 2012; Fisher \& Natarella, 1982; Terry, 1974), maar dergelijke onderzoeken geven geen nauwkeurig inzicht in ontwikkelingen in de poëtische voorkeuren van kinderen naarmate ze ouder worden. Ook vertellen ze niets over de rol die de pragmatische context en de wijze van aanbieding en verwerking van poëzie in de klas spelen in de waardering van kinderen. Ze dragen daarmee niet bij aan het begrijpen waarom kinderen de genoemde voorkeuren hebben en boe kinderen poëzie verwerken en verwerven. Vanwege de alomtegenwoordigheid van 'muzikaal taalspel' in volksculturele poëzie voor kinderen is mijn verwachting dat dit kenmerk een belangrijke rol speelt in de aansluiting van poëzie op de culturele competentie en voorkeuren van kinderen in groep 2 en ook groep 4. Voor de ontwikkeling van de Leeskalender waarmee een selectie van kinderpoëzie is geïmplementeerd in de praktijk van het basisonderwijs, was het noodzakelijk om een nauwkeuriger beeld te krijgen van (a) specifieke vormen van muzikaal taalspel zoals veelvuldig aanwezig in volksculturele baker- en kinderrijmen, (b) hoe deze vormen terugkomen in kinderpoëzie uit het literaire domein ${ }^{67}$, en (c) hoe de voorkeuren van kinderen voor specifieke soorten muzikaal taalspel in poëzie zich naar verwachting ontwikkelen. Vanwege het ontbreken van precies en longitudinaal inzicht in welke vormen van muzikaal taalspel het meest nauwkeurig aansluiten op de voorkeuren en vaardigheden van kinderen in groep 2 en in groep 4, beoogt dit hoofdstuk de volgende deelvraag te beantwoorden:

KINDERPOËZIE: DEELVRAAG 2.b.

Hoe kenmerkt 'muzikaal taalspel' zich in 'het taalspel poëzie' voor kinderen in groep 2 en kinderen in groep 4, zowel in relatie tot pragmatische contexten van tekstgebruik als in relatie tot ontwikkelingskenmerken van de kinderen?

Om deze vraag te beantwoorden, geef ik eerst een algemene typering van de muzikaliteit van het volksculturele kindervers ( $(4.2)$ en plaats ik muzikaal taalspel in taalontwikkelingsperspectief op basis van bestaande studies (\$4.3). Vervolgens ga ik in op specifieke kenmerken die bijdragen aan de muzikaliteit van volksculturele poëzie en kinderpoëzie, te weten metrum en ritme $(\$ 4.4)$, rijm $(\$ 4.5)$ en muzikale segmenten $(\$ 4.6)$. Daarna bespreek ik muzikale soorten van 'het taalspel poëzie' voor kinderen, eerst in de vorm van taal- en uitspraakrijmen ( $(4.7)$ en dan in de vorm van rijmen, liedjes en gedichten die de muzikale structuur ook ruimtelijk ervaarbaar maken (\$4.8). In deze exploratie van 'muzikaal taalspel' betrek ik ook steeds kinderpoëzie uit het literaire domein om de rakvlakken te laten zien ${ }^{68}$. Ten slotte trek ik conclusies over 'muzikaal taalspel' als verwachte indicator van canoniciteit in kinderpoëzie, gespecificeerd naar groep 2 en groep 4 ( $(4.9)$.

\footnotetext{
${ }^{67}$ Zowel voor de typering van 'muzikaal taalspel' in volksculturele baker- en kinderrijmen als voor de inventarisatie van vergelijkbare verschijningsvormen in kinderpoëzie uit het literaire domein is stapsgewijs bronnenonderzoek gedaan, zoals beschreven in Hoofdstuk 7, \$7.2. Een overzicht van geraadpleegde primaire bronnen is opgenomen in Bijlage 1.

${ }^{68}$ De exploratie van 'muzikaal taalspel' in kinderpoëzie waar dit hoofdstuk een weerslag van is, vormde binnen dit onderzoek de basis voor de selectie van kinderpoëzie zoals opgenomen in en geïmplementeerd via het interventieprogramma. Veel van de voorbeelden van poëzie die ik in dit hoofdstuk bespreek, zijn aangeboden in de klas via de Leeskalender voor groep 2 en voor groep 4. Om dit zichtbaar te maken zijn de rijmen, liedjes en gedichten die een plaats hebben gekregen in het interventieprogramma gemarkeerd met [titel] ${ }^{\mathrm{G} 2}$ of [titel] ${ }^{\mathrm{G} 4}$.
} 


\subsection{De muzikaliteit van het kindervers}

Iona en Peter Opie citeren in hun inleiding op The Oxford Dictionary of Nursery Rhymes Emile Cammaerts die schreef: "The nursery rhyme is essentially poetical because essentially musical." (Cammaerts, 1925, geciteerd in Opie \& Opie, 1973, p. 2) Het bakerrijm is in essentie poëtisch omdat het in essentie murikaal is. Deze stelling is te beperkt om poëzie in zijn algemeenheid af te bakenen van andere tekstsoorten. Wel herkennen we hierin heel sterk de ansluiting op de 'communicatieve muzikaliteit' die ook 'motherese' zo effectief maakt in de totstandkoming van betekenisvolle interactie met pasgeboren kinderen (zie ook Hoofdstuk 2 en 3). Voor een groot deel van de volksculturele baker- en kinderrijmen geldt ook dat ze in essentie muzikaal zijn. Dat heeft te maken met de communicatiesituatie waarin ze niet zozeer als poëzie worden gelezen, maar als poëzie worden gebruiket en ervaren in aansluiting op de culturele competentie van jonge kinderen. Die communicatiesituatie wordt voor baker- en kinderrijmen gevormd door de, in Hoofdstuk 3 beschreven, pragmatische situaties waarin de teksten zijn ingebed, zoals interacties tussen ouder en kind of tussen kinderen onderling. De communicatiesituatie waarin deze teksten als gebruikspoëzie functioneren, wordt allereerst gekenmerkt door de mondelinge performance waardoor we kunnen spreken van belichaamde poëzie. Kenmerkend voor de communicatiesituatie waarin baker- en kinderrijmen gebruikt worden, is ook dat er sprake is van geritualiseerde interactie tussen ten minste twee personen die op dezelfde manier met betekenisvolle intervallen wordt herhaald. Vocale en niet-vocale handelingen overlappen elkaar in deze gebruikssituaties doorgaans. Niet alleen de lichamelijke bewegingen die ermee gepaard gaan, maar ook de taal in baker- en kinderrijmen is dan te typeren als 'poëtisch geritualiseerd taalgebruik', tot stand gekomen door 'de verbijzondering van alledaags routinematig taalgebruik door formalisering (simplificatie en stereotypering), herhaling, overdrijving, uitbreiding en toepassing in een nieuwe context om een andere, onalledaagse, boodschap te communiceren' (vgl. Dissanayake, 2009, p. 154). Door die 'redundantie' is de taal van baker- en kinderrijmen duidelijk afgebakend van ons natuurlijke, dagelijks, taalgebruik waardoor het ook voor zeer jonge kinderen al als een bijzondere vorm van taalgebruik herkenbaar is. Ook het 'verhaaltje voor het slapen gaan' is in veel gezinnen een geritualiseerd gebruik, maar bij het vertellen of voorlezen van een verhaal is er meestal een duidelijk verschil tussen de concrete situatie waarin het verhaal verteld wordt, het reële hier-en-nu, en de voorgestelde werkelijkheid in het verhaal. Een mooi verhaal maakt dat we ons tijdelijk minder bewust zijn van het hier-en-nu; de taal van verhalen is er, zeker voor jonge kinderen, op gericht de 'lezer' mee te nemen in de voorgestelde werkelijkheid, te laten opgaan in het verhaal. Baker- en kinderrijmen doen iets anders: zij zorgen in de belichaamde performance juist voor een 'geïntensiveerde beleving van een momentane ervaring' waarbij zowel beleving als ervaring niet alleen door de specifieke pragmatische context, maar ook door de tekst, als ritmisch script, worden bemiddeld. Het vers 'Tikke-takke-tonen', bijvoorbeeld, kan vanuit een poëtische leeshouding gelezen worden (zie Hoofdstuk 2), maar 'werkt' in de gebruikspraktijk als een markering van een reële interactie tussen het kind en degene die het lied zingt. Die interactie wordt in het moment vormgegeven door de koppeling tussen ritmische klankpatronen en ritmische bewegingen. De tekst van bakerrijmen fungeert dan ook vaak primair als een script waarin klank en ritme besloten liggen: "De klank is belangrijker dan de tekst en er 
komt dan ook veel 'taalmuziek' in de wiegeliederen voor: veel rijm en veel - vanuit het alledaagse taalgebruik bekeken - 'onzinwoorden' als eia poppeia, suja suja, ea ea enzovoorts." (Meijer, 1997, p. 150) Die taalmuziek ontstaat door een dichte opeenpakking van herhalingen, allerlei vormen van rijm, en een stevig metrum. In dit muzikale taalspel is de inzet van deze formele eigenschappen van poëzie dan ook niet zozeer gericht op het creeren van een surplus aan betekenis binnen de tekst, maar een 'surplus aan klank en ritme' dat in de performance van een vers als een akoestisch kader voor de fysieke interactie fungeert. Dit geldt niet alleen voor bakerrijmen, maar ook voor veel kinderrijmen verbonden aan allerlei fysieke spelvormen: "De functie van metrum, woordaccenten en zinsmelodie in kinderrijmen is waarschijnlijk dat kinderen op de rijmpjes moeten kunnen klappen, dansen, springen of hinkelen,” stellen Piet Mooren en Jeanne Kurvers (2012, p. 149).

In repertoires van traditionele baker- en kinderrijmen zijn tekstaspecten aan te wijzen die de pragmatische communicatiesituatie van baker- en kinderrijmen als tekstextern aspect in extremis vertegenwoordigen. Allereerst zijn er de pure klankrijmen die niet veel meer zijn dan specifieke klankpatronen in een vaste, herhaalbare vorm gegoten en aan vaste, herhaalbare handelingspatronen gekoppeld. 'Oze wieze woze' is daarvan een heel duidelijk voorbeeld, of een bakerrijm als 'Jantje,/ Wide, wadde, wantje,/ Wide, wadde, winkel, tinkel, tantje;/ "Hip!" zeî Jantje.' (Vloten, 1874, p. 90) Dit rijm gaat gepaard met het door een ouder/verzorger zachtjes op en neer bewegen van het kindje op de beklemtoonde lettergrepen: eerst één keer ('Jantje'), dan drie keer (Wide, wadde, wantje), dan vijf keer (Wide, wadde, winkel, tinkel, tantje), en dan op 'Hip!' onverwacht hoog de lucht in. En als het kind geen Jantje heet dan wordt het klankpatroon gewoon aangepast: 'Pieter,/ Wide, wadde, wieter,/ Wide, wadde, winkel, tinkel, tieter/ "Hip!” zeî Pieter.' (p. 90) In het spel van wat oudere kinderen zijn eveneens rijmen en liedjes te vinden waarin sprake is van puur ritmisch klankspel, zoals in aftelrijmen waarbij op elke beklemtoonde lettergreep een andere speler in de kring wordt aangewezen door degene die aftelt. Bijvoorbeeld: 'Inke, tinke, tullepetijnen/ Vieze vaze, dubbele daze,/ Iksem tien, Gouden riem,/ Erum, blerum, zestien;/ Pief, pof, paf,/ Le bent er eer-lijk af.' (p. 153) Doorgaans is alleen de laatste regel van aftelrijmen betekenisvol in referentiële zin: de rest van het vers functioneert als ritmisch script voor het aftellen (zie Hoofdstuk 3). Op papier vormen dergelijke teksten niet meer dan een 'vertaling' van de akoestische kenmerken van de verbale uitvoering van het vers naar het symbolisch taalsysteem waarin klanken corresponderen met tekens (letters). Echter, we kunnen de meeste 'woorden' in deze teksten niet van betekenis voorzien op basis van ons symbolisch taalsysteem: we kunnen ze wel verklanken en verdelen in klankeenheden, maar die klankeenheden komen niet overeen met woorden waarvoor we een betekenis hebben afgesproken. 'Oze wieze woze' 69 of 'Suja, suja' zijn muzikale frasen die volgens dat symbolisch taalsysteem geen betekenis hebben: het woord 'suja' komt in de Dikke V an Dale

\footnotetext{
${ }^{69}$ Frank Martinus Arion stelde dat verschillende in Nederland bekende baker- en kinderrijmen een Creoolse achtergrond hebben en daarmee stille getuigen zijn van het Nederlandse slavernij verleden. Hij vertaalde rijmen als 'Oze wieze woze', maar ook 'Iene miene mutte', 'terug' naar hoe ze in het Creools geklonken zouden hebben en de betekenis die de woorden dan krijgen (Frank Martinus Arion, 'Vliegende negers.' In: De Groene Amsterdammer, 28 januari 1981, p. 20, geciteerd in: Vries, 2002) In het kader van de pragmatische benadering van hoe dergelijke rijmen in het Nederlands taalgebied functioneren, als klankverzen, zijn dergelijke historische en etymologische benaderingen en de discussies die daar uit voortkomen minder relevant.
} 
niet voor $^{70}$. Maaike Meijer heeft er al eens op gewezen dat de poëtische klanktaal betekenisvol is in een ander, niet-symbolisch, taalsysteem, door Julia Kristeva aangeduid als het semiotisch taalsysteem: “... de taallaag waarin taal geen betekenis is, maar pure klank, ritme en muziek.” (Meijer, 1997, pp. 150-151) In de context van het gebruik van baker- en kinderrijmen kunnen we stellen dat klanken, ritmes, en bijbehorende bewegingen en gebaren betekenis overdragen in het semiotisch systeem van de belichaamde taal. De muzikaliteit van klankrijmen komt voort uit het prosodisch ordeningsprincipe dat aan hun interne opbouw ten grondslag ligt. Een ordeningsprincipe dat vooral ervaarbaar wordt wanneer de tekst wordt gevocaliseerd en dus akoestisch gestalte krijgt. Fysieke ervaring van taal is in dit semiotisch systeem voorwaarde voor de communicatieve functie die deze poëtische taal kan vervullen en is noodzakelijkerwijze gebaseerd op de 'materiële', de zintuiglijk waarneembare, aspecten van taal.

Naast pure klankverzen vormt ook indexicaliteit een tekstkenmerk dat erop wijst dat betekenis bij veel baker- en kinderrijmen niet in de tekst, maar in de relatie tussen de tekst en externe pragmatische context gezocht moet worden. Een duidelijk voorbeeld is het vers

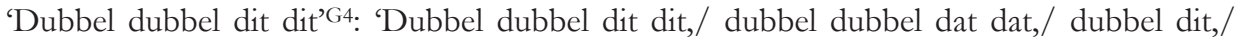
dubbel dat,/ dubbel dubbel dit dat'. We weten niet exact waar 'dit', 'dat', 'die' of 'deze' naar verwijst als we de tekst buiten de gebruikscontext bekijken. Deze woorden zijn enkel betekenisvol in hun directe koppeling aan de fysieke handelingen die door de gebruikers van het vers in de geleefde praktijk worden uitgevoerd. 'Dit voetje' is een van de voetjes van een kind; 'Deze man' is de duim. 'Dubbel, dubbel, dit, dit' betekent op zichzelf, als tekst, niets, totdat we de woorden koppelen aan de bewegingen in het bijbehorende klapspel. Dan zien we dat elk woord voor een bepaalde klapbeweging staat: 'dit' betekent 'ruggen van handen tegen elkaar' en 'dat' betekent 'palmen van handen tegen elkaar'. Zowel taalmuziek als indexicaliteit drukt onze neus op het feit dat baker- en kinderrijmen onderdeel zijn van een orale gebruikstraditie: dit zijn geen verzen om stil te lezen uit een boek, maar verzen om te gebruiken en fysiek te ervaren. Tekst en fysieke handelingen zijn in deze gevallen zo nauw met elkaar verbonden, dat we ze nauwelijks als aparte eenheden kunnen beschouwen. Zelfs als de gebaren, het klappen, dansen, springen of hinkelen worden weggelaten, zorgt het in hoofdzaak prosodische ordeningsprincipe van dergelijke rijmen voor een expliciet fysieke ervaring van taal. In zijn boek The Singing Neanderthals: The Origins of Music, Language, Mind and Body schrijft Steven Mithen ${ }^{71}$ :

\footnotetext{
70 Alleen het puzzelwoordenboek vermeldt 'suja' als woord, maar de betekenis ervan kan enkel omschreven worden op basis van de gebruiksfunctie: 'Woordje om kleine kinderen te troosten.' (http://www.mijnwoorden boek.nl/puzzelwoordenboek/SUJA/1)

${ }_{71}$ Mithen is een van de vertegenwoordigers van de groeiende wetenschappelijke aandacht voor de 'evolutie van taal' waarin gezocht wordt naar de oorsprong van taal in de lijn van de evolutie van de menselijke soort. Een aantal van deze studies geeft een indicatie dat wat we nu als formele kenmerken van 'poëtisch taalgebruik' kennen dichter bij de oorsprong van taal ligt dan ons huidig 'natuurlijk' taalgebruik dat er in hoofdzaak op gericht is informatie over de werkelijkheid over te dragen (zie Dissanayake, 2007; 2009; Roder, 2002; Jakobson \& Waugh, 1987). Ons huidig 'natuurlijk' taalgebruik is dan wellicht artificiëler dan poëtisch taalgebruik voor zover het de ritmische verschijnselen betreft (zie ook Roder, 2002). Hoewel zeer interessant, reikt het te ver om hier in het kader van dit onderzoek diep op in te gaan. Een in dit kader interessante visie vinden we in The Sound Shape of Language waarin de auteurs op basis van het poëtische als natuurlijk verschijnsel in de taalontwikkeling van kinderen, dus vanuit synchroon i.p.v. diachroon perspectief, stellen: "Since both aspects of language, the ordinary and the poetic, are two copresent and coacting universals familiar to the human being from his first linguistic steps, one could with equal right and equal one-sidedness speak about poetry and its 'ungrammaticality' or on the
} 
"Indeed, to separate rhythmic and melodic sound from rhythmic and melodic movement - song from dance - is quite artificial .... The easiest way to appreciate this is simply to recognize that song itself is no more than a product of movement, made by the various parts of the vocal tract reaching from the diaphragm to the lips." (Mithen, 2005, p. 15)

Of we nu te maken hebben met bakerrijmen gekoppeld aan het wiegen, wassen, voeden, kleden van of spelen met het zeer jonge kind, met kinderrijmen en -liedjes die gepaard gaan met ingewikkelde klapspelletjes, touwspringtechnieken, handgebaren of danspatronen, of met 'taal- en uitspraakrijmen': ze doen zonder uitzondering, zowel in productieve als in receptieve zin, een beroep op het lichaam, op de zintuigen en de motoriek. Ritmische en melodische klank kan hier dus niet los worden gezien van ritmische en melodische beweging. Die lichamelijke ervaring van taal wordt in veel baker- en kinderrijmen versterkt doordat taal er hoofdzakelijk gebruikt wordt als muzikaal instrument waarin klank en ritme de primaire ordeningsprincipes zijn.

Dergelijke rijmen en liedjes zijn daarmee aan te duiden als lyrische tekstsoorten, waarbij 'lyrisch' hier bedoeld is in de traditionele zin van 'muzikaal', als - lang geleden met de lier begeleide - gezongen of ritmisch en melodisch opgezegde versvorm (vgl. Thomas, 2004, p. 169). Om verwarring met het lyrische in de vorm van het 'lyrisch ik' te voorkomen, gebruik ik verder de term 'muzikaal'. Het spel dat in deze rijmen op tekstueel niveau wordt gespeeld, is dan een muzikaal spel, i.e. een muzikaal taalspel, dat vocale en niet-vocale handelingen ritmisch met elkaar verbindt.

\subsection{Muzikaal taalspel en taalontwikkeling}

Bij een inventarisatie van poëzie voor kinderen die gekenmerkt wordt door 'muzikaal taalspel', i.e. door een overheersende nadruk op de prosodische eigenschappen van taal, wordt al snel duidelijk dat 'muzikaliteit' op vele manieren tot stand kan komen. De veelvormigheid van het muzikaal taalspel zoals we dat in volksculturele en ook literaire poëzie voor kinderen aantreffen, wijst er op dat er verschillen bestaan in de soorten muzikaal taalspel die kinderen op verschillende leeftijden en in verschillende contexten het meest aanspreken. Het is in het kader van dit onderzoek van belang een nauwkeuriger beeld te krijgen van de aansluiting van vormen van muzikaal taalspel op ontwikkelingskenmerken van kinderen in de leeftijd van vijf tot en met acht jaar om poëzie te kunnen selecteren die een grote potentie heeft om bij de beoogde doelgroep in de smaak te vallen. In verschillende wetenschappelijke studies wordt het spelen met de poëtische functie van taal aangewezen als 'natuurlijk fenomeen' in taalverwervingsprocessen bij kinderen, ongeacht welke taal ze leren (zie Geller, 1985; Waugh, 1980; Schaerlaekens, 1977; Chukovsky, 1971/1925). Dit wijst erop dat, zo stellen verschillende auteurs, de poëtische functie van taal een belangrijke rol in de taalontwikkeling speelt:

contrary assail ordinary language for its casual, crude, and retrograde grammatical organization and character." (Jakobson \& Waugh, 1987, p. 225) 
"[W]e know ... that all normal children in all cultures go through a stage in the language acquisition process in which they invent or repeat rhymes, play with sound, etc. in other words, they play with the poetic function, both as the dominant function and as a subordinate function. Jump-rope rhymes, counting-out rhymes, street games of all sorts, ... all attest to the importance of the poetic function in language learning." (Waugh, 1980, p. 60)

Kinderen houden ervan om te rijmen, om allitererende tongbrekers uit te spreken, en om te lachen om grappig klinkende namen (Fleischman, 1986, p. 553). Echter, omdat het type taalspel dat kinderen op een bepaalde leeftijd het meest aanspreekt nauw verbonden is met hun taalontwikkeling, moeten we er rekening mee houden dat wat kinderen van vijf en zes (groep 2) aanspreekt niet per definitie hetzelfde is als wat kinderen van zeven en acht aanspreekt (groep 4). Als een van Ruslands favoriete dichters van kinderpoëzie publiceerde Kornei Chukovsky zijn boek From Two to Five om zijn inzichten in wat kinderen in de leeftijd van twee tot vijf jaar aanspreekt in poëzie te delen. Hij stelde op basis van zijn eigen observaties van jonge kinderen in zijn omgeving en de vele brieven die hij van (groot)ouders ontving over het taalgebruik van hun jonge (klein)kinderen vast dat kinderen al vanaf de leeftijd van twee jaar plezier beleven aan de herhaling van betekenisloze klanken en aan het creëren van rijmende woordparen. Dit vermogen groeit vanuit de vroegste fasen van het taalontwikkelingsproces waarin alle taal zich nog als ritmische klankpatronen aan kinderen voordoet. Kinderen beginnen al in de wieg met het vormen en herhalen van bepaalde klanken en dit breidt zich allengs uit naar de herhaling van eerste woordjes als 'mama' en 'papa', het herhalen van rijmende woordparen en het creëren van rijmende 'verzen'. "In the beginning of our childhood we are all 'versifiers'- it is only later that we begin to speak in prose." (Chukovsky, 1971/1925, p. 64) In de peuter- en kleuterfase gaat de creatie van uitgebreidere rijmende regels door kinderen zelf samen met fysieke ritmische beweging, zoals klappen, springen, rennen en dansen: "Often these rhymes grow out of ecstatic, rhythmic movement, are meaningless, and fulfill mainly the function of accompanying music." (p. 65) De vroege voorkeur van kinderen voor de in hoge mate betekenisloze (in referentiële zin), doch even goed zeer expressieve en functionele klankrijmen die voortkomen uit uitbundige en ritmische beweging, ziet Chukovsky als verklaring voor de aard van veel bakerrijmen: "This inclination of small children to get 'drunk' on melodic rhymes accounts for the nature of many nursery songs ...." (p. 65) Naarmate het kind ouder wordt, stelt Chukovsky, gaat referentiële betekenis een steeds belangrijker rol spelen en zullen kinderen meer geneigd zijn zich te uiten in vrije versvorm waarin inhoud voorop staat, "since clapping and chanting are now displaced by thought and introspection." (p. 70)

Chukovsky makkt dus onderscheid tussen de fase 'van twee tot vijf' waarin het kind zich nog kan verliezen in spontane mondelinge 'versificatie' op basis van ritme en klank in combinatie met klappen, stampen en springen, en de fase waarin kinderen in zelfgeschreven (vrijere) versvormen hun gedachten en gevoelens samenhangend kunnen uiten. Die laatste fase begint volgens Chukovsky vanaf een jaar of negen á tien. In de ontwikkeling van de eerste naar de laatste fase komt de poëzie die kinderen (re)produceren steeds losser te staan van hun taalontwikkeling, die op zichzelf weer samenhangt met de cognitieve, motorische, sociale en emotionele ontwikkeling en de totale leef- en belevingswereld van 
het kind (zie Schaerlaekens, 1977). Waar poëzie aanvankelijk een ritmische en melodische ondersteuning of intensivering is van belichaamde en lichamelijke interactie in concrete tekstexterne communicatiesituaties wordt poëzie volgens Chukovsky voor kinderen vanaf een jaar of negen een op zichzelf staand middel om eigen gedachten en gevoelens in tekst te vatten: "Up to the age of about four the child was poet, singer, and dancer -all at the same time - but now poetry has become, for the first time, a creative activity separated from any other art ...." (Chukovsky, 1971/1925, p. 72) Daartussen ligt de periode waarin kinderen hun 'honger naar de harmonie en melodie van poëzie' stillen door gebruik te maken van het werk van andere dichters, zo stelt Chukovsky (idem, p. 70). Hij gaat echter niet nader in op het soort poëzie dat kinderen in die fase 'van vijf tot negen' het meest aanspreekt en de ontwikkelingen die in die fase plaatsvinden. En dat is nu juist de fase die in dit onderzoek centraal staat. In De taalontwikkeling van het kind schrijft Anne Marie Schaerlaekens over de fase vanaf vijf jaar dat kinderen zich in principe het hele complexe en subtiele communicatiesysteem van het mondeling taalgebruik al hebben eigen gemaakt (1977, p. 6). Tegelijk wijst ze erop “ $\ldots$ dat het kind in deze periode op uitzonderlijke wijze de taal gebruikt als een uitdrukking van spel en fantasie.... [M] en kan eigenlijk gerust zeggen dat het poëzie maakt. Het kind ... gebruikt taal als louter ludiek en 'artistiek' middel. Deze eigen creaties van het kind worden al dan niet doorspekt met fragmenten uit bestaande rijmpjes." (pp. 177-179) Een van de vele voorbeelden die Schaerlaekens hier geeft, is: 'Tikke takke tokke/ 't meiske in de klokken/ Tikke takke tie/ 't meiske in de piepie' (Gerrit, 6 $\mathrm{j} / 4 \mathrm{~m}$ ). Waar dit nog een voorbeeld van individueel taalspel betreft, gaan oudere kleuters en schoolkinderen steeds meer participeren in collectieve poëtische taalfantasieën en putten ze steeds vaker uit repertoires van bestaande baker- en kinderverzen (pp. 179-181). Daar waar het repertoire door volwassenen wordt overgedragen, spreekt Schaerlaekens over de participatie van kinderen in een bestaande taalcultuur, daarnaast gaan ze ook in toenemende mate deel uitmaken van een kindercultuur "met zeer eigen mondelinge overleveringen en met een eigen taalcultus, die in zekere mate ook ritueel mag heten." (p. 181) Waar Chukovsky de fase waarin 'poetry has become, for the first time, a creative activity separated from any other art' rond een jaar of jaar of negen plaatst, spreekt Schaerlaekens al over poëzie in het taalspel van kinderen vanaf 5 jaar, want het kind 'gebruikt taal als louter ludiek en 'artistiek' middel'. Wat we uit de beschrijving van Schaerlaekens ook kunnen afleiden, is dat in de fase vanaf 5 jaar de verwerving en het gebruik van bestaande poëzie de spontane productie van poëtisch taalgebruik bij kinderen steeds meer gaat overnemen.

Linda Gibson Geller schrijft in Wordplay and Language Learning for Children: "... while the toddler may run about half-singing, half-chanting partly remembered rhymes and songs, the more sophisticated preschooler is busy mastering a relatively extensive repertoire of traditional nursery rhymes repeated with parents, teachers, and peers. Indeed, ... ways to play with the sounds of language are investigated [by children] throughout the three-toeleven age range." (1985, p. 16) De fase van vijf tot en met zeven jaar wordt wel getypeerd als 'The Transition Years' (p. 28). Dit is de fase waarin kinderen de cognitieve ontwikkeling doormaken van pre-operationeel naar concreet operationeel denken: een proces waarin ze, zoals beschreven door Piaget (zie Hoofdstuk 1, \$1.6), geleidelijk aan meer abstracte concepten kunnen gaan begrijpen, zoals tijd, oorzaak en gevolg en vergelijkingen, en een logisch denkvermogen ontwikkelen. Ze zijn in hun spontane taalspel steeds meer bezig met 
de exploratie van het principe dat woorden symbolisch zijn, dus naar iets verwijzen, maar niet intrinsiek met (eigenschappen van) het object of de persoon verbonden zijn. Dit opent een heel scala aan nieuwe mogelijkheden om te spelen met de referentiële relatie tussen symbolische taal en de werkelijkheid ${ }^{72}$. Wat muzikaal taalspel betreft schrijft Geller dat kinderen in deze fase nog steeds veel plezier beleven aan de ordening van taal op basis van klankovereenkomsten, zoals in het gebruik van binnen- en eindrijm, maar zeker ook alliteratie (p. 38). Ook onomatopeeën zijn geliefd: "In the primary years, youngsters are fascinated by the sheer aural expressiveness generated by words in this category." (p. 40) Kinderen maken in de leeftijd van vijf tot acht jaar steeds meer gebruik van bestaande vormen van taalspel, zoals raadsels, moppen en tongbrekers, en exploreren in hun productie en reproductie van rijmen en liedjes op speelse wijze, naast hoe de wereld in elkaar zit, de poëtische middelen die de taal hen ter beschikking stelt: "Patterns in sound represented by intonation, rhyme, and rhythm are carefully examined in spontaneous play, as well as in the ritual repetitions of traditional playforms." (p. 41) Geller stelt dat het is alsof kinderen in het proces zijn 'de poëzie van grammatica te verwerven als voorbereiding op de verwerving van de grammatica van poëzie' (pp. 41-42). Hieruit kunnen we afleiden dat ook Geller van mening is dat 'het taalspel poëzie' door kinderen van vijf tot acht jaar nog vooral wordt ervaren en gewaardeerd als 'taalspel', als speelse exploratie van allerlei aspecten van het taalsysteem, en nog niet zozeer als 'poëzie', als tekstueel genre. Daarbij is het in deze fase volgens Geller vooral van groot belang dat kinderen op school regelmatig worden blootgesteld aan taalspelvormen, zoals poëzie, zodat ze geleidelijk een repertoire kunnen opbouwen dat vroeg of laat een uitwerking heeft in hun eigen uitingen (p. 42).

Omdat kinderen in de 'transition years' (van vijf tot acht jaar) nog altijd veel plezier beleven aan 'muzikaal taalspel' blijft het in deze fase van belang om poëzie mondeling over te dragen:

"Even after learning to read and becoming at least partially literate, children retain their love for, and use of, sound games. Still in what psycholinguists call the age of resonance, children continue through grade school $^{73}$ to learn by ear and to relish sequences where a phonetic rather than an intellectual logic rules." (Anderson \& Apseloff, 1989, p. 50)

Omdat de genoemde studies 'muzikaal (of poëtisch) taalspel' beschrijven als verschijnsel binnen het taalontwikkelingsproces van kinderen is het moeilijk in te schatten hoe productie en receptie zich precies tot elkaar verhouden waar het muzikaal taalspel in poëtische vorm betreft en op welke manier de verwerving van dergelijke poëtische vormen verloopt. Het bewust creëren en plezier beleven aan muzikaal taalspel duidt er wel op dat een belangrijke rol is weggelegd voor de zintuiglijke, fysieke, ervaring van de prosodische kenmerken van taal in de waardering en verwerving van poëzie voor kinderen in zowel groep 2 als

\footnotetext{
${ }_{72}$ Vormen van spel met de referentiële functie van taal komen in het volgende hoofdstuk verder aan bod.

73 'Grade school' staat voor 'elementary school' of 'primary school' waar kinderen in het (US- of Brits-) Engelse schoolsysteem $1^{\text {st }}$ Grade tot en met $8^{\text {th }}$ Grade doorlopen. 1st Grade correspondeert met wat we in Nederland als groep 3 aanduiden, maar het primair onderwijs loopt langer door dan in Nederland. De leeftijden per groep zijn in het Engelse schoolsysteem als volgt: 1 st grade: 6- tot 7-jarigen; 2 nd grade: 7 - tot 8-jarigen; 3rd grade: 8- tot 9jarigen; 4th grade: 9- tot 10-jarigen; 5 th grade: 10 - tot 11 -jarigen; 6 th grade: 11 - tot 12 -jarigen; 7 th grade: 12 - tot 13-jarigen; 8 th grade: 13 - tot 14 -jarigen.
} 
groep 4. De belangrijkste conclusie die ik uit de besproken studies kan trekken is dat we mogen verwachten dát kinderen in zowel groep 2 als groep 4 muzikaal taalspel als tekstueel kenmerk in kinderpoëzie waarderen. Daarbij geven de studies een globale ontwikkeling weer van een voorkeur voor spontaan muzikaal taalspel gekoppeld aan spontane vormen van ritmische fysieke beweging bij de jongste kinderen naar een toenemende voorkeur voor bestaande vormen van taalspel - moppen, raadsels, rijmen en liedjes als 'rituele taalhandelingen' - al dan niet gekoppeld aan sterk geritualiseerde spelvormen bij oudere kinderen. Wat deze studies echter niet bieden, is nauwkeurig inzicht in de voorkeuren van kinderen voor bepaalde soorten poëzie of specifieke vormen van 'muzikaal taalspel' in poëzie. In het vorige hoofdstuk heb ik er, op basis van de exploratie van de relatie tussen poëzie voor kinderen en pragmatische contexten al op gewezen dat zowel baker- als kinderrijmen van oudsher bijna zonder uitzondering zijn gebonden aan concrete gebruikscontexten. Dit wijst erop dat jonge kinderen 'het taalspel poëzie' bijna uitsluitend (leren) spelen in combinatie met (niet-vocale) fysieke handelingspatronen. Getuige het feit dat de ritmische verschijnselen in de 'poëzie van de speelplaats' zeer expliciet aanwezig zijn en vaak nog eens extra benadrukt worden door de overlapping met ritmische fysieke beweging (klappen, stampen, springen, dansen, etc.), blijft de lichamelijke ervaring voor kinderen in de basisschoolleeftijd nog lange tijd een belangrijke rol spelen in hun voorkeuren en beleving van 'het taalspel poëzie'. Tegelijk is zichtbaar dat 'het taalspel poëzie' naarmate kinderen ouder worden ook steeds meer als spel op zich gespeeld wordt. Op het moment dat kinderen een lied of rijm formeel als 'rituele taalhandeling' (zie Hoofdstuk 2) herkennen en de bijbehorende gebruiksconventies hebben verworven, dan verschuift de focus in het handelen met 'het taalspel poëzie' van de context naar de tekst. Het feit dat ook 'taal- en uitspraakrijmen' zoals de tongbrekers geliefd zijn bij kinderen van vijf tot acht jaar (Geller, 1985, p. 41) is een teken dat de poëtische functie van taalgebruik in deze fase in relatief autonome vormen van 'het taalspel poëzie' langzaamaan op de voorgrond komt te staan. De tekst, als 'rituele taalhandeling', gaat nu op zichzelf het rituele kader vormen terwijl de externe, concrete, rituele gebruikscontext die aanvankelijk nog zo belangrijk was om 'het taalspel poëzie' haar functie en betekenis te geven, steeds meer door kinderen wordt verinnerlijkt en niet langer concreet, maar conceptueel meespeelt in de poëtische communicatiesituatie. Hoe vertaalt dit zich in concrete tekstkenmerken van verschillende soorten muzikale poëzie? Waar moeten we op letten als we poëzie willen selecteren die gekenmerkt wordt door 'muzikaal taalspel', i.e. wat zijn de belangrijkste 'indicatoren van muzikaliteit' in kinderpoëzie?

\subsection{Metrum en ritme in het muzikale kindervers}

In het vorige hoofdstuk heb ik het gebruik van baker- en kinderrijmen in terugkerende contexten van tekstgebruik al gekoppeld aan het concept 'ritme' dat vorm krijgt in patronen van herhaling en afwisseling. Op het ingebedde niveau van poëziegebruik in context zorgen rijmen en liedjes voor de ritualisering van overlappende taal- en handelingspatronen die bepaalde terugkerende situaties markeren (bijvoorbeeld 'naar bed gaan'). Deze koppeling tussen geritualiseerd gebruik en context kan niet los worden gezien van de factor tijd: het gebruik van baker- en kinderrijmen markeert momenten in de tijd waardoor er verschil 
ontstaat tussen de doorlopende alledaagse tijd en de terugkerende vaste momenten in dat tijdverloop (bijvoorbeeld 'bedtijd' of 'Sinterklaastijd'). Op overkoepelend niveau markeert het geritualiseerde gebruik van baker- en kinderrijmen daarmee ritmische patronen in het verloop van de dagelijkse, wekelijkse, maandelijkse en jaarlijkse tijd. Op beide niveaus vervult het geritualiseerde gebruik van rijmen en liedjes belangrijke functies in het waarneembaar en ervaarbaar maken van tijd. "Het absoluut eenmalige is voor ons niet waarneembaar, en evenmin het zich ongedifferentieerd tot in het oneindige herhalende," schrijft Bronzwaer (1993, pp. 15-16). Voor waarneming is 'periodisering' nodig: "Periodisering heeft ... te maken met afwisseling, met terugkeer van hetzelfde na het andere, met ritme." (pp. 1516) Naast de in het vorige hoofdstuk besproken niveaus waarop het gebruik van baker- en kinderrijmen voor jonge kinderen gekoppeld is aan ritme, voeg ik nu een derde niveau toe: het tekstuele niveau. Op dat tekstuele niveau hebben we te maken met de ordening van taal in de tijd, i.e. de temporele ordening van taal. Die temporele ordening speelt ook in ons alledaags taalgebruik een rol, maar is in baker- en kinderrijmen expliciet en sterk gestructureerd aanwezig.

De temporele ordening van taal wordt in het kindervers allereerst bepaald door het metrum. Metrum is de meest basale vorm van geperiodiseerde herhaling in de tekst en kan als zodanig worden omschreven als de herhaling van beklemtoning op regelmatige, voorspelbare tijdsafstanden. Een zeer veelvoorkomend metrum in traditionele baker- en kinderrijmen is, om met Bronzwaer te spreken: “... een standaard-variant van de trocheïsche tetrameter, waarbij de laatste daling weg kan vallen.” (p. 81) In veel kinderverzen bepaalt dit metrum, gekenmerkt door vier versvoeten (tetrameter) die elk bestaan uit een beklemtoonde en een onbeklemtoonde lettergreep (weergegeven als ' / x / x / x / x'), de basismaat. Dit metrum komt sterk overeen met de overheersende metrische patronen in onze natuurlijke taal. In poëtische vorm is dit metrum echter veel sterker geformaliseerd en dwingender dan in het alledaagse taalgebruik, waardoor het de aandacht op zichzelf vestigt en afleidt van betekenis (p. 81). Het is een sterk maatbepalend metrum - één, twee, drie, vier, vijf, zes, zeven - dat in traditionele baker- en kinderrijmen volgens Bronzwaer al snel tot een dreun verwordt:

"Hoe sterker de dreun in de poëzie, des te muzikaler zal zij aandoen, althans in één betekenis van het woord muzikaal. We bedoelen dit: in de muziek komt het accent vóóraan in de maat en alle maten duren even lang, zodat de accenten op precies dezelfde afstand van elkaar liggen.” (Bronzwaer, 1993, pp. 84-85)

Dit muzikaal trocheïsch metrum herkennen we, hoewel niet altijd als tetrameter, heel duidelijk in liedjes als 'Schaapje, schaapje,/ heb je witte wol? / Ja, baas, 迆, baas,/ drie zakken vol', 'Witte zwanen, zwarte zwanen', 'Eén, twee, drie, vier, vijf, zes, zeven,/ waar is Berend Botje gebleven' en 'Altijd is Kortiakje ziek, / midden in de week maar 's zondags niet'. Hoewel deze teksten in bundels en bloemlezingen lang niet altijd met melodie worden weergegeven, kennen we ze als liedjes, dus zijn ze als vanzelf muzikaal. Het trocheïsch metrum ligt echter ook ten grondslag aan veel van de rijmen die doorgaans worden opgezegd zoals 'Iene miene mutte, / tien pond grutten,/ tien pond kaas, / iene miene mutte/ is de baas' en zeker in 'Een, twee, in de maat,/ anders wordt de juffrouw kwaad,/ maar de juffrouw wordt niet kwaad,/ want ze is van prikkeldraad'. Ook al hebben deze rijmen geen melodie, ze zijn 
dankzij het overheersende metrum niet minder muzikaal. "Muzikale poëzie ... zal het trocheïsche ritme zoeken, of ook het dactylische.” (p. 86) De meeste Nederlandse poëzie voor volwassenen wordt gekenmerkt door tegenovergestelde metrische patronen: ze zijn vaker jambisch (versvoeten met een onbeklemtoonde en een beklemtoonde lettergreep) “...omdat ze meer aandacht eist voor haar semantische inhoud dan voor haar klankkwaliteiten.” (p. 86) Bronzwaer stelt terecht dat het trocheïsch metrum heel nauw verbonden is met traditionele baker- en kinderrijmen. Echter, wanneer we dergelijke rijmen benaderen als de gesproken en gezongen uitingen die ze zijn, dus los van papier, dan wordt al snel duidelijk dat dit metrum slechts de basismaat is. In de mondelinge uitvoering wordt de 'dreun', of de 'cadans', van het metrum vaak aangevuld met persoonlijke variaties van de specifieke gebruikers gekoppeld aan specifieke geritualiseerde handelingspatronen in een specifieke context. Zoals Theodore Roethke schrijft in zijn ritmische analyse van een aantal van zijn favoriete bakerrijmen: “... much of memorable or passionate speech is strongly stressed, irregular, even 'sprung,' if you will.” (2001/1965, p. 65) Juist door variaties wordt de dreun doorbroken en ontstaat ritme en door dat ritme blijft de tekst in de performance ervan de aandacht vasthouden. Op papier bekeken, worden de variaties niet altijd onthuld; gehoord in de gebruikscontext blijkt er weinig sprake van 'dreun', behalve wanneer die dreun functioneel is, zoals in marsliederen of touwspringliedjes waarin de maat moet corresponderen met de regelmaat van het lopen of het draaien van het touw.

Niettemin is het trocheïsch metrum een sterk structurerend middel in baker- en kinderrijmen dat bijdraagt aan de muzikale klank van deze teksten. Het is de maat waarop vervolgens gepaste variaties worden toegevoegd in de overige prosodische aspecten, toonhoogte, intonatie en tempo, die alleen in de uitvoering waarneembaar worden. Een mooi voorbeeld van het variëren in toonhoogte en intonatie is het Marokkaanse wiegelied Nienie ya moemoe ${ }^{3 \mathrm{G} 2 / \mathrm{G} 4}$ zoals opgenomen op de cd Walla kristalla: liedjes van overal (Van Camp, 2011). De tekst luidt (fonetisch): "Nienie ya moemoe/ taytieb 3ashaana,/ iela maTaab 3ashaana,/ yetieb 3asha_d diraana.// Nienie ya hbayyib,/ ya sghier, ya zwien,/ ya hbieb ma-ma!” De vrouw die dit bekende Marokkaanse slaapliedje, met een door haar zelf toegevoegd tweede deel, inzong voor de cd laat horen hoe het, zoals gebruikelijk bij slaapliedjes, voor het grootste deel op een langzaam tempo wordt gezongen binnen een beperkt bereik. In de laatste regel ('ya hbieb ma-ma!') valt echter een rust na 'hbieb' en gaat de stem ineens een heel eind omhoog op 'ma-' en dan een heel eind naar beneden op de tweede '-ma'. De inbreng van een rust en de verrassende intonatie van 'ma-ma' doorbreekt als het ware het rustgevende effect van de voorgaande regels. Dit doet vermoeden dat op 'ma-ma' ook een andere dan de wiegende beweging wordt gemaakt: waarschijnlijk een beweging die de stijging en daling van de stem volgt. Naast de toevoeging van prosodische variaties kan ritme in de uitvoering van traditionele kinderverzen ook voortkomen uit de wijze waarop nonverbale en verbale handelingen zich tot elkaar verhouden. Denk bijvoorbeeld aan 'Zagen zagen, wiedewiedewagen'. Twee kinderen staan tegenover elkaar en houden elkaars handen kruiselings vast. Op de basismaat van het lied bewegen ze de linker- en rechterhanden beurtelings naar voren en naar achteren: het tempo van deze bewegingen is stabiel. Tegelijk zingen ze het lied waarin soms precies een lettergreep per maat (beweging naar voren of beweging naar achteren) klinkt, maar soms ook twee lettergrepen in een maat, bijvoorbeeld: 


\begin{tabular}{llllllll}
\hline Za- & gen & za- & gen & wiede & wiede & wa- & gen \\
Rechts & links & rechts & links & rechts & links & rechts & links \\
\hline
\end{tabular}

De niet-vocale handelingen geven dus de basismaat aan, terwijl het tempo in de zang varieert tussen hele en halve maten per lettergreep. Dit geeft een ritmisch effect in de totale fysieke ervaring van verbale en non-verbale handelingen. Hetzelfde geldt voor bijvoorbeeld 'Schuitje varen, theetje drinken' waarbij twee kinderen tegenover elkaar op de grond zitten en, elkaars handen vasthoudend, naar voren en naar achteren bewegen. Hier vinden we een afwisseling van één, twee en drie lettergrepen per maat:

\begin{tabular}{|c|c|c|c|c|c|c|c|}
\hline $\begin{array}{l}\text { Schuitje } \\
\text { vooruit }\end{array}$ & $\begin{array}{l}\text { varen, } \\
\text { achteruit }\end{array}$ & $\begin{array}{l}\text { theetje } \\
\text { vooruit }\end{array}$ & $\begin{array}{l}\text { drinken, } \\
\text { achteruit }\end{array}$ & $\begin{array}{l}\text { varen we } \\
\text { vooruit }\end{array}$ & $\begin{array}{l}\text { naar de } \\
\text { achteruit }\end{array}$ & $\begin{array}{l}\text { Over- } \\
\text { vooruit }\end{array}$ & $\begin{array}{l}\text { toom } \\
\text { achteruit }\end{array}$ \\
\hline
\end{tabular}

Bij kringspelliedjes als 'Zakdoekje leggen' of 'Zeg, Roodkapje, waar ga je henen?' corresponderen tempowisselingen in het zingen met de tempowisselingen in het lopen van degene die rond de kring gaat. Zo komen veel van de ritmische verschijnselen in baker- en kinderrijmen voort uit de interactie tussen vocale en niet-vocale handelingen. Daarbij zien we vanuit pragmatisch perspectief dat het specifieke arrangement in de uitvoering steeds gerelateerd is aan de specifieke gebruikscontext en -functie. Een wiegelied, gezongen door een ouder of verzorger, moet het kind sussen en tot rust brengen en wordt dus gekenmerkt door veel herhaling, een rustige melodie en een wiegende maat (3/4 of 6/8 maat), terwijl een kietelliedje het kind moet activeren of afleiden (van een huilpartij bijvoorbeeld) en dus allerlei tempowisselingen bevat en een duidelijke climax aan het eind die gepaard gaat met een 'onverwachte' kietelaanval. In kinderrijmen, door wat oudere kinderen onderling gebruikt, kan de relatie tussen vocale en niet-vocale handelingen ook een spel op zich vormen. In veel klapspelletjes is het bijvoorbeeld een uitdaging om het klappatroon goed te blijven uitvoeren terwijl het tempo van de zang steeds hoger wordt. Op deze manier worden de ritmische verschijnselen in poëzie steeds zeer expliciet ervaarbaar in de vocale en niet-vocale uitvoering. Zoals Karen Coats stelt: "The rhythms and sounds of poetry for children, whose metrics, phonetics, and structures resonate with bodily architecture and processes, preserve the body in language ....” (2013, p. 134)

\subsection{Rijm in het muzikale kindervers}

Om het metrum of 'metrisch ritme' van teksten waarneembaar te maken, is klank nodig. De herhaling van klanken of klankgroepen op regelmatige, voorspelbare tijdsafstanden, dus de geperiodiseerde herhaling van klank, noemen we 'rijm'. In de gebruikspraktijk en ook in de analysepraktijk kunnen ritme en rijm in het muzikale kindervers eigenlijk niet van elkaar worden gescheiden. Rijm is feitelijk een vorm van geperiodiseerde klankherhaling die interfereert met het basismetrum van een vers en daarmee bijdraagt aan het geheel van de ritmische verschijnselen die in de uitvoering van een vers worden ervaren. Toch is het van belang om apart aandacht te besteden aan rijm in het muzikale kindervers, omdat het een zeer veelzijdige stijlfiguur is die in muzikale kinderrijmen een andere rol speelt dan in rijmen 
waar muzikaliteit minder op de voorgrond staat. Zo stelde Willem Wilmink dat gepaard eindrijm (abb) zich bij uitstek leent voor verhalende gedichten, het is het vertellersrijm; in gedichten waarin ideeën centraal staan is omarmend eindrijm (abba of abca) volgens hem geschikter (Wilmink, 1990; zie ook Mooren \& Kurvers, 2012, p. 149). Zo past de ene vorm van rijm beter bij de ene tekstsoort dan een andere vorm, maar welke vorm(en) van rijm zijn dan kenmerkend voor het muzikale kindervers?

In zijn inleiding op Het spel van moeder en kind: Oude Kinderrijmen voor Jonge Ouders schrijft Jop Pollmann: "Het rhythme van de rijmpjes, zowel van de liedjes als van de versjes die alleen maar gezegd worden, wordt voor het grootste gedeelte gedragen door het oude Germaanse stafrijm.” (Troelstra-Bokma de Boer \& Pollmann, 1948, p. XIV) Dat oude Germaanse stafrijm kennen we als alliteratie, wat staat voor de geperiodiseerde herhaling van medeklinkers aan het begin van de woorden in een regel, als in 'Tikke - takke - tonen', 'Geeze, geeze, goeze gat' en 'Klein klein kleutertje'. Een fenomeen dat ook de regels van het oudste bewaard gebleven stukje Oudnederlands schrift, 'Hebban olla vogala', kenmerkt, zo stelt Frits van Oostrom: “... nog niet met eindrijm maar met stafrijm (hebban-hagunnanbinase en wat-we) en veel assonanties.” (2006, p. 97) Pollmann citeert ook Guido Gezelle die al allitererend stelde: 'de Stafrijmen zijn gelijk Stapstenen, waarop men Steunt met de Stemme’ (1948, p. XIV). Terecht merkt Pollmann op dat niet alleen het traditionele kindervers, maar ook de ontluikende taal van jonge kinderen veel alliteratie bevat: "woefwoef, tiktak, piefpaf, mama, papa" (p. XV). Wat de voorbeelden die Pollmann vervolgens geeft, laten zien is dat dit stafrijm in hoofdzaak de muzikale introducties op bakerrijmen kenmerkt. We kunnen hier ook eindeloos veel voorbeelden van 'refreinen' uit baker- en kinderrijmen aan toevoegen: 'Mari Marijne, Mari Maron', 'Spetter spetter spat/ ik word klets kledder nat', 'Dieroem daroem doem', 'Kling klokje klingelingeling' (allen in Linders \& Duijx, 2011). Zoals ik verderop in dit hoofdstuk laat zien, zijn dergelijke opmaten en refreinen in baker- en kinderrijmen meestal pure klank terwijl in de rest van de tekst semantische betekenis meer aan de oppervlakte ligt. Daar waar referentiële betekenis de kop op steekt, neemt de dichtheid van de alliteratie af: 'Rikke, tikke, tofie./ Rikke, tikke, tom!/ Je bent voor zo'n heel klein kindje/ Nog helemaal niet dom!' (Troelstra-Bokma de Boer \& Pollmann, 1948, p. XV) Alliteratie is in traditionele baker- en kinderverzen dus sterk verbonden aan de muzikale klanktaal die we in (de opmaten en refreinen van) veel teksten aantreffen. In veel aftelrijmen ligt de verhouding tussen klanktaal en betekenistaal andersom: daar bestaat het grootste deel van de tekst vaak uit klanktaal, meestal (maar niet altijd) gevolgd door een semantisch betekenisvolle coda. We zien dan dat ook in de klanktaal in veel aftelrijmen alliteratie voorkomt, zoals in: 'Engeltje, drengeltje, dros,/ Kaatje, fiemeltje, fros,/ Een minuutje, kabelekuutje,/ Olie - of.' (Vloten, 1874, p. 151), of in een verre afstammeling 'Pot,/ ingele mingele mangele mot/ kaatje vingele vangele vod/ een minuutje, apetuutje/ iet, wiet, waai, weg.' (Eiselin, 1996, p. 17) Omdat alliteratie zich aan het begin van de woorden in een regel bevindt en in de meeste traditionele baker- en kinderrijmen de accenten (in het trocheïsch of dactylisch metrum) ook aan het begin van de woorden vallen, krijgen de allitererende medeklinkers veel nadruk. Hierdoor wordt de ervaring van klankeenheid door de aanwezigheid van alliteratie versterkt. Alliteratie, de geperiodiseerde herhaling van medeklinkers aan het begin van de woorden in een regel, is echter niet de enige vorm van rijm die we in het muzikale kindervers aantreffen. 
Ook assonantie, de geperiodiseerde herhaling van klinkers, is een belangrijk middel dat bijdraagt aan de samenhang in de klanktaal van lyrische, i.e. muzikale, rijmen. In pure klankrijmen als 'Jantje,/ Wide, wadde, wantje,/ Wide, wadde, winkel, tinkel, tantje;/ "Hip!" zeî Jantje.' (Vloten, 1874, p. 90) en 'Epompee, poedenee, poedenaska,/ Epompee, epompa!/ Epompee, poedenee, poedenaska,/ Epompee, o wee, o wee!/ Academie, vaselemie,/ Academie, vaselemie, emie,/ Epompee!' (Kes, Pollmann \& Tiggers, 1947, p. 104) is assonantie even sterk aanwezig als alliteratie. In 'Epompee'G2 is het gamma van herhaalde klinkers beperkt tot 'a', 'e', 'ee', 'ie', 'o' en 'oe'; in 'Jantje' zelfs tot slechts de 'a', de 'e' (hoewel nergens beklemtoond) en de ' $i$ '. In combinatie met de alliteratie die in beide rijmen eveneens veelvuldig aanwezig is, maakt dit dat beide rijmen een zeer coherent 'klankbeeld' opleveren. In dergelijke traditionele klankrijmen is eindrijm onderdeel van het totale klankbeeld, maar nauwelijks als zelfstandige stijlfiguur te onderscheiden van alle andere geperiodiseerde klankherhalingen waarmee het omringd is. Binnenrijm, dus volrijm of halfrijm binnen een versregel, is hier sterker aanwezig, zoals in 'epompee, poedenee', 'academie, vaselemie', 'minuutje, kabelekuutje', et cetera. In verschillende muzikale rijmen is te zien hoe klanken als het ware van het begin van de regel naar het eind van de regel worden uitgerold waardoor een soort klankketting ontstaat, zoals in 'Epompee, poedenee, poedenaska' het einde van het eerste woord, 'pee', wordt uitgebreid om het tweede woord te vormen, 'poedenee', waarvan het einde vervolgens wordt vervangen om het derde woord te vormen, 'poedenaska'. We zouden dit 'klankvariaties binnen een thema' kunnen noemen ${ }^{74}$. De enorme klankdichtheid en klankeenheid in deze teksten heeft een bezwerende werking zowel in het produceren als in het horen van de klanken. Verschillende schrijvers van kinderpoëzie maken, minder vaak maar even effectief, gebruik van dit 'klank-ketting-effect'. Annie M.G. Schmidt opent het gedicht 'De katten', een van haar meest muzikale gedichten, met "Ringel, rangel, ronde" (Ziezo, p. 148) en namen als 'Joris Pudoris Pudittelman' (p. 93), 'Hansje Pansje Pingeling' (p. 194) en 'Pimmetje Dimmetje Dee' (p. 159) zijn gebaseerd op hetzelfde principe. Ook de naam 'Klisklaskloentje'G2 uit het gelijknamige gedicht van Theo Olthuis past in dit rijtje. En Shel Silverstein past klankvariaties binnen een thema toe in de namen 'Ikkeltje, Tikkeltje, Spikkeltje Boem'G2 die in het gelijknamige gedicht tegelijk het refrein vormen omdat elke strofe met de namen wordt geopend en afgesloten. Hierdoor heeft ook dit gedicht een sterk muzikaal karakter.

Pure klankverzen met de klankeenheid die de volksculturele voorbeelden hierboven kenmerkt, komen in de geschreven kinderpoëzie echter nauwelijks voor. Een teken dat het pure klankvers een typisch verschijnsel uit de orale volkscultuur is waar het 'al spelend en zingend' is gemaakt. Wel zijn er verschillende dichters die in hun kinderpoëzie klank regelmatig de hoofdrol laten spelen, zoals Joke van Leeuwen, Paul Biegel, of Toon Tellegen, en heel veel dichters die, ook wanneer ze een verhaal vertellen, ritme, rijm en taalmuziek gebruiken. En dan zijn er nog dichters die bepaalde vormen van rijm heel expliciet centraal stellen in het muzikaal taalspel dat ze binnen een gedicht spelen. De Amerikaanse schrijver Shel Silverstein, bijvoorbeeld, schreef een lang en ogenschijnlijk verhalend gedicht met de

\footnotetext{
${ }^{74}$ Het verschijnsel van de klankketting herkennen we ook in 'Engeltje, drengeltje, dros'. Daarin wordt het eerste woord aan de voorkant aangevuld om 'drengeltje' te vormen, waarvan vervolgens de achterkant ('engeltje') vervangen wordt om 'dros' te vormen. In 'wieze walla kristalla', 'ingele mingele mangele mot', 'Iene miene mutte', 'Dieroem daroem doem', 'Eun deun dip' of 'Eun deun dansen' zien we hetzelfde of een soortgelijk mechaniek aan het werk.
} 
titel 'Pinokkio'G4. Het gedicht telt tien strofes waarin het hele verhaal van Pinokkio wordt naverteld, maar bij het horen van het gedicht wordt de aandacht vooral opgeëist door een spel met de klank van de naam 'Pinokkio':

\author{
Pinokkio, Pinokkio, \\ Dat kleine galgebrokkio. \\ 'Mijn reukorgaan voelt anders aan', \\ Sprak hij, 'wanneer ik jokkio'.
}

Van de tien strofes beginnen er acht (strofes 1 en 2, 4, 5 en 6, 8, 9 en 10) met een regel waarin de naam 'Pinokkio' wordt herhaald. Deze geperiodiseerde herhaling wordt niet eentonig omdat Silverstein een aantal variaties heeft aangebracht: in strofes 4, 5 en 9 wordt de herhaling van de naam voorafgegaan door een ander woord ('Dus Pinokkio, Pinokkio' of 'Maar Pinokkio, Pinokkio) en in strofes 3 en 7 wordt de naam maar een keer genoemd, ingebed in een zin ('Ze schreeuwden 'Hé Pinokkio,' en 'Hij sloop naar huis, Pinokkio'). In alle strofes zijn het steeds de tweede en de laatste regel die rijmen op 'Pinokkio', met 'quasineologismen' als 'betrokkio', 'rokkio', 'stokkio', 'circustentnokkio', hokkio', 'schrokkio' en ga zo maar door. De tussenliggende regel rijmt niet op 'Pinokkio', maar bevat binnenrijm zoals: 'Heel het badseizoen moest hij kunstjes doen' en 'Een reusachtige vis greep een keer of wat mis'. Omdat het eindrijm in dit gedicht volkomen kunstmatig tot stand is gekomen en zo overdadig aanwezig is, trekt het alle aandacht naar zich toe. Dit taalspel krijgt daardoor een humoristisch effect. Een soortgelijk taalspel stelt dezelfde dichter centraal in het gedicht 'Poëzietsie op mijn fietsie' (Ik val omboog, p. 133):

Als je ietsie aan je pop plakt

wordt hij dan een popietsie?

Wordt een mop een mopietsie?

Wordt een kop een kopietsie?

...

Jeempietsie ik kan niet stopietsie.

Ohietsie, watietsie ergietsie

alsietsie ikietsie immerietsie

zoietsie verderietsie praatietsie...

Nietietsie?

Een taalspel dat aanvankelijk gecontroleerd en doelbewust door de 'ik' in het gedicht wordt toegepast, maar wat vervolgens volledig de overhand neemt. De kunstmatigheid van deze, daarom overigens niet minder leuke, rijmspelletjes blijkt uit de continue herhaling van dezelfde klankgroep 'ietsie'. Er is in dit gedicht steeds minder klankafwisseling en steeds meer -herhaling wat ten koste gaat van het ritmische, het muzikale. Deze 'over-manipulatie' van taal maakt dat er iets ontstaat dat meer op geheimtaal lijkt dan op poëtische klanktaal. Dit gedicht is dan ook vooral een uitspraakrijm en niet, zoals bij veel traditionele baker- en kinderrijmen het geval is, verbonden aan ritmische non-verbale handelingen. Het fenomeen 
van de uitspraakrijmen, dat meestal voor iets oudere kinderen is bedoeld dan de bakerrijmen, komt later in dit hoofdstuk nog terug.

\subsection{Muzikale segmenten in het kindervers}

Metrum, rijm en ook melodie zijn belangrijke mnemonische middelen: ze helpen bij het onthouden van teksten en zijn dan ook veelvuldig aanwezig in mondeling overgeleverde verssoorten (Grijp, 2000b, p. 353). Daarnaast spelen ook allerlei vormen van formules en geperiodiseerd herhaalde tekstsegmenten, zoals refreinen, een belangrijke rol in de onthoudbaarheid van verzen. In repertoires van traditionele baker- en kinderrijmen zijn deze elementen veelvuldig aanwezig. Hierdoor kunnen we spreken van overlapping tussen muzikale en mnemonische middelen in het mondeling overgeleverde kindervers. Dit is een indicatie dat muzikale tekstuele kenmerken, die grotendeels overlappen met formele poëtische kenmerken, een belangrijke bijdrage kunnen leveren aan de canoniciteit van baker- en kinderrijmen omdat ze een steun zijn voor het geheugen ${ }^{75}$. In deze paragraaf bespreek ik een aantal van de meest voorkomende soorten muzikale tekstsegmenten in repertoires van traditionele baker- en kinderrijmen, te weten refreinen en introducties of opmaten.

Een voor de hand liggende 'indicator van muzikaliteit' in poëzie voor kinderen is het refrein. Bij 'refrein' denken we doorgaans aan een op zichzelf staand aantal regels in een lied dat na ieder couplet wordt herhaald. Volksculturele baker- en kinderliedjes zijn echter bijna nooit opgebouwd in de [couplet - refrein - couplet - refrein] liedstructuur. In het domein van het kindervers vinden we het 'refrein' meestal terug als 'een of meer woorden of versregels die geregeld terugkeren in een gedicht en daardoor ritme of structuur aanbrengen' (Bork et al: lemma 'refrein-1'). Het refrein is in deze vorm een van de vele herhalingsfiguren die we in poëzie aantreffen, specifiek: “... een aan het einde van elke strofe herhaalde versregel.” (Bronzwaer, 1993, p. 142) We herkennen dit verschijnsel bijvoorbeeld in de regel 'Hi, hi, hi! Ha, ha, ha!/ 'k Stond erbij en ik keek ernaar' aan het einde van elk couplet van ' $k$ Zag twee beren broodjes smeren'G2/G4 (Aarts \& Etten, pp. 158). Dit soort refreinen komt overigens per definitie alleen voor in gezongen teksten die in meerdere strofen of coupletten verdeeld zijn, maar dat betekent niet dat dit type refrein alleen in volksculturele liedjes voorkomt. Denk aan Buddingh's gebruik van het refrein in 'De blauwbilgorgel'G4 ('Raban! Raban! Raban!'; 'Rabijst! Rabijst! Rabijst!' et cetera). Willem Wilmink eindigt elk couplet van 'Chinese taalles'G4 met de regels "Li tsjeh li tsjeh loempia,/ loempia fong leng” (2006, p. 77) en in 'Lekker en toch gezond' beslaat het refrein in elk van de drie coupletten wel vier van de zes regels: "Maar't mooiste liedje dat ik weet,/ dat is een knetterende scheet./ Doe je hand maar voor je mond, prr, prr, prr./ O wat lekker en gezond, prr, prr, prr." (p. 145) Dit type refrein zorgt voor een ernorme 'herhalingsdichtheid' in de tekst waardoor het snel en gemakkelijk mee te zingen en te onthouden is. In veel

\footnotetext{
${ }^{75}$ Mijn opvatting is dat tekstverwerving bij jonge kinderen niet alleen gebaseerd is op het onthouden van een tekst: ook plezier of waardering en begrip spelen een rol in dat proces en alle drie factoren (onthouden, waarderen en begrijpen) zijn gerelateerd aan de aansluiting tussen tekst en 'lezer'. Hier kom ik later in dit hoofdstuk nog op terug. Onthouden is echter een basiselement dat zeker bij kinderen die nog niet kunnen lezen een cruciale rol speelt in processen van tekstverwerving.
} 
kinderliedjes is zelfs sprake van een herhalingsfiguur te omschrijven als 'aan het begin én einde van een vers herhaalde versregels'. De meest voorkomende vorm van deze figuur is dat de twee eerste regels en de twee laatste regels van een vers exact aan elkaar gelijk zijn, met daar tussenin twee of meerdere regels die verschillend zijn. Bijvoorbeeld: 'Boer, wat zeg je van mijn kippen?/ Boer wat zeg je van mijn haan?/ Hebben ze dan geen mooie veren/ of staat jou de kleur niet aan?/ Boer, wat zeg je van mijn kippen?/ Boer wat zeg je van mijn haan?' (in Linders \& Duijx, 2011, p. 22) Hetzelfde geldt voor 'Schaapje, schaapje, heb je witte wol?' (p. 24), 'Mari Marijne, Mari Maron' (p. 36), 'Spetter spetter spat/ ik word klets kledder nat' (p. 41), 'Sneeuwman, sneeuwman,/ pak me dan, als je kan' (p. 46), 'Dieroem daroem doem' (p. 66), 'Kling klokje klingelingeling', 'O denneboom, o denneboom' (p. 86), et cetera.

Deze enorme herhalingsdichtheid maakt dat de teksten ook voor jonge kinderen gemakkelijk te onthouden zijn. Een ander soort muzikaal tekstsegment dat veelvuldig aanwezig is in traditionele kinderrijmen en -liedjes bestaat uit de al eerder genoemde 'onzinwoorden' als eia poppeia die vaak de eerste regel van een vers vormen, zoals ook in 'Tikketakke-tonen, / 't Varkentje in de bonen,/ et cetera.' (Vloten, 1874, pp. 4-5) In de eerste regel ('Tikke-takke-tonen') wordt taal enkel gebruikt voor het creëren van klank en ritme en vormt daarmee een soort muzikale introductie als opmaat of aanloop naar de compositie van de daarop volgende parallelle regels. Deze regels functioneren in Kristeva's semiotisch taalsysteem zoals ook het 'Ai ai ai' van flamenco zangers en zelfs als het 'Er was eens...' in sprookjes: ze signaleren heel duidelijk de overgang van het alledaagse naar het bijzondere, van het routinematige naar het geritualiseerde. Heel veel traditionele kinderrijmen en liedjes worden geopend met een dergelijke betekenisloze klankcombinatie die door middel van metrum en rijm aan de erop volgende regels verbonden is, zoals: 'Trararetje (bis),/ Een koetje en een paardje,/ et cetera.' (p. 3), 'Geeze, geeze, goeze gat,/ Die achter op de sjeeze zat;/ et cetera.' (p. 4), 'Eya, popeya,/ kookt kindekens pap,/ et cetera.' (p. 9), 'Suja, suja' (p. 5), 'Din din din' (p. 6), 'Damme, Damme, poppen,/ We zullen je schoppen,/ et cetera.' (p. 20), of 'Schoppe, schoppe, meien,/ De bruid, die komt van Leien,/ et cetera.' (p. 103). In veel rijmen en liedjes die horen bij knierijspelletjes is de opmaat een onomatopee, een klanknabootsing, van het rijden op een paard of een kar: 'Schok, schok, schok;/ De boer rijdt om een rok;/ et cetera.' (p. 12), of 'Hossetent, hossetent,/ Zoo rijen we naar Brugge,/ Zoo rijen we naar Gent,/ et cetera.' (p. 15). Regelmatig ook wordt de opmaat letterlijk uitgeteld: 'Een, twee, drie, vier,/ hoedje van, hoedje van,/ et cetera.' (p. 93), 'Een, twee, drie,/ Mijn zuster hiet Marie,/ En als ze geen Marie en hiet,/ Dan hiet ze een, twee, drie./ et cetera.' (p. 101), 'Een, twee, drie, vier, vijf, zes, zeven,/ waar is [Berend Botje] gebleven?/ et cetera. ${ }^{76}$ (Dijk, 1999), of worden de eerste letters van het alfabet gebruikt als opmaat: 'ABC/ De kat gaat meê,/ et cetera.' (Vloten, 1874, pp. 3-4), of 'A, b, c, d, e, f, g,/ meester, de jongens nemen de knikkers van me mee!/ et cetera.' (Abramsz, 1984/1910, p. 120). En bij uitzondering wordt de toonladder gebruikt, zoals in 'Ut, re, mi, fa, sol,/ De boer die stal een knol' (Vloten, 1874, p. 34). Ook dichters van kinderpoëzie gebruiken

\footnotetext{
76 Marie van Dijk (1999) identificeert deze tekst, die wij vooral kennen als onderdeel van 'Berend Botje ging uit varen', op basis van de verzamelingen van Boekenoogen en Anne de Vries Sr. als een tekst die door heel Nederland bekend is geweest als op zichzelf staand aftelrijm, waarbij niet Berend Botje, maar een andere meer alledaagse naam werd ingevuld.
} 
dergelijke opmaten of introducties. In zijn bespreking van de bundel Ssssst! niets verklappen van Geert de Kockere schrijft Jan Van Coillie: "Verschillende versjes vangen aan met klankspelletjes, meestal met een herhaling en/of alliteratie: Bos bos; Dik dik; Koest in de kast; Rijen rijen rennen; Rekken rokken ruiken. Wiegel Wagel/in de wei.... Deze eerste regel bepaalt ook het ritme.” (1990, p. 44)

Het gebruik van herhaalde tekstsegmenten en formules weerspiegelt het proces van orale tekstformatie en -overdracht (Hearne, 2011, p. 211). Ze trekken de aandacht en markeren de tekst heel duidelijk als een vorm van onalledaags taalgebruik. Mogelijk hebben jonge kinderen die enorme klank- en herhalingsdichtheid nodig om poëzie als zodanig te herkennen, dus te begrijpen als 'rituele taalhandeling' waarvoor andere conventies gelden dan voor normaal taalgebruik. Zeker daar waar de verzen verbonden zijn met fysieke handelingspatronen zorgen ze ervoor dat het ritme direct gevonden wordt en de vele herhalingen zorgen voor ritmische en melodische 'flow'. Op tekstueel niveau wordt taal in veel traditionele kinderrijmen en -liedjes voelbaar, fysiek ervaarbaar gemaakt. De op klank en ritme gebaseerde samenhang in de meest muzikale rijmen zorgt ervoor dat ze lekker in de mond liggen, dat klanken in elkaar overlopen en woorden aan elkaar worden gesmeed waardoor ze melodisch kunnen worden uitgesproken. De tot nu toe besproken 'indicatoren van muzikaliteit' in poëzie sluiten allemaal aan op de “. .. inclination of small children to get 'drunk' on melodic rhymes ..." (Chukovsky, 1971/1925, p. 65). Ook veel 'poëzie van de speelplaats' gekoppeld aan ritmische spelvormen zoals touwspringen en klapspelletjes wordt door dergelijke muzikaliteit gekenmerkt, wat erop wijst dat ook iets oudere kinderen hier nog plezier aan beleven.

\subsection{Tongbrekers en struikelzinnen}

Echter, zoals ik al eerder heb opgemerkt, bestaan er ook allerlei vormen van spel met de formele, of materiële, kenmerken van taal die de flow juist doorbreken. Dan wordt het uitspreken van bepaalde klankformaties een spel op zich. Wie het volgende rijm uitspreekt, merkt vanzelf dat taal in kinderrijmen ons ook weleens over onze eigen tong kan laten struikelen: "Daar gingen eens drie oude wijfjes/ over een zwik-zwak bruggetje./ De een heette vrouw Biba,/ de tweede Biba de Binka/ en de derde Sina Snikna Knikker de Kninka./ Toen nam vrouw Biba een steen,/ en smeet die naar vrouw Biba de Binka haar been,/ zodat vrouw Sina Snikna Knikker de Kninka daarom green.” (Abramsz, 1984/1910, pp. 122-123) Het uitspreken van dergelijke rijmen dwingt ons om de klankcombinaties heel bewust te vormen, zeker als het onverwachte of ongebruikelijke combinaties zijn, zoals in 'Sina Snikna Knikker de Kninka' de 'nk' onverwacht is omdat die volgt op verschillende 'kn' klanken. Van Vloten plaatste dit rijm in de categorie speelrijmen, verbonden aan het speltype 'pandverbeuren'. In deze categorie komen we ook het rijm 'Hier is de sleutel van de Bibelebontse berg' tegen, dat op snelheid al even lastig uit te spreken is. Dergelijke rijmen zijn heel duidelijk bedoeld om uit te spreken, om te 'verklanken', echter niet zozeer omdat ze zo lekker muzikaal dreunen, maar juist omdat ze onze spraak de-automatiseren. Daarin ligt precies het spelelement van deze rijmen. Ze zijn dus in zekere zin amuzikaal, 
maar toch schaar ik ze onder de noemer 'muzikaal taalspel' omdat het taalspel ook in deze rijmen volledig gebaseerd is op de manipulatie van de prosodische eigenschappen van taal.

In de verzameling van Van Vloten vinden we meer van dergelijke rijmen in de categorie 'Taal- en uitspraakrijmen', zoals het nog steeds bekende 'de kat krabt de krullen van de trap' (1874, p. 166). Dit zijn zogeheten 'tongbrekers', een term afgeleid van het Engelse begrip 'tongue twisters' 77 ; onderdeel van het, hoofdzakelijk mondeling overgeleverde, taalspel waar kinderen doorgaans al vroeg mee in aanraking komen en een blijvend populair fenomeen in de taalcultuur. We kennen er allemaal wel een aantal: 'Leentje leerde Lotje lopen langs de lange Lindelaan,/ maar toen Lotje niet wou lopen,/ liet Leentje Lotje staan', of 'Wie weet waar Willem Wever woont? / Willem Wouter woont wijd weg./ Wie weet wat Willem Wever weeft?/ Willem Wever weeft witte warme wollen winterwanten', of 'De knecht van Klaas de knappe kapper knipt en kapt nog knapper dan Klaas de knappe kapper knippen en kappen kan'. Tongbrekers zijn er in verschillende soorten en maten. Op basis van het specifieke taalspel dat er in gespeeld wordt en het effect dat dat kan hebben in het uitspreken, zijn vier categorieën te onderscheiden (zie ook Beers, 2008). De meest exclusieve categorie is die van woorden met de eigenschap dat bij snelle herhaling bepaalde klanken vervagen, in elkaar overlopen of met elkaar worden verwisseld waardoor een nieuw woord ontstaat, zoals bij het snel achter elkaar herhalen van het woord 'boterklontje ${ }^{97}$. De tweede categorie bevat de allitererende zinnen die veel door logopedisten worden gebruikt, zoals 'Leentje leerde Lotje lopen', 'Wie weet waar Willem Wever woont' en 'Bakker Bas bakt de bolle broodjes bruin'. Moeilijker wordt het in de derde categorie waar alliteratie wordt gecombineerd met de herhaling en afwisseling van bepaalde medeklinkercombinaties. Dit is bijvoorbeeld het geval in 'Ruud Rups raspt rap rode ronde radijsjes': in het uitspreken van deze zin verandert 'raspt' al gauw in 'rapst'. Een vergelijkbaar effect hebben de specifieke medeklinkercombinaties in 'De koetsier poetst de roest van de postkoets met de poetsdoek'. De vierde categorie bevat zinnen die grotendeels zijn gebaseerd op gelijkluidende woorden met verschillende betekenissen, zoals in 'Voor was was was was was is' of 'Als achter vliegen vliegen vliegen vliegen vliegen vliegen achterna'. Kinderen, en ook volwassenen, maken er een spel van om dergelijke zinnen en rijmen zo snel mogelijk uit te spreken zonder fouten te maken.

Veel dichters van kinderpoëzie houden ervan om met klank te spelen en soms benaderen deze vormen van taalspel het effect van tongbrekers. Frank Adam komt met zijn gedicht 'Jeukt de jeuk die jeukt in jou net zoals de jeuk die jeukt in mij?' (2011, p. 27) dicht in de buurt van de tongbreker 'Jeukt jouw jeukende neus ook zo als mijn jeukende neus jeukt?'. En Paul Biegel, die overigens lijkt te zijn geïnspireerd door het traditionele vogelrijm 'Karre, karre, kiet, kiet, kiet,/ Ik bouw mijn nestje in het riet,/ En niemand die het ziet.' (Vloten, 1874, p. 96), creëerde het tongbrekende gedicht 'Een kikker en een karekiet'G2/G4, uit de bundel Eén been, stokekebeen: voorleesversjes (2002):

\footnotetext{
77 Tongbrekers en verwante vormen van taalspel zijn een wereldwijd fenomeen, getuige onder meer de website http://www.uebersetzung.at/twister/index.htm

78 Als dit woord vaak en snel genoeg wordt herhaald, wordt de 'l' als ware het magie getransporteerd van de positie voor de laatste 'o' naar de positie voor de eerste 'o'. Hierdoor verandert 'boterklontje' in 'bloterkontje', doorgaans tot grote hilariteit van de omstanders.
} 
Een kikker en een karekiet

zaten samen in 't riet.

Nee nee, kietel niet,

kietel niet, riep de karekiet.

Ik ben een karekietelniet!

Maar je kikkert er van op,
sprak het kikkertje daarop,
van een opkik kikker je op.
Karekiet, kikker op, karekikkerkietel op!
De kikker kietelt de karekiet
in 't riet, in 't riet
zonder dat een mens het ziet.
Karekiet, karekiet, karekikkerkietelniet,
karekiet, karekiet, karekikkerkietelniet!

Biegel speelt in dit gedicht met de klanken in 'kikker' en 'karekiet', in het bijzonder de 'k', de 'r', de ' $i$ ' en de 'ie' klanken. Door woorden bij elkaar te plaatsen waarin die klanken veelvuldig aanwezig zijn, komen die klanken heel sterk naar de voorgrond, wat nog eens extra versterkt wordt in de zelfverzonnen woorden 'karekietelniet', 'karekikkerkietel op' en 'karekikkerkietelniet'. Het uitspreken van die woorden, en het gedicht als geheel, geeft als vanzelf de sensatie van een mond vol k's, r-en en ie's: klanken die zo dicht op elkaar gepakt de eigenschap kunnen krijgen dat ze gaan kietelen in de keel. Die klanken krijgen op deze manier betekenis in het semiotisch taalsysteem omdat ze de sensatie van kietelen als eigenschap aannemen. Iets soortgelijks vindt plaats in het 'Versje om te mompelen als je niet goed in slaap kunt komen'G4 van Joke van Leeuwen, opgenomen in de bundel Ozo beppie en andere versjes (2000):

de slome slak slaapt in de slappe sla de slome slak slaapt in de slappe sla de slome slak slaapt in de slappe sla de slome slak slaap idde slappe sla de slowe slah slawidde slawe sla de sllde slll saal asssasssssssss de sll de sll sssssss $^{79}$

De dichteres neemt hier een tongbreker als uitgangspunt, maar verlegt de aandacht naar het rustgevende effect dat we associëren met de s-klank (als in 'suja', 'sssst', 'slaap', 'stil'). Dat

\footnotetext{
${ }^{79}$ Van Leeuwen maakte ook een 'Versje om te mompelen als je niet goed wakker kunt worden', waarin de taal vanuit pure klank langzaam maar zeker ontwaakt en haar betekenisvolle gestalte aanneemt: "mmhohmmhohmmhohpfff/ mmhohmmhohmmhohpfff// izzolekkewarmier/ izzolekkewarmier// mamoewakkewoh/ mamoewakkewoh// Moemewazze/ moemewazze// hup."
} 
doet ze door woorden te kiezen waarin het associatieve betekenisveld van de s-klank samenvalt met de semantische betekenis van de woorden zelf, zoals in 'sloom', 'slak, 'slaapt' en 'slap'. De sl-klank kost daarbij relatief veel tijd om uit te spreken waardoor de spraak vanzelf vertraagt. Dit vers werkt als een geheel, als gebruikspoëzie die in een specifieke pragmatische context (in bed, als je niet goed in slaap kunt komen) een specifieke functie vervult. Dit brengt ons weer terug bij de semiotische taallaag “... waarin taal geen betekenis is, maar pure klank, ritme en muziek.” (Meijer, 1997, pp. 150-151)

Tegelijk zijn dit in zekere zin 'autonome' vormen van taalspel omdat de lichamelijke ervaring van de ritmische effecten en het klankspel enkel in en met de vocale performance tot stand komen. Ze zijn niet zozeer gericht op het oproepen van ritmische lichamelijke beweging, maar zijn primair gericht op talig handelen. In die zin sluiten deze vormen naar verwachting aan op de voorkeuren van wat oudere kinderen die steeds meer gebruik gaan maken van bestaande vormen van taalspel, zoals raadsels, moppen en tongbrekers (Geller, 1985, p.41).

\subsection{Kettingen, cirkels en slingers: ruimtelijke spelstructuren in taal gevat}

Tot nu ben ik in dit hoofdstuk vooral ingegaan op muzikaal taalspel in rijmen, liedjes en gedichten voor jonge kinderen als een geritualiseerd poëtisch taalspel dat alles te maken heeft met ritmische patronen, dus de ordening van taal in de tijd. De nadruk in de bespreking van vormen van muzikaal taalspel heeft dan ook vooral gelegen op verschijnselen van geperiodiseerde herhaling in de ordening van taal in poëzie voor kinderen. Er zijn echter nog meer niveaus waarop rijmen, liedjes en gedichten kunnen functioneren in het semiotisch systeem van de belichaamde taal. Om dat te illustreren, moeten we ons denken over poetisch taalgebruik transporteren van de dimensie 'tijd' naar de dimensie 'ruimte'. In het vorige hoofdstuk ben ik kort ingegaan op de structurele kenmerken van de spelvormen op schoolplein en speelplaats waar doorgaans rijmen en liedjes aan verbonden zijn. Ik heb daarover gezegd dat die spelvormen, die geritualiseerde handelingspatronen, in zekere zin 'poëtisch' zijn omdat het in deze klap-, spring- en dansspelletjes hoofdzakelijk draait om vorm en ritme en niet, of veel minder, om inhoud. Dit zijn over het algemeen geen vormen van symbolisch spel, maar van sterk geformaliseerd spel waarin, zoals Judith Eiselin stelt, de woorden, maar zeker ook de gebaren en handelingen vastliggen en steeds volgens een vast stramien worden uitgevoerd (zie \$3.7). De spelhandelingen zijn gestileerd: ze volgen een vast verloop in de tijd én ze vormen vaste figuren in de ruimte. Bepaalde basale figuren die in dergelijke fysieke spelletjes aanwezig zijn, zijn ook op tekstueel niveau te herkennen ín kinderrijmen en -liedjes. In deze paragraaf bespreek ik een aantal van die structurele vormen, te weten kringen (of cirkels), kettingen, slingers en 'stapels', in hun tekstuele verschijningsvormen in het kindervers. Het zijn poëtische patronen die betrekking hebben op de 'bewegingen' die in de tekst besloten liggen, de structurele figuren die in de opbouw en het verloop van een tekst als geheel vorm krijgen.

Om te beginnen is in verschillende rijmen en liedjes een circulaire structuur te herkennen. Met een 'circulaire structuur' bedoel ik dat we feitelijk te maken hebben met teksten 
'zonder einde'. Een voorbeeld is het klapspellied 'Er is een vrouw vermoord'. Het lied begint zo: 'Er is een vrouw vermoord/ Aan een gordijnenkoord/ Ik heb het zelf gezien/ Het was op nummer 10/ Het bloed liep langs de trap/ Het leek net bessensap/ Ik nam er een likje van/ Ik werd er misselijk van/ Ik belde de politie op...'. Het lied kan nu verder gezongen worden met een duidelijk einde: 'Ik zei mijn naam hardop/ Mijn naam is: ...// eja Thea/ Dikke dikke Thea/ Olle bolle whiskie/ Elastiek!' Op de hele tekst wordt door twee spelers tegen elkaars handen geklapt in een zich herhalend patroon tot aan 'Mijn naam is' waarna het ritme vertraagt, de melodie van het vers verandert en ook het klappatroon. Op 'Elastiek!' maken de spelers een klein sprongetje en zetten hun voeten iets verder uit elkaar om het hele lied weer te herhalen, net zo vaak tot beide spelers hun voeten zo ver uit elkaar hebben dat ze niet meer kunnen blijven staan. Hier is vaak wel sprake van herhaling, maar niet van circulariteit in de tekst. De tekst wordt echter ook wel gezongen met een ander vervolg na 'Tk belde de politie op...', namelijk: '...en zei: ...// Er is een vrouw vermoord/ Aan een gordijnenkoord/ et cetera.' In deze versie loopt de tekst in zichzelf door en kan eindeloos worden doorgezongen waarbij, bijvoorbeeld, het tempo steeds iets wordt opgevoerd net zo lang tot de spelers het tempo met het klappen niet meer kunnen bijhouden. Eenzelfde circulariteit gebruikt bijvoorbeeld Frank Adam in zijn gedicht met de veelzeggende titel 'Versje om te rappen (zonder einde)'G4 dat begint met "Dit is een versje/ om te rappen./ Geen versje/ om te zeggen/ bij de juf/ op de bank,/ met je knuffel/ in je hand." En na twee volgende strofes en een 'break' eindigt met "Een nieuw versje/ om te rappen/ gaat vertrekken/ uit mijn kop!// Geen versje/ om te zeggen/ bij de juf..." (Adam, 2011, p. 9) ${ }^{80}$.

Naast deze doordraaiende teksten worden er ook allerlei kettingen geregen in de kinderpoëzie. Eerder in dit hoofdstuk had ik het al over refreinen in het kindervers. Een specifieke vorm van het refrein in het kindervers is het zogeheten 'kettingrefrein': een refrein, als onderdeel van de coupletten of strofes, dat steeds langer wordt naarmate het vers vordert of vaker herhaald wordt. Een heel bekend voorbeeld is het refrein van 'Heb je wel gehoord van de zevensprong'. In dit lied wordt het couplet steeds in exact dezelfde vorm zeven keer herhaald, 'Heb je wel gehoord van de zeven, de zeven,/ Heb je wel gehoord van de zevensprong/ Ze zeggen dat ik niet dansen kan,/ Ik kan dansen als een edelman', maar wordt bij elke herhaling het refrein en het bijbehorende handelingspatroon een stukje uitgebreid: van 'Dat is één...' tot en met 'Dat is één.../ Dat is twee.../ Dat is drie.../ Dat is vier.../ Dat is vijf.../ Dat is zes.../ Dat is ze-e-ven...'. Het vers kan, als er genoeg tijd en animo voor is, ook veertien keer herhaald worden: na de zevende keer wordt er dan teruggeteld waarbij het refrein en het bijbehorende handelingspatroon steeds weer een regel/beweging korter wordt tot men weer bij één uitkomt. Dit spiegeleffect dat een mooie curve van opbouw en afbouw creëert, herkennen we ook in de volgende uitvoering van 'In Holland staat een huis'. Het vers begint met: 'In Holland staat een huis./ In Holland staat een huis./ In Holland staat een huis, jaja,/ van je singela singela hopsasa./ In Holland staat een huis./ In

\footnotetext{
${ }^{80}$ Frank Adam is overigens een dichter die in verschillende vormen een expliciet beroep doet op de mondelinge performance van kinderpoëzie: naast dit 'Versje om te rappen' en 'Jeukt de jeuk' (zie $\$ 4.6$ ) heeft hij ook 'Drie Rovers! (Aanbel-versje om de mensen mee te overvallen en te beroven in hun huis op 6 januari op het feest van Driekoningen)' geschreven en zelfs 'Er is er een verdrietig (versje om te huilen)'. In deze titels wordt de gebruiksfunctie benadrukt: iets dat we kennen uit de orale volkscultuur waar wordt gesproken van wiegeliedjes, klapspelrijmen, enzovoort. Adam legt dus een expliciete relatie tussen geschreven kinderpoëzie en mondelinge kinderpoëzie.
} 
Holland staat een huis.' (Linders \& Duijx, 2011, p. 105) Dit couplet wordt gekenmerkt door een heleboel herhaling, met een kleine afwisseling in regel 3 en 4, en vormt de mal voor de volgende coupletten waarin de frase 'In Holland staat een huis' steeds vervangen wordt door een andere frase:

2. In dat huis daar woont een heer.

3. De heer die kiest een vrouw.

4. De vrouw die kiest een kind.

5. Het kind dat kiest een meid.

6. De meid die kiest een knecht.

7. De knecht die kiest een hond.

8. De hond die kiest een kat.

9. De kat die kiest een muis. ${ }^{81}$

Tijdens het zingen van de eerste negen coupletten lopen de kinderen in een kring rond. Bij het tweede couplet stapt een kind, de 'heer', naar het midden van de kring en kiest bij couplet 3 een 'vrouw' uit de kring; de 'vrouw' kiest een 'kind'; het 'kind' kiest een 'meid'; en zo verder. $\mathrm{Na}$ het negende couplet vindt er een omkering plaats:

10. Nu jagen we de muis uit huis.

11. Nu jagen we de kat uit huis.

12. $\mathrm{Nu}$ jagen we de hond uit huis.

13. Nu jagen we de knecht uit huis.

14. $\mathrm{Nu}$ jagen we de meid uit huis.

15. $\mathrm{Nu}$ jagen we het kind uit huis.

16. Nu jagen we de vrouw uit huis.

17. Nu jagen we de heer uit huis.

Tijdens het zingen van deze coupletten worden de kinderen die binnenin de kring stonden één voor één teruggestuurd naar hun plek tot alle kinderen weer onderdeel uitmaken van de kring. Net als bij 'Heb je wel gehoord van de zevensprong' corresponderen de op- en afbouw in de tekst met fysieke handelingspatronen waardoor de structuur ook heel concreet gezien en ervaren wordt door de spelers. In de hierboven weergegeven versie van 'In Holland staat een huis', zoals opgenomen in een zeer populaire bundel kinderliedjes van Linders en Duijx, gaat het lied nog verder. In couplet 18 staat het huis alleen, in couplet 19 'steken we 't huis in brand', in couplet 20 'schoppen we 't huis omver', in couplet 21 'bou-

\footnotetext{
${ }^{81}$ De volgorde waarin de figuren worden genoemd, is een duidelijke illustratie van de traditionele gezinshiërarchie met bovenaan de man, die in dit geval ook als enige 'eigendomsrecht' heeft van het huis, gevolgd door de vrouw, het kind, enzovoort, die allemaal worden gekozen. Op dezelfde manier dragen heel veel traditionele kinderrijmen en -liedjes sporen van sociaal-maatschappelijke verhoudingen die tegenwoordig lang niet meer zo sterk gelden. Een ander interessant voorbeeld is 'Zie, zo rijen de heren' waarin het contrast tussen maatschappelijke 'standen' benut wordt om een verrassend ritmisch effect te creëren voor het kind dat op de knie 'paardje rijdt'. Eerst is het ritme traag en statig: 'Zie, zó rijen de heren,/ met hun bonte kleren;/ zie, zó rijen de vrouwen,/ met hun wije mouwen;/ zie, zó rijen de joffertjes,/ met hun mooie pantoffeltjes.' Dan, plotseling, versnelt het ritme en wordt het kind op de knie alle kanten op 'gehobbeld': 'zie, zó rijdt de akkerman/ met zijn paardje/ achteran.' (Abramsz, 1984/1910, p. 75)
} 
wen we 't huis weer op' en in couplet 22 'staat het huis weer klaar'. Het in brand steken, omver schoppen en weer opbouwen van het huis wordt door alle kinderen uitgebeeld. In deze laatste sectie van het lied wordt de curve omgekeerd: van afbraak naar opbouw. Het ritmische patroon van afwisseling, met terugkeer van hetzelfde na het andere, krijgt hier dus gestalte in de slingerbeweging van opbouw en afbraak in de tekst en de bijbehorende spelhandelingen. Een ander type kettingrefrein dan dat van 'Heb je wel gehoord van de zevensprong' is te vinden in de volgende versie van het rijm 'Daar was een mannetje, dat was niet wijs', opgenomen in de verzameling van Van Vloten. Het begint met: 'Daar was ereis een mannetje,/ Dat was niet wijs;/ En die bouwde een huisje/ Al op het ijs;/ En hij wou, dat hij een hoentje had,/ Tjip, tjip, mijn hennetje,/'s Avonds in de korte kooi/ En 's morgens in het rennetje.' Vervolgens wil het mannetje steeds meer ('En hij wou, dat hij een ... had'): dieren, dingen en mensen volgen elkaar op. En al die dieren, dingen en mensen krijgen een naam toegekend en worden toegevoegd aan het refrein tot het uiteindelijk bijna uit zijn voegen barst waarbij de spanning of het ijs het wel zal houden voelbaar oploopt (Vloten, 1874, pp. 138-139) ${ }^{82}$. Dit type kettingrefrein heeft ongetwijfeld gediend als inspiratie voor een dichter als Theo Olthuis bij het schrijven van het gedicht 'Klisklaskloentje'G2:83 (Buul \& Stigter, 1993). Dergelijke stapelrefreinen doen een zwaar beroep op het geheugen, maar het geheugen wordt ook hier geholpen door metrum, rijm, parallellisme in de regelstructuur en herhaling.

Waar in de hierboven beschreven voorbeelden sprake is van uitbreiding door de toevoeging van regels die elk op zichzelf staan, is er nog een andere vorm van structurele uitbreiding te vinden in het domein van het traditionele kindervers. In 1834 werd een prentenboek uitgebracht onder de titel Historie van het huis van Adriaan, later opnieuw uitgegeven als Historie van het huis van Adriaan: eene grappige vertelling (anoniem, 1870), waarin de vertelling op rijm de vorm heeft van wat we een linguïstisch stapelvers kunnen noemen. De vertelling begint met de regels 'Dit is het graan,/ dat lag in het huis van Adriaan' en via negen uitbreidingen uitkomt op:

Dit is de stal waar het paard in stond,

Dat mooi is en vlug en zoo draaft langs den grond,

En wegdroeg Filip met den hoorn in zijn mond,

Die ving den vos, die het kippenhok vond,

En wegstal den haan, die in d'ochtendstond

Kraait wakker de dochter van Hillegond,

Die melkte de koe van zeshonderd pond,

Die omhoog smeet den hond,

Die wegjoeg de kat,

\footnotetext{
${ }^{82}$ Het uiteindelijke refrein is: 'En hij wou, dat hij een kind had,/ Welbemind, zoo heet mijn kind./ Hou en trouw, zo heet mijn vrouw,/ Welbereid, zo heet mijn meid,/ Alberecht, zo heet mijn knecht,/ Welbehagen heet mijn wagen,/ Vlasstaart, zo heet mijn paard,/ Namentoe, zo heet mijn koe,/ Roodkalf, zo heet mijn kalf,/ Blè heet mijn schaapje,/ Kibbeldekaan zo heet mijn haan,/ Tjip, Tjip, mijn hennetje,/ 's Avonds in de korte kooi/ En 's morgens in het rennetje.'

${ }^{83}$ Dit gedicht begint met 'Klisklaskloentje,/ Zo heet mijn hoentje' en eindigt met: "Koetje dat vroeg aan mij,/ Komt er geen paardje bij?/ Vlug-van-aard, zo heet het paard,/ Boeboeboe, zo heet mijn koe,/ Koetje-half, zo heet mijn kalf,/ Knorknorknarken, zo heet het varken,/ Wollenknaap, zo heet mijn schaap,/ Waggelhans, zo heet mijn gans,/ Kukelaan, zo heet mijn haan./ Klisklaskloentje,/ Zo heet mijn hoentje."
} 
Die pakte de rat,

Die at van het graan,

Dat lag in het huis van Adriaan.

De hele 'vertelling' is feitelijk een enkele samengestelde zin die stukje bij beetje wordt opgebouwd door steeds een nieuw element toe te voegen, van 'Dit is het graan,/ dat lag in het huis van Adriaan' naar 'Dit is de rat,/ Die at van het graan,/ Dat lag in het huis van Adriaan' naar 'Dit is de kat,/ Die pakte de rat,/ Die at van het graan,/ Dat lag in het huis van Adriaan' en zo verder. Het is een complexe zinsstructuur: het vers begint met een hoofdzin ('Dit is het graan') en een betrekkelijke bijzin ('dat lag in het huis van Adriaan'), maar iedere keer dat er een element wordt toegevoegd, verandert de eerdere hoofdzin ook in een betrekkelijke bijzin ('Dit is het graan' wordt 'Die at van het graan' als betrekkelijke bijzin bij 'Dit is de rat'). Dit is een cumulatief proces waardoor de zinsdelen steeds dieper worden ingebed. Dat we hier eerder te maken hebben met een vorm van cumulatief taalspel dan met een 'vertelling' blijkt uit het feit dat er eigenlijk niets 'verhaald' wordt. 'Het huis van Adriaan' dat aanvankelijk het onderwerp van de vertelling lijkt, blijkt uiteindelijk slechts het begin van een netwerk van relaties tussen objecten ${ }^{84}$. In de bloemlezing Al mijn later is met jou treffen we een andere variant, door Edward van de Vendel (uit het Duits) vertaald als 'Het poppenkopmannetje'G4 dat begint met het huis van het poppenkopmannetje en eindigt als: "Dat is de slager die slacht/ de os die dronk/ het water dat bluste/ het vuur dat verbrandde/ de knuppel die sloeg/ de hond die beet/ de kat die at/ de muis die knaagt aan het koord aan de sleutel voor het slot op de deur naar het huis van het poppenkopmannetje.” (Vendel \& Jacoby, 2005, z.p.)

In deze paragraaf heb ik een aantal structurele vormen in kinderpoëzie besproken die doen denken aan bepaalde vormen die ook in het fysieke kinderspel aanwezig zijn, zoals het maken van kringen, kettingen en slingers. Dergelijke ruimtelijke structuren van opbouw en afbraak, van slingers, cirkels en kettingen, gevat in vormen van poëtisch taalspel zijn fysiek ervaarbaar in de orale performance. Hier heb ik dergelijke ruimtelijke structuren besproken binnen het kader van het muzikaal taalspel dat op formeel en structureel tekstniveau wordt gespeeld; in het volgende hoofdstuk komen we dezelfde, en andere, vormen opnieuw tegen, maar dan met het oog op hun inhoudelijke toepassingen en effecten. Al deze patronen brengen, of ze nu op fysiek niveau, formeel tekstniveau of referentieel tekstniveau worden toegepast, specifieke effecten teweeg in de performance en vervullen specifieke functies die via die ervaarbare ritmische effecten betekenis tot stand brengen (zie Hoofdstuk 2 en 3).

\footnotetext{
${ }^{84}$ Deze Nederlandstalige versie komt dicht in de buurt van het Engelstalige vers 'This is the house that Jack built' dat begint met 'This is the house that Jack built' en eindigt met 'This is the horse and the hound and the horn/ That belonged to the farmer sowing his corn/ That kept the rooster that crowed in the morn/ That woke the judge all shaven and shorn/ That married the man all tattered and torn/ That kissed the maiden all forlorn/ That milked the cow with the crumpled horn/ That tossed the dog that worried the cat/ That chased the rat that ate the corn/ That lay in the house that Jack built.' Onder meer uitgegeven in prentenboek vorm onder de titel The House that Jack built. One of R. Caldecott's Picture Books door Frederick Warne \& Co., in 1878. Het type vers/verhaal is veel ouder en is in de Roud Folk Song Index opgenomen onder nummer 20584 en in heeft in de AarneThompson verhaaltype index nummer 2035. In de bloemlezing Ik geef je niet voor een kaperschip Met tweehonderd witte zeilen vinden we een kortere variant getiteld 'Dit is het hondje van Jantje en Antje' die eindigt met "Dit is de haas,/ Die plaagde de kat,/ Die loerde op de rat,/ Die wou slapen in 't mandje/ Van het hondje van Jantje en Antje." (Buul \& Stigter, 1993, p. 36)
} 


\subsection{Conclusie: 'muzikaal taalspel' een tweede indicator van canoniciteit in kinderpoëzie}

In dit hoofdstuk heb ik 'muzikaal taalspel', als pervasief tekstueel kenmerk van volksculturele en literaire poëzie voor kinderen, aangewezen als verwachte indicator van canoniciteit in kinderpoëzie voor kinderen in groep 2 en groep 4 van het basisonderwijs. De verschillende vormen van muzikaal taalspel in rijmen, liedjes en gedichten die ik heb beschreven, hebben met elkaar gemeen dat de betekenis van taal, in referentiële zin, geen of nauwelijks aandeel heeft in de wijze waarop de taal in deze teksten is geordend en in de wijze waarop ze worden ervaren. De ordeningsprincipes die ten grondslag liggen aan het muzikaal taalspel dat in deze teksten besloten ligt, zijn hoofdzakelijk gebaseerd op de temporele ordening van prosodische eigenschappen van taal. Een muzikaal metrum, een hoge klankdichtheid door klankherhaling binnen een klankthema, het gebruik van pure 'taalmuziek', veel herhaling door refreinen, ritmische verschijnselen die voortkomen uit de verhouding tussen vocale en niet-vocale handelingen: het zijn allemaal elementen die bijdragen aan de benadrukking van muzikale klankpatronen van taal die in de uitvoering fysiek worden ervaren. In de meeste gevallen hebben deze muzikale teksten de functie om vocale en niet-vocale handelingen ritmisch aan elkaar te binden. Het creëren van bijzondere klankeffecten kan echter ook een spel op zich vormen, zoals gebeurt in tongbrekers. En naast klankpatronen die temporeel geordend zijn, heb ik een aantal voorbeelden besproken waarin ook sprake is van ruimtelijke patronen die in rijmen, liedjes en gedichten voorkomen, zoals kettingen, cirkels en slingers. In deze vormen worden bepaalde structurele, vooral syntactische, eigenschappen van taal als spelmateriaal gebruikt, zoals de mogelijkheid tot 'oneindigheid' door circulariteit of eindeloze inbedding (een vorm van recursiviteit). Al deze (temporeel en ruimtelijk geordende) ritmische patronen brengen betekenis tot stand doordat ze fysiek ervaarbare effecten teweegbrengen die maken dat deze muzikale poëzie haar gebruiksfuncties in de cultuur van het dagelijks leven vervult, of dat nu de rustgevende effecten van een wiegelied zijn of de opzwepende effecten van een klapspel- of touwspringrijm zijn. Zo fungeren de ritmische patronen in dit type poëtisch taalspel als 'patronen van betekenis'. Het mag duidelijk zijn dat deze muzikale poëzie 'conceptualisering' en 'interpretatie' omzeilt en direct en expliciet een beroep doet op de belichaamde ervaring om haar effecten te produceren die 'referentiële betekenis' te buiten gaan (vgl. Coats, 2013, p.133).

Verschillende studies naar de taalontwikkeling van kinderen en de plaats die vormen van taalspel en ook poëtische vormen daarin innemen, laten zien dat muzikaal taalspel onderdeel uitmaakt van het taalgebruik van kinderen, zowel in groep 2 (vijf en zes jaar) als in groep 4 (zeven en acht jaar). Het spelen met klankpatronen in taal en ook pure klanktaal zoals onomatopeeën vormt onderdeel van zowel het spontane individuele taalspel van kinderen binnen deze leeftijdsspanne, als het gezamenlijk uitgevoerde en op bestaande repertoires van rijmen en liedjes gebaseerde taalspel van deze kinderen. Zien we 'muzikaal taalspel' in haar pragmatische context, dan kunnen we uit bovenstaande exploratie van 'indicatoren van muzikaliteit' afleiden dat er binnen 'muzikaal taalspel' onderscheid te maken is tussen: (i) vormen van muzikaal taalspel ter ondersteuning van niet-vocale handelingspatronen, en (ii) vormen van muzikaal taalspel als relatief autonoom taalspel (zoals tongbrekers). Mijn verwachting is dat kinderen in groep 2 nog sterk de voorkeur geven aan 
die eerste vorm terwijl kinderen in groep 4 al beter uit de voeten kunnen met de meer autonome vormen van muzikaal taalspel:

\begin{tabular}{lll}
\hline $\begin{array}{l}\text { KINDERPOËZIE } \\
\text { Verwachte 'indicatoren van canoniciteit' }\end{array}$ & Groep 2 & Groep 4 \\
\hline 2. 'muzikaal taalspel' & 'vormen van muzikaal taalspel ter & 'vormen van muzikaal taalspel \\
& ondersteuning van non-verbale & $\begin{array}{l}\text { als relatief autonoom taalspel } \\
\text { handelingspatronen' }\end{array}$ \\
\hline
\end{tabular}

Wat uit de besproken studies niet is af te leiden, is de precieze verhouding tussen productie en receptie waar het kinderpoëzie betreft en het verloop van de verwerving van poëtische vormen tussen groep 2 en groep 4. Een andere vraag die nog open staat, is wat de effecten zullen zijn die uitgaan van het feit dat in het kader van de Leeskalender 'muzikaal taalspel' wordt aangeboden binnen de context van de schoolklas. In kleutergroepen zijn 'opzegversjes' doorgaans nog onderdeel van de dagelijkse activiteiten (zie Hoofdstuk 2), maar in groep 4 is poëzie überhaupt niet altijd standaard onderdeel van het aanbod van kinderliteratuur, laat staan poëzie die (ook als het geschreven is) 'werkt' bij de gratie van orale performance en soms zelfs gekoppeld aan fysieke spelvormen. Kunnen leerkrachten deze poëzie goed overbrengen? En hoe reageren kinderen in groep 4 op dergelijke poëtische vormen die ze eerder op het schoolplein dan in de klas verwachten?

Om nauwkeurig inzicht te krijgen in de rol die verschillende vormen van 'muzikaal taalspel' spelen in het samenspel van pragmatische, tekstuele en ontwikkelingsfactoren die vorm geven aan processen van poëzieverwerving bij kinderen in groep 2 en in groep 4 heb ik in de Leeskalenders voor beide groepen poëzie opgenomen waarin verschillende vormen van 'muzikaal taalspel' aanwezig zijn en waarin dat 'muzikaal taalspel' op verschillende manieren samengaat met inbedding in pragmatische contexten en/of nonsensicaliteit (zie Hoofdstuk 7, 9 \& 10). Inzichten in de receptie van muzikaal taalspel in poëtische vorm die binnen dit onderzoek verkregen worden op basis van observaties van de aanbieding van poëzie in groep 2 en in groep 4 bieden daarmee een belangrijke aanvulling op bestaande studies. Daarnaast kunnen deze inzichten vertaald worden naar criteria voor de selectie van kinderpoëzie die effectief bijdraagt aan de ontluikende culturele geletterdheid van kinderen in groep 2 en in groep 4. 
HOOFDSTUK 5

Kinderpoëzie en het spel met de wereld 



\subsection{Introductie}

In dit hoofdstuk richt ik me op een tweede soort poëtisch spel dat kinderen, volksculturele en literaire poëzie met elkaar delen: een spel waarin de taal in poëtische vorm wordt gebruikt om de voorstelling van aspecten van de wereld op bijzondere wijze te ordenen en manipuleren. Anders dan het muzikaal taalspel is dit spel gericht op de betekeniscategorieen van taal, op de referentiële relatie tussen taal en de wereld. Zoals in Hoofdstuk 2 al aangegeven, is een typerend kenmerk van volksculturele baker- en kinderrijmen dat ze aspecten van de werkelijkheid zoals we die kennen, beschrijven, "but shaped according to a certain pattern of play.” (Bakhtin, 1984, p. 7) Dit type tekstuele 'betekenisloosheid' duid ik aan als '(carnavaleske) nonsensicaliteit': een vorm van taalspel die kinderen op haar eigen specifieke wijze kan helpen de wereld te begrijpen en te controleren (Lurie, 1990), enerzijds gekoppeld aan verschillende gebruikscontexten en anderzijds gerelateerd aan specifieke ontwikkelingskenmerken (de culturele competentie) van jonge kinderen. De veelvormigheid van 'nonsens' in kinderpoëzie vraagt om specifieker inzicht in de aansluiting van de verschillende vormen op de poëtische voorkeuren van kinderen in groep 2 en in groep 4. Nonsens, als alomtegenwoordig kenmerk van volksculturele kinderrijmen en als literair genre', maar ook als breed gedragen cultureel fenomeen, onttrekt zich aan interpretatie en heeft, misschien wel juist daarom, grote belangstelling onder (taal)filosofen, etnologen, cultuur- en literatuurwetenschappers (o.a. Bruijn \& Mooren, 2013; Boelens \& Komrij, 2007; Mooren, 2000b; Lurie, 1990; Anderson \& Apseloff, 1989; Tigges, 1988; Livingston, 1981; Stewart, 1989/1978; Sewell, 1952; Chukovsky, 1971/1925; Cammaerts, 1925). In relatie tot kinderliteratuur, en specifiek kinderpoëzie, wordt nonsensicaliteit vooral op tekstueel niveau geanalyseerd, worden allerlei vormen en strategieën van nonsens uitvoerig beschreven, wordt ook gekeken naar wat die nonsensstrategieën op tekstueel niveau doen en wordt de werking van nonsens voor kinderen getheoretiseerd (zie Bruijn \& Mooren, 2013; Mooren, 2000b; Lurie, 1990; Anderson \& Apseloff, 1989). Ook is nonsensicaliteit als verschijnsel in de taal- en humorontwikkeling van jonge kinderen bestudeerd en als kenmerk van hun spel (zie Cunningham, 2005; Mooren 2000b; Varga, 2000; Sutton-Smith, 1999; Geller, 1985; Chukovsky, 1971/1925). Er is in die zin een enorme hoeveelheid aan perspectieven, theorieën, tekstuele analyses, (pogingen tot) definities, afbakeningen, en bestuderingen van nonsens die elkaar aanvullen, tegenspreken, afwijzen en bevestigen. Echter, theoretici, hermeneutici en empirici komen niet zo vaak bij elkaar om hun kennis en opvattingen van nonsens uit te wisselen en bij elkaar te brengen.

Omdat we in dit onderzoeksproject uitgaan van het samenspel tussen pragmatische, tekstuele en ontwikkelingsfactoren die vorm geven aan processen van tekstverwerving bij kinderen in groep 2 en groep 4, is het juist van belang om die perspectieven bij elkaar te brengen. In aanloop naar de implementatie van de Leeskalender in de praktijk van het basisonderwijs heb ik selecties van kinderpoëzie samengesteld die naar verwachting nauwkeurig aansluit op de culturele competentie en voorkeuren van de kinderen. Vanwege de alomtegenwoordigheid van 'nonsens' - als spel met de betekeniscategorieën van taal, met de referentiële relatie tussen taal en de wereld - in volksculturele poëzie voor kinderen is mijn verwachting dat dit kenmerk een belangrijke rol speelt in de aansluiting van poëzie op de culturele competentie en voorkeuren van kinderen in groep 2 en ook groep 4 . Voor de 
ontwikkeling van de Leeskalender waarmee een selectie van kinderpoëzie is geïmplementeerd in de praktijk van het basisonderwijs, was het noodzakelijk om een nauwkeuriger beeld te krijgen van (a) specifieke vormen van nonsensicaliteit zoals veelvuldig aanwezig in volksculturele kinderrijmen, (b) hoe deze vormen terugkomen in kinderpoëzie uit het literaire domein ${ }^{85}$, en (c) hoe de voorkeuren van kinderen voor specifieke soorten nonsensicaliteit in poëzie zich naar verwachting ontwikkelen. Vanwege het ontbreken van nauwkeurig en longitudinaal inzicht in welke vormen van nonsensicaliteit het meest nauwkeurig aansluiten op de voorkeuren en vaardigheden van kinderen in groep 2 en in groep 4, beoogt dit hoofdstuk de volgende deelvraag te beantwoorden:

KINDERPOËZIE: DEELVRAAG 2.c.

Hoe kenmerkt '(carnavaleske) nonsensicaliteit' zich in 'het taalspel poëzie' voor kinderen, zowel in relatie tot pragmatische contexten van tekstgebruik als in relatie tot ontwikkelingskenmerken van de kinderen?

Om deze vraag te beantwoorden, begin ik met een verkenning van de meest vitale verschijningsvormen van dit poëtisch spel met de wereld in kinderrijmen en in literaire kinderpoezie (\$5.2). Deze eerste verkenning wordt gevolgd door een theoretische typering van de functie(s) en vorm(en) van dit soort poëtisch taalspel voor kinderen als 'carnavaleske nonsensicaliteit' (\$5.3). Vervolgens beschrijf ik verschillende verschijningsvormen van '(carnavaleske) nonsensicaliteit' die we zowel in volksculturele kinderrijmen als in literaire kinderpoëzie aantreffen ( $\$ 5.5 \mathrm{t} / \mathrm{m} 5.7)$. Ten slotte plaats ik dit type poëtisch taalspel in ontwikkelingsperspectief $(\$ 5.8)$ en trek ik conclusies over '(carnavaleske) nonsensicaliteit' als verwachte indicator van canoniciteit, gespecificeerd naar groep 2 en groep $4(\$ 5.9)^{86}$.

\subsection{Subversiviteit als raakvlak tussen volkscultuur, kindercultuur en kinderpoëzie}

Het thema van het volksculturele kindervers is de wereld, stelde Ruth Lorbe (1984, p. 200). Inhoudelijk hebben de meeste rijmen en liedjes, de volledig betekenisloze klankrijmen daargelaten, betrekking op de verbeelding van (aspecten van) de externe leefwereld van kinderen. De verbeeldingswereld is volop vertegenwoordigd in voorstellingen, soms in de realistische verbeelding, maar meestal in de fantastische. Uitingen van (kinderlijke) gevoelens zijn in volksculturele kinderrijmen en -liedjes echter nauwelijks als tekstaspect te vinden (Meijer, 1997). We kunnen daarom stellen dat het volksculturele kindervers een

\footnotetext{
85 Zowel voor de typering van 'nonsensicaliteit' in volksculturele baker- en kinderrijmen als voor de inventarisatie van vergelijkbare verschijningsvormen in kinderpoëzie uit het literaire domein is stapsgewijs bronnenonderzoek gedaan, zoals beschreven in Hoofdstuk 7, \$7.2. Een overzicht van geraadpleegde primaire bronnen is opgenomen in Bijlage 1.

${ }^{86}$ De exploratie van 'nonsensicaliteit' in kinderpoëzie waar dit hoofdstuk een weerslag van is, vormde binnen dit onderzoek de basis voor de selectie van kinderpoëzie zoals opgenomen in en geïmplementeerd via het interventieprogramma. Veel van de voorbeelden van poëzie die ik in dit hoofdstuk bespreek, zijn aangeboden in de klas via de Leeskalender voor groep 2 en voor groep 4. Om dit zichtbaar te maken zijn de rijmen, liedjes en gedichten die een plaats hebben gekregen in het interventieprogramma gemarkeerd met [titel] ${ }^{\mathrm{G} 2}$ of [titel] ${ }^{\mathrm{G} 4}$.
} 
'hoofdzakelijk extravert karakter' heeft. Daarbij moeten we wel bedenken dat de specifieke weergave van de buitenwereld in het kindervers alleen dan bij kinderen in de smaak valt als het op de een of andere manier aansluit op zowel de buitenwereld - de leefwereld - áls op de binnenwereld - de belevingswereld - van kinderen. In Hoofdstuk 3 is al kort aangestipt dat het gebruik van 'het taalspel poëzie' in een gegeven rituele context zo sterk geworteld kan zijn dat er binnen dat vaste gebruikskader op tekstueel niveau een enorme vrijheid ontstaat om te spelen. Ik bedoel dan niet alleen het muzikale taalspel, maar ook het spelen met de referentiële functie van taal. Een veelvoorkomend inhoudelijk kenmerk van volksculturele baker- en kinderrijmen waarin dit spel met de referentiële functie van taal zeer expliciet tot uitdrukking komt, is een bepaalde mate van transgressiviteit. Die grensoverschrijding kan op velerlei gebied voorkomen, maar als we bijvoorbeeld de verzameling Nederlandsche baker- en kinderrijmen van Johannes van Vloten nalopen op de meest voorkomende vormen van transgressiviteit of subversie van normen, dan zien we dat het vooral de fatsoensnormen zijn die eraan moeten geloven. Personen van enig aanzien worden nogal eens voor gek gezet, zoals in dit alternatieve einde van 'Hoe laat is 't?/ Twaalf uren!': 'Voor de kleine Poppedeine./ En den grooten Monsieur,/ Die heeft een broek met een scheur,/ De billen komen er deur.' (Vloten, 1874, p. 24) En wat te denken van de volgende beschrijving van Prins Robbert: 'Prins Robbert was een gentelman,/ Een gentelman was hij;/ Hij had een broek van krenten an,/ En een rokjen van rijstenbrij;/ Zijn beentjens waren hoendertjes,/ Zijn billetjes waren bout,/ Zijn handjes waren kapoendertjes,/ En zijn neusje was van zoethout;/ Prins Robbert was een gentelman,/ Een gentelman van zoethout.' (p. 30) De koning wordt al niet veel beter voorgesteld: 'Daar was eens een koning,/ Die smeerde zijn billen met honing;/ Toen riep hij: 'kindertjes, lik, lik!/ Ziet, wat een zoete koning ben ik!' (p. 48)

Ook agressief gedrag is een terugkerend thema in de rijmen en liedjes die Van Vloten bijeen bracht. Er wordt heel wat geschopt en geslagen, zoals in 'Jan, die sloeg Lijsje,/ En Lijsje die sloeg Jan,/ Al met de koekepan./ O, wat een ongeluk!/ De koekepan was stuk.' (p. 51) Ook het volgende aftelrijm is niet echt onschuldig: 'Een, twee, drie, vier, vijf,/ De bakker sloeg zijn wijf,/ Al met een houten hamertje,/ De darmen uit het lijf.' (p. 36) Naast de ridiculisering van aanzienlijke personen en de voorstelling van agressief gedrag als iets heel normaals, vinden we bij Van Vloten ook een keur aan rijmen waaruit een voorkeur voor zaken van scatologisch belang naar voren komt: 'Van turelure letjen,/ De boer die liet een wind;/ Hij ving hem in een netjen,/ En hij bracht hem aan zijn vrind./ 'Wel, tureluur, tureluur, tingeling,/ Wat breng je me daar een stinkend ding!' (p. 58) of 'Klein, klein keuteltje!/ Hij leî het op een scheuteltje;/ Hij bracht het naar mijnheer zijn disch;/ En zeî: 'mijnheer, 't is stokvisch'./ Mijnheer, die stak het in zijn mond,/ En zeî 'Wel, ouwe, ouwe schelm! 't is paardestr....' (p. 58). De volgende wens begint weliswaar idyllisch, maar neemt een onverwachte wending: 'Ik wou, dat ik was een boterblom,/ Die op de velden stond;/ En slikten me dan de koetjes op,/ Dan zat ik in 'er buik;/ En poepten me dan de koetjes uit,/ Dan was ik weer een spruit.' (p. 59) Deze volksculturele rijmen geven een indicatie van de duurzame geliefdheid van dit transgressieve taalspel dat ook bij hedendaagse kinderen, zij het in iets actueler rijmen en liedjes, nog steeds populair is. Als het gaat om welke weergave van de buitenwereld kinderen in de basisschoolleeftijd in het bijzonder op prijs 
stellen, is het schoolplein of de speelplaats een goede plek om 'eigen' creaties van kinderen op te vangen. Peter van den Hoven schrijft:

"De leefwereld, de materiële en sociale umwelt, en de belevingswereld, de mede daarop gebaseerde verbeeldingsrijke innenwelt, vormen in een voortdurende wisselwerking met elkaar de voedselrijke humuslaag waarop het spontane kindervers kan bloeien." (Hoven, 1997, p. 226)

Dat 'spontane kindervers' - vaak door oudere kinderen op jongere kinderen overgeleverd omvat allerlei soorten, waaronder 'het scabreuze kindervers'. Een term die Van den Hoven gebruikt om de door kinderen zelf gebezigde "liedjes, nonsensicale versjes, klankspelen, aftelrijmpjes, spot- en naamdichten, parodieën, raadsels, rijmdialogen, verhalende gedichten en verbasterde gezegden met een schandaleuze, beledigende, erotische of scatalogische [sic] inslag" aan te duiden (p. 213). Typerend voor het scabreuze kindervers is dat het toebehoort aan de orale traditie binnen de kindercultuur en dat het bestaan ervan buiten dat domein weinig erkenning of waardering krijgt. We hebben hier te maken met een fenomeen dat deel uitmaakt van de 'speelplaatspoëzie'. Bewijsmateriaal voor het bestaan van het scabreuze kindervers als levende traditie onder Nederlandse basisschoolkinderen vinden we in de toevallige vondsten van onderzoekers die in Nederland veldwerk verrichten naar de rijmen en liedjes die kinderen tegenwoordig onderling delen en gebruiken. Marie van Dijk en Theo Meder, bijvoorbeeld, verzamelden in hun onderzoek naar de orale vertelcultuur in de multiculturele wijk Lombok in Utrecht ook een groot aantal liedjes en rijmen dat daar bij de kinderen bekend is. Naast de vele keurige kinderliedjes en -rijmen die kinderen van school kennen, tekenden zij onder andere het volgende couplet van ' $k$ Zag twee beren' op:
'k Zag twee heksen
An 't seksen.
$\mathrm{O}$, het was een wonder.
't Was een wonder
Boven wonder
Dat die heksen seksen konden.
Hihihi, hahaha,
Ik stond erbij en ik keek erna.

Van Dijk en Meder merken daarbij op: "De meest succesvolle [variant] is die over de heksen die samen seksen. De jongen die het op Salaam Lombok zong, kon, evenals de jongens om hem heen, zijn lachen niet houden.” (2000, p. 71) Nog verrassender was de tekst die ze optekenden uit de monden van drie jongetjes, een van acht en twee van negen, die met vishengels over de schouders langs het water liepen en ondertussen een rijmpje opdreunden over de Teletubbies. Een ogenschijnlijk onschuldig tafereeltje, tot we lezen wat de jongens nu eigenlijk reciteerden: "De Teletubbies komen/ Ze schieten met condomen/ Laa-Laa kan niet wachten/ Om Dipsy te verkrachten.” (p. 183) ${ }^{87}$ Ook in de context van de

\footnotetext{
${ }^{87}$ Uit mijn eigen basisschooltijd weet ik nog goed dat wij ook met televisie-tunes aan de haal gingen, zoals die van Sesamstraat ('Sesamstraat, tralala,/ Sesamstraat, tralala,/ Sla je moeder neer,/ Verkracht je teddybeer,/ voor
} 
feesten van het jaar komen we het scabreuze kindervers veelvuldig tegen. Het lijkt wel of elk algemeen bekend, keurig en geaccepteerd feestlied een scabreuze tegenvoeter heeft in het domein waar kinderen onderling de dienst uitmaken. Zo wordt het geritualiseerde verzoek om geld of wat lekkers in de context van Sint-Maarten door kinderen regelmatig omgebogen tot een regelrechte belediging, zoals: 'Sinte Maarten mik-mak/ Je moeder is een dikzak/ Je vader is een hamer/ Smijt hem door de kamer' (opgetekend in Alkmaar, 2001, in: Marie van Dijk, 'Bedelliedjes en Sint Maarten', z.p.). De liedjes die binnen gezin of school worden gezongen om Sinterklaas op poëtisch geritualiseerde wijze te verzoeken om cadeautjes of wat lekkers, staan op straat of het schoolplein in het teken van de 'ontheiliging' van Sinterklaas: 'Sinterklaas is jarig,/ 'k Zet 'm op de pot./ O wat zal ie stinken,/ 'k Doe de deur op slot./ Doe de deur weer open,/ En wat zien we daar?// De zak van Sinterklaas, Sinterklaas, Sinterklaas etc.' ${ }^{98}$ Zelfs kinderen die qua leeftijd naar verwachting binnen de context van het Sinterklaasfeest in gezin of op school nog geloven in het bestaan van de Goedheiligman, delen in de gezagsondermijnende repertoires van het schoolplein of de speelplaats, getuige twee vijfjarige meisjes die al bekend zijn met de alternatieve versie van 'Zie ginds komt de stoomboot': 'Zie ginds komt de stoomboot/ uit Spanje weer aan./ Hij drukt op het knopje/ en vliegt naar de maan./ etc.' (Emma en Julia, 5 jaar, in: LzL 59, achterflap). En zélfs Kerstliedjes blijven niet gespaard: 'Jingle bell(s), jingle bell(s),/ geef de kat een lel./ Schop hem in het ziekenhuis,/ dan zegt-ie dankjewel. ${ }^{99}$

Die subversiviteit is overigens een speels kenmerk dat niet zozeer een enorme kloof vormt tussen het orale kindervers en de literaire kinderpoëzie, maar juist een raakvlak tussen de volkscultuur, de kindercultuur en een deel van de kinderliteratuur (zie o.a. Mooren, 2000; Stephens, 1992; Lurie, 1990; Chukovsky, 1971/1925). Het is de subversief expressieve adem van veel van de volksculturele kinderrijmen die we ook in hedendaagse speelplaatspoëzie herkennen en die daarmee kan worden aangewezen als verwachte indicator van canoniciteit' in deze orale poëzie. Het is diezelfde adem die ook verschillende volwassen dichters van kinderpoëzie heeft geïnspireerd tot het schrijven van wat we 'gedomesticeerde speelplaatspoëzie' kunnen noemen (Thomas, 2007, p. xv). In de gedomesticeerde

Sesamstraat'), Meneer de Uil ('Hallo meneer de Uil,/ uw onderbroek is vuil./ En wat zit er dan wel in?/ Een dikke vette spin!') of The Freggles ('Freggles opgelet/ (naam slachtoffer) in het stapelbed/ (ander slachtoffer) komt erbij/ dat wordt echt een sekspartij!'). En Vader Abrahams 'Smurfenlied' is onsterfelijk geworden in de subversieve versie: 'Waar komen jullie toch vandaan?/ Uit de kut van tante Sjaan./ Hoe kwamen jullie daar dan in?/ Door de lul van ome Wim./ Wat hebben jullie daar gegeten?/ Spermaballen, niet te vreten!/ Hoe kwamen jullie er weer uit?/ Via de roltrap achteruit.' Ook reclame jingles leenden zich prima voor subversieve bewerking: 'Voel je goed/ voel je lekker,/ scheer je kut (of lul)/ met Black \& Dekker.'

${ }^{88}$ Deze versie, die ik ook zelf nog goed ken uit mijn eigen jeugd, is in deze weergave afkomstig van het Wikisource artikel 'Sinterklaas is jarig': http://nl.wikisource.org/wiki/Sinterklaas_is_jarig De originele beginregels luiden: 'Sinterklaas is jarig!/ 'k Zet mijn schoen vast klaar./ Wellicht dat hij hem vol doet met,/ ja wist ik het maar.' Het originele lied telt drie strofes, elk bestaand uit acht regels, maar is bij de meeste mensen vooral bekend in gezagsondermijnende uitvoering. Er zijn overigens verschillende subversieve versies van dit lied in omloop. Alternatieve varianten zijn onder meer: '[...]/ Doe de deur weer open,/ want de pot is vol./ Alle kind'ren vechten/ om die dikke drol' (met dank aan Maaike Meijer voor deze variant uit haar herinnering), of '[...]/ Paardje zwaar beladen,/ liet een harde scheet./ Pietje wou hem pakken,/ maar hij was te heet'. Helemaal anders is de versie 'Sinterklaas is jarig,/ hang ' $\mathrm{m}$ aan de muur,/ schiet ' $\mathrm{m}$ in z'n ballen,/ met een mitrailleur.' Op internet zijn vele forums te vinden waarop mensen met elkaar uitwisselen welke vieze liedjes zij als kind zongen. Dergelijke uitwisselingen geven een levendig beeld van de effecten van de mondelinge overlevering: veel rijmen zijn door heel Nederland bekend, maar met een groot aantal verschillende varianten.

${ }^{89}$ In het tijdschrijft 'Onze taal' is zelfs een artikel gewijd aan het fenomeen van de vieze liedjes (Jansen \& Aukema, 2013, p. 10). 
vormen van speelplaatspoëzie worden de tropen en thema's van de speelplaats benut, maar in enigszins getemde vorm zodat het materiaal geschikt is voor publicatie en verkoop (idem, p. xvi). De mate van 'domesticatie' heeft alles te maken met heersende kindbeelden en literatuuropvattingen, die in de kinderliteratuur nooit helemaal los van elkaar staan (zie Hoofdstuk 2). Met name in de periode na de Tweede Wereldoorlog, toen de kinderpoëzie door schrijvers als Hans Andreus, Diet Huber, Annie M.G. Schmidt en Han G. Hoekstra met veel humor en poëtisch vakmanschap werd losgeweekt van haar moreel-opvoedende taak, zien we een sterke opleving van het subversief en soms zelfs scarbreus aandoende taalspel dat raakt aan de thema's en strategieën van de speelplaats. En ook het schrijverscollectief ${ }^{90}$ wist wel raad met de thema's van de speelplaats. Een schrijver als Hans Dorrestijn heeft zich er duidelijk door laten inspireren, getuige bijvoorbeeld het 'Poep en Pies Menuet' dat hij schreef voor het kinderprogramma De stratemakeropzeeshow (uitgezonden in de $3^{\mathrm{e}}$ aflevering in 1972). In de coupletten staat ogenschijnlijk de norm centraal: "Hé! De woorden 'poep' en 'pies',/ die zijn niet netjes, die zijn vies./ Je moet die woorden niet gebruiken,/ anders ga je d'r naar ruiken!' De boodschap in de coupletten wordt al op ironische wijze teniet gedaan door het feit dat de woorden 'poep' en 'pies' er herhaaldelijk in voorkomen en dat zelfondermijnend effect wordt nog eens versterkt door het refrein:

Kakkedrolleschijtepoep.

Hanepikkelullie.

Poepjanknor.

Dit scatologisch intermezzo vormt een scabreuze catharsis voor kinderen die dagelijks worden onderworpen aan de volwassen eisen der properheid, en helemaal leuk is het wanneer volwassenen deze woorden in de mond nemen. Dat Dorrestijn hier zelf de grens opzocht van het vanuit volwassen perspectief pedagogisch (en literair) toelaatbare werd hem (en vooral de VARA) niet door alle ouders in dank afgenomen. Eenzelfde soort viering van grensoverschrijdend taalgebruik uit de regionen van de onderbuik, hoewel iets meer 'gedomesticeerd' dan Dorrestijns menuet, vinden we terug in 'Ik ben lekker

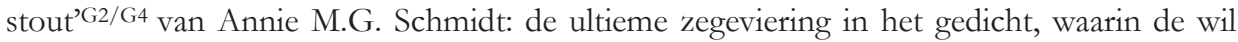
van het kind krachtig wordt neergezet in oppositie met dat wat volgens volwassen normen wel moet en niet mag, vinden we aan het slot: "En dat is alles wat ik wil/ en als ze kwaad zijn, zeg ik: Bil!” (Schmidt, 2004, p. 166) En wat te denken van de in-en-in vieze 'Slordige Saartje' (Schmidt, 2004, p. 182) die niet alleen de heersende fatsoensnormen en haar moeder (als vertegenwoordiger daarvan) het nakijken geeft, maar ook het bekende Assepoestermetamorfose-motief ('from rags to riches') ondersteboven keert door, 'in-en-in vies' als ze is, naar het Slordige Sloerie-land te vertrekken en daar dolgelukkig te worden met de Slordige Prins en al hun slordige kindertjes. Een al even recalcitrante viering van de viezigheid vinden we in Willem Wilminks 'Stinklied' waarin 'officieel' wordt verkondigd: 'Dag, dames en meneren,/ wij dragen vuile kleren,/ van modder staan ze stijf,/ ze plakken aan ons lijf." (Wilmink, 2006, p. 183) Vies en goor zijn wordt in dit lied tot de norm van het kind verhe-

\footnotetext{
${ }^{90}$ Het collectief van Willem Wilmink, Hans Dorrestijn, Karel Eykman, Fetze Pijlman, Ries Moonen en Jan Riem dat vanaf 1970 vele bijdragen leverde aan televisieprogramma's als De Stratemakeropzeeshow, Het Klokbuis, De Film van Ome Willem, Sesamstraat en Kinderen voor Kinderen.
} 
ven en volwassen opvattingen van properheid worden ontmaskerd als de werkelijke viezigheid: "Mijn moeder wast mijn oren,/ ze wast me ook van voren./ Mijn moeder wast mijn kont./ Dat is toch niet gezond?” (p. 183) Het verzet dat kinderen in hun eigen rijmen kunnen verwerken tegen volwassen gezagsdragers en de normen en waarden die zij vertegenwoordigen, heeft ook een auteur als Shel Silverstein geïnspireerd. Dit blijkt bijvoorbeeld uit het gedicht 'Dwaze droom'G4 waarin een 'ik' vertelt over de droom van de afgelopen nacht. In die droom staat het kind zelf voor een klas vol juffen en meesters en benut deze machtspositie voor het uitleven van allerlei wraakfantasieën. Het huiswerk voor de leerkrachten is ‘honderd boeken lezen voor morgen' en dan ook nog zonder licht en op de kop staand; de schoolreis gaat naar Canada, waar ze zwemmend naartoe moeten; een grote mond wordt bestraft met nablijven tot tien uur. Wie een vraag als 'Wat is er roder, groen of blauw?' niet weet te beantwoorden, wordt aan zijn oren opgehangen aan een touw. Het gedicht eindigt: "De juffrouw huilde traan na traan./ Ik prikte met mijn stok./ En toen ik 's morgens wakker schrok,/ Toen was ik zeer voldaan.” (Silverstein, 1998) Dit gedicht biedt een dubbele sanctionering van de inhoud: het is een gedicht en dus ingekaderd, niet 'echt', maar het is daarbij ook nog eens gedicht dat verhaalt over een droom, een tweede inkadering als niet 'echt'.

\subsection{Het subversieve kindervers als carnavaleske nonsensicaliteit begrepen}

De voorbeelden van het 'scabreuze' kindervers bespreek ik niet voor niets: ze vormen, als onderdeel van de 'taalcultus' binnen de kindercultuur, een belangrijke fase die volgt op en overlapt met het eerder besproken 'muzikaal taalspel' in kinderrijmen en -liedjes. Deze fase in de taalontwikkeling van kinderen begint al zo rond hun vierde of vijfde levensjaar en vermengt zich niet veel later met de toetreding tot de kindercultuur die door groepen kinderen zelf wordt onderhouden. In die kindercultuur worden ook de grensoverschrijdende rijmen en liedjes overgeleverd aan volgende generaties (leeftijdscohorten) van kinderen op schoolpleinen en speelplaatsen (Fine, 1980). In het Nederlandse schoolsysteem begint deze fase doorgaans in groep 3, dus vanaf de leeftijd van zes jaar (zie Hoofdstuk 3). Naast de vele rijmen en liedjes waarin muzikaal taalspel de boventoon voert, eerst vooral ter ondersteuning van allerlei spelvormen en later ook als 'autonoom' taalspel (tongbrekers, etc.), kunnen we er niet omheen dat kinderen zeker vanaf een jaar of zes groot plezier beleven aan poëtisch taalspel dat ze, althans gevoelsmatig, tijdelijk bevrijdt van of (de illusie van) controle geeft over het volwassen gezag dat in de context van school of gezin hun leven reguleert:

“... what children find most enjoyable is often ecstatic or subversive: It is a revelry of their own youthful actions that no longer seem profound or moving to adults or it is an antithetical reaction to the institutional and everyday hegemonies of the life about them." (Sutton-Smith, 1999, p. 6) 
Vanaf het moment dat kinderen op schoolpleinen en speelplaatsen toetreden tot de kindercultuur, volgt "een lange periode waarin kinderen, meestal wanneer ze zich onbespied wanen door volwassenen, op basis van bestaande liedjes, rijmpjes, spreuken, raadsels, moppen en dergelijke, eigen teksten maken, ter begeleiding van hun spel en/of als reactie op ver- en geboden van allerlei gezagsdragers." (Hoven, 1994, p. 152) Hierin herkennen we opnieuw wat ik, in de woorden van Betsy Hearne (2011, p. 211), ook in Hoofdstuk 2 al heb opgemerkt: kinderen verwerven poëtische teksten - of ze deze nu oppikken van andere personen, uit print- of elektronische media - om ze even later naar eigen behoefte te gebruiken en te adapteren in een proces van productieve receptie. Wat kinderen met de poëtische teksten doen, zowel op het niveau van fysiek handelen als op het niveau van tekstinhoudelijke adaptatie, levert bruikbare inzichten op in wat kinderen van een bepaalde leeftijd het meest aanspreekt. De vraag is dan: welk soort spel wordt er in de subversieve of zelfs scabreuze kinderrijmen precies gespeeld en wat doet dit spel voor kinderen?

Om het specifiek soort (taal)spel dat in subversieve kinderrijmen en -liedjes gespeeld wordt vanuit pragmatisch perspectief te identificeren, is het verhelderend om de inhoudelijke ingrepen die in het subversieve kindervers worden gedaan te bekijken vanuit Mikhail Bakhtins notie van de 'carnavaleske volkshumor'. Bakhtin beschrijft carnaval en carnavaleske volkshumor in Rabelais and His World als de sfeer van de Middeleeuwse volkshumor die een tweede leven, of tweede wereld creëert naast of binnen de eerste. Deze tweede wereld is afgebakend in tijd en plaats, vaak in de vorm van een volksfeest, en wordt gekenmerkt door een omgekeerde logica ten opzichte van de eerste wereld:

'We find here a characteristic logic, the peculiar logic of the 'inside out' (à l'envers), of the 'turnabout,' of a continual shifting from top to bottom, from front to rear, of numerous parodies and travesties, humiliations, profanations, comic crownings and uncrownings. A ... second world of folk culture is thus constructed; it is to a certain extent a parody of the extracarnival life, a 'world inside out'.” (Bakhtin, 1984, p. 11)

In de Middeleeuwen stond de carnavalscultuur van het volk in contrast met het kader van het klassensysteem en de feodale politieke structuur die het dagelijks leven beheersten en met de officiële kerkelijke vieringen waarin de maatschappelijke ongelijkheid juist werd bevestigd. Voor de duur van het carnaval en vergelijkbare volksfestivals gingen mensen een utopisch domein binnen van gemeenschappelijkheid, vrijheid, gelijkheid en overvloed (p. 9). In dat carnavaleske domein ontstond een speciale carnavaleske stijl van expressie, bevrijd van de normen van hiërarchie, etiquette en fatsoen die in de eerste wereld heersten, gebaseerd op de logica van het 'binnenstebuiten' of 'ondersteboven' keren van de normen en verhoudingen uit het dagelijks leven. Ook tekstuele vormen, zoals carnavaleske bewerkingen van officiële geschriften, gebeden, testamenten, evangeliën, liederen gekoppeld aan religieuze feesten, enzovoort, behoorden tot het carnavalesk repertoire (pp. 13-15). De carnavaleske wereld werd daarbij gekenmerkt door veel aandacht voor het lichaam en het lichamelijke, voor seks, voor eten en drinken, voor ontlasting. Binnen het carnavaleske kader werd het 'heilige' en 'ideële' uit de eerste wereld naar het lichamelijke en aardse niveau gebracht en vervolgens in materiële vorm als grandioos, overdreven en onmetelijk voorgesteld (p. 19). In werkelijkheid, zo stelt Bakhtin, is carnaval dus het leven zelf, "but 
shaped according to a certain pattern of play.” (p. 7) Wat subversieve of scabreuze kinderrijmen en -liedjes verbindt met deze carnavaleske wereld, is niet alleen de antithetische houding ten opzichte van de normen die in het institutioneel georganiseerde leven gelden, maar ook de specifieke carnavaleske manipulaties van de verhoudingen, normen en conventies die het leven in de 'eerste wereld' beheersen en de hierboven al genoemde thema's die aan die manipulaties worden onderworpen. Die manipulaties in carnavaleske uitingsvormen zijn omkeringen, overdrijvingen, verdraaiingen of combinaties op basis van tegenstrijdigheden die, zoals gezegd, worden toegepast op de normen, waarden en - hiërarchische - verhoudingen die in het dagelijks leven van kracht zijn, én op de vormen die gewoonlijk uiting geven aan die culturele categorieën (pp. 422-424). Het is opvallend hoezeer de subversieve en scabreuze kinderrijmen, ook die van hedendaagse kinderen, gelijkenis vertonen met de principes die carnaval en carnavaleske uitingsvormen al eeuwenlang beheersen. De overdreven representatie van transgressief gedrag, de omkering van maatschappelijke verhoudingen en normen, de veelvuldige verwijzingen naar het lichaam en lichamelijke functies, zeker die in de 'regionen van de onderbuik', de subversieve bewerkingen van 'heilige' feestliederen en lieflijke tunes van (opvoedkundige) televisieprogramma's. Al deze kenmerken van subversieve kinderrijmen delen de specifieke spelpatronen van de carnavaleske volkshumor: de spelpatronen van de omgekeerde wereld.

Ook de hierboven gegeven voorbeelden van gedichten van schrijvers die zich hebben laten inspireren door de subversief expressieve adem van speelplaatspoëzie laten soortgelijke thema's en manipulaties zien. Wat in het domein van de kindercultuur als transgressief, scabreus of subversief kan worden aangemerkt, heeft in gedomesticeerde vorm in het domein van de kinderliteratuur het predicaat 'Nonsens' gekregen. Velen zien de nonsensicaliteit van volksculturele rijmen als de bakermat van nonsens als literair genre ${ }^{91}$ zoals dat in de negentiende eeuw groot is gemakkt door Lewis Carroll en Edward Lear (zie Tigges ${ }^{92}, 1988$, pp. 99-101). Als literair genre - niet voorbehouden, maar wel heel vaak gekoppeld aan poëtische vormen omdat die de nonsensicale 'chaos' in het gareel houden - wordt Nonsens beschreven als eigenwijs, tegendraads, als een daad van verzet tegen de gevestigde orde:

\footnotetext{
91 Pogingen om 'nonsens' te vatten in een sluitende en allesomvattende definitie, en dan met name de literaire pendant ervan, leiden nogal eens tot bijzonder ingewikkelde constructies. Elizabeth Sewell schrijft in The Field of Nonsense: "A logical game with language, played between order and disorder in the human mind according to the rules of language and logic, in order to create a simple universe of 'oneness' of meaning, and therefore balancing between 'nothingness' and 'everythingness'. To this end, connotations which evoke emotions are avoided." (Sewell, 1952) In de bewerking van Wim Tigges in An Anatomy of Literary Nonsense: "Een verhalend genre waarin de schijnbare aanwezigheid van een zinvolle betekenis of meerdere betekenissen in evenwicht wordt gehouden door gelijktijdige suggestie van afwezigheid van zinvolle betekenis. Dit evenwicht komt tot stand door de afwezigheid van met name emotioneel geladen bijbetekenissen, en door een creatief spel met de regels van taal, logica en vorm." (Tigges, 1988) Tysger Boelens en Gerrit Komrij maken het in hun inleiding op het Perplexicon: Het abc van de nonsens helemaal bont en stellen: "Nonsensicale humor is humor die nergens goed voor is. Het is absolute humor, l'bumour pour l'bumour. De pointe is juist het ontbreken van een pointe. Nonsens balanceert tussen filosofische verbazing en schizofrenie, en verandert de lacher in wie hij was toen hij voor het eerst moest lachen." (2007, p. 9) De verhouding tussen nonsens en humor is overigens niet onbetwist. Sommigen zien nonsens als absolute humor, sommigen zien het als een verzamelnaam voor specifieke vormen van humor, sommigen wijzen erop dat nonsens lang niet altijd grappig bedoeld is en dus los gezien moet worden van humor, en sommigen lopen vast in hun poging dit vraagstuk op te lossen en geven het verder op. Voor een uitgebreid overzicht van de verschillende opvattingen van de relatie tussen nonsens en humor, zie Wim Tigges' An Anatomy of Literary Nonsense (1988, pp. 90-99).

92 Wim Tigges zelf rekent het bakerrijm overigens niet tot de nonsens (1988, pp. 99-101).
} 
"Nonsense is a literary genre whose purpose is to rebel against not only reason but the physical laws of nature. It rejects established tenets and institutions, pokes fun at rational behavior, and touts destruction. It champions aberrations." (Livingston, 1981, p. 123)

Nonsensliteratuur wordt nog wel eens voorgesteld als iets dat vrij is van elke vorm van 'betekenis' en per definitie vanuit een autonomistische literatuuropvatting bekeken moet worden omdat het een afgesloten universum vormt, los van de tekstexterne werkelijkheid. Dat is echter niet helemaal terecht: nonsens verhoudt zich áltijd tot de tekstexterne werkelijkheid, maar dan onderworpen aan specifieke manipulaties. Daarom beschouw ik 'nonsensicaliteit' of 'nonsens' in het kader van dit onderzoek niet zozeer als genre, maar als set van manipulaties waarmee de representatie van (aspecten van) de wereld op specifieke wijze vervormd wordt. In Nonsense Literature for Children. Aesop to Seuss geven Celia Anderson en Marilyn Apseloff een opsomming van wat nonsens is die aansluit op de opvatting van nonsens als specifiek soort behandeling van de gerepresenteerde werkelijkheid. Zij spreken van 'nonsens als de wereld op zijn kop, binnenstebuiten of licht gekanteld; nonsens als absurde verbindingen, als de juxtapositie van doodgewone, maar onlogische ideeën of objecten om het belachelijke te creëren. Andere vormen van nonsens, zoals extreme overdrijving (sterke verhalen), figuurlijk taalgebruik dat letterlijk wordt genomen en het gebruik van de logica als basis voor onlogische gebeurtenissen koppelen steeds het alledaagse met het bizarre.' (Anderson \& Apseloff, 1989, p. 5) Net als carnaval en het carnavaleske biedt nonsensicale poëzie de gebruiker een tijdelijke bevrijding van de heersende waarheid en van de gevestigde orde, niet door deze volledig te verwerpen of los te laten, maar door deze te onderwerpen aan omkering, verdraaiing of overdrijving (vgl. Bakhtin, 1984, pp. 10-11). Het presenteert een speelse herordening van de tekstexterne wereld in een tweede, tekstuele, wereld met een eigen logica, met eigen regels en grenzen. De functies van nonsens kunnen dan ook beschreven worden in termen die sterk aan Bakhtins carnaval-theorie doen denken:

"Nonsense does much more than simply move us to immediate laughter. It wears the motley coat of a court jester and it serves us as the jester served the king: mocks pompousness, reveals false sentiments and false logic, and, most importantly, keeps us from taking ourselves too seriously. For the young it serves as a release from the demands of the sometimes threatening world of grown-ups and allows children to negotiate in that world in a playful way." (Anderson \& Apseloff, 1989, p. 39)

De overeenkomsten tussen de vormen en functies van nonsensicaliteit in de literatuur en het carnavaleske in de orale volkscultuur zijn zo talrijk en overduidelijk, dat we ze als synoniem zouden kunnen behandelen. Zeker wanneer de nonsens in kinderliteratuur is gebaseerd op een non-conformistische speelsheid die oppositie voert tegen autoritarisme en ernst, of tot uiting komt in de parodiëring van heersende literaire vormen en genres, kan het ook het predicaat 'carnavalesk' of 'interrogatief' krijgen (Stephens, 1992, p. 121). 'Nonsens' heeft, als predicaat, vooral betrekking op de representatie van (aspecten van) de werkelijkheid in de tekst, herkenbaar aan de specifieke manipulaties zoals de omkering, overdrijving of verdraaiing; 'carnavalesk' heeft, als predicaat, vooral betrekking op de pragmatische functie. Die pragmatische functie, i.e. de carnavaleske werking die nonsensicale poëzie 
kán hebben, hangt naar verwachting echter sterk samen met de inbedding van poëzie in de specifieke gebruikscontext en met de aansluiting op ontwikkelingskenmerken van kinderen. Ik kom hier in $\$ 5.8$ nog op terug. Ik behandel het carnavaleske en nonsens binnen het kader van dit onderzoek in ieder geval als complementair. Het carnavaleske is dan een modaliteit van nonsens die betrekking heeft op een verankering van het nonsensicale spel in de herkenbare sociale werkelijkheid als kenmerk dat volgens Bakhtin zo tekenend is voor de carnavaleske volkshumor. Het carnavaleske als modaliteit van nonsens heeft ook betrekking op het effect dat nonsensicale poëzie teweeg kan brengen als een plezierig transgressieve ervaring of beleving. Ik benadruk 'plezierig' omdat de nonsensicale omkering van de werkelijkheid voor jonge kinderen mogelijk ook verwarrend kan zijn. Om aansluiting op de leef- en belevingswereld en de ontwikkeling van jonge kinderen te garanderen en om een carnavaleske ervaring teweeg te brengen, acht ik de concrete verankering van nonsensicale poëzie in 'de cultuur van het dagelijks leven' van cruciaal belang.

Ik spreek binnen het kader van dit onderzoek daarom over 'carnavaleske nonsensicaliteit' als verwachte 'indicator van canoniciteit' die in het volksculturele kindervers en in literaire kinderpoëzie te herkennen is aan de toepassing van specifieke stijlfiguren, te weten inversie (omkering), hyperbool (overdrijving) en incongruente combinaties toegepast op voor kinderen herkenbare aspecten van de sociale werkelijkheid - met haar normen, waarden en machtsverhoudingen - die leiden tot een humoristisch absurde verbeelding van (die aspecten van) de werkelijkheid. Het is daarbij van groot belang dat de carnavaleske nonsensicaliteit aansluit op dat waar kinderen in hun ontwikkeling en belevingswereld aan toe zijn. "Ook taboedoorbreking is leeftijdsgebonden," schrijft Rita Ghesquière in Jeugdliteratuur in perspectief: "Jonge kinderen zijn eerder gefascineerd door alles wat met ontlasting te maken heeft, bij oudere schoolkinderen zijn seksuele grapjes populair." (2009a, p. 135) Die leeftijdsgebondenheid geldt ook voor andere categorieën waarmee het spel van de carnavaleske nonsensicaliteit gespeeld kan worden in poëtische vorm. Bij het formuleren van voorlopige criteria voor de selectie van rijmen, liedjes en gedichten die bij kunnen dragen aan de ontluikende culturele geletterdheid van kinderen in groep 2 en kinderen in groep 4 van het basisonderwijs is dat iets waar sterk rekening mee moet worden gehouden. Daarnaast is het van belang rekening te houden met de cultureel pluriforme samenstelling van schoolklassen. Wat zijn de gedeelde kaders waarbinnen het transculturele fenomeen van de nonsensicale manipulaties van de werkelijkheid voor kinderen met verschillende culturele achtergronden als plezierig, humoristisch, i.e. carnavalesk wordt beleefd? Hier kom ik verderop in dit hoofdstuk op terug. Eerst bespreek ik, onderverdeeld in een aantal categorieën, verschillende verschijningsvormen van '(carnavaleske) nonsensicaliteit' in kinderrijmen, -liedjes en gedichten als exploratie van deze verwachte indicator van canoniciteit in kinderpoëzie die de basis heeft gevormd voor de selectie van poëzie voor de Leeskalender voor groep 2 en groep 4. 


\subsection{De omgekeerde 93 wereld}

In een van zijn vele nonsenslimericks laat Edward Lear, naast Lewis Carroll een van 's werelds bekendste auteurs van nonsensliteratuur voor kinderen, de lezer kennismaken met een oude man uit Port Grigor die de lezer uitnodigt een onconventionele benadering van de wereld te overwegen:

\section{There was an old man of Port Grigor, Whose actions were noted for vigour; \\ He stood on his head, \\ Till his waistcoat turned red, \\ That eclectic old man of Port Grigor.}

Dat deze oude man op zijn hoofd staat, mag vreemd heten, maar dat het zijn vest is dat rood kleurt, is niet minder dan een wonder. Annie M.G. Schmidt gaat in het gedicht 'Prins Piramente'G2 (Ziezo, p. 265) nog een stapje verder. In eerste instantie wordt deze jonge prins als ongehoorzaam gepresenteerd omdat hij steeds maar op zijn hoofd gaat staan. De vier meesters die moeten proberen hem de letters te leren, komen geen stap verder met het omgekeerde jongetje. Na vele pogingen het kind weer op zijn benen te laten staan, drijft de ongehoorzaamheid van de prins de koning van het land van de Krenten tot wanhoop: "Hij pakte het prinsje kordaat bij de oren/ en stopte hem weg in de bovenste toren." In de hoop dat deze straf de prins een lesje heeft geleerd, kijkt de koning na een uurtje of wat door het sleutelgat, maar (het is niet te geloven): de prins staat weer ondersteboven. Schmidt had er nu voor kunnen kiezen om de koning nog bozer te laten worden op zijn zoontje of hem met een andere conventionele straf op de proppen te laten komen, maar dat doet ze niet. Ze kiest radicaal voor het kind en laat de koning het volgende besluit uitvaardigen: "Thans wil ik, dat iedere onderdaan/ van dit moment af op zijn hoofd gaat staan,/ want - staat iedereen in mijn land op zijn kop,/ dan is het niet erg meer, dan valt het niet op." Dat dit een volkomen rechtmatige beslissing is, wordt bevestigd in de laatste regels waarin de geruststellende boodschap staat dat het, sinds ook de meesters op de kop staan, met leren verder uitstekend is gegaan.

De letterlijke omkering die Lear toepast op de man uit Port Grigor en Schmidt op prins Piramente is een voorbeeld van een nonsensicale strategie of stijlfiguur dat de gedichten van beide auteurs met elkaar verbindt: de inversie. Ook in de illustraties bij beide gedichten zien we dit motief duidelijk terug:

\footnotetext{
${ }^{93}$ Een wiskundige zou wellicht liever onderscheid maken tussen 'tegengestelde' en 'omgekeerde' werelden, waarbij het tegengestelde staat voor omdraaiing zonder dat de concrete waarde van iets verandert (zoals 2 en het tegengestelde -2 beide, zij het de een in positieve en de ander in negatieve zin, een concrete waarde van 2 vertegenwoordigen), terwijl het omgekeerde staat voor omdraaiing waarbij ook de concrete waarde van iets verandert (zoals $1 / 2$ en $2 / 1$ omgekeerd aan elkaar zijn waarbij de een de waarde 0,5 en de ander de waarde 2 vertegenwoordigt). Een dergelijk onderscheid zou, mijns inziens, voor de nauwkeurige analyse van nonsensicaliteit best op zijn plaats zijn, maar reikt voor de context van dit onderzoek iets te ver.
} 

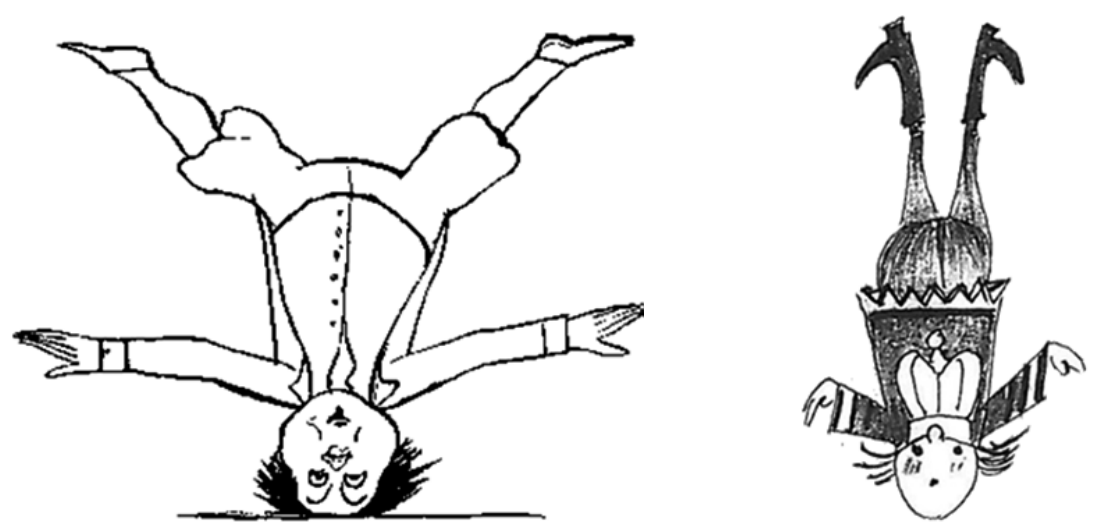

Figuur 1. Edward Lears weergave van zijn 'old man of Port Grigor' en Fiep Westendorps weergave van 'Prins Piramente'

Opvallend detail is dat zowel door Lear, die zelf illustraties bij zijn gedichten maakte, als door Fiep Westendorp die prins Piramente tekende, een belangrijk aspect behouden is gebleven: de figuren staan beide letterlijk op hun hoofd en niet, zoals we wellicht denken bij iemand die op zijn kop of ondersteboven staat, op hun handen. Lear en Schmidt hebben er in de genoemde gedichten voor gekozen de inversie in heel letterlijke zin toe te passen door personages op hun kop te zetten waardoor ze de wereld om hen heen ondersteboven waarnemen. In de meeste nonsensicale kinderrijmen, -liedjes en -gedichten komen we de omkering echter tegen op andere gebieden van de werkelijkheid.

Zoals ik al heb laten zien aan de hand van de transgressieve rijmen bij Van Vloten en het scabreuze kindervers dat we op schoolpleinen en speelplaatsen aantreffen, zijn het in volksculturele kinderrijmen en -liedjes regelmatig gedragsnormen die categorisch worden omgekeerd. Wat we in nonsensicale kinderpoëzie veel tegenkomen, is de inversie van bepaalde rolpatronen: volwassenen krijgen eigenschappen toegedicht die (door volwassenen) vaak juist aan kinderen worden toegeschreven of, denk aan het eerder gegeven voorbeeld 'Dwaze droom'G4 van Shel Silverstein, kinderen worden in machtsposities voorgesteld die doorgaans aan volwassenen zijn voorbehouden. Gedichten uit de eerste categorie vinden we veel terug in onder andere het oeuvre van Annie M.G. Schmidt. Geheel in lijn met de carnavaleske omkering van hiërarchische verhoudingen, zijn het bij Schmidt in het bijzonder hoogwaardigheidsbekleders die zich alles behalve 'koninklijk' gedragen. In 'Waar de koning trek in had' (Ziezo, p. 16) treffen we een koning die bij zijn ontbijt steeds iets anders op zijn brood wil: eerst wil hij honing, maar als hij honing krijgt, wil hij toch liever hagelslag. Als hij hagelslag krijgt, wil hij rammenas, daarna pindakaas, bosbessenjam, nee, toch liever een suikerklont, dan frambozengelei, muisjes, en ten slotte pasta. Als de koningin de besluiteloosheid van haar man zat is, stuurt ze de koning zonder ontbijt naar buiten, waarmee zij de 'kinderlijkheid' van de koning nog eens benadrukt. Dit pakt voor de koning uiteindelijk niet verkeerd uit:

En zo ging Zijne Majesteit

de straat op zonder zijn ontbijt. 
Daar stond hij te huilen, en wie kwam daar an?

De ijscoman, de ijscoman!

Toen at de koning een liter ijs

vlak voor 't koninklijk paleis.

In 'De koning en de pompelmoes' (Ziezo, p. 35) maken we kennis met al net zo'n koppige koning die zijn gehele hofhouding uitfoetert omdat hij per se een pompelmoes wil in plaats van al het andere fruit dat hij krijgt voorgeschoteld. 'De burgemeester van Hogezande' (Ziezo, p. 159), dan wel geen koning, maar toch een man van (ver)stand, "tekende eendjes op de wanden,/ tekende eendjes op de muren/ en op de schutting van de buren,/ allemaal eendjes op een rijtje,/ met een rood krijtje, met een rood krijtje." Omdat zelfs de raadsbesluiten, de ruiten, de deuren en daken, het tafellaken, de rug van juffrouw Kuiter én het standbeeld van De Ruyter helemaal zijn ondergekliederd met eendjes, wordt de burgemeester voor een jaar naar de tropen gestuurd in de hoop dat hij van zijn tekendrang af raakt. Als hij terugkomt, tekent hij inderdaad geen rode eendjes meer: nu tekent hij rode tijgertjes. 'De ridder van Vogelenzang' (Ziezo, p. 152) is overdag een dappere ridder die draken verslaat, maar blijkt's nachts zo bang te zijn in het donker dat hij om zijn moeder roept. Er is ook een koning die helemaal geen zin heeft om het land te regeren en te zorgen dat er geld in de schatkist komt, maar zich liever opsluit op de wc om zich aan zijn verantwoordelijkheden te onttrekken (Ziezo, pp. 163-164). Weer een andere koning zit heel verdrietig te wezen met zijn kroon en hermelijnen jas en dertig paarden voor de koets in zijn witte kasteel: "En als de koningin dan zei:/ Wat heb je toch? Wat heb je?/ dan zei de koning treurig:/ Ik wil een keer op een stepje." (Ziezo, p. 220) En dan hebben we nog Sinterklaas die verstrikt raakt in televisieantennes (Ziezo, p. 59) en tante Mathilde die niet gelooft dat Sinterklaas echt is en zijn baard eraf trekt waarna ze mee moet in de zak (Ziezo, pp. 97-98).

Gedichten uit de tweede categorie, waarin kinderen juist in een machtspositie staan, kunnen zoals in het geval van Silversteins 'Dwaze droom' heel expliciet de rollen omdraaien. Willem Wilmink stelt zich in het gedicht 'Het feest van Çocuk Bayrami' (Ik snap het, p. 97) voor hoe het is als kinderen mochten bevelen hoe je leven moet: er zou veel gespeeld worden, vies eten zouden de kinderen laten staan en huiswerk werd niet gedaan. "Ouders naar hun bedje sturen/ om een uur of acht/ en dan zelf nog lange uren/ fluisteren in de nacht." Wilmink schreef dit gedicht in relatie tot het Turkse feest Çocuk Bayrami als rituele context waarbinnen kinderen letterlijk voor de duur van het feest posities van volwassen leiders mogen innemen. Er zijn ook gedichten waarin de rollen als het ware worden omgedraaid doordat die gedichten transgressief of onfatsoenlijk gedrag van kinderen 'vieren'. Dat zagen we al in het eerdergenoemde 'Poep en pies menuet' van Dorrestijn en 'Ik ben lekker stout'G2/G4 en 'Slordige Saartje' van Schmidt, maar dat zijn zeker niet de enige gedichten waarin kinderen worden aangemoedigd tot transgressief gedrag. Wilmink geeft ze de opdracht om scheetgeluiden te maken onder het motto 'Lekker en toch gezond': "Maar 't mooiste liedje dat ik weet,/ is een knetterende scheet./ Doe je hand maar voor je mond, prr, prr, prr./ O wat lekker en gezond, prr, prr, prr." (Ik snap het, p. 145). In 'Stinklied' biedt hij een lijflied voor kinderen die liever vies zijn dan schoon en zich afzetten tegen de ultieme vertegenwoordiger der properheid: "Mijn moeder wast mijn oren,/ ze wast me ook van voren./ Mijn moeder wast mijn kont./ Dat is toch niet gezond?” (Ik snap het, p. 183) Frank 
Adam geeft in 'Tien dingen naar keus die je kunt doen met dingen uit je neus'G4 een hele opsomming van wat je zoal met snot kan doen (Als de bomen, p. 35) en biedt een hedendaagse versie van Driekoningen-liedjes in 'Drie rovers! (Aanbel-versje om mensen mee te overvallen en te beroven in hun huis op 6 januari op het feest van Driekoningen)'. Dit keer wordt er niet gevraagd om een ouderwets 'oortje' of 'geld', maar staan de kinderen voor de deur als 'drie kerels met geweren/ in een vreselijk slecht humeur!': "Voor uw parels in dit doosje,/ voor uw chique gouden ring,/ voor uw zilveren horloge,/ uw nieuwe gsm,/ (...)" (Als de bomen, p. 82) Dit zijn stuk voor stuk voorbeelden die kinderen uitnodigen om deze teksten te gebruiken, om ze zelf uit te spreken, te zingen of zelfs mee langs de deuren te gaan. Die expliciete gebruiksfunctie draagt naar verwachting sterk bij aan de waardering van kinderen (zie Hoofdstuk 3).

In de bundel $I k$ snap het van Willem Wilmink komen we ook een gedicht getiteld 'Rond of vierkant'G2 tegen waarin de omkering is toegepast op, zoals de titel al aangeeft, de vormen rond en vierkant. Dit is daarmee een veel abstracter vorm van nonsensicaliteit die nog steeds past binnen het spelpatroon van de omgekeerde wereld, maar geen aanspraak maakt op de 'carnavaleske ervaring' omdat de omkering is toegepast op kenmerken van objecten en niet op categorieën van menselijke verhoudingen en gedrag:

Toen ik nog een jongen was, had ik appels in mijn tas.

Appels smaken juist zo fijn omdat appels vierkant zijn.

Harrie Jekkers en Koos Meinderts presenteren in het lied 'Leuk is raar/Raar is leuk'G4 (Leve het nijlpaard!, z.p.) een hele reeks omkeringen van zowel abstracte als concrete categorieën. We vinden er regels als 'De ballon die stijgt omlaag/ En de baksteen valt omhoog', 'De kat die blaft de hele dag/ En de hond die zegt: miauw', maar ook 'Wie steelt, krijgt een beloning,/ Wie weggeeft is een dief' en 'Mijn moeder is een kerel/ En mijn vader draagt een jurk.' In het refrein van dit lied wordt de omkering gevierd als een manier om de sleur te doorbreken en jezelf te onderscheiden:

Raar is leuk, gewoon dat is zo saai.

Keer het om, geef de boel een draai.

Raar is leuk, gewoon dat is zo saai.

Aap niet na, je bent geen papegaai.

In dit lied lopen nonsensicale omkeringen op het niveau van de 'natuurlijke wetmatigheden' en op het niveau van 'culturele categorieën' door elkaar heen, wat aangeeft dat de scheiding van het carnavaleske domein en het domein van de abstractere nonsens geen strikte scheiding is, maar dat ze in elkaar kunnen overlopen. Wat kinderen het meest aanspreekt, zal samenhangen met hun cognitieve ontwikkeling en hun kennis van de wereld (zie \$5.9). 


\subsection{Liegen, dromen en wensen}

Volksculturele poëtische tekstsoorten waarin representaties van de omgekeerde wereld hoogtij vieren zijn de aloude leugen-, droom- of wensliederen: genres die herleid zijn tot de middeleeuwse liedcultuur (zie o.a. Kalff, 1972/1884, pp. 480-499). In Het lied in de middeleeuwen plaatste Kalff de leugen- en wensliederen samen met de raadselliederen in de categorie van liederen 'voor den gezelligen omgang': "In hen liet het volk zijner verbeeldingskracht den vrijen loop, beproefden zij de scherpte van elkanders verstand of trachten zij elkander te overtreffen in de kunst van vroolijken onzin voor den dag te brengen." (p. 480) Wanneer we in de (digitale) Nederlandse Liederenbank (www.liederenbank.nl) zoeken op 'leugenlied', dan vinden we titels vanaf de zeventiende eeuw waarin de meest wonderlijke taferelen worden voorgesteld door figuren met veelzeggende namen als 'De Zingende Reysiger, op een Ezel zonder Staart', 'De tweede Zingende Reysiger, op een Vliegende Kat' en 'De derde Zingende Reysiger, of wonderlyke Droomer in Zee', maar ook 'De Leugenagtige Kaas-Boer' of 'De Amsterdamsche Leugenaar'.

Zo verhaalt 'De Zingende Reysiger, op een Ezel zonder Staart' ${ }^{\prime} 4$ over zijn reis rond de wereld, die hij in negen dagen tijd aflegde (op een ezel zonder staart): iets wat op zichzelf de relatie tussen afstand, tijd en snelheid al vervormt. Op die reis zag hij wonderlijke dingen, te beginnen in Rome alwaar hij een walvis in de bomen zag die een liedje in het Latijn zong. Dit deel van de tekst is een eigen leven gaan leiden en los van de rest van het leugenlied in de kinderkamer terecht gekomen, getuige de volgende tekst die als zelfstandig kinderlied is opgenomen in de latere verzameling baker- en kinderrijmen van Van Vloten (1874, p. 50):

Laatstmaal kwam ik binnen Romen ${ }^{95}$

Daar zat een walvischje in de boomen,

Die zong een liedje al in 't Latijn;

Hij wist zijn stemmetje zoo zoet te mengelen,

Gelijk de klokjes, die daar bengelen,

Dat is te zeggen grof en fijn.

Het lied van de zingende reiziger gaat veel verder, langs Groenland waar hij een kater ziet schaatsen met een sater en twee beren een ijsslee zag maken, langs Spanje waar hij twee kamelen ziet klaverjassen, Duitsland waar hij vier grote waterhonden ziet vliegen en een vleermuis die heel rood was en als een olifant zo groot was 'Die liep voor Vasten Avonds Gek', Frankrijk waar hij een tijger ziet met een bek als een reiger en vier poten als een

\footnotetext{
${ }^{94}$ De volledige tekst is te vinden in: De roemrugtige Haagsche faam, of de nieuwe Amsterdamsche fonteyn. Jacobus van Egmont, Amsterdam 1721 (vierde druk), te vinden op: http://www.dbnl.org/

${ }_{95}$ De eerste regel wordt in andere versies van dit liedje ook wel weggelaten, zoals blijkt uit verschillende inzendingen van dit liedje die zijn opgenomen in de collectie Boekenoogen bij het Meertens Instituut. In de collectie van Nienke van Hichtum (pseudoniem van Sjoukje Troelstra-Bokma de Boer) is een versie opgenomen die begint met 'Ik kwam ereis ien 't land van Hoorn,/ Doar zat 'n walvisch op de toren'. Zie Liederenbank: http://www.liederenbank.nl/
} 
zwijn, Engeland waar hij twee apen gele rapen ziet schillen ${ }^{96}$, enzovoort. In de tekst van dit lied staan vele verwijzingen naar de gebruiken op Vastenavond, zoals de 'ik' die aan het begin van zijn lied stelt dat zijn wonderlijke verhaal toch wel 'een oortje' waard zal zijn, de rommelpot die wordt genoemd (in combinatie met twee dode dansende Hottentotten), en de bovengenoemde verwijzing naar 'voor Vasten Avonds Gek' lopen. Deze aanwijzingen doen vermoeden dat dit lied in deze versie door een volwassen zanger werd gezongen op Vastenavond in ruil voor wat eten of geld.

De (carnavaleske) nonsenstraditie in Nederlandse kinderlied- en -rijmrepertoires heeft nog niet zoveel aandacht gekregen. Er is zelfs gesteld dat de nonsens zoals deze door bijvoorbeeld Kornei Chukovsky werd aangewezen in de Russische en Engelse bakerrijmen in Nederlandse baker- en kinderrijmen zou ontbreken (Meelis-Voorma, 1973; geciteerd in Mooren, 2000b, p. 21). De leugenliederen vormen echter een belangrijke sleutel om de (carnavaleske) nonsens in het volksculturele kinderlied op het spoor te komen. Zoals ook het hierboven gegeven voorbeeld van het walvisje in de bomen al aangeeft, hoeven we enkel de sporen van de leugenliedtraditie door de tijd heen te volgen om vanzelf in de kinderkamer terecht te komen. In repertoires van volksculturele kinderliederen ${ }^{97}$ vinden we verschillende overblijfselen van het leugenlied, zoals ' $\mathrm{k}$ Zag twee beren/ broodjes smeren'G2/G4 en zeker ook het volgende voorbeeld (Vloten, 1874, pp. 151-152):
Toen 'k lest in Lombardijen kwam,
Hoor eens, wat ik daar vernam:
't Koetje zat bij 't vuur en spon,
't Kalfje lag in de wieg en zong,
't Katje karnde boter,
't Hondje waschte de schotels,
De zwarte muis, die veegde 't huis,
De zwaluw droeg het mot er uit
Op zijn vergulde vleugeltjes;
Zijn dat geen dikke leugentjes?

In de literaire kinderpoëzie zien we dat ook dichters zich hebben laten inspireren door de grappige en fantastische voorstellingen uit nonsensicale baker- en kinderrijmen. Lea Smulders schreef bijvoorbeeld een eigen variatie op het Engelse 'Hey diddle diddle, / The Cat and the fiddle,/ The Cow jumped over the moon./ The little Dog laughed,/ To see such sport,/ And the Dish ran away with the Spoon', onder de titel 'In de gekke-dingenschool'G2 (1978):

\footnotetext{
${ }^{96}$ Verschillende fragmenten in de tekst van dit lange lied doen ook denken aan " $k$ Zag twee beren broodjes smeren'.

${ }^{97}$ Wie online in de 'Nederlandse Liederbank' (http://www.liederenbank.nl/ ) zoekt op 'leugenlied' ziet dat bij de meeste van deze titels als genre 'kinderlied / leugenlied' vermeld staat. Veel van deze liedjes zijn dan ook via collecties van kinder(speel)liederen en -rijmen uit zowel Nederland als Vlaanderen bij het Meertens Instituut terecht gekomen. Helaas is er tot op heden nog geen bundeling van leugenliedjes (voor kinderen) uitgekomen en geen structurele analyse van de kenmerken van dit type teksten: we treffen er de meest fantastische voorstellingen in aan die een beeld schetsen van 'de omgekeerde wereld' in de Germaanse traditie. Iets wat tot op heden nog ontbreekt.
} 
In de gekke-dingen-school

Speelt de poes op de viool

Springt de koe over de maan

Heeft de hond een rokje aan

Bord en lepel gaan op sjouw

En er is géén schooljuffrouw

Door de verder heel duidelijk op 'Hey diddle diddle' gebaseerde tekst in te bedden in een 'school-raamwerk' raakt Smulders aan het al eerder genoemde carnavaleske thema van de omkering van machtsverhoudingen. Spelen met het idee van onafhankelijkheid van volwassenen begint bij kinderen vaak al in de peuter- en kleuterfase door zich bijvoorbeeld voor te stellen hoe het leven zou zijn zonder leid(st)ers en leerkrachten (zie o.a. Geller, 1985, pp. 10-11). Een school zonder schooljuffrouw biedt voor jonge kinderen onbegrensde mogelijkheden om de boel op de kop te zetten en omdat het hier om een 'gekke-dingen-school' gaat, past alles wat gek is júist binnen het kader. Een gelijksoortige logica zorgt ervoor dat liegen binnen het leugenlied is gerechtvaardigd: de vorm sanctioneert de inhoud. Dit is de logica van de 'rituele taalhandeling' als taalhandeling die zich onttrekt aan de waarheidscondities die in ons dagelijks taalgebruik wel kracht zijn. Voor kinderen bieden dergelijke rijmen veilige, want repercussie-loze, vormen om uiting te geven aan hun verlangen naar onafhankelijkheid en naar het onderzoeken van de grenzen van het mogelijke en toelaatbare. Ook Hans Andreus zag daar de aantrekkingskracht van in, zoals blijkt uit het gedicht 'De drie vliegen'G4 (1975) waarin drie vliegen op een balkon om het hardst zitten te liegen:

De eerste zei: 'Met dere poot

Sloeg ik vijf olifanten dood.'

De tweede zei: 'Ik vlieg zo vlug,

In 'n uurtje naar Afrika en terug.'

De derde zei: 'Ik vlieg zo hoog,

Nog hoger dan de regenboog.'

Het liegen van de vliegen wordt hier nog eens flink aangezet door de overdrijving, en omdat in het gedicht expliciet vermeld wordt dat de vliegen een lekker potje zitten te liegen, is die overdrijving van het toch al onmogelijke volkomen op zijn plaats. Het benoemen van het specifiek soort taalhandeling dat ín deze poëzie centraal staat (liegen) of het benoemen van het specifiek soort pragmatische context dat ín deze poëzie wordt opgeroepen (gekkedingen-school) markeert deze teksten expliciet als rituele taalhandelingen wat het voor jonge kinderen naar verwachting gemakkelijker maakt het taalspel als zodanig mee te spelen en te waarderen.

Een ander, eveneens tot het middeleeuwse lied te herleiden, fenomeen dat rechtvaardigt om er eens lekker op los te fantaseren, nu op het vlak van de lichamelijke functies, is het 
fenomeen van 'Luilekkerland'98 (ook wel bekend als het land van Cocagne, zie o.a. Pleij, 1997). Theo Meder beschrijft hoe deze overdreven voorstelling van het spreekwoordelijke land van melk en honing afhankelijk van tijd en plaats verschillende vormen en functies heeft gekend, van profaan droombeeld van overvloedig zintuiglijk genot tot moralistisch middel in een beschavingsoffensief tegen lust, luiheid en vraatzucht, maar dat Luilekkerland uiteindelijk vrij van moraal en, voeg ik daar aan toe, in al zijn groteske glorie de kinderkamer bereikte ${ }^{99}$ :

"In het kinderboekje De nieuwe reis naar Luilekkerland, in de eerste helft van de 19e eeuw uitgegeven door Jan-Baptist Ulrich te Rotterdam, passeren zonder zedenles de volgende elementen de revue: de rijstebrijberg, de os die pannenkoeken kakt en de boom die stroop verschaft, het paardje dat geld schijt en de boom waar dubbeltjes aan hangen, het gebraden varken, de gebraden eendenbout en de gebraden appelen, de wijnfontein, de ezel die vijgen kakt, de banketboom en de gratis speelwagen." (Meder, Van A tot Z Reeks: lemma 'Luilekkerland')

Dit 'luie en lekkere land' heeft door de jaren heen veel schrijvers van kinderpoëzie geïnspireerd. Wie door Komrij's De Nederlandse Kinderpoëzie in 1000 en enige gedichten heen bladert, komt de $19^{\text {de }}$-eeuwse dichter P.J. Cohen de Vries tegen die in 'De kindertjes uit Luilekkerland' vermeldt dat deze gekke kindertjes graag een boterham met zand lusten, het liefst bij poes in haar mand slapen, naar school lopen met de klompjes in de hand, hun soep eten van een bordje zonder rand en hun les leren uit de krant (Komrij, 2008, p. 495). Rie Cramer komt in de eerste helft van de twintigste eeuw met een gedicht 'Luilekkerland' waarin ze dit land beschrijft als een wonderlijk land waar alles (straten, huizen, rivieren, beken, fonteinen) uit zoetigheid bestaat, 'En er lopen gebraden biggetjes rond/ Met lepel en vork aan hun staartjes'. Wat al dat lekkers met de kinderen doet, ontdekken we in de laatste strofe: 'De kindertjes zijn er als modder zo vet/ van al dat lekker eten;/ Natuurlijk zijn ze niet bijster vlug,/ Ze liggen de hele dag lui op hun rug,/ En hoeven er nooit iets te weten.' (Komrij, 2008, p. 500) In dezelfde periode schrijft Henk van Laar 'In het stadje Suikerhuizen', een plaats in Luilekkerland waar Sinterklaas zijn Pieten op muizenjacht stuurt zodat hij alle kinderen die zich netjes hebben gedragen een chocolademuis kan geven (Komrij, 2008, p. 527). Willem Wilmink schrijft over 'Hoe het was in Luilekkerland': 'Ik ben er vroeger vaak geweest, / het was er alle dagen feest'. Ook hij beschrijft het als een land vol lekkers, inclusief de 'gebraden varkens liepen rond/ met mes en vork al in hun rug', maar in de laatste regels krijgt dit gedicht een nostalgische draai die het ontmaskert als volwassenenpoëzie (Komrij, 2008, pp. 702-703). Het gedicht 'Luilekkerland expres' van Annie M.G. Schmidt heeft Komrij niet in zijn verzameling opgenomen, maar in dat gedicht lezen we

\footnotetext{
${ }^{98}$ Luilekkerland is niet alleen bekend in liedvorm, maar ook in de vorm van een volkssprookje opgenomen in de collectie van de gebroeders Grimm: in verhaalvorm ontbreekt overigens enige vorm van plot en gaat het vooral om een opsomming van onmogelijke voorstellingen die de verteller zou hebben gezien 'in het apenland'. Bron: http://www.beleven.org/verhaal/het_sprookje_van_luilekkerland

${ }_{99}$ In liedvorm zijn beschrijvingen van Luilekkerland of Cocagne overigens tot ver in de twintigste eeuw vooral overgeleverd als onderdeel van de volwassen amusementsliederen (zie Nederlandse Liederenbank); tegelijk zien we het zeker vanaf het begin van de twintigste eeuw opduiken als regelmatig terugkerend thema in kinderpoëzie in de literaire traditie (zie o.a. in Komrij, 2008). Het lijkt erop dat dit thema het traditionele kindervers heeft overgeslagen.
} 
over een bus die kinderen naar Luilekkerland brengt alwaar ze zich eerst, in overeenstemming met de overlevering, een weg door de rijstebrijberg moeten eten om vervolgens in het land vol zoetigheid te komen. Ook bij Schmidt worden de kinderen nogal dik van al dat eten, zo dik zelfs dat drie kinderen niet meer mee terug kunnen omdat ze niet in de bus passen: 'En, zijn ze alle drie maar in Luilekkerland gebleven?/ Jazeker, maar ze hebben wel een brief naar huis geschreven:/ Dag mam, we eten noga-ijs uit hele grote schalen!/ En als je ons terug wilt hebben, kom ons dan maar halen!' (Ziezo, p. 84)

\subsection{Een koe en een kalf en een heel paard half, en ja, er kan nog meer bij...}

Niet alleen in kinderrijmen, -liedjes en -gedichten over Luilekkerland is het thema 'eten' oververtegenwoordigd. Het thema 'eten' is overigens überhaupt niet voorbehouden aan de carnavaleske nonsenspoëzie, het is tenslotte een alledaags thema dat in veel verhalen en gedichten voor kinderen voorkomt, ook in realistische (pro)porties. In nonsensicale gedichten neemt eten echter vaak groteske proporties aan zoals Bakhtin dat ook identificeerde in de sfeer van de carnavaleske volkshumor. Allereerst maken we in de carnavaleske nonsenspoëzie voor kinderen kennis met een scala aan figuren die de meest vreemde voorkeuren hebben als het op eten aan komt. Bij Diet Huber komen we een beest tegen dat Boeboe heet en dolgraag kinderboeken eet (Daar moet je nou een beest voor zijn, p. 5), of de mannetjes op Mars die graag kauwen op een steen en knagen op een teen, maar bang zijn voor Marsepein (omdat ze denken dat dat pijn doet) (pp. 10-11). De heks Klazina K. van Keeten eet een maaltijd bestaande uit: "één ons onweer, twee pond rots, / zes stuks wrakhout en een knots,/ vijf zak steenkool, tien pond roet,/ strikjes voor een heksenhoed,/ acht pond veren en wat kant/ en een berg van vochtig zand." (pp. 30-31), en de Veter-eter (de naam zegt het al) eet meters veters, alleen de eindjes spuugt hij uit (pp. 78-79). De Orrekiedorren van Annie M.G. Schmidt eten kiezelstenen met boter en suiker gestoofd (Ziezo, p. 49) en de pater Zwierelier kookt soep van bordpapier (Ziezo, p. 153). Buddingh's BlauwbilgorgelG4 lust alleen maar korgel, behalve als de nachtuil krijst, dan eet hij riep en rimmelrijst (Buddingh', 2003). Stuk voor stuk uitermate ongewoon, maar niet zo gevaarlijk als types zoals de kinderverslinder van Harrie Jekkers en Koos Meinderts: "De verslinder lust totaal geen grote mensen/ Die zijn te taai en hebben veel te vette penzen/ Maar een malse meid/ Of een jongen op zijn tijd/ En elke dag het liefst een kleuter als ontbijt." (Leve het nijlpaard!, pp. 13-14).

Ook de hyperbolische representatie van eten vinden we terug in kinderrijmen, -liedjes en -gedichten. Denk bijvoorbeeld aan de enorme hoeveelheden die 'Holle bolle Gijs'100 op zijn holle bolle wagen naar binnen schrokt: 'een koe en een kalf,/ een heel paard half,/ een os en een stier,/ zeven tonnen bier,/ een schip vol rapen,/ een kerk vol schapen-/ en nog

100 'Onze' Holle Bolle Gijs heeft overigens een tweelingbroer in de Engelse traditie, getuige het bakerrijm 'Robin the Bobbin': 'Robin the Bobbin, the big-bellied Ben,/ He ate more meat than fourscore men; / He ate a cow, he ate a calf,/ He ate a butcher and a half;/ He ate a church, he ate a steeple,/ He ate the priest and all the people!/ A cow and a calf,/ An ox and a half,/ A church and a steeple,/ And all the good people,/ And yet he complained that his stomach wasn't full.' Bron: The Nursery Rhyme Book, edited by Andrew Lang and illustrated by L. Leslie Brooke (1897). 
kon Gijs / van de honger niet slapen!' (Abramsz, 1984/1910, pp. 86-87) Voor de mogelijke herkomst van dit rijm (of lied) verwijst Annemieke Arendsen naar het boek De volksvermaken (1871) waarin Jan Ter Gouw de tekst verbindt aan een oud Paasgebruik, het zogenoemde 'veel-eten': 'Een persoon werd met pasen [sic] uitgedaagd om zoveel mogelijk te eten. Ter Gouw schrijft '...oudtijds werd aan zulke helden openbare eer ${ }^{101}$ bewezen. Zij werden op een wagen gezet en in triomf rondgevoerd, en er werden liederen bij gezongen.' Inderdaad wordt hier het lied over de holle bolle wagen genoemd." (Nieuwsbrief Meertens Instituut, maart 2011, z.p.) Het heiligen van overdadig eten is, als omkering van de religieuze ideologie van het vasten, volgens Bakhtin een typisch carnavalesk gebruik en de (vaak nog eens extra aangedikte) weergave ervan in beeld of tekst een voorbeeld van het grotesk realisme. In het gedicht 'Tot tien tellen'G2 laat Erik van Os het personage Pepijn bij ieder getal in de telrij van één tot en met negen het genoemde aantal van iets eten, van één aardbei tot en met negen negerzoenen, waarna Pepijn tien dagen buikpijn heeft (1997). Veel verder gaat Shel Silverstein in het gedicht 'Hongerige Harry'G4 (1985): ook in dit gedicht is de opbouw gebaseerd op toenemende hoeveelheden, maar hier begint Harry bij het eten van dat wat op tafel staat (en dat is al een heleboel), dan de tafel zelf, zijn ouderlijk huis en zijn ouders, dan de straat met iedereen die zich daarop vertoont (inclusief politie en leger die hem proberen te stoppen), de stad, het land, andere landen en ook zeeën, uiteindelijk de hele wereld en vervolgens begint hij aan het heelal. Het gedicht eindigt met de volgende strofe:
Hij begon met de wolken hij slurpte de wind op en toen dat was gedaan verslond hij de sterren, de zon en de maan.
Daar zat hij nu in de donkere koude lucht
hij begon aan zijn voeten te knabbelen
toen aan zijn benen, z'n heupen, z'n kont
zijn buik en zijn borst, zijn nek en zijn mond.
Toen zat hij te knagen op zijn allerlaatste kies
want verder was er
helemaal nergens meer iets...

Eenzelfde onmetelijke eetlust komen we tegen in het gedicht 'Mijn hemel, wat een honger!' van Stijn Vranken waarin de 'ik' begint met het eten van een appel, vervolgens de boom waar die appel aan hing (met vogel en wortel en al), de tuin met de vijver, het huis van de buurvrouw en de buurvrouw zelf, de straat inclusief papa die daar fietst, het dorp, de stad, het land, de zee, de wolken, enfin: de hele wereld. Dit gedicht eindigt met de mysterieuze regels: "En toen, als toetje,/ viel ik de hemel in..." (Ik wil een naam van chocola, p. 27).

Maar: er kan nog meer bij ... De hyperbolische representatie van hoeveelheden die in de hierboven beschreven teksten werd toegepast op het thema 'eten', komen we ook tegen in relatie tot andere thema's. De meesten van ons zijn wel bekend met Schmidts 'Hendrik

\footnotetext{
101 Arendsen gaat hier niet op in, maar we kunnen ons afvragen of het alleen om eer ging, of ook (wellicht tegelijk) een beetje om hoon. De overduidelijke overdrijving in het lied en de eindregel 'En nóg kon Gijs van de honger niet slapen' doen vermoeden, en dit is volkomen speculatief, dat er best enig sarcasme kan hebben doorgeklonken in de stemmen die opklonken uit de menigte.
} 
Haan' uit Koog aan de Zaan die de kraan open liet staan. In dit gedicht is het het effect van roddelen dat het verhaal steeds dramatischer maakt: volgens de eerste die het verhaal vertelt, heeft de kraan uren open gestaan en is de keuken ondergelopen, volgens mevrouw Van Voort, die het doorvertelt, stond de kraan zeven dagen open en is heel het huis ondergelopen, volgens mevrouw Van Doren was het zeven weken en dreven alle auto's door de straat, en volgens mevrouw Van Wal stond de kraan zeven maanden open, is heel de stad ondergelopen en was er niemand meer in leven. Als ten slotte Hendrik zelf langs komt, blijkt echter dat het maar heel even was: "De keukenmat/ een tikkie nat" (Zięo, pp. 270271). Schmidt heeft de hyperbolische representatie van omvang en massa veel vaker toegepast. 'De oren van koning Maggelhaan' (Ziezo, p. 22) zijn zo groot als vliegmachines en blijven maar doorgroeien wat, begrijpelijkerwijze, veel problemen oplevert. 'Het vrouwtje in de peel' (Zięo, pp. 176-177) bakt zoveel oliebollen dat alle mensen, schuren, huizen en stallen vol raken en er een enorme oliebollenberg ontstaat die uiteindelijk 'met veel gerommel en gedonder' omvalt bovenop het vrouwtje. Minstens zo tragisch is toch het lot van 'De koning van Savoye'G4 (Ziezo, p. 258) die heel veel jonge dochters had ('zeventien lelijke, zeventien mooie,/ zeventien blonde, zeventien rooie'). Die dochters hadden drie kamerheren elk, iedere kamerheer had drie lakeien om zich heen, iedere lakei had een aapje met een staart en "al die aapjes in hun kooien/ hadden wel honderdduizend vlooien". Die vlooien gingen zich binnenshuis verstrooien en kropen 'in des konings hemd'. Al met al heeft die arme koning van Savoye dus last van:

- Aantal dochters: $4 \times 17=68$

- Per dochter drie kamerheren: 68 × $3=204$

- Per kamerheer drie lakeien: 204 × $3=612$

- Per lakei een aapje met een staart: $612 \times 1=612$

- Per aapje honderdduizend vlooien: $612 \times 100.000=61.200 .000$ vlooien!

Een bijzondere variant op dit hyperbolische spel met de grote aantallen, is gerelateerd aan de uitdrukking: 'De druppel die de emmer doet overlopen', of 'The straw that broke the camel's back'. Het gaat hier om situaties waarin een toch al enorme hoeveelheid uiteindelijk instort, omvalt, overloopt, of de drager doet zwichten, door de toevoeging van een laatste eenheid die qua omvang en gewicht in het niet valt bij de omvang en het gewicht van de al aanwezige massa. In de kinderpoëzie komen we deze structuur tegen in onder andere 'Het grote bed'G2 van Rudy Kousbroek en 'De brug bij Breukelen'G4 van Annie M.G. Schmidt. In het eerste gedicht is het een kleine mier die als tiende (na een kind, een zeehond, een nijlpaard, een hond, een koe, een paard, een geit, een schaap en een varken) op het grote bed klimt waarna het bed het begeeft. De andere dieren weten wel door wie het komt: 'Toen riepen ze, in toorn ontstoken:/ Die mier! Die heeft ons bed gebroken!' (Buul \& Stigter, 1993, p. 192) In 'De brug bij Breukelen' is het een kleine mug die er de schuld van krijgt dat de overvolle brug instort: 'Die brug was tot nu toe nog helemaal heel,/ maar nou met die mug was het net iets te veel./ En zo kwam het dan dat van krikkerdekrak/ de ijzeren brug in twee helften brak.' (Ziezo, p. 197)

De hyperbolische representatie van hoeveelheden, omvang en/of gewicht zijn in laatstgenoemde voorbeelden redelijk abstract, zeker als het gaat om concrete getallen, en vraagt 
veel van het inbeeldingsvermogen van kinderen. Het is evenwel een fenomeen dat ook Bakhtin opmerkte als terugkerend kenmerk in verschillende vormen van komische tekstuele composities die gerelateerd zijn aan carnaval en het carnavaleske, zowel toegepast op het lichaam en het lichamelijke, als grote concrete getallen (Bakhtin, 1984, pp. 150, 190, 221). Toch moeten we er, met het oog op de doelgroepen in dit onderzoek, rekening mee houden dat deze teksten een beroep doen op conceptueel denkvermogen, tenzij de voorgestelde situaties worden gevisualiseerd door uitbeelding of het gebruik van attributen in de klas.

\subsection{Varen in een hoed en het breken van narratologische conventies}

Een terugkerend element in nonsensicale kinderpoëzie is de incongruente combinatie van handelingen en objecten, van objecten (of subjecten) en categorische kenmerken, van oorzaken en gevolgen en ga zo maar door. Met andere woorden: er worden regelmatig zaken met elkaar in verband gebracht die normaal gesproken niet op de voorgestelde manier met elkaar in verband staan (vaak staan ze normaal gesproken helemaal niet met elkaar in verband). Hoewel dit in bepaalde opzichten ook geldt voor de eerder besproken omkeringen, gaat deze categorie veel verder dan alleen het één-op-één omkeren of verwisselen van aspecten van de werkelijkheid. Zoals in leugenliederen walvissen in de bomen zitten, kalfjes in de wieg liggen te zingen, poezen op de viool spelen en lepels en borden met elkaar aan de wandel gaan, zo treffen we in de kinderpoëzie regelmatig soortgelijke fantastische voorstellingen aan, maar nu zonder de expliciete ontmaskering als 'leugens'. Met andere woorden: het identificeren van de incongruentie en het vinden van de resolutie van die incongruentie doet in deze categorie een groot beroep op de kennis en op het concreetoperationele en zelfs het formeel operationele denkvermogen van kinderen.

Annie M.G. Schmidt laat 'De kikker van Worrekie-bel' (Ziezo, p. 102) trouwen met een lantaarnpaal ('Wie zwijgt, stemt toe'), en in 'O, juffrouw Pook' (Ziezo, p. 157) een pook trouwen met een tang. In een variatie op de welbekende versjes waarin dierengeluiden en dieren aan elkaar gekoppeld worden, laat Judith Herzberg de geit 'kukeleku' kraaien, het biggetje miauwen, de hond mekkeren, het schaap kwaken, en ga zo maar door (Dichter bij de dieren 1991). Shel Silverstein laat 'Ikkeltje, Tikkeltje, Spikkeltje Boem'G2 op reis gaan in een vliegende schoen, waarmee ze een aantal keren om de zon cirkelen om vervolgens voorgoed te verdwijnen (Randje van de wereld 1985). Iets soortgelijks vormt de centrale incongruentie in het gedicht 'Drie apothekertjes'G4 van Annie M.G. Schmidt (Ziezo, p. 140). Kort samengevat vertelt het gedicht het volgende 'verhaal': drie apothekers werken in de apotheek in Goes, maar zijn toe aan iets nieuws. Ze roepen enthousiast dat ze willen gaan varen naar Nieuw-Guinee en ze besluiten daarop een bottertje te gaan kopen. Na veel wikken en wegen blijkt geen enkel bottertje goed, dus nemen ze maar een hoed. In die hoed varen ze drie nachten op de Schelde bij donkere maan en spoelen dan eindelijk aan. Wat blijkt? Ze zijn weer terug op de plaats waar ze waren begonnen en gaan weer aan het werk in de apotheek in Goes. Dit gedicht leent zich heel goed om te laten zien dat nonsensicaliteit in kinderpoëzie kan worden toegepast op verschillende niveaus die op hun beurt corresponderen met verschillende kennisniveaus. 
Het eerste niveau waarop we nonsens aantreffen, is het redelijk concrete en visuele niveau van het vaartuig: de drie apothekers zijn van mening dat een hoed het aangewezen vervoermiddel is voor hun zeereis. De incongruente combinatie van object, een hoed, en handeling, varen, heeft een centrale plaats gekregen in het gedicht en is ook voor jonge kinderen herkenbaar, mede doordat Fiep Westendorp er voor heeft gekozen om de hoed als nonsensicaal vaartuig de hoofdrol te laten spelen in de illustratie bij het gedicht. Om de nonsens op dit concrete niveau te herkennen, is in hoofdzaak kennis nodig van conventionele vaartuigen en kan ook de gebruikelijke functie van hoeden een aanwijzing vormen (die

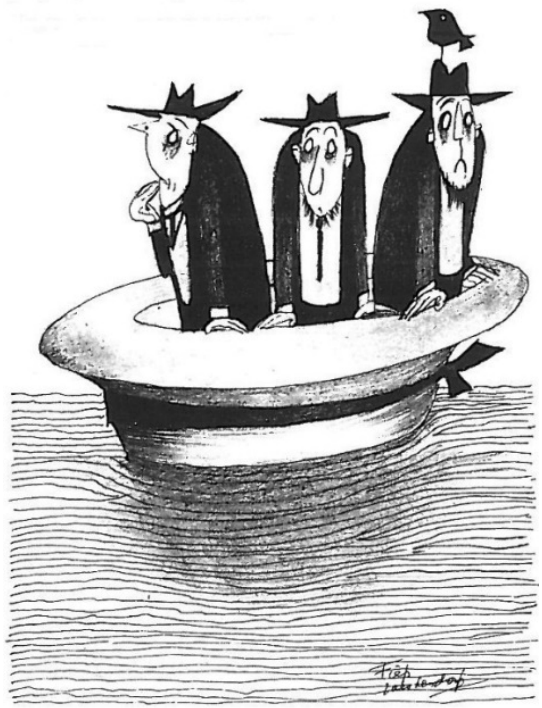

Figuur 2: (C) Fiep Amsterdam bv; Fiep Westendorp Illustrations draagt men doorgaans op het hoofd). Deze concreet operationele nonsens wordt in het gedicht echter gecombineerd met abstracter niveaus van nonsensicaliteit. Zo kun je je afvragen of een hoed nog wel een hoed is wanneer deze het formaat van een bootje heeft en niet meer van de omvang van een hoofd: toch hangen de drie apothekers de hoed gewoon weer aan de kapstok aan het einde van het gedicht. Je kunt je ook afvragen hoe het mogelijk is dat de hoed met de apothekertjes na drie nachten varen op de Schelde bij donkere maan weer aanspoelt op het punt van vertrek. Dit gegeven vereist meer specialistische kennis: kennis van de ligging van Goes en de Schelde en kennis van stromingen en getijden. Voor het antwoord op deze vraag verwijs ik naar Bijlage 8 met de titel 'Zeilexpertise nodig bij onderzoek naar nonsens'. Vervolgens speelt Schmidt ook een nonsensicaal spel met de logica door de apothekertjes een ijzersterk doch ongeldig argument toe te dichten in hun keuze voor de hoed: "Daar voeren ze dan op de Schelde/ en waren geen ogenblik bang./ Want hoeden vergaan er maar zelden,/ dat wisten ze al zolang!" Dat je met het spel van de logica nonsens kunt creëren wist ook Lewis Carroll, als wiskundige, maar al te goed (zie ook Anderson \& Apseloff, 1989, p. 20). De logische redenering die de apothekertjes hier volgen, zal ongeveer als volgt zijn:

\section{(voorwaarde) Hoeden vergaan maar zelden op de Schelde;}

(voorwaarde) Wij varen in een hoed;

(conclusie) De kans dat onze hoed zal vergaan op de Schelde is zeer klein.

De logische redenering is op zichzelf niet verkeerd; de apothekertjes hebben alleen niet stilgestaan bij de vraag waarom er maar zelden hoeden vergaan op de Schelde. Een uitgangspunt dat de hele redenering ongeldig maakt. Schmidt past hier een vorm van 'false reasoning' toe die ook veel voorkomt in fabels en schelmenverhalen waarin een personage een ander personage voor de gek houdt door een ongeldige redenering te gebruiken (Anderson \& Apseloff, 1989, p. 13). In het eerder genoemde gedicht 'Dwaze droom'G4 van 
Shel Silverstein herkennen we dit procedé in de vorm van de volkomen nonsensicale vraag die de 'ik' voorlegt aan de juffen en meesters: 'Wat is er roder, groen of blauw?' De grens die hiermee wordt overschreden is een schending van het waarheidsprincipe waar de meeste vragen, zeker in de les op school, op gebaseerd zijn. Vanuit taalfilosofisch perspectief is de vraag ongeldig omdat geen van de voorgestelde antwoorden (groen of blauw) roder is dan de ander (ze zijn beiden helemaal niet rood). Erger nog: het antwoord op de vraag is altijd fout (ook als ze het antwoord niet weten), maar daarmee is de vraag in dit gedicht wel een prima garantie om de juffen en meesters te kunnen bestraffen.

$\mathrm{Na}$ dit abstracte niveau waarop nonsens voortkomt uit een spel met de logica, volgt nog een laatste niveau waarop we nonsensicaliteit kunnen aanwijzen in 'Drie apothekertjes', te weten op narratologisch niveau. Op dit niveau bestaat de nonsens in het gedicht uit de volkomen circulariteit van de plot. Wat in de narratieve structuur ontbreekt, is een clou: de reis van de apothekertjes heeft geen enkele betekenis, de gewenste bestemming wordt niet bereikt, de apothekertjes geven geen blijk van teleurstelling wanneer ze weer terugkomen op hun vertrekpunt en ze hebben ook geen les geleerd. Ze stellen vast dat ze weer terug zijn in Goes (want ze herkennen hun poes) en gaan weer aan het werk in de apotheek. Op dit metaniveau doet de nonsens in dit gedicht beroep op de literaire competentie van de lezer: wie geen kennis heeft van narratieve conventies zal de nonsens op dit niveau niet herkennen. Wie wel kennis heeft van narratieve conventies zal na het lezen van dit gedicht waarschijnlijk denken: "Ja, dus, en toen?" Dit gedicht bevat nonsens op niet minder dan vier niveaus: het concrete niveau van de hoed als vaartuig, het specialistische niveau van de afgelegde vaarroute, het abstracte niveau van bijvoorbeeld de logische redenering en ten slotte het meta-tekstuele niveau van de narratieve conventies. Schmidt speelt een meervoudig cognitief spel dat door verschillende lezers op verschillende niveaus kan worden herkend en gewaardeerd. Voor kinderen van vijf of zes zal alleen de hoed als vaartuig een herkenbare afwijking van de normale gang van zaken zijn; kinderen in groep 4 kunnen, vanwege hun uitgebreidere ervaring met verhalen, wellicht ook opmerken dat het een vreemd soort verhaal is. Het spel met de logica en de specialistische kennis van de wereld zullen ook voor hen nog te moeilijk zijn.

\subsection{De carnavaleske lach die onderbuik en intellect verbindt: de zin van de onzin in ontwikkelingsperspectief}

Het feit dat (carnavaleske) nonsensicaliteit in baker- en kinderrijmen een breed gedragen en diepgeworteld cultuurverschijnsel vertegenwoordigt (zie ook Hoofdstuk 2), dwingt ons te vragen wat het is dat dit kenmerk in de vorm van baker- en kinderrijmen doet voor kinderen. Met andere woorden: wat kan de functie van (carnavaleske) nonsensicaliteit voor kinderen zijn? Als breed gedragen en diepgeworteld onderdeel van 'het taalspel poëzie' zoals dat vorm krijgt in de communicatiesituatie waarin het baker- en kinderrijm uit de orale volkscultuur van oudsher functioneert, kan nonsensicaliteit alleen begrepen worden in de sociale gebruikscontext. Om de 'betekenis' van nonsensicale poëzie te achterhalen, moeten we ons afvragen: "wie gebruikt het (sociaal) op welke manier (technisch) voor welk doel (functie), waar (ruimte), wanneer (tijd) en op welke wijze markeert men zich daarmee ten 
opzichte van anderen (betekenis)?” (vgl. Rooijakkers, 2000a, pp. 110-111) De vormen van nonsensicaliteit die we in baker- en kinderrijmen aantreffen, sluiten dan op de een of andere manier aan op de poëtische gebruikshouding, gebaseerd op specifieke poëtische gebruiksconventies, van waaruit jonge kinderen 'het taalspel poëzie' aanvankelijk (leren) spelen. Sterker nog, als tekstaspect van het baker- en kinderrijm mogen we er van uit gaan dat nonsensicaliteit haar gebruikers helpt de wereld te begrijpen en, ten minste gevoelsmatig, te controleren (Lurie, 1990, p. 196). Dat lijkt wellicht contra-intuïtief: hoe kan nonsens jonge kinderen nu helpen de wereld te begrijpen en controleren wanneer het weerstand biedt aan interpretatie en juist betekenisondermijnend werkt?

Peter van den Hoven heeft er al op gewezen dat de subversieve rijmen van kinderen door volwassenen gemakkelijk en stelselmatig gediskwalificeerd worden omdat ze zo vaak “... tegen de algemeen geaccepteerde fatsoensnormen indruisen, beledigend en discriminerend zijn (blasfemisch, seksistisch), en bovendien opvoedingsidealen belachelijk maken en gewenste sociale verhoudingen ondermijnen" (Hoven, 1997, p. 217). Juist hierin ligt echter ook de zin van die rijmen. Zoals Bakhtin benadrukt met betrekking tot carnaval en carnavaleske humor, is er nooit sprake van een volledige scheiding tussen de eerste en de tweede, carnavaleske, wereld, maar is er een continu dialogisch proces gaande. In dat dialogisch proces wordt alles wat binnen de officiële cultuur hoog, heilig, ideëel of gezaghebbend is door omkering en omvorming op humoristische wijze naar het concrete materiële niveau gebracht (Bakhtin, 1984, p. 19). In (het gebruik van) subversieve of scabreuze rijmen en liedjes kunnen kinderen aspecten van de hen omringende wereld naar hartenlust manipuleren tot groteske (omgekeerde, overdreven, vervormde) weergaven ervan. Dit grotesk realisme kan, ook in het domein van het scabreuze kindervers, worden ontmaskerd als een bevestiging van de normatieve, officiële, cultuur juist doordat de carnavaleske vervorming van de (sociale) werkelijkheid heersende normen en waarden blootlegt. Anderson en Apseloff beschrijven nonsens, in lijn met wat Bakhtin over carnaval en het carnavaleske zegt, als de logica van de omgekeerde, of ten minste lichtjes gekantelde, wereld en stellen: "The very notion of topsy-turvy implies that there is a right side up. Essentially dyadic, nonsense consists of humorous absurdities with double or split meanings, of contrasts, reversals, and mirror images." (1989, p. 5) De constructie van nonsens staat in die zin altijd in relatie tot de constructie van 'common sense': “... nonsense always implies a contrast to some linguistic, spatial, emotional or ethical form that is accepted as sense." (p. 4) Bakhtin biedt aanvullend inzicht in de motivatie die ten grondslag ligt aan de creatie van carnavaleske nonsens. Carnaval en het carnavaleske zijn volgens hem nooit volledig negatief of afwijzend, maar creëren een tweede domein dat is georganiseerd op basis van de lach (1984, p. 8). Dit is een belangrijk principe dat de functies van het subversieve kindervers verbindt met de functies van carnavaleske volkshumor: geen van beide heeft zin, of betekenis, als er geen plezier aan beleefd kan worden. Bakhtin beschrijft de carnavaleske lach ten eerste als een feestelijke lach: het is niet de individuele lach van iemand die reageert op een geïsoleerd komisch voorval, maar het is een lach die mensen in de context van die tijdelijke tweede carnavaleske wereld met elkaar verbindt. Ten tweede is de carnavaleske lach volgens Bakhtin universeel van aard, in die zin dat ze gericht is op de relativiteit van alles en iedereen, inclusief de deelnemers zelf. Ten derde is de carnavaleske lach ambivalent: het is een vrolijke en triomfantelijke en tegelijkertijd spottende lach, het is een bevestigende en tegelijker- 
tijd ontkennende lach (pp. 11-12). In het subversieve kindervers komt het belang van de lach heel duidelijk naar voren in het onbedaarlijke plezier dat door kinderen beleefd wordt aan 'twee heksen die samen seksen' of Sinterklaas die op de pot zit te stinken. In het hoofdstuk dat hij in het boek Poetry's Playground aan 'Child poets and the poetry of the playground' besteedt, merkt Joseph Thomas hier in een vergelijking met heersende opvattingen over wat poëzie is over op:

"These poems are not $[\ldots]$ concerned with the mind, but with the body. They are composed and performed with the aim of producing strong, bodily reaction: laughter, guffaws, gasps, groans, or in the case of jump-rope rhymes, facilitating vigorous play." (Thomas, 2007, p. 47)

Het belang van de lach, maar ook van het lichaam en de lichamelijkheid, mag in de context van het schoolplein en de speelplaats niet worden onderschat, zoals het belang van deze elementen ook in het kader van de carnavaleske weergave van de wereld niet mag worden onderschat. Tegelijk duidt het plezier dat kinderen beleven aan subversieve rijmen en liedjes erop dat kinderen zich bewust zijn van de afwijking, van de grensoverschrijding of taboedoorbreking. De lach is dus (vaak) ook een indicator van kennis en begrip van de aspecten van de wereld die aan de carnavalesk speelse herordening zijn onderworpen. In tegenstelling tot wat Thomas zegt, is de scabreuze speelplaatspoëzie dus wel degelijk ook gerelateerd aan het verstand al is het lichamelijk effect voor kinderen van groot belang.

Gezien de thema's die dit effect voor hen bewerkstelligen, gaat de voorkeur van kinderen op de basisschool vooral uit naar het spel met de zogeheten 'culturele categorieën', i.e. de normen en waarden, van de culturele gemeenschap(pen) waar deze kinderen deel van uitmaken. Als specifiek subversief soort 'cultural frame' ervaren we een uiting als nonsens voor zover het op herkenbare wijze afwijkt van een herkenbaar deel van onze kennis van de gebruikelijke, als 'common sense' geaccepteerde, normen of conventies en brengt het een carnavaleske ervaring teweeg voor zover de herkenning van die afwijking gedeelde fysieke effecten veroorzaakt (met elkaar lachen, etc.). Het boek From Two to Five van de Russische kinderdichter Kornei Chukovsky kan gelezen worden als een manifest waarin hij de zin van de onzin voor de ontwikkeling van kinderen (in de leeftijd van twee tot vijf jaar) verdedigde tegen het rationalisme van de Verlichting dat een zware stempel drukte op, onder meer, het onderwijs (zie ook Bruijn \& Mooren, 2008; Mooren, 2000b). Wanneer op een dag zijn jonge dochter voor hem komt staan en verklaart dat honden miauwen om vervolgens in lachen uit te barsten, realiseert Chukovsky zich dat hij zojuist getuige was van de geboorte van haar gevoel voor humor. Op basis van zijn eigen observaties en vele brieven die hij ontving van (groot)ouders legt Chukovsky verband tussen de taal- en humorontwikkeling van jonge kinderen en het type rijmen waaraan zij het grootste plezier beleven. Hij stelt vast:

"Hardly has the child comprehended with certainty which objects go together and which do not, when he begins to listen happily to verses of absurdity. For some mysterious reason the child is attracted to that topsy-turvy world where legless men run, wa- 
ter burns, horses gallop astride their riders, and cows nibble on peas on top of birch trees." (Chukovsky, 1971/1925, p. 96)

De humorreactie van kinderen op dergelijke absurditeiten, wijst erop dat ze de afwijking van de werkelijkheid herkennen: “... the pleasure is the greater the less [the child] believes in the illusion created by his imagination." (p. 101) Het spel van de nonsensicale omkering leidt kinderen niet af van de werkelijkheid, maar biedt hen juist houvast en laat hen meesterschap en controle ervaren in de doorlopende stroom aan nieuwe ervaringen en informatie die dagelijks op hen afkomt. "Het gaat in het spel van de omkering om een superieure vorm van metacognitie, waarmee het kind laat zien dat het wel beter weet," schrijft Piet Mooren: "Volgens Chukovsky zijn liedjes, versjes en verhalen die afwijken van het normale dan ook een baken voor de kinderlijke conceptie van wat er als normaal geldt. ... Dat leidt niet tot verzwakking maar tot versterking van het realiteitsbesef en daarmee ook tot het broodnodige zelfvertrouwen." (2000b, p. 23)

Jennifer Cunningham schrijft in het kader van de humorontwikkeling van kinderen: “Even the simple scatological 'jokes' of a preschooler ('You poo in your pants!') are just instances of enjoyable pretense that observe the rules for ordering the real world by breaking them." (Cunningham, 2005, p. 94) En John Stephens stelt in Language and Ideology in Children's Fiction dat carnavaleske uitingsvormen onderzoeken waar de grenzen liggen, juist door die grenzen te doorbreken (1992, pp. 135-136). Bewust afwijken van de norm of het bewust opzoeken van de grens en daar plezier in hebben, kan alleen wanneer kinderen weten, of vermoeden, wat de norm is en waar de grens ligt. Die dubbelzinnige relatie met de culturele hegemonie van de door volwassenen beheerste wereld is een belangrijk kenmerk van het spel met de verbeelding in de kindercultuur.

"Both mimicry and mockery are the substance of child play and children's folklore, at least as viewed through spectacles of a rhetoric of fancy. Our rhetoric of children's folklore, then, is that it is a branch of folklore characterized by that dialectical mimicry and mockery, performance and parody, of which children seem to be especially capable, given their adaptively neotonous and sociologically marginal characteristics." (SuttonSmith, 1999, p. 7)

Hierin ligt een belangrijk argument om het carnavalesk nonsensicale karakter van veel kinderrijmen, -liedjes en gedichten serieus te nemen als repertoire dat zich leent voor de versterking van de ontluikende culturele geletterdheid van kinderen in de leeftijd van vijf tot en met acht jaar. Over de leeftijdsgroep die in dit onderzoek centraal staat, schrijft Linda Gibson Geller: "Conceptually, (...) youngsters are often engaged in the process of confirming how things work by exploring how they don't. In language play, this frequently means describing a world that doesn't exist -telling it like it isn't- as a way of exhibiting mastery over what is." (1985, p. 41) Deze benadering van carnavaleske nonsensicaliteit wijst op een mogelijke samenhang tussen poëtische kenmerken als de komische inversie, verdraaiing en overdrijving van culturele betekeniscategorieën en de humorontwikkeling van kinderen. Volgens Paul McGhee (1979) verloopt de humorontwikkeling bij kinderen doorgaans via vier op elkaar aansluitende stadia. Eerst, en dit gebeurt al vroeg in de ontwikke- 
ling, beleven kinderen plezier aan het incongruent combineren van handeling en object, zoals een schoen aan je hand doen. Vervolgens komt daarbij dat kinderen ook plezier gaan beleven aan het 'verkeerd' labelen van objecten, dieren of mensen, dus een jongetje een meisje noemen en andersom, en het toekennen van zelfbedachte gekke namen, zoals 'Meneertje Koekepeertje'. Deze eerste twee fases doorlopen de meeste kinderen tussen hun tweede en vijfde levensjaar en beide fases zijn gebaseerd op het concrete handelen met objecten en woorden. In de derde fase, in de leeftijd van vijf tot een jaar of zeven of acht, kunnen kinderen humor op conceptueel niveau gaan waarderen. De handelingsgerichtheid van de eerste twee fases is nu geen voorwaarde meer en gedurende de derde fase neemt ook de nood aan visualisatie af: het denkvermogen wordt steeds conceptueler waardoor ook steeds abstracter vormen van humor binnen het bereik vallen. In de laatste fase van de humorontwikkeling, die McGhee zo rond het zevende of achtste levensjaar plaatst, komt ook de talige humor binnen het bereik van kinderen te liggen, dat wil zeggen, de humor waarin hoofdzakelijk gespeeld wordt met het feit dat woorden en uitdrukkingen meerdere betekenissen kunnen hebben.

Studies laten zien dat kinderen zo jong als drie jaar in hun talige interacties al allerlei speelse vormen van carnavaleske nonsensicaliteit kunnen produceren voor hun eigen plezier. In Wordplay and Language Learning for Children geeft Linda Gibson Geller het voorbeeld van twee driejarige jongens in gesprek met hun leerkracht op het speelplein. Een van de jongens wil weten hoe kinderen in de klaslokalen komen die boven in het schoolgebouw zijn. De leerkracht laat het hem zelf bedenken, waarop hij zegt dat ze een hele lange ladder kunnen gebruiken. De leerkracht vraagt vervolgens de tweede jongen, die heeft staan luisteren, wat hij denkt, waarop hij antwoordt: 'Ik denk dat ze daar komen ... [pauzeert en grijnst] in een kopje!' (vertaald naar Geller, 1985, p. 9) Een ander voorbeeld is dat van twee kinderen in de leeftijd van 3 tot 4 jaar die samen met een stel kinderen aan het spelen zijn op (pre-)school. Het jongetje is wortels aan het schoonmaken en zegt: 'Zou het niet grappig zijn als deze wortels gif waren! [hij lacht] Zou het niet grappig zijn als er geen leraren waren! [hij lacht harder].' Een meisje dat met klei speelt stelt voor dat zij een grote taart gaat maken, met grote lolly's erop in alle kleuren. Een juf die in de buurt is, zegt dat dat heel mooi klinkt, waarop het meisje met veel voldoening in haar stem toevoegt: 'En ze zijn allemaal gif!' (vertaald naar Geller, 1985, p. 10) Het eerste voorbeeld van Geller laat een relatief concreet spel zien waarin het ene object (de ladder) wordt vervangen door een ander object (het kopje) dat categorisch incongruent is in deze context (een kopje valt niet in de categorie van dingen die je gebruikt om boven te komen). In het tweede voorbeeld stellen de kinderen zich een werkelijkheid voor waarin een element (de leraar) is verwijderd uit de context waarin de kinderen zich bevinden (de pre-school). In een artikel waarin ze het gebruik van de hyperbool beschrijft in humoristische mondelinge uitwisselingen tussen kinderen in de leeftijd van vier tot vijf jaar, geeft Donna Varga het voorbeeld van een groepje vierjarige kinderen dat tijdens 'snack time' aan een tafel zit te eten. Een meisje stelt dat ze wel een heel appartement kan eten; een jongetje antwoordt dat hij wel een heel gebouw kan eten; het meisje antwoordt dat zij wel een hele dokterspraktijk kan eten mét alle mensen; het jongetje voegt toe dat hij zelfs hun magen kan eten; het meisje herhaalt deze laatste stelling, waarop het jongetje bedenkt dat hij zelfs hun achterwerken kan eten; het meisje stelt ten slotte dat zij ook hun tanden kan eten (Varga, 2000, pp. 144-145). De beide 
kinderen hebben groot plezier in hun spel dat wel gebaseerd is in de waarneembare werkelijkheid (eten) maar via de hyperbolische interactie tussen de kinderen een redelijk abstract niveau bereikt. Dit laat zien dat McGhee's stadia van humorontwikkeling geen wet van meden en perzen zijn, maar slechts een indicatie geven van wat kinderen in een bepaalde leeftijdscategorie kunnen waarderen.

Daarbij weten we eigenlijk nog heel weinig over wat kinderen in de context van de schoolklas en in poëtische vorm receptief waarderen. Martha Wolfenstein, die vanuit psychologisch perspectief onderzoek heeft gedaan naar de humorontwikkeling van kinderen, heeft opgemerkt dat kinderen tot een jaar of zes vooral plezier beleven aan hun eigen spontane humoristische uitingen terwijl kinderen vanaf het zesde levensjaar in toenemende mate gebruik gaan maken van 'ready-made' vormen van humor (moppen, grappen, raadsels): een interesse die zich tussen het zevende en tiende levensjaar verder ontwikkelt (Bariaud, 2013/1989, p. 27). Die verschuiving van de 'self-made' naar 'ready-made' vormen van humor staat onder meer in verband met de toenemende verinnerlijking van cultureel repertoire, waaronder normen en waarden. Zeer jonge kinderen voelen zich nog niet 'gehinderd' door dergelijke culturele categorieën waardoor ze zich, zo stelt Wolfenstein, bijvoorbeeld vrijelijk scatologisch of anderszins lichamelijk georiënteerd uiten, terwijl kinderen zeker vanaf een jaar of zes externe 'rechtvaardiging' zoeken, ook voor hun grensoverschrijdend gedrag, omdat ze zijn doordrongen van wat wel en niet geaccepteerd is. Rijmen, liedjes en gedichten met carnavaleske nonsensicaliteit zijn feitelijk 'ready-made' vormen van carnavaleske humor. Dit roept de vraag op of de jongsten van de kinderen in dit onderzoek deze 'ready-mades' al zullen waarderen, of dat het verschil dat Wolfenstein heeft waargenomen ook binnen het kader van dit onderzoek van invloed is op het plezier dat kinderen aan poëtische teksten met dit tekstuele kenmerk beleven. Een aanvullende vraag is wat het effect zal zijn van het feit dat niet de kinderen zelf, maar de leerkrachten degenen zijn die de poëzie aanbieden.

\subsection{Conclusie: '(carnavaleske) nonsensicaliteit' een derde indicator van canoniciteit in kinderpoëzie}

'(Carnavaleske) nonsensicaleit' wijs ik binnen het kader van dit onderzoek aan als (inter)tekstueel kenmerk dat een cruciale rol speelt in de duurzame populariteit en vitaliteit van kinderrijmen, -liedjes en -gedichten voor kinderen in groep 2 en in groep 4 van het basisonderwijs. Carnavaleske nonsensicaliteit in kinderrijmen, -liedjes en -gedichten herkennen we aan specifieke manipulaties of strategieën, zoals de omkering, de overdrijving of de verdraaiing, die worden toegepast op de representatie van de (machts-)verhoudingen, normen en conventies die de alledaagse leefwereld van kinderen beheersen om een omgekeerde of binnenstebuiten gekeerde wereld te creëren. In de tweede plaats, en dit is een belangrijke toevoeging, kan alleen van een carnavaleske ervaring van nonsensicale rijmen en liedjes gesproken worden wanneer de specifieke manipulaties van de wereld een humoristisch effect teweeg brengen bij kinderen. Een humoristisch effect dat niet voortkomt uit het hardgrondig beledigen, buitensluiten of afwijzen van gezag, van anderen, van normen en conventies uit de 'eerste wereld', maar uit een gedeeld plezier in de tijdelijke opheffing 
van die aspecten binnen het kader van het carnavaleske spel met de wereld. Voor kinderen dient carnavaleske nonsenspoëzie als een tijdelijke ontsnapping aan de eisen die er vanuit de soms bedreigende wereld van volwassenen aan hen gesteld worden en biedt hen de mogelijkheid om op een speelse manier met die wereld om te gaan (Anderson \& Apseloff, 1989, p. 39). Sterker nog: het helpt kinderen, als gebruikers van dergelijke rijmen en liedjes, de wereld te begrijpen en zo mogelijk te controleren - of tenminste het gevoel te geven dat ze de wereld controleren - met taal (Mooren, 2000b; Lurie, 1990; Chukovsky, 1971/1925). Tegelijk duidt de humorreactie die carnavaleske nonsenspoëzie bij kinderen teweeg kan brengen op hun herkenning van de aspecten van de wereld die in dat 'taalspel poëzie' op de kop worden gezet. Hierin ligt de dubbele relevantie van carnavaleske nonsenspoëzie in het kader van dit onderzoek: enerzijds sluit dit type poëtisch taalspel naar verwachting aan bij de voorkeuren van kinderen en anderzijds sluit dit type poëtisch taalspel naar verwachting aan bij hun ontluikende kennis van de wereld. Die kennis van de wereld kan in het kader van (carnavaleske) nonsensicaliteit globaal worden ingedeeld in kennis van 'natuurlijke wetmatigheden' en kennis van 'culturele categorieën'.

Zien we '(carnavaleske) nonsensicaliteit' in haar pragmatische context, dan is er binnen deze indicator onderscheid te maken tussen: (i) carnavaleske vormen van nonsensicaliteit, die een lichamelijke/affectieve ervaring van 'incongruentie' (de afwijking van het 'normale') teweegbrengen, bemiddeld door subversief fysiek handelen in relatie tot de sociale context en de culturele categorieën (waarden en normen) die in die sociale context gelden, en (ii) carnavaleske vormen van nonsensicaliteit, die een lichamelijke/affectieve ervaring van 'incongruentie' (de afwijking van het 'normale') teweegbrengen, bemiddeld door subversief talig handelen in relatie tot de sociale context en de culturele categorieën (waarden en normen) die in die sociale context gelden. Naast de carnavaleske vormen zijn er ook (iii) vormen van nonsensicaliteit die een meer cognitieve ervaring van 'incongruentie' teweegbrengen, bemiddeld door een voorstelling van de werkelijkheid die afwijkt van de 'natuurlijke wetmatigheden' die gelden in de waarneembare werkelijkheid of - op abstracter niveau door een conceptueel spel met bijvoorbeeld tijd, taal, logica of getal. Gesimplificeerd samengevat komt het onderscheid tussen carnavaleske en 'intellectueler' vormen van nonsensicaliteit neer op het verschil tussen ervaringen van 'Dat mág (eigenlijk) niet' en ervaringen van 'Dat kán (eigenlijk) niet'. Ik verwacht dat kinderen in groep 2 de intellectueler vormen ook kunnen waarderen, mits gerelateerd aan de waarneembare werkelijkheid en ondersteund door visualisatie; voor groep 4 verwacht ik dat ze de intellectueler vormen ook kunnen waarderen en ook al op wat abstracter, conceptueler niveau. Echter, mijn verwachting is dat zowel kinderen in groep 2 als kinderen in groep 4 generaliter carnavaleske (op de sociaal-culturele context gerichte) nonsensicaliteit sterker waarderen dan de meer intellectuele (op kennis en logica gerichte) vormen van nonsensicaliteit. In relatie tot ontwikkelingskenmerken van kinderen in groep 2 en in groep 4 is te verwachten dat kinderen in groep 2 nog meer steunen op de waarneembare werkelijkheid en concreet handelen voor het begrijpen van nonsens terwijl kinderen in groep 4 ook op conceptueel niveau de 'incongruentie' in (carnavaleske) nonsenspoëzie al kunnen herkennen en waarderen: 


\begin{tabular}{lll}
\hline $\begin{array}{l}\text { KINDERPÖ̈ZIE } \\
\text { Verwachte 'indicatoren van canoniciteit' }\end{array}$ & Groep 2 & Groep 4 \\
\hline 3. '(carnavaleske) nonsensicaliteit' & 'carnavaleske vormen van & 'carnavaleske vormen van \\
& nonsensicaliteit, die een & nonsensicaliteit, die een \\
& lichamelijke/affectieve ervaring & lichamelijke/affectieve ervaring van \\
& van 'incongruentie' (de afwijking & 'incongruentie' (de afwijking van \\
& van het 'normale') teweegbrengen, & het 'normale') teweegbrengen, \\
& bemiddeld door subversief fysiek & bemiddeld door subversief talig \\
& handelen in relatie tot de sociale & handelen in relatie tot de sociale \\
& context en de culturele categorieën & context en de culturele categorieën \\
& (waarden en normen) die in die & (waarden en normen) die in die \\
& sociale context gelden' & sociale context gelden' \\
\hline
\end{tabular}

Voor beide groepen geldt dat humorreacties van kinderen in de praktijk gezien mogen worden als indicator van hun begrip en waardering van (carnavaleske) nonsenspoëzie. Transculturele thema's als 'eten' en transculturele vormen als liegen, dromen en wensen, maar ook overdrijven en 'de omgekeerde wereld' lenen zich naar verwachting goed voor toepassing in een cultureel pluriforme context. Daarnaast vormt 'de school(klas)' een contextueel kader dat de kinderen met elkaar delen.

Vragen die nog open staan, hebben allereerst betrekking op de effecten die uitgaan van het feit dat in het kader van de Leeskalender niet de kinderen zelf, maar de leerkrachten degenen zijn die de poëzie introduceren: dit is een belangrijk aspect om inzicht in te krijgen want mogelijk werkt de positie van de leerkracht, als vertegenwoordiger van de volwassen autoriteit, de werking van met name carnavaleske nonsenspoëzie tegen. Ten tweede is het de vraag of kinderen in groep 2 rijmen, liedjes en gedichten met carnavaleske nonsensicaliteit als 'ready-made' vormen van carnavaleske humor waarderen, of dat dit type representatie van de werkelijkheid voor hen alleen 'werkt' als het tot uiting komt in spontane 'self-made' grappen. Om in de praktijk van het basisonderwijs te zien of mijn verwachtingen juist zijn en om de nog openstaande vragen te kunnen beantwoorden, zijn verschillende van de in dit hoofdstuk besproken ('gedomesticeerde') gedichten, rijmen en liedjes opgenomen in het interventieprogramma voor groepen 2 en groepen 4 in het basisonderwijs, zoals besproken in de nu volgende hoofdstukken. 
HOOFDSTUK 6

Het Leeskalenderproject:

de opzet en uitvoering van een empirisch onderzoek 


\subsection{Introductie}

Dit onderzoek heeft tot doel criteria te formuleren, implementeren en valideren voor de selectie van kinderpoëzie en -liedjes die effectief bijdragen aan de ontluikende culturele geletterdheid van kinderen in groep 2 en groep 4 van het basisonderwijs. In de vorige hoofdstukken heb ik verschillende 'indicatoren van canoniciteit' geformuleerd voor de kinderpoëzie; de nu volgende hoofdstukken zijn een weergave van de wijze waarop deze voorlopige indicatoren in de praktijk van het basisonderwijs zijn geïmplementeerd en de resultaten die uit dit empirisch deel van het onderzoek naar voren zijn gekomen. De implementatie heeft plaatsgevonden in de vorm van een interventieprogramma getiteld 'Leeskalenderproject', waarin vanuit de drie deelprojecten Deugden \& Dilemma’s, Kinderpoëzie en Narratieve Genres gezamenlijk een selectie van teksten is aangeboden aan kinderen in groepen 2 en groepen 4. In dit hoofdstuk komen eerst de empirische onderzoeksvragen

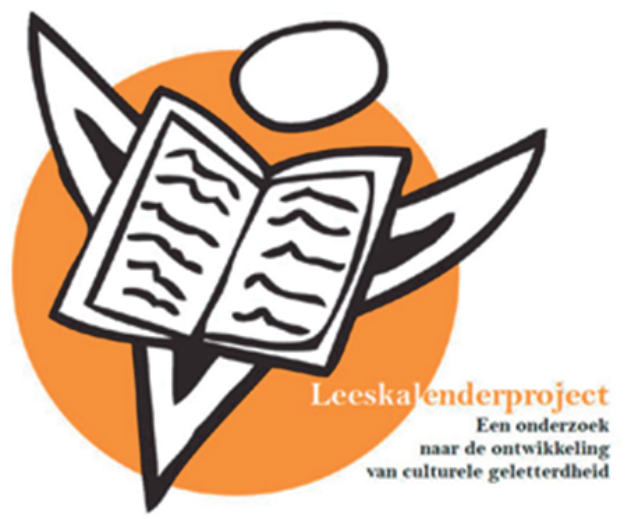

Figuur 3. Het logo van het Leeskalenderproject aan bod (\$6.2), gevolgd door de opzet van het Leeskalenderproject (het onderzoeksdesign, \$6.3). Daarna beschrijf ik de interventiematerialen (\$6.4) en het ontwikkelingstraject van die materialen (\$6.5). Vervolgens komen de meetinstrumenten aan bod (\$6.6). Ten slotte zet ik de werving, selectie en toewijzing van scholen aan de onderzoekscondities uiteen (\$6.7). In dit hoofdstuk staan die aspecten van het empirisch onderzoek beschreven die voor het geheel van het interventieprogramma, dus voor de drie deelprojecten gezamenlijk zijn ontwikkeld en uitgevoerd.

\subsection{De empirische onderzoeksvragen}

We hebben, in het kader van dit onderzoek, niet genoeg aan enkel een theoretisch en hermeneutisch onderbouwde formulering van verwachte indicatoren: we moeten die verwachtingen ook toetsen aan de praktijk van het basisonderwijs. Dat is nodig omdat we bruikbare kennis willen genereren voor de onderwijspraktijk. En bruikbaarheid van kennis hangt samen met de betrouwbaarheid en geldigheid van de uitspraken die we doen. Dan willen we dat die uitspraken niet alleen theoretisch van aard zijn, maar ook betrouwbaar en geldig in de waarneembare werkelijkheid van het basisonderwijs. We hebben dus ook empirische onderzoeksmethoden nodig om inzicht te krijgen in de bijdrage van kinderliteratuur aan de ontluikende culturele geletterdheid van de kinderen, in de wijze waarop kinderen zich teksten in concrete situaties eigen maken en welke rol de geformuleerde 'indicatoren van canoniciteit' hierin spelen. Voor de implementatie en validering van de geformuleerde 'indica- 
toren van canoniciteit' in de praktijk zijn de drie deelprojecten uit het Emergent Cultural Literacy onderzoeksproject (Deugden \& Dilemma's, Kinderpoëzie, en Narratieve Genres) verenigd in een interventieprogramma waarmee een selectie van teksten is geïntroduceerd in groepen 2 en groepen 4 van het basisonderwijs. Dit empirisch deel, dat we in de communicatie met scholen en andere betrokken partijen het 'Leeskalenderproject' ${ }^{\text {'02 }}$ hebben genoemd, is erop gericht onderzoeksvragen 3 en 4 te beantwoorden:

PROJECTBREDE ONDERZOEKSVRAGEN

1. Welke langdurig geliefde en (trans)cultureel diepgewortelde tekstsoorten en/of genres sluiten naar verwachting nauw aan op de ontluikende culturele competentie van kinderen in groep 2 en kinderen in groep 4 ?

2. Welke contextuele, tekstuele en ontwikkelingskenmerken van deze langdurig geliefde en (trans)cultureel diepgewortelde tekstsoorten en/of genres dragen naar verwachting het meest effectief bij aan bottom-up canonvorming, i.e. 'natuurlijke' processen van tekstverwerving, bij kinderen in groep 2 en kinderen in groep 4 (verwachte 'indicatoren van canoniciteit')?

3. Wat zijn de effecten van de structurele aanbieding van teksten die gekenmerkt worden door de geformuleerde indicatoren van canoniciteit op de ontluikende culturele geletterdheid van kinderen in groep 2 en kinderen in groep 4 ?

4. Welke contextuele, tekstuele en ontwikkelingskenmerken zijn cruciaal te noemen voor de effectieve bijdrage van kinderliteratuur aan de ontluikende culturele geletterdheid van kinderen in groep 2 en in groep 4 op basis van observaties, logboekaantekeningen en gesprekken met leerkrachten met betrekking tot de presentatie van het tekstaanbod in de klas, de reacties van de kinderen op deze teksten en hun waardering daarvan?

Om onderzoeksvraag 3 te kunnen beantwoorden, hebben we naast een interventie, dat wil zeggen de implementatie van het tekstaanbod in groepen 2 en groepen 4 via de 'Leeskalender', gebruik gemaakt van een door onszelf ontwikkelde Toets Ontluikende Culturele Geletterdheid (Toets OCG in het vervolg). Deze toets is zowel voorafgaand aan als na afloop van de interventie bij alle kinderen afgenomen: bij kinderen in groepen die wel met de Leeskalender hebben gewerkt én bij kinderen in groepen die niet met de Leeskalender hebben gewerkt (zie \$6.3). Om de uitkomsten van de toets beter te kunnen interpreteren, hebben we daarnaast gebruik gemaakt van verzamelde CITO-gegevens over de kinderen, van een oudervragenlijst om gegevens over het thuisklimaat van de kinderen met betrekking tot de aanwezigheid van boeken en voorlezen te verzamelen, en van de informatie die leerkrachten noteerden in een logboek over het werken met de Leeskalender. We willen echter niet alleen de 'opbrengsten' meten van het aanbieden van kinderliteratuur voor de ontwikkeling van ontluikende culturele geletterdheid; we willen juist ook, want daar ontbreekt het nog grotendeels aan, begrijpen hoe jonge kinderen '(trans)cultureel relevante'

\footnotetext{
102 Voor een consequente en herkenbare vormgeving van de interventiematerialen is een logo ontwikkeld. Dit logo is getekend door een (12-jarige) vriend van de zoon van de bij dit project betrokken scholencoördinator, Ingeborg Hendriks, en is gebruikt op brieven, een brochure, presentaties en het weblog (leeskalender.blogspot.nl), en op de interventiematerialen voor de scholen. Binnen het onderzoeksproject stond dit logo symbool voor het empirisch deel.
} 
genres en tekstsoorten verwerven, hoe ze deze teksten begrijpen, hoe ze op deze teksten reageren, en wat hun voorkeuren zijn. Om onderzoeksvraag 4 te beantwoorden, is per deelproject gebruik gemaakt van de informatie die leerkrachten noteerden in een logboek, van observaties in de klas en van gesprekken met leerkrachten. De wijze waarop het interventieprogramma en de verschillende instrumenten voor dataverzameling zijn ontwikkeld en geïmplementeerd, wordt in de volgende paragrafen beschreven.

\subsection{De opzet van het Leeskalenderproject: het onderzoeksdesign}

Het Leeskalenderproject is opgezet als een praktijkgericht evaluatieonderzoek (zie ook Hart, 2001, p. 196). Enerzijds om na te gaan of de aanbieding van teksten die naar verwachting effectief bijdragen aan de ontwikkeling van de ontluikende culturele geletterdheid van jonge kinderen inderdaad het beoogde effect heeft. Anderzijds om na te gaan of de geformuleerde 'indicatoren van canoniciteit' in de praktijk ook daadwerkelijk het sterkst bijdragen aan de ontwikkeling van ontluikende culturele geletterdheid via processen van tekstverwerving bij jonge kinderen. Het Leeskalenderproject bestaat uit een interventieprogramma, de Leeskalender, waarmee dertig weken lang is gewerkt in bestaande groepen 2 en groepen 4 op Nederlandse basisscholen. Dit interventieprogramma is ingebed in een experimenteel onderzoeksdesign met voor- en nametingen en controlegroepen (voor zowel groep 2 als groep 4). De controlegroepen hebben niet gewerkt met de Leeskalender; wel is bij kinderen in de controlegroepen de Toets OCG afgenomen (voor- en nameting) en zijn ook over deze kinderen aanvullende gegevens verzameld om de toetsresultaten beter te kunnen interpreteren (zie Hoofdstuk 8 voor de resultaten). In Tabel 1 is het gebruikte onderzoeksdesign schematisch weergegeven. We hebben gewerkt met bestaande schoolklassen: kinderen binnen een schoolklas kunnen niet in verschillende condities terechtkomen (een klas werkt in zijn geheel met of zonder de Leeskalender). Zelfs groepen binnen een school zijn niet in verschillende condities terecht gekomen omdat er dan een te groot risico is op 'verspreiding van de ingreep', i.e. de verspreiding van interventiematerialen of informatie van een groep in de experimentele conditie naar een groep in de controleconditie binnen dezelfde school ${ }^{103}$ (Hart, 2001, p. 214). Aan scholen is niet verteld welke andere scholen meededen aan het project om verspreiding tussen scholen te voorkomen. Omdat de interventie is uitgevoerd op schoolniveau, is gekozen voor zogeheten 'clusterrandomisatie' waarbij de scholen de clusters vormden.

Tabel 1. Schematische weergave van het onderzoeksdesign van het experimenteel onderzoek.

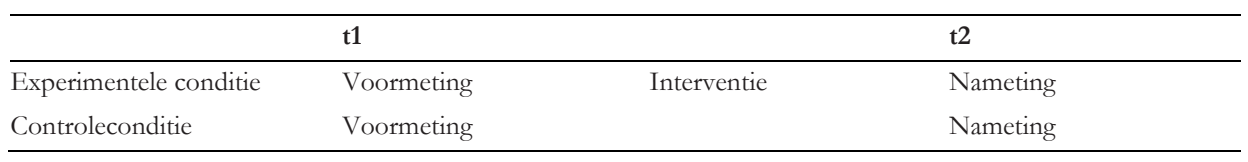

\footnotetext{
${ }^{103}$ Als dit wel zou gebeuren, dan is de controleconditie feitelijk geen controleconditie meer omdat groepen in deze conditie dan ook met de interventie in aanraking komen. In dit onderzoek kwam het daarom nooit voor dat op een school de ene klas in de controleconditie en de andere klas in de experimentele conditie viel. Omdat leerkrachten op scholen ook niet verteld werd welke andere scholen aan het onderzoek meededen, is de kans dat er verspreiding tussen scholen heeft plaatsgevonden klein.
} 
Dit brengt met zich mee dat in de werving van scholen zoveel mogelijk is geprobeerd scholen te vinden die met zowel groep 2 als groep 4 konden meedoen (zie $\$ 6.7$ voor verdere toelichting van de werving en selectie van scholen alsmede de gevolgde procedure voor toewijzing van scholen aan de experimentele en controle conditie).

De effectmeting met behulp van de Toets OCG is wel op het niveau van individuele kinderen gedaan (zie $\$ 6.6$ over de toets en Hoofdstuk 8 voor de resultaten). De Toets OCG is zowel voor aanvang van en na afloop van de implementatie van de Leeskalender in de schoolgroepen afgenomen (zowel in de controle- als in de experimentele conditie). De voormeting vond aan het begin van het schooljaar plaats, in de periode van medio augustus 2013 tot medio september 2013. Vervolgens startte op de scholen in de experimentele conditie de dertig weken durende implementatie van de Leeskalender (zie \$6.4). Aan het einde van het schooljaar is de Toets OCG opnieuw bij de kinderen uit de deelnemende groepen 2 en 4 in beide onderzoekscondities afgenomen, in de periode van medio mei 2014 tot medio juni 2014.

\subsection{Interventiematerialen: de Leeskalender}

Het interventieprogramma bestond er uit dat er dertig weken lang, in de periode van medio september 2013 tot medio mei 2014, is gewerkt met de Leeskalender in groepen 2 en groepen 4 van het basisonderwijs. Er is om verschillende redenen voor de vorm van een kalender gekozen. Allereerst omdat een kalender een logische vorm is in aansluiting op de verwachting dat kinderen zich teksten gemakkelijker eigen maken als deze zijn ingebed in een duidelijke context: de aansluiting van de verhalen en gedichten op de vieringen in het jaar, als pragmatische contexten van tekstgebruik, komt in kalendervorm goed tot uitdrukking. Daar komt bij dat het dagelijks omslaan en bekijken van de kalenderbladen op zichzelf ook een vorm van ritualisering is die naar verwachting bijdraagt aan de inbedding van de Leeskalender in de klas. Omdat in Nederland mensen uit verschillende culturen leven, hebben we ervoor gekozen om in de Leeskalenders niet alleen Christelijke en (niet-religieuze) Nederlandse vieringen op te nemen, maar ook aandacht te besteden aan vieringen die een belangrijke rol spelen in bijvoorbeeld de Islamitische jaarkalender, mits deze feesten in Nederland ook actief worden gevierd en herkenbaar zijn voor jonge kinderen, zoals het Offerfeest en het Suikerfeest. Gebruiken en rituelen die bij vieringen horen en de betekenissen die eraan verbonden worden, zijn bij uitstek cultuurgebonden en komen vaak voort uit of staan centraal in verhalen of poëtische teksten die bij deze feesten horen. Denk aan het Offerfeest in relatie tot het verhaal over de beproeving van Ibrahim, of de vele verhalen en -liedjes die verbonden zijn aan het Sinterklaasfeest, of Chinees Nieuwjaar. De vieringen vormen dus cruciale contexten die de ontwikkeling van ontluikende culturele geletterdheid bij jonge kinderen in 'de cultuur van dagelijks leven' in gang zetten: aansluiting bij deze contexten vormt daarmee niet alleen een belangrijke contextualisering van teksten, maar vormt ook een belangrijke brug naar de thuiscultuur van kinderen. In de week rond of voorafgaand aan een feest of op de dag zelf is in het aanbod van teksten gelet op thematische aansluiting op de betekenis van en tradities rond het betreffende feest. Ook met vieringen als Koningsdag, Werelddierendag en de Internationale Dag van de Rechten van het 
Kind is rekening gehouden, evenals Chinees Nieuwjaar en de Turkse feestdag Çocuk Bayrami. Daarnaast wordt aandacht besteed aan levensrituelen rond verjaardagen, maar ook rond de dood.

In groep 2 kregen de kinderen in de volledige versie ${ }^{104}$ van de Leeskalender drie nieuwe teksten per week aangeboden, op maandag, dinsdag en woensdag, waarbij steeds een vaste volgorde van de deelprojecten is aangehouden. Op maandag werd er een tekst uit het deelproject Deugden \& Dilemma's aangeboden, op dinsdag een tekst uit het deelproject Kinderpoëzie en op woensdag een tekst uit het deelproject Narratieve Genres, gevolgd door twee keuzedagen, donderdag en vrijdag. Op de keuzedagen mochten de kinderen zelf aangeven welke tekst ze het meest had aangesproken: bij deze tekst volgde dan een herhalingsopdracht. In groep 4 kregen de kinderen in de volledige versie van de Leeskalender vier nieuwe teksten per week aangeboden, van maandag tot en met donderdag, gevolgd door een keuzedag op vrijdag. Ook in de Leeskalender voor groep 4 is een vaste volgorde van de deelprojecten aangehouden -maandag Deugden \& Dilemma's, dinsdag Kinderpoëzie en woensdag Narratieve Genres-, en is op de donderdag steeds een tweede tekst van een van de deelprojecten opgenomen. De invulling van de donderdag volgde eveneens een vast ritme: in de eerste week een tweede tekst van Deugden \& Dilemma's, in de tweede week een tweede tekst van Kinderpoëzie en in de derde week een tweede tekst van Narratieve Genres. Ditzelfde ritme werd herhaald in de daaropvolgende weken. Schematisch ziet de indeling van de volledige Leeskalender voor groep 2 en voor groep 4 er als volgt uit:

Tabel 2. Overzicht van verdeling van deelprojecten over de interventieweken in de Leeskalender voor groep 2 en 4.

\begin{tabular}{llll}
\hline Week & Dag & Groep 2 & Groep 4 \\
\hline 1 & Maandag & Deugden \& Dilemma's & Deugden \& Dilemma's \\
& Dinsdag & Kinderpoëzie & Kinderpoëzie \\
& Woensdag & Narratieve Genres & Narratieve Genres \\
& Donderdag & Keuzedag & Deugden \& Dilemma's \\
& Vrijdag & Keuzedag & Keuzedag \\
Maandag & Deugden \& Dilemma's & Deugden \& Dilemma's \\
Dinsdag & Kinderpoëzie & Kinderpoëzie \\
Woensdag & Narratieve Genres & Narratieve Genres \\
Donderdag & Keuzedag & Kinderpoëzie \\
Vrijdag & Keuzedag & Keuzedag \\
Maandag & Deugden \& Dilemma's & Deugden \& Dilemma’s \\
Dinsdag & Kinderpoëzie & Kinderpoëzie \\
Woensdag & Narratieve Genres & Narratieve Genres \\
Donderdag & Keuzedag & Narratieve Genres \\
Vrijdag & Keuzedag & Keuzedag \\
\hline
\end{tabular}

De Leeskalender voor groep 2 bevatte dertig teksten van elk van de deelprojecten, dus negentig teksten in totaal. De Leeskalender voor groep 4 bevatte negenendertig ${ }^{105}$ teksten van elk van de deelprojecten, dus honderdzeventien teksten in totaal.

\footnotetext{
$104 \mathrm{Op}$ basis van methodologische overwegingen is besloten om de kalenders voor beide groepen in verschillende versies uit te voeren. Dit wordt in $\$ 6.5$ nader toegelicht.

$105 \mathrm{Op}$ basis van een interventieduur van dertig weken met eens in de drie weken een extra tekst per deelproject zouden dit veertig teksten per deelproject moeten zijn, ware het niet dat drie weken in de interventieperiode vallen
} 
De Leeskalender zelf was een papieren kalender uitgevoerd op A3-formaat in kleur, gebonden met een ringband bovenaan waarmee de kalender kon worden opgehangen in de klas (zie Figuur 3). De kalender bevatte voor elke Leeskalenderdag een blad met daarop een afbeelding die het uitgangspunt vormde voor de aanbieding van de bijbehorende tekst in de klas (zie Figuur 4). In de meeste gevallen is er gekozen voor een illustratie uit de bron waaruit de tekst afkomstig was. Wanneer echter geen bestaande illustratie bij de tekst beschikbaar was of de illustratie bij de tekst geen goed uitgangspunt vormde voor de aanbieding van de tekst, hebben de onderzoekers zelf een bijpassende afbeelding geselecteerd uit een andere bron. Op keuzedagen stonden er meerdere afbeeldingen op het blad: bij alle teksten van die week een afbeelding. De afbeelding op de keuzedag was een andere dan de afbeelding op de maandag, dinsdag of woensdag. De reden hiervoor is dat er bij de herhaling van een tekst een andere insteek is gekozen dan bij de eerste aanbieding van een tekst.
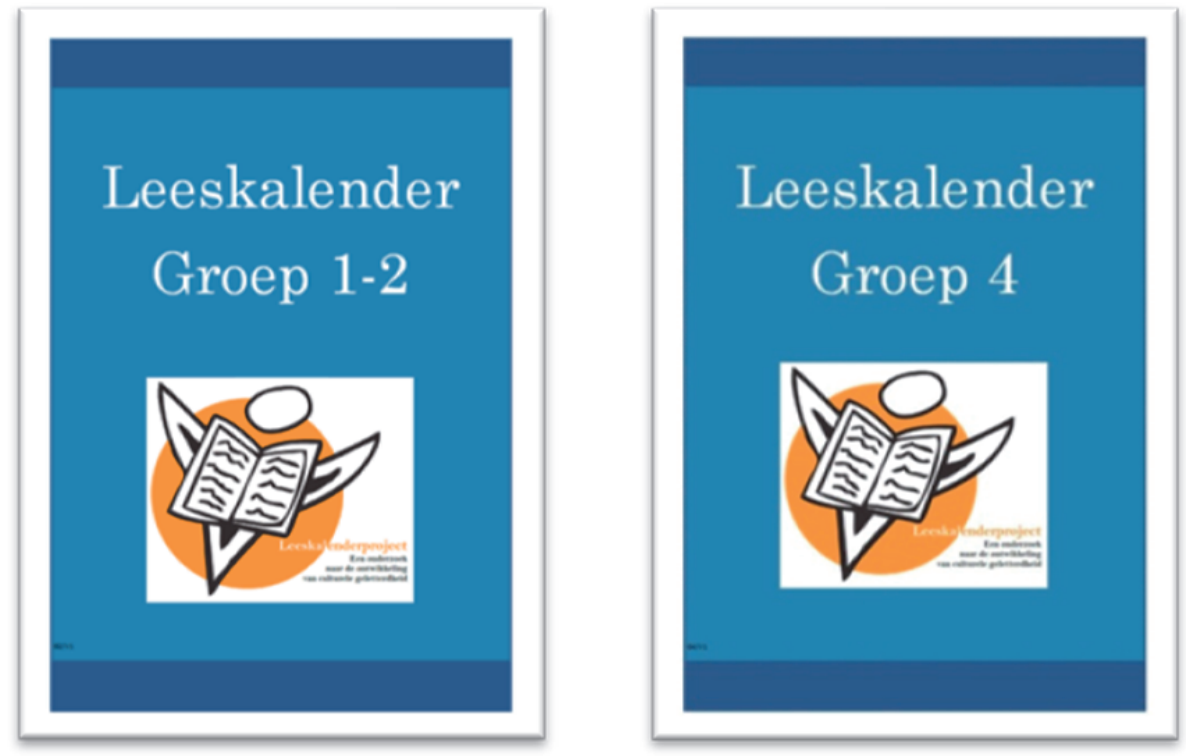

Figuur 4. De voorbladen van de Leeskalender voor groep 1-2 en de Leeskalender voor groep 4.

Tenzij een week korter was vanwege een feestdag bevat de Leeskalender vijf bladen per interventieweek. In weken rond of in aanloop naar feestdagen zijn de teksten thematisch gekozen in aansluiting op de betreffende feestdag; in andere weken was er niet altijd sprake van thematische samenhang.

waar een dag minder te vullen is vanwege feestdagen. In die kortere weken is ervoor gekozen de extra tekst te laten vallen, dus zijn er van elk deelproject negenendertig teksten opgenomen in de kalender voor groep 4 . 

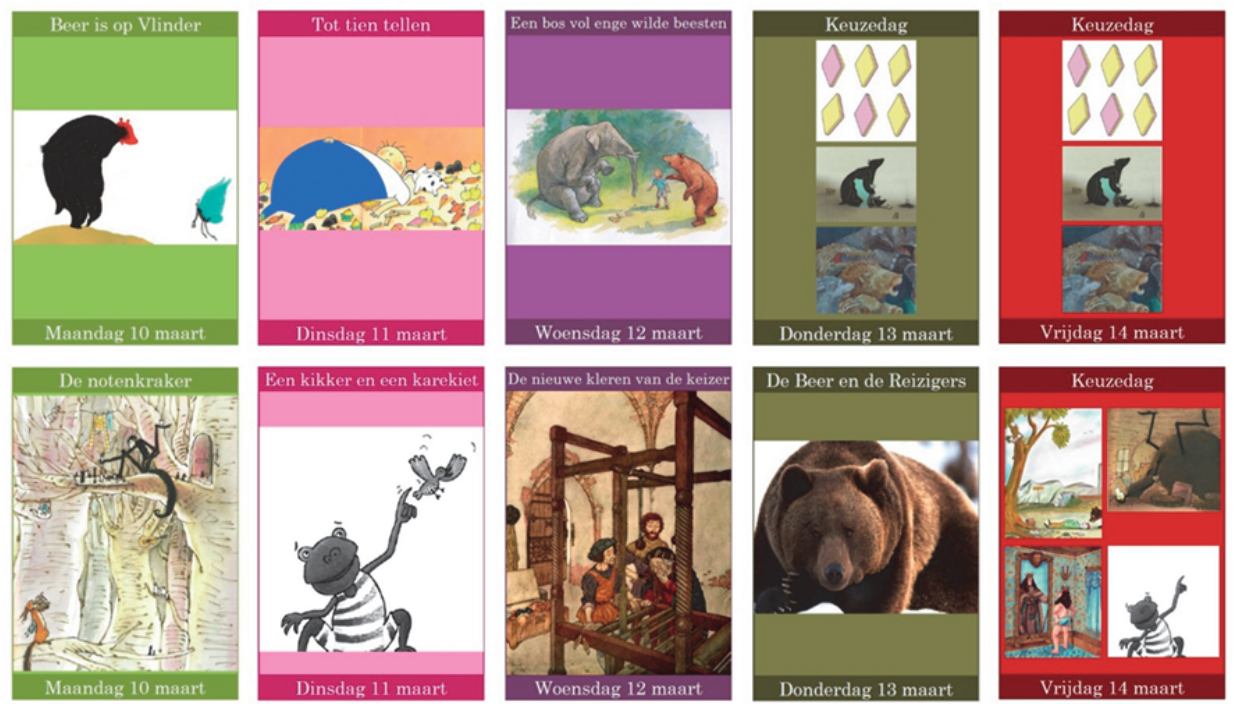

Figuur 5. Kalenderbladen interventieweek 22, volledige versie groep 2 en groep 4.

Het werken met de Leeskalender gebeurde aan de hand van een handleiding (zie Figuur 5). De handleiding bestond uit drie onderdelen: een algemeen deel, Deel I, waarin toelichting werd gegeven op het begrip 'ontluikende culturele geletterdheid', op de plaats die de Leeskalender heeft binnen het onderzoeksproject en op de wijze waarop leerkrachten verwacht werden met de Leeskalender te werken. Het volgende onderdeel van de handleiding, Deel II, bevatte per schooldag een instructie voor het werken met de Leeskalender in de klas. Concreet betrof het uitgewerkte instructies voor de aanbieding, het voorlezen en het verwerken van de tekst die op de betreffende datum op de kalender stond. Deze instructies waren zeer gedetailleerd omdat we streefden naar een zo groot mogelijke vergelijkbaarheid van implementatie in de verschillende groepen. Leerkrachten zijn dan ook met nadruk gevraagd de instructies in de handleiding zo nauwkeurig mogelijk te volgen. In het laatste deel van de handleiding, Deel III, was een logboek opgenomen waarin leerkrachten per dag dat er met de Leeskalender gewerkt werd notities maakten over de uitvoering en de waardering van de betreffende tekst en activiteiten. De opzet van dit logboek staat beschreven in de paragraaf over de onderzoeksinstrumenten. 

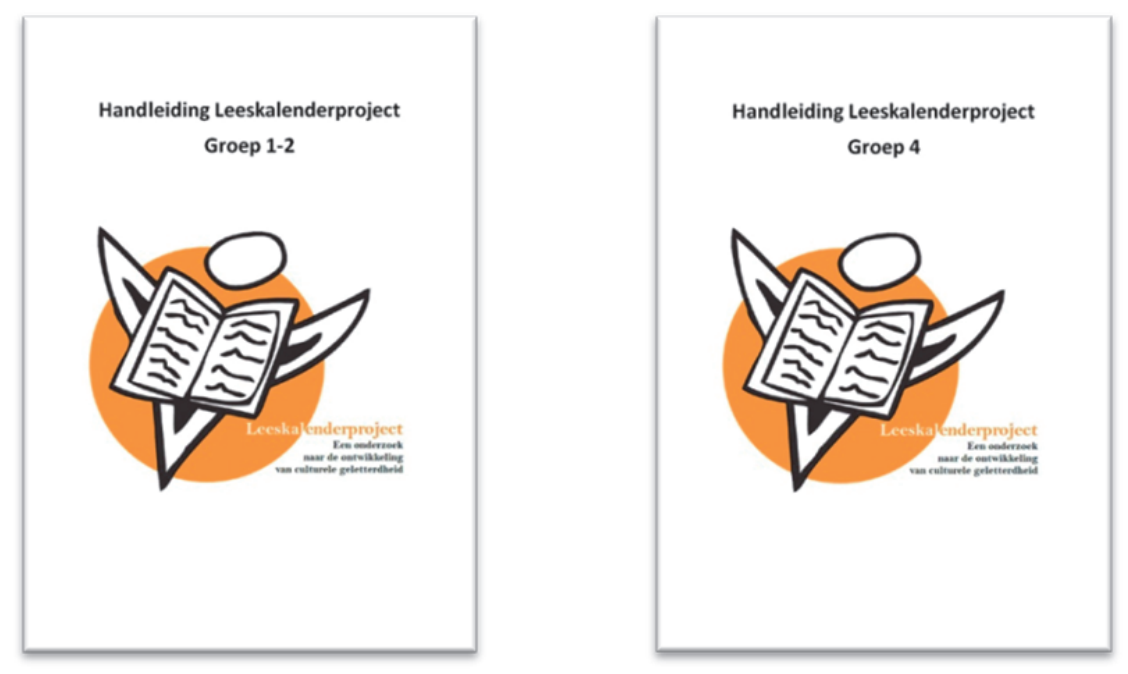

Figuur 6. De voorbladen van de handleidingen bij het Leeskalenderproject voor groep 1-2 en voor groep 4.

Omdat de Leeskalender een groot en gevarieerd aanbod van verhalen, gedichten en liedjes bevatte, zijn ook alle teksten aangeleverd aan de scholen. Daar waar mogelijk en nodig zijn de teksten in boekvorm beschikbaar gesteld. Hiervoor is samengewerkt met de openbare bibliotheken van Maastricht, Heerlen, Venlo en Tilburg: zij hebben in twee etappes een groot deel van de benodigde boeken verzameld en beschikbaar gesteld voor ons onderzoek. Daar waar de bibliotheken een boek niet konden leveren of wij het niet noodzakelijk achtten dat een tekst uit een boek werd voorgelezen, zijn de teksten opgenomen in Deel II van de handleiding. Ook is er bij de handleiding een cd aangeleverd met de liedjes die onderdeel uitmaakten van het tekstaanbod. Vanwege de omvang van de kalenders en handleidingen is ervoor gekozen de materialen in drie delen te maken en aan te leveren op de scholen: week $1 \mathrm{t} / \mathrm{m} 13$ (medio september tot aan de kerstvakantie 2013), week $14 \mathrm{t} / \mathrm{m} 21$ (januari tot aan de carnavalsvakantie 2014) en week $22 \mathrm{t} / \mathrm{m} 30$ (maart tot en met medio mei 2014). De aanlevermomenten vormden direct ook de contactmomenten waarop onderzoekers, de scholencoördinator of de onderzoeksassistent langskwamen op de scholen voor een evaluatiegesprek, het controleren van de door de bibliotheken geleverde boekenpakketten en/of het tussentijds ophalen van ingevulde delen van het logboek.

\subsection{De Leeskalender: het ontwikkelingstraject}

De interventiematerialen zoals hierboven beschreven, zijn het resultaat van een ontwikkelingstraject dat bestond uit verschillende fasen. Omdat het ontwikkelingstraject van de interventiematerialen en van de Toets Ontluikende Culturele Geletterdheid in fase 3 en fase 4 (zie Tabel 3 hieronder) samenvielen, staat de toets in dit overzicht ook vermeld. Projectbrede toelichting op de ontwikkeling van de toets volgt verderop in dit hoofdstuk (zie 
\$6.6); in het volgende hoofdstuk wordt nader ingegaan op de ontwikkeling van het aandeel vanuit het deelproject Kinderpoëzie in zowel de interventiematerialen als de Toets OCG.

\section{Fase 1: De eerste expertraadpleging}

In de eerste fase zijn de voorlopige tekstselecties vanuit de drie deelprojecten voor de eerste keer samengevoegd in een kalenderformat met dertig interventieweken. In de eerste opzet was de kalender voor groep 2 gevuld met vier nieuwe teksten per week (maandag $\mathrm{t} / \mathrm{m}$ donderdag) en die voor groep 4 met vijf nieuwe teksten per week. In deze fase is de eerste expertraadpleging gehouden (11 juli 2012). Deze bestond uit een gesprek met twee experts op basis van de voorlopige tekstselecties die zij van te voren hadden ontvangen. De experts kregen vooraf twee concrete vragen voorgelegd:

a. Zijn de geselecteerde teksten volgens jullie geschikt voor de beoogde leeftijdsgroepen?

b. Missen we voor de hand liggende, uitermate geschikte teksten, m.a.w. doen zich schrijnende omissies voor in onze tekstselecties?

De eerste expert is al lange tijd actief als leesbevorderaar en boekpromotor en tevens als (hoofd)redacteur betrokken bij de online projecten 'Leesplein' en 'Boek en Jeugd Online' en het voorschoolse (voor)leesbevorderingsproject 'BoekStart'. De tweede expert is eigenaresse van een kinder- en jeugdboekwinkel en zet zich tevens actief in voor leesbevordering, in het bijzonder in de provincie Limburg. Vooraf hadden beide experts een overzicht van de titels in het kalenderformat gekregen met daarbij vanuit elk deelproject een korte toelichting op de in de teksten aanwezige 'indicatoren van canoniciteit' en een beschrijving van het onderzoeksprogramma als geheel. De experts was specifiek gevraagd de samenstelling van het tekstaanbod voor groep 2 en voor groep 4 te beoordelen; daarnaast hebben beide experts ons, vanuit hun kennis van en ervaring met leesbevorderingsmethoden voor het basisonderwijs, geadviseerd over de wijze waarop teksten effectief kunnen worden aangeboden in de klas. In het gesprek met de experts is vooral ingegaan op de kalender voor groep 2 omdat de experts hier de meeste vragen en opmerkingen over hadden. De feedback had betrekking op de omvang en opbouw van de kalender en op de aanbiedingsvorm van de kalender als geheel en van de afzonderlijke teksten. Het belangrijkste inzicht uit deze expertraadpleging is dat in de praktijk van het basisonderwijs nauwelijks meer aparte groepen 2 bestaan: meestal wordt er gewerkt met combinatiegroepen 1-2 (wat ook bij hogere groepen voor kan komen, maar minder structureel). Op basis van overwegingen van de haalbaarheid en methodologische implicaties hebben we besloten vast te houden aan de insteek dat we ons binnen dit onderzoek richten op kinderen in groep 2 en kinderen in groep 4. Wel is in de aanbiedings- en verwerkingsvormen bij teksten getracht enige rekening te houden met groep 1, maar deze leerlingen zijn verder niet bij de effectmeting betrokken. De uitkomsten van deze expertraadpleging voor het aanbod van kinderpoëzie bespreek ik in Hoofdstuk 7, $\$ 7.2$. 
Tabel 3. Weergave van het ontwikkelingstraject van de Leeskalenders voor groep 2 en 4

\begin{tabular}{lll}
\hline Fase & Activiteiten & Periode tot \\
Fase 1: & - Ontwikkeling voorlopige tekstselecties & \\
& - Expertraadpleging 1 & jul-2012 \\
Fase 2: & - Doorontwikkeling tekstselecties en bijbehorende interventiematerialen & \\
& - Expertraadpleging 2 & nov-2012/ jan-2013 \\
Fase 3: & - Doorontwikkeling tekstselecties en bijbehorende interventiematerialen & \\
& - Ontwikkeling Toets Ontluikende Culturele Geletterdheid & \\
& - Pilot 1 & feb/mrt-2013 \\
Fase 4: & - Doorontwikkeling tekstselecties en bijbehorende interventiematerialen & \\
& - Doorontwikkeling Toets Ontluikende Culturele Geletterdheid & \\
& - Pilot 2 & mei/jun-2013 \\
\hline
\end{tabular}

\section{Fase 2: De tweede expertraadpleging}

In de tweede fase zijn op basis van de evaluatie van de eerste expertraadpleging aanpassingen gedaan in de tekstselecties per deelproject, in het aantal teksten dat per interventieweek wordt aangeboden (groep 1-2: 3 teksten per week in plaats van 4/ groep 4: 4 teksten per week in plaats van 5), en is besloten over de vormgeving van de Leeskalender. De aanpassingen resulteerden, naast aanpassing van het gehele aanbod op punten die later nog uitgebreider aan bod komen, concreet in de ontwikkeling van pilot-Leeskalenders en handleidingen ter voorbereiding op de eerste pilotstudie in de praktijk (fase 3). Eerst zijn de pilotmaterialen echter voorgelegd aan een panel in de tweede expertraadpleging. De tweede expertraadpleging vond plaats in de periode van 26 november 2012 tot 18 december 2012, met uitloop tot januari 2013 . Het panel ${ }^{106}$ bestond uit:

- 1 onderwijsadviseur;

- 3 leesbevorderaars/methodeontwikkelaars;

- 6 groep 1-2 leerkrachten;

- 3 groep 4 leerkrachten

Dit panel van experts is gevraagd feedback te geven op de pilotmaterialen: de pilotLeeskalender voor groep 1-2 en voor groep 4, beide ontwikkeld om een periode van 3 weken te beslaan, en pilot-handleidingen voor groep 1-2 en voor groep 4 met daarin voor dezelfde periode een selectie van teksten, een algemene toelichting en voor elke tekst concrete introductie-, voorlees- en verwerkingsinstructies. Via beoordelingsformulieren werd de experts gevraagd verschillende onderdelen van de materialen op basis van concrete stellingen te scoren op een 5-punts Likertschaal. De experts werd ook gevraagd een schatting te doen van de tijd die de behandeling van elke tekst met aanbieding en verwerking in de klas in beslag zou nemen en te beoordelen of dit haalbaar zou zijn in de praktijk. Daarnaast kreeg elke expert een pakket met losse teksten uit de tekstselecties van de drie deelprojecten met daarbij een aantal gerichte vragen van de onderzoekers. Deze vragen hadden

106 Geen van de leerkrachten betrokken bij de expertraadpleging heeft deelgenomen aan de eigenlijke interventie: alle panelleden zijn speciaal voor deze expertraadpleging benaderd. De scholencoördinator betrokken bij dit onderzoeksproject, Ingeborg Hendriks, heeft het grootste aandeel gehad in de werving van panelleden en de organisatie van de expertraadpleging. 
betrekking op de leeftijdsgeschiktheid van teksten, de lengte van een tekst, de keuze tussen twee versies van een verhaal of tussen twee gedichten bij een thema. Afhankelijk van de functie van de expert ontvingen zij het hele pakket voor groep 1-2, voor groep 4 of voor beide groepen; daarbij was een deel van de beoordelingsvragen alleen voor de leerkrachten bestemd.

Over het geheel genomen waren de experts neutraal tot positief gestemd over de Leeskalender; de voorleesinstructie was vooral te lang en niet overzichtelijk genoeg; er kwam naar voren dat enige flexibiliteit in de weekinvulling wel nodig was, vanwege onvermijdelijke uitval van dagen, de nodige inhaaltijd voor andere vakgebieden of, door bijvoorbeeld een keuzedag in te voeren, voor het vergroten van de betrokkenheid van leerkrachten en kinderen. Tijd bleek de belangrijkste factor: voorbereidingstijd, tijd besteed aan de Leeskalender per dag, aantal dagen per week en inpassing in toch al overvolle lesprogramma's baarden de experts enige zorgen. Daartegenover stond dat het gevarieerde aanbod van teksten uit verschillende genres als zeer positief werd beoordeeld, hoewel het soms vragen opriep over de geschiktheid van dit aanbod voor groepen met veel leerlingen met een taalachterstand. De uitkomsten van deze expertraadpleging voor het aanbod van kinderpoëzie bespreek ik in Hoofdstuk 7, \$7.2.

\section{Fase 3: Pilot 1, drie weken nitproberen in de klas}

In de derde fase zijn op basis van de resultaten van de tweede expertraadpleging enkele aanpassingen gedaan in de tekstselecties als geheel en zijn de pilot-materialen doorontwikkeld voor een eerste pilotstudie in de praktijk van het basisonderwijs. De kalenderbladen kregen nu kleur en werden gedrukt, er werden keuze- en herhalingsdagen ingevoerd en in de verwerkingsopdrachten werd meer variatie en levendigheid gebracht, de handleiding is zo beknopt en precies mogelijk gemaakt en logboekbladen werden opgezet en toegevoegd. De derde fase van het ontwikkelingstraject van de Leeskalenders en handleidingen stond verder geheel in het teken van de voorbereiding, uitvoering, verwerking en evaluatie van de eerste pilotstudie. Drie weken lang, in de periode van 18 februari tot en met 8 maart 2013, werd in drie groepen 1-2 en in een groep 4 op een brede school in Weert en in een groep 12 en een groep 3-4 op een Montessorischool in 's-Hertogenbosch gewerkt met proefversies van de Leeskalender. Gedurende de drie weken waarin pilot 1 op de scholen liep, is er regelmatig geobserveerd in de groepen om zoveel mogelijk inzicht te krijgen in de wijze waarop leerkrachten met de materialen werkten en in de wijze waarop de kinderen op de materialen reageerden. $\mathrm{Na}$ afloop van de eerste pilot is er een nagesprek met de leerkrachten gehouden om hun ervaringen te inventariseren en te bespreken op welke punten aanpassing van het materiaal wenselijk of noodzakelijk was. De observaties leverden daarnaast inspiratie op voor het aanpassen van aanbiedings- en verwerkingsopdrachten en bracht ons tot het besluit bij de herhaling van een tekst een nieuwe afbeelding te kiezen in plaats van dezelfde afbeelding als bij de eerste aanbieding. Regelmatig lieten kinderen tijdens de pilot een teleurgesteld "Die hebben we al gehad..." of "Alweer die..." horen. Inzichten uit deze pilot voor het deelproject Kinderpoëzie staan beschreven in Hoofdstuk 7. Naast het werken met de Leeskalender werden op deze scholen ook de eerste versies van de Toets Ontluikende Culturele Geletterdheid voor groep 2 en groep 4 getest in pilot 1 en pilot 2 (alleen 
toets). Dit staat nader beschreven in $\$ 6.6$ en, specifiek voor het deelproject Kinderpoëzie, in Hoofdstuk 7, \$7.6.

\section{Fase 4: Ontwikkeling definitieve Leeskalenders}

In de vierde fase, ten slotte, zijn de resultaten van de eerste pilot verwerkt in de materialen. Vervolgens zijn de definitieve Leeskalenders en bijbehorende handleidingen voor de eerste dertien interventieweken ontwikkeld waarbij alleen nog interne feedbackrondes binnen het onderzoeksteam zijn gehouden. In deze fase is ook de Toets Ontluikende Culturele Geletterdheid aangepast op basis van de ervaringen uit de eerste pilot en is de toets opnieuw getest in een tweede pilot op dezelfde pilotscholen (zie $\$ 6.6$ en Hoofdstuk 7, \$7.6).

\section{De belangrijkste beslissingen in de ontwikkeling van de Leeskalender}

De raadplegingen van de experts en de ervaringen uit de eerste pilot maakten duidelijk dat het werven van scholen voor deelname aan een dermate omvangrijk interventieprogramma een uitdaging zou zijn ${ }^{107}$ en dat bepaalde keuzes in de inhoud, omvang en vorm van ons interventiemateriaal de werving al dan niet zouden kunnen bevorderen of juist bemoeilijken. In het ontwikkelingstraject stuitten we dan ook regelmatig op afwegingen die neerkwamen op het zoveel mogelijk vasthouden aan theoretische uitgangspunten en methodologische vereisten enerzijds, en het tegemoetkomen aan de praktijk van het basisonderwijs anderzijds. Hieronder volgt een bespreking van de belangrijkste beslissingen die zijn genomen in de ontwikkeling van de Leeskalender waarbij wetenschappelijke en praktische argumenten soms in elkaars verlengde lagen en soms ook tegenover elkaar stonden.

\section{Vormgeving van de Leeskalender}

In vroege fases van de ontwikkeling van de Leeskalenders hebben we overwogen om het materiaal digitaal te ontwikkelen en aan te bieden. Op veel basisscholen wordt tegenwoordig met digitale schoolborden gewerkt en veel onderwijsmethoden bieden (een deel van) hun materiaal ook in digitale vorm aan. De reden waarom we de Leeskalender uiteindelijk toch in papieren vorm hebben ontwikkeld is tweeledig: enerzijds heeft deze beslissing betrekking op consistentie binnen de experimentele conditie, anderzijds heeft deze beslissing betrekking op de zichtbaarheid van het materiaal in de klas. Uit navraag bij onder andere een schoolbegeleidingsdienst bleek dat het merendeel van basisscholen tegenwoordig beschikt over digitale schoolborden, maar niet altijd voor alle klassen. Mogelijkheid was om de Leeskalender in digitale vorm te ontwikkelen met daarnaast een papieren versie voor klassen zonder digitaal schoolbord. Hiermee zouden we echter onnodig variatie creëren binnen de experimentele conditie. Er kan een ander effect uitgaan van het werken met een digitale versie dan van het werken met een papieren kalender. Omdat we ons met de interventie niet tot doel stellen onderzoek te doen naar mogelijke effecten van dergelijke verschillen, achtten we het beter dit verschil te voorkomen. Dat liet ons de keuze tussen het

${ }^{107}$ De werving en selectie van scholen staan beschreven in $\$ 6.7$ van dit hoofdstuk. 
voorwaardelijk stellen van de aanwezigheid van digitale schoolborden voor deelname aan het onderzoek of het volledig overgaan tot een papieren uitvoering van de Leeskalender. Het uitsluiten van scholen op basis van technische overwegingen was echter niet realistisch. Er was ons tenslotte verteld dat het vinden van scholen die willen deelnemen aan een dergelijk interventieprogramma al uitdagend genoeg zou zijn.

Wat betreft de aanbiedingsvorm benadrukten de experts tijdens de eerste expertraadpleging dat de Leeskalender als een tastbaar en zichtbaar object in de klas beter zou 'werken' dan wanneer we deze in digitale vorm aanbieden. Het idee van een groot formaat papieren scheurkalender werd hier geboren. De kalender wordt daarmee een zichtbaar onderdeel van de leeromgeving van de kinderen wat de inbedding van de Leeskalender als vast onderdeel van de dagelijkse onderwijspraktijk versterkt. De ervaringen tijdens de eerste pilotstudie bevestigden dit idee. De zichtbare aanwezigheid van de Leeskalender in de klas wekte de nieuwsgierigheid van de kinderen naar wat er die dag of de volgende dag ging komen. Tijdens de eerste pilot werd er regelmatig door de kinderen 'gespiekt' om te zien wat er zou komen. Dit werd vervolgens tijdens de aanbieding van de betreffende tekst in de klas ook even gemakkelijk door kinderen 'opgebiecht': "Juf, die had ik al gespiekt!" Een digitale kalender zou niet de hele dag door zichtbaar zijn en brengt het risico van uitval door een technische storing met zich mee. Om die redenen is besloten de Leeskalenders voor alle groepen in de experimentele conditie uit te voeren als tastbaar object in de klas.

\section{De omvang van het aanbod}

Tijdens de eerste expertraadpleging werden we er op gewezen dat de hoeveelheid teksten, vier nieuwe teksten per week in de kalender voor groep 2 en vijf nieuwe teksten per week voor groep 4, een te zware belasting vormt voor zowel kinderen als leerkrachten. Met name voor groep 2 ging het aanbieden van vier nieuwe teksten per week zonder vorm van herhaling in tegen het gebruikelijke uitgangspunt van leesbevorderingsmethoden dat herhaling cruciaal is voor tekstverwerving. Wat de experts betreft betekende dit dat het aantal aangeboden teksten per week het beste kon worden teruggebracht tot een of twee en dat er iedere dag een activiteit aan die tekst zou worden gekoppeld. We hebben het aantal nieuwe teksten per week voor beide groepen teruggebracht, we hebben herhaling toegevoegd in de vorm van herhalings- en keuzedagen en we hebben nog eens kritisch nagedacht over de thematische samenhang. Toch hebben we er in de samenstelling van de Leeskalenders voor gekozen om ook voor de kleutergroepen vast te houden aan de aanbieding van meerdere teksten per week met maximaal een herhaling per tekst en zijn niet alle weken in de kalenders thematisch samenhangend. Deze keuzes zijn gebaseerd op een aantal argumenten.

In de eerste plaats was het uitdunnen van de kalender voor groep 2 tot een aanbod van een of twee teksten per week niet in overeenstemming met onze conceptualisering van ontluikende culturele geletterdheid. Ons aanbod is niet opgebouwd rond specifieke teksten waarvan wij vinden dat ieder kind ze moet kennen; ons aanbod is opgebouwd rond genres en specifieke (inter)tekstuele kenmerken binnen die genres waaraan vaak al eeuwenlang culturele waarde wordt toegekend. Omdat we in dit onderzoek uitgaan van specifieke genre- en tekstkenmerken als onderdeel van ontluikende culturele geletterdheid, zijn de tekstselecties en de verdeling van teksten over de kalender gebaseerd op uitgangspunten over 
frequentie en spreiding van die specifieke genre- en tekstkenmerken. Het draait in ons aanbod van teksten om de aanwezigheid van tekstsoorten en -kenmerken die samen een soort cultureel basisrepertoire vormen dat toegang geeft tot een veelheid aan andere teksten. Het gaat ons dus niet om de frequentie van aanbieding van een bepaald verhaal of gedicht, maar om de frequentie van aanbieding van een specifiek genre of tekstkenmerk. De herhaling is daarmee minder expliciet, maar wel degelijk aanwezig binnen het aanbod. Tegelijk hebben we door de toevoeging van herhalings- en keuzedagen ook expliciete herhaling ingebouwd. In de tweede plaats heeft de keuze voor het vasthouden aan het aanbieden van meerdere teksten per week een methodologische reden die in het verlengde ligt van bovenstaande conceptuele reden. Hoe kleiner het aantal teksten in de kalender, hoe lager namelijk de frequentie van een specifiek kenmerk in de kalender, ongeacht de frequentie van de aandacht voor een specifieke tekst. Omdat het interventiemateriaal selecties bevat vanuit de drie deelprojecten, zou een aanbod van bijvoorbeeld een tekst per week in de kleutergroepen betekenen dat vanuit ieder deelproject slechts 10 teksten kunnen worden geselecteerd binnen het aanbod van in totaal 30 teksten. Omdat binnen ieder deelproject gekeken wordt naar meerdere genres en/of naar meerdere kenmerken binnen een of enkele genres, zou een totale selectie van 10 teksten per deelproject betekenen dat er wellicht 2 of 3 teksten in de hele kalender konden worden opgenomen van een bepaald genre of met een bepaald tekstkenmerk. Van een dergelijk lage aanbiedingsfrequentie kan niet verwacht worden dat het een effect heeft op de ontwikkeling van de ontluikende culturele geletterdheid van de kinderen. Door in de Leeskalender voor groep 1-2 terug te gaan naar een aanbod van 3 nieuwe teksten per week kon er vanuit elk deelproject per interventieweek een tekst worden aangeboden: dertig teksten in totaal dus.

\section{De opbouw van bet aanbod}

Tijdens de beide expertraadplegingen benadrukten de experts dat er in de onderbouw van het basisonderwijs veel wordt gewerkt met methoden die thematisch zijn opgebouwd en waarvan het voorlezen van prentenboeken doorgaans een vast onderdeel is. De Leeskalender is gemakkelijker in te passen in de bestaande (voor)leespraktijk in de kleutergroepen als we aansluiting kunnen vinden op die thematische methoden, zoals de veelgebruikte Piramide-methode van CITO. De structuur van de kalender wordt er dan een die gebaseerd is op aanbiedingsweken met verschillende activiteiten rond een tekst, of een paar teksten gekoppeld aan een thema. Tijdens de eerste expertraadpleging brachten de experts als tweede argument voor een opbouw gebaseerd op themaweken naar voren dat dit de nodige flexibiliteit zou bieden voor leerkrachten om te schuiven of zelfs te kiezen wat ze wel of niet behandelen in de klas. Themaweken zouden bijvoorbeeld kunnen worden omgewisseld om aan te sluiten op eventuele onvoorziene gebeurtenissen in de klas, zoals het overlijden van een opa of oma, of de geboorte van een broertje of zusje. Onze eerste reactie op dat voorstel was dat het idee van een opbouw op basis van themaweken op zich interessant is en waarschijnlijk ook meerwaarde heeft wanneer het gaat om de ontwikkeling van een lesmethode voor de markt. Het Leeskalenderproject is echter een onderzoeksproject waarbij andere factoren meespelen. 
Allereerst creëert het mogelijk maken van flexibiliteit ook extra variatie binnen de experimentele conditie. Daar komt bij dat we ons in de selectie van teksten niet primair hebben laten leiden door thema's; onze selectieprocedure is gebaseerd op de aanwezigheid van wat wij 'indicatoren van canoniciteit' noemen. Het gaat ons primair om het onderzoeken van de effecten van teksten met deze indicatoren op de ontluikende culturele geletterdheid van de kinderen en dus moeten we voorrang geven aan indicatoren boven inhoudelijke thema's zoals 'mensen' of 'verkeer'. De experts dachten op dit punt met ons mee en stelden voor die indicatoren dan te concentreren in themaweken rond specifieke verhaalfiguren die voorkomen in het aanbod, zoals een Hodjaweek en een Kikkerweek, een specifiek genre zoals een fabelweek en een sprookjesweek, of een specifiek type strategie zoals een omgekeerde-wereldweek en een overdrijvingsweek. In deze situatie brengt de clustering van indicatoren in themaweken die leerkrachten kunnen verschuiven of omwisselen een extra risico met zich mee. Het kan zijn dat leerkrachten om wat voor reden dan ook bepaalde thema's en dus indicatoren of genres structureel overslaan, wat het voor ons onmogelijk makkt om de effecten van de betreffende indicatoren en genres in beeld te brengen. Daarbij bestaat ook het probleem van grote ongelijkheid in het tijdverloop tussen de aanbieding van verschillende indicatoren en genres en de toetsing van de kennis en het begrip die de kinderen hebben opgedaan in de nameting. Als bijvoorbeeld alle geselecteerde Hodjaverhalen vanuit het deelproject Narratieve Genres waren geclusterd in een themaweek en aangeboden in interventieweek 3 terwijl alle geselecteerde fabels waren geclusterd in een themaweek en aangeboden in interventieweek 29, dan zouden de resultaten op de bijbehorende toetsitems in de nameting mogelijk vooral het effect van de factor tijd laten zien. Vanuit deze overweging was spreiding dus juist van groot belang. Wat is blijven staan, is dat er rond feestdagen wel is gekeken naar thematische aansluiting op het betreffende feest en onderlinge samenhang tussen de teksten uit de drie deelprojecten.

\section{De verschillende versies van de Leeskalender}

Een van de ideeën die tijdens de eerste expertraadpleging werd aangedragen, was om de tekstselecties uit de drie deelprojecten op verschillende scholen aan te bieden of om een mix toe te passen, waarbij sommige scholen een Leeskalender krijgen waarin teksten uit alle deelprojecten zijn opgenomen en andere scholen een Leeskalender krijgen met teksten uit slechts één van de drie projecten. Tijdens de expertraadpleging werd dit idee geopperd na bespreking van de grote omvang van het totale tekstaanbod en de intensiviteit van het weekprogramma, met name voor groep 1-2. Dit idee om het tekstaanbod per kalender uit te dunnen kent een aantal nadelen: een Leeskalender waarin slechts een van de drie deelprojecten vertegenwoordigd is, bevat per week een of twee teksten. Dan moet er ofwel iedere dag van de week iets met die tekst(en) gedaan worden, ofwel een aantal dagen van de week helemaal niets met de Leeskalender gedaan worden. In het eerste geval ontstaat er een groot verschil in de wijze waarop een tekst in een uitgedunde versie van de Leeskalender wordt verwerkt en waarop dat in de volle versie gebeurt. In het tweede geval wordt het idee van het dagelijkse Leeskalenderritueel doorbroken en is het idee van een kalender weg. Het belangrijkste nadeel was echter dat het aantal scholen in de experimentele conditie omhoog moest bij deze opzet. Als er in totaal wordt uitgegaan van tien scholen in de experimentele 
conditie, dan zijn er in deze opzet bijvoorbeeld vier scholen die dertig weken lang werken met een volledige Leeskalender en steeds twee scholen die werken met een Leeskalender waarin teksten van slechts een van de deelprojecten zitten. Om in die situatie toch nog met statistische betrouwbaarheid uitspraken te kunnen doen over de effecten van het aanbod van een deelproject op de ontluikende culturele geletterdheid van de kinderen, moeten er per deelproject meer scholen deelnemen. Omdat ons door dezelfde experts ook op het hart werd gedrukt niet te optimistisch te zijn over het werven van scholen voor deelname aan het project, wilden we niet bij voorbaat al uitgaan van een opzet waarvoor meer scholen nodig zijn.

Toch bleek het principe van verschillende kalenderversies vanuit een ander oogpunt wel degelijk mogelijkheden te bieden. Bij het bespreken van de samenstelling van de Leeskalender en het doel van het kwantitatief deel van het empirisch onderzoek, kwam steeds de vraag terug of de resultaten op de Toets Ontluikende Culturele Geletterdheid terug te voeren zijn op een van de deelprojecten of dat alle resultaten, buiten andere mogelijke verklarende variabelen, enkel aan de Leeskalender als geheel gekoppeld konden worden. Wanneer alle scholen in de experimentele conditie werken met een Leeskalender waarin alle genres en indicatoren vanuit de drie deelprojecten aanwezig zijn dan weten we feitelijk niet of kinderen van deze scholen, hypothetisch gesproken, in de nameting beter scoren op toetsitems over morele dilemma's omdat ze teksten met morele dilemma's aangeboden hebben gekregen, óf omdat ze sprookjes hebben gehoord, óf omdat ze nonsensgedichten hebben opgezegd, óf... et cetera. Om hier toch enig inzicht in te verkrijgen, zonder ons daarbij te richten op statistische betrouwbaarheid, maar alleen op statistische indicatie, hebben we besloten naast de volledige versie van de Leeskalender voor groep 2 en voor groep 4 ook drie uitgedunde versies te maken waaruit steeds een deelproject is weggelaten. In versie 1 van de Leeskalender zijn alle deelprojecten vertegenwoordigd; in versie 2 is het deelproject Narratieve Genres weggelaten, in versie 3 het deelproject Kinderpoëzie en in versie 4 het deelproject Deugden \& Dilemma's. Het weglaten van teksten heeft uiteraard wel gevolgen voor de verdeling van de teksten over de week. Om het principe van het dagelijks werken met de Leeskalender in stand te houden, is besloten de volgende indeling aan te houden in de verschillende versies voor groep 2 (zie Tabel 4) en voor groep 4 (zie Tabel 5).

Tabel 4. Overzicht kalenderversies groep 2

\begin{tabular}{lllll}
\hline GROEP 1-2 & G2V1 & G2V2 & G2V3 & G2V4 \\
\hline Alle weken & & & & \\
Maandag & Deugden \& Dilemma’s & Deugden \& Dilemma’s & Deugden \& Dilemma's & Kinderpoëzie \\
Dinsdag & Kinderpoëzie & Herhalingsdag & Herhalingsdag & Herhalingsdag \\
Woensdag & Narratieve Genres & Kinderpoëzie & Narratieve Genres & Narratieve Genres \\
Donderdag & Keuzedag & Herhalingsdag & Herhalingsdag & Herhalingsdag \\
Vrijdag & Keuzedag & Deze week... & Deze week... & Deze week... \\
\hline
\end{tabular}


Tabel 5. Overzicht kalenderversies groep 4 (week 1-3)

\begin{tabular}{|c|c|c|c|c|}
\hline GROEP 4 & G4V1 & G4V2 & G4V3 & G4V4 \\
\hline \multicolumn{5}{|l|}{ Week 1} \\
\hline Maandag & Deugden \& Dilemma’s & Deugden \& Dilemma’s & Deugden \& Dilemma’s & Kinderpoëzie \\
\hline Dinsdag & Kinderpoëzie & Kinderpoëzie & Narratieve Genres & Narratieve Genres \\
\hline Woensdag & Narratieve Genres & Deugden \& Dilemma's & Deugden \& Dilemma's & Keuzedag \\
\hline Donderdag & Deugden \& Dilemma’s & Keuzedag & Keuzedag & Keuzedag \\
\hline Vrijdag & Keuzedag & Keuzedag & Keuzedag & Deze week... \\
\hline \multicolumn{5}{|l|}{ Week 2} \\
\hline Maandag & Deugden \& Dilemma's & Deugden \& Dilemma’s & Deugden \& Dilemma’s & Kinderpoëzie \\
\hline Dinsdag & Kinderpoëzie & Kinderpoëzie & Narratieve Genres & Narratieve Genres \\
\hline Woensdag & Narratieve Genres & Kinderpoëzie & Keuzedag & Kinderpoëzie \\
\hline Donderdag & Kinderpoëzie & Keuzedag & Keuzedag & Keuzedag \\
\hline Vrijdag & Keuzedag & Keuzedag & Deze week... & Keuzedag \\
\hline \multicolumn{5}{|l|}{ Week 3} \\
\hline Maandag & Deugden \& Dilemma's & Deugden \& Dilemma’s & Deugden \& Dilemma's & Kinderpoëzie \\
\hline Dinsdag & Kinderpoëzie & Kinderpoëzie & Narratieve Genres & Narratieve Genres \\
\hline Woensdag & Narratieve Genres & Keuzedag & Narratieve Genres & Narratieve Genres \\
\hline Donderdag & Narratieve Genres & Keuzedag & Keuzedag & Keuzedag \\
\hline Vrijdag & Keuzedag & Deze week... & Keuzedag & Keuzedag \\
\hline
\end{tabular}

In de Leeskalender voor groep 4 hebben we ervoor gekozen een ritme aan te houden dat gebaseerd is op drie weken, met in week 1 twee teksten van het deelproject Deugden \& Dilemma's, in week 2 twee teksten van het deelproject Kinderpoëzie en in week 3 twee teksten van het deelproject Narratieve Genres. Hierdoor ontstaat in de uitgedunde versies de situatie dat er eens in de drie weken maar twee teksten worden behandeld. Naast de twee keuzedagen is er in die weken voor gekozen om de vrijdag aan te wijzen als dag om kort terug te blikken ('Deze week...').

\subsection{De onderzoeksinstrumenten}

Om de uitvoering, waardering en effecten van de interventie zo nauwkeurig mogelijk in beeld te brengen, hebben we gebruik gemaakt van een combinatie van kwantitatieve en kwalitatieve instrumenten. Allereerst hebben we de Toets Ontluikende Culturele Geletterdheid ontwikkeld om de effecten van het werken met de Leeskalender op specifieke onderdelen van de ontluikende culturele geletterdheid van de kinderen te meten. Daarnaast hebben we gegevens verzameld van scores op reguliere (CITO-)schooltoetsen voor taal en rekenen. Omdat we er van uit mogen gaan dat het leesklimaat thuis van invloed is op de ontluikende culturele geletterdheid van kinderen, hebben we hier via een oudervragenlijst zoveel mogelijk inzicht in proberen te krijgen. Om te kunnen monitoren hoe er in de verschillende schoolklassen met de Leeskalender is gewerkt en hoe de aangeboden teksten, aanbiedings- en verwerkingsopdrachten door leerkrachten en kinderen zijn ontvangen, hebben we gebruik 
gemaakt van logboeken en hebben we gesprekken (semigestructureerde interviews) gevoerd met leerkrachten. Om met eigen ogen te zien hoe er in de klas gewerkt is met de materialen, hoe leerkrachten en kinderen omgaan met de aangeboden teksten en hoe het samenspel tussen pragmatische contexten, specifieke (inter)tekstuele kenmerken en ontwikkelingskenmerken van kinderen in de praktijk 'werkt', hebben we observaties gedaan in de klas tijdens het werken met de Leeskalender. De projectbrede ontwikkeling en toepassing van deze instrumenten worden in de nu volgende paragrafen besproken; de deelprojectspecifieke invulling van zowel de Leeskalender, de Toets Ontluikende Culturele Geletterdheid en de observaties worden in het volgende hoofdstuk besproken.

\section{Toets Ontluikende Culturele Geletterdheid}

De Toets Ontluikende Culturele Geletterdheid (Toets OCG) hebben we speciaal voor dit onderzoek ontwikkeld in een ontwikkelingstraject dat verschillende fases kent. De verschillende fases in de ontwikkeling van de toets staan, met een focus op het aandeel vanuit het deelproject Kinderpoëzie, beschreven in het volgende hoofdstuk. De toets is ontwikkeld met het doel te kunnen meten wat de effecten van de implementatie van de Leeskalender zijn op de ontluikende culturele geletterdheid van kinderen in groep 2 en in groep 4. In overeenstemming met het design van het experiment, is de toets eenmaal aan het begin van het interventiejaar (aug-sept 2013) afgenomen bij alle kinderen uit de groepen 2 en groepen 4 in beide onderzoekscondities (experimenteel en controle), en eenmaal aan het einde van het interventiejaar (mei-jun 2014) bij dezelfde kinderen. Op de scholen in de experimentele conditie is tussen de voormeting en de nameting gewerkt met de Leeskalender; op de scholen in de controleconditie niet. De voormeting, of nulmeting, was bedoeld om vast te stellen welke (voor)kennis en welk begripsniveau kinderen hebben van specifieke kenmerken van verschillende genres, verhaalfiguren en stijlfiguren. Dit zijn aspecten die op scholen in de experimentele conditie vervolgens aan bod kwamen in de Leeskalender. In de nameting is dezelfde toets opnieuw afgenomen bij de kinderen uit beide onderzoekscondities zodat kan worden vastgesteld welke verschillen er zijn ontstaan tussen voormeting en nameting. Op deze manier kunnen we de groeiscores van de populatie kinderen in de experimentele en in de controle conditie vaststellen en deze vervolgens met elkaar vergelijken om te zien in hoeverre deze verschillen worden verklaard door de Leeskalender. In totaal werd de voormeting verricht bij 698 kinderen (352 uit groep 2 en 346 uit groep 4) en de nameting bij 665 kinderen (339 uit groep 2 en 326 uit groep 4).

\section{De toetsvrijwilligers}

Om alle, in totaal bijna 700, kinderen in een periode van vier weken te kunnen toetsen, waren we aangewezen op de hulp van vrijwilligers ${ }^{108}$. Met behulp van een wervingsbrief werden vrijwilligers in diverse kringen gezocht - onder studenten, onder familieleden van leden van het projectteam, en onder mensen met affiniteit voor onderwijs, kinderen en/of

\footnotetext{
108 We zijn enorme dank verschuldigd an alle vrijwilligers die hebben geholpen bij de toetsafnames, zowel bij de voormeting als bij de nameting. Zonder hun hulp en inzet was een effectmeting van deze omvang en in deze opzet niet uitvoerbaar geweest.
} 
jeugdliteratuur uit vrienden- of kennissenkringen. Uiteindelijk waren in totaal vijfentwintig personen betrokken bij het afnemen van de voormeting, inclusief de onderzoekers, de onderzoeksassistent en scholencoördinator, en de begeleiders. De scholencoördinator inventariseerde de beschikbaarheid van de vrijwilligers en de data waarop op de scholen kon worden getoetst, om vervolgens een planning op te stellen. Alle vrijwilligers kregen van tevoren een toetsprotocol toegestuurd (opgenomen in Bijlage 4). Daarin waren naast algemene 'spelregels' voor de toetsafname ook specifieke instructies opgenomen voor de afnameleider - degene die de vragen stelde uit het toetsboekje - en de scoorder - degene die de antwoorden van het kind noteerde op het scoreformulier -. In het protocol is bijvoorbeeld benadrukt dat de afnameleider zich aan het script in het toetsboekje moest houden en geen eigen vragen mocht toevoegen. Ook is benadrukt dat de kinderen wel mochten worden aangemoedigd of gerustgesteld (bijvoorbeeld: 'Wat doe jij goed je best, zeg'), maar dat hen niet verteld mocht worden of ze een vraag goed beantwoord hadden. Dit in verband met de herhaling van dezelfde toets na afloop van de interventie. Bij de voormeting en nameting is steeds gezorgd dat vrijwilligers hun eerste toetsafnames deden samen met een van de onderzoekers, de onderzoeksassistent of de scholencoördinator, zodat ze voldoende 'oefening' hadden opgedaan voordat ze zelfstandig (met een andere vrijwilliger) aan de slag gingen. Op deze manier konden alle vrijwilligers ook van de nodige materialen worden voorzien.

De nameting vond plaats in de periode 19 mei tot en met 20 juni 2014. De nameting werd wederom uitgevoerd op de zeventien scholen: elf experimentele scholen (waarvan één school in december met het werken met de Leeskalender was gestopt) en zes controlescholen. Vanwege feestdagen en bijzondere activiteiten aan het einde van het schooljaar (schoolreisje, sportdag e.d.) was de totale toetsperiode geen vier, maar vijf weken. Ook deze keer kregen we hulp van vrijwilligers. Die werden eerst geworven onder de vrijwilligers van de voormeting en vervolgens aangevuld op basis van dezelfde netwerken die ook aan het begin van de interventie waren benaderd. Uiteindelijk werden er achtentwintig vrijwilligers ingezet voor uitvoering van de nameting.

\section{De toetsafname: opret en uitvoering}

Voordat de voormeting plaatsvond, ontvingen de ouders van kinderen in alle deelnemende groepen een brief met informatie (via de scholen). De ouders van de kinderen op de experimentele scholen kregen een brief met informatie over zowel het Leeskalenderproject als de toetsafname; de ouders van de kinderen op de controlescholen kregen alleen informatie over de toetsafname. In deze brief kwam het Leeskalenderproject niet ter sprake, maar motiveerden we de toetsafname door te spreken over "een onderzoeksproject van de universiteiten van Maastricht en Tilburg" waarin we een toets gebruiken "om na te gaan wat kinderen aanspreekt in teksten". In beide gevallen zat onderaan de brief een strookje dat ouders konden invullen en aan de leerkracht overhandigen als ze niet wilden dat hun kind werd getoetst of als ze niet wilden dat er video-opnamen werden gemaakt tijdens het toetsen. Bij de voormeting was er voor gezorgd dat er op de eerste dag van de toetsafnames op een school altijd een onderzoeker of de scholencoördinator aanwezig was. Leerkrachten gaven de ingeleverde strookjes aan ons en wij noteerden op de klassenlijst welke kinderen 
niet getoetst mochten worden en van welke kinderen geen video-opname gemaakt mocht worden. Het volgende toetsteam dat op de school kwam voor verdere toetsafnames werkte op basis van deze klassenlijst. Een enkele keer gebeurde het dat een kind al getoetst was en de ouders daarna alsnog het strookje aan de leerkracht gaven: in deze gevallen zijn het scoreformulier en/of de video-opname van het betreffende kind vernietigd. Over het algemeen vonden de kinderen het heel leuk om de toets te maken - ze zagen dan ook allerlei leuke plaatjes en hoorden mooie/gekke/grappige verhaaltjes en kregen de volle aandacht -; een heel enkele keer gebeurde het dat een kind halverwege de toetsafname niet meer verder wilde ( 2 op de 700 kinderen). Als kinderen ook na aanmoediging nog steeds terug naar de klas wilden, dan is daaraan gehoor gegeven. Deze afnames zijn niet meegenomen in de verdere verwerking van de resultaten.

De voormeting vond plaats van 19 augustus tot en met 16 september 2013 op zeventien scholen (elf experimentele scholen en zes controlescholen) in Limburg (Maastricht, Heerlen, Venlo/Tegelen), Noord-Brabant (Tilburg, Sprang-Capelle/Waalwijk) en Gelderland (Nijmegen). De toets werd steeds bij één kind tegelijk afgenomen en altijd door twee personen: een afnameleider en een scoorder. Bij ieder kind werd een volledig toetsboekje afgenomen; de toetsafname duurde gemiddeld twintig minuten per kind. Elke afname werd vastgelegd met een (digitale) videocamera of webcam, tenzij de ouders van het kind hadden aangegeven bij de leerkracht dat hun kind niet gefilmd mocht worden. In een aantal gevallen is, om technische redenen, overgegaan op audio-opnamen. Ieder toetsduo had de beschikking over de volgende materialen: een toetsboekje voor groep 2 of groep 4, bijbehorende scoreformulieren, een cd met daarop de PowerPoint-presentatie met afbeeldingen en geluidsfragmenten voor groep 2 en groep 4, een laptop waarop de PowerPoint-presentatie kon worden afgespeeld en een camera of webcam voor opname van de toetsafnames. De toets werd afgenomen in een (relatief) rustige ruimte op de school. Leerkrachten hadden de leerlingen van te voren ingelicht. Steeds werd een kind door de afnameleider opgehaald uit de klas en begeleid naar de toetsruimte. Het kind nam plaats voor de laptop en de afnameleider ging naast het kind zitten. De afnameleider vertelde vervolgens (op basis van het toetsboekje) wat ze gingen doen:

Afnameleider: $\quad$ Ik ga je allemaal vragen stellen. Soms mag je een plaatje kiezen en soms mag je me gewoon vertellen wat jij denkt.

Bij de voormeting begon de Toets OCG met een oefenvraag ('De eerste vraag is een oefenvraag. Hier zie je een plaatje van een jongen en een meisje. Nu komt de vraag: Ben jij een jongen of een meisje?'), gevolgd door twee items over het voorleesklimaat thuis ('Hebben jullie thuis kinderboeken? En: Hoeveel?'; 'Wordt jij thuis wel eens voorgelezen? En: Vraag je thuis wel eens of iemand je wil voorlezen?'). Daarna volgde de eigenlijke toets met in totaal dertien items op het gebied van specifieke genres, verhaalfiguren en stijlfiguren. Bij deze items zagen de kinderen een illustratie op het scherm, hoorden een kort (fragment van een) verhaaltje of een rijmpje en kregen een aantal vragen over dat verhaal of rijm:

Deugden \& Dilemma's: de Toets OCG bevatte vier items uit dit deelproject waarin kinderen bijvoorbeeld werd gevraagd na te vertellen of te voorspellen 
Kinderpoëzie: $\quad$ in de vijf items uit dit deelproject werd kennis en begrip gemeten van verschillende stijlfiguren, zoals nonsensicale inversie en toepassingen van rijm (zie Hoofdstuk 7 voor een uitvoeriger beschrijving van de items).

Narratieve Genres: $\quad$ in de vier items uit dit deelproject werd nagegaan in hoeverre de kinderen bekend zijn met personages en kenmerkende elementen in verschillende soorten verhalen, te weten schelmenverhalen, spannende verhalen en sprookjes.

De items van de drie deelprojecten zijn in de Toets OCG om en om aan bod gekomen, waarbij de items met de langste tekstfragmenten aan het begin van de toets zijn geplaatst in verband met de aandacht van de kinderen. De Toets OCG voor groep 2 en de Toets OCG voor groep 4 waren voor een deel gelijk, maar voor een deel ook gedifferentieerd. Die differentiatie zat soms in het al dan niet bieden van keuzemogelijkheden (bij groep 2 meerkeuze en bij groep 4 open), en soms in het gebruik van andere verhalen of verhaalfiguren in overeenstemming met wat er in de verschillende groepen is opgenomen in de Leeskalender (bij groep 2 Hodja en bij groep 4 Anansi, bijvoorbeeld). Aan het einde van de afname werd het kind door de afnameleider teruggebracht naar de klas en werd het volgende kind opgehaald. De scoorder schreef de antwoorden van het kind op een gestandaardiseerd scoreformulier. Bij meerkeuzevragen konden de antwoorden direct gescoord worden; bij open vragen werden antwoorden zoveel mogelijk letterlijk overgenomen en vervolgens, indien duidelijk, gescoord. Open antwoorden zijn later door de onderzoekers en door een tweede beoordelaar onafhankelijk van elkaar gescoord (zie Hoofdstuk 8 voor interbeoordelaarsbetrouwbaarheid). Over het algemeen konden 's morgens acht kinderen getoetst worden in de beschikbare tijd en 's middags nog vier kinderen.

Bij de nameting zijn alleen kinderen getoetst die bij de voormeting ook getoetst waren. Uiteraard zijn er in de loop van het schooljaar kinderen verhuisd, dus viel het aantal getoetste kinderen bij de nameting iets lager uit dan bij de voormeting (zie Hoofdstuk 8 voor overzicht van uitval). Bij de nameting zijn de oefenvraag en de vragen over het voorleesklimaat bij de kinderen thuis niet gesteld: kinderen wisten over het algemeen nog wel een beetje hoe het de vorige keer in zijn werk ging, dus een geleidelijk opstapje was niet meer nodig. De afname van de toets verliep verder precies hetzelfde als bij de voormeting.

\section{Reguliere schooltoetsen}

Het zou zo kunnen zijn dat kinderen op scholen die de Leeskalender hebben gebruikt het na afloop van de interventie beter doen op (onderdelen van) reguliere CITO-toetsen dan de kinderen in de controlegroep. Het zou ook zo kunnen zijn dat niet ons aanbod van 
teksten, maar de 'intelligentie', of specifieker de woordenschat, of de vaardigheid in begrijpend lezen van kinderen bepalend is voor onze conceptualisering van ontluikende culturele geletterdheid. Om dergelijke zaken na te kunnen gaan, hebben we van alle deelnemende scholen de gegevens verzameld van de reguliere schooltoetsen die voorafgaand aan het interventiejaar zijn afgenomen tot en met de gegevens van de reguliere toetsen die na afloop van het interventiejaar zijn afgenomen. We hebben scholen naast de gegevens van de taaltoetsen ook om de gegevens van de rekentoetsen gevraagd omdat we daarmee een vergelijking kunnen maken met een minder direct aan de interventie gerelateerd domein, waarop we geen (of minder) effecten van de interventie verwachten en waarvan we ook geen (of minder) eventuele effecten op de Toets OCG kunnen verwachten. Bij het verzamelen van gegevens van reguliere schooltoetsen zijn we uitgegaan van vier punten:

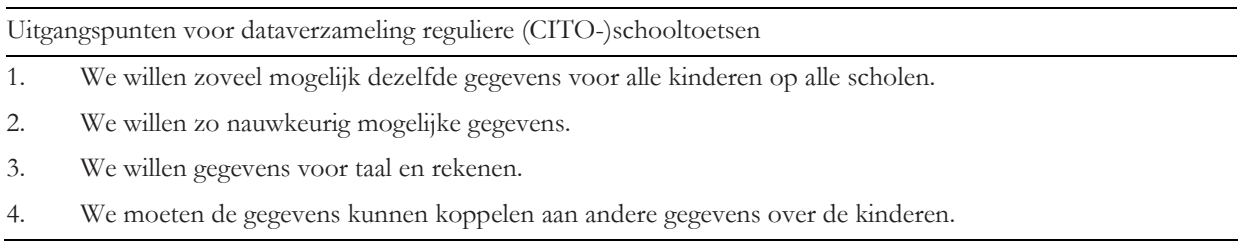

Uiteraard waren we hierbij afhankelijk van welke toetsen er op de deelnemende scholen worden afgenomen. Scholen zijn niet verplicht om te toetsen, maar de toenemende druk vanuit de Onderwijsinspectie draagt eraan bij dat steeds meer basisscholen ook in de onder- en middenbouw al (CITO-)toetsen afnemen. Er wordt op veel scholen gewerkt met het zogeheten Leerlingvolgsysteem, waarin de voortgang van de kinderen gedurende hun basisschoolloopbaan wordt geregistreerd op basis van ten minste een toetsmoment voor verschillende leergebieden per leerjaar. Er bestaan verschillende versies van taal- en rekentoetsen, afhankelijk van het jaar van uitgave en of het een digitale of papieren versie van de toets is. Inzicht in welke versie van een toets scholen gebruiken, was dus ook van belang.

We hebben scholen gevraagd naar de vaardigheidsscores op het laatste afnamemoment van reguliere taal- en rekentoetsen van het schooljaar voorafgaand aan de interventie. Deze gegevens fungeren als een nulmeting en hebben we onder andere gebruikt om vast te stellen of er qua schoolprestaties van tevoren al verschillen waren tussen experimentele en de controlegroep. We hebben scholen ook gevraagd naar de vaardigheidsscores op het laatste afnamemoment in het schooljaar waarin de interventie heeft plaatsgevonden om na te gaan of er inderdaad effecten van de interventie op met name de taalscores te zien zijn (zie Hoofdstuk 8). Alle deelnemende scholen bleken te werken met CITO-schooltoetsen. Daar waar de eindtoets (E-toetsen die in juni worden afgenomen) niet is afgenomen of niet beschikbaar was, hebben we gevraagd naar de scores op de toetsen die in het midden van het jaar zijn afgenomen (M-toetsen die in januari worden afgenomen). Voor de groepen 2 is gevraagd naar de toets 'Taal voor Kleuters' (TVK) en 'Rekenen voor Kleuters' (RVK); op sommige scholen wordt gewerkt met de toetsen 'Taal voor Peuters en Kleuters' (TVPK) en 'Rekenen voor Peuters en Kleuters' (RVPK). Voor de groepen 4, waar taal is onderverdeeld in verschillende deeltoetsen, is gevraagd naar de resultaten van de kinderen op de taaltoetsen 'Begrijpend Lezen', 'Spelling' en 'Woordenschat' en daarnaast naar de resultaten op de toets 'Rekenen Wiskunde'. Voor alle toetsen zijn de zogeheten 'vaardig- 
heidsscores' gebruikt. Deze scores zouden volgens de makers van de toetsen vergelijkbaar moeten zijn per vaardigheid (taal, rekenen etc.), ongeacht de exacte versie van de toets die gebruikt is. Op deze manier kunnen de kinderen van alle deelnemende scholen met elkaar vergeleken worden, ook al gebruikten verschillende scholen soms verschillende versies van de toetsen. Voor uitgangspunt 4 was het belangrijk dat we de toetsgegevens met de naam van het kind erbij zouden krijgen ${ }^{109}$. Alle deelnemende scholen hebben de gevraagde gegevens beschikbaar gesteld.

\section{Oudervragenlijst}

De kennis, vaardigheden en prestaties van kinderen worden door vele factoren beïnvloed. Een belangrijke factor is het thuismilieu, en meer specifiek, met het oog op de ontwikkeling van culturele geletterdheid, het leesklimaat thuis. Om inzicht te krijgen in het (voor)leesklimaat (ook zingen van liedjes en opzeggen van rijmen) bij de kinderen thuis, is een oudervragenlijst ontwikkeld. Deze oudervragenlijst is ontwikkeld door dr. Elma NapKolhoff ${ }^{110}$ in samenspraak met de onderzoekers. Hierin zijn ten eerste vragen te vinden over onder andere het opleidingsniveau van de ouders, land van herkomst, de thuistaal of talen, boekenbezit, voorlezen en bibliotheekbezoek. Een deel van deze vragen is ontleend aan de onderzoekspublicatie In de ogen van de ouders. Basisrapportage oudervragenlijst (NapKolhoff, 2011). Ten tweede zijn er vragen in opgenomen over de bekendheid met boekfiguren waarvan we verwachten dat die bekend zullen zijn in gezinnen waarin regelmatig wordt (voor-)gelezen. Het gaat dan om klassiek te noemen boekfiguren uit prentenboeken en verhalenbundels voor kinderen vanaf de peuterleeftijd tot en met de onderbouw, zoals Dribbel, Nijntje, Kikker, Jip en Janneke, Robin, Winnie de Poeh en Madelief. Een deel van deze boekfiguren is ook in de Leeskalender te vinden. De selectie van de boekfiguren is gebaseerd op de selectie op Leesplein (www.leesplein.nl), in de Boek en Jeugd Gids (tegenwoordig te vinden op www.boekenjeugd.nl) en in de onderzoekspublicatie Elke dag boekendag (Ghonem-Woets, 2009a). Daarnaast zijn er vragen opgenomen over specifieke boektitels die relevant zijn voor (een van) de drie deelprojecten. Die titels behoren tot de categorieën sprookjes en fabels, gedichten en liedjes en religieuze verhalen. Deze titels zijn ontleend aan het bestand met titels waaruit de teksten voor de Leeskalender zijn geselecteerd.

\footnotetext{
${ }^{109}$ Voor wetenschappelijk onderzoek is een wettelijke uitzondering gemaakt waardoor scholen ons deze persoonsgegevens mogen geven. Omdat we hier met vertrouwelijke en privacygevoelige informatie te maken hebben, zijn de ontvangen resultaten geanonimiseerd voor verdere verwerking en worden ruwe gegevens bewaard in een afgeschermde omgeving voor dataopslag.

${ }^{110}$ Dr. Elma Nap-Kolhoff was als methodoloog betrokken bij het onderzoeksproject Emergent Cultural Literacy.
} 
Tabel 6. Respons oudervragenlijst eerste ronde

\begin{tabular}{|c|c|c|}
\hline Scholen & Respons OVL $1^{\mathrm{e}}$ ronde $(\%)$ & Respons OVL $1^{\mathrm{e}}$ ronde (aantal) \\
\hline S10 - trio 1 & $96 \%$ & 44 \\
\hline S11 - trio 5 & $46 \%$ & 12 \\
\hline $\mathrm{S} 12-$ trio 2 & $60 \%$ & 18 \\
\hline S13 - trio 3 & $75 \%$ & 15 \\
\hline S14 - trio 3 & $42 \%$ & 15 \\
\hline S15 - trio 1 & $25 \%$ & 11 \\
\hline S16 - trio 2 & $65 \%$ & 39 \\
\hline S17 - trio 1 & $40 \%$ & 21 \\
\hline S18 - trio 3 & $52 \%$ & 28 \\
\hline S19 - trio 4 & $27 \%$ & 6 \\
\hline S20 - trio 2 & $53 \%$ & 17 \\
\hline $\mathrm{S} 21-$ trio 3 & $64 \%$ & 28 \\
\hline S22 - trio 4 & $68 \%$ & 50 \\
\hline S23 - trio 4 & $0 \%$ & 0 \\
\hline S24 - trio 3 & $48 \%$ & 14 \\
\hline S25 - trio 5 & $49 \%$ & 32 \\
\hline S26 - trio 5 & $42 \%$ & 15 \\
\hline Totaal & $50 \%$ & 365 \\
\hline
\end{tabular}

De oudervragenlijst is vanaf medio september 2013 verspreid over de deelnemende scholen, zowel in de experimentele als in de controleconditie. De vragenlijsten zijn ofwel aan de betreffende leerkrachten overhandigd ofwel opgestuurd naar de betreffende contactpersoon op school. Voor de ouders van elk kind kregen de leerkrachten een open envelop met daarin een vragenlijst met begeleidende brief (dd. 17-9-2013). In de brief werd de ouders gevraagd om de vragenlijst in te vullen, of op de begeleidende brief aan te vinken dat zij de lijst niet wilden invullen, en voor 1-10-2013 in de (gesloten) envelop aan de leerkracht terug te geven. De ouders konden er ook voor kiezen om de vragenlijst zelf in de envelop op te sturen naar een van de onderzoekers. Dit om ouders de mogelijkheid te geven de vragenlijst aan ons te retourneren zonder tussenkomst van de leerkracht. Op één school vermoedden de leerkrachten dat de respons zeer laag zou zijn vanwege een beperkte Nederlandse taalvaardigheid van veel ouders. Op die school is ouders de gelegenheid geboden om in het bijzijn van leerkrachten en van een van de onderzoekers met eventuele ondersteuning door tolken (Marokkaans Arabisch, Standaard Arabisch, Somalisch en Turks) de oudervragenlijst in te vullen. Op de overige scholen is aan de leerkrachten gevraagd om de enveloppen te verzamelen en deze aan ons te retourneren in een bijgevoegde verzamelenvelop. Aan de scholen waarvan we enige tijd na het verstrijken van de deadline nog geen vragenlijsten hadden teruggekregen, heeft de scholencoördinator een herinneringsmail gestuurd.

Op de school waar ouders de oudervragenlijst hebben ingevuld in het bijzijn van leerkrachten, onderzoeker en desgewenst een tolk leverde de aanpak in combinatie met een actieve houding van de betrokken leerkrachten uiteindelijk een respons op van 96\%. Begin 
2014 bleek echter dat de responspercentages van de deelnemende scholen/schoolgroepen hier en daar sterk uiteen liepen (een range van $0 \%$ tot $96 \%$ ), zoals te zien is in Tabel 6. Dit kwam de betrouwbaarheid van de oudervragenlijst als onderzoeksinstrument niet ten goede. We besloten daarop nog een tweede poging te doen om de respons op een aantal scholen te verhogen. We stelden het criterium van $60 \%$ aan teruggekregen oudervragenlijsten per school: in het geval dat een school een lagere respons had dan de 60\%-norm, hebben we vervolgens gekeken voor welke groepen op die school dat gold. Met een aangepaste begeleidende brief (dd. 17-2-2014) voor de ouders zijn de oudervragenlijsten opnieuw opgestuurd naar de groepen waar de respons onder de 60\% was. De enveloppen waren nu op naam gesteld van de betreffende kinderen. In de brief is de ouders gevraagd om de vragenlijst voor 14-3-2014 aan de leerkracht terug te geven. Ook nu hadden de ouders de mogelijkheid de vragenlijst oningevuld te retourneren en konden de leerkrachten de oudervragenlijsten naar ons terugsturen met behulp van een antwoordnummer. Uiteindelijk zijn in totaal 463 vragenlijsten ingevuld geretourneerd; er zijn 21 vragenlijsten leeg ingeleverd. Per school zijn er tussen de 11 en 50 vragenlijsten ingevuld. Er zijn 235 ingevulde vragenlijsten ontvangen voor groep 2 (66\% van 354 leerlingen) en 228 voor groep 4 (66\% van 346 leerlingen).

\section{Logboeken}

Het logboek was opgenomen in de handleiding en bevatte een toelichting waarin werd uitgelegd wat de verschillende onderdelen van het logboekblad inhielden, gevolgd door een blad voor iedere interventiedag. Het logboek was zo opgezet dat dit niet meer dan vijf minuten per dag in beslag hoefde te nemen. Op ieder logboekblad bij een reguliere Leeskalender-dag konden leerkrachten bovenaan noteren hoeveel tijd ze die dag aan de Leeskalenderactiviteit hadden besteed, of aanvinken dat ze die dag niet met de Leeskalender hadden gewerkt ${ }^{111}$. Verder konden ze aangeven (a) hoe de uitvoering was verlopen (al dan niet 'als in handleiding', aanvinken en afwijking van handleiding eventueel toelichten), (b) welke waardering leerkrachten gaven aan de activiteiten en de tekst (op basis van stellingen met een 5-punts Likert schaal van 'helemaal niet' tot 'goed'), en (c) wat leerkrachten was opgevallen en/of hoe de kinderen reageerden (open schrijfruimte). Voor keuzedagen, herhalingsdagen en terugblikdagen waren speciale logboekbladen ontwikkeld. Op keuzedagen konden leerkrachten bovenaan naast bestede tijd of 'niet gewerkt met Leeskalender' ook invullen of ze die dag hadden gebruikt als inhaaldag voor een eerder gemiste tekst (en zo ja, welke). Vervolgens werd gevraagd naar de titel van de door de kinderen gekozen tekst en was onderaan schrijfruimte gereserveerd om toe te lichten waarom de kinderen voor die tekst kozen. Zo fungeerden de keuzedagen voor ons ook als meetinstrument om de voorkeuren van de kinderen in kaart te kunnen brengen. Daarnaast werd op zowel keuze- als herhalingsdagen opnieuw gevraagd naar (a) hoe de uitvoering was verlopen, (b) welke waardering leerkrachten gaven aan de activiteiten en de tekst, en (c) wat leerkrachten was

\footnotetext{
111 Tijdens de leerkrachtinstructie gaven leerkrachten vaak al direct aan dat het onmogelijk zou zijn iedere dag met de Leeskalender te werken (bijvoorbeeld vanwege overvolle lesprogramma's, toetsweken, project- en/of studiedagen). We hebben benadrukt dat het van belang was dat ze zoveel mogelijk zouden doen, maar in drukke weken prioriteit konden geven aan het 'kernaanbod' (de dagen waarop een nieuwe tekst werd aangeboden) en dat ze, indien nodig, een keuze-, herhalings- of terugblikdag konden benutten om een tekst in te halen.
} 
opgevallen en/of hoe de kinderen reageerden. Op de logboekbladen bij terugblikdagen kon bovenaan worden aangegeven hoeveel tijd er was besteed, of dat er niet was gewerkt met de Leeskalender, of dat de dag was gebruikt als inhaaldag en zo ja, voor welke datum. Daaronder was enkel schrijfruimte gereserveerd voor een beschrijving van wat er was gedaan en/of reacties van de kinderen.

Naast inzicht in de waardering van de aangeboden teksten door de leerkrachten, de voorkeuren van kinderen en kwalitatieve informatie over reacties van kinderen, zijn de logboeken van belang voor inzicht in hoeveel tijd er in de verschillende klassen daadwerkelijk aan de Leeskalender is besteed en welke teksten wel/niet zijn aangeboden. Het is van belang hier zicht op te hebben om de resultaten uit de Toets OCG beter te kunnen interpreteren $^{112}$. Tijdens de leerkrachtinstructie voor aanvang van de interventie en in het eerste evaluatiegesprek is benadrukt dat het logboek van groot belang is voor onze onderzoeksdoeleinden en dat het daarom cruciaal is dat leerkrachten het logboek per dag zouden invullen. In totaal zijn door 33 groepen logboeken ingevuld. Vier groepen (één school) zijn voor de kerstvakantie met de Leeskalender gestopt, zodat er voor de analyses 29 groepen beschikbaar zijn. Er zijn logboeken van 17 groepen 2 en 12 groepen 4. Er is in de logboeken gezocht naar kwantificeerbare gegevens die iets zeggen over de mate waarin de leeskalender daadwerkelijk gebruikt is in de klas. Uiteindelijk zijn de volgende maten geselecteerd: 'logboektrouw', 'kalendertrouw', 'bestede tijd (duur)' en 'algemene waardering'. In Bijlage 5 staan de logboekgegevens voor groep 2 en groep 4 beschreven.

\section{Gesprekken met leerkrachten}

Gedurende de interventieperiode, die liep van medio september 2013 tot medio mei 2014, is op twee momenten een evaluatiegesprek gevoerd met de betrokken leerkrachten op de scholen in de experimentele conditie. De eerste ronde evaluatiegesprekken heeft plaatsgevonden in december 2013. Dit moment viel samen met het rondbrengen van het tweede deel van de Leeskalender en de bijbehorende handleiding op de scholen en het ophalen van de ingevulde logboekbladen tot dan toe. $\mathrm{Nu}$ de leerkrachten een goede drie maanden met het materiaal hadden gewerkt, leek het ons daarbij een goed moment om onze betrokkenheid bij de scholen en de leerkrachten te tonen en te peilen of zich ergens problemen voordeden. We waren ons er namelijk sterk van bewust dat we veel van de leerkrachten vroegen met een project waaraan ze dagelijks aandacht en tijd moesten besteden. Twee scholen vormden een uitzondering op de regel. Op een school was eerder al een gesprek gevoerd door de scholencoördinator omdat de leerkrachten hadden aangegeven dat de Leeskalender niet was in te passen in het lesprogramma. Met die school is afgesproken dat ze tot de kerstvakantie zouden doorgaan om daarna te stoppen. Met de leerkrachten van deze school is geen evaluatiegesprek meer ingepland omdat ze hun ervaringen in het eerdere gesprek al hadden verwoord. Op een andere school was ook al eerder een gesprek gevoerd omdat de contactpersoon al aan het begin van de interventie, bij het ontvangen van het eerste deel van de materialen, had aangegeven niet zeker te weten of ze daadwerkelijk konden partici-

\footnotetext{
112 Stel dat er in een bepaalde klas standaard op de dinsdag geen tijd was om met de Leeskalender te werken en de gemiste teksten ook niet altijd zijn ingehaald, dan kan dit betekenen dat de kinderen in die klas nauwelijks in aanraking zijn gekomen met het tekstaanbod uit een van de deelprojecten.
} 
peren. Op deze school was toen afgesproken dat ze in ieder geval tot aan de herfstvakantie zouden werken met het materiaal en we dan opnieuw in gesprek zouden gaan. Tijdens dit gesprek, dat vlak voor de herfstvakantie plaatsvond, bleek dat de leerkrachten volledig overtuigd waren door het materiaal. Omdat de leerkrachten ook op deze school hun ervaringen al in het eerdere gesprek hadden verwoord, is hier eveneens gekozen om geen evaluatiegesprek te houden in december. Wel zijn hier in december de materialen voor de periode van januari tot en met februari afgeleverd en zijn de logboekbladen tot dan toe opgehaald.

Dat betekent dat er op negen van de elf experimentele scholen gesprekken zijn gevoerd in december. De gesprekken zijn door de scholencoördinator of de onderzoeksassistent gevoerd waarbij ernaar is gestreefd met ten minste een leerkracht per deelnemende klas te spreken. De scholencoördinator en de onderzoekers hebben gezamenlijk een format opgezet voor deze gesprekken (semigestructureerde interviews) om van iedere school in ieder geval eenzelfde soort basisinformatie over het werken met de Leeskalender te krijgen. Dat format werd gebaseerd op de zogenoemde SWOT-analyse (Strengths, Weaknesses, Opportunities, Threats). Er is met leerkrachten gesproken over wat zij de sterke en de zwakke (minder sterke) kanten vinden aan (het werken met) de Leeskalender, denkend aan vorm, structuur, inhoud, aansluiting op het lesprogramma, de uitvoering en zichtbare effecten. Er is hen ook gevraagd hoe (het werken met) de Leeskalender aantrekkelijker kan worden gemaakt. Omdat we eerder al hadden gezien dat de logboeken niet altijd even trouw werden ingevuld, is ook het werken met het logboek aan de orde gesteld in het gesprek en is er opnieuw op gewezen dat dit voor ons een belangrijk onderzoeksinstrument is. Ook is in het gesprek gewezen op enkele kleine wijzigingen in het logboek ten opzichte van de eerste periode. In februari, vlak voor de carnavalsvakantie, is het laatste deel van de materialen op de scholen afgeleverd en is het tweede deel van de ingevulde logboekbladen opgehaald. Op dit contactmoment is geen gesprek gevoerd. Het tweede evaluatiegesprek is aan het einde van de interventieperiode gevoerd, in juni, op alle nog deelnemende scholen in de experimentele conditie, tien in totaal. Deze gesprekken werden door een van de onderzoekers of door de scholencoördinator geleid waarbij er opnieuw naar is gestreefd ten minste een leerkracht per deelnemende klas te spreken. Vanwege de drukte op de scholen rond de afsluiting van het schooljaar is dit niet overal gelukt; wel is op alle scholen met ten minste een leerkracht gesproken. De afsluitende gesprekken zijn gevoerd op basis van een vooraf opgestelde vragenlijst waarin we een aantal onderdelen onderscheidden. We hebben de leerkrachten gevraagd naar hoe ze terugkeken op het werken met de Leeskalender (prettig $\mathrm{ja} /$ nee en waarom; zinvol ja/nee en waarom); we hebben gevraagd naar de combinatie van de Leeskalender met de andere taal- en leesactiviteiten in het lesprogramma (aansluiting op bestaande methoden; totale tijd besteed aan (voor)lezen) en of leerkrachten de Leeskalender een vaste plaats zouden willen geven in hun lesprogramma. We hebben leerkrachten ook gevraagd of ze bepaalde effecten van het werken met de Leeskalender hebben waargenomen bij de kinderen in hun klas (luisterhouding; tekstbegrip; tekstwaardering; het terugkomen van teksten in het spel van de kinderen). Ten slotte hebben we leerkrachten gevraagd naar hun mening over de organisatie van het Leeskalenderproject (contact; instructie/begeleiding; verspreiding van materialen) en hebben we kort toegelicht wat wij met de verzamelde data doen en wanneer ze de resultaten konden verwachten. 


\section{Observaties}

Om zicht te krijgen op het samenspel tussen pragmatische, tekstuele en ontwikkelingsfactoren in relatie tot tekstverwervingsprocessen bij kinderen in groep 2 en groep 4 is ervoor gekozen naast de al genoemde onderzoeksinstrumenten ook gebruik te maken van observaties in de klas. Door te observeren terwijl er met de Leeskalender werd gewerkt, konden we zien hoe leerkrachten het materiaal aanboden, hoe kinderen daarop reageerden en welke factoren van invloed zijn op de interacties rond de aangeboden teksten. De observaties zijn per deelproject opgezet en uitgevoerd naar inzicht en behoefte van de betreffende onderzoeker (zie Hoofdstuk 7 voor een nadere beschrijving van de opzet en uitvoering van de observatie voor het deelproject Kinderpoëzie). De observaties zijn in alle gevallen gericht ingezet als instrument voor het verzamelen van aanvullende kwalitatieve data die ons helpen inzicht te krijgen in het samenspel van pragmatische, tekstuele en ontwikkelingsfactoren in het proces van tekstverwerving bij kinderen in groep 2 en groep 4 van het basisonderwijs. De observaties zijn, samen met logboekaantekeningen van en de gesprekken met de leerkrachten, gebruikt om antwoord te kunnen geven op de laatste empirische onderzoeksvraag:

4. Welke contextuele, tekstuele en ontwikkelingskenmerken zijn cruciaal te noemen voor de effectieve bijdrage van kinderliteratuur aan de ontluikende culturele geletterdheid van kinderen in groep 2 en in groep 4 op basis van observaties, logboekaantekeningen en gesprekken met leerkrachten met betrekking tot de presentatie van het tekstaanbod in de klas, de reacties van de kinderen op deze teksten en hun waardering daarvan?

Daarbij heeft elke onderzoeker uiteraard specifiek gekeken naar de eigen 'indicatoren van canoniciteit', maar de observaties leverden ook aanvullende inzichten op in de wijze waarop leerkrachten werkten met het Leeskalendermateriaal, in factoren die van invloed zijn op de wijze waarop leerkrachten dat deden, in de manieren waarop kinderen reageerden op het Leeskalenderaanbod en de factoren die daar van invloed op zijn, in de inbedding van teksten in pragmatische contexten in de schoolklas, in specifieke verwerkingsvormen waarmee de teksten in de klas zijn aangeboden, in de werking van specifieke tekstuele eigenschappen en in de aansluiting op relevante ontwikkelingstheorieën, zoals taalontwikkeling, humorontwikkeling, ontwikkeling van tijdbesef en morele ontwikkeling. Een gedetailleerder beschrijving van de kwalitatief-empirische onderzoeksvragen en de uitvoering van de observaties staat beschreven in Hoofdstuk 7, \$7.8. De kwalitatieve resultaten staan, specifiek met betrekking tot het deelproject Kinderpoëzie, beschreven in Hoofdstuk 9 en Hoofdstuk 10.

\subsection{De werving en selectie van scholen}

In de periode voorafgaand aan de start van het interventieprogramma zijn er scholen geworven voor deelname aan het onderzoeksproject. Voor de gekozen onderzoeksopzet hadden we ten minste vijftien scholen nodig (met per school ten minste een groep 2 en een groep 4) waarvan tien scholen in de experimentele conditie en vijf scholen in de controleconditie. We zochten naar scholen met een gemengde populatie, zowel op het gebied van 
etnische als van sociaaleconomische achtergronden van de kinderen. Leerlinggewichten en aanvullende informatie van scholen zijn geraadpleegd en gebruikt om vergelijkbaarheid tussen de experimentele en controle conditie te garanderen. De wijze waarop de selectie van scholen en de toewijzing aan de onderzoekscondities heeft plaatsgevonden, staat hieronder nauwkeurig beschreven. Voor deze taak is Ingeborg Hendriks aangetrokken als scholencoördinator. Zij heeft de werving van scholen georganiseerd en uitgevoerd en heeft in aanloop naar en ook gedurende de interventie het contact onderhouden met de deelnemende scholen. Voor de werving van scholen heeft de scholencoördinator in de periode van november 2012 tot mei 2013 een stappenplan opgesteld en uitgevoerd (zie Tabel 7). Openbare bibliotheken bleken een zeer bruikbare ingang om scholen te bereiken. Bibliotheken en basisscholen werken nauw samen op het gebied van activiteiten rond boekpromotie en leesbevordering: bibliotheken hebben aangewezen leesconsulenten die contact hebben met de leescoördinatoren op basisscholen. De leesconsulenten van verschillende openbare bibliotheken hebben leescoördinatoren in hun netwerk op verzoek van de scholencoördinator gewezen op het Leeskalenderproject. De scholencoördinator heeft geïnteresseerde leescoördinatoren voorzien van schriftelijke informatie waarin het Leeskalenderproject werd toegelicht.

Tabel 7. Stappenplan voor werving van scholen

\begin{tabular}{|c|c|}
\hline & Periode eind 2012 tot mei 2013 \\
\hline Stap 1 & $\begin{array}{l}\text { Scholen zijn per gemeente geïnformeerd over het onderzoeksproject via nieuwsbrieven (Boekenproeverij } \\
\text { Maastricht, BCO, OCGH, bibliotheken), boekoverleg Maastricht, taalcoördinatoren Tilburg. } \\
\text { Geïnteresseerde scholen konden contact opnemen met de scholencoördinator (november - januari). }\end{array}$ \\
\hline Stap 2 & $\begin{array}{l}\text { In Tilburg, Venlo, Helmond en Roermond heeft de scholencoördinator zelf directies benaderd van } \\
\text { geschikte scholen (op basis van criteria opgesteld door de methodoloog voor het vormen van } \\
\text { matchingtrio's [zie hieronder] en op basis van advies van bibliotheken en onderwijsbegeleiders over } \\
\text { bereidwillige/potentieel geïnteresseerde scholen). Directies die geïnteresseerd zijn, ontvingen informatie } \\
\text { over het project en zijn uitgenodigd voor een informatiebijeenkomst in de gemeente. Als ze binnen een } \\
\text { week niet reageerden op de uitnodiging, werden ze gebeld (januari-februari). }\end{array}$ \\
\hline Stap 3 & $\begin{array}{l}\text { Na de informatiebijeenkomsten zijn lijsten opgesteld van scholen die echt geïnteresseerd zijn. Over die } \\
\text { scholen is de nodige informatie verzameld om geschiktheid te kunnen beoordelen (voor het vormen van } \\
\text { matchingtrio's) en om de school op maat te kunnen informeren over wat het project voor hen kan } \\
\text { betekenen. In volgorde van geschiktheid zijn geïnteresseerde scholen individueel benaderd (februari-mei). }\end{array}$ \\
\hline Stap 4 & $\begin{array}{l}\text { Toen uit stap } 1 \text { tot en met } 3 \text { nog niet voldoende scholen waren voortgekomen, zijn scholen in Heerlen } \\
\text { benaderd volgens stap } 2 \text { en } 3 \text { (februari-mei). }\end{array}$ \\
\hline
\end{tabular}

Halverwege maart 2013 hadden zich, op basis van de schriftelijke informatie, al elf scholen aangemeld uit de steden Maastricht, Venlo, Helmond en Tilburg. Daarnaast had een achttal scholen in Tilburg en Heerlen aangegeven meer informatie te willen. In beide steden is daarom een informatiebijeenkomst georganiseerd. Ook is er op de BCO Taaldag op 10 april 2013 aandacht besteed aan het project door er een workshop te geven (scholencoördinator en een van de onderzoekers) en brochures uit te delen aan geïnteresseerde leerkrachten. 


\section{De toewijzing van scholen aan onderzoekscondities}

In totaal hebben negentien basisscholen zich aangemeld bij de scholencoördinator voor deelname aan het Leeskalenderproject. Dertien scholen konden meedoen met zowel groep 2 als groep 4, drie scholen met alleen groep 2 en drie scholen met alleen groep 4. We hebben in het onderzoek vijftien scholen nodig die meedoen met groep 2 en vijftien scholen die meedoen met groep 4. Dit aantal is gebaseerd op (a) de van te voren vastgestelde streefomvang van de onderzoekspopulatie (per jaargroep 200 tot 250 leerlingen in de experimentele conditie en 100 tot 80 leerlingen in de controle conditie), (b) het uitgangspunt dat scholen in clusters worden ingedeeld op basis van bepaalde kenmerken om vergelijkbaarheid van scholen te waarborgen, en (c) het feit dat we werken met vier verschillende versies van de Leeskalender. Er hebben zich dus meer scholen aangemeld dan we nodig hebben. Dit betekent dat de scholen die zich hebben aangemeld via een aantal procedures worden toegewezen aan de verschillende onderzoekscondities. Allereerst wordt een aantal scholen toegewezen aan de reservelijst. Vervolgens moeten de overige scholen worden verdeeld over de experimentele en de controle conditie. Om te zorgen dat de experimentele en controle conditie zo veel mogelijk met elkaar vergelijkbaar zijn en beide representatief zijn voor de totale poel van deelnemende scholen, zijn scholen eerst in trio's aan elkaar gematcht op basis van specifieke kenmerken. Per trio van aan elkaar gematchte scholen is bepaald met welke versie van de kalenders de scholen die binnen het trio in de experimentele conditie terecht komen, zullen gaan werken. Uit de trio's is vervolgens steeds een school toebedeeld aan de controle conditie en komen de twee andere scholen in de experimentele conditie terecht. De wijze waarop de toewijzing van scholen aan de reservelijst, het vormen van matchingtrio's, de verdeling van kalenderversies en de toewijzing van scholen binnen de trio's aan de onderzoekscondities is verlopen, wordt in de volgende vier stappen toegelicht en verantwoord.

\section{Stap 1: Toewijzing aan de reservelijst}

Bij de in totaal negentien scholen die zich hebben aangemeld voor deelname aan het Leeskalenderproject, zaten drie scholen die alleen konden meedoen met groep 2 en drie scholen die alleen konden deelnemen met groep 4. De overige dertien scholen die zich hebben aangemeld, konden allemaal deelnemen met zowel groep(en) 2 als groep(en) 4. Dit betekende dat er in totaal zestien scholen zijn aangemeld met groep 2 en zestien scholen met groep 4. Uiteindelijk hadden we vijftien scholen nodig die deelnemen met groep 2 en vijftien scholen die deelnemen met groep 4. In verband met de logistiek en reistijd wilden we liefst zoveel mogelijk scholen die deelnemen met zowel groep 2 als groep 4. Om die reden is ervoor gekozen om alleen de scholen die met slechts één groep mee konden doen, mee te nemen in de procedure voor toewijzing aan de reservelijst. Op basis van toeval ${ }^{113}$ zijn twee scholen geselecteerd voor de reservelijst. Een school met alleen groep 2 en een school met alleen groep 4 .

${ }^{113}$ Hiervoor is steeds de functie 'rand)' in Excel gebruikt. 


\section{Stap 2: Matchingstrio's maken}

In de volgende stap zijn de overgebleven scholen opgedeeld in trio's van enigszins op elkaar gelijkende scholen. Wanneer scholen op basis van toeval aan de experimentele en controle conditie worden toegewezen zonder eerst matchingtrio's te maken, kan het zo zijn dat de beide onderzoekscondities 'toevallig' zoveel van elkaar verschillen dat ze niet meer vergelijkbaar zijn. Daarom is ervoor gekozen de scholen eerst in te delen in matchingtrio's (zie Tabel 8). De criteria voor het vormen van matchingtrio's waren: het percentage allochtone leerlingen en leerlinggewichten ${ }^{114}$, de mate van verstedelijking en de mate waarin een school zich identificeert als religieuze school. Op de scholen in trio 1 speelt het godsdienstonderwijs een relatief grote rol. Het gaat daarbij om twee islamitische scholen en een protestants-christelijke school. Er zijn wel grote verschillen in het aantal allochtone leerlingen en de mate van verstedelijking. Trio 2 bevat scholen met relatief veel allochtone leerlingen en hoge percentages leerlinggewichten. De scholen in trio 3 hebben redelijk hoge aantallen allochtone leerlingen en/of leerlinggewichten, maar minder dan trio 2. Er zitten vijf scholen in dit 'trio', omdat in deze categorie ook de scholen vallen die met slechts één groep meedoen. Een school met alleen groep 4 is steeds gekoppeld aan een school met alleen groep 2. Deze koppels zijn in de rest van het lotingsproces steeds als één school behandeld. Dit trio bevat één school met beide groepen en twee koppels met deelname van slechts één groep. De scholen in trio 4 zijn relatief 'witte' scholen en/of liggen in gebieden met relatief weinig verstedelijking. Trio 5 ten slotte bevat drie scholen met relatief weinig allochtonen en leerlinggewichten in verstedelijkte gebieden.

Tabel 8. Matchingtrio's van scholen op basis van \% allochtone leerlingen, \% leerlinggewichten, verstedelijking en religieuze identiteit

\begin{tabular}{llll}
\hline & \%allochtonen & \%gewicht & Godsdienst \\
\hline TRIO 1 & 95 & 35 & + \\
S15-Nijmegen & 92 & 51 & + \\
S10-Tilburg & 0 & 4 & + \\
S17-Sprang Capelle & & & \\
TRIO 2 & 30 & 45 & \\
S20-Maastricht & 45 & 41 \\
S16-Tilburg & 70 & 42 \\
S12-Blerick & & 39 \\
'TRIO' 3 & 12 & 13 \\
S24-Maastricht & 15 & \\
S14-Tilburg (gr. 2)* &
\end{tabular}

114 Leerlinggewichten worden bij binnenkomst in het basisonderwijs toegekend aan leerlingen met (een vergroot risico op) leerachterstanden. Het opleidingsniveau van de ouders bepaalt het gewicht dat de school toekent aan een achterstandsleerling. Is er sprake van maximaal basisonderwijs of (v)so-zmlk van een of beide ouders, dan krijgt het kind leerlinggewicht 1,2 toegekend; is er sprake van maximaal lbo/vbo, praktijkonderwijs of vmbo basisof kaderberoepsgerichte leerweg van beide ouders of van de ouder die voor het kind zorgt, dan krijgt de leerling gewicht 0,3 toegekend. Ligt een school in een zogeheten 'impulsgebied' (postcodegebied met veel gezinnen met een laag inkomen of een uitkering), dan krijgt een school extra geld voor elke leerling met een leerlinggewicht (www.rijksoverheid.nl). 


\begin{tabular}{|c|c|c|c|}
\hline & $\%$ allochtonen & \%gewicht & Godsdienst \\
\hline S18-Heerlen (gr. 4)* & 35 & 35 & \\
\hline S13-Maastricht (gr. 2)** & 10 & 21 & \\
\hline S21-Tilburg (gr. 4)** & 45 & 20 & \\
\hline \multicolumn{4}{|c|}{$\begin{array}{l}\text { * Samen als } 1 \text { school opgenomen. } \\
\text { ** Idem. }\end{array}$} \\
\hline \multicolumn{4}{|l|}{ TRIO 4} \\
\hline S22-Tegelen & 0 & 11 & \\
\hline S00-Asten* & 12 & 30 & \\
\hline S23-Venlo & 8 & 0 & \\
\hline \multicolumn{4}{|c|}{ * Deze school is vervangen (zie De nodige reparaties voor toelichting). } \\
\hline \multicolumn{4}{|l|}{ TRIO 5} \\
\hline S26-Heerlen & 10 & 25 & \\
\hline S00-Helmond* & 20 & 15 & \\
\hline S11-Heerlen & 15 & 25 & \\
\hline
\end{tabular}

\section{Stap 3 Toewijzing aan de kalenderversies}

Binnen de experimentele conditie hebben we gewerkt met verschillende kalenderversies: sommige scholen krijgen de volledige versie, andere een afgeslankte versie waaruit een van de deelprojecten is weggelaten. Zowel de kalender voor groep 2 als de kalender voor groep 4 is dus ontwikkeld in vier verschillende versies:

- Versie 1: de volledige kalender (G2V1 en G4V1)

- Versie 2: de kalender zonder deelproject Narratieve Genres (G2V2 en G4V2)

- Versie 3: de kalender zonder deelproject Kinderpoëzie (G2V3 en G4V3)

- Versie 4: de kalender zonder deelproject Deugden \& Dilemma's (G2V4 en G4V4)

Hoewel in stap 4 scholen binnen de trio's pas aan de onderzoekscondities worden toegewezen, is eerst vastgesteld welke versie de scholen in de trio's krijgen als ze tot de experimentele groep gaan behoren. Van de vijf trio's kunnen er twee aan de volledige versie van de kalender deelnemen en drie aan de afgeslankte versies (zonder Kinderpoëzie, Narratieve Genres of Deugden \& Dilemma's). Aan deze loting is een voorwaarde verbonden, namelijk dat trio 1 niet de versie zonder Deugden \& Dilemma's mocht krijgen. Dit zijn namelijk de scholen met relatief veel aandacht voor godsdienstonderwijs en daarom met name voor het deelproject Deugden \& Dilemma's interessant. Indien dit trio in de loting toch aan de versie zonder religieuze verhalen toegewezen zou worden, zou er opnieuw geloot worden. Bij de eerste loting was dit echter niet het geval, zodat opnieuw loten niet nodig was. 
Tabel 9. Uitkomst toewijzing trio's aan kalenderversies

\begin{tabular}{ll}
\hline Trio & Kalenderversie \\
\hline Trio 1 & Zonder Kinderpoëzie (G2V3 en G4V3) \\
Trio 2 & Zonder Deugden \& Dilemma’s (G2V4 en G4V4) \\
Trio 3 & Zonder Narratieve Genres (G2V2 en G4V2) \\
Trio 4 & Volledig (G2V1 en G4V1) \\
Trio 5 & Volledig (idem) \\
\hline
\end{tabular}

\section{Stap 4 Toewijzing aan controlegroep}

In de laatste stap is binnen de trio's geloot welke school er controlegroep werd, met twee voorwaarden:

Voorwaarde 1: In trio 1 moest één van de twee islamitische scholen een controlegroep zijn. De vergelijking tussen de scholen in dit trio zou erg scheef zijn indien beide islamitische scholen in de experimentele groep terecht zouden komen en de protestants-christelijke school de controlegroep voor dit trio zou vormen.

Voorwaarde 2: $\quad$ In verband met de logistiek van de te gebruiken boeken uit de bibliotheek kunnen er maximaal vijf schoolgroepen per gemeente in de experimentele groep opgenomen. De loting begon met trio 1 en dan oplopend naar trio 5. Indien er vijf schoolgroepen binnen een gemeente aan de experimentele groep waren toegewezen, zouden de scholen die nog geloot moesten worden in die gemeente automatisch controlegroep worden. Deze situatie deed zich bij de loting niet voor.

De loting resulteerde in een overzicht van scholen, op basis van clusterrandomisatie op het niveau van de gevormde trio's toegewezen aan de experimentele of de controleconditie. Echter ... In experimenteel onderzoek is er altijd het gevaar dat scholen afhaken wanneer ze aan de controlegroep toegewezen worden. Ze waren enthousiast geworden over de interventie, maar zien deelname zonder de interventie niet zitten. In dit onderzoek hebben we dat gevaar op twee manieren geprobeerd te ondervangen. Allereerst is de opzet van het onderzoek aan de scholen uitgelegd (zie werving). De scholen begrepen dat het voor experimenteel onderzoek belangrijk is om met een controlegroep te werken en dat zij dat mogelijk konden zijn. Ten tweede is ook aan de controlegroep een presentje in het vooruitzicht gesteld, wanneer zij aan het onderzoek meedoen: alle scholen zouden een boek over het werken met kinderliteratuur in het basisonderwijs ontvangen (Verborgen talenten), een boekenpakket (samengesteld uit boeken die wij voor het project hebben aangeschaft, daar waar bibliotheken het boek niet konden leveren) en/of een boekenbon per deelnemende groep. Toch zijn twee scholen afgehakt toen ze hoorden dat ze voor de controlegroep geselecteerd waren en waren enkele 'reparaties' nodig. 


\section{Stap 5 De nodige reparaties}

Nadat de loting binnen de trio's was gedaan en er voor alle deelnemende scholen bekend was of zij reserve-, controle- of experimentschool zouden worden, heeft de scholencoördinator de scholen hier schriftelijk van op de hoogte gebracht en gevraagd hun deelname te bevestigen door ondertekening van een deelnameformulier. Dit resulteerde in een aantal wijzigingen. Een tweetal scholen zag geen voordeel in hun rol als controleschool en haakte daarom af. De twee scholen op de reservelijst werd gevraagd of zij alsnog wilden deelnemen, nu als controleschool. Een van beide scholen stemde daar mee in; de andere school had zich in de tussentijd al helemaal afgemeld. Omdat echter nog een aantal nieuwe scholen interesse in het project had getoond bij de scholencoördinator is de laatste controleschool vervangen door een nieuwe school die het meest overeenkwam met de andere scholen binnen het betreffende trio. Door de verschillende verschuivingen ontstond een volgende uitdaging: de nieuwe controleschool in trio 4 deed alleen mee met groep 4 en de nieuwe controleschool in trio 5 had zich alleen aangemeld met groep 2. De school in trio 5 was op verzoek van de scholencoördinator bereid ook met groep 4 mee te doen; ter vervanging van de ontbrekende groep 2 in de controleconditie van trio 4 is uiteindelijk de controleschool uit trio 3, die zich aanvankelijk alleen met groep 4 had aangemeld, bereid gevonden om ook met groep 2 mee te doen. Uiteindelijk ziet de verdeling van scholen over de trio's en onderzoekscondities er als volgt uit:

Tabel 10. De definitieve indeling van de onderzoekscondities op basis van clusterrandomisatie en de nodige reparaties

\begin{tabular}{ll}
\hline SCHOOL & ONDERZOEKSCONDITIE \\
\hline Trio 1 & Controle \\
S15-Nijmegen & Experiment (zonder Kinderpoëzie) \\
S10-Tilburg & Experiment (zonder Kinderpoëzie) \\
S17-Sprang Capelle & \\
Trio 2 & Experiment (zonder Deugden \& Dilemma's) \\
S20-Maastricht & Experiment (zonder Deugden \& Dilemma's) \\
S16-Tilburg & Controle \\
S12-Blerick & \\
Trio 3 & Experiment (zonder Narratieve Genres) \\
S24-Maastricht & Controle \\
S14-Tilburg (gr. 2) & Controle \\
S18-Heerlen (gr. 4) & Experiment (zonder Narratieve Genres) \\
S13-Maastricht (gr. 2) & Experiment (zonder Narratieve Genres) \\
S21-Tilburg (gr. 4) & \\
Trio 4 & Experiment (volledige versie) \\
S22-Tegelen & Controle \\
S18-Heerlen (gr. 2) & Controle \\
S19-Heerlen (gr. 4) & Experiment (volledige versie) \\
S23-Venlo & \\
\hline
\end{tabular}




\begin{tabular}{ll}
\hline SCHOOL & ONDERZOEKSCONDITIE \\
\hline Trio 5 & \\
S26-Heerlen & Experiment (volledige versie) \\
S25-Blerick & Controle \\
S11-Heerlen & Experiment (volledige versie) \\
\hline
\end{tabular}

Deze wijzigingen voldoen niet aan het principe van randomisatie in de toewijzing aan onderzoekscondities, maar waren noodzakelijke ingrepen om de gevormde trio's waar nodig te repareren en zo de omvang van de onderzoekspopulatie te waarborgen. Bij het in kaart brengen van de aantallen kinderen en groepen die nu aan de verschillende condities waren toegewezen, bleek dat we uiteindelijk ook niet volledig konden voldoen aan de hierboven weergegeven voorwaarde 2. Omdat de meeste scholen werken met combinatiegroepen 1-2, deze groepen vaak relatief klein worden gehouden gezien de leeftijd van de kinderen, en veel scholen dus over meerdere groepen 1-2 beschikken, zouden de bibliotheken van Maastricht, Tilburg en Venlo elk voor zes groepen 2 de boeken moeten leveren. We hebben toen besloten zelf budget vrij te maken voor de aanschaf van boeken in het geval de bibliotheken niet voldoende exemplaren konden leveren.

\section{Consequenties voor het onderzoek}

Wanneer een school de bereidheid om deel te nemen aan het onderzoek wijzigt nadat ze weet aan welke onderzoeksconditie ze is toegewezen, tast dat de op matching en toeval gebaseerde opzet van het onderzoek aan. Groepen die alleen willen deelnemen áls ze in de controleconditie terechtkomen of juist áls ze in de experimentele conditie terechtkomen, zijn anders dan de andere groepen 2 en 4 in het onderzoeksproject. Waar dit anders-zijn uit bestaat weten we niet precies. Het kan iets zijn dat wel degelijk van invloed is op de ontluikende culturele geletterdheid van de kinderen, zoals minder interesse hebben in jeugdliteratuur of daar juist zelf al wel veel mee doen. Het kan iets zijn wat niet zozeer te maken heeft met het onderzoeksthema, maar het onderwijsniveau in de klas, zoals ziekte of overspannenheid van de leerkracht of minder organisatievermogen om het project te draaien. Het kan ook iets zijn wat niets zegt over de betreffende groep in het algemeen, maar iets incidenteels was, bijvoorbeeld wanneer de leerkracht gevraagd werd deel te nemen na een nacht slecht geslapen te hebben. We weten dus niet of het verschil in bereidheid een effect heeft op wat het onderzoek wil meten. En indien het een effect heeft weten we niet hoe sterk dat is. In de interpretatie van de onderzoeksresultaten zullen we dit echter wel in het achterhoofd moeten houden.

Een tweede gevolg van uitval en vervanging van de scholen is dat de trio's niet meer zo goed matchen als bij de aanvankelijke selectie. Qua verstedelijking is het verschil niet heel groot, maar qua leerlingpopulatie wel. De school die bereid was in te springen met groep 4 heeft relatief veel gewichtenleerlingen ten opzichte van de scholen uit hetzelfde trio die in de experimentele conditie terecht zijn gekomen (trio 4: scholen met relatief weinig allochtone leerlingen en/of liggen in gebieden met relatief weinig verstedelijking). De school die bereid was met zowel kleutergroepen als groep 4 in te springen heeft eveneens tamelijk veel gewichtenleerlingen ten opzichte van de andere scholen uit hetzelfde trio die in de experi- 
mentele conditie terecht zijn gekomen (trio 5: scholen met relatief weinig allochtonen en leerlinggewichten in verstedelijkte gebieden). Het gemiddeld aantal gewichtenleerlingen in de onderzoekspopulatie als geheel is daarmee gestegen van $27 \%$ naar $31 \%$. De stijging in de controlegroep is aanzienlijk groter: van $28 \%$ naar $42 \%$. Daarmee is het percentage gewichtenleerlingen in de controlegroep groter dan in de experimentele groep $(26 \%)$. Ook met dit verschil moet (en kan) in de analyses rekening gehouden worden. 



\section{HOOFDSTUK 7}

Kinderpoëzie in Leeskalender en Toets 



\subsection{Introductie}

Om de verwachte 'indicatoren van canoniciteit' in poëzie voor kinderen in groep 2 en groep 4, zoals in Hoofdstuk 3 tot en met 5 geformuleerd, te toetsen aan de praktijk is het Leeskalenderproject ontwikkeld en als interventieprogramma dertig weken lang geïmplementeerd in het basisonderwijs in de periode van medio september 2013 tot en met medio mei 2014. Daarnaast hebben we de Toets Ontluikende Culturele Geletterdheid ontwikkeld om via een voor- en nameting na te kunnen gaan wat de effecten van de implementatie van de Leeskalender zijn op de ontluikende culturele geletterdheid van kinderen in groep 2 en in groep 4. In dit hoofdstuk ga ik specifiek in op het deelproject Kinderpoëzie zoals dat vertegenwoordigd was in de Leeskalender en in de Toets Ontluikende Culturele Geletterdheid. In $\$ 7.2$ ga ik nader in op het ontwikkelingstraject van de Leeskalender en de samenstelling van het aanbod van kinderpoëzie daarin; $\$ 7.3$ gaat in op de uiteindelijke selecties van kinderpoëzie voor groep 2 en voor groep 4 die uit dat ontwikkelingstraject zijn voortgekomen, met een overzicht van de criteria die aan die selecties ten grondslag liggen en een beschrijving van hoe de drie verwachte indicatoren van canoniciteit in die selecties aanwezig zijn. Na deze paragrafen over het tekstaanbod ga ik in op de Toets OCG. In \$7.4 bespreek ik de belangrijkste bestaande meetinstrumenten met betrekking tot (effecten van) kinderliteratuur en de Toets OCG in vergelijking met deze instrumenten. In $\$ 7.5$ geef ik een verantwoording van de operationalisering van de relatie tussen kinderpoëzie en ontluikende culturele geletterdheid in de deeltoets Kinderpoëzie; in $\$ 7.6$ beschrijf ik de ontwikkeling van de items in de deeltoets Kinderpoëzie en in $\$ 7.7$ beschrijf ik de uiteindelijke items zoals ze zijn opgenomen in de definitieve Toets OCG. Naast de Toets OCG zijn ook kwalitatieve methoden van dataverzameling gebruikt: $\$ 7.8$, ten slotte, bespreekt de methoden van kwalitatieve dataverzameling die zijn gebruikt en geeft een verantwoording van de validiteit, betrouwbaarheid en objectiviteit van de uitspraken die ik (in Hoofdstuk 9 \& 10) doe op basis van de analyse en interpretatie van deze kwalitatieve data.

\subsection{De Leeskalender: de ontwikkeling van een interventie}

De Leeskalender is voorafgaand aan, en ook tijdens, de daadwerkelijke implementatie op scholen in de experimentele conditie in een aantal fasen ontwikkeld en is na afloop geëvalueerd. In alle fasen van de ontwikkeling van de interventiematerialen zijn experts betrokken met deskundigheid op het gebied van kinderliteratuur, leesbevordering en boekpromotie, en de praktijk van het basisonderwijs (zie Hoofdstuk 6). Dit ontwikkelingstraject leidde tot beslissingen met betrekking tot de vorm van de Leeskalender (papier of digitaal), de omvang en samenstelling van het tekstaanbod (hoeveel teksten per week en welke teksten), de indeling van het tekstaanbod (al dan niet thematisch, verspreiding van de deelprojecten), de uitwerking van de aanbiedingsvormen (instructies 'Voor het lezen', 'Lezen' en 'Na het lezen'), en het aanleveren van het tekstaanbod (in boekvorm en/of in handleiding) (zie Hoofdstuk 6). Ik richt me hier op de wijze waarop de tekstselecties met bijbehorende aanbiedings- en verwerkingsinstructies vanuit het deelproject Kinderpoëzie tot stand zijn ge- 
komen. De fasen die de ontwikkeling van de Leeskalender heeft doorlopen, staan weergegeven in Tabel 11.

Tabel 11. Overzicht van de fasen in het ontwikkelingstraject van de Leeskalender

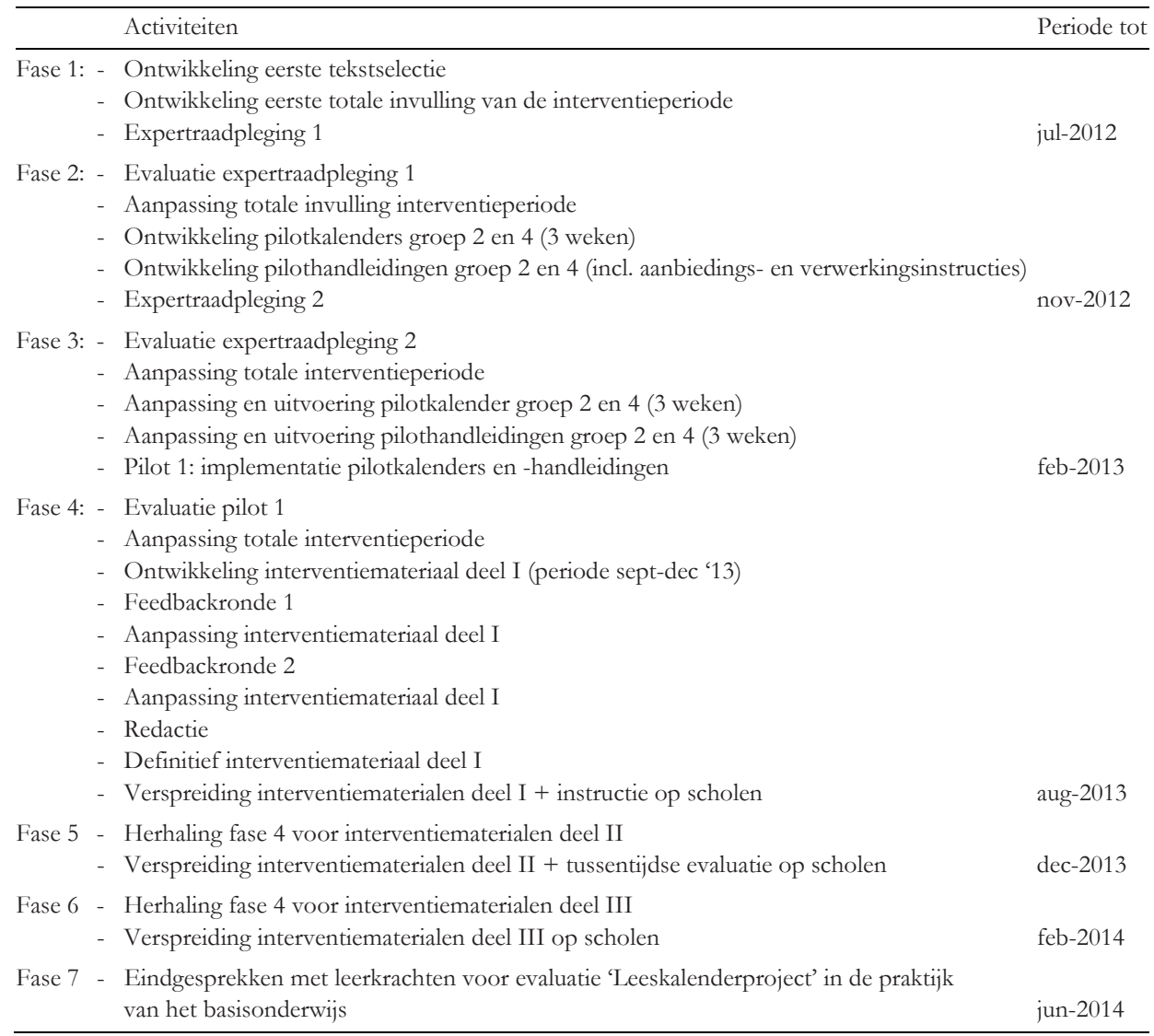

Dit ontwikkelingstraject heb ik in Hoofdstuk 6 al op projectbreed niveau besproken; in dit hoofdstuk bespreek ik per fase de belangrijkste inzichten en beslissingen in de ontwikkeling van het aandeel kinderpoëzie in de interventiematerialen.

\section{Fase 1: verzamelen van teksten en expertraadpleging 1}

Voor het samenstellen van de selectie poëzie voor de Leeskalenders ben ik begonnen met een algemene inventarisatie van bundels met baker- en kinderrijmen en -liedjes uit de orale volkscultuur. Op basis van een vergelijking van volksculturele poëzie voor kinderen in combinatie met literatuur- en ontwikkelingstheoretische en etnologische inzichten heb ik verschillende 'indicatoren van canoniciteit' geformuleerd en gespecificeerd voor groep 2 en groep 4 (zie Hoofdstuk 2, en $3 \mathrm{t} / \mathrm{m}$ 5). Tabel 12 geeft een overzicht van de geformuleerde verwachte indicatoren van canoniciteit in kinderpoëzie voor groep 2 en groep 4 . Vervol- 
gens heb ik een inventarisatie gedaan van auteurs en bundels van kinderpoëzie uit het literaire domein waarin de geformuleerde 'indicatoren van canoniciteit' in relatie tot ontwikkelingskenmerken van de kinderen aanwezig zijn ${ }^{115}$. Daarvoor ben ik eerst door een groot aantal bloemlezingen van kinderpoëzie gegaan om namen van auteurs en titels van gedichten te noteren die aansluiten op de indicatoren uit de volksculturele poëzie. Daarna heb ik verschillende bundels poëzie van genoemde auteurs bekeken en heb de gedichten en liedjes waarin een of meerdere van de indicatoren aanwezig zijn, opgenomen in een databestand $^{116}$. Daarin heb ik teksten gelabeld op basis van bron, verwachte leeftijdsgeschiktheid (groep 2 / groep 4), en de aanwezigheid en typering van de indicator(en) van canoniciteit. Vanuit die brede inventarisatie heb ik een eerste selectie van gedichten, rijmen en liedjes voor groep 2 en voor groep 4 samengesteld op basis van de eerste opzet van het projectbrede kalenderformat waarin we uitgingen van de aanbieding van vier teksten per week in groep 2 (39 teksten per deelproject over een periode van dertig weken) en vijf teksten per week in groep 4 (49 teksten per deelproject over een periode van dertig weken). Deze eerste selectie, gebaseerd op aansluiting op de vieringen in de kalender, de aanwezigheid en spreiding van indicatoren van canoniciteit, en de verwachte leeftijdsgeschiktheid van poezie, diende als input voor de eerste expertraadpleging, gehouden op 11 juli 2012.

Tabel 12. Overzicht van de verwachte indicatoren van canoniciteit in kinderpoëzie voor groep 2 en voor groep 4

\begin{tabular}{|c|c|c|}
\hline $\begin{array}{l}\text { KINDERPOËZIE } \\
\text { Verwachte 'indicatoren van canoniciteit' }\end{array}$ & Groep 2 & Groep 4 \\
\hline $\begin{array}{l}\text { 1. 'de directe evocatie van poëtisch } \\
\text { geritualiseerde handelingspatronen in de } \\
\text { context van dagelijkse routines, feesten } \\
\text { en spel' }\end{array}$ & $\begin{array}{l}\text { 'de directe evocatie van poëtisch } \\
\text { geritualiseerde fysieke } \\
\text { handelingspatronen in de context } \\
\text { van dagelijkse routines, feesten en } \\
\text { spel' }\end{array}$ & $\begin{array}{l}\text { 'de directe evocatie van poëtisch } \\
\text { geritualiseerde talige } \\
\text { handelingspatronen in de context } \\
\text { van dagelijkse routines, feesten en } \\
\text { spel' }\end{array}$ \\
\hline 2. 'muzikaal taalspel' & $\begin{array}{l}\text { 'vormen van muzikaal taalspel ter } \\
\text { ondersteuning van non-verbale } \\
\text { handelingspatronen' }\end{array}$ & $\begin{array}{l}\text { 'vormen van muzikaal taalspel als } \\
\text { relatief autonoom taalspel (zoals } \\
\text { tongbrekers)' }\end{array}$ \\
\hline 3. '(carnavaleske) nonsensicaliteit' & $\begin{array}{l}\text { 'carnavaleske vormen van } \\
\text { nonsensicaliteit bemiddeld door } \\
\text { subversief fysiek handelen in relatie } \\
\text { tot de sociale context en de } \\
\text { culturele categorieën (waarden en } \\
\text { normen) die in die sociale context } \\
\text { gelden' }\end{array}$ & $\begin{array}{l}\text { 'carnavaleske vormen van } \\
\text { nonsensicaliteit bemiddeld door } \\
\text { subversief talig handelen in relatie } \\
\text { tot de sociale context en de } \\
\text { culturele categorieën (waarden en } \\
\text { normen) die in die sociale context } \\
\text { gelden' }\end{array}$ \\
\hline Relatie tot ontwikkelingskenmerken & Pre-operationele cognitie $\rightarrow \rightarrow \rightarrow$ & Concreet operationele cognitie \\
\hline
\end{tabular}

De eerste expertraadpleging had tot doel feedback te krijgen op de eerste tekstselecties en opzet van het kalenderformat. Deze expertraadpleging had de vorm van een feedbackgesprek met twee experts met kennis en ervaring op het gebied van leesbevordering en boekpromotie in relatie tot het basisonderwijs (zie Hoofdstuk 6). De experts kregen van te vo-

\footnotetext{
${ }^{115}$ Het is van belang hierbij expliciet te vermelden dat ik in mijn tekstselectie niet heb gestreefd naar representativiteit op de gebieden 'de canoniciteit van specifieke auteurs' (op basis van publicatiecijfers, uitleencijfers of literaire prijzen) en/of 'perioden en stromingen' (gelijkmatige vertegenwoordiging van teksten/auteurs uit verschillende perioden).

${ }^{116}$ Een overzicht van alle geraadpleegde bloemlezingen en bundels is opgenomen in Bijlage 1.
} 
ren de tekstselecties per deelproject aangeleverd in een pakket bestaande uit een totaaloverzicht van de geselecteerde titels, kopieën van specifieke teksten en achtergrondinformatie over de opzet en het doel van het onderzoek en de selectiecriteria op basis waarvan de teksten per deelproject waren geselecteerd. De experts kregen twee concrete vragen voorgelegd:

a. Zijn de geselecteerde teksten volgens jullie geschikt voor de beoogde leeftijdsgroepen?

b. Missen we voor de hand liggende, uitermate geschikte teksten, m.a.w. doen zich schrijnende omissies voor in onze tekstselecties?

Het gesprek met de experts leverde veel ideeën en aandachtspunten op met betrekking tot de Leeskalender als middel in de klas, zoals omvang, vormgeving, ordening en aanbieding, zoals beschreven in Hoofdstuk 6. Er waren in deze fase geen inhoudelijke suggesties voor aanpassing van de gekozen teksten vanuit het deelproject Kinderpoëzie. De heroverweging van het aantal teksten dat per week werd aangeboden in de Leeskalenders, leidde wel tot het verwijderen van titels uit de selectie kinderpoëzie: de selectie werd teruggebracht tot 30 teksten voor groep 2 en 39 teksten voor groep 4 .

\section{Fase 2: ontwikekeling pilotkalenders en expertraadpleging 2}

De tweede fase van het ontwikkelingstraject van de interventiematerialen begon met een evaluatie van de eerste expertraadpleging. Op basis van die evaluatie werd de omvang van het aanbod van teksten in de Leeskalender voor groep 2 en groep 4 teruggebracht. Vervolgens richtten we ons in deze fase op de ontwikkeling van 3-weken-kalenders en handleidingen met bijbehorende aanbiedings- en verwerkingsinstructies in aanloop naar de eerste pilotstudie. De pilotmaterialen zijn echter eerst voorgelegd aan een panel van experts in de tweede expertraadpleging (zie ook Hoofdstuk 6). De tweede expertraadpleging vond plaats in de periode van 26 november 2012 tot 18 december 2012, met uitloop tot januari 2013. Het panel van experts bestond uit een onderwijsadviseur, drie leesbevorderaars/methodeontwikkelaars, zes groep 1-2 leerkrachten en drie groep 4 leerkrachten. Zij kregen een pakket toegestuurd met daarin een drie weken tellende proefkalender, vormgegeven op basis van de input van de experts uit de eerste expertraadpleging. In deze versie van de pilot-Leeskalender waren voor groep 2 drie teksten per week opgenomen en donderdag en vrijdag leeg gelaten; voor groep 4 waren vier teksten per week opgenomen en vrijdag leeg gelaten. Ook ontvingen de experts een bijbehorende proefhandleiding en kopieën van de geselecteerde teksten voor beide groepen ( 2 en 4). Zoals in Hoofdstuk 6 beschreven staat, is de experts gevraagd om het materiaal op verschillende onderdelen op basis van concrete stellingen te scoren op een 5-punts Likertschaal.

Vanuit het deelproject Kinderpoëzie waren drie teksten voor groep 2 opgenomen in de pilotkalender (een tekst per week): 'Juffrouw Boggemog' van Annie M.G. Schmidt, 'Ikkeltje, Tikkeltje, Spikkeltje Boem' van Shel Silverstein en 'Klap eens in je handen' van Ivo de Wijs. Bij elk van deze teksten was een aanbiedings- en verwerkingsinstructie geschreven en een kalenderblad gemaakt. Deze teksten waren geselecteerd op basis van aanwezige indicatoren van canoniciteit en verwachte leeftijdsgeschiktheid. Zowel 'Juffrouw Boggemog' als 'Ikkeltje, Tikkeltje, Spikkeltje Boem' bevatten nonsensicaliteit, in het eerste geval op het voor kleuters nog zeer abstracte niveau van het tijdverloop en in het laatste geval op 
het meer concrete niveau van de combinatie van handeling en object. In het laatstgenoemde gedicht is daarbij veel klankspel en herhaling, 'muzikaal taalspel', aanwezig dat kinderen naar verwachting stimuleert om vocaal mee te doen (meezeggen van de namen 'Ikkeltje, Tikkeltje, Spikkeltje Boem!'), terwijl 'Juffrouw Boggemog' meer aanleiding geeft tot meedoen met fysieke bewegingen (uitbeelden van haar activiteiten). 'Klap eens in je handen' is heel direct verbonden aan spel: het vers vormt een combinatie van een vinger- en klapspel waarbij wordt afgeteld. Dit vers zou kinderen naar verwachting moeten aansporen tot zowel vocaal als niet-vocaal meedoen (opzeggen en klappen). In alle gevallen is experts gevraagd de leeftijdsgeschiktheid van de tekst en bijbehorende activiteiten te beoordelen. Alle teksten en bijbehorende activiteiten in de proefkalender voor groep 2 werden door de experts $(\mathrm{N}=6)$ beoordeeld van 'voldoende' tot 'goed'117. De enige uitzondering was de leeftijdsgeschiktheid van 'Juffrouw Boggemog' die door een van de experts als 'onvoldoende' werd beoordeeld.

Voor groep 4 waren vanuit het deelproject Kinderpoëzie vier teksten opgenomen in het proefmateriaal (per week een tekst, waarvan een week met twee teksten uit een deelproject): 'Chinese taalles' van Willem Wilmink, 'Leuk is raar' van Koos Meinderts en Harrie Jekkers, 'De heks van Sier-kon-fleks' van Annie M.G. Schmidt en 'Hongerige Harry' van Shel Silverstein. Ook hier was bij elk van de teksten een aanbiedings- en verwerkingsinstructie geschreven en een kalenderblad gemaakt. 'Chinese taalles' is puur muzikaal taalspel, maar vergt enige oefening en flexibiliteit van leerkrachten; 'Leuk is raar' is een opeenvolging van omkeringen en bevat regels die mogelijk ongewenste reacties oproepen in de klas ('Achmed komt uit Holland/ En Johan is een Turk./ Mijn moeder is een kerel/ En mijn vader draagt een jurk'); 'De heks van Sier-kon-fleks' bevat verouderd taalgebruik en moeilijke woorden ('een mokkastel', 'een griffier'), maar kent een sterke interne structuur die dat mogelijk compenseert; en 'Hongerige Harry' is een voorbeeld van een extreem hyperbolische weergave van eetlust, maar is ook een complex gedicht vanwege de abstracte inhoud en de vrije versvorm. Ook hier is de experts gevraagd naar de leeftijdsgeschiktheid van de teksten en bijbehorende activiteiten. Opnieuw werden alle teksten en bijbehorende activiteiten in de proefkalender, nu voor groep 4, door de relevante experts $(\mathrm{N}=4)$ beoordeeld van 'voldoende' tot 'goed'. De enige uitzondering hier was de leeftijdsgeschiktheid van de activiteiten rond 'De heks van Sier-kon-fleks' die door een expert werden beoordeeld als 'onvoldoende' vanwege de moeilijke woorden die inhoudelijke verwerking in de weg zouden staan.

\section{Fase 3: Een eerste kijkje in de schoolklas}

Op basis van expertraadpleging 2 zijn de pilotmaterialen aangepast. De laatste stap in de ontwikkeling van de Leeskalenders bestond uit een drie weken durende pilotstudie, uitgevoerd in de periode van 18 februari tot en met 8 maart 2013, in een groep 1-2 en een groep 3-4 van Montessorischool De AQUAmarijn in 's-Hertogenbosch en in drie groepen 1-2 en een groep 4 van Brede School Moesel in Weert. In de deelnemende groepen werd gewerkt met proefversies van de Leeskalender. Naast de Leeskalender ontvingen de leerkrachten van de deelnemende groepen ook een handleiding. Deze handleiding bevatte per tekst

${ }^{117}$ De 5-punts Likertschaal was als volgt onderverdeeld: $1=$ helemaal niet, $2=$ onvoldoende, $3=$ voldoende, 4=ruim voldoende, 5 =goed. Stellingen luidden bijvoorbeeld: 'Dit vers sluit aan op de leeftijd van de kinderen'. 
instructies die zijn onderverdeeld in 'Voor het lezen', 'Lezen' en 'Na het lezen'. Deze indeling is gebaseerd op de indeling die in verschillende leesbevorderingsmethoden in het basisonderwijs wordt gehanteerd en is dus herkenbaar voor leerkrachten. De introductieactiviteit die onder 'Voor het lezen' beschreven staat, gaat steeds uit van de afbeelding op het bijbehorende kalenderblad en vormt een korte opstap naar de tekst. Kinderen worden daarmee aangespoord bepaalde verwachtingen te formuleren over de vorm en/of de inhoud van de tekst die volgt, wat hun tekstbegrip kan ondersteunen. Ook werd de leerkrachten in deze pilot gevraagd om een logboek bij te houden. Per dag dat ze met de Leeskalender werkten, gaven ze in het logboek een waardering voor de mate waarin de aanbieding ('Voor het lezen') de nieuwsgierigheid van de kinderen opwekte en voorkennis activeerde, de mate waarin de kinderen aandacht hadden voor de tekst ('Lezen'), en de mate waarin de verwerking ('Na het lezen') bijdroeg aan het begrip van de tekst en de beleving van de tekst. Verder was er ruimte in het logboek om toelichting te geven op de waarderingen en om reacties van kinderen bij de tekst en bij de verwerking te noteren. Ook hielden leerkrachten bij hoeveel tijd ze die dag hadden besteed aan de Leeskalenderactiviteit. Daarnaast hebben we tijdens deze pilot geobserveerd in de deelnemende groepen om zoveel mogelijk inzicht te krijgen in wat werkt en wat niet, hoe leerkrachten met het materiaal omgaan en hoe kinderen erop reageren. Ten slotte zijn na afloop van de pilot gesprekken gevoerd met de leerkrachten waarin we ze vroegen naar hun algemene ervaringen met de Leeskalender, naar hun mening over de aangeboden teksten en de wijze van aanbieden en verwerken, en naar hun mening over de vormgeving van de Leeskalender.

De inzichten uit de pilot die leidden tot aanpassing van de interventiematerialen op projectbreed niveau heb ik in Hoofdstuk 6 al besproken. Ik beperk me hier tot een aantal voorbeelden met betrekking tot de kinderpoëzie. Zo observeerde ik in een van de kleutergroepen bij de aanbieding van 'Juffrouw Boggemog': een relatief moeilijk gedicht omdat hier een nonsensicaal spel met de tijd wordt gespeeld. Tijdens de pilot zag ik echter hoe de leerkracht 'Juffrouw Boggemog' als personage helemaal tot leven liet komen, wat sterk bijdroeg aan de beleving en het plezier van de kinderen en ook hun begrip ondersteunde. Het begint ermee dat op de Leeskalender een afbeelding te zien is van een kalender waar op de datum van die dag 'Juffrouw Boggemog' staat geschreven. De leerkracht wijst erop dat dat betekent dat ze jarig is, want 'ze staat op de kalender!' Ze vraagt of de kinderen juffrouw Boggemog kennen, want dan kunnen ze haar feliciteren. De kinderen kijken om zich heen, maar niemand kent die juffrouw. Na het aanbieden, voorlezen en verwerken van het gedicht, komt de leerkracht hier weer op terug:

De leerkracht wil de bespreking van juffrouw Boggemog afronden. "Als jullie nog iets bedenken dat je tegen juffrouw Boggemog wilt zeggen, dan kan je dat straks nog even aan mij doorgeven," zegt ze. "Wanneer gaan we haar dan bellen?" vraagt een van de kinderen uit het niets. Dat brengt de leerkracht op een idee. "We kunnen haar nu wel bellen, dat kan nog wel even. Dan kunnen we haar meteen feliciteren." De leerkracht pakt haar telefoon en doet of ze juffrouw Boggemog aan de lijn krijgt. De kinderen kijken vol spanning toe. De leerkracht zegt dat ze juffrouw Boggemog willen feliciteren en de kinderen zingen uit volle borst mee met 'Lang zal ze leven'. De leerkracht besluit het telefoongesprek met: "Ik moest van S. zeggen dat u wel wat meer moet drinken, en ik 
zou u wel willen aanraden uw voeten wat vaker te wassen, anders gaan ze zo stinken." Om dit laatste moeten verschillende kinderen besmuikt lachen, alsof ze vinden dat je dat eigenlijk niet kan zeggen. De leerkracht zegt juffrouw Boggemog gedag. (observatie pilot 1 Weert, groep 1-2a, 19-02-2013)

In dezelfde week vertelt de leerkracht ons dat een jongetje uit de klas de volgende ochtend had gevraagd of ze juffrouw Boggemog nog had gesproken en of het wel goed met haar ging. Juffrouw Boggemog werd een concrete persoon. Dit makkte het makkelijker voor de kinderen om te bedenken wat er vreemd, of zorgwekkend, was aan haar gedrag. De vraagstelling in de handleiding ging steeds uit van de maanden van het jaar ('wat doet juffrouw Boggemog in januari?' etc.), maar de leerkracht trok de verwerking naar het concrete niveau: "Die juffrouw Boggemog moeten we een lesje leren," zegt een van de kinderen. "Welk lesje moet ze dan leren?" vraagt de leerkracht. "Stel, ik ben juffrouw Boggemog, wat zouden jullie dan tegen mij zeggen?" vraagt ze. Een van de kinderen zegt dat ze meer moet drinken. Een jongen merkt op dat ze ook moet eten (wat opvallend / opmerkzaam is omdat eten helemaal niet voorkomt in het gedicht). "Als ze zo weinig drinkt dan wordt ze een rozijntje," zegt een jongen. Die concretisering in de verwerking heb ik gebruikt als uitgangspunt voor de definitieve instructie waarin niet alleen aandacht is voor het abstractere niveau van het tijdverloop, maar ook voor het concrete niveau van het handelen van juffrouw Boggemog.

Uit de observaties in groep 4 werd onder meer duidelijk dat de moeilijke (verouderde) woorden in 'De heks van Sier-kon-fleks' geen probleem hoeven vormen voor de beleving en het plezier van de kinderen. In groep 3-4 op de school in 's-Hertogenbosch observeerde een van de andere onderzoekers in het project:

... een mokkastel. Weten de kinderen wat dat is? Ze besluiten om met Google een afbeelding te zoeken op het digibord. Daar komt een soort melk- en suikerkannetje en een koffiekan in beeld. Dat is het dus. De leerkracht herhaalt: op woensdag neemt ze de kolonel en verandert hem in een mokkastel, en op woensdag pakt ze het mokkastel en tovert het om in een kolonel. De vreugd is maar van korte duur: hij zit nog onder het glazuur. Ze controleert of de kinderen het woord glazuur kennen. Een kind kan dat heel goed vertellen: dat is het plakkerige spul dat op cakejes zit. Daarmee zit de kolonel nu dus onder... Vervolgens vraagt de lkr.: Was er niet ook iets met een dameskoor? Eén kind weet het meteen: die schoof ze onder de voordeur door. De lkr. leest nu ook het couplet over de griffier nog uit de reader voor en legt de woorden griffier en vloeipapier kort uit. Daarna laat ze het liedje nog eens horen. De kinderen luisteren weer met veel plezier naar het lied. Ze bewegen mee en zingen spontaan ook al stukjes mee van het refrein. Sommige stukjes uit het couplet kunnen ze mee afmaken (de rijmwoorden). Tot slot vraagt de leerkracht of de mensen nu blij zijn met de heks van Sier-kon-fleks. De kinderen roepen in koor: néé! De lkr bevestigt dit. In het gedicht staat ook dat ze haar het bos in willen jagen. Eén kind roept dan: Maar heksen bestaan niet! Lkr: in versjes en liedjes wel. Een ander kind: En in sprookjes! (observatie pilot 1 Den-Bosch, groep 3-4, 28-02-2013) 
Er zijn tegenwoordig genoeg hulpmiddelen in de klas om de betekenis van woorden te achterhalen, zelfs wanneer de leerkracht ze niet kent. Wel is het van belang niet al teveel nadruk op de woorden te leggen in de verwerking van de tekst. Het aanbieden van dit gedicht als lied helpt daarbij: het taalgebruik vormt geen belemmering voor het plezier dat kinderen beleven aan het meezingen van het lied en het meebewegen met de muziek. Mijn angst was anderzijds dat muziek wellicht teveel zou afleiden van de tekst, maar dat - zo blijkt ook uit de pilotobservatie van de aanbieding van 'Leuk is raar' - is niet het geval. De kinderen in groep 4 reageerden op beide pilotscholen bijzonder positief op de liedjes én bleken tegelijk ook aandacht voor de inhoud te hebben. In de definitieve Leeskalenders heb ik daarom verschillende gedichten in liedvorm laten aanbieden. De pilot leverde, wat betreft het aanbod van kinderpoëzie in de Leeskalenders, vooral zeer waardevolle inzichten en inspiratie op met betrekking tot de aanbiedings- en verwerkingsinstructies. De kinderen bleken alle geselecteerde poëzieteksten in de pilotkalenders te waarderen, met in groep 4 de aanvulling dat teksten met moeilijke woorden, zoals 'De heks van Sier-kon-fleks', in liedvorm toch zeer bij de kinderen in de smaak vallen.

\subsection{Kinderpoëzie in de Leeskalender}

Het verwerven van 'cultureel waardevolle' teksten levert een belangrijke bijdrage aan de ontwikkeling van de ontluikende culturele geletterdheid van jonge kinderen. Die culturele waarde vatten we binnen dit onderzoeksproject niet zozeer op als kennis van 'klassieke titels' of van 'gecanoniseerde auteurs'. Die culturele waarde lezen we af aan het feit dat bepaalde genres of tekstsoorten en de specifieke formele en inhoudelijke kenmerken die daarin samenkomen al eeuwenlang deel uitmaken van de 'volkscultuur', "als aanduiding van de brede, alledaagse cultuur, waar iedereen, elite of volk, vreemd of eigen, in participeert." (Dekker et al, 2000b, p. 10) Het is die alledaagse cultuur en de tekstsoorten die daar van oudsher een vaste plaats in hebben die vorm geeft aan de ontluikende culturele geletterdheid van jonge kinderen. Door kinderpoëzie te selecteren die nauwe verwantschap toont met volksculturele vormen van 'het taalspel poëzie' zoals aanwezig in baker- en kinderrijmen kan naar verwachting aansluiting gevonden worden op de ontluikende culturele competentie $^{118}$ van kinderen in de pluriforme Nederlandse samenleving en van daaruit effectief worden bijgedragen aan de ontwikkeling van hun ontluikende culturele geletterdheid. Door te bekijken wat baker- en kinderrijmen kenmerkt (Hoofdstuk 2 en $3 \mathrm{t} / \mathrm{m}$ 5), heb ik de eerdergenoemde verwachte 'indicatoren van canoniciteit' in kinderpoëzie voor groep 2 en voor groep 4 geformuleerd (zie \$7.2). Deze verwachte indicatoren zijn niet alleen op basis van theoretische en hermeneutische onderbouwing geformuleerd, maar ook geïmplementeerd in het basisonderwijs via de Leeskalender zodat de verwachtingen 'getoetst' kunnen worden aan de werkelijkheid. Op basis van de verwachte indicatoren heb ik voor het deelproject Kinderpoëzie dertig teksten geselecteerd voor de Leeskalender voor groep 2 en

118 'Ontluikende culturele competentie' heeft betrekking op wat kinderen aan cultuur kunnen verwerven; 'ontluikende culturele geletterdheid heeft betrekking op wat kinderen aan cultuur bebben verworven. 
negenendertig ${ }^{119}$ teksten voor de Leeskalender voor groep 4. In Bijlage 2 is een overzicht opgenomen van het totale tekstaanbod voor groep 2 en voor groep 4.

De tekstselectie is aangeboden in de vorm van een kalender met daarin vieringen die verschillende culturele groepen in de Nederlandse samenleving vertegenwoordigen. Daarbij hebben we gekozen voor een vast ritme in de verdeling van teksten uit de drie deelprojecten over de dagen van de week (zie Hoofdstuk 6). Dit betekende dat bij de uiteindelijke selectie van gedichten, rijmen en liedjes ook meespeelde op welke concrete data de poëzie aan bod kwam in de verschillende versies van de Leeskalender. Bijzondere dagen met bijbehorende gebruiken als 1-april, Sint-Maarten of Çocuk Bayrami120 waren vooral van invloed op het deelproject dat in de kalenders op de precieze datum van die feestdag aan de beurt was. Bij vieringen als Sinterklaas, Pasen of (Nederlands, Chinees of Islamitisch) Nieuwjaar hebben we getracht het tekstaanbod thematisch op de viering af te stemmen in een periode voorafgaand aan of na afloop van de viering zelf. De aansluiting op de vieringen van het jaar zoals ingegeven door het kalenderformat sloot in het deelproject Kinderpoëzie nauw aan op het pragmatische kenmerk van kinderrijmen dat 'de zang van het kind vrijwel nooit abstract is, maar gebonden aan de feesten van het jaar en vooral aan het spel' (Kes, Pollmann \& Tiggers, 1947, p. 7). Toch vroeg de aansluiting op feestdagen in de kalender soms om enig kunst- en vliegwerk. Zo zijn er verrassend weinig gedichten, rijmen en liedjes die expliciet horen bij 1 april (er zijn vooral veel moppen), maar omdat poëzie in de volledige versie van de Leeskalenders wel op die datum werd aangeboden, moest ik zoeken naar aansluiting. Daar kwam bij dat we de selectie van teksten zo wilden samenstellen dat verschillende culturele en religieuze groepen in de Nederlandse samenleving niet alleen in de feesten, maar ook in specifieke teksten gerepresenteerd waren. We trachten tenslotte vorm te geven aan het uitgangspunt dat 'culturele geletterdheid' in de pluriforme Nederlandse samenleving betrekking moet hebben op "de verschillende culturen die de collage van onze samenleving uitmaken", waarbij het nog steeds gaat "om gedeelde kennis die allen, ongeacht hun culturele achtergrond, moeten verwerven, maar het is kennis van culturele verscheidenheid." (Meijer, 1996, pp. 25-26; Hoofdstuk 1) Daarom is zowel in de feestdagen die aan bod kwamen als in de keuze voor teksten rekening gehouden met een bepaalde mate van culturele pluriformiteit. Pluriformiteit die in het tekstaanbod hoofdzakelijk betrekking heeft op etniciteit en religie, maar ook op leeftijd, gender, et cetera. Religieuze diversiteit is overigens uitsluitend in het deelproject Deugden \& Dilemma's expliciet meegewogen in de selectie van verhalen. Zo waren er dus verschillende criteria die, naast de geformuleerde 'indicatoren van canoniciteit', een rol speelden in de selectie van teksten. Bij

\footnotetext{
119 Op basis van een interventieduur van dertig weken met eens in de drie weken een extra tekst per deelproject zouden dit veertig teksten per deelproject moeten zijn, ware het niet dat in drie van de interventieweken een dag minder te vullen was vanwege feestdagen. In die kortere weken is ervoor gekozen de extra tekst te laten vallen, dus zijn er van elk deelproject negenendertig teksten opgenomen in de kalender voor groep 4.

${ }^{120}$ Çocuk Bayrami is een Turkse feestdag die wordt gevierd op 23 april. Deze dag werd door Atatürk uitgeroepen tot nationale dag van de Turkse soevereiniteit en tot nationale Kinderdag. De combinatie van de twee onderwerpen van deze feestdag komt tot uiting in het feit dat een aantal kinderen, als vertegenwoordigers van alle kinderen uit heel Turkije, op deze dag mag plaatsnemen in de functies van president, premier, kabinetsleden en provinciale bestuurders en in die tijdelijke posities besluiten mogen nemen over specifieke onderwijs- en milieuzaken. In de laatste decennia van de $20^{\text {ste }}$ eeuw heeft de feestdag een internationaler karakter gekregen doordat kinderen van over de wereld uitgenodigd worden om in Turkije deel te nemen aan de vieringen en zich uit te spreken voor internationale vrede en broederschap. Sinds 1979 erkent UNICEF de viering van 23 april in Turkije als internationale kinderdag.
} 
het selecteren van teksten voor de Leeskalender vanuit het deelproject Kinderpoëzie zijn al met al de volgende criteria in acht genomen:

Tabel 13. Overzicht van alle criteria die zijn gehanteerd in de samenstelling van het aanbod van kinderpoëzie in de Leeskalenders

Criterium en specificatie

1 Teksten zijn geselecteerd op basis van de aanwezigheid van één of meerdere van de in de vorige hoofdstukken beschreven 'indicatoren van canoniciteit'

a. De directe evocatie van poëtisch geritualiseerde handelingspatronen in de context van feesten en spel, verdeeld in:

i. De evocatie van poëtisch geritualiseerde fysieke handelingspatronen;

ii. De evocatie van poëtisch geritualiseerde talige handelingspatronen.

b. De aanwezigheid van muzikaal taalspel, onderverdeeld in:

i. Muzikaal taalspel ter ondersteuning van non-verbale handelingspatronen;

ii. Muzikaal taalspel als spel op zich.

c. De aanwezigheid van nonsensicaliteit, onderverdeeld in:

i. Carnavaleske nonsensicaliteit bemiddeld door subversief fysiek handelen;

ii. Carnavaleske nonsensicaliteit bemiddeld door subversief talig handelen.

2 Teksten zijn geselecteerd op basis van hun theoretisch veronderstelde leeftijdsgeschiktheid voor kinderen in groep 2 en kinderen in groep 4, zoals aangegeven in de hoofdstukken waarin de 'indicatoren van canoniciteit' zijn uitgewerkt

a. Theoretische inzichten met betrekking tot de cognitieve ontwikkeling van kinderen;

b. Theoretische inzichten met betrekking tot de taalontwikkeling van kinderen;

c. Theoretische inzichten met betrekking tot de humorontwikkeling van kinderen.

3 De teksten vertegenwoordigen een bepaalde mate van culturele pluriformiteit

a. Pluriformiteit in talen;

b. Pluriformiteit in 'bron' van teksten (orale volkscultuur/kinderliteratuur);

c. Pluriformiteit in thema's;

d. Pluriformiteit in feesten (zie criterium 4).

4 De teksten zijn, waar nodig, geselecteerd in aansluiting op de feestdagen en vieringen zoals opgenomen in de Leeskalender

5 Een deel van de teksten is zowel in de Leeskalender voor groep 2 als in de Leeskalender voor groep 4 opgenomen, zodat een vergelijking gemaakt kan worden tussen reacties van leerlingen in groep 2 en in groep 4

De verschillende criteria die ten grondslag hebben gelegen aan de samenstelling van het aanbod, in combinatie met het feit dat de Leeskalenders ook teksten bevatten vanuit de deelprojecten Deugden \& Dilemma's en Narratieve Genres, dragen het risico in zich dat het aanbod zo verstrooid raakt dat er voor leerkrachten noch kinderen enige samenhang in te ontdekken valt. Dit zou ook negatieve gevolgen kunnen hebben voor de mate waarin we gerichte 'opbrengsten' van dit aanbod mogen verwachten op de Toets Ontluikende Culturele Geletterdheid. Voor leerkrachten en kinderen kwam de samenhang voort uit het feit dat herkenbare genres of tekstsoorten ${ }^{121}$ geregeld terugkwamen in het aanbod. Daarbij gaf de vaste volgorde van de soorten teksten in de week houvast, alsmede de inbedding in het

121 Religieuze verhalen en fabels, poëzie (gedichten, rijmen en liedjes), en sprookjes, raadsels, schelmenverhalen, serieverhalen en griezelverhalen. 
kalenderformat. Vanuit onderzoeksperspectief gezien zijn het de verwachte indicatoren van canoniciteit die samenhang in het aanbod binnen de deelprojecten aanbrengen.

\section{De evocatie van poëtisch geritualiseerde handelingspatronen in de Leeskalender}

In Hoofdstuk 2 en 3 heb ik al beschreven dat baker- en kinderrijmen, als onderdeel van terugkerende routines en rituelen in het dagelijks leven, erop wijzen dat jonge kinderen het 'taalspel poëzie' aanvankelijk in concrete tekstexterne communicatiesituaties (pragmatische contexten) leren spelen. Daarin is nog geen sprake van een poëtische leeshouding, maar van een poëtische gebruikshouding van waaruit de 'gebruiker(s)' van slaap- en kietelliedjes, wensliedjes en scheldrijmen, aftel- en klapspelrijmen het 'taalspel poëzie' (mee)spelen. Dat 'taalspel poëzie' is dus ingebed in concrete, handelingsgerichte, gebruikscontexten: “De zang van het kind is vrijwel nooit abstract. De zang is gebonden aan de feesten van het jaar en vooral aan het spel. Het lied heeft een functie in het kinderlijke leven." (Kes, Pollmann \& Tiggers, 1947, p. 7, cursief in origineel) Om dit kenmerk operationeel te maken als criterium om poëzie voor kinderen te selecteren, moest de vraag worden beantwoord: waaraan herkennen we of een tekst gebonden is aan dagelijkse routines, feesten en spel? Waarin komt de relatie tussen tekst en gebruikscontext tot uitdrukking? In Hoofdstuk 3 heb ik de relatie tussen poëzie en de gebruikscontexten waarin het van oudsher is ingebed in het leven van kinderen uitgewerkt en heb ik die verbondenheid aan feesten en spel vertaald in de indicator: 'de directe evocatie van poëtisch geritualiseerde handelingspatronen in de context van feesten en spel'. Ik heb ook laten zien dat die relatie tussen tekst en gebruikscontext globaal in twee soorten geritualiseerde handelingspatronen is onder te verdelen: (i) fysieke handelingspatronen (zoals wiegen, dansen, klappen, et cetera), en (ii) taalhandelingen (zoals wensen, aftellen, verwensen, vragen, et cetera).

In de selectie van poëzie voor de Leeskalenders is dit onderscheid bijvoorbeeld zichtbaar in het verschil tussen de volgende twee teksten. Kleuters kregen in de laatste week voor de kerstvakantie het liedje "Boom versieren tiere liere liere/ boom versieren, doe maar mee!/ Kijk daar hangen de sterretjes al,/ tussen de groene takken./ Boom versieren tiere liere liere/ boom versieren, doe maar mee!" aangeboden. Daarin wordt opgeroepen tot concrete handelingspatronen die horen bij het versieren van de kerstboom. Kinderen in groep 4 kregen het volgende rijm aangeboden waarin het toewensen (of verwensen) als taalhandeling in de context van de viering van het begin van het nieuwe jaar centraal staat: "Ik wens je al wat wenselijk is, / een bochel die ordentelijk is,/ twee benen als een ooievaar,/ dat wens ik je voor het nieuwe jaar,/ een kop met rooie luizen,/ dan heb je wat te pluizen." Ik wil echter ook kwalitatieve vergelijkingen kunnen maken van de rol die de evocatie van fysieke handelingspatronen versus taalhandelingen speelt in de aansluiting op de culturele competentie van kinderen in groep 2 versus kinderen in groep 4. Daarom kregen kinderen in groep 2 naast poëzie die gekenmerkt wordt door de evocatie van poetisch geritualiseerde fysieke handelingspatronen, ook poëzie aangeboden waarin poëtisch geritualiseerde taalhandelingen centraal staan, zoals 'Ik wens je al wat wenselijk is', maar ook 'Lieve Sinterklaas' en 'Als ik nou een hondje mag' waarin vragen (en dreigen) centraal staat. Kinderen in groep 4 kregen naast poëzie waarin geritualiseerde taalhandelingen centraal staan, ook poëzie aangeboden die gekenmerkt wordt door de evocatie van gerituali- 
seerde fysieke handelingspatronen. Bijvoorbeeld het rijm "Dubbel dubbel dit dit,/ dubbel dubbel dat dat,/ dubbel dit,/ dubbel dat,/ dubbel dubbel dit dat", waarin de woorden geen andere functie hebben dan het aangeven van het specifieke klappatroon (zie ook Hoofdstuk 4).

De volgende vieringen zijn in de selecties van poëzie in de Leeskalenders vertegenwoordigd: Nieuwjaar, Driekoningen, Chinees Nieuwjaar, Carnaval, 1-april, Koningsdag, Pasen, Çocuk Bayrami, Werelddierendag, Sint Maarten, Sinterklaas, Kerstmis en verjaardagen. De poëzie die rechtstreeks is verbonden aan spelvormen omvat klapspelrijmen, telrijmen, het aftelrijm (bij verstoppertje) en 'meestamprijmen', en verder zijn er verschillende taal- en uitspraakrijmen opgenomen voor zowel groep 2 als groep 4. Terugkerende routines zijn ook in het poëzie-aanbod vertegenwoordigd, van Opa Bakkebaard die van alles doet in zijn huisje tot Juffrouw Boggemog die van alles doet door het jaar heen, maar vormen geen externe contexten van tekstgebruik. In zowel de Leeskalender voor groep 2 als de Leeskalender voor groep 4 is daarnaast een gedicht opgenomen waarin de 'gebondenheid aan de feesten van het jaar' als het ware 'incongruent' aanwezig is. In groep 2 wordt die bijzondere categorie vertegenwoordigd door het gedicht '12 januari' van Hans en Monique Hagen: "sinterklaas/ is nu in Spanje/ ik probeer het toch een keer/ vanavond/ zet ik zachtjes/ mijn nieuwe schoenen neer” (1988). In groep 4 was dat het gedicht 'Vrolijk...' van Shel Silverstein, aangeboden op 25 maart: "Niemand hangt de klokjes op/ niemand bakt een taart/ niemand steekt de lichtjes aan/ niemand stuurt een kaart/ niemand gaat op zoek naar een ster/ niemand praat van vrede op aard/ en niemand bewondert een kerstboom/ op vijfentwintig maart." (1985) Hoe reageren kinderen op die evocatie van poëtisch geritualiseerde handelingspatronen in het kader van Sinterklaas en Kerstmis, maar dan 'misplaatst' in de tijd? Helpt de 'afwijking van de norm' de grenzen van deze contextuele 'indicator van canoniciteit' scherper te formuleren?

Buiten de pragmatische contexten die vormen van 'het taalspel poëzie' verbinden met de bredere culturele gemeenschappen waarin kinderen opgroeien (de gezinscultuur, de kindercultuur en de Nederlandse samenleving met de vele culturele groepen die daarin vertegenwoordigd zijn), moeten we er ook rekening mee houden dat 'de schoolklas' in dit onderzoek eveneens een contextueel kader vormt. Ook die context brengt eigen normen, waarden en gebruiken met zich mee en zal dus van invloed zijn op de aanbieding en verwerving van kinderpoëzie. In de vertaling van de verwachte 'indicatoren van canoniciteit' naar de selectie van poëzie voor de Leeskalenders heb ik hier rekening mee gehouden. Soms door poëzie te selecteren die de schoolcontext expliciet evoceert ('In de gekkedingen-school' of 'Dwaze droom'); soms door poëzie te selecteren die in zekere zin 'incongruent' is binnen die context, zoals het introduceren van speelplaatspoëzie in groep 4 ('Dubbel dubbel dit dit'). In de toelichting op de aanwezigheid van 'muzikaal taalspel' en met name '(carnavaleske) nonsensicaliteit' kom ik hier nog op terug. Omdat dit onderzoek beoogt bruikbare kennis voor het basisonderwijs op te leveren, kan ik 'de schoolklas' als pragmatische context niet negeren. 


\section{Murikaal taalspel in de Leeskalender}

Zoals ik in Hoofdstuk 4 heb uitgewerkt, kunnen veel teksten die van oudsher vorm geven aan 'het taalspel poëzie' zoals jonge kinderen dat thuis, op de peuterspeelzaal, kinderdagverblijf of kleuterschool en op de speelplaats leren spelen, gekarakteriseerd worden als vormen van 'muzikaal taalspel'. Eerst is alle poëzie voor jonge kinderen alleen maar klank en ritme die bepaalde geritualiseerde fysieke handelingspatronen begeleiden. Naarmate kinderen ouder worden, gaan ze ook plezier beleven aan poëzie waarin een spel met de formele en prosodische eigenschappen van taal op zich wordt gespeeld. Betekenis, in de referentiële zin van het woord, is in dergelijke poëzie ofwel volkomen afwezig, of speelt slechts een ondergeschikte rol: betekenis komt tot stand vanuit de functionele koppeling met de pragmatische context en/of vanuit de fysiek ervaarbare ritmische effecten die de specifieke ordening van taal in poëzie teweegbrengt (zie Hoofdstuk 2 en 3). Zien we 'muzikaal taalspel' in haar pragmatische context, dan is er binnen de indicator 'muzikaal taalspel' onderscheid te maken tussen: (i) vormen van muzikaal taalspel ter ondersteuning van nonverbale handelingspatronen, en (ii) vormen van muzikaal taalspel als relatief autonoom spel. Mijn verwachting is dat kinderen in groep 2 nog de voorkeur geven aan die eerste vorm terwijl kinderen in groep 4 al beter uit de voeten kunnen met de meer autonome vormen van muzikaal taalspel.

In de Leeskalender voor groep 2 is deze indicator in beide vormen vertegenwoordigd, maar ligt de nadruk vooral op murikaal taalspel ter ondersteuning van non-verbale handelingspatronen. Een gedicht als 'Lekker stampen met dit weer' van Joke van Leeuwen wordt niet alleen gekenmerkt door een opvallend ritme, maar zet ook heel expliciet aan tot meedoen. Verschillende dieren passeren de revue, allemaal met hun eigen manier van lopen, te beginnen met 'mamma beer': 'Lekker stampen met dit weer/ zei mamma beer/ zei mamma beer/ lekker samen stevig stampen/ tegen kou en tegen krampen/ poot omhoog en zet 'm neer/ zei mamma beer/ zei mamma beer.” (1984) Daarna volgen 'pappa kat' die sluipt, 'pappa haan' die paradeert als een soldaatje, en 'mamma vrouw' die helemaal niets van stampen moet weten en iedereen op de tenen laat lopen. De woorden in het gedicht vormen de aanwijzingen voor de bewegingen, niet meer en niet minder. Net als in 'Een meestampertje' (1977) van Karel Eykman waarin een rinoceros, een olifant, een nijlpaard en een mammoet samen muziek ${ }^{122}$ proberen te maken; net als in 'Klap eens in je handen' (in Smeekens, 2008) van Ivo de Wijs; net als in 'Boterhammen smeren' van Willem Wilmink: “Smeer nog maar een boterham,/ Amsterdam, Rotterdam,/ Boterhammen lust ik graag,/ Rotterdam, Den Haag." (2010) Deze teksten laten kinderen ritme en klank direct ervaren door meestampen, meeklappen en meezeggen. Bij een klankliedje als 'Epompee' kan bekeken worden in hoeverre de koppeling met fysieke handelingspatronen verschil maakt in de beleving en de waardering van kinderen in groep 2 door het eerst zonder bewegingen en vervolgens met een bijbehorend klapspel te laten aanbieden. Een uitspraakvers als 'Een kikker en een karekiet' is al veel sterker gericht op het meer 'autonome, puur verbale klankspel. Ook in groep 4 is 'muzikaal taalspel' in beide vormen vertegenwoordigd, maar ligt de nadruk vooral op murikaal taalspel in de vorm van verbale handelingspatronen, dus muzikaal taalspel als auto-

${ }^{122}$ Het feit dat elke strofe eindigt met "(ROMPETOMPETOM, ROMPETOMPETOM)”, zegt genoeg over het soort muziek. 
noom talig spel op zich. Dit komt bijvoorbeeld tot uitdrukking in poëzie met veelzeggende titels als 'Versje om te rappen (zonder einde)', 'Versje om te mompelen als je niet goed in slaap kunt komen' en 'Chinese taalles'. In deze voorbeelden ligt de nadruk heel duidelijk op de taal en op verbale uitingsvormen als rappen en mompelen. Ook 'Blauwbilgorgel' en 'Een kikker en een karekiet' zijn typische uitspraakverzen gebaseerd op muzikaal taalspel. Ter vergelijking zijn ook 'Pinokkio' en 'Wauwelwok' in de kalender voor groep 4 opgenomen: in deze gedichten, zeker in 'Wauwelwok', staat de beleving van het klankspel mogelijk op gespannen voet met de narratieve structuur van de gedichten. De in Hoofdstuk 4 beschreven ruimtelijke structuren zijn in het aanbod bijvoorbeeld vertegenwoordigd in 'Het poppenkopmannetje': een bijzonder type 'linguïstisch stapelvers' zoals ook 'This is the house that Jack built'. En zelfs poëzie die gebonden is aan specifieke contexten van tekstgebruik, kenmerkt zich in het aanbod voor groep 4 in de meeste gevallen door relatief autonoom taalspel. Zo is het vers 'Gekleurde eitjes en een haas', thematisch gekoppeld aan Pasen, volledig opgebouwd uit vergelijkingen: 'Zoals het zoemen bij een bijtje,/ zoals een juffrouw/meester bij de school,/ zoals het bord hoort bij het krijtje,/ zo hoort worst bij boerenkool./ etc.' (Busser \& Schröder, 2002) In het vers zelf ligt de nadruk dus primair op de poëtische structuur. Ditzelfde geldt voor 'Verstoppertje' en 'Vrolijk ...', de eerste gekoppeld aan het gelijknamige spel en de tweede aan Kerstmis, maar beide tekstueel gezien geconcentreerd rond een spel met de talige structuur. Waar de koppeling tussen 'muzikaal taalspel' en non-verbale handelingspatronen in het poëzie-aanbod voor groep 4 het meest expliciet vorm krijgt, is met het hierboven al geïntroduceerde klapspelrijm 'Dubbel dubbel dit dit'.

\section{(Carnavaleske) nonsensicaliteit in de Leeskalender}

In Hoofdstuk 5 ben ik ingegaan op verschillende vormen van nonsensicaliteit in poëzie voor kinderen. Nonsensicaliteit wordt beschouwd als structureel tekstkenmerk van bakeren kinderrijmen (zie o.a. Cammaerts, 1925; Chukovsky, 1971/1925; Anderson \& Apseloff, 1989; Mooren, 2000b; Bruijn \& Mooren, 2013). Veelal wordt daar zowel de 'betekenisloosheid' van klankrijmen mee aangeduid als de 'betekenisloosheid' van vreemde verhaaltjes en situatieschetsen waarin aspecten van de wereld op de kop worden gezet. Vanuit pragmatisch perspectief hebben die beide soorten van 'betekenisloosheid' echter verschillende functies (zie Hoofdstuk 2). Nonsensicaliteit heeft daarom binnen dit onderzoek alleen betrekking op de wijze waarop de werkelijkheid wordt voorgesteld in poëzie én, vanuit pragmatisch handelingsperspectief, ook op hoe de tekstexterne werkelijkheid wordt benaderd met poëzie. Zien we '(carnavaleske) nonsensicaliteit' in haar pragmatische context, dan is er binnen deze indicator onderscheid te maken tussen: (i) carnavaleske vormen van nonsensicaliteit, die een lichamelijke/affectieve ervaring van 'incongruentie' (de afwijking van het 'normale') teweegbrengen, bemiddeld door subversief fysiek handelen in relatie tot de sociale context en de culturele categorieën (waarden en normen) die in die sociale context gelden, en (ii) carnavaleske vormen van nonsensicaliteit, die een lichamelijke/affectieve ervaring van 'incongruentie' (de afwijking van het 'normale') teweegbrengen, bemiddeld door subversief talig handelen in relatie tot de sociale context en de culturele categorieën (waarden en normen) die in die sociale context gelden. Naast de carnavaleske vormen zijn 
er ook (iii) vormen van nonsensicaliteit die een meer intellectuele ervaring van 'incongruentie' teweegbrengen, bemiddeld door een voorstelling van de werkelijkheid die afwijkt van de 'natuurlijke wetmatigheden' die gelden in de waarneembare werkelijkheid of - op abstracter niveau - door een conceptueel spel met bijvoorbeeld tijd, taal, logica of getal. Gesimplificeerd samengevat komt het onderscheid tussen carnavaleske en 'intellectueler' vormen van nonsensicaliteit neer op het verschil tussen ervaringen van 'Dat mág (eigenlijk) niet' en ervaringen van 'Dat kán (eigenlijk) niet'. Ik verwacht dat kinderen in groep 2 de intellectueler vormen ook kunnen waarderen, mits gerelateerd aan de waarneembare werkelijkheid en ondersteund door visualisatie; voor groep 4 verwacht ik dat ze de intellectueler vormen ook kunnen waarderen en ook al op wat abstracter, conceptueler niveau. Echter, mijn verwachting is dat zowel kinderen in groep 2 als kinderen in groep 4 generaliter carnavaleske (op de sociaal-culturele context gerichte) nonsensicaliteit sterker waarderen dan de meer intellectuele (op kennis en logica gerichte) vormen van nonsensicaliteit. In relatie tot ontwikkelingskenmerken van kinderen in groep 2 en in groep 4 is te verwachten dat kinderen in groep 2 nog meer steunen op de waarneembare werkelijkheid en concreet handelen voor het begrijpen van nonsens terwijl kinderen in groep 4 ook op conceptueel niveau de 'incongruentie' in (carnavaleske) nonsenspoëzie al kunnen herkennen en waarderen.

In de Leeskalender voor groep 2 ligt de nadruk in de selectie van poëzie op concreet gecontextualiseerde en handelingsgerichte vormen van (carnavaleske) nonsensicaliteit. Het carnavaleske is in groep 2 ingebed in de waarneembare context van de school in het vers 'In de gekke-dingen-school' en in de viering van carnaval in het liedje 'Carnaval' die beide aanleiding geven tot het figuurlijk op de kop zetten van de wereld binnen de aangegeven kaders. Het oproepen van de ervaring van het carnavaleske via talig handelen krijgt vorm in bijvoorbeeld 'Ik ben lekker stout', 'Als ik nou een hondje mag' en 'Ik wens je al wat wenselijk is'. Intellectueler vormen van nonsens zijn in het aanbod voor groep 2 aanwezig in bijvoorbeeld 'Mr. Van Zoeten' die zijn voeten in het aquarium wast en 'Ikkeltje, Tikkeltje, Spikkeltje Boem' die op reis gaan in een vliegende schoen. Hoewel 'Opa Bakkebaard' in de originele versie van het lied heel normaal handelt (de vloer veegt met een bezem, de soep roert met een lepel, etc.), krijgt dit lied in de klas een nonsensicale draai doordat handelingen en objecten door elkaar worden gehusseld. In die uitvoering veegt hij de vloer met een lepel, roert zijn soep met een bezem, enzovoort. Dit lied biedt ook mogelijkheden tot fysiek meedoen via uitbeelden en zelf op soortgelijke manier 'incongruent' te handelen met objecten uit de klas. In deze drie voorbeelden van intellectueler vormen van nonsens is echter ook 'muzikaal taalspel' als indicator aanwezig, om te zien of en op welk niveau de kleuters deze poëzie waarderen. Ook 'Prins Piramente' die de hele dag door op zijn hoofd staat, kan worden nagedaan door de kinderen om te ervaren wat die letterlijke omkering doet met de wereld, maar is meer verhalend dan muzikaal. Een gedicht als 'Rond of vierkant' is abstracter omdat hierin de vormen van objecten worden omgekeerd (een vierkante ballon, etc.), maar is nog wel gekoppeld aan de concreet waarneembare werkelijkheid; anders is dat bij 'Juffrouw Boggemog' waarin het verloop van tijd incongruent wordt voorgesteld, wat voor de kleuters mogelijk nog te abstract is. In de Leeskalender voor groep 4 komen eveneens verschillende vormen van nonsensicaliteit voor. Carnavaleske nonsensicaliteit is hoofdzakelijk in talig handelen vertegenwoordigd: net als in groep 2 bevat de Leeskalender voor groep 4 'Ik ben lekker stout', 'Als ik nou een hondje mag' en 'Ik wens je al 
wat wenselijk is'. Daarnaast vormt de context van de schoolklas ook het kader waarbinnen een vers als 'Tien dingen naar keus die je kunt doen met dingen uit je neus' naar verwachting een carnavaleske beleving oproept, evenals het gedicht 'Dwaze droom'. In die droom staat het kind zelf voor een klas vol juffen en meesters en benut deze machtspositie voor het uitleven van allerlei wraakfantasieën (zie Hoofdstuk 5). Autonome vormen van nonsensicaliteit zijn voor groep 4 vertegenwoordigd in gedichten als 'Drie apothekertjes' en 'De mislukte fee'; ook 'Hongerige Harry' en 'De koning van Savoye' bevatten nonsens op abstract niveau, maar zijn tegelijk te typeren als grotesk vanwege de koppeling met het lichaam, dus worden mogelijk vooral op het niveau van de carnavaleske beleving begrepen en gewaardeerd.

Het mag duidelijk zijn dat in de verschijningsvormen van de drie 'indicatoren van canoniciteit' zowel in het poëzie-aanbod voor groep 2 als voor groep 4 variatie is aangebracht. Door deze variatie kan, op basis van kwalitatieve methoden van onderzoek, nauwkeuriger inzicht verkregen worden in hoe deze verwachte indicatoren van canoniciteit in kinderpoëzie werken in de praktijk van het basisonderwijs, zowel afzonderlijk als in samenspel. Hiermee kan de tweede empirische onderzoeksvraag voor mijn deelproject worden beantwoord (Hoofdstuk 9 en 10). Tegelijk heeft dit deelproject ook tot doel na te gaan welke effecten de aanbieding van kinderpoëzie heeft op de ontluikende culturele geletterdheid van kinderen in groep 2 en in groep 4 (de eerste empirische onderzoeksvraag). Om die vraag te beantwoorden, is het construct 'ontluikende culturele geletterdheid' voor de kinderpoëzie geoperationaliseerd naar het niveau van items in de Toets Ontluikende Culturele Geletterdheid.

\subsection{Het meten van ontluikende culturele geletterdheid}

Onze opvatting van het begrip 'ontluikende culturele geletterdheid', te weten kennis en begrip van kenmerken van breed gedragen (transculturele en langdurig geliefde) tekstsoorten en genres, hebben we geoperationaliseerd in de Toets Ontluikende Culturele Geletterdheid. Dat hebben we om twee redenen gedaan: (1) om na te kunnen gaan welke effecten ons aanbod van verhalen en poëzie heeft op de ontluikende culturele geletterdheid van kinderen in groep 2 en in groep 4, en (2) omdat de ontwikkeling van bruikbare kennis voor de praktijk van het basisonderwijs vereist dat wordt aangetoond dat 'methoden' effectief zijn in hun bijdrage aan het beoogde ontwikkelingsdomein (zie Hoofdstuk 8, §8.1). Operationaliseren betekent dat we het abstracte en niet rechtstreeks waarneembare construct 'ontluikende culturele geletterdheid' stapsgewijs hebben geconcretiseerd tot het niveau van vragen in de toets waarmee beoogd wordt bepaalde onderdelen van de ontluikende culturele geletterdheid van kinderen waarneembaar en meetbaar te maken. Welke 'opbrengsten' van de voorleeservaringen die kinderen via de Leeskalender hebben opgedaan, verwachtten we te zien na afloop van de interventie? En hoe verhoudt de Toets OCG, als meetinstrument voor het in kaart brengen van effecten van het (voor)lezen van kinderliteratuur, zich tot bestaande meetinstrumenten?

Het kwantificeren van de bijdrage die kinderliteratuur kan leveren aan de ontluikende culturele geletterdheid van kinderen is om verschillende redenen complex. Allereerst laten 
niet alle aspecten van die bijdrage zich vertalen naar objectief meetbare verschijnselen. Dit is vergelijkbaar met de redenen waarom de opbrengsten van cultuureducatie, waar ook leesbevordering en literatuureducatie onder vallen, in het onderwijs (nog) niet worden getoetst. De Onderwijsraad en Raad voor Cultuur stellen dat opbrengstgericht werken, zoals dat in het onderwijs heet, bij cultuureducatie wordt bemoeilijkt doordat bepaalde 'opbrengsten', zoals beleving, lastig te meten zijn: "De vraag is steeds in hoeverre meetinstrumenten die uitgaan van rationaliteit, objectiviteit en vergelijkbaarheid, bruikbaar zijn voor kunstzinnige processen die sterk verbonden zijn met emoties, subjectiviteit en individuele kwaliteiten (Van de Kamp, 2010)." (Onderwijsraad \& Raad voor Cultuur, 2012, p. 15) Dit geldt deels ook voor onze opvatting dat kinderliteratuur die nauwkeurig aansluit op de culturele competentie en voorkeuren van kinderen bijvoorbeeld kan bijdragen aan de ontwikkeling van het plezier dat kinderen aan poëzie en andere genres en tekstsoorten beleven. Hoe de beleving van verschillende genres en tekstsoorten bij kinderen wordt beïnvloed door de Leeskalender, is moeilijk te meten en is ook niet iets dat we zouden willen 'normeren'. Het is wel een aspect waar we op basis van kwalitatieve empirische methoden meer inzicht in beogen te krijgen omdat we simpelweg nog niet precies weten hóe jonge kinderen zich langdurig geliefde en cultureel diepgewortelde tekstsoorten en genres eigen maken. Een bijkomende uitdaging is het om effecten van (voor)leeservaringen bij jonge kinderen te meten (Ghesquière, 2009a, p. 130). Taal- en cognitieve ontwikkeling, niveau van geletterdheid, relatieve onervarenheid met toetssituaties en een kortere concentratieboog: dergelijke factoren moeten allemaal worden meegenomen in de ontwikkeling van een meetinstrument voor het 'toetsen' van deze doelgroep. Daarbij zijn gedrag, houdingen en voorkeuren, dus zaken waar respondenten zich bewust van zijn of kunnen worden, over het algemeen gemakkelijker te bevragen dan meer impliciete aspecten van kennis en begrip. "Leesgedrag, leesattitudes en genrevoorkeuren kan men gemakkelijk via grootschalig onderzoek in kaart brengen," schrijft Rita Ghesquière in Jengdliteratuur in perspectief: "Moeilijker is het om vat te krijgen op de tekstverwerking zelf. Lezen kinderen wat er staat? Hoe bouwen ze een verhaal op? Hoe interpreteren ze een verhaal en wat vinden ze mooi?" (p. 129) We willen binnen dit onderzoeksproject juist weten wat de effecten zijn van de aanbieding van verschillende tekstsoorten en genres op kennis en begrip van specifieke (kenmerken van) langdurig geliefde en (trans)cultureel diepgewortelde tekstsoorten en genres (soorten kinderpoëzie binnen dit deelproject) (ontluikende culturele geletterdheid). Er zijn in de loop der tijd verschillende instrumenten ontwikkeld waarmee aspecten van lezen ${ }^{123}$ bij kinderen in kaart worden gebracht, waarvan ik er een aantal kort bespreek. Deze specifieke voorbeelden laten een graduele ontwikkeling zien van de meting van (percepties van) gedrag en houdingen ten aanzien van lezen naar de meting van effecten van lezen op dieperliggende kennisstructuren en vaardigheden bij kinderen.

Een instrument dat jarenlang in het onderwijs is gebruikt, is de door Cor Aarnoutse en collega's in de jaren 1980 ontwikkelde Lees Attitude Schaal (LAS). De makers van de LAS onderscheiden drie componenten van het begrip 'leesattitude', ofwel "de houding van een

\footnotetext{
${ }^{123}$ Instrumenten die zijn ontwikkeld voor het meten van effecten van lezen op aspecten van geletterdheid (woordenschat met name) laat ik hier buiten beschouwing. Omdat wij uitgaan van de bijdrage die bestaande kinderliteratuur kan leveren aan de ontwikkeling van ontluikende culturele geletterdheid, zijn onderzoeksinstrumenten waarmee voorkeuren, kennis en vaardigheden die voortkomen uit 'natuurlijk' leesgedrag interessanter binnen het kader van dit onderzoek.
} 
leerling ten aanzien van lezen en leesmateriaal": "(a) de predispositie of neiging om op lezen en leesmateriaal te reageren, (b) de kennis of ervaring die een leerling heeft opgedaan ten aanzien van lezen en (c) de gevoelens die een leerling heeft ten aanzien van lezen" (Aarnoutse e.a., 1985, p. 314). De LAS brengt vooral in beeld of kinderen (vanaf groep 4) neigen naar een positieve of negatieve houding ten aan zien van lezen en leesmateriaal (Ghonem-Woets, 1993, p. 82). 'De kennis of ervaring die een leerling heeft opgedaan ten aanzien van lezen' heeft vooral betrekking op kwantitatieve aspecten van vrijetijdlezen. Kwalitatieve aspecten van kennis en ervaring (zoals welke formele en inhoudelijke kennis kinderen hebben opgedaan via hun leeservaringen) komen niet aan bod. Piet Mooren operationaliseerde 'leeservaring' voor zijn dissertatieonderzoek naar cultuurspreiding en leesbevordering door prentenboeken bij kinderen in groep 3. Hiervoor ontwikkelde hij de zogenoemde Leeservaringsschaal (LES). Met dit instrument ging hij de daadwerkelijke ervaring van kinderen met specifieke boeken en met voorlezen na, anders dan de LAS die de houding ten aanzien van lezen meet. Voor zijn onderzoek had hij die andere invalshoek nodig, los van het feit dat de LAS een niveau van lees- en schrijfvaardigheid vereist waarover kinderen in groep 3 nog niet beschikken:

\begin{abstract}
"Bovendien leek het in het kader van dit onderzoek niet zozeer zinvol om de attitude van leerlingen ten opzichte van boeken en lezen vast te stellen, als wel de mate waarin kinderen ook daadwerkelijk ervaring hebben met boeken en lezen. Het ligt immers in de rede om vooraf aan het ontstaan van een positieve leesattitude het een en ander aan leeservaring te veronderstellen en bij ontstentenis daarvan naar middelen te zoeken om die lacunes in kaart te brengen, met het oog op mogelijke compensatorische maatregelen in het onderwijs. Daartoe werd als instrument de Leeservaringsschaal (LES) ontwikkeld". (Mooren, 2000a, p. 387)
\end{abstract}

Omdat Mooren de leeservaring na ging van kinderen die nauwelijks konden lezen, bestaat de LES uit illustraties. In totaal zijn er 53 items waarvan er 5 "bedoeld zijn om na te gaan in hoeverre de kinderen vertrouwd zijn met het boek in het algemeen (bijvoorbeeld: Wie houdt het boek goed vast? Leest je pappa of mamma wel eens voor?), 5 items hebben betrekking op de voorkeur van kinderen en hun attitude ten opzichte van lezen in het algemeen, vergelijkbaar met de items uit de LAS (Wat zou je graag voor je verjaardag krijgen?), terwijl de overige 43 items zijn bedoeld om te weten te komen in hoeverre de kinderen bekend zijn met enkele genres van de kinderliteratuur, en vooral met hoofdfiguren uit meer of minder bekende kinderboeken als de helden uit hun mogelijke lectuur. Daarbij wordt de leerlingen telkens verzocht uit drie verschillende afbeeldingen het plaatje te kiezen van het genoemde personage (Hier ze je drie beren. Welke is Kummeling?) ${ }^{124}$ (...)." (Mooren, 2000a, p. 387) De LES werd gebruikt in een interventieprogramma met een voor- en nameting en controlescholen. Hoewel Mooren de voorkeur gaf aan individuele afname van de LES, werd de 'toets' om praktische redenen klassikaal afgenomen.

${ }^{124} \mathrm{Om}$ preciezer te zijn: de afgebeelde verhaalfiguren komen uit sprookjes, strips, kinderversjes en "meer of minder bekende verhalen als Jip en Janneke, Kummeling, Kikker en Pad, Brammert en Tissie en Kikker is verliefd" (Mooren, 2000a, p. 388). 
Door Groningse onderzoekers werd de VLES-K ontwikkeld: de VoorLeesErvaringsSchaal Kleuters. Dit instrument is ontwikkeld in het kader van het PICO-project (Picture Books and Concept Development ${ }^{125}$. De toets is een instrument waarmee aan het begin van de drie interventieprojecten waaruit het onderzoeksproject bestaat, na werd gegaan wat de verschillen in leeservaring tussen kinderen zijn ${ }^{126}$. De resultaten kunnen vervolgens gebruikt worden bij het interpreteren van de resultaten van de interventieprojecten (Gosen, Besselse, Glopper \& Berenst, 2009). De toets begint met een aantal algemene items over de ervaring van de kinderen met boeken, voorlezen en peuter- en kleutertijdschriften: "De hierbij horende algemene items stellen op een directe manier de ontluikende geletterdheid, de interesse voor boeken en het aanbod van boeken en de ervaring met voorlezen in de thuissituatie aan de orde." (pp. 71-72) Daarna volgen de items van wat de makers "de eigenlijke VLES-K" noemen: "Hier wordt de voorleeservaring gemeten door de ervaring met specifieke boeken te bevragen. Deze items meten dus op een meer indirecte manier de voorleeservaring" (p. 72). De toets is, anders dan de door Mooren gebruikte LES, individueel afgenomen. De eerste versie van de VLES-K was een papieren versie, de uiteindelijke versie digitaal. De items zijn voor het merendeel gebaseerd op prentenboeken, zoals de reeksen over Dikkie Dik, Nijntje, Dribbel, Kiki, Kleine Ezel en Kikker alsook losse titels en niet-prentenboeken, zoals Floddertje, Jip en Janneke en Pluk van de Petteflet van Annie M.G. Schmidt en de verhalenreeks over Iris en Michiel van Carry Slee. De keuze voor de titels werd bepaald door cijfers over de meest geleende en meest verkochte boeken van dat moment. Dit leidt ertoe dat de onderzoekers de volgende kanttekening zetten bij de duurzaamheid van de VLES-K: "De toetsen zullen van tijd tot tijd geactualiseerd moeten worden in verband met de gangbaarheid van de boeken die in de toets worden gebruikt" (p. 77).

Coosje van der Pol, een van de onderzoekers uit het hierboven genoemde project, ontwikkelde daarnaast een taak om literaire competentie bij kleuters te meten. Met haar interventieonderzoek, waarin leerkrachten 24 prentenboeken voorlazen in de klas met behulp van leesaanwijzingen, richtte ze zich op het vergroten van de literaire competentie van kleuters: "Een kleuter die literair competent is weet dat er binnen een prentenboek een wereld bestaat die opgebouwd is uit tekst en beeld. Deze wereld lijkt op de echte wereld, maar er zijn ook belangrijke verschillen. Een literair competente kleuter is zich bewust van deze verschillen en schept daar mogelijk genoegen in" (Pol, 2010, p. 49). Van der Pol onderscheidt daarbij drie subdomeinen waarin kleuters literaire competentie kunnen ontwik-

\footnotetext{
125 Een door de Programmaraad Onderwijsonderzoek (NWO-MaGW) gesubsidieerd onderzoeksproject, uitgevoerd aan de universiteiten van Groningen en Tilburg en het Freudenthal Instituut. In dit onderzoeksproject worden de effecten van het voorlezen van prentenboeken op drie domeinen nagegaan: wiskundige ontwikkeling, sociaal-emotionele ontwikkeling en literaire competentie.

${ }^{126}$ Over de inhoud van de VLES-K schrijven de onderzoekers: "Behalve dat er gesloten en open vragen worden gesteld, zijn de specifieke boekenitems ook verschillend van karakter: De helft van de items is gericht op het benoemen of herkennen van een personage (...) De andere helft van de items vergt een extra denkstap: er wordt bijvoorbeeld gevraagd naar een vriend van een personage of er dient een link te worden gelegd tussen twee personages (bijvoorbeeld bij een afbeelding van Takkie: wie horen hierbij?) Dergelijke vragen zijn opgenomen om uit te sluiten dat kinderen de items kunnen beantwoorden doordat ze alleen de hoofdpersonen uit verschillende media (te denken valt aan televisieprogramma's, DVD's en videospellen) of door merchandising (zoals bij figuren die gekoppeld zijn aan een bekende winkelketen in Nederland of aan fruithapjes). Daarnaast kent de keuze voor items waarbij een extra denkstap wordt vereist soms ook een praktische onderliggende reden. Wanneer een verhaalpersonage bijvoorbeeld geen duidelijke naam heeft of niet centraal staat, is het niet logisch de kinderen een personage te laten benoemen". (Gosen et al, 2009, p. 72)
} 
kelen: personages, spanning en ironische humor. Over welke mate van literaire competentie kinderen beschikken met betrekking tot die drie subdomeinen, leest ze af aan drie categorieën waarin ze uitingen van literaire competentie onderverdeelt, te weten: analyse, interpretatie en evaluatie. Wat analyse, interpretatie en evaluatie betekenen op het niveau van het jonge kind, definieert Van der Pol als volgt: "heeft kennis van de wijze waarop verhalen zijn opgebouwd en van vertelconventies" (analyse), "gebruikt zijn/haar kennis van verhalen en van de wereld om betekenissen toe te kennen aan een verhaal" (interpretatie), en "beschikt over een basisvocabulaire voor het spreken over verhalen en kent basiscriteria voor het beoordelen van verhalen" (evaluatie) (p. 49). Ze ontwikkelde een taak om de literaire competentie van kleuters te meten op basis van een vergelijking tussen een voor- en nameting. In navolging van wat A.H. Paris en S.G. Paris (2001) deden voor hun Narrative Comprehension Task, baseerde Van der Pol haar taak geheel op één prentenboek, namelijk Watje Wimpie ${ }^{127}$ van Jeanne Willis en Tony Ross. De Watje Wimpie-taak is individueel bij de kleuters afgenomen, deels met behulp van de computer. De taak bestond uit drie onderdelen. Ten eerste mochten kinderen het boek doorbladeren en commentaar leveren op wat ze zagen. Voor het tweede onderdeel van de taak kregen ze via de computer het verhaal te horen - ingesproken door een vrouwelijke kleuterleerkracht "met een duidelijke voorleesstem" (Pol, 2010, p. 137) - waarbij de bladzijden uit het prentenboek te zien waren op het scherm. De kinderen werd nu gevraagd het verhaal na te vertellen. Het derde onderdeel bestond uit vragen over het verhaal, die werden gesteld door degene die de toets afnam. Het waren open vragen zoals 'Wie doen er allemaal mee in het verhaal?', met zogenoemde 'prompts', vragen die erop gericht zijn om kinderen de vraag verder te laten beantwoorden, zoals 'Wie heb je allemaal gezien in het verhaal?' (p. 139). Alleen aan het derde onderdeel heeft Van der Pol scores toegekend; de andere onderdelen heeft ze kwalitatief geanalyseerd.

De hierboven kort besproken instrumenten laten, zoals gezegd, een ontwikkeling zien van het in kaart brengen van leesattitude, naar (voor)leeservaring, naar literaire kennis en vaardigheden. Hoewel ons doel niet is om de literaire competentie van kinderen te meten, zoals Van der Pol (2010) met de Watje Wimpie-taak deed, hebben kennis, begrip en vaardigheden waar onze Toets OCG een beroep op doet de meeste raakvlakken met het instrument voor het meten van literaire competentie (in vergelijking met de andere besproken instrumenten). Het belangrijkste verschil is echter dat wij interpretatie en evaluatie, als literaire vaardigheden, niet beschouwen als beoogde 'opbrengsten'128. In dit onderzoeksproject staan specifieke (trans)cultureel diepgewortelde tekstsoorten en -kenmerken centraal die naar verwachting effectief bijdragen aan de ontluikende culturele geletterdheid van kinderen in groep 2 en in groep 4. We hebben de Toets OCG ontwikkeld met het doel kennis en begrip met betrekking tot die specifieke tekstsoorten en -kenmerken bij kinderen te meten. Het verschil met literaire competentie, zoals geoperationaliseerd in de Watje Wimpie-taak, is dat wij waarneembaar willen maken welke kennis kinderen hebben opgedaan van

\footnotetext{
${ }^{127}$ De keuze viel op dit prentenboek, omdat het onderwerp en de vormgeving kleuters aanspreken, het boek zich leent voor een literaire leeswijze met aanknopingspunten voor vragen over de drie door Van der Pol onderscheiden indicatoren van literaire competentie (personages, spanning, ironische humor), tekst en beeld op een complementaire wijze het verhaal vertellen, en het boek hoogstwaarschijnlijk onbekend is bij de kinderen die de taak gaan maken (Van der Pol, 2010, p. 132).

${ }^{128}$ Dat wil zeggen: de implementatie van de Leeskalender is niet gericht op het verbeteren van interpretatieve of evaluatieve vaardigheden bij de kinderen.
} 
specifieke (trans)cultureel diepgewortelde tekstsoorten en -kenmerken, en niet of zij teksten als literatuur interpreteren en evalueren. De Toets OCG beoogt bijvoorbeeld de kennis en herkenning van specifieke soorten personages te meten, vooral op basis van typerend gedrag binnen een tekstsoort. We kijken daarbij dus niet naar interpretatie en evaluatie, zoals wel onder literaire competentie wordt verstaan, en ook niet naar de identificatie van personages op basis van illustraties zoals in de LES. Wel hebben we uit de hierboven beschreven instrumenten en de wijze waarop die instrumenten zijn ontwikkeld en gebruikt verschillende aandachtspunten afgeleid voor de ontwikkeling en implementatie van de Toets OCG. Zo hebben we ervoor gekozen de toets bij de kinderen individueel af te nemen, zoals bij de LAS, VLES-K en Watje Wimpie-taak, om onderlinge beïnvloeding van kinderen te voorkomen. Omdat we deels te maken hebben met kinderen die nog niet kunnen lezen (groep 2) en ook niet willen dat verschillen in technische leesvaardigheid de resultaten beïnvloeden (groep 4), hebben we Toets OCG ontwikkeld voor mondelinge afname. Taken zijn ook in de Toets OCG opgehangen aan afbeeldingen die te zien zijn op een scherm; tekstfragmenten hebben ook wij laten inspreken om de invloed van de bemiddelaar te neutraliseren. Anders dan bij de Watje Wimpie-taak waren de taken in de Toets OCG geheel gebaseerd op het beantwoorden van gerichte vragen over de gehoorde tekst(fragment)en.

Het construct 'ontluikende culturele geletterdheid' is in de Toets OCG geoperationaliseerd tot items die stuk voor stuk betrekking hebben op de herkenning en kennis van een specifiek genre of specifieke tekstsoort (het schelmenverhaal, de fabel, het nonsensrijm, het sprookje, et cetera) en de daarbinnen aanwezige typerende kenmerken, zoals personages (Hodja/Anansi; Jezus/Mohammed), formules ('Er was eens'), stijlfiguren (de omkering; rijm), en motieven en thema's ('voor wat hoort wat'; 'de oplichter opgelicht'; 'hoogmoed komt voor de val'). Het construct 'ontluikende culturele geletterdheid' vormt daarmee een aanvulling op de meetinstrumenten die tot nu toe ontwikkeld zijn om effecten van het (voor)lezen van kinderliteratuur in kaart te brengen. Naast de LAS die attitudes ten aanzien van lezen en boeken in kaart brengt bij kinderen vanaf groep 4, de LES die de ervaring van kinderen in groep 3 met prentenboeken en vooral met specifieke titels/personages meet, de VLES-K die de voorleeservaring met prentenboeken bij kleuters nagaat, en de Watje Wimpie-taak die inzicht geeft in de literaire competentie bij kleuters, is de Toets OCG gericht op het in kaart brengen van de kennis en het begrip van kenmerkende eigenschappen van 'cultureel relevante' tekstsoorten en genres die kinderen in groep 2 en in groep 4 naar verwachting opdoen uit hun ervaring met die tekstsoorten en genres. Omdat in elk van de drie deelprojecten andere genres of tekstsoorten centraal staan, is vanuit elk deelproject een 'deeltoets' ontwikkeld die uiteindelijk in de Toets OCG zijn verenigd. Hieronder beschrijf ik de ontwikkeling van de deeltoets Kinderpoëzie.

\subsection{Operationalisering van de relatie poëzie - ontluikende culturele geletterdheid}

Binnen het deelproject Kinderpoëzie heb ik me in de ontwikkeling van de Toets OCG gericht op het meten van kennis en begrip van specifieke kenmerken die een centrale rol spelen in langdurig geliefde en (trans)cultureel diepgewortelde vormen van het 'taalspel 
poëzie' zoals dat in de alledaagse cultuur vorm krijgt. De geformuleerde 'indicatoren van canoniciteit' heb ik in de context van de Toets OCG vertaald naar 'indicatoren van ontluikende culturele geletterdheid'.

De indicator 'de directe evocatie van poëtisch geritualiseerde handelingspatronen in pragmatische contexten’, zoals uitgewerkt in Hoofdstuk 3, staat voor de bijdrage die poëzie kan leveren aan ervaring van ritmische patronen op het niveau van terugkerende routines, rituelen en spel die op hun beurt ritmische ordening aanbrengen in interactie en, op overkoepelend niveau, in het circulaire en lineaire verloop van tijd. Kennis en begrip kunnen in relatie tot deze indicator op meerdere niveaus worden opgevat, dus als kennis en begrip van 'tijd', van specifieke routines en rituelen (van opstaan tot slapengaan; van Nieuwjaarsdag tot Oudjaarsavond; van geboorte tot dood) en van de vaste uitingsvormen/handelingspatronen die vorm geven aan die routines en rituelen, onderverdeeld in een fysieke en een talige handelingscomponent. Deze in hoge mate op interactie, ervaring en beleving gebaseerde aspecten van ontluikende culturele geletterdheid zijn om verschillende redenen niet vertaald naar objectief meetbare 'opbrengsten' in de Toets OCG ${ }^{129}$. De indicatoren 'muzikaal taalspel' en '(carnavaleske) nonsensicaliteit'130 zijn beide gebaseerd op concrete tekstuele strategieën, of stijlfiguren, die in verschillende rijmen, liedjes en gedichten voorkomen en die kinderen dus kunnen leren (her)kennen, begrijpen en gebruiken (toepassen) via het aanbod van poëzie in de Leeskalender. De indicator 'muzikaal taalspel' is gebaseerd op toepassin-

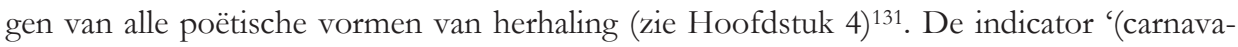
leske) nonsensicaliteit' is gebaseerd op de toepassing van stijlfiguren als de (letterlijke) omkering (inversie) en de overdrijving (hyperbool), en in abstractere vormen als een spel met de toepassingen van logica, van tijd, taal of getallen in het handelen van personages die afwijken van wat we als 'normaal' of 'logisch' (her)kennen (zie Hoofdstuk 5). Omdat deze beide indicatoren zich niet zozeer laten typeren door specifieke cultuurinhouden - muzikaal taalspel helemaal niet en nonsensicaliteit kent in principe geen thematische inperkingen heb ik me beperkt tot het operationaliseren van kennis en begrip van formele tekstkenmerken (stijlfiguren) in de deeltoets Kinderpoëzie. De Toets OCG als geheel gaat uit van de overdraagbaarheid van kennis, begrip en vaardigheden die kinderen in de experimentele

\footnotetext{
${ }^{129}$ Op het niveau van kennis en begrip van (het verloop van) tijd valt na een interventie van dertig weken weinig effect te verwachten: routines en rituelen zouden over een langere periode terugkerend aan bod moeten komen om bij te dragen aan de ervaring van tijd. En ervaring betekent nog niet per definitie dat er ook sprake is van expliciete en actief inzetbare kennis: er bestaan grote verschillen in het tijdbesef van kleuters en van kinderen in groep 4 vanwege het conceptuele karakter van 'tijd'. Vanwege het handelings- en ervaringsgerichte karakter van deze indicator op het niveau van terugkerende routines en rituelen en van de vaste poëtische uitingsvormen/handelingspatronen die aan die routines en rituelen gekoppeld zijn, is deze indicator in de ontwikkeling van de volledig verbale Toets OCG buiten beschouwing gelaten. Het aandeel van deze indicator in het samenspel tussen pragmatische, tekstuele en ontwikkelingsfactoren dat vorm geeft aan de 'canoniciteit' (i.e. langdurige geliefdheid) van poëzie voor kinderen is alleen via kwalitatieve methoden in beeld gebracht.

130 'Carnavaleske' staat hier tussen haakjes omdat deze specificatie betrekking heeft op het lichamelijk aspect dat voor jonge kinderen naar verwachting een cruciale rol speelt in hun waardering voor nonsensicale poëzie (zie Hoofdstuk 5). Dat lichamelijk aspect kan in de verbale Toets OCG niet (ten volle) tot uiting komen en is dus alleen via observaties in kaart gebracht.

131 Metrum en ritme laten zich echter moeilijk vertalen in concrete items voor een toets gebaseerd op vragen die mondeling worden gesteld. Tijdens pilot 1 heb ik een toetsitem uitgeprobeerd waarin niet alleen rijm, maar ook metrum een rol speelde, dus niet alleen gekeken werd naar of kinderen een rijmwoord konden verzinnen om een bepaalde reeks aan te vullen, maar daarbij ook te letten op het aantal lettergrepen dat dat rijmwoord had. Dit is uiteraard sterk afhankelijk van taalontwikkeling en zeker woordenschat en het bleek voor kinderen al lastig genoeg om zelf te rijmen, laat staan kritisch te zijn op het aantal lettergrepen.
} 
conditie naar verwachting hebben opgedaan tijdens het werken met het tekstaanbod in de Leeskalender naar nieuwe teksten die een beroep doen op diezelfde kennis, begrip en vaardigheden in de toets. Als uitgangspunt in de ontwikkeling van de items voor kinderpoëzie in de Toets OCG voor groep 2 en groep 4 heb ik de indicatoren van ontluikende culturele geletterdheid als volgt geoperationaliseerd:

Tabel 14. Eerste operationalisering van de 'indicatoren van ontluikende culturele geletterdheid' in relatie tot kinderpoëzie

\begin{tabular}{ll}
\hline Indicator van OCG & Operationalisering \\
\hline Kennis en begrip van & Het kind kan veelvoorkomende stijlfiguren die in poëzie een nonsensicaal effect \\
veelvoorkomende stijl-figuren die bewerkstelligen, herkennen in en kan kennis en begrip van die stijlfiguren \\
in poëzie een nonsensicaal effect & toepassen op nieuwe teksten, waarbij het specifiek gaat om: \\
be-werkstelligen. & - omkeringen (inversie); \\
& - overdrijvingen (hyperbool); \\
& - contra-intuïtieve toepassingen van logica, tijd, taal of getal in het handelen \\
& van personages. \\
Kennis en begrip van & Het kind kan veelvoorkomende stijlfiguren die in poëzie muzikaal taalspel \\
veelvoorkomende stijl-figuren & bewerkstelligen, herkennen in en kan kennis en begrip van die stijlfiguren \\
die in poëzie muzikaal taalspel & toepassen op nieuwe teksten, waarbij het specifiek gaat om: \\
bewerkstelligen. & - herhalingspatronen in klank (rijm); \\
& - herhalingspatronen in regelopbouw (parallellisme); \\
& - herhalingspatronen in beklemtoning (metrum). \\
\hline
\end{tabular}

Deze eerste algemene operationalisering van 'muzikaal taalspel' en 'nonsensicaliteit' (ik laat de toevoeging 'carnavaleske' hier achterwege omdat ik inhoudelijke of thematische kenmerken niet heb meegenomen in de operationalisering), heb ik verder geoperationaliseerd tot concrete toetsitems in het ontwikkelingsproces van de deeltoets Kinderpoëzie als onderdeel van de Toets OCG als geheel. Die ontwikkeling is via verschillende fasen verlopen en wordt hieronder per fase toegelicht.

\subsection{Toetsontwikkeling}

De ontwikkeling van de Toets $\mathrm{OCG}^{132}$ bestond uit drie fasen, van elkaar gescheiden door twee pilotstudies waarin versies van de toets zijn uitgeprobeerd met medewerking van een groep 1-2 en een groep 3-4 van basisschool De AQUAmarijn in 's-Hertogenbosch en in drie groepen 1-2 en een groep 4 van Brede School Moesel in Weert.

Tabel 15. Overzicht van het ontwikkelingstraject van de kinderpoëzie-items in de Toets OCG

\begin{tabular}{lll}
\hline & Activiteiten & Periode tot \\
\hline Fase 1: & - Ontwikkeling Toets Ontluikende Culturele Geletterdheid, versie 1 & \\
& - Pilot 1 & feb $/ \mathrm{mrt}-2013$ \\
\hline
\end{tabular}

132 Feitelijk hebben we twee toetsen ontwikkeld: een toets voor groep 2 en een toets voor groep 4. De mate waarin de instrumenten van elkaar verschillen, hangt samen met beslissingen per deelproject op basis van inzichten uit pilot 1 en 2. Gemakshalve spreek ik van 'de Toets OCG', maar bedoel hiermee dus feitelijk 'de Toets OCG groep 2 en de Toets OCG groep 4'. 


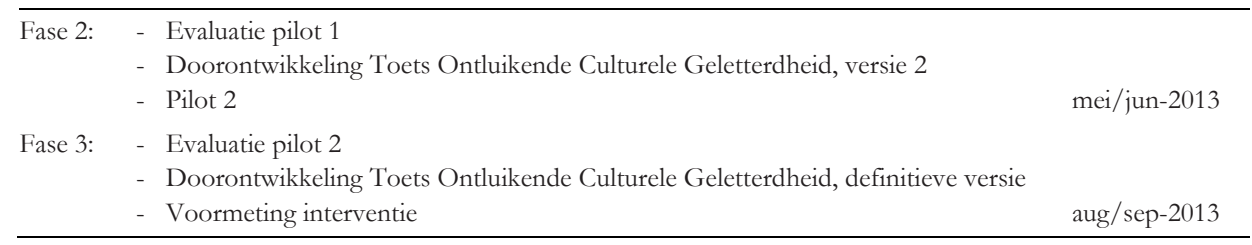

Fase 1: een eerste toetsing van de toets

In de eerste fase van de ontwikkeling van de Toets OCG hebben we in overleg met de bij het project betrokken methodoloog beslissingen genomen over verschillende aspecten van de toets en toetsafname. Omdat we zowel kinderen uit groep 2 als kinderen uit groep 4 zouden toetsen, hebben we gekozen voor mondelinge afname: kinderen in groep 2 kunnen nog niet zelfstandig lezen en bij kinderen in groep 4 wilden we voorkomen dat verschillen in technische leesvaardigheid de resultaten zouden beïnvloeden. Omdat er in totaal zestien scholen en zo'n zevenhonderd kinderen bij dit onderzoek betrokken zijn, is individuele afname een tijd- en arbeidsintensief proces. De duur van de toetsafname per kind moest daarom beperkt blijven, ook met het oog op de concentratieboog van de kinderen. We besloten de toets uit twee delen op te bouwen: een eerste deel met een aantal vragen over boekenbezit en voorlezen bij de kinderen thuis (op basis van de VLES-K), en het tweede deel met de eigenlijke items met betrekking tot ontluikende culturele geletterdheid. Het eerste deel van de vragen geeft specifiek inzicht in het geletterdheidsklimaat bij de kinderen thuis. Antwoorden op deze vragen kunnen, samen met gegevens uit de oudervragenlijsten, worden benut om resultaten nauwkeuriger te kunnen interpreteren. Dit deel is alleen bij de voormeting afgenomen. Voor beide delen van de toets besloten we de verbale taken te ondersteunen met illustraties die kinderen op een laptop te zien kregen. Elk item in het tweede deel van de toets werd gebaseerd op een bestaande tekst (verhaal, rijm, gedicht) waarvan een fragment of verkorte versie zou worden voorgelezen. De items vanuit elk van de drie deelprojecten werden ontworpen om kennis en begrip van (deelaspecten van) de geformuleerde indicatoren van canoniciteit bij de kinderen te meten.

De eerste fase van de ontwikkeling van de toetsitems eindigde met de eerste pilot. Hiervoor werden twee toetsboekjes samengesteld met items uit de drie deelprojecten: een toetsboekje bedoeld voor groep 2 met daarin 24 verschillende toetsitems en een toetsboekje voor groep 4 met 26 toetsitems. Deze testversie van de Toets OCG is getest in de drie weken durende pilot 1 waarin tevens prototypes van de Leeskalender werden uitgeprobeerd, gehouden van 18 februari t/m 8 maart 2013. Verspreid over week twee en drie van de pilot is de toets afgenomen bij een aantal kinderen uit de drie groepen 1-2 en de groep 4 op de brede school in Weert en de groep 1-2 en groep 3-4 op de Montessorischool in 'sHertogenbosch. De meewerkende leerkrachten selecteerden de kinderen op basis van ons verzoek om variatie in mondigheid en taalvaardigheid. Het doel van deze pilottoets was het uitproberen van de items. We wilden bijvoorbeeld achterhalen of de vragen ondubbelzinnig waren, of toetsitems te makkelijk of te moeilijk waren, wat voor soort antwoorden de kinderen zouden geven en hoe lang de kinderen, met name de kleuters, het zouden volhouden om achter elkaar naar verhaalfragmenten en gedichten te luisteren en daar vragen over te beantwoorden. Alle toetsafnames werden door twee personen gedaan: de bij het project 
betrokken scholencoördinator samen met een van de drie onderzoekers, of twee van de onderzoekers samen. Kinderen werden uit de klas gehaald en naar een rustige plek, meestal een kantoor, in de school gebracht, niet te ver van het klaslokaal. Kinderen namen plaats op een stoel voor het laptopscherm. Iedere toetsafname startte met een korte uitleg, waarbij de toets als een spelletje werd geïntroduceerd, gevolgd door algemene vragen over boeken(bezit) en voorlezen thuis. Niet alleen zouden deze vragen in de uiteindelijke toets dienen om een beeld te krijgen van het leesklimaat bij het kind thuis, maar het kind kon zo ook wennen aan de manier van vragen en antwoorden in de toets. Vervolgens kwamen de eigenlijke OCG-items aan bod waarbij de afnameleider de tekstfragmenten zelf voorlas en de bijbehorende vragen stelde; de scoorder noteerde de antwoorden in het toetsboekje. Het streven was om elk toetsitem minstens acht keer af te nemen, dat wil zeggen elk van beide toetsboekjes minstens acht keer door te werken met meerdere kinderen. Uiteindelijk hebben we in totaal elf boekjes van groep 1-2 en tien boekjes van groep 4 volledig doorgewerkt.

Tabel 16. Verdere operationalisering van de 'indicatoren van ocg' in relatie tot kinderpoëzie voor toetspilot 1

\begin{tabular}{l} 
Indicator van OCG \\
\hline Kennis en begrip van \\
veelvoorkomende stijl-figuren \\
die in poëzie een nonsensicaal \\
effect be-werkstelligen.
\end{tabular}

Operationalisering

(1) Het kind kan de incongruente combinatie van handeling en object herkennen in en kan kennis en begrip van de incongruente combinatie van handeling en object toepassen op een nieuwe tekst ('Drie apothekertjes')

(2) Het kind kan de incongruente combinatie van objecten en eigenschappen herkennen in en kan kennis en begrip van de incongruente combinatie van objecten en eigenschappen toepassen op een nieuwe tekst ('Leuk is raar')

(3) Het kind kan een nonsensicaal personage herkennen in en kan kennis en begrip van nonsensicale logica toepassen op het handelen van dat personage in een nieuwe tekst ('De reus Pak-in Pak-op')

(4) Het kind kan inversie herkennen in en kan kennis en begrip van inversie toepassen op een nieuwe tekst ('Klaas Krentje')

(5) Het kind kan het principe van 'de druppel die de emmer doet overlopen' herkennen in en kan kennis en begrip van het principe van 'de druppel die de emmer doet overlopen' toepassen op een nieuwe tekst ('Het grote bed')

Kennis en begrip van veelvoorkomende stijl-figuren die in poëzie muzikaal taalspel be-werkstelligen.
(6) Het kind kan eindrijm en metrum herkennen in en kan kennis en begrip van eindrijm en metrum toepassen op een nieuwe tekst ('Vijf nette heren')

(7) Het kind kan volrijm herkennen in en kan kennis en begrip van volrijm toepassen op een nieuwe tekst ('Popietsie')

(8) Het kind kan het gebruik van klanktaal om binnenrijm te creëren herkennen in en kan kennis en begrip van het gebruik van klanktaal om binnenrijm te creëren toepassen op een nieuwe tekst ('Daar was een smid - attivit')

(9) Het kind kan het gebruik van de naam van een personage om eindrijm te creëren herkennen en kan kennis en begrip van het gebruik van de naam van een personage om eindrijm te creëren toepassen op een nieuwe tekst ('Wippel Wappel')

Een toetsafname duurde gemiddeld 20 minuten per kind: dit was dus de tijd die voor de meeste kinderen 'haalbaar' was. In deze eerste proefversie van de Toets Ontluikende Culturele Geletterdheid waren uit het deelproject Kinderpoëzie negen items opgenomen, zowel in de versie voor kinderen uit groep 2 als in de versie voor kinderen uit groep 4 . In dit 
stadium was er in de poëzie-items geen differentiatie aangebracht tussen groep 2 en groep 4 zodat er op basis van de antwoorden uit beide groepen een vergelijking kon worden gemaakt van de leeftijdsgeschiktheid van de items. Van de negen items vormden er vijf concrete operationaliseringen van specifieke aspecten van kennis en begrip van 'nonsensicaliteit' en vier concrete operationaliseringen van specifieke aspecten van kennis en begrip van 'muzikaal taalspel'. Tabel 16 geeft een overzicht van de operationaliseringen van 'ontluikende culturele geletterdheid' in de pilotitems van de deeltoets Kinderpoëzie.

De items die uiteindelijk samen de deeltoets Kinderpoëzie in de Toets OCG vormen, waren ook al onderdeel van deze eerste pilotversie: die items worden verderop besproken, dus laat ik hier buiten beschouwing. Ter illustratie bespreek ik een proef-item dat na de evaluatie van pilot 1 is afgevallen: een item waarin de operationalisering van 'nonsensicaliteit' centraal stond. Nonsensicaliteit werd onder meer vertegenwoordigd door Annie M.G. Schmidts 'Drie apothekertjes' waarbij de vragen toegespitst waren op de hoed als vaartuig. Op een beeldscherm zagen de kinderen een plaatje met de drie apothekertjes achter een toonbank waarbij de afnameleider het gedicht voorlas tot aan de regels: 'Ze vonden geen enkel klein bootje ${ }^{133}$ goed,/ toen namen ze maar een...?' Vervolgens werd herhaald dat de apothekertjes dus niet kiezen voor een bootje en werd de kinderen gevraagd wat de apothekertjes volgens hen zouden kiezen om in te varen. Uiteraard zouden ze hier geholpen kunnen zijn door het rijmschema om te weten dat het iets moet zijn dat rijmt op 'goed'. Veel kinderen kozen echter voor het vliegtuig of de auto (en negeerden dus het 'varen' en het rijmschema). Andere kinderen antwoordden "grote boot". Pas na afloop van de pilot viel bij mij het kwartje: in het gedicht staat "Ze vonden geen enkel klein bootje goed,/ toen namen ze maar een ... ?" Na deze vraag kregen kinderen het 'goede' antwoord te horen ('ze gaan varen in een hoed') en kregen op het scherm drie plaatjes te zien waarbij de vraag werd gesteld hoe de kinderen dachten dat het versje verder zou gaan: de apothekers gaan niet echt varen, ze gaan varen maar de hoed zinkt, of ze gaan varen in de hoed.

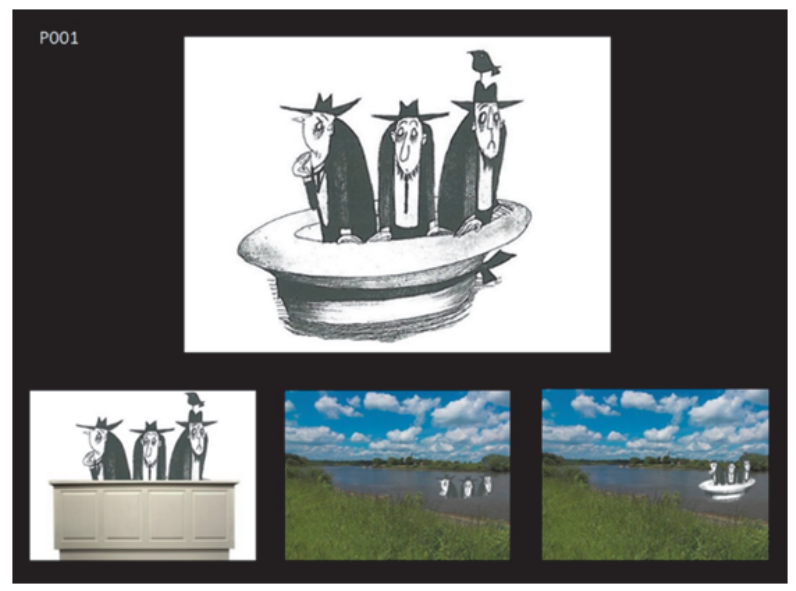

\footnotetext{
${ }^{133}$ Het gedicht was omwille van de begrijpelijkheid enig geweld aangedaan: in de originele tekst wordt gesproken van 'bottertjes' in plaats van 'bootjes', maar omdat kinderen het woord 'bottertje' naar verwachting niet zouden kennen, was het hier aangepast naar 'bootjes'.
} 
Oplettend als ze zijn, kozen veel kinderen voor 'ze gaan varen in de hoed'. Op de vraag 'waarom denk je dat?' zeiden ze dan: “omdat je dat net hebt verklapt!” En inderdaad, dat was ook zo. Dit item is na pilot 1 uit de Toets OCG verwijderd omdat het gedicht te lang was (kost teveel tijd), omdat geen van de kinderen bij de eerste vraag op basis van rijm antwoordde, en omdat het erg lastig bleek alle valkuilen in de vraagstelling te omzeilen. Het gedicht 'Drie apothekertjes' is uiteindelijk opgenomen in de Leeskalender voor groep 4.

Buiten het kiezen van de 'beste' items uit de negen pilotitems (op basis van de ervaringen en analyse van de scores), was een belangrijke beslissing op basis van pilot 1 dat de tekst die de basis vormde voor het item waarin begrip en kennis van het principe van 'de druppel die de emmer doet overlopen' is aangepast. In pilot 1 werd in dit item het gedicht 'Het grote bed' gebruikt, maar dit correspondeerde alleen met een gedicht in de kalender voor groep 4 ('De brug bij Breukelen'). Na pilot 1 is besloten 'Het grote bed' op te nemen in de kalender voor groep 2 en de tekst 'Er kan nog meer bij' (over Bever en zijn vrienden op het vlot) te gebruiken in de deeltoets Kinderpoëzie.

\section{Fase 2: een tweede toetsing van de toets}

Op basis van onze ervaringen tijdens pilot 1 zijn alle toetsitems geëvalueerd, zowel op basis van onze praktijkervaringen, als op basis van enkele statistische analyses ${ }^{134}$. De Toets Ontluikende Culturele Geletterdheid is aan de hand van de evaluaties aangepast. Het aantal items per toetsboekje werd teruggebracht tot negentien items inclusief drie algemene vragen over boekenbezit en voorlezen. Hierdoor was het mogelijk om met ieder kind een volledig toetsboekje door te werken. Zes van de vragen waren slechts voor groep 1-2 of voor groep 4 bedoeld, de overige vragen werden aan kinderen uit beide groepen gesteld. Een andere aanpassing betrof het voorlezen van de tekstfragmenten. Tijdens pilot 1 werd dat nog door de afnameleider gedaan. Om er zeker van te zijn dat ieder kind dezelfde fragmenten te horen zou krijgen, zonder variaties in uitspraak en zonder accent, besloten we alle fragmenten door dezelfde persoon te laten voorlezen. We vonden iemand bereid om dat voor ons te doen met een duidelijke voorleesstem en 'algemeen Nederlandse' uitspraak. Tijdens een voorleessessie werden alle fragmenten opgenomen, zodat ze tijdens de toetsafname afgespeeld zouden kunnen worden.

De aangepaste versies van de Toets OCG voor groep 2 en groep 4 werden uitgeprobeerd in een tweede pilot op dezelfde twee scholen, maar met andere kinderen. Deze pilot had, naast het verder ontwikkelen van de vraagstellingen en verfijnen van de antwoordcategorieën, tot doel na te gaan in hoeverre kinderen in groep 2 en in groep 4 van elkaar verschillen in hun scores op de items, hoe de verdeling van scores eruitziet per item en per deeltoets (normaal verdeeld of niet) en of er nog ruimte voor groei is in de scores. Belangrijk was om te kijken of items niet te gemakkelijk dan wel te moeilijk zijn. Als kinderen het voor de interventie al heel goed doen, zien we geen verbetering na de interventie, maar het moet ook niet zo moeilijk zijn dat ze het na de interventie nog steeds niet goed doen. Om-

\footnotetext{
134 Deze analyses lieten zien hoe lang een toetsafname per kind gemiddeld duurde en hoeveel items er in deze tijd gemiddeld behandeld waren. Deze analyses hebben de omvang van de uiteindelijke toets bepaald. Verder is gekeken naar het type antwoorden dat kinderen gaven voor het bijstellen van de antwoordcategorieën op het scoreformulier en of er ruimte voor groei was.
} 
dat de toetsafnames in juni, vlak voor de zomervakantie, plaatsvonden, konden we minder kinderen toetsen dan gewenst: twintig kinderen uit groep 2 en negentien kinderen uit groep 4. Uit een vergelijkende analyse van de scores bleken er geen verschillen te zijn tussen jongens en meisjes en geen verschillen tussen leerlingen van de twee scholen. Wel bleken de leeftijdsgroepen met statistische zekerheid van elkaar te verschillen op de deeltoets Kinderpoëzie als geheel en op de meeste poëzie-items ${ }^{135}$ en scoorde groep 4, zoals verwacht, structureel hoger dan groep 2. Hoewel groep 2 met een gemiddelde van 2,6 van de 14 punten beduidend lager scoorde dan groep 4 met een gemiddelde van 6,5 van de 14 punten, gaf de verdeling van de scores voor beide leeftijdsgroepen geen aanleiding om items aan te passen. Bij groep 2 variëerden de scores van 0 tot 7 punten met een enigszins rechtsscheve verdeling; bij groep 4 variëerden de scores van 2 tot 12 punten met een enigszins bimodale distributie (piek op 5 punten en op 8 en 9 punten). We hadden echter te weinig kinderen kunnen toetsen om een mooie standaardnormale verdeling te kunnen verwachten. Voor de deeltoets Kinderpoëzie leidde pilot 2 alleen tot een laatste aanpassing van het item over de reus Pak-in Pak-op voor groep 4. Omdat meer dan de helft van de getoetste kinderen in groep 4 de maximale score op dit item haalde, is besloten groep 2 wel keuzemogelijkheden voor te leggen (zoals in pilot 2 het geval was), maar groep 4 in de uiteindelijke toets niet meer. In de uiteindelijke versies van de Toets OCG die zijn gebruikt om de effecten van de implementatie van de Leeskalender op specifieke aspecten van de ontluikende culturele geletterdheid van kinderen te meten, zijn zowel in de toets voor groep 2 als in de toets voor groep 4 vijf items opgenomen uit het deelproject Kinderpoëzie.

\subsection{Kinderpoëzie: de items in de Toets Ontluikende Culturele Geletterdheid}

Zoals in de toetsitems van het deelproject Narratieve Genres specifieke narratologische kenmerken van schelmenverhalen, sprookjes en griezelverhalen centraal stonden en de toetsitems vanuit het deelproject Deugden \& Dilemma's inspeelden op sociale deugden en morele dilemma's zoals deze in religieuze verhalen uit Bijbel en Koran en in fabels aanwezig zijn, zo zijn alle taken die vanuit het deelproject Kinderpoëzie in de Toets OCG zijn opgenomen, gebaseerd op de herkenning van een specifieke stijlfiguur/strategie en de toepassing daarvan. De beschrijvingen in de kolom 'Taak/stijlfiguur' in Tabel 17 laten zien wat de items in de deeltoets Kinderpoëzie beogen te meten.

Hieronder bespreek ik elk van de items uit de deeltoets Kinderpoëzie afzonderlijk, waarbij ik beschrijf hoe het item tijdens de afname van de Toets OCG aan de kinderen is gepresenteerd, welke inzichten uit de pilots bij de definitieve formulering zijn meegenomen, en wat de verwachte effecten van de implementatie van de Leeskalender zijn op hoe kinderen in de experimentele conditie scoren op het item.

\footnotetext{
135 De verschillen waren significant voor de items over de reus Pak-in Pak-op, Klaas Krentje en Daar was een smid-attivit; niet voor de items over Bever en Wippel Wappel.
} 
Tabel 17. Definitieve operationalisering van de 'indicatoren van ocg' in relatie tot kinderpoëzie voor de definitieve Toets OCG

\begin{tabular}{|c|c|c|}
\hline Taak/stijlfiguur & Tekst voor groep 2 & Tekst voor groep 4 \\
\hline $\begin{array}{l}\text { Nagaan of kinderen het principe van 'de laatste druppel' } \\
\text { (een laatste toevoeging van iets kleins aan een enorme } \\
\text { hoeveelheid waardoor de boel vervolgens mis gaat) } \\
\text { herkennen en kunnen toepassen. }\end{array}$ & $\begin{array}{l}\text { 'Er kan nog meer bij' } \\
\text { (bewerking tekst Ingrid en } \\
\text { Dieter Schubert, 2001) }\end{array}$ & $\begin{array}{l}\text { 'Er kan nog meer bij' } \\
\text { (bewerking tekst Ingrid en } \\
\text { Dieter Schubert, 2001) }\end{array}$ \\
\hline $\begin{array}{l}\text { Nagaan of kinderen de analogie in het handelen van een } \\
\text { personage in nonsenspoëzie herkennen en kunnen } \\
\text { toepassen. }\end{array}$ & $\begin{array}{l}\text { 'De reus Pak-in Pak-op' } \\
\text { (bron: Diet Huber, 1989) }\end{array}$ & $\begin{array}{l}\text { 'De reus Pak-in Pak-op' } \\
\text { (bron: Diet Huber, 1989) }\end{array}$ \\
\hline $\begin{array}{l}\text { Nagaan of kinderen de inversie in het handelen van een } \\
\text { personage in nonsenspoëzie herkennen en kunnen } \\
\text { toepassen. }\end{array}$ & $\begin{array}{l}\text { 'Klaas Krentje' } \\
\text { (bron: Diet Huber, 1959) }\end{array}$ & $\begin{array}{l}\text { 'Klaas Krentje' } \\
\text { (bron: Diet Huber, 1959) }\end{array}$ \\
\hline $\begin{array}{l}\text { Nagaan of kinderen een specifiek rijmprocedé waarin } \\
\text { 'klanktaal' wordt gebruikt om binnenrijm te creëren, } \\
\text { herkennen en kunnen toepassen. }\end{array}$ & $\begin{array}{l}\text { 'Daar was een smid-attivit' } \\
\text { (bron: Vloten, 1874) }\end{array}$ & $\begin{array}{l}\text { 'Daar was een smid-attivit' } \\
\text { (bron: Vloten, 1874) }\end{array}$ \\
\hline $\begin{array}{l}\text { Nagaan of kinderen een specifiek rijmprocedé waarin de } \\
\text { naam van een personage wordt gebruikt om eindrijm te } \\
\text { creëren, herkennen en kunnen toepassen. }\end{array}$ & $\begin{array}{l}\text { 'Wippel Wappel' } \\
\text { (bron: Diet Huber, 1989) }\end{array}$ & $\begin{array}{l}\text { 'Wippel Wappel' } \\
\text { (bron: Diet Huber, 1989) }\end{array}$ \\
\hline
\end{tabular}

\section{Wie komt er laatste bij op het vlot?}

"Op dit plaatje zie je Bever en zijn vrienden. Je hoort nu een kort verhaaltje over hem: luister maar goed." Dit is de inleiding die kinderen kregen op het toetsitem over Bever en zijn vrienden, terwijl ze op het beeldscherm Bever in zijn bootje zien zitten en zijn vrienden op de kant zien staan. Vervolgens kregen de kinderen het geluidsfragment met een korte bewerking van het verhaal over Bever en zijn vrienden te horen:

Bever heeft een mooi klein bootje gemaakt en hij peddelt over de rivier om zijn bootje aan zijn vrienden te laten zien. Zijn vrienden zijn niet zo erg onder de indruk van het bootje, want zij passen er niet bij. Omdat zijn vrienden ook graag willen varen, bouwt Bever een vlot. Eén voor één komen alle vrienden van Bever erbij op het vlot: eerst komt Mol erbij, dan Egel, dan Haas en Das. Het wordt steeds zwaarder om het vlot vooruit te duwen voor Bever. Bever vindt dat het vlot wel vol genoeg is, maar zijn vrienden vinden dat Beer er ook nog wel bij kan. Dan komt Beer erbij: het vlot blijft nog net drijven. Als laatste komt er nog één dier bij: daarna

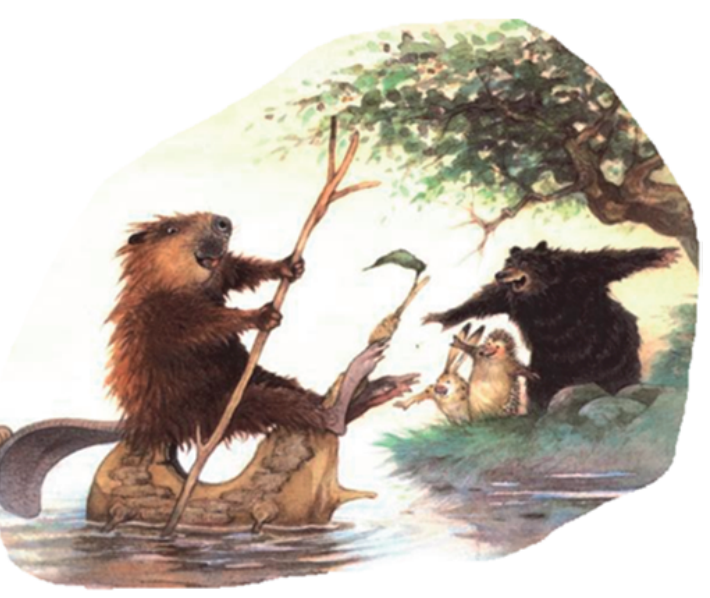
kiept het vlot om en liggen alle dieren in het water. 
Op de volgende dia zagen de kinderen een plaatje van Bever met al zijn vrienden op het vlot. De afnameleider wees het plaatje aan: "Hier zie je Bever en zijn vrienden op het vlot. Er komt nog één dier bij op het vlot. Daarna kiept het hele vlot om. Welk dier komt er als laatste bij, denk je?" Op het scherm zagen de kinderen drie antwoordmogelijkheden, benoemd en aangewezen door de afnameleider: "Een everzwijn, een vos, of een vlinder?"
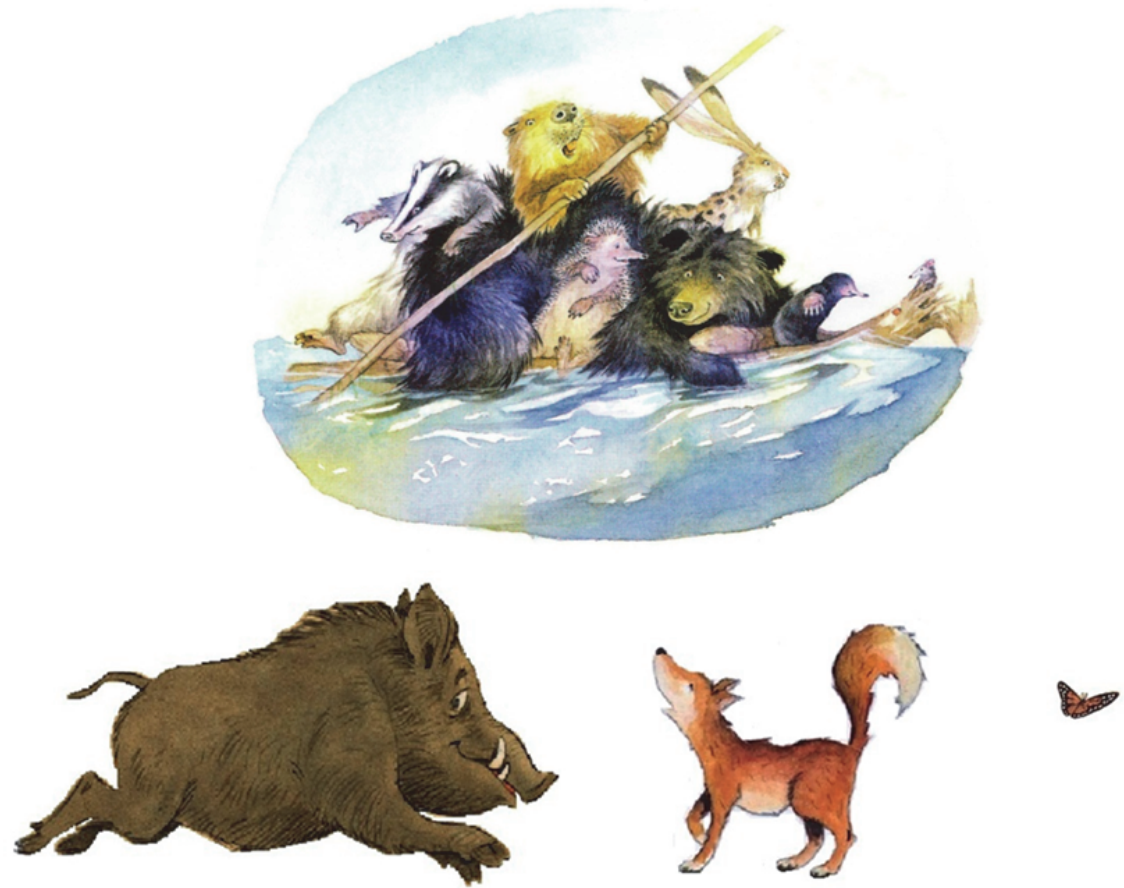

Nadat kinderen deze vraag hadden beantwoord, volgde de vraag: "Waarom denk je dat?", waarop de kinderen beargumenteerden waarom ze voor het ene of andere dier kozen.

Dit item in de toets is gekoppeld aan een specifiek stijlfiguur dat in gedichten als 'Het grote bed' van Rudy Kousbroek, opgenomen in de Leeskalender voor groep 2, en 'De brug bij Breukelen' van Annie M.G. Schmidt, opgenomen in de Leeskalender voor groep 4, ten volle wordt benut. Het gaat hier om het principe van 'de druppel die de emmer doet overlopen' of 'the straw that broke the camel's back'. Het is een stijlfiguur waar, wanneer toegepast in bijvoorbeeld strips, commercials of films, een humoristisch effect vanuit gaat vanwege de ironie van de situatie. Er is steeds sprake van een enorme en meestal ook onstabiele hoeveelheid objecten, personen en/of dieren op een daarvoor doorgaans ongeschikte plek. Bij Kousbroek zijn dat een kind en een hele verzameling grote en zware dieren op een bed; bij Schmidt een massa mensen, dieren en dingen op een brug; bij de Schuberts zijn het Bever en al zijn vrienden (inclusief Beer) op het vlot. Vervolgens wordt er nog iets héél kleins aan de enorme massa toegevoegd, iets dat qua omvang en gewicht volledig in het niet valt bij wat er al was. Bij Kousbroek: de mier. Bij Schmidt: een mug. Bij de Schuberts: een vlinder. Dan, alsóf het komt door die allerlaatste allerkleinste toevoeging, stort de 
hele boel ineen. Het grote bed van Kousbroek zegt 'Krák!'; de brug bij Breukelen brak, 'krikkerdekrak', in twee helften; het vlot met Bever en zijn vrienden kiept om en alle dieren vallen in het water. En wie krijgt de schuld? Natuurlijk de laatste die erbij kwam ...

De resultaten uit pilot 1 lieten zien dat slechts één van de negen kinderen die deze vraag beantwoordden, koos voor de vlinder en dat als volgt beargumenteerde: "omdat hij al heel zwaar is, dus er is alleen nog een mier nodig voor het instort. Ik heb eens eerder zo'n verhaal gehoord, met een boot en op het laatst komt er een luis bij en dan zinken ze." De verwachting is dan ook dat de meeste kinderen, zowel uit groep 2 als uit groep 4, die niet bekend zijn met deze stijlfiguur intuïtief kiezen voor een groot en zwaar dier, het everzwijn en eventueel de vos, als degene die als laatste op het vlot komt waarna de hele boel omkiept. De vlinder wordt naar verwachting alleen gekozen door kinderen die het verhaal over Bever of een soortgelijk verhaal kennen, of omdat ze hier in de Leeskalender ${ }^{+ \text {Kinderpoëzie }}$ kennis mee hebben gemaakt in de vorm van 'Het grote bed' (groep 2) of 'De brug bij Breukelen' (groep 4).

\section{Waarmee haalt de reus Pak-in Pak-op zijn haar nit de war?}

Tijdens het testen van de Toets OCG in de twee pilots bleken kinderen regelmatig sterk te reageren op het plaatje van de reus Pak-in Pak-op. Er werd niet alleen veel om het plaatje gelachen, maar er klonk ook vaak commentaar als: "Is dat een heks?!”, “Bah, die is lelijk!", of "Die is eng!" Bij het horen van het rijmpje over de reus volgden soms nog meer, of andere, reacties: lachen, verbazing, of "Huh? Dat kan niet!" Om die reden heb ik bij dit item in de voor- en nameting ook laten vastleggen of kinderen reageerden en, zo ja, waarop (plaatje en/of tekst) en hoe (lachen/verbazing/anders, namelijk...). Wijst een merkbare reactie op plaatje en/of tekst (direct of indirect) op beter begrip, wellicht doordat de aandacht is gefocust?

$\mathrm{Na}$ een korte introductie door de afnameleider ("Hier zie je de reus Pak-in Pak-op. Je hoort zo een rijmpje over hem, luister maar goed:”) hoorden de kinderen de opname van een deel van het gedicht van Diet Huber dat wordt voorgelezen:

De reus Pak-in Pak-op

Die had een kale kop.

Hij zaaide er wat grasjes op

Wat plantjes en wat haver, Wat berken en een denneboom

En ook een bedje klaver.

En door de regen en de mest

Deed het gewas het opperbest,

Het groeide

En groeide

En groeide

En groeide

En zo heeft nu die reus groen haar

In alle maanden van het jaar.

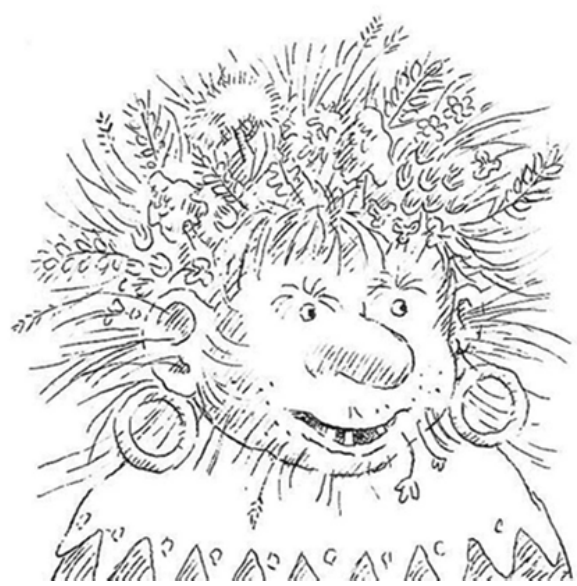


Vervolgens kregen de kinderen uit groep 2 drie antwoordmogelijkheden te zien bij de vraag: "Soms raakt het groene haar van de reus in de war. Waarmee haalt hij zijn haar weer uit de war, denk je? Met een kam, met een borstel, of met een hark?" Ook hier werden de objecten aangewezen door de afnameleider:
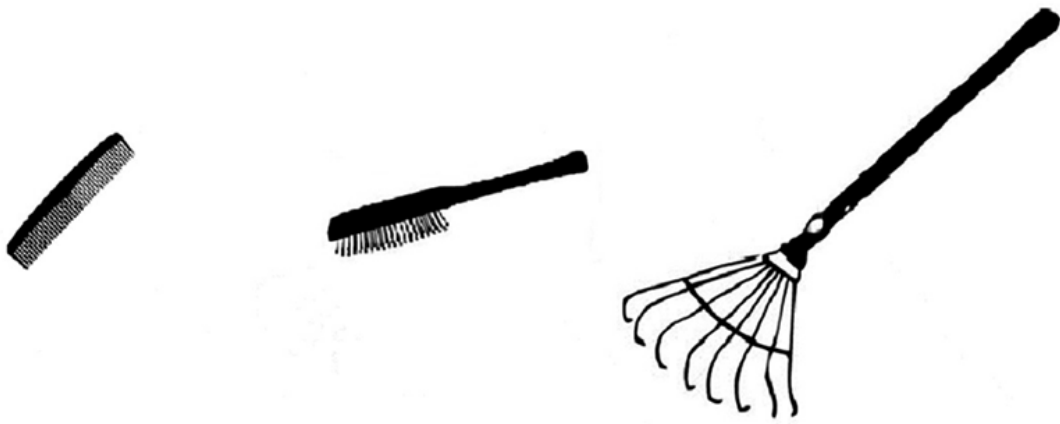

Vervolgens werden de kinderen ook hier gevraagd hun keuze te beargumenteren: "Waarom denk je dat hij dat met een <antwoord kind> doet?" Kinderen uit groep 4 kregen ditzelfde item, maar dan zonder antwoordmogelijkheden op de eerste vraag. Omdat tijdens pilot 1 bleek dat 2 op de 3 kinderen uit groep $4(\mathrm{~N}=9)$ mét de meerkeuze-mogelijkheden voor de hark koos, is het item voor de definitieve toets aangepast en kregen de kinderen in groep 4 hier geen antwoordmogelijkheden te zien. Het feit dat kinderen uit groep 4 gemiddeld hoger scoorden was ook een indicatie van de groeipotentie voor kinderen uit groep 2: zij konden er duidelijk nog op vooruit gaan bij het oplossen van deze vraag. Het originele gedicht van Huber eindigt ermee dat de reus Pak-in Pak-op zijn haar uit de war haalt met een hark (in het park $)^{136}$. Dit item vraagt een relatief moeilijke, want conceptuele, puur mentale operatie van kinderen, te weten het maken van een analogie (in de psychologische opvatting), een type vergelijking met de vaste structuur 'A staat tot B als C staat tot D'. In dit geval: haar staat tot kam/borstel als gras/plantjes staat tot ...? Het is bekend dat kinderen in de kleuterleeftijd nog geneigd zijn te redeneren op basis van hun persoonlijke ervaring (zie ook Pol, 2010). Dit maakt het aannemelijk dat zij eerder voor de kam of borstel kiezen dan voor de hark. De informatie uit het gedicht over het 'groene haar' van de reus en de hark als antwoordmogelijkheid vormen echter aanwijzingen voor kinderen om het conceptuele verband te leggen.

De verwachting is dat kinderen die gedurende dertig weken regelmatig met nonsenspoezie bezig zijn geweest, deze gedachtesprong vaker zullen maken dan kinderen die niet met de Leeskalender ${ }^{+ \text {Kinderpoëzie }}$ hebben gewerkt.

\footnotetext{
${ }^{136}$ Het officiële einde van het gedicht 'De reus Pak-in Pak-op' luidt: "En raakt het soms wat door elkaar,/ dan vindt de reus dat geen bezwaar -/ dan gaat hij even naar het park/ en kamt zich daar wat met de hark." (Huber, 1989: 6-7)
} 


\section{Klaas Krentje, dát is me toch een ventje!}

Klaas Krentje is een typisch voorbeeld van een nonsensicaal personage: als hij koude voetjes heeft, dan draagt hij heel veel hoedjes en voldoet daarmee aan het principe van de omkering. Net als de reus Pak-in Pak-op ontlokte ook het plaatje van Klaas Krentje tijdens de pilots nogal eens reacties aan de kinderen en dus is ook bij dit item in de voor- en nameting bijgehouden of kinderen reageerden op het plaatje en/of de tekst en zo ja, wat voor soort reactie ze dan gaven. In de introductie van Klaas Krentje werd expliciet benoemd dat de kinderen een grappig rijmpje over hem te horen kregen: "Hier zie je Klaas Krentje. Je hoort nu een grappig rijmpje over hem. Luister maar goed". Vervolgens hoorden de kinderen het gedicht over Klaas Krentje:

Kijk kijk daar komt Klaas Krentje,

dát is me toch een ventje!

Op z’n kop

draagt ie een hoge dop

en dáárop een muts, en dáárop een pet,

en dáárop nog drie paar hoedjes,

en vraag je hem: 'Klaas wat betekent dat toch?'

dan zegt ie: 'Ik had koude voetjes.'

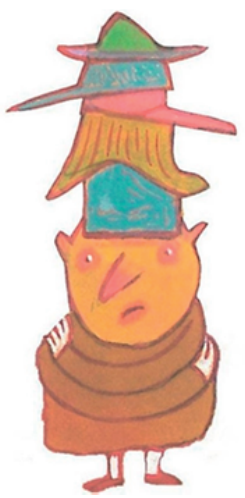

De vraag luidde: "Dus als Klaas Krentje koude voetjes heeft, dan draagt hij heel veel hoedjes. En als hij nu een koud hoofd heeft, wat zou hij dan dragen?" De kinderen werden ook hier weer gevraagd hun antwoord uit te leggen: "Waarom denk je dat?"

De verwachting is dat kinderen uit groepen waar met de Leeskalender+Kinderpoëzie gewerkt is, meer kennis en begrip hebben van het nonsensicale stijlfiguur van de inversie en daardoor de omgekeerde logica van Klaas Krentje vaker zullen herkennen en toepassen op de nieuwe situatie ('als hij nu een koud hoofd heeft') dan kinderen uit groepen waar niet met de Leeskalender ${ }^{+ \text {Kinderpoëzie }}$ is gewerkt.

En die kat-atti... wat?

Het eerste item in de Toets Ontluikende Culturele Geletterdheid waarin rijm centraal staat, is gebaseerd op het aloude taal- of uitspraakrijm 'Daar was een smid - attivit', onder meer opgenomen in de verzameling Nederlandsche baker-en kinderrijmen van Johannes van Vloten uit 1874. Dit rijm vertelt weliswaar een klein verhaaltje, maar legt de nadruk op het klankspel in de vorm van rijm door de toevoeging van betekenisloze 'woorden' achter elke regel. Op het scherm zien de kinderen het silhouet van een kat met haar poot omhoog. Ter introductie werd ze verteld dat ze nu het begin van een rijmpje gaan horen en "zodra het rijmpje stopt, mag jij het afmaken”. De kinderen hoorden vervolgens het volgende fragment van het rijm: 
Daar was een smid - attivit,

Die had een kat - attivat

En die kat - attivat

Brak haar poot - attivoot

Toen kwam de smid - attivit

En zette de poot - attivoot

Van de kat $-\ldots$

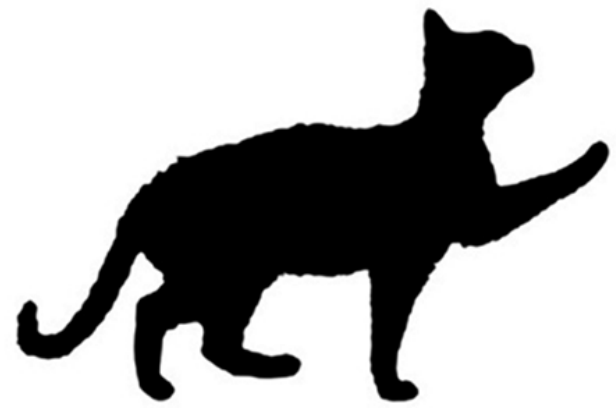

De kinderen kregen nu enige bedenktijd om een antwoord te formuleren. Bleef het stil, dan werd ze hulp geboden in de herformulering: "Zal ik je een beetje helpen? Maak maar af: 'Toen kwam de smid - attivit/ en zette de poot - attivoot/ van de kat - atti...?'.'

Deze taak heeft betrekking op de poëtische toepassing van rijm. Dat zeg ik expliciet om duidelijk onderscheid te maken tussen rijm zoals dat in gedichten, rijmen en liedjes wordt gebruikt en 'rijm' zoals dat bijvoorbeeld in de Rijmtoets voor Kleuters (CITO) wordt geoperationaliseerd. In het laatste geval slaat 'rijm' op het bij elkaar zoeken van plaatjes waarvan de benamingen voor afgebeelde objecten op elkaar rijmen (doorgaans eenlettergrepig volrijm). Het type taak in dit item is dus wezenlijk anders dan wat kinderen gewend zijn. De verwachting is dat kinderen uit de groepen waar is gewerkt met de Leeskalender ${ }^{+ \text {Kinderpoëzie }}$ vaker in staat zullen zijn het rijm af te maken dan kinderen uit groepen waarin niet is gewerkt met de Leeskalender. Deze verwachting geldt zowel voor kinderen uit groep 2 als voor kinderen uit groep 4 . In de scores differentieer ik, naast het niet kunnen afmaken van het rijm (score $=0)$, tussen het afmaken van het rijm sec (rijmen op 'kat' of op 'attivoot' met een zelfbedacht rijmwoord: score $=1$ ) en het afmaken van het rijm in lijn met het rijmprocedé dat in deze tekst geldt (afmaken met 'attivat': score $=2$ ).

\section{Waarom zit de vlieg Wippel Wappel het liefst op een appel?}

In poëzie voor kinderen is rijm vaak een middel dat personages, objecten, handelingen en locaties die normaal niets met elkaar te maken hebben, of niet eens bestaan, met elkaar verbindt. Dat levert vaak grappige effecten op, zeker als dichters eigennamen gebruiken om mee te rijmen: Buddingh's 'Blauwbilgorgel' eet alleen maar 'korgel' (Leeskalender groep 4), Silversteins 'Pinokkio' is een galgebrokkio (Leeskalender groep 4), Schmidts 'Meester Van Zoeten' wast niet zijn handen, maar zijn voeten (Leeskalender groep 2), en Olthuis noemt zijn hoentje 'Klisklaskloentje', zijn haan Kukelaan, zijn gans Waggelhans, zijn schaap Wollenknaap, et cetera (Leeskalender groep 2). Zo wordt in veel rijmen en gedichten voor kinderen de willekeurigheid van relaties tussen hoe een personage heet en wat hij/zij is, of wat hij/zij doet, opgeheven. Doorzien kinderen die strategie eerder wanneer ze veel met poëzie in aanraking zijn gekomen? In de Toets OCG heb ik geprobeerd dat na te gaan met het gedicht 'Wippel Wappel' van Diet Huber. Zowel kinderen in groep 2 als in groep 4 eindigden de Toets OCG met dit laatste item, dat als volgt werd ingeleid door de afnameleider terwijl de kinderen de illustratie van de vlieg op het beeldscherm zagen: "Hier zie je 
de vlieg Wippel Wappel. Je hoort nu een stukje van een rijmpje over hem. Luister maar goed:"

Wippel Wappel

zat op een appel

en wiegde zich zachtjes wat

heen en weer.

Ach, dacht Wippel Wappel,

't is leuk op een appel,

misschien is het leuker nog

op een peer.

En hij vloog naar een peer

en hij zette zich neer.

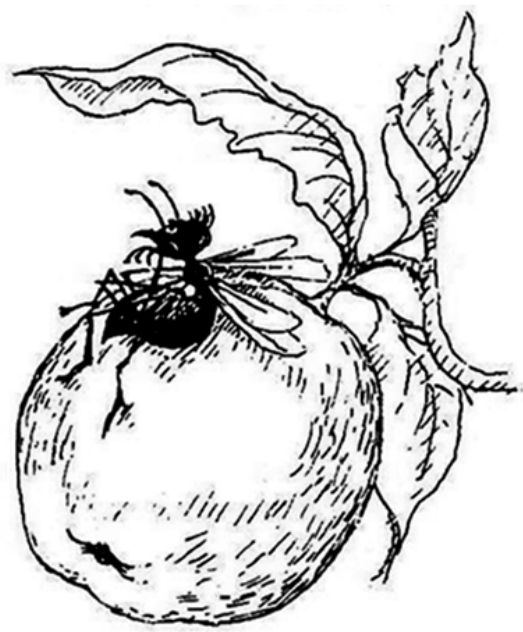

$\mathrm{Na}$ het horen van het geluidsfragment, ging de afnameleider verder: "Wippel Wappel probeert of het leuk is op de peer en daarna of het leuk is op een pruim en daarna of het leuk is op een noot, maar uiteindelijk vindt Wippel Wappel het toch het leukst op de appel. Waarom, denk jij, zit hij het liefst op een appel?” (prompt: Waarom zit die vlieg het liefst op een appel, denk jij?) $\mathrm{Nu}$ is dit een beetje een strikvraag: er wordt niet expliciet gevraagd naar de relatie tussen de naam van de vlieg en zijn favoriete zitplaats. Ter controle kregen kinderen vervolgens een andere afbeelding te zien, nu van een vlieg die op een peer zit, met een vraagstelling waarin de relatie tussen de soortnaam van het fruit en de eigennaam van de vlieg meer op de voorgrond stond.

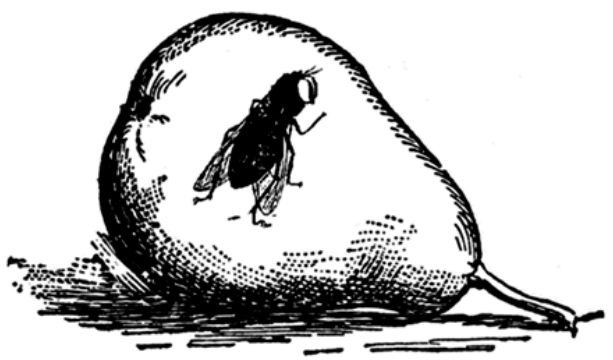

\begin{abstract}
"Nu komt er een andere vlieg en díe zit het liefst op een peer. Kun jij een naam bedenken voor de vlieg die het liefst op een peer zit?" (prompt: "Welke naam zullen we die vlieg geven? Op de peer zit de vlieg ...?”)
\end{abstract}

Kinderen die een naam voor deze vlieg wisten te bedenken, werd vervolgens ook naar hun motivatie gevraagd om te achterhalen of ze een bewuste relatie legden tussen de klank van 'peer' en de naam die ze voor de vlieg hadden bedacht: "Waarom vind je < antwoord kind> een goede naam voor de vlieg die het liefst op een peer zit?" (prompt: "Waarom denk je dat de vlieg die het liefst op een peer zit < antwoord kind $>$ heet?")

Op basis van de inzichten uit pilot 1 en 2 was de verwachting dat kinderen op de voormeting en kinderen uit de controlegroep ook op de nameting vooral geneigd zijn een antwoord te geven op basis van tekstexterne logica, in de trant van: "Misschien omdat 'ie 
dat beter of lekkerder vindt dan die andere." (antwoord uit pilot 1) Kinderen die tijdens de interventieperiode met de Leeskalender ${ }^{+ \text {Kinderpoëzie }}$ hebben gewerkt - waarin rijmen met (opvallende) namen veelvuldig aanwezig is -, kiezen naar verwachting in de nameting vaker voor antwoorden gebaseerd op overeenkomst in klank.

\subsection{De verzameling en analyse van kwalitatieve data}

Zoals in het vorige hoofdstuk al aangegeven, hebben we naast kwantitatieve methoden voor het in kaart brengen van de effecten van de implementatie van de Leeskalender op de ontluikende culturele geletterdheid van de kinderen, ook kwalitatieve methoden benut. Juist omdat we inzicht willen krijgen in het samenspel van pragmatische, tekstuele en ontwikkelingsfactoren die vorm geven aan processen van tekstverwerving bij kinderen in groep 2 en in groep 4, volstaat het enerzijds niet om ons te beperken tot tekstuele analyses en volstaat het anderzijds niet om alleen gebruik te maken van kwantitatieve empirische methoden. Kwalitatieve empirische methoden zijn binnen dit onderzoeksproject ingezet om antwoord te kunnen geven op onderzoeksvraag 4 :

\section{KWALITATIEF-EMPIRISCHE ONDERZOEKSVRAAG}

4. Welke contextuele, tekstuele en ontwikkelingskenmerken zijn cruciaal te noemen in processen van de verwerving van langdurig geliefde en (trans)cultureel diepgewortelde vormen van 'het taalspel poëzie' bij kinderen in groep 2 en in groep 4 op basis van observaties, logboekaantekeningen en gesprekken met leerkrachten met betrekking tot de presentatie van het tekstaanbod in de klas, de reacties van de kinderen op deze teksten en hun waardering daarvan?

Het doel van de verzameling, analyse en interpretatie van de kwalitatieve data voor het deelproject Kinderpoëzie is deze onderzoeksvraag te kunnen beantwoorden, gespecificeerd en onderverdeeld in deelvragen (zie hieronder). Voor beantwoording van deze kwalitatiefempirische onderzoeksvragen is gebruik gemaakt van gegevens die zijn verkregen door inzet van verschillende methoden of instrumenten voor kwalitatieve dataverzameling (zie ook Hoofdstuk 6, \$6.6):

1. Gegevens die verkregen zijn door observaties in een aantal van de deelnemende groepen in de experimentele conditie door de onderzoeker(s);

2. Gegevens die verkregen zijn uit de logboeken waarin de leerkrachten in de deelnemende groepen in de experimentele conditie dagelijks hebben bijgehouden wat hun ervaringen met de Leeskalender zijn;

3. Gegevens die verkregen zijn uit de gesprekken die we tijdens en na afloop van de interventie met de leerkrachten in de experimentele conditie hebben gevoerd (semigestructureerde interviews).

In elk van de deelprojecten zijn kwalitatieve data verzameld uit deze drie bronnen. Gedurende de interventieperiode zijn 'participerende waarnemingen' (observaties en ook terloopse gesprekken met leerkrachten) gedaan op verschillende scholen in de experimentele conditie en in verschillende groepen (groepen 2 en groepen 4), geleid door, maar niet beperkt tot, de geformuleerde deelvragen. 
ONDERZOEKSVRAAG 4: DEELVRAGEN KINDERPOËZIE

KP4a. Wat vertellen observaties, logboekaantekeningen en gesprekken met leerkrachten met betrekking tot de presentatie van het poëzie-aanbod in de klas, de reacties van de kinderen op deze teksten en hun waardering daarvan ons over de rol van 'de directe evocatie van poëtisch geritualiseerde handelingspatronen in de context van feesten en spel', onderverdeeld in

(i) fysieke handelingspatronen (zoals wiegen, dansen, klappen, et cetera), en

(ii) performatieve taalhandelingen (zoals wensen, aftellen, verwensen, verzoeken, et cetera)

in processen van poëzieverwerving bij kinderen in groep 2 en groep 4?

KP4b. Wat vertellen observaties, logboekaantekeningen en gesprekken met leerkrachten met betrekking tot de presentatie van het poëzie-aanbod in de klas, de reacties van de kinderen op deze teksten en hun waardering daarvan ons over de rol van 'muzikaal taalspel', onderverdeeld in

(i) vormen van muzikaal taalspel ter ondersteuning van non-verbale handelingspatronen, en

(ii) vormen van muzikaal taalspel als relatief autonoom spel in processen van poëzieverwerving bij kinderen in groep 2 en groep 4 ?

KP4c. Wat vertellen observaties, logboekaantekeningen en gesprekken met leerkrachten met betrekking tot de presentatie van het poëzie-aanbod in de klas, de reacties van de kinderen op deze teksten en hun waardering daarvan ons over de rol van '(carnavaleske) nonsensicaliteit', onderverdeeld in

(i) carnavaleske vormen van nonsensicaliteit bemiddeld door subversief fysiek handelen in relatie tot de sociale context en de culturele categorieën (waarden en normen) die in die sociale context gelden, en

(ii) carnavaleske vormen van nonsensicaliteit bemiddeld door subversief talig handelen in relatie tot de sociale context en de culturele categorieën (waarden en normen) die in die sociale context gelden, en

(iii) vormen van nonsensicaliteit die een meer intellectuele ervaring van 'incongruentie' teweegbrengen, bemiddeld door een voorstelling van de werkelijkheid die afwijkt van de 'natuurlijke wetmatigheden' die gelden in de waarneembare of conceptuele werkelijkheid

in processen van poëzieverwerving bij kinderen in groep 2 en groep 4 ?

KP4d. Wat vertellen observaties, logboekaantekeningen en gesprekken met leerkrachten met betrekking tot de presentatie van het poëzie-aanbod in de klas, de reacties van de kinderen op deze teksten en hun waardering daarvan ons over de inbedding van culturele pluriformiteit in groep 2 en groep 4 via kinderpoëzie?

Voor het deelproject Kinderpoëzie heb ik aanvankelijk participerende waarnemingen gedaan op alle scholen in de experimentele conditie in Heerlen en Maastricht. Ik heb me uit praktische overwegingen beperkt tot deze twee steden (bereikbaarheid). Vervolgens heb ik mijn observaties toegespitst op een school in Maastricht die deelnam met een groep 2 en 
een groep 4 en werkte met de Leeskalender met teksten uit het deelproject Deugden \& Dilemma's en Kinderpoëzie (zie Tabel 18). Verspreid over de periode van eind oktober 2013 tot en met medio mei 2014 heb ik in totaal achtendertig keer geobserveerd in groepen 2 en groepen 4. Van die achtendertig observaties hebben er twintig plaatsgevonden in groepen (1-)2 en achttien in groepen 4. Aanvankelijk, in de periode van 24 oktober 2013 t/m 14 november 2013, heb ik vier verschillende basisscholen (en verschillende groepen per basisschool) bezocht (beperkt tot de experimentscholen in Zuid-Limburg). Van de vijf experimentscholen in deze regio had een school al aangegeven te willen stoppen met de Leeskalender: op deze school heb ik niet geobserveerd. De vier resterende experimentscholen in Zuid-Limburg, twee in Maastricht en twee in Heerlen, heb ik in de eerste fase van de observaties allemaal bezocht: drie scholen heb ik twee keer bezocht en een school heb ik een keer bezocht. Op elk van deze scholen werd met een de Leeskalender ${ }^{+K i n d e r p o e ̈ z i e ~}$ gewerkt: de twee scholen in Heerlen werkten met de volledige versies van de Leeskalender, de twee scholen in Maastricht werkten met de versies van de Leeskalender zonder teksten uit het deelproject Narratieve Genres.

Tabel 18 Overzicht van de inzet van observaties voor kwalitatieve dataverzameling in twee fasen

\begin{tabular}{|c|c|c|}
\hline & Activiteiten & Periode \\
\hline Fase 1: & $\begin{array}{l}\text { Observaties op alle experimentele scholen in Maastricht en Heerlen } \\
\text { (behalve school die in december zou stoppen): } \\
\text { - Beeld krijgen van het werken met de Leeskalender op de } \\
\text { verschillende scholen; } \\
\text { - Aftasten waar mogelijkheden liggen voor intensivering observaties. }\end{array}$ & eind okt- t/m medio nov-2013 \\
\hline Fase 2: & $\begin{array}{l}\text { Observaties beperken tot focusschool Maastricht: } \\
\text { - 1x per week in beide groepen observeren (dinsdag groep 4; } \\
\text { woensdag groep 2); } \\
\text { - Vanaf interventieweek } 20 \text { ook geluidsopnames maken (beide } \\
\text { leerkrachten gingen wel akkoord met geluidsopnames, niet met } \\
\text { beeldopnames); } \\
\text { - Focus van observaties ligt op de momenten waarop er met de } \\
\text { Leeskalender wordt gewerkt en daarbinnen op de kinderpoëzie met } \\
\text { als doel de evaluatie van verwachte indicatoren van canoniciteit en } \\
\text { inbedding van culturele pluriformiteit in de praktijk. }\end{array}$ & $\begin{array}{l}\text { Eind nov- } t / m \text { medio mei- } \\
2014\end{array}$ \\
\hline
\end{tabular}

Van eind november 2013 t/m medio mei 2014 heb ik de observaties geconcentreerd op twee 'focusklassen': een groep 2 en een groep 4 op dezelfde basisschool. Dit is een basisschool gelegen in het Manjefiek Kindcentrum in de wijk Malberg, in het noordwesten van Maastricht. De school valt bestuurlijk onder MosaLira, stichting voor leren, onderwijs en opvoeding, en heeft een Rooms-Katholieke grondslag hoewel de school zich niet heel sterk als zodanig profileert. De school telde op 1 oktober 2013 in totaal honderdzevenentwintig leerlingen, waarvan zo'n 12\% van allochtone afkomst; 39\% van alle leerlingen op deze school had op dat moment een leerlinggewicht. In de kleutergroepen wordt gewerkt met de methode 'Speelplezier'137. In een onderzoek naar de kwaliteit van voor- en vroegschoolse

${ }_{137}$ Het vve-programma Speelplezier is eigendom van Margot Wouterse. Zij ontwikkelde dit programma in de periode 2002 t/m 2004 voor de regio Zuid en Midden Limburg, vernieuwde het op basis van praktijkervaringen en nieuwe onderwijsinzichten in de periode 2009 t/m 2011 en nam in 2012 de auteursrechten over in het bedrijf Speelpleziermethodiek. De methodiek is landelijk erkend en wordt toegepast in voor- en vroegschoolse educatie 
educatie in Maastricht, uitgevoerd op de twee basisscholen en de peuterspeelzaal in Manjefiek in november 2013, rapporteert de Onderwijsinspectie dat 32\% van de kleuters (groep 1 en 2) op deze basisschool een leerlinggewicht heeft. De Onderwijsinspectie schrijft in het rapport: "Omdat uit de analyse van toets- en observatiegegevens bleek dat het aanbod voor taal en rekenen vanuit Speelplezier niet voldoende was, hebben beide vroegscholen het vve-programma aangevuld. Zo wordt op [een van de basisscholen] naast Speelplezier gebruik gemaakt van De wereld in getallen voor het rekenaanbod met daarnaast ambrasoftactiviteiten en het Leeskalenderproject ter verrijking van het taalaanbod.” (2014, p. 9) Dit geeft een duidelijk beeld van de motivatie van deze school om mee te doen aan ons onderzoeksproject: zij zagen het Leeskalenderproject voor de kleutergroep(en) als passende aanvulling op 'Speelplezier' om het taalaanbod te versterken. De school heeft zich op basis van schriftelijke informatie over het project aangemeld.

De redenen om juist deze school te kiezen voor intensivering van de observaties in de tweede fase, waren (a) dat de school gemakkelijk bereikbaar, klein en overzichtelijk is met een open en gemoedelijke sfeer, (b) dat het een school is met een leerlingpopulatie die zowel etnisch als sociaal-maatschappelijk pluriform is, (c) dat de leerkrachten betrokken zijn, de communicatie vlot verloopt en ze ook in de eerste fase al open stonden voor observaties, (d) dat de school meedeed met zowel de kleutergroep als groep 4, en een gescheiden groep 1 en groep 2 heeft, wat het mogelijk makkte om in de observaties bij de kleuters specifiek te kijken naar de kinderen die ook getoetst zijn, dus alleen de kinderen in groep 2 . Ik heb gekozen voor ongestructureerde participerende observaties: ik wilde de gebeurtenissen in de klas, ook wanneer ze niet rechtstreeks en expliciet aan de Leeskalender gerelateerd waren, waarnemen en beschrijven. Het uitgangspunt was om in de periode van eind november $\mathrm{t} / \mathrm{m}$ medio mei $1 \mathrm{x}$ per week te observeren in zowel groep 2 als groep 4 . Tijdens het observeren nam ik plaats op een plek in de klas van waaruit ik de interactie tussen de leerkracht en de kinderen goed kon zien: in groep 2 zat ik met de kinderen in de kring en in groep 4 (waar de kinderen aan tafeltjes zaten in groepen van 4 kinderen) zat ik op de bank die achter in het lokaal stond zodat ik de hele groep kon zien. Ik heb tijdens het observeren zoveel mogelijk aantekeningen gemaakt van wat ik zag en hoorde en heb deze aantekeningen direct na afloop van elke observatie uitgewerkt. In de analyse en interpretatie van het observatiemateriaal en de aanvullende kwalitatieve data heb ik me deels laten leiden door de geformuleerde onderzoeksvragen, maar tijdens het observeren heb ik getracht mijn blik zo open en breed mogelijk te houden en bij de analyse en interpretatie heb ik ook naar aanvullende factoren gekeken die van invloed zijn op hoe er met het Leeskalenderaanbod gewerkt werd en hoe kinderen daarop reageerden. De tijd/plaats van de observaties was steeds beperkt tot de Leeskalenderactiviteiten, specifiek op de dagen waarop steeds de eerste aanbieding van de poëzietekst van die week gepland stond. In mijn focusgroep 2 besloeg elke observatie het laatste half uur dat iedere woensdagochtend aan de Leeskalender werd besteed, van 12:00 uur tot 12:30 uur; in groep 4 was dinsdag de vaste observatiedag en werd de Leeskalender aanvankelijk aan het einde van de middag gedaan, maar na verloop

door scholing van gebruikers onder leiding van gecertificeerde Speelpleziertrainers. De methodiek is gebaseerd op het uitgangspunt dat de ontwikkeling van jonge kinderen in hoge mate steunt op en gestimuleerd wordt door spel. Bij Speelplezier gaat het er vooral om de kinderen, met een hoge mate van betrokkenheid van de leerkracht, zinvol spel aan te bieden en via het spel hun ontwikkeling op velerlei gebied te stimuleren. Bron: http://www.speelpleziermethodiek.nl/ (geraadpleegd op 13-4-2015). 
van tijd verplaatste de leerkracht de activiteit naar het begin van de middag in verband met een betere concentratie van de kinderen. Ik heb dus geen volledige 'etnografie van de schoolklas' gedaan, maar een binnen de specifieke onderzoekskaders en -doelstellingen toegepaste etnografische methodiek. Naast de uitwerking in observatieverslagen heb ik vanaf februari 2014 ook geluidsopnames in de klas gemaakt als 'back-up' van mijn aantekeningen. De leerkrachten gingen niet akkoord met video-opnamen omdat ze zich daar zelf ongemakkelijk bij voelden - het deed ze denken aan beoordeling - en omdat een aantal ouders al in het kader van de toetsafname geen toestemming had gegeven voor het maken van video-opnamen van hun kind.

In de verzameling, analyse en interpretatie van de kwalitatieve data uit observaties, logboeken en gesprekken heb ik getracht zoveel mogelijk kwaliteitsprocedures voor kwalitatief onderzoek te volgen voor het waarborgen van een zo goed mogelijke interne en externe validiteit, betrouwbaarheid en objectiviteit van de uitspraken die ik op basis van de verzamelde data doe (zie Hoofdstuk 9 \& 10). Het Netwerk Kwalitatief Onderzoek AMCUvA geeft het overzicht van procedures zoals weergegeven in Tabel 19. Met betrekking tot de geloofwaardigheid worden de uitspraken die ik doe ondersteund door het gebruik van verschillende databronnen, te weten observaties in de klas, logboekaantekeningen van leerkrachten uit alle groepen die hebben gewerkt met de Leeskalender ${ }^{+ \text {Kinderpoëzie }}$ en de gesprekken die tijdens en na afloop van de interventie met leerkrachten zijn gevoerd. In de analyse van de data heb ik deze verschillende bronnen naast elkaar gelegd en bevindingen daaruit met elkaar gecombineerd danwel geconfronteerd. Ik heb leerkrachten niet meer naar hun mening over de geloofwaardigheid van mijn interpretaties en bevindingen gevraagd: de dataverzameling was nog niet afgerond op het moment dat het schooljaar (en het interventieprogramma) afliep - logboeken moesten nog verzameld en verwerkt worden, afsluitende gesprekken werden gevoerd - en de analyse en interpretatie kwam pas daarna. In de gesprekken zijn leerkrachten gevraagd naar hun ervaringen met en hun meningen over de Leeskalender als geheel en specifieke teksten en tekstsoorten, aanbiedings- en verwerkingsvormen. Deze gegevens zijn gebruikt in de analyse en interpretatie van de kwalitatieve data, maar die interpretaties en bevindingen zijn niet meer aan de leerkrachten voorgelegd. Omdat dit onderzoeksproject tot doel heeft evidence-based criteria te ontwikkelen voor de selectie van kinderliteratuur die bij de kinderen in de smaak valt en bijdraagt aan hun ontluikende culturele geletterdheid, zijn de kwalitatieve data geanalyseerd en geïnterpreteerd om te komen tot een nauwkeurige, valide en betrouwbare formulering van de factoren die een cruciale rol spelen in tekstverwerving door de kinderen. De verwachte indicatoren van canoniciteit zijn geëvalueerd op basis van de kwalitatieve data: de verwachte indicatoren vormden het uitgangspunt, maar zijn waar nodig gespecificeerd, aangevuld en/of vervangen op basis van de beproeving in de praktijk van het onderwijs (zie Hoofdstuk 9 \& 10). In de interpretatie van de verkregen kwalitatieve data heb ik zoveel mogelijk gebruik gemaakt van bestaande theorieën om de geloofwaardigheid van de interpretaties te vergroten. Daarbij waren de verwachte 'indicatoren van canoniciteit' op zich al gebaseerd op verschillende theoretische perspectieven en de analyse van poëzie (zie Hoofdstuk $3 \mathrm{t} / \mathrm{m}$ 5) wat hun theoretische validiteit ondersteunt. 
Tabel 19. Kwaliteitsprocedures voor kwalitatief onderzoek (Bron: Netwerk Kwalitatief Onderzoek AMC-UvA, 2002)

\begin{tabular}{|c|c|}
\hline Criterium & Strategieën \\
\hline \multirow[t]{3}{*}{$\begin{array}{l}\text { Geloofwaardigheid } \\
\text { (interne validiteit) }\end{array}$} & $\begin{array}{l}\text { Triangulatie: combineren van verschillende databronnen, methoden en theorieën om } \\
\text { zoveel mogelijk bevestigend bewijs te verschaffen. Dataverzamelingsgeldigheid wordt } \\
\text { hiermee gewaarborgd. }\end{array}$ \\
\hline & $\begin{array}{l}\text { Zoeken naar ontkrachtend bewijs ('afwijkende' of 'negatieve gevallen'): in plaats van het } \\
\text { negeren van gevallen of informatie die niet past, zoekt de onderzoeker actief naar gevallen } \\
\text { die niet passen in het patroon en verfijnt de theorie totdat alle gevallen passen, waardoor } \\
\text { alle uitschieters en uitzonderingen geëlimineerd worden. }\end{array}$ \\
\hline & $\begin{array}{l}\text { Beoordeling onderzoeksparticipanten: de onderzoeker vraagt in een dialoog met de } \\
\text { participanten naar hun mening over de geloofwaardigheid van interpretaties en } \\
\text { bevindingen. }\end{array}$ \\
\hline $\begin{array}{l}\text { Overdraagbaarheid } \\
\text { (externe validiteit) }\end{array}$ & $\begin{array}{l}\text { Gedetailleerde beschrijving van de onderzoekscontext: de rol van de onderzoeker en een } \\
\text { heldere omlijning van hoe de context mogelijkheid biedt de onderzoeksvraag te } \\
\text { beantwoorden. }\end{array}$ \\
\hline \multirow[t]{2}{*}{$\begin{array}{l}\text { Afhankelijkheid } \\
\text { (betrouwbaarheid) }\end{array}$} & $\begin{array}{l}\text { Archiveren van data en controle creëren: de onderzoeker dient te zorgen voor volledigheid } \\
\text { en juistheid van de documenten (bijv. interviews en enquetes) en helder te zijn over het } \\
\text { coderingsschema en het data-analyseproces. Personen die niet verbonden zijn aan het } \\
\text { onderzoek dienen toch een duidelijk beeld kunnen vormen van de ondersteuning voor } \\
\text { bevindingen, interpretaties en conclusies. }\end{array}$ \\
\hline & $\begin{array}{l}\text { Sceptische peer review: een sceptische peer reviewer speelt de rol van de advocaat van de } \\
\text { duivel en stelt lastige vragen over methoden, betekenissen en interpretatie van data. Dit } \\
\text { zorgt voor een externe controle op het onderzoek. }\end{array}$ \\
\hline \multirow{4}{*}{$\begin{array}{l}\text { Bevestigingsgraad } \\
\text { (objectiviteit) }\end{array}$} & Triangulatie (zie boven) \\
\hline & Sceptische peer review (zie boven) \\
\hline & Zoeken naar ontkrachtend bewijs (zie bewijzen) \\
\hline & $\begin{array}{l}\text { Reflectief dagboek bijhouden door onderzoekers: omdat bij kwalitatief onderzoek de } \\
\text { ondrzoeker het onderzoeksinstrument is, dient hij of zij een dagboek met aantekeningen bij } \\
\text { te houden met hoe zijn of haar persoonlijke kenmerken, gevoelens en vooroordelen het } \\
\text { werk kunnen beïnvloeden. }\end{array}$ \\
\hline
\end{tabular}

De overdraagbaarbeid van de uitspraken die ik doe wordt eveneens ondersteund door het feit dat ik mijn observatiemateriaal steeds heb vergeleken en geconfronteerd met de logboek-

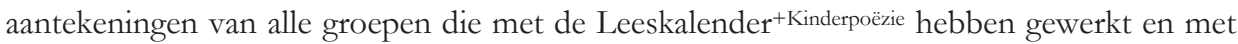
de gegevens uit de gesprekken. De uitspraken die ik doe op basis van de kwalitatieve data zijn dan geldig voor het deel van de onderzoekspopulatie dat met kinderpoëzie heeft gewerkt in het kader van de Leeskalender ${ }^{138}$. De betroumbaarheid van de uitspraken wordt ondersteund door de vastlegging en archivering van de verzamelde kwalitatieve data: observatieverslagen zijn uitgewerkt en gearchiveerd, deels zijn de verslagen aangevuld met geluidsopnamen - hoewel deze geen aanvullende inzichten opleverden -, de ingevulde logboeken zijn eveneens gear-

138 NOTA BENE: Alleen de scholen uit trio 1 hadden geen poëzie in de Leeskalender. Omdat dit de expliciet religieuze scholen zijn (Islamitisch en Protestants-Christelijk), is het goed mogelijk dat mijn conclusies anders, of minder eenduidig, waren geweest wanneer deze scholen wel met het poëzie-aanbod hadden gewerkt, gezien de expliciete aanwezigheid van subversieve elementen in dat aanbod die (door de leerkrachten) op deze scholen mogelijk minder was gewaardeerd. Hoewel ik dit niet met zekerheid kan zeggen, is het formeel een beperking van de externe validiteit van de uitspraken die ik doe op basis van de kwalitatieve data: de geldigheid van deze uitspraken voor expliciet religieuze scholen - met uitzondering van Rooms-Katholieke basisscholen - heb ik niet kunnen nagaan. 
chiveerd alsmede de uitgewerkte verslagen van de gesprekken die met leerkrachten zijn gevoerd. De kwalitatieve data uit de logboeken zijn (projectbreed) ingevoerd in een databestand: hieruit heb ik alle op de poëzie betrekking hebbende aantekeningen van leerkrachten verzameld in een apart databestand voor groep 1-2 en voor groep 4. Eerst heb ik in de drie datasets aangegeven welke fragmenten betrekking hebben op welke 'indicator van canoniciteit'; vervolgens heb ik fragmenten met betrekking tot culturele pluriformiteit gemarkeerd; ten slotte ben ik de overige fragmenten nagelopen op terugkerende elementen ${ }^{139}$. Onder al deze labels heb ik de betreffende fragmenten met elkaar vergeleken op de aanwezigheid van patronen door de drie databronnen heen op het niveau van de indicatoren (welke rol spelen pragmatische contexten, hoe reageren kinderen op muzikaal taalspel/nonsens, welke verwerkingsvormen zijn daarbij effectief?), maar ook op het niveau van individuele teksten (hoe worden ze over de populatie heen gewaardeerd, worden ze door leerkrachten na afloop genoemd als opvallende 'flops' of 'hits', geven observaties inzicht in het waarom van die waardering?). Externe controle op de analyse en interpratie in de vorm van 'sceptische peer review' was er niet expliciet, hoewel uitwisseling van inzichten en ervaringen tussen de drie onderzoekers en het commentaar van supervisoren op de uitwerking van de data hier wel aan bij heeft gedragen. Op deze manieren heb ik zoveel mogelijk getracht de validiteit, betrouwbaarheid en objectiviteit van de uitspraken die ik doe op basis van de verzamelde kwalitatieve data te waarborgen.

\footnotetext{
139 Voor het labelen en analyseren van de kwalitatieve data is geen gebruik gemaakt van speciale software. Het labelen en analyseren is gedaan op basis van Word- en Excelbestanden waarin gebruik is gemaakt van kleurcodering en de toevoeging van 'comments' (bij wijze van label).
} 


\section{HOOFDSTUK 8}

Experimenteel onderzoek naar de bijdrage van kinderliteratuur aan ontluikende culturele geletterdheid (Of: Het Mysterie van het Lokaliseren van Effecten van Kinderpoëzie) 



\subsection{Introductie}

\begin{tabular}{llll}
\hline & $\mathrm{t} 1$ & & $\mathrm{t} 2$ \\
\hline Experimentele groep & $\mathrm{O} 1$ & $\mathrm{X}$ & $\mathrm{O} 2$ \\
Controlegroep & $\mathrm{O} 1$ & & $\mathrm{O} 2$ \\
\hline
\end{tabular}

Figuur 7. Schematische weergave van het onderzoeksdesign voor groep 2 en groep 4.

De aanname die ten grondslag ligt aan dit onderzoeksproject is dat kinderliteratuur op allerlei manieren een belangrijke bijdrage kan leveren aan de ontluikende culturele geletterdheid van jonge kinderen in het basisonderwijs. Rita Ghesquière schreef in Jeugdliteratuur in perspectief al dat literatuur een toegang tot cultuur is en dat lezen deel uitmaakt van wat men in het Duits 'Enkulturationsprozess' noemt, in het Engels 'cultural literacy' (= culturele geletterdheid) (2009a, p. 112; zie Hoofdstuk 1). Via kinderliteratuur kunnen jonge kinderen kennis maken met gedeelde uitingsvormen en de daarin gerepresenteerde normen, waarden, kennis en gebruiken die aan de basis liggen van de culturele gemeenschap(pen) waarin ze opgroeien. Binnen het kader van dit onderzoek vatten we 'ontluikende culturele geletterdheid' op als kennis en begrip van breed gedragen (transculturele en langdurig geliefde) tekstsoorten en genres als 'cultural frames' waarin specifieke vorm- en inhoudskenmerken samenkomen. Door met een brede waaier van '(trans)cultureel relevante' genres en tekstsoorten in aanraking te komen, kunnen jonge kinderen hun ontluikende culturele geletterdheid ontwikkelen, zo is het theoretisch uitgangspunt. Voorwaarde voor een effectieve bijdrage van die brede waaier van '(trans)cultureel relevante' genres en tekstsoorten aan de ontluikende culturele geletterdheid van kinderen in groep 2 en in groep 4 is echter dat het aanbod nauwkeurig aansluit op de kennis, vaardigheden en voorkeuren waarover de kinderen beschikken. In Hoofdstuk $2 \mathrm{t} / \mathrm{m} 5$ heb ik op basis van theoretische inzichten en hermeneutische tekstanalyses verwachte 'indicatoren van canoniciteit' geformuleerd voor mijn deelproject, de kinderpoëzie. Die indicatoren vormen naar verwachting cruciale raakvlakken tussen de 'culturele relevantie' van tekstsoorten en genres enerzijds en 'aansluiting op de doelgroep' anderzijds. In de andere twee deelprojecten zijn op vergelijkbare wijze 'indicatoren van canoniciteit' geformuleerd voor fabels en teksten uit religieuze tradities (deelproject Deugden \& Dilemma's) en voor sprookjes, schelmenverhalen en griezelverhalen (deelproject Narratieve Genres). Op basis van die 'indicatoren van canoniciteit' is een tekstaanbod samengesteld voor groep 2 en voor groep 4, vormgegeven in de Leeskalender: een methode voor het basisonderwijs die, zo is onze verwachting, effectief bijdraagt aan de ontluikende culturele geletterdheid van de kinderen.

Maar is dat ook zo? De ontwikkeling van een methode voor het basisonderwijs kan niet slechts gebaseerd zijn op vermoedens of verwachtingen: het is essentieel dat er objectieve uitspraken kunnen worden gedaan over de vraag of een bepaalde aanpak echt werkt of niet $^{140}$. Daarom kent dit onderzoeksproject ook een empirisch deel waarin we enerzijds nagaan óf de aanbieding van de Leeskalender in groep 2 en in groep 4 inderdaad bijdraagt

\footnotetext{
${ }^{140}$ Er wordt groot belang gehecht aan de ontwikkeling van 'evidence-based' onderwijsinnovatie waarbij op basis van experimenteel onderzoek uitspraken kunnen worden gedaan over de effectiviteit van methoden. Het Ministerie van Onderwijs, Cultuur en Wetenschap zet hier dan ook actief op in (zie bijvoorbeeld: http://www.onderwijs bewijs.nl/).
} 
aan de ontluikende culturele geletterdheid van de kinderen; anderzijds willen we nagaan hóe de verwerving van culturele geletterdheid via kinderliteratuur in zijn werk gaat en welke factoren daar een cruciale rol in spelen. Dit zijn verschillende soorten empirische vragen: om de eerste vraag te beantwoorden moet worden nagegaan of het aanbieden van teksten die de geformuleerde 'indicatoren van canoniciteit' bevatten een (positief) effect heeft gehad op de ontluikende culturele geletterdheid van de onderzochte kinderen. De beantwoording van deze eerste vraag staat in dit hoofdstuk centraal ${ }^{141}$; in de volgende hoofdstukken staat de tweede empirische vraag naar het hóe centraal.

\subsection{Kwantitatieve onderzoeksvragen}

De eerste empirische vraag die we in dit onderzoeksproject stellen, is een vraag naar het effect van een 'stimulus' of 'onafhankelijke variabele', de aanbieding van teksten met de geformuleerde 'indicatoren van canoniciteit' via de Leeskalender, op een 'afhankelijke variabele', de ontluikende culturele geletterdheid van kinderen in groep 2 en kinderen in groep 4. Om die vraag te kunnen beantwoorden voor de praktijk van het basisonderwijs, gebruiken we een experimenteel onderzoeksdesign met een voor- en nameting en controlegroepen (zie Hoofdstuk 6 en Figuur 6). De werving en selectie van scholen voor deelname aan dit onderzoek alsmede de procedure voor matching en random toewijzing van onderzoekscondities staat beschreven in Hoofdstuk 6. In totaal hebben 16 scholen deelgenomen aan het Leeskalenderproject, met in totaal 30 groepen 2 en 17 groepen 4 (zie Tabel 20 voor een overzicht ${ }^{142}$.

Tabel 20. Aantal deelnemende scholen en groepen 2 en 4, verdeeld over de onderzoekscondities

\begin{tabular}{llll}
\hline & Aantal scholen & Aantal groepen 2 & Aantal groepen 4 \\
\hline Experimentele conditie & 10 & 18 & 11 \\
Controleconditie & 6 & 12 & 6 \\
\hline TOTAAL & 16 & 30 & 17 \\
\hline
\end{tabular}

$\mathrm{Na}$ toewijzing van de onderzoekscondities telde de experimentele conditie in totaal 10 scholen met in totaal 18 groepen 2 en 11 groepen 4. In deze groepen is 30 weken lang met het interventiemateriaal, de Leeskalender, gewerkt in de periode tussen de voor- en de nameting. De controleconditie telde in totaal 6 scholen met in totaal 12 groepen 2 en 6 groepen 4: op deze scholen is niet met de Leeskalender gewerkt. Bij alle kinderen uit alle deelnemende groepen - zowel in de experimentele als in de controleconditie - is een voormeting en een nameting verricht met het door ons ontwikkelde meetinstrument, de Toets Ontluikende Culturele Geletterdheid (zie ook Hoofdstuk 6 en 7). De onderzoeksvraag die we, projectbreed, met dit experiment beogen te beantwoorden, is:

\footnotetext{
${ }^{141}$ De statistische analyses die in dit hoofdstuk zijn opgenomen, zijn op aanvraag van de onderzoekers van het Emergent Cultural Literacy project uitgevoerd door dr. Elma Nap-Kolhoff, als methodoloog betrokken bij het onderzoeksproject. Zij gebruikte daarvoor IBM SPSS Statistics Versie 21.0.

${ }^{142}$ In deze aantallen is de school die uitviel in de experimentele conditie niet meegerekend. Deze school telde drie groepen 2 en een groep 4.
} 
Hoofdvraag: Wat zijn de effecten van de structurele aanbieding van teksten die gekenmerkt worden door de geformuleerde indicatoren van canoniciteit via de Leeskalender op de ontluikende culturele geletterdheid van kinderen in groep 2 en kinderen in groep 4 ?

Deze projectbrede hoofdvraag is vervolgens binnen elk van de drie deelprojecten gespecificeerd in deelvragen die betrekking hebben op de aspecten van ontluikende culturele geletterdheid die het betreffende deelproject beoogt te meten. Voor de deelvragen binnen het deelproject dat hier centraal staat, Kinderpoëzie, en de bespreking van de deelprojectspecifieke resultaten verwijs ik naar \$8.5. De effecten van de Leeskalender op de ontluikende culturele geletterdheid van de onderzoekspopulatie zijn gemeten met behulp van de Toets Ontluikende Culturele Geletterdheid die zowel voorafgaand aan als na afloop van de interventie is afgenomen bij de kinderen uit de groepen 2 en groepen 4 op scholen in de experimentele en in de controle conditie ${ }^{143}$.

De veronderstelling is dat bij kinderen in de experimentele conditie onder invloed van de interventie (implementatie van de Leeskalender) een grotere toename van ontluikende culturele geletterdheid wordt waargenomen dan bij kinderen in de controleconditie. Bij kinderen in de controleconditie wordt wel een toename van ontluikende culturele geletterdheid verwacht, simpelweg omdat ze in de loop van een schooljaar ouder worden, zich ontwikkelen, en met kinderliteratuur in aanraking komen. Als onderdeel van het gebruikelijke onderwijsaanbod wordt in alle groepen (voor)gelezen, bijvoorbeeld als onderdeel van de gebruikte taalmethode of leesbevorderings- en boekpromotieactiviteiten. Deze normale (voor)leesactiviteiten liepen zowel bij groepen in de experimentele conditie als bij groepen in de controleconditie door gedurende de interventieperiode. Onder die normale omstandigheden doen kinderen ook kennis en ervaring op uit de literatuur die ze wordt aangeboden. De toename in ontluikende culturele geletterdheid zal bij kinderen in de controleconditie naar verwachting echter kleiner zijn dan bij kinderen in de experimentele conditie. Om inzicht te krijgen in de toegevoegde waarde van ons tekstaanbod, i.e. de effecten die uitgaan van de Leeskalender op de ontluikende culturele geletterdheid van de kinderen, kijken we naar de verschillen in de gemiddelde groeiscores (score nameting minus score voormeting) tussen de experimentele en controlegroep van zowel groep 2 als groep 4. In de volgende paragrafen bespreek ik eerst de betrouwbaarheid en validiteit van het onderzoek en specifiek van het meetinstrument dat is gebruikt om effecten van de Leeskalender op de ontluikende culturele geletterdheid van de kinderen te meten. Vervolgens komen de resultaten aan bod. Eerst kijken we naar het onderzoeksproject als geheel; daarna ga ik specifiek in op de effecten van het aanbod van kinderpoëzie op de scores die kinderen haalden op de deeltoets Kinderpoëzie.

\footnotetext{
$143 \mathrm{Om}$ de resultaten van de Toets OCG beter te kunnen interpreteren en om na te gaan in hoeverre deze resultaten daadwerkelijk worden verklaard door de implementatie van de Leeskalender, zijn aanvullende data verzameld, te weten de scores van dezelfde kinderen op reguliere (CITO-)schooltoetsen op de gebieden taal en rekenen, de oudervragenlijsten en kwantitatieve gegevens uit de logboeken over de daadwerkelijke uitvoering van het interventieprogramma in de deelnemende groepen in de experimentele conditie (zie Hoofdstuk 6).
} 


\subsection{Betrouwbaarheid en validiteit}

Voordat ik uitspraken kan doen over effecten van de Leeskalender, is het van belang na te gaan of de meting van die effecten zoals we die gedaan hebben, ook betrouwbaar en valide is. Betrouwbaarheid heeft hier betrekking op de mate waarin metingen herhaalbaar of repliceerbaar zijn wanneer ze worden uitgevoerd door andere personen op andere momenten onder andere omstandigheden, met instrumenten die hetzelfde zouden moeten meten. Kort gezegd: betrouwbaarheid is consistentie van de meting over tijd, of stabiliteit van de meting over een variatie aan condities waarin eenzelfde of vergelijkbaar resultaat verkregen zou moeten worden (Drost, 2011, p. 105). Een belangrijk basisprincipe waarop de betrouwbaarheid berust, is dat er geen sprake mag zijn van een 'toevallige' uitkomst. Methodologische keuzes maken of breken de betrouwbaarheid van onderzoeksresultaten; daarnaast kan op verschillende niveaus worden gecontroleerd of er inderdaad geen sprake is van een toevallig resultaat. Naast de betrouwbaarheid van de opzet en uitvoering van de meting, willen we ook dat de uitspraken die we op basis van dit onderzoek doen, geldig (valide) zijn waarbij we zowel streven naar interne als naar externe validiteit.

\section{Betrouwbaarheid en validiteit van het Leeskalenderproject}

Betrouwbaarheid van de uitspraken die we doen op basis van uitkomsten van empirisch onderzoek komt grotendeels voort uit het gekozen onderzoeksdesign, de omvang van de onderzoekspopulatie en de nauwkeurigheid waarmee het onderzoek is uitgevoerd en vastgelegd (zie o.a. Hart, Dijk, Goede, Jansen \& Teunissen, 2001). In het vorige hoofdstuk zijn veel van deze 'randvoorwaarden' al besproken en in de volgende paragraaf komen aspecten daarvan nauwkeuriger aan bod in de bespreking van de betrouwbaarheid en validiteit van het meetinstrument. In hoeverre zijn de resultaten verkregen met dit onderzoek generaliseerbaar naar de totale populatie van 'groepen 2 en groepen 4 op Nederlandse basisscholen'? Deze vraag betreft de externe validiteit van het onderzoek (Hart et al, 2001). Dit onderzoek is uitgevoerd met een steekproef van bestaande groepen 2 en groepen 4 op Nederlandse basisscholen. Dat we hebben gewerkt met bestaande schoolgroepen en de interventie is uitgevoerd op de scholen zelf, door geïnstrueerde leerkrachten, draagt bij aan de ecologische validiteit van het interventieprogramma. Dat wil zeggen dat de waarnemingen die we hebben gedaan, zowel kwantitatief als kwalitatief, betrekking hebben op gedrag dat in een relatief 'natuurlijke' omgeving heeft plaatsgevonden op een relatief 'natuurlijke' tijd en plaats. Deze ecologische validiteit draagt bij aan de generaliseerbaarheid van de waarnemingen naar 'groepen 2' en 'groepen 4' in het algemeen: we mogen verwachten dat de implementatie van de Leeskalender in groepen 2 en groepen 4 op andere basisscholen dezelfde waarnemingen oplevert.

Bij het samenstellen van de steekproef (zie Hoofdstuk 6 voor een gedetailleerde beschrijving van de werving, selectie en clusterrandomisatie van scholen) is daarbij expliciet gebruik gemaakt van de matchingprocedure voor de clustering van scholen op basis van bepaalde kenmerken om vergelijkbaarheid van scholen in de controle- en experimentele conditie en een brede representativiteit van de totale onderzoekspopulatie te waarborgen. 
Die kenmerken betroffen het percentage allochtone leerlingen en leerlinggewichten ${ }^{144}$, de mate van verstedelijking en de mate waarin een school zich profileert met een religieuze denominatie. Door zowel voor groep 2 als voor groep 4 vijf clusters (trio's) van scholen te vormen op basis van deze kenmerken en per cluster at random een school aan de controleconditie toe te wijzen, is gestreefd naar een goede vergelijkbaarheid van de onderzoekscondities en een omvang en samenstelling van de steekproef die maken dat de onderzoekspopulatie een goede afspiegeling is van de populatie waarover we uitspraken willen doen (groepen 2 en groepen 4 in het basisonderwijs). Deze methodologische keuzes dragen bij aan de populatievaliditeit van de steekproef en daarmee aan de externe validiteit van de onderzoeksresultaten. Scholen zijn expliciet geworven om mee te doen aan het 'Leeskalenderproject'. De beschrijving van de werving en selectie van scholen en het feit dat sommige scholen afhaakten toen ze in de controleconditie terechtkwamen (zie Hoofdstuk 6, \$6.7), laat zien dat scholen die meededen ook expliciet gemotiveerd waren voor het 'Leeskalenderproject'. Dit betekent dat de deelnemende scholen bereidwillig waren om met de Leeskalender te werken: dat is enerzijds een beperking, anderzijds is dit een goede afspiegeling van de realiteit want ook als de Leeskalender als onderwijsmethode op de markt zou komen, zouden alleen scholen die dit materiaal willen invoeren, er daadwerkelijk mee gaan werken.

Binnen dit empirisch onderzoek zijn de uitspraken die we doen op basis van resultaten verkregen met een steekproef van bereidwillige scholen dus valide voor de beoogde doelgroep van de Leeskalender. Uit praktische overwegingen zijn alleen scholen geworven in de provincies Limburg en Noord-Brabant en dan vooral in steden ${ }^{145}$. Onze steekproef is dan representatief voor basisscholen in steden bezuiden de grote rivieren. Dit zou een beperking van de externe validiteit van de onderzoeksresultaten kunnen zijn. Echter, in Nederland zijn er geen grote verschillen tussen de regio's: het basisonderwijs is door heel Nederland volgens hetzelfde onderwijssysteem georganiseerd, er wordt door heel Nederland gewerkt met een relatief beperkt aantal methoden en op de meerderheid van basisscholen worden CITO-toetsen gebruikt om het leerproces van leerlingen te volgen. Daar komt bij dat de vorming van clusters van scholen op basis van genoemde kenmerken - het percentage allochtone leerlingen, leerlinggewichten, de mate van verstedelijking en de mate waarin een school zich profileert met een religieuze denominatie - garandeert dat de steekproef een afspiegeling is van verschillende 'soorten' scholen zoals die door heel Nederland voorkomen. We mogen er dan redelijkerwijs van uit gaan dat de praktische beperkingen van de schoolpopulatie waaruit wij onze steekproef getrokken hebben, geen beperking van de externe validiteit van onze uitspraken op basis van dit onderzoek vormen.

\footnotetext{
${ }^{144}$ Leerlinggewichten worden bij binnenkomst in het basisonderwijs toegekend aan leerlingen met (een vergroot risico op) leerachterstanden. Het opleidingsniveau van de ouders bepaalt het gewicht dat de school toekent aan een leerling. Is er sprake van maximaal basisonderwijs of (voortgezet) speciaal onderwijs-zmlk (zeer moeilijk lerende kinderen) van een of beide ouders (voogden/verzorgers), dan krijgt het kind leerlinggewicht 1,2 toegekend; is er sprake van maximaal lbo/vbo, praktijkonderwijs of vmbo basis- of kaderberoepsgerichte leerweg van beide ouders of van de ouder die voor het kind zorgt, dan krijgt de leerling gewicht 0,3 toegekend. Ligt een school in een zogeheten 'impulsgebied' (postcodegebied met veel gezinnen met een laag inkomen of een uitkering), dan krijgt een school extra geld voor elke leerling met een leerlinggewicht (www.rijksoverheid.nl; geraadpleegd op 1 september 2014).

${ }^{145} \mathrm{Er}$ is een school in de provincie Gelderland betrokken bij het onderzoek, in de stad Nijmegen: deze Islamitische school is geworven omdat er nog scholen nodig waren om het cluster van scholen met een sterk religieuze profilering (trio 1) te kunnen vormen (zie Hoofdstuk 6).
} 


\section{Betrouwbaarheid en validiteit van de Toets OCG}

Betrouwbaarheid en validiteit van de uitspraken die we op basis van de uitkomsten van dit experimenteel onderzoek doen, hangen uiteraard in hoge mate samen met de betrouwbaarheid en validiteit van het meetinstrument waarmee we de effectmetingen hebben gedaan: de Toets Ontluikende Culturele Geletterdheid voor groep 2 en voor groep 4. Het gebruik van een toetsprotocol, een gestandaardiseerde afnamehandleiding (toetsboekje) en een gestandaardiseerd beoordelingsprotocol (scoreformulier) maken dat de meting in hoge mate navolgbaar en herhaalbaar is (zie Hoofdstuk 6, \$6.6). De video-opnamen van de toetsafnames en het gebruik en de archivering van de gestandaardiseerde formulieren voor de dataverzameling ${ }^{146}$ garanderen daarbij de controleerbaarheid van de gevolgde procedure (zie ook Pol, 2010, p. 143). Om de betrouwbaarheid en validiteit van de Toets OCG zelf te controleren, zijn we nagegaan of er sprake is van voldoende interne consistentie binnen de toets voor groep 2 en de toets voor groep 4 als geheel en of er consistentie is in de toekenning van scores aan de antwoorden die kinderen hebben gegeven door verschillende beoordelaars. Daarnaast is een belangrijke vraag: wat heeft de Toets OCG gemeten? Mogen we er redelijkerwijs van uit gaan dat de toets inderdaad ontluikende culturele geletterdheid heeft gemeten? 'Ontluikende culturele geletterdheid' is een breed en veelomvattend construct. Om redenen van haalbaarheid (beperking in de beschikbare tijd voor toetsontwikkeling) en uitvoerbaarheid (beperking in de omvang van de toets met het oog op de duur van de toetsafname) hebben we slechts een beperkt aantal aspecten van de bijdrage van kinderliteratuur aan de ontluikende culturele geletterdheid geoperationaliseerd tot items in de toets. De Toets OCG voor groep 2 en de Toets OCG voor groep 4 zijn daarmee meetinstrumenten op basis waarvan we uitspraken kunnen doen over een aantal specifieke aspecten van ontluikende culturele geletterdheid. Dit is een beperking van de inhoudsvaliditeit van het gebruikte meetinstrument. We kunnen echter wel nagaan of het aannemelijk is dat de Toets OCG inderdaad de beoogde aspecten van de binnen dit onderzoek gehanteerde definitie van ontluikende culturele geletterdheid meet. Het draait in deze paragraaf dus om de betrouwbaarheid van het meetinstrument voor groep 2 en voor groep 4 en om de geldigheid van de operationalisering van het begrip 'ontluikende culturele geletterdheid', te verdelen in de inhouds- en begripsvaliditeit van het instrument. Inhoudsvaliditeit wil zeggen dat de toets inhoudelijk aansluit op wat de kinderen via de Leeskalender is aangeboden;

\footnotetext{
${ }^{146}$ Dit onderzoek is opgezet en uitgevoerd in overeenstemming met De Nederlandse Gedragscode Wetenschapsbeoefening. Principes van goed wetenschappelijk onderwijs en onderzoek (Vereniging van Nederlandse Universiteiten (VSNU), 2004, herziening 2012). De normen die in de gedragscode staan, hebben betrekking op zorgvuldigheid, betrouwbaarheid, controleerbaarheid, onpartijdigheid en onafhankelijkheid van wetenschappelijk onderzoek. De controleerbaarheid van de resultaten zoals die in dit proefschrift gerapporteerd worden, wordt onder meer gewaarborgd door archivering van de ruwe data die met de verschillende onderzoeksinstrumenten verzameld zijn. Het papieren archief van dit onderzoeksproject omvat alle ingevulde oudervragenlijsten die we hebben ontvangen, alle ingevulde scoreformulieren van de voormeting, alle ingevulde scoreformulieren van de nameting en alle logboeken. Het digitale archief omvat, naast de interventiematerialen, documenten met verslaglegging van de uitgevoerde onderzoeksactiviteiten zoals de werving en selectie van scholen en de uitvoering van de pilots en expertraadplegingen. Daarnaast omvat het digitale archief de databestanden waarin onderzoeksresultaten zijn ingevoerd, zoals gebruikt voor de statistische analyses, en de videoopnamen die zijn gemaakt van alle toetsafnamen. Om de anonimiteit van de kinderen te garanderen, zijn in de databestanden de namen van de kinderen vervangen door 'leerlingnummers'. Ook in de opslag van de video-bestanden zijn de leerlingnummers gebruikt om opnamen aan bijbehorende scoreformulieren te kunnen koppelen.
} 
begripsvaliditeit wil zeggen dat de Toets OCG inderdaad toetst wat hij moet toetsen (zie ook Hoeflaak, 2012). Met de 'Toets OCG' bedoel ik hier: de toets als geheel, dus met alle toetsitems vanuit de drie deelprojecten.

\section{Interne consistentie van de Toets OCG}

De interne consistentie van de toets, geïndexeerd met Cronbachs alfa $(\alpha)$, heeft betrekking op de samenhang tussen de toets-componenten. De Toets OCG bestaat uit verschillende items afkomstig uit de drie deelprojecten die elk specifieke onderdelen van het construct 'ontluikende culturele geletterdheid' moeten meten. In principe zijn de verschillende items dus bedoeld als parallelle operationaliseringen van het begrip 'ontluikende culturele geletterdheid'. Of dat zo is, kan worden nagegaan door te kijken naar de mate van samenhang tussen de score op elk afzonderlijk item en de score op de test (of schaal) als geheel (zie o.a. Wijk, 2000, pp. 116-117; Hart et al, 2001, p. 184). Bijvoorbeeld: een kind met een (relatief) lage culturele geletterdheid zou niet alleen laag moeten scoren op een item over een Bijbelverhaal of een schelmenverhaal, maar ook op de andere items. Wanneer er sprake is van een adequate interne samenhang $(\alpha \geq 70)$ dan mogen we er van uit gaan dat de verschillende items inderdaad kennis en vaardigheden meten op eenzelfde schaal. Met andere woorden: dan vormen de items samen een 'schaal van ontluikende culturele geletterdheid'.

Tabel 21 Interpretatie van Cronbachs alfa m.b.t. de interne consistentie van een set van items (Wijk, 2000: 217)

\begin{tabular}{ll}
\hline $\begin{array}{l}\text { Interpretatie van Cronbachs alfa }(\alpha) \\
\text { Waarde }\end{array}$ & Kwalificatie \\
\hline$>, 80$ & goed \\
, $70-, 80$ & adequaat \\
, $60-, 70$ & matig \\
$<, 60$ & onvoldoende \\
\hline
\end{tabular}

Kijken we naar de Toets OCG voor groep 2 (zie Tabel 22), met in totaal 32 items $^{147}$, dan is de interne consistentie op de voormeting net aan adequaat $(\alpha=, 70)$. Ook is geanalyseerd hoe de interne consistentie wordt beïnvloed bij het verwijderen van elk van de items. In principe geldt dat Cronbachs alfa lager wordt naarmate er minder items zijn, dus als de alfa hoger wordt als een item wordt weggelaten, weten we dat dat item niet bijdraagt aan de interne consistentie van de toets. In de analyses zijn items alleen als (mogelijk) problematisch beschouwd als Cronbachs alfa zonder dat item minimaal ,01 punt hoger is. Daaruit blijkt de eerste vraag over Bever en zijn vrienden op het vlot ('Wie komt er als laatste bij voordat het vlot omkiept? Het everzwijn, de vos of de vlinder?') de interne consistentie van de Toets OCG voor groep 2 negatief te beïnvloeden: zonder dit item zou de interne consistentie sterker zijn $(\alpha=, 71)$. Hieruit kunnen we concluderen dat de eerste vraag over Bever op het vlot mogelijk niet past binnen de 'schaal van ontluikende culturele geletterdheid'

\footnotetext{
${ }^{147}$ Het aantal van 32 items dat hier genoemd wordt, verwijst naar het aantal vragen dat aan kinderen gesteld is. Zo zijn bij de taak over Bever en zijn vrienden op het vlot in totaal 2 vragen aan de kinderen gesteld (Wie komt erbij? en Waarom denk je dat?).
} 
zoals die met de resterende 31 items gevormd kan worden. Echter, ook inclusief dit item is de Toets OCG voor groep 2 op de voormeting al net aan adequaat en meet dit item wel een aspect van ontluikende culturele geletterdheid dat we willen meten: er is dus geen overtuigende reden om het item uit de toets te verwijderen. Cronbachs alpha zegt daarbij niets over de inhouds- of begripsvaliditeit van items: ik kom hier nog op terug in de bespreking van de validiteit van de deeltoets Kinderpoëzie. Wat opvalt, is dat Cronbachs alfa voor de Toets OCG voor groep 2 met in totaal alle 32 items op de nameting een sterkere interne consistentie geeft $(\alpha=, 79)$. Opnieuw zou de interne samenhang omhoog gaan bij het verwijderen van de eerste vraag over Bever, maar niet substantieel $(<, 01)$ en ook met deze vraag erbij is er sprake van voldoende interne consistentie. Dit item is dan ook niet uit de Toets OCG voor groep 2 verwijderd voor de verdere analyses.

Tabel 22. Interne consistentie van de Toets OCG groep 2 op voor- en nameting, met en zonder item 'vlota', uitgedrukt in Cronbachs alpha

\begin{tabular}{lll}
\hline GROEP 2 & Voormeting & Nameting \\
$(\mathrm{N}$ items $=32)$ & $(\mathrm{N}$ respons=352) & $(\mathrm{N}$ respons=339) \\
\hline Met item 'vlota' &, 695 &, 787 \\
Zonder item 'vlota' &, 712 &, 795 \\
\hline
\end{tabular}

De Toets OCG voor groep 4 (zie Tabel 23), met in totaal eveneens 32 items, heeft op de voormeting een interne consistentie die net aan adequaat genoemd mag worden $(\alpha=, 70)$. Geen enkel item 'drukt' de interne consistentie met ,01 punt of meer.

Tabel 23. Interne consistentie van de Toets OCG groep 4 op voor- en nameting, uitgedrukt in Cronbachs alpha

\begin{tabular}{lll}
\hline $\begin{array}{l}\text { GROEP } 4 \\
(\mathrm{~N} \text { items }=32)\end{array}$ & $\begin{array}{l}\text { Voormeting } \\
(\mathrm{N} \text { respons }=346)\end{array}$ & $\begin{array}{l}\text { Nameting } \\
(\mathrm{N} \text { respons }=326)\end{array}$ \\
\hline Alle items &, 699 &, 755 \\
\hline
\end{tabular}

Ook bij groep 4 geldt dat de interne consistentie hoger is op de nameting $(\alpha=, 76)$. Concreet betekent dit dat de score van een kind op elk afzonderlijk item van de toets op de nameting sterker samenhangt met de score op de totale toets dan op de voormeting. Dit geldt zowel voor groep 2 als voor groep 4, over het geheel van scores van kinderen in de experimentele conditie en in de controleconditie. Een mogelijke verklaring voor deze sterkere interne consistentie op de nameting is dat er sprake is van een leereffect: kinderen maken de toets voor de tweede keer en weten dus beter wat ze kunnen verwachten. Mogelijk werden kinderen op de voormeting 'verrast' door de variatie in de items waardoor ze 'inconsistenter' waren in hun beantwoording van de vragen; op de nameting was dit 'verrassingseffect' weg of minder omdat ze de toets al eens gemaakt hadden. Sommige kinderen merkten op de nameting ook expliciet bij items op dat ze 'deze nog wisten' van de voormeting. Omdat dit testeffect zowel in de controle- als in de experimentele groep aanwezig is, is dit een gecontroleerd effect dat de validiteit van de toetsresultaten niet aantast. Een andere verklaring voor de toegenomen interne consistentie op de nameting is dat een deel van de kinderen via de Leeskalender in aanraking is gekomen met de verhaalfiguren en met het type teksten dat ook in de Toets OCG aan bod komt. In dat geval is het de interventie die de herken- 
ning van items in de Toets OCG in de nameting vergroot waardoor kinderen eveneens 'consistenter' zijn in hun scores. In ieder geval mogen we op basis van de toetsing van de interne consistentie (betrouwbaarheid) van de Toets OCG concluderen dat deze acceptabel is en voldoende goed voor zowel de versie voor groep 2 als voor groep 4 op zowel de voor- als de nameting. We mogen er van uit gaan dat zowel de Toets OCG voor groep 2 als de Toets OCG voor groep 4 kennis en vaardigheden meet op eenzelfde schaal.

\section{Interbeoordelaarsbetrouwbaarheid}

Naast de controle van de interne consistentie van de Toets OCG voor groep 2 en voor groep 4 is ook nagegaan of de scores die zijn toegekend aan de open antwoorden van de kinderen betrouwbaar zijn. De vragen in de toetsen waren, op basis van inzichten uit de twee pilots waarin versies van de toetsen zijn uitgeprobeerd, voorzien van antwoordcategorieën waarop de antwoorden van de kinderen tijdens het afnemen van de toets gescoord werden op het scoreformulier:

\section{p019}

p019a

[DIA] Je hoort zo het begin van een rijmpje: zodra het rijmpje stopt, mag jij het afmaken.

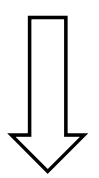

Daar was een smid - attivit

Die had een kat - attivat

En die kat - attivat

Brak haar poot - attivoot;

Toen kwam de smid - attivit

En zette de poot - attivoot

Van de kat -

Zal ik een beetje helpen? Maak maar af:

Toen kwam de smid - attivit

En zette de poot - attivoot

Van de kat - atti...?
0:9 geen antwoord/weet ik niet

1:0 antwoord dat niet rijmt

2:2 direct het goede antwoord: attivat

3:1 attivat na tweede vraagstelling

4:1 antwoord met ander rijmend woord

5:1 herhaling attivoot / attivit

6:-1 antwoord: ...

Bij alle open vragen was een categorie voor open antwoorden opgenomen op het scoreformulier dat tijdens de toetsafnames is gebruikt. In de mondelinge instructie was alle toetsvrijwilligers op het hart gedrukt de antwoorden van de kinderen zoveel mogelijk eerst te noteren op het scoreformulier, vervolgens te kijken of het duidelijk in een antwoordcategorie paste, en anders als 'ander antwoord' te laten staan. Bij het invoeren van de scoreformulieren in het databestand (Excel-sheet) zijn alle antwoorden van de kinderen die niet duidelijk in een antwoordcategorie pasten, letterlijk overgenomen in het bestand als 'ander antwoord'. Aan al deze 'andere antwoorden' moesten vervolgens scores worden toegekend binnen de range aan mogelijke scores op het betreffende item. Om het scoren betrouwbaar en controleerbaar te maken, is een deel van de open antwoorden door meerdere beoorde- 
laars gescoord. Allereerst hebben de drie onderzoekers de 'andere antwoorden' op items van de eigen deelprojecten gescoord. Vervolgens is willekeurig $20 \%$ van de toetsen in de voormeting geselecteerd (71 toetsen voor groep 2; 69 voor groep 4) voor beoordeling door een tweede beoordelaar. Deze toetsen zijn blind - dus zonder de scores van de onderzoekers - aan de tweede beoordelaar ${ }^{148}$ voorgelegd. Aan de hand van scoreprotocollen die door de onderzoekers waren opgesteld, heeft de tweede beoordelaar de betreffende open antwoorden gescoord. Aangezien niet bij iedere toetsafname een open antwoord gegeven werd, verschilde het aantal toetsen dat gescoord moest worden en het aantal dat dubbel gescoord is per item. Indien het aantal dubbel gescoorde toetsen minder dan twintig was, heeft een derde beoordelaar ${ }^{149}$ ook de overige toetsen voor het betreffende item (blind) gescoord.

Tabel 24. Interpretatie van Cohens Kappa m.b.t. de interbeoordelaarsbetrouwbaarheid (Wijk, 2000, p. 224)

\begin{tabular}{ll}
\hline Interpretatie van Cohens Kappa $(\boldsymbol{x})$ \\
\hline Waarde & Kwalificatie \\
$, 81-1,0$ & (bijna) perfect \\
, $61-, 80$ & voldoende tot goed \\
, $41-, 60$ & redelijk \\
, $21-, 40$ & matig \\
, $00-, 20$ & gering \\
\hline
\end{tabular}

Voor de dubbel gescoorde items is vervolgens de interbeoordelaarsbetrouwbaarheid nagegaan door allereerst de overeenkomst tussen de twee beoordelaars te berekenen. Bijvoorbeeld: bij toetsitem p016b gaven de beoordelaars zeventien keer allebei de score ' 0 ' en drie keer allebei de score ' 1 '. Het kwam één keer voor dat de tweede beoordelaar een score van ' 0 ' had gegeven terwijl de onderzoeker een score van ' 1 ' gaf. De geobserveerde overeenkomst voor dit item is dan: 20/21=95\%. De geobserveerde overeenkomst zegt echter niet alles, want ook op basis van toeval kunnen twee beoordelaars tot dezelfde score komen. Cohens Kappa is een maat die daar rekening mee houdt en gebruikt kan worden om de betrouwbaarheid van itemscores op basis van twee beoordelaars te meten. De interpretatie van Cohens Kappa staat weergegeven in Tabel 24. Voor alle dubbel gescoorde items is Cohens Kappa berekend; bij items waar de voor kans gecorrigeerde overeenkomst 'redelijk' of minder was $(\boldsymbol{x}<, 61)$, is door de onderzoekers gekeken naar de verschillen tussen de toegekende scores en is het protocol voor de toekenning van scores aangepast om dubbelzinnigheden of onduidelijkheden te verwijderen. Vervolgens zijn alle open antwoorden op de betreffende items opnieuw door de onderzoeker gescoord en is een deel daarvan opnieuw dubbel blind gescoord op basis van het aangepaste scoreprotocol. Daarna is de voor kans gecorrigeerde overeenkomst in de beoordeling opnieuw berekend. Dit proces is her-

\footnotetext{
148 De tweede beoordelaar was de onderzoeksassistent betrokken bij het project: zij was op de hoogte van de opzet en doelstellingen van het onderzoek en had ook meegeholpen met het afnemen van de Toets OCG op de voormeting.

${ }^{149}$ De derde beoordelaar was de methodoloog betrokken bij het project: zij was op de hoogte van de opzet en doelstellingen van het onderzoek, maar had zelf geen rol in de afname van de Toets OCG.
} 
haald tot de overeenkomst in de beoordeling van open antwoorden op alle items 'voldoende tot goed' of '(bijna) perfect' was ${ }^{150}$.

\section{Interne validiteit}

De interne validiteit heeft betrekking op de interne geldigheid, of interpretatieexclusiviteit', van uitspraken gebaseerd op een experimenteel ontwerp (Hart et al, 2001, p. 211). Als het vrijwel zeker is dat de Leeskalender in de verwachte richting van invloed is geweest op de scores van kinderen op de Toets Ontluikende Culturele Geletterdheid, dan is er sprake van een hoge interne validiteit: een belangrijk kwaliteitscriterium bij experimenteel onderzoek (p. 211). Om dat vast te kunnen stellen, moet echter ook vrijwel zeker zijn dat er geen andere variabelen in het spel zijn die verantwoordelijk zijn voor de veranderingen in ontluikende culturele geletterdheid. Veel van de mogelijke 'storende factoren', zoals de natuurlijke ontwikkeling van de kinderen gedurende de periode van onderzoek en testof leereffecten die optreden omdat de kinderen tweemaal dezelfde toets is afgenomen, worden 'geneutraliseerd' doordat we met controlegroepen werken. Dit zou, dankzij de op clusterrandomisatie gebaseerde toewijzing van scholen aan de controle- en experimentele conditie, ook moeten gelden voor verschillen op andere variabelen die mogelijk van invloed zijn op de ontwikkeling van culturele geletterdheid, zoals leerlinggewichten, taalvaardigheid, leeftijd en aanvankelijke mate van ontluikende culturele geletterdheid. Als de controle- en experimentele groep op deze kenmerken vergelijkbaar zijn dan filteren we in principe alleen dat deel van de waargenomen toename in ontluikende culturele geletterdheid uit de resultaten dat toe te schrijven is aan de Leeskalender door te kijken naar de verschillen in gemiddelde groeiscores tussen experimentele en controlegroepen op de Toets OCG. De eerste vraag is dan óf de controle- en experimentele groep inderdaad vergelijkbaar zijn. Daarnaast moet de Toets OCG ook een valide meetinstrument zijn: we mogen ervan uit gaan dat de toets vaardigheden en kennis op een schaal meet, maar is dat inderdaad een schaal van ontluikende culturele geletterdheid?

\section{Vergelijkbaarheid van de controle- en experimentele groepen}

In de selectie van scholen is, via de matchingprocedure en clusterrandomisatie, zoveel mogelijk getracht vergelijkbaarheid van de experimentele en controleconditie (zowel voor groep 2 als voor groep 4) te waarborgen. Door per trio op basis van toeval steeds een school aan de controleconditie toe te wijzen, vormt de controlegroep een afspiegeling van de experimentele groep op de kenmerken waarop de trio's gevormd waren. Om te controleren of de groepen leerlingen in de beide condities inderdaad vergelijkbaar zijn, is op basis van leerlinggegevens en CITO-vaardigheidsscores nagegaan of er verschillen zijn op kenmerken die naar verwachting samenhangen met ontluikende culturele geletterdheid. Ook is nagegaan of er bij de voormeting al dan niet sprake was van verschillen tussen de experimentele en controlegroepen op de Toets OCG. Bij een vergelijking van de onderzoekscondities voor groep 2 blijken er geen verschillen in 'leerlinggewicht' en 'leeftijd' te zijn. Ook

${ }^{150}$ Voor de interbeoordelaarsbetrouwbaarheid op de items uit het deelproject Kinderpoëzie: zie \8.6. 
zijn er geen verschillen in CITO-vaardigheidsscores voor taal en rekenen en scoren de experimentele en controlegroep vergelijkbaar op de voormeting van de Toets OCG. Voor groep 2 geldt dus dat de controle en experimentele groep inderdaad vergelijkbaar zijn op deze kenmerken.

Tabel 25. Vergelijking van gemiddelde scores van de controlegroep en de experimentele groep 4 op CITO-toetsen voor Woordenschat, Begrijpend Lezen, Spelling en Rekenen, afgenomen voor aanvang van de interventie

\begin{tabular}{lccl}
\hline GROEP 4: CITO-scores eind groep 3 & $\begin{array}{l}\text { Controleconditie } \\
\text { (gemiddelde) }\end{array}$ & $\begin{array}{l}\text { Experimentele conditie } \\
\text { (gemiddelde) }\end{array}$ & $\begin{array}{l}\text { Significantie verschil } \\
\text { (p) }\end{array}$ \\
Woordenschat E3 & 39,4 & 46,4 & $0,01 * *$ \\
Begrijpend Lezen E3 & $-12,3$ & $-3,5$ & $0,01 * *$ \\
Spelling E3 & 115,1 & 114,5 & 0,46 \\
Rekenen E3 & 34,6 & 40,2 & $0,001 * *$ \\
\hline
\end{tabular}

Voor groep 4 blijken wel verschillen te bestaan tussen de controle- en experimentele groep. Bij de scholen die meededen met groepen 4 was de matchingsprocedure moeilijker waardoor de kenmerken niet helemaal gelijkmatig te verdelen waren (zie Hoofdstuk 6, \$6.7). Ook de uitval van een school (uit trio 2 met hoog percentage allochtone leerlingen en hoge leerlinggewichten) uit de experimentele conditie tijdens de interventie kan hier een rol in hebben gespeeld (zie hieronder). De leerlingen in de controlegroep hebben significant vaker een leerlinggewicht $(36 \%$ met verhoogd gewicht) dan de leerlingen in de experimentele groep (20\% met verhoogd gewicht) $(\mathrm{t}(342)=3,474 ; \mathrm{p}=, 001)$ en waren ten tijde van de voormeting gemiddeld zeven weken ouder dan de leerlingen in de experimentele groep $(\mathrm{t}(322)=2,281$; $\mathrm{p}=$,02). De experimentele groep scoort al voor aanvang van de interventie significant hoger op de CITO-toetsen, behalve op Spelling (scores van de toetsafname eind groep 3) (zie Tabel 25). Ook scoren kinderen in de experimentele conditie al bij de voormeting hoger op de Toets OCG (gemiddelde score 15,0) dan de controlegroep (gemiddelde score 12,8) $(\mathrm{t}(344)=-3,224 ; \mathrm{p}=, 001)$. Voor groep 4 geldt dus dat de controle- en experimentele conditie niet vergelijkbaar zijn. Deze verschillen bestonden al bij de voormeting, dus worden deels 'geneutraliseerd' wanneer we kijken naar de verschilscores tussen voor- en nameting (de toename van OCG, ongeacht het niveau van OCG). Echter, een belangrijke overweging bij de vastgestelde verschillen is dat het feit dat de experimentele groep 4 al op de voormeting hoger scoorde op de Toets OCG en ook hoger scoorde op CITO-toetsen het Mattheüseffect in de hand kan werken (zie Hoofdstuk 1). Dit zou betekenen dat een grotere groei op de Toets OCG die we van de experimentele groep 4 verwachten na afloop van de interventie mogelijk niet alleen door de interventie, maar door de al aanwezige 'voorsprong' wordt veroorzaakt. Bij het interpreteren van de resultaten houden we hier rekening mee (zie \8.4, Effecten van de Leeskalender op ontluikende culturele geletterdheid in groep 4).

"Een bedreigende factor voor een experiment is dat bij een nameting minder mensen meedoen dan bij een voormeting, zeker als de tussenliggende periode lang is." (Hart et al, 2001, p. 214) Dit verschijnsel wordt uitval genoemd en het komt vaak voor dat de uitvallers een 'selecte' groep vormen (ook als ze elkaar in werkelijkheid niet kennen), bijvoorbeeld degenen die het minst positief tegen het onderwerp van een onderzoek aankijken. In de omvang van de steekproef was rekening gehouden met uitval, dat wil zeggen toevallige 
uitval van individuele kinderen. De belangrijkste redenen waarom kinderen in het Leeskalenderproject uitvielen, waren 'verhuizen' of meer algemeen 'van school af', en 'ziek' in de periode van de nameting. Ook waren er ouders die geen toestemming gaven voor het toetsen van hun kind ${ }^{151}$. Dit type uitval kwam voor, maar deze kinderen vormen geen 'selecte' groep en uitval van dit type kwam in zowel de controle- als in de experimentele groepen voor (zie Tabel 26).

Tabel 26. Overzicht van toevallige uitval uit beide onderzoekscondities bij groep 2 en groep 4

\begin{tabular}{lll}
\hline & Uitval groep 2 & Uitval groep 4 \\
\hline Controleconditie & $6(5,0 \%)$ & $9(8,4 \%)$ \\
Experimentele conditie & $7(3,0 \%)$ & $16(6,7 \%)$ \\
Uitval per groep totaal & $13(3,7 \%)$ & $25(7,2 \%)$ \\
\hline
\end{tabular}

Waar we echter ook mee te maken kregen, was de uitval van een hele school uit de experimentele conditie tijdens de interventie: een school met drie kleutergroepen en een groep 4 die nog voor de kerstvakantie afhaakte. Personele veranderingen hadden ertoe geleid dat de contactpersoon die de school voor de zomervakantie had aangemeld voor het Leeskalenderproject bij de start van de interventie niet meer op school werkte en de leerkrachten enigszins overvallen werden met de deelname aan het project (contact was verder via de directeur verlopen). De leerkrachten waren al bij de instructie terughoudend, maar wilden het wel 'proberen'. Helaas ervoeren ze het werken met de Leeskalender als te intensief en waren de teksten en verwerkingsopdrachten volgens hen ook 'te moeilijk' voor de leerlingen. Deze school komt uit trio 2: het trio van scholen met relatief veel allochtone leerlingen en hoge percentages leerlinggewichten. Niet alleen zijn we met het afhaken van deze school een groot aantal leerlingen kwijtgeraakt uit de experimentele conditie van groep 2 en van groep 4; we zijn ook een 'selecte' groep kwijtgeraakt. Dit heeft, zoals ik hierboven al stelde, mogelijk bijgedragen aan de verschillen tussen de controle- en experimentele conditie bij groep 4: verschillen waar rekening mee gehouden moet worden bij het analyseren en interpreteren van de resultaten op de effectmeting.

\section{Afnemer-effecten}

Ook afnemer-effecten kunnen de validiteit van de interpretatie van de resultaten in de weg staan als blijkt dat niet de ontluikende culturele geletterdheid van de kinderen is gemeten, maar vooral de invloed van de afnameleider. Vanwege het grote aantal kinderen dat in een relatief korte periode getoetst moest worden, hebben we gewerkt met een team van toetsers dat zowel uit leden van het onderzoeksteam als uit vrijwilligers bestond. Zoals in Hoofdstuk 6 beschreven, hebben we alle toetsers voorzien van een gedetailleerd toetsboekje en afnameprotocol om zoveel mogelijk te waarborgen dat de scores op de Toets OCG niet systematisch werden beïnvloed door wie de toets bij de kinderen afnam. Om te controleren

151 Zie ook Hoofdstuk 6. Alle ouders ontvingen voorafgaand aan de voormeting een brief (via de leerkracht) waarin ze op de hoogte werden gebracht van het feit dat de klas van hun kind deelneemt aan een onderzoek. Onderaan die brief zat een strookje dat ouders konden invullen en inleveren bij de leerkracht wanneer ze niet wilden dat hun kind getoetst zou worden. 
of er al dan niet sprake is van afnemer-effecten, is de t-toets gebruikt om de gemiddelde score die kinderen bij een specifieke afnameleider haalden te vergelijken met het gemiddelde dat bij alle andere toetsafnemers werd behaald. Hiervoor zijn de scores op de voormeting gebruikt omdat daar nog geen sprake kan zijn van Leeskalender-effecten en eventuele afnemer-effecten beter kunnen worden herleid. Bij groep 2 blijkt dat bij één afnameleider kinderen significant lager scoorden op de Toets OCG $(\mathrm{t}(352)=3,110 ; \mathrm{p}=, 002)$ en bij één afnameleider significant hoger $(t(352)=-2,646 ; p=, 009)$. Dit wijst echter niet per definitie op daadwerkelijke afnemer-effecten. De toetsafnemers waren uit praktische overwegingen ingepland op een select aantal scholen (in de buurt van de woonplaats vanwege de bereikbaarheid), dus significante verschillen kunnen ook samenhangen met de betreffende school- en/of leerlingkenmerken. Bij nadere analyse blijkt dat de gemiddeld significant lagere scores bij een van de afnameleiders verklaard kunnen worden door de gemiddeld significant hogere leerlinggewichten $(t(62)=-2,524 ; p=, 014)$ en significant lagere scores op de CITO-taaltoets (meting E1: $\mathrm{t}(329)=3,145$; $\mathrm{p}=$,002) van kinderen die door deze afnameleider getoetst zijn ${ }^{152}$. Er blijft één afnemer-effect over: de kinderen die door deze toetsafnemer getoetst zijn, scoorden hoger dan de kinderen die door andere toetsafnemers getoetst werden, hoewel ze gemiddeld niet een lager leerlinggewicht hadden en ook niet hoger scoorden op de CITO-taaltoets. Het gaat hier echter om slechts 23 van de 354 getoetste kinderen uit groep 2 (6,5\%). De validiteit van de Toets OCG voor groep 2 als geheel is daarmee nog altijd voldoende.

Kijken we naar groep 4, dan zien we dat de kinderen daar bij één afnameleider significant lager scoorden op de toets $(t(344)=3,275 ; p=, 001)$ en bij twee hoger $(t(344)=-2,953$; $\mathrm{p}=, 003 / \mathrm{t}(344)=-2,504 ; \mathrm{p}=, 013)$. De gemiddeld lagere scores bij een van de afnemers zijn opnieuw te plaatsen tegen de achtergrond van gemiddeld significant hogere leerlinggewichten $(\mathrm{t}(63)=3,297 ; \mathrm{p}=, 002)$ en significant lagere scores op de CITO-toets Begrijpend Lezen $(\mathrm{t}(310)=2,813 ; \mathrm{p}=, 005)$ die deze kinderen aan het einde van het voorgaande schooljaar gemaakt hebben. Hieruit mogen we concluderen dat de significant lagere scores die kinderen bij deze afnameleider behaalden op de voormeting van de Toets OCG niet zozeer een effect van de afnameleider zijn, maar van kenmerken van de leerlingen/school. De gemiddeld hogere scores bij een van de afnameleiders vallen samen met gemiddeld significant lagere leerlinggewichten $(\mathrm{t}(103)=2,730 ; \mathrm{p}=, 007)$. De afnemereffecten voor deze afnemer kunnen dus verklaard worden door het feit dat de kinderen die door deze afnameleider getoetst zijn juist een lager leerlinggewicht hadden en daarmee samenhangend hoger scoorden op de Toets OCG. Bij de laatste afnemer zien we dat de kinderen gemiddeld significant hoger scoorden op de Toets OCG, maar ook gemiddeld hoger scoren op de CITO-toets Begrijpend Lezen (meting E3) wat een mogelijke verklaring kan zijn. Daar komt bij dat het hier slechts om 22 van de in totaal 346 getoetste kinderen uit groep $4(6,4 \%)$. Al met al is de conclusie dat afnemereffecten geen negatieve invloed hebben op de validiteit van de Toets OCG voor groep 4.

\footnotetext{
${ }^{152}$ Kinderen met een hoger leerlinggewicht hebben ouders met een lager opleidingsniveau wat vaak betekent dat er thuis minder wordt (voor)gelezen en we dus mogen aannemen dat kinderen een lagere OCG hebben. Scores op de CITO-taaltoets kunnen niet beïnvloed zijn door de Toets OCG-afnameleider en we weten dat er wel een correlatie is met de toets OCG: kinderen die hoger scoren op de CITO-taaltoets (afgenomen vóór het Leeskalender-interventiejaar), scoren vaak ook hoger op de Toets OCG.
} 


\section{Inhouds- en begripsvaliditeit van de Toets OCG}

De inhouds- en begripsvaliditeit van een meetinstrument hebben betrekking op de aansluiting van het instrument op de experimentele 'ingreep' die gedaan is, dus op wat de kinderen in de experimentele conditie via de Leeskalender is aangeboden, en op de vraag of de Toets OCG inderdaad toetst wat hij moet toetsen (zie ook Hoeflaak, 2012). Dat eerste aspect, de aansluiting van het meetinstrument op de experimentele ingreep, is een aspect dat binnen dit onderzoeksproject hoofdzakelijk per deelproject verantwoord moet worden. Het overkoepelende uitgangspunt is dat de teksten/tekstfragmenten en de vragen die in de Toets OCG zijn gebruikt om 'ontluikende culturele geletterdheid' te meten, betrekking hebben op (een deel van de) teksten die de kinderen via de Leeskalender zijn aangeboden. In \$8.6 over de betrouwbaarheid en validiteit van de deeltoets Kinderpoëzie ga ik hier nader op in voor mijn eigen aandeel in de Toets OCG voor groep 2 en voor groep 4. Voor de toetsen als geheel geldt dat (een deel van) de 'indicatoren van canoniciteit' zoals aanwezig in het Leeskalenderaanbod ook de leidraad vormden voor de operationalisering van onze definitie van 'ontluikende culturele geletterdheid' naar concrete toetsitems. Omdat we 'ontluikende culturele geletterdheid' opvatten als kennis en begrip van kenmerken van breed gedragen (transculturele en langdurig geliefde) tekstsoorten en genres gaat de Toets OCG als geheel uit van de toepassing van kennis en begrip die kinderen in de experimentele conditie naar verwachting hebben opgedaan tijdens het werken met het tekstaanbod in de Leeskalender op nieuwe (soortgelijke) teksten in de toets. Het gaat daarbij in hoofdzaak om kennis en begrip die kinderen in de experimentele conditie naar verwachting hoofdzakelijk impliciet hebben opgedaan: er heeft geen expliciete instructie plaatsgevonden in het kader van de Leeskalender. Bijvoorbeeld: kinderen die gedurende dertig weken regelmatig hebben gewerkt met schelmenverhalen uit verschillende culturele tradities, deze verhalen hebben nagespeeld of erover hebben gepraat, zullen op de nameting naar verwachting vaker een specifieke schelm herkennen en kunnen voorspellen wat hij doet en/of uitleggen waarom hij iets doet in een nieuw verhaal. Idem dito voor het type moraal dat kinderen in fabels herkennen en/of voorspellen of de specifieke nonsensstrategie die ze in een gedicht herkennen en/of voorspellen. De soortgelijkheid van de kenmerken van specifieke genres en tekstsoorten die in de toetsitems centraal staan en de kenmerken van specifieke genres en tekstsoorten waar kinderen in de experimentele conditie via de Leeskalender mee hebben gewerkt, moet de inhoudsvaliditeit van de Toets OCG voor groep 2 en voor groep 4 garanderen. Dit is een aanvulling op bestaande meetinstrumenten waarmee effecten van het (voor)lezen van kinderliteratuur tot nu toe in kaart zijn gebracht, zoals de LAS, de LES, de VLES-K en de Watje Wimpie-taak (zie Hoofdstuk 7, \$7.4). We hebben binnen dit onderzoek niet gekozen voor een attitude- of retentietest omdat verandering in attitude ten aanzien van of het onthouden van titels en verhaalfiguren op zichzelf geen indicatoren van culturele geletterdheid in onze opvatting van het begrip zijn. We hebben ook niet gekozen voor het meten van literaire competentie, i.e. interpretatie en evaluatie als literaire vaardigheden, als opbrengst van het werken met kinderliteratuur. Het construct 'ontluikende culturele geletterdheid' is in de Toets OCG geoperationaliseerd tot items die stuk voor stuk betrekking hebben op de herkenning en kennis van een specifiek genre of specifieke tekstsoort (het schelmenverhaal, de fabel, het nonsensrijm, het sprookje, et cetera) en de daar- 
binnen aanwezige typerende kenmerken, zoals personages (Hodja/Anansi; Jezus/Mohammed), formules ('Er was eens'), stijlfiguren (de omkering; rijm), en motieven en thema's ('voor wat hoort wat'; 'de oplichter opgelicht'; 'hoogmoed komt voor de val').

Om na te gaan of de Toets OCG een instrument is dat inderdaad aspecten van de ontluikende culturele geletterdheid van kinderen meet, zijn we nagegaan of bepaalde aannamen over verbanden tussen ontluikende culturele geletterdheid en specifieke kenmerken van kinderen waarop we zelf geen invloed hebben uitgeoefend al dan niet geldig zijn. De volgende aannamen zijn getoetst:

Aanname 1: $\quad$ OCG neemt toe met leeftijd (ervaring), dus kinderen die ouder zijn (binnen een groep) scoren hoger op de toets dan jongere kinderen (correlatie OCG/leeftijd).

Aanname 2: $\quad$ Kinderen die thuis meer kinderboeken hebben en lezen, scoren hoger op de toets OCG (correlatie OCG/geletterd thuisklimaat).

Aanname 3: $\quad$ Kinderen met een hogere OCG doen het beter op school, met name op het gebied van taal (correlatie OCG/schoolprestaties) ${ }^{153}$.

Dit kunnen we nagaan omdat we via oudervragenlijsten, CITO-vaardigheidsscores aangeleverd door scholen en algemene vragen die aan de kinderen zelf gesteld zijn aanvullende informatie hebben verzameld over onze onderzoekspopulatie. Deze aannamen zijn getoetst op basis van de resultaten op de voormeting van de Toets OCG omdat we daarmee de 'nullijn' van de ontluikende culturele geletterdheid van de kinderen in kaart hebben gebracht zonder dat daar effecten van de Leeskalender in meespelen. De aannamen zijn getoetst voor zowel de Toets OCG voor groep 2 als voor de Toets OCG voor groep 4 en ik bespreek hier de uitkomsten voor de Toetsen OCG als geheel (dus voor alle toetsitems bij elkaar).

Aanname $1 \quad$ Voor de Toets OCG voor groep 2 is nagegaan of er sprake is van correlatie tussen de totaalscore op de voormeting en de leeftijd van de kinderen (in weken) op het moment van de toetsafname, indien kinderen jonger waren dan 300 weken $^{154}$ (5,8 jaar). Die samenhang is er bij kinderen in groep 2 inderdaad (tweezijdig): naarmate kinderen ouder zijn, scoren ze hoger op de Toets OCG ( $r=, 269$; $\mathrm{p}<, 001)$. Voor de Toets OCG voor groep 4 is nagegaan of er verband bestaat tussen de totaalscore op de voormeting en de leeftijd van de kinderen (in weken) op het moment van afname, indien kinderen jonger waren dan 405 weken ${ }^{155}$ (7,8 jaar). Bij groep 4 wordt het verwachte verband tussen leeftijd en ontluikende culturele geletterdheid niet gevonden $(\mathrm{r}=, 061 ; \mathrm{p}=, 348)$. Dit ondersteunt de

${ }^{153}$ Welke kant de relatie op werkt is niet per se duidelijk: lezen talige kinderen meer boeken omdat ze taliger zijn? Of zijn ze taliger omdat ze meer boeken lezen (voorgelezen krijgen)? We gaan er in ieder geval van uit dat er een relatie is. We verwachten dat de relatie met rekenen minder sterk is (hoewel mogelijk nog steeds aanwezig: wat geldt voor 'talige' kinderen geldt ook meer in het algemeen voor 'intelligentere' kinderen).

154 Deze leeftijdslimiet is gebruikt omdat in groep 2 ook kinderen zitten die qua leeftijd naar groep 3 hadden gemogen, maar toch een jaar langer 'kleuteren' omdat ze nog niet toe zijn aan de overgang naar groep 3. De OCG van deze kinderen is mogelijk lager en dit kan de correlatie tussen leeftijd en OCG 'vertroebelen'. Daarom zijn de kleuters die aan het begin van het leerjaar 'groep 2' ouder zijn dan 300 weken buiten deze analyse gelaten.

155 Deze leeftijdslimiet is gebruikt omdat in groep 4 ook kinderen zitten die langer 'gekleuterd' hebben of zijn blijven zitten. De OCG van deze kinderen is mogelijk lager en dit kan de correlatie tussen leeftijd en OCG 'vertroebelen'. Daarom zijn de kinderen die aan het begin van het leerjaar 'groep 4' ouder zijn dan 405 weken buiten deze analyse gelaten. 
validiteit van de Toets OCG voor groep 4 niet volgens onze verwachting. We kunnen het ontbreken van het verband hier echter ook koppelen aan het idee dat de culturele geletterdheid van kinderen in groep 4 in vergelijking met kinderen in groep 2 al meer bepaald is door school dan door thuis. Dan zou er inderdaad geen relatie met leeftijd moeten zijn, alleen met schoolervaring (en die is in veel grotere mate voor alle kinderen in dezelfde groep gelijk). We kunnen dus ook stellen dat 'correlatie tussen ontluikende culturele geletterdheid en leeftijd' voor kinderen in groep 4 geen indicator meer is voor de validiteit van de Toets OCG. Eerder hebben we vastgesteld dat kinderen in de controleconditie van groep 4 gemiddeld ouder zijn dan in de experimentele conditie: het feit dat leeftijd in groep 4 niet correleert met de ontluikende culturele geletterdheid van de kinderen wijst erop dat dit verschil tussen de onderzoekscondities niet problematisch is.

Aanname 2 We mogen er van uit gaan dat kinderen die thuis meer kinderboeken lezen (voorgelezen worden) en hebben ook een hogere mate van ontluikende culturele geletterdheid hebben dan kinderen die thuis minder kinderboeken lezen (voorgelezen worden) of hebben. Voor de Toets OCG voor groep 2 en voor groep 4 is nagegaan of de gemiddelde totaalscore van kinderen op de voormeting inderdaad correleert met kenmerken van een 'geletterd thuisklimaat'. De term 'geletterd' moet hier worden gelezen als 'aanwezigheid en voorlezen van kinderboeken'. Tijdens de voormeting is aan de kinderen zelf gevraagd of ze thuis kinderboeken hebben (ja/nee), hoeveel dat er ongeveer zijn (op basis van plaatjes: weinig/gemiddeld/veel), of ze worden voorgelezen (ja/nee) en of ze wel eens aan iemand vragen om hen voor te lezen (ja/nee). We zien dat kinderen die zeggen wel kinderboeken te hebben thuis ook een hogere aanvankelijke ontluikende culturele geletterdheid hebben dan kinderen die geen kinderboeken bezitten $(\mathrm{t}(349)=-2,656 ; \mathrm{p}=, 008)$. Ook kinderen die zeggen wel voorgelezen te worden thuis scoren gemiddeld hoger op de voormeting dan kinderen die zeggen niet te worden voorgelezen thuis $(\mathrm{t}(351)=-3,079$; $\mathrm{p}=, 002)$. Tellen we de scores op de vragen naar 'geletterd thuisklimaat bij elkaar op ${ }^{156}$, dan zien we dat ontluikende culturele geletterdheid inderdaad hoger is naarmate 'thuis' ook meer 'geletterd' is $(\mathrm{F}(2,351)=9,052 ; \mathrm{p}<, 001)$. Dit ondersteunt de validiteit van de Toets OCG voor groep 2. Naast de vragen die aan de kinderen zelf zijn gesteld, is via oudervragenlijsten informatie verzameld over voorlezen, bibliotheekbezoek, en het aantal boeken dat ouders kennen (op basis van een lijst met titels). Voor groep 2 geldt dat met name de frequentie waarmee ouders hun kinderen zeggen voor te lezen ${ }^{157}$ positief samenhangt met de score van het kind op de Toets OCG $(\mathrm{F}(3,221)=5,720$; $\mathrm{p}=, 001)$. Dit ondersteunt opnieuw de validiteit van de Toets OCG voor groep $2^{158}$. Voor groep 4 zien we het volgende: kinderen die zelf zeggen wel kinderboeken te bezitten, scoren ook hoger op de Toets OCG dan kinderen die zeggen geen kinderboeken te bezitten $(\mathrm{t}(343)=-3,622 ; \mathrm{p}<, 001)$, maar wel of niet voorgelezen worden, makkt geen verschil. Voorlezen is bij kinderen in groep 4 ook

\footnotetext{
${ }^{156}$ Er waren in totaal 5 punten te behalen. De kinderen zijn op basis van hun antwoorden op de vragen naar 'geletterd thuisklimaat' in drie groepen onderverdeeld: score 0-1 (minst geletterd), score 2-4 (gemiddeld geletterd) en score 5 (meest geletterd).

${ }^{157}$ De frequentie van voorlezen is onderverdeeld in 4 groepen: $1=$ maximaal $1 \mathrm{x}$ per week, $2=$ meerdere keren per week, $3=$ dagelijks, $4=$ meerdere keren per dag.

${ }^{158}$ Kinderen die vaker naar de bibliotheek gaan scoren ook hoger op de toets evenals kinderen van ouders die meer boeken in de boekenlijst zeggen te kennen: deze verschillen zijn niet significant, maar vormen wel een voorzichtige ondersteuning van de validiteit van de Toets OCG voor groep 2.
} 
minder aan de orde dan bij kinderen in groep 2: kinderen in groep 4 lezen vaker zelf. Tellen we de scores op de vragen naar 'geletterd thuisklimaat' weer bij elkaar op, dan is er wel een verschil in ontluikende culturele geletterdheid met name tussen de groep met het 'minst geletterd' thuisklimaat en de groep met 'gemiddeld' of 'meest geletterd' thuisklimaat ( $\mathrm{F}(2$, $343)=4,205 ; \mathrm{p}=, 016)$. Of en hoe valk ouders hun kinderen zeggen voor te lezen en ook bibliotheekbezoek hangt in groep 4 niet samen met de score op de Toets OCG: kinderen lezen vaker zelf en zoals ook bij leeftijd is 'school' hier mogelijk al meer bepalend dan thuis. Er is wel een significante (maar lage) correlatie tussen de score op de Toets OCG en het aantal boeken van de boekenlijst dat ouders zeggen te kennen $(r=, 238 ; p=, 001)$. Dit alles ondersteunt de validiteit van de Toets OCG voor groep 4 in lichte mate en geeft eenzelfde beeld als we bij aanname 1 al zagen: in groep 4 heeft 'school' waarschijnlijk al meer invloed gehad op de ontluikende culturele geletterdheid van de kinderen dan in groep 2. Andere factoren, zoals leeftijd en geletterd thuisklimaat, spelen dan ook een veel grotere rol bij groep 2 dan bij groep 4.

Aanname 3 We mogen verwachten dat er een verband bestaat tussen de mate van ontluikende culturele geletterdheid en schoolprestaties, met name op het gebied van taal. Omdat we van alle kinderen CITO-vaardigheidsscores op de taal- en rekentoetsen hebben verzameld, kunnen we nagaan of dit verband ook daadwerkelijk bestaat. Bij groep 2 vinden we inderdaad een significante correlatie tussen de totaalscore op de Toets OCG (voormeting) en CITO-vaardigheidsscores op zowel de reken- als taaltoets (meting E1). De correlatie tussen de Toets OCG en Taal $(\mathrm{r}=, 459 ; \mathrm{p}<, 001)$ is duidelijk sterker dan tussen de Toets OCG en Rekenen ( $r=, 285 ; \mathrm{p}<, 001)$. Voor groep 4 hebben we gegevens van drie verschillende taaltoetsen: Woordenschat, Begrijpend Lezen en Spelling. We verwachten een correlatie tussen de Toets OCG en Woordenschat en Begrijpend Lezen, maar niet met Spelling. De Toets OCG meet mogelijk in hoge mate begrijpend 'lezen' (luisteren). We verwachten in dat geval een hoge correlatie met die CITO-vaardigheidsscores. Wat we vinden is dat er, zoals verwacht, een zeer lage correlatie tussen de OCG-scores en de CITO-Spellingscores bestaat $(\mathrm{r}=, 117 ; \mathrm{p}=, 041)$. Daarnaast zien we een significante correlatie tussen de OCGtoetsscores en de vaardigheidsscores op Rekenen $(r=, 400 ; \mathrm{p}<, 001)$, Woordenschat $(\mathrm{r}=, 447$; $\mathrm{p}<, 001)$ en Begrijpend Lezen $(\mathrm{r}=, 339 ; \mathrm{p}<, 001)$. De correlatie met Rekenen is ongeveer even sterk als die met de CITO-toetsen voor taal (behalve Spelling). Dit is onverwacht, maar wel verklaarbaar: enerzijds gaat het in het Toets OCG ook om redeneren, iets wat juist bij rekenen aangeleerd wordt, en anderzijds speelt in Rekentoetsen ook taalvaardigheid een belangrijke rol. De correlatie tussen de OCG-toetsscores en de vaardigheidsscores op de CITO-toets Begrijpend Lezen is significant, maar niet heel sterk. Deze resultaten wijzen erop dat de Toets OCG niet vooral begrijpend lezen/luisteren toetst: een belangrijke indicatie dat de toets de beoogde specifieke kennis en vaardigheden met betrekking tot tekstsoorten en -kenmerken meet. 


\subsection{Effecten van de Leeskalender op ontluikende culturele geletterdheid}

Een belangrijke algemene opmerking is dat we binnen dit evaluatief praktijkgericht onderzoek geen norm stellen die aangeeft wanneer een kind voldoende 'ontluikend cultureel geletterd' is. We gaan er van uit dat elk kind in een bepaalde mate 'ontluikend cultureel geletterd' is. We willen met dit onderzoek nagaan of (op basis van specifieke criteria geselecteerde) kinderliteratuur al dan niet effectief bijdraagt aan de verdere ontwikkeling van die ontluikende culturele geletterdheid. We spreken dus niet in termen van 'wel cultureel geletterd' en 'niet cultureel geletterd' of 'voldoende/onvoldoende cultureel geletterd' met een bepaalde grenswaarde; we gaan uit van een schaal van ontluikende culturele geletterdheid en gaan na of de ontluikende culturele geletterdheid van kinderen in de experimentele conditie in groep 2 en in groep 4 onder invloed van de Leeskalender gemiddeld meer is toegenomen dan de ontluikende culturele geletterdheid van kinderen in de controleconditie. Om dat na te gaan, kijken we per groep ( 2 of 4 ) eerst naar de gemiddelde scores die op de voormeting en op de nameting werden behaald door kinderen in de controleconditie en kinderen in de experimentele conditie op de Toets OCG als geheel. Vervolgens vergelijken we de gemiddelde groeiscores tussen de voor- en nameting van kinderen in de controleconditie en kinderen in de experimentele conditie.

\section{Effecten van de Leeskalender op ontluikende culturele geletterdheid in groep 2}

Voor groep 2 geldt dat de gemiddelde totaalscores op de voormeting van de Toets OCG $(\mathrm{N}=352)$ voldoende normaal verdeeld zijn $(\mathrm{W}=, 94)^{159}$ en dat er geen significant verschil is tussen de gemiddelde totaalscore van de controleconditie en de experimentele conditie. De scores variëren van 1 tot en met 23 waarbij de controlegroep gemiddeld 7,5 punten behaalde en de experimentele groep gemiddeld 7,9 punten. Het gemiddelde over beide onderzoekscondities heen was 7,7 punten (met een standaardafwijking van 4,3). Dit is nagegaan met een t-toets voor onafhankelijke metingen (zie Tabel 27).

Tabel 27. Vergelijking van de resultaten in groep 2 op de voormeting, naar onderzoeksconditie

\begin{tabular}{|c|c|c|}
\hline $\begin{array}{l}\text { VOORMETING TOETS OCG } \\
\text { GROEP } 2\end{array}$ & $\begin{array}{l}\text { Controle groep } \\
(\mathrm{N}=120)\end{array}$ & $\begin{array}{l}\text { Experimentele groep } \\
(\mathrm{N}=232)\end{array}$ \\
\hline Gemiddelde & 7,48 & 7,87 \\
\hline Standaard afwijking & 4,08 & 4,46 \\
\hline Levene toets voor gelijkheid varianties & \multicolumn{2}{|c|}{ Het verschil tussen de varianties is niet significant $(\mathrm{F}=1,46 ; \mathrm{p}=, 227)$} \\
\hline t-toets voor gelijkheid van gemiddelden & \multicolumn{2}{|c|}{$\begin{array}{l}\text { De OCG-score verschilde niet tussen beide condities }(t(350)=-, 80 \\
p=, 43)\end{array}$} \\
\hline
\end{tabular}

${ }^{159}$ Voor verschillende statistische toetsen is het van belang dat de data normaal verdeeld zijn. Dat betekent dat een histogram een mooie belvorm heeft, met evenveel leerlingen boven en onder het gemiddelde en met evenveel afwijking van het gemiddelde aan beide kanten. Het meten van de normaliteit van de verdeling kan op verschillende manieren. Voor een dataset als deze, met een sample size van ruim 300, is de Shapiro-Wilk normaliteitstoets het meest geschikt. Bij een sample size van groter dan 50 geeft deze toets vaak een significante afwijking van een normaalverdeling. Daarom wordt hier gekeken naar de waarde van de Shapiro-Wilk statistiek zelf (W). Deze kan een waarde tussen de 0 en 1 hebben. Wanneer deze groter dan 0,9 is, zijn de data voldoende normaal verdeeld. 
Op de nameting van de Toets OCG (N=339) zien we dat de gemiddelde totaalscores opnieuw voldoende normaal verdeeld zijn $(\mathrm{W}=, 98)$. Beide onderzoekscondities zijn, zoals verwacht, gemiddeld vooruit gegaan op de Toets OCG. De scores variëren van 1 tot en met 31 waarbij de controlegroep gemiddeld 12,3 punten scoort en de experimentele groep gemiddeld 13,9 punten. Het gemiddelde over beide condities heen is nu 13,3 (met een standaardafwijking van 6,3). Het verschil tussen de gemiddelde score van kinderen in de controleconditie en kinderen in de experimentele conditie, nagegaan met een t-toets van onafhankelijke metingen, is nu echter wel significant en in het voordeel van de experimentele conditie $(\mathrm{t}(337)=-2,241 ; \mathrm{p}=, 026)$ (zie Tabel 28$)$.

Tabel 28. Vergelijking van de resultaten in groep 2 op de nameting, naar onderzoeksconditie

\begin{tabular}{lll}
\hline $\begin{array}{l}\text { NAMETING TOETS OCG } \\
\text { GROEP 2 }\end{array}$ & $\begin{array}{l}\text { Controle groep } \\
(\mathrm{N}=114)\end{array}$ & $\begin{array}{l}\text { Experimentele groep } \\
(\mathrm{N}=225)\end{array}$ \\
\hline Gemiddelde & 12,25 & 13,85 \\
Standaard afwijking & 5,90 & 6,41 \\
Levene toets voor gelijkheid varianties & Het verschil tussen de varianties is niet significant $(\mathrm{F}=2,09 ; \mathrm{p}=, 149)$ \\
t-toets voor gelijkheid van gemiddelden & De OCG-score verschilde wel tussen beide condities $(\mathrm{t}(337)=-2,24 ;$ \\
& $\mathrm{p}=, 03)$
\end{tabular}

De groep kinderen die tussen de voor- en nameting met een versie van de Leeskalender heeft gewerkt, heeft op de nameting een hogere gemiddelde score op de Toets OCG dan de groep kinderen die niet met de Leeskalender heeft gewerkt. Dit bevestigt onze verwachting. In Figuur 7 staan de gemiddelde scores van de controle- en experimentele groep 2 op de voor- en de nameting grafisch weergegeven.

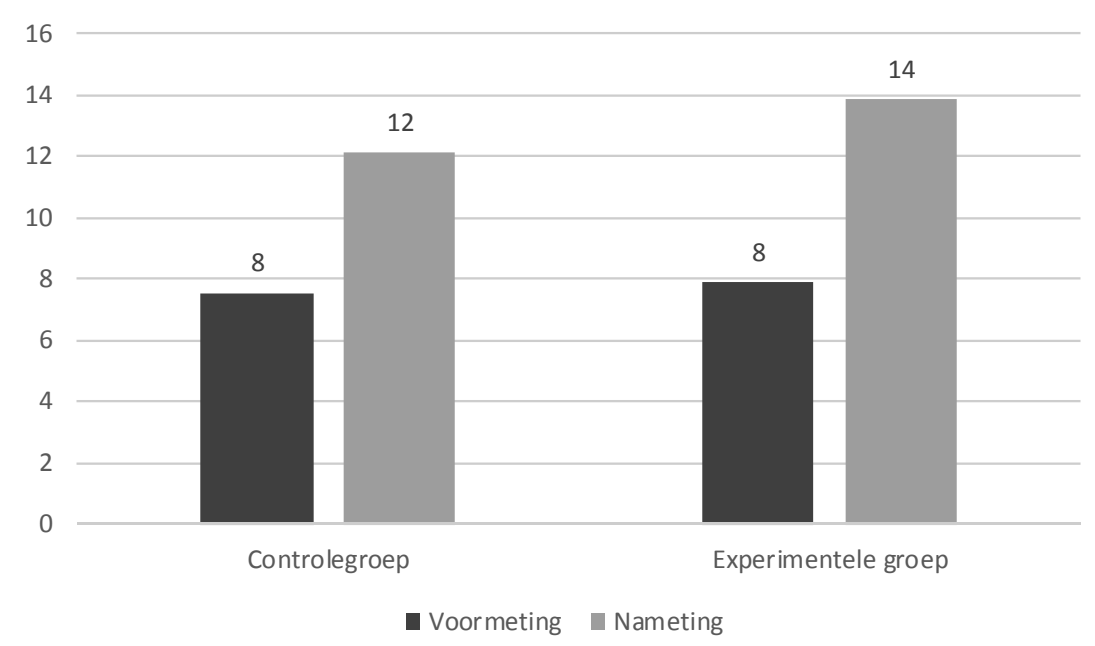

Figuur 8. Grafische weergave van de gemiddelde scores van de controle- en experimentele groep 2 op de voor- en nameting met de Toets OCG 
De uitkomsten tot nu toe zeggen echter nog niet zoveel over de daadwerkelijke toename van ontluikende culturele geletterdheid bij kinderen in groep 2. Om nauwkeuriger en betrouwbaarder uitspraken te kunnen doen over de effecten van de Leeskalender op de ontluikende culturele geletterdheid van kinderen in groep 2, kijken we naar de gemiddelde verschil- of groeiscores van de kinderen in de controle- en experimentele groep. De verwachting is dat kinderen in de experimentele conditie een grotere toename in ontluikende culturele geletterdheid laten zien dan kinderen in de controleconditie. De verschilscores worden berekend door per kind de score op de voormeting (de 'nullijn') van de score op de nameting af te trekken (verschilscore is nameting minus voormeting). Vervolgens kunnen we de verschilscores van de kinderen in de controleconditie en de kinderen in de experimentele conditie met elkaar vergelijken. De verdeling van de gemiddelde verschilscores van controle- en experimentele groep $(\mathrm{N}=338)$ is opnieuw voldoende normaal verdeeld $(\mathrm{W}=, 99)$.

Tabel 29. Vergelijking van de verschilscores in groep 2 tussen de nameting en de voormeting, naar onderzoeksconditie

\begin{tabular}{lll}
\hline $\begin{array}{l}\text { VERSCHILSCORES TOETS OCG } \\
\text { GROEP 2 }\end{array}$ & $\begin{array}{l}\text { Controle groep } \\
(\mathrm{N}=114)\end{array}$ & $\begin{array}{l}\text { Experimentele groep } \\
(\mathrm{N}=224)\end{array}$ \\
\hline Gemiddelde & 4,65 & 5,96 \\
Standaard afwijking & 5,22 & 4,97 \\
Levene toets voor gelijkheid varianties & Het verschil tussen de varianties is niet significant $(\mathrm{F}=, 036 ; \mathrm{p}=, 849)$ \\
t-toets voor gelijkheid van gemiddelden & De OCG-score verschilde wel tussen beide condities $(\mathrm{t}(336)=-2,26 ;$ \\
& $\mathrm{p}=, 024)$ & \\
\hline
\end{tabular}

De verschil- of groeiscores variëren over het geheel van de controle- en experimentele groep van -17 tot en met 21 punten met een gemiddelde verschilscore van 5,5 punten. De negatieve scores betekenen dat een deel van de kinderen $(9,8 \%)$ achteruit is gegaan in hun score op de Toets OCG. Hiervoor kunnen tal van redenen zijn die op zichzelf niet iets over de ontluikende culturele geletterdheid van die kinderen hoeven zeggen, zoals vermoeidheid (de nameting vond plaats aan het einde van het schooljaar in een periode waarin ook de laatste CITO-toetsen van het schooljaar worden afgenomen). De controlegroep heeft een gemiddelde verschilscore van 4,6 punten en de experimentele groep een gemiddelde verschilscore van 6,0 punten. Het verschil tussen de gemiddelde verschilscore van de controleconditie en de experimentele conditie, nagegaan met een t-toets van onafhankelijke metingen, is significant en in het voordeel van de experimentele conditie $(\mathrm{t}(336)=-2,260$; $\mathrm{p}=$,024) (zie Tabel 29).

Op basis van de meting met de Toets OCG kan worden geconcludeerd dat de Leeskalender een positief effect heeft gehad op de ontwikkeling van de ontluikende culturele geletterdheid van kinderen in groepen 2 van het basisonderwijs. Dit resultaat is gebaseerd op de Toets OCG als geheel, dus inclusief de toetsitems van de drie deelprojecten, zonder onderscheid te maken op basis van de specifieke versie van de Leeskalender waarmee is gewerkt. In de paragraaf over de deeltoets Kinderpoëzie ga ik nader in op de differentiatie naar deelproject en kalenderversie. Eerst bespreek ik de resultaten voor groep 4 op basis van de Toets OCG als geheel zonder onderscheid te maken op basis van deelprojecten en de specifieke versie van de Leeskalender waarmee is gewerkt. 


\section{Effecten van de Leeskalender op ontluikende culturele geletterdheid in groep 4}

De gemiddelde totaalscores op de voormeting van de Toets OCG voor groep 4 zijn voldoende normaal verdeeld $(W=, 99)$, maar - zoals eerder al is vastgesteld in het kader van de vergelijkbaarheid van onderzoekscondities - al op de voormeting scoort de experimentele groep 4 gemiddeld hoger dan de controlegroep $(\mathrm{t}(344)=-3,224 ; \mathrm{p}=, 001)$. De scores variëren van 1 tot en met 32 waarbij kinderen in de controleconditie gemiddeld 12,8 punten behaalden en kinderen in de experimentele groep gemiddeld 15,0 punten. Het gemiddelde over beide onderzoekscondities heen was 14,3 punten (met een standaardafwijking van 5,8 ). Dit is nagegaan met een t-toets van onafhankelijke metingen (Tabel 30).

Tabel 30. Vergelijking van de resultaten in groep 4 op de voormeting, naar onderzoeksconditie

\begin{tabular}{lll}
\hline $\begin{array}{l}\text { VOORMETING TOETS OCG } \\
\text { GROEP 4 }\end{array}$ & $\begin{array}{l}\text { Controle groep } \\
(\mathrm{N}=107)\end{array}$ & $\begin{array}{l}\text { Experimentele groep } \\
(\mathrm{N}=239)\end{array}$ \\
\hline Gemiddelde & 12,83 & 14,96 \\
Standaard afwijking & 5,70 & 5,67 \\
Levene toets voor gelijkheid varianties & Het verschil tussen de varianties is niet significant $(\mathrm{F}=, 206 ; \mathrm{p}=, 650)$ \\
t-toets voor gelijkheid van gemiddelden & De OCG-score verschilde tussen beide condities $(\mathrm{t}(344)=-3,224 ; \mathrm{p}=, 001)$ \\
\hline
\end{tabular}

Op de nameting van de Toets OCG $(\mathrm{N}=326)$ zien we dat de gemiddelde totaalscores in groep 4 opnieuw voldoende normaal verdeeld zijn $(W=, 99)$. Beide onderzoekscondities zijn, zoals verwacht, gemiddeld vooruit gegaan op de Toets OCG. De scores variëren op de nameting van 3 tot en met 38 waarbij kinderen in de controlegroep gemiddeld 17,1 punten scoorden en kinderen in de experimentele groep gemiddeld 21,6 punten. Het gemiddelde over de condities heen is nu 20,1 punten (met een standaardafwijking van 6,9). Het verschil tussen de gemiddelde totaalscore van de controleconditie en de experimentele conditie is ook nu weer significant en in het voordeel van de experimentele conditie $(t(319)=-5,656 ; p<, 001)$. Dit is opnieuw nagegaan met een $t$-toets van onafhankelijke metingen (zie Tabel 31).

Tabel 31. Vergelijking van de resultaten in groep 4 op de nameting, naar onderzoeksconditie

\begin{tabular}{lll}
\hline $\begin{array}{l}\text { NAMETING TOETS OCG } \\
\text { GROEP } 4\end{array}$ & $\begin{array}{l}\text { Controle groep } \\
(\mathrm{N}=98)\end{array}$ & $\begin{array}{l}\text { Experimentele groep } \\
(\mathrm{N}=223)\end{array}$ \\
\hline Gemiddelde & 17,06 & 21,57 \\
Standaard afwijking & 6,49 & 6,61 \\
Levene toets voor gelijkheid varianties & Het verschil tussen de varianties is niet significant $(\mathrm{F}=, 010 ; \mathrm{p}=, 919)$ \\
t-toets voor gelijkheid van gemiddelden & De OCG-score verschilde tussen beide condities $(\mathrm{t}(319)=-5,656 ; \mathrm{p}<, 001)$ \\
\hline
\end{tabular}

Zowel op de voormeting als op de nameting bestaat een significant verschil tussen de gemiddelde score van de controlegroep en de gemiddelde score van de experimentele groep op de Toets OCG voor groep 4 in het voordeel van die laatste groep. In Figuur 8 staan de gemiddelde scores van de controle- en experimentele groep 4 op de voor- en de nameting grafisch weergegeven. 


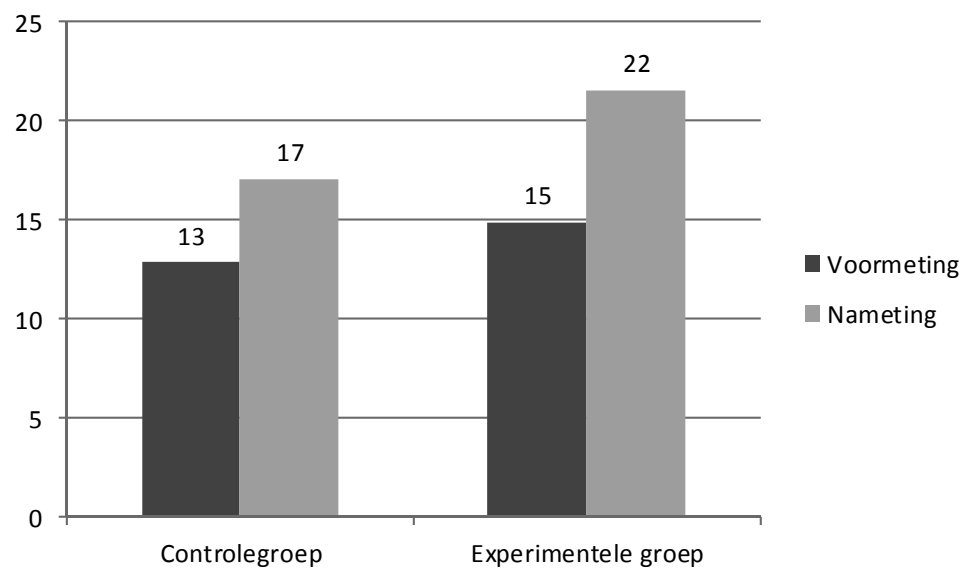

Figuur 9. Grafische weergave van de gemiddelde scores van de controle- en experimentele groep 4 op de voor- en nameting met de Toets OCG

In beide condities zijn de kinderen gemiddeld vooruit gegaan op de Toets OCG. Echter, omdat de experimentele en controleconditie bij groep 4 op de voormeting al significant van elkaar verschillen, kunnen we op basis van deze inzichten geen uitspraken doen over effecten van de Leeskalender.

Om nauwkeuriger en betrouwbaarder uitspraken te kunnen doen over de effecten van de Leeskalender op de ontluikende culturele geletterdheid van kinderen in groep 4, kijken we ook nu weer naar de verschil- of groeiscores van de kinderen in de controle- en experimentele conditie. Die scores worden berekend door per kind de score op de voormeting (de 'nullijn') van de score op de nameting af te trekken (verschilscore is nameting minus voormeting). Vervolgens kunnen we de verschil- of groeiscores van de kinderen in de controleconditie en de kinderen in de experimentele conditie met elkaar vergelijken. De verdeling van de gemiddelde verschilscores van de controlegroep en van de experimentele groep $(\mathrm{N}=321)$ is opnieuw voldoende normaal verdeeld $(\mathrm{W}=, 99)$. De verschilscores variëren over het geheel van de controle- en experimentele conditie van -10 tot en met 21 punten met een gemiddelde verschilscore van 5,9 punten. Van de kinderen in groep 4 is $13,7 \%$ achteruit gegaan in hun score op de Toets OCG. Hiervoor kunnen opnieuw tal van redenen zijn die op zichzelf niet per se iets over de ontluikende culturele geletterdheid van die kinderen zeggen, zoals vermoeidheid. De nameting vond plaats aan het einde van het schooljaar: dit is niet alleen een periode waarin het op basisscholen vaak toch al wat onrustig is vanwege de naderende zomervakantie, maar ook de periode waarin de laatste CITO-toetsen van het schooljaar worden afgenomen. Dit kan eraan bijdragen dat sommige kinderen last krijgen van 'toets-moeheid', zeker in groep 4 waar vier verschillende CITO-toetsen worden afgenomen. 
Tabel 32. Vergelijking van de verschilscores in groep 4 tussen de nameting en de voormeting, naar onderzoeksconditie

\begin{tabular}{lll}
\hline $\begin{array}{l}\text { VERSCHILSCORES TOETS OCG } \\
\text { GROEP } 4\end{array}$ & $\begin{array}{l}\text { Controle groep } \\
(\mathrm{N}=98)\end{array}$ & $\begin{array}{l}\text { Experimentele groep } \\
(\mathrm{N}=223)\end{array}$ \\
\hline Gemiddelde & 4,23 & 6,70 \\
Standaard afwijking & 5,72 & 5,58 \\
Levene toets voor gelijkheid varianties & Het verschil tussen de varianties is niet significant $(\mathrm{F}=, 220 ; \mathrm{p}=, 640)$ \\
t-toets voor gelijkheid van gemiddelden & De OCG-score verschilt tussen beide condities $(\mathrm{t}(319)=-3,634 ; \mathrm{p}<, 001)$ \\
\hline
\end{tabular}

Kinderen in de controleconditie zijn gemiddeld 4,2 punten vooruit gegaan op de Toets OCG en kinderen in de experimentele groep gemiddeld 6,7 punten. Het verschil tussen de gemiddelde verschilscore van de controleconditie en de experimentele conditie, nagegaan met een t-toets van onafhankelijke metingen, is significant en in het voordeel van de experimentele conditie $(\mathrm{t}(319)=-3,634 ; \mathrm{p}<, 001)$ (zie Tabel 32).

Bij de bespreking van de interne validiteit van de meting van ontluikende culturele geletterdheid zoals we die binnen dit onderzoek verricht hebben, is al naar voren gebracht dat de controle- en experimentele conditie bij groep 4 op een aantal kenmerken van elkaar verschillen. Kinderen in de controleconditie hadden gemiddeld een iets hogere leeftijd ten tijde van de meting, hoewel we ook al hebben gezien dat 'leeftijd' in groep 4 niet meer samenhangt met de score op de Toets OCG. Dit verschil werkt dus niet in het voordeel van de controleconditie of in het nadeel van de experimentele conditie. De kinderen in de controleconditie hebben gemiddeld echter ook een hoger leerlinggewicht dan de kinderen in de experimentele conditie. Als we de leerlingen indelen in groepen op basis van leerlinggewicht ('0'; ' 0,3 '; ' 1,2 ') en opnieuw kijken naar de scores op de Toets OCG voor groep 4, dan blijken er verschillen te bestaan in de gemiddelde scores van deze subgroepen op de toets, zowel op de voormeting $(\mathrm{F}(2,337)=13,524 ; \mathrm{p}<, 001)$ als op de nameting $(\mathrm{F}(2,321)=14,652 ; \mathrm{p}<, 001)$ (zie Tabel 33).

Tabel 33. Resultaten groep 4 nader bekeken: verschillen tussen scores op voor- en nameting, naar leerlinggewicht

\begin{tabular}{llrlll}
\hline & & G & Gemiddelde & $\begin{array}{l}\text { Standaard } \\
\text { afwijking }\end{array}$ & Verschil \\
\hline Voormeting & Leerlinggewicht 0 & 256 & 15,18 & 5,77 & $\begin{array}{l}\text { Significant verschil tussen groepen } \\
(\mathrm{F}(2,337)=13,524 ; \mathrm{p}<, 001)\end{array}$ \\
& Leerlinggewicht 0,3 & 41 & 12,56 & 4,83 & \\
& Leerlinggewicht 1,2 & 43 & 10,86 & 4,67 & Significant verschil tussen groepen \\
\multirow{2}{*}{ Nameting } & Leerlinggewicht 0 & 244 & 21,28 & 6,66 & $(\mathrm{~F}(2,321)=14,652 ; \mathrm{p}<, 001)$ \\
& Leerlinggewicht 0,3 & 37 & 16,65 & 6,73 & \\
\hline
\end{tabular}

Door het uitvoeren van zogeheten post hoc-analyses voor meervoudige paarsgewijze vergelijkingen wordt zichtbaar dat het verschil in gemiddelde score op de Toets OCG voor groep 4 tussen de groep zonder leerlinggewicht en de groep met leerlinggewicht 0,3 significant is op zowel de voor- als nameting (Fishers LSD $\mathrm{p}<, 001$; Bonferroni $\mathrm{p}<, 001$ ), net als het verschil in gemiddelde score tussen de groep zonder leerlinggewicht en de groep met leerlinggewicht 1,2 (Fishers LSD $\mathrm{p}<, 001$; Bonferroni $\mathrm{p}<, 001$ ). Met andere woorden: de 
scores van kinderen zonder verhoogd leerlinggewicht en kinderen met verhoogd leerlinggewicht (ongeacht het de 'zwaarte' van het gewicht) verschillen van elkaar. In Figuur 9 is te zien hoe leerlinggewicht en score op de Toets OCG zich tot elkaar verhouden op de vooren op de nameting bij groep 4.

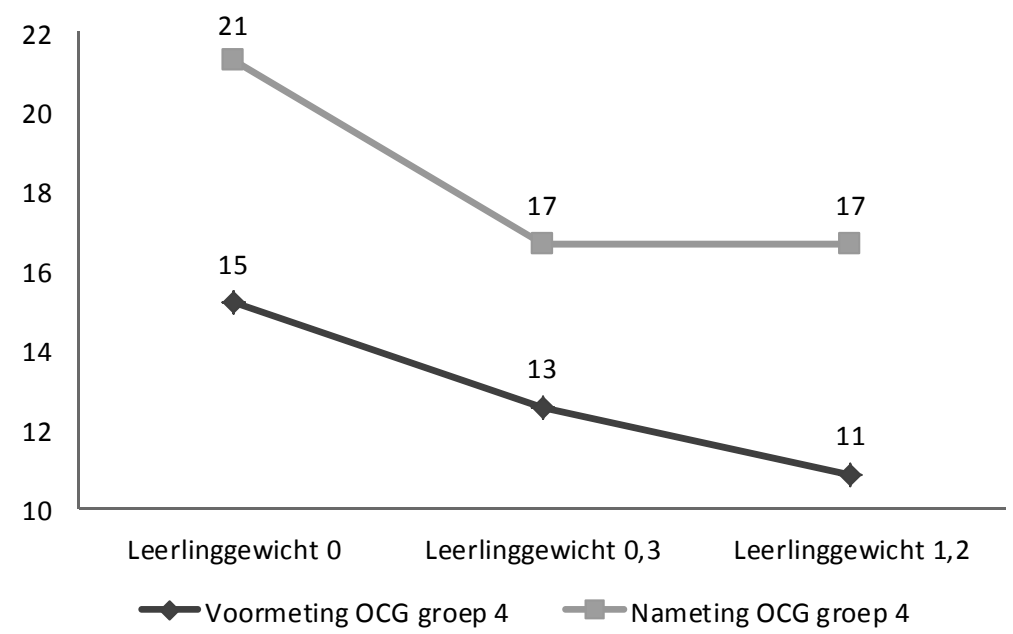

Figuur 10. Gemiddelde score op de voor- en nameting Toets OCG voor groep 4 naar leerlinggewicht

Het verschil tussen de groep met leerlinggewicht 0,3 en met leerlinggewicht 1,2 is op de voormeting noch de nameting significant, waaruit we kunnen opmaken dat een verhoogd leerlinggewicht, ongeacht de precieze 'zwaarte' ervan, nadelig is voor de mate van ontluikende culturele geletterdheid. In deze analyses is geen onderscheid gemaakt tussen de onderzoekscondities, maar de resultaten geven een indicatie dat het feit dat de experimentele conditie bij groep 4 gemiddeld lagere leerlinggewichten heeft dan de controleconditie, in het voordeel van de experimentele conditie werkt en dus mede verantwoordelijkheid kan zijn voor de hogere scores op de Toets OCG op zowel de voor- als de nameting.

We hebben eveneens al vastgesteld dat de kinderen in groepen 4 in de experimentele conditie, naast een hogere gemiddelde score op de Toets OCG en een gemiddeld lager leerlinggewicht, ook hoger scoorden op de CITO-toetsen. Deze verschillen zouden het Mattheüs-effect in de hand kunnen werken: zoals kinderen met een grotere woordenschat hun woordenschat ook sneller uitbreiden, zo kan dat eveneens gelden voor culturele geletterdheid (zie Hoofdstuk 1). Dit zou betekenen dat de grotere groei op de Toets OCG van de experimentele groepen 4 mogelijk niet alleen door de interventie, maar door de al aanwezige 'voorsprong' is veroorzaakt. We weten dus al dat er verschillen bestaan tussen de controle- en experimentele conditie van groep 4 op basis van de achtergrondkenmerken van de leerlingen. Hoe kunnen we dan toch inzicht krijgen in welk deel van de groei in ontluikende culturele geletterdheid van kinderen in de experimentele conditie is toe te schrijven aan het werken met de Leeskalender? Aanvullende analyses met gegevens uit de 
oudervragenlijsten laten zien dat de onafhankelijke variabele 'opleiding moeder'160 samenhangt met de score op de voormeting van de Toets OCG voor groep 4 en zorgt voor verschillen in ontluikende culturele geletterdheid tussen groepen kinderen ingedeeld op basis van het opleidingsniveau van de moeder $(F(2,177)=4,927 ; \mathrm{p}=, 008)^{161}$. De variabele 'opleiding moeder' is voor de analyses onderverdeeld in drie categorieën, te weten (1) 'Maximaal vmbo of voortgezet onderwijs zonder vervolgopleiding', (2) 'MBO' en (3) 'HBO of WO'. Vervolgens is nagegaan of het controleren van deze variabele effecten van de Leeskalender op de ontluikende culturele geletterdheid van kinderen in groep 4 duidelijker zichtbaar zou maken. Als we de groep 4 kinderen in zowel de controle- als in de experimentele conditie herindelen op basis van deze categorieën, dan zien we dat de opleidingsniveaus van de moeder relatief gelijkmatig over de experimentele en controleconditie verdeeld zijn $\left(\chi^{2}(2)=5,412 ; p=, 067\right)$. Wanneer we leerlingen binnen een groep op basis van het opleidingsniveau van de moeder uit de beide onderzoekscondities met elkaar vergelijken, dan zijn er op de voormeting geen significante verschillen in de scores op de Toets OCG tussen controleconditie en experimentele conditie. Binnen 'opleiding moeder' zijn kinderen uit de controle- en experimentele conditie nu dus vergelijkbaar en tekenen zich ook verschillen op de nameting af die we met grotere zekerheid aan de Leeskalender kunnen toeschrijven (zie Tabel 34).

\footnotetext{
160 Nota bene: de variabele 'opleiding moeder' is gebaseerd op gegevens verkregen via de oudervragenlijsten. Omdat niet voor alle kinderen in groep 4 een oudervragenlijst is geretourneerd (zie Hoofdstuk 6) en binnen de geretourneerde vragenlijsten niet altijd het opleidingsniveau van de moeder is ingevuld, spreken we hier dus over een subgroep van de onderzoekspopulatie, die evenwel meer dan de helft van het totale aantal kinderen in groep 4 bedraagt (180 kinderen; 56\% van de groep 4 leerlingen bij wie zowel voor- als nameting is afgenomen).

${ }^{161}$ Waarom het opleidingsniveau van de moeder? Als we kijken naar correlatieanalyses met de gegevens uit de oudervragenlijst, zien we dat deze variabele vrij sterk samenhangt met toetsscore op de voormeting. Datzelfde geldt voor het opleidingsniveau van de vader: een kenmerk dat sterk samenhangt met het opleidingsniveau van de moeder (zie Tabel 35). Kijken we naar groepen kinderen op basis van andere achtergrondkenmerken, zoals het aantal (groot)ouders dat in Nederland is geboren, het al dan niet Christelijk of Islamitisch zijn, en het bezit van en bekendheid met kinderliteratuur thuis, dan zien we ook verschillen in aanvankelijke ontluikende culturele geletterdheid in groep 4, maar deze kenmerken dwingen tot een grove indeling (ja/nee; weinig/veel) en hangen minder sterk met de OCG-toetsscore op de voormeting samen dan het opleidingsniveau van een van de ouders. Het is daarbij logisch om naar opleidingsniveau van de ouders te kijken: leerlinggewichten zijn ook op het opleidingsniveau van de ouder(s) gebaseerd, maar kijkt slechts naar een kleine groep (een of beide ouder(s) heel laag opgeleid, met maximaal lbo/vbo, praktijkonderwijs of vmbo basis- of kaderberoepsgerichte leerweg om het 'lichtste' gewicht te krijgen). Het opleidingsniveau van de moeder geeft een gelijkmatige verdeling van kinderen in drie groepen, zowel in de experimentele als in de controleconditie. Deze variabele leent zich daarmee het best voor een nadere exploratie van effecten van de Leeskalender op de OCG van kinderen in groep 4.
} 
Tabel 34. Resultaten groep 4 nader bekeken: de variabele 'opleiding moeder' gecontroleerd (ingedeeld in (1) 'Maximaal vmbo of voortgezet onderwijs zonder vervolgopleiding', (2) 'MBO' en (3) 'HBO of WO') 162 $^{2}$

\begin{tabular}{|c|c|c|c|c|c|c|}
\hline & & Conditie & $\mathrm{N}$ & Gemiddelde & $\begin{array}{l}\text { Standaard } \\
\text { afwijking }\end{array}$ & \\
\hline \multirow{6}{*}{$\begin{array}{l}\text { Opleiding } \\
\text { moeder ' } 1 \text { ' }\end{array}$} & \multirow[t]{2}{*}{ voormeting } & controle & 28 & 13,2857 & 5,30449 & \multirow{4}{*}{$\begin{array}{l}\text { Significant verschil } \\
(\mathrm{t}(68)=2,575 ; \mathrm{p}=, 012)\end{array}$} \\
\hline & & experimenteel & 46 & 13,3478 & 5,01649 & \\
\hline & \multirow[t]{2}{*}{ nameting } & controle & 27 & 16,2593 & 5,88736 & \\
\hline & & experimenteel & 43 & 20,2326 & 6,51678 & \\
\hline & \multirow[t]{2}{*}{ verschilscore } & controle & 27 & 3,2593 & 4,22067 & \multirow{2}{*}{$\begin{array}{l}\text { Significant verschil } \\
(\mathrm{t}(68)=2,907 ; \mathrm{p}=, 005)\end{array}$} \\
\hline & & experimenteel & 43 & 7,2093 & 6,20890 & \\
\hline \multirow{6}{*}{$\begin{array}{l}\text { Opleiding } \\
\text { moeder ' } 2 \text { ' }\end{array}$} & \multirow[t]{2}{*}{ voormeting } & controle & 17 & 14,1176 & 5,85109 & \\
\hline & & experimenteel & 51 & 14,8824 & 5,54129 & \\
\hline & \multirow[t]{2}{*}{ nameting } & controle & 17 & 19,9412 & 4,91771 & \\
\hline & & experimenteel & 47 & 23,1915 & 6,51633 & \\
\hline & \multirow[t]{2}{*}{ verschilscore } & controle & 17 & 5,8235 & 6,70108 & \\
\hline & & experimenteel & 47 & 8,1277 & 5,55845 & \\
\hline \multirow{6}{*}{$\begin{array}{l}\text { Opleiding } \\
\text { moeder ' } 3 \text { ' }\end{array}$} & \multirow[t]{2}{*}{ voormeting } & controle & 7 & 13,7143 & 7,04070 & \\
\hline & & experimenteel & 31 & 17,4516 & 5,78411 & \\
\hline & \multirow[t]{2}{*}{ nameting } & controle & 7 & 19,5714 & 6,70465 & \multirow{4}{*}{$\begin{array}{l}\text { Significant verschil } \\
(\mathrm{t}(34)=2,172 ; \mathrm{p}=, 037)\end{array}$} \\
\hline & & experimenteel & 29 & 24,7931 & 5,47318 & \\
\hline & \multirow[t]{2}{*}{ verschilscore } & controle & 7 & 5,8571 & 7,19788 & \\
\hline & & experimenteel & 29 & 7,2759 & 5,45040 & \\
\hline
\end{tabular}

Deze vergelijking van subgroepen gevormd op basis van de variabele 'opleiding moeder' (de verschillen tussen deze subgroepen zijn nu dus gecontroleerd) laat zien dat de gemiddelde scores met name op de nameting gestaag oplopen met het oplopen van 'opleiding moeder'. Daarbij wordt zichtbaar dat zowel in de subgroep met de laagst behaalde opleiding aan moeders kant (1: 'Maximaal vmbo of voortgezet onderwijs zonder vervolgopleiding') als in de subgroep met de hoogst behaalde opleiding aan moeders kant (3: 'HBO of WO') de interventie positief effect heeft gehad op de ontluikende culturele geletterdheid van kinderen in groep $4^{163}$. Dit is een interessante uitkomst omdat het aangeeft dat onze

\footnotetext{
162 Nota bene: eerder zagen we dat de controlegroep op de nameting gemiddeld 17,1 punten scoort en de experimentele groep gemiddeld 21,6 punten. Als we kijken naar Tabel 34 waarin de gemiddelde scores zijn gecontroleerd voor de variabele 'opleiding moeder', zien we dat de totale gemiddelden iets hoger liggen. Voor de controlegroep is het overall gemiddelde op de nameting $(16,3+19,9+19,6) / 3=18,6$; voor de experimentele groep is het overall gemiddelde op de nameting $(20,2+23,2+24,8) / 3=22,7$. De hogere overall gemiddelden zoals we die uit Tabel 34 kunnen afleiden, komen voort uit het feit dat we hier met een deelpopulatie van de totale onderzoekspopulatie te maken hebben, namelijk alleen die kinderen van wie een van de ouders de oudervragenlijst heeft ingevuld. Deze subgroep wijkt in de gemiddelde scores dus iets naar boven toe af van de totale onderzoekspopulatie wat ermee kan samenhangen dat er een lagere respons op de oudervragenlijst is van lager-opgeleide ouders en/of niet-Nederlandstalige ouders. Voor deze laatste groep is de respons overigens deels gewaarborgd doordat op een van de Islamitische basisscholen tolken en leerkrachten waren ingeschakeld om ouders te helpen bij het invullen (zie Hoofdstuk 6).

${ }_{163}$ Nota bene: omdat de kinderen in deze analyses in subgroepen zijn onderverdeeld en alleen kinderen van wie de ouders een oudervragenlijst hebben ingevuld hierin konden worden meegenomen, zijn de aantallen leerlingen per subgroep relatief klein. Dit maakt het statistisch gezien moeilijker om significantie van verschillen te krijgen: mogelijk verklaart dit waarom de verschillen in de middelste groep niet significant zijn.
} 
opzet om een aanbod van teksten samen te stellen dat ontluikende culturele geletterdheid bij een cultureel pluriforme groep kinderen kan stimuleren (zie Hoofdstuk 1) ten minste deels is geslaagd. In ieder geval zijn significante verschillen tussen de controlegroep en de experimentele groep op de nameting niet alleen aanwezig bij kinderen met een hoogopgeleide moeder $(\mathrm{t}(34)=2,172 ; \mathrm{p}=, 037)$, maar ook bij kinderen met een (relatief) laagopgeleide moeder $(\mathrm{t}(68)=2,575 ; \mathrm{p}=, 012)$. Bij deze laatstgenoemde groep is de experimentele conditie ook significant meer vooruit gegaan in ontluikende culturele geletterdheid tussen de voor en nameting dan de controleconditie $(t(68)=2,907 ; \mathrm{p}=, 005)$.

Overigens staat 'opleiding moeder' als variabele niet helemaal op zichzelf. In een analyse van de correlatie tussen verschillende achtergrondkenmerken van de kinderen waarover via de oudervragenlijsten informatie is verzameld, blijkt 'opleiding moeder' met veel van de andere bevraagde kenmerken van de thuissituatie samen te hangen ${ }^{164}$. 'Opleiding moeder' correleert positief met het opleidingsniveau van de tweede ouder, met het doen van betaald werk door beide ouders, met het aantal (groot)ouders geboren in Nederland, met het bezit van kinderboeken, met de frequentie van voorlezen, met bekendheid met liedjes en versjes, met het aantal bij ouders bekende kinderboekenhelden en gedichten- en liedjesbundels, en met het totale aantal aangekruiste titels op de boekenlijst in de oudervragenlijst. 'Opleiding moeder' hangt daarnaast negatief samen met de variabele 'Moslim', wat wil zeggen dat naarmate 'opleiding moeder' hoger is er minder vaak sprake is van een Islamitische geloofsovertuiging in het gezin (zie Tabel 35).

Tabel 35. Overzicht van positieve correlatie van 'opleiding moeder' met andere kenmerken van 'thuisklimaat'

\begin{tabular}{|c|c|c|c|c|c|c|c|c|c|c|c|}
\hline & $\begin{array}{l}\frac{\overrightarrow{0}}{\overrightarrow{0}} \\
\frac{\overrightarrow{0}}{\overrightarrow{0}} \\
\frac{\overrightarrow{0}}{0} \\
\overrightarrow{0}\end{array}$ & 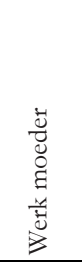 & 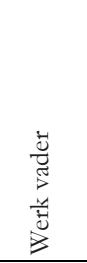 & 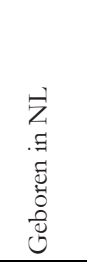 & 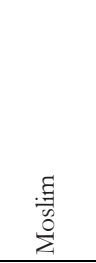 & 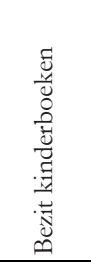 & 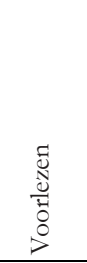 & 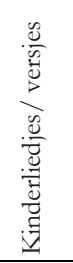 & 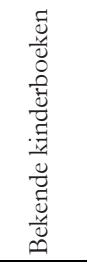 & 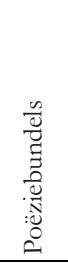 & 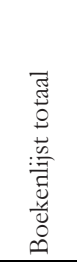 \\
\hline Opl. ma &, $542^{* *}$ & ,314** & ,193** & ,208** &,$- 249 * *$ & ,395** & ,188** &, $126^{*}$ & ,261** & ,122* &, $215^{* *}$ \\
\hline
\end{tabular}

**. Correlatie is significant op het 0,01 niveau (2-tailed).

*. Correlatie is significant op het 0,05 niveau (2-tailed).

'Opleiding moeder' is dus niet los te zien van andere gezinskenmerken van de kinderen en deze kenmerken interfereren bij kinderen in groep 4 duidelijk met de effecten van de Leeskalender op de ontluikende culturele geletterdheid van de kinderen. Dit lijkt in tegenspraak met de eerdere vaststelling dat ontluikende culturele geletterdheid bij kinderen in groep 4 al meer door 'school' wordt bepaald dan door het thuisklimaat (zie $\$ 8.3$ over inhouds- en begripsvaliditeit van de Toets OCG). Dat kan verklaard worden door het feit dat het construct 'geletterd thuisklimaat' gebaseerd was op de vragen die aan kinderen zelf zijn gesteld tijdens de voormeting. Aan kinderen in groep 2 en kinderen in groep 4 zijn dezelfde vragen gesteld, waarbij niet

164 Waar 'opleiding moeder' op basis van de analyses van de oudervragenlijsten niet mee samenhangt, is het aantal ouders en grootouders dat in Marokko, het Caraibisch gebied of Turkije geboren is, of een gezin al dan niet Christelijk is, bibliotheekbezoek, bekendheid met sprookjesboeken, schelmenverhalen en fabels, en religieuze boeken. 
gevraagd is naar zelf lezen, alleen naar voorlezen. Op de vraag 'Word jij thuis wel eens voorgelezen?' kregen we van kinderen in groep 4 regelmatig een antwoord als 'Vroeger toen ik klein was las mijn moeder wel voor, maar nu lees ik zelf' wat dan als een 'nee' op het scoreformulier werd aangegeven. Idem dito voor de vraag of kinderen zelf wel eens aan iemand thuis vragen om hem/haar voor te lezen. Dit vertekent het beeld van 'geletterd thuisklimaat' voor kinderen in groep 4. In de oudervragenlijsten daarentegen is niet alleen naar voorlezen gevraagd, maar ook meer algemeen naar boekenbezit en bekendheid met titels en is daarnaast ook naar aanvullende sociaaleconomische en etnische achtergrondkenmerken gevraagd. Op basis van de oudervragenlijsten heeft 'thuisklimaat' dus een bredere invulling gekregen en zien we nu, op basis van 'opleiding moeder' dat kenmerken van thuis wel degelijk een rol spelen in de ontluikende culturele geletterdheid van kinderen in groep 4.

Op basis van de meting met de Toets OCG en de aanvullende analyses die zijn uitgevoerd, kan worden geconcludeerd dat de Leeskalender een positief effect heeft gehad op de ontwikkeling van de ontluikende culturele geletterdheid van een deel van de kinderen in groep 4. Na controle van de variabele 'opleiding moeder' zien we dat de Leeskalender een positief effect heeft op de ontluikende culturele geletterdheid van kinderen van hoogopgeleide moeders ('HBO of WO') én van kinderen met (relatief) laagopgeleide moeders ('Maximaal vmbo of voortgezet onderwijs zonder vervolgopleiding'), maar niet voor kinderen van moeders die een $\mathrm{MBO}$ hebben afgerond. Dit resultaat is gebaseerd op de meting van de effecten van de Leeskalender als geheel, dus inclusief alle versies, met de Toets OCG als geheel, dus inclusief de toetsitems van de drie deelprojecten. In de nu volgende paragraaf ga ik nader in op de bijdrage van het aanbod van kinderpoëzie in de Leeskalender aan de ontluikende culturele geletterdheid van kinderen in groep 2 en in groep 4 zoals gemeten met de deeltoets Kinderpoëzie.

\subsection{De deeltoets Kinderpoëzie: resultaten groep 2 en groep 4}

Tot nu toe hebben we gekeken naar effecten van de implementatie van de Leeskalender op de ontluikende culturele geletterdheid van kinderen in groep 2 en in groep 4, zoals gemeten met de Toets OCG als geheel. Zowel 'de Leeskalender' als 'de Toets OCG' omvatten tot nu toe tekstaanbod en items uit elk van de drie deelprojecten. In het nu volgende deel kijken we specifiek naar effecten van de Leeskalender+Kinderpoëzie op de scores die kinderen in groep 2 en kinderen in groep 4 behaalden op de Kinderpoëzie-items in de Toets OCG, oftewel de deeltoets Kinderpoëzie. De Kinderpoëzie-items staan beschreven in Hoofdstuk 7.

Voor het nagaan van de effecten van de interventie met kinderpoëzie op de scores die kinderen behalen op de deeltoets Kinderpoëzie onderscheiden we, naast de controleconditie waarin geen interventie heeft plaatsgevonden, twee verschillende experimentele condities: een experimentele conditie waarin de interventie zonder kinderpoëzie in het tekstaanbod heeft plaatsgevonden en een experimentele conditie waarin de interventie met kinderpoëzie in het tekstaanbod heeft plaatsgevonden. Deze indeling in verschillende experimentele condities is gebaseerd op de verschillende versies van de Leeskalender, zoals beschreven in Hoofdstuk 6. In Tabel 36 staan de drie onderzoekscondities die in de nu volgende analyses onderscheiden zijn, weergegeven aan de hand van de Leeskalenderversies waarmee is gewerkt. 
Tabel 36. De onderzoekscondities zoals onderscheiden bij het analyseren van resultaten op de deeltoets Kinderpoëzie

\begin{tabular}{|c|c|c|c|c|}
\hline $\mathrm{Conditie}_{\text {Conterventie }}$ & $\begin{array}{l}\text { Leeskalender V1 } \\
\text { (alle teksten) }\end{array}$ & $\begin{array}{l}\text { Leeskalender V2 } \\
\text { (teksten DD en KP) }\end{array}$ & $\begin{array}{l}\text { Leeskalender V3 } \\
\text { (teksten DD en NG) }\end{array}$ & $\begin{array}{l}\text { Leeskalender V4 } \\
\text { (teksten KP en NG) }\end{array}$ \\
\hline \multicolumn{5}{|l|}{ Controle } \\
\hline Experiment 1 & & & $\mathrm{X}$ & \\
\hline Experiment 2 & $\mathrm{X}$ & $\mathrm{X}$ & & $\mathrm{X}$ \\
\hline
\end{tabular}

Deze indeling in drie condities geldt zowel voor groep 2 als voor groep 4 en heeft specifiek betrekking op het deelproject Kinderpoëzie. Voor dit deelproject is de kwantitatiefempirische hoofdvraag deelprojectspecifiek geherformuleerd en onderverdeeld in deelvragen ${ }^{165}$ die ik beoog te beantwoorden met betrekking tot het aandeel van kinderpoëzie in de Leeskalenders en de kinderpoëzie-items in de Toets OCG (zie ook Hoofdstuk 7, \$7.7):

Tabel 37. Overzicht van de kwantitatieve hoofdvraag en deelvragen voor het deelproject Kinderpoëzie

\begin{tabular}{|c|c|}
\hline \multicolumn{2}{|c|}{ KWANTITATIEVE HOOFDVRAAG EN DEELVRAGEN: DEELPROJECT KINDERPOËZIE } \\
\hline Phoofdvraag: & $\begin{array}{l}\text { Is de herkenning en het begrip van specifieke stijlfiguren die ten grondslag liggen aan muzikaal } \\
\text { taalspel en nonsensicaliteit in kinderpoëzie bij de kinderen in groepen } 2 \text { en in groepen } 4 \text { vergroot } \\
\text { onder invloed van de implementatie van de Leeskalender }{ }^{+ \text {Kinderpoëzie }} \text { zoals gemeten met de deeltoets } \\
\text { OCG-Kinderpoëzie? }\end{array}$ \\
\hline $\mathrm{KP}_{\text {deelvraga } 1:}$ & $\begin{array}{l}\text { Is de herkenning en het begrip van de toepassing van het principe van 'de laatste druppel' bij de } \\
\text { kinderen in groepen } 2 \text { en in groepen } 4 \text { vergroot onder invloed van de implementatie van de } \\
\text { Leeskalender }{ }^{+ \text {Kinderpoëzie }} \text { zoals gemeten met de deeltoets OCG-Kinderpoëzie? }\end{array}$ \\
\hline KP deelvraga: & $\begin{array}{l}\text { Is de herkenning en het begrip van de toepassing van de analogie in het handelen van een } \\
\text { personage in nonsenspoëzie bij de kinderen in groepen } 2 \text { en in groepen } 4 \text { vergroot onder invloed } \\
\text { van de implementatie van de Leeskalender }{ }^{\text {Kinderpoëzie }} \text { zoals gemeten met de deeltoets OCG- } \\
\text { Kinderpoëzie? }\end{array}$ \\
\hline $\mathrm{KP}_{\text {deelvraag3: }}$ & $\begin{array}{l}\text { Is de herkenning en het begrip van de toepassing van de omkering in het handelen van een } \\
\text { personage in nonsenspoëzie bij de kinderen in groepen } 2 \text { en in groepen } 4 \text { vergroot onder invloed } \\
\text { van de implementatie van de Leeskalender }{ }^{+ \text {Kinderpoëzie }} \text { zoals gemeten met de deeltoets OCG- } \\
\text { Kinderpoëzie? }\end{array}$ \\
\hline $\mathrm{KP}_{\text {deelvraag} 4:}$ & $\begin{array}{l}\text { Is de herkenning en het begrip van de toepassing van een rijmprocedé waarin klanktaal wordt } \\
\text { gebruikt om binnenrijm te creëren in poëzie bij de kinderen in groepen } 2 \text { en in groepen } 4 \text { vergroot } \\
\text { onder invloed van de implementatie van de Leeskalender }{ }^{+ \text {Kinderpoëzie }} \text { zoals gemeten met de deeltoets } \\
\text { OCG-Kinderpoëzie? }\end{array}$ \\
\hline $\mathrm{KP}_{\text {deelvraag } 5:}$ & $\begin{array}{l}\text { Is de herkenning en het begrip van de toepassing van een rijmprocedé waarin de naam van } \\
\text { personage wordt gebruikt om eindrijm te creëren bij de kinderen in groepen } 2 \text { en in groepen } 4 \\
\text { vergroot onder invloed van de implementatie van de Leeskalender }{ }^{+ \text {Kinderpoëzie }} \text { zoals gemeten met de } \\
\text { deeltoets OCG-Kinderpoëzie? }\end{array}$ \\
\hline
\end{tabular}

165 Deze set van empirische onderzoeksvragen heeft betrekking op de effecten van de implementatie van de Leeskalenders inclusief kinderpoëzie op de ontluikende culturele geletterdheid van kinderen in groep 2 en in groep 4 , en specifiek op de kennis en het begrip van de in het vorige hoofdstuk beschreven 'indicatoren van ontluikende culturele geletterdheid' zoals ik die voor het deelproject Kinderpoëzie heb geoperationaliseerd in de deeltoets Kinderpoëzie. Omdat dit onderzoek niet tot doel heeft de bijdrage van verschillende genres of tekstsoorten aan de ontluikende culturele geletterdheid van kinderen met elkaar te vergelijken, bespreek ik hier alleen de uitkomsten voor het deelproject Kinderpoëzie en ga ik niet in op de uitkomsten voor de andere twee deelprojecten. 
De veronderstelling is dat bij kinderen in de experimentele conditie met kinderpoëzie in de Leeskalender onder invloed van de interventie (implementatie van de Leeskalender ${ }^{+ \text {Kinderpoëzie }}$ ) een grotere toename van ontluikende culturele geletterdheid wordt waargenomen dan bij kinderen in de controleconditie, zowel op de deeltoets Kinderpoëzie als geheel als op de afzonderlijke items. De verwachting is dus dat de hierboven weergegeven hoofdvraag en deelvragen allemaal met 'ja' beantwoord kunnen worden. Overigens verwacht ik dat ook kinderen in controleconditie hoger scoren op de nameting dan op de voormeting, simpelweg omdat ze in de loop van het schooljaar ouder zijn geworden en zich hebben ontwikkeld. Echter, de verschilscores tussen voor- en nameting zijn naar verwachting bij de experimentele groep 2 en groep 4 groter dan bij de controlegroep 2 en 4 . Eerst bespreek ik de resultaten op de deeltoets Kinderpoëzie voor groep 2 en voor groep 4 en ga vervolgens, bij wijze van discussie, in op de betrouwbaarheid en validiteit van de deeltoets Kinderpoëzie.

\section{De deeltoets Kinderpoëzie: resultaten groep 2}

De deeltoets Kinderpoëzie voor groep 2 bestaat uit vijf items waarmee in totaal een maximale score van 14 punten te behalen was. De verwachting is dat alle condities, dus zowel de controlegroep als de twee experimentele groepen, vergelijkbaar scoren op deeltoets Kinderpoëzie op de voormeting. Een analyse van de resultaten bevestigt deze verwachting. De kinderen in groep 2 scoren tussen de 0 en 7 punten met een gemiddelde van 1,6 punten waarbij er geen significante verschillen bestaan tussen de gemiddelde scores van de drie condities. Op de nameting is de verwachting dat de experimentele groep met kinderpoëzie hoger scoort dan de controlegroep en de experimentele groep zonder kinderpoëzie in de Leeskalender. De kinderen scoren op de nameting tussen de 0 en 10 punten met een gemiddelde van 2,6 punten. Over het geheel zijn de kinderen dus een punt vooruit gegaan op de deeltoets Kinderpoëzie voor groep 2, maar er zijn op de nameting geen significante verschillen tussen de drie condities. Ook als we kijken naar de gemiddelde verschilscores tussen voor- en nameting zijn er geen significante verschillen tussen de drie condities. In Tabel 38 staan de gemiddelde scores op de voormeting en op de nameting en de gemiddelde verschilscores per onderzoeksconditie voor groep 2 weergegeven. De verschillen zijn statistisch gezien niet van toeval te onderscheiden. Ik kan dus geen geldige uitspraken doen over de waargenomen verschillen in gemiddelde scores. Toch vallen twee dingen op als we naar de scores kijken. Allereerst valt op hoe laag er gemiddeld gescoord is: op de voormeting werden maximaal 7 punten behaald en op de nameting maximaal 10 punten, maar het hoogst behaalde gemiddelde is slechts 3 van de 14 punten. 
Tabel 38. Gemiddelde scores op de voormeting en nameting en de gemiddelde verschilscores per onderzoeksconditie voor groep 2, op de deeltoets Kinderpoëzie

\begin{tabular}{llll}
\hline $\begin{array}{l}\text { DEELTOETS KINDERPOEZIE } \\
\text { GROEP 2 }\end{array}$ & Controle groep & $\begin{array}{l}\text { Experimentele groep 1 } \\
\text { (zonder KP) }\end{array}$ & $\begin{array}{l}\text { Experimentele groep 2 } \\
\text { (met KP) }\end{array}$ \\
\hline Gemiddelde score voormeting & $1,64(\mathrm{~N}=120)$ & $1,80(\mathrm{~N}=39)$ & $1,54(\mathrm{~N}=195)$ \\
Gemiddelde score nameting & $2,37(\mathrm{~N}=115)$ & $3,03(\mathrm{~N}=38)$ & $2,70(\mathrm{~N}=187)$ \\
Gemiddelde verschilscore & $0,72(\mathrm{~N}=115)$ & $1,24(\mathrm{~N}=38)$ & $1,13(\mathrm{~N}=187)$ \\
\hline
\end{tabular}

Ten tweede valt op dat de experimentele groep die wel met de Leeskalender heeft gewerkt, maar een versie zonder kinderpoëzie, structureel de hoogste gemiddelde score heeft behaald op de deeltoets Kinderpoëzie. Hoewel dit statistisch niet van toeval te onderscheiden is, had ik toch ten minste verwacht dat de experimentele groep met kinderpoëzie in de Leeskalender gemiddeld hoger zou scoren op de nameting en ook een hogere verschilscore zou hebben dan de beide andere condities. Er lijkt dus geen effect te zijn uitgegaan van het aanbod van kinderpoëzie in de Leeskalender op de score die kinderen in groep 2 behalen op de deeltoets Kinderpoëzie. Omdat de interne consistentie van de deeltoets echter onvoldoende is (zie \$8.6) moeten we ook naar de scores op de afzonderlijke Kinderpoëzieitems kijken.

De verwachting voor elk van de items is dat er op de voormeting geen verschillen zijn tussen de drie onderzoekscondities en dat op de nameting de experimentele conditie met kinderpoëzie in de Leeskalender gemiddeld hoger scoort dan de twee andere condities. Er is slechts één item dat slechts gedeeltelijk aan de verwachting voldoet: het item over Klaas Krentje. Bij dit item zijn er geen verschillen op de voormeting en op de nameting scoort de controleconditie significant lager. Kijken we naar de verschilscores dan heeft de controlegroep vaker geen vooruitgang geboekt ( 0 punten verschil) dan de andere twee condities. Opnieuw zien we echter dat de experimentele groep zonder kinderpoëzie in de Leeskalender gemiddeld vaker vooruit is gegaan tussen voor- en nameting dan de experimentele groep met kinderpoëzie in de Leeskalender, terwijl de experimentele groep met kinderpoëzie in de Leeskalender vaker achteruit is gegaan tussen voor- en nameting (zie Tabel 39).

Tabel 39. Vergelijking van de resultaten behaald op het item 'Klaas Krentje' in groep 2 op de voor-, nameting en verschilscores, naar onderzoeksconditie

\begin{tabular}{|c|c|c|c|c|c|}
\hline \multicolumn{2}{|c|}{$\begin{array}{l}\text { DEELTOETS KINDERPOEZIE } \\
\text { GROEP 2; item p018 } \\
\text { (Klaas Krentje) }\end{array}$} & \multirow{2}{*}{$\begin{array}{l}\text { Controle groep } \\
90(90,9)^{*}\end{array}$} & \multirow{2}{*}{$\begin{array}{l}\text { Experimentele } \\
\text { groep } 1 \\
\text { (zonder KP) }\end{array}$} & \multirow{2}{*}{$\begin{array}{l}\text { Experimentele } \\
\text { groep } 2 \\
(\text { met KP) }\end{array}$} & \multirow{2}{*}{$\begin{array}{l}\text { Significantie van } \\
\text { verschillen tussen de } \\
\text { condities } \\
\text { n.s. }\end{array}$} \\
\hline Voormeting & 0 punten & & & & \\
\hline & 1 of meer & $9(9,1)$ & $5(14,3)$ & $27(17,8)$ & \\
\hline \multirow[t]{2}{*}{ Nameting } & 0 punten & $83(79,8)$ & $21(61,8)$ & $116(67,8)$ & $\left(\chi^{2}(2)=6,177 ; p=, 046\right)$ \\
\hline & 1 of meer & $21(20,2)$ & $13(38,2)$ & $55(32,2)$ & \\
\hline \multirow[t]{3}{*}{ Verschilscore } & -1 of lager & $3(3,3)$ & $1(3,2)$ & $11(7,7)$ & $\left(\chi^{2}(4)=11,528 ; p=, 021\right)$ \\
\hline & 0 punten & $75(81,5)$ & $19(61,3)$ & $89(62,7)$ & \\
\hline & 1 of meer & $14(15,2)$ & $11(35,5)$ & $42(29,6)$ & \\
\hline
\end{tabular}

* De getallen in deze tabel geven het aantal kinderen weer dat een bepaalde score haalde (met tussen haakjes het percentage binnen de onderzoeksconditie). 
Op geen van de andere items in de deeltoets Kinderpoëzie zijn er verschillen tussen de drie condities; op het item over Klaas Krentje scoort de controlegroep zoals verwacht lager, maar scoort de experimentele groep met kinderpoëzie in de interventie niet hoger dan de experimentele groep zonder kinderpoëzie in de interventie.

Hieruit kunnen we concluderen dat de interventie met de Leeskalender ${ }^{+K i n d e r p o e ̈ z i e ~ g e e n ~}$ effect heeft op de scores van kinderen op de deeltoets Kinderpoëzie voor groep 2 als geheel of op de afzonderlijke items. Zowel de hoofdvraag als de vijf deelvragen moeten voor groep 2 dus met 'nee' beantwoord worden voor het deelproject Kinderpoëzie. Noch de herkenning en het begrip van specifieke vormen van nonsensicaliteit, noch de herkenning en het begrip van specifieke toepassingen van rijm in poëzie zijn bij kinderen in groep 2 vergroot onder invloed van de implementatie van de Leeskalender+Kinderpoëzie zoals gemeten met de deeltoets OCG-Kinderpoëzie. Een mogelijke verklaring hiervoor is dat de deeltoets erg moeilijk was voor de kinderen in groep 2, wat blijkt uit de zeer lage gemiddelde scores die op zowel de voor- als de nameting behaald werden. Hier kom ik op terug in de bespreking van de betrouwbaarheid en validiteit van de deeltoets (zie \$8.6).

\section{De deeltoets Kinderpoëziie: resultaten groep 4}

De deeltoets Kinderpoëzie voor groep 4 bestaat eveneens uit vijf items waarmee in totaal een maximale score van 15 punten te behalen was. De verwachting is opnieuw dat alle condities, dus zowel de controlegroep als de twee experimentele groepen, vergelijkbaar scoren op de deeltoets Kinderpoëzie op de voormeting. Over alle condities heen scoren de kinderen in groep 4 op de voormeting tussen de 0 en 11 punten met een gemiddelde van 3,6 punten. We zagen in de bespreking van de Toets OCG als geheel echter al dat de experimentele groep 4 op de voormeting hoger scoort dan de controlegroep en ditzelfde verschil zien we op de deeltoets Kinderpoëzie. De verschillen tussen de groepen zijn op de voormeting al significant $(\mathrm{F}(2,343)=5,883 ; \mathrm{p}<, 005)$. De experimentele conditie met kinderpoëzie in de Leeskalender heeft al voor aanvang van de interventie de hoogste gemiddelde score (zie Tabel 40).

Tabel 40. Gemiddelde scores op de voormeting en nameting en de gemiddelde verschilscores per onderzoeksconditie voor groep 4, op de deeltoets Kinderpoëzie

\begin{tabular}{llll}
\hline $\begin{array}{l}\text { DEELTOETS KINDERPOEZIE } \\
\text { GROEP 4 }\end{array}$ & Controle groep & $\begin{array}{l}\text { Experimentele groep 1 } \\
\text { (zonder KP) }\end{array}$ & $\begin{array}{l}\text { Experimentele groep 2 } \\
\text { (met KP) }\end{array}$ \\
\hline Gemiddelde score voormeting & $2,98(\mathrm{~N}=107)$ & $3,29(\mathrm{~N}=55)$ & $4,10(\mathrm{~N}=184)$ \\
Gemiddelde score nameting & $4,63(\mathrm{~N}=98)$ & $5,65(\mathrm{~N}=52)$ & $5,97(\mathrm{~N}=171)$ \\
Gemiddelde verschilscores & $1,63(\mathrm{~N}=98)$ & $2,48(\mathrm{~N}=52)$ & $1,94(\mathrm{~N}=171)$ \\
\hline
\end{tabular}

Door het uitvoeren van zogeheten post hoc-analyses voor meervoudige paarsgewijze vergelijkingen wordt zichtbaar dat op de voormeting alleen het verschil in gemiddelde scores tussen de controlegroep en de experimentele groep met kinderpoëzie in de Leeskalender significant is (Fishers LSD $\mathrm{p}<, 001$; Bonferroni $\mathrm{p}<, 003$ ). Op de nameting is de verwachting dat alle groepen vooruit zijn gegaan ten opzichte van de voormeting, en dat de experimentele groep met kinderpoëzie in de Leeskalender hoger scoort dan de controlegroep en de 
experimentele groep zonder kinderpoëzie in de Leeskalender. De kinderen scoren op de nameting tussen de 0 en 13 punten met een gemiddelde van 5,5 punten. Over het geheel zijn de kinderen dus vooruit gegaan op de deeltoets Kinderpoëzie voor groep 4, zoals verwacht. Op de nameting zien we opnieuw een significant verschil tussen de drie condities $(\mathrm{F}(2,318)=5,949 ; \mathrm{p}<, 005)$ en nog steeds scoort de experimentele groep met kinderpoëzie in de interventie het hoogst (zie Tabel 40). Ook op de nameting laten de post hoc-analyses zien dat alleen het verschil in gemiddelde scores tussen de controlegroep en de experimentele groep met kinderpoëzie in de Leeskalender significant is (Fishers LSD $\mathrm{p}<, 001$; Bonferroni $\mathrm{p}<, 002)$. Omdat de verschillen tussen de groepen al op de voormeting bestonden, zeggen de verschillen tussen de groepen op de nameting echter niet veel, behalve dat de al bestaande verschillen van de voormeting op de nameting nog steeds aanwezig zijn. Om te zien of er een effect is uitgegaan van de Leeskalender ${ }^{+K i n d e r p o e ̈ z i e ~ o p ~ d e ~ s c o r e s ~ v a n ~ k i n d e r e n ~}$ op de deeltoets Kinderpoëzie, moeten we naar de verschilscores kijken. De verwachting is dat kinderen in de experimentele conditie met kinderpoëzie een grotere groei op de deeltoets Kinderpoëzie laten zien dan kinderen in de controleconditie en kinderen in de experimentele conditie zonder kinderpoëzie. Kijken we echter naar de verschilscores op de deeltoets Kinderpoëzie, dan zijn de significante verschillen die we op de voor- en nameting zagen als sneeuw voor de zon verdwenen. Daar komt bij dat we, hoewel ik hier geen geldige uitspraken over kan doen omdat de resultaten statistisch gesproken niet van toeval te onderscheiden zijn, opnieuw zien dat de uitkomsten wijzen in de richting van een grotere groei bij de kinderen in de experimentele conditie zonder kinderpoëzie op de deeltoets Kinderpoezie (zie Tabel 40). Nadere analyses van de verschillen bij kinderen met dezelfde achtergrond (opleidingsniveau moeder of leerlinggewicht) leveren hetzelfde resultaat op: kleine verschillen op de voormeting en de nameting, maar geen verschillen op de verschilscores. Er lijkt dus geen effect te zijn uitgegaan van het aanbod van kinderpoëzie in de Leeskalender op de score die kinderen in groep 4 behalen op de deeltoets Kinderpoëzie. Ook hier geldt echter dat de deeltoets Kinderpoëzie onvoldoende interne consistentie heeft (zie \$8.6) en we dus ook naar de scores op de afzonderlijke Kinderpoëzie-items moeten kijken.

De verwachting voor elk van de items is dat er op de voormeting geen verschillen zijn tussen de drie onderzoekscondities en dat op de nameting de experimentele conditie met kinderpoëzie in de Leeskalender gemiddeld hoger scoort dan de twee andere condities. Er is bij groep 4 één item dat aan de verwachting voldoet: het item over Bever en zijn vrienden op het vlot (item p015 in de Toets OCG). Bij dit item zijn er geen verschillen tussen de onderzoekscondities op de voormeting. Op de nameting zijn de verschillen tussen de condities wel significant $\left(\chi^{2}(2)=21,609 ; \mathrm{p}<, 001\right)$ en zien we dat de experimentele groep met kinderpoëzie in de Leeskalender beduidend vaker een punt of meer heeft gescoord dan de beide andere condities (zie Tabel 41). 
Tabel 41. Vergelijking van de resultaten behaald op het item 'Bever' in groep 4 op de voor- en nameting, naar onderzoeksconditie

\begin{tabular}{lcclll}
\hline $\begin{array}{l}\text { DEELTOETS KINDERPOEZIE } \\
\text { GROEP 4; item p015 (Bever) }\end{array}$ & Controlegroep & $\begin{array}{l}\text { Experimentele } \\
\text { groep 1 } \\
\text { (zonder KP) }\end{array}$ & $\begin{array}{l}\text { Experimentele } \\
\text { groep 2 } \\
\text { (met KP) }\end{array}$ & $\begin{array}{l}\text { Significantie van } \\
\text { verschillen tussen de } \\
\text { condities }\end{array}$ \\
\hline Voormeting & 0 punten & $99(93,4)^{*}$ & $49(89,1)$ & $157(85,3)$ & n.s. \\
\multirow{2}{*}{ Nameting } & 1 of meer & $7(6,6)$ & $6(10,9)$ & $27(14,7)$ & \\
& 0 punten & $92(94,8)$ & $44(84,6)$ & $123(71,9)$ & $\left(\chi^{2}(2)=21,609 ; \mathrm{p}<, 001\right)$ \\
\hline
\end{tabular}

* De getallen in deze tabel geven het aantal kinderen weer dat een bepaalde score haalde (met tussen haakjes het percentage binnen de onderzoeksconditie).

Op dit item blijft het significante verschil tussen de condities bestaan als we kijken naar de verschilscores $\left(\chi^{2}(2)=21,449 ; \mathrm{p}<, 001\right)$ waarbij de experimentele groep met kinderpoëzie in de Leeskalender beduidend vaker een punt of meer vooruit is gegaan (zie Tabel 42).

Tabel 42. Vergelijking van verschilscores tussen nameting en voormeting behaald op het item 'Bever' in groep 4, naar onderzoeksconditie

\begin{tabular}{|c|c|c|c|c|}
\hline \multicolumn{2}{|c|}{$\begin{array}{l}\text { DEELTOETS KINDERPOEZIE } \\
\text { GROEP 4; item p015 (Bever) }\end{array}$} & Controlegroep & Experimentele groep* & \multirow{2}{*}{$\begin{array}{l}\text { Significantie van } \\
\text { verschillen tussen de } \\
\text { condities } \\
\left(\chi^{2}(2)=21,449 ; \mathrm{p}<, 001\right)\end{array}$} \\
\hline \multirow[t]{3}{*}{ Verschilscore } & -1 of lager & $6(4,1)$ & $10(5,8)$ & \\
\hline & 0 punten & $134(90,5)$ & $121(70,8)$ & \\
\hline & 1 of meer & $8(5,4)$ & $40(15,0)$ & \\
\hline
\end{tabular}

\footnotetext{
* NB: De experimentele conditie zonder kinderpoëzie in de Leeskalender is hier samengenomen met de controleconditie, omdat er anders te weinig kinderen met een verschilscore anders dan 0 waren.
}

Op geen van de andere items in de deeltoets Kinderpoëzie voor groep 4 zijn er verschillen tussen de drie condities; op het item over Bever en zijn vrienden op het vlot zijn er significante verschillen op de nameting en in de verschilscores in het voordeel van de experimentele conditie met kinderpoëzie.

$\mathrm{Al}$ met al is de conclusie dat de interventie met kinderpoëzie weinig effect heeft gehad op de ontluikende culturele geletterdheid van kinderen in groep 4 zoals gemeten met de deeltoets Kinderpoëzie. De deelvragen kunnen, op basis van de resultaten, als volgt worden beantwoord voor groep 4: de herkenning en het begrip is bij kinderen in groep 4 op geen van de specifieke stijlfiguren vergroot onder invloed van de implementatie van de Leeskalender ${ }^{+ \text {Kinderpoëzie }}$ zoals gemeten met de deeltoets OCG-Kinderpoëzie, met uitzondering van de herkenning en het begrip van de toepassing van het principe van 'de druppel die de emmer doet overlopen' of 'the straw that broke the camel's back' zoals nagegaan met item p015 over Bever en zijn vrienden op het vlot. Met andere woorden: alleen $\mathrm{KP}_{\text {deelvraag1 }}$ kan bevestigend worden beantwoord. Het is goed mogelijk dat deze resultaten verklaard worden door problemen met de betrouwbaarheid en validiteit van de deeltoets Kinderpoëzie. Hier ga ik in de nu volgende paragraaf nader op in. 


\subsection{De deeltoets Kinderpoëzie ter discussie: betrouwbaarheid en validiteit}

Het moge duidelijk zijn dat het aanbieden van kinderpoëzie, geselecteerd op basis van specifieke criteria, nauwelijks effect heeft gehad op de ontluikende culturele geletterdheid van kinderen in groep 2 en in groep 4 zoals gemeten met de deeltoets Kinderpoëzie in de Toets OCG. Zoals in de volgende hoofdstukken duidelijk zal worden, betekent dit echter niet dat kinderpoëzie niets 'doet' voor de ontluikende culturele geletterdheid van kinderen. Het betekent ook niet dat kinderen in groep 2 en groep 4 geen plezier aan kinderpoëzie beleven, dat ze het niet waarderen of onthouden, dat ze het niet verwerven. De experimentele ingreep, i.e. de aanbieding van de geselecteerde poëzie in groep 2 en in groep 4, levert kwalititatief positieve resultaten op (zie Hoofdstuk 9 en 10). De hierboven beschreven resultaten roepen dan vooral vragen op over de betrouwbaarheid en validiteit van de deeltoets Kinderpoëzie. Daarnaast roepen ze ook de vraag op of en, zo ja, hoe de bijdrage van kinderpoëzie aan de ontluikende culturele geletterdheid van kinderen in groep 2 en in groep 4 geoperationaliseerd kan worden in een objectief en gestandaardiseerd meetinstrument. Het belang van deze vragen ligt enerzijds in het (maatschappelijke) feit dat 'opbrengstgericht werken' centraal staat in het Nederlandse basisonderwijs en we de 'opbrengsten' van kinderpoëzie dus op de een of andere wijze objectief waarneembaar moeten maken, willen we een meer structurele plaats voor kinderpoëzie in het onderwijsaanbod bewerkstelligen. Anderzijds ligt het belang van deze vragen in het (wetenschappelijke) feit dat kinderpoëzie en de functies die het voor jonge kinderen kan vervullen nog nauwelijks van een theoretisch en objectief empirisch fundament zijn voorzien ${ }^{166}$. Dit onderzoeksproject beoogt op beide vlakken een bijdrage te leveren. Om die reden is het van belang de deeltoets Kinderpoëzie op haar betrouwbaarheid en validiteit te evalueren.

\section{De betrouwbaarheid van de deeltoets Kinderpoëzie}

Als deel van de Toets OCG is de deeltoets Kinderpoëzie gebruikt als meetinstrument binnen hetzelfde onderzoeksdesign, met dezelfde steekproefomvang en procedures voor clusterrandomisatie in de toewijzing van scholen aan de onderzoekscondities. De betrouwbaarheid van de afname van de deeltoets Kinderpoëzie staat gelijk aan (want was geïntegreerd in) de afname van de Toets OCG als geheel, met dezelfde protocollen voor afname, vastlegging en beoordeling. Tabel 43 toont de interbeoordelaarsbetrouwbaarheid van de items van de deeltoets Kinderpoëzie. Hierin zijn de scores voor groep 2 en 4 op een item samengenomen voor het berekenen van de interbeoordelaarsbetrouwbaarheid wanneer het betreffende item voor groep 2 en voor groep 4 gelijk was. Van de tien te scoren items hebben er vijf een betrouwbaarheid die (bijna) perfect is (p015b, p016b, p018a, p020a en p020b) na de eerste vergelijking van de door mijzelf toegekende scores aan de open antwoorden en de blinde toekenning van scores door de tweede (en soms derde) beoordelaar. Nog eens twee

${ }^{166}$ Een uitzondering op deze uitspraak vormt de relatie tussen poëzie en de ontwikkeling van fonemisch bewustzijn bij kinderen in de voor- en vroegschoolse fase. Deze relatie is in het kader van taalontwikkelingsonderzoek veelvuldig onderzocht en zowel theoretisch als empirisch stevig onderbouwd (zie o.a. Bryant en Bradley, 1989; Bryant et al, 1990). 
items hebben een betrouwbaarheid die voldoende tot goed is ( $\mathrm{p} 019 \mathrm{a}$ en $\mathrm{p} 020 \mathrm{c}$ ). Drie items hebben een redelijke betrouwbaarheid (p018b, p017a en p017b). De (relatief) lage betrouwbaarheid van item $\mathrm{p} 018 \mathrm{~b}$ wordt verklaard doordat er slechts zeer weinig variatie in de behaalde scores was (in slechts drie gevallen was de score hoger dan ' 0 '). Nadere analyse van de antwoorden gaf geen reden tot het aanpassen van het scoreprotocol voor dit item. Aangezien de geobserveerde overeenkomst op dit item wel heel hoog is, is de beoordeling ervan verder niet aangepast. Voor de items p017a en p017b is het protocol voor toekenning van scores aan de open antwoorden wel herschreven om onduidelijkheden te verwijderen. Bij herbeoordeling was de interbeoordelaarsbetrouwbaarheid voor beide items wel goed.

Tabel 43. Interbeoordelaarsbetrouwbaarheid van de deeltoets Kinderpoëzie, per item

\begin{tabular}{llrrrl}
\hline Item & Groep & $\mathrm{N}$ & \multicolumn{2}{c}{ Geobserveerde overeenkomst Cohens Kappa } & Interpretatie \\
\hline p015b & $2-4$ & 24 & $100 \%$ & 1,00 & (Bijna) perfect \\
p016b & 2 & 21 & $95 \%$ & 0,83 & (Bijna) perfect \\
p018a & $2-4$ & 73 & $100 \%$ & - & (Bijna) perfect \\
*p018b & $2-4$ & 120 & $95 \%$ & 0,58 & Redelijk \\
p019a & $2-4$ & 30 & $87 \%$ & 0,78 & Voldoende tot goed \\
*p020a & $2-4$ & 97 & $99 \%$ & 0,88 & (Bijna) perfect \\
p020b & $2-4$ & 44 & $98 \%$ & 0,88 & (Bijna) perfect \\
p020c & $2-4$ & 24 & $96 \%$ & 0,65 & Voldoende tot goed \\
p017a & 4 & 35 & $69 \%$ & 0,45 & Redelijk \\
*p017b & 4 & 150 & $81 \%$ & 0,56 & Redelijk \\
**p017a & 4 & 183 & $94 \%$ & 0,87 & (Bijna) perfect \\
**017b & 4 & 149 & $91 \%$ & 0,78 & Voldoende tot goed \\
\hline
\end{tabular}

*Op basis van derde beoordelaar.

** Op basis van derde beoordelaar en herbeoordeling met aangepast scoreprotocol.

De interbeoordelaarsbetrouwbaarheid op de Kinderpoëzie-items varieerde uiteindelijk van 'voldoende tot goed' tot '(bijna) perfect', met uitzondering van item p018b vanwege de beperkte variatie in de antwoorden van de leerlingen en de hoge geobserveerde overeenkomst in de beoordelingen.

Echter, de interne consistentie van de deeltoets is zowel voor groep 2 als voor groep 4 niet adequaat. Op de voormeting is Cronbachs alfa voor de deeltoets Kinderpoëzie voor groep $2(\mathrm{~N}=352)$ onvoldoende $(\alpha=, 31)$ en op de nameting $(\mathrm{N}=339)$ matig $(\alpha=, 63)$ bij een aantal van 10 items (alle subvragen zijn als item meegenomen in de berekening); bij hetzelfde aantal items is Cronbachs alfa op de voormeting bij groep $4(\mathrm{~N}=346)$ eveneens onvoldoende $(\alpha=, 58)$ en op de nameting $(\mathrm{N}=326)$ nog steeds $(\alpha=, 59)$. Voor beide deeltoetsen is de interne consistentie vervolgens geoptimaliseerd door het weglaten van items. De verbetering van de interne consistentie na optimalisering is echter in geen van de gevallen zodanig dat op basis daarvan een select aantal items uit de analyses kan worden verwijderd om wel een adequate betrouwbaarheid van het instrument te krijgen (zie Tabel 44). 
Tabel 44. Interne consistentie van de deeltoets Kinderpoëzie voor groep 2 en 4, op voor- en nameting, met alle items en geoptimaliseerd, uitgedrukt in Cronbachs alpha

\begin{tabular}{lllll}
\hline Deeltoets KP & $\begin{array}{l}\text { Cronbachs alfa } \\
\text { voormeting (alle items) }\end{array}$ & $\begin{array}{l}\text { Cronbachs alfa } \\
\text { voormeting }(\text { optimaal })\end{array}$ & $\begin{array}{l}\text { Cronbachs alfa } \\
\text { nameting (alle items) }\end{array}$ & $\begin{array}{l}\text { Cronbachs alfa } \\
\text { nameting (optimaal) }\end{array}$ \\
\hline Groep 2 &, $311(\mathrm{~N}$ of items $=10)$ &, $413(\mathrm{~N} \text { of items }=6)^{*}$ &, $626(\mathrm{~N}$ of items $=10)$ &, $684(\mathrm{~N} \text { of items }=6)^{*}$ \\
Groep 4 &, $580(\mathrm{~N}$ of items $=10)$ &, $653(\mathrm{~N} \text { of items }=4)^{* *}$ &, $588(\mathrm{~N}$ of items $=10)$ &, $627(\mathrm{~N} \text { of items }=7)^{* * *}$ \\
\hline
\end{tabular}

* Items 'Reus (a, b)', 'Klaas (a, b)' en 'Wappel (b, c)'

** Items 'Reus (a, b)' en 'Klaas (a, b)'

*** Items 'Vlot (a, b)', 'Klaas (a, b)' en 'Wappel (a, b, c)'

Het enige item dat na optimalisering van de betrouwbaarheid zowel voor groep 2 als voor groep 4 'overeind' blijft, is het item over Klaas Krentje: dit item draagt in beide deeltoetsen zowel op de voormeting als op de nameting bij aan de interne consistentie en is daarmee het meest betrouwbare item. Alleen het weglaten van het rijm-item 'Attivat' verhoogt de betrouwbaarheid bij elke versie: dit is dus het meest onbetrouwbare item waar het de interne consistentie van de deeltoets Kinderpoëzie betreft. In de deeltoets Kinderpoëzie voor groep 2 moet ook het item over Bever en zijn vrienden op het vlot op zowel de voormeting als de nameting worden verwijderd voor een optimalisering van de interne consistentie: voor groep 2 hebben dus zowel het rijm-item 'Attivat' en het nonsens-item 'Bever' een negatieve invloed op de interne consistentie van de scores die kinderen behaalden. In de deeltoets voor groep 4 is, buiten het rijm-item 'Attivat', minder eenduidig welke items de interne consistentie negatief beïnvloeden.

De onvoldoende interne samenhang tussen de items in de deeltoets Kinderpoëzie zoals uitgedrukt in Cronbachs alfa vertelt ons dat er onvoldoende correlatie is tussen de itemscores en de totale schaalscore die kinderen in groep 2 en groep 4 behaalden op de deeltoets. De vuistregel is dat we er pas bij een waarde van ,70 of hoger van uit mogen gaan dat de items onderdelen van hetzelfde construct meten. Als we een strikte positie innemen, is de consequentie van een waarde onder de ,70 dat we de items niet mogen samennemen als een schaal, maar alleen apart mogen analyseren en rapporteren. Voor Cronbachs alfa geldt echter ook dat een kleiner aantal items doorgaans leidt tot een lagere waarde van de interne consistentie: in dat geval is het standpunt dat elke waarde onder de ,70 onvoldoende is, te streng. Bij een interne consistentie tussen ,60 en ,70 is het gebruikelijk de items wel als schaal te analyseren, maar dit apart te motiveren; bij een interne consistentie van minder dan ,60 moeten de itemscores apart worden geanalyseerd en gerapporteerd (Wijk, 2000, p. 216-217). Omdat de betrouwbaarheid van de deeltoets Kinderpoëzie als één schaal varieert tussen een waarde van minder dan ,60 en meer dan ,60 (maar minder dan ,70), is in de analyses van de resultaten én van de validiteit van de deeltoets zowel naar de gemiddelde scores op de deeltoets als geheel, als naar de scores op de afzonderlijke items gekeken (zie paragrafen hierboven en ook hierna).

\section{De interne validiteit van de deeltoets Kinderpoëzie}

Als we kijken naar de validiteit van de deeltoets Kinderpoëzie voor groep 2 en voor groep 4, dan hebben we het opnieuw over de geldigheid van de operationalisering van het begrip 
'ontluikende culturele geletterdheid' naar het niveau van de items in de toets, te verdelen in de inhouds- en begripsvaliditeit van het instrument. Inhoudsvaliditeit wil zeggen dat de deeltoets inhoudelijk aansluit op wat de kinderen via de Leeskalender aan kinderpoëzie is aangeboden; begripsvaliditeit wil zeggen dat de deeltoets Kinderpoëzie inderdaad toetst wat hij moet toetsen (zie ook Hoeflaak, 2012). Zoals bij de Toets OCG als geheel wordt de begripsvaliditeit van de deeltoets Kinderpoëzie en de afzonderlijke items geëvalueerd door een aantal aannamen te toetsen:

Aanname 1: $\quad$ OCG neemt toe met leeftijd (ervaring), dus kinderen die ouder zijn (binnen een groep) scoren hoger op de deeltoets dan jongere kinderen (correlatie OCG-KP/leeftijd).

Aanname 2: $\quad$ Kinderen die thuis meer kinderboeken hebben en lezen, scoren hoger op de deeltoets (correlatie OCG-KP/geletterd thuisklimaat).

Aanname 3: $\quad$ Kinderen met een hogere OCG doen het beter op school, met name op het gebied van taal (correlatie OCG-KP/schoolprestaties) ${ }^{167}$.

Deze aannamen ${ }^{168}$ zijn getoetst op basis van de resultaten op de voormeting omdat we daarmee de 'nullijn' van de ontluikende culturele geletterdheid van de kinderen in kaart hebben gebracht zonder dat daar eventuele effecten van de Leeskalender in meespelen. De aannamen zijn getoetst voor zowel de deeltoets Kinderpoëzie voor groep 2 als voor de deeltoets Kinderpoëzie voor groep 4 die ik hieronder apart van elkaar bespreek. Gezien de lage betrouwbaarheid van de deeltoetsen zijn de aannamen ook steeds voor elk van de items afzonderlijk getoetst.

\section{De begripsvaliditeit van de deeltoets Kinderpoëzie voor groep 2}

Een probleem met de deeltoets Kinderpoëzie voor groep 2 is dat de toets erg moeilijk was voor deze leeftijdsgroep. Van alle kinderen in groep 2 met een leeftijd van maximaal 300 weken $(\mathrm{N}=270)$ haalde ruim de helft voor dit deel geen punten of slechts één punt $(56 \%)$ op de voormeting. Nog eens $20 \%$ van de kinderen haalde 2 punten op de deeltoets Kinderpoëzie en de overige 24\% van de kinderen haalde 3 of meer van de in totaal 14 te behalen punten. Dit vormt al een stevige beperking van de validiteit van de deeltoets voor groep 2 als gevolg van de hoge mate van complexiteit en daardoor geringe 'eerlijkheid' van de deeltoets voor de kleuters (zie ook Pol, 2010, p. 143). De cognitieve complexiteit van de items blijkt niet goed aan te sluiten op de cognitieve ontwikkeling van kinderen in deze leeftijd waardoor de deeltoets hen feitelijk niet de kans biedt om hun kennis en begrip van de stijlfiguren te tonen. De uitkomsten van de deeltoets voor groep 2 zeggen daarmee niet zoveel over de ontluikende culturele geletterdheid van de kinderen. De score op de deeltoets als geheel loopt wel op ( 0 tot 1 punt; 2 punten; 3 of meer punten) met de leeftijd van

\footnotetext{
${ }^{167}$ Welke kant de relatie op werkt is niet per se duidelijk: lezen talige kinderen meer boeken omdat ze taliger zijn? Of zijn ze taliger omdat ze meer boeken lezen (voorgelezen krijgen)? We gaan er in ieder geval van uit dat er een relatie is. We verwachten dat de relatie met rekenen minder sterk is (hoewel mogelijk nog steeds aanwezig: wat geldt voor 'talige' kinderen geldt ook meer in het algemeen voor 'intelligentere' kinderen).

168 Ik rapporteer hier alleen over de samenhangen die voor de gehele Toets OCG ook nagegaan zijn: andere analyses zijn voor de deeltoets Kinderpoëzie wel gedaan, maar leverden geen aanvullende inzichten op, dus zijn verder ook niet gerapporteerd.
} 
de kinderen (zie Tabel 45). De groep kinderen die 3 of meer punten scoorde, is gemiddeld beduidend ouder dan de groepen kinderen die minder punten scoorden $(F(2,267)=4,715$; $\mathrm{p}=, 01)$, maar voor drie kwart van de groep 2 leerlingen geldt dat ze maximaal slechts 2 punten behaalden.

Tabel 45. Begripsvaliditeit deeltoets Kinderpoëzie groep 2: gemiddelde totaalscore op de voormeting, naar leeftijd

\begin{tabular}{llll}
\hline & Score 0 of 1 & Score 2 & Score 3 of meer \\
\hline Gemiddelde leeftijd (in weken) & 272,48 & 274,95 & 278,88 \\
Minimum leeftijd (in weken) & 243 & 245 & 251 \\
Maximum leeftijd (in weken) & 299 & 298 & 299 \\
N (\% van totale N voormeting) & $151(56 \%)$ & $55(20 \%)$ & $64(24 \%)$ \\
\hline
\end{tabular}

Als we naar de afzonderlijke itemscores kijken, dan blijken die bij elk afzonderlijk item wel in de verwachte richting op te lopen met leeftijd, maar geen significante verschillen in score op te leveren en dus niet van toeval te onderscheiden. Daar moet ook bij vermeld worden dat op elk van de items een overgrote meerderheid van de kinderen 0 punten scoorde. De deeltoets was dus in zijn geheel te moeilijk voor groep 2, onafhankelijk van de leeftijd van de kinderen. De vraag is nu hoe dit, gezien het feit dat het experiment en de daarin gebruikte instrumenten met de grootst mogelijke zorgvuldigheid en nauwkeurigheid en met inachtneming van de eisen van navolgbaarheid en herhaalbaarheid zijn opgezet, ontwikkeld en uitgevoerd, te verklaren is. Daarvoor moet ik kort terugblikken op het ontwikkelingstraject van de deeltoets Kinderpoëzie (zie Hoofdstuk 7, \$7.6). In de aanloop naar de eerste toetspilot (pilot 2 in het ontwikkelingstraject van de interventiematerialen) zijn vanuit elk van de drie deelprojecten items ontworpen om kennis en begrip van (deelaspecten van) de geformuleerde indicatoren van canoniciteit bij de kinderen te meten. In deze eerste proefversie van de Toets Ontluikende Culturele Geletterdheid waren uit het deelproject Kinderpoëzie negen items opgenomen, zowel in de versie voor kinderen uit groep 2 als in de versie voor kinderen uit groep 4 . In dit stadium was er in de poëzie-items geen differentiatie aangebracht tussen groep 2 en groep 4 zodat er op basis van de antwoorden uit beide groepen een vergelijking kon worden gemaakt van de leeftijdsgeschiktheid van de items. Van de negen items vormden er vijf concrete operationaliseringen van specifieke aspecten van kennis en begrip van 'nonsensicaliteit' en vier concrete operationaliseringen van specifieke aspecten van kennis en begrip van 'muzikaal taalspel'. Nadat deze items bij 11 kleuters en 10 kinderen uit groep 4 waren afgenomen, zijn alle toetsitems geëvalueerd, zowel op basis van onze praktijkervaringen, als op basis van enkele statistische analyses ${ }^{169}$. Aan de hand van deze evaluaties heb ik de items laten afvallen die problematisch bleken (te moeilijk, te gemakkelijk, te dubbelzinnig) en heb ik de resterende items daar waar nodig aangepast. Ik heb geen nieuwe items toegevoegd omdat de resterende items ook goed leken te werken. De tweede toetspilot bevestigde dit in kwalitatieve zin en gaf ook in de statistische

\footnotetext{
${ }^{169}$ Deze analyses lieten zien hoe lang een toetsafname per kind gemiddeld duurde en hoeveel items er in deze tijd gemiddeld behandeld waren. Deze analyses hebben de omvang van de uiteindelijke toets bepaald. Verder is gekeken of de scores op de items voldoende normaal verdeeld waren en of er ruimte voor groei was (als kinderen in de pilot allemaal al de maximale score op een vraag halen, valt er weinig effect meer te verwachten van het aanbieden van teksten).
} 
evaluatie geen aanleiding tot zorg: bij kinderen in groep 2 variëerden de scores van 0 tot 7 punten van de maximale 14 punten en ze scoorden gemiddeld significant lager dan kinderen uit groep 4, maar dat was volgens verwachting. We zagen bij de tweede toetspilot wel dat er sprake was van een enigszins rechtsscheve verdeling in de scores van kinderen uit groep 2 op de deeltoets Kinderpoëzie. We hadden echter te weinig kinderen kunnen toetsen om een mooie standaardnormale verdeling te mogen verwachten. Doorgaans mag men er van uit gaan dat een grotere omvang van de populatie vanzelf een 'normaler' verdeling van de scores oplevert. Daar kwam bij dat de kinderen in de pilot geen 30 weken durende interventie hadden gehad en de verwachting was dat de interventie zou zorgen voor hogere scores. Deze twee verwachtingen leidden tot het besluit de items in de deeltoets Kinderpoezie voor groep 2 te laten zoals ze in de tweede toetspilot waren. Ik kan dan niet anders dan concluderen dat het feit dat de deeltoets Kinderpoëzie te moeilijk is gebleken voor kinderen in groep 2 niet zozeer het resultaat is van fouten of onzorgvuldigheden in de toetsontwikkeling, de toetsafname of -beoordeling, maar een uitkomst tegen de verwachtingen in.

De tweede aanname is dat kinderen hoger scoren op de deeltoets voor groep 2 naarmate ze thuis meer kinderboeken hebben en meer voorgelezen worden ('geletterd thuisklimaat $\left.{ }^{170}\right)$. Op de deeltoets Kinderpoëzie als geheel zien we geen relatie met het bezit van kinderboeken; kinderen die thuis worden voorgelezen, scoren wel hoger op de deeltoets $(\mathrm{t}(86)=-3,036 ; \mathrm{p}=, 003)$. Als we alle kenmerken van 'geletterd thuisklimaat' samennemen, dan zijn er echter geen verschillen in score op de deeltoets Kinderpoëzie tussen kinderen met een meer of minder geletterd thuisklimaat. Scores op de afzonderlijke items variëren nauwelijks met de mate van 'geletterd thuisklimaat'. Alleen doen kinderen die thuis worden voorgelezen het beter op het item over de vlieg Wippel Wappel (Fisher Exact Test ${ }^{171}$, $\mathrm{p}=$,032). Opvallend genoeg zien we dat kinderen die thuis wel kinderboeken hebben juist lager scoren op de vraag over Bever en zijn vrienden op het vlot $\left(\chi^{2}(1)=5,281 ; p=, 022\right)$ : kinderen in groep 2 halen dus een hogere score op dat item als ze naar eigen zeggen geen kinderboeken hebben thuis. Via de oudervragenlijst zijn gegevens verzameld over de frequentie van voorlezen (verdeeld in de categorieën: $1=$ maximaal $1 \mathrm{x}$ per week, $2=$ meerdere keren per week, $3=$ dagelijks of meerdere keren per dag), maar er zijn geen verschillen in de score van kinderen op de deeltoets Kinderpoëzie als geheel in relatie tot de frequentie van voorlezen. Voor de afzonderlijke items geldt dat voorleesfrequentie opnieuw een verband in onverwachte richting laat zien met de score op het item over Bever op het vlot, dus kinderen die minder vaak worden voorgelezen, scoren gemiddeld hoger op dit item $\left(\chi^{2}(2)=9,948 ; p=, 007\right)$. Er is wel een verband in de verwachte richting tussen voorleesfrequentie en de score op het item over Klaas Krentje $\left(\chi^{2}(2)=13,328 ; p=, 001\right)$. Bibliotheekbezoek toont geen verband met de score op de deeltoets Kinderpoëzie en omdat slechts tien ouders hebben ingevuld dat ze wel eens gedichtenbundels lenen, is deze groep te klein om een goede vergelijking te maken met de ouders die 'nee' hebben aangekruist. Ouders hebben op de oudervragenlijst ook aangegeven welke kinderpoëzie- en/of kinderliedbundels ze kennen, maar op de deeltoetsscore noch op de afzonderlijke itemscores is er een verband

170 Deze gegevens zijn verzameld door de kinderen bij de voormeting zelf te vragen of ze thuis kinderboeken hebben en hoeveel ongeveer (op basis van afbeeldingen), of ze thuis worden voorgelezen en of ze thuis zelf wel eens aan iemand vragen of die persoon ze wil voorlezen.

${ }^{171}$ Een cel bevat een waarde lager dan 5, daarom is hier Fishers Exact Test gebruikt en niet de chi-kwadraattoets. 
met het aantal poëzieboeken en versjesbundels dat bekend is. Deze uitkomsten ondersteunen de validiteit van de deeltoets Kinderpoëzie niet. Daarbij moet wel worden opgemerkt dat kinderpoëzie slechts in beperkte mate bekend of aanwezig blijkt bij kinderen thuis - al wordt er veel gezongen, naar het lijkt (zie Bijlage 6) - en dat om die reden ook geen samenhang met de score op de deeltoets verwacht kan worden.

De derde aanname is dat kinderen met een hogere OCG het ook beter doen op school (en/of andersom), met name op het gebied van taal, dus dat er een correlatie bestaat tussen de score op de deeltoets Kinderpoëzie en de CITO-scores op vooral de taaltoets bij kinderen in groep 2. Om dit voor groep 2 na te gaan, zijn de CITO-vaardigheidsscores op de toets 'Taal voor (peuters en) kleuters' en op de toets 'Rekenen voor (peuters en) kleuters' die zijn afgenomen aan het einde van groep 1 gebruikt (de laatste afname voor aanvang van het interventiejaar). Voor de deeltoets Kinderpoëzie als geheel $(\mathrm{N}=317)$ is er een significante correlatie met de scores op de CITO-toets TaalE1 ( $\mathrm{r}=, 153$; $\mathrm{p}=, 006)$, maar ook de CITOtoets RekenenE1 ( $r=, 120 ; \mathrm{p}=, 032)$. Ook voor de meeste items in de deeltoets Kinderpoëzie vinden we verbanden met de CITO-vaardigheidsscores, meestal in de verwachte richting (zie Tabel 46).

Tabel 46 Begripsvaliditeit deeltoets Kinderpoëzie groep 2: verbanden tussen gemiddelde itemscores en CITOvaardigheidscores

\begin{tabular}{|c|c|c|c|c|c|c|}
\hline & Item & Itemscore & $\mathrm{N}$ & $\begin{array}{l}\text { Gemiddelde } \\
\text { CITO-score }\end{array}$ & $\begin{array}{l}\text { Standaard- } \\
\text { afwijking }\end{array}$ & Significantie \\
\hline \multirow[t]{11}{*}{ TaalE1 } & \multirow[t]{2}{*}{ Bever op vlot } & Score 0 & 252 & 60,29 & 13,254 & \multirow[t]{2}{*}{$\mathrm{t}(106)=5,612 ; \mathrm{p}<, 001$} \\
\hline & & Score 1 of 2 & 59 & 51,29 & 10,521 & \\
\hline & \multirow[t]{3}{*}{ Reus Pak-in } & Score 0 & 200 & 59,47 & 13,273 & \multirow[t]{3}{*}{ n.s. } \\
\hline & & Score 1 & 73 & 56,45 & 12,630 & \\
\hline & & Score 2 & 32 & 60,69 & 12,973 & \\
\hline & \multirow[t]{2}{*}{ Klaas Krentje } & Score 0 & 227 & 57,74 & 13,301 & \multirow[t]{2}{*}{$\mathrm{t}(263)=-3,142 ; \mathrm{p}=, 002$} \\
\hline & & Score $1,2,3$ of 4 & 38 & 64,97 & 12,019 & \\
\hline & \multirow[t]{2}{*}{ Attivat } & Score 0 & 49 & 54,24 & 14,411 & \multirow[t]{2}{*}{$t(216)=-3,131 ; p=, 002$} \\
\hline & & Score 1 & 169 & 60,86 & 12,605 & \\
\hline & \multirow[t]{2}{*}{ Wippel Wappel } & Score 0 & 245 & 58,08 & 13,102 & \multirow[t]{2}{*}{$\mathrm{t}(264)=-3,829 ; \mathrm{p}<, 001$} \\
\hline & & Score 1,2 of 3 & 21 & 69,52 & 13,600 & \\
\hline \multirow[t]{11}{*}{ RekenenE1 } & \multirow[t]{2}{*}{ Bever op vlot } & Score 0 & 251 & 75,50 & 12,056 & \multirow[t]{2}{*}{$\mathrm{t}(105)=4,290 ; \mathrm{p}<, 001$} \\
\hline & & Score 1 of 2 & 60 & 69,12 & 9,908 & \\
\hline & \multirow[t]{3}{*}{ Reus Pak-in } & Score 0 & 201 & 74,58 & 11,516 & \multirow[t]{3}{*}{ n.s. } \\
\hline & & Score 1 & 72 & 74,60 & 11,802 & \\
\hline & & Score 2 & 32 & 74,66 & 12,233 & \\
\hline & \multirow[t]{2}{*}{ Klaas Krentje } & Score 0 & 226 & 72,85 & 11,240 & \multirow[t]{2}{*}{$\mathrm{t}(262)=-3,589 ; \mathrm{p}<, 001$} \\
\hline & & Score $1,2,3$ of 4 & 38 & 80,05 & 12,685 & \\
\hline & \multirow[t]{2}{*}{ Attivat } & Score 0 & 49 & 71,00 & 11,536 & \multirow[t]{2}{*}{$\mathrm{t}(216)=-2,289 ; \mathrm{p}=, 023$} \\
\hline & & Score 1 & 169 & 75,35 & 11,759 & \\
\hline & \multirow[t]{2}{*}{ Wippel Wappel } & Score 0 & 244 & 74,25 & 12,022 & \multirow[t]{2}{*}{ n.s. } \\
\hline & & Score 1,2 of 3 & 21 & 76,81 & 11,635 & \\
\hline
\end{tabular}


Wat opvalt, is dat het item over de Reus Pak-in Pak-op geen verband laat zien met CITOvaardigheidsscores op taal of rekenen: de score die kinderen op dit item behaalden op de voormeting loopt wel op met een oplopende score op de CITO-toets voor rekenen, maar verschillen zijn niet significant. De score op dit item correspondeert dus niet met het niveau van taal- of rekenvaardigheid van de kleuters. Wat eveneens opvalt, is dat het verband tussen de itemscores en de CITO-scores op het item over Bever en zijn vrienden op het vlot opnieuw in onverwachte richting wijst: kinderen die lager scoren op de CITO-toetsen voor Taal én Rekenen, scoren hoger op dit item (en/of andersom). Dit item is in die zin uitzonderlijk: kinderen in groep 2 die thuis geen kinderboeken hebben, niet of weinig worden voorgelezen en (relatief) lager scoren op de CITO-toetsen Taal en Rekenen halen gemiddeld hogere scores op dit item. Bij het bespreken van de inhoudsvaliditeit kom ik hier nog op terug.

In principe vormen de positieve verbanden met de CITO-scores een ondersteuning van de validiteit van de deeltoets en de afzonderlijke items, behalve het item over de Reus Pakin Pak-op dat geen verband met CITO-vaardigheidsscores laat zien en het item over Bever dat wel verbanden met de CITO-scores laat zien, maar in onverwachte richting. Echter, gezien de opmerkingen die ik bij aanname 1 al heb gemaakt over de te hoge moeilijkheidsgraad van de deeltoets Kinderpoëzie gezien de zeer lage scores, blijft de interne validiteit en dan met name de begripsvaliditeit van de deeltoets Kinderpoëzie voor groep 2 problematisch.

\section{De begripsvaliditeit van de deeltoets Kinderpoëzie voor groep 4}

De eerste aanname is dat kinderen binnen groep 4 hoger scoren op de deeltoets naarmate ze ouder zijn, hoewel we op de Toets OCG voor groep 4 als geheel al hebben gezien dat er geen verband met leeftijd meer is. Datzelfde geldt voor de deeltoets Kinderpoëzie en alle afzonderlijke items: er is in groep 4 geen verband tussen de deeltoetsscores of de itemscores en de leeftijd van de kinderen. Aanname 2 is dat kinderen die thuis meer kinderboeken hebben en meer voorgelezen worden, hoger scoren op de deeltoets Kinderpoëzie. Terwijl deze aanname bij groep 2 niet ondersteund wordt door de analyses, blijkt bij groep 4 wel dat kinderen die op de voormeting zelf aangeven thuis kinderboeken te hebben ook hoger scoren op de deeltoets Kinderpoëzie: zij behaalden gemiddeld 3,8 punten terwijl kinderen die aangaven thuis geen kinderboeken te hebben gemiddeld 2,5 punten scoorden. Dit verschil is significant $(t(343)=-2,873 ; p=, 004)$. Kijken we naar de afzonderlijke items, dan blijken kinderen in groep 4 die aangeven wel kinderboeken te hebben thuis op de voormeting vaker punten te halen op het item over Klaas Krentje dan kinderen die geen kinderboeken hebben $\left(\chi^{2}(1)=11,028 ; p=, 001\right)$. De kinderen in groep 4 is op de voormeting eveneens gevraagd of ze thuis worden voorgelezen, maar er blijken geen verbanden te bestaan tussen deeltoetsscores en/of itemscores en al dan niet worden voorgelezen. Wanneer we alle aspecten van 'geletterd thuisklimaat' samennemen als een variabele dan blijken er geen significante verschillen tussen gemiddelde scores op de deeltoets Kinderpoëzie van kinderen met een 'laag', 'gemiddeld' of 'hoog' geletterd thuisklimaat (laag=score 0-1, gemiddeld=score $2-4$, hoog=score 5) hoewel de gemiddelde scores grosso modo wel oplopen naarmate het thuisklimaat meer geletterd is. Op de afzonderlijke items zien we ook geen 
significante verschillen. Verder is opnieuw gekeken naar gegevens uit de oudervragenlijsten. Als we kijken naar de voorleesfrequentie (verdeeld in de categorieën: 1=maximaal 1x per week, $2=$ meerdere keren per week, $3=$ dagelijks of meerdere keren per dag) dan zien we dat er geen verband is met de totaalscore op de deeltoets Kinderpoëzie voor groep 4 . Wel is er sprake van een verband op het item over Bever, maar dan - zoals we ook bij groep 2 zagen - tegengesteld aan de verwachting: naarmate kinderen vaker worden voorgelezen, scoren ze lager op dit item $\left(\chi^{2}(2)=9,948 ; p=, 007\right)$. Op het item over Klaas Krentje zien we eveneens een verband met de voorleesfrequentie en nu wel zoals verwacht: kinderen die het meest worden voorgelezen, scoren ook vaker punten op dit item dan kinderen die minder vaak worden voorgelezen $\left(\chi^{2}(2)=13,382 ; \mathrm{p}=, 001\right)$. Bibliotheekbezoek vertoont bij kinderen in groep 4 , net als bij groep 2, geen verband met de score op de voormeting van de deeltoets Kinderpoëzie of met de afzonderlijke itemscores. Er is in de oudervragenlijst ook gevraagd wat voor soort boeken kinderen van de bibliotheek lenen. Slechts vier ouders hebben echter ' $\mathrm{ja}$ ' aangekruist bij 'gedichtenbundels' en die groep is te klein om een goede vergelijking te maken met de ouders die 'nee' hebben aangekruist bij 'gedichtenbundels'. Daarnaast is er noch op de deeltoetsscore, noch op de afzonderlijke itemscores een verband met 'bekendheid met kinderpoëzie- en kinderliedbundels', zoals gerapporteerd in de oudervragenlijsten. $\mathrm{Al}$ met al bieden deze resultaten weinig overtuigende ondersteuning voor de validiteit van de deeltoets Kinderpoëzie voor groep 4, hoewel we zien dat er bij kinderen thuis weinig poëziebundels bekend zijn (zie Bijlage 6). Om die reden kan ook worden gesteld dat er geen verband tussen de mate waarin poëzie onderdeel is van geletterdheidskenmerken van het thuisklimaat en de score op de deeltoets Kinderpoëzie verwacht kan worden.

Ten slotte is er nog aanname 3: de verwachting dat kinderen met een hogere OCG het ook beter doen op school (en/of andersom), vooral op het gebied van taal. We verwachten dat de relatie met rekenen minder sterk is. Voor groep 4 hebben we gegevens van drie verschillende taaltoetsen: woordenschat, begrijpend lezen en spelling. We verwachten een correlatie tussen de deeltoets Kinderpoëzie en woordenschat en tussen de deeltoets en begrijpend lezen, maar niet zozeer tussen de deeltoets en spelling. Ook voor de deeltoets Kinderpoëzie kan gelden dat de toets mogelijk in hoge mate begrijpend 'lezen' (luisteren) meet. We verwachten in dat geval een hoge correlatie met die betreffende CITOvaardigheidsscores. Als we eerst naar de correlaties tussen de verschillende CITO-toetsen (afgenomen voorafgaand aan de interventie) en de deeltoetsscores Kinderpoëzie voor groep 4 (voormeting) kijken, dan zien we zoals verwacht dat er geen correlatie is tussen de deeltoetsscore en Spelling. Verder zien we wel correlaties tussen de deeltoetsscore en Rekenen, Woordenschat en Begrijpend Lezen (zie Tabel 47). De correlatie met Rekenen is het sterkst, wat wel verklaarbaar is omdat het zeker in de deeltoets Kinderpoëzie veel om redeneren gaat (zowel in het beantwoorden van de hoofdvraag als in het beantwoorden van de waaromvragen), iets wat juist ook bij rekenen nodig is. De correlatie met Begrijpend Lezen is niet heel sterk: de resultaten wijzen er dus niet op dat de deeltoets vooral begrijpend lezen/luisteren toetst. 
Tabel 47. Begripsvaliditeit deeltoets Kinderpoëzie groep 4: correlaties deeltoetsscore voormeting en CITOvaardigheidsscores

\begin{tabular}{lllllll}
\hline GROEP 4 & & $\begin{array}{l}\text { Deeltoets } \\
\text { poëzie }\end{array}$ & Rekenen E3 & $\begin{array}{l}\text { Woordenschat } \\
\text { E3 }\end{array}$ & $\begin{array}{l}\text { Begrijpend } \\
\text { Lezen E3 }\end{array}$ & Spelling E3 \\
\hline $\begin{array}{l}\text { Deeltoets } \\
\text { poëzie }\end{array}$ & Pearson Correlation & 1 &, $337^{* *}$ &, $260^{* *}$ &, $266^{* *}$ &, 096 \\
& Sig. (2-tailed) & &, 000 &, 000 &, 000 &, 094 \\
& $\mathrm{~N}$ & 346 & 330 & 249 & 298 & 306 \\
\hline
\end{tabular}

**. Correlatie is significant op het 0,01 niveau (2-tailed).

Als we dan verder kijken naar de afzonderlijke items dan vinden we nog een aantal interessante correlaties die inzicht geven in het soort kennis waar de verschillende items in de deeltoets mee in verband staan (zie Tabel 48).

Tabel 48. Begripsvaliditeit deeltoets Kinderpoëzie groep 4: correlaties itemscores voormeting en CITOvaardigheidsscores

\begin{tabular}{lllllll}
\hline GROEP 4 & & Item & Rekenen E3 & Woordenschat E3 & Begrijpend Lezen E3 & Spelling E3 \\
\hline Item Bever & Pearson Correlation & 1 &, 062 &,- 056 &, 050 &,- 006 \\
& Sig. (2-tailed) & &, 260 &, 379 &, 393 &, 910 \\
& $\mathrm{~N}$ & 345 & 329 & 248 & 297 & 305 \\
Item Reus & Pearson Correlation & 1 &, 123 &,- 015 &, 046 &,$- 133^{*}$ \\
& Sig. (2-tailed) & &, 052 &, 839 &, 489 &, 042 \\
& $\mathrm{~N}$ & 263 & 250 & 191 & 227 & 235 \\
Item Klaas & Pearson Correlation & 1 &, $320^{* *}$ &, $315^{* *}$ &, $335^{* *}$ &, $151^{*}$ \\
& Sig. (2-tailed) & &, 000 &, 000 &, 000 &, 010 \\
& $\mathrm{~N}$ & 326 & 311 & 234 & 281 & 288 \\
Item Attivat & Pearson Correlation & 1 &, 101 &, $156^{*}$ &, 077 &, $235^{* *}$ \\
& Sig. (2-tailed) & &, 096 &, 025 &, 227 &, 000 \\
& $\mathrm{~N}$ & 287 & 272 & 206 & 247 & 255 \\
Item W Wappel & Pearson Correlation & 1 &, $205^{* *}$ &, $251^{* *}$ &, 108 &, 075 \\
& Sig. (2-tailed) & &, 000 &, 000 &, 074 & 281 \\
\hline & $\mathrm{N}$ & 318 & 303 & 227 & 273 & \\
\hline
\end{tabular}

**. Correlatie is significant op het 0,01 niveau (2-tailed).

*. Correlatie is significant op het 0,05 niveau (2-tailed).

Het item over Bever op het vlot correleert niet met CITO-scores; het item over de reus Pak-in Pak-op correleert zwak negatief met Spelling ( $\mathrm{r}=-, 133 ; \mathrm{p}=, 042)$. Het item over Klaas Krentje correleert, net als de deeltoets Kinderpoëzie als geheel, met Rekenen $(r=, 320$; $\mathrm{p}<, 001)$, Woordenschat $(\mathrm{r}=, 315 ; \mathrm{p}<, 001)$ en Begrijpend Lezen $(\mathrm{r}=, 335 ; \mathrm{p}<, 001)$; ook is er samenhang met Spelling, hoewel zeer zwak $(r=, 151 ; \mathrm{p}=, 010)$. De score op het rijm-item 'Daar was een smid - attivit' hangt positief (hoewel niet heel sterk) samen met de CITOSpellingscore $(r=, 235 ; \mathrm{p}<, 001)$ en de score op het andere rijm-item over de vlieg Wippel Wappel correleert positief met Rekenen $(r=, 205 ; \mathrm{p}<, 001)$ en Woordenschat $(r=, 251$; $\mathrm{p}<, 001)$. Geen van deze correlaties is zo sterk dat we eruit af moeten leiden dat het betreffende item in hoofdzaak de betreffende vaardigheid toetst. We zien wel dat de verschillen- 
de items met een variatie aan vaardigheden samenhangen: voor de validiteit van een item zien we het liefst een gelijkmatige correlatie met zoveel mogelijk vaardigheden. Als we alleen vanuit het oogpunt van de item-validiteit kijken, dan wijzen de hierboven beschreven correlatieanalyses er, net als de betrouwbaarheidsanalyse, op dat in de deeltoets Kinderpoezie voor groep 4 het item over Klaas Krentje het 'beste' (meest betrouwbare en meest valide) item is. Het item over Bever en zijn vrienden op het vlot laat, daarentegen, helemaal geen correlaties met CITO-vaardigheidsscores zien en zou vanuit dat perspectief als het minst valide item kunnen worden beschouwd. Dit was in de deeltoets Kinderpoëzie voor groep 4 echter juist het enige item dat een effect van de interventie met de Leeskalender ${ }^{+ \text {Kinderpoëzie }}$ liet zien.

\section{De inhoudsvaliditeit van de deeltoets Kinderpoëzie onder de loep}

Tot nu toe ben ik ingegaan op de begripsvaliditeit door na te gaan of de deeltoetsen Kinderpoëzie voor groep 2 en voor groep 4 als geheel, en vanwege de beperkte betrouwbaarheid van de deeltoets ook alle items afzonderlijk, verbanden laten zien met leeftijd, 'geletterd thuisklimaat' en CITO-vaardigheidsscores, omdat we mogen verwachten dat ontluikende culturele geletterdheid met deze kenmerken samenhangt. Dat blijkt voor de deeltoets Kinderpoëzie en de afzonderlijke items geen eenduidig beeld op te leveren, maar er zijn voor de kinderpoëzie ook kanttekeningen te plaatsen bij de verwachte verbanden zelf. Bijvoorbeeld: als (het voorlezen van) kinderpoëzie slechts in zeer beperkte mate onderdeel is van een 'geletterd thuisklimaat' - specifiek kinderpoëzie die gekenmerkt wordt door de onderscheiden indicatoren van ontluikende culturele geletterdheid -, in hoeverre mogen we dan verwachten dat dit achtergrondkenmerk een verband vertoont met scores op de (voormeting van de) deeltoets Kinderpoëzie? Dit sluit op zichzelf echter niet uit dat de aanbieding van kinderpoëzie via de Leeskalender positief bijdraagt aan een groei van ontluikende culturele geletterdheid bij kinderen in de experimentele conditie. Waarom zien we dit, naast het feit dat de deeltoets Kinderpoëzie voor groep 2 te moeilijk is gebleken, ook in de deeltoets Kinderpoëzie voor groep 4 slechts op een van de items terug? Een laatste niveau waarop de deeltoets Kinderpoëzie en de afzonderlijke items geëvalueerd kunnen worden, is op het niveau van de inhoudsvaliditeit van de deeltoets/items. De inhoudsvaliditeit heeft betrekking op de vraag of de deeltoets inhoudelijk aansluit op wat de kinderen via de Leeskalender aan kinderpoëzie is aangeboden. Een al eerder opgemerkte beperking van de inhoudsvaliditeit van het meetinstrument, zowel de Toets OCG als geheel als de deeltoets Kinderpoëzie, is dat het instrument niet alle aspecten van het construct 'ontluikende culturele geletterdheid' zoals we dat binnen dit onderzoeksproject hebben gedefinieerd en zoals ik dat binnen mijn deelproject hebt gespecificeerd ${ }^{172}$, beslaat. Uit praktische overwe-

\footnotetext{
172 Onze opvatting van het begrip 'ontluikende culturele geletterdheid' binnen het onderzoeksproject als geheel is: kennis en begrip van kenmerken van breed gedragen (transculturele en langdurig geliefde) tekstsoorten en genres. Deze brede definitie is binnen elk van de drie deelprojecten verder gespecificeerd voor het eigen deelgebied van tekstsoorten/genres. Binnen dit deelproject met betrekking tot kinderpoëzie heb ik de brede definitie eerst gespecificeerd op het niveau van de indicatoren 'nonsensicaliteit' en 'muzikaal taalspel', in (1) kennis en begrip van veelvoorkomende stijl-figuren die in poëzie een nonsensicaal effect bewerkstelligen, en (2) kennis en begrip van veelvoorkomende stijlfiguren die in poëzie muzikaal taalspel bewerkstelligen. Deze twee categorieën heb ik vervolgens geoperationaliseerd op item-niveau (zie Hoofdstuk 7, §7.7).
} 
gingen (omvang/tijdsduur van de toets) hebben we een selectie van aspecten van ontluikende culturele geletterdheid in de Toets OCG opgenomen. De inhoudsvaliditeit van de deeltoets Kinderpoëzie evalueer ik door voor elk item afzonderlijk na te gaan in hoeverre het kennis en begrip van 'een verschijnsel' in kinderpoëzie - een specifieke stijlfiguur meet in relatie tot wat de kinderen in de Leeskalender is aangeboden. Daarna ga ik kort in op enkele algemene problemen met betrekking tot het waarborgen van de inhoudsvaliditeit van een meetinstrument dat effecten van poëzie beoogt te meten.

BEVER EN ZIJN VRIENDEN OP HET VLOT Het item over Bever en zijn vrienden op het vlot is qua betrouwbaarheid en begripsvaliditeit problematisch: in de Toets OCG voor groep 2 als geheel moet het verwijderd worden om een adequate interne samenhang van de toets te krijgen en bij het optimaliseren van de interne samenhang van de deeltoets Kinderpoëzie moet dit item voor groep 2 op zowel de voor- als de nameting verwijderd worden om de samenhang te vergroten (bij groep 4 alleen op de voormeting). Daarnaast roept de begripsvaliditeit van het item vragen op. We zien bij groep 2 dat kinderen die thuis geen kinderboeken hebben, niet of weinig worden voorgelezen en (relatief) lager scoren op de CITO-toetsen voor Taal én Rekenen gemiddeld hoger scoren op dit item op de voormeting. Bij groep 4 zien we dat naarmate kinderen vaker worden voorgelezen, ze lager scoren op dit item op de voormeting en dat het item niet correleert met CITO-scores. Toch sluit het van alle items in de deeltoets Kinderpoëzie het meest nauwkeurig aan op kinderpoëzie die in de Leeskalender is aangeboden. Het item vraagt om een vorm van redeneren die tegengesteld is aan intuitief of op basis van 'gezond verstand' redeneren, namelijk dat er juist niet iets groots en zwaars, maar iets kleins en lichts wordt toegevoegd voordat een grote massa in elkaar stort ('de druppel die de emmer doet overlopen'; zie ook de beschrijving van het item in Hoofdstuk 7, \$7.7). In de Leeskalender voor groep 2 kwamen kinderen met deze stijlfiguur in aanraking in de vorm van het gedicht 'Het grote bed' waar een mier er als laatste bij komt voordat het bed doorzakt; in de Leeskalender voor groep 4 maakten de kinderen kennis met 'De brug bij Breukelen' waar het een mug is die er als laatste bij komt voordat de brug het begeeft. Het item over Bever in de toets vraagt om een 'vertaling' van de stijlfiguur naar een nieuwe tekst/situatie, namelijk naar het overvolle vlot van Bever (met ook Mol, Egel, Haas, Das én Beer erop). Welk dier komt er als laatste bij voordat het vlot omkiept? Een everzwijn, een vos, of een vlinder? Veel kinderen motiveerden hun keuze voor - meestal - het everzwijn of de vos op de voormeting met argumenten als "Omdat die de grootste/zwaarste is" (wat past in de serie van klein naar groot en logisch redeneren), "Omdat die er nog niet op zit" (wat feitelijk voor alle keuzemogelijkheden gold en dus neerkomt op gokken) of zelfs "Omdat die ook in het bos leeft, net als die anderen". De vlinder werd vooral gekozen "omdat ik die het mooiste vind" of "omdat ik die al zie" (op het plaatje, hoewel daar geen vlinder op te zien is). Kinderen zochten duidelijk naar argumenten op basis van hun kennis van de (tekstexterne) wereld of hun persoonlijke voorkeuren. Het ging hier echter hoofdzakelijk om de herkenning van de situatie die een specifieke stijlfiguur oproept ("Ik denk de vlinder, want zo'n verhaal ken ik"), of eventueel om wiskundig redeneren ("Er zitten al heel veel dieren op, dus dan denk ik de kleinste/lichtste”). Voor groep 2 geldt dat de gehele deeltoets Kinderpoëzie, inclusief dit item, te moeilijk was. Bij groep 4 zien we dat dit het enige item is dat een effect van de Leeska- 
lender ${ }^{+ \text {Kinderpoëzie }}$ laat zien. Omdat er geen correlatie tussen de score op dit item en CITOvaardigheidsscores is en deze stijlfiguur niet voorkwam in het tekstaanbod vanuit de andere twee deelprojecten, mogen we er vanuit gaan dat het inderdaad specifiek de kennis van de betreffende stijlfiguur meet. De grotere vooruitgang op dit item bij de experimentele groep 4 die heeft gewerkt met de Leeskalender ${ }^{+K i n d e r p o e ̈ z i e ~ i s ~ d u s ~ a l l e e n ~ t e ~ i n t e r p r e t e r e n ~ a l s ~ e e n ~}$ effect van die interventie ${ }^{173}$. Ondanks de problemen met de betrouwbaarheid en de begripsvaliditeit, is de inhoudsvaliditeit van dit item dus juist goed te noemen.

DE REUS PAK-IN PAK-OP In dit item staat een reus centraal die op zijn hoofd geen gewoon haar, maar planten, gras en een boom heeft. Wat gebruikt hij om zijn 'groene haar', zoals het aan het einde van het tekstfragment wordt genoemd, uit de war te halen? Dit item vraagt een relatief moeilijke, want conceptuele, puur mentale operatie van kinderen, te weten het maken van een analogie (in de psychologische opvatting), een type vergelijking met de vaste structuur 'A staat tot B als C staat tot D'. In dit geval: haar staat tot $\mathrm{kam} /$ borstel als gras/plantjes staat tot ...? In groep 2 kregen de kinderen drie keuzemogelijkheden (plaatjes): een kam, een borstel of een hark. Voor hen waren alle onderdelen voor het maken van de analogie (A, B, C en D) dus al uit de tekst en de antwoordmogelijkheden te halen. In groep 4 was dit een open vraag omdat tijdens de pilots was gebleken dat de vraag anders veel te gemakkelijk was: zij moesten dus op eigen denkkracht B en D invullen. Het feit dat het hier om een vergelijking gaat, wijst er al op dat dit item een groot beroep doet op de cognitieve ontwikkeling van de kinderen: kinderen in groep 2 redeneren vooral vanuit eigen ervaring ("De kam, want mijn mama doet mijn haren ook met de kam") of vanuit reële, tekstexterne logica ("De borstel, want dan maak je ze weer glad"). Kinderen in groep 4 zochten veelal wel naar alternatieven ("Zijn handen", "De regen", "Een stok"), maar beargumenteerden dat lang niet altijd op een manier waaruit overtuigend kon worden afgelezen dat ze de situatie begrepen ("Dan kan hij de klitten eruit halen", "Dan spoelt het schoon", "Dan kan hij het kammen"). Slechts in sommige gevallen was de uitleg van een kind zo overtuigend dat alle punten voor dit item werden toegekend ("Een heggenschaar/grasmaaier, want hij heeft gras en plantjes op zijn hoofd/want dat gebruik je ook in de tuin"). Woordenschat kan een belangrijke rol spelen bij dit item, maar dat komt uit de correlatieanalyses met CITO-scores niet naar voren: de correlatie met Woordenschat bij groep 4 is zwak en daarbij ook niet significant ${ }^{174}$. Los daarvan staat in dit item een verschijnsel centraal dat in de Leeskalender niet als zodanig voorkwam. Het is wel een type logica dat binnen de nonsensicale traditie past, maar in deze hoedanigheid niet rechtstreeks

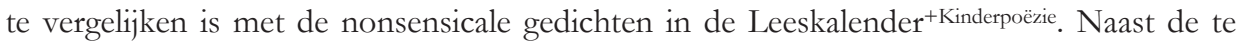
hoge moeilijkheidsgraad van dit item, is dus ook de aansluiting op de interventie, i.e. de inhoudsvaliditeit, van dit item niet goed.

KLAAS KRENTJE Het item over Klaas Krentje komt uit de bus als het meest betrouwbaar en als het meest valide op begripsniveau, zeker voor groep 4. In dit item staan kennis en

\footnotetext{
${ }^{173}$ Voor alle items geldt dat goed gokken of toevallige kennis van een soortgelijke tekst uit eigen ervaringen in de controlegroep ook voorkomen en dus gecontroleerd zijn als we naar de verschilscores kijken.

$174 \mathrm{Al}$ weet ik niet of het thema 'tuingereedschap' deel uitmaakt van de CITO-Woordenschat toets, maar we mogen er toch van uit gaan dat kinderen die een grote CITO-woordenschat hebben, ook in het algemeen een grote woordenschat hebben.
} 
begrip van de nonsensicale stijlfiguur van de omkering (inversie) centraal. Klaas Krentje, zo is in het tekstfragment te horen, draagt heel veel hoedjes, want hij heeft koude voetjes. Wat zou hij dan dragen als hij een koud hoofd heeft? Opnieuw, zoals voor de gehele deeltoets geldt, was dit item moeilijk voor de kleuters: veel van hen redeneren op basis van hun eigen gedrag ("Een muts, want dat doe ik ook op als het sneeuwt"). Een gemiste kans is dat ik in de antwoordcategorieën (gevormd op basis van de pilots) geen rekening heb gehouden met de overdrijving in het gedicht over Klaas Krentje ('hij draagt heel veel hoedjes'), maar alleen met de omkering ('want hij heeft koude voetjes'). Regelmatig antwoordden kinderen in groep 2 wel in lijn met de overdrijving, maar niet in lijn met de omkering ("Heel veel mutsen”, "Heel veel jassen”). Eventuele effecten van de Leeskalender ${ }^{+K i n d e r p o e ̈ z i e ~ o p ~ h e r k e n n i n g ~}$ en begrip van de overdrijving zijn echter niet gemeten; alleen eventuele effecten op herkenning en begrip van de omkering. De nonsensicale omkering was in de Leeskalen-

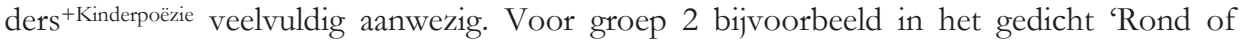
vierkant', in de verwerking van het liedje 'Carnaval' en in (de verwerking van) het gedicht 'Prins Piramente' (zie ook Hoofdstuk 9). Klaas Krentje is daarbij een voorbeeld van de omkering toegepast op de categorische kenmerken van objecten: 'hoedjes' behoren doorgaans niet tot de dingen die je draagt bij 'koude voetjes'. Dit type omkering, of verwisseling, kwam het meest vergelijkbaar aan de orde in de aanbieding en verwerking van 'Opa Bakkebaard'. Of de aanbieding van kinderpoëzie in de Leeskalender een positief effect heeft gehad op kennis en begrip van de omkering bij kinderen in de experimentele conditie kan niet aangetoond worden, maar bij groep 2 is dit het enige item uit de deeltoets waar de controleconditie significant lager op de nameting scoort dan de experimentele condities met en zonder kinderpoëzie in de Leeskalender $(F(2,306)=3,043 ; \mathrm{p}<, 05)$. In groep 4 kwam de omkering, of verwisseling, ook aan bod in de Leeskalender, zoals in (de verwerking van) het lied 'Leuk is raar' en in (de verwerking van) het liedje 'Dierencarnaval', hoewel niet in precies dezelfde verschijningsvorm als bij Klaas Krentje. Dit item heeft dan ook een twijfelachtige inhoudsvaliditeit. Daar komt bij dat kinderen in groep 4 het, ongeacht de onderzoeksconditie, goed deden op dit item: het was voor hen wellicht te gemakkelijk.

DAAR WAS EEN SMID - ATTIVIT Dit is het meest onbetrouwbare item in de deeltoets Kinderpoëzie: de enige expliciete rijmtaak in de Toets OCG en daarmee ook het meest 'afwijkend' in de reeks van taken die in de Toets OCG aan kinderen werden voorgelegd. Deze rijmtaak is dan op zich al moeilijk omdat het om een plotselinge omschakeling vraagt van een hele reeks items waarop kinderen herkennings- en begripsvragen moesten beantwoorden en hun antwoorden beargumenteren, naar een item waar ze ineens een rijmpje moesten afmaken. Sommige kinderen konden deze omschakeling dan ook niet maken en vulden het vers (Daar was een smid - attivit,/ Die had een kat - attivat/ En die kat - attivat/ Brak haar poot - attivoot/ Toen kwam de smid - attivit/ En zette de poot - attivoot/ Van de kat - ...) aan met "weer op de grond" of "die moet naar het ziekenhuis" of "mijn poes had ook zijn poot gebroken". Sommige kinderen probeerden wel te rijmen of begrepen wel dat ze moesten rijmen, maar slaagden niet helemaal ("in de bak" of "ehm, ik kan geen rijm verzinnen"). Zeker voor kinderen in groep 2 blijkt zelf rijmen nog een moeilijke taak, ook in de meer spontane context van de klas (zie Hoofdstuk 9). Daar komt bij dat het specifieke rijmpatroon in het vers niet één-op-één vergelijkbaar is met de rijmpatronen die 
de kinderen in de Leeskalender is aangeboden. In die zin is elk vers uniek en is de inhoudsvaliditeit waar het kinderpoëzie betreft wellicht überhaupt moeilijk te waarborgen. Hier kom ik nog op terug. Bij groep 4 behaalden beduidend meer kinderen het maximale aantal punten op dit item in de nameting en zijn de kinderen over het geheel genomen gemiddeld ook vooruit gegaan, maar zijn er geen significante verschillen tussen de controleconditie en de twee experimentele condities (zonder en met kinderpoëzie in de Leeskalender). Wellicht is 'rijmen' dan ook een taak die kinderen in groep 4 al dusdanig onder de knie hebben dat een interventie met poëzie geen verschil meer makkt (zie ook Hoofdstuk 10).

WIPPEL W APPEL De vlieg Wippel Wappel zit het liefst op een ...? Appel. Maar waarom is dat zo in kinderpoëzie? Omdat het rijmt. Zijn passieve kennis en begrip van kinderen met betrekking tot de toepassing van rijm in poëzie meetbaar te maken in een toetsitem? Dat is heel lastig, maar het item over Wippel Wappel beoogde dat toch te doen en wel op twee verschillende manieren. Allereerst door kinderen, nadat ze (een deel van) het gedicht over de vlieg Wippel Wappel hadden gehoord, rechtstreeks te vragen: 'Waarom zit Wippel Wappel het liefst op een appel, denk jiij?' (en niet op een peer of een noot of een pruim, zoals daarvoor was verteld) Dit is een vraagstelling waarin de nadruk mogelijk teveel op de appel is komen te liggen. Het overgrote deel van de kinderen droeg allerlei eigenschappen van appels aan om de vraag te beantwoorden: "Omdat dat rond is", "Dan kan hij wiebelen", "Omdat dat lekker/sappig is", "Omdat dat blaadje schaduw geeft", "Omdat die andere te hard/klein/niet lekker zijn", enzovoort. De vraag had wellicht anders geformuleerd moeten worden om meer nadruk op de naam te leggen, bijvoorbeeld: 'Die vlieg die zit het liefst op een appel, maar waarom heet hij Wippel Wappel?' Om de kinderen een tweede kans te geven om te laten zien of ze het klankspel wel hadden opgemerkt, volgde een plaatje van een vlieg op een peer: 'Nu komt er een andere vlieg en die vlieg zit het liefst op een peer. Kan jij nu eens een mooie naam verzinnen voor die vlieg die het liefst op een peer zit?' Opnieuw helpt het verrassingseffect van plotseling zelf iets moeten verzinnen niet mee: veel kinderen gaven geen antwoord of grepen terug op kennis en ervaring dicht bij huis ("Mike, want zo heet ik", "Japie, want zo noemt de juf alle vliegen", "Snuffie, want zo heet mijn konijn", "Fruitvlieg" en zelfs "Strontvlieg want zo heet zo'n soort vlieg"), toch werd er ook aardig gerijmd op peer ("Veer", "Weer", "Keer", etc.) of op iets anders ("Vliegje wiegje", "Vlieg de pieg", etc.). Dit rijmen met namen kwam in het kinderpoëzieaanbod in de Leeskalenders veelvuldig voor en was bij de aanbieding van poëzie in de klas voor de kleuters ook een duidelijke trigger voor rijmherkenning (zie Hoofdstuk 9). In die zin is de inhoudsvaliditeit van dit item redelijk te noemen; het is vooral de vraag of dit type taak in de context van de Toets OCG waarin inhoudelijk reageren en redeneren de overhand hadden, goed tot zijn recht komt. Het was daarbij het allerlaatste item van de toets, dus heeft mogelijk ook enigszins geleden onder vermoeidheid en verlies van concentratie/motivatie bij de kinderen. Aanpassing van de eerste vraag binnen dit item kan het item verbeteren.

Wat is het belangrijkste probleem waar de deeltoets Kinderpoëzie met de afzonderlijke items zoals die in dit onderzoeksproject ontwikkeld en gebruikt zijn, mee kampt waar het de inhoudsvaliditeit betreft? Het is bijzonder moeilijk gebleken om één-op-één aansluiting van 
items op het aanbod van kinderpoëzie in de Leeskalender te waarborgen. 'Kinderpoëzie' is een breed begrip dat een enorme variëteit aan soorten teksten en tekstkenmerken omvat. De afbakening van de soorten kinderpoëzie die in de Leeskalenders zijn opgenomen, is gebaseerd op de analyse van structurele kenmerken van langdurig geliefde en (trans)cultureel diepgewortelde poëtische vormen uit de volksculturele traditie, vanuit een pragmatisch perspectief op poëziegebruik in context (zie Hoofdstuk 2 en Hoofdstuk $3 \mathrm{t} / \mathrm{m}$ 5). Daaruit zijn 'muzikaal taalspel' en 'nonsensicaliteit' naar voren gekomen als tekstaspecten die naar verwachting cruciale raakvlakken vormen tussen langdurig geliefde (trans)cultureel diepgewortelde poëtische vormen en de culturele competentie (kennis, vaardigheden en houdingen) van kinderen in groep 2 en groep 4 én operationaliseerbaar zijn in het type toetsitems dat we binnen de Toets OCG voor ogen hadden. Daarbij is het echter, zoals uit bovenstaande evaluaties van de items mag blijken, een grote uitdaging om meerdere gedichten te selecteren die dermate gelijksoortig zijn in de verschijningsvorm van een specifieke stijlfiguur dat de tekst die in de toets wordt gebruikt eenduidig en voor kinderen herkenbaar overeenkomt met poëzie in de Leeskalender. Het item over Bever en zijn vrienden op het vlot was voor kinderen in groep 4 op het niveau van de stijlfiguur voldoende in overeenstemming met 'De brug bij Breukelen' om de stijlfiguur te herkennen; het item was evenwel niet in overeenstemming met 'De brug bij Breukelen' op het niveau van de tekstsoort (verhaal versus gedicht). Op zich is dat laatste ook niet noodzakelijk - kennis en begrip van stijlfiguren is kennis en begrip van stijlfiguren -, maar dit laat zien dat ook hier de overeenkomst tussen de tekst zoals aangeboden in de Toets OCG en de teksten zoals aangeboden in de Leeskalender niet perfect is. Feitelijk zou voor elk poëzie-item in de deeltoets ten minste één tekst in de Leeskalender moeten zijn opgenomen die sterke overeenkomst vertoont in de verschijningsvorm van een specifieke stijlfiguur. Deze 'matching' van teksten zou de inhoudsvaliditeit van de items in de deeltoets Kinderpoëzie moeten waarborgen. Maar geen twee gedichten zijn gelijk.

Dat geldt ook voor verhalen, maar in bijvoorbeeld schelmenverhalen is een bepaald type logica heel duidelijk gemarkeerd door de aanwezigheid van een herkenbare terugkerende verhaalfiguur, zoals Hodja of Anansi. Herkenning van het personage ondersteunt dan wellicht ook herkenning van het type logica dat ten grondslag ligt aan het handelen van het personage: 'hij maakt vast een grapje, want Hodja maakt altijd grapjes'175. In de deeltoets Kinderpoëzie zijn nonsensicale vormen van handelen ook gekoppeld aan personages, maar is dat een zeer divers gezelschap en staat in elk gedicht een unieke figuur centraal. 'Klaas Krentje' of 'De reus Pak-in Pak-op' kwamen in de Leeskalender niet voor; wel andere nonsensicale personages, doorgaans herkenbaar aan hun vreemde namen (zie Hoofdstuk 9), maar de personages zelf vormen geen herkenbare relatie tussen Leeskalenderaanbod en toetsitems. Zonder die één-op-één herkenning, komen de herkenning en het begrip van de specifieke vormen van nonsensicaliteit hoofdzakelijk aan op de herkenning van onderliggende structuren en doet daarmee een beroep op relatief abstract denkvermogen van de kinderen. Daarmee worden de kleuters, zoals we ook hebben moeten vaststellen, eigenlijk

\footnotetext{
175 Dit zal overigens nog moeten blijken uit de analyses van de deeltoetsen 'Deugden \& Dilemma's' en 'Narratieve Genres': beide deeltoetsen bevatten zowel items gekoppeld aan een herkenbare verhaalfiguur die ook regelmatig in de Leeskalender aan bod kwam (Hodja/Anansi; Jezus/profeet Mohammed) als items die betrekking hebben op implicieter genrekenmerken, zoals de moraal in fabels of de plot in een bepaald type sprookje.
} 
bij voorbaat al benadeeld omdat de taken te moeilijk voor hen zijn: zij bevinden zich in een andere fase van cognitieve ontwikkeling dan kinderen in groep 4. Tegelijk is cognitieve ontwikkeling een proces dat zich ook los van het werken met kinderpoëzie voltrekt. Mogelijk hebben de kinderpoëzie-items bij kinderen uit groep 4 vooral cognitieve ontwikkeling gemeten wat zou verklaren dat er geen effecten van de Leeskalender ${ }^{+K i n d e r p o e ̈ z i e ~ g e v o n d e n ~}$ zijn: zowel kinderen in de controleconditie als kinderen in de experimentele conditie zijn in dezelfde mate vooruit gegaan in hun cognitieve ontwikkeling en daarmee ook op de deeltoets Kinderpoëzie. Het feit dat de deeltoets Kinderpoëzie sterker correleert met de rekenvaardigheid van kinderen in groep 4 dan met de verschillende onderdelen van taalvaardigheid ondersteunt dit idee: bij rekenen is relatief abstract redeneren een belangrijk onderdeel van de vaardigheden en bij de deeltoets Kinderpoëzie ook. Dit verklaart tevens waarom juist het item over Bever en zijn vrienden op het vlot wél een effect van de Leeskalender ${ }^{+K i n d e r p o e ̈ z i e ~ l a a t ~ z i e n ~ b i j ~ g r o e p ~ 4: ~ d i t ~ i t e m ~ t o o n d e ~ e e n ~ n e g a t i e v e ~ c o r r e l a t i e ~ m e t ~ ' g e l e t t e r d ~ t h u i s-~}$ klimaat' en geen correlaties met CITO-vaardigheidsscores wat impliceert dat het item iets meet dat afwijkt van de verwachtingshorizon die ‘belezen' kinderen aanvankelijk hadden en dat het item daarbij om onlogisch redeneren vraagt. Dan zijn het alleen kinderen die de specifieke stijlfiguur (her)kennen die op dit item punten scoren en blijkt het werken met de Leeskalender ${ }^{+ \text {Kinderpoëzie }}$ daar significant aan te hebben bijgedragen. De vormen van rijm die in de Kinderpoëzie-items aanwezig zijn, zijn eveneens unieke verschijningsvormen van specifieke soorten toepassingen van rijm in kinderpoëzie. Ze waren niet in exact dezelfde vorm aanwezig in de Leeskalender en dus komt de herkenning en het begrip van de toepassing van rijm zoals aanwezig in de toetsitems vooral aan op de cognitieve ontwikkeling en de rijmvaardigheid en/of het fonemisch bewustzijn van de kinderen. Daar komt bij dat de toets-setting een beperkte ecologische validiteit heeft voor taken waarin klankspel gespeeld moet worden: het spontaan afmaken van een rijm of het spontaan verzinnen van een rijmende naam vereist een setting waarin kinderen ook voelen dat spontaniteit en speelsheid op zijn plaats is en een toets is dat doorgaans niet. Dit type taak wijkt dermate af van de andere taken in de Toets OCG, waarbij vooral goed moet worden nagedacht, dat plotseling een rijm afmaken te zeer uit de toon valt. Zoals in de volgende hoofdstukken zal blijken, moeten kinderen in groep 2 allerlei poëtische vormen nog verwerven door heel letterlijk meedoen met en nadoen van de leerkracht terwijl kinderen in groep 4 al meer typen taalspel (her)kennen in poëzie en daar vervolgens zelf op kunnen variëren.

De herkenning en het begrip van onderliggende tekstuele structuren of strategieën (stijlfiguren) zoals geoperationaliseerd in de deeltoets Kinderpoëzie lijken dus vooral binnen het bereik van de oudere kinderen in onze onderzoekspopulatie te liggen. Echter, omdat één-op-één aansluiting van poëzie-items op het poëzie-aanbod zich moeilijk laat waarborgen, moet geconcludeerd worden dat de meeste poëzie-items naar alle waarschijnlijkheid de cognitieve ontwikkeling van de kinderen in beeld brengen en niet specifiek de effecten van poëzie op aspecten van hun ontluikende culturele geletterdheid. Er kunnen andere soorten metingen worden overwogen om specifiek zicht te krijgen op de bijdrage van kinderpoëzie aan de ontluikende culturele geletterdheid van kinderen. Te denken valt aan een retentietest waarbij 'ontluikende culturele geletterdheid' dus wordt opgevat als kennis (herkenning) van specifieke gedichten en liedjes die zijn aangeboden in de Leeskalender. Bijvoorbeeld: 'Weet je nog hoe dit versje gaat? Doe maar mee en maak maar af: 
"Toen ik nog een jongen was/ zat ik heel vaak in het gras/ en ik speelde in de zon/ met mijn...?"'. Dit is het type taak zoals in de VLES-K/LES voorkomt. Dan komen we echter terug op het punt van de top-down canonvorming dat in Hoofdstuk $1 \mathrm{al}$ is besproken. We vatten ontluikende culturele geletterdheid binnen dit onderzoek vanuit het oogpunt van pluriforme canonvorming juist niet op als kennis van specifieke titels, maar als kennis en begrip van onderliggende gedeelde kenmerken van genres of tekstsoorten die geworteld zijn in de orale volkscultuur. Kennis en begrip die daarmee bijdraagt aan een brede culturele geletterdheid die toegang biedt tot een brede waaier aan genres of tekstsoorten. Een andere mogelijkheid zou zijn dat we de bijdrage van kinderpoëzie aan ontluikende culturele geletterdheid meer op het niveau van de interpretatieve of evaluatieve vaardigheden van kinderen operationaliseren, zoals Coosje van der Pol dat met betrekking tot prentenboeken heeft gedaan in haar onderzoek Prentenboeken lezen als literatuur (2010). Echter, de opzet van de Leeskalender is niet gericht op het verbeteren van de literaire competentie van kinderen (zie Hoofdstuk 7, \$7.5). We willen kinderen via de Leeskalender juist kennis laten maken met alomtegenwoordige, transcultureel diepgewortelde, (formele en inhoudelijke kenmerken van) tekstsoorten en genres om een brede culturele geletterdheid op te bouwen. Een alternatieve optie is dat we er simpelweg op moeten vertrouwen dat het aanbieden van poëzie in zowel groep 2 als in groep 4 wel degelijk effect heeft op de ontwikkeling van ontluikende culturele geletterdheid, al ware het maar dat het kinderen laat kennismaken met en genieten van - in dit geval - het veelzijdige 'taalspel poëzie' als bijzondere vorm van communicatie. Waarbij het maar de vraag is of de bijdrage van kinderpoëzie aan ontluikende culturele geletterdheid bij jonge kinderen zich überhaupt objectief laat meten. De kwalitatief-empirische resultaten, zoals beschreven in de volgende hoofdstukken, bieden hier aanvullende inzichten in. Het mysterie van het lokaliseren van effecten van kinderpoëzie is in die zin nog niet opgelost...

\subsection{Conclusies en discussie}

Een van de doelen van het uitgevoerde interventieprogramma, het Leeskalenderproject, was na te gaan welke effecten het aanbieden van verhalen, gedichten en liedjes - geselecteerd op basis van verwachte 'indicatoren van canoniciteit' - met de Leeskalender heeft op de ontluikende culturele geletterdheid van kinderen in groep 2 en in groep 4 van het basisonderwijs. Een effectmeting vraagt om een objectief en gestandaardiseerd meetinstrument dat in de ontwikkeling en uitvoering herhaalbaarheid en controleerbaarheid waarborgt; de uitspraken die worden gedaan op basis van dit meetinstrument moeten valide en betrouwbaar zijn. Binnen dit onderzoeksproject is de Toets Ontluikende Culturele Geletterdheid voor dit doeleinde ontwikkeld en zowel voorafgaand aan als na afloop van de implementatie van de Leeskalender afgenomen bij kinderen in groep 2 en kinderen in groep 4 in de experimentele conditie en in de controleconditie. De Toets Ontluikende Culturele Geletterdheid bestaat uit items uit elk van de drie deelprojecten binnen het onderzoeksproject: het instrument als geheel meet dus verschillende aspecten van ontluikende culturele geletterdheid zoals geoperationaliseerd binnen de verschillende deelprojecten, i.e. de Toets OCG als geheel is een combinatie van drie deeltoetsen. Daarnaast is in de ontwikkeling van 
het interventiemateriaal, de Leeskalender, gekozen voor differentiatie van versies waardoor voor elk van de deelprojecten geldt dat driekwart van de onderzoekspopulatie in de experimentele conditie heeft gewerkt met een Leeskalender inclusief het tekstaanbod uit het betreffende deelproject en dat een kwart van de onderzoekspopulatie in de experimentele conditie heeft gewerkt met een Leeskalender zonder het tekstaanbod uit het betreffende deelproject. Dit maakt het mogelijk om zowel voor groep 2 als voor groep 4 voor elk van de deelprojecten apart na te gaan wat de effecten van de Leeskalenders inclusief het eigen tekstaanbod op de eigen deeltoets zijn in vergelijking met de controleconditie zonder Leeskalender en met een 'controleconditie' zonder het eigen tekstaanbod in de Leeskalender. Hier staat het deelproject Kinderpoëzie centraal. Daarom zijn in dit hoofdstuk zowel de resultaten van de effectmeting voor het onderzoeksproject als geheel, als de effectmeting voor het deelproject Kinderpoëzie besproken. Ik vat de resultaten van de meting van effecten van de Leeskalender met de Toets OCG als geheel en vervolgens de resultaten van de meting van effecten van de Leeskalender+Kinderpoëzie op de deeltoets Kinderpoëzie kort samen. Na bespreking van de resultaten ga ik in op de belangrijkste beperkingen van deze effectmeting voor het deelproject Kinderpoëzie.

\section{Samenvatting van de resultaten}

RESULTATEN TOETS OCG GROEP 2 De Toets OCG voor groep 2 mag op basis van verschillende statistische controles die daarop zijn uitgevoerd een betrouwbaar en valide meetinstrument genoemd worden. Uit de analyses van de effecten van de aanbieding van 'de Leeskalender' (niet gedifferentieerd naar versie) op de scores op 'de Toets OCG' (niet gedifferentieerd naar deeltoets) bij kinderen in groep 2 blijkt dat de groepen in de experimentele en controleconditie vergelijkbaar scoren op de voormeting en op de nameting van elkaar verschillen. De controlegroep scoort dan gemiddeld 12,2 punten op de toets en de experimentele groep gemiddeld 13,9 punten. Dat verschil is significant $(\mathrm{t}(337)=-2,241$; $\mathrm{p}=, 026)$ en in het voordeel van de experimentele conditie. Ook wanneer we kijken naar de gemiddelde verschilscores zijn de verschillen significant en in het voordeel van de kinderen in de experimentele conditie. De controlegroep 'groeide' gemiddeld 4,6 punten in ontluikende culturele geletterdheid en de experimentele groep gemiddeld 6,0 punten $(\mathrm{t}(336)=-$ 2,260; $\mathrm{p}=$,024). Omdat de controle- en experimentele conditie bij groep 2 op andere variabelen met elkaar vergelijkbaar zijn (leerlinggewichten, leeftijd, scores op CITO-toetsen voor taal en rekenen en score op de nulmeting met de Toets OCG), mogen we concluderen dat het werken met de Leeskalender in de klas dus een positief effect heeft gehad op de ontluikende culturele geletterdheid van kinderen in groep 2, buiten de 'natuurlijke' ontwikkeling van ontluikende culturele geletterdheid zoals we die bij de controlegroep zien. De verwachting dat de interventie als geheel een positief effect heeft op de ontwikkeling van de ontluikende culturele geletterdheid bij kinderen in groep 2 wordt daarmee bevestigd.

RESULTATEN TOETS OCG GROEP 4 De Toets OCG voor groep 4 mag op basis van verschillende statistische controles die daarop zijn uitgevoerd een betrouwbaar en valide meetinstrument genoemd worden. Bij groep 4 scoort de experimentele groep al op de voormeting hoger op de Toets OCG dan de controlegroep. De controlegroep scoort gemiddeld 
12,8 punten en de experimentele groep gemiddeld 15,0 punten, een aanzienlijk verschil $(\mathrm{t}(344)=-3,224 ; \mathrm{p}=, 001)$. Op de nameting scoort de experimentele groep ook hoger dan de controlegroep. De controlegroep scoort op de nameting gemiddeld 17,1 punten en de experimentele groep gemiddeld 21,6 punten $(\mathrm{t}(319)=-5,656 ; \mathrm{p}<, 001)$. De experimentele groep is eveneens sterker vooruit gegaan op de toets dan de controlegroep. De controlegroep is gemiddeld 4,2 punten 'gegroeid' en de experimentele groep gemiddeld 6,7 punten $(\mathrm{t}(319)=-3,634 ; \mathrm{p}<, 001)$. Omdat de groepen echter op de voormeting al van elkaar verschillen, mogen we er niet zomaar van uit gaan dat de grotere groei van de experimentele groep is toe te schrijven aan de Leeskalender. Uit nadere analyses blijkt dat de samenstelling van de experimentele en controleconditie van elkaar verschilt op achtergrondkenmerken van de leerlingen. De leerlingen in de controlegroep hebben bijvoorbeeld gemiddeld een hoger leerlinggewicht: een kenmerk dat, ongeacht de zwaarte ervan $(0,3$ of 1,2$)$ negatief correleert met scores op de Toets OCG. Uit analyses op basis van gegevens uit de oudervragenlijsten blijkt onder meer dat het opleidingsniveau van de moeders uiteenloopt: een kenmerk dat samenhangt met een groot aantal sociaaleconomische gezinskenmerken alsmede kenmerken van het geletterdheidsklimaat thuis. Wanneer we in de effectanalyses voor groep 4 de variabele 'opleiding moeder'176 controleren, dus groepen leerlingen met elkaar vergelijken waarvan de moeders eenzelfde opleidingsniveau hebben, dan zijn er op de voormeting geen verschillen meer tussen de experimentele en controlegroepen en op de nameting wel. Binnen de groep leerlingen met moeders met maximaal vmbo of voortgezet onderwijs zonder vervolgopleiding, scoren leerlingen in de experimentele conditie hoger op de nameting dan leerlingen in de controleconditie $(t(68)=2,575 ; \mathrm{p}=, 012)$. Bij deze groep is de experimentele conditie ook significant meer vooruit gegaan in ontluikende culturele geletterdheid tussen de voor en nameting dan de controleconditie $(\mathrm{t}(68)=2,907 ; \mathrm{p}=, 005)$. Dit is de groep met relatief laagopgeleide moeders en de laagste gemiddelde score op de voormeting wat aangeeft dat het tekstaanbod in de Leeskalender niet alleen bijdraagt aan de ontluikende culturele geletterdheid van kinderen uit 'hogere' sociaaleconomische milieus, maar ook de ontluikende culturele geletterdheid stimuleert van kinderen uit 'lagere' sociaaleconomische milieus. Ook binnen de groep leerlingen met moeders met een afgeronde HBO of WO scoren leerlingen in de experimentele conditie hoger op de nameting dan leerlingen in de controleconditie $(\mathrm{t}(34)=2,172 ; \mathrm{p}=, 037)$. Voor beide groepen heeft de interventie met de Leeskalender dus een positief effect gehad op de ontluikende culturele geletterdheid van de kinderen.

RESULTATEN KINDERPOËZIE GROEP 2 Uit de analyses van de effecten van de aanbieding van de Leeskalender ${ }^{+K i n d e r p o e ̈ z i e ~ o p ~ d e ~ s c o r e s ~ o p ~ d e ~ d e e l t o e t s ~ K i n d e r p o e ̈ z i e ~ b i j ~ k i n-~}$ deren in groep 2 blijkt dat leerlingen in de experimentele condities (met en zonder kinderpoëzie in de Leeskalender) en de controleconditie op de voormeting niet van elkaar verschillen. Echter, op de nameting noch in de verschilscores zijn er verschillen tussen de groepen. Vanwege de lage interne consistentie van de scores op de deeltoets is ook naar de afzonderlijke items gekeken. Daaruit blijkt dat het item over Klaas Krentje een uitzondering vormt: dit item voldoet deels aan de verwachtingen. Op de voormeting zijn er geen

\footnotetext{
${ }^{176}$ De variabele 'opleidingsniveau moeder' is onderverdeeld in drie categorieën, te weten (1) 'Maximaal vmbo of voortgezet onderwijs zonder vervolgopleiding', (2) 'MBO' en (3) 'HBO of WO'.
} 
verschillen, maar op de nameting wel. De controlegroep scoort dan significant lager dan de twee experimentele groepen $(\mathrm{F}(2,306)=3,043 ; \mathrm{p}<, 05)$. Hoewel niet significant en dus niet van toeval te onderscheiden, wijst de vergelijking van de twee experimentele groepen echter in onverwachte richting: de experimentele groep zonder kinderpoëzie in de Leeskalender scoort iets hoger dan de experimentele groep met kinderpoëzie in de Leeskalender. Op geen van de andere items worden significante verschillen gevonden. Hieruit kunnen we concluderen dat de interventie met Kinderpoëzie geen effect heeft gehad op de scores van kinderen op de deeltoets Kinderpoëzie voor groep 2. De deeltoets blijkt echter, gezien de zeer lage gemiddelde scores, te moeilijk voor de leerlingen in groep 2: meer dan de helft van de kinderen $(56 \%)$ scoorde op de voormeting 0 of 1 punt en nog eens $20 \%$ scoorde slechts 2 punten van de in totaal 14 te behalen punten. De deeltoets blijkt in die zin geen valide instrument om de ontluikende culturele geletterdheid van leerlingen in groep 2 te meten met betrekking tot kinderpoëzie. De resultaten zeggen daarmee weinig over de mogelijke bijdrage van kinderpoëzie aan de ontluikende culturele geletterdheid in groep 2.

RESULTATEN KINDERPOËZIE GROEP 4 Uit de analyses van de effecten van de aanbieding van de Leeskalender ${ }^{+K i n d e r p o e ̈ z i e ~ o p ~ d e ~ s c o r e s ~ o p ~ d e ~ d e e l t o e t s ~ K i n d e r p o e ̈ z i e ~ b i j ~ k i n-~}$ deren in groep 4 blijkt dat leerlingen in de experimentele condities (met en zonder kinderpoëzie in de Leeskalender) en de controleconditie op de voormeting al significant van elkaar verschillen $(\mathrm{F}(2,343)=5,883 ; \mathrm{p}<, 005)$. Hier zien we dat de experimentele conditie met kinderpoëzie in de Leeskalender al voor aanvang van de interventie de hoogste gemiddelde score behaalde. Op de nameting zien we opnieuw een significant verschil tussen de drie condities $(\mathrm{F}(2,318)=5,949 ; \mathrm{p}<, 005)$ en nog steeds scoort de experimentele groep met kinderpoëzie in de interventie het hoogst. Kijken we echter naar de verschilscores op de deeltoets Kinderpoëzie, dan zijn de significante verschillen die we op de voor- en nameting zagen als sneeuw voor de zon verdwenen. Daar komt bij dat we, hoewel ik hier geen geldige uitspraken over kan doen omdat de resultaten statistisch gesproken niet van toeval te onderscheiden zijn, opnieuw zien dat de uitkomsten wijzen in de richting van een grotere groei bij de kinderen in de experimentele conditie zonder kinderpoëzie in de Leeskalender op de deeltoets Kinderpoëzie. Nadere analyses van de verschillen bij kinderen met dezelfde achtergrond (opleidingsniveau moeder of leerlinggewicht) leveren hetzelfde resultaat op: kleine verschillen op de voormeting en de nameting, maar geen verschillen op de verschilscores. Vanwege de lage interne consistentie van de deeltoets is ook hier naar de afzonderlijke items gekeken. Er is bij groep 4 één item dat aan de verwachting voldoet: het item over Bever en zijn vrienden op het vlot. Er zijn geen verschillen op de voormeting; op de nameting zijn de verschillen tussen de condities significant $(F(2,317)=12,487 ; p<, 001)$ en zien we dat de experimentele groep met kinderpoëzie in de Leeskalender de hoogste gemiddelde score behaalt. Het significante verschil tussen de groepen blijft bestaan als we kijken naar de verschilscores $(\mathrm{F}(2,316)=6,828 ; \mathrm{p}=, 001)$ waarbij de experimentele groep met kinderpoezie in de Leeskalender de grootste groei heeft doorgemaakt. Al met al is de conclusie dat de interventie met kinderpoëzie weinig effect heeft gehad op de ontluikende culturele geletterdheid van kinderen in groep 4 zoals gemeten met de deeltoets Kinderpoëzie. 


\section{Beperkingen van de effectmeting voor het deelproject Kinderpoëzie}

Het contrast tussen de Toets OCG als geheel en de deeltoets Kinderpoëzie op het niveau van validiteit en betrouwbaarheid en op het niveau van de gevonden effecten van de interventie is opmerkelijk. De opzet en uitvoering van het experiment, inclusief de ontwikkeling en uitvoering van de effectmeting met de Toets OCG zijn gedaan met grote zorgvuldigheid en nauwkeurigkeurigheid, met inachtneming van de nodige procedures om herhaalbaarheid en controleerbaarheid, betrouwbaarheid en validiteit te waarborgen. De Toets OCG als geheel mag een betrouwbaar en valide meetinstrument genoemd worden en laat zowel bij kinderen in groep 2 als bij kinderen in groep 4 effecten zien van het werken met de Leeskalender. De Leeskalender als geheel mag daarmee een effectieve methode voor de ontwikkeling van ontluikende culturele geletterdheid bij kinderen in groep 2 en kinderen in groep 4 genoemd worden.

Voor het deelproject Kinderpoëzie geldt echter dat de deeltoets Kinderpoëzie voor groep 2 geen valide instrument blijkt voor het meten van de ontluikende culturele geletterdheid van de kinderen: de deeltoets is te moeilijk voor groep 2. De cognitieve complexiteit van de items blijkt niet goed aan te sluiten op de cognitieve ontwikkeling van kinderen in deze leeftijd waardoor de deeltoets hen feitelijk niet de kans biedt om hun kennis en begrip van de stijlfiguren te tonen. Daarmee zeggen de resultaten voor groep 2 weinig over de werkelijke ontluikende culturele geletterdheid van de kinderen of over de bijdrage die de aanbieding van kinderpoëzie in de Leeskalender daar mogelijk aan heeft geleverd. De deeltoets Kinderpoëzie voor groep 4 is in beperkte mate betrouwbaar en valide. Hier wordt de betrouwbaarheid van het instrument beperkt door een matige interne consistentie en is het vooral de problematische inhoudsvaliditeit van de toetsitems die de validiteit van het instrument beperkt. Uit de analyses van de resultaten op de deeltoets voor groep 4 komt naar voren dat op vier van de vijf items kinderen in de experimentele conditie en kinderen in de twee controlecondities niet significant verschillen in de gemiddelde groei die ze tussen de voormeting en de nameting hebben doorgemaakt. Hoewel niet statistisch betrouwbaar, wijzen de verschilscores op de meeste items zelfs in de richting van een sterkere vooruitgang bij kinderen die met de Leeskalender zonder kinderpoëzie hebben gewerkt. Het enige item dat wel aan de verwachtingen voldoet, is het item over Bever en zijn vrienden op het vlot. De wijze waarop de bijdrage van kinderpoëzie aan de ontluikende culturele geletterdheid van kinderen in groep 2 en in groep 4 is geoperationaliseerd in de deeltoets Kinderpoezie (zie ook Hoofdstuk 7, $\$ 7.5 \mathrm{t} / \mathrm{m} \$ 7.7$ ), blijkt niet geschikt om effecten van kinderpoëzie op de ontluikende culturele geletterdheid van de kinderen waarneembaar te maken. De resultaten wijzen erop dat een andere operationalisering nodig is. Tegelijk is zichtbaar geworden dat de deeltoets Kinderpoëzie zich op een aantal punten afwijkend gedraagt ten opzichte van de Toets OCG als geheel. Mogelijk hebben de kinderpoëzie-items bij kinderen uit groep 4 vooral cognitieve ontwikkeling gemeten wat zou verklaren dat er nauwelijks effecten van de Leeskalender ${ }^{+K i n d e r p o e ̈ z i e ~ g e v o n d e n ~ z i j n: ~ z o w e l ~ k i n d e r e n ~ i n ~ d e ~ c o n t r o l e-~}$ conditie als kinderen in de experimentele conditie zijn in dezelfde mate vooruit gegaan in hun cognitieve ontwikkeling en daarmee ook op de deeltoets Kinderpoëzie. Het feit dat de score op de deeltoets Kinderpoëzie als geheel sterker correleert met de rekenvaardigheid van kinderen in groep 4 dan met de verschillende onderdelen van taalvaardigheid onder- 
steunt dit idee: bij rekenen is relatief abstract redeneren een belangrijk onderdeel van de vaardigheden en bij de deeltoets Kinderpoëzie ook. Abstract redeneren sluit niet aan op de pre-operationele cognitieve ontwikkelingsfase van de kleuters, wat verklaart dat de deeltoets voor hen te moeilijk was. Dit verklaart tevens waarom juist het item over Bever en

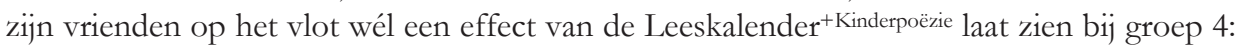
dit item toonde een negatieve correlatie met 'geletterd thuisklimaat' en geen correlaties met CITOvaardigheidsscores wat impliceert dat het item iets meet dat afwijkt van de verwachtingshorizon die 'belezen' kinderen aanvankelijk hadden en dat het item daarbij om onlogisch redeneren vraagt. Omdat kinderen die 'onlogica' van de betreffende stijlfiguur in het Leeskalenderaanbod van poëzie hebben leren kennen ('De brug bij Breukelen'), wisten ze deze vraag in de toets op de nameting vaker goed te beantwoorden dan de andere (groepen) kinderen en zijn ze gemiddeld meer vooruit gegaan dan de kinderen in de andere onderzoekscondities.

Het aanbieden van poëzie heeft, zo kan worden afgeleid uit deze redenering, dus ook geen spontane vooruitgang teweeggebracht in het abstracte denkvermogen van kinderen, gezien het feit dat er op de overige vier items geen significante verschillen zijn in de groei van kinderen uit de drie onderzoekscondities. Wat heeft de poëzie dan wel gedaan en kán dat überhaupt objectief meetbaar worden gemaakt met het type meetinstrument dat de Toets OCG is? Het gebruik van een gestandaardiseerd meetinstrument stelt grenzen aan wat objectief meetbaar gemaakt kan worden. Een toets voor jonge kinderen kan niet te lang zijn in verband met de concentratiespanne; de items in een toets kunnen niet te ver uiteenlopen in wat ze beogen te meten en in hóe ze dat beogen te meten (het type taken); een toetssetting is niet de meest optimale setting voor taken die een zekere beleving en spontaniteit vragen, zoals de rijmtaken; én een verbale toets als de Toets OCG vereist dat de respondenten in staat zijn hun gedachten verbaal uit te drukken of zelfs hun reflectie op die gedachten, zoals in de Toets OCG bij het beantwoorden van de vraag 'Waarom denk je dat ... ?'. Het type meetinstrument dat de Toets OCG is, vooronderstelt daarbij ook een type kennis en begrip dat rationeel is en verwoord kan worden. Het toetsen van kennis en begrip bij jonge kinderen, zeker bij de kleuters, vormt een extra uitdaging omdat hun verbale reacties op een taak (de performance) niet altijd weerspiegelen wat ze weten en begrijpen (de competence). Daar komt bij dat we, zoals ik in Hoofdstuk 2 heb besproken, feitelijk nog niet precies weten wat poëzie voor kinderen is en doet: "due to muddled and often contradictory perspectives about who we want children to be, do, and mean, and what we want poetry to be, do, and mean, we don't yet have a clear understanding of what children's poetry is, does, and means." (Coats, 2013, p. 132) Ik heb ook al aangegeven dat de poëzie waarvan ik verwacht dat het nauwkeurig aansluit op de culturele competentie van kinderen, dat zij die poëzie verwerven en op die manier hun ontluikende culturele geletterdheid uitbreiden, in hoge mate wordt gekenmerkt door 'betekenisloosheid' op tekstueel niveau (zie Hoofdstuk 2). 'Betekenis' en 'tekstbegrip' moeten in het geval van kinderpoëzie dan wellicht op een heel andere manier opgevat worden dan wat voorondersteld wordt in het type toets zoals ik die ontwikkeld heb.

Dit onderzoeksproject heeft een dubbele empirische doelstelling, namelijk enerzijds het nagaan van de effecten van kinderliteratuur op de ontluikende culturele geletterdheid van kinderen en anderzijds nagaan welke factoren een cruciale rol spelen in de verwerving van 
'cultureel relevante' tekstsoorten en genres door kinderen, als voorwaarde voor de effectieve bijdrage van teksten aan de ontluikende culturele geletterdheid van de kinderen. Die twee doelstellingen kunnen elkaar ondersteunen en bevestigen, maar omdat er nog nauwelijks structureel empirisch onderzoek is gedaan naar wat poëzie nu precies is en doet voor kinderen, kan ik de vraag of de bijdrage van poëzie aan de ontluikende culturele geletterdheid van kinderen in groep 2 en 4 überhaupt objectief gemeten kan worden en, zo ja, hoe, met grotere zekerheid beantwoorden na bespreking van de kwalitatieve inzichten in hoe kinderen poëzie verwerken, waarderen en begrijpen en welke kenmerken daar een cruciale rol in spelen zoals beschreven in de volgende hoofdstukken. Áls de volgende theoretische aanname juist is, dan zal het operationaliseren van die bijdrage in ieder geval op een geheel ander niveau en op een andere manier moeten gebeuren: “... poetry bypasses concepts and interpretation and reaches directly into embodied experience to produce its effects, which exceed its linguistic meaning." (Coats, 2013, p. 133) Die discussie voer ik in Hoofdstuk 11; eerst bespreek ik de resultaten van het kwalitatief-empirisch deel van dit onderzoek voor groep 2 (Hoofdstuk 9) en voor groep 4 (Hoofdstuk 10). 



\section{HOOFDSTUK 9}

Het taalspel poëzie in groep 2:

Het belang van de waarneembare pragmatische context 



\subsection{Introductie}

Dertig weken lang hebben kinderen in groepen 2 op de deelnemende scholen in de experimentele conditie via de Leeskalender ${ }^{+ \text {Kinderpoëzie }}$ kennisgemaakt met allerlei rijmen, liedjes en gedichten. Ze hebben erbij gespeeld, gezongen, geklapt, gestampt, uitgebeeld, geteld en gekleurd; ze hebben zelf gerijmd, ze hebben op teksten gevarieerd, ze hebben erover nagedacht en gepraat. Op basis van een 'pragmatische benadering van poëzie' (Hoofdstuk 2) waarin poëriegebruik in pragmatische context centraal staat - en de uitwerking van verwachte 'indicatoren van canoniciteit' voor kinderpoëzie (Hoofdstuk $3 \mathrm{t} / \mathrm{m}$ 5), heb ik voor groep 2 verwachtingen geformuleerd over de kenmerken die een cruciale rol spelen in processen van poëzieverwerving bij deze doelgroep. Of die verwachtingen kloppen, is een vraag die niet beantwoord kan worden op basis van theoretische inzichten, hermeneutische tekstanalyse of de Toets OCG. Om die vraag te beantwoorden is inzicht nodig in daadwerkelijke toepassingen van 'het taalspel poëzie' in de klas. De instrumenten die binnen het kader van dit onderzoek zijn gebruikt om inzicht te krijgen in hoe kinderen op verschillende rijmen, liedjes en gedichten reageren, wat ze het meest aanspreekt, wat ze onthouden en opnieuw willen horen, zijn: eigen observaties, logboekaantekeningen van en gesprekken (semigestructureerde interviews) met leerkrachten. De brede onderzoeksvraag die ik hiermee beoog te beantwoorden, is:

\section{KWALITATIEF-EMPIRISCHE ONDERZOEKSVRAAG}

4. Welke contextuele, tekstuele en ontwikkelingskenmerken zijn cruciaal te noemen in processen van de verwerving van langdurig geliefde en (trans)cultureel diepgewortelde vormen van 'het taalspel poëzie' bij kinderen in groep 2 op basis van observaties, logboekaantekeningen en gesprekken met leerkrachten met betrekking tot de presentatie van het tekstaanbod in de klas, de reacties van de kinderen op deze teksten en hun waardering daarvan?

Om deze vraag te beantwoorden, bespreek ik in dit hoofdstuk de inzichten die zijn verkregen uit de verzamelde kwalitatieve data aan de hand van de kwalitatief-empirische deelvragen zoals weergegeven in Tabel 18 (Hoofdstuk 7, \$7.8) voor 'het taalspel poëzie' in groep 2. Bij het beantwoorden van deze deelvragen vormden de observaties het uitgangspunt: de observaties gaven indicaties van factoren die van invloed zijn op de aanbieding van teksten door leerkrachten en de beleving, waardering en voorkeuren van poëzie bij de kinderen. Zoals beschreven in Hoofdstuk 7 zijn de observaties grofweg in twee fases in te delen. De eerste fase (okt t/m nov-2013) bestond uit observaties in verschillende groepen op verschillende scholen; in de tweede fase (dec-2013 t/m mei-2014) zijn de observaties toegespitst op een groep 2 (en een groep 4). De observaties zijn uiteraard momentopnamen en er is daarbij altijd sprake van een zeker 'observatie-effect' waardoor de geobserveerde realiteit ook weer beïnvloed wordt. Om de geldigheid, betrouwbaarheid en objectiviteit van inzichten voor groep 2 te versterken, heb ik na afloop van de interventieperiode de obser- 
vaties vergeleken met wat leerkrachten, ook uit de andere kleutergroepen ${ }^{177}$, in de logboeken noteerden en wat er uit de gesprekken met leerkrachten naar voren kwam (zie Hoofdstuk 7, \$7.8).

Zo ontstond een beeld van de realiteit in de kleuterklas, de belangrijkste 'externe' factoren die daarin van invloed zijn op hoe het taalspel poëzie in het kader van de Leeskalender vorm krijgt en de belangrijkste kenmerken die bijdragen aan processen van poëzieverwerving. Eerst bespreek ik de belangrijkste 'externe' factoren die in de kleutergroepen van invloed waren op de aanbieding van de Leeskalender - en daarin de kinderpoëzie - in de klas (\$9.2). Vervolgens bespreek ik de inzichten verkregen uit observaties, logboekaantekeningen van en gesprekken met leerkrachten met betrekking tot de verwachte indicatoren van canoniciteit' en tot de inbedding van culturele pluriformiteit voor kinderpoëzie in groep 2 (\$9.3). Dat doe ik per deelvraag en de daarbij geformuleerde verwachtingen. Ten slotte trek ik conclusies, zowel met betrekking tot de 'externe' factoren als met betrekking tot de verwachte indicatoren $(\$ 9.4)$.

\subsection{Een globaal beeld van de Leeskalender en poëzie in de kleuterklas}

De eerste fase had tot doel een beeld te krijgen van het werken met de Leeskalender in groepen 2 op verschillende scholen. Wat zijn de belangrijkste 'externe' factoren die in die dagelijkse onderwijspraktijk van invloed zijn op hoe teksten worden aangeboden en verwerkt? De kleuterklas is geen volledig gecontroleerde laboratoriumomgeving: het is een 'natuurlijke' omgeving waarin altijd meerdere variabelen meespelen die niet direct betrekking hebben op de geformuleerde 'indicatoren van canoniciteit', maar wel interacteren met het specifieke onderzoeksobject. Dit betekent dat de kwalitatieve inzichten in poëzieverwerving bij de kleuters die ik beschrijf nooit zuiver betrekking hebben op de geformuleerde indicatoren van canoniciteit, maar altijd interacteren met andere factoren. Dit betekent ook dat het juist in die levendige praktijk van de kleuterklas spannend is om te zien welke teksten 'overeind' blijven en welke niet, welke kenmerken structureel 'werken' en welke niet. Het is dan wel van belang een beeld te krijgen van die realiteit en de belangrijkste 'externe' factoren die daarin mede van invloed zijn op hoe het 'taalspel poëzie' vorm krijgt in de klas. Observaties in verschillende groepen (1-)2, logboekaantekeningen van leerkrachten en de gesprekken die met leerkrachten zijn gevoerd over hun ervaringen, helpen dat beeld te schetsen.

\footnotetext{
177 De school die vroegtijdig gestopt is niet meegerekend, werd in total in veertien kleutergroepen op zeven scholen met een Leeskalender ${ }^{+ \text {Kinderpoëzie }}$ gewerkt; daarvan werkten vier scholen $(9$ groepen) met de volledige versie, twee scholen (3 groepen) met de versie zonder Narratieve Genres, en een school (2 groepen) met de versie zonder Deugden \& Dilemma's. Omdat dit onderzoek niet tot doel heeft de deelprojecten met elkaar te vergelijken, laat ik de scholen waarop geen kinderpoëzie is aangeboden buiten beschouwing.
} 


\section{De samenstelling van de groep: verschillen tussen jongste en oudste kleuters}

Allereerst is de omvang, maar vooral ook de samenstelling van de kleutergroep van invloed op de aanbieding en verwerking van poëzie in de klas. Op veel basisscholen wordt gewerkt met combinatiegroepen 1-2. Hierdoor ontstaan soms grote groepen en kunnen er tegelijk grote verschillen bestaan tussen de jongste en oudste kleuters. Op een van de experimentscholen kregen de kinderen uit groep 2 om die reden regelmatig les in een aparte ruimte. Ook de Leeskalender werd hier met groep 2 apart behandeld, maar dat kon enkel op de dagen dat beide groepsleerkrachten, of een groepsleerkracht en klassenassistent, gelijktijdig aanwezig waren. Toen ik de leerkracht na afloop van een observatie vroeg of ik de volgende dag nog een keer kon komen kijken, zei ze: "Maar donderdag heb ik de hele groep, dus dan zit ik tussendoor steeds kinderen tot de orde te roepen!" (observatie 7, 12-11-13) Deze leerkracht ervoer de aanwezigheid van de groep 1 leerlingen bij de Leeskalenderactiviteiten zelf als 'storend' wat een negatief effect heeft gehad op hoe vaak in deze groep met de Leeskalender is gewerkt ${ }^{178}$.

Tijdens het observeren in groepen 1-2 was niet direct zichtbaar welke kinderen in groep 2 zitten en welke in groep 1. In de logboeken wordt het verschil tussen de jongste en oudste kleuters echter verschillende keren door leerkrachten genoemd als factor die de verwerking van een tekst beïnvloedde. Bij 'Mr. van Zoeten', van Annie M.G. Schmidt, was de eerste verwerking gericht op tekstbegrip (wat doet hij, wanneer, waarom?) en schrijft een leerkracht: "Groep 1 leerlingen vonden 't moeilijk. Weinig respons." (2621179, logboek week 1) In de andere kleutergroep op dezelfde school merkte de leerkracht hetzelfde op: "Groep 2 kinderen begrepen alléén de verwerkingsopdracht. Groep 1 kinderen vonden het een stuk moeilijker." (2622, logboek week 1) Het gedicht 'Het grote bed'180 brengt verschillen in tekstbegrip tussen de jongste en oudste kleuters expliciet aan het licht. Een leerkracht schrijft: "Direct na het voorlezen reageerde al een jongste kleuter: 'hè, wat gek over dat de mier het bed liet krakken'. Verontwaardiging over het kraken door de mier was bij de jongsten groot. Oudere kleuters beseften dat het niet kon komen door de mier. 'De mier was gewoon heel snel nog in het bed gesprongen, anders had het bed ook gekrakt'." (2321, logboek week 12) Een leerkracht uit een andere groep 1-2 van dezelfde school schrijft iets soortgelijks: "Enkele kinderen vonden dat het de schuld was van de mier: voornamelijk de jongsten. De oudsten snapten snel dat dat niet kon en vonden het de schuld van iedereen." (2323, logboek week 12) Op een derde school schreef de leerkracht de reactie van een leerling op: “'De arme mier, die denkt nu dat het zijn schuld is, maar de andere dieren zijn te dik' zei een 6-jarig meisje uit groep 2." (1321, logboek week 12) Ondanks de verschillen in opvattingen over wie het bed gebroken heeft, valt uit de logboeken af te lezen dat de

\footnotetext{
${ }^{178}$ In Bijlage 5 is een overzicht opgenomen van gegevens over hoe vaak en hoe lang er in groepen 1-2 met de Leeskalender ${ }^{+ \text {Kinderpoëzie }}$ is gewerkt en hoe het aanbod werd gewaardeerd.

179 In de verwerking, analyses en beschrijving van de kwalitatieve data, verzameld via observaties, logboeken en gesprekken met leerkrachten, zijn namen van scholen en groepen vervangen door codes om anonimiteit te waarborgen. Dit zijn dezelfde codes die in de verwerking van de kwantitatieve data zijn gebruikt om scholen en groepen te identificeren. De coderingssleutel is bekend bij de onderzoekers en de methodoloog van het onderzoeksproject.

${ }^{180}$ Dit is een cumulatief gedicht van Rudy Kousbroek waarin eerst heel veel grote en zware dieren zich op een bed stapelen en ten slotte een mier zich bij het gezelschap voegt waarna het bed doorzakt, vergelijkbaar met 'De brug bij Breukelen' van Annie M.G. Schmidt en corresponderend met het item 'Er kan nog meer bij' in de Toets OCG.
} 
kleuters ongeacht hun leeftijd sterk betrokken waren bij de verwerking van dit vers. Toen ik twee maanden na de aanbieding van 'Het grote bed' in mijn vaste observatiegroep was, bleek dat die betrokkenheid er nog steeds was bij de kinderen:

"Na afloop vraagt de leerkracht welk ander versje ze nu ook alweer ook zo leuk vonden. Er worden verschillende dingen genoemd: 'met die varkens', 'die met één voet in het bad' (hoe heet ze ook alweer?), 'met juf Boggemog!'. En dan weet J het weer: 'Die van dat de mier het bed stuk had gemaakt!' Ja, dat was 'm. Wanneer hadden ze die ook alweer gehad? J weet het nog: dat was vlakbij de kerst. Inderdaad, 'Het grote bed' was in december. Er is geen tijd meer om het vers voor te lezen, maar de discussie over wie het bed nu eigenlijk had gebroken barst weer in volle kracht los. J vindt nog steeds dat het door het nijlpaard kwam, want die was de aller zwaarste. Andere kinderen noemen toch de mier, want die kwam er als laatste bij. A is van mening dat het door alle dieren samen kwam.” (observatie 20, 5-2-2014)

Wanneer de kinderen in dezelfde mate betrokken zijn en alleen van mening verschillen dan kunnen die verschillen de verwerking van een tekst intensiveren, zoals bij 'Het grote bed'; een lage betrokkenheid van een deel van de groep kan de verwerking echter negatief beïnvloeden, zoals bij 'Mr. Van Zoeten'. Die betrokkenheid hangt overigens niet alleen samen met de mate waarin de tekst aansluit op de kennis, vaardigheden en voorkeuren van de kinderen. In het afsluitende evaluatiegesprek merkt een leerkracht op dat ook het type verwerkingsvorm een belangrijke rol speelt in het al dan niet 'slagen' van een tekstaanbieding in groep 1-2: “... verwerkingsvormen waarbij de kinderen zelf moeten rijmen, of redeneren, zijn lastig voor de jongste kleuters en dat beïnvloedt de hele groep." (evaluatie 2, S13, 23-6-14) Een andere leerkracht geeft aan dat zij vaak meemaakte dat een aantal van de oudste kleuters de clou van een tekst door had, terwijl bij driekwart van de klas het kwartje niet viel. Degenen die het snapten waren dan ver in de minderheid. Toch konden ook de kinderen die de kern niet hadden begrepen wel plezier aan zo'n tekst beleven ('Hé, dat rijmt!') (evaluatie 2, S23, 25-06-2014). In principe was het tekstaanbod voor de kleuters afgestemd op groep 2. Afhankelijk van de specifieke tekst en de bijbehorende verwerkingsvorm waren de jongste kleuters al dan niet betrokken en/of aandachtig. We mogen er van uit gaan dat dit van invloed is op hoe een tekst klassikaal overkomt, hoewel leerkrachten zelf waarschijnlijk manieren kennen om met deze verschillen om te gaan. Toch zijn de verschillen in ontwikkeling tussen de jongste en oudste kleuters factoren die meewegen in hoe het 'taalspel poëzie' vorm krijgt in de kleutergroepen. Welke (soorten) teksten en verwerkingsvormen ondanks die verschillen goed werkten in de kleutergroepen, komt verderop aan bod.

\section{Voorkeuren, attitudes en vaardigheden van leerkrachten}

Ook de (door henzelf gepercipieerde) vaardigheden, voorkeuren en attitudes van leerkrachten ten aanzien van verschillende tekstsoorten en -inhouden spelen een rol in óf en hóe ze teksten in de klas aanbieden. Dit kan heel concreet samenhangen met de denominatie en/of het beleid van de school. Op een openbare basisschool werden de verhalen uit de 
Bijbel vanuit het deelproject Deugden \& Dilemma's uit principiële overwegingen niet behandeld. Op de Protestants-Christelijke basisschool lagen de sprookjes en griezelverhalen uit het deelproject Narratieve Genres gevoelig vanuit religieuze overtuigingen en op de Islamitische basisschool werd het thema 'Sinterklaas' overgeslagen en werd een godsdienstleerkracht ingeschakeld om de aanbieding van Bijbelverhalen inbedding en uitleg te geven. Buiten deze schoolbrede factoren, waar leerkrachten ongeacht hun eigen overtuigingen en voorkeuren mee te maken hadden, waren in de dagelijkse Leeskalenderpraktijk in de klas ook voorkeuren en attitudes van individuele leerkrachten waarneembaar die de overdracht van het tekstaanbod op de kinderen merkbaar beïnvloedden.

Het gedicht 'Prins Piramente', een humoristisch verhalend gedicht met een aantal nonsensicale wendingen, zag ik op dezelfde dag in twee verschillende groepen 1-2 aangeboden worden. Bij de eerste observatie noteerde ik over de voordracht van de leerkracht: "Ze leest het gedicht voor: rustig en duidelijk, maar met weinig inleving en ze spreekt de naam Piramente steeds uit als Pirmanente. In het begin zijn verschillende kinderen erg onrustig, maar naarmate het gedicht vordert, worden ze rustiger." (observatie 5, 12-11-13) Later die dag op een andere school observeerde ik: "De leerkracht leest het gedicht geweldig voor! Ze legt verbazing en spanning en boosheid in de tekst: het verhaal komt helemaal tot leven. De kinderen zitten ademloos te luisteren en zijn volledig op de leerkracht gericht." (observatie 7, 12-11-13) Eenzelfde verschil in 'tekstbeleving' in de voordracht door de leerkracht kwam tot uiting bij het gedicht 'Boterhammen smeren': een zeer ritmisch opzegvers, met veel herhaling en klankspel. Bij de eerste observatie noteerde ik: "Ze leest 'Boterhammen smeren' voor: hoewel het een kort, ritmisch opzegvers is, leest ze het langzaam en formeel voor. Hierdoor komt het speelse karakter van het versje niet zo goed tot uiting. De kinderen reageren nauwelijks tijdens deze eerste voordracht. Dan vraagt ze of de kinderen denken dat het boterhammen smeren leuker wordt met dit versje. 'Nee', zegt een meisje." (observatie 3, 6-11-13) Twee dagen later ben ik terug op dezelfde school, nu in de andere groep 1-2 met een andere leerkracht. Het is de dag waarop ze terugblikken op de week: "De leerkracht doet het gedichtje nog een keer helemaal, zeer ritmisch: de kinderen doen de smeerbewegingen enthousiast en ritmisch mee en kunnen de meeste rijmwoorden invullen.” (observatie 4, 8-11-13) Dit opzegvers van Willem Wilmink maakte duidelijk dat niet alle leerkrachten gewend zijn om in hun voordracht de nadruk op ritme en klank te leggen $^{181}$. In het algemeen blijken leerkrachten én kinderen snel de aandacht op de inhoud te richten terwijl veel van de aangeboden poëzie vooral op muzikaal niveau functioneert. Veel nadruk op klank en ritme in de performance van dergelijke poëzie is niet voor alle leerkrachten even vanzelfsprekend. Dit zou wellicht op te lossen zijn door leerkrachten instructie te geven over de aanbieding van dit soort poëzie.

Voorkeuren of houdingen van leerkrachten speelden ook een expliciete rol bij 'Als ik nou een hondje mag’ (Lieshout, 2009): een gedicht waarin een kind met veel overdrijving

\footnotetext{
181 Wilmink gebruikt plaatsnamen als rijmwoorden ("Smeer nog maar een boterham,/ Amsterdam, Rotterdam,/ Boterhammen lust ik graag,/ Rotterdam, Den Haag."), maar verschillende leerkrachten vonden het vers door die woorden inhoudelijk te moeilijk. Een leerkracht schreef in het logboek: "Versje was te moeilijk voor de kinderen. Steden als Amsterdam, Rotterdam en Den Haag zijn bij hen niet bekend." (2023, logboek week 7) En een andere leerkracht schrijft: "Kinderen begrepen de steden niet in deze context." (2322, logboek week 7) Dit had overigens niet alleen met de voordracht te maken; ook met de tekst en verwerkingsvorm zelf (zie bespreking 'Muzikaal taalspel' hieronder).
} 
en dreigementen 'zeurt' om een huisdier. De inhoud weerhield een aantal kleuterleerkrachten ervan om dit gedicht van Ted van Lieshout voor te lezen. "Ik vind de keuze van dit gedicht niet passen bij de doelgroep," schrijft een leerkracht (1321, logboek week 9). Een leerkracht die het wel voorlas, schreef: "De lln vonden het gedicht grappig. Zelf vond ik echter de strofe over het roken, de kinderlokker en het café niet gepast." (2321, logboek week 9)
Als ik nou een poesje mag, dan zal ik nooit meer zeuren.
Dan jok ik niet en loop niet weg en blijf uit het café.
Maar als ik nou géén poesje krijg, dan zal d'r wat gebeuren!
Dan spuug ik in de yoghurt en dan hoest ik in de thee.
Dan kom ik alle trappen afgegleden met een slee.
Dan ga ' $\mathrm{k}$ de muur besmeuren
En het behang inkleuren;
Dan neem ik snoepjes aan en ga met kinderlokkers mee!

Een poesje met een lieve snuit?

Je krijgt geen poes en daarmee wit!

Een andere leerkracht schrijft: "De kinderen vonden het een heel leuk gedicht!! Vooral door de intonatie ging het verhaal leven." (2322, logboek week 9) En ook op een derde school werd het voorgelezen en door de kinderen zeer gewaardeerd: "Ze genieten van alles wat niet mag! Stout versje zeggen ze. Deze zinnen moet ik nogmaals herhalen. Veel plezier!" (2222, logboek week 9) Leerkrachten dragen verantwoordelijkheid voor wat er in de klas gebeurt en het is volkomen rechtmatig dat ze bepaalde inhoud ongeschikt vinden. Dit gedicht is op drie scholen (vijf groepen) niet aan bod gekomen, vanwege de inhoud en/of omdat het niet expliciet aansloot op het Sinterklaasthema dat in die periode centraal stond in de kleutergroepen. Zo vormen niet alleen voorleesvaardigheden of tekstbeleving, maar ook de houding ten aanzien van specifieke tekstinhouden van leerkrachten, als bemiddelaars tussen aanbod en doelgroep, factoren die in de praktijk van invloed zijn op hoe kinderen kennismaken met (in dit geval) poëzie en welke poëzie aan bod komt. Met name de poëzie waarin 'carnavaleske nonsensicaliteit' een centrale rol speelt, zal voor sommige leerkrachten niet altijd 'gedomesticeerd' genoeg zijn. Dit staat evenwel los van hoe de kinderen een dergelijk gedicht beleven en waarderen.

Tijdens de afsluitende gesprekken ging een van de leerkrachten ('juf Y') expliciet in op verschillen in leerkrachtafhankelijke voorkeuren en (gepercipieerde) vaardigheden als antwoord op de vraag welke factoren volgens haar het sterkst bijdragen aan de waardering die de kinderen hebben voor teksten:

"De waardering die kinderen voor teksten hebben, is volgens [juf $\mathrm{Y}$ ] heel sterk afhankelijk van het onderwerp van teksten, maar het is ook leerkrachtafhankelijk, voegt ze toe. Ze geeft het voorbeeld van het Chinese liedje ('Gong Xi Gong Xi'). Kort daarvoor was er een kind van Chinese afkomst nieuw in de klas gekomen. Toen [juf $\mathrm{X}$ ] het liedje voor de eerste keer met de kinderen deed, was het een enorm succes. Dat had [juf X] aan [juf 
$\mathrm{Y}$ ] laten weten, maar toen [juf Y] de dag erna de herhaling deed, reageerden de kinderen nauwelijks. [Juf X] was die dag wel op school, dus heeft [juf $\mathrm{Y}$ ] haar erbij gevraagd, want 'blijkbaar deed ik toch iets verkeerd...'. [Juf X] nam het over en meteen deden de kinderen weer vol enthousiasme mee. 'Ik ben niet zo'n taalliefhebber,' zegt [juf Y], 'dat geef ik eerlijk toe. [Juf $\mathrm{X}$ ] deed het liedje met een heel ander ritme, bewegingen en uitspraak dan ik en dat vonden de kinderen heel leuk, maar toen ik het deed, gebeurde er niets, alsof ze het niet herkenden'." (evaluatie 2, S13, 23-6-14)

Zeker bij poëzie waarin muzikaal taalspel een primair tekstkenmerk is en 'onderwerp' of 'inhoud' dus niet of nauwelijks bijdraagt aan de werking of betekenis van het specifieke 'taalspel poëzie' dat er gespeeld wordt, speelt de performance van de leerkracht een bepalende rol in hoe het taalspel vorm krijgt in de klas. Op een andere school vertelt een leerkracht dat ze een stagiaire had die ook een keer een gedicht heeft gedaan, maar er niet in slaagde het ritme te pakken te krijgen: 'Dan is het hele gedicht weg en ook de aandacht verdwijnt.' (evaluatie 2, S23, 25-06-2014) In het hierboven weergegeven fragment komt ook een gerelateerde factor aan bod die op verschillende scholen ten minste op de beleving van de leerkrachten van invloed was: de 'deeltijdfactor'. Op de meeste scholen wordt, zeker in de onderbouw, veel met duo-partners gewerkt die elk een deel van de week voor de groep staan. In de hierboven beschreven situatie kwam het zo uit dat de ene leerkracht de eerste aanbieding van poëzie op de woensdagen deed en een andere leerkracht de herhaling ervan op de donderdagen. Bij het genoemde Chinese Nieuwjaars-liedje was het verschil in voordrachtstijl van de twee leerkrachten duidelijk van invloed op de herkenning en beleving van de tekst bij de kinderen. Ongeacht of de ene leerkracht het beter deed dan de andere, deden ze het zo verschillend dat er geen herkenning was bij de herhaling: de performance van de leerkracht geeft gestalte aan 'het taalspel poëzie', i.e. iedere leerkracht maakt een eigen versie het gedicht, lied of rijm. Ook verschillen in voorkeuren spelen daarin mee. Op deze school gaven de leerkrachten van de andere kleutergroep al bij de tussentijdse evaluatie in december 2013 aan dat ze wel eens zouden willen ruilen omdat degene die de verhalen deed meer met gedichten/liedjes had en andersom (evaluatie 1, S13, 16-12-2013).

Leerkrachten bemiddelen het proces van literaire communicatie tussen teksten en jonge 'lezers' (kinderen) en spelen daarmee een sleutelrol in de overdracht van het aanbod. Die sleutelrol omvat allereerst wat er wel en wat er niet wordt aangeboden aan de kinderen, ofwel vanuit schoolbeleid, ofwel vanuit de individuele overtuiging van de leerkracht die verantwoordelijkheid draagt voor waar de kinderen in de klas mee in aanraking komen. Daarnaast omvat die sleutelrol ook voorkeuren en vaardigheden van individuele leerkrachten met betrekking tot specifieke tekstsoorten en -inhouden. De leerkracht belichaamt daarmee een hele set aan factoren die in de realiteit van de schoolklas van invloed zijn op of en hoe het 'taalspel poëzie' gestalte krijgt.

\section{Inpassing in het programma: taal en thema in het kleuteronderwijs}

Hoewel de Leeskalender ontwikkeld is om de ontluikende culturele geletterdheid van de kinderen te stimuleren, zijn de leerkrachten in de kleutergroepen sterk gericht op de bijdrage van het aanbod aan de taalontwikkeling van de kleuters. "In de kleutergroepen draait 
bijna alles om taal," concludeert een van de leerkrachten tijdens het afsluitende gesprek (evaluatie 2, S13, 23-6-14). Er wordt op het gebied van taal vooral veel aandacht besteed aan de ontwikkeling van woordenschat en fonologisch bewustzijn. Het was regelmatig merkbaar dat de Leeskalenderactiviteiten werden aangegrepen als extra mogelijkheid om expliciet aandacht te besteden aan de taalontwikkeling van de kinderen. Moeilijke of nieuwe woorden die in een verhaal of gedicht aan bod kwamen, werden uitgelicht en met de kinderen geoefend. Daarbij kon de nadruk op betekenis worden gelegd, maar ook op structuur. Zo heb ik in de loop van de observaties kleuters zien 'woordhakken' met 'bo-ter-hammen', 'ka-len-der', 'bog-ge-mog' (van 'Juffrouw Boggemog'), 'po-lo-nai-se', enzovoort; ze hebben het woord 'P-AA-S-BR-OO-D' geleerd, ze hebben de vormen (rond en cirkel, vierkant, driehoek, rechthoek) besproken, de dagen van de week, de maanden van het jaar, en ga zo maar door. Het was in ieder geval opvallend dat in de kleutergroepen mogelijkheden die het Leeskalenderaanbod bood om expliciete aandacht te besteden aan vooral taal, maar ook rekenen (tellen), met beide handen werden aangegrepen. In het afsluitende gesprek vroegen we leerkrachten of ze het werken met de Leeskalender als zinvol hadden ervaren en, zo ja, op welk gebied. Een van de kleuterleerkrachten noemt de bijdrage die de Leeskalender als geheel en de versjes in het bijzonder hebben geleverd aan het klank/rijmbewustzijn van de kinderen. Ze vertelt dat dit jaar voor het eerst geen enkel kind uit haar klas is 'uitgevallen' op het onderdeel klank/rijm in de Cito-toets Taal voor Kleuters: andere jaren was dat wel anders. Ze koppelt dit resultaat rechtstreeks aan de Leeskalender (evaluatie 2, S24, 18-06-2014) ${ }^{182}$. Het is moeilijk te zeggen of de expliciete toevoeging van taal- en teloefeningen in het kader van de Leeskalender van invloed was op hoe kinderen teksten ervoeren en waardeerden; het is in ieder geval een factor die in kleutergroepen meespeelt in hoe leerkrachten teksten (deels) bekijken en/of behandelen.

Op een school waar al met een (voor)leesprogramma werd gewerkt waarin aandacht voor woordenschat een zeer expliciet onderdeel is, waardeerden de kleuterleerkrachten de Leeskalender juist om andere redenen. De ene kleuterleerkracht heeft het idee dat de kinderen, in vergelijking met de andere methode, bij de Leeskalender meer echt van de teksten konden genieten. 'Het lekkere lezen', noemt ze de manier van tekstaanbieding in de Leeskalender. De andere leerkracht beaamt dat: de beleving van de kinderen staat voorop bij de Leeskalender (evaluatie 2, S26, 10-06-2014). Ondanks dat 'lekkere lezen' vonden de leerkrachten het wel jammer dat het aanbod niet op thema is samengesteld waardoor het niet altijd goed aansluit op waar ze in de klas mee bezig zijn. Wat het voor de leerkrachten in de kleutergroepen een nog aantrekkelijker methode zou maken, stellen deze leerkrachten voor, is een thematische insteek. Bijvoorbeeld meerdere themakalenders steeds voor de duur van drie of vier weken, dan kan elke school zelf de thema's pakken die op een bepaald moment aansluiten op waar ze mee bezig zijn. Een van beide leerkrachten denkt dat je dan nog meer aan de Leeskalender hebt, buiten dat het gewoon heel leuk is. Ze noemt de seizoenen als een overkoepelend thema dat in elk geval op alle scholen terugkomt. Als er vier 'seizoenskalenders' zouden zijn, of iets in die geest (andere themakalenders), dan zou het materiaal beter aansluiten op wat er in de klas wordt gedaan (evaluatie 2, S26, 10-06-2014). Ook op

$182 \mathrm{Op}$ basis van de door ons verzamelde CITO-vaardigheidsscores hebben we eventuele effecten van het Leeskalenderaanbod op de taaltoets voor kleuters niet kunnen vaststellen (zie Hoofdstuk 8), maar die gegevens zijn niet gespecificeerd naar deelgebieden binnen de taaltoets. 
andere scholen kwam aansluiting op het thematisch werken naar voren als iets dat de leerkrachten in de kleutergroepen hadden gemist. Zouden de leerkrachten met de Leeskalender als methode willen werken? "Ja," zegt een leerkracht volmondig. Wat haar betreft zou ze het ook weer dagelijks willen, alleen zouden de teksten wat meer moeten aansluiten op de thema's waarmee ze op school werken. We zouden eigenlijk op scholen moeten inventariseren met welke thema's er wordt gewerkt en daar dan de meest voorkomende uit moeten halen voor de Leeskalender, stelt ze voor (evaluatie 2, S24, 18-06-2014). Op een volgende school hetzelfde verhaal: "... het tekstaanbod sloot thematisch niet altijd zo goed aan op waar ze dan in de klas mee bezig waren, daardoor stond het een beetje los van de rest." (evaluatie 2, S11, 24-06-2014) In de logboeken komt dit aspect niet vaak expliciet naar voren. Als het gebrek aan aansluiting op het thema te storend was, zoals in de periode rond Sinterklaas, dan werden Leeskalenderactiviteiten overgeslagen. En bij de aanbieding van 'Een meestampertje' in de laatste Leeskalenderweek schrijft een leerkracht: "We zijn bezig met het thema groente en fruit. Dit gedicht gaat dan over iets heel anders." (1322, logboek week 30) Dit belang van aansluiting op het thematisch werken in de kleutergroepen was ons al tijdens de eerste expertraadpleging verteld, maar vanuit onderzoeksperspectief hadden we daar in het interventiemateriaal nog geen rekening mee gehouden (zie Hoofdstuk 6). Voor doorontwikkeling van de interventiematerialen naar een bruikbaar product voor de onderwijspraktijk is dit echter een belangrijk punt voor aanpassing.

\subsection{Poëzieverwerving in de kleuterklas}

In de tweede fase heb ik mijn observaties toegespitst op een groep 2 op een basisschool in Maastricht (zie Hoofdstuk 7). Op woensdagen was ik tussen 12.00 uur en 12.30 uur in de klas aanwezig bij de aanbieding van poëzie in het kader van de Leeskalender. Vanaf de tweede keer dat ik in de klas kom, word ik standaard begroet met een uitbundig 'Goeiemorgen/-middag, juf Annet!' Vooral de jongen naast wie ik in de kring zit, is bijzonder in me geïnteresseerd: "Zoals de vorige keren ook het geval was, word ik weer enthousiast ontvangen in de klas. De kinderen groeten mij en ik groet de kinderen. Ik neem weer plaats op de stoel in de kring, naast mijn grote vriend D die al meerdere keren opmerkingen heeft gemaakt over mijn schoenen (als ik sneakers draag: 'Zijn dat Nikes?'; als ik mijn Dr. Martens draag: 'Zijn dat jouw schoenen?') en keer op keer verbijsterd is over hóe groot ik ben als ik opsta." (observatie 17, 22-1-14) Hoewel verschillende andere kinderen af en toe hun kans schoon zien om me iets te vertellen of te laten zien, zijn er in het begin van de observaties in deze groep vooral twee kinderen die heel expliciet op mijn aanwezigheid reageren. Naast D is er ook een meisje, A, dat als het maar even kan mijn aandacht vraagt, iets wil vertellen en behulpzaam wil zijn. Als ik een week later weer in de klas kom, is de leerkracht net even weg: “'Hallo juf Annet,' roepen verschillende kinderen. 'Kom maar binnen hoor, juf Annet,' voegt A toe. 'Juf T is even plassen, maar ze komt zo weer en dan gaan we Leeskalender doen!' Ik stap het lokaal binnen en D komt meteen naar me toe gerend en pakt mijn jas vast. 'Ik heb de stoel al neergezet,' zegt hij, terwijl hij naar me op kijkt." (observatie 19, 29-1-14) In de loop van de tweede fase van de observaties neemt de merkbare reactie van de kinderen op mijn aanwezigheid af. De leerkracht vertelt me dat ze drie 'pientere' 
kinderen in de groep heeft die ik er zelf al snel tussenuit kan pikken. Twee van de drie zijn daarbij ook zeer verbaal; de derde is wat stiller. Omdat de twee niet alleen 'pienter', maar ook verbaal sterk zijn, overheersen hun uitspraken in de aantekeningen die ik maak. Tegelijk besef ik me dat hun reacties, hoewel zeer interessant, niet representatief zijn voor de groep als geheel; de meeste kinderen zijn veel lichamelijker in hun reacties op de poëzie. Naast aandacht voor die lichamelijke reacties, heb ik ook hier de observatiematerialen aangevuld met logboekaantekeningen van en de gesprekken met leerkrachten van andere groepen 1-2.

\section{Het samenspel tussen tekst en pragmatische context: \\ De Leeskalender is in de war, het is geen Sinterklaastijd!'}

In de Leeskalender voor groep 2 was poëzie opgenomen in het kader van verschillende vieringen, te weten: Dierendag, Sinterklaas, Kerstmis, Nieuwjaar, Chinees Nieuwjaar, Carnaval, 1-april, Pasen, en de verjaardag. Er was daarnaast een 'misplaatst' feestrijm opgenomen waarmee het geritualiseerde zetten van de schoen, als Sinterklaasgebruik, in januari aan bod kwam. Ook waren verschillende teksten opgenomen die fysieke spelhandelingen opriepen, vooral stampen en klappen. Zo waren in totaal zeventien van de dertig poëzieteksten expliciet gekoppeld aan geritualiseerde handelingspatronen in de context van feesten en van het spel (zie Hoofdstuk 7). De deelvraag die ik op basis van deze teksten wil beantwoorden, is:

\section{KINDERPOËZIE: KWALITATIEVE DEELVRAAG 4a.}

Wat vertellen observaties, logboekaantekeningen en gesprekken met leerkrachten met betrekking tot de presentatie van het poëzie-aanbod in de klas, de reacties van de kinderen op deze teksten en hun waardering daarvan ons over de rol van 'de directe evocatie van poëtisch geritualiseerde handelingspatronen in de context van feesten en spel', onderverdeeld in

(i) fysieke handelingspatronen (zoals wiegen, dansen, klappen, et cetera), en

(ii) performatieve taalhandelingen (zoals wensen, aftellen, verwensen, verzoeken, et cetera) in processen van poëzieverwerving bij kinderen in groep 2 ?

Mijn verwachting is dat voor kinderen in groep 2 de evocatie van geritualiseerde fysieke handelingspatronen het sterkst bijdraagt aan poëzieverwerving, anders dan in groep 4 waar de evocatie van geritualiseerde taahandelingen naar verwachting beter aansluit op de culturele competentie en voorkeuren van de kinderen. In hoeverre wordt deze verwachting voor groep 2 door de verkregen kwalitatieve data ondersteund? Hoe werkt het samenspel tussen tekst en pragmatische context in de praktijk van de kleuterklas? En zijn er in de verwerving van poëzie bij kleuters verschillen waar te nemen in de werking van handelingspatronen in de context van vieringen enerzijds en spel anderzijds? 


\section{De vieringen door het jaar heen als pragmatische contexten van tekstgebruik}

De eerste viering uit de jaarkalender die bij groep 2 op het Leeskalender-poëzieprogramma stond, was Dierendag. Hoewel 4 oktober 2013 op vrijdag viel, hadden we besloten de hele Leeskalenderweek in het thema van dieren/Dierendag te stellen. Vanuit het deelproject Kinderpoëzie had ik het feestelijke 'Alle hokken mogen open' van Marianne Busser en Ron Schröder gekozen als vers waarin rechtstreeks tot (symbolisch) handelen wordt opgeroepen. Een fragment:

\section{Geef de olifant een slinger geef de krokodil een vlag geef de tijger wat ballonnen, want het is nu dierendag.}

Het vers werd, afhankelijk van de versie van de Leeskalender, op dinsdag of op woensdag aangeboden. Uit de logboeken blijkt dat de discrepantie tussen de dag van aanbieding en de dag waarop het daadwerkelijk Dierendag was in verschillende kleutergroepen voor verwarring zorgde. Een leerkracht schrijft: "De kinderen vonden het raar dat het gedicht over dierendag ging. Dierendag is immers pas vrijdag." (2322, logboek week 3) In twee andere groepen werd iets soortgelijks genoteerd door de leerkracht. Op een school waar vrijdag 'Keuzedag' was, werd het vers in beide kleutergroepen door de kinderen gekozen. Een van de leerkrachten schrijft in het logboek dat ze het kozen omdat "het vandaag dierendag was. Ze wisten dat het in het versje voorkwam." (2621, logboek week 3) De kinderen kozen het vers dus omdat het op Dierendag past/hoort. In de andere kleutergroep op dezelfde school viel het vers op Dierendag zelf ook zeer in de smaak: "Vonden het een leuk versje. Buiten op speelplaats werd het versje gezongen door een aantal kinderen." (2622, logboek week 3) Een vers waarin je wordt aangemoedigd dieren allerlei feestartikelen te geven omdat het $n u$ Dierendag is terwijl het geen Dierendag is, komt op de kleuters als vreemd en misplaatst over. Dit laat zien dat de totstandkoming van 'betekenis' van poëzie die gebonden is aan een viering voor de kleuters heel sterk afhankelijk is van de concrete inbedding in de bijbehorende context van tekstgebruik.

Dat werd eveneens duidelijk bij de aanbieding van het verjaardagslied. Verschillende leerkrachten slaagden erin om het liedje 'Fijne verjaardag voor jou' te laten landen bij de kinderen, ook als er niemand jarig was, maar in die groepen werd vooral aandacht besteed aan het zingen in verschillende talen en werd de nadruk dus op 'muzikaal taalspel' gelegd ${ }^{183}$. Een van de leerkrachten schrijft echter: "Sloot niet echt aan omdat niemand jarig was." (2322, logboek week 20) Ook een andere leerkracht rapporteert dit, maar voegt toe: "Ze vonden het wel leuk om te dansen op de verjaardagsliedjes die op de cd staan." Bij de herhaling was dat effect van het muzikaal taalspel echter uitgewerkt en schrijft de leerkracht: "Het boeide niemand om nog eens verjaardagsliedjes te zingen terwijl er niemand jarig was! (sorry)." (1622, logboek week 20) Het zingen van verjaardagsliedjes is een sterk contextgebonden geritualiseerd gebruik; komt dit gebruik los van de pragmatische context te staan,

${ }^{183}$ Hier kom ik in de alinea over culturele pluriformiteit in het aanbod nog op terug. 
dan verliest het verjaardagslied haar functie en dus haar 'betekenis' voor de kleuters, zoals dat ook met het Dierendagvers gebeurde. Bovenstaande reacties wijzen erop dat het ontbreken van de concrete pragmatische context die dergelijke poëzie functie en betekenis geeft een negatief effect heeft op de waardering van de kleuters voor (het gebruik van) de tekst. Tot zover laten deze inzichten zien dat kleuters concreet pragmatisch redeneren: waarom zou je ook een verjaardagslied zingen als er niemand jarig is? Echter, de relatie tussen feestlied of -rijm en de bijbehorende rituele gebruikscontext is genuanceerder. De nuancering van die specifieke relatie komt voort uit de rol die geritualiseerde fysieke handelingspatronen spelen in het samenspel tussen tekst en context dat vorm geeft aan de beleving van 'het taalspel poëzie' bij de kleuters. Kijken we naar het 'misplaatste' feestgedicht ' 12 januari' van Hans en Monique Hagen (1988), dan wordt zichtbaar dat het samenspel tussen tekst en rituele context voor de kleuters heel sterk wordt bemiddeld door de uitvoering van geritualiseerde fysieke handelingspatronen die de rituele context evoceren. Het vers gaat als volgt:

\author{
sinterklaas \\ is nu in Spanje \\ ik probeer het toch een keer \\ vanavond \\ zet ik zachtjes \\ mijn nieuwe schoenen neer
}

Als verwerkingsactiviteit werd eerst met de kinderen besproken wat hun verwachting is: zou er iets in de schoen komen als ze hem nu, in januari, zetten? Vervolgens mochten ze het uitproberen door hun schoen te zetten, te doen alsof ze er stro, een tekening/verlanglijstje, en een wortel in deden, en een Sinterklaasliedje te zingen. Een leerkracht schrijft: "Spannend vonden ze het toen we sinterklaasliedjes zongen en 't schoentje gingen zetten. We hebben 't schoentje met wortel, verlanglijstje, water laten staan, schoentje gezet bij verwarming. Morgenvroeg benieuwd of er iets in zit. We krijgen er niets in dat geloofden de meeste kinderen. Een paar zeiden van wel. Benieuwd ben ik zelf naar hun reacties. Reactie 'Zie je nou wel, niks erin'." (2421, logboek week 15) Een andere leerkracht rapporteert over de verwachtingen van de kinderen: "Waren niet geheel overtuigd dat er niks in de schoen zou komen. Sommige kinderen dachten van wel. ... Een van de kinderen kon wel al goed benoemen dat hij volgend jaar pas weer komt. Ook maakte een kind een opsomming: Sinterklaas, kerst, oud en nieuw, carnaval." (2321, logboek week 15) De volgende leerkracht schrijft: "Over Sinterklaas hebben ze allemaal een mening. De meesten denken dat er niets in komt. Enkelen denken van wel. F zei: luisterpieten zijn wel soms in Nederland, maar die brengen geen cadeautjes." (2323, logboek week 15)

Veel kleuters balanceren op het randje tussen geloof in de werking van de rituele handelingen (schoen zetten, liedje zingen) en hun ontluikende kennis over de tijdgebondenheid van Sinterklaas. Dit verschil komt mogelijk overeen met de al eerder genoemde verschillen tussen jongste en oudste kleuters. Het uitvoeren van de rituele handelingen draagt voor de kleuters echter sterk bij aan de beleving in het moment, waardoor hun kennis op metaniveau (kennis over wanneer Sinterklaas wordt gevierd) bij sommigen naar de achtergrond ver- 
dwijnt. Voor een aantal leerkrachten was dit reden om de handelingen -schoen zetten, liedje zingen - over te slaan en het gedicht alleen te bespreken. In een van die groepen waren de kleuters heel stellig: "De kinderen vonden het heel raar dat het over Sinterklaas ging. Reactie: 'Schoen zetten kan nu echt niet, Sinterklaas is allang naar Spanje'. 'De Leeskalender is in de war, het is geen Sinterklaastijd!"' (1622, logboek week 15) Dit biedt een aanvullend inzicht in de effecten die het Dierendagvers en het verjaardagslied teweeg brachten. Een viering is altijd afgebakend in tijd en ruimte: "het vindt op een welomschreven plaats en een bepaald moment in de kalender of levensloop plaats." (Rooijakkers, 2000b, p. 191) Buiten dat vastomlijnde kader hebben de rituele handelingen die horen bij de specifieke viering geen betekenis. De reacties van de kleuters op het Dierendagvers en het verjaardagslied bevestigen dit: wanneer een feestlied of -rijm buiten de tijd- en plaatsgebonden rituele gebruikscontext wordt gebruikt dan wijzen de kleuters de tekst op functioneel betekenisniveau af. Een verjaardagslied is zinloos/betekenisloos als er niemand jarig is, al kan het best 'gewoon' een leuk lied zijn om te zingen of op te dansen. De tekst heeft buiten de rituele context geen rituele functie of betekenis. Echter, de uitvoering van geritualiseerde fysieke handelingspatronen lijkt voor de meeste kleuters het rituele kader -in elk geval de rituele ruimte - als het ware op te roepen en sommigen van hen ten minste aan het twijfelen te brengen over het belang van de afbakening in de tijd. De rituele handelingen lijken het hier-en-nu te 'sacraliseren', hoewel dit op gespannen voet staat met de ontluikende kennis van de gebruikelijke plaats van de viering in de jaarkalender. Kleuters die in dat tijdbesef al wat zekerder zijn, accepteren deze verstoring van 'de orde der dingen' in de tijd niet en activeren hun kennis van de jaarkalender om hun houding kracht bij te zetten: "Sinterklaas, kerst, oud en nieuw, carnaval." (2321, logboek week 15) In alle gevallen is evenwel duidelijk dat de pragmatische context die de gebruikspoëzie van functie en betekenis voorziet in de beleving van kleuters een concrete externe context is. Die externe context kan in de beleving van de kleuters worden opgeroepen door fysiek ritueel handelen, maar niet door enkel talig ritueel handelen.

Dat laatste wordt bevestigd door de logboekaantekeningen bij de herhalingsactiviteit van '12 januari'. Bij de herhaling werden geritualiseerde handelingen genoemd die refereren aan andere vieringen (eieren zoeken, kerstboom versieren, etc.) en werd de kinderen steeds gevraagd of die gebruiken bij vandaag pasten. Vervolgens werd gevraagd wat ze wel bij vandaag vinden passen. Een leerkracht noteerde verschillende reacties van de kinderen in het logboek: “Gekleurde eieren: 'Dat is toch voor Pasen.' Kerstboom: Alle kinderen schreeuwen: 'Neeeee', de heks ${ }^{184}$ is gek geworden, door de bliksem. Het is toch niet kerstmis.' Vandaag kunnen we wel buiten spelen, beetje warm." (2421, logboek week 15) In een andere groep noemden de kinderen nog meer voorbeelden van activiteiten die volgens hen wel op 12 januari passen: "Wat wel kan op 12 januari: je kamer opruimen (alles netjes maken), als het lekker weer is buiten spelen, lekker gaan koken en koekjes bakken, als het gaat sneeuwen kunnen we een sneeuwpop maken van onszelf, sneeuwballen maken en gooien, een kasteel in de sneeuw maken, televisie kijken: Telekids en tekenfilms." (1622, logboek week 15) Op dit rationele niveau, zonder de directe beleving bemiddeld door geritualiseerde fysieke handelingen, weten de kleuters heel goed dat 12 januari niet de juiste tijd is voor

${ }^{184} \mathrm{Op}$ de afbeelding op de kalender was een meisje verkleed als heks te zien met een pompoen, als verwijzing naar Halloween. 
schoen zetten, paaseieren zoeken, of een kerstboom optuigen. Ze laten ook zien dat ze, bewust of onbewust, begrijpen dat er verschil bestaat tussen kalendergebonden rituele gebruiken en andere soorten handelingen. Routines en spel behoren tot de handelingsrepertoires die volgens de kinderen wel op deze willekeurige datum passen; rituele handelingen zijn veel sterker gebonden aan een specifieke plaats en tijd, dus wie op 12 januari een kerstboom wil optuigen, is gek geworden 'door de bliksem'. Wanneer een rituele context enkel op tekstueel niveau wordt geëvoceerd buiten de betreffende rituele context, dan komt er geen beleving en daarmee geen betekenis tot stand bij de kleuters.

\section{Talig versus fysiek poëtisch handelen in de context van de feesten van het jaar}

Om het samenspel tussen poëtische teksten en rituele gebruikscontexten als dimensie in het proces van poëzieverwerking en -verwerving bij kleuters verder te nuanceren, kunnen we nog nauwkeuriger kijken naar de werking van talig versus fysiek handelen in rituele contexten. Vele van de liedjes en -rijmen die van oudsher aan de feesten van het jaar verbonden zijn, zoals verjaardagsliedjes en Sinterklaasliedjes, zijn vormen van geritualiseerde performatieve taahandelingen die concrete pragmatische functies vervullen in de gegeven context: er wordt iets gevraagd en/of toegewenst. Draagt deze tekstuele pragmatiek voor kleuters bij aan hun poëziebegrip, -beleving en plezier? Marie van Dijk schreef over Sint-Maartenzingen: "Het zingen is het onvoorwaardelijke middel om het beoogde doel te bereiken (...). Voor het overige lijkt het niets uit te maken wat of hoe er wordt gezongen." (2000, p. 1) Hoe verhouden het fysieke handelingsniveau -het doen van een lied of rijm op zichzelf - en het talige handelingsniveau -wat er met dat lied of rijm gedaan wordt in relatie tot de pragmatische context - zich voor kleuters tot elkaar in de context van vieringen? Het feit dat kleuters het zingen van een verjaardagslied als er niemand jarig is, of het zeggen van een Dierendagvers als het geen Dierendag is, afwijzen, kan een indicatie zijn dat deze jonge kinderen zich bewust zijn van de performatieve functie van dergelijke poëzie. Het kan echter ook betekenen dat ze het thematisch niet vinden passen om een verjaardagslied of Dierendagvers te doen buiten de context.

Op de eerste poëzie-dag na het begin van het nieuwe jaar werd in de kleuterklas het vers 'Ik wens je al wat wenselijk is' behandeld. Voor het lezen werd besproken of en hoe kinderen Oud en Nieuw hadden gevierd en werd specifieke aandacht besteed aan het elkaar 'gelukkig Nieuwjaar' wensen. De leerkracht in mijn observatiegroep legt aan de kinderen uit:

We wensen elkaar goede dingen, zoals geluk en gezondheid. Hoe doen we dat? Ze vraagt een jongetje naar voren te komen. 'Zo doen we dat,' zegt de leerkracht terwijl ze haar hand uitsteekt naar R. 'Zalig nieuw jaar,' zegt de leerkracht. 'Zalig nieuw jaar,' zegt R terwijl hij haar de hand schudt. De leerkracht spoort nu de andere kinderen ook aan om hetzelfde te doen met hun maatje. De kinderen wensen elkaar in tweetallen een zalig nieuw jaar terwijl ze elkaar de hand schudden. (observatie 14, 8-1-14)

Vervolgens brengt de leerkracht het vers ten gehore: 'Ik wens je al wat wenselijk is,/ een bochel die ordentelijk is, / twee benen als een ooievaar,/ dat wens ik je voor het nieuwe jaar,/ een kop met rooie luizen,/ dan heb je wat te pluizen.' De rituele (performatieve) 
taalhandeling van de Nieuwjaarswens (het een ander iets toewensen) krijgt in dit vers een carnavaleske draai op functioneel niveau van wens naar verwensing. In de verwerking wordt eerst aandacht besteed aan tekstbegrip: de moeilijke woorden hadden wat uitleg nodig en werden door uitbeelding duidelijk. Vervolgens vroeg de leerkracht of de kinderen nog meer van dit soort nieuwjaarswensen voor elkaar konden verzinnen. In mijn observatiegroep werden de volgende wensen bedacht:

Kind (m): Ik zou wensen dat ik een paard kreeg.

Kind (j): Een lange neus van een olifant.

Kind (j): Ik vind het leuk om een tijger in mijn bed te wensen.

Kind (m): Een konijn.

Kind (m): Ik weet niks.

Kind (j): Of een kop van een konijn!

Kind (j): Lange schoenen.

Kind $(\mathrm{m})$ : Ik wil een lange giraf in mijn bed.

Kind (m): Een grote bril.

Kind (j): Een mega-super-bril. (observatie 14, 8-1-14)

In de antwoorden van de kinderen in deze groep 2 is te zien dat er geen onderscheid wordt gemaakt tussen 'iets voor jezelf wensen' en 'een ander iets toewensen'. Sommige kinderen wensten expliciet iets voor zichzelf ('Ik vind het leuk om een tijger in mijn bed te wensen'; 'Ik wil een lange giraf in mijn bed'); andere kinderen noemen iets dat ze grappig vinden, maar formuleren dit niet als wens. De leerkracht 'vertaalde' de wensen steeds in een volzin ('Ik wens je een lange neus van een olifant'; 'Ik wens je een tijger in je bed'). De kinderen namen dit echter niet over. Het is dus opvallend dat formuleringen als 'ik wens' of 'ik wil' alleen expliciet opduiken in de op zichzelf gerichte uitspraken van de kinderen. Naast het feit dat kinderen bij dit puur talige handelen voor tekstbegrip en -beleving sterk afhankelijk zijn van hun taalontwikkeling, is ook zichtbaar dat het principe van de specifieke taalhandeling van het toewensen nog niet door alle kleuters duidelijk wordt onderscheiden van het doen van een wens voor zichzelf. In het volgende hoofdstuk wordt duidelijk dat dit bij kinderen in groep 4 heel anders is. Dit verschil kan samenhangen met het idee dat kinderen in de kleuterleeftijd zich nog in de egocentrische fase van hun ontwikkeling bevinden waarin de ontdekking van het eigen 'ik' maakt dat ze sterk vanuit hun eigen positie en behoeften denken en handelen. De receptie van 'Ik wens je al wat wenselijk is' liep in de kleutergroepen sterk uiteen: van groepen waarin het helemaal geen reacties opriep ("Er werd totaal niet op het versje gereageerd. De humor herkenden ze niet. De woorden begrepen ze niet. Het sloeg niet aan." 2323, logboek week 14) tot groepen waarin het vers blijkbaar wel landde ("Super enthousiast." 2622, logboek week 14) en daartussenin heel veel groepen waar de leerkrachten veel ondersteuning moesten bieden om de kinderen op gang te laten komen. Het talig handelen in de vorm van 'Ik wens je ...' kwam in geen van de groepen zonder hulp tot stand: de kinderen konden wel grappige dingen verzinnen en de leerkracht verwerkte ze in de vorm van het vers. Het niveau van het type taalhandeling lijkt voor de kleuters dus geen rol te spelen in hun beleving en begrip van poëzie gekoppeld aan vieringen. 
De beleving was veel sterker bij de liedjes bij Kerstmis ('Boom versieren') en Pasen ('Gekleurde stippen op een ei'). Dit waren in de meerderheid van de groepen grote successen waarbij zingen/opzeggen en fysieke - 'doen-alsof' of concrete - handelingspatronen (boom versieren, eieren kleuren) nauw op elkaar, op de directe pragmatische context (de vieringen) en op de belevingswereld en ervaring van de kinderen aansloten. Opvallend was het carnavalsliedje dat zich ergens tussen 'sloeg-niet-aan' en 'doorslaand-succes' bevond. In mijn observatiegroep waren ze al weken bezig met de voorbereidingen van Carnaval toen ik kwam observeren op de dag dat het carnavalsliedje aan bod kwam. Bij de voorbespreking van het carnavalsliedje vertellen de kinderen honderduit over wat ze zoal doen met Carnaval: optocht, verkleden, confetti gooien, feesten met confetti en een pak aan, schminken, muziek maken, dansen, polonaise maken. De leerkracht geeft aan dat ze een liedje over Carnaval gaan doen. Eerst leest ze de tekst een keer voor zonder muziek en controleert of de kinderen de moeilijke woorden (zoals 'kiel') kennen:

Vervolgens speelt ze het liedje af [alleen instrumentaal] en zingt de tekst zelf mee: de kinderen luisteren, maar reageren nauwelijks. De leerkracht doet dit nog een keer en makkt bewegingen bij de tekst. Weer komt er weinig reactie van de kinderen.

Kind (j): Juffrouw, zouden we zo nog het Chinese liedje kunnen doen?

[ $D$ begint 'Gong xi gong xi' al fonetisch te zingen]

Leerkracht: Nee, jong. Nu zijn we met dit liedje bezig.

De leerkracht speelt en zingt het liedje nog een keer en stimuleert de kinderen om mee te doen. Kinderen doen vooral de bewegingen na; sommigen lijken een beetje verveeld. Dan doet de leerkracht het nog een keer en laat de kinderen bij het refrein gaan staan en meedansen. Meezingen blijft wat voorzichtig en mat. Dansen vinden ze erg leuk! (observatie 25, 26-2-14)

De kinderen zijn het erover eens dat carnavalsliedjes vrolijk moeten zijn, maar dit liedje maakt weinig vrolijkheid los. De leerkracht legt uit: “ons carnavalsliedje 'Gekleurd op stap' (van Roger Villevoye) dat is in het Maastrichts, in Maastrichts dialect. Dat zijn we aan het oefenen, juf Annette, om polonaise op te lopen bij de optocht." Ze zoekt dit lied op Youtube op en terwijl het klinkt, mogen de kinderen laten zien hoe goed ze het al kennen én hoe goed ze al polonaise kunnen lopen:

De kinderen zingen -op de momenten dat ze niet aan het discussiëren zijn over de richting van de polonaise, de snelheid, wie er op wier tenen heeft getrapt en wie er te hard schreeuwt - mee met het carnavalsnummer dat via het digibord te zien en te horen is. Het is georganiseerde chaos, maar de kinderen hebben er grote lol in (behalve dan wanneer ze vinden dat een ander iets verkeerd doet). Uiteindelijk krijgt de leerkracht de hele klas in een lange rij en lukt het 'Keren!' en 'Hurken!' en 'Dansen!' heel aardig. (observatie $25,26-2-14$ ) 
Voor de kinderen is dit oefenen een leuke, maar tegelijk ook zeer serieuze aangelegenheid. Op het ene moment wordt er gelachen; op het volgende moment wordt er vurig bediscussieerd hoe het moet, wie het goed en wie het fout doen. Op basaal niveau is hierin al de dynamiek tussen spel en ritueel, tussen 'communitas'185 en structuur, waarneembaar die de gezamenlijke viering van feesten kenmerkt (Rooijakkers, 2000b, p. 190). Het is echter vooral die structuur waar de kleuters nog meesterschap over moeten verwerven voordat ze volledig kunnen opgaan in de beleving. Een 'vreemd' carnavalsliedje kan niet concurreren met het 'eigen' carnavalsnummer. De inbedding in de voorbereidingen van de carnavalsviering heeft dat eigen nummer een vaste plaats, functie en betekenis gegeven voor deze groep kinderen. In andere kleutergroepen werd het nieuwe carnavalsliedje wel door de kinderen gewaardeerd, waarschijnlijk omdat het direct werd gekoppeld aan de fysieke handelingspatronen binnen de context van carnaval. Een leerkracht schrijft: "polonaise gelopen. Kinderen vonden het hartstikke leuk! Waren heel enthousiast en hebben goed meegedaan!" (1321, logboek week 21) En ook in een andere groep was dit effect waarneembaar: "polonaise op het lied geoefend! De kinderen vonden het erg leuk. Het liedje sprak meteen aan en ze werden er vrolijk van." (2223, logboek week 21) Voorwaarde voor de beleving en waardering van het carnavalslied is dat het onderdeel wordt van de rituele structuur, gekoppeld aan geritualiseerde fysieke handelingspatronen (polonaise lopen) die voor de kleuters het rituele kader (Carnaval) creëren.

\section{Het taalspel poëzie gekoppeld aan fysieke spelvormen}

Dagelijkse routines en spel, zo hebben we al gezien bij de herhalingsopdracht van '12 januari' zijn voor de kleuters veel minder aan een specifieke tijd en plaats gebonden dan de vieringen van het jaar en de daarbij behorende rituele gebruiken. Kijken we nu naar de invloed van de koppeling tussen het 'taalspel poëzie' en spel op de poëziebeleving en waardering van de kleuters, dan is opnieuw zichtbaar dat de uitvoering van fysieke handelingen hierin een cruciale rol speelt. Verschillende gedichten in het Leeskalenderaanbod voor de kleuters waren heel expliciet gericht op de evocatie van fysieke spelhandelingen, waarbij de titels veelzeggend zijn: 'Lekker stampen met dit weer', 'Klap eens in je handen' en 'Een meestampertje'. Ook het klankliedje 'Epompee' werd gekoppeld aan fysiek spel in de vorm van een klapspel. Dit vers komt nog uitgebreid aan de orde in de paragraaf over 'muzikaal taalspel', maar het was als klapspel in ieder geval een groot succes en werd in die vorm door verschillende leerkrachten genoemd als een van de succesnummers uit de Leeskalender. Op een school vertellen de leerkrachten van beide kleutergroepen dat het klapspelletje ('Epompee') een tijd een rage is geweest (evaluatie 2, S16, 16-06-2014). De verschillende vormen van talig spel (rijmen, variëren, uitbreiden van een tekst) komen in de paragrafen over 'muzikaal taalspel' en '(carnavaleske) nonsensicaliteit aan bod; hier ligt de nadruk op de fysieke verwerkingsvormen.

De logboekaantekeningen bij 'Lekker stampen met dit weer' van Joke van Leeuwen maken direct duidelijk dat de uitvoering van fysieke spelhandelingen in combinatie met het

\footnotetext{
185 Victor Turner gebruikte het begrip ‘communitas' om “een onmiddellijke en totale momentane beleving van de groep als een homogene, niet-hiërarchische, ongestructureerde en vrije gemeenschap” (Rooijakkers, 2000b, p. 190) aan te duiden, zoals dat bij het gezamenlijk vieren van een feest als tijdelijke toestand kan worden bereikt.
} 
'taalspel poëzie' zonder twijfel een cruciale rol speelt in de waardering en verwerving van kinderpoëzie bij kleuters. Een leerkracht schrijft in het logboek waarom de kinderen op de keuzedag voor dit vers kozen: "Omdat ze lekker konden stampen. Ze konden me vertellen over welke dieren en personen het ging." (2621, logboek week 4) Een andere leerkracht schrijft bij de eerste aanbieding: "Vooral het stampen vonden ze leuk. Het was voor veel kinderen lastig om de 'sterkte van het stampen' te laten passen bij de dieren in het versje." (1622, logboek week 4) Bij de tweede aanbieding, waarin gevarieerd werd door weersomstandigheden toe te voegen die van invloed zouden zijn op het soort stampen, schrijft ze: "Ook vandaag: vooral bezig met stampen; het stukje over de sneeuw sprak niet echt aan. In deze tijd v/h jaar was 'stampen in de plas' beter geweest. Daar hadden ze het ook meteen over toen ze de afbeelding van het weer zagen.” (1622, logboek week 4) En bij de terugblikdag van die week schrijft de andere leerkracht van deze groep: "Het versje vonden ze superleuk (die indruk had ik niet -> verrassend!) Dat hebben we herhaald.” (1622, logboek week 4) De logboeken van alle kleutergroepen geven een vergelijkbaar beeld en over het geheel genomen was het vooral het stampen dat de kinderen aansprak: "De kinderen vonden het stampen heel leuk. Ook op je tenen lopen hard-zacht. Marcheren. Allemaal prachtig." (1322, logboek week 4) Een leerkracht rapporteert de volgende reactie van een kind uit de klas op de vraag waarom ze dit vers leuk vonden: "Omdat je dan moet stampen, en bij andere liedjes doen we dat niet, dat is saai." (2421, logboek week 4) Actief meedoen werd met groot enthousiasme ontvangen: "R. riep: 'Nu kunnen we allemaal meedoen!' Alle kinderen deden enthousiast mee." (1321, logboek week 4) In een andere groep schrijft de leerkracht over waarom de kinderen dit vers weer wilden doen: "Omdat ze dan mochten meedoen met de tekst." En aanmoediging hadden de kinderen bij deze verwerkingsvorm niet nodig: "De kinderen deden meteen de bewegingen mee, ik hoefde er niet eens om te vragen.” (2221, logboek week 4)

Klappen was de andere fysieke spelvorm die in de aanbieding van een aantal versjes een expliciete rol speelde, zoals in 'Klap eens in je handen' van Ivo de Wijs (in Smeekens, 2008). Anders dan het klapspel bij 'Epompee', waarbij doorlopend op het ritme werd meegeklapt in paren, is dit een 'cumulatief' klapspel waarbij het van belang was om op het juiste moment te klappen:

Klap eens in je handen

Vijf vette varkens zaten in een stal.

Jan, Piet, Wim, Kees en Parsifal.

Vier vette varkens zaten in een stal.

Jan, Piet, Wim (klap) en Parsifal.

Drie vette varkens zaten in een stal. Jan, Piet (klap) (klap) en Parsifal.

Twee vette varkens zaten in een stal. Jan (klap) (klap) (klap) en Parsifal. 
Eén vettig varken woonde in een stal. (klap) (klap) (klap) (klap) Parsifal.

De varkens werden aangewezen op de vingers en telkens als er weer een varken uit de stal verdween, werd de naam vervangen door een klap. In sommige groepen vonden de kleuters het nog lastig om het specifieke klapspel door te krijgen: "Kinderen vonden Parsifal een rare naam. Klappen was lastig (op de maat). Herhaalden wel vanzelf de namen van de dieren en konden benoemen bij welk dier we waren (hoeveel er over waren)." (2321, logboek week 17) In andere groepen ging het klappen wel goed: "Kinderen hadden snel in de gaten wanneer ze mochten klappen." (2322, logboek week 17) Een andere leerkracht schrijft: "Veel stralende gezichtjes bij het aanleren en inoefenen van 't versje. Was erg leuk!!" (1622, logboek week 17) Een volgende leerkracht rapporteert de herkenning van de vorm bij kinderen: "De leerlingen legden zelf al de link met het versje 'Naar bed, naar bed zei Duimelot'. Ze deden snel en uit zichzelf mee.” (2221, logboek week 17) En in sommige groepen hadden de leerkrachten zelf wat moeite om het vers onder de knie te krijgen: "Ik had zelf moeite om het versje goed te brengen. Ik maakte steeds fouten. Daardoor kwam het niet goed over." (2323, logboek week 17) In mijn observatiegroep 2 vond de leerkracht het ook wat lastig om het klapspel te doen zoals in de handleiding stond beschreven. Ze besloot daarom halverwege om niet de vingers, maar kinderen de varkens te laten 'zijn'. Vijf kinderen stonden op een rij, elk kreeg de naam van een van de varkens ('Parsifal' was reuzetrots op zijn bijzondere naam), en steeds als er een varken verdween, ging dat kind op de hurken zitten en klapte de rest van de groep. Na afloop van de verwerking vraagt de leerkracht of de kinderen het een leuk versje vonden om te doen: "Jaaaaa, vinden de kinderen. En wat vonden ze er dan leuk aan? 'Dat we moesten bukken!'” (observatie 19, 29-114)

Uit een analyse van de observaties, logboeknotities en gesprekken komt heel duidelijk naar voren dat verwerkingsvormen waarbij de kleuters fysiek mogen meedoen, met stampen, klappen of uitbeelden, hun beleving van en hun plezier in 'het taalspel poëzie' sterk intensiveren. Soms voegden leerkrachten de fysieke beweging zelf aan een verwerking toe om de beleving van de kinderen te versterken, zoals bij ' $\mathrm{k}$ Zag twee beren': "Dit in de gymzaal werd gedaan. Om te bewegen. Er was meer fantasie van de kinderen.” (1121, logboek week 6) Het mag duidelijk zijn dat kleuters poëzie niet waarderen als iets dat je dwingt "om stil te staan, om in je hoofd te kijken en van daaruit de wereld anders te zien," zoals de hedendaagse (jeugd)literaire kritiek dat doet (Van Coillie, 2014, p. 247; zie Hoofdstuk 2). Fysiek meedoen en nadoen dienen zich voor groep 2 aan als effectieve modellen voor de verwerving van poëzie waarbij de koppeling tussen vocale en niet-vocale handelingen voor de sterkste beleving van 'het taalspel poëzie' zorgt. Dat we hier (deels) te maken hebben met een leeftijdgebonden indicator van canoniciteit blijkt uit een vergelijking met groep 4, zoals beschreven in het volgende hoofdstuk, waar 'productieve receptie' door zelf op 'het taalspel poëzie' te variëren zich aandient als effectieve verwerkingsvorm. 


\section{Murikaal taalspel: 'Het rijmt, juf!'}

De tweede verwachte 'indicator van canoniciteit' in poëzie voor kinderen in groep 2 en groep 4 van het basisonderwijs is 'muzikaal taalspel'. Dit is een formulering die betrekking heeft op het type taalspel dat in, of met, rijmen, liedjes en gedichten gespeeld wordt: een poëtisch taalspel gespeeld met de prosodische, of materiële, aspecten van taal dat een fysieke ervaring van ritmische patronen in poëzie bewerkstelligt. Vanuit pragmatisch perspectief is er binnen de indicator 'muzikaal taalspel' onderscheid te maken tussen: (i) vormen van muzikaal taalspel ter ondersteuning van non-verbale handelingspatronen, en (ii) vormen van muzikaal taalspel als relatief autonoom spel. In de Leeskalender voor groep 2 waren beide vormen van muzikaal taalspel vertegenwoordigd, maar lag de nadruk op de koppeling tussen muzikaal taalspel en non-verbale handelingspatronen. Uit de paragraaf hiervoor blijkt al hoezeer de kleuters fysieke beweging waarderen, maar wat kunnen we zeggen over de rol die 'muzikaal taalspel' als tekstuele indicator van canoniciteit speelt in processen van poëzieverwerving bij kinderen in groep (1-)2? De deelvraag die ik wil beantwoorden, is:

KINDERPOËZIE: KWALITATIEVE DEELVRAAG 4b.

Wat vertellen observaties, logboekaantekeningen en gesprekken met leerkrachten met betrekking tot de presentatie van het poëzie-aanbod in de klas, de reacties van de kinderen op deze teksten en hun waardering daarvan ons over de rol van 'muzikaal taalspel', onderverdeeld in

(i) vormen van muzikaal taalspel ter ondersteuning van non-verbale handelingspatronen, en

(ii) vormen van muzikaal taalspel als relatief autonoom spel in processen van poëzieverwerving bij kinderen in groep 2?

Mijn verwachting is dat vormen van muzikaal taalspel ter ondersteuning van non-verbale handelingspatronen beter aansluiten op de culturele competentie en voorkeuren van kinderen in groep (1-)2, terwijl kinderen in groep 4 al beter uit de voeten kunnen met de meer autonome vormen van muzikaal taalspel. In hoeverre wordt deze verwachting voor groep (1-)2 door de verkregen kwalitatieve data ondersteund? Hoe werkt 'muzikaal taalspel' in de praktijk van de kleuterklas? In hoeverre en in welke vorm(en) draagt deze indicator bij aan het plezier dat kleuters aan poëzie beleven?

\section{Murikeaal taalspel en de ontdekeing van onverwachte patronen}

Het meest opvallende effect van 'muzikaal taalspel' op de verwerking en waardering van poëzie door kleuters is dat ze heel sterk reageren zodra ze een bepaalde toepassing van rijm herkennen. In de logboeken werd bij verschillende teksten door leerkrachten opgeschreven dat kinderen opmerkten dat de tekst rijmde. Zo werd 'Klisklaskloentje' in een groep op de keuzedag gekozen "omdat alles zo leuk rijmde" (2221, logboek week 5) en schrijft een leerkracht bij 'Prins Piramente' in het logboek: "Ze vonden het grappig. Op een gegeven moment werd geroepen: 'het rijmt, juf."' (2223, logboek week 8) En bij het klapspel 'Klap eens in je handen' schrijft een leerkracht: "Een kind riep 'Parsifal rijmt op stal!!” (1321, logboek week 17) Soortgelijke signalen van rijmherkenning rapporteerden leerkrachten ook 
bij 'Meester van Zoeten', 'Juffrouw Boggemog' en 'Ikkeltje, Tikkeltje, Spikkeltje Boem'. Tijdens mijn observatie van de aanbieding van dat laatste gedicht noteerde ik: "De leerkracht vertelt nu dat die mannetjes een naam hebben. Ze noemt de voornamen een voor een op: Ikkeltje, Tikkeltje en Spikkeltje. De kinderen moeten erg lachen om die grappige namen en J merkt op: 'Dat zijn rijmwoordjes!'” (observatie 33, 9-4-14) Zelfs bij 'Ik wens je al wat wenselijk is' - dat op het niveau van de performatieve taalhandeling niet bijdroeg aan de waardering van de kleuters -, schrijft een leerkracht als reactie van een leerling: "'Hé, het rijmt!'” (1621, logboek week 14) In het afsluitende gesprek gaat deze leerkracht expliciet in op dit verschijnsel. Ze vond het mooi dat, als ze halverwege een versje of gedicht was, een kind ineens heel enthousiast uitriep: 'Hé, het rijmt!' Ze lacht als ze zegt dat ze dat gedurende het jaar steeds sneller doorhadden. Dat is, zo voegt ze toe, niet alleen aan de Leeskalender toe te schrijven, omdat ze ook op andere momenten veel met rijmen bezig zijn (evaluatie 2, S16, 16-06-2014). De rijmherkenning binnen het kader van de Leeskalender is dus niet los te zien van de rijmactiviteiten die buiten de Leeskalender plaatsvonden in de kleutergroepen, maar het vertelt ons wel iets heel interessants.

De manier waarop kleuters reageren op het moment dat ze rijm herkennen, is opvallend: ze maken het zonder aarzelen wereldkundig door spontaan te roepen en daarbij uitdrukkingen van verbazing als 'Hé!' te gebruiken. Dit duidt erop dat hun herkenning van rijm de kleuters zelf in deze instanties verrast ${ }^{186}$. Voor ervaren lezers zijn rijm en andere duidelijk herkenbare herhalingspatronen te verwachten in (kinder)poëzie, of zijn deze kenmerken zelfs al zo 'alledaags' dat we ze afwijzen omdat ze niet vernieuwend genoeg zijn (zie Hoofdstuk 2). Bij kleuters is dat niet zo, maar - en hier wordt het spannend: deze reacties duiden erop dat hier iets anders gaande is dan de, voor kleuters o zo prettige, bevestiging van hun verwachtingspatroon. Het feit dat ze verrast reageren op (hun eigen herkenning van) bepaalde vormen van rijm, duidt erop dat deze vormen voor hen een 'afwijking' van hun verwachtingspatroon zijn. Vaak gaat dit echter ook gepaard met lachen of andere signalen dat ze het grappig vinden. Deze humorreactie in combinatie met het benoemen dat een tekst rijmt, duidt erop dat we hier ook niet alleen te maken hebben met een afwijking van hun verwachtingspatroon, maar met de herkenning van een verrassend patroon: "The humorous response is evoked by the surprise recognition of a pattern." (Clarke, 2008, p. 27; als geciteerd in Coats, 2010, p. 121) Dit is een belangrijk inzicht dat erop wijst dat jonge kinderen niet alleen houvast hebben aan en daarmee positieve waardering hebben voor kenmerken als 'stereotypie en herhaling', zoals vaak gedacht wordt (vgl. Ghesquière, 2009a, p. 137; zie Hoofdstuk 1). Jonge kinderen beleven ook expliciet plezier aan de herkenning van (voor hen) onverwachte patronen in poëzie, wat volgens de cognitieve humortheorie via een andere route, maar in dezelfde mate belonend is als bevestiging van verwachtingen:

"As sequences of entities develop into patterns, children can act on expectations of pattern repetition, and this produces a kind of reward or sense of mastery. Humour, on the other hand, produces a different kind of reward, because it is based not on the expectations of the repetition of a familiar pattern, but on the surprise of discerning a pattern

${ }^{186}$ Iets dat de kleuters sporadisch verraste aan de poëzie was het feit dat dit vaak maar korte teksten zijn. Bij 'Lieve Sinterklaas' schrijft een leerkracht in het logboek: "Reactie: dat is snel, kort." (2222, logboek week 11) Dit kenmerk van poëzie wekte vaker verbazing op bij de kinderen in groep 4 (zie Hoofdstuk 10). 
... in an unexpected place, and thus rewards our ability to parse innovation." (Coats, 2010, p. 121)

De onverwachte herkenning van rijm in het taalspel poëzie 'beloont' kinderen met het gevoel dat ze iets nieuws hebben ontdekt en hun emfatische uitroepen geven verbale uitdrukking aan dat gevoel.

Echter, álle poëzie in de Leeskalender voor groep 2 bevatte (veelal eind-) rijm. Toch werd niet bij alle poëzie gerapporteerd dat kinderen zo expliciet uiting gaven aan hun rijmherkenning. Daarnaast zijn kleuters bekend met rijm - het is onderdeel van hun verwachtingshorizon -, dus rijst de vraagt wat dan precies het verrassingseffect teweeg brengt in de genoemde voorbeelden. Wat maakt dat het klankspel 'rijm' dusdanig opvalt dat het bij kleuters een humorreactie teweeg brengt en ze hun ontdekking spontaan wereldkundig maken? Als we de hierboven genoemde gedichten waarbij leerkrachten rapporteerden over de spontane rijmherkenning van de kleuters met elkaar vergelijken, dan valt op dat de eigennamen van de personages hier steeds een belangrijk onderdeel vormen van het rijmpatroon: 'Meester Van Zoeten waste zijn voeten', 'Klisklaskloentje, zo heet mijn hoentje', 'Vijf vette varkens zaten in een stal/ Jan, Piet, Wim, Kees en Parsifal', 'Ikkeltje, Tikkeltje, Spikkeltje Boem', 'Och och och, die gekke juffrouw Boggemog', en in 'Prins Piramente' begint elk van de vier strofes met een regel die eindigt op 'het land van de krenten' gevolgd door een regel die eindigt op 'prins Piramente'. De meeste van deze namen zijn op zich al opvallend: het zijn onzinnamen. De reacties op de naam 'Juffrouw Boggemog' illustreren het verrassingseffect dat die vreemde namen bij de kleuters teweeg brengen: "De leerkracht wijst op het kalenderblad waar bij 22 januari iets geschreven staat. Ze laat het zien aan D en Lb en zegt dan: 'Er staat: juffrouw Boggemog'. De kinderen moeten lachen om die naam. J verwoordt dat ook: 'Rare naam!', zegt hij lachend." (observatie 17, 22-01-2014) Hoewel ik dit niet structureel kan nagaan op basis van de overige kwalitatieve data, is het voorstelbaar dat de aandacht van de kleuters, die op zich bekend zijn met rijm, aanvankelijk wordt opgeeist door die gekke namen. Op het moment dat ze opmerken dat die namen in klank overeenkomst vertonen met nabijgelegen woorden, vallen ze op hun plaats als onderdeel van een onverwacht klankpatroon en is er het eureka-moment: "'Parsifal rijmt op stal!!" (1321, logboek week 17)

Het vernieuwende en onverwachte is dan niet zozeer rijm op zich, maar het specifieke gebruik van opvallende namen als onderdeel van dat klankpatroon. Dit is in lijn met theorieën over taal- en humorontwikkeling waar het plezier dat jonge kinderen kunnen beleven aan grappige namen wordt gekoppeld aan de pre-operationele fase van de cognitieve ontwikkeling: een fase waarin ze onder meer expliciet plezier gaan beleven aan het spelen met namen, zowel het incorrect labelen van objecten, dieren en personen als het spelen met de klank van (zelfbedachte) namen ('Meneertje Koekepeertje', etc.) (McGhee, 1979; Fleischman, 1986, p. 553). Wat betreft de relatie van 'muzikaal taalspel' tot de ontwikkelingskenmerken van de kleuters is dit dus geen verrassend inzicht. Echter, in relatie tot hun 'poëtische ontwikkeling', als onderdeel van hun ontluikende culturele geletterdheid, is dit wel een spannend verschijnsel, want net als ervaren lezers beleven kleuters plezier aan (de herkenning van) vernieuwende elementen. Wat vernieuwend ís, moet dan, net als wat poëzie ís, in pragmatisch ontwikkelingsperspectief gezien worden (zie Hoofdstuk 2). 


\section{De semantisering en conceptualisering van 'murikaal taalspel'}

Bij de herhaling van 'Mr. Van Zoeten' mochten de kleuters proberen op dezelfde manier te rijmen met namen als in het gedicht, bijvoorbeeld: 'Juffrouw Van Laren waste haar haren'. Voor de kleuters bleek dat deels een lastige opdracht. Een leerkracht schrijft: "Het rijmen was voor de kinderen nog erg moeilijk. Het bedenken van een naam vonden ze leuk. Kwamen originele namen uit." (2622, logboek week 1) De opdracht om zelf nieuwe varianten te verzinnen 'in de trant van' vereist conceptueel begrip van het rijmprincipe dat, in dit geval, aan de regel 'Mr. Van Zoeten waste zijn voeten' ten grondslag ligt. Dat kan nog erg lastig zijn voor kleuters, zeker omdat het klankspel hier geen directe relatie heeft tot de waarneembare werkelijkheid. Grappige namen verzinnen is iets - zoals hierboven al opgemerkt - dat kinderen in de pre-operationele fase van hun cognitieve en humorontwikkeling wel kunnen en ook erg leuk vinden wat hun beleving en plezier in het taalspel positief beïnvloed. Er waren in de loop van de interventie vaker 'voorvallen' die de grenzen van de beleving van 'muzikaal taalspel' als murikaal taalspel bij kleuters aangeven. Bij het al eerder besproken 'Boterhammen smeren' werd niet op de hierboven beschreven wijze over rijmherkenning gerapporteerd, ondanks dat dit een typisch opzegvers is waarin ritme en rijm sterk aanwezig zijn en plaatsnamen een centrale rol spelen in het rijmschema. De steden (Amsterdam, Rotterdam en Den Haag) werkten voor kinderen in Limburg en NoordBrabant blijkbaar te vervreemdend en trokken daarmee teveel aandacht ten koste van het muzikaal taalspel. Een leerkracht schrijft zelfs: "Een kind vond dat ik Rotterdam niet mocht zeggen: stom woord. Kwam vanwege rot erin. Slechts 1 kind hoorde de rijm met deze woorden / boterham." (2223, logboek week 7) In dit voorbeeld wordt het rijmwoord 'Rotterdam' gesemantiseerd op basis van het woorddeel dat een van de kinderen herkent: 'rot'. De rijmherkenning is in dit geval ook niet spontaan: in de verwerking van dit vers werd het klankspel expliciet besproken. Ook in de groep waar ik op dat moment observeerde, kon dit specifieke klankspel echter niet op herkenning rekenen:

De leerkracht vraagt de kinderen waarom er 'Amsterdam, Rotterdam' in het versje zit. De kinderen kijken haar vragend aan: ze weten het niet. Waar lijkt dat op? De kinderen weten niet wat ze bedoelt. Luister maar goed, zegt de leerkracht, dan horen jullie het misschien: 'Smeer nog maar een boterham, Amsterdam, Rotterdam'. Ze benadrukt boterham en de plaatsnamen deze keer sterk. De kinderen reageren niet. Dat lijkt op elkaar, vult ze zelf in: boterham en Amsterdam, Rotterdam, dat klinkt een beetje hetzelfde. En waarom staat er dan Den Haag? Dat lijkt op? Hagelslag, zegt een meisje. (observatie 3, 6-11-2013)

Hoewel de plaatsnamen in dit vers zijn opgenomen omwille van hun klankeigenschappen, gaat de aandacht van de kleuters juist uit naar de betekenis van die woorden. 'Den Haag' en 'hagelslag' hebben absoluut klankovereenkomsten, maar 'hagelslag' is hier meer een associatie op 'boterham': in het vers rijmt 'Den Haag' op '(lust ik) graag'. Mogelijk heeft deze aandacht van de kinderen voor betekenis- in plaats van klankaspecten deels te maken met de wijze waarop het vers door leerkrachten is 'gebracht', de specifieke performance (zie paragraaf over voorkeuren en attitudes van leerkrachten). En de expliciete aandacht voor de 
relatie tussen 'Amsterdam, Rotterdam' en 'boterham' in de verwerking deconstrueert het 'taalspel poëzie' zoals dat in de andere groep op dezelfde school wel gestalte kreeg in combinatie met 'meedoen' en ritmische beweging.

Het semantiseren van klanktaal is echter een verschijnsel dat vaker voorkwam. Ook bij het pure klankvers 'Epompee, poedenee, poedenaska,/ Epompee, epompa,/ Epompee, poedenee, poedenaska,/ Epompee, o wee, o wee!/ Academie, vaselemie,/ Academie, vaselemie,/ Emie, epompa'. Een leerkracht schrijft in het logboek: "zochten erg naar herkenbare stukjes, 'demie' leuk, bijv. als naam klasgenootje.” (2321, logboek week 24) In mijn observatiegroep gebeurde hetzelfde. Nadat de leerkracht de tekst eerst heeft voorgelezen, dan heeft voorgezongen (ze kende het nog uit haar eigen jeugd) en vervolgens heeft laten horen van de cd wil ze de kinderen laten meezingen, maar een van hen wil heel graag iets zeggen:

Kind (j): $\quad$ Demie is ook van mij!

[hij blijkt een zus in groep 3 te hebben die Demie heet]

Leerkracht: Maar in het liedje zeggen ze 'emie' en niet 'demie'.

[terwijl de leerkracht de kinderen nog een keer stimuleert om mee te zingen, hoor ik Lb tegen $\mathrm{D}$ zeggen: 'academie', met extra nadruk op 'demie'; D herhaalt het woord 'academie' samen met Lb waar ze allebei om moeten lachen] (observatie 31, 26-3-14)

Als de kinderen proberen mee te zingen, blijkt dat nog erg lastig. $\mathrm{Na}$ de eerste poging, die de kinderen overigens wel 'leeeeuuuuk' vinden -een reactie die ze bijna altijd geven als de leerkracht vraagt wat ze van een tekst vinden -, gaat de leerkracht nog even in op wat voor liedje dit nu is:

Leerkracht: Wat is het voor taal, dit liedje?

Kind (j): $\quad$ Geen flauw idee.

Leerkracht: Hebben jullie het verstaan?

Kinderen: $\quad$ Neeeee.

Kind (j): $\quad$ Het is fantasie.

Leerkracht: Ja, dat zeg je goed, het is fantasietaal. Hebben jullie ook fantasietaal? Wie praat er wel eens in een taal die je zelf hebt bedacht? [de meeste kinderen schudden van 'nee'; een of twee knikeken]

Kind (m): $\quad$ Ik wel, ik zeg wel eens 'panchau' (?).

Leerkracht: Ja, en ehm, 'abracadabra', is dat fantasietaal?

Kind (j): $\quad$ Nee, dat is goocheltaal.

Leerkracht: Oh, kindjes, luister eens wat $\mathrm{M}$ zegt, hij zegt 'abracadabra is goocheltaal'. Heel goed, M!

De leerkracht besprak dit aspect met de kinderen op basis van de verwerkingsinstructies in de handleiding: ik wilde er graag achter komen of kleuters al op meta-niveau over dergelijk muzikaal taalspel kunnen nadenken en spreken. Het nadenken en redeneren óver 'muzikaal taalspel' als relatief autonoom verschijnsel - zonder inbedding in een gebruikscontext - en op conceptueel niveau gaat bij kleuters evenwel ten koste van hun directe beleving ervan. 


\section{De ervaring van muzikaal taalspel, bemiddeld door non-verbaal en verbaal bandelen}

Het meedoen met het 'taalspel poëzie', zeker in combinatie met fysieke beweging, heeft het tegenovergestelde effect: dit versterkt de beleving en vergroot daarmee ook de waardering van de kleuters. In een van de groepen werd direct de koppeling tussen 'Epompee' en fysiek spel gemaakt: "meteen het klapspelletje erbij gedaan. Heel veel keer gewisseld van tweetal en met zéér enthousiaste leerlingen het klapspel gedaan. Het was een groot succes!" (1622, logboek week 24) En ook in de andere groepen werd vooral de combinatie met het klapspel zeer door de kinderen gewaardeerd. Twee leerkrachten van een kleutergroep weten in het afsluitende gesprek weinig voorbeelden te noemen van bepaalde teksten die terugkwamen in het spel van de kinderen, behalve het klapspelletje 'Epompee': dat was echt een succes! (evaluatie 2, S16, 16-06-2014) Ook op mijn observatieschool werd het liedje dankzij het klapspel toch door de kinderen gewaardeerd en toegeëigend: de leerkracht noemt 'Epompee' en 'Gong Xi' als liedjes die de kinderen ook zelf nog steeds zingen ('Opa Bakkebaard' tot haar verbazing niet) (evaluatie 2, S24, 18-06-2014).

De kleuters genieten van muzikaal taalspel in combinatie met fysieke beweging; wanneer de aandacht expliciet op de taal wordt gericht dan gaan ze al snel op zoek naar betekenis. De observatie hierboven laat zien dat sommige kleuters het verschijnsel 'fantasietaal' of 'goocheltaal' op zich wel kennen, maar voor de meeste kleuters is het nadenken en praten óver taal, op meta-talig niveau, nog erg lastig. Muzikaal taalspel als spel op zich, zonder bijbehorende bewegingen, vinden de kleuters wel leuk, maar werkt anders dan wanneer het gecombineerd is met niet-vocale handelingspatronen. 'Een kikker en een karekiet', bijvoorbeeld, leverde reacties op als: "Kinderen vonden het grappig en moesten lachen om de onzinwoorden.” (2221, logboek week 23) En: "Genieten van de tekst. Lachen! Veel plezier herhalen woordje 'karekiet'.” (2222, logboek week 23) In mijn observatiegroep vinden de kinderen het grappig klinken en merken ook direct op dat het rijmt ('de kikker kietelt de karekiet in het riet'). Vervolgens doet de leerkracht dit tongbrekende gedicht (bijna) zonder struikelen en met levendige intonatie en gebaren nog een keer voor:

De kinderen luisteren wel, maar geven weinig reactie. $\mathrm{Na}$ het voorlezen vraagt de leerkracht:

$\begin{array}{ll}\text { Leerkracht: } & \text { Vinden jullie dit versje nu grappig, of mooi of gek...? } \\ \text { Kind }(\mathrm{m}): & \text { Gek } \\ \text { Leerkracht: } & \text { Hoezo? Waarom vind je het een gek versje? } \\ \text { Kind }(\mathrm{m}): & \text { Dat het grappig is } \\ \text { Leerkracht: } & \text { Wat is er dan grappig? } \\ \text { Kind }(\mathrm{m}): & \text { Dat de kikker hem kietelt } \\ & \text { [de leerkracht loopt nu door naar het volgende kind] } \\ \text { Leerkracht: } & \text { Wat vind jij van het versje? } \\ \text { Kind }(\mathrm{m}): & \text { Ook grappig! } \\ \text { Leerkracht: } & \text { Wat vind je grappig? } \\ \text { Kind }(\mathrm{m}): & \text { Dat hij niet stopt met kietelen! (observatie 29, 19-3-14) }\end{array}$


In deze korte evaluatie van het gedicht door twee meisjes in de groep is de eerste reactie: 'Gek'. Dat wordt bijgesteld naar grappig wat vooral betrekking heeft op de betekenis, het verhaaltje, dat in het vers verteld wordt (een vreemde situatieschets). Het tweede meisje neemt deze inhoudelijke waardering over. Wanneer de leerkracht de kinderen vervolgens rijmwoorden laat invullen en een aantal van de gekke woorden uit het vers ('karekietelniet', 'karekikkerkietel op' en 'karekikkerkietelniet') laat zeggen, doen de kinderen wel mee, maar is het moeilijk te zien of ze het ook leuk vinden. Ze nemen het vooral heel serieus waardoor het meer op een taalles lijkt dan op muzikaal taalspel. De leerkracht deelt na afloop mijn twijfel over of de kinderen dit vers nu leuk vonden of niet. Echter:

Zodra de leerkracht de kinderen naar de gang laat gaan om hun jassen en tassen te gaan halen, horen we daar een kakafonie van kikkers en karekieten: 'karekiet, karekiet', 'een kikker en een karekiet', 'karekietelmeniet'. De leerkracht kijkt me aan en zegt: Hoor nou toch, ze hebben het toch opgepikt! (observatie 29, 19-3-14)

In het afsluitende gesprek gaat een van de kleuterleerkrachten in op het verschil in tekstbeleving bij de kinderen dat ze opmerkte bij het aanbieden van poëzie- versus prozateksten. Ze merkt op dat de kinderen anders reageren op gedichtjes en versjes dan op verhalen: in het eerste geval proberen de kinderen automatisch mee te rijmen, proberen ze klanken na te zeggen en willen ze het heel vaak direct nog een keer horen. Bij verhalen ziet ze aan de mimiek en de houding dat kinderen meegaan in de verschillende emoties, dat ze soms helemaal opgaan in een verhaal (evaluatie 2, S26, 10-06-2014). Een andere leerkracht geeft aan dat de kinderen in groep 1-2 de gedichtjes heel duidelijk waardeerden: 'Het spel met klank en rijm vinden de kleuters erg leuk.' (evaluatie 2, S11, 24-06-2014). In mijn observatiegroep 2 kwam na afloop van de eerste aanbieding van 'Gong Xi' ook 'Mr. Van Zoeten' op verzoek van de kinderen nog een keer aan bod:

De leerkracht zegt tegen mij dat er een versje is dat de kinderen nog heel graag een keer willen horen: Mr. Van Zoeten. Ze pakt Ziezo erbij, maar terwijl ze zoekt naar de juiste bladzijde beginnen verschillende kinderen al uit het hoofd het eerste couplet op te zeggen en bij 'hum tiedelum tiedelum' vallen de andere kinderen ook bij. Dan heeft de leerkracht de juiste pagina gevonden en leest het hele gedicht voor. De kinderen kunnen, naast het eerste couplet, nog grote delen van de tekst invullen. Bij 'hum tiedelum tiedelum' bewegen ze ritmisch heen en weer op hun stoel. De kinderen vinden het heerlijk. (observatie 20, 05-02-2014)

De kleuters zijn sterk gericht op klankspel dat ze het meest direct ervaren wanneer ze meedoen door te zingen of op te zeggen, rijmwoorden in te vullen en vooral ook door te bewegen. In mijn observatiegroep 2 spraken de versjes met onzinwoorden (zoals 'karekikkerkietelniet') speciaal aan en de klankliedjes: 'Epompee' en 'Gong Xi' zongen de kinderen aan het eind van het schooljaar nog steeds (evaluatie 2, S24, 18-06-2014).

Zelf moeten rijmen bleek over het algemeen voor de kleuters lastiger dan rijm herkennen, meedoen terwijl de leerkracht voordraagt, of het invullen van rijmwoorden nadat ze een tekst al eens gehoord hebben. Zelf rijm verzinnen lukte de kleuters in de meeste groe- 
pen goed bij '"k Zag twee beren', ofwel omdat dit lied al bekend was, ofwel omdat het gebaseerd is op een heel duidelijk principe. Zelf rijm verzinnen bij onbekende vormen was moeilijker. Soms lukte het wel, zoals in de vorm van 'Klisklaskloentje, zo heet mijn hoentje' waarbij de kinderen zelf rijmende namen mochten verzinnen voor dieren. Omdat het moet rijmen, was de fantasie in het verzinnen van namen echter beperkt. Een leerkracht schrijft: "De namen / rijmwoorden op hun genoemde dieren waren eenvoudig. Poes- loes. Egel vegel. Gorilla - lorilla." (2221, logboek week 5) Bij 'Mr. Van Zoeten' mochten de kinderen bij de herhaling ook zelf nieuwe rijmcombinaties verzinnen in de trant van 'Meester Van Zoeten waste zijn voeten': "Het rijmen was voor de kinderen nog erg moeilijk. Het bedenken van een naam vonden ze leuk. Kwamen originele namen uit.” (2622, logboek week 5) Rijm, een sterk muzikaal metrum en andere ritmische patronen, i.e. 'muzikaal taalspel', valt bij de kleuters vooral in de smaak omdat het verbaal en non-verbaal meedoen stimuleert (zie \$9.2, Het 'taalspel poëzie' gekoppeld aan fysieke spelvormen). Als vanzelf gaan de kleuters meebewegen met muzikale poëzie en als vanzelf gaan ze rijmwoorden nazeggen en vervolgens zelf invullen terwijl de leerkracht voordraagt. Zelf nieuw rijm verzinnen, kan echter de beleving en fantasie van de kleuters beperken: het nadenken over rijm, het zoeken naar woorden, leidt af van de fysieke ervaring van 'het taalspel poëzie' en makkt de verwerking van poëzie een intellectuele activiteit.

\section{(Carnavaleske) nonsensicaliteit: 'Gek he, juf!'}

"Children ... reveal their grasp of what is sense and what nonsense through their responses to absurd descriptions of things," schrijft Linda Gibson Geller in Wordplay and Language Learning for Children (1985, p. 13). '(Carnavaleske) nonsensicaliteit', als verwachte indicator van canoniciteit in kinderpoëzie, moet gezien worden als iets dat per definitie tot stand komt in interactie met de culturele schemata van kinderen die de referentiekaders vormen waarbinnen ze iets als 'normaal', 'mogelijk' en 'betekenisvol' begrijpen. Nonsensicaliteit heeft in dit onderzoek betrekking op incongruente voorstellingen van de werkelijkheid in poëzie én, vanuit pragmatisch handelingsperspectief, ook op incongruente benaderingen van de tekstexterne werkelijkheid met poëzie. Carnavaleske nonsensicaliteit heeft daarbinnen specifiek betrekking op ervaringen van 'incongruentie' in relatie tot de sociale context en de culturele categorieën (waarden en normen) die in die sociale context gelden. De deelvraag die ik wil beantwoorden, is:

KINDERPOËZIE: KWALITATIEVE DEELVRAAG 4c.

Wat vertellen observaties, logboekaantekeningen en gesprekken met leerkrachten met betrekking tot de presentatie van het poëzie-aanbod in de klas, de reacties van de kinderen op deze teksten en hun waardering daarvan ons over de rol van '(carnavaleske) nonsensicaliteit', onderverdeeld in

(i) carnavaleske vormen van nonsensicaliteit bemiddeld door subversief fysiek handelen in relatie tot de sociale context en de culturele categorieën (waarden en normen) die in die sociale context gelden, en

(ii) carnavaleske vormen van nonsensicaliteit bemiddeld door subversief talig handelen in re- 
latie tot de sociale context en de culturele categorieën (waarden en normen) die in die sociale context gelden, en

(iii) vormen van nonsensicaliteit die een meer intellectuele ervaring van 'incongruentie' teweegbrengen, bemiddeld door een voorstelling van de werkelijkheid die afwijkt van de 'natuurlijke wetmatigheden' die gelden in de waarneembare of conceptuele werkelijkheid in processen van poëzieverwerving bij kinderen in groep 2?

Mijn verwachting is dat kinderen in groep 2 de intellectueler vormen van nonsensicaliteit ook kunnen waarderen, mits gerelateerd aan de waarneembare werkelijkheid en ondersteund door visualisatie (bijvoorbeeld door uitbeelden). Echter, mijn verwachting is dat zowel kinderen in groep 2 als kinderen in groep 4 generaliter carnavaleske (op de sociaalculturele context gerichte) nonsensicaliteit sterker waarderen dan de meer intellectuele vormen van nonsensicaliteit. In relatie tot ontwikkelingskenmerken van kinderen in groep 2 en in groep 4 is te verwachten dat kinderen in groep 2 nog sterk steunen op de waarneembare werkelijkheid en subversief fysiek handelen voor het ervaren en waarderen van (carnavaleske) nonsensicaliteit.

\section{Incongruent handelen binnen de schoolcontext: de juffen moeten op het klimrek!}

Een kenmerk van veel nonsenspoëzie is dat er 'incongruente combinaties van handelingen en objecten' in voorkomen, zoals varen in een hoed of zeef en rijden op een kip of kat. Voor kleuters, met hun ontluikende kennis van de wereld en fluide beleving van wat fantasie is en wat echt is, roepen veel van dergelijke incongruente combinaties naar verwachting eerder een 'Dat hoort/mág (eigenlijk) niet' ervaring op dan een 'Dat kán (eigenlijk) niet' ervaring. Tegelijk moet daarbij de culturele context in overweging genomen worden: wat hoort/mag of kan daarin wel en niet? Mijn verwachting was dat de gewoonte van 'Mr. van Zoeten' om zijn voeten 's zaterdags in het aquarium te wassen (omdat hij zijn vissen geen ogenblik kan missen) een 'Dat hoort/mag (eigenlijk) niet' ervaring teweeg zou brengen bij kleuters, maar blijkt in de huidige culturele context ook voor kleuters deels al 'genormaliseerd'. In twee kleutergroepen waren kinderen bekend met het verschijnsel van de 'Dr. Fish' behandeling: "Soms doe je je voeten bij de vissen zodat ze aan je tenen knabbelen," werd in een van de groepen opgemerkt (2321, logboek week 1). Een andere leerkracht schrijft: "Leerlingen vonden het idee niet raar. Tegenwoordig heb je de 'visjes spa', een aantal lln benoemden dit." (1322, logboek week 1) Dit bevestigt dat wat we ervaren als 'nonsens' altijd gerelateerd is aan wat maatschappelijk wordt geaccepteerd als 'common sense’ (Anderson \& Apseloff, 1989; Stewart, 1978/1989). Het laat ook zien dat kinderen putten uit hun kennis van de wereld om de gewoonte van Mr. van Zoeten als zinvol te duiden. In andere groepen, waar deze kennis niet aanwezig was in de 'stock of knowledge' van de kinderen, bleek het taalgebruik in het gedicht (uit 1950) een drempel om het nonsensicale aspect van dit gedicht te herkennen. Een leraar schrijft: "Dit gedicht was erg pittig voor de kinderen. Zowel het taalgebruik 'in hun hum' 'tobbe' als ook inhoudelijk (-> 1 keer per week... is dat genoeg?)" (1621, logboek week 1) In verschillende groepen werd het gedicht vooral gewaardeerd om het muzikale taalspel en niet om het nonsensicale spel: “'Hum tiedelum' vonden de lln erg leuk," schrijft dezelfde leerkracht (ibidem). 
Het plezier dat kleuters kunnen beleven aan incongruente combinaties van handelingen en objecten kwam sterker naar voren bij 'Opa Bakkebaard', mede omdat hier de incongruentie voortkwam uit het 'verkeerd' handelen van de leerkrachten. Leerkrachten hadden expliciet de instructie gekregen om dit liedje 'verkeerd' voor te zingen, dus 'hij veegt de vloer met een lepel, met een lepel' en 'hij roert de soep met een bezem, met een bezem'. De kleuters vonden de versprekingen over het algemeen erg grappig: "De kinderen reageerden meteen toen het liedje verkeerd werd gezongen. Het leidde tot grote hilariteit! Het was erg gezellig," schrijft een leerkracht (1322, logboek week 2). De kleuters beleefden ook groot plezier aan het corrigeren van de leerkracht: "De kinderen namen verdraaiingen niet over, vonden het grappig dat ik me versprak en bleven me verbeteren.” (2321, logboek week 2) Dit bevestigt wat Kornei Chukovsky schreef over waarom jonge kinderen het spel van de nonsens zo leuk vinden: "This ... amuses them so much because it is so easy to refute it, and thus the arguments against it become a sort of game by means of which the children, so to speak, test themselves." (1971/1925, p. 106) Nog leuker is het wanneer de leerkracht het (expres) verkeerd doet: dan zijn de kinderen even 'slimmer' dan de leerkracht en zijn de rollen dus tijdelijk omgedraaid, wat een carnavaleske beleving teweeg brengt. Bij de herhaling mochten kinderen zelf objecten verzinnen of in de klas aanwijzen die in de tekst werden ingevuld. Kozen de kinderen voor 'incongruente' objecten? “'Hij maait het gras, met een (plastic) neushoorn'," geeft een leerkracht als voorbeeld (2221, logboek week 2). Een ander schrijft: "Kinderen hadden plezier en dachten goed mee met 'wat wel en niet kan'. Ramen zemen met een boterham? Kan toch niet. Vraag: hoe moet het dan wel: met een spons en een doek! Hoe heet die doek? 'ZEEM' - Broek naaien met een spijker? 'NAALD en DRAAD'." (1321, logboek week 2) De kinderen hadden het principe in de meeste groepen snel door en manipuleerden de tekst via hun keuzes bewust in nonsensicale ('grappige') richting. Een leerkracht noteerde: "Enthousiaste reacties. Leuk om te zien dat ze na 1 voorwerp oppakken snappen wat er gaat gebeuren; dat lokt leuke reacties uit voor de volgende voorwerpen!” (1622, logboek week 2)

Naast incongruente combinaties van handelingen en objecten, is ook de omkering een veelvoorkomend verschijnsel in (carnavaleske) nonsenspoëzie. Dit kan een letterlijke omkering zijn, maar ook een meer figuurlijke invulling krijgen. Het liedje 'Carnaval' dat de kleuters vlak voor de Carnavalsvakantie aangeboden kregen, eindigt met de regel: 'en zet de hele school maar op z'n kop'. Bij de herhaling van het liedje stond dit 'omgekeerde-wereld' aspect van carnaval, de wereld "shaped according to a certain pattern of play" (Bakhtin, 1984, p. 7), centraal. Past 'op z'n kop' bij carnaval? En wat betekent het als de school op zijn kop wordt gezet? In een groep schrijft de leerkracht uitgebreid in het logboek over de reacties van de kinderen:

"Het past bij carnaval, want: met carnaval sta je wel eens op je kop, het is leuk, het hoort bij dansen. Het past niet bij carnaval, want: als je op je kop staat en je gaat dansen dan stoot je iemands hoofd met je voet, grote mensen met hakken kunnen dan botsen tegen iemand anders, als je op je kop staat met je handen op de vloer en je wilt weer rechtop gaan staan, dan kan je tegen iemand aanstoten met je voeten.” (1622, logboek week 21) 
De leerkracht concludeert: "Het begrip 'op z'n kop zetten' snappen ze niet. Ze nemen het erg letterlijk." (1622, logboek week 21) Het is interessant om te zien dat de kinderen 'op z'n kop' hier heel concreet duiden als onderdeel van dansen: iets dat voor hen een herkenbaar onderdeel van de Carnavalsgebruiken is. Daar komt bij dat 'op zijn kop' al eerder aan bod was gekomen in de Leeskalender, bij 'Prins Piramente' in interventieweek 8. In dat gedicht ging het juist over een letterlijk ‘op je kop staan' (zie Hoofdstuk 5). In dezelfde groep sloeg dit gedicht sterk aan bij de kinderen. Bij de herhaling schrijft de leerkracht: "De kinderen vonden het leuk om te bedenken wat je ondersteboven zou kunnen doen en wat er dan zou gebeuren. Bijv. - ondersteboven plassen: dan moet je met je hoofd in de wc. - Ondersteboven douchen: dan komt het water tegen het plafond. Toen we het ook nog gingen 'uitbeelden' was het 'begrip van de tekst' compleet." Bij de korte nabespreking op vrijdag plaatsten de kinderen prins Piramente "in op z'n kop land, 'onderstebovenland'." (1622, logboek week 8) De letterlijke opvatting van 'op zijn kop' bij het carnavalsliedje is dus niet zo vreemd in het licht van de eerdere ervaringen met Prins Piramente. In een andere groep werd 'de school op de kop zetten' wel in figuurlijke zin opgevat. Hier kwamen de kinderen tot de volgende ideeën: “'Daar zijn de juffen kindjes en dan zeggen de kindjes tegen de juffen: hop, hop aan het werk'; 'School 's nachts en overdag/'s middags slapen en is de school afgelopen'; 'We kunnen bedjes neerzetten, slapen en dan vlug weer aan 't werk'; 'We zeggen dat we heel lang buitenspelen, tot 't regent en dan gaan we naar binnen'; 'De juffen zijn de kindjes, die moeten op 't klimrek, en moeilijke werkjes'; 'Moeten de juf op de kleine stoel en de kn op de grote stoel'." (2421, logboek week 21)

De beleving van nonsensicaliteit is bij de kleuters duidelijk verbonden aan hun cognitieve ontwikkeling enerzijds, maar ook heel sterk aan hun 'culturele schemata' van wat $\mathrm{wel} /$ niet kan of hoort in relatie tot de context waarin ze opgroeien. Je voeten in een aquarium doen is daarin (deels) normaal, maar als de leerkracht gekke dingen zingt, dan is dat heel grappig omdat de kinderen op dat moment plotseling 'de baas' zijn en háár kunnen verbeteren. Deze carnavaleske omkering van rollen binnen de schoolklas als herkenbare context valt zeer bij de kleuters in de smaak, zoals ook naar voren komt uit de ideeën over het 'op de kop zetten' van de school die in een kleutergroep bedacht werden. Daarbij moet wel worden opgemerkt dat concrete en letterlijke omkeringen voor de kleuters gemakkelijker te herkennen zijn (zoals bij Prins Piramente). De ervaring van incongruentie en daar plezier aan beleven, wordt bij kleuters vooral opgeroepen door concrete handelingsgerichte nonsens, op basis van subversief fysiek handelen en de omkering van rollen in relatie tot de waarneembare werkelijkheid, waarbij de context van de schoolklas zich goed leent om op te treden als 'carnavalesk kader'.

\section{De berkenning van rituele taalhandelingen in pragmatische context: het is grapjesdag}

Carnavaleske vormen van nonsensicaliteit omvatten binnen dit onderzoekskader ook vormen van subversief talig handelen in relatie tot de sociale context en de culturele categorieen (waarden en normen) die in die sociale context gelden. In de Leeskalender voor groep 2 waren die subversieve vormen van talig handelen aanwezig in 'Als ik nou een hondje mag', 'Ik ben lekker stout' en 'Ik wens je al wat wenselijk is'. Het eerst- en laatstgenoemde vers zijn al behandeld en tot nu toe hebben we gezien dat kleuters “... genieten van alles wat 
niet mag!' (2222, logboek week 9) 'Ik ben lekker stout' viel bij de kleuters zeer in de smaak, vooral vanwege het 'stoute woord' waarmee het gedicht wordt afgesloten ('En als ze kwaad zijn zeg ik: Bill'). Zo schrijft een leerkracht in het logboek: "Ze vonden het erg spannend om te horen wat het jongetje voor 'stoute dingen' wilde doen. Er werden veel dingen genoemd die ze wel en niet leuk vonden om te doen (borden wassen - kamer stofzuigen speelgoed opruimen). Ze gaan allemaal thuis 'bil' zeggen als ze iets niet leuk vinden... ben benieuwd!?” (1622, logboek week 10). Op de keuzedag kozen de kinderen het gedicht in deze groep opnieuw en blijkt uit het logboek duidelijk waar hun waardering naar uitgaat: "Versje, wisten ze niet helemaal meer. 'Bil!' wisten ze nog goed.” (1622, logboek week 10) Dit soort subversief talig handelen (het zeggen van 'stoute' woorden) spreekt de kleuters duidelijk aan. Als het niveau van de pragmatische functie van de poëtische taalhandeling wordt onderworpen aan een carnavaleske manipulatie, zoals bij 'Ik wens je al wat wenselijk is' van toewensen naar verwensen, herkennen de kleuters de humor echter niet als zodanig (zie \$9.2). Ze vinden het wel grappig dat er gekke dingen in het vers staan, maar uit de observatie en logboekaantekeningen blijkt dat de kleuters het spel hier niet op het niveau van de specifieke taalhandeling meespelen.

Een belangrijke vraag binnen het kader van dit onderzoek is wanneer en hoe kinderen poëzie herkennen als 'rituele taalhandeling', vrij van de eis om te voldoen aan waarheidscondities (vgl. Dijk, 1980, p. 9). Bij verschillende van de nonsensicale gedichten in de Leeskalender, zoals 'Juffrouw Boggemog', 'Meester Van Zoeten' en 'Ikkeltje, Tikkeltje, Spikkeltje Boem', valt uit observaties en logboekaantekeningen op te maken dat de meeste kleuters sterker reageren op het muzikale taalspel dat in deze teksten gespeeld wordt dan op het spel met de referentiële functie van taal. Tijdens mijn observatie van de aanbieding van 'Ikkeltje, Tikkeltje, Spikkeltje Boem' is de eerste expliciete indicatie van de herkenning van 'het taalspel poëzie' als bijzondere vorm van taalgebruik de opmerking over de namen van de personages: 'Dat zijn rijmwoordjes!' (observatie 33, 9-4-14) In de verdere verwerking van het vers, waarin de drie mannetjes in hun vliegende schoen om de zon heen vliegen, komt ook de categorisering van dit gedicht op meta-tekstueel niveau aan bod:

Leerkracht: Kan dat in het echt?

Kinderen: Neeeee!

Leerkracht: Hoe noemen we dat? Wat voor versje is het dan?

Kind (j): $\quad$ Flauwekul.

Kind (j): $\quad$ Gek.

Kind (m): $\quad$ Net zoals de gekke-dingen-school, deze hoort ook in de gekkedingen-school! (observatie 33, 9-4-14)

Het laatste meisje - een van de drie 'pientere' kinderen uit mijn observatiegroep - verwijst naar de tekst die een week eerder aan bod kwam en legt daarmee een intertekstuele relatie die, als categorisering van gelijksoortige teksten, de opbouw van ontluikende genrekennis aangeeft. Het vers waarnaar ze verwijst, 'In de gekke-dingen-school' (Smulders, in Komrij, 2008), vormt een concreet kader van waaruit ze nu ook andere 'onzinversjes' kan duiden: 
In de gekke-dingen-school speelt de poes op de viool springt de koe over de maan heeft de hond een rokje aan bord en lepel gaan op sjouw en er is géén schooljuffrouw

Dit vers werd aangeboden op 1-april. De leerkrachten was gevraagd de Leeskalender te verstoppen en te vertellen dat er die nacht een koe in de klas was die de Leeskalender heeft meegenomen. En waar die koe naartoe is gegaan? Die koe sprong over de maan! Voor de kleuters was de onmogelijkheid hiervan niet direct vanzelfsprekend, zeker niet omdat de leerkracht het zegt. In een groep rapporteert de leerkracht: "Kinderen waren verwonderd dat de juf ze voor de gek had gehouden. Een aantal kinderen had het gewoon aangenomen (in fantasie kan alles), daarna heb ik gevraagd welke dag het was en daarna pas de kalender gepakt." (2321, logboek week 25) De inbedding in de context van 1-april als 'grapjesdag' maakte voor de kleuters veel duidelijk: "Eén leerling zegt: dat doet de juf omdat het grapjesdag is. Ze genieten van het versje en vragen zelf om herhaling. De grapjes komen nu los." (2222, logboek week 25)

Ingekaderd als 'grap' binnen de pragmatische context van 1-april als 'grapjesdag' was niet alleen de grap van de leerkracht voor de kleuters te duiden, maar was ook het vers voor hen gemakkelijk te herkennen als bijzondere vorm van taalgebruik. Grapjes zijn voor deze jonge kinderen al bekend als 'rituele taalhandeling', vrij van de eis om te voldoen aan waarheidscondities (vgl. Dijk, 1980, p. 9). Doordat dit vers expliciet in een ritueel gebruikskeader geplaatst werd dat voor de kleuters herkenbaar is als onderdeel van de cultuur van het dagelijks leven, werd het voor hen gemakkelijker om dit taalspel mee te spelen. Opnieuw zien we hier de sterke bijdrage van de pragmatische inbedding van poëzie, als bijzonder soort taalgebruik in context, op het begrip en de waardering van de tekst bij kleuters. De 'gekke-dingen-school' als bijzonder soort school vormde daarbij een derde inkadering die voor de kinderen voorstelbaar was: "daar leer je niks, alleen maar gekke dingen." (2421, logboek week 25) Ook konden de kleuters de 'grapjes' in het gedicht al goed 'toetsen' aan hun eigen kennis en ervaring van de wereld. Een leerkracht schrijft in het logboek, nadat ze eerst expliciet de koppeling met 1-april had gemaakt: "De kinderen hadden goed in de gaten dat het versje niet waar kon zijn. Een aantal kon al goed verwoorden waarom niet: koeien kunnen niet zo hoog springen, mijn kat kan goed onder hekjes kruipen maar geen viool vasthouden!" (2321, logboek week 25) Een andere leerkracht zegt in het afsluitende gesprek: "Soms maakt de verwerking echt een aantoonbaar verschil. Dat was bijvoorbeeld het geval bij het gedicht 'In de gekke-dingen-school'. Dat begon voor de kinderen pas te leven, nadat ze hen vroeg zich voor te stellen dat ze van hun eigen school zo'n gekkedingen-school zouden maken én nadat ze zelf een concreet voorbeeld had gegeven. Ze vroeg hen hoe het zou zijn als alle wc's ondersteboven waren." (evaluatie 2, S16, 16-062014)

Dit maakt duidelijk dat de herkenning en beleving van het soort taalspel dat in nonsensicale poëzie wordt gespeeld, sterk gestimuleerd wordt door contextualisering op meerdere niveaus. Het voorbeeld hierboven laat zien dat allereerst de inbedding van het vers in de 
pragmatische context van de viering van 1-april als 'grapjesdag' de kleuters helpt om de 'grap' van de leerkracht te duiden. Vervolgens wordt het vers zelf binnen die pragmatische context geduid als 'grapje' en wordt daarmee een voor kleuters herkenbare rituele taalhandeling die het kader vormt van het spel dat daarbinnen met de werkelijkheid wordt gespeeld. Dat spel dat binnen de tekst wordt gespeeld is op haar beurt ingebed in een voor kleuters herkenbare concrete context, namelijk 'de school' die na onderwerping aan een carnavaleske omkering tot 'gekke-dingen-school' wordt omgedoopt, expliciet voorgesteld als 'grap' binnen de pragmatische context van 'grapjesdag'. Dit alles wordt bemiddeld door de leerkracht en kan door de kleuters getoetst worden aan hun eigen kennis van de wereld. Deze meervoudige pragmatische inbedding en cognitieve en sociale verankering maakt het voor de kleuters gemakkelijker herkenbaar als 'niet echt' en 'veilig ingekaderd', waardoor ze het carnavalesk nonsensicale spel ook als plezierig en grappig kunnen beleven en meespelen.

\section{Intellectuele ervaringen van 'incongruentie' bij kleuters: nu wordt het echt té gek}

Concrete carnavaleske nonsens, ingebed in een externe pragmatische context (zoals 'grapjesdag') en gerelateerd aan een bekend en waarneembaar referentiekader (zoals 'de school') is voor de kleuters duidelijk herkenbaar en maakt het voor hen mogelijk om het spel van de (carnavaleske) nonsensicaliteit mee te spelen en te sturen. Dit werd zichtbaar bij 'Opa Bakkebaard', 'Carnaval', 'Prins Piramente' en 'In de gekke-dingen-school'. Nonsens kan echter ook veel abstracter vormen aannemen, zoals het geval is bij 'Juffrouw Boggemog' van Annie M.G. Schmidt. Juffrouw Boggemog leeft in een wereld waar de relatie tussen handelingen en tijdsduur anders is dan wij gewend zijn: "Die gekke juffrouw Boggemog!/ In januari slaapt ze nog.// In februari staat ze op/ en doet haar wasje in het sop.// In maart doet zij haar jasje aan/ om even naar de kerk te gaan.// En als zij thuiskomt in april,/ dan blijft het weer een poosje stil.// En in de mooie maand van mei/ dan springt ze touwtje in de wei.// ...." (Ziezo, p. 210) En zo vult juffrouw Boggemog een heel jaar met activiteiten die gemakkelijk in een dag passen. In mijn observatiegroep leest de leerkracht het gedicht zeer levendig voor, zoveel mogelijk uit het hoofd, en beeldt alle activiteiten van juffrouw Boggemog uit met gebaren en bewegingen (slapen, opstaan, wasje in het sop doen, etc.). De kinderen reageren hier heel sterk op en doen al wat van de bewegingen na. Aan het eind van het gedicht legt ze extra veel overdrijving in de regel: 'Och och och, die gekke juffrouw Boggemog!', wat de kinderen erg grappig vinden. Vervolgens gaat de leerkracht over tot de verwerking die erop gericht is te achterhalen (a) of de kinderen iets vreemds herkennen in de voorgestelde werkelijkheid, en specifiek (b) of de kinderen het spel met de relatie tussen handelingen en tijd begrijpen, een spel dat op zeer abstract niveau gespeeld wordt. De leerkracht herhaalt dat in het vers wordt gezegd dat juffrouw Boggemog gek is:

Leerkracht: Wat was er zo gek?

Kind $(\mathrm{m})$ : Ze dronk een kop koffie in een andere dag en dan wordt de koffie koud! De leerkracht kijkt even met een verbijsterde blik naar mij: ze snapt het... Dat is heel knap, maar niet alle kinderen lijken dat al te hebben begrepen. (observatie 17, 22-01-2014) 
De leerkracht richt de aandacht eerst op hoe lang juffrouw Boggemog slaapt. In december gaat ze naar bed, in januari slaapt ze nog en in februari staat ze op: hebben de kinderen dat opgemerkt? De kinderen weten het niet uit hun hoofd.

De leerkracht laat het zien aan de hand van een andere kalender die in de klas hangt. Ze bladert van december (in december slaapt ze in met de deken tot aan haar kin) naar januari (in januari slaapt ze nog) en februari (in februari staat ze op).

Kind (m): $\quad$ Die is pas echt gek geworden! (observatie 17, 22-01-2014)

Hetzelfde meisje als zo-even geeft ook nu weer blijk van haar herkenning van de vreemde voorstelling; de andere kinderen reageren niet op dit inhoudelijke aspect. De leerkracht telt samen met de hele groep alle dagen van de maanden waarin juffrouw Boggemog slaapt. Ze tellen 62 dagen. De leerkracht maakt een vergelijking met de egels waar ze het blijkbaar eerder over gehad hebben: die houden een winterslaap en eigenlijk doet juffrouw Boggemog dat ook. Dat vinden alle kinderen grappig: de vergelijking tussen het slaapgedrag van juffrouw Boggemog en dat van egels is voor hen herkenbaar als 'gek'. De leerkracht leest het gedicht nu nog een keer voor waarbij ze opnieuw de activiteiten van juffrouw Boggemog uitbeeldt (de kinderen doen dit na). Ze laat de kinderen nu ook de rijmwoorden invullen ('slaapt ze nog', 'wasje in het sop', etc.): dat kunnen ze, met hulp van de uitbeelding, al heel goed en doen ze met veel enthousiasme. $\mathrm{Na}$ het voorlezen vraagt de leerkracht aan een van de jongens:

\section{Leerkracht: L, slaap jij ook 62 dagen? \\ Kind (j): $\quad$ Nee. \\ Leerkracht: Wanneer ga jij naar bed?}

[met enige hulp komt $L$ tot de volgende conclusie:]

Kind (j): $\quad$ Om zeven uur's avonds ga ik naar bed en om één uur sta ik op, de volgende ochtend. (observatie 17, 22-01-2014)

Er volgt een ingewikkeld gesprek tussen de leerkracht en verschillende kinderen over wanneer ze gaan slapen en wanneer ze weer opstaan. Uit de antwoorden van de kinderen blijkt dat het voor deze vijf- en zesjarigen nog bijzonder lastig is om dagdelen en andere tijdsaanduidingen te gebruiken en uit elkaar te houden. In de verdere bespreking van het gedicht zijn het vooral de door de leerkracht al eerder als 'pienter' aangeduide kinderen die reageren op de inhoudelijke vragen van de leerkracht. Het niveau waarop de meeste kinderen het gedicht waarderen, is dat van het muzikaal taalspel. In een groep kozen de kinderen het gedicht daarom ook op de keuzedag: "Juffrouw Boggemog. Grappig: rijmden mee uit zichzelf." (2221, logboek week 16) In de herhaling was de verwerking op concreter niveau gericht, in een vergelijking tussen 'Juffrouw Boggemog' (die haar voeten een keer per jaar wast) en 'Mr. Van Zoeten' (die zijn voeten elke zaterdag wast). Dit sloeg eveneens bij meer kinderen aan dan het abstracter niveau van de tijd. Een leerkracht schrijft: "Ze herkenden meteen meester van Zoeten, er was ook een leerling die nog wist dat hij z'n voeten waste in een aquarium. De andere leerlingen wisten dat hij z'n voeten wast in een vissenkom. We hebben vergeleken welke voeten het meest zouden stinken: die van juf Boggemog, en een toneelstukje gespeeld van juf Boggemog die op visite kwam en haar schoenen uittrok. Het 
was een groot succes! Neuzen dichtknijpen en verstoppen onder de tafels." (1622, logboek week 16)

In het gedicht 'Rond of vierkant' worden rond en vierkant als vormen met elkaar verwisseld in regels als 'ik speelde in de zon/ met mijn vierkante ballon' en 'Appels smaken juist zo fijn/ omdat appels vierkant zijn'. We hebben hier te maken met incongruentie op het niveau van eigenschappen van objecten, dus op het niveau van categorisering. Dit is een concreter niveau dan het conceptuele spel met tijd in 'Juffrouw Boggemog' en werd in de verwerking gerelateerd aan de waarneembare werkelijkheid. In mijn observatieklas gingen de kinderen eerst op zoek naar ronde en vierkante objecten en werden de vormen besproken. Vervolgens leest de leerkracht het hele gedicht voor en vraagt na het voorlezen wat de kinderen van dit versje vinden:

Kind (j): $\quad$ Leeeuk en grappig omdat dat meisje zegt dat die appel vierkant is.

Leerkracht: Was er nog iets geks?

Kind $(\mathrm{m})$ : $\quad$ Het boterham, hij is cirkel maar een boterham is normaal half vierkant en half zo [beeldt uit in de lucht] kantjes.

Leerkracht: $\quad \mathrm{O}, \mathrm{ja}$, je bedoelt een driehoek. Een boterham is normaal een vierkant en als je die doorsnijdt wordt het een driehoek, ja. Wat was er nog gek?

Kind (m): $\quad$ Een ballon.

Leerkracht: Wat was daar gek aan?

Kind $(\mathrm{m})$ : $\quad$ Dat dat rond is.

Leerkracht: Was dat in het versje, was de ballon in het versje rond?

Kinderen: Neeee.

Leerkracht: Welke vorm had de ballon in het versje dan?

Kind (m): $\quad$ Een vierkant.

De kinderen hebben veel 'gekke' elementen uit het gedicht opgepikt en onthouden. Nadat de leerkracht het vers nog een keer voorleest waarbij de kinderen meedoen met het invullen van de vormen, de rijmwoorden en met uitbeelden, wordt ook het laatste 'gekke' element uit het gedicht met hulp van de leerkracht nog benoemd: 's avonds hadden we ontbijt. In het gedicht wordt ook de zon genoemd, maar niet de vorm van de zon. In de verwerking komt de leerkracht daar, volgens de instructie in de handleiding, op terug:

Leerkracht: In het versje staat 'Ik speelde in de zon met mijn vierkante ballon'. Als de ballon in dit versje vierkant is en de appel ook, welke vorm zou de zon dan hebben?

Kind (m): $\quad$ Rond.

Leerkracht: De zon is rond, maar dit is een grappig versje, he, dus welke vorm zou de zon in dit versje dan hebben?

[De leerkeracht gaat de kring rond en laat alle kinderen zeggen welke vorm zij denken dat de zon in het versje zou hebben. Alle kinderen zeggen 'rond', behalve twee jongens die allebei denken dat de zon in dit versje vierkant is. De leerkracht geeft aan dat de twee jongens gelijk hebben: in dit grappige versje zou de zon vierkant rijn. Een meisje reageert hier heel sterk, bijna boos, op:]

Kind (m): $\quad$ Maar eigenlijk zijn zonnen rond! (observatie 22, 12-2-14) 
Ondanks pogingen van de leerkracht om het verschil tussen de 'werkelijkheid' in het versje en de 'echte werkelijkheid' duidelijk te maken, blijft dit meisje vasthouden aan haar positie: 'Zonnen zijn altijd rond!' zegt ze nog een keer. Nonsens is heel sterk gekoppeld aan de 'kennis van de wereld' waarover kinderen beschikken. De eigenschappen van de zon behoren voor de meeste kleuters waarschijnlijk wel tot hun kennisrepertoire, maar het is conceptuele kennis die ze niet kunnen controleren in de direct waarneembare werkelijkheid. Een leerkracht schreef een veelzeggende reactie van een van de kinderen in het logboek: "Uitspraak: ik weet niet of de zon wel helemaal rond is, ik ben er nog nooit dichtbij geweest." (2222, logboek week 19) Deze onzekerheid maakt de 'willing suspension of disbelief' die nodig is om nonsens als speelse herordening van de werkelijkheid te waarderen, een risicovolle onderneming. Het tegenovergestelde is ook waar: niet alleen onzekerheid over de 'waarheidscondities' van bepaalde uitspraken doorbreekt de ervaring van nonsens als 'grappig', ook te grote zekerheid maakt dat het spel niet tot stand komt. Een andere leerkracht schrijft in het logboek: "Vormen cirkel + vierkant zijn al zodanig bekend bij de kinderen dat ze het 'saai' en 'te makkelijk' vinden om daarover te werken zeiden ze zelf." (1321, logboek week 19) En dan zijn er nog kinderen die de disbalans die de nonsensicale voorstelling van de werkelijkheid teweeg kan brengen, opheffen door heel praktisch te denken. Een van de kinderen in mijn observatiegroep had zich tijdens de bespreking van de gekke elementen in het vers op de achtergrond gehouden, maar nadat ze het vers nog een keer vol enthousiasme hebben meegedaan, heeft hij een ingeving: "[wijzend naar de appel die in het midden van de kring op tafel ligt Als je zo een stuk eraf snijdt, dan heb je een vierkant!” (observatie $22,12-2-14$ )

In die zin is de positieve ervaring van het nonsensicale niet alleen afhankelijk van de 'stock of knowledge' die kinderen voorhanden hebben, maar balanceert het al dan niet plezier beleven aan nonsens voor deze jonge kinderen als het ware op de onder- en bovengrens van het limineel gebied waarin de speelse manipulatie van nieuw verworven kennis functioneel is voor het vergroten van hun 'controle over de wereld'. Aan de ondergrens van dat gebied is hun grip op (kennis van) de werkelijkheid nog niet stevig genoeg om ermee te spelen; aan de bovengrens van dat gebied is hun grip al te stevig en heeft het spel geen toegevoegde waarde meer. Daarnaast is het voor de ludieke beleving van nonsensicale poëzie ook nodig dat kinderen de tekst herkennen (en erkennen) als vorm waarin dit type spel met de werkelijkheid 'veilig' gespeeld kan worden. De herkenning van rijm is voor de kleuters een belangrijke indicator van 'het taalspel poëzie' als bijzondere vorm van taalgebruik op formeel niveau, maar draagt het inhoudelijke spel met de referentiële eigenschappen van taal daar voor de kleuters ook aan bij? In bovenstaand fragment uit de observaties zien we hoe de leerkracht dit probeert te stimuleren: 'maar dit is een grappig versje, he, dus welke vorm zou de zon in dit versje dan hebben?' Slechts twee kinderen gaan hierin mee en stellen dat de zon in het versje vierkant is; de andere kinderen houden vast aan hun ontluikende kennis van de zon. Kleuters in andere groepen herkenden dit gedicht soms als 'gek'. “Ze gaven aan dat deze 'gek' was. 'Gek he juf'," schrijft een leerkracht (2622, logboek week 19) en een andere leerkracht noteert: "De kinderen vonden het wel gek. Reageerden met 'huh' onder het lezen.” (2321, logboek week 19) Deze abstracter vormen van nonsens, niet rechtstreeks ingebed in een externe pragmatische context, helpen niet alle kleuters “... to understand and if possible to control the world - or at least to feel that they are controlling 
it -." (Lurie, 1990, p. 196) De afstemming van nonsensicaliteit in poezie op de culturele competentie en ontwikkeling van kinderen luistert bijzonder nauw.

\section{Poëzie en de representatie van culturele pluriformiteit in de kleuterklas}

Zoals in Hoofdstuk 1 aangegeven, was een van de expliciete uitgangspunten in dit onderzoeksproject dat culturele geletterdheid in de hedendaagse Nederlandse samenleving en cultuur betrekking moet hebben op de veelheid aan culturen die onze samenleving rijk is. Wilna Meijer stelde al: "Dan dient de pluriformiteit in zekere zin in het leerplan van algemene vorming gerepresenteerd te worden. Wel gaat het nog steeds om gedeelde kennis die allen, ongeacht hun culturele achtergrond, moeten verwerven, maar het is kennis van culturele verscheidenheid." (Meijer, 1996, pp. 25-26) In het kader van dit onderzoek gaat het ons overigens niet zozeer om het aanwijzen van kennis 'die allen, ongeacht hun culturele achtergrond, moeten verwerven', maar juist om het achterhalen wat maakt dat kinderliteratuur nauw aansluit bij de ontluikende culturele kennis en vaardigheden waarover 'allen (kinderen in groep 2 en groep 4 van het basisonderwijs), ongeacht hun culturele achtergrond, beschikken'. We zoeken naar aansluiting op de culturele competentie die kinderen in het basisonderwijs van thuis uit meebrengen om hun ontluikende (inter-)culturele geletterdheid van daaruit te stimuleren via kinderliteratuur. Daarom hebben we in het Leeskalenderaanbod verhalen en poëzie uit verschillende landen en culturen bijeengebracht die in al hun verscheidenheid tegelijk ook gedeelde tradities uit de 'cultuur van het dagelijks leven' vertegenwoordigen. Binnen het onderzoeksproject als geheel was culturele diversiteit al deels gerepresenteerd in het kalenderformat door niet alleen Nederlandse vieringen, maar ook vieringen uit andere religieuze en etnische tradities die vertegenwoordigd zijn in de Nederlandse samenleving aan bod te laten komen. Buiten de impliciete vertegenwoordiging van 'transculturele' tekstkenmerken in poëzie in de vorm van muzikaal taalspel en nonsensicaliteit, is in het poëzie-aanbod voor groep 2 ook expliciete aandacht besteed aan culturele pluriformiteit in de vorm van verschillende gebruiken en in de vorm van verschillende talen. De deelvraag die ik wil beantwoorden, is:

KINDERPOËZIE: KWALITATIEVE DEELVRAAG 4d.

Wat vertellen observaties, logboekaantekeningen en gesprekken met leerkrachten met betrekking tot de presentatie van het poëzie-aanbod in de klas, de reacties van de kinderen op deze teksten en hun waardering daarvan ons over de inbedding van culturele pluriformiteit in groep 2 via kinderpoëzie?

Omdat directe aansluiting op de kennis en ervaring, de leef- en belevingswereld bij kleuters cruciaal is voor hun begrip en waardering van poëzie, is de vraag of aandacht voor verschillende gebruiken en/of voor verschillende talen zinvolle ingangen zijn om culturele pluriformiteit al in deze vroegschoolse fase een plaats in het leerplan te geven. 


\section{De berkenning en beleving van 'eigen' talen en gebruiken}

Momenten waarop culturele pluriformiteit expliciet aan bod kwam in het aanbod en/of de verwerkingen van kinderpoëzie in de Leeskalender in groep 2, waren in alle gevallen gekoppeld aan pragmatische contexten van tekstgebruik. De eerste gelegenheid was de herhalingsactiviteit bij het liedje 'Boom versieren' dat in de eerste aanbieding uiteraard gekoppeld was aan de viering van Kerstmis. Bij de eerste aanbieding leerden de kinderen het liedje en beeldden daarbij uit dat ze een kerstboom aan het versieren waren, waarbij ze vervolgens ook zelf nieuwe dingen mochten bedenken die ze (denkbeeldig) in de boom wilden hangen. Deze traditie was in de meeste kleutergroepen bekend: "Heel herkenbaar en dicht bij de belevingswereld. Veel kinderen hadden thuis geholpen, dus ze konden veel vertellen," schrijft een leerkracht (2223, logboek week 13). In een andere groep schreef de leerkracht op wat de kinderen zoal hadden verzonnen: "Dit hangen we in de boom: piek - poppetjes - kerstballetjes - slingers - beren - lampjes - veren - vogelpoppetjes - 'hello-kitties' ridders - tandenbostels - draken - cadeautjes - batman." (1622, logboek week 13) In de herhaling van dit liedje werd de aandacht verschoven naar andere tradities waarbij er iets versierd wordt in het kader van een viering. Op de Leeskalender waren plaatjes te zien met gekleurde paaseieren, een versierde taart, en handen versierd met henna; in de handleiding waren bijpassende adaptaties van de liedtekst opgenomen om te zingen. Dit ter inspiratie om de kinderen zelf te laten vertellen over wat ze thuis versieren bij een feest en dit te verwerken in het liedje. De afbeelding met de handen bracht in een kleutergroep direct herkenning teweeg: "De allochtone meisjes straalden helemaal bij 'handen versieren'. Ze deden ons voor hoe dat gedaan wordt 'met schaapfeest'." (2421, logboek week 13) Bij het terugblikken op het liedje blijkt dat de kinderen in deze groep alle vormen van versieren op de kalender konden plaatsen. De leerkracht noteerde de reacties van de kinderen: "'Dat is een leuk liedje.' 'Ze waren de kerstboom aan 't versieren, optuigen' 'Dat was een liedje' 'Handen versieren met 'n dun penseel, 't schaapfeest, met henna' 'Feesttaart met vuur erop, kaarsjes met vuur, als iemand jarig is'. 'Ze zijn paasei aan het versieren. Als het Pasen is'."' (2421, logboek week 13) Dergelijke kennis van rituele contexten en bijbehorende gebruiken vormt een belangrijk onderdeel van de ontluikende culturele geletterdheid van deze kinderen, ook in relatie tot hun kennis en begrip van 'de poëzie van het dagelijks leven' die in deze pragmatische contexten is ingebed. Ook in het afsluitende gesprek refereert de leerkracht van mijn observatiegroep 2 expliciet aan de keer dat er met henna beschilderde handen op de kalender stonden. Bij die gelegenheid konden de Marokkaanse kinderen in haar groep uitleg geven over bijvoorbeeld het 'schaapfeest' (zoals een meisje het zelf noemde) (evaluatie 2, S24, 18-06-2014).

Herkenning is een belangrijke voorwaarde voor het begrip en de waardering die kleuters voor een tekst hebben en dat geldt eveneens voor het stimuleren van hun 'cultureel pluriform' bewustzijn. Het besef en begrip dat er mensen zijn met andere gebruiken en ook andere talen dan zijzelf komt dan ook vooral tot stand wanneer er kinderen in de groep zitten die die gebruiken of talen kunnen plaatsen. Het Chinese Nieuwjaarsliedje 'Gong xi gong xi' werd in veel groepen gewaardeerd op het niveau van het muzikaal taalspel: "de kinderen waren erg enthousiast over het liedje, we hebben het heel vaak gezongen en erbij gedanst." (1622, logboek week 18) Zelf zingen was lastig, hoewel de kinderen in mijn ob- 
servatiegroep daar wonderwel in slaagden. Toen ik drie weken later kwam kijken bij de behandeling van het carnavalsliedje zongen de kinderen na afloop het hele Chinese liedje mee met de cd (observatie 25, 26-02-2014). Dit betekent echter niet per definitie dat kinderen beseffen dat ze een taal zingen die door heel veel mensen op de wereld gesproken wordt. Dit werd duidelijker in een andere groep: "Moeilijk! Wat wel erg leuk was: 1 jongetje verstaat Chinees vanwege zijn Chinese moeder. Hij verstond dat er eigenlijk 'gefeliciteerd' werd gezongen en wist ook dat ze dat zeiden bij 'Gelukkig Nieuwjaar'." (2221, logboek week 18) Deze concrete herkenning zorgt ervoor dat het liedje context krijgt: het betekent iets. Bij 'Fijne verjaardag voor jou', de Nederlandse versie van 'Happy birthday to you', werd bij de eerste aanbieding al aandacht besteed aan verschillende talen. Ze zongen het lied een keer in het Nederlands en kozen daarna een andere taal. In de handleiding waren verschillende versies opgenomen: Engels (origineel), Antilliaans, Spaans, Arabisch, Duits, Frans en Turks. Een paar versies was ook op de Leeskalender-cd te beluisteren. In de kleutergroepen waar talen werden herkend door kinderen in de klas, versterkte dat de beleving van de kinderen. "Wat rommelig omdat ze allemaal hun eigen variant zongen. Veel betrokkenheid bij eigen taal," rapporteert een leerkracht (1621, logboek week 20). Op de cd was onder meer de Arabische versie te horen waarin ook de muziek in stijl was aangepast en het zogeheten 'ululeren' te horen was (het soort 'gillen met tongbeweging'). Een leerkracht in een groep met verschillende kinderen van Marokkaanse afkomst vroeg of zij deze versie herkenden, maar: “'Wij zingen thuis in Nederlands en bij L ook (reactie Marokkaanse jongen)." Wel was er herkenning van het 'ululeren': "Marokkaans meisje reactie: 'Ik doe dat zo' Je zag haar helemaal glunderen. Juf vroeg: Hoe doe je dat met je tong? 'Klakken' zei L. Ander kind: 'zoals indianen'." (2421, logboek week 20) Deze leerkracht komt hier in het afsluitend gesprek op terug als voorbeeld van een situatie waarin de kinderen het leuk vonden om met elkaars gebruiken kennis te maken (evaluatie 2, S24, 18-06-2014). Dat kinderen die thuis (deels) een andere taal spreken het verjaardagsliedje niet in de thuistaal kennen, kan velerlei redenen hebben. Het wordt in ieder geval ook in andere groepen opgemerkt: "Turkse lln wisten niet hoe het gezongen moest worden (kwam zelfs kijken in map), daarom overgegaan op Duits nalv een reactie van een andere lln," schrijft een leerkracht (2321, logboek week 20). In een andere groep werd deze taalbarrière bij de herhaling van het liedje opgeheven met hulp: "De Turkse stagiaire kon de Turkse versie goed zingen. De Turkse lln in de klas durfden dat niet zo goed, vooral omdat de rest moest lachen. We hebben de Spaanse versie nog aangeleerd en gaan kijken of we deze 'erin' houden bij de verjaardagen." (2221, logboek week 20)

Belangrijk in deze laatste logboekaantekening is het 'vooral omdat de rest moest lachen'. Bij de eerste aanbieding van het liedje noteerde de leerkracht: "We hebben enorm gelachen om de teksten van andere landen!” (2221, logboek week 20) Voor de kleuters klinkt een vreemde taal niet veel anders dan een betekenisloos klankspel. Daarbij is het voor de meeste kleuters nog heel lastig om te bevatten dat iemand anders die taal begrijpt en spreekt. Lachen is hier een signaal dat er geen herkenning optreedt. Een leerkracht merkte dit ook op in haar groep: "Moeilijk om te doorzien dat het in andere landen anders is." (2223, logboek week 20) Bij het eerder besproken klankvers 'Epompee, poedenee, poedenaska' kwam dit al aan het licht. Naar aanleiding van de verwerking van dat vers, waarin expliciet werd ingegaan op verschillende talen, schrijft een leerkracht: "Kinderen 
vonden het moeilijk te begrijpen dat kinderen een andere taal maken, met name omdat er in de klas een geadopteerd jongetje zit dat ook 'gewoon' Nederlands praat." (2321, logboek week 24) Op de Leeskalender was bij dit vers een illustratie te zien met kinderen uit verschillende landen die samen spelen. Naar aanleiding daarvan werd met de kleuters nagedacht over hoe die kinderen elkaar kunnen begrijpen, en met elkaar kunnen spelen, terwijl ze verschillende talen spreken. Tijdens mijn observatie werd duidelijk hoe vreemd het idee dat mensen verschillende talen spreken voor veel kleuters is:

De leerkracht vat samen dat ze op het plaatje dus al een Chinees, een Afrikaans, een Marokkaans, en een Nederlands kindje hebben gezien.

Leerkracht: Hoe kunnen die kindjes elkaar begrijpen?

Kind (j): $\quad$ Naar Maastricht reizen.

Leerkracht: Maar dan spreken ze nog steeds verschillende talen, dus hoe kunnen ze elkaar dan begrijpen?

Kind (m): $\quad$ Nederlands praten.

Leerkracht: Ze kunnen niet allemaal Nederlands praten, het Chinese kindje spreekt Chinees, hoe kunnen ze dan toch samen spelen?

Kind (j): $\quad$ Chinees praten.

Leerkracht: $\quad$ Maar dat spreken de andere kindjes niet.

Kind (j): $\quad$ Dan kan een ander Chinees kindje zeggen wat dat Chinese kindje zegt. [een tolk?]

[de leerkeracht probeert de kinderen van de gesproken talen af te krijgen door steeds te wijzen op de beperkingen van het voorstel: ook dit plan gaat niet door, want op het plaatje zien de kinderen maar 1 Chinees kindje, dus wie moet er dan vertalen?]

Kind (m): Maar je kunt wel tekentjes maken om te laten zien wat ze bedoelen, zo met de handen [ze probeert iets uit te beelden wat ze wel eens heeft gezien, maar zegt dan dat ze vergeten is hoe het gaat] (observatie 31, 26-03-2014)

Uiteindelijk komen ze uit op het idee dat je inderdaad met gebaren duidelijk kan maken wat je bedoelt en dat je op die manier ook best met elkaar kan spelen; de rol die talen (eigen, buitenlandse, fantasie- of andersoortige talen) daarbij kunnen spelen, staat voor de kleuters echter te ver van hun kennis en belevingswereld. Een bestaande taal is voor hen 'gek' of 'grappig' zolang ze die taal niet herkennen, niet verstaan.

Wanneer er wel herkenning optreedt bij kinderen in de klas én het zingen in een andere taal is pragmatisch ingebed in een herkenbare gebruikscontext, dan krijgt deze wijze van inbedding van culturele pluriformiteit in het kinderpoëzie-aanbod wel betekenis voor de kleuters. Een van de leerkrachten vertelt in het afsluitende gesprek dat ze het liedje 'Happy birthday to you' ('Fijne verjaardag voor jou') nu nog steeds bij iedere verjaardag laat zingen in alle talen die de kinderen in de klas thuis spreken (Turks, Marokkaans, Papiaments). De herkenbaarheid is erg leuk voor de kinderen, zegt ze, ze zijn verrast als ze hun eigen taal herkennen: "Net als de Marokkaanse moeder die laatst in de klas was voor de verjaardag van haar dochter. Zij vond het erg leuk toen ze ineens in het Marokkaans begonnen te zingen." (evaluatie 2, S16, 16-06-2014) Buiten het feit dat culturele pluriformiteit in het onderzoeksproject als geheel al deels gerepresenteerd was in de kalender waarin niet alleen Nederlandse vieringen, maar ook vieringen uit andere religieuze en etnische tradities die 
vertegenwoordigd zijn in de Nederlandse samenleving aan bod kwamen, en de impliciete vertegenwoordiging van 'transculturele' tekstkenmerken in poëzie in de vorm van muzikaal taalspel en nonsensicaliteit, kan in het poëzie-aanbod voor groep 2 dus ook expliciete aandacht besteed aan culturele pluriformiteit in de vorm van verschillende gebruiken en in de vorm van verschillende talen. In beide gevallen is het van belang dat er herkenning optreedt bij kleuters: zowel de talen als de gebruiken die aan bod komen, moeten aansluiten op de thuistaal en -cultuur van ten minste een paar van de kinderen in een groep.

\subsection{Conclusies}

In dit hoofdstuk heb ik de inzichten besproken die zijn verkregen op basis van observaties, logboekaantekeningen van en gesprekken met leerkrachten van groepen (1-)2 die gedurende de interventieperiode met de Leeskalender ${ }^{+ \text {Kinderpoëzie }}$ hebben gewerkt. Dit hoofdstuk is gericht op het beantwoorden van de geformuleerde kwalitatief-empirische deelvragen, maar zoals ik in de introductie al aangaf, is de kleuterklas geen volledig gecontroleerde laboratoriumomgeving en spelen er dus altijd andere, 'externe', factoren een rol in het werken met de Leeskalender en in óf en hóe 'het taalspel poëzie' vorm krijgt in de daadwerkelijke praktijk. Het is van belang inzicht te krijgen in deze factoren, niet alleen omdat ze interacteren met de 'indicatoren van canoniciteit', maar ook omdat dit onderzoek beoogt criteria te ontwikkelen voor de selectie van kinderpoëzie die in de praktijk van het basisonderwijs kan bijdragen aan de ontwikkeling van ontluikende culturele geletterdheid. In $\$ 9.2$ ben ik daarom eerst ingegaan op de belangrijkste 'externe' factoren die in de kleuterklas met de Leeskalender en met het daarin opgenomen aanbod van kinderpoëzie interacteren en, soms, interfereren. Ik vat de inzichten kort samen:

SAMENSTELLING VAN DE KLEUTERGROEPENDe eerste belangrijke factor is de samenstelling van de kleutergroepen. Uit methodologische overwegingen zijn we in de ontwikkeling van de interventiematerialen en meetinstrumenten steeds uitgegaan van groep 2 (en groep 4), maar in de praktijk zijn de meeste kleutergroepen combinatiegroepen 1-2. Op een van de scholen werd de Leeskalender alleen met de oudste kleuters uit de combinatiegroep apart behandeld en dit kon in de praktijk alleen op dagen dat beide groepsleerkrachten aanwezig waren. Dit had een negatief effect op de 'kalendertrouw' in deze groep. Leerkrachten van andere groepen gaven echter ook bij verschillende teksten aan dat verschillen in begrip en voorkeuren tussen de jongste en oudste kleuters de verwerking negatief beïnvloedden. Soms werkte verschillen in begrip juist in het voordeel omdat er discussie ontstond. Niet alleen de tekst, maar ook de gekozen verwerkingsvorm speelt hierin een belangrijke rol. Centraal begrip in dezen is 'betrokkenheid': ongeacht verschillen in het begrip van een tekst, is het van cruciaal belang dat de betrokkenheid van de jongste en oudste kleuters niet verschilt. Omdat de meeste kleutergroepen combinatiegroepen zijn, kan uit de conclusies met betrekking tot de indicatoren worden afgelezen welke teksten en aanbiedingsvormen 'werkten' voor alle kleuters (zie hieronder). 
VOORKEUREN, ATTITUDES EN VAARDIGHEDEN VAN LEERKRACHTEN De tweede belangrijke factor wordt gevormd door 'de leerkracht', als belichaming van zowel school- als persoonsafhankelijke voorkeuren, attitudes en vaardigheden. Op schoolbreed niveau werden we, ondanks dat scholen van te voren op de hoogte waren gesteld van de soorten teksten in het Leeskalenderaanbod, geconfronteerd met aan specifieke genres gerelateerde problemen of zelfs weigeringen op basis van de denominatie en/of het beleid van de school. Buiten deze schoolbrede attitudes, waar leerkrachten ongeacht hun eigen overtuigingen en voorkeuren mee te maken hadden, waren in de dagelijkse Leeskalenderpraktijk in de klas ook voorkeuren en attitudes van individuele leerkrachten waarneembaar die de overdracht van het tekstaanbod op de kinderen merkbaar beïnvloedden. Die voorkeuren en attitudes konden betrekking hebben op de inhoud van teksten (die leerkrachten af en toe bij voorbaat al te moeilijk of ongeschikt voor de doelgroep vonden), maar ook op de vorm van teksten. Ik heb grote verschillen in de performance van poëzie door leerkrachten waargenomen en sommige leerkrachten namen die verschillen zelf ook waar. Leerkrachten kunnen een persoonlijke voorkeur hebben voor verhalen dan wel poëzie, maar dit zou de tekstbeleving in de aanbieding eigenlijk niet te sterk mogen beïnvloeden. Expliciete (persoonlijke) instructie in de voordracht van verschillende soorten rijmen, liedjes en gedichten zou kunnen helpen om niet de voorkeuren, maar de vaardigheden van leerkrachten meer te 'controleren'.

INPASSING IN HET PROGRAMMA: TAAL EN THEMA IN HET KLEUTERONDERWIJS “In de kleuter-groepen draait bijna alles om taal," concludeert een van de leerkrachten tijdens het afsluitende gesprek (evaluatie 2, S13, 23-6-14). Het was regelmatig merkbaar dat de Leeskalenderactiviteiten werden aangegrepen als extra mogelijkheid om expliciet aandacht te besteden aan de taalontwikkeling van de kinderen (woordenschat, fonologisch bewustzijn). Zolang die aandacht voor taalontwikkeling om de aanbieding en verwerking van teksten heen wordt toegevoegd, lijkt dit geen invloed te hebben op hoe kinderen het aanbod begrijpen $^{187}$ en waarderen. Echter, in de gesprekken na afloop van de interventie is merkbaar dat leerkrachten in de kleutergroepen ook minder gericht zijn op de bijdrage van het aanbod aan 'culturele geletterdheid'; veel vaker ging hun aandacht uit naar de relatie tussen het aanbod en de taalontwikkeling van de kinderen. De idee van culturele geletterdheid lijkt in de kleutergroepen minder gemakkelijk te aarden dan in groepen 4, hoewel kleuterleerkrachten het gevarieerde aanbod van genres en tekstsoorten wel waardeerden. Expliciete toelichting op wat met culturele geletterdheid bedoeld wordt en hoe dit zich verhoudt tot geletterdheid en taalontwikkeling kan helpen om dit concept ook in kleutergroepen inbedding te geven. Belangrijker is dat in alle kleutergroepen aansluiting van de Leeskalender op het thematisch werken in de klas werd gemist. Dit was ons al tijdens de eerste expertraadpleging verteld, maar vanuit onderzoeksperspectief hadden we daar in het interventiemateriaal slechts op het gebied van de vieringen van het jaar rekening mee gehouden (zie Hoofdstuk

\footnotetext{
${ }^{187}$ Het gaat hier niet om het uitleggen van moeilijke woorden die van belang zijn voor het begrijpen van een verhaal of gedicht: deze woorden en een mogelijke uitleg of vervangend woord waren, per tekst, opgenomen in de handleiding en onderdeel van de aanbieding en/of verwerking. Leerkrachten hadden expliciet de instructie gekregen om teksten zoveel mogelijk ononderbroken voor te lezen. Ik heb ook niet waargenomen dat leerkrachten een verhaal of gedicht onderbraken voor uitleg van woorden.
} 
6). Voor doorontwikkeling van de interventiematerialen naar een bruikbaar product voor de onderwijspraktijk is dit echter een belangrijk punt voor aanpassing.

In $₫ 9.3$ heb ik per kwalitatief-empirische deelvraag de inzichten uit observaties, logboekaantekeningen van en gesprekken met leerkrachten besproken met betrekking tot de verwachte 'indicatoren van canoniciteit' die ik, zoals uiteengezet in Hoofdstuk $3 \mathrm{t} / \mathrm{m} 5$, heb geformuleerd voor de kinderpoëzie, gespecificeerd naar groep 2 en groep 4. Ook de inbedding van culturele pluriformiteit in het aanbod van kinderpoëzie is aan de orde gekomen. Op basis van de verkregen inzichten uit de praktijk van de kleutergroepen, vat ik hier de belangrijkste conclusies eerst per deelvraag samen om vervolgens in een synthese enkele algemene conclusies te trekken over de aanbieding van kinderpoëzie in de kleutergroepen.

\section{Beantwoording van de eerste kwalitatief-empirische deelvraag}

KINDERPOËZIE: KWALITATIEVE DEELVRAAG 4a.

Wat vertellen observaties, logboekaantekeningen en gesprekken met leerkrachten met betrekking tot de presentatie van het poëzie-aanbod in de klas, de reacties van de kinderen op deze teksten en hun waardering daarvan ons over de rol van 'de directe evocatie van poëtisch geritualiseerde handelingspatronen in de context van feesten en spel’, onderverdeeld in

(i) fysieke handelingspatronen (zoals wiegen, dansen, klappen, et cetera), en

(ii) performatieve taalhandelingen (zoals wensen, aftellen, verwensen, verzoeken, et cetera) in processen van poëzieverwerving bij kinderen in groep 2?

Mijn verwachting is dat voor kinderen in groep 2 de evocatie van poëtisch geritualiseerde fysieke handelingspatronen het sterkst bijdraagt aan poëzieverwerving, anders dan in groep 4 waar de evocatie van poëtisch geritualiseerde taahandelingen naar verwachting beter aansluit op de culturele competentie en voorkeuren van de kinderen. In hoeverre wordt deze verwachting voor groep 2 door de verkregen kwalitatieve data ondersteund? Hoe werkt het samenspel tussen tekst en pragmatische context in de praktijk van de kleuterklas? En zijn er in de verwerving van poëzie bij kleuters verschillen waar te nemen in de werking van handelingspatronen in de context van vieringen en spel? Op basis van de hierboven beschreven kwalitatieve inzichten, kan de eerste kwalitatieve deelvraag voor groep 2 als volgt beantwoord worden:

1. Poëzie waarin de context van een viering direct wordt geëvoceerd, wordt door de kleuters alleen als zodanig gewaardeerd binnen de in tijd en plaats afgebakende pragmatische context, i.e. een feestlied of -rijm is alleen zinvol/betekenisvol als feestlied of -rijm binnen de betreffende viering (Dierendag, verjaardag, Sinterklaas, et cetera);

2. In het samenspel tussen 'het taalspel poëzie' en de bijbehorende concrete rituele gebruikscontext (viering) worden processen van betekenisgeving bemiddeld door de uitvoering en daarmee de directe ervaring van fysieke rituele gebruiken die de bijbehorende rituele context oproepen, i.e. bij de kleuters werkt poëzie in rituele contexten als onderdeel van de rituele structuur, het geheel van rituele handelingspatronen; 
3. Wanneer we specifiek kijken naar de verhouding tussen talig en fysiek handelen met poëzie in rituele contexten, dan zien we dat het talig handelen op zichzelf nog geen 'autonome' betekenis heeft in de belevingswereld van de kleuters, i.e. dát je een verjaardagsliedje doet als iemand jarig is, dat weten ze wel, maar wát dat verjaardagsliedje op zich doet -als culturele vorm waarmee je iemand iets toewenst - voegt voor de kleuters op zichzelf niets toe aan de beleving en betekenis van 'het taalspel poëzie' in rituele contexten;

4. Bekijken we 'het taalspel poëzie' in de pragmatische context van spel, dan blijkt de koppeling van 'het taalspel poëzie' aan niet-vocale (fysieke) spelhandelingen, zoals stampen, klappen, bukken, et cetera, zeer sterk bij te dragen aan de beleving en waardering van 'het taalspel poëzie' bij kleuters, i.e. ze waarderen poëzie gekoppeld aan fysieke spelhandelingen omdat ze mogen meestampen, -klappen of bukken.

'De directe evocatie van poëtisch geritualiseerde fysieke handelingspatronen in de context van feesten en spel' is dus inderdaad een cruciale indicator van canoniciteit in poëzie voor kinderen in groep 2, mits feestliedjes en -rijmen worden aangeboden binnen de context van de betreffende viering, waarbij de nadruk ligt op het doen van het lied of rijm als onderdeel van de rituele structuur (de overige handelingen die bij de viering horen). Dat rituele kader, opgeroepen door de directe beleving van fysieke handelingspatronen, geeft functie en betekenis aan het gebruik van de tekst. Een liedje is pas een carnavalsliedje als het onderdeel is van (de voorbereiding van) de viering van Carnaval, een Dierendagvers wordt niet beleefd en gewaardeerd als Dierendagvers als het geen Dierendag is, zoals ook een verjaardagsliedje niet wordt beleefd en gewaardeerd als verjaardagsliedje als er niemand jarig is. Ook fysieke spelhandelingen dragen sterk bij aan de beleving en waardering van 'het taalspel poëzie' bij kleuters: beweging makt poëzie tot spel, dus spel als pragmatische context wordt via fysieke handelingspatronen geëvoceerd.

\section{Beantwoording van de tweede kwalitatief-empirische deeluraag}

KINDERPOËZIE: KWALITATIEVE DEELVRAAG 4b.

Wat vertellen observaties, logboekaantekeningen en gesprekken met leerkrachten met betrekking tot de presentatie van het poëzie-aanbod in de klas, de reacties van de kinderen op deze teksten en hun waardering daarvan ons over de rol van 'muzikaal taalspel', onderverdeeld in

(i) vormen van muzikaal taalspel ter ondersteuning van non-verbale handelingspatronen, en

(ii) vormen van muzikaal taalspel als relatief autonoom spel

in processen van poëzieverwerving bij kinderen in groep 2?

Mijn verwachting is dat vormen van muzikaal taalspel ter ondersteuning van non-verbale handelingspatronen beter aansluiten op de culturele competentie en voorkeuren van kinderen in groep (1-)2, terwijl kinderen in groep 4 al beter uit de voeten kunnen met de meer autonome vormen van muzikaal taalspel. In hoeverre wordt deze verwachting voor groep (1-)2 door de verkregen kwalitatieve data ondersteund? Hoe werkt 'muzikaal taalspel' in de praktijk van de kleuterklas? In hoeverre en in welke vorm(en) draagt deze indicator bij aan het plezier dat kleuters aan poëzie beleven? Op basis van de hierboven beschreven kwalita- 
tieve inzichten, kan de tweede kwalitatieve deelvraag voor groep 2 als volgt beantwoord worden:

1. We hebben gezien dat kleuters in verschillende instanties (voor hen) nieuwe patronen in 'muzikaal taalspel' ontdekten en dit spontaan meedeelden: 'Hé juf, het rijmt!' In relatie tot hun (taal- en humor-) ontwikkeling stimuleert poëzie gekenmerkt door muzikaal taalspel waarin grappige namen van personages onderdeel zijn van het rijmpatroon deze onverwachte herkenning van een patroon dat kleuters beloont met het gevoel dat ze iets nieuws hebben ontdekt (waar ze veel plezier aan beleven);

2. Het plezier dat kleuters aan 'muzikaal taalspel' in poëzie beleven, kan op verschillende manieren verstoord worden: (a) door van ze te vragen om 'in de trant van' een vers zelf nieuwe rijmende variaties te verzinnen als ze niet bekend zijn met het vers, (b) door van ze te vragen om op meta-tekstueel niveau na te denken en te praten óver muzikaal (in referentiële zin) betekenisloos taalspel, of (c) doordat er in 'muzikaal taalspel' woorden een centrale rol spelen die verwijzen naar iets dat voor de kleuters te ver van hun leefen belevingswereld verwijderd is en daarmee de aandacht van de kleuters afleiden van de muzikaliteit van het vers (zoals 'Amsterdam, Rotterdam'). Afleiding van het 'muzikaal taalspel' in poëzie gebeurt bij de kleuters sneller wanneer ze niet expliciet kunnen meedoen met de performance. Alleen maar 'zitten en luisteren' is nadelig voor hun beleving van en plezier in 'muzikaal taalspel', meezingen of -zeggen is al beter, maar fysiek handelen dat het muzikaal taalspel expliciet ervaarbaar maakt, is het best;

3. Poëzie met veel rijm, een sterk muzikaal metrum en andere ritmische patronen, i.e. 'muzikaal taalspel', valt bij de kleuters vooral in de smaak als en omdát het verbaal en vooral ook non-verbaal meedoen stimuleert: klappen, stampen, dansen of bukken máken 'het taalspel poëzie' voor kleuters. Het zijn de klankliedjes verbonden aan ritmische beweging die bij de kleuters het sterkst in de smaak vielen en ook het best werden onthouden (zie conclusie 4, deelvraag 4a).

De actieve fysieke verwerkingsvormen brengen echter ook enig 'risico' met zich mee. Een leerkracht schrijft over de aanbieding en verwerking van 'Lekker stampen met dit weer': "Ik heb de activiteit in de speelzaal gedaan. ... Kinderen vonden het stampen leuk, werden er echter nog drukker van.” (2321, logboek week 4) En soms werd de actieve verwerking preventief achterwege gelaten: "leerlingen waren vandaag te druk om erbij te bewegen" (2622, logboek week 24) Hoewel in de kleutergroepen nog veel ruimte en aandacht is voor beweging en spel wordt met name bij de oudere kleuters ook al aandacht besteed aan specifiek schoolse gebruiken die ze zeker vanaf groep 3 geacht worden te kennen. Tijdens een van mijn observaties was ik getuige van het proces van expliciete socialisatie van de groep 2 kinderen in de 'schoolcultuur':

Leerkracht: We hebben iets nieuws geleerd. Weten jullie nog wat? [Een paar kinderen steek.t een vinger op]

Kind (j): $\quad$ Vinger opsteken! (roept hij zonder eerst zijn vinger op te steken)

Leerkracht: Ja, dat je je vinger opsteekt als je iets wilt zeggen. (observatie 12, 4-12-13) 
In de kleutergroepen wordt actief gewerkt aan het aanleren van verschillende 'houdingen'. De luisterhouding, bijvoorbeeld, was in dezelfde groep 2: rechtop op de stoel zitten, twee voeten op de grond en handen in de schoot. Spontaniteit en beweeglijkheid worden stukjebij-beetje ingeperkt en krijgen hun eigen inkadering in tijd en ruimte. Zeker in kleutergroepen waar de Leeskalender tijdens de fruitkring of tijdens de eet- en drinkpauze behandeld werd, waren fysiek actieve verwerkingsvormen niet altijd handig: "We hebben op de plaats gestampt omdat ze aan het eten waren. Hierdoor hebben we het een beetje anders gedaan." (2223, logboek week 4) Gezien het feit dat kleuters zo overtuigend genieten van de ritmische beweging bij 'het taalspel poëzie' en dat ze fysiek meedoen ook nodig hebben om poëzie als poëzie, als 'onalledaagse' rituele taalhandeling, te ervaren, is het een groot gemis als daar om genoemde redenen geen plaats voor kan zijn in de kleuterklas. Het moet een gepaste tijd en plaats hebben (en dat heeft het in voor- en vroegschoolse educatie vaak ook). In het kader van een Leeskalender die ook lange luisterverhalen bevat, moet dan nagedacht worden over het moment en de plaats waarop het 'muzikale taalspel poëzie' gekoppeld aan fysieke spelvormen kan worden aangeboden.

\section{Beantwoording van de derde kwalitatief-empirische deelvraag}

\section{KINDERPOËZIE: KWALITATIEVE DEELVRAAG 4c.}

Wat vertellen observaties, logboekaantekeningen en gesprekken met leerkrachten met betrekking tot de presentatie van het poëzie-aanbod in de klas, de reacties van de kinderen op deze teksten en hun waardering daarvan ons over de rol van '(carnavaleske) nonsensicaliteit', onderverdeeld in

(i) carnavaleske vormen van nonsensicaliteit bemiddeld door subversief fysiek handelen in relatie tot de sociale context en de culturele categorieën (waarden en normen) die in die sociale context gelden, en

(ii) carnavaleske vormen van nonsensicaliteit bemiddeld door subversief talig handelen in relatie tot de sociale context en de culturele categorieën (waarden en normen) die in die sociale context gelden, en

(iii) vormen van nonsensicaliteit die een meer intellectuele ervaring van 'incongruentie' teweegbrengen, bemiddeld door een voorstelling van de werkelijkheid die afwijkt van de 'natuurlijke wetmatigheden' die gelden in de waarneembare of conceptuele werkelijkheid in processen van poëzieverwerving bij kinderen in groep 2?

Mijn verwachting is dat kinderen in groep 2 de intellectueler vormen van nonsensicaliteit ook kunnen waarderen, mits gerelateerd aan de waarneembare werkelijkheid en ondersteund door visualisatie (bijvoorbeeld door uitbeelden). Echter, mijn verwachting is dat zowel kinderen in groep 2 als kinderen in groep 4 generaliter carnavaleske (op de sociaalculturele context gerichte) nonsensicaliteit sterker waarderen dan de meer intellectuele vormen van nonsensicaliteit. In relatie tot ontwikkelingskenmerken van kinderen in groep 2 en in groep 4 is te verwachten dat kinderen in groep 2 nog sterk steunen op de waarneembare werkelijkheid en subversief fysiek handelen voor het ervaren en waarderen van (carna- 
valeske) nonsensicaliteit. Op basis van de hierboven beschreven kwalitatieve inzichten, kan de derde kwalitatieve deelvraag voor groep 2 als volgt beantwoord worden:

1. De herkenning van (carnavaleske) nonsensicaliteit in poëzie als rituele taalhandeling komt bij kleuters vooral tot stand via een meervoudige pragmatische inbedding en cognitieve en sociale verankering van 'het taalspel poëzie'. Binnen de pragmatische context van de viering van 1-april als 'grapjesdag', bijvoorbeeld, kan een vers door kleuters worden begrepen als 'grapje' en de leerkracht als iemand die het 'grapje' maakt;

2. Daarbij moet de 'grap', de incongruentie, gemakkelijk te snappen of te weerleggen zijn voor de kleuters, dus aansluiten op de concreet waarneembare werkelijkheid en hun kennis van de wereld. Dit maakt het voor de kleuters gemakkelijker een vers en het taalspel dat daarin gespeeld wordt te herkennen als 'niet echt' en 'veilig ingekaderd', waardoor ze het carnavalesk nonsensicale spel ook als plezierig en grappig kunnen beleven en meespelen;

3. De ervaring van incongruentie en daar plezier aan beleven, wordt bij kleuters vooral ondersteund door concrete handelingsgerichte nonsens, op basis van (de voorstelling van) subversief fysiek handelen in relatie tot de waarneembare werkelijkheid, waarbij de context van de schoolklas zich goed leent om op te treden als 'carnavalesk kader' ('gekke-dingen-school');

4. Het al dan niet pleqier beleven aan de ervaring van incongruentie via de aanbieding van nonsenspoëzie balanceert voor kleuters als het ware op de onder- en bovengrens van het limineel gebied waarin de speelse manipulatie van nieuw verworven kennis functioneel is voor het vergroten van hun 'controle over de wereld'. Aan de ondergrens van dat gebied is hun grip op (kennis van) de werkelijkheid nog niet stevig genoeg om ermee te spelen; aan de bovengrens van dat gebied is hun grip al te stevig en heeft het spel geen toegevoegde waarde meer. Deze nauwkeurige afstemming op de intellectuele behoeften' van kleuters is het meest cruciaal, maar ook het meest lastig zeker in combinatiegroepen 1-2 waar die behoeften ver uiteen kunnen lopen, wanneer er geen sprake is van inbedding in een externe pragmatische context die een nonsensvers van rituele functie en betekenis voorziet.

Humor wordt door leerkrachten in de kleutergroepen wel genoemd als kenmerk dat bijdraagt aan de waardering van teksten door de kinderen: "Wat draagt het meest bij aan de waardering die kinderen voor een tekst hebben? De leerkracht antwoordt onmiddellijk: 'Humor'. Volgens haar is dat ook de reden dat de kinderen daarom Hodja zo leuk vonden [uit het deelproject Narratieve Genres]. 'Vooral omdat Hodja niet zo slim is en zij dan slimmer zijn. Dat doet het goed. En Mr. Van Zoeten, dat het vies is dat hij zijn voeten maar één keer per week wast. Dat ze het grappig vinden, dat werkt meestal het best en puur het rijmen ook."' (evaluatie 2, S16, 16-06-2014) Echter, dát kleuters iets grappig vinden, vereist een zeer nauwkeurige afstemming op hun ontluikende culturele competentie, inclusief hun kennis van de wereld en cognitieve ontwikkeling. Kleuters herkennen 'het taalspel poëzie' niet vanzelfsprekend als rituele taalhandeling, als kader waarbinnen een spel met de representatie van de werkelijkheid kan worden gespeeld zonder dat dat iets hoeft te veranderen aan hoe wij de werkelijkheid kennen en begrijpen. Voor (carnavaleske) nonsensicali- 
teit in kinderpoëzie geldt dan dat het als tijdelijk spel herkenbaar moet zijn én dat kleuters zeker genoeg zijn van hun kennis van de wereld om daar een spel mee te spelen. Pragmatische contextualisering en verankering in de waarneembare werkelijkheid zijn belangrijke voorwaarden voor de plezierige ervaring van incongruentie via 'het taalspel poëzie' bij kleuters.

Beantwoording van de vierde kwalitatief-empirische deelvraag

KINDERPOËZIE: KWALITATIEVE DEELVRAAG 4d.

Wat vertellen observaties, logboekaantekeningen en gesprekken met leerkrachten met betrekking tot de presentatie van het poëzie-aanbod in de klas, de reacties van de kinderen op deze teksten en hun waardering daarvan ons over de inbedding van culturele pluriformiteit in groep 2 via kinderpoëzie?

Omdat directe aansluiting op de kennis en ervaring, de leef- en belevingswereld bij kleuters cruciaal is voor hun begrip en waardering van poëzie, is de vraag of aandacht voor verschillende gebruiken en/of voor verschillende talen zinvolle ingangen zijn om culturele pluriformiteit al in deze vroegschoolse fase een plaats in het leerplan te geven. Op basis van de hierboven beschreven kwalitatieve inzichten, kan de vierde - en tevens laatste - kwalitatieve deelvraag voor groep 2 als volgt beantwoord worden:

1. Om herkenning en beleving bij de kleuters tot stand te brengen, moet de representatie van culturele pluriformiteit in het aanbod van kinderpoëzie in de vorm van verschillende talen voor de kleutergroepen specifiek moeten worden afgestemd op de samenstelling van de groep (de talen die vertegenwoordigd zijn);

2. Ook inbedding in een terugkerende pragmatische context helpt de inbedding van verschillende talen in het poëzie-aanbod. Enerzijds omdat het zingen in een andere taal daarmee tot vast gebruik wordt gemaakt; anderzijds omdat de pragmatische context de tekst voor de kleuters van functie en daarmee van betekenis voorziet;

3. Naar aanleiding van poëzie ruimte bieden voor de bespreking van verschillende rituele gebruiken die de kinderen van thuis kennen (welke feesten ze vieren en wat ze dan zoal doen, bijvoorbeeld), biedt eveneens mogelijkheden om culturele pluriformiteit een plaats te geven in het 'leerplan'.

Ook voor de inbedding van culturele pluriformiteit in het aanbod van kinderpoëzie in de kleutergroep spelen handelingsgerichtheid en pragmatische inbedding in contexten van tekstgebruik een belangrijke rol. Opnieuw geldt dat de schoolklas zelf een belangrijk referentiekader vormt waarin begrip van 'vreemde' talen, maar vooral gebruiken tot stand kan komen wanneer een of meerdere kinderen in de groep een taal of gebruik herkennen en hier vanuit eigen ervaring over kunnen vertellen. 


\section{Synthese van de kwalitatief-empirische inzichten in poëzieverwerving in groep (1-)2}

Er is een aantal 'patronen van betekenis' te herkennen in deze inzichten uit de praktijk over factoren die een cruciale rol spelen in processen van poëzieverwerving bij kleuters. Allereerst is er de inbedding van 'het taalspel poëzie' in pragmatische contexten van tekstgebruik. Dit is voor kleuters een factor die sterk bijdraagt aan de totstandkoming van beleving en betekenis in het gebruik van poëzie. Poëzie waarin de context van een viering direct wordt geëvoceerd, wordt door de kleuters alleen als zodanig gewaardeerd binnen de in tijd en plaats afgebakende pragmatische context, i.e. een feestlied of -rijm is alleen zin$\mathrm{vol} /$ betekenisvol als feestlied of -rijm binnen de betreffende viering (Dierendag, verjaardag, Sinterklaas, et cetera). Buiten de specifieke rituele context wijzen de kleuters het betreffende lied of rijm als feestlied of -rijm af. Dit getuigt van een ongelooflijk sterke relatie tussen poëzie en de rituele contexten van tekstgebruik waarin het in de cultuur van het dagelijks leven is ingebed en bevestigt dat 'het taalspel poëzie' haar functie en betekenis voor kleuters nog in hoge mate ontleent aan de externe pragmatische context (zie Hoofdstuk 2). Buiten de rituele context kan een lied, rijm of gedicht 'nieuwe' functie en betekenis krijgen wanneer het wordt verbonden aan fysieke spelvormen: als er niemand jarig is, kan een verjaardagsliedje door kleuters nog best gewaardeerd worden als dansliedje dóór erop te dansen. Deze functionele 'reappropriatie' werkt bij de kleuters echter niet lang. Ze zijn in die zin 'conservatief': een verjaardagslied is en blijft toch een verjaardagslied en als er niemand jarig is, heeft het geen zin, geen functie, om het te doen.

Kleuters zijn zich daarbij nog niet bewust van de specificiteit van het type taalhandeling dat de tekst is; wat je met 'het taalspel poëzie' doet in rituele context is voor hen een fysieke handeling. Bekijken we 'het taalspel poëzie' in de pragmatische context van spel, dan blijkt de koppeling van 'het taalspel poëzie' aan niet-vocale (fysieke) spelhandelingen, zoals stampen, klappen, bukken, et cetera, zeer sterk bij te dragen aan de beleving en waardering van 'het taalspel poëzie' bij kleuters, i.e. ze waarderen poëzie gekoppeld aan fysieke spelhandelingen omdat ze mogen meestampen, -klappen of bukken. Concreet fysiek meedoen (meezingen, -rijmen, dansen, etc.) is de meest effectieve verwerkings- en verwervingsvorm voor de kleuters. Poëzie gekenmerkt door 'muzikaal taalspel' leent zich het best voor concreet fysiek meedoen en valt dus ook het meest in de smaak bij de kleuters. Echter, 'muzikaal taalspel' valt bij de kleuters vooral in de smaak áls en omdát het verbaal en vooral ook nonverbaal meedoen stimuleert: klappen, stampen, dansen of bukken máken 'het taalspel poëzie' voor kleuters. Zonder de directe fysieke beleving van het taalspel gaan kleuters op zoek naar betekenis in de referentiële zin van het woord wat hun beleving in de weg kan staan. Ook poëzie gekenmerkt door (carnavaleske) nonsensicaliteit wordt door kleuters het meest gewaardeerd wanneer ze het concreet handelend kunnen verwerken: door koppeling van het voorgestelde spel met de werkelijkheid aan concreet fysiek spel met de werkelijkheid ontstaat bij kleuters begrip en waardering van de nonsensicaliteit. De waardering is het sterkst voor carnavaleske nonsensicaliteit, gericht op de direct waarneembare context van de school(klas): de school(klas) is een belangrijk kader voor de totstandkoming van de beleving van het carnavaleske. Het al dan niet plezier beleven aan de ervaring van incongruentie via de aanbieding van nonsenspoëzie balanceert voor kleuters op de onder- en bovengrens van het limineel gebied waarin de speelse manipulatie van nieuw verworven kennis 
functioneel is voor het vergroten van hun (gevoelsmatige) 'controle over de wereld'. Dit is in overeenstemming met wat humortheoretici hebben waargenomen:

"McGhee (1979) wijst ... op de incongruentie als grondslag voor de humor, maar wijst er wel op dat die afwijking van het normale niet te ver af moet liggen van wat het kind cognitief aankan, maar ook niet te simpel moet zijn om leuk gevonden te worden. (...) Shultz wijst ook op een ander belangrijk facet: de assimilatie in de fantasie. (...) Pas wanneer de incongruentie op speelse wijze in de fantasie geassimileerd wordt - het is niet echt zo - ontstaat volgens Shultz een echte humorreactie." (Kurvers, 2004, pp. 194-195)

De herkenning van (carnavaleske) nonsensicaliteit in poëzie als rituele taalhandeling - als 'niet echt' - komt bij kleuters vooral tot stand via een meervoudige pragmatische inbedding en cognitieve en sociale verankering van 'het taalspel poëzie'. Binnen de pragmatische context van de viering van 1-april als 'grapjesdag', bijvoorbeeld, kan een vers door kleuters worden begrepen als 'grapje' en de leerkracht als iemand die het 'grapje' maakt. Nonsensicaliteit moet voor kleuters dus herkenbaar en veilig ingekaderd zijn. Dit duidt erop dat dit type taalspel met de referentiële functie van taal voor hen minder vertrouwd is dan 'muzikaal taalspel'. We hebben gezien dat kleuters in verschillende instanties (voor hen) nieuwe patronen in 'muzikaal taalspel' ontdekten en dit spontaan meedeelden: 'Hé juf, het rijmt!' In relatie tot hun (taal- en humor-) ontwikkeling stimuleert poëzie gekenmerkt door muzikaal taalspel waarin grappige namen van personages onderdeel zijn van het rijmschema deze onverwachte herkenning van een patroon dat kleuters beloont met het gevoel dat ze iets nieuws hebben ontdekt (waar ze veel plezier aan beleven). Dit duidt er enerzijds op dat 'rijm' in principe onderdeel is van de verwachtingshorizon van kleuters, maar dat ze plezier beleven aan het (onverwacht) opmerken van een voor hen vernieuwend klankpatroon. Mijns inziens geeft dit aan dat 'muzikaal taalspel' in de vorm van rijm een convergentiepunt is tussen tekstuele kenmerken van 'het taalspel poëzie' en de culturele competentie van kleuters. Hier vormt de tekst het referentiekader en niet de externe pragmatische context. 


\section{HOOFDSTUK 10}

Het taalspel poëzie in groep 4:

De verinnerlijking van de pragmatische context 



\subsection{Introductie}

Ook de kinderen in groepen 4 op de deelnemende scholen in de experimentele conditie hebben via de Leeskalender ${ }^{+K i n d e r p o e ̈ z i e ~}$ dertig weken lang kennisgemaakt met allerlei rijmen, liedjes en gedichten. Ze hebben erbij gezongen, geklapt, gestampt, uitgebeeld, voorgedragen; ze hebben zelf gerijmd, ze hebben op teksten gevarieerd, ze hebben erover nagedacht en gepraat. Net als in groep 2 bevatten alle rijmen, liedjes en gedichten in de Leeskalender voor groep 4 een of meerdere van de geformuleerde 'indicatoren van canoniciteit', te weten (a) 'de directe evocatie van poëtisch geritualiseerde handelingspatronen gekoppeld aan feesten en spel', in combinatie met: (b) 'muzikaal taalspel' en/of (c) '(carnavaleske) nonsensicaliteit'. Echter, de specifieke verwachtingen over de vorm waarin en manier waarop deze indicatoren meespelen in de voorkeuren voor en waardering van vormen van het taalspel poëzie' bij kinderen in groep 4 zijn net even anders. Ook voor groep 4 zijn eigen observaties, logboekaantekeningen van en gesprekken (semigestructureerde interviews) met leerkrachten gebruikt om inzicht te krijgen in 'het taalspel poëzie' in de klas. De onderzoeksvraag die ik hiermee beoog te beantwoorden, is:

\section{KWALITATIEF-EMPIRISCHE ONDERZOEKSVRAAG}

4. Welke contextuele, tekstuele en ontwikkelingskenmerken zijn cruciaal te noemen in processen van de verwerving van langdurig geliefde en (trans)cultureel diepgewortelde vormen van 'het taalspel poëzie' bij kinderen in groep 4 op basis van observaties, logboekaantekeningen en gesprekken met leerkrachten met betrekking tot de presentatie van het tekstaanbod in de klas, de reacties van de kinderen op deze teksten en hun waardering daarvan?

In dit hoofdstuk komen opnieuw - net als in Hoofdstuk 9 - de deelvragen zoals weergegeven in Tabel 18 (Hoofdstuk 7, \$7.8) aan bod voor 'het taalspel poëzie', nu met betrekking tot groep 4. De kwalitatieve data zijn op dezelfde wijze verkregen als voor de kleutergroepen het geval was. De observaties zijn uiteraard ook hier momentopnamen en er is daarbij altijd sprake van een zeker 'observatie-effect' waardoor de geobserveerde realiteit ook weer beïnvloed wordt. Om de geldigheid van inzichten voor groep 4 te versterken, heb ik na afloop van de interventieperiode de inzichten uit de observaties vergeleken met wat leerkrachten, ook uit de andere groepen $4^{188}$, in de logboeken noteerden en wat er uit de gesprekken met leerkrachten naar voren kwam. Zo ontstond een beeld van de realiteit in groep 4, de belangrijkste 'externe' factoren die daarin van invloed zijn op hoe het taalspel poëzie in het kader van de Leeskalender vorm krijgt en de belangrijkste kenmerken die bijdragen aan processen van poëzieverwerving.

Eerst bespreek ik de belangrijkste 'externe' factoren die in de groepen 4 van invloed waren op de aanbieding van de Leeskalender - en daarin de kinderpoëzie - in de klas

\footnotetext{
${ }^{188}$ De school die vroegtijdig gestopt is niet meegerekend, werd in totaal in 10 groepen 4 op 7 scholen met een Leeskalender ${ }^{+ \text {Kinderpoëzie }}$ gewerkt; daarvan werkten 4 scholen (6 groepen) met de volledige versie, 2 scholen (3 groepen) met de versie zonder Narratieve Genres, en 1 school (1 groep) met de versie zonder Deugden \& Dilemma's. Omdat dit onderzoek niet tot doel heeft de deelprojecten met elkaar te vergelijken, laat ik de scholen waarop geen kinderpoëzie is aangeboden buiten beschouwing.
} 
(\$10.2). Vervolgens bespreek ik de inzichten verkregen uit observaties, logboekaantekeningen van en gesprekken met leerkrachten met betrekking tot de verwachte 'indicatoren van canoniciteit' voor kinderpoëzie in groep 4 (\$10.3). Dat doe ik per deelvraag en de daarbij geformuleerde verwachtingen. Ten slotte trek ik conclusies, zowel met betrekking tot de 'externe' factoren als met betrekking tot de verwachte indicatoren (\$10.4).

\subsection{Een globaal beeld van de Leeskalender en poëzie in groep 4}

Deze eerste fase had tot doel een beeld te krijgen van het werken met de Leeskalender in groepen 4 op verschillende scholen. Wat zijn de belangrijkste 'externe' factoren die in die dagelijkse onderwijspraktijk van invloed zijn op hoe teksten worden aangeboden en verwerkt? Ook voor groep 4 geldt dat de klas geen volledig gecontroleerde laboratoriumomgeving is, maar een 'natuurlijke' omgeving waarin meerdere variabelen meespelen die niet direct betrekking hebben op de geformuleerde 'indicatoren van canoniciteit', maar wel interacteren met het specifieke onderzoeksobject. De kwalitatieve inzichten in poëzieverwerving bij kinderen in groep 4 die ik in dit hoofdstuk beschrijf, hebben daarmee nooit zuiver betrekking op de geformuleerde indicatoren van canoniciteit, maar interacteren altijd met andere factoren die in de praktijk meespelen. Tegelijk is het interessant om juist in de strak volgeplande doch altijd veranderlijke praktijk van groep 4 te bekijken welke teksten 'overeind' blijven en welke niet, welke kenmerken structureel 'werken' en welke niet. Het is dan echter wel van belang een beeld te krijgen van die praktijk en de belangrijkste 'externe' factoren die mede van invloed zijn op hoe het 'taalspel poëzie' vorm krijgt in de klas. Observaties, logboekaantekeningen van leerkrachten en de gesprekken die met leerkrachten zijn gevoerd over hun ervaringen, helpen dat beeld te schetsen.

\section{Inpassing in het programma: tijd, tijd, en nog eens tijd...}

“Op de dag dat het klapspelrijm 'Dubbel dubbel dit dit' op de planning staat, kijk ik in een van de groepen 4 mee naar hoe deze Leeskalenderactiviteit in de klas vorm krijgt. Het is het einde van de dinsdagmiddag, er is hard gewerkt en er staan nog tien minuten op de klok wanneer ze aan de Leeskalender beginnen. Ik ben benieuwd hoe ver ze komen... In deze groep weten de kinderen altijd veel te vertellen. Bij het zien van de afbeeldingen op de Leeskalender en het bijbehorende inleidende gesprekje over wat de kinderen zelf op het schoolplein spelen, komt er al zoveel los dat ze hier gemakkelijk tot het einde van de schooldag over door kunnen praten. Maar daar is geen tijd voor. De leerkracht doet het vers met bijbehorend klapspel een keer voor met een van de jongens. Het is even puzzelen, maar ze komen er wel uit. Vervolgens doen de leerkracht en de jongen het nog een keer voor. De leerkracht verdeelt de klas daarna in paren en zegt dat de kinderen nu mee mogen doen met de bewegingen. Zodra ze begint, springen de kinderen op, verspreiden zich over het klaslokaal en beginnen met elkaar het rijm en klapspel te doen. De leerkracht komt er niet eens aan toe om het hele vers nog een keer voor te doen want er is in één klap chaos. Voorin is een jongen die weigert om mee te doen waardoor zijn partner wat verloren heen en weer loopt. Achter in de klas heeft een van de meisjes het klapspel al een keer gedaan 
met haar aangewezen partner en legt zich nu toe op het helpen van andere kinderen. Bij sommige kinderen gaat het goed; anderen raken steeds de draad kwijt. Er wordt geklapt, gerijmd, gediscussieerd en gelachen. De leerkracht probeert hier en daar aanwijzingen te geven en is tegelijk bezig om de weigeraar streng toe te spreken. Ondertussen komt er een meisje het lokaal binnen die weg was om een toets te maken en nu geen flauw idee heeft wat er aan de hand is en twee tellen later gaat de schoolbel." (observatie 15, 14-01-2014)

In de kleutergroepen waren 'taal en thema' de belangrijkste factoren die meespeelden in hoe leerkrachten de inpassing van de Leeskalender in het dagelijkse programma ervoeren. De belangrijkste externe factor die de inpassing van de Leeskalenderactiviteiten in groep 4 beïnvloedde was: tijd. Feitelijk: een gebrek aan tijd. Hoewel leerkrachten het werken met de Leeskalender in de kleutergroepen ook als intensief ervoeren en best eens een dag oversloegen, vonden zij zonder uitzondering een vast moment op de dag waarop standaard met de Leeskalender werd gewerkt. Of dat nu tijdens het eten, de (fruit)kring, aan het begin of einde van de ochtend, aan het begin of einde van de middag was. In groepen 4 bleek dat een grotere uitdaging. Niet alleen hebben ze een zeer vol lesprogramma, er zijn ook nog eens allerlei projecten en tussentijdse activiteiten, studiedagen, toetsperiodes, en ga zo maar door. Een van de leerkrachten vertelt tijdens het afsluitende gesprek dat het structureel dagelijks werken met het materiaal in groep 4 heel lastig was, hoewel ze op de Leeskalender als geheel terugkijkt als een prettige activiteit. Het eerste half jaar is in groep 4 al zeer intensief omdat de kinderen veel nieuwe vakken en lesstof krijgen waar vaak al meer tijd voor nodig is dan gepland, legt ze uit. Daardoor heeft deze leerkracht zeker op de keuzedagen/terugblikdagen de Leeskalender regelmatig overgeslagen: ze kreeg het gewoon niet allemaal gedaan in de tijd (evaluatie 2, S24, 18-06-2014). Een andere leerkracht legt uit dat ze bewust niet tijdens het eten met de Leeskalender heeft gewerkt, al was dat wel een schaarse mogelijkheid om een vast moment te kiezen: 'Onder het eten lezen we ook vaak voor, maar die interactie is gewoon lastig als kinderen brood zitten te eten. Dat is dan inderdaad meteen het nadeel: het [de Leeskalender] is vijf keer een kwartier in de week. Dus het gaat wel ten koste van tijd voor andere dingen. Van de ene kant is het heel leuk en leerzaam, maar van de andere kant zijn er ook wel eens andere dingen die voorrang moeten hebben.' (evaluatie 2, S23, 25-06-2014) Dat het structureel inplannen van de Leeskalenderactiviteiten in het programma een uitdaging was, had volgens een van de leerkrachten ook te maken met de variatie in de lengte van de teksten en verwerkingsopdrachten: 'De ene dag doe je er 10 minuten over en de andere dag heb je aan 20 minuten nog niet genoeg.' Dat zorgde ervoor dat de Leeskalender wel eens lastig was in te passen, omdat ze vond dat ze niet minder tijd aan andere vakken, zoals rekenen, kon besteden (evaluatie 2, S22, 17-062014).

Hoewel het lastig was om in groep 4 structureel met de Leeskalender te werken, is er niet aanmerkelijk minder tijd aan de Leeskalender besteed dan in groepen (1-) $2^{189}$. Leerkrachten in groep 4 merkten ook op dat de kinderen de Leeskalender al snel als vast onderdeel van het programma zagen en er naar uitkeken. Gevraagd naar haar ervaring met de Leeskalender zegt een leerkracht: 'De kinderen vinden dat het leukste moment van de dag. Ze leven er echt naar toe. 's Morgens wordt er al gekeken naar welke plaat er die dag is en

189 In Bijlage 5 is een overzicht opgenomen van gegevens over hoe vaak en hoe lang er in groepen 4 met de Leeskalender ${ }^{+ \text {Kinderpoëzie }}$ is gewerkt en hoe het aanbod werd gewaardeerd. 
zodra we met de Leeskalender beginnen, schieten de vingers in de lucht en luisteren ze heel aandachtig. Echt een groot succes!' Deze leerkracht is ook verbaasd over wat de kinderen, zelfs van de moeilijke verhalen, allemaal onthouden (evaluatie 2, S22, 17-06-2014). Een volgende leerkracht zegt: “...de kinderen vroegen vaak zelf om de Leeskalender. 'Dus bij de kinderen zat het helemaal in het systeem,' stel ik (onderzoeker) vast. De leerkracht voegt met een lach toe: 'Ja, bij hen wel, ja!' (evaluatie 2, S26, 10-06-2014) Een andere leerkracht merkt in het afsluitende gesprek op dat de kinderen de Leeskalender vanaf het begin heel interessant vonden. Als ze het een dag oversloeg vanwege tijdgebrek, werd ze er door de kinderen aan herinnerd (evaluatie 2, S23, 25-06-2014). Op de vraag of ze de Leeskalender een vaste plaats zou willen geven in het lesprogramma, antwoordt een van de leerkrachten volmondig 'ja': ze vond het echt heel leuk, maar heeft er spijt van dat ze geen vast moment hadden ingeroosterd voor de Leeskalender. Op dagen dat er weinig tijd was, verviel het werken met de kalender daarom vaak. Ze voegt toe: 'Ik vind het sowieso leuk dat je elke dag ruimte hebt voor een stukje voorlezen. Dat vind ik namelijk hartstikke leuk, maar het is het eerste dat vervalt' (evaluatie 2, S16, 16-06-2014). Hoewel ze het wel heel leuk vond, geeft een volgende leerkracht aan dat ze het gewoon niet structureel kan doen en zeker niet dagelijks. Als het meer flexibel was, niet aan dagen/data gekoppeld, maar gewoon een aanbod van teksten met daarbij de uitgewerkte aanbieding en verwerking, dan zou ze dat wel interessant vinden. Dan kun je als leerkracht zelf bepalen hoeveel je doet en wanneer (evaluatie 2, S24, 18-06-2014). Zij merkte daarbij wel op dat de kalenderplaat en het standaard beginnen met het bespreken daarvan heel goed werkt: zo activeer je interesse, voorkennis en verwachtingen bij de kinderen waar je na het voorlezen weer op terug kunt komen. Het vaste stramien van voorbespreken, voorlezen en verwerken, werkte sowieso heel goed, ook omdat de kinderen op een gegeven moment die vaste structuur kenden. Datzelfde geldt voor het vaste weekritme van de verschillende soorten teksten: kinderen wisten 'wat voor dag het was' (verhaal of gedicht) (evaluatie 2, S24, 18-06-2014).

Veel vaker dan in groepen (1-)2 plaatsen leerkrachten in groep 4 hun overweging van een structurele inbedding van de Leeskalender in het lesprogramma expliciet in de context van het resultaatgericht werken dat binnen het primair onderwijs een grote rol speelt. Op de vraag of ze het werken met de Leeskalender een zinvolle activiteit heeft gevonden, reageert een van de leerkrachten afwachtend: 'Dat zal toch moeten blijken uit de toetsresultaten, dat kan ik zo niet zeggen.' Op de vraag of ze de Leeskalender als methode interessant zou vinden, geeft ze aan dat het voor groep 4 wel interessant zou kunnen zijn, maar dan moet eerst uit de resultaten blijken dat het ook echt bijdraagt aan de culturele geletterdheid van de kinderen. Ook vindt zij het in de huidige vorm te intensief: ze zou er maximaal drie keer per week mee willen werken, dat is goed haalbaar (evaluatie 2, S11, 24-06-2014). Een andere leerkracht zegt, op de vraag of ze de Leeskalender een vaste plaats zouden willen geven in hun lesprogramma, wel erg benieuwd te zijn naar wat het opgeleverd heeft: 'Als je ziet dat het iets toevoegt, dan sta ik er wel open voor, maar als je weinig verschil ziet, weet ik niet of ik het structureel zou willen invoeren.' (evaluatie 2, S23, 25-06-2014) Het idee dat de Leeskalender in groepen 4 altijd in plaats van een ander onderdeel van het lesprogramma komt en er in verschillende groepen 4 al veel aan (voor)lezen wordt gedaan, maakt dat er in deze groepen explicieter belang wordt gehecht aan een zichtbare (meetbare) toegevoegde waarde van het aanbod voor de ontwikkeling van de kinderen. Tegelijk waren leerkrachten 
toegewijd aan het project omdat ze merkten dat de Leeskalender over het geheel genomen bij de kinderen in de smaak viel. Verschillende leerkrachten waren vanuit die ervaring ook overtuigd van een 'intrinsieke waarde' van het materiaal. Een van de leerkrachten gaf in het afsluitende gesprek aan overtuigd te zijn dat de Leeskalender effect heeft gehad op de kennis van verschillende culturen bij de kinderen in haar groep 4 (zie ook $\$ 10.3$, Poëzie en de representatie van culturele pluriformiteit in groep 4). Ze denkt dat de Leeskalender ook heeft bijgedragen aan de algemene taalontwikkeling van de kinderen, al verwacht ze niet dat dat terugkomt in de Cito-scores omdat het daar om heel andere soorten aspecten van taal gaat dan de taal van verhalen en gedichten (evaluatie 2, S24, 18-06-2014).

\section{De variatie in het aanbod}

Waar de leerkrachten in de kleutergroepen in hun evaluatie van de Leeskalender aangaven meer thematische aansluiting op het lesprogramma te willen, spelen thema's in groep 4 een veel minder grote rol. Hierdoor kwam uit de gesprekken met groep 4 leerkrachten veel vaker hun expliciete waardering naar voren juist voor de variatie in het Leeskalenderaanbod. Die variatie had vooral betrekking op de genres. Verschillende leerkrachten gaven aan via de Leeskalender in aanraking te zijn gekomen met soorten teksten die ze zelf niet snel zouden kiezen. Zo geeft een van de leerkrachten aan dat hij het werken met de Leeskalender op het niveau van individuele teksten niet altijd zinvol vond omdat sommige teksten de kinderen in zijn groep niet zo aanspraken, maar over het geheel vond hij het wel zinvol omdat de kinderen met zoveel verschillende soorten teksten in aanraking komen (evaluatie 2, S26, 10-06-2014). “Met de Leeskalender ga je veel dieper op teksten in!” zegt een van de leerkrachten. Daarnaast bevat de Leeskalender teksten waaraan ze zelf niet zo snel zou hebben gedacht: de soorten gedichten en liedjes en de soorten verhalen zijn gewoon anders dan waar ze normaal gesproken mee zouden werken (evaluatie 2, S24, 18-06-2014). Ook de culturele pluriformiteit in het aanbod speelde daar voor verschillende leerkrachten een belangrijke rol in: hier kom ik later in dit hoofdstuk nog op terug (zie $\$ 10.3$, Poëzie en de representatie van culturele pluriformiteit in groep 4). De Leeskalender biedt bewust een grote variatie aan tekstsoorten aan en anders, zo stelt een volgende leerkracht, blijft het bij het voorlezen van een verhaal of een versje in het taalboek. Bovendien is de verwerking van zo'n tekst in de methodes volgens deze leerkracht 'platter'. De verwerkingsvormen bij de Leeskalender waren heel leuk en gingen veel dieper. Het prikkelde de kinderen echt tot nadenken (evaluatie 2, S21, 05-06-2014). Soms geheel tegen de eigen verwachting in, zagen leerkrachten dat tekstsoorten als fabels, schelmenverhalen, en ook poëzie in de smaak vielen bij de kinderen. Met name op het niveau van tekstbegrip werden leerkrachten soms verrast door hun eigen leerlingen. Bij het gedicht 'Pinokkio' van Shel Silverstein (zie Hoofdstuk 4) schrijft een leerkracht in het logboek: "Mij leek het erg moeilijk te begrijpen maar de kinderen vonden het heel leuk en snapten de bedoeling." (1141, logboek week 7) Een leerkracht schiet te binnen dat zijn groep 4 'De nieuwe kleren van de keizer' heel leuk vond en dat is een verhaal, voegt hij toe, dat pas in groep 7 aan de orde komt in de taalmethode, dus 'dat is wel lachen, hoor', vindt hij (evaluatie 2, S26, 10-06-2014).

Een van de leerkrachten trekt de vraag naar wat het sterkst bijdroeg aan de waardering van teksten bij de kinderen in haar groep samen met wat zij zelf waardevol vindt hen 'te 
leren waarderen': 'Dat is net als bij klassieke muziek', zegt ze, 'kinderen moeten ermee in aanraking komen om het te leren waarderen.' Deze leerkracht acht het vanuit dit perspectief zinvol dat de kinderen met een grote variatie aan tekstsoorten in aanraking zijn gekomen via de Leeskalender, waarbij ze specifiek de versjes en liedjes noemt omdat daar in de methode begrijpend lezen weinig aandacht aan besteed wordt (evaluatie 2, S21, 05-062014). Het is interessant om te zien dat tekstsoorten die wij hebben geselecteerd vanwege hun verbinding met de orale volkscultuur en daarmee in zekere zin als 'cultureel gemeengoed' kunnen worden beschouwd, door deze leerkracht worden gezien als 'te verwerven smaak'. Uit de expliciete waardering die de meeste leerkrachten voor de gekozen genres en tekstsoorten uitspreken, kunnen we afleiden dat ook zijzelf niet gewend waren dagelijks met deze typen teksten te werken. Het feit dat deze tekstsoorten - soms geheel tegen de verwachting van de leerkracht in - over het algemeen bij de kinderen in de smaak vielen, bevestigt ons theoretisch uitgangspunt dat putten uit de orale volkscultuur een effectieve insteek is om kinderliteratuur te selecteren die enerzijds aansluit op de ontluikende culturele competentie en voorkeuren van de kinderen en anderzijds toegang biedt tot een brede waaier aan uitingsvormen die als 'cultureel relevant' worden ervaren. Het vertelt ons alleen nog niet zoveel over welke specifieke kenmerken van de aangeboden teksten, in dit geval specifiek van de aangeboden poëzie, het sterkst bijdragen aan een nauwe aansluiting op de ontluikende culturele kennis, vaardigheden en voorkeuren van kinderen in groep 4. Net als in het vorige hoofdstuk stond die vraag centraal in de tweede fase van de observaties waarin ik inzoom op inzichten verkregen in een vaste observatiegroep, aangevuld met inzichten uit logboeken van en gesprekken met andere leerkrachten.

\subsection{Poëzieverwerving in groep 4}

Waar de leerkracht in 'mijn' observatiegroep 4 in de loop van de tijd steeds minder (zichtbaar) op mijn aanwezigheid reageert, gingen de kinderen in de groep 4 waarin ik in deze tweede fase (bijna) wekelijks aanwezig was gaandeweg steeds explicieter op mijn aanwezigheid reageren. Dit kwam het meest direct tot uiting bij de verwerking van het gedicht 'Verstoppertje' waar de kinderen zelf op mochten variëren. Het is op dat moment maart en ik ben al voor de twaalfde keer in deze groep aanwezig: de kinderen zijn ondertussen gewend aan mijn aanwezigheid en verschillende kinderen hebben me, meestal op de gang, al ondervraagd over wie ik ben en wat ik kom doen. Op een gegeven moment zie ik dat een van de jongens in de gaten houdt hoeveel ik opschrijf tijdens de verwerking van het gedicht. Hij ziet dat ik de kinderen maar moeilijk kan bijhouden: ze reageren graag, veel en snel op de vragen die de leerkracht stelt. Vervolgens wijst hij de kinderen om hem heen hierop en daarna ook de hele klas: 'ze kan het bijna niet bijhouden!' Aan het eind van de verwerking laat ik op hun verzoek aan de kinderen zien hoeveel ik heb opgeschreven, wat ze erg leuk vinden: zoveel! (observatie 28, 18-03-2014) De daaropvolgende keren worden er gelijksoortige verwerkingen gedaan: steeds hielden verschillende kinderen tussendoor in de gaten hoeveel kantjes ik al had volgeschreven. Dat de kinderen veel te zeggen hadden in het kader van de Leeskalender was overigens niet uitzonderlijk voor deze groep 4 . In het afsluitende gesprek noemt de leerkracht dit een praatgrage groep waar verwerkingsvormen 
waarbij de kinderen mochten navertellen, ervaringen delen, meningen geven, varianten bedenken, verder rijmen, et cetera, eigenlijk allemaal wel goed gingen. Ze moest de kinderen eerder beperken in hun spreektijd dan dat ze ze moest aansporen: soms duurde het voorbespreken al zo lang dat ze nauwelijks meer tijd had voor de verwerking (evaluatie 2, S24, 18-06-2014).

\section{Het samenspel tussen tekst en pragmatische context: 'Toch geen 'vrolijk kerstfeest'? Het is helemaal niet vrolijk, het boompje is helemaal kaal'}

In de Leeskalender voor groep 4 was poëzie opgenomen in het kader van verschillende vieringen: Dierendag, Sint-Maarten, Sinterklaas, Kerstmis, Nieuwjaar, Carnaval, Pasen, 1april, Çocuk Bayrami, en de verjaardag. Ook in het aanbod voor groep 4 was een 'misplaatst' feestrijm opgenomen waarmee gebruiken die horen bij de viering van Kerstmis worden opgeroepen in maart. Daarnaast waren verschillende teksten opgenomen die fysieke spelvormen opriepen, zoals een klapspel, verstoppertje, en meestampen op de maat. Zo waren in totaal negentien van de negenendertig poëzieteksten expliciet gekoppeld aan vieringen in het jaar, specifieke gebruiken of spel als pragmatische contexten die in de tekst worden opgeroepen (zie Hoofdstuk 7). De deelvraag die ik op basis van deze teksten wil beantwoorden, is:

KINDERPOËZIE: KWALITATIEVE DEELVRAAG 4a.

Wat vertellen observaties, logboekaantekeningen en gesprekken met leerkrachten met betrekking tot de presentatie van het poëzie-aanbod in de klas, de reacties van de kinderen op deze teksten en hun waardering daarvan ons over de rol van 'de directe evocatie van poëtisch geritualiseerde handelingspatronen in de context van feesten en spel', onderverdeeld in

(i) fysieke handelingspatronen (zoals wiegen, dansen, klappen, et cetera), en

(ii) performatieve taalhandelingen (zoals wensen, aftellen, verwensen, verzoeken, et cetera) in processen van poëzieverwerving bij kinderen in groep 4 ?

Voor kinderen in groep 4 zou die koppeling met een pragmatische context naar verwachting het sterkst moeten bijdragen aan poëzieverwerving in de vorm van de evocatie van geritualiseerde talige handelingspatronen, anders dan in groep 2 waar de evocatie van geritualiseerde fysieke handelingspatronen beter aansluit op de kennis, vaardigheden, leef- en belevingswereld van de kinderen. In hoeverre wordt deze verwachting door de verkregen kwalitatieve data ondersteund? En zijn er in de verwerving van poëzie bij kinderen in groep 4 verschillen waar te nemen in de werking van handelingspatronen in de context van vieringen en spel?

\section{De vieringen door het jaar heen en de verinnerlijking van pragmatische contexten}

In het vorige hoofdstuk werd duidelijk dat de kleuters voor het plaatsen en duiden -en daarmee ook voor het waarderen - van feestliedjes en -rijmen nog heel sterk steunen op de inbedding van poëzie in de betreffende pragmatische context waarin 'het doen' van een lied of rijm op 
zich een concrete functie vervult als onderdeel van het geheel van rituele handelingen en in die vorm als betekenisvol wordt ervaren en gewaardeerd. Kinderen in groep 4 steunen voor hun tekstbegrip en -waardering al veel meer op hun opgebouwde kennis en ervaring óver rituele contexten en allerlei standaardvormen van rituele handelingspatronen die daarmee geassocieerd worden. Processen van betekenisgeving en waardering zijn voor deze zevenen achtjarigen minder sterk verbonden aan de inbedding van poëzie in de bijbehorende geritualiseerde fysieke gebruikscontext; de betrokkenheid van kinderen in groep 4 bij 'het taalspel poëzie' wordt ook bij feestrijmen en -liedjes al veel sterker bepaald door het poetisch taalspel op zich.

Terwijl de kleuters het vreemd vonden toen ze het Dierendagvers 'Alle hokken mogen open' kregen aangeboden terwijl het nog geen Dierendag was en het vers buiten die context afwezen, hadden de kinderen in groep 4 er een paar dagen voor Dierendag geen enkele moeite mee het vers als Dierendagvers te waarderen. In groep 4 viel dit vers in de smaak omdat de kinderen zelf konden variëren op de specifieke vorm waarin het Dierendagthema aan de orde werd gesteld ('Geef de olifant een slinger/ geef de krokodil een vlag/ geef de tijger wat ballonnen,/ want het is nu dierendag../ et cetera'). Het feit dat het bij de eerste aanbieding nog geen Dierendag was, kwam nergens in de logboekaantekeningen aan de orde. Waar een leerkracht bij de kleuters schrijft: "De kinderen vonden het raar dat het gedicht over dierendag ging. Dierendag is immers pas vrijdag." (2322, logboek week 3), schrijven leerkrachten van groep 4 opmerkingen op als: "De kinderen vonden het versje erg leuk! Ze konden ook heel veel bedenken om het versje uit te breiden.” (2341, logboek week 3) In groep 4 was het hoofdzakelijk de aansluiting van de tekst en de verwerkingsvorm bij de belevingswereld van de kinderen die zorgde voor de positieve waardering. Zelfs de introductie van een niet-bestaande feestdag ('Wereldmensendag') in de herhalingsactiviteit op de keuzedag belemmerde het plezier van de kinderen niet: "De kinderen kozen de tekst omdat de tekst meer aansluit [dan de andere teksten van de week]. Er waren veel leuke ideeën voor Wereldmensendag." (2141, logboek week 3) Nu was het Dierendagvers, hoewel niet óp Dierendag aangeboden, wel ingebed in de week van Dierendag waarin ook de andere teksten in de Leeskalender in het teken van deze viering stonden. Anders was dat bij het 'misplaatste' feestgedicht dat in groep 4 werd aangeboden: 'Vrolijk ...' (Silverstein, 1985):
Vrolijk...
Niemand hangt de klokjes op
niemand bakt een taart
niemand steekt de lichtjes aan
niemand stuurt een kaart
niemand gaat op zoek naar een ster
niemand praat van vrede op aard
en niemand bewondert een kerstboom
op vijfentwintig maart 
Het is eind maart en op het kalenderblad zien de kinderen een zielig, kaal, verdord boompje waar nog wat ballen in hangen en een piek op staat. "Ze zagen meteen dat het een kerstboom was," schrijft een leerkracht in het logboek: "Eén kind is op 25 december jarig, dus die wist meteen dat het drie maanden geleden was." (2142, logboek week 24) Ook in mijn observatiegroep 4 hadden de kinderen al snel door wat er aan de hand was:

Zoals gewoonlijk leest een van de kinderen eerst de titel die bovenaan het kalenderblad staat:

$\begin{array}{ll}\text { Kind (m): } & \text { Vrolijk ... } \\ \text { Leerkracht: } & \text { Wat zouden die puntjes betekenen? } \\ \text { Kind (j): } & \text { Misschien dat je er iets bij moet verzinnen. } \\ \text { Leerkracht: } & \text { Wat zou je hier op de puntjes kunnen invullen? Vrolijk ... ? } \\ \text { Kind (j): } & \text { Toch geen 'vrolijk kerstfeest'? Het is helemaal niet vrolijk, het } \\ & \text { boompje is helemaal kaal. } \\ \text { Leerkracht: } & \text { Waarom denk je bij dit boompje dan toch aan kerst? } \\ \text { Kind }(\mathrm{m}): & \text { Er zit een ster op. (observatie 30, 25-03-2014) }\end{array}$

In de eerste reactie op de vraag wat er op de puntjes na 'Vrolijk ...' kan worden ingevuld, komt naar voren dat het hier vooral het 'vrolijk' is dat uit de toon valt en niet zozeer dat het over 'kerstfeest' gaat. In vergelijking met de kleuters zien we hier een verschuiving van de pragmatische context waarbinnen de kinderen het tekstaanbod beschouwen: in groep 4 wordt de titel gerelateerd aan de afbeelding op de kalender om te duiden wat er bedoeld wordt met 'Vrolijk ...' en de incongruentie wordt ook binnen die relatie ervaren ('Het is helemaal niet vrolijk, het boompje is helemaal kaal.'). Kinderen in groep 4 vinden het daarnaast ook wel vreemd dat het in maart over een kerstboom gaat. Een leerkracht schrijft: "Gepraat over een kerstboom: wanneer komt kerst? Vreemd nu verhaal, misschien een paasboom." (1641, logboek week 24) En een andere leerkracht merkt op: "Kerstmis leeft nu niet, Pasen wel een beetje." (2241, logboek week 24) In deze groep noemen de kinderen het boompje op de afbeelding een 'bedorven boompje'. In groep 4 wordt de tekst echter niet afgewezen omdat het geen kerst is: begrip en waardering van het gedicht komen tot stand op basis van de interactie tussen de tekst (inclusief titel), de afbeelding en de culturele schemata van de kinderen. Niet op basis van de interactie tussen de tekst en de externe pragmatische context, zoals dat bij de kleuters wel het geval was. De leerkracht in mijn observatiegroep leest het gedicht voor: ze doet dat op een mooie, beetje droevige toon. Dan vraagt ze:

Leerkracht: Waar gaat het over?

Kind: $\quad$ Dat niemand iets gedaan heeft met de boom.

Leerkracht: Ja, dat wordt gezegd in het gedicht, maar waarom heeft niemand iets gedaan met de boom?

Kind: $\quad$ Omdat ze het vergeten zijn.

Kind: $\quad$ Omdat het geen kerst is! (observatie 30, 25-03-2014)

De kinderen mogen nu verder associëren op kerst, met de bedoeling dat de leerkracht aan het eind van de verwerking het gedicht uitbreidt met wat de kinderen nog meer opnoemen. Eerst schrijven ze een woordweb op het bord rond het woord 'Kerst' en vervolgens gaan 
ze verder met een (gesproken) woordslang omdat dat sneller gaat en de kinderen heel veel weten te bedenken. Ze noemen: kerstman, kerstboom, kerstvrouw, kerstkaart, kerstster, Jezus, en kerstbal. Nu wijst de leerkracht erop dat ze bijna allemaal iets noemen dat begint met 'kerst' en vraagt ze of ze ook dingen kunnen bedenken zonder dat woord. Dat kunnen ze ook: cadeautjes, gezelligheid, God, slee, feest, Katholiek feest, Jezus geboren, sommige herten die lijken op een 'hertenezel' [rendier], kerstslingers, sneeuw, in december en vrolijkheid. Na deze eerste ronde van vrije associaties die laten zien wat zoal onderdeel uitmaakt van de mentale 'kerst-schemata' van de kinderen, vraagt de leerkracht of de kinderen zelf nieuwe regels voor uitbreiding van het gedicht kunnen bedenken, dus beginnend met 'niemand ...' Dit gaat zo snel dat ik niet eens kan bijhouden wie wat zegt. De zinnen die ter aanvulling bedacht worden, zijn:

Kinderen: Niemand is nog blij; Niemand hangt slingers op; Niemand kijkt naar Jezus; Niemand denkt aan Jezus; Niemand hangt kerstballen op; Niemand zet de kerstboom op; Niemand is blij; Niemand viert kerst op 25 maart; Niemand zet zo'n huisje neer met stro en de ezel en poppetjes; Niemand krijgt cadeautjes; Niemand denkt aan de Kerstman; Niemand speelt in de sneeuw;

[in de handleiding staat als voorbeeld 'niemand trekt z'n nieunste kleren aan': de leerkeracht probeert de kinderen hierop te duiden door met haar hand een gebaar te maken langs haar kleren, waarop de kinderen wel in de richting van kleren gaan denken, maar het duurt even voor ze door hebben wat ze bedoelt:]

Kinderen: Niemand verkleed zich als Kerstman; Niemand trekt warme kleren aan; Ik zie twee mogelijkheden: of gewoon een jas, of kerstkleren; Niemand trekt een pyjama aan; Niemand trekt communiekleren aan;

Leerkracht: Niemand trekt nette kleren aan, dat is wat ik bedoelde. Met kerst doen mensen toch vaak hun nieuwe of netste kleren aan?

Kind (j): $\quad$ Net als met Suikerfeest! Of net als met Kerstontbijt.

[de leerkracht herinnert twee jongens er aan dat ze met het kerstontbijt vorig jaar heel netjes gekleed waren, in pak, dat zijn toch speciale kerstkleren]. (observatie 30, 25-03-2014)

Hierna gaan ze nog even door tot alle kinderen minstens een keer aan de beurt zijn geweest. De leerkracht vindt het daarna wel genoeg: de vaart is er een beetje uit en de kinderen vallen in herhaling. Tegelijk hoor ik bij het groepje links voor in het lokaal dat er kerstliedjes gezongen worden ('Jingle bells'). De leerkracht slaat de handleiding dicht en kondigt aan wat ze de rest van de middag gaan doen. Heel toepasselijk: knutselen voor de lente! Direct hoor ik wat kinderen mompelen: 'we kunnen ook kerststerren maken enzo...' (observatie 30, 25-03-2014). Waar het uitvoeren van geritualiseerde fysieke handelingspatronen in januari de Sinterklaasbeleving kan oproepen bij kleuters, is het in groep 4 het poetisch taalspel dat ze in de Kerststemming brengt. Tegelijk maken de kinderen zich de structuur en het concept van het gedicht effectief eigen, niet door meedoen en nadoen zoals bij de kleuters, maar door zelf binnen die structuur en binnen dat concept op het gedicht te variëren. Het is opvallend hoe goed ze de 'essentie' van het origineel hebben begrepen. 
De effectiviteit van het zelf variëren binnen de poëtische structuur als middel voor poëzieverwerving in groep 4 komt ook naar voren uit de verwerking van het gedicht dat vlak voor Pasen werd aangeboden, 'Gekleurde eitjes en een haas' (Busser \& Schröder, 2002), waarin niet de ontkenning, maar de vergelijking centraal staat ('Zoals het zoemen bij een bijtje,/ zoals een juffrouw/meester bij de school,/ zoals het bord hoort bij het krijtje,/ zo hoort worst bij boerenkool..// (...)// Zoals een kaarsje bij het kerstfeest/ en marsepein bij Sinterklaas,/ zo horen er bij ieder paasfeest/ gekleurde eitjes en een haas.'). Al na een keer voorlezen door de leerkracht hebben de kinderen het idee te pakken:

De leerkracht leest het gedicht een keer voor en vraagt vervolgens wat de kinderen is opgevallen.

Kind (j): $\quad$ Zoals bij de vaas een bloem, bij de vis een vijver, ze zet telkens hetzelfde plaatje bij elkaar.

[de leerkracht legt de link naar een soort memoryspel dat ze eerder een keer hebben gespeeld waarbij ze niet steeds twee dezelfde plaatjes bij elkeaar moesten zoeken, maar twee plaatjes die bij elkaar horen]

Leerkracht: Wie hoorde er nog meer van dat soort dingen?

Kind (j): $\quad$ Gekleurde eitjes en een haas.

Kind (m): $\quad$ De kaas met de gaten.

Kind (j): $\quad$ Sinterklaas en speculaas

[de leerkeracht corrigeert dat in het gedicht marsepein wordt genoemd, maar ze snapt wel waarom hij speculaas zegt, want dat rijmt]

Kind (j): $\quad$ Zoals de kaars bij Kerst hoort, zo horen zoemen en een bijtje ook bij elkaar. (observatie 34, 15-04-2014)

Kunnen de kinderen zelf ook nog andere vergelijkingen bedenken? Dus iets dat net zo goed bij elkaar past als gekleurde eitjes en een haas bij Pasen passen? Jazeker, en dat gaat opnieuw zo snel dat ik nauwelijks kan bijhouden wie wat zegt. Om een aantal voorbeelden te noemen: Frankrijk en de Eiffeltoren, hond en kat, de kerstman en de kerstboom, schrift en pen, Sinterklaas en Zwarte Piet, computer en i-pad, muis en kaas, kraan en water (de leerkracht geeft aan dat dit een heel goed voorbeeld is, want wat is een kraan zonder water? Dat soort dingen zoeken ze dus, dingen die echt altijd samen gaan), letters en cijfers, scooter en brandstof, broek en trui, vliegtuig en piloot, bh en onderbroek, boeken en letters, vrouw en man, en ook bh en string, seconden en minuten, ijskast en kou, sigaret en vuur, natuur en groen. "Ja," sluit de leerkracht af, "en al die dingen passen bij elkaar, volgens jullie, zoals gekleurde eitjes en een haas passen bij Pasen...”. De leerkracht leest het gedicht nu nog een laatste keer voor. Ze laat de kinderen rijmwoorden invullen en aan het einde, met z'n allen tegelijk: 'gekleurde eitjes en EEN HAAAAAAASSSS!!!!' (dat laatste wordt gebruld door de kinderen) (observatie 34, 15-04-2014).

Kinderen in groep 4 kunnen een Dierendagvers ook waarderen wanneer het nog geen Dierendag is; ze kunnen vanuit hun kennis van Dierendag ook 'omdenken' naar wat je zoal kan doen op de hypothetische 'Wereldmensendag'. Zelf associëren en variëren op poëtisch taalspel heeft een sterk effect op het oproepen van hun beleving van een 'misplaatst' feestgedicht en het actief verwerven van zowel poëtische vormen als het centrale concept waar dergelijk poëtisch taalspel op gebaseerd is. Dit alles staat bij kinderen in groep 4 los van de 
inbedding van het taalspel poëzie in de concrete pragmatische context, de viering, die in de tekst wordt opgeroepen. Dit betekent echter niet dat directe aansluiting op de kennis en ervaring van de kinderen geen rol speelt in hun beleving en waardering van poëzie in het kader van de vieringen in het jaar. 'Sint-Maarten' is een feest dat tegenwoordig op verschillende plaatsen in Nederland nog wordt gevierd. Meestal gaan kinderen met lampions langs de deuren om geld of iets lekkers te vragen; hier en daar worden nog vuren ontstoken op deze feestdag (zie Hoofdstuk 3). Het is echter een gebruik dat zeer regio- en plaatsgebonden is en zeker niet overal bekend is. Dit blijkt ook uit de logboekaantekeningen bij het gedicht 'Sint-Maarten'; aantekeningen die er tegelijk op wijzen dat 'onbekend maakt onbemind' ook in groep 4 nog opgaat in dit kader. Op een school in Venlo schrijft een leerkracht: "Het verhaal van Sintermerte besproken -> wat vieren we. Sintermertens veugelke gezongen. Er kwamen veel reacties vanuit hun eigen ervaring. Wilde nog langer doorgaan. Geen tijd.” (2343, logboek week 8a) Op een school in Heerlen, daarentegen, konden de kinderen geen rechtstreeks beroep doen op hun eigen ervaring: "Veel uitleg gegeven. Kinderen kennen St Maarten niet." (1141, logboek week 8a) Op deze school was ik aanwezig bij de aanbieding, waar het bespreken van de titel op het kalenderblad al duidelijk maakte dat Sint-Maarten als viering niet aansloot op de culturele schemata van de kinderen:

Wat staat er vandaag op de kalender? 'Sint-Maarten,' leest een jongen vlak bij de kalender. 'Wat is dat, Sint-Maarten, wie kent die?' vraagt de leerkracht. Vier kinderen steken hun vinger op en denken te weten wie of wat Sint-Maarten is. Een jongen vooraan zegt: 'Dat is een stad.' Later vertelt hij nog dat hij daar familie heeft wonen. De leerkracht bevestigt dat het inderdaad ook een stad is (waar ook alweer: Curaçao of Aruba, vraagt ze zich hardop af), maar dat is niet waar het nu over gaat. 'Dat is een kind die zichzelf sint makkt,' denkt een meisje. Die opmerking begrijpt de leerkracht niet helemaal, maar dat is het in elk geval ook niet. 'Dat is een lampionnenoptocht,' denkt een jongen die goed naar het plaatje op de kalender kijkt waar kinderen met lampionnen op te zien zijn. 'Dat is een stad waar ze feest vieren,' denkt de volgende die de eerste opmerking en de afbeelding op de kalender met elkaar lijkt te verbinden. (observatie 6, 12-11-2013)

De kinderen proberen allemaal betekenis toe te kennen aan 'Sint-Maarten', ofwel vanuit de kennis dat het een stad is, ofwel door onderdelen van de titel en de afbeelding te interpreteren. In het betreffende gedicht van Willem Wilmink wordt eerst vanuit een 'wij'-perspectief verteld dat een groep kinderen 's avonds met lampionnen door de straten loopt. Vervolgens wordt uitgelegd met welke bedoeling ze dat doen: 'Wij vragen iedereen beleefd/ of hij wat lekkers voor ons heeft,/ wij lopen door de duisternis/ omdat het 11 november is,/ dus omdat het Sint-Maarten is.// Als we iets krijgen, loopt ons koor/ met alle lampions weer door,/ als ons niet open wordt gedaan,/ dan blijven wij gewoonweg staan,/ blijven wij vannacht hier staan.' In deze groep 4 helpt een vergelijking met Halloween de kinderen om zich een beeld te vormen van hoe Sint-Maarten gevierd wordt, maar het gebrek aan eigen ervaring makkt dat het gedicht niet tot leven komt:

De leerkracht geeft aan dat ze nu het versje van vandaag gaat voorlezen. Terwijl ze voorleest, zit een meisje uitgebreid en hardop te gapen, waarbij ze haar hand dramatisch 
heen en weer wappert voor haar mond. Andere kinderen mompelen de rijmwoorden een beetje met de leerkracht mee: ze kennen de tekst niet, maar lijken deze in zich op te nemen door de rijmwoorden na te echoën. Direct na het voorlezen, vraagt de leerkracht of ze dat nog een keer zal doen. 'Neeee,' klinkt het. Een meisje vertelt dat haar vader Halloween niet wil doen want dat is meer van Amerika. Een ander meisje vertelt dat ze dat een keer bijna had gedaan, want ze woont in een flat en een meisje dat vlakbij woont, had gevraagd of ze met haar langs de deuren wilde gaan. Maar het ging niet door omdat ze ziek was. (observatie 6, 12-11-2013)

Het gebrek aan tekstbeleving komt hier voort uit het feit dat er geen aansluiting is op eigen kennis en ervaringen: liever vertellen de kinderen over ervaringen die ze wél (of bijna) zelf gehad hebben met een andere viering dan dat ze nog een keer naar het gedicht willen luisteren. Hoewel de leerkracht hierna toch nog een keer het gedicht voorleest waarbij de kinderen al veel rijmwoorden kunnen invullen, tonen ze weinig betrokkenheid of enthousiasme. Dit gedicht ligt voor hen te ver van de eigen belevingswereld af. Wanneer de leerkracht vraagt of de kinderen dit een leuk versje vinden of niet, geven vijf kinderen aan dat ze het versje stom vonden: een meisje vond het zelfs 'hartstikke stom'. De andere kinderen zeggen het wel leuk te vinden, maar wanneer de leerkracht vraagt of ze het nog een keer willen horen, opperen kinderen zelf om 'Naïma maakt muziek' of 'Pinokkio' nog een keer te doen (observatie 6, 12-11-2013).

Een gedicht over een viering die de kinderen goed kennen, zoals Kerstmis, hoeft niet per sé in de kerstperiode te worden aangeboden om beleving bij de kinderen op te roepen; een gedicht over een viering die de kinderen niet kennen, roept geen beleving op ook al wordt het gedicht op de dag van die viering aangeboden. De context waarin 'het taalspel poëzie' gekoppeld aan de vieringen in het jaar betekenis krijgt, is bij kinderen in groep 4 voor een belangrijk deel een mentaal construct, gevormd door de culturele schemata waarover ze beschikken. Met andere woorden: kinderen in groep 4 hebben de pragmatische contexten die ze uit ervaring kennen 'verinnerlijkt'. Dit is een enorme ontwikkeling ten opzichte van de kleuters die grote gevolgen heeft voor hoe kinderen in groep 4 'het taalspel poëzie' verwerken, verwerven, begrijpen en waarderen; een ontwikkeling die samenvalt met de overgang van pre-operationeel naar concreet operationeel denken (zie o.a. Verhulst, 2005, p. 116). Tegelijk werken die verinnerlijkte gebruikscontexten nog steeds als het raamwerk waarbinnen verschillende vormen van 'het taalspel poëzie' (al dan niet) functie en betekenis krijgen. Welke functies en betekenissen het best aansluiten op die culturele schemata, bespreek ik in de paragrafen over 'muzikaal taalspel' en '(carnavaleske) nonsensicaliteit'. Eerst roepen bovenstaande inzichten nog de vraag op wat de verinnerlijking van de gebruikscontexten die bij deze kinderen zichtbaar is en hun vermogen om mentaal te handelen, betekent voor de rol van fysiek en talig handelen in de verwerving en waardering van vormen van 'het taalspel poëzie' in de context van de vieringen van het jaar bij kinderen in groep 4. 


\section{Talig en fysiek poëtisch handelen in de context van de feesten van het jaar}

In het vorige hoofdstuk heb ik beschreven hoe de kleuters reageerden op het Nieuwjaarsvers 'Ik wens je al wat wenselijk is'. Voor de kleuters was dit vers, als speels subversieve verdraaiing van de taahandeling van het elkaar iets goeds toewensen voor het nieuwe jaar, erg moeilijk te bevatten op dat talige handelingsniveau: de vorm van de wens als taalhandeling ging in de verwerking direct verloren. In groep 4 is 'Ik wens je al wat wenselijk is' ook aangeboden. De leerkracht laat de kinderen in mijn observatiegroep 4 eerst, zoals gebruikelijk, de titel op het kalenderblad lezen en de afbeelding bekijken. Daarna bespreken ze of en hoe de kinderen Oud en Nieuw hebben gevierd. Het liefst zouden ze nog honderduit willen vertellen over wat zij zelf hebben gedaan, zoals opblijven, lekker eten, en vooral vuurwerk kijken (en afsteken), maar de leerkracht brengt de aandacht al snel op het elkaar een gelukkig Nieuwjaar wensen door dit voor te doen bij een van de meisjes: 'De beste wensen voor het nieuwe jaar!' Vervolgens leest ze het gedicht aan de groep voor. Ze doet dat alsof ze heel vriendelijke dingen zegt ('Ik wens je al wat wenselijk is, / een bochel die ordentelijk is, / twee benen als een ooievaar,/ et cetera') en schudt een ander meisje ondertussen hartelijk de hand. Als ze klaar is met het vers zijn de eerste reacties: 'Huh?' en 'Zo kort?'190 De leerkracht vraagt wat ze de kinderen nu precies gewenst heeft, waarop een van de kinderen antwoordt: "Een vrolijk nieuw jaar een beetje." De leerkracht gaat nauwkeuriger in op tekstbegrip. Wat is een bochel? Een jongen vertelt dat zijn moeder altijd tegen zijn zus zegt dat ze een bochel krijgt omdat ze altijd een beetje voorover gebogen zit. Hoe zien de poten van een ooievaar eruit? Verschillende kinderen geven een gedeeltelijke beschrijving: ze zijn een beetje geel of oranje, ze hebben van die bobbeltjes, ze zijn heel lang. Zouden de kinderen daar blij mee zijn, met een bult op je rug die mooi staat? Een meisje moet lachen en schudt hard haar hoofd. En twee poten als een ooievaar? Verschillende kinderen lachen: nee, liever niet.

De leerkracht staat op en begint verschillende kinderen de hand te schudden en ze een bochel of ooievaarspoten toe te wensen. De kinderen moeten hier erg hard om lachen. Ik hoor verschillende kinderen eigen wensen tegen hun buurman of -vrouw fluisteren. De enige die ik kan verstaan is van een jongetje achter in de klas die zich tot de leerkracht richt nadat zij hem een bochel heeft toegewenst. 'Ik wens u een meloenenhoofd', zegt hij terwijl hij lacht. De leerkracht gaat mee in dit gewaagde spel en moet er ook hartelijk om lachen. De leerkracht loopt weer naar voren en begint met de verwerkingsopdracht:

Leerkracht: Wat kun je elkaar nog meer wensen? Kunnen jullie nog andere wensen bedenken? Ze moeten wel grappig bedoeld zijn en niet gemeen, he! Het mag de ander geen pijn doen. Bijvoorbeeld (terwijl ze naar een jongen toe loopt en hem de hand schudt): ik wens je zweettenen. Tja, ik verzin zomaar wat, het is een grapje!

\footnotetext{
190 Ook een andere leerkracht rapporteert dit in het logboek: "De kinderen vonden het versje erg kort. Te kort volgens sommigen.” (2342, logboek week 14a) Hetzelfde observeerde ik bij de aanbieding van 'Vrolijk ...'. Zodra de leerkracht klaar is met voorlezen, hoor ik een aantal kinderen zeggen: 'Was dat het al?' en 'Zo kort?!' (observatie 30, 25-03-2014) Dit is me vaker opgevallen bij de kortere gedichten: de kinderen zijn altijd verbaasd als het vers snel is afgelopen. Dat is blijkbaar een opvallende afwijking van hun verwachtingspatroon, vergelijkbaar met 'Het rijmt, juf!' bij de kleuters.
} 
[De kinderen lachen hard. Er schieten een heleboel vingers de lucht in van kinderen die wel wat weten. De leerkracht wijst als eerste een jongen aan en zegt hem iemand anders de hand te schudden en zijn wens te geven. Vervolgens mag diegene naar een volgende, net zolang tot iedereen die wil aan de beurt is geweest. Dit is een afwijking van de instructie in de handleiding waarin enkel werd aangegeven de kinderen te vragen zelf soortgelijke wensen te bedenken. Ze doen dit 'elkaar de hand schudden' echter keurig terwijl ze bun wensen geven]

Kind: $\quad$ Ik wens je goeie kippenpoten.

Kind: $\quad$ Ik wens je een nieuwe bananenschil.

Kind: $\quad$ Ik wens je grote oren.

[De kinderen hebben grote lol. Degenen die de wens doen, lopen steeds naar een klasgenoot en ze schudden elkaar de hand. De jongens lopen echter alleen maar naar andere jongens. De leerkracht grijpt in en spoort de volgende aan om een meisje te kiezen omdat er anders alleen maar jongens aan de beurt komen. De jongen die nu aan de beurt is, moet enige moed bij elkaar verzamelen en loopt dan opvallend (of overdreven) zelfverzekerd naar een meisje:]

Kind: $\quad$ Ik wens je een heel mooi boek, waar je veel bij kan lachen, het gaat over een varken en dat je dan als je dat leest een varkensneus krijgt.

Leerkracht: O, ik dacht al dat je haar niet zoiets durfde te wensen! Maar je nam alleen een lange aanloop... Nou, de volgende. (observatie 13, 07-012014)

Een voor een kiezen de kinderen een volgend 'slachtoffer' en wensen diegene: 'twee ogen als oliebollen', 'twee benen als potloden', 'dat je oogbulten krijgt' (wat de leerkracht wel heel vies vindt), 'dikke tenen', 'een dikke rozenneus', 'een dikke reet' (wat de leerkracht corrigeert naar 'dikke billen', want reet klinkt te onaardig), 'een huis vol bandieten', 'een kaal hoofd' en 'varkenspoten'. Halverwege begint een van de jongens vlak voor mij fanatiek te zwaaien dat hij wil waarbij hij steeds naar mij kijkt en wijst alsof hij wil zeggen: 'ik wil haar wat wensen!' Helaas is hij al aan de beurt geweest ...

Deze verwerkingsvorm was een risicovolle onderneming en de leerkracht geeft achteraf aan dat ze enigszins verbaasd is dat de kinderen het leuk hielden en elkaar zo keurig de hand schudden. 'Er zijn er een paar waarvan ik had verwacht dat ze over de grens zouden gaan, die van de dikke reet is er een van, maar het viel me reuze mee. Het ging eigenlijk wel heel goed, zo.' (observatie 13, 07-01-2014) Het was bijzonder om te zien hoe sterk deze verwerkingsactiviteit werd beïnvloed door de balans tussen de plechtigheid waarmee de kinderen elkaar de hand schudden en de speelse subversiviteit waarmee ze elkaar tegelijkertijd, binnen de grenzen van het aanvaardbare, onwenselijke dingen toewensten. In vergelijking met de kleuters mag daarbij duidelijk zijn dat de kinderen in groep 4 al volkomen vertrouwd zijn met de taalhandeling van het elkaar iets toewensen. De combinatie met het formele 'elkaar de hand schudden' creëerde daarbij een ritueel kader dat het spel betekenisvol maakte en een bepaalde gewichtigheid gaf. Ook in groepen 4 waar de instructie in de handleiding werd gevolgd, "werden leuke wensen bedacht" (1141, logboek week 14a), zoals: “'Ik wens je grote tanden, pas op dat je niet bijt in je handen' en 'Ik wens je een grote kont, zodat je niet in de wc valt'." (2341, logboek week 14a) Maar het spel kwam niet overal van de grond. Een leerkracht schrijft: "Veel moeite met wensen bedenken. Snappen het principe van de nieuwjaarswens niet. Kinderen komen met 'fijne feestdagen' voor 2014.” (1641, logboek week 14a) Een andere leerkracht merkte op: "Kinderen vonden het lastig 
om deze rijmpjes te bedenken. Ook zonder rijm bleef het lastig. Ze herhaalden veelal de voorbeelden. Te weinig tijd om dit echt goed op te pakken. Ik wens je olifantenbollen met olifantendrollen. Ik wens je een goed oud jaar." (2241, logboek week 14a) In mijn observatiegroep versterkte de concrete performance en de daarin ervaarbare dissonantie tussen fysieke en talige handeling juist het 'begrip' van het Nieuwjaarsvers als performatieve taalhandeling. De kinderen konden de wrijving tussen wat ze deden en wat ze zeiden aan den lijve ondervinden: een fysieke ervaring van de essentie van het vers die gevormd wordt door de spanning tussen vorm (Nieuwjaarswens) en de inhoud (verwensing). Die fysieke ervaring intensiveerde de beleving bij de kinderen en vergrootte daarmee hun begrip van het soort spel dat in het vers wordt gespeeld. Dit wijst erop dat de expliciet fysieke ervaring van 'het taalspel poëzie' ook voor kinderen in groep 4 nog sterk, veel sterker dan verwacht, wordt ondersteund door fysiek handelen, zeker bij vormen van poëtisch taalspel die nieuw zijn voor de kinderen.

Rond Sinterklaas kregen de kinderen in groep 4 de gedichten 'Als ik nou een hondje mag', 'Wat we zo graag zouden willen, Sinterklaas' en 'Ik ben lekker stout' aangeboden. Het eerste en het laatste gedicht zijn niet rechtstreeks aan Sinterklaas gekoppeld, maar 'zeuren' en 'stout zijn' contrasteren met het soort gedrag dat met Sinterklaas beloond wordt. Ook 'Als ik nou een hondje mag' werd door kinderen in groep 4 het meest expliciet gewaardeerd in combinatie met rechtstreekse ervaring: "Hilarisch, heel leuk! We hebben het vers uitgespeeld!" schrijft een leerkracht in het logboek (1141, logboek week 11a). Zonder die rechtstreekse ervaring reageerden kinderen in groep 4 veel rationeler, vanuit hun moreel besef van wat wel en geen 'passend' gedrag is. Een leerkracht schrijft over de verwerking van 'Ik ben lekker stout': "We moesten een link maken naar de realiteit. Toen kwam er wel iets los, maar vooral: stout zijn is niet leuk!” (2343, logboek week 12) In het daadwerkelijke Sinterklaasvers, 'Wat we zo graag zouden willen, Sinterklaas' (Wilmink, 2010), is sprake van een zelfde soort discrepantie tussen taalhandeling en Sinterklaascontext als in de twee omringende gedichten, bijvoorbeeld: 'Wat we zo graag zouden willen, Sinterklaas:/ we willen nooit meer van die nare dromen,/ er mag nog wel een heel nieuw zusje komen,/ 't mag ook een broertje zijn om mee te spelen,/ maar we gaan niet van alles delen,/ Sinterklaas.' Vanuit een morele (rationele) houding wezen kinderen in groep 4 dit gedicht af, waarbij ze zich op inhoudelijk én formeel niveau bewust waren van het type taalhandeling dat passend is in de context van de viering van Sinterklaas: "De kinderen gaven meteen aan dat je niet alles aan sinterklaas kunt vragen. Daarnaast vonden de kinderen het gemeen als je niet samen wilde delen en het was niet netjes gevraagd. In het gedichtje stond alleen maar 'ik wil'." (2343, logboek week 11b) Zo tonen deze kinderen hun 'meesterschap' over de inhoudelijke normen of conventies die gelden wanneer je iets aan Sinterklaas wilt vragen én over de vorm waarin je dat doet. We kunnen echter ook stellen dat deze rationele benadering ten koste gaat van de beleving van, en daarmee ook het begrip en de waardering voor, het soort spel dat in dit gedicht gespeeld wordt door de bewuste afwijking van de conventies. We zien dus een opvallende paradox in de wijze waarop kinderen in groep 4 'het taalspel poëzie' in het kader van de vieringen van het jaar ervaren, begrijpen en waarderen: wanneer ze 'het taalspel poëzie' zelf kunnen (mee)spelen dan begrijpen en waarderen ze de subversiviteit of incongruentie ervan ook als zodanig, terwijl ze een soortgelijk spel vanuit 
een morele houding afkeuren wanneer ze het enkel rationeel verwerken. Die morele, rationele, houding werkt de ervaring en waardering van 'het taalspel poëzie' tegen.

Rechtstreekse ervaring van het 'taalspel poëzie' speelt in groep 4 dus nog steeds een belangrijke rol in het samenspel van factoren dat vorm geeft aan processen van poëzieverwerving. Bij de kleuters hebben we gezien dat hun waardering vaak expliciet uitging naar de lichamelijke beweging. Ze wilden een vers bijvoorbeeld nog een keer doen: "Omdat je dan moet stampen, en bij andere liedjes doen we dat niet, dat is saai." (2421, logboek week 4) Bij de kleuters werkte fysiek handelen ook sterker dan talig handelen. In groep 4 versterkt fysieke ervaring de beleving en daarmee ook het begrip van specifieke vormen van 'het taalspel poëzie': door die geïntensiveerde beleving waarderen ze een gedicht of lied ook meer dan wanneer ze er alleen over praten of redeneren. 'Zitten en luisteren (en redeneren)' werkt ook in groep 4 niet in het voordeel van poëzie: poëzie moeten de kinderen ervaren, doen. Dat is wellicht de meest cruciale factor in het samenspel van factoren dat vorm geeft aan processen van poëzieverwerving, en niet alleen bij kinderen in groep (1-)2. Meer dan in de kleutergroepen treedt de fysieke ervaring van 'het taalspel poëzie' bij kinderen in groep 4 echter ook op wanneer ze dat taalspel op talig niveau kunnen spelen. Fysiek én talig handelen staan in groep 4 beide in contrast met redeneren. Nu heb ik het hier feitelijk nog steeds specifiek over poëzie gekoppeld aan de vieringen van het jaar, maar het valt op dat die rituele contexten op zich niet meer zo'n belangrijke rol spelen in groep 4 voor zover ze al zijn 'verinnerlijkt', i.e. onderdeel geworden zijn van de culturele schemata van de kinderen. Zolang kinderen 'het taalspel poëzie' zoals dat in de uitvoering van een gedicht of lied vorm krijgt, actief kunnen meespelen, is concrete inbedding in de bijbehorende externe rituele context niet meer nodig. Wat gebeurt er dan wanneer vormen van poëtisch taalspel gekoppeld zijn aan fysieke spelvormen als contexten van tekstgebruik?

\section{Het 'taalspel poëzie' gekoppeld aan fysieke spelvormen}

Buiten de feesten van het jaar zijn veel volksculturele kinderrijmen en -liedjes van oudsher gekoppeld aan fysieke spelvormen, zoals klapspelrijmen, touwspringliedjes, aftelrijmen, kring- en rijspelliedjes, en ga zo maar door. Die vormen van poëzie worden van oudsher dus heel fysiek door kinderen gebruikt en beleefd. Dat geldt overigens ook voor het soort 'speelplaatspoëzie' dat door inhoudelijke transgressiviteit fysieke reacties bij kinderen losmaakt. In zijn boek Poetry's Playground merkt Joseph Thomas over deze 'Child poets and the poetry of the playground' op dat deze poëzie, in tegenstelling tot heersende opvattingen over wat poëzie is, geen betrekking heeft op de geest, maar op het lichaam: "They are composed and performed with the aim of producing strong, bodily reaction: laughter, guffaws, gasps, groans, or in the case of jump-rope rhymes, facilitating vigorous play." (Thomas, 2007, p. 47; zie ook Hoofdstuk 5) Dat die poëzie niets van doen heeft met het verstand ben ik niet met Thomas eens, maar de lichamelijkheid van die 'speelplaatspoëzie' wijst erop dat de expliciete fysieke ervaring voor kinderen in deze leeftijd een belangrijke bijdrage levert aan het plezier dat zij beleven aan 'het taalspel poëzie'. Het is nog in hoge mate via die expliciete fysieke beleving dat 'speelplaatspoëzie' haar functies in het leven van deze kinderen vervult. De koppeling tussen poëzie en fysieke spelvormen - als concrete contexten van poëziegebruik waarin vormen van poëzie een keur aan 'pragmatisch-esthetische' 
functies vervullen -, dient zich dan aan als effectief middel in processen van poëzieverwerving bij kinderen in groep 4. Echter, het laat zich soms moeilijk verenigen met de context van het klaslokaal waarin een steeds sterkere nadruk op het verstand en het verstandelijk benaderen van tekst en van de wereld komt te liggen. Daar komt bij dat kinderen in groep 4 ook veel plezier kunnen beleven aan talig spel. Wat doen vormen van poëzie die gekoppeld zijn aan fysieke spelvormen in groep 4? Een drietal gedichten in de Leeskalender zou daar inzicht in moeten geven: 'Dubbel dubbel dit dit' werd aangeboden als klapspel, 'Een meestampertje' nodigde uit tot meestampen (de titel zegt het al), en 'Verstoppertje' was in de verwerking gekoppeld aan taalspel, maar ik was benieuwd of de titel en de specifieke performance van de leerkracht kinderen zouden verleiden tot spontaan spel.

'Een meestampertje' leverde weinig eenduidige inzichten op: het werd in de allerlaatste Leeskalenderweek aangeboden en slechts vier leerkrachten vulden iets in op het logboekblad. Op deze dag was ik ook niet aanwezig in mijn observatiegroep 4. De notities varieerden daarbij van "Leerlingen vonden het leuk om op de maat mee te stampen: hoge betrokkenheid." (2241, logboek week 30) tot "Dit gedicht sprak minder aan. Ze vonden het een moeilijk woord. Ze dachten eerst dat het over Mees zou gaan. Mees Stampertje.” (2142, logboek week 30) 'Dubbel dubbel dit dit' leverde meer inzicht op. De observatie van de verwerking staat al beschreven in de paragraaf over de invloed van het gebrek aan tijd op de aanbieding van teksten in groep 4. Daarnaast schreven negen van de tien leerkrachten over de aanbieding van dit vers in het logboek en waren de kinderen onverdeeld enthousiast, hoewel ze in de ene groep iets meer moeite hadden met de uitvoering dan in de andere groep. Een leerkracht schrijft: "In een lange dubbele rij het klapspel gedaan, telkens met een ander kind. Het klapspel was erg leuk. Ook later deze dag speelden de kinderen het nog." (2342, logboek week 15) Over een andere groep lezen we: "Kinderen erg enthousiast. Veel moeite met de afwisseling van bewegingen (zeker wanneer het tempo wordt opgevoerd)." (1641, logboek week 15) Kinderen vonden het in het bijzonder leuk omdat dit iets is dat ze kennen: "Was leuk, want dit soort spellen doen de kinderen vaak buiten." (2142, logboek week 15) Ook in mijn observatiegroep bleek al bij de bespreking vooraf dat kinderen graag vertellen over wat ze onderling zoal aan spelletjes spelen en ze willen ook graag laten zien wat ze kunnen:

De leerkracht vraagt welke spelletjes de kinderen nu zoal spelen op het schoolplein. Ze noemen: tikkertje, voetbal, stelten (lopen), verstoppertje, thuis ook wel eens een spel met een blinddoek voor en een jongen vertelt dat hij 'atletiekt' op zijn kamer. Z noemt ook nog 'freestylen', dat is op straat rondrennen en overal overheen springen. A noemt 'baltikkertje'. Er wordt ook iets gespeeld dat 'iemand is ' $\mathrm{m}$, niemand is ' $\mathrm{m}$ ' heet, 'stoepranden' en 'Annemaria Koekoek'. De leerkracht vraagt nu specifiek naar klapspelletjes: doen de kinderen dat wel eens? De meisjes roepen in koor: Jaaaaa! Kunnen ze een klapspelletje voor doen? J en J komen voor de klas staan en doen 'Pepsi cola' voor, al raken ze halverwege een beetje in de war. Als iedereen kijkt, is het toch lastiger. Vervolgens doen $\mathrm{J}$ en andere $\mathrm{J}$ nog een klapspelletje voor met als tekst:

Aaa bbb ccc

Tik de grond 
Draai je rond

Pak' $m$ aan en tik (??) je kont

Ze klappen op de eerste regel en doen de andere bewegingen die genoemd worden op de maat van het rijmpje. Op de laatste regel geven ze elkaar eerst een hand en stoten vervolgens de (zijkant van) hun billen tegen elkaar aan, wat grote hilariteit in de klas oplevert. J eindigt haar 'performance' met een spontaan 'Aha aha, I like it', waarbij ze een dansbeweging makt met haar handen. De dames krijgen applaus. Er zitten nu ook andere meisjes met hun hand in de lucht omdat ze nog een ander klapspelletje weten. De leerkracht geeft aan dat ze i.v.m. de tijd nu toch wel naar de tekst bij de Leeskalender moeten, ook al is het wel leuk om het zo te hebben over spelletjes die de kinderen doen. (observatie 15, 14-01-2014)

'Dubbel dubbel dit dit' was een groot succes en werd op verschillende scholen door de kinderen, vooral de meisjes, toegevoegd aan hun klapspel-repertoire. Bij de herhaling van het vers op de keuzedag schrijft de leerkracht van deze groep dat de kinderen het kozen "omdat ze het een leuk spelletje vonden en thuis hadden geoefend!" (2441, logboek week 15) In het afsluitende gesprek vertelt een leerkracht dat het klapspelletje een hit was: iedere pauze en iedere les wilden de kinderen er mee doorgaan (evaluatie 2, S16, 16-06-2014).

'Verstoppertje' (Hagen, 2007) was in de verwerking niet aan het daadwerkelijke spel gekoppeld, maar aan poëtisch taalspel. Het gedicht is op zichzelf een poëtische variatie op het aftellen zoals dat bij het spel verstoppertje gebruikelijk is:

\author{
Verstoppertje \\ wie niet ziet is blind \\ wie niks zegt is stom \\ wie niks hoort is doof \\ wie niet denkt is dom \\ wie niet leeft is dood \\ wie niks aan heeft bloot \\ recht \\ is niet krom \\ na negen komt tien \\ wie niet stil is wordt gehoord \\ wie niet weg is wordt gezien
}

\title{
IK KOM
}

De aanbieding begon met het bespreken van de titel en de afbeelding op de kalender (een muurschildering met een meisje dat met haar gezicht naar de muur staat en de getallen 1 $\mathrm{t} / \mathrm{m} 10$ die boven haar hoofd op de muur staan). De kinderen in mijn observatiegroep herkennen de voorstelling direct: 'ze spelen verstoppertje en de andere kinderen zitten al 
verstopt!' In de handleiding was in de instructie opgenomen dat leerkrachten het vers met hun rug naar de klas gekeerd moesten voorlezen, alsof ze aan het aftellen waren. De leerkracht in mijn observatiegroep draait zich inderdaad om en leest 'Verstoppertje' voor, maar doet dat snel en het is achterin niet heel goed hoorbaar. Een aantal kinderen kijkt verbaasd en sommigen moeten lachen als het woord 'bloot' valt. Geen van de kinderen heeft zich spontaan verstopt en de leerkracht kijkt verrast/opgelucht als ze zich gauw weer omdraait naar de klas.

Leerkracht: Wat zeggen jullie als je verstoppertje gaat spelen?

Kind (j): $\quad 1 \mathrm{t} / \mathrm{m} \mathrm{10}$, wie niet weg is, is gezien, ik kom, poepie!

Kind (m): $\quad$ Ook tellen en dan 'Wie voor me staat, wie achter me staat, wie naast me staat, die is hem!'

Kind (j): $\quad$ Eerst tot zeven tellen, dan 'koetje knal, koetje knal' en dan verder tellen.

Leerkracht: In het gedicht wordt ook zoiets gedaan, maar dan heeft de schrijver zelf iets bedacht. Kunnen jullie ook zelf iets verzinnen?

Kind $(\mathrm{m})$ : Wie niet weg is, krijgt bloemkolen!

Kind $(\mathrm{m})$ : $\quad$ Ik doe dat met mijn zusje van toen ze nog niet kon tellen, dan zei ik gewoon 'ik tel een maal tot tien, wie niet weg is, is gezien' en dan moest ze verstoppen.

Kind (j): $\quad$ Ik tel twee keer tot tien en dan zeg ik de laatste keer 'tien trien!' (observatie $28,18-03-2014$ )

De leerkracht probeerde de kinderen al te laten variëren binnen de structuur van het gedicht, maar ze waren nog niet uitverteld over hun eigen manieren van aftellen bij verstoppertje. De leerkracht stelt vast dat de kinderen allerlei manieren hebben, maar ze had eigenlijk bedoeld dat ze nu iets konden verzinnen zoals in het gedichtje. Ze leest een aantal regels nog eens voor. Een van de jongens denkt door te hebben dat het gaat om tegenovergestelden. $\mathrm{Nu}$ vraagt de leerkracht de kinderen opnieuw om zelf, eerst in hun hoofd, ook zo'n zin beginnend met 'Wie niet ...' en dan 'is ...' te bedenken. De kinderen denken kort na en er gaan al snel vingers de lucht in. In rap tempo wijst de leerkracht het ene na het andere kind aan om de zelfbedachte regel te zeggen. Dat zijn er zó veel dat ik het nauwelijks kan bijhouden - dit was ook de verwerking waarbij de kinderen ontdekten dat het een leuk spel is om sneller te reageren dan ik kan schrijven -. Een aantal (van de in totaal 26) bedachte regels: 'wie niet zit, die staat', 'wie niet lelijk is, is mooi', 'wie niet rijk is, is blut', 'wie niet blij is, is droevig' en 'wie niet dun is, is dik'. Kinderen bedachten ook regels die een beetje afweken van de gevraagde vorm, zoals 'wie bloot is, is naakt', 'de tv staat aan en dan weer uit', 'wie geen tanden heeft, heeft ook geen kies' en 'wij zijn snel, maar een slak is langzaam'. In deze groep vinden de kinderen het variëren erg leuk. Uit de logboeken van de andere groepen valt echter niet goed af te leiden of dit gedicht in groep 4 nu overwegend wel of niet in de smaak viel. Een leerkracht schrijft: "Variaties zelf bedenken vonden ze erg moeilijk. Het gedicht was wel leuk. Gestimuleerd om ze het te laten gebruiken bij het buitenspelen." (2141, logboek week 23a) Een andere leerkracht noteert: "Niet omgedraaid: niet verstandig bij deze groep. Wie niet dik is, is dun; ... snel kan rennen, is langzaam; wie niet vies is schoon; ... oud is, is jong; ... groot is, is klein; wie niet grappig is... is chagrijnig." (2241, logboek week 23a) En een derde leerkracht schrijft: “Alleen het gedicht voor- 
gelezen en besproken. ... Ik zag geen meerwaarde in het met mijn rug naar de klas staan. In de klas is ook geen mogelijkheid om te verstoppen." (2142, logboek week 23a) Deze reacties variëren van een nadruk op fysiek spel (gebruiken bij het buitenspelen), een nadruk op taalspel, tot een nadruk op het verstand (bespreken).

Het klapspel was een groot succes; 'Verstoppertje' was minder overtuigend, zowel op het niveau van de suggestie van het fysieke spel (dat leerkrachten soms te spannend vonden om mee te spelen) als op het niveau van het poëtisch taalspel. Dit lijkt erop te duiden dat de koppeling tussen poëzie en fysiek spel in ieder geval bij de kinderen sterker bijdraagt aan hun beleving en waardering van poëzie dan enkel taalspel. Dit bevestigt het beeld dat ook al uit poëzie gekoppeld aan de vieringen in het jaar naar voren kwam en speelt daarmee een explicietere rol dan ik verwacht had. In groep 4 versterkt fysieke ervaring de beleving en daarmee ook het begrip van specifieke vormen van 'het taalspel poëzie': door die geïntensiveerde beleving waarderen ze een gedicht of lied ook meer dan wanneer ze er alleen over praten of redeneren. De fysieke ervaring van 'het taalspel poëzie' kan bij kinderen in groep 4 ook tot stand komen wanneer ze dat taalspel op talig niveau kunnen spelen, maar fysieke beweging zorgt voor extra intensivering van de beleving. Het vormt in groep 4 echter ook een nog sterker contrast met de gebruikelijke leer-, lees- en luisterhouding die de kinderen wordt aangeleerd dan in de kleutergroepen. Welk beeld komt naar voren wanneer we naar kijken naar poëzie waarin 'muzikaal taalspel' centraal staat?

\section{Muqikaal taalspel: 'Juf, staat dat er echt?'}

In het vorige hoofdstuk kwam naar voren dat muzikaal taalspel in de vorm van rijm, ritme en andere vormen van herhaling in groep (1-)2 een belangrijke rol speelt in het samenspel van factoren dat vorm geeft aan processen van tekstverwerving bij de kleuters voor zover dit kenmerk de kleuters stimuleert het taalspel poëzie mee te doen of na te doen met vocale, maar vooral ook niet-vocale handelingspatronen. Zelf variëren, nieuw rijm bedenken, of een tekst uitbreiden, is voor de meeste kleuters nog lastig en remt hun directe beleving van en plezier in het taalspel poëzie. Hoe werkt dat in groep 4? De hierboven gegeven voorbeelden van 'Vrolijk ...', 'Gekleurde eitjes en een haas' en ook 'Verstoppertje', laten al zien dat zelf variëren, uitbreiden of nieuwe regels en strofes bedenken voor kinderen in groep 4 over het algemeen geen probleem is. Maar draagt 'muzikaal taalspel' als tekstkenmerk ook effectief bij aan het plezier dat de kinderen in groep 4 aan het taalspel poëzie beleven en, zo ja, in welke vorm(en)? De deelvraag die ik wil beantwoorden, is:

KINDERPOËZIE: KWALITATIEVE DEELVRAAG 4b.

Wat vertellen observaties, logboekaantekeningen en gesprekken met leerkrachten met betrekking tot de presentatie van het poëzie-aanbod in de klas, de reacties van de kinderen op deze teksten en hun waardering daarvan ons over de rol van 'muzikaal taalspel', onderverdeeld in

(i) vormen van muzikaal taalspel ter ondersteuning van non-verbale handelingspatronen, en

(ii) vormen van muzikaal taalspel als relatief autonoom spel in processen van poëzieverwerving bij kinderen in groep 4? 
Mijn verwachting is dat kinderen in groep 4 vormen van muzikaal taalspel ter ondersteuning van fysieke handelingspatronen wel waarderen - getuige de hierboven beschreven inzichten -, maar dat ze de meer autonome vormen van muzikaal taalspel binnen het kader van de schoolklas mogelijk nog sterker waarderen. In hoeverre wordt deze verwachting voor groep 4 door de verkregen kwalitatieve data ondersteund? Hoe werkt 'muzikaal taalspel' in de praktijk van groep 4? In hoeverre en in welke vorm(en) draagt deze indicator bij aan het plezier dat deze zeven- en achtjarigen aan 'het taalspel poëzie' beleven? Op basis van de kwalitatieve data maak ik daarbij ook onderscheid tussen de rol van de tekst en de rol van muziek in de beleving bij kinderen in groep 4 .

\section{Rijm en de fysieke ervaring van ritmische patronen in 'bet taalspel poëzie'}

In het vorige hoofdstuk bleken kleuters regelmatig verrast te zijn door hun eigen herkenning van (voor hen) verrassende toepassingen van rijm. De humorreactie die kleuters in die gevallen lieten zien, duidt erop dat we hier te maken hebben met een onverwachte herkenning van een patroon (vgl. Clarke, 2008, p. 27). Voor kinderen in groep 4 werk.t rijm niet meer zo sterk of onverwacht als een markering van 'onalledaags taalgebruik'. Voor hen is 'rijm' een kenmerk dat ze in poëzie verwachten. Bij de verwerking van het gedicht 'Sint-Maarten' vraagt een leerkracht aan de kinderen: 'Hoe kun je weten dat dit een versje is?' 'Omdat het een beetje langzaam gaat en niet zoals een liedje, dat is met instrumenten,' zegt een meisje. De leerkracht bevestigt dat en zegt: 'Ja, een liedje heeft een melodie, he, maar er zijn ook verhalen en wat makt dan dat dit een versje is en niet gewoon een verhaal?' 'Omdat het rijmt,' zegt een jongen. 'Ja, inderdaad,' bevestigt de leerkracht. $\mathrm{Na}$ een paar tellen voegt ze er aan toe dat er ook versjes zijn die niet rijmen, maar dat versjes inderdaad meestal rijmen (observatie 6, 12-11-2013).

Voor kinderen in groep 4 is de aanwezigheid van eindrijm in poëzie geen verrassing, behalve misschien wanneer het plotseling een centrale rol krijgt in een gedicht dat ook een verhaal vertelt, zoals bij het gedicht 'Pinokkio' (Silverstein, 1998; zie ook Hoofdstuk 4 en 7). Dit gedicht telt tien strofes waarin het hele verhaal van Pinokkio wordt naverteld, maar bij het horen van het gedicht wordt de aandacht vooral opgeëist door een spel met de klank van de naam 'Pinokkio':

\section{Pinokkio, Pinokkio, \\ Dat kleine galgebrokkio. \\ 'Mijn reukorgaan voelt anders aan', Sprak hij, 'wanneer ik jokkio'.}

De vraag is of kinderen in groep 4 zich simpelweg kunnen verliezen in het grappige klankspel waarvoor de dichter allerlei bestaande woorden heeft omgebogen om ze op 'Pinokkio' te laten rijmen, of dat ze de spanning tussen het klankspel en het verhaal dat in het gedicht verteld wordt, niet waarderen. De ontvangst van dit gedicht loopt sterk uiteen en we kunnen ons afvragen of dit te maken heeft met de nadruk die leerkrachten in hun performance op het muzikale of op het verhalende aspect gelegd hebben. De ene leerkracht schrijft in het logboek: "Moeilijk! Te weinig betekenisvol voor veel kinderen." (2341, logboek week 7) 
Het tekort aan betekenis speelde de waardering hier parten; een andere leerkracht wijt het gebrek aan waardering in haar groep echter juist aan het type klankspel: "Gedicht sprak niet aan. Humor van rijmen kwam helemaal niet over." (2241, logboek week 7) Een volgende stelt vast dat een zeer expliciete nadruk op ritme en rijm wel bijdraagt aan de waardering: "Moeilijke tekst. Rappen wel leuk." (2343, logboek week 7) Weer een ander was verrast door het feit dat de kinderen wel leken te begrijpen wat de bedoeling was: "Mij leek het erg moeilijk te begrijpen maar de kinderen vonden het heel leuk en snapten de bedoeling." (1141, logboek week 7) En de laatste weet een mooie overgang te maken van gedicht naar verhaal: "De kinderen vonden het erg leuk, hebben het afgesloten met het kijken van de film." (2141, logboek week 7) Het is moeilijk om hier een eenduidig beeld uit af te leiden over de waardering van dit gedicht door kinderen in groep 4. De moeilijke inhoud van dit gedicht biedt alleen houvast wanneer kinderen goed bekend zijn met het verhaal van Pinokkio; van rijmen op zich worden kinderen in groep 4 niet meer onverdeeld warm.

De logboekaantekeningen bij het welbekende ' $k$ Zag twee beren' geven aanvullende inzichten over de werking van rijm en rijmen in de totstandkoming en waardering van het taalspel poëzie in groep 4. Een leerkracht schrijft: "In eerste instantie deden de kinderen enthousiast mee. Er werden genoeg liedjes verzonnen.” (2641, logboek week 2a) Dit suggereert dat de kinderen -in tweede instantie - snel uitgekeken raakten op het spel. Tijdens het afsluitend gesprek noemt deze leerkracht 'k Zag twee beren broodjes smeren' dan ook als tekst die onverwacht tegenviel in zijn groep (evaluatie 2, S26, 10-06-2014). In de klas zullen de kinderen niet snel de meest subversieve varianten laten horen, en dan is rijmen alleen niet genoeg om speciale betrokkenheid bij en waardering voor dit lied te genereren. Een aantal leerkrachten noemt voorbeelden van variaties die wel werkten. "Rijmen vinden ze een leuke bezigheid. Zeker als er ook onzinwoorden aan te pas komen," schrijft een van hen (2141, logboek week 2a). En een ander verzon op de keuzedag zelf varianten die erg in de smaak vielen: "Leerlingen vonden het geweldig toen ik overstapte op: ik zag 2 deuren papiertjes scheuren; 2 pennen samen rennen etc.” (1641, logboek week 2a) Dit lied spreekt kinderen in groep 4 waarschijnlijk al meer aan op het niveau van het (carnavalesk) nonsensicale taalspel dat erin gespeeld wordt (zie verderop). Rijmen alleen is voor kinderen in groep 4 iets dat ze wel leuk vinden, maar vooral als er een onverwachte draai wordt gegeven aan het rijmprocedé, dus door te rijmen met onzinwoorden, of door het zelf bedenken van nieuwe varianten op een welbekend rijmspel als ' $k$ Zag twee beren broodjes smeren' een opfrisser te geven door de dieren te vervangen door objecten. De rol van rijm en zelf rijmen in de beleving en waardering van kinderen in groep 4 voor 'het taalspel poëzie' lijkt echter een grotendeels gepasseerd station. Dat passeren moet dan, zo lijkt het, plaatsvinden in de loop van groep 3 want bij de kleuters draagt het ontdekken van verrassende klankpatronen in 'het taalspel poëzie' wel bij aan hun beleving en waardering, maar is zelf rijmen vaak nog te moeilijk en remt de beleving.

\section{Muziek en de fysieke ervaring van ritmische (klank)patronen}

Muzikaal taalspel is vaak een primair kenmerk van rijmen en liedjes die fysieke spelvormen evoceren, zoals het klapspel 'Dubbel dubbel dit dit' en het gedicht 'Verstoppertje'. Muzikaal taalspel kan echter ook subtielere vormen van fysieke ervaring oproepen. Ritme is een 
belangrijk onderdeel van 'muzikaal taalspel' en in groep 4 viel me op dat de kinderen zeer ritmegevoelig zijn. Dit kwam het sterkst naar voren bij de liedjes. Van de in totaal negenendertig poëzieteksten die waren opgenomen in de Leeskalender voor groep 4, waren zeven teksten als liedje bijgeleverd op de Leeskalender-cd. Twee van de zeven liedjes werden daarbij aanvankelijk angeboden als gedicht en pas in de herhalingsactiviteit als lied. De kinderen in groep 4 reageerden heel sterk op muziek in de klas: dit is op de meeste scholen iets dat vanaf groep 3 vooral nog in de muziekles aan de orde komt, of bij bijzondere gelegenheden of projecten. Muziek en ritmische beweging zijn in die zin uitzonderlijk als onderdeel van het lesprogramma in de klas. Bij ieder liedje dat werd aangeboden, zag ik de kinderen direct meebewegen op hun stoel. Meestal werd dit enigszins ingetoomd door de leerkracht. Bij mijn observatie van de aanbieding van het lied 'Leuk is raar', geselecteerd vanwege de nonsensicale omkeringen in de tekst, zie ik verschillende kinderen bij de eerste keer luisteren al ritmisch bewegen:

De kinderen gaan steeds meer meebewegen op de maat van de muziek. Als een aantal jongens wil mee gaan trommelen, worden ze door de leerkracht tot de orde geroepen: 'Niet trommelen!' (observatie 8, 14-11-2013)

Wanneer de leerkracht aangeeft dat hij het liedje nog een keer zal laten horen, vraagt een van de meisjes: 'Mogen we dansen?' Zolang ze op hun stoel blijven zitten mag het wel van de leerkracht. De kinderen swingen bij de tweede keer direct mee op de maat; verschillende kinderen bedenken spontaan speciale armbewegingen of draaien op hun stoel bij 'geef de boel een draai' (observatie 8, 14-11-2013). Een andere leerkracht schrijft in het logboek: "Liedjes met een vlot ritme spreken altijd aan." (2241, logboek week 8b)

De kinderen genieten van de fysieke ervaring van het ritme, de melodie en ook de betekenis van de liedjes. 'Naïma maakt muziek', dat uitgebreider aan bod komt in de paragraaf over 'culturele pluriformiteit', is een lied waar in ieder couplet een ander muziekinstrument centraal staat, steeds gevolgd door een muzikaal intermezzo waarin het betreffende instrument te horen is. Bij de eerste instrumentale break in het liedje doen de kinderen alsof ze op de viool spelen en bij de andere breaks doen ze eveneens of ze het betreffende instrument bespelen. Bij de tabla trommelen ze mee op hun knieën: een jongen probeert het op de tafel, maar wordt direct gecorrigeerd door de leerkracht, 'Niet op de tafel, moet ik dat nu weer zeggen?' Bij het volgende couplet zijn er ook kinderen die mee neuriën of proberen fonetisch mee te zingen en dit doen bij elk couplet steeds meer kinderen (observatie 2, 24-10-2013). Na afloop schrijft de leerkracht in het logboek: "De kinderen waren heel enthousiast," en op de keuzedag wilden ze het lied opnieuw horen "omdat ze graag meezingen." (2441, logboek week 5b) Een andere leerkracht schrijft: "Kinderen waren enthousiast bij het uitbeelden van de instrumenten." (2341, logboek week 5b) Het lied werd dan ook vaak gekozen op de keuzedag: "Naima maakt muziek! Vrolijk element om er muziek bij te hebben." (2141, logboek week 5b) De kinderen in groep 4 hebben weinig aanleiding nodig om vanzelf mee te gaan doen met liedjes zoals de kleuters dat ook lieten zien in het meedoen met rijmen die fysieke beweging oproepen.

Een van de gedichten die zowel zonder als met muziek werden aangeboden, was 'De heks van Sier-kon-fleks' van Annie M.G. Schmidt. Uit de logboeken spreekt een duidelijk 
verschil tussen de twee vormen van aanbieden. Een van de leerkrachten schrijft over de tekstuele verwerking: "Verhaal was lastig te begrijpen, dus uitbeelden was lastig. Het bespreken kostte veel tijd. Lln begrepen dat de heks gemeen deed, maar niet wat ze deed." Ze voegt toe: "Meezingen hadden ze een leukere verwerking gevonden." (2241, logboek week 16) Dat is goed te begrijpen met regels als 'Op zondag neemt zij de kolonel/ en tovert hem om in een mokka-stel'. In de verwerking mochten kinderen vervolgens zelf rijmende coupletten verzinnen om de activiteiten van de heks te moderniseren. In een groep droeg deze vorm van productieve receptie duidelijk bij aan de waardering van de kinderen die het gedicht op de keuzedag opnieuw wilden doen: "Heks van Sier-kon-fleks: omdat ze het leuk vonden om te rijmen. De rijmpjes waren heel leuk verzonnen door de kinderen." (2141, logboek week 16) In andere groepen spreekt er weinig enthousiasme uit de logboekaantekeningen, mede door de drukke CITO-toetsperiode: "Door het rooster en de toetsen alleen tijd voor het voorlezen.” (2342, logboek week 16) Dat was niet genoeg om de kinderen het gedicht opnieuw te doen kiezen; anders was dat in een groep waar direct voor een muzikale aanbieding was gekozen. Daar kozen de kinderen het gedicht wel op de keuzedag: "De kinderen zingen het lied al goed mee en willen dit liedje graag in hun klapper." (2441, logboek week 16) Eenzelfde verdeeldheid is zichtbaar in de logboekaantekeningen bij Willem Wilminks 'Chinese taalles' (2010), een sterk ritmisch klankvers waarin allerlei losse Chineesklinkende woorden en namen achter elkaar zijn geplaatst als ware het vloeiend Chinees:

\author{
Taugeh, taugeh, Thé Tjong King \\ Ik wou dat ik naar China ging \\ Taugeh, taugeh, Tsjeu La Ling \\ Hoor eens wat ik zing \\ Litsjeh litsjeh loempia \\ Loempia fong leng
}

Dit vers telt in totaal drie strofes, of coupletten, afgewisseld door het refrein. Bij de eerste aanbieding werd het als liedje aangeboden en werd er bekeken of de kinderen dachten of dit 'echt' Chinees is of niet. Vervolgens zou het liedje geoefend worden. Een leerkracht schrijft bij de eerste aanbieding dat ze de verwerking niet hebben gedaan, alleen het benoemen van de woorden die de kinderen herkenden: "Andere niet relevant / te druk in deze groep. Lacherig om liedje: les minder geschikt voor mijn groep.” (2241, logboek week 23b) Een tweede leerkracht schrijft in het logboek: "De woorden in het Chinees benoemen was educatief. De rest van de les was wat ingewikkeld. Ik vond het niet veel toegevoegde waarde hebben." 191 (2141, logboek week 23b) Toch kozen de kinderen op de keuzedag weer voor het liedje, waar ze nu op mochten dansen: "Chinese les: vonden het lied grappig. Dansje was erg leuk! Lekker veel beweging!” (2141, logboek week 23b)

\footnotetext{
${ }^{191}$ De leerkracht die dit schrijft, geeft elders in het logboek en ook tijdens het afsluitende gesprek aan dat ze het jammer vond dat er zoveel verhalen en gedichten 'over de Islam en andere landen' in de Leeskalender waren opgenomen (zie paragraaf over culturele pluriformiteit). Het kan dus goed zijn dat zij de 'Chinese taalles' van Wilmink vanuit dat perspectief bekijkt, hoewel het hier gaat om puur taalspel. Op de keuzedag staat in deze groep een andere leerkracht voor de klas wat het scherpe contrast tussen deze logboeknotitie en die op de keuzedag mede kan verklaren.
} 
Muziek werkt in groep 4 duidelijk in het voordeel van de beleving en waardering van poezie, maar we kunnen ons afvragen of het bijdraagt aan de beleving en waardering van 'het taalspel poëzie' of van muziek. Hoewel ze veel met elkaar gemeen hebben, is het voorstelbaar dat kinderen in groep 4 ze als gescheiden vormen zien, getuige het eerder al weergegeven antwoord van een van de kinderen op vraag 'Hoe kun je weten dat dit een versje is?': 'Omdat het een beetje langzaam gaat en niet zoals een liedje, dat is met instrumenten.' (observatie 6,12-11-2013) De liedjes behoorden wel vaak tot de favorieten in de betreffende Leeskalenderweek en met name 'Naïma maakt muziek' was langere tijd een terugkerend verzoeknummer, in ieder geval in mijn observatiegroep. Dat had ook te maken met de tweetaligheid van het lied (zie hieronder, Poëzie en de representatie van culturele pluriformiteit in groep 4). De muziek droeg in ieder geval sterker bij aan de beleving en waardering van poezie in groep 4 dan rijm, zeker in combinatie met meezingen, dansen of anderszins ritmisch bewegen.

\section{Autonome vormen van muzikaal taalspel en de (her)ontdekeking van het opzegvers}

We kunnen de werking van poëzie nooit helemaal los zien van de fysieke ervaring van ritme, klank en allerlei andere vormen van geperiodiseerde herhaling. In sommige vormen van poëzie staan deze prosodische en ritmische eigenschappen van taal echter zo sterk op de voorgrond dat er niet of nauwelijks meer sprake is van enige referentiële betekenis. Die poëtische klanktaal is betekenisvol in een ander, niet-symbolisch, taalsysteem, door Julia Kristeva aangeduid als het semiotisch taalsysteem: “... de taallaag waarin taal geen betekenis is, maar pure klank, ritme en muziek." (Meijer, 1997, pp. 150-151) Die taallaag speelt een belangrijke rol ter ondersteuning van fysieke handelingspatronen in pragmatische contexten van poëziegebruik, vooral in het spel. Die taallaag kan echter ook een belangrijke spelfunctie op zich vervullen, zoals blijkt uit 'standaardvormen' van het poëtisch taalspel in de cultuur van het dagelijks leven als de tongbreker, het kettingrijm en allerlei andere soorten 'taal- en uitspraakrijmen'. Hoewel deze vormen relatief autonoom functioneren, spelen de fysiek ervaarbare effecten die ze teweeg brengen via de mondelinge performance een cruciale rol in de beleving van deze vormen van spel.

In Hoofdstuk 4 besprak ik al hoe dichters van kinderpoëzie kunnen spelen met de effecten van tongbrekers, zoals Paul Biegel doet in 'De kikker en de karekiet' en Joke van Leeuwen in haar 'Versje om te mompelen als je niet goed in slaap kunt komen'. Hoe reageren kinderen in groep 4 op deze vormen van poëtisch taalspel in de klas? Uit de logboekaantekeningen blijkt dat 'Een kikker en een karekiet' in de groepen 4 waarin het behandeld is een groot succes was, ondanks (of dankzij) het tongbrekende effect. Een leerkracht schrijft: "Lastig versje, maar wel heel leuk." (1141, logboek week 22) Op een andere school viel het vers dusdanig in de smaak dat kinderen er ook buiten de Leeskalenderactiviteit om nog mee bezig waren: "Leuk gedicht. De kinderen zijn er tijdens het buitenspelen nog mee doorgegaan.” (2141, logboek week 22) Op de keuzedag wilden de kinderen in deze groep het vers opnieuw horen en blijkt het zelf variëren op de tekst ook een succes: "Kikkerversje: zinnen bedacht (met een veelvoorkomende letter), gekozen omdat ze het versje grappig vonden. Kwamen met leuke zinnen!” (2141, logboek week 22) In een volgende groep was er weinig tijd: "De klas in groepen verdelen met de hele verwerking is te veel werk ivm het 
rooster in groep 4." Ondanks dat viel het wel in de smaak: "Ze vonden het gedicht leuk!" (2142, logboek week 22) Op de keuzedag kwam het vers ook in deze groep nog een keer terug: "Kikker en karekiet: gekozen omdat het een leuke mengeling is van woorden die beginnen met de letter K.” (2142, logboek week 22) In mijn observatiegroep 4 werd het gedicht, zoals aangegeven in de handleiding, na het voorlezen eerst op de inhoud besproken, maar kwamen de opvallende klankeigenschappen vanzelf al aan bod:

De leerkracht leest het gedicht een keer voor: het gaat bijna zonder te struikelen. Tijdens het voorlezen klinkt er af en toe wat gelach. Na het voorlezen vraagt de leerkracht waarom de karekiet zegt dat hij een 'karekietelniet' is. Een van de jongens snapt het: 'Hij is een vogel die niet gekieteld wil worden'. En wat is een opkikker? Een andere jongen denkt dat dat iets is waar je blij van wordt. De leerkracht vult aan dat je van een opkikker weer e... energie krijgt. Dan gaat ze naar de laatste zin van het gedicht met de vraag: wat zegt de kikker? Ze laat de kinderen de laatste regel een paar keer opzeggen. Het lukt nog niet helemaal vlekkeloos. Wat zou het betekenen? 'Misschien dat de karekiet de kikker een beetje moet kietelen', denkt iemand. De anderen lachen: 'Neeee, precies andersom!' De leerkracht laat de kinderen opnieuw de laatste regel opzeggen. Vervolgens leest ze het hele gedicht opnieuw voor. Zodra ze stopt hoor ik een van de kinderen zeggen: 'Hier zitten echt veel k's in!' (observatie 26, 11-03-2014)

Vervolgens verdelen de kinderen in paren de tekst en mogen ze het gedicht, als ze willen/durven, voor de klas opvoeren. De meeste kinderen willen dat heel graag en hoewel ze zich soms nog een beetje achter het papier met de tekst verschuilen, gaat het opzeggen steeds vlotter en in veel gevallen ook opvallend ritmisch. Ik had bij deze 'les' actief geholpen met de rolverdelingen en het oefenen waardoor ik weinig aantekeningen heb gemaakt, maar de leerkracht schrijft achteraf in het logboek: "De kinderen vonden de verwerking erg leuk en hebben het gedicht in tweetallen allemaal voorgedragen. Rollen verdelen vonden ze lastig." (2441, logboek week 22) Dat de kinderen het leuk vonden, blijkt ook hier uit het feit dat ze het gedicht opnieuw kozen op de keuzedag: "Ze vonden deze tekst erg leuk. Druk, enthousiast!" (2441, logboek week 22) De kinderen waarderen dit type klankspel en vinden het erg leuk om het zelf te doen. Ook de aanbieding van het 'Versje om te mompelen als je niet goed in slaap kunt komen' (Leeuwen, 2000) bevestigt dat kinderen in groep 4 veel plezier beleven aan dit type taalspel. Het vers is een bewerking van een tongbreker en gaat als volgt:

de slome slak slaapt in de slappe sla de slome slak slaapt in de slappe sla de slome slak slaapt in de slappe sla de slome slak slaap idde slappe sla de slowe slah slawidde slawe sla de sllde slll saal asssasssssssss 
de sll de sll

sssssss $^{192}$

In Hoofdstuk 4 schreef ik al dat de aandacht in dit vers ligt op het rustgevende effect dat we associëren met de 's'-klank (als in 'suja', 'sssst', 'slaap', 'stil'). Dat effect wordt versterkt doordat het associatieve betekenisveld van de 's'-klank samenvalt met de semantische betekenis van de woorden zelf, zoals in 'sloom', 'slak, 'slaapt' en 'slap'. De 'sl'-klank kost daarbij relatief veel tijd om uit te spreken waardoor de spraak vanzelf vertraagt. Dit vers werkt als een geheel, als gebruikspoëzie die in een specifieke pragmatische context (in bed, als je niet goed in slaap kunt komen) een specifieke functie vervult. De leerkrachten was in de instructie gevraagd dit effect nog eens te verduidelijken door in hun voordracht van het vers ook steeds trager te gaan spreken en daarbij te doen of ze echt in slaap vielen. In sommige groepen werkte dit heel goed en een van de leerkrachten ziet wel mogelijkheden in die pragmatische functie: "Dat je juf zelf erbij in slaap valt is natuurlijk hilarisch. Een fijn versje om in een drukke groep als deze een rustmoment te creëren." (2342, logboek week 10) Ook in een andere groep had het vers een rustgevend effect op de hele groep: "Kinderen vonden het geweldig! Ze vielen ervan in slaap... sommigen werden erg ontspannen." (2341, logboek week 10) In andere groepen kwam het slaapverwekkende effect niet zo goed tot stand, hoewel dit niet afdeed aan de waardering van het vers door de kinderen: "Ze waren vandaag heel druk. Dus t versje langzaam voordragen ging niet zo goed. Ze vonden t wel leuk." (2142, logboek week 10) Over het algemeen vonden de kinderen het vers grappig, mede door de fysieke beleving: "Ze vonden het uitbeelden erg leuk en vroegen een paar x om herhaling." (2343, logboek week 10) In meerdere groepen werd dit vers dan ook opnieuw gekozen op de keuzedag: "Iedereen koos voor: versje om te mompelen." (1641, logboek week 10)

Ook in mijn observatiegroep 4 werd dit vers in de week van de aanbieding erg gewaardeerd door de kinderen, ondanks de opwinding in de aanloop naar Sinterklaas. De leerkracht waarschuwt me van te voren 'want het is een beetje chaotisch: vandaag doen we schoentje zetten, dus de kinderen zijn helemaal in de Sinterklaas stemming en ik wil straks ook nog een liedje met ze zingen, dus het wordt niet zo'n uitgebreide sessie met de kalender en de kinderen zijn waarschijnlijk niet zo geconcentreerd' (observatie 10, 26-11-2013). Nadat in de klas besproken is wat 'mompelen' betekent en wat de kinderen op de afbeelding zien, vraagt de leerkracht of de kinderen wel eens niet goed in slaap kunnen komen en wat ze dan doen. Een van de jongens demonstreert zijn methode en daarmee onbewust ook precies het effect van het vers:

De leerkracht vraagt nu of de kinderen ook trucjes hebben om dan toch in slaap te vallen. 'In je kop schaapjes tellen,' weet L en hij doet meteen voor hoe dat gaat: 'Eén, twee, drie,' telt hij, 'vieeer, vfff, zssssss.' De leerkracht wijst erop dat je dan slaperig wordt van het tellen en dus gaat... mompelen. (observatie 10, 26-11-2013)

\footnotetext{
192 Van Leeuwen maakte ook een 'Versje om te mompelen als je niet goed wakker kunt worden', waarin de taal vanuit pure klank langzaam maar zeker ontwaakt en haar betekenisvolle gestalte aanneemt: "mmhohmmhohmmhohpfff/ mmhohmmhohmmhohpfff// izzolekkewarmier/ izzolekkewarmier// mamoewakkewoh/ mamoewakkewoh// Moemewazze/ moemewazze// hup."
} 
Andere kinderen hebben zo hun eigen methoden: water drinken, springen op bed tot je benen moe worden, een beetje dromerig dansen, gewoon net zolang opblijven tot je vanzelf in slaap valt, heel lang tv kijken, je broer een heel saai verhaaltje laten vertellen, en muziek luisteren. Hoewel de kinderen nog veel meer zouden kunnen vertellen over wanneer ze niet goed kunnen slapen (bijvoorbeeld voordat je op schoolreisje gaat) en wat je er zoal aan kunt doen, geeft de leerkracht aan dat ze verder moeten want ze wil ook nog wat tijd over hebben om een Sinterklaasliedje te zingen:

Ze heeft de map op haar schoot, maar doet het vers uit haar hoofd en leeft zich helemaal in: eerst zegt ze de regels duidelijk en opgewekt, maar gaandeweg gaat ze steeds meer mompelen en trager spreken, gaapt eens tussendoor en als ze helemaal niet meer te verstaan is, doet ze of ze in slaap valt (ze laat haar ogen dichtvallen en haar hoofd zakken). Al na de eerste regel roept een jongen van achter uit de klas vol ongeloof: 'Juf, staat dat er echt?' $\mathrm{Na}$ afloop van de voorstelling vraagt hij dat opnieuw. Verschillende kinderen staan op en kijken in de handleiding: ja, het staat er echt. 'Ja joh, anders zou de juf het toch ook niet voorlezen!' roept een meisje. De kinderen moeten een beetje lachen, al is het niet duidelijk of ze moeten lachen om het versje, om de slapende leerkracht, om de opmerking van de jongen of om de reactie van zijn klasgenootje. Als afsluiter merkt L nog op: 'Dat is hetzelfde als bij schaapjes tellen, dat je dan steeds minder kan zeggen.' (observatie 10, 26-11-2013)

In andere groepen werd al duidelijk dat het 'afwijkende' gedrag van de leerkracht (door in slaap te vallen) grappig werd gevonden door de kinderen; tijdens mijn observatie komt ook naar voren dat deze tekst voor sommige kinderen dusdanig afwijkt van hun door lezen en schrijven gevormde referentiekader dat het bijna niet te geloven is dat zoiets geschreven staat. Autonome vormen van 'muzikaal taalspel' brengen dan als het ware een herontdekking van 'het opzegvers' met zich mee (zie ook Hoofdstuk 2) en tegelijk het besef dat ook dergelijke taal geschreven kan staan. De kinderen in deze groep kozen het vers op de keuzedag dan ook precies vanwege de overtuigende performance door de leerkracht. Ze wilden: "Slome Slak. Omdat ze het leuk vonden hoe deze tekst werd voorgelezen." (2441, logboek week 10) De performance is bij alle 'muzikaal taalspel' van cruciaal belang, maar onverwachte vormen van poëzie performances lijken in groep 4, vanwege het verrassingseffect, in het bijzonder bij te dragen aan het plezier en de waardering van de kinderen. Dat was al zichtbaar bij de aanbieding van het 'Versje om te mompelen' en kwam nog duidelijker naar voren bij de aanbieding van het 'Versje om te rappen (zonder einde)': "Leerlingen vonden het geweldig dat de juf 'rapte'. Ik heb het 6x gedaan," schrijft een leerkracht in het logboek (1641, logboek week 4). Dit vers van Frank Adam, dat eindeloos kan doorlopen vanwege de circulaire structuur (zie Hoofdstuk 4), had op de kinderen een tegenovergestelde uitwerking in vergelijking met het 'Versje om te mompelen': “Super leuk, sommigen werden er wel erg druk van... :)" (2341, logboek week 4) Zoals aangegeven in de handleiding werden de kinderen in sommige groepen ingezet voor de begeleidende 'muziek' bij de rap, soms in combinatie met beatbox-demo's van internet, en dat smaakte duidelijk naar meer: "Heel orkest met beatbox erbij. Erg enthousiast. Ook kinderen probeerden een rap. Ze willen een rap bij de groepsshow doen." (2343, logboek week 4) De kinderen vonden het vers 'cool' 
(1141, logboek week 4) en konden bij de herhaling op de keuzedag ook heel goed zelf mee rappen (2441, logboek week 4). In een groep blijft het rappen op de keuzedag niet alleen bij dit vers: "Ritme erbij dat door de leerlingen meegedaan werd. Daarna nog met een versje van Annie M.G. Schmidt 'De bezige bij'. Enthousiasme. Roept beweging op." (2241, logboek week 4)

Een laatste autonome vorm van muzikaal taalspel die in de Leeskalender voor groep 4 vertegenwoordigd was, is het type cumulatief taalspel zoals dat onder meer in 'This is the house that Jack built' wordt gespeeld (zie Hoofdstuk 4). In groep 4 kregen de kinderen het vers 'Het poppenkopmannetje' aangeboden dat begint met 'Dat is het huis van het poppenkopmannetje' en eindigt met: 'Dat is de slager die slacht/ de os die dronk/ het water dat bluste/ het vuur dat verbrandde/ de knuppel die sloeg/ de hond die beet/ de kat die at/ de muis die knaagt aan het koord aan de sleutel voor het slot op de deur naar het huis van het poppenkopmannetje.' (Vendel \& Jacoby, 2005, zp) Deze complexe, cumulatieve, linguïstische structuur werd ondersteund door de afbeelding op het kalenderblad waarop de onderdelen konden worden aangewezen (zie Figuur 10). Uit de logboeken blijkt dat de vorm van dit vers nieuw was voor de kinderen en ze het (daardoor) ook heel grappig vonden: "Leuke vorm: kenden ze nog niet, verrassend!" (1141, logboek week 14b) Een andere leerkracht beschrijft het effect van deze vorm: "De leerlingen moesten lachen als het verhaal steeds langer werd. Het verhaal kon door de plaatjes door de meeste leerlingen wel gevolgd worden. Afmaken van het verhaal was wat lastiger." (2341, logboek week 14b) Vanwege de moeilijkheidsgraad van de verwerkingsopdracht (het vers zelf verder uitbreiden) en/of tijdgebrek kozen verschillende leerkrachten voor een andere verwerkingsvorm: "De leerlingen alles laten herhalen. Erg leuk, vind alleen de tekst erg lang. Hierdoor (helaas) weinig tijd voor de verwerking. ... de krokodil, die beet in de bil. De kinderen vonden het leuk om 'mee te doen'. Veel leerlingen lukte dat. Aan het eind kon één leerling het verhaal nazeggen. Dit lukte: knap!" (2241, logboek week 14b)

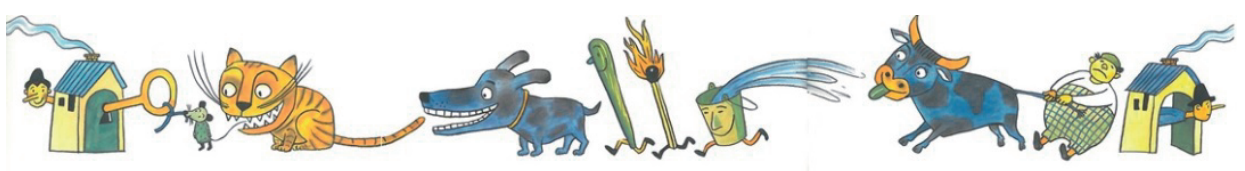

Figuur 11. Illustratie bij het gedicht 'Het poppenkopmannetje', uit de bundel Al mijn later is met jou. Met tekeningen van Rotraut Susanne Berner (Vendel \& Jacoby, 2005).

Bij nieuwe vormen van 'het taalspel poëzie' is het zichtbaar effectiever om de kinderen te laten meedoen in plaats van zelf variëren: in die instanties moeten ze hun kennis van poëtische structuren nog actief opbouwen en uitbreiden, terwijl ze het bij bekende en herkenbare structuren leuk vinden om zelf te variëren. De autonome vormen van 'muzikaal taalspel' vielen juist door de verrassingseffecten die ze teweeg brachten bij de kinderen in de smaak: ze riepen humorreacties op (enthousiasme, verrassing, lachen, vragen om herhaling). In relatie tot de 'poëtische ontwikkeling' van deze kinderen, als onderdeel van hun ontluikende culturele geletterdheid, is dit opnieuw een bevestiging van wat we bij de kleuters al zagen in relatie tot hun herkenning van verrassende rijmpatronen: net als ervaren lezers beleven kinderen plezier aan (de herkenning van) vernieuwende elementen in poëzie. Wat vernieu- 
wend ís, moet, net als wat poëzie ís, ook hier in pragmatisch ontwikkelingsperspectief gezien worden (zie Hoofdstuk 2). De vernieuwing hangt in groep 4 enerzijds samen met de verwachtingspatronen van de kinderen met betrekking tot 'het taalspel poëzie' en anderzijds met hun verwachtingspatroon binnen de context van de schoolklas. Vormen van poëtisch taalgebruik die - in relatie tot de gebruikelijke rol van de leerkracht, in relatie tot de gebruikelijke geschreven tekst, of in relatie tot de structurele eigenschappen van taal - verrassend zijn, dragen bij aan de beleving en het plezier van de kinderen. Formele 'transgressiviteit' wordt door kinderen in groep 4 dus gewaardeerd in (de performance van) poëzie, waarbij 'transgressie' hoofdzakelijk gerelateerd is aan twee aspecten van de culturele competentie van de kinderen: hun 'poëtische schemata' enerzijds en hun 'school(klas) schemata' anderzijds.

\section{(Carnavaleske) nonsens: "Alles met 'bil' of 'plas' of žo, dat vinden ze heel leuk!"}

Nonsens is nonsens voor zover het afwijkt van de 'stock of knowledge' die binnen een bepaalde culturele gemeenschap voor handen is, stelde Susan Stewart. Althans, die 'stock of knowledge' bepaalt voor een belangrijk deel wat we als 'normaal', 'natuurlijk', 'zinvol' of 'betekenisvol' ervaren en interpreteren in ons alledaagse doen en laten. Sterker nog: "Our stock of knowledge at hand, derived from our biographical situation and from tradition, influences not only the content and details of our interpretations, but also their style, the general lines along which the world will be constructed and understood." (Stewart, 1989, p. 14) 'Sense making' is iets waar we de hele dag door mee bezig zijn, meestal zonder dat we ons daar bewust van zijn. 'Nonsense making' gebeurt met dezelfde middelen, maar dan bewnst zo gemanipuleerd dat de voorgestelde werkelijkheid zich aan ons voordoet als tegenovergesteld, (letterlijk) omgekeerd, 'krom-evenredig', extreem overdreven, of verkeerd samengesteld in verhouding tot de werkelijkheid zoals we die als 'normaal' of 'betekenisvol' ervaren. Carnavaleske nonsens, zo heb ik in Hoofdstuk 5 gesteld, richt zich daarbij specifiek op categorieën waarmee we ons sociale leven reguleren, zoals allerlei taboes, gedragsnormen of omgangsvormen, machtsverhoudingen en officiële vormen van taalgebruik. Carnavaleske poëzie maakt die impliciete 'regels' die bepalen wat we als wenselijk, fatsoenlijk, 'natuurlijk' sociaal gedrag zien, expliciet door die regels juist te breken, of het breken van die regels als onderwerp te nemen. De kinderen in groepen 4 in de experimentele conditie hebben met de Leeskalender ${ }^{+K i n d e r p o e ̈ z i e ~}$ verschillende vormen van nonsensicaliteit in poëzie aangeboden gekregen, van het relatief abstracte spel met taal en (extreem) grote getallen tot en met het carnavaleske spel met fatsoensnormen en van alles daartussenin. De deelvraag die ik wil beantwoorden, is: 
KINDERPOËZIE: KWALITATIEVE DEELVRAAG 4c.

Wat vertellen observaties, logboekaantekeningen en gesprekken met leerkrachten met betrekking tot de presentatie van het poëzie-aanbod in de klas, de reacties van de kinderen op deze teksten en hun waardering daarvan ons over de rol van '(carnavaleske) nonsensicaliteit', onderverdeeld in

(i) carnavaleske vormen van nonsensicaliteit bemiddeld door subversief fysiek handelen in relatie tot de sociale context en de culturele categorieën (waarden en normen) die in die sociale context gelden, en

(ii) carnavaleske vormen van nonsensicaliteit bemiddeld door subversief talig handelen in relatie tot de sociale context en de culturele categorieën (waarden en normen) die in die sociale context gelden, en

(iii) vormen van nonsensicaliteit die een meer intellectuele ervaring van 'incongruentie' teweegbrengen, bemiddeld door een voorstelling van de werkelijkheid die afwijkt van de 'natuurlijke wetmatigheden' die gelden in de waarneembare of conceptuele werkelijkheid in processen van poëzieverwerving bij kinderen in groep 4 ?

Carnavaleske nonsens wordt, naar verwachting, door kinderen in groep 4 als 'grensoverschrijdender' ervaren dan intellectueler vormen van nonsens en wordt daardoor naar verwachting ook meer door hen gewaardeerd. Valt uit de reacties van kinderen en leerkrachten op de aanbieding van dit brede scala aan vormen van nonsensicaliteit af te leiden of - en, zo ja, in welke vorm(en) - (carnavaleske) nonsensicaliteit effectief bijdraagt aan de waardering die kinderen in groep 4 hebben voor en het plezier dat zij beleven aan kinderpoëzie? Op basis van de verkregen inzichten, bespreek ik de meer intellectueel gerichte vormen van nonsens en de carnavaleske vormen van nonsens apart, maar maak ik in die laatste categorie geen expliciet onderscheid tussen fysiek en talig handelen omdat dat onderscheid, zoals duidelijk wordt, geen rol meer speelt in het samenspel van factoren dat vorm geeft aan de waardering en verwerving van carnavalesk nonsensicale poëzie bij kinderen in groep 4.

\section{De intellectuele ervaring van nonsens gegrond in de carnavaleske lichamelijkheid}

In gedichten als 'De mislukte fee', 'Drie apothekertjes' en 'De koning van Savoye', allemaal van Annie M.G. Schmidt, treffen we nonsensicaliteit in haar meer abstracte hoedanigheden aan (zie Hoofdstuk 5). Het gedicht 'De mislukte fee' begint met een moederfee die twee feeënkindertjes heeft, waarvan er een niet helemaal voldoet aan de uiterlijke voorschriften voor feeën: ze was niet lelieblank, zoals dat hoort bij feetjes, maar zat vol met sproeten! De moederfee, vreselijk ontdaan, probeert van alles om de sproeten te verwijderen, maar niets helpt. 'M'n dochter, zei de moeder toen,/ nu kan ik niets meer aan je doen./ Je bent als fee (zacht uitgedrukt)/ volledig en totaal mislukt.' Uit pure wanhoop besluit de moederfee haar dochter naar de koning te sturen, die haar wellicht nog wel als keukenmeid in dienst wil nemen. Zij instrueert haar dochter zich aan te dienen bij de koning met de woorden: 'Uwe Majesteit,/ m'n moeder doet de groeten./ Ik ben een fee met sproeten.' Onderweg naar het paleis oefent het feetje wat ze moet zeggen, maar eenmaal oog in oog met de koning is ze zo zenuwachtig dat ze zegt: 'Uwe Majesteit,/ m'n moeder doet de groeten./ Ik ben een spree met foeten.' Deze verspreking leidt echter niet tot een nog grotere mislukking van het 
feetje, nee, de koning is juist diep onder de indruk. Een spree heeft hij nooit eerder gezien. De koning benoemt haar zelfs tot opperspree aan het hof waarna het gedicht triomfantelijk wordt afgesloten: 'Waaruit een ieder weer kan lezen/ dat men als fee mislukt kan wezen/ maar heel geslaagd kan zijn als spree./ Dit stemt ons dankbaar en tevree.' (Ziezo, p. 193) Die verspreking die vervolgens (door de koning) als betekenisvol wordt aangenomen en leidt tot de transformatie van de kleine fee van 'totale mislukking' naar 'opperspree' is een typische ingreep uit de literaire nonsenstraditie (Tigges, 1988, pp. 77-78). Uit de logboeken blijkt dat dit puur linguïstische element voor kinderen in groep 4 niet bijdroeg aan hun plezier of begrip van het gedicht: "Sommige woorden in het gedicht waren moeilijk/onbekend. Uitleg was nodig. De verspreking van de fee was niet voor iedereen duidelijk." (1141, logboek week 9) Kinderen waren meer gericht op de inhoud vanuit een morele houding: "Ze vonden het maar raar dat je niet goed bent als je er anders uit ziet." (2341, logboek week 9) De nonsensicale beleving kwam dus niet tot stand en vanuit een morele beleving keurden de kinderen de voorgestelde situatie af. De 'Drie apothekertjes' hadden meer kans om in de smaak te vallen omdat in dit gedicht op verschillende niveaus sprake is van nonsensicaliteit (zie Hoofdstuk 5). In sommige groepen 4 werd dit gedicht wel gewaardeerd, al valt er weinig af te lezen over het specifieke niveau waarop kinderen het waardeerden uit aantekeningen als "Héél leuk!" (2342, logboek week 2b) of "De kinderen vonden de tekst grappig. De tekst was wat lastig!” (2441, logboek week 2b) In andere groepen voerde de moeilijkheid de boventoon: "De kinderen luisterden goed. Gaven weinig terug bij de verwerking. Volgens mij werd het verhaal onvoldoende begrepen." (2641, logboek week $2 \mathrm{~b}$ ) Al was er wel sprake van voortschrijdend inzicht door herhaling op de keuzedag, hoewel niet vrijwillig: "3 apothekertjes: versje nog een keer laten horen. Ik heb gekozen omdat er veel onbekende woorden waren, die na 1 keer niet blijven hangen. LL begrepen het beter dan gisteren." (1641, logboek week 2b)

Bij de aanbieding van 'De mislukte fee' schreef een leerkracht in het logboek: "De kinderen luisterden goed naar het gedichtje. Zelf vond ik dit een leuke leeskalender." (2141, logboek week 9); bij de aanbieding van 'De koning van Savoye' schrijft een andere leerkracht: "Leerlingen vonden tekst grappig. Ik vond hem minder leuk." (2241, logboek week 26a) Dat wat de leerkracht waardeert ('De mislukte fee') wordt door de kinderen minder gewaardeerd, terwijl dat wat door de leerkracht minder gewaardeerd wordt ('De koning van Savoye') door de kinderen juist wel wordt gewaardeerd. Dit verschil is op zichzelf al een indicatie dat 'De koning van Savoye' door een zekere subversiviteit gekenmerkt wordt. In dit gedicht neemt de nonsens de vorm aan van het spel met de (extreem) grote getallen, maar is tegelijk als carnavalesk te typeren omdat de 'onaantastbaarheid' van een koning wordt aangetast door lichamelijk ongemak. De koning van Savoye heeft last van héél erg veel vlooien en om erachter te komen hóeveel dat er zijn, moest er gerekend worden (zie Hoofdstuk 5). De rekensom op zich is voor kinderen in groep 4 nog te moeilijk, dus leerkrachten was gevraagd te kijken hoe ver de kinderen konden komen om vervolgens zelf verder te gaan. Een leerkracht schrijft: "Gelukkig waren er bovenbouwers op bezoek die hebben geholpen met uitrekenen." (2342, logboek week 26a) Een andere leerkracht vat samen: "Leuk, maar moeilijk." (1141, logboek week 26a) In een volgende groep komt opnieuw naar voren dat de kinderen reageren op afwijkingen van hun verwachtingspatroon: "Heel leuk verhaal/gedicht. Het viel de kinderen op dat het aan het eind niet rijmde." 
(2142, logboek week 26a) En in een laatste groep stond vooral de moeilijkheid van de tekst op de voorgrond: "Moeilijke tekst. Veel tijd kwijt met uitleggen van woorden. Geen tijd voor verwerking." (1641, logboek week 26a) Daar waar de aanbieding van het gedicht 'slaagde', bleef het de kinderen ook bij. Het was opvallend hoe veel de kinderen in mijn observatiegroep 4 op de allerlaatste Leeskalenderdag nog van dit gedicht weten. Op die dag werd in spelvorm 'getest' wat de kinderen nog wisten van teksten uit de voorafgaande maanden, eerst door ze titels en/of personages te laten benoemen bij afbeeldingen en vervolgens door ze 'raadsels' als 'Als hij sterft, wordt hij een blauwe kiezelsteen'193 te laten oplossen. De teksten/personages die in deze groep aan bod kwamen, waren Kikker en Pad, De barmhartige Samaritaan en De eend en de vos uit het deelproject Deugden \& Dilemma's, en 'Blauwbilgorgel', 'Hongerige Harry' en 'De koning van Savoye' uit het deelproject Kinderpoëzie. Zodra een van de kinderen 'De koning van Savoye' bij het betreffende plaatje benoemt, beginnen de kinderen meteen over dat die zóveel vlooien had en Z. denkt zelfs nog te weten dat het er wel 6 miljoen 631 waren!'194 'Hongerige Harry' bevindt zich, net als 'De koning van Savoye', op het randje tussen abstractie en carnavaleske humor: het gedicht vormt een tot in het extreme overdreven opsomming van wat Harry allemaal opeet, tot het heelal en zichzelf aan toe (zie Hoofdstuk 5), en deze groteske voorstelling geeft aanleiding tot conceptuele overpeinzingen. Een leerkracht schrijft: "Meeste leerlingen: is niet echt gebeurd. Eén leerling: wel echt gebeurd, want ik denk dat wij nu in de buik van hongerige Harry wonen. Hongerige Harry kan geen buikpijn hebben, want hij heeft zijn buik opgegeten. (Ze hebben goed geluisterd!!!)" (2241, logboek week 18) ${ }^{195}$ Ook in de andere groepen 4 viel dit gedicht zeer in de smaak: "Ze vonden het een superleuk gedicht. Ook leuk dat alles steeds groter werd wat hij opat. Er ontstond discussie over wat nu precies groter was dan wat. Erg grappig." (2141, logboek week 18) En kinderen kozen het gedicht opnieuw: “omdat ze het geweldig vonden: iemand die alles opat. Ze gaven aan dat Hongerige Harry ook vergeleken kan worden met een stofzuiger of een hond.” (2142, logboek week 18)

Dit laat duidelijk zien dat de beleving en het plezier bij kinderen in groep 4 steeds sterker worden naarmate de nonsensicaliteit in poëzie een meer carnavalesk karakter heeft, stevig gegrond in de lichamelijkheid. Vanuit die lichamelijke verankering zijn de abstracter elementen in gedichten als 'De koning van Savoye' en 'Hongerige Harry' beter behapbaar en voorstelbaar voor de kinderen dan de ongrijpbaarheid van de verspreking van 'De mislukte fee' en de valse logica van de 'Drie apothekertjes. Iedereen eet en iedereen heeft wel eens jeuk: vanuit die concrete referentiekaders komen de jeuk die miljoenen vlooien veroorzaken en de mogelijkheid om álles op te eten plotseling binnen het bereik van voorstellingsvermogen van zeven- en achtjarigen te liggen.

\footnotetext{
${ }^{193}$ Het antwoord is natuurlijk: de blauwbilgorgel.

${ }^{194}$ Het waren 61.200 .000 vlooien.

195 In deze groep werd op de keuzedag de herhalingsopdracht bij het gedicht (eigen versie maken), waarschijnlijk met veel hulp van de leerkracht, speciaal opgedragen aan de meester die op andere dagen voor de klas staat: “Zelfbedacht verhaal gemaakt voor meneer M en ook aan hem voorgelezen: Hongerige meneer M zat aan tafel / nam zijn mes, lepel en vork / at spruitjes met ketchup en 'petettjes' / erwtjes, rijst en spekjes / tien pizza's met uitjes / en honderd beschuitjes / en toen dat op was / begon hij aan de tafel// Hij at duizend raketjes en de wc / en toen kwam er een pakketje / hij at heel Parijs / toen zei de regering stop ermee / en toen stuurde hij al zijn bommenwerpers / hij at tien brommers en heel Londen / en toen ook nog heel Nederland / hij verslond toen nog de hele planeet Mars." (2241, logboek week 18)
} 


\section{Carnavaleske nonsens: rituele taalhandelingen en de conventies van de schoolklas}

Brian Sutton-Smith stelde op basis van de rijmen, liedjes, grappen, moppen, raadsels en verhalen die onderdeel uitmaken van de orale kindercultuur vast dat wat kinderen in de basisschoolleeftijd het meest aanspreekt, “... is often ecstatic or subversive: It is a revelry of their own youthful actions that no longer seem profound or moving to adults or it is an antithetical reaction to the institutional and everyday hegemonies of the life about them." (Sutton-Smith, 1999, p. 6; zie Hoofdstuk 5) In verschillende van de Leeskalenderactiviteiten komt de liefde voor en het zelf opzoeken van de grenzen in de vorm van subversief taalgebruik bij de kinderen in groep 4 spontaan naar buiten. In bovenstaande paragrafen is al een aantal voorbeelden voorbij gekomen. Als bij de voordracht van het gedicht 'Verstoppertje' het woord 'bloot' valt, moeten kinderen lachen; bij de verwerking van 'Gekleurde eitjes en een haas' grijpen ze hun kans om, al grijnzend, 'bh en onderbroek' en 'bh en string' te noemen; een waaghals wenst zijn klasgenootje 'een dikke reet' in de verwerking van 'Ik wens je al wat wenselijk is'. Zo grepen kinderen in groep 4 allerlei gelegenheden aan om, binnen het spelkader van de poëzieverwerking, hun plezier te tonen in het opzoeken van de grenzen van wat wel en niet gezegd mag worden.

Verschillende van de gedichten die in groep 4 zijn aangeboden, thematiseren of zijn te karakteriseren als carnavaleske uitingsvormen. 'Ik wens je al wat wenselijk is', bijvoorbeeld, is een carnavaleske vorm in die zin dat de traditionele Nieuwjaarswens wordt omgevormd tot verwensing; in 'Als ik nou een hondje mag' worden zeuren, beloven en dreigen met elkaar vermengd; in 'De drie vliegen' staat liegen, of heel erg overdrijven, centraal. In pragmatische termen zijn dergelijke soorten van taalgebruik in poëtische vorm voor kinderen in groep 4 naar verwachting herkenbaar als 'rituele' taalhandelingen die functioneel gezien behoren tot hetzelfde domein als standaardvormen uit de orale volkscultuur zoals de grappen en moppen, raadsels, broodje-aapverhalen, et cetera (vgl. Dijk, 1980, p. 9). In poëtische vorm is er, net als in de vorm van de mop of de grap, geen sprake van écht liegen, verwensen of dreigen en is er dus ook geen sprake van de consequenties van écht liegen, verwensen of dreigen; in poëtische vorm kunnen die vormen van taalgebruik wel worden benut om een bepaalde indruk te maken op of bepaalde reacties los te maken bij 'het publiek'. In dat rituele taalhandelingskader vonden de kinderen in groep 4 'Als ik nou een hondje mag' dan ook heel grappig (2441/1641, logboek week 11a) of zelfs hilarisch (1141, logboek week 11a): duidelijke indicaties dat het gedicht een humorreactie opriep. De kleuters vonden het gedicht heel grappig omdat het stout was en vanwege het nijlpaard: "De kinderen vonden het erg 'spannend' en zijn tot de conclusie gekomen dat een nijlpaard niet zo'n handig huisdier is, vooral omdat hij veel moet plassen + poepen...." (1622, logboek week 9) Het valt helaas niet uit de logboekaantekeningen af te leiden, maar mijn vermoeden is dat kinderen in groep 4 vooral de enorme overdrijving en grensoverschrijdende dreigementen (naar het café gaan, eerste sigaret roken, met een kinderlokker meegaan) in het gedicht konden waarderen. De herkenning van het rituele kader bij 'Ik wens je al wat wenselijk is' heb ik eerder al uitgebreid beschreven op basis van mijn observatie, maar blijkt ook uit een logboekaantekening als "Leerlingen vonden de tekst leuk, grappig (kleine mopjes), raar," waarin de vergelijking met 'kleine mopjes' veelzeggend is. Die herkenning van het type rituele taalhandeling is voorwaarde voor het plezier dat de kinderen beleven aan het zelf variëren: "Ze 
moesten erom lachen. Ik wens je... olifantenbollen met olifantendrollen, smakelijk eten met een bord vol scheten, een kop van een ooievaar want je doet maar al te raar, heel veel ringen en een kop vol gekke dingen.” (2241, logboek week 14a)

Beide genoemde gedichten waren daarbij ingebed in de pragmatische context van een viering, Sinterklaas en Oud en Nieuw respectievelijk; het feit dat beide gedichten conventioneel/wenselijk gedrag (taalgebruik) in relatie tot die context ondermijnen en dus 'dissonant' zijn binnen die context, vormde voor de kinderen in groep 4 over het algemeen geen probleem. De poëtische vorm schiep het rituele kader dat de pragmatische functie van de tekst bepaalde en niet de context die voor de kleuters nog zo belangrijk is. Het gedicht 'De drie vliegen' (Andreus, 1975) was eveneens ingebed in een rituele gebruikscontext, maar in dit geval was er geen dissonantie tussen het type rituele taalhandeling en de rituele context. Dit gedicht was in de Leeskalender gekoppeld aan 1-april en in verschillende groepen versterkte die pragmatische verdubbeling de werking van de tekst nog eens extra.

De drie vliegen

Er zaten eens drie vliegen

Om het hardst te liegen,

Buiten op een balkon,

Luierend in de zomerzon.

De eerste zei: 'Met deze poot

Sloeg ik vijf olifanten dood.'

De tweede zei: 'Ik vlieg zo vlug,

In 'n uurtje naar Afrika en terug.'

De derde zei: 'Ik vlieg zo hoog,

Nog hoger dan de regenboog.'

Toen werd 't wat kil en 't waaide wat

De vliegen riepen: 'Voel je dat?

En vlogen gauw het huis weer binnen

Om daar nóg meer leugens te verzinnen.

Een leerkracht schrijft over waarom de kinderen het vers op de keuzedag weer wilden horen: "Drie vliegen: omdat ze 1 april een hele leuke dag vinden. Het leuke in het verhaal was dat een kleine vlieg de 5 olifanten met zijn ene poot kon doden. Iedereen wees met zijn vinger naar de vliegen en er kwamen volop 1-aprilmoppen.” (2142, logboek week 25) Net als bij de kleuters, die 'In de gekke-dingen-school' binnen het kader van 1-april als 'grapjesdag' ook konden duiden als 'grap', leggen de kinderen in groep 4 de relatie tussen de tekst en de op 1-april gebruikelijke rituele taalhandeling van de mop. In groep 4 werkt die concrete pragmatische inbedding van poëzie in de context van 1-april echter andersom: kinderen kiezen de tekst nog een keer omdat ze 1 -april een leuke dag vinden en de tekst de pragmati- 
sche context als het ware met zich meebrengt naar een andere dag in de week. Die willekeurige dag wordt dan tijdelijk 'gesacraliseerd' zodat er - zolang de herhaling van het gedicht duurt - opnieuw moppen verteld kunnen worden. De pragmatische context is dus onderdeel van de tekst geworden, zoals we eerder al zagen dat kinderen de vieringen van het jaar als pragmatische contexten ook hebben verinnerlijkt.

Wat in groep 4 ook duidelijk wordt, is dat de school en de schoolklas voor deze kinderen nog explicieter een specifiek tijd- en plaatsgebonden kader vormen met de daarin geldende structuren, regels en conventies dan bij de kleuters al merkbaar was. Dat specifieke 'schoolkader' speelt voor kinderen in groep 4 dan ook een belangrijke rol in de verwachtingspatronen die ze hebben op het gebied van wat hen wordt aangeboden en hóe het hen wordt aangeboden. In de paragraaf over autonome vormen van muzikaal taalspel stelde ik al vast dat onverwachte vormen van poëzie performances in groep 4, vanwege het verrassingseffect, in het bijzonder bij lijken te dragen aan het plezier en de waardering van de kinderen voor poëzie gekenmerkt door 'muzikaal taalspel'. Dat was al zichtbaar bij de aanbieding van het 'Versje om te mompelen' en kwam nog duidelijker naar voren bij de aanbieding van het 'Versje om te rappen (zonder einde)'. Het is één ding dat kinderen af en toe de 'outdoor freedom of expression (and behavior)' van de speelplaats meebrengen binnen het kader van de 'indoor repression' van de schoolklas (vgl. Thomas, 2004, p. 174); het is iets heel anders wanneer de leerkracht, als personificatie van de 'indoor repression', dat doet. De onverwachte transgressie van de conventies van de schoolklas kan via de specifieke vorm van de performance gebeuren, maar dat kan ook in de specifieke inhoud van de performance gebeuren. Eind januari stond er een heel belangrijke les op het programma van de Leeskalender. Een les waarvoor de leerkrachten de volgende instructie ontvingen:

\section{Lezen}

Lees het gedicht (...) voor alsof u een serieuze les geeft. Beeldt de handelingen zoveel mogelijk uit tijdens het voorlezen.

\section{$\mathrm{Na}$ het lezen}

Zeg dat u hoopt dat de kinderen goed hebben opgelet, want u gaat ze nu overhoren.... (handleiding G4V1_Deel 2_wk 14-21, p.46)

Het betreffende gedicht is: 'Tien dingen naar keus die je kunt doen met dingen uit je neus' (Adam, 2011). Het geeft een opsomming van allerlei mogelijkheden: 'Pak ze met een tangetje,/ leg ze op hun zij./ Rol ze tot een slangetje,/ gooi ze bij de klei.// Kneed ze, boetseer ze,/ wrijf ze glad./ Maak een vorm, een worm,/ of sla ze plat.// ...' Een leerkracht schrijft: "Ze vonden het gedicht supergrappig. Ik heb het 3x voorgelezen." (2441, logboek week 17b) Een volgende leerkracht schrijft: “Lekker vies, haha!” (1141, logboek week 17b) En weer een ander stelt vast: "De kinderen genoten van het 'vieze' snotverhaaltje." (2341, logboek week 17b) Net als bij de onverwachte vormen (rap, etc.) of bij het voordragen van 'Ik wens je al wat wenselijk is' of 'Als ik nou een hondje mag', doorbreekt de leerkracht met het voordragen van deze tekst zelf de conventies van de schoolklas en maakt daarmee de weg vrij voor de kinderen om het subversieve spel mee te spelen. Een andere leerkracht schrijft, naast de waardering voor het vers, ook allerlei dingen op die kinderen in de ver- 
werking bedachten om met snot te doen: "Wat een betrokkenheid: leukste les ooit! Ketting, kontgat, plas, poep, oorbel, prullenbak, ranja, lippen, navel, oordopjes." (2241, logboek week 17b) En op de keuzedag kozen de kinderen de tekst opnieuw want: "het was de leukste les ooit! Super enthousiast, veel fantasie." (2241, logboek week 17b)

In de afsluitende gesprekken met leerkrachten van groepen 4 werd hen gevraagd wat, in hun ervaring, het sterkst bijdraagt aan de waardering van de kinderen voor teksten uit het (gehele) aanbod. Humor kwam in die gesprekken sterk naar voren als kenmerk van verhalen en gedichten dat kinderen in groep 4 waarderen. De kinderen vonden grappige verhalen of teksten waarin een grapje zit erg leuk, zegt een van de leerkrachten: 'dan liggen ze helemaal dubbel en houden ze niet meer op met lachen.' Op de vraag of humor volgens haar het sterkst bijdraagt aan de waardering die kinderen voor een tekst hebben, antwoordt deze leerkracht bevestigend. Als ze een verhaal spannend probeert te maken, trekt dat de kinderen iets minder, voegt ze toe. Het leukst vinden ze dingen die niet mogen, zoals een vies woord (evaluatie 2, S16, 16-06-2014). Stoute dingen en vieze woorden als specifieke vormen van humor worden door veel van de groep 4 leerkrachten genoemd als kenmerken die positief bijdroegen aan de waardering en het plezier van de kinderen. Een leerkracht met een groep 3-4 noemt verhalen met veel herhaling, gedichten met vieze woorden, en teksten waarin personages stout of ondeugend waren als de favorieten van de kinderen (evaluatie 2, S11, 24-06-2014). Een leerkracht van groep 4 zegt: “Alles met 'bil' of 'plas' ofzo, dat vinden ze heel leuk!” (evaluatie 2, S26, 10-06-2014). Subversiviteit in poëzie wordt sterk gewaardeerd door kinderen in groep 4, of dat nu subversief talig of fysiek handelen is, en de ervaring van de 'incongruentie' van deze subversiviteit in relatie tot de sociaal-culturele context wordt versterkt wanneer de schoolklas fungeert als het carnavaleske kader waarbinnen de specifieke carnavalesk-nonsensicale elementen in poëzie functie en betekenis krijgen. Met andere woorden: kinderen in groep 4 hebben een sterke voorkeur voor datgene wat in het kader van de schoolklas (eigenlijk) niet hoort of niet mag, behalve wanneer het de vorm heeft van een gedicht (of verhaal) als rituele taalhandeling. "For the young it serves as a release from the demands of the sometimes threatening world of grown-ups and allows children to negotiate in that world in a playful way." (Anderson \& Apseloff, 1989, p. 39)

\section{Poëzie en de representatie van culturele pluriformiteit in groep 4}

Op een dag kom ik op mijn observatieschool en zie ik dat ze in de klas nog druk zijn met werken, dus ik neem even plaats aan de grote tafel op de gang. Daar zitten ook twee jongens uit groep 4, beide van Marokkaanse afkomst. Ze zitten er omdat ze werk moeten afmaken, maar zodra ik plaats neem, komt het gesprek (dat ze al aan het voeren waren) al snel op de Leeskalender. M zegt: 'Weet u wat ik het allerleukste vind van Nieuwsbegrip, eh, o nee, van de Leeskalender?' Hij vult het antwoord zelf direct al in en wordt daarin bijgevallen door Z: 'Die verhalen van Marokko'. De jongens vertellen over een verhaal dat ging over dat je naar Mekka gaat. Het bijbehorende kalenderblad met de afbeelding van Mekka met al die mensen hadden ze allebei wel graag willen hebben voor thuis. $Z$ wil zeker een keer naar Mekka. Dat moet één keer in je leven, vertelt hij, maar nu nog niet want nu zou hij verdwalen, denkt hij. Ze leggen aan me uit wat je in Mekka moet doen: allemaal rondjes lopen en bidden. De vader van $\mathrm{Z}$ is al wel naar Mekka geweest. M verlangt er nu al naar om 
weer op vakantie naar Marokko te gaan, met lekker warm weer en bergen en lekker eten. Z deelt dat verlangen: 'Ja man, dat is veel lekkerder weer dan hier!' Dan vraagt M naar hoeveel landen ik al ben geweest in mijn leven. Ik vertel dat dat er best veel zijn, teveel om zo even op te noemen. Ben ik wel eens in London geweest? Ja. De moeder van M ook. En ben ik wel eens in Hollywood geweest? Nee. Nou, daar zou hij wel een keer naartoe willen. Vervolgens zijn de jongens erg nieuwsgierig naar mijn leeftijd (...) (observatie 16, 21-012014).

We zoeken in dit onderzoeksproject naar aansluiting op de culturele kennis en vaardigheden die kinderen in het basisonderwijs van thuis uit meebrengen om hun ontluikende (inter-)culturele geletterdheid van daaruit te stimuleren via kinderliteratuur. We plaatsen 'culturele geletterdheid' in dit onderzoek expliciet in de context van de Nederlandse multiculturele samenleving, die zich ook heel concreet vertaalt in multiculturele schoolpopulaties. De deelvraag die ik wil beantwoorden, is:

KINDERPOËZIE: KWALITATIEVE DEELVRAAG 4d.

Wat vertellen observaties, logboekaantekeningen en gesprekken met leerkrachten met betrekking tot de presentatie van het poëzie-aanbod in de klas, de reacties van de kinderen op deze teksten en hun waardering daarvan ons over de inbedding van culturele pluriformiteit in groep 4 via kinderpoëzie?

Om inzicht te krijgen in waar de raakvlakken liggen tussen kenmerken van langdurig geliefde ('canonieke') soorten teksten en de factoren die een cruciale rol spelen in processen van tekstverwerving bij kinderen in die multiculturele context, hebben we in het Leeskalenderaanbod verhalen en poëzie (met invloeden) uit verschillende landen en culturen opgenomen die in al hun verscheidenheid tegelijk ook gedeelde (soorten) tradities uit de 'cultuur van het dagelijks leven' vertegenwoordigen. Dat zijn niet alleen (gedeelde) verhalen uit Bijbel en Koran, maar ook interculturele genres zoals sprookjes, schelmenverhalen, het nonsensrijm en het feestlied, en verhalen waarin bepaalde gebruiken of tradities uit verschillende culturele contexten aan bod komen. Ook voor groep 4 was culturele diversiteit al deels gerepresenteerd in het kalenderformat door niet alleen aandacht te besteden aan Nederlandse vieringen, maar ook aan vieringen uit andere culturen die vertegenwoordigd zijn in de Nederlandse samenleving. De kinderpoëzie in het Leeskalenderaanbod voor groep 4 bevatte, buiten de impliciete vertegenwoordiging van 'transculturele' tekstkenmerken in poëzie in de vorm van muzikaal taalspel en nonsensicaliteit, ook expliciete aandacht voor culturele pluriformiteit, in hoofdzaak in de vorm van de aanbieding van poëzie in verschillende talen en in slechts een geval -omdat dat zo uitkwam - gekoppeld aan een Turkse feestdag. Zijn dit potentieel effectieve manieren om culturele pluriformiteit in zekere zin in het leerplan van algemene vorming te representeren' om aan te sluiten op de culturele schemata van de kinderen en van daaruit via kinderpoëzie bij te dragen aan hun 'kennis van culturele verscheidenheid' (vgl. Meijer, 1996, pp. 25-26)? 


\section{Culturele pluriformiteit en 'bet taalspel poëzie' in groep 4: daar zit muriek in}

Er was in het poëzie-aanbod in groep 4 minder expliciete aandacht voor de representatie van culturele pluriformiteit in categorieën als 'tradities' of 'gebruiken' en 'vieringen' dan in het aanbod voor groep 2. Wel blijkt het expliciet opnemen van verschillende talen in het aanbod voor groep 4 een effectiever middel voor het stimuleren van bewustwording van culturele pluriformiteit in de schoolklas via poëzie dan in groep 2. Het tweetalige liedje 'Naïma maakt muziek' (Arabisch/Nederlands) was in groep 4 een groot succes. In de week waarin dat lied werd aangeboden, was ik op de keuzedag in groep 4 aanwezig om te observeren. Nadat de leerkracht kort met de leerlingen had teruggeblikt op alle teksten van die week, mogen de kinderen stemmen welke tekst ze nog een keer willen horen. De leerkracht noemt de titels één voor één en de kinderen mogen hun vinger opsteken als ze die tekst nog een keer willen. Bij 'Het rode kippetje' gaan er geen vingers omhoog. Bij 'De blauwbilgorgel' gaan er twee vingers omhoog. Bij 'Naïma maakt muziek' gaan alle andere vingers de lucht in. De leerkracht begint te zeggen dat ze de cd al had klaargezet en bij 'cd' juichen en klappen de kinderen al luid. Een van de jongens die voor de blauwbilgorgel hadden gestemd, juicht niet mee: hij blijft de rest van de les met zijn hoofd in zijn handen voor zich uit staren. De leerkracht opent via het digitale schoolbord de cd en zegt: 'Het Arabische gedeelte kunnen we misschien niet meezingen, maar...' Ze wordt onderbroken door een jongen die roept: 'Jawel! Dat is juist het leukste!' De leerkracht maant de kinderen tot orde en zegt erbij dat er deze keer niet gegiecheld hoeft te worden. Zodra het nummer speelt en de Arabische tekst te horen is, moet een aantal kinderen toch een beetje lachen, maar ze doen wel mee (observatie 2, 24-10-2013).

Ook voor kinderen in groep 4 kan het horen van een 'vreemde' taal aanleiding zijn om te gaan lachen, maar ze zijn zich er wel van bewust dat het een bestaande taal is. Het is voor sommigen wat vervreemdend om niet te kunnen verstaan wat er wordt gezongen; voor anderen is het des te leuker om plotseling te herkennen dat het een taal is die ze van thuis (of elders) kennen. Een leerkracht schrijft in het logboek: "LL waren erg verrast dat ze Arabische tekst hoorden. Ze wilden allemaal meezingen. Op verzoek nog een keer laten horen." (1641, logboek week 5b) Ook op een derde school viel het lied erg bij de kinderen in de smaak, waarschijnlijk door de combinatie van het feit dat het een vrolijk en ritmisch lied is met muziek en het feit dat kinderen het Arabisch herkenden: "Aantal Turkse/Marokkaanse kinderen kende de tekst. Was leuk om te doen.” (2141, logboek week 5b) Op de keuzedag werd het liedje ook in deze groep gekozen: "Naima maakt muziek. Kenden de tekst. Leuk om te zingen. Heel enthousiast, bewust van de 2 talen.” (2141, logboek week 5b) Op dezelfde school in de andere groep 4 werd het lied ook gekozen en schrijft de leerkracht: "Naima maakt muziek! Vrolijk element om er muziek bij te hebben. Kinderen hebben goed onthouden wat de inhoud van de muziektekst was. Arabisch-Nederlands. Konden dit natuurlijk ook vlot meezingen." (2142, logboek week 5b) Drie weken na de aanbieding, tijdens mijn observatie van de aanbieding van het gedicht 'Sint-Maarten' op weer een andere school, vraagt de leerkracht wat de kinderen het leukst vonden van de Leeskalender tot dan toe (na twee maanden Leeskalender). Een meisje zegt meteen: 'Die van Naïma maakt muziek'. Andere kinderen zijn het met haar eens: dat was leuk omdat het in een andere taal was. 'In het Arabisch,' weet een jongen (observatie 6, 12-11-2013). 
Waar de kleuters bij de aanbieding van het verjaardagslied 'Fijne verjaardag voor jou', waarbij ze mochten kiezen uit verschillende talen, wel sterke betrokkenheid toonden bij het zingen in de eigen taal of talen, was het voor hen moeilijk te bevatten dat verschillende mensen ook verschillende talen kunnen spreken. In groep 4 toonden de kinderen al veel meer begrip van en betrokkenheid bij het zingen in verschillende talen. In mijn observatiegroep 4 is er direct herkenning:

De leerkracht vertelt dat ze een verjaardagsliedje gaat laten horen in een andere taal. Ze start de Engelse versie, wat eigenlijk niet de bedoeling was, en improviseert snel door te zeggen dat de kinderen deze wel kennen, maar dat er daarna een komt in een taal die sommige kinderen wel kennen, maar de meesten niet. Zodra de Arabische versie van 'Happy birthday' speelt, hoor ik een van de meisjes al zeggen: 'Dat is Arabisch!'

Leerkracht: Wie herkende de taal?

[er gaan veel vingers de lucht in]

Leerkracht: Volgens mij hoorde ik het jou al zeggen, J?

Kind (m): $\quad$ Arabisch.

Kind $(\mathrm{m})$ : $\quad$ Marokkaans.

Leerkracht: Ja, het lijkt ook veel op Marokkaans, maar dat is Arabisch. Jullie kennen dit liedje misschien allemaal in je eigen taal, de taal die je thuis spreekt. Wie kan het zingen zoals jullie dat thuis zouden doen?

Kind (m): [J zingt het liedje een keer in het Marokkaans-Arabisch, zoals rij het kent]

Leerkracht: $\quad$ O, jij spreekt het een beetje anders uit dan op de cd. Hoe spreek je de woorden uit?

Kind (m): $\quad$ Sena hilwa (uitgesproken als chelwe) ja gamiel.

U herhaalt het een paar keer, vooral de uitspraak van 'bilwa', en de leerkeracht schrijft de woorden op het bord zoals J ze uitspreekt. De andere kinderen oefenen de uitspraak een paar keer]

Kind (m): $\quad$ Mijn zusje heet ook Sena en soms zingen ze 'Sena hilwa' en dan de naam...

Ik heb de indruk dat J graag nog meer wil vertellen, maar de leerkracht wil de vaart erin houden en geeft aan dat ze het liedje nu een keer met z'n allen in het Arabisch gaan meezingen. Ze start de cd weer. De kinderen zingen de tekst eerst wat aarzelend, maar steeds enthousiaster mee vanaf het bord en klappen op aangeven van de leerkracht mee op de maat. (observatie 23, 18-02-2014)

$\mathrm{Na}$ dit eerste onderdeel van de verwerking waarin de leerkracht een van de meisjes de mogelijkheid biedt om haar thuistaal met haar klasgenoten te delen en hen ook iets van die taal te leren, is de leerkracht benieuwd of er kinderen in de klas zijn die het liedje, of een ander verjaardagsliedje, in nog andere talen kennen. Ten minste vijf kinderen kennen het in het Marokkaans-Arabisch; een meisje kent het in het Turks; een jongen kent een ander verjaardagsliedje in het Kroatisch; een andere jongen spreekt een van de Pakistaanse talen (al kan of durft hij geen verjaardagsliedje zingen); alle kinderen kennen het in het Engels en in het Nederlands; er wordt zelfs een meisje uit groep 3 gehaald om het lied in het Frans voor te zingen. Nadat al deze zeven talen aan bod zijn gekomen, bedenkt de leerkracht nóg een taal die in de klas vertegenwoordigd is: 
Leerkracht: En kan het ook in het Maastrichts? Ik spreek dat niet. Is het in het Maastrichts iets anders of gewoon 'fijne verjaardag voor jou'?

Kinderen: Jawel! [wordt volgens mij ter plekke bedacht door een aantal kinderen dat Maastrichts spreekt] 'Fijne verjaardag für dich' ofzo. (observatie 23, 18-02-2014)

De klas is apetrots op al die talen die ze met elkaar vertegenwoordigen en de leerkracht schrijft later in het logboek: "Vooral liedjes in andere talen maken sprak de kinderen aan!" (2441, logboek week 20a) Ook in een van de andere groepen 4 is in verschillende talen gezongen, hoewel dan een ander verjaardagsliedje: "We hadden een jarige in de klas. Begonnen met 'lang zal ze leven'. Daarna de vraag gesteld: 'Wie kent dit in een andere taal?' Liedjes gezongen op 'lang zal ze leven' uit andere landen. Kinderen waren enthousiast." (2341, logboek week 20a) Op andere scholen werd er niet zozeer in verschillende talen gezongen, maar werd het kennismaken met verschillende talen in deze vorm wel gewaardeerd. Een leerkracht schrijft: "We hebben nog meer verjaardagsliedjes (buitenlandse) gezocht en daarop gedanst." (1141, logboek week 20a) En een vierde leerkracht noteert: " $\mathrm{Na}$ het lezen geen liedje geleerd, maar wel aan elkaar verschillende versies laten horen. Veel verschillende talen en versies: erg leuk!” (1641, logboek week 20a)

Het zoeken naar gedeelde geritualiseerde taalhandelingen, zoals het zingen van een verjaardagsliedje, is een effectief middel om culturele pluriformiteit via poëzie expliciet onderdeel te maken van het aanbod in groep 4; andere feestliedjes, maar ook slaapliedjes ${ }^{196}$ en aftelrijmen uit verschillende landen en culturen kunnen hiervoor worden geselecteerd. Ook tweetalige teksten, zoals 'Naïma maakt muziek', lenen zich hier goed voor, al speelt daarin mee dat een tekst gemakkelijk moet zijn mee te zingen of zeggen door veel herhaling en een duidelijk herkenbare structuur. Veel sterker dan in de gesprekken met kleuterleerkrachten brachten leerkrachten van groep 4 de aandacht voor andere talen en culturen als onderdeel van het Leeskalenderaanbod naar voren in de gesprekken die we met hen voerden over hun ervaringen. Dit had uiteraard betrekking op gehele aanbod van teksten. Een van de leerkrachten geeft aan dat ze door het gevarieerde aanbod veel nieuwe dingen gedaan heeft die ze anders niet zo snel zou doen, maar die toch heel leuk zijn gebleken. Gevraagd naar voorbeelden noemt ze de 'Moslimverhalen' die veel gespreksstof opleverden in haar groep en waarbij de Islamitische kinderen in de klas duidelijk blij waren met de herkenning en erkenning van hun geloof. Zo konden ze bijvoorbeeld vertellen over de feesten die ze vieren (evaluatie 2, S11, 24-06-2014). Een leerkracht op een andere school merkte iets soortgelijks op. Verhalen uit de Leeskalender die aansloten bij de (culturele) achtergrond van sommige kinderen in de klas gaven aanleiding tot het vergelijken van gewoontes. Kinderen vertelden elkaar dan hoe het er bij hen thuis aan toe gaat en constateerden dat er verschillen zijn. Daar bleef het volgens deze leerkracht bij. Er werd niet verder doorgevraagd (evaluatie 2, S16, 16-06-2014). Ook op een derde school heeft de leerkracht dit als heel positief ervaren: ze heeft gemerkt dat teksten die aansluiten bij de cultuur van sommige kinderen in de klas aanleiding gaven tot wederzijdse interesse in elkaars achtergrond, gewoonten van thuis, et cetera. Dat vond ze heel mooi. Als voorbeeld noemt ze dat er met

\footnotetext{
${ }^{196}$ Slaapliedjes in verschillende talen waren ook opgenomen in de Leeskalender, zowel in groep 2 als in groep 4, maar helaas bleek dat een week te zijn waarin de meeste scholen Meivakantie hadden.
} 
Nieuwjaar iets in een andere taal was. Toen gingen de kinderen uit Marokko en een meisje uit Somalië opzoeken hoe je dat bij hen zegt (evaluatie 2, S22, 17-06-2014). Ook de leerkracht van mijn observatie-groep 4 maakt speciale vermelding van de aandacht voor verschillende culturen/religies in de Leeskalender: verhalen uit de Islamitische traditie spraken enorm aan bij de Islamitische kinderen in haar groep en alle kinderen vonden het interessant om daar verhalen over te horen. Hetzelfde geldt voor liedjes in het Arabisch of een andere taal: dat vinden de kinderen prachtig, zeker als ze hun eigen thuistaal herkennen (evaluatie 2, S24, 18-06-2014).

\subsection{Conclusies}

In dit hoofdstuk heb ik de inzichten besproken die zijn verkregen op basis van observaties, logboekaantekeningen van en gesprekken met leerkrachten van groepen 4 die gedurende de interventieperiode met de Leeskalender ${ }^{+ \text {Kinderpoëzie }}$ hebben gewerkt. Dit hoofdstuk is gericht op het beantwoorden van de geformuleerde kwalitatief-empirische deelvragen, maar zoals ik in de introductie al aangaf, is ook groep 4 geen volledig gecontroleerde laboratoriumomgeving en spelen er dus altijd andere, 'externe', factoren een rol in het werken met de Leeskalender en in óf en hóe 'het taalspel poëzie’ vorm krijgt in de daadwerkelijke praktijk.

In $\$ 10.2$ ben ik daarom eerst ingegaan op de belangrijkste 'externe' factoren die in de kleuterklas met de Leeskalender en met het daarin opgenomen aanbod van kinderpoëzie interacteren en, soms, interfereren. Ik vat de inzichten kort samen:

INPASSING IN HET PROGRAMMA: TIJD, TIJD, EN NOG EENS TIJD... In de kleutergroepen waren 'taal en thema' de belangrijkste factoren die meespeelden in hoe leerkrachten de inpassing van de Leeskalender in het dagelijkse programma ervoeren. De belangrijkste externe factor die de inpassing van de Leeskalenderactiviteiten in groep 4 beïnvloedde was: tijd. Feitelijk: een gebrek aan tijd. En deze factor is in groep 4 gerelateerd aan het feit dat hier veel tijd en aandacht wordt besteed aan de verplichte lesstof voor de verschillende onderdelen van taal (begrijpend lezen, spelling, woordenschat) en rekenen. Leerkrachten gaven aan dat ze niet minder tijd aan deze vakken konden besteden. De Leeskalender is dan een van de eerste dingen die ze lieten vallen; ondanks dat waren de kinderen al snel aan de Leeskalender gewend en keken ze er naar uit. Veel vaker dan in groepen (1-)2 plaatsen leerkrachten in groep 4 hun overweging van een structurele inbedding van de Leeskalender in het lesprogramma expliciet in de context van het resultaatgericht werken dat binnen het primair onderwijs een grote rol speelt. Omdat de Leeskalender in groep 4 altijd ten koste van tijd besteed aan verplichte lesstof gaat, hechten leerkrachten in groep 4 groot belang aan de toetsresultaten. Dit bevestigt het beeld dat ik in Hoofdstuk 1 al schetste op basis van de vaststelling van de Raad voor Cultuur en Onderwijsraad over de moeilijkheid om (vormen van) cultuureducatie structureel plaats te geven in het basisonderwijs, want opbrengsten daarvan zijn nu juist zo moeilijk meetbaar te maken... (zie ook Hoofdstuk 8).

DE VARIATIE IN HET AANBOD Waar de leerkrachten in de kleutergroepen in hun evaluatie van de Leeskalender aangaven meer thematische aansluiting op het lesprogramma 
te willen, spelen thema's in groep 4 een veel minder grote rol. Hierdoor kwam uit de gesprekken met groep 4 leerkrachten veel vaker hun expliciete waardering naar voren juist voor de variatie in het Leeskalenderaanbod. Die variatie had vooral betrekking op de genres. Verschillende leerkrachten gaven aan via de Leeskalender in aanraking te zijn gekomen met soorten teksten die ze zelf niet snel zouden kiezen. De leerkrachten vinden dit zinvol, belangrijk en uit hun reacties blijkt dat ze een intrinsieke waarde toekennen aan dit aspect van het Leeskalenderaanbod. Het feit dat deze tekstsoorten - soms geheel tegen de verwachting van de leerkracht in - over het algemeen ook bij de kinderen in de smaak vielen, bevestigt ons theoretisch uitgangspunt dat putten uit de orale volkscultuur een effectieve insteek is om kinderliteratuur te selecteren die enerzijds aansluit op de ontluikende culturele competentie en voorkeuren van de kinderen en anderzijds toegang biedt tot een brede waaier aan uitingsvormen die (ook door leerkrachten) als 'cultureel relevant' worden ervaren.

In $\$ 10.3$ heb ik per kwalitatief-empirische deelvraag de inzichten uit observaties, logboekaantekeningen van en gesprekken met leerkrachten besproken met betrekking tot de verwachte 'indicatoren van canoniciteit' die ik, zoals uiteengezet in Hoofdstuk $3 \mathrm{t} / \mathrm{m} 5$, heb geformuleerd voor de kinderpoëzie, gespecificeerd naar groep 2 en groep 4. Op basis van de verkregen empirische inzichten uit de praktijk van de kleutergroepen, vat ik hier de belangrijkste conclusies eerst per deelvraag samen om vervolgens in een synthese enkele algemene conclusies te trekken over de aanbieding van kinderpoëzie in groep 4.

\section{Beantwoording van de eerste kwalitatief-empirische deelvraag}

KINDERPOËZIE: KWALITATIEVE DEELVRAAG 4a.

Wat vertellen observaties, logboekaantekeningen en gesprekken met leerkrachten met betrekking tot de presentatie van het poëzie-aanbod in de klas, de reacties van de kinderen op deze teksten en hun waardering daarvan ons over de rol van 'de directe evocatie van poëtisch geritualiseerde handelingspatronen in de context van feesten en spel’, onderverdeeld in

(i) fysieke handelingspatronen (zoals wiegen, dansen, klappen, et cetera), en

(ii) performatieve taalhandelingen (zoals wensen, aftellen, verwensen, verzoeken, et cetera) in processen van poëzieverwerving bij kinderen in groep 4 ?

Voor kinderen in groep 4 zou die koppeling met een pragmatische context naar verwachting het sterkst moeten bijdragen aan poëzieverwerving in de vorm van de evocatie van poëtisch geritualiseerde talige handelingspatronen, anders dan in groep 2 waar de evocatie van poëtisch geritualiseerde fysieke handelingspatronen beter aansluit op de kennis, vaardigheden, leef- en belevingswereld van de kinderen. In hoeverre wordt deze verwachting door de verkregen kwalitatieve data ondersteund? En zijn er in de verwerving van poëzie bij kinderen in groep 4 verschillen waar te nemen in de werking van handelingspatronen in de context van vieringen en spel? Op basis van de hierboven beschreven kwalitatieve inzichten, kan de eerste kwalitatieve deelvraag voor groep 4 als volgt beantwoord worden:

1. De context waarin 'het taalspel poëzie' gekoppeld aan de vieringen in het jaar betekenis krijgt, is bij kinderen in groep 4 voor een belangrijk deel een mentaal construct, ge- 
vormd door de culturele schemata waarover ze beschikken. Met andere woorden: kinderen in groep 4 hebben de pragmatische contexten die ze uit ervaring kennen 'verinnerlijkt'. Een feestlied of -rijm hoeft daarom niet meer binnen de in tijd en plaats afgebakende context van de viering te worden aangeboden om door kinderen in groep 4 als feestlied of-rijm te worden begrepen en gewaardeerd;

2. Tegelijk werken die verinnerlijkte gebruikscontexten nog steeds als het raamwerk waarbinnen verschillende vormen van 'het taalspel poëzie' (al dan niet) functie en betekenis krijgen. Wanneer kinderen niet bekend zijn met een viering ontstaat er geen beleving, en daarmee ook geen begrip en waardering, van 'het taalspel poëzie' als feestlied of-rijm;

3. In groep 4 versterkt fysieke ervaring de beleving en daarmee ook het begrip van specifieke vormen van 'het taalspel poëzie': door die geïntensiveerde beleving waarderen ze een gedicht of lied ook meer dan wanneer ze er alleen over praten of redeneren. De fysieke ervaring van 'het taalspel poëzie' kan bij kinderen in groep 4 ook tot stand komen wanneer ze dat taalspel op talig niveau zelf kunnen spelen, maar de toevoeging van fysiek handelen zorgt voor extra intensivering van de beleving;

4. Hoewel ik dit niet structureel kan nagaan op basis van de verkregen kwalitatieve data, wijzen de observaties erop dat de combinatie van fysiek en talig handelen in de verwerking van 'het taalspel poëzie' niet alleen nauw aansluit op de culturele competentie en voorkeuren van de kinderen, maar het begrip en het bewustzijn van specifieke vormen van 'het taalspel poëzie' bij kinderen in groep 4 kan uitbreiden.

Meer nog dan in de kleutergroepen zijn leerkrachten in groep 4 gericht op het handhaven van orde en is spel veel minder vanzelfsprekend onderdeel van de dagelijkse gang van zaken in de klas. In 'Child Poets and the Poetry of the Playground' schrijft Joseph Thomas:

"Often, as children grow older, they neither maintain a taste for playground poetry nor develop a taste for official school poetry. Because teachers and other adults fail to tap into the playful spirit of playground poetry, there is no mechanism for bridging the distance between what appears to be outdoor freedom of expression and indoor repression." (Thomas, 2004, p. 174)

Thomas wijst hier op het ontbreken van een mechanisme om de afstand tussen speelplaatspoëzie en officiële (school)poëzie te overbruggen. Die afstand wordt, mijns inziens, vooral gevormd door opvattingen over wat kinderpoëzie is, of zou moeten zijn, in combinatie met opvattingen over wat er in het klaslokaal hoort en mag en wat niet. Dat heeft niet alleen betrekking op de keuze voor onderwerpen, maar ook op hoe er met poëzie wordt omgegaan. Dat laatste aspect hangt daarbij samen met de sterke nadruk op leren lezen en schrijven die vanaf groep 3 haar intrede doet in het basisonderwijs. De afstand tussen de 'outdoor freedom of expression' en de 'indoor repression' valt dan voor een aanzienlijk deel samen met verschillen tussen de poëtische gebruikshouding zoals die voor kinderen letterlijk en figuurlijk gemodelleerd wordt in het gebruik van kinderrijmen op bijvoorbeeld de speelplaats enerzijds en de leeshouding zoals die figuurlijk gemodelleerd wordt in heersende poëzieopvattingen én letterlijk gemodelleerd wordt in 'de cultuur van het lezen' waarin kinderen in het basisonderwijs worden ingewijd. Vanuit de vraag welke kenmerken een 
cruciale rol spelen in de duurzame geliefdheid van (soorten) poëzie bij kinderen in groep 2 en in groep 4, kunnen we er niet omheen dat de fysieke ervaring van 'het taalspel poëzie' een cruciale rol speelt in hoe kinderen poëzie begrijpen, verwerven en waarderen. En die fysieke ervaring wordt in groep 4 nog altijd sterk gesteund door (een combinatie van talig en) fysiek handelen met poëzie. In het kader van poëzie waarin geritualiseerde handelingspatronen in de context van feesten en spel direct geëvoceerd worden, is het goed te begrijpen dát fysiek handelen een cruciale rol speelt in processen van poëzieverwerving.

Beantwoording van de tweede kwalitatief-empirische deelvraag

KINDERPOËZIE: KWALITATIEVE DEELVRAAG 4b.

Wat vertellen observaties, logboekaantekeningen en gesprekken met leerkrachten met betrekking tot de presentatie van het poëzie-aanbod in de klas, de reacties van de kinderen op deze teksten en hun waardering daarvan ons over de rol van 'muzikaal taalspel', onderverdeeld in

(i) vormen van muzikaal taalspel ter ondersteuning van non-verbale handelingspatronen, en

(ii) vormen van muzikaal taalspel als relatief autonoom spel in processen van poëzieverwerving bij kinderen in groep 4 ?

Mijn verwachting is dat kinderen in groep 4 vormen van muzikaal taalspel ter ondersteuning van fysieke handelingspatronen wel waarderen - getuige ook de hierboven beschreven inzichten -, maar dat ze de meer autonome vormen van muzikaal taalspel binnen het kader van de schoolklas mogelijk nog sterker waarderen. In hoeverre wordt deze verwachting voor groep 4 door de verkregen kwalitatieve data ondersteund? Hoe werkt 'muzikaal taalspel' in de praktijk van groep 4? In hoeverre en in welke vorm(en) draagt deze indicator bij aan het plezier dat deze zeven- en achtjarigen aan 'het taalspel poëzie' beleven? Op basis van de hierboven beschreven kwalitatieve inzichten, kan de tweede kwalitatieve deelvraag voor groep 4 als volgt beantwoord worden:

1. Rijmen alleen is voor kinderen in groep 4 iets dat ze wel leuk vinden, maar vooral als er een onverwachte draai wordt gegeven aan het rijmprocedé. De rol van rijm en zelf rijmen in de beleving en waardering van kinderen in groep 4 voor 'het taalspel poëzie' lijkt echter een grotendeels gepasseerd station;

2. Muziek werkt in groep 4 duidelijk in het voordeel van de beleving en waardering van poëzie, maar we kunnen ons tegelijk afvragen of het bijdraagt aan de beleving en waardering van 'het taalspel poëzie' of van muziek. Het als lied (op muziek) aanbieden van gedichten draagt in ieder geval sterker bij aan de beleving en waardering in groep 4 dan rijm, zeker in combinatie met meezingen, dansen of anderszins ritmisch bewegen;

3. Met name de autonome vormen van 'muzikaal taalspel', zoals het 'Versje om te mompelen', het 'Versje om te rappen' en 'Het poppenkopmannetje', brengen bij kinderen in groep 4 verrassingseffecten teweeg die bijdragen aan hun beleving en waardering van 'het taalspel poëzie'. Wat verrassend is voor kinderen in groep 4 kan samenhangen met verschillende referentiekaders, zoals hun kennis van de conventies van poëzie, de conventies van de schoolklas of de conventies van taal; 
4. Bij nieuwe vormen van 'het muzikaal taalspel poëzie' is het effectiever om de kinderen te laten meedoen in plaats van zelf te laten variëren: in die instanties moeten ze hun kennis van poëtische structuren nog actief opbouwen en uitbreiden, terwijl ze het bij bekende en herkenbare structuren leuk vinden om zelf te variëren.

In het afsluitende gesprek vertelt een van de leerkrachten dat het haar opviel dat de kinderen het meest enthousiast waren over de versjes. De gekke rijmwoorden en het speelse element spreken erg aan, zegt ze. De andere leerkracht voegt toe dat ze toch ook de verhalen erg leuk vonden. In ieder geval is humor iets dat aanspreekt en dingen met een doeelement, zoals het 'meestampertje', stellen ze vast (evaluatie 2, S21, 05-06-2014). Over het geheel genomen werd poëzie waarin muzikaal taalspel sterk aanwezig is door kinderen in groep 4 positief gewaardeerd, vooral in vormen die op de een of andere manier hun verwachtingspatroon doorbraken. En dat verwachtingspatroon werd minstens zo sterk bepaald door de conventies van de schoolklas als door poëtische conventies. Verrassende vormen als het 'Versje om te mompelen' of 'Het poppenkopmannetje' spraken de kinderen aan, maar van de twee werd het 'Versje om te mompelen' sterker gewaardeerd vanwege de meerwaarde van de 'juf die er zelf bij in slaap valt'. Gedichten op muziek spreken de kinderen sterk aan, vooral wanneer ze er - bij hoge uitzondering - op mogen bewegen, stampen, trommelen, dansen of mogen meezingen. Zo ook het klapspel, dat doorgaans niet binnen de muren van de klas voorkomt, en het 'Versje om te rappen (zonder einde)': dit waren favorieten, zo rapporteert een leerkracht in het afsluitend gesprek (evaluatie 2, S23, 25-06-2014). 'Muzikaal taalspel' levert op basis van genoemde criteria een belangrijke bijdrage aan processen van poëzieverwerving, en daarmee aan de ontwikkeling van ontluikende culturele geletterdheid, bij kinderen in groep 4.

\section{Beantwoording van de derde kwalitatief-empirische deelvraag}

KINDERPOËZIE: KWALITATIEVE DEELVRAAG 4c.

Wat vertellen observaties, logboekaantekeningen en gesprekken met leerkrachten met betrekking tot de presentatie van het poëzie-aanbod in de klas, de reacties van de kinderen op deze teksten en hun waardering daarvan ons over de rol van '(carnavaleske) nonsensicaliteit', onderverdeeld in

(i) carnavaleske vormen van nonsensicaliteit bemiddeld door subversief fysiek handelen in relatie tot de sociale context en de culturele categorieën (waarden en normen) die in die sociale context gelden, en

(ii) carnavaleske vormen van nonsensicaliteit bemiddeld door subversief talig handelen in relatie tot de sociale context en de culturele categorieën (waarden en normen) die in die sociale context gelden, en

(iii) vormen van nonsensicaliteit die een meer intellectuele ervaring van 'incongruentie' teweegbrengen, bemiddeld door een voorstelling van de werkelijkheid die afwijkt van de 'natuurlijke wetmatigheden' die gelden in de waarneembare of conceptuele werkelijkheid in processen van poëzieverwerving bij kinderen in groep 4 ? 
Carnavaleske nonsens wordt, naar verwachting, door kinderen in groep 4 als 'grensoverschrijdender' ervaren dan intellectueler vormen van nonsens en wordt daardoor naar verwachting ook meer door hen gewaardeerd. Valt uit de reacties van kinderen en leerkrachten op de aanbieding van dit brede scala aan vormen van nonsensicaliteit af te leiden of - en, zo ja, in welke vorm(en) - (carnavaleske) nonsensicaliteit effectief bijdraagt aan de waardering die kinderen in groep 4 hebben voor en het plezier dat zij beleven aan kinderpoëzie? Op basis van de verkregen inzichten, bespreek ik de meer intellectueel gerichte vormen van nonsens en de carnavaleske vormen van nonsens apart, maar maak ik in die laatste categorie geen expliciet onderscheid tussen fysiek en talig handelen omdat dat onderscheid geen rol meer speelt in het samenspel van factoren dat vorm geeft aan de waardering en verwerving van carnavalesk nonsensicale poëzie bij kinderen in groep 4. Op basis van de hierboven beschreven kwalitatieve inzichten, kan de derde kwalitatieve deelvraag voor groep 4 als volgt beantwoord worden:

1. De kwalitatieve data laten zien dat de beleving en het plezier bij kinderen in groep 4 steeds sterker worden naarmate de nonsensicaliteit in poëzie een meer carnavalesk karakter heeft, gegrond in de lichamelijkheid. Vanuit die lichamelijke verankering zijn ook abstracter elementen zoals enorme hoeveelheden beter behapbaar en voorstelbaar voor de kinderen dan de ongrijpbaarheid van de nonsensicale manipulatie van taal of logica;

2. Subversiviteit in poëzie wordt sterk gewaardeerd door kinderen in groep 4, of dat nu subversief talig of fysiek handelen is, en de ervaring van de 'incongruentie' van deze subversiviteit in relatie tot de normen en conventies van de sociaal-culturele context wordt versterkt wanneer de schoolklas fungeert als het carnavaleske kader waarbinnen de specifieke carnavalesk-nonsensicale elementen in poëzie functie en betekenis krijgen.

Ook op mijn observatieschool noemt de leerkracht van groep 4 direct humor als het belangrijkste kenmerk dat bijdroeg aan de waardering van de kinderen voor teksten; de leerkracht van groep 2, die ook bij het gesprek aanwezig is, geeft aan dat humor in haar groep moeilijker ligt omdat niet alle kinderen alles al begrijpen. In groep 2 is het klankspel wel voor alle kinderen aantrekkelijk (evaluatie 2, S24, 18-06-2014). Deze vergelijking maakt duidelijk dat, hoewel ze ook nog steeds veel plezier beleven aan muzikaliteit in poëzie, de waardering voor poëzie bij kinderen in groep 4 heel sterk positief wordt beïnvloed door humor in het algemeen en meer specifiek door carnavaleske nonsensicaliteit, gegrond in de lichamelijkheid of verankerd in het (carnavaleske) kader van de schoolklas.

\section{Beantwoording van de vierde kwalitatief-empirische deelvraag}

KINDERPÖ̈ZIE: KWALITATIEVE DEELVRAAG 4d.

Wat vertellen observaties, logboekaantekeningen en gesprekken met leerkrachten met betrekking tot de presentatie van het poëzie-aanbod in de klas, de reacties van de kinderen op deze teksten en hun waardering daarvan ons over de inbedding van culturele pluriformiteit in groep 4 via kinderpoëzie? 
Ook voor groep 4 was culturele diversiteit al deels gerepresenteerd in het kalenderformat door niet alleen aandacht te besteden aan Nederlandse vieringen, maar ook aan vieringen uit andere culturen die vertegenwoordigd zijn in de Nederlandse samenleving. De kinderpoëzie in het Leeskalenderaanbod voor groep 4 bevatte, buiten de impliciete vertegenwoordiging van 'transculturele' tekstkenmerken in poëzie in de vorm van muzikaal taalspel en nonsensicaliteit, ook expliciete aandacht voor culturele pluriformiteit, in hoofdzaak in de vorm van de aanbieding van poëzie in verschillende talen en in slechts een geval -omdat dat zo uitkwam - gekoppeld aan een Turkse feestdag. Zijn dit potentieel effectieve manieren om culturele pluriformiteit in zekere zin in het leerplan van algemene vorming te representeren' om aan te sluiten op de culturele schemata van de kinderen en van daaruit via kinderpoëzie bij te dragen aan hun 'kennis van culturele verscheidenheid' (vgl. Meijer, 1996, pp. 25-26)? Op basis van de hierboven beschreven kwalitatieve inzichten, kan de vierde en tevens laatste - kwalitatieve deelvraag voor groep 4 als volgt beantwoord worden:

1. Het zoeken naar gedeelde geritualiseerde taalhandelingen en deze gedeelde gebruiksvormen in verschillende talen aanbieden, zoals het zingen van een verjaardagsliedje, is een effectief middel om culturele pluriformiteit via poëzie expliciet onderdeel te maken van het aanbod in groep 4; andere feestliedjes, maar ook slaapliedjes en aftelrijmen uit verschillende landen en culturen kunnen hiervoor worden geselecteerd; ook tweetalige liedjes, zoals 'Naïma maakt muziek', lenen zich hier goed voor, al speelt daarin mee dat een tekst gemakkelijk moet zijn mee te zingen of zeggen door veel herhaling en een duidelijk herkenbare structuur;

2. Muziek, ter ondersteuning van liedjes, is voor groep 4 eveneens een effectieve manier om culturele pluriformiteit in te bedden in het poëzie-aanbod, omdat ook kinderen die de taal niet (her)kennen plezier kunnen beleven aan het bewegen op de muziek. Dit waarborgt dat het een gedeelde activiteit is.

Naast de 'gekke gedichten' spraken ook de 'cultuurteksten', zoals de leerkracht van groep 4 op mijn observatieschool ze noemt, dus teksten waarin expliciet aandacht was voor gebruiken en talen van etnische minderheidsgroepen in Nederland, de kinderen erg aan (evaluatie 2, S24, 18-06-2014). Dit werd door meer leerkrachten in groepen 4 opgemerkt en tijdens de afsluitende gesprekken ook genoemd als opvallend effect van het Leeskalenderaanbod. Op een van de scholen noemt een leerkracht juist als kritiekpunt dat er 'veel meer Islamitische verhalen' waren dan Christelijke verhalen. Als [leerkracht op een] katholieke basisschool vindt ze dat een gemis (evaluatie 2, S21, 05-06-2014). In het logboek van deze groep 4 kwam dit aspect ook naar voren bij het gedicht 'Dwaze droom' dat expliciet gekoppeld was aan de Turkse feestdag Çocuk Bayrami. De leerkracht noteerde: "Weer een aantal Turkse kinderen konden vertellen over de dag. ... Ik merk aan mezelf dat ik het wel veel verhalen en gedichten vind over de Islam en andere landen. Mis een beetje de katholieke identiteit die wij als school toch uitdragen." (2141, logboek week 28) Het is interessant om te zien dat leerkrachten de culturele pluriformiteit in het aanbod op deze manier kunnen ervaren. In principe waren Christelijke, en meer algemeen Westerse, tradities sterker vertegenwoordigd in de Leeskalender, zowel in het aanbod van teksten als in de feestdagen die aan bod kwamen. Dit werd feitelijk door geen van de leerkrachten als zodanig genoemd. Wel geeft 
een andere leerkracht aan (ook van een katholieke basisschool) dat als de Leeskalender zou worden doorontwikkeld tot een methode, er wat haar betreft meer verschillende culturen/religies in moeten terugkomen (ook Boeddhisme, Hindoeïsme, Jodendom) (evaluatie 2, S24, 18-06-2014).

\section{Synthese van de kwalitatief-empirische inzichten in poëzieverwerving in groep 4}

Er is een aantal 'patronen van betekenis' te herkennen in deze inzichten uit de praktijk over factoren die een cruciale rol spelen in processen van poëzieverwerving bij kinderen in groep 4. Allereerst zien we dat zich, in vergelijking met de kleuters, een opvallende ontwikkeling heeft voltrokken met betrekking tot de inbedding van 'het taalspel poëzie' in de pragmatische context. De context waarin 'het taalspel poëzie' functie en betekenis krijgt, is bij kinderen in groep 4 voor een belangrijk deel een mentaal construct, gevormd door de culturele schemata waarover ze beschikken. Met andere woorden: kinderen in groep 4 hebben de pragmatische contexten die ze uit ervaring kennen 'verinnerlijkt'. Nog steeds is het van belang dat poëzie aansluit op de culturele schemata waarover de kinderen beschikken om beleving en waardering tot stand te brengen. Een gedicht over een viering die ze niet uit ervaring kennen, roept geen beleving op en vinden ze 'saai': een andersoortig negatief waardeoordeel dan het 'De Leeskalender is in de war, het is geen Sinterklaastijd!' van de kleuters. 'Saai' is een oordeel op basis van interne waarden (het doet niets met de beleving, er is geen herkenning); 'de Leeskalender is in de war' is een oordeel op basis van externe waarden (het hoort niet op dit moment, er is geen functie in de context). Die verinnerlijking van de pragmatische context waarin kinderen in groep 4 poëzie ook herkennen als 'rituele' taalhandeling (als 'niet echt') betekent echter niet dat lichamelijke ervaring van 'het taalspel poëzie' er niet meer toe doet bij deze zeven- en achtjarigen. In groep 4 versterkt fysieke ervaring de beleving en daarmee ook het begrip van specifieke vormen van 'het taalspel poëzie': door die geïntensiveerde beleving waarderen ze een gedicht of lied ook meer dan wanneer ze er alleen over praten of redeneren. De fysieke ervaring van 'het taalspel poëzie' kan bij kinderen in groep 4 ook tot stand komen wanneer ze dat taalspel op talig niveau zelf kunnen spelen, maar de toevoeging van fysiek handelen zorgt voor extra intensivering van de beleving. Zeker bij poëzie waar sprake is van een zekere incongruentie of dissonantie tussen pragmatisch en semantisch niveau (poëzie die niet doet wat het zegt, of doet wat het niet zegt) kan fysiek handelen ervoor zorgen dat kinderen de specifieke incongruentie zintuiglijk waarnemen en daarmee ook beter begrijpen.

Kinderen in groep 4 waarderen humor, maar wat door deze kinderen als humoristisch wordt ervaren in 'het taalspel poëzie' kan op verschillende niveaus worden waargenomen. 'Muzikaal taalspel' kan verrassingseffecten teweegbrengen die een humorreactie oproepen als: (a) de performance door de leerkracht afwijkt van het verwachtingspatroon van de kinderen (leerkrachten die rappen, of in slaap vallen), (b) de vorm van het gedicht nieuw is voor de kinderen (zoals 'Het poppenkopmannetje'), of (c) de vorm van het gedicht afwijkt van het verwachtingspatroon van de kinderen over geschreven taal (zoals het 'Versje om te mompelen'). Met name de autonome vormen van 'muzikaal taalspel', zoals het 'Versje om te mompelen', het 'Versje om te rappen' en 'Het poppenkopmannetje', brengen bij kinderen in groep 4 verrassingseffecten teweeg die bijdragen aan hun beleving en waardering 
van 'het taalspel poëzie'. Ze vinden deze vormen grappig (want vernieuwend) en willen ze vaak meerdere keren horen. Bij deze nieuwe vormen geldt dat meedoen een effectiever verwerkingsvorm is dan zelf variëren: ze moeten de vorm nog appropriëren in hun culturele schemata. Ook als 'het taalspel poëzie' inhoudelijk afwijkt van wat kinderen in groep 4 verwachten, brengt het verrassingseffecten teweeg die positief kunnen bijdragen aan de waardering. Dit is het sterkst wanneer er sprake is van een zekere subversiviteit in poëzie, of dat nu subversief talig of fysiek handelen is. De ervaring van de 'incongruentie' van deze subversiviteit in relatie tot de normen en conventies van de sociaal-culturele context wordt versterkt wanneer de schoolklas fungeert als het carnavaleske kader waarbinnen de specifieke carnavalesk-nonsensicale elementen in poëzie functie en betekenis krijgen. Kinderen in groep 4 laten over de gehele linie zien dat ze sterker gericht zijn op de tekst dan op de externe pragmatische context en dat ze poëzie herkennen als rituele taalhandeling waarvoor andere pragmatische conventies gelden dan voor alledaags taalgebruik. Ze tonen sterke waardering voor vernieuwende elementen in 'het taalspel poëzie', elementen die afwijken van hun verwachtingspatroon, of die vernieuwing nu voortkomt uit de vorm, de performance of de inhoud van poëzie. Nog steeds speelt de pragmatische context een belangrijke rol en dan met name de normen en conventies die gelden in de schoolklas: kinderen in groep 4 waarderen de speelse (carnavaleske) transgressie van de schoolklas als pragmatische context. Hoewel ze de conventies en normen van die context al grotendeels verinnerlijkt hebben, heeft de fysieke aanwezigheid van de schoolklas en de leerkracht een versterkende werking op de beleving van de transgressie, zolang de leerkracht zelf ook deelnemer is aan het carnavaleske spel. Het gezamenlijke plezier dat kinderen en leerkracht kunnen beleven aan een gedicht als 'Tien dingen naar keus die je kunt doen met dingen uit je neus' is alleen al voor de sociale cohesie in de klas van onschatbare waarde. 



\section{HOOFDSTUK 11}

\section{Tegen de verwachtingen in ... (conclusies en discussie)}

"The key focus in all scientific research is the search for 'understanding' or for 'knowing' with the aim of contributing to the body of knowledge or a theory in the domain of research. Other broad aims of doing educational research are to provide insights and contributions for improving practice, and to inform decision making and policy development in the domain of education.” (Plomp, 2010, p. 10) 



\subsection{Het belang van (onderzoek naar) culturele geletterdheid in het basisonderwijs}

Het is van belang kinderen al vanaf jonge leeftijd kennis te laten maken met teksten die hen introduceren in gedeelde uitingsvormen, maar ook in normen, waarden, kennis en gebruiken die aan de basis liggen van de culturele gemeenschap(pen) waarin ze opgroeien. Het opdoen van culturele geletterdheid via kinderliteratuur makt dan ook een belangrijk deel uit van de culturele socialisatie van kinderen in een geletterde samenleving. Niet alleen vormt brede culturele geletterdheid een noodzakelijke voorwaarde voor het duidend kunnen lezen van een grote variatie aan teksten; het kan ook culturele vorming faciliteren (Heath, 1982; Hirsch, 1983; Dickinson \& Smith, 1994; Ghesquière, 2009a). Beide aspecten zijn van belang voor het functioneren in de samenleving. In Hoofdstuk 1 is echter vanuit verschillende invalshoeken duidelijk geworden dat expliciete aandacht voor de bijdrage van kinderliteratuur aan culturele geletterdheid alles behalve vanzelfsprekend is in het hedendaagse basisonderwijs in Nederland. Het belang van culturele geletterdheid, als een resultaat van brede cultuuroverdracht en -verwerving, wordt op zichzelf niet ontkend, maar over het hoe en wat van cultuuroverdracht wordt men het maar moeilijk eens. In verschillende debatten die de afgelopen decennia gevoerd zijn (en nog steeds worden), komt naar voren dat het begrip 'culturele geletterdheid' - en gerelateerde concepten van 'cultuur', van 'nationaal discours' of een 'common reader', van 'het culturele lezen', cultuuroverdracht en culturele en/of literaire canonvorming - zich moeilijk verhoudt tot een veelheid aan sociaal-culturele en wetenschappelijke ontwikkelingen die zich in de Nederlandse samenleving hebben voltrokken (en die zich nog steeds voltrekken). Cultureel-maatschappelijke vorming van kinderen en jongeren is complexer en minder vanzelfsprekend geworden. Bijvoorbeeld door afnemende invloed van traditionele levensbeschouwelijke instituties, toenemende culturele pluriformiteit in de samenleving, de toenemende dynamiek van de huidige netwerksamenleving, en het toegenomen belang dat aan economisch nut en rendement wordt gehecht, ook op het gebied van kennis, cultuur en wetenschap (Onderwijsraad, 2011). Tegelijk zijn deze ontwikkelingen in de afgelopen jaren aanleiding geweest om cultuureducatie, brede culturele vorming en het introduceren van leerlingen in de literaire en culturele canon opnieuw te agenderen als expliciete taak van het onderwijs en de druk op scholen om hier structurele vorm en inhoud aan te geven neemt toe (Onderwijsraad, 2013; Onderwijsraad \& Raad voor Cultuur, 2012; Onderwijsraad, 2011). Het aanpakken van achterstanden van Nederlandse leerlingen op het gebied van taal en rekenen die lange tijd in internationale vergelijkingen werden waargenomen, heeft haar vruchten afgeworpen. Maar de eenzijdige aandacht voor de basisvaardigheden die het (basis)onderwijs in de afgelopen decennia is gaan beheersen, heeft volgens de Onderwijsraad ook geleid tot een 'verschraling van het onderwijs' ten koste van (onder meer) cultuureducatie en burgerschapsvorming: "Meetbare doelen zijn de maatstaf geworden voor de kwaliteit van het onderwijs. De raad roept op discussie te voeren over wat het Nederlandse onderwijs leerlingen en studenten moet meegeven.” (2013, pp. 4-5)

Vorm geven aan cultuureducatie blijkt voor scholen een lastige opgave omdat er nauwelijks richtlijnen zijn om te bepalen wat en hoe er aan cultuureducatie gedaan moet worden (Heusden, 2010); hetzelfde geldt voor burgerschapsvorming (Onderwijsraad, 2012; 
2013). Er is in de afgelopen decennia wel sterk ingezet op de inbedding van het lezen van literatuur in het (basis)onderwijs via leesbevorderingsbeleid, als onderdeel van het cultuunbeleid. Hoewel het stimuleren van het 'culturele lezen', het lezen van 'cultureel waardevolle en literaire teksten', een hoofddoelstelling van het leesbevorderingsbeleid was, wijst de Raad voor Cultuur er op dat ook de kennis en vaardigheden die nodig zijn voor het culturele lezen in de samenleving en in het onderwijs minder vanzelfsprekend zijn geworden: "Het accent is in de afgelopen periode verschoven van literatuur naar leesvaardigheid en leesplezier in het algemeen." (2005b, p. 6) In de praktijk van het basisonderwijs wordt leesbevordering vaak impliciet of expliciet gekoppeld aan taalontwikkeling en het leren lezen en schrijven (Nicolaas, 2005). Om het culturele lezen steviger te positioneren in het onderwijs is in de afgelopen jaren vooral veel aandacht uitgegaan naar het begrip 'literaire competentie'. Dat begrip heeft concrete uitwerking gekregen, eerst voor het voortgezet onderwijs en vervolgens ook voor het basisonderwijs (zie o.a. Coenen, 1992; Duijx, 2005; Dormolen et al, 2005; Ven, 2006; Witte, 2008; Ghonem-Woets, 2009, 2010; Pol, 2010). De nadruk ligt daarbij op de formele vaardigheden die van belang worden geacht voor het toegang krijgen tot en het lezen van literatuur ${ }^{197}$. De vraag wat 'cultureel waardevolle teksten' zijn, i.e. welke teksten cruciaal zijn om te lezen en waarom, en welke teksten zowel culturele waarde vertegenwoordigen als geschikt zijn voor de beoogde doelgroep, is daarmee echter nog niet beantwoord. Net als op het gebied van cultuureducatie en burgerschapsvorming is de overheid terughoudend in het formuleren van inhoudelijke richtlijnen, in overeenstemming met "de Nederlandse vrijheid van onderwijs, waarbij scholen autonoom zijn als het om de onderwijsinhoud en de pedagogisch-didactische aanpak gaat." (Onderwijsraad, 2012) Cultuuroverdracht is hierdoor echter nauwelijks verankerd in het onderwijs en het is voor scholen onduidelijk wat en hoe ze op leerlingen dienen over te dragen, mede omdat er ook nauwelijks systematische kennis voorhanden is over wat werk $\mathrm{t}^{198}$.

Dit onderzoeksproject levert een belangrijke bijdrage aan de discussie en kennisopbouw over cultuuroverdracht in het basisonderwijs door het begrip 'culturele geletterdheid' centraal te stellen. Dit begrip kreeg vanaf de jaren 1980 in de Verenigde Staten grote bekendheid door het werk van E.D. Hirsch Jr., werd in Nederland overgenomen door de makers van Het Cultureel Woordenboek, en De Nederlandse Taalunie wijdde in 1993 en 1994 twee opeenvolgende conferenties aan 'culturele geletterdheid' waarvan lezingen werden gebundeld in Een beeld van belezenheid: Over culturele geletterdheid (1996). Daarna is de term 'culturele geletterdheid' als zodanig weer naar de achtergrond verdwenen, mogelijk omdat hij te zeer 'besmet' was door de 'back-to-basics' beweging van waaruit de term in de Verenigde Staten opdook in "een aanzwellende lastercampagne waarin de onwetendheid van de massa in het algemeen en de jeugd in het bijzonder, bron van ergernis en vermaak werd." (Soetaert \& Top, 1996, p. 7) Sinds de jaren 1980 groeide in Nederland juist het besef dat cultuuroverdracht in de zin van 'ingevoerd worden in de canon' problematisch was geworden. Mede doordat het onderwijs zich sinds de jaren 1960 heeft ontwikkeld naar een leerlinggerichte aanpak met een grote nadruk op individuele vaardigheden en competenties, doordat de

\footnotetext{
197 "Gesproken wordt van literaire competentie als iemand de weg weet in het brede aanbod van boeken en organisaties (wegwijs raken), kennis heeft van kenmerken van literaire teksten en daarmee waardering kan ontwikkelen (tekstgerichte vaardigheden) en vervolgens die waardering beargumenteerd kan formuleren (lezersgerichte vaardigheden)." (Nicolaas, 2005, p.7)

198 Zie het dossier 'Vorming en burgerschap' van de Onderwijsraad, op: https://www.onderwijsraad.nl/dossiers/
} 
informatiemaatschappij en nieuwe media maken dat inhoudelijke kennis steeds sneller veroudert, en doordat de onderwijspopulatie breder en meer divers is geworden (zie o.a. Vriend, 2004; Moerbeek, 1998; Peer \& Soetaert, 1993).

Na de woelige jaren 1980 en ' 90 waarin felle canondebatten in de literatuurwetenschappen werden gevoerd, was Paul Scheffers scherpe kritiek op wat hij 'het multiculturele drama' noemde en zijn roep om het 'onder woorden brengen wat onze samenleving bijeen houdt' (NRC, 29 januari 2000), aanleiding voor vernieuwde maatschappelijke aandacht voor het belang van een canon als richtsnoer of maatstaf voor samenleving en onderwijs. Tegelijk kon ieder initiatief, zoals de ontwikkeling van de officiële Canon van Nederland, ook op felle kritiek rekenen. "De canon-kritiek komt vooral voort uit de groeiende twijfel over het bestaansrecht van 'een canon van de samenleving', een lijst met boeken die ... 'functionele geldigheid heeft voor de maatschappij als geheel'," stellen Helma van LieropDebrauwer en Piet Mooren vast: "Pogingen om een dergelijke canon vast te leggen, leiden keer op keer tot verhitte discussies.” (2004, p. 8) Daarbij worden een leerlinggerichte en een cultuuroverdrachtgerichte onderwijsopvatting vaak recht tegenover elkaar geplaatst: "Dé canon op school moet het afleggen tegen persoonlijke voorkeur en competentie van leerlingen." (Schram, 2003, p. 6) Dit is, naar onze opvatting, echter een schijntegenstelling. Het centraal stellen van individuele voorkeuren en competenties is op zichzelf al een ideologisch uitgangspunt. En ook als (kinder)literatuur wordt aangeboden voor het bevorderen van leesplezier en/of literaire competentie, speelt de inhoud een rol: "Jeugd- en kinderboeken dragen manifest of latent vooroordelen, gedragspatronen, normen en waarden over." (Ghesquière, 2009a, p. 120) Vernieuwde aandacht voor de 'socialiserende functie' van kinderliteratuur, “ $\ldots$ in die zin dat ze mee het proces bewerkt en bevordert waardoor een individu, dat met een enorme waaier van mogelijkheden en gedragspatronen geboren wordt, bij de uitbouw van zijn feitelijke gedrag een beperkt aantal mogelijkheden kiest" (p. 120), is van belang omdat deze aspecten van literatuur benut kunnen worden om kinderen kennis en begrip te laten opbouwen van de normen, waarden, kennis en gebruiken die aan de basis liggen van de culturele gemeenschap(pen) in de samenleving waarin ze opgroeien.

Dit onderzoeksproject sluit aan bij de Onderwijsraad wanneer ze stelt dat kinderen, juist vanwege de toegenomen complexiteit en de afgenomen vanzelfsprekendheid, behoefte hebben aan brede cultuuroverdracht, inclusief kennis van tradities en moraal, en dat scholen en leraren daar een taak in hebben (2011, p. 12). Als het onderwijs geen actieve en structurele rol speelt in de 'democratisering' van brede cultuuroverdracht, dan is dat vooral in het nadeel van kinderen die de brede culturele kennis en vaardigheden die nodig zijn in het onderwijs en voor deelname aan de Nederlandse cultuur en samenleving van huis uit niet (kunnen) meekrijgen (Bourdieu, 1979; Bourdieu \& Passeron, 1981; Mooren, 2000a). We achten kinderliteratuur een zeer geschikt middel om bij te dragen aan de ontluikende culturele geletterdheid van jonge kinderen. Echter, de vraag wat 'cultureel waardevolle en literaire teksten' zijn, is blijvend onderwerp van kritisch debat en 'rendementsdenken' in het onderwijs belemmert aandacht voor de bredere culturele ontwikkeling van kinderen, mede omdat de 'culturele ontwikkeling' van leerlingen zo moeilijk te vertalen is naar meetbare resultaten (Onderwijsraad \& Raad voor Cultuur, 2012, p. 15). Het onderzoeksproject Emergent Cultural Literacy: Assimilating Children's Literature stelt, ondanks de maatschappelijke en wetenschappelijke complexiteit, juist de rol die kinderliteratuur kan spelen in het ontwikke- 
len van de ontluikende culturele geletterdheid van kinderen in het basisonderwijs centraal. Die complexiteit, de debatten, en de terugkerende roep om aandacht voor cultuuroverdracht benadrukken de relevantie van dit onderzoek naar de mogelijkheden die kinderliteratuur biedt om al vanaf het begin van het basisonderwijs structureel bij te dragen aan de ontwikkeling van de ontluikende culturele geletterdheid van kinderen. Daarbij houdt dit onderzoeksproject rekening met verschillende 'complicerende factoren' in het beantwoorden van de vraag wat 'cultureel waardevolle teksten' zijn, i.e. welke teksten cruciaal zijn in de culturele ontwikkeling van kinderen en waarom. Dit onderzoeksproject richt zich op kinderen in groep 2 en groep 4 van het basisonderwijs en houdt er rekening mee dat deze jonge kinderen nog geen uitgebreide literaire schemata hebben opgebouwd en nog niet volledig geletterd zijn waardoor ze literatuur noodzakelijkerwijze anders begrijpen, waarderen en verwerven dan ervaren en geschoolde lezers. Dit onderzoeksproject houdt er ook rekening mee dat schoolklassen de culturele pluriformiteit van de Nederlandse samenleving vertegenwoordigen. We mogen er niet van uit gaan dat kinderen allemaal over dezelfde (maten en soorten van) culturele competentie, i.e. dezelfde kennis, vaardigheden, leef- en belevingswereld, beschikken. Zeker wanneer we het over jonge kinderen hebben, is het van belang te realiseren dat debatteren over wat er aan cultuur zou moeten worden overgedragen weinig zin heeft als er niet ook gekeken wordt naar wat en hoe de beoogde doelgroep aan cultuur kan verwerven.

De centrale vraag die ten grondslag ligt aan dit onderzoeksproject is dan: waar liggen de raakvlakken tussen 'cultureel waardevolle' teksten en de factoren die een cruciale rol spelen in processen van tekstverwerving bij jonge kinderen met verschillende etnische, religieuze en sociaalmaatschappelijke achtergronden? Deze centrale vraag doet iets nieuws in relatie tot onderwijs- en canonvormingsdebatten: ze presenteert de culturele competentie van individuele leerlingen en de culturele waarde van teksten als twee zijden van dezelfde medaille. Daarmee komen leerlinggericht en cultuuroverdrachtgericht onderwijs in elkaars verlengde te liggen. Deze centrale vraag doet ook iets nieuws in relatie tot wetenschappelijke benaderingen van canonvorming: ze stelt de raakvlakken tussen kenmerken van literatuur en kenmerken van de beoogde doelgroep centraal waarmee hermeneutische en empirische benaderingen van 'canoniciteit' en canonisering in elkaars verlengde komen te liggen. En dit alles plaatsen we, gezien het feit dat dit onderzoeksproject een praktijkgericht oogmerk heeft, in het kader van de beoogde doelgroep van jonge kinderen in het basisonderwijs. De relevantie van dit onderzoek is dan tweezijdig: enerzijds draagt dit onderzoek bij aan een concrete oplossing voor het probleem van de structurele inbedding van brede cultuuroverdracht in het basisonderwijs en anderzijds draagt dit onderzoek bij aan de ontwikkeling van een innovatieve methodologie voor de evidence-based selectie van 'cultureel waardevolle' literatuur die effectief bijdraagt aan de ontwikkeling van de ontluikende culturele geletterdheid van kinderen in groep 2 en in groep 4. 


\subsection{Pluriforme canonvorming vanuit de cultuur van het dagelijks leven}

De idee van literatuuronderwijs als cultuuroverdracht, in de zin van 'ingevoerd worden in de canon', kwam met de invoering van de Mammoetwet in 1968 - met 'het nastreven van individuele ontplooiing' als algemene doelstelling voor het voortgezet onderwijs - op losse schroeven te staan. Sindsdien is canonvorming voor het onderwijs een 'kwestie', want "[v]oor het literatuuronderwijs betekende het centraal stellen van de persoonlijke ontwikkeling, dat de leeservaring en het ontwikkelen van de individuele smaak voorop kwamen te staan. Ofwel: culturele competentie komt in plaats van canons ...." (Vriend, 2004, p. 22) Niet alleen in het onderwijs werd canonvorming een 'kwestie', maar ook - vooral sinds de jaren 1980 - in de literatuurwetenschap. In de jaren 1960 en 1970 werd die nog gedomineerd door de tekstgerichte benadering, maar:

"Er kwam verandering in toen nieuwe denkbeelden opdoken, over de receptie en werking van literatuur, maar ook over andere tekstdomeinen, zoals dat van de jeugdliteratuur. Bovendien was er inmiddels strenge methodologische kritiek uitgesproken over de tekstgerichte analyse. Ten slotte mag de opkomst van de empirische en de institutionele literatuursociologie ... niet ongenoemd blijven.” (Vriend, 2004, p. 24)

Het zou een te grote uitweiding vergen om de - soms zeer felle - (canon)debatten tussen (en onder) hermeneutici en empirici in de literatuurwetenschap in de jaren 1980 hier met de nodige detaillering te bespreken. Globaal kan gezegd worden dat de empirici van mening waren dat canonvorming weinig van doen heeft met 'de tekst' en de uitspraken van hermeneutici over de kwaliteit van literatuur op basis van analyse en interpretatie van een literair werk zouden te subjectief en 'onwetenschappelijk' zijn (Verdaasdonk, 1985). Van Rees liet zien hoe de drievoudige selectie van een werk door de journalistieke, essayistische en academische kritiek een werk tot een meesterwerk en potentiële klassieker kan bestempelen (1983): een proces waarin vooral heersende literatuuropvattingen en de invloed van toonaangevende critici een belangrijke rol spelen (Rees, 1985). In deze 'top down' benadering van canonvorming is echter sprake van een tautologie: het gaat uit van een culturele elite die bepaalt wat canoniek is en wat culturele geletterdheid is, terwijl het 'bezitten' van datgene wat canoniek is en je cultureel geletterd maakt, bepaalt of je tot de culturele elite behoort of niet (zie ook Hoofdstuk 1, \$1.3). De hermeneutische analyse en interpretatie van 'canonieke werken' nóch de empirische bestudering van geïnstitutionaliseerde canonvormingsprocessen kan (volledig) verklaren waarom bepaalde (soorten) verhalen en poëzie in de smaak vallen bij achtereenvolgende generaties van jonge kinderen. Dat kunnen ze niet omdat beide benaderingen uitgaan van geïnstitutionaliseerde conventies, of dat nu de conventies van de literatuurwetenschap of de conventies van het systeem van de literaire kritiek zijn. Jonge kinderen zijn nog niet (volledig) in die conventies gesocialiseerd: het zijn geen professionele lezers (zie Hoofdstuk 2). Willen we dat jonge kinderen literatuur verwerven dan is het van cruciaal belang dat geselecteerde werken nauwkeurig aansluiten op hun leef- en belevingswereld. Om kinderliteratuur te selecteren die aansluit op de ontluikende culturele competentie van kinderen moeten we er rekening mee houden dat ze niet op dezelfde 
manier met literatuur omgaan als een ervaren (en geschoolde) lezer die is gesocialiseerd in bepaalde conventies voor het lezen van literatuur of een criticus die onderdeel uitmaakt van canonvormende instituties. Competentie- of leerlinggerichtheid is van groot belang voor het selecteren van kinderliteratuur die effectief kan bijdragen aan ontluikende culturele geletterdheid.

De kwestie van canonvorming is evenwel een centrale kwestie wanneer we het hebben over culturele geletterdheid omdat culturele geletterdheid altijd een onderliggende opvatting over de 'culturele waarde' van bepaalde kennis, literatuur, et cetera impliceert. Niet alleen is het voor alle kinderen van belang om al vanaf jonge leeftijd kennis te maken met 'cultureel waardevolle' teksten die, eenmaal verworven, toegang bieden tot een brede waaier aan culturele uitingsvormen; het is voor alle kinderen van minstens zoveel belang dat ze kennis maken met de normen, waarden, kennis en gebruiken die in die teksten gerepresenteerd worden en zich daartoe leren verhouden. Voor het stapsgewijs opdoen van kennis van cultureel relevante uitingsvormen én inhouden via kinderliteratuur achten we een structurele aanbieding van een verscheidenheid aan genres en tekstsoorten een zeer geëigend middel. Genres kunnen worden omschreven als 'bodies of shared knowledge' of 'repositories of cultural memory' waarin steeds bepaalde vormen en inhouden samenkomen (Wesseling, 1991; Van Gorp \& Musarra-Schroeder, 2000). We hebben in dit onderzoek echter te maken met een doelgroep van jonge kinderen. Wat zijn hun 'bodies of shared knowledge', hoe ziet hun 'cultureel geheugen' eruit, welke cultureel waardevolle genres sluiten daar op aan en hoe? We hebben daarbij ook te maken met de pluriforme Nederlandse samenleving die weerspiegeld wordt in pluriforme schoolklassen. Tegen die achtergrond is het van belang ons af te vragen in hoeverre we kunnen vasthouden aan "een canon, aan een gedeelde cultuur, zoals in de idee van culturele geletterdheid (met haar 'common reader') en in de idee van algemene vorming (de vorming van allen gemeenschappelijk) is voorondersteld" (Meijer, 1996, pp. 25-26). Tegelijk betekent dit niet dat er, gezien het belang van cultuuroverdracht, geen keuzes kunnen en moeten worden gemaakt. Uitgangspunt is dan: "Om kinderen op de pluriforme samenleving voor te bereiden, is ... ook kennis nodig van de verschillende culturen die de collage van onze samenleving uitmaken. Dan dient de pluriformiteit in zekere zin in het leerplan van algemene vorming gerepresenteerd te worden." (pp. 25-26) Zijn er genres die aansluiten op de 'bodies of shared knowledge' van pluriforme groepen jonge kinderen? Aansluiting van de aangeboden literatuur op de kennis, vaardigheden, voorkeuren en leef- en belevingswereld, i.e. de culturele competentie ${ }^{199}$, waarover kinderen beschikken, is voorwaarde voor de effectieve bijdrage van kinderliteratuur aan de ontwikkeling van ontluikende culturele geletterdheid van kinderen. En de ontwikkeling van ontluikende culturele geletterdheid bij jonge kinderen begint niet met 'hoogwaardig cultureel kapitaal' zoals dat in cultuursociologisch onderzoek veelal wordt ingevuld, en ook niet met kennis van 'alle in de taal van die samenleving beschreven en geschreven producten', zoals de makers van Het Cultureel Woordenboek in navolging van Hirsch als uitgangspunt gebruikten. Zeker als we kinderen van wie de ouders, om wat voor reden dan ook, niet

\footnotetext{
199 'Ontluikende culturele competentie' heeft betrekking op wat kinderen aan cultuur kunnen verwerven; 'ontluikende culturele geletterdheid heeft betrekking op wat kinderen aan cultuur bebben verworven. Binnen het kader van dit onderzoeksproject bedoelen we met 'cultuur' specifieke (kenmerken van) langdurig geliefde en (trans)cultureel diepgewortelde tekstsoorten en genres (soorten kinderpoëzie binnen dit deelproject).
} 
over 'kwalitatief hoogwaardige culturele hulpbronnen' beschikken (Kraaykamp, 2009, p. 7), of kinderen die beschikken over culturele competentie die binnen de dominante cultuur niet als waardevol wordt aangemerkt, niet bij voorbaat al in een achterstandspositie willen plaatsen, is een alternatieve opvatting van 'culturele canonvorming' geboden.

Voor die alternatieve opvatting hebben we ons laten informeren door de etnologie met haar 'canon met de kleine c' (Meder, Koman \& Rooijakkers, 2008), maar voegen daar een ontwikkelingsperspectief op culturele socialisatie aan toe. De ontluikende culturele competentie van jonge kinderen ontspruit in de voedingsbodem van de 'cultuur van het dagelijks leven' waarin kinderen binnen primair en secundair opvoedingsmilieu worden ingewijd. Ingebed in allerlei soorten vaste en regelmatig herhaalde praktijken maken alle kinderen (in meer of mindere mate) kennis met allerlei soorten teksten, van verhalen in de context van religieuze vieringen tot en met een liedje voor het slapen gaan. Putten uit 'de canon van de volkscultuur' ligt dan voor de hand. Allereerst omdat we via die volkscultuur, "als aanduiding van de brede, alledaagse cultuur, waar iedereen, elite of volk, vreemd of eigen, in participeert" (Dekker et al, 2000b, p. 10), inzicht krijgen in de gedeelde culturele praktijken die vorm geven aan de ontluikende culturele competentie van jonge kinderen, ongeacht het milieu waarin ze opgroeien. Daarbij houden we er rekening mee dat die culturele praktijken in een cultureel pluriforme samenleving divers zijn. En ten tweede putten we uit de 'canon van de volkscultuur', “... omdat rijmpjes en versjes, sprookjes en fabels, raadsels en spreuken, moppen en grappen deel uitmaken van een internationale traditie." (LieropDebrauwer \& Mooren, 2004, p. 11) De 'canon van de volkscultuur' vertelt ons ook dat teksten en de culturele praktijken waarin ze zijn ingebed, in processen van cultuuroverdracht en -verwerving niet los van elkaar te zien zijn. Door niet alleen te kijken naar breed gedragen (transculturele en langdurig geliefde) tekstsoorten en genres, maar ook naar de contexten waarin processen van overdracht en verwerving van deze tekstsoorten vorm krijgen voor jonge kinderen en deze beide factoren in ontwikkelingsperspectief te zien, beogen we met dit onderzoek een belangrijke bijdrage te leveren aan pluriforme canonvorming voor het basisonderwijs. Het draait daarbij niet om de selectie van 'canonieke' titels. Met het oog op pluriforme canonvorming zijn we uitgegaan van 'een route in de diepte' door de bijdrage die kinderliteratuur kan leveren aan de ontluikende culturele geletterdheid van jonge kinderen op te vatten als het opbouwen van kennis en begrip van allerlei formele en inhoudelijke kenmerken van verschillende (trans)cultureel diepgewortelde genres of tekstsoorten. We zijn nagegaan welke kenmerken van deze genres en tekstsoorten een cruciale rol spelen in hun langdurige en (trans)cultureel diepgewortelde volksculturele canoniciteit. Deze kenmerken zijn vertaald naar een selectie van kinderliteratuur waarmee in de praktijk van het basisonderwijs is nagegaan (a) of deze literatuur effectief bijdraagt aan de ontluikende culturele geletterdheid van kinderen in groep 2 en in groep 4, en (b) welke rol de 'canonieke kenmerken' spelen in de overdracht en verwerving van kinderliteratuur in de klas. Het doel van dit onderzoeksproject is dan ook de ontwikkeling van evidence-based criteria voor de selectie van kinderliteratuur die effectief bijdraagt aan de ontwikkeling van de ontluikende culturele geletterdheid van kinderen in groep 2 en groep 4 van het basisonderwijs.

Het tekstaanbod zoals dat vanuit de drie deelprojecten - Deugden \& Dilemma's, Kinderpoëzie en Narratieve Genres - is samengesteld en gedurende dertig weken is aangebo- 
den in groepen 2 en groepen 4 van het basisonderwijs heeft, zoals met de Toets Ontluikende Culturele Geletterdheid is nagegaan, als geheel een positief effect gehad op de ontwikkeling van de culturele geletterdheid van de kinderen (zie Hoofdstuk 8, $\mathbb{8} 8.4)^{200}$. Uit logboeken en gesprekken met leerkrachten spreekt ook waardering voor de gekozen genres en tekstsoorten en voor de culturele pluriformiteit die in het aanbod vertegenwoordigd was. Leerkrachten spraken expliciete waardering uit voor de variatie in het Leeskalenderaanbod. Verschillende leerkrachten gaven aan via de Leeskalender in aanraking te zijn gekomen met soorten teksten die ze zelf niet snel zouden kiezen. Ook als het werken met de Leeskalender op het niveau van individuele teksten niet altijd als zinvol werd ervaren omdat sommige teksten de kinderen niet zo aanspraken, werd het feit dat de kinderen met zoveel verschillende soorten teksten in aanraking komen op zichzelf als waardevol ervaren. Soms geheel tegen de eigen verwachting in, zagen leerkrachten dat fabels, schelmenverhalen, en poëzie in de smaak vielen bij de kinderen. Een van de leerkrachten stelde: 'Dat is net als bij klassieke muziek. Kinderen moeten ermee in aanraking komen om het te leren waarderen.' Deze leerkracht acht het vanuit dit perspectief zinvol dat de kinderen met een grote variatie aan tekstsoorten in aanraking zijn gekomen via de Leeskalender, waarbij ze specifiek de poëzie noemt omdat daar in de methode begrijpend lezen weinig aandacht aan besteed wordt (evaluatie 2, S21, 05-06-2014). Het is interessant om te zien dat tekstsoorten die wij hebben geselecteerd vanwege hun verbinding met de orale volkscultuur en daarmee in zekere zin als 'cultureel gemeengoed' kunnen worden beschouwd, door deze leerkracht worden gezien als 'te verwerven smaak'. Uit de expliciete waardering die de meeste leerkrachten voor de gekozen genres en tekstsoorten uitspreken, kunnen we afleiden dat het aanbod als 'cultureel waardevol' werd ervaren. Leerkrachten, vooral die van groep 4, uitten ook expliciete waardering voor de aandacht voor andere talen en culturen als onderdeel van het Leeskalenderaanbod. Een terugkerend voorbeeld waren de 'Moslimverhalen' die veel gespreksstof opleverden en waarbij de Islamitische kinderen in de klas merkbaar blij waren met de herkenning en erkenning van hun geloof. Zo konden ze bijvoorbeeld vertellen over de feesten die ze vieren. Verhalen uit de Leeskalender die aansloten bij de (etnische of religieuze) achtergronden van kinderen in de klas gaven aanleiding tot het vergelijken van gewoontes en het constateren dat er verschillen zijn. Leerkrachten merkten dat teksten die aansluiten bij de cultuur van sommige kinderen in de klas aanleiding gaven tot wederzijdse interesse in elkaars achtergrond, gewoonten van thuis, et cetera. Verhalen uit de Islamitische traditie spraken enorm aan bij de Islamitische kinderen en alle kinderen vonden het interessant om daar verhalen over te horen. Hetzelfde geldt voor liedjes in het Arabisch of een andere taal: dat vinden de kinderen prachtig, zeker als ze hun eigen thuistaal herkennen.

Zowel de inbedding van culturele pluriformiteit als de specifieke genres en tekstsoorten in het aanbod werden door leerkrachten gezien als belangrijke aanvulling van de Leeskalender op het type teksten waar ze doorgaans mee werken in het kader van taalmethoden en/of leesbevorderingsactiviteiten. De waardering van leerkrachten en kinderen voor het Leeskalenderaanbod bevestigt ons theoretisch uitgangspunt dat putten uit de orale volkscultuur een effectieve insteek is om kinderliteratuur te selecteren die enerzijds aansluit op

${ }^{200}$ Kijken we naar het deelproject Kinderpoëzie op zichzelf dan moeten andere conclusies getrokken worden (zie $\$ 11.5)$. 
de ontluikende culturele competentie en voorkeuren van de kinderen en anderzijds toegang biedt tot een brede waaier aan uitingsvormen die als 'cultureel waardevol' worden ervaren. Naast deze maatschappelijke relevantie draagt dit onderzoeksproject zowel theoretisch als methodologisch bij aan het vergroten van wetenschappelijke kennis en begrip op verschillende gebieden. Zowel de theoretische benadering die is gekozen voor het formuleren van verwachte indicatoren van canoniciteit als de empirische benadering die is gekozen voor het op de proef stellen van die verwachtingen in de onderwijspraktijk leveren belangrijke aanvullende inzichten in hoe verschillende genres en tekstsoorten werken voor jonge kinderen, hoe kinderen zich verschillende genres en tekstsoorten eigen maken, hoe zij die genres en tekstsoorten begrijpen en waarderen. De ontwikkeling en afname van de Toets OCG levert daarbij inzichten in hoe effecten van de aanbieding van de gekozen genres en tekstsoorten op de ontluikende culturele geletterdheid van kinderen in groep 2 en groep 4 (al dan niet) meetbaar kunnen worden gemaakt. De verkregen evidence-based inzichten in 'bottom-up' processen van pluriforme canonvorming voor en door jonge kinderen vormen een belangrijke aanvulling op 'top-down' processen van canonvorming in de kinder- en jeugdliteratuur en op het hermeneutisch en empirisch literatuurwetenschappelijk onderzoek naar canoniciteit van werken en naar institutionele canonvorming tot nu toe. Ten slotte levert dit onderzoeksproject kennis op die het uitgangspunt kan vormen voor het verder ontwikkelen van de verkregen inzichten naar 'transculturele geletterdheidsprogramma's' voor het basisonderwijs.

\section{3 'Confronting the Snark' (of: Bestaat er wel zoiets als kinderpoëzie?)}

Tot dusver heb ik het gehad over het onderzoeksproject als geheel. Dit proefschrift handelt echter specifiek over de bijdrage van kinderpoëzie aan de ontwikkeling van ontluikende culturele geletterdheid bij kinderen in groep 2 en in groep 4 van het basisonderwijs ${ }^{201}$. In Hoofdstuk 2 citeerde ik Peter Hunt die in 'Confronting the Snark: The Non-Theory of Children's Poetry'schrijft:

"As a term, children's poetry offers the same problem as children's literature - it consists of two complex terms and a possessive. Children denotes a broad and highly variable construct, often bearing little relation to reality - although its use is often unavoidable. By the possessive, do we mean belonging to, written by, written for, adopted by, of childhood ... and so on. (...) Poetry is equally problematic; the judgement that something is poetry or good poetry is nothing to do with what is on the page - it is

\footnotetext{
$201 \mathrm{Om}$ twee redenen maak ik geen vergelijking tussen mijn deelproject en de andere twee deelprojecten - Deugden \& Dilemma's en Narratieve Genres: (1) omdat dit onderzoek niet is opgezet om verschillende genres of tekstsoorten met elkaar te vergelijken, maar om per genre/tekstsoort inzicht te verkrijgen in de belangrijkste kenmerken die een rol spelen in processen van tekstverwerving bij jonge kinderen, en (2) omdat de uitwerking van de resultaten in de drie proefschriften niet gelijk loopt in de tijd, iedere onderzoeker dat op haar manier doet, daarin eigen specifieke benaderingen hanteert en aandachtspunten heeft. Praktisch noch inhoudelijk zijn de drie deelprojecten op dit moment 1-op-1 met elkaar te vergelijken; wel zal op enig moment een synthese van alle resultaten worden gemaakt voor publicatie.
} 
nothing do to with form: it is a cultural value-judgement, exactly equivalent to the decision as to what literature is." (Hunt, 2010, p. 20)

In hetzelfde artikel stelt hij: "It is an uncomfortable - possibly blasphemous - thought that very many people fundamentally do not believe that children's poetry exists." (2010, p. 17) De twijfel rond het bestaan van kinderpoërie herkennen we ook in de vraag waarmee kinderpoëzie wordt ingeleid in De hele Bibelebontse berg: "Bestaat er eigenlijk wel zo iets als kinderpoëzie, met de nadruk op poëzie? Is er niet alleen maar poëzie, even begrijpelijk (of onbegrijpelijk, in de zin van mysterieus) voor kinderen als voor volwassenen? Is het niet zo, dat gedichten voor kinderen meestal als 'versjes' betiteld worden en niet als poëzie?” (Bekkering, 1989, p. 341) Deze vraag, of er wel zoiets als kinderpoëzie bestaat, is direct gerelateerd aan de literatuur- of poëzieopvatting waarmee kinderpoëzie vanaf de jaren 1970 en vooral sinds 1980 in de jeugdliteraire kritiek benaderd wordt, met de maatstaven van een autonome literatuuropvatting "waarin het gaat om een abstracte Literaire Waarde" (Vries, 1990 , p. 65). Het ideaal van de emancipatie van de kinderliteratuur dat hieraan ten grondslag lag, betekende in de context van de jaren 1980 concreet dat kinderliteratuur volgens de jeugdliteraire kritiek moest worden losgemaakt van pedagogische perspectieven die op dat moment overheersten en moest worden gezien en beoordeeld als kunst, als Literatuur (zie ook Ghesquière, Joosen \& Lierop-Debrauwer, 2014, p. 27). Volgens Hunt heeft dit er in de kinderpoëziekritiek toe geleid dat keer op keer wordt vastgesteld dat kinderpoëzie niet is wat 'echte' poëzie, althans vanaf de Romantiek, volgens de literatuurkritiek wel is. Kinderpoëzie is daarmee een negatieve categorie geworden, een vorm van niet-poëzie. Secularisering is duidelijk aan te wijzen als een van de oorzaken van het feit dat er "minder religieuze teksten worden gelezen" en veel jongeren "religieuze teksten, themata, genres, motieven, en stijlen niet meer (her)kennen." (Peer \& Soetaert, 1993, p. 13) Als we SLO mogen geloven, krijgt kinderpoëzie in het basisonderwijs nauwelijks meer voet aan de grond na de kleuterfase. En in de verkoop gaat het al niet veel beter: "Enkele bundels (vooral voor kleuters) halen weliswaar enorme oplagen, maar het aantal bundels daalt en er verschijnen nauwelijks nog debuten." (Van Coillie, 2014, p. 247) Moeten we de Romantiek dan aanwijzen als een oorzaak voor de hachelijke situatie waarin de kinderpoëzie verkeert? Hoe komt het dat het genre het zo moeilijk heeft? Heeft kinderpoëzie last van 'een vercommercialiseerde, jachtige wereld' (p. 247)? Of heeft kinderpoëzie (ook) last van haar eigen emancipatieproces?

Vanaf de jaren 1980, schrijft Van Coillie, komen de domeinen van de kinderpoëzie en de poëzie voor volwassenen nader tot elkaar vanuit een gedeelde esthetische poëtica: "Meer dichters dan voorheen publiceerden voor beide doelgroepen. De gedichten hadden een vrijere vorm en een complexere beeldspraak. Centrale thema's uit de poëzie voor volwassenen, zoals tijd, vergankelijkheid en veranderlijkheid, drongen binnen in de kinderpoëzie, eerst voor tieners, daarna voor jongere kinderen en kleuters." (pp. 246-247) En dat terwijl grote survey-onderzoeken naar de poëtische voorkeuren van kinderen in het basisonderwijs, uitgevoerd in de Verenigde Staten in diezelfde tijd, lieten zien dat kinderen in het basisonderwijs narratieve gedichten en limericks het meest waardeerden, gevolgd door rijmende verzen; vrije versvormen, lyrische gedichten en haiku daarentegen werden het minst gewaardeerd (Fisher \& Natarella, 1982, p. 346). Van de poëtische elementen viel figuratief taalgebruik niet bij de kinderen in de smaak. In het algemeen sprak er weinig 
waardering voor beeldspraak uit de resultaten. Kinderen in groep 3 tot en met 5 waardeerden vooral het gebruik van rijm, evenals andere klankeffecten als alliteratie en onomatopeeen; inhoudelijke voorkeuren gingen vooral uit naar vreemde en fantastische voorstellingen, gevolgd door gedichten over dieren en over kinderen en herkenbare ervaringen (pp. 349348). Als de hedendaagse poëtica van de kinderpoëziekritiek en de voorkeuren van kinderen daadwerkelijk zo lijnrecht tegenover elkaar staan als uit deze vergelijking naar voren komt, is het niet vreemd dat het genre het zowel in het onderwijs als op de markt moeilijk heeft. In internationaal perspectief stelt Karen Coats vast:

"The problem is that, due to muddled and often contradictory perspectives about who we want children to be, do, and mean, and what we want poetry to be, do, and mean, we don't yet have a clear understanding of what children's poetry is, does, and means." (Coats, 2013, p. 132)

Er zijn ondertussen ook steeds meer critici die zich daar ongemakkelijk bij beginnen te voelen (zie Thomas, 2004; Hunt, 2010; Coats, 2013). Ze komen echter niet allemaal met even bruikbare oplossingen, zoals Hunt die feitelijk voorstelt dat volwassen critici zich helemaal niet moeten bezighouden met de vraag wat kinderpoëzie is omdat 'ware' kinderpoëzie precies dat is wat volwassenen NIET aanspreekt (2010, pp. 22-23). Coats vindt dat er een nieuw perspectief nodig is dat poëzie voor kinderen primair als zinvol of betekenisvol begrijpt in het gebruik ervan door kinderen in plaats van in de literaire interpretaties van haar formele en inhoudelijke eigenschappen door volwassen en ervaren lezers en stelt een cognitieve benadering van poëzie voor kinderen voor (2013, p. 133). Dit is een interessant perspectief, in lijn met bredere ontwikkelingen die de ervaring van kunst en cultuur als cognitieve processen beschouwen (zie ook Heusden, 2010; 2011). Echter, Hunt noch Coats raadpleegt kinderen zelf. Ik ben het met Coats eens dat het van belang is poëzie voor kinderen primair als zinvol of betekenisvol te begrijpen in het gebruik ervan door kinderen, zeker vanuit het oogpunt van het hierboven al beschreven belang van pluriforme canonvorming voor het basisonderwijs. De selectie van kinderpoëzie voor het basisonderwijs gebeurt nu hoofdzakelijk in het kader van taal- en leesmethoden. Dat gebeurt echter in beperkte mate (Wassink, 2014), het zijn niet de favoriete lessen van leerkrachten (SLO, online lexicon, lemma 'Kinderpoëzie') en staat vooral in het teken van taal- en leesvaardigheid (Nicolaas, 2005; Raad voor Cultuur, 2005b). Hoe kunnen we poëzie voor kinderen wérkelijk primair als zinvol of betekenisvol begrijpen in het gebruik ervan door kinderen? Hoe kunnen we inzicht krijgen in wat kinderen aanspreekt in poëzie en in welke manieren van poëzieverwerking in de klas voor zowel leerlingen als leerkrachten werken?

Binnen het kader van dit onderzoek hanteer ik een 'pragmatische benadering van kinderpoëzie'. In navolging van de auteurs van $O p$ poëtische wijze ga ik er van uit dat wat 'het poëtische' tot stand brengt en karakteriseert, gezien moet worden als het resultaat van de specifieke communicatiesituatie waarin poëzie als poëzie functioneert (Alphen et al, 2010/1996). In 'het taalspel poëzie' zoals de auteurs van Op poëtische wijze dat identificeren, brengen zowel de poëtische leeshouding van de lezer als de poëtische spreekhouding van de woordvoerder in de tekst, het 'lyrisch subject', 'het poëtische' tot stand (zie ook Meijer, 1997, p. 148). De lezer mag meeluisteren, of afluisteren, met het 'lyrisch ik' die in een in- 
tieme monoloog de eigen gevoelens of gedachten tot uiting brengt in relatie tot iets of iemand anders (Alphen et al, 2010/1996, p. 10). Dit maakt dat we het poëtische kunnen identificeren als " ...de culturele vorm die onze cultuur heeft gereserveerd voor de exploratie van het innerlijk leven.” (Meijer, 1997, p. 144) De aandacht voor de communicatiesituatie die 'het poëtische' karakteriseert, vormt een bruikbaar uitgangspunt om ook kinderpoezie als betekenisvol te begrijpen in het gebruik ervan door kinderen omdat het proces van poëtische communicatie hier wordt voorgesteld als sociale actie, als een op conventies gebaseerde vorm van handelen. Echter, jonge kinderen verschillen op twee cruciale vlakken van de lezer zoals deze in Op poëtische wijze wordt voorgesteld: (1) kinderen zijn nog niet gesocialiseerd in de poëtische leeshouding en de bijbehorende leesconventies, en (2) jonge kinderen kunnen nog niet lezen. Dat jonge kinderen niet 'de poëzielezer' zijn zoals die in literatuurwetenschappelijke poëzietheorieën wordt voorgesteld (of geïmpliceerd), wordt gereflecteerd in het feit dat de hierboven genoemde lyrische communicatiesituatie in volksculturele poëzie voor kinderen afwezig is (zie Meijer, 1997). Dan kunnen we stellen dat het baker- en kinderrijm niet poëtisch zijn; we kunnen ook stellen dat 'het poëtische' voor jonge kinderen iets anders is en doet dan voor (jong) volwassenen. Als onderdeel van de 'cultuur van het dagelijks leven' is volksculturele poëzie voor kinderen van oudsher sterk ingebed in concrete handelingsgerichte gebruikscontexten, van opstaan tot slapen gaan, van Nieuwjaarsdag tot Oudjaarsavond, van geboorte tot dood, en van de eerste kietel- en schootspelletjes tot touwspringen, klapspellen en verstoppertje op het schoolplein. In de primaire 'poëtische socialisatie' leren kinderen doorgaans dus eerst wat je met poëzie doet binnen een specifieke gebruikscontext. Ook de verschillende soorten 'betekenisloosheid' die volksculturele baker- en kinderrijmen op tekstueel niveau typeren - vanuit pragmatisch perspectief onder te verdelen in 'muzikaal taalspel' en 'carnavaleske nonsensicaliteit' -, duiden erop dat 'betekenis' niet primair in de tekst gezocht moet worden. Om de betekenis van baker- en kinderrijmen voor kinderen te achterhalen, moeten we dus niet zozeer naar de tekst als tekst kijken, maar naar de tekst als gebruiksobject. Zoals hedendaagse etnologen objecten niet als opzichzelfstaande artefacten bestuderen, maar hun aandacht richten op de maatschappelijke context waarin een object voor en door een bepaalde groep mensen van een bepaalde betekenis wordt voorzien, moeten we ook poëzie voor jonge kinderen begrijpen als onderdeel van " $\ldots$ the actual living performance of these ... materials ... in their particular settings, with their functional or aesthetic character in particular contexts." (Sutton-Smith, 1999, p. 3) Het is deze blik ${ }^{202}$ die, mijns inziens, noodzakelijk is om te leren begrijpen wat poëzie voor kinderen is en doet en hoe we nauwkeurige aansluiting van kinderpoëzie op hun ontluikende culturele competentie kunnen waarborgen. Dit voegt een analysekader toe aan de kinderpoëziebeschouwing: ik kijk niet alleen naar de 'tekst', zelfs niet alleen naar de interactie tussen 'lezer' en 'tekst', maar naar de interactie tussen 'lezer'

202 Gemodelleerd naar inzichten die baker- en kinderrijmen in context bieden in de aansluiting van 'het taalspel poëzie' op de ontluikende culturele competentie van de beoogde doelgroep van jonge kinderen, vraagt het identificeren van cruciale 'indicatoren van canoniciteit' in kinderpoëzie als het ware om een 'antropologisering van de kinderpoëziebeschouwing'. Dat wil zeggen dat ik verbindingen heb gelegd tussen literatuurwetenschappelijke benaderingen enerzijds en disciplines die zich bezighouden met de 'geleefde praktijk' van kinderrijmen, -liedjes en -gedichten in hun sociale context anderzijds. Vanwege hun positie tussen oraliteit en geletterdheid is de houding van jonge kinderen ten aanzien van poëzie per definitie anders dan die van ervaren en geschoolde lezers: jonge kinderen zijn noodzakelijkerwijze aangewezen op een (fysieke en mondelinge) gebruikshouding ten aanzien van poëzie. 
(gebruiker(s)) en 'tekst' (gebruiksobject) in de concrete pragmatische context waarin 'het taalspel poëzie’ door en met kinderen gebruikt wordt.

Dit perspectief vormt de basis voor pluriforme canonvorming in de kinderpoëzie als belangrijke aanvulling op de institutionele canonvormingsprocessen van de journalistieke, essayistische en academische kritiek. En die van de educatieve kritiek die hun waardeoordelen met het oog op de doelgroep vormen en waarbinnen ook rekening gehouden wordt met de leeftijdsgroep waarvoor ze literatuur beoordelen (Lierop-Debrauwer, 2004b, p. 31). De educatieve kritiek kijkt vaak naar plankstanden, uitleen- of verkoopcijfers of raadpleegt ervaringsdeskundigen om te weten wat kinderen graag lezen (of horen), maar er is in het Nederlands taalgebied nog geen structureel empirisch onderzoek gedaan naar de poëtische voorkeuren van kinderen van verschillende leeftijden in de praktijk van het basisonderwijs waarbij ook beoogd wordt te begrijpen wat kinderen in poëzie aanspreekt, en waarom, en hoe hun poëtische voorkeuren zich ontwikkelen. Dat begrijpen is van belang om los te komen van een relatief statische invulling van 'de canon' als lijst met titels en/of auteurs. Met het oog op pluriforme canonvorming heeft dit onderzoek evidence-based criteria ontwikkeld voor de selectie van kinderpoëzie die bij de beoogde doelgroep in de smaak valt en bijdraagt aan hun ontluikende culturele geletterdheid. De 'indicatoren van canoniciteit' in kinderpoëzie die uit dit onderzoek naar voren zijn gekomen vormen de basis voor die criteria waarmee steeds weer nieuwe gedichten, rijmen en liedjes geselecteerd kunnen worden die de potentie hebben om duurzaam geliefd te worden bij de beoogde doelgroep. De verkregen inzichten in de aansluiting van kinderpoëzie op de culturele competentie en voorkeuren van kinderen en in effectieve verwerkingsvormen van kinderpoëzie in de praktijk van het basisonderwijs vormt een belangrijke basis om de positie van kinderpoëzie te verstevigen door de drempel voor het doen van poëzie met kinderen in het basisonderwijs te verlagen en structurele inbedding van poëzie in het basisonderwijs te bevorderen. De pragmatische benadering die ik gehanteerd heb, levert daarbij tot nu toe niet eerder verkregen inzichten in de cruciale rol van de pragmatische context in relatie tot de cognitieve ontwikkeling van kinderen in hoe zij 'het taalspel poëzie' als zodanig herkennen, waarderen en begrijpen.

Vanuit een pragmatisch perspectief op wat poëzie voor kinderen is en doet, was een centrale vraag binnen dit onderzoek welke pragmatische conventies kinderen hanteren in hun benadering van 'het taalspel poëzie' en hoe en wanneer zij die conventies verwerven, i.e. opnemen in hun culturele schemata. Om poëzie als poëzie te gebruiken, begrijpen en waarderen, moeten kinderen een gedicht, rijm of lied eerst als 'onalledaags' taalgebruik, als 'rituele taalhandeling', herkennen omdat poëzie zich - zoals alle literatuur en kunst - onttrekt aan de 'waarheidscondities' die in ons natuurlijk taalgebruik gelden. Dat is niet vanzelfsprekend het geval bij jonge kinderen, getuige de boze reactie van een van de kleuters op de stelling dat de zon vierkant zou zijn binnen het kader van het gedicht 'Rond of vierkant' van Willem Wilmink (zie Hoofdstuk 9). Hoofdstuk 9 en 10 hebben laten zien dat tussen de kleuterleeftijd en groep 4 een enorme ontwikkeling plaatsvindt in hoe kinderen poëzie begrijpen en waarderen: een ontwikkeling die alles te maken heeft met de pragmatische context, i.e. de communicatiesituatie, waarin 'het taalspel poëzie' voor kinderen functie en betekenis krijgt. Voor de kleuters geldt dat poëzie in rituele contexten, zoals de vieringen in het jaar en in het leven, binnen die concreet waarneembare pragmatische context begrepen 
wordt, maar buiten die context haar functie en daarmee ook haar betekenis verliest. Bijvoorbeeld: binnen de pragmatische context van de viering van 1-april als 'grapjesdag' kan een nonsensvers door kleuters worden begrepen als 'grapje', maar een verjaardagsliedje zingen als er niemand jarig is of een Dierendagvers opzeggen als het (nog net) geen Dierendag is, maakt dat de kleuters het vers verwerpen. Hoe wordt 'het taalspel poëzie' door de kleuters het sterkst gewaardeerd en het meest effectief verworven? Ingebed in rituele contexten en/of in combinatie met fysieke handelingspatronen. Kleuters tonen enorme waardering voor het feit dat ze met bepaalde gedichten en liedjes kunnen meedoen, vooral wanneer 'meedoen' klappen, stampen, dansen of uitbeelden betekent. Zoals een leerkracht rapporteert over waarom de kinderen 'Lekker stampen met dit weer' van Joke van Leeuwen leuk vonden: "Omdat je dan moet stampen, en bij andere liedjes doen we dat niet, dat is saai.” (2421, logboek week 4) $\mathrm{Na}$ afloop van 'Klap eens in je handen' van Ivo de Wijs vraagt een andere leerkracht of de kinderen het een leuk versje vonden: "Jaaaaa, vinden de kinderen. En wat vonden ze er dan leuk aan? 'Dat we moesten bukken!”' (observatie 19, 29-1-14) Terwijl een klankliedje als 'Epompee' bij alleen luisteren aanleiding vormt voor het zoeken naar herkenbare woorden ("Demie', zo heet mijn zus"), gaan de kleuters volledig op in het (klank)spel wanneer direct de koppeling met fysiek spel gemaakt wordt: "meteen het klapspelletje erbij gedaan. Heel veel keer gewisseld van tweetal en met zéér enthousiaste leerlingen het klapspel gedaan. Het was een groot succes!" (1622, logboek week 24) Waar een 'vreemd' carnavalsliedje niet werkt als de kinderen het alleen maar horen en mogen meezingen, wordt het liedje 'Carnaval' direct toegeëigend wanneer het gekoppeld is aan de fysieke handelingspatronen die horen bij de viering van carnaval: "polonaise op het lied geoefend! De kinderen vonden het erg leuk. Het liedje sprak meteen aan en ze werden er vrolijk van." (2223, logboek week 21) Zo simpel is het, maar toch ook weer niet, want die fysieke beweging is niet alleen 'leuk' voor de kleuters, het is ook de meest effectieve manier om kleuters 'het taalspel poëzie' als zodanig te laten ervaren en daarmee te begrijpen als iets dat anders is dan verhalen en ook anders is dan 'gewoon' taalgebruik. Dit onderzoek toont aan dat de externe, waarneembare, pragmatische context voor kleuters een cruciale rol speelt in de toekenning van functie en betekenis aan poëzie. Een feestdag vormt zo'n waarneembare context voor een verjaardagsliedje, een Dierendagvers, enzovoort. Fysieke beweging doet voor de beleving van poëzie bij kleuters hetzelfde: het voorziet een gedicht of liedje van een pragmatische functie en makkt het daarmee herkenbaar als rituele taalhandeling. 'Muzikaal taalspel' in poëzie wordt als zodanig ervaren als je er op stampt, klapt of danst; 'carnavaleske nonsensicaliteit' in poëzie wordt als zodanig ervaren als het is ingebed in de context van 1-april als 'grapjesdag' of als kleuters zelf nonsensicaal kunnen handelen zoals in het vers voorgesteld. Als er geen rituele context - zoals een viering - voorhanden is, wordt de rituele context geëvoceerd door geritualiseerde fysieke handelingspatronen waarvan de rituele functie of vorm herkenbaar is (zoals schoen zetten, maar ook allerlei vormen van spel). De ritualiteit van poëzie als specifiek soort taalhandeling (vgl. Dijk, 1980) komt voor kleuters nog niet primair voort uit de herkenning van de tekstsoort, maar uit de herkenning van het type gebruiksfunctie en die herkenning wordt bemiddeld door fysiek handelen in context. Poëzie die niet op deze concrete manier geïdentificeerd kan worden door kleuters, zoals de abstracter vormen van nonsensicale poëzie, is voor hen moeilijker te duiden en te waarderen en leidt tot verwarring. Deze inzichten sluiten aan op de pre- 
operationele fase van cognitieve ontwikkeling van kleuters en bevestigen mijn verwachte indicatoren van canoniciteit in kinderpoëzie voor groep 2, met de specificatie dat de grootste en meest duurzame favorieten bij de kleuters de rijmen, liedjes en gedichten gekenmerkt door 'muzikaal taalspel' en gekoppeld aan fysieke handelingspatronen zijn.

De pragmatische context waarin 'het taalspel poëzie' als rituele taalhandeling functie en betekenis krijgt, is bij kinderen in groep 4 voor een belangrijk deel 'verinnerlijkt', i.e. een mentaal construct als onderdeel van de culturele schemata waarover ze beschikken. Dit sluit aan op de concreet operationele fase van cognitieve ontwikkeling waarin deze kinderen zich bevinden. Dit betekent dat kinderen in groep 4 een verjaardagslied, bijvoorbeeld, nog steeds als verjaardagslied begrijpen ook als er niemand jarig is: het verjaardagslied is voor hen een herkenbare rituele taalhandeling die relatief autonoom wordt gewaardeerd en begrepen, wat erop wijst dat deze vorm als concept is opgenomen in hun mentale culturele schemata ${ }^{203}$. Effectieve verwerving en waardering komt in groep 4 dan ook voort uit andere eigenschappen van 'het taalspel poëzie' en bijbehorende verwerkingsvormen zoals aangeboden via de Leeskalender dan bij de kleuters. Allereerst blijken kinderen in groep 4 het zelf variëren binnen de poëtische structuur heel leuk te vinden, gerelateerd aan de herkenning van formele eigenschappen van 'het taalspel poëzie'. Zelf variëren gaat het best en is daarmee ook het leukst voor de kinderen wanneer de structuur van een gedicht duidelijk op de voorgrond staat door de aanwezigheid van parallellisme en andere herhalingsfiguren, zoals bij de gedichten 'Vrolijk ...', 'Gekleurde eitjes en een haas' en 'Verstoppertje’. Wanneer het specifieke spel dat in een vers wordt gespeeld niet direct herkenbaar is, kan de toevoeging van fysiek handelen een cruciale rol spelen in het ervaarbaar maken van dat spel, zoals bij 'Ik wens je al wat wenselijk is'. Door de kinderen elkaar de hand te laten schudden en tegelijk iets onwenselijks toe te laten wensen, ervaren ze de dissonantie of incongruentie tussen pragmatisch en semantisch niveau in dit carnavaleske vers, i.e. de incongruentie tussen rituele vorm of structuur en het inhoudelijk subversieve spel. De carnavaleske ervaring die de performance van poëzie teweeg kan brengen, wordt door kinderen in groep 4 sterk gewaardeerd, zowel wanneer ze de speelse incongruentie zelf rechtstreeks ervaren, of bemiddeld door de leerkracht. De grootste succesnummers in groep 4 waren dan ook die gedichten die een humorreactie opriepen, vooral door de herkenning van een onverwachte transgressie van de culturele conventies van de schoolklas. Autonome vormen van 'muzikaal taalspel' zoals 'Het versje om te mompelen als je niet goed in slaap kan komen', 'Het versje om te rappen (zonder einde)' en 'Het poppenkopmannetje' vielen zeer in de smaak vanwege de onverwachte performance van de leerkracht (in slaap vallen, rappen) en de onverwachte vorm (opzegvers dat conventies van geschreven taal doorbreekt en poëtische vormen die de kinderen nog niet kennen). Bij voor hen nieuwe vormen van

\footnotetext{
${ }^{203}$ Het verschil tussen de pragmatische context, i.e. de pragmatische conventies op basis waarvan 'het taalspel poëzie' als rituele taalhandeling wordt herkend en begrepen, als concreet, extern, construct bij de kleuters en als conceptueel, mentaal, construct bij kinderen in groep 4 wordt ook gereflecteerd in het type negatieve waardeoordelen dat ze geven. Een gedicht over een viering die ze niet uit ervaring kennen, roept bij kinderen in groep 4 geen beleving op en vinden ze 'saai'. Dit bevestigt het blijvende belang van aansluiting op de culturele competentie van de kinderen, maar is een andersoortig waardeoordeel dan het 'De Leeskalender is in de war, het is geen Sinterklaastijd!' van de kleuters. 'Saai' is een oordeel op basis van interne evaluatie (het doet niets met mijn beleving, ik herken of begrijp het niet); 'de Leeskalender is in de war' is een oordeel op basis van externe evaluatie (het hoort niet op dit moment, het heeft geen functie in de context). De positieve waardering van 'het taalspel poëzie' komt bij kleuters voor een belangrijk deel voort uit herkenning en vooral ook fysieke beleving.
} 
'het taalspel poëzie' is het zichtbaar effectiever om de kinderen te laten meedoen in plaats van zelf variëren: in die instanties moeten ze hun kennis van poëtische vormen nog actief opbouwen en uitbreiden, terwijl ze het bij bekende en herkenbare structuren leuk vinden om zelf te variëren. Niet alleen is de waardering voor de formele afwijking van de verwachtingen groot, maar ook voor de inhoudelijke afwijking van de verwachtingen, zoals bij de aanbieding van 'Tien dingen naar keus die je kunt doen met dingen uit je neus' ('Leukste les ooit!') en 'Als ik nou een hondje mag' ('Hilarisch!'), vooral als er kan worden gevarieerd of uitgebeeld. 'Blauwbilgorgel' vormt daarin een eigen categorie als muzikaal gedicht dat echter vooral om het 'bil' erin erg werd gewaardeerd. En de extreme overdrijving, zolang deze gegrond is in het lichamelijke zoals in 'De koning van Savoye' en 'Hongerige Harry', kan bij kinderen in groep 4 ook op grote waardering rekenen. Uiteindelijk 'concurreren' de gedichten die humorreacties oproepen in groep 4 met de liedjes (op muziek) die ritmische beweging oproepen: 'Naïma maakt muziek', 'De heks van Sier-kon-fleks' (op muziek), 'Leuk is raar' (op muziek) en 'Chinese taalles' (op muziek) behoorden in verschillende klassen eveneens tot de favorieten.

\subsection{Subversiviteit: een 'neo-Romantisch kindbeeld'?}

In Hoofdstuk 2 heb ik aangegeven dat vragen als 'Bestaat er eigenlijk wel zo iets als kinderpoëzie, met de nadruk op poëzie?’ niet de juiste, of meest relevante, vragen zijn als we willen weten wat poëzie voor kinderen is en doet, wat hen aanspreekt in poëzie, hoe ze het begrijpen en waarderen. Ik heb ook gesteld dat dit type vraag voortkomt uit wat we, in navolging van Maria Nikolajeva, 'aetonormativiteit' kunnen noemen, i.e. de "adult normativity that governs the way children's literature has been patterned from its emergence until the present day." (2010, p. 8; zie ook Beauvais, 2012) Een term die niet alleen op tekstuele representaties van de machtspositie van 'het kind' in kinderliteratuur toepasbaar is, maar ook op de wijze waarop (literaire) kinderpoëzie vanaf haar ontstaan tot op de dag van vandaag wordt gewaardeerd. Tegelijk is het - impliciet of expliciet - hanteren van een bepaald kindbeeld in de beschouwing van kinderpoëzie onontkoombaar voor volwassen critici. Het feit dat ik voor het formuleren van verwachte indicatoren van canoniciteit een zekere 'antropologisering van de kinderpoëziebeschouwing’ voor ogen heb gehad en me heb laten informeren door de volksculturele baker- en kinderrijmen brengt in die zin een risico met zich mee. De vroege verzamelaars van orale volkscultuur, zoals het (kinder-)volkslied, deden dat vaak vanuit bepaalde romantische overtuigingen dat 'de volkscultuur' de enige authentieke cultuur was en dat zij 'de volksziel' (of 'kinderziel) weerspiegelde (zie Grijp, 2000b, p. 339). In de kinderpoëziebeschouwing kwam aan het einde van de negentiende eeuw een romantisch kindbeeld op en kwam in kinderpoëzie - vanuit een opvoedende strekking - het geromantiseerde (lieflijke, onschuldige en spelende) kind centraal te staan, een kind dat als zodanig beschermd en gekoesterd moest worden (Van Coillie, 2014, p. 246). Van recenter datum is een ontwikkeling in de internationale (Amerikaanse) kinderpoeziebeschouwing waarin steeds vaker een 'neo-romantisch' kindbeeld als uitgangspunt dient voor de waardering van kinderpoëzie: 
"Rather than seeing the child as one who lives close to nature and trails clouds of glory from his heavenly origin into stilted, because conventional, poetic images and rhymes, [the neo-Romantic] child is anarchic and subversive, knowing what adults expect of him and thus how to appall them, but he is no less 'natural' or 'true' because of this; in fact, it is his tendency toward rebellion and specifically sexual knowingness that makes him attractive to many contemporary critics of children's literature." (Coats, 2013, p. 131)

Is dit 'het kind' dat mij voor ogen stond toen ik me, vooral in Hoofdstuk 5, liet informeren door de subversiviteit en transgressiviteit van traditionele en hedendaagse kinderrijmen uit de kindercultuur? Ten dele wel. Voor de formulering van verwachte indicatoren van canoniciteit voor kinderpoëzie heb ik 'het kind' als gebruiker van poëzie ge(re)construeerd op basis van verzamelingen van baker- en kinderrijmen, aangevuld met empirische inzichten van etnologen en antropologen die zich hebben beziggehouden met de orale uitingsvormen binnen de kindercultuur. Binnen de kindercultuur is 'het kind' per definitie 'wetend' want alle uitingsvormen binnen die cultuur behoren tot het cultureel eigendom van 'het kind'; en gezien vanuit de institutionele kinderpoëziebeschouwing, zijn de rijmen en liedjes die kinderen onderling delen vaak subversief omdát 'ongegeneerde taaluitingen uit de regionen van de onderbuik, en zeker wanneer die te maken hebben met de kinderwereld, niet tot de officiële, gecanoniseerde taal- en letterkunde behoren' en ook nog eens 'indruisen tegen de algemeen maatschappelijke fatsoensnormen' (Hoven, 1997, p. 217). Wie de 'poëzie van de speelplaats' als voorbeeld neemt om literaire kinderpoëzie aan te spiegelen, hanteert als vanzelf een vanuit volwassen perspectief gezien 'neo-Romantisch' kindbeeld.

Echter, op twee manieren heb ik getracht dat kindbeeld niet normatief te hanteren in het identificeren van verwachte indicatoren van canoniciteit in kinderpoëzie, niet als keurslijf waar de echte kinderen in de deelnemende schoolgroepen ingepropt moesten worden. Allereerst heb ik baker- en kinderrijmen als uitgangspunt gebruikt met het oog op pluriforme canonvorming voor kinderen in de multiculturele samenleving: "Putten uit de canon van de volkscultuur ligt voor de hand, omdat rijmpjes en versjes, sprookjes en fabels, raadsels en spreuken, moppen en grappen deel uitmaken van een internationale traditie." (Lierop-Debrauwer \& Mooren, 2004, p. 11) Wat ik binnen het kader van dit onderzoek uit die canon van de volkscultuur heb geput, zijn kenmerken die veel van de baker- en vooral kinderrijmen met elkaar gemeen hebben en die naar verwachting zorgen voor een nauwe aansluiting op de ontluikende culturele competentie en poëtische voorkeuren van kinderen in groep 2 en in groep 4 van het basisonderwijs. Alomtegenwoordige kenmerken van volksculturele rijmen en liedjes zijn in die zin heuristische middelen geweest in de zoektocht naar 'indicatoren van canoniciteit' voor kinderpoëzie, waarbij ik me steeds mede heb laten informeren door cultuur- en literatuurwetenschappelijke, ontwikkelingspsychologische en etnologische inzichten in de poëtische voorkeuren van kinderen enerzijds en in de ontwikkeling van kinderen anderzijds. In de tweede plaats heb ik mijn verwachtingen getoetst aan de praktijk van het basisonderwijs waar al snel duidelijk werd dat de kenmerken die ik als verwachte 'indicatoren van canoniciteit' heb aangewezen ook daadwerkelijk 'werkten' in de praktijk, zij het met de nodige specificering voor de beide leeftijdsgroepen. Op mijn observatieschool werkten ze met de versie van de Leeskalender waarin kinderpoezie en teksten uit het deelproject Deugden \& Dilemma's waren opgenomen. Als ik op de 
allerlaatste Leeskalenderdag in groep 4 aanwezig ben om te observeren, vraagt de leerkracht de kinderen wat ze het leukst vonden van de hele Leeskalender:

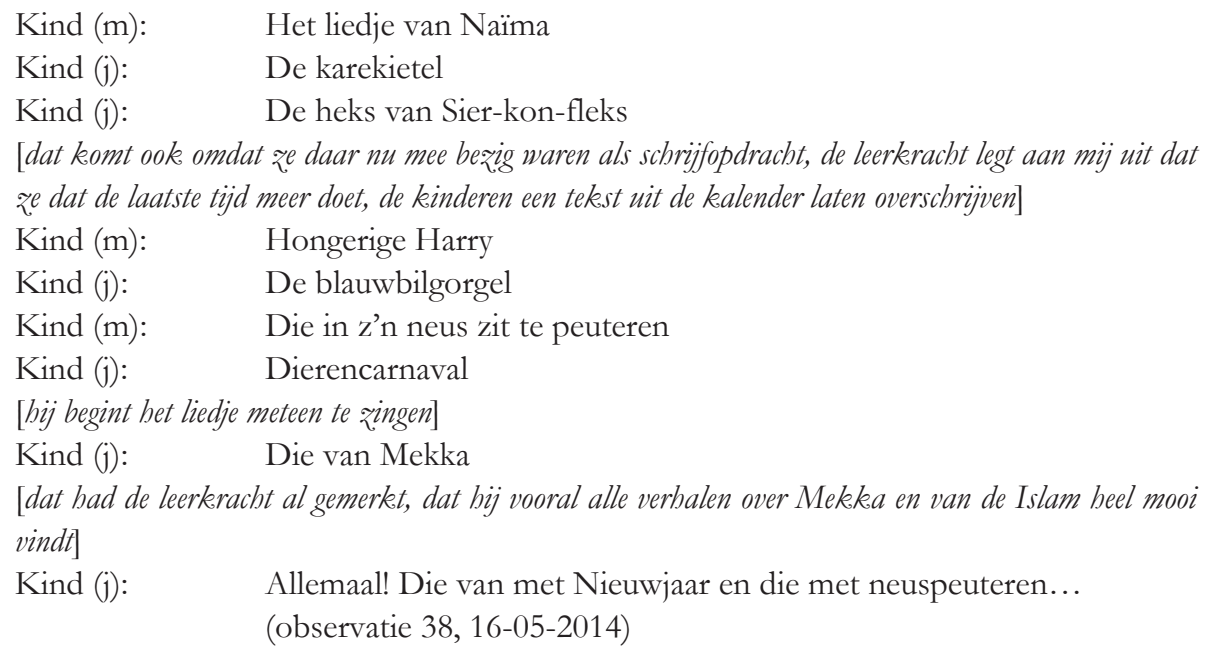

Dat de kinderen op één na allemaal een tekst uit het poëzie-aanbod noemen, kan enerzijds te maken hebben met het feit dat ik in de voorafgaande maanden steeds op de poëzie-dag aanwezig was in de klas en ze in de richting van poëzie denken omdat ik er ook op deze laatste dag weer ben. Anderzijds zijn het teksten waarvan ook tijdens het observeren en/of uit de logboeken al was gebleken dat ze erg bij de kinderen in de smaak vielen ${ }^{204}$. Helaas heb ik de laatste Leeskalenderdag niet kunnen observeren in de kleutergroep, maar ook daar bleek uit de overige observaties en de logboeken duidelijk wat bij de kinderen in de smaak viel en wat niet of minder. Op basis van die inzichten heb ik de 'indicatoren van canoniciteit' voor kinderpoëzie gespecificeerd en daar waar nodig bijgesteld voor de beide leeftijdsgroepen. In beide groepen werden specifieke vormen van subversiviteit of transgressie in of via 'het taalspel poëzie' sterk gewaardeerd. Leerkrachten bevestigen dat kinderen in de kleutergroepen "genieten van alles wat niet mag" (gr2222, logboek week 9) en kinderen in groep 4 "alles met 'bil' of 'plas' ofzo" heel leuk vinden (evaluatie 2, S26, 10-062014). Het intense plezier dat kinderen kunnen beleven aan carnavaleske nonsenspoëzie en aan poëtische performances die tegen de verwachtingen en tegen de culturele conventies binnen de kaders van de schoolklas in werken, is een te veelvuldig aanwezig aspect in de observaties en logboeknotities om te negeren, maar duidt er vanuit pragmatisch perspectief ook op dat die subversiviteit een functie vervult voor kinderen. Dit vereist dat we proberen te begrijpen waarom kinderen hier zo van genieten. Bekeken vanuit de werking van het carnavaleske is het plezier dat kinderen beleven aan de transgressie van culturele conventies in het kader van 'het taalspel poëzie' niet zozeer gericht tegen de autoriteit van de leerkracht, maar op de intensivering van de beleving van het tijdelijk uitoefenen van 'controle' over de normen, waarden en conventies die in de culturele context 'normaal' gesproken gelden (zie Hoofdstuk 5) en dat plezier is enkel groter wanneer de leerkracht zelf mee gaat in dit spel. ${ }^{204}$ Een uitzondering is 'Dierencarnaval' dat tijdens de aanbieding door een aantal kinderen werd ontvangen met
opmerkingen als 'Nou, heel saai' en 'Dat hebben de kleuters' (observatie 24, 25-02-2014). 
Daar komt bij dat de (concrete en/of conceptuele) pragmatische context de kinderen 'het taalspel poëzie' als rituele taalhandeling helpt herkennen en die context wordt niet alleen opgeroepen door de poëzie en wat daar (in concrete zin) mee gedaan wordt; die 'onalledaagse' rituele context waarbinnen 'het taalspel poëzie' als zodanig wordt ervaren, wordt ook waarneembaar op het moment dat de poëzie herkenbaar afwijkt van de alledaagse conventies binnen het kader van de schoolklas.

Als specifiek subversief soort 'cultural frame' ervaren we een uiting als nonsens voor zover het op herkenbare wijze afwijkt van een herkenbaar deel van onze kennis van de gebruikelijke, als 'common sense' geaccepteerde, normen of conventies. En deze nonsens brengt het een carnavaleske ervaring teweeg voor zover de herkenning van die afwijking gedeelde lichamelijke, affectieve, effecten veroorzaakt (met elkaar lachen, etc.) (zie Hoofdstuk 5, \5.8). Dit geldt, zo is gebleken, feitelijk voor alle poëzie voor jonge kinderen: voor hen is poëzie als poëzie herkenbaar voor zover het op herkenbare wijze afwijkt van een herkenbaar deel van hun kennis van de gebruikelijke, als 'common sense' geaccepteerde, normen of conventies. Die afwijking kan voor kinderen herkenbaar zijn door inbedding in een rituele context (vieringen, 'grapjesdag', fysieke spelvormen), door de onverwachte performance door de leerkracht (rappen, in slaap vallen, vieze dingen zeggen), of door de formele kenmerken van 'het taalspel poëzie' ('Hé juf, dat rijmt!', 'Juf, staat dat er echt?’). Herkenning is zowel voor kinderen in de kleutergroep als voor kinderen in groep 4 belangrijk voor hun begrip en waardering van 'het taalspel poëzie'. Echter, het is niet zo dat enkel "[s]tereotypie en herhaling ... een kind juist plezier verschaffen." (Ghesquière, 2009a, p. 137) Een belangrijk aanvullend inzicht dat naar voren komt uit de kwalitatieve data is dat zowel voor kinderen in de kleuterleeftijd als voor kinderen in groep 4 geldt dat hun waardering voor 'het taalspel poëzie' ook voortkomt uit (de onverwachte herkenning van) nieuwe patronen. Herkenning van het al bekende vormt de basis en is een signaal dat vormen of inhouden van 'het taalspel poëzie' al tot de culturele geletterdheid van kinderen behoren. Echter, net als ervaren lezers beleven kinderen dus ook plezier aan (de herkenning van) vernieuwende elementen. Wat voor kinderen vernieuwend ís moet daarbij wel, net als wat poëzie voor kinderen ís, in pragmatisch ontwikkelingsperspectief gezien worden. Wat in de praktijk een veel sterkere indicator van canoniciteit in (het gebruik van) kinderpoëzie voor groep 4 is gebleken dan verwacht, is de cruciale rol die expliciete fysieke ervaring van 'het taalspel poëzie' voor deze kinderen nog steeds speelt. In zijn boek Poetry's Playground merkt Joseph Thomas over 'Child poets and the poetry of the playground' op dat deze poëzie, in tegenstelling tot heersende opvattingen over wat poëzie is, geen betrekking heeft op het verstand, maar op het lichaam: "They are composed and performed with the aim of producing strong, bodily reaction: laughter, guffaws, gasps, groans, or in the case of jump-rope rhymes, facilitating vigorous play.” (Thomas, 2007, p. 47; zie Hoofdstuk 5) De lichamelijkheid van die 'speelplaatspoëzie' wijst erop dat de expliciete fysieke ervaring voor kinderen in deze leeftijd een belangrijk aspect van hun beleving en waardering van 'het taalspel poezie' is. De poëzie die in de klas lachen, bewegen, verbazing, gruwel of andersoortige lichamelijke reacties en ervaringen opriep, werd in groep 4 ook het sterkst gewaardeerd door de kinderen. Dat wil overigens niet zeggen dat deze poëzie geen betrekking heeft op het verstand, zoals Thomas suggereert. Het is alleen zo dat de fysieke ervaring van 'het taalspel poëzie' ook in groep 4 nog heel expliciet bijdraagt aan de beleving en het begrip van het 
specifieke spel dat in een vers gespeeld wordt en dat fysieke reacties, zoals lachen, maar ook ritmisch meebewegen en als vanzelf gaan meezingen of -rijmen, nog heel expliciet signalen van verwerving en waardering zijn. Fysieke reactie vormt in groep 4 een nog sterker contrast met de gebruikelijke leer-, lees- en luisterhouding die de kinderen wordt aangeleerd dan in de kleutergroepen. Echter, om plezier te beleven aan poëzie móet er (begrensde) ruimte zijn voor fysieke ervaring, voor afwijking van het normale, voor het speelse opzoeken en aftasten van de grenzen van de verwachtingshorizon, voor het oproepen en uiten van lichamelijke reacties.

Voor de kleuters noch voor kinderen in groep 4 valt de poëzie die zij het sterkst waarderen te karakteriseren als kinderpoëzie die je dwingt "om stil te staan, om in je hoofd te kijken en van daaruit de wereld anders te zien" (Van Coillie, 2014, p. 247). Althans, niet in meditatieve zin. Wel is het poëzie die tegen bepaalde verwachtingen ingaat en duidelijk herkenbaar afwijkt van 'het normale' in taalgebruik, in voorstellingen van de werkelijkheid en in de context van de conventies van de schoolklas. Maar die afwijking wordt primair ervaren en roept fysieke reacties op. Voor beide leeftijdsgroepen wordt het begrijpen van poëzie dus nog sterk lichamelijk bemiddeld. Een teken dat "[t]he rhythms and sounds of poetry for children, whose metrics, phonetics, and structures resonate with bodily architecture and processes, preserve the body in language, while its metaphors, which are almost always rooted in sensual experience, help us understand who we are as subjects and objects in a world of signs." (Coats, 2013, p. 134) Uiteraard spelen de esthetische kwaliteiten van 'het taalspel poëzie' daarin een belangrijke rol. Echter, die kwaliteiten moeten vanuit een 'pragmatische benadering van kinderpoëzie' begrepen worden, omdat de waardering van poëzie door jonge kinderen niet van doen heeft met een 'abstracte Literaire Waarde', maar primair gebaseerd is op wat er met poëzie gedaan wordt, waar, wanneer, hoe, door wie en waartoe.

\section{5 'Confronting the other Snark' (of: Het Mysterie van het Lokaliseren van Effecten van Kinderpoëzie)}

Dit onderzoeksproject gebruikt een innovatieve methodologie voor de ontwikkeling van empirisch onderbouwde criteria voor de selectie van kinderliteratuur die effectief bijdraagt aan de ontluikende culturele geletterdheid van kinderen in groep 2 en in groep 4 van het basisonderwijs. Zowel in de formulering als in de implementatie en evaluatie van 'indicatoren van canoniciteit' in verschillende cultureel waardevolle genres en tekstsoorten - religieuze verhalen en fabels, poëzie, schelmenverhalen, sprookjes en moppen - is dit onderzoeksproject interdisciplinair. Cultuur- en literatuurwetenschappelijke, ontwikkelingspsychologische en etnologische inzichten liggen ten grondslag aan de formulering van verwachte indicatoren van canoniciteit in kinderliteratuur voor kinderen in groep 2 en groep 4; sociaalwetenschappelijke en etnografische onderzoeksmethoden liggen ten grondslag aan de implementatie en evaluatie van die indicatoren in de praktijk van het basisonderwijs. Omdat dit onderzoeksproject tot doel heeft empirisch onderbouwde criteria te ontwikkelen voor de selectie van kinderliteratuur die effectief bijdraagt aan de ontluikende culturele gelet- 
terdheid van kinderen in groep 2 en in groep 4 van het basisonderwijs, is een experimenteel onderzoek uitgevoerd: het Leeskalenderproject. Daarin is via een effectmeting nagegaan of de - op basis van de aanwezigheid van verwachte indicatoren van canoniciteit geselecteerde - aangeboden kinderliteratuur inderdaad heeft bijgedragen aan de ontluikende culturele geletterdheid van de kinderen. Het experiment is opgezet en uitgevoerd met inachtneming van de eisen der zorgvuldigheid, betrouwbaarheid en controleerbaarheid van wetenschappelijk onderzoek. Het ontwikkelde meetinstrument, de Toets Ontluikende Culturele Geletterdheid, mag als geheel een betrouwbaar en valide instrument genoemd worden voor het meten van effecten van de aanbieding van kinderliteratuur op de in de toets geoperationaliseerde aspecten van ontluikende culturele geletterdheid (zie Hoofdstuk 8, \$8.3). We mogen er dan ook van uit gaan dat de projectbrede uitspraken over de gevonden positieve effecten van de Leeskalender als geheel op de ontluikende culturele geletterdheid van kinderen zowel betrouwbaar als valide zijn voor groepen 2 en groepen 4 op scholen die bereidwillig zijn met de Leeskalender te werken in het Nederlandse basisonderwijs (zie Hoofdstuk 8, \8.4). Het construct 'ontluikende culturele geletterdheid' is in de Toets OCG geoperationaliseerd tot items die stuk voor stuk betrekking hebben op de herkenning en kennis van een specifiek genre of specifieke tekstsoort (het schelmenverhaal, de fabel, het nonsensrijm, het sprookje, et cetera) en daarbinnen aanwezige typerende kenmerken, zoals personages (Hodja/Anansi; Jezus/Mohammed), formules ('Er was eens'), stijlfiguren (de omkering; rijm), en motieven en thema's ('voor wat hoort wat'; 'de oplichter opgelicht'; 'hoogmoed komt voor de val'). Het construct 'ontluikende culturele geletterdheid' vormt daarmee een aanvulling op de meetinstrumenten die tot nu toe ontwikkeld zijn om effecten van het (voor)lezen van kinderliteratuur zichtbaar te maken. De LAS brengt attitudes ten aanzien van lezen en boeken in kaart bij kinderen vanaf groep 4 (Aarnoutse et al, 1985), de LES meet de ervaring van kinderen in groep 3 met prentenboeken en vooral met specifieke titels/personages (Mooren, 2000a), de VLES-K gaat de voorleeservaring met prentenboeken bij kleuters na (Gosen et al, 2009), en de Watje Wimpie-taak geeft inzicht in de literaire competentie bij kleuters (Pol, 2010). De Toets OCG is gericht op het in kaart brengen van kennis en begrip van kenmerkende eigenschappen van 'cultureel relevante' tekstsoorten en genres die kinderen in groep 2 en in groep 4 naar verwachting opdoen uit hun ervaring met die tekstsoorten en genres. "Leesgedrag, leesattitudes en genrevoorkeuren kan men gemakkelijk via grootschalig onderzoek in kaart brengen," schrijft Rita Ghesquière in Jeugdliteratuur in perspectief: "Moeilijker is het om vat te krijgen op de tekstverwerking zelf. Lezen kinderen wat er staat? Hoe bouwen ze een verhaal op? Hoe interpreteren ze een verhaal en wat vinden ze mooi?" (2009a, p. 129) De Toets OCG is ontwikkeld om de vraag te beantwoorden in welke mate en op welke gebieden kinderen kennis en begripsvermogen opbouwen op basis van kinderliteratuur. Niet zozeer kennis en begrip ván bepaalde boeken, maar kennis en begrip van en úit bepaalde genres. Het onderzoeksproject als geheel levert daarmee een belangrijke wetenschappelijke bijdrage aan de ontwikkeling van objectieve en gestandaardiseerde meetinstrumenten waarmee effecten, 'opbrengsten', van het aanbieden van kinderliteratuur op verschillende ontwikkelingsgebieden van kinderen in kaart gebracht worden.

Kijken we echter specifiek naar de Leeskalender ${ }^{+ \text {Kinderpoëzie }}$ als stimulus en de scores die kinderen halen op de deeltoets Kinderpoëzie dan blijkt er nauwelijks sprake van waar- 
neembare effecten van het aanbod. Zoals ik in Hoofdstuk 8 al besproken heb, vormen de betrouwbaarheid en geldigheid (validiteit) van uitspraken op grond van een onderzoek voorwaarden voor de bruikbaarheid van de kennisbijdrage van het onderzoek (Hart et al, 2001, p. 188). Voor het deelproject Kinderpoëzie geldt dat de deeltoets voor groep 2 geen valide meetinstrument blijkt voor het meten van de bijdrage van kinderpoëzie aan de ontluikende culturele geletterdheid van de kinderen. De Kinderpoëzie-items waren voor deze groep te moeilijk wat een grote beperking van de validiteit van de deeltoets voor groep 2 vormt als gevolg van de hoge mate van complexiteit en daardoor geringe 'eerlijkheid' van de deeltoets voor de kleuters (zie ook Pol, 2010, p. 143). De deeltoets voor groep 4 is slechts in beperkte mate betrouwbaar en valide, in die zin dat de interne consistentie van de deeltoets niet voldoende is en het nagaan van de begripsvaliditeit laat zien dat de deeltoets Kinderpoëzie zich anders verhoudt tot bepaalde kenmerken van de kinderen dan de Toets OCG als geheel. De deeltoets Kinderpoëzie blijkt zich in zekere zin afwijkend te gedragen. Dat wil zeggen: de samenhang tussen ontluikende culturele geletterdheid en kenmerken van het 'geletterd thuisklimaat' en CITO-vaardigheidsscores van de kinderen blijkt voor de poëzie-items soms volkomen tegengesteld aan onze verwachtingen, ook wanneer deze aannamen voor de toets als geheel wel werden bevestigd. Zo geldt voor 'Bever en zijn vrienden op het vlot' dat de score van de kleuters op dit item negatief correleert met voorlezen thuis en met de schoolprestaties van de kinderen; bij kinderen in groep 4 is er opnieuw een negatieve correlatie met voorlezen thuis en helemaal geen correlatie met CITOvaardigheidsscores. 'Bever' is in die zin het minst valide item in de deeltoets Kinderpoëzie voor groep 2 en voor groep 4; tegelijk is dit het item dat het meest nauwkeurig aansluit op aanbod in de Leeskalenders en het enige item dat (bij groep 4) een effect van de Leeskalender ${ }^{+K i n d e r p o e ̈ z i e ~ l a a t ~ z i e n . ~ D e ~ i n h o u d s v a l i d i t e i t ~ v a n ~ d e ~ K i n d e r p o e ̈ z i e-i t e m s ~ i s ~ p r o b l e m a t i s c h . ~}$ Omdat één-op-één aansluiting van poëzie-items op het poëzie-aanbod zich moeilijk laat waarborgen, moet geconcludeerd worden dat de meeste poëzie-items naar alle waarschijnlijkheid de cognitieve ontwikkeling van de kinderen in beeld brengen en niet specifiek de effecten van poëzie op aspecten van hun ontluikende culturele geletterdheid. De deeltoets Kinderpoëzie is daarmee geen geschikt instrument gebleken voor de doeleinden waarvoor de deeltoets binnen dit onderzoek is ontwikkeld. De theoretisering van kinderpoëzie staat nog in de kinderschoenen en, bij mijn weten, is dit de eerste poging om effecten van kinderpoëzie - buiten effecten van rijm op taalontwikkeling - objectief meetbaar te maken. Binnen het kader van dit onderzoek is gebleken dat kwalitatieve methoden - observaties, interviews, logboekaantekeningen - meer inzicht geven in 'effecten' van de aanbieding van kinderpoëzie in de klas. Deze kwalitatieve methoden laten niet zien of kinderen de beoogde kennis uit het aanbod hebben opgedaan, maar geven wel goed en nauwkeurig inzicht in hoe kinderen in groep 2 en in groep 4 poëzie verwerken, hoe zij poëzie waarderen en begrijpen, welke factoren een cruciale rol spelen in de aansluiting van het aanbod van poëzie op de ontluikende competentie van jonge kinderen. De kwalitatieve methoden zijn in die zin geschikter gebleken om vat te krijgen op de poëzieverwerking zelf (vgl. Ghesquière, 2009a, p. 129). De overdracht van poëzie die gekenmerkt wordt door alomtegenwoordige eigenschappen van volksculturele baker- en kinderrijmen die in een internationale traditie staan (vgl. Lierop-Debrauwer \& Mooren, 2004) introduceert kinderen in een specifiek cultureel erfgoed, in een deel van de taalcultuur, met haar eigen pragmatische en esthetische eigen- 
schappen, en de carnavaleske verzen spelen daarnaast met allerlei culturele conventies. Door het kalenderformat van de Leeskalender en door de van oudsher sterke verbondenheid van volksculturele kinderrijmen aan de vieringen in het jaar en in het leven introduceert het kinderen eveneens in feestcultu(u)ren met de daarbij behorende gebruiken. De kwalitatieve data laten tegelijk zien dat de aangeboden kinderpoëzie in de verwerving en waardering ervan door kinderen ervan sterk steunt op fysieke ervaring en beleving, op geritualiseerde handelingspatronen en ook op de expliciet waarneembare afwijking van bepaalde verwachtingspatronen. Dit wijst erop dat wat deze kinderpoëzie primair is en doet voor kinderen zich niet zozeer op het niveau van het intellect, van expliciete kennis, maar op het niveau van ervaring, van impliciete beleving en zintuiglijke waarneming van poëtische (muzikale / nonsensicale) effecten, laat aanwijzen. De kwalitatieve data zijn in het kader van dit onderzoek echter niet verzameld en geanalyseerd vanuit de vraag wat de aangeboden poezie bijdraagt aan de ontluikende culturele geletterdheid van de kinderen.

Wat betekent het dat de deeltoets Kinderpoëzie zich op meerdere manieren afwijkend gedraagt ten opzichte van de Toets OCG als geheel en dat kinderpoëzie in de klas primair op een ander niveau werkt dan het niveau van het verstand? Zijn effecten van kinderpoëzie op de ontluikende culturele geletterdheid van jonge kinderen überhaupt meetbaar te maken? Als vanzelf roept dit deel van het onderzoek vragen op over de mogelijkheid en de wenselijkheid van het meetbaar maken van effecten van kunstzinnige processen. De Onderwijsraad en Raad voor Cultuur stelden al eerder vast dat er moeilijkheden zijn om 'culturele ontwikkeling' van leerlingen te vertalen naar meetbare resultaten:

"De vraag is steeds in hoeverre meetinstrumenten die uitgaan van rationaliteit, objectiviteit en vergelijkbaarheid, bruikbaar zijn voor kunstzinnige processen die sterk verbonden zijn met emoties, subjectiviteit en individuele kwaliteiten (...). Hoewel in de afgelopen jaren diverse instrumenten en methoden zijn ontwikkeld om de beoordeling van kunstproducten betrouwbaarder te maken, blijven betrouwbaarheids- en validiteitsaspecten onderwerp van discussie (Haanstra \& Schönau, 2006).” (Onderwijsraad \& Raad voor Cultuur, 2012, p. 15)

Tegelijk werd ook duidelijk dat vooral leerkrachten in groep 4 hun eindoordeel over of ze de Leeskalender als 'methode' zouden willen gebruiken, lieten afhangen van 'de resultaten van de toets'. Zo stelde een leerkracht: 'Als je ziet dat het iets toevoegt, dan sta ik er wel open voor, maar als je weinig verschil ziet, weet ik niet of ik het structureel zou willen invoeren.' (evaluatie 2, S23, 25-06-2014) Op de vraag of het werken met de Leeskalender zinvol is, antwoordt een leerkracht: 'Dat zal toch moeten blijken uit de toetsresultaten, dat kan ik zo niet zeggen.' Op de vraag of ze de Leeskalender als methode interessant zou vinden, geeft ze aan dat het voor groep 4 wel interessant zou kunnen zijn, maar dan moet eerst uit de resultaten blijken dat het ook echt bijdraagt aan de culturele geletterdheid van de kinderen (evaluatie 2, S11, 24-06-2014). In groep 4 is weinig speelruimte en alles dat aan het lesprogramma wordt toegevoegd, gaat ten koste van 'opbrengstgerichte' activiteiten. Een leerkracht noemt dan ook als nadeel van de Leeskalender dat het wel 'vijf keer een kwartier in de week' is: 'Dus het gaat wel ten koste van tijd voor andere dingen. Van de ene kant is het heel leuk en leerzaam, maar van de andere kant zijn er ook wel eens andere 
dingen die voorrang moeten hebben.' (evaluatie 2, S23, 25-06-2014) Een andere leerkracht stelt expliciet dat ze vond dat ze niet minder tijd aan andere vakken, zoals rekenen, kon besteden waardoor de Leeskalender het eerste was dat ze liet vallen bij tijdgebrek (evaluatie 2, S22, 17-06-2014).

Dergelijke reacties van leerkrachten ondersteunen de relevantie van de effectmeting die in dit onderzoeksproject is gedaan voor de bruikbaarheid van de onderzoeksresultaten voor de praktijk van het basisonderwijs. Tegelijk is het een houding die gezien moet worden tegen de achtergrond van de eenzijdige aandacht voor de basisvaardigheden en meetbare doelen die het (basis)onderwijs in de afgelopen decennia zijn gaan beheersen. Een ontwikkeling die, volgens de Onderwijsraad, tot een verbetering van de basisvaardigheden (taal en rekenen) heeft geleid, maar tevens tot een 'verschraling van het onderwijs' ten koste van (onder meer) cultuureducatie en burgerschapsvorming: "Meetbare doelen zijn de maatstaf geworden voor de kwaliteit van het onderwijs. De raad roept op discussie te voeren over wat het Nederlandse onderwijs leerlingen en studenten moet meegeven.” (2013, pp. 4-5) Leerkrachten zijn in zekere zin 'gesocialiseerd' in het gebruik van toetsen en het sturen op meetbare resultaten (opbrengstgericht werken), zeker op de kerngebieden taal en rekenen. In 2013 benadrukt de Onderwijsraad echter: "Leerlingen en studenten moeten optimaal worden voorbereid op vervolgopleidingen en het functioneren in de samenleving. Daarvoor moeten zij kennis en vaardigheden opdoen in verschillende leerdomeinen. Ze moeten ook bepaalde waarden en normen meekrijgen, én culturele bagage. In de afgelopen periode was de aandacht eenzijdig gericht op meetbare doelen, in het bijzonder op taal- en rekenprestaties." (Onderwijsraad, 2013, p. 24) Met de ontwikkeling van de Leeskalender geven we juist gehoor aan de roep om (de terugkeer van) aandacht voor het lezen van 'cultureel waardevolle teksten' (Raad voor Cultuur, 2005b) en voor 'brede cultuuroverdracht' en 'culturele vorming' (Onderwijsraad, 2011) in het onderwijs. Aandachtsgebieden waarmee, zo laten we met dit onderzoek zien, al vroeg kan worden begonnen via het aanbieden van kinderliteratuur mits het tekstaanbod nauwkeurig is afgestemd op de culturele competentie van de kinderen. Tegenover de vraag naar 'harde' resultaten stond ook een toewijding van leerkrachten aan het project die gesteund werd door het aanbod in de Leeskalender en door de reacties van de kinderen daarop. Verschillende leerkrachten waren vanuit die gedachte wel overtuigd van een 'intrinsieke waarde' van het materiaal. Die intrinsieke waarde had enerzijds te maken met de verschillende genres die waren opgenomen in het aanbod. Daarnaast waardeerden de meeste leerkrachten ook de culturele pluriformiteit in het aanbod. Een van de leerkrachten gaf in het afsluitende gesprek aan overtuigd te zijn dat de Leeskalender effect heeft gehad op de kennis van verschillende culturen bij de kinderen in haar groep 4. Ze denkt dat de Leeskalender ook heeft bijgedragen aan de algemene taalontwikkeling van de kinderen, al verwacht ze niet dat dat terugkomt in de Cito-scores omdat het daar om heel andere soorten aspecten van taal gaat dan de taal van verhalen en gedichten (evaluatie 2, S24, 18-06-2014).

Er wordt groot belang gehecht aan de ontwikkeling van evidence-based onderwijsinnovatie waarbij op basis van empirisch onderzoek uitspraken kunnen worden gedaan over de effectiviteit van methoden of programma's. Dat is noodzakelijk voor het waarborgen van onderwijskwaliteit. Onderwijsonderzoek gericht op de ontwikkeling van methoden voor cultuuroverdracht of culturele vorming zal daarbij echter altijd te maken hebben met de 
vraag of en hoe de effectiviteit van de methode objectief waarneembaar gemaakt kan worden. Dat is zowel een wetenschappelijk vraagstuk - waarbij keuzes in onderzoeksmethoden altijd in relatie tot de specifieke onderzoeksdoelstelling(en) gemaakt worden - als een vraagstuk voor onderwijsontwikkelaars en -beleidsmakers. Voor de praktijk van het onderwijs stelde de Onderwijsraad in haar advies Naar meer evidence based onderwijs: "De hardste vorm van bewijs ... zijn gecontroleerde experimenten met aselecte toewijzing van proefpersonen aan condities. Andersoortige onderzoeksopzetten zijn onder meer pilots, cohortstudies en gevalstudies. Naast deze vormen van (hardere en zachtere) geobjectiveerde kennis kan ook ervaringskennis van professionals bijdragen aan inzicht in 'wat werkt'." (2006, p. 9) Voor de onderwijspraktijk kan - zoals in het zeer recent verschenen Cultuur in de Spiegel in de praktijk: Een leerplankader voor cultuuronderwijs (Hoeven et al, 2014) - ook gebruik worden gemaakt van gestandaardiseerde instrumenten voor de kwalitatieve evaluatie van de ontwikkeling van kinderen op bepaalde (culturele) domeinen (Sasbrink, 2012). Daarvoor kan aansluiting op de kerndoelen van leergebieden als 'kunstzinnige oriëntatie' en 'oriëntatie op jezelf en de wereld' 205 als uitgangspunt worden genomen voor een inbedding van nieuwe methoden in bestaande onderwijsdoelen. Naast het aantoonbaar maken van 'evidente voordelen voor leerlingen en studenten' beschouwt de Onderwijsraad een nieuwe methode of aanpak ook als effectiever "wanneer er geen sprake is van evidente nadelen voor het functioneren van leerlingen (ze functioneren niet slechter)." (2006, p. 9) Voor het Leeskalenderproject is nagegaan of het werken met de Leeskalender, wat toch de nodige onderwijstijd heeft gekost, een negatief effect heeft op de CITO-scores op de gebieden taal en rekenen van kinderen in de experimentele conditie ten opzichte van kinderen in de controleconditie. Geen van de uitkomsten vormt overtuigend bewijs van een negatief effect van het werken met de Leeskalender: wellicht alleen dat weinig met de Leeskalender werken nadelig is voor de ontwikkeling van woordenschat in vergelijking met zowel niet met de Leeskalender werken als veel met de Leeskalender werken (zie Bijlage 7). Tegelijk vragen de inzichten die in dit onderzoek verkregen zijn in hóe kinderen poëzie beleven, en van daaruit 'begrijpen' en waarderen om een omslag in het denken over 'opbrengsten' die toch meestal in termen van 'het verstand' worden geformuleerd, ook bij kwalitatieve evaluatie. De kwalitatieve resultaten ondersteunen de tot nu toe alleen theoretisch geformuleerde aanname dat " $\ldots$ poetry bypasses concepts and interpretation and reaches directly into embodied experience to produce its effects, which exceed its linguistic meaning." (Coats, 2013, p. 133) Het intellectualiseren van de 'opbrengsten' van poëzie vormt in die zin altijd een reductie van de belichaamde ervaring van poëtische effecten die zich moeilijk in verbale taken laten vertalen.

\footnotetext{
${ }^{205}$ Het leergebied 'Kunstzinnige oriëntatie primair onderwijs' omvat de volgende drie kerndoelen: (54) De leerlingen leren beelden, taal, muziek, spel en beweging te gebruiken, om er gevoelens en ervaringen mee uit te drukken en om er mee te communiceren. (55) De leerlingen leren op eigen werk en dat van anderen te reflecteren. (56) De leerlingen verwerven enige kennis over en krijgen waardering voor aspecten van cultureel erfgoed. Het leergebied 'Oriëntatie op jezelf en de wereld' omvat kerndoelen verdeeld over de thema's: mens en samenleving (kerndoelen $34 \mathrm{t} / \mathrm{m}$ 39), natuur en techniek (40 t/m 46), ruimte (47 t/m 50) en tijd (51 t/m 53). In de omschrijving van dit leergebied staat onder meer: "In dit leergebied oriënteren leerlingen zich op zichzelf, op hoe mensen met elkaar omgaan, hoe ze problemen oplossen en hoe ze zin en betekenis geven aan hun bestaan. Leerlingen oriënteren zich op de natuurlijke omgeving en op verschijnselen die zich daarin voordoen. Leerlingen oriënteren zich ook op de wereld, dichtbij, veraf, toen en nu en maken daarbij gebruik van cultureel erfgoed." (TULE Kerndoelen primair onderwijs, 2006, p. 47)
} 


\subsection{De vertaling van de resultaten naar de praktijk van het basisonderwijs}

Dit onderzoeksproject heeft als expliciet oogmerk bruikbare kennis te genereren voor de praktijk van het basisonderwijs. De resultaten uit elk van de drie deelprojecten vormen samen de basis voor verdere exploratie en ontwikkeling van de Leeskalender tot een bruikbare methode. In Hoofdstuk 6 is besproken dat we binnen het onderzoekskader in de ontwikkeling van het interventieprogramma verschillende afwegingen hebben moeten maken tussen aansluiting op de onderwijspraktijk enerzijds en de onderzoeksdoelstellingen anderzijds. Hoewel we steeds de aansluiting op de praktijk hebben meegewogen, hadden wetenschappelijke overwegingen een groter gewicht omdat we voor dit onderzoek primair wetenschappelijke verantwoording moeten afleggen. Voor een verdere ontwikkeling gericht op de onderwijspraktijk is een (gedeeltelijke) heroverweging van de operationalisering van de relatie tussen de beoogde methode, de Leeskalender, en 'ontluikende culturele geletterdheid' zinvol omdat aansluiting op de praktijk daarbij als primaire doelstelling geldt:

"Bij de operationalisering wordt de vraagstelling concreet gemaakt. Dat betekent dat wordt beslist wat wel en wat niet wordt onderzocht en welke waarnemingsuitspraken op het onderzoek kunnen worden gebaseerd. Als opdrachtgevers en uitvoerders meedenken komen ze niet voor verrassingen te staan en is de kans het grootst dat op het onderzoek gebaseerde aanbevelingen ook uitvoerbaar zijn.” (Hart et al, 1998, p. 189)

De resultaten voor het onderzoeksproject als geheel en voor het deelproject Kinderpoëzie zoals in dit proefschrift beschreven, geven aanleiding tot verschillende richtingen voor verder onderzoek en voor uitwerking richting de onderwijspraktijk. Ik bespreek hier de belangrijkste drie.

Uit gesprekken die na afloop van het Leeskalenderproject met de betrokken leerkrachten zijn gevoerd, blijkt dat zowel in de kleutergroepen als in groep 4 interesse bestaat om de Leeskalender als methode te gebruiken, maar leerkrachten uit beide groepen stelden daar verschillende voorwaarden aan. In de kleutergroepen kwam sterk naar voren dat leerkrachten behoefte hebben aan betere aansluiting van het materiaal op het thematisch werken dat in de kleutergroepen centraal staat. Een van de leerkrachten stelde voor dat er een inventarisatie gemaakt wordt van de meest gebruikte thema's in het kleuteronderwijs om de materialen in de Leeskalender zo te ontwikkelen dat ze aansluiten op die thema's en op de duur van die thema's (meestal een aantal weken). Een andere leerkracht stelde 'vier seizoenskalenders' voor om betere aansluiting op het thematisch werken te waarborgen. Onderzoekers zouden in samenwerking met onderwijs- en methodeontwikkelaars en scholen moeten nagaan wat de belangrijkste thema's zijn en bekijken hoe de Leeskalender voor de kleutergroepen daar op aan kan sluiten zonder het principe van 'ontluikende culturele geletterdheid' daarbij uit het oog te verliezen. Leerkrachten in groep 4 vroegen om meer flexibiliteit in het aanbod, bijvoorbeeld door minder teksten per week aan te bieden, minder dagen per week met het materiaal te werken en activiteiten minder strikt te koppelen aan data. Een van de leerkrachten denkt aan 'gewoon een aanbod van teksten met daarbij de uitgewerkte aanbieding en verwerking, dan kun je als leerkracht zelf bepalen hoeveel je doet en wan- 
neer'. Leerkrachten zien zelf in dat dit het 'principe van een kalender' zou doorbreken, maar het volle onderwijsprogramma laat in groep 4 weinig ruimte om er dagelijks 'nog iets bij te doen'. Ook hier zouden onderzoekers in samenwerking met onderwijs- en methodeontwikkelaars en scholen moeten nagaan in welke vorm het Leeskalenderaanbod voor leerkrachten 'werkbaar' is. De verschillen in werkwijze in de kleutergroepen en groep 4 wijzen er ook op dat hier feitelijk sprake is van behoefte aan verschillende methoden. De verdere ontwikkeling van het Leeskalendermateriaal zou dan voor de kleutergroepen en hogere groepen apart moeten worden uitgewerkt. Gedacht kan worden aan de ontwikkeling van een Leeskalender voor de onderbouw (groep 1 en 2), een Leeskalender voor de middenbouw (groep $3 \mathrm{t} / \mathrm{m}$ ) en mogelijk ook een Leeskalender voor de bovenbouw (groep $6 \mathrm{t} / \mathrm{m} 8$ ). Niet alleen vraagt dit om een nauwkeuriger inventarisatie van en onderzoek naar effectieve vormgeving en indeling van de materialen; ook nader onderzoek naar de bijdrage van kinderliteratuur aan de culturele geletterdheid van kinderen in groep 3 en 5 (en mogelijk ook groep $6 \mathrm{t} / \mathrm{m}$ ) is nodig om de Leeskalender als methode voor de middenbouw (en eventueel bovenbouw) te ontwikkelen. De verkregen inzichten in de poëtische voorkeuren van kinderen in groep 2 en in groep 4 laten zien dat zich een interessante ontwikkeling voordoet tussen die groepen. Dat betekent dat groep 3 naar verwachting een belangrijk 'overgangsjaar' is in die ontwikkeling. Het is dan van groot belang daar inzicht in te krijgen voordat criteria voor de selectie van kinderpoëzie voor deze groep kunnen worden geformuleerd. Wanneer het vanuit de onderwijspraktijk gezien wenselijk is om de Leeskalender ook voor hogere groepen te ontwikkelen, dan zal voor die groepen eveneens moeten worden nagegaan welke en hoe kinderliteratuur kan worden geselecteerd die nauwkeurig aansluit op de culturele competentie van de kinderen.

Het onderzoeksproject Emergent Cultural Literacy hanteert een innovatieve methodologie om een antwoord te formuleren op de vraag wat 'cultureel waardevolle teksten' zijn, i.e. welke teksten cruciaal zijn om te lezen en waarom, en welke teksten tegelijk nauwkeurig aansluiten op de culturele competentie van kinderen in het basisonderwijs. Deze tweezijdige verankering van het aanbod presenteert de culturele competentie van individuele leerlingen en de culturele waarde van teksten als twee zijden van dezelfde medaille waarmee leerlinggericht en cultuuroverdrachtgericht onderwijs in elkaars verlengde komen te liggen. Omdat we daarbij expliciet rekening willen houden met het feit dat de Nederlandse samenleving cultureel pluriform is en dat groepen kinderen - en de culturele competentie waarover die kinderen beschikken - die pluriformiteit vertegenwoordigen, beogen we met dit onderzoek evidence-based criteria te formuleren voor de ontwikkeling van een effectieve methode om de 'transculturele geletterdheid' van leerlingen te stimuleren. In de Leeskalender is culturele pluriformiteit enerzijds vertegenwoordigd in de vieringen die in het kalenderformat zijn opgenomen; anderzijds is culturele pluriformiteit in het aanbod van genres en specifieke teksten vertegenwoordigd. Echter, op beide vlakken vraagt de inbedding van culturele pluriformiteit om verdieping en verbreding. Er zou - op basis van bestaand onderzoek, raadpleging van experts en in samenspraak met onderwijsbegeleidingsdiensten, ontwikkelaars en scholen - systematisch moeten worden onderzocht welke vieringen in de Leeskalender vertegenwoordigd moeten zijn om een evenwichtige afspiegeling van de Nederlandse samenleving en schoolpopulaties te waarborgen. Op die manier zou een 'feestcanon' moeten worden samengesteld voor verschillende leeftijdsgroepen. Op het 
niveau van de aangeboden genres en varianten van tekstsoorten is binnen dit onderzoek uitgegaan van de algemene aanname dat 'putten uit de canon van de volkscultuur' een transcultureel aanbod waarborgt "omdat rijmpjes en versjes, sprookjes en fabels, raadsels en spreuken, moppen en grappen deel uitmaken van een internationale traditie." (LieropDebrauwer \& Mooren, 2004, p. 11) In het aanbod van kinderpoëzie waren, in aanvulling hierop, ook varianten van specifieke soorten poëzie (verjaardagslied, wiegelied) in verschillende talen opgenomen en was in verwerkingsvormen waar mogelijk ruimte gecreëerd voor aandacht voor culturele diversiteit op het niveau van gebruiken bij vieringen. Echter, de mogelijkheden hiervoor zijn niet systematisch onderzocht. Niet-Westerse vieringen en poëzie zijn duidelijk ondervertegenwoordigd: repertoireonderzoek naar vergelijkbare poëtische vormen uit niet-Westerse culturen zou een steviger onderbouwing moeten vormen van het uitgangspunt dat 'putten uit de volkscultuur' inderdaad een internationale traditie vertegenwoordigt. Repertoireonderzoek kan de inbedding van cultureel pluriforme varianten van volksculturele poëtische vormen verbreden en verdiepen om de culturele pluriformiteit in de Nederlandse samenleving te weerspiegelen. Omdat de herkenning van talen en gebruiken door kinderen een belangrijke voorwaarde is voor waardering en verwerving in de klas, zouden verschillende varianten moeten worden opgenomen in het poëzie-aanbod zodat leerkrachten die varianten kunnen selecteren voor aanbieding die aansluiten op de etnische achtergronden en thuistalen die in hun groep vertegenwoordigd zijn.

De betrouwbaarheid en geldigheid (validiteit) van uitspraken op grond van een onderzoek vormen voorwaarden voor de bruikbaarheid van de kennisbijdrage van het onderzoek (Hart et al, 2001, p. 188). Voor het experiment dat we in het kader van het Emergent Cultural Literacy onderzoeksproject hebben uitgevoerd mogen we er van uit gaan dat de projectbrede uitspraken zowel betrouwbaar als valide zijn voor groepen 2 en groepen 4 op scholen die bereidwillig zijn met de Leeskalender te werken in het Nederlandse basisonderwijs. Voor het deelproject Kinderpoëzie geldt dat de deeltoets voor groep 2 geen betrouwbaar en valide instrument blijkt voor het meten van effecten van het aanbod van kinderpoëzie op de ontluikende culturele geletterdheid van de kinderen; de deeltoets voor groep 4 is slechts in beperkte mate betrouwbaar en valide. De validiteitsanalyses van de poëzie-items wijzen op structurele problemen met het meetbaar maken van effecten van kinderpoëzie (zie Hoofdstuk 8, §8.6). Uit observaties, logboekaantekeningen en gesprekken met leerkrachten komt echter duidelijk naar voren dat poëzie wel degelijk iets voor kinderen doet, dat ze het waarderen en er intens van kunnen genieten. Kwalitatief-empirische methoden dienen zich aan als geschikter manier om effecten van kinderpoëzie op de ontluikende culturele geletterdheid bij kinderen waarneembaar te maken. De kwalitatief-empirische data die in het kader van dit onderzoek zijn vergaard, zijn echter niet verzameld en geanalyseerd vanuit de vraag wat de aangeboden poëzie bijdraagt aan de ontluikende culturele geletterdheid van de kinderen. Met het oog op de praktijk van het basisonderwijs zou nader onderzoek nodig zijn om de bijdrage van kinderpoëzie aan ontluikende culturele geletterdheid te operationaliseren naar een kwalitatief-empirisch instrument waarmee die bijdrage kan worden waargenomen en geëvalueerd om de effectiviteit van het aanbieden van kinderpoëzie voor de ontwikkeling van ontluikende culturele geletterdheid na te gaan en de kwaliteit van het aanbod in die zin te waarborgen. Die 'effecten' zullen dan echter niet zozeer op het niveau van expliciete kennis en begrip gezocht moeten worden, maar op het niveau van de op- 
bouw van ervaring van en met poëtisch geritualiseerde fysieke en talige handelingspatronen in verschillende contexten van tekstgebruik. 

Bijlages 


\title{
Bijlage 1
}

\section{Geraadpleegde primaire bronnen}

\author{
Volksculturele baker-en kinderrijmen
}

ABRAMSZ, S. (samenst.) (1984/1910). Rijmpjes en versjes uit de oude doos. Amsterdam: Meulenhoff, 31ste druk.

AARTS, C.J. \& ETTEN, M.C. van (samenst.) (2004). Alles in de wind: De bekendste kinderversjes van vroeger. Amsterdam: Uitgeverij Bert Bakker.

BUUL, T. van \& STIGTER, B. (samenst.) (1993). Ik geef je niet voor een kaperschip Met tweebonderd witte zeilen. Amsterdam: Querido.

GOEVERNEUR, J.J.A. (ca. 1880-1890). Goeverneur's kinderdeuntijes, wiegeliedjes, speel-, tel-, raadsel-en andere rijmpjes. Arnhem / Nijmegen: Gebr. E. \& M. Cohen.

KES, POLLMANN en TIGGERS (1947). Kinderzang en Kinderspel I, II en III. Haarlem: Uitgeverij De Toorts.

TROELSTRA-BOKMA DE BOER en POLLMANN (1956). Kinderzang en Kinderspel IV: Het spel van moeder en kind. Haarlem: Uitgeverij De Toorts.

TROELSTRA-BOKMA DE BOER en POLLMANN (1956). Kinderzang en Kinderspel V: Het spel van moeder en kind. Haarlem: Uitgeverij De Toorts.

TROELSTRA-BOKMA DE BOER en POLLMANN (1948). Oude Kinderrijmen voor Jonge Ouders: Het spel van moeder en kind. Heemstede: Uitgeverij De Toorts.

\section{Kinderliedjes}

EYKMAN, K. (1977). De liedjes van Ome Willem. Amsterdam: Uitgeverij De Harmonie, 1977.

HOKS, M. \& SCHAIK, P. van (2004). En nu allemaal! Liedjes en spelletjes van kinderen in kleurrijk Nederland. Amsterdam: PlanPlan producties, 2de druk.

LINDERS, J. en DUIJX, T. (samenst.) (2004). Alle liedjes met een boepeljje erom: De meest gezongen kinderliedjes van dit moment, in tekst, muziek, en beeld. Houten: Uitgeverij Van Holkema \& Warendorf, 4de druk.

OS, E. van \& LIESHOUT, E. van (2006). Het grote prentenboekenliedjesboek. Rotterdam: Lemniscaat, 2006.

SCHOLTEN, H. (1995). Roltrap naar de maan. Nederlandse kinderliedjes vanaf 1950 voor kleine en grote mensen. Bussum: Novella Uitgeverij.

STAM-VAN DER STAAY, M. (samenst.) (2006). Een mandje vol amandelen: Kinderliedjes met pianobegeleiding. Amsterdam: Uitgeverij Ploegsma, 16de druk. 


\section{Bloemlezingen}

BUUL, T. van \& STIGTER, B. (samenst.) (2006). Als je goed om je heen kijkt qie je dat alles gekleurd is. Amsterdam: Querido, 11de druk.

KOMRIJ, G. (2008). De Nederlandse kinderpoezie in 1000 en enige gedichten. Amsterdam: Prometheus, 6de druk, oktober.

LEEUWEN, J. van (samenst.) (2010). Tikken tegen de maan. 50 kindergedichten wit Nederland en Vlaanderen verzameld door Joke van Leeuwen. Met 48 gloednieuwe illustraties. Rekkem: Ons Erfdeel.

LIESHOUT, T. van (samenst.) (2010). Ik wil een naam van chocola. Querido's Poëziespektakel 2. Amsterdam: Querido.

LIESHOUT, T. van (samenst.) (2010). Wie heeft hier met verf lopen smijten? Querido's Poëziespektakel 3. Amsterdam: Querido.

OPSTAL, L. van (samenst.) (2011). Van Boerke Naas tot Dikkertje Dap: 111 kindergedichten om nooit meer te vergeten. Tielt: Uitgeverij Lannoo.

REIJT, V. van de (red.) (2004). Ik, wou dat ik twee hondjes was. Nederlandse nonsens- en plezierdichters van de twintigste eeuw. Amsterdam: Uitgeverij Bert Bakker.

SMEEKENS, J. (samenst.) (2008). Wie knipt de tenen van de reus? Versjesgroeiboek voor kleuters. De mooiste kinderpoëzie van klein naar groter. Leuven: Davidsfonds / Infodok.

\section{Bundels per dichter}

ADAM, F.; Milja Praagman (illustraties) (2011). Als de bomen straks gaan rijden. Wielsbeke: Uitgeverij De Eenhoorn.

ANDREUS, H. (1976). Waarom daarom. Haarlem: Uitgeversmaatschappij Haarlem.

ANDREUS, H. (2004). Verzamelde gedichten. Amsterdam: Uitgeverij Bert Bakker, 7de druk. BIEGEL, P. (2002). Eén been, stokkebeen. Haarlem: Uitgeverij Holland.

BIEMANS, I. (1989). Ik was de zee. Amsterdam: Querido.

BIEMANS, I. (2001). Met mijn rechteroog dicht, mijn linkeroog open. Amsterdam: Leopold.

BIEMANS, I. (2003). Onder de maan. Amsterdam: Leopold.

BIEMANS, I. (2006). Paperasje. Amsterdam: Nieuw Amsterdam Uitgevers.

BIEMANS, I. (2008). Paperasje ging op reis. Amsterdam: Nieuw Amsterdam Uitgevers.

BIEMANS, I. (2010). Rosa en de wonderschoenen. Amsterdam: Nieuw Amsterdam Uitgevers.

BUDDINGH', C. (2003). Alle gorgelrijmen. Amsterdam: De Bezige Bij.

DIEKMANN, M. (2008). Ik zie je wel, ik hoor je wel. Amsterdam: Querido, 2008.

GERLACH, E. (1998). Hee meneer Eland. Amsterdam: Querido, 1998.

GERLACH, E. (2001). Oog in oog in oog in oog. Amsterdam: Querido, 2001.

HAGEN, H. \& M. (1988). Daar komt de tijger. Amsterdam: Van Goor.

HAGEN, H. \& M. (2000). Jij bent de liefste. Amsterdam: Querido.

HAGEN, H. \& M. (1990). Misschien een olifant. Amsterdam: Van Goor.

HAGEN, H. \& M. (2007). Van mij en van jou. Amsterdam: Querido.

HOEKSTRA, H.G. (2007). Rijmpjes en versjes uit de nieune doos. Amsterdam: Meulenhoff, 15de druk (uitgave uit 1976).

HUBER, D. (1959). De uil met de zeven zuurtjes. Amsterdam: Ploegsma. 
HUBER, D. (1989). Dáár moet je nou een Beest voor zijn. Amsterdam: Leopold.

HUBER, D. (2001). De spookjesprins. Tilburg: Uitgeverij Zwijsen, Leesleeuw Groep 5, Leerjaar 3, Boekje 5 .

JEKKERS, H. \& MEINDERTS, K. (2001). Leve het nijlpaard! Amsterdam: Uitgeverij De Harmonie.

KUIPER, N. (2008). Soms rie ik 1000 lichtjes. Amsterdam: Leopold, 2de druk.

KUYPER, H. \& HAERINGEN, A. van (ill.) (2003). Ik kan alle woorden lijmen. Amsterdam: Leopold.

LAUREY, H. (1976). Kinderversjes. Haarlem: Uitgeversmaatschappij Holland.

LAUREY, H. (2001). Een Schelp aan je Oor. Haarlem: Uitgeverij Holland.

LEEUWEN, J. van. (1995). Ik ben ik. Tilburg: Zwijsen.

LEEUWEN, J. van (2000). Oro heppie en andere versjes. Amsterdam: Querido.

LIESHOUT, T. van \& Posthuma, S. (ill.) (2008). Spin op sokken. Amsterdam: Leopold.

LIESHOUT, T. van \& Posthuma, S. (ill.) (2009). Koekjes! Amsterdam: Leopold.

OS, E. van \& LIESHOUT, E. van (2008). Ik weet wat ik worden wil. Haarlem: Gottmer, 2008.

OS, E. van \& LIESHOUT, E. van (2007). Klapzoen. Tilburg: Zwijsen, 2007.

OS, E. van (1995). Er loopt een liedje door de lucht (versjes voor beginnende lezers). Tilburg: Zwijsen, 1995.

OS, E. van (1997). Dit boek is voor jou, het gaat over mij (versjesstripboek.). Tilburg: Zwijsen, 1997.

OS, E. van (2001). Ik was zo'n steentje in jouw schoen: over liefde. Amsterdam: DiVers, 2001.

OS, E. van (2002). De man die in sprookjes geloofde. Amsterdam: DiVers, 2002.

RENSSEN, P. van (1950). De geschiedenis van Pig Pag Pengeltje en andere versjes. Den Haag / Batavia z.j.: G.B. van Goor Zonen's Uitgeversmaatschappij.

ROBBEN, J. (2009). De nacht krekelt. Breda: Uitgeverij De Geus, 2007, 3de druk.

ROBBEN, J. (2004). Twee vliegen. Uitgegeven in eigen beheer: Uitgeverij Steunzool.

ROBBEN, J. (2009). Zullen we een bos beginnen? Breda: Uitgeverij De Geus, 2008, 3de druk.

SCHMIDT, A.M.G. (2004). Ziezo. De 347 kinderversjes. Amsterdam: Querido, 15de druk.

SILVERSTEIN, S. (1985). Het Randje van de Wereld. Baarn: Uitgeverij De Fontein.

SILVERSTEIN, S. (1998). Ik V al Omhoog. Baarn: Uitgeverij De Fontein.

SILVERSTEIN, S. (1983). Licht op Zolder. Baarn: Uitgeverij De Fontein.

STIP, K. (1981). Beestenboel van Trijntje Fop. Amsterdam / Antwerpen: Elsevier Manteau.

VENDEL, E. van de (2003). Superguppie. Amsterdam: Querido, met tekeningen van Fleur van der Weel.

VENDEL, E. van de (2005). Superguppie krijgt kleintjes. Amsterdam: Querido, met tekeningen van Fleur van der Weel.

VENDEL, E. van de (2008). De groeten van Superguppie. Amsterdam: Querido, met tekeningen van Fleur van der Weel.

VENDEL, E. van de (2010). Hoera voor Superguppie! Amsterdam: Querido, met tekeningen van Fleur van der Weel.

WILMINK, W. (2010). Verzamelde liedjes en gedichten. Amsterdam: Prometheus.

ZONDERLAND, D. (2007). Er zwom een garnaal door het Kattegat. Amsterdam: Uitgeverij Bert Bakker. 


\section{Bijlage 2}

\section{Overzicht van het volledige Leeskalenderaanbod}

(DD=Deugen \& Dilemma's; KP=Kinderpoëzie; NG=Narratieve Genres)

\begin{tabular}{|c|c|c|c|c|c|c|}
\hline \multirow{2}{*}{\multicolumn{3}{|c|}{2013}} & \multicolumn{2}{|c|}{ GROEP 2} & \multicolumn{2}{|c|}{ GROEP 4} \\
\hline & & & & Titel & & Titel \\
\hline & \multicolumn{6}{|l|}{ SEP } \\
\hline 1 & $\mathrm{ma}$ & 16 & $\mathrm{DD}$ & Kikker en een heel bijzondere dag & $\mathrm{DD}$ & De hoed \\
\hline 1 & di & 17 & $\mathrm{KP}$ & Meester van Zoeten & $\mathrm{KP}$ & Een jarige \\
\hline 1 & wo & 18 & NG & Wat staat daar? & NG & Sotje is jarig \\
\hline 1 & do & 19 & & keuzedag & DD & De twee geiten \\
\hline 1 & $\mathrm{vr}$ & 20 & & keuzedag & & keuzedag \\
\hline 2 & $\mathrm{ma}$ & 23 & $\mathrm{DD}$ & De vos en de kraanvogel & DD & De vos en de ooievaar \\
\hline 2 & di & 24 & $\mathrm{KP}$ & Opa Bakkebaard & $\mathrm{KP}$ & k Zag twee beren \\
\hline 2 & wo & 25 & NG & Morgen & NG & De ezel die kon lezen \\
\hline 2 & do & 26 & & keuzedag & KP & Drie apothekertjes \\
\hline 2 & $\mathrm{vr}$ & 27 & & keuzedag & & keuzedag \\
\hline \multirow[t]{2}{*}{3} & $\mathrm{ma}$ & 30 & $\mathrm{DD}$ & Noach bouwt een ark & DD & Fransiscus praat met de vogels \\
\hline & \multicolumn{2}{|c|}{ OKT } & & & & \\
\hline 3 & di & & $\mathrm{KP}$ & Alle hokken mogen open & $\mathrm{KP}$ & Alle hokken mogen open \\
\hline 3 & wo & 2 & $\mathrm{NG}$ & Moppen / Pietje en de beer & NG & Mooie stoffen te koop \\
\hline 3 & do & 3 & & keuzedag & NG & Moppen / Pietje en de beer \\
\hline 3 & $\mathrm{vr}$ & 4 & & keuzedag & & keuzedag \\
\hline 4 & $\mathrm{ma}$ & 7 & $\mathrm{DD}$ & Kleine Ezel en jarige Jakkie & DD & De bedevaart van de schoenlapper \\
\hline 4 & di & 8 & $\mathrm{KP}$ & Lekker stampen met dit weer & $\mathrm{KP}$ & Versje om te rappen (zonder einde) \\
\hline 4 & wo & 9 & NG & De verrassing & NG & De wolf en de zeven geitjes \\
\hline 4 & do & 10 & & keuzedag & DD & De wolf en de kraanvogel \\
\hline 4 & vr & 11 & & keuzedag & & keuzedag \\
\hline 5 & $\mathrm{ma}$ & 21 & $\mathrm{DD}$ & De brief & DD & Het rode kippetje \\
\hline 5 & di & 22 & $\mathrm{KP}$ & Klisklaskloentje & $\mathrm{KP}$ & De blauwbilgorgel \\
\hline 5 & wo & 23 & NG & Gruwelijke gorilla & NG & Assepoester \\
\hline 5 & do & 24 & & keuzedag & $\mathrm{KP}$ & Naima maakt muziek \\
\hline 5 & $\mathrm{vr}$ & 25 & & keuzedag & & keuzedag \\
\hline 6 & $\mathrm{ma}$ & 28 & $\mathrm{DD}$ & Kleine Beer heeft de hik & DD & De verrassing \\
\hline 6 & di & 29 & $\mathrm{KP}$ & k Zag twee beren & $\mathrm{KP}$ & Luilekkerland \\
\hline 6 & wo & 30 & NG & Monsterlied & NG & Het verhaal van Janneke van Zomeren \\
\hline \multirow[t]{2}{*}{6} & do & 31 & & keuzedag & NG & Griezelen \\
\hline & \multicolumn{3}{|c|}{$\mathrm{NOV}$} & & & \\
\hline 6 & $\mathrm{vr}$ & 1 & & keuzedag & & keuzedag \\
\hline 7 & $\mathrm{ma}$ & 4 & DD & Kikker en het vogeltje & $\mathrm{DD}$ & Dat is heel wat voor een kat \\
\hline
\end{tabular}




\begin{tabular}{|c|c|c|c|c|c|c|}
\hline \multirow{2}{*}{\multicolumn{3}{|c|}{$\begin{array}{l}2013 \\
\text { Iv-week }\end{array}$}} & \multicolumn{2}{|c|}{ GROEP 2} & \multicolumn{2}{|c|}{ GROEP 4} \\
\hline & & & & Titel & & Titel \\
\hline 7 & di & 5 & $\mathrm{KP}$ & Boterhammen smeren & $\mathrm{KP}$ & Pinokkio \\
\hline 7 & wo & 6 & NG & Weesopa & NG & Lelietjes-van-dalen \\
\hline 7 & do & 7 & & keuzedag & DD & De olifant en de krokodil \\
\hline 7 & $\mathrm{vr}$ & 8 & & keuzedag & & keuzedag \\
\hline 8 & $\mathrm{ma}$ & 11 & $\mathrm{DD}$ & De kakelbonte kameleon & DD & Kikker en de vreemdeling \\
\hline 8 & di & 12 & $\mathrm{KP}$ & Prins Piramente & $\mathrm{KP}$ & Sint-Maarten \\
\hline 8 & wo & 13 & NG & Goudhaartje en de drie beertjes & NG & Met gelijke munt terugbetaald \\
\hline 8 & do & 14 & & keuzedag & $\mathrm{KP}$ & Leuk is raar \\
\hline 8 & $\mathrm{vr}$ & 15 & & keuzedag & & keuzedag \\
\hline 9 & $\mathrm{ma}$ & 18 & DD & Een zoon komt thuis & $\mathrm{DD}$ & Zoon en dochter \\
\hline 9 & di & 19 & KP & Als ik nou een hondje mag & $\mathrm{KP}$ & De mislukte fee \\
\hline 9 & wo & 20 & NG & Assepoester & NG & Wassilissa \\
\hline 9 & do & 21 & & keuzedag & NG & De prinses op de erwt \\
\hline 9 & $\mathrm{vr}$ & 22 & & keuzedag & & keuzedag \\
\hline 10 & $\mathrm{ma}$ & 25 & DD & De spreeuw en de pauwen & DD & De rijkaard en de schoenmaker \\
\hline 10 & di & 26 & KP & Ik ben lekker stout & $\mathrm{KP}$ & Versje om te mompelen \\
\hline 10 & wo & 27 & NG & Djoha helpt de maan uit de put & NG & Waarss de boter? \\
\hline 10 & do & 28 & & keuzedag & DD & De kraai met de pauwenveren \\
\hline \multirow[t]{2}{*}{10} & $\mathrm{vr}$ & 29 & & keuzedag & & keuzedag \\
\hline & $\mathrm{DE}$ & & & & & \\
\hline 11 & $\mathrm{ma}$ & 2 & DD & Schoenen voor Sinterklaas & DD & De stoute jongen \\
\hline 11 & di & 3 & KP & Lieve Sinterklaas & $\mathrm{KP}$ & Als ik nou een hondje mag \\
\hline 11 & wo & 4 & NG & Kleine Ezel en Sinterklaas & NG & Ruzie \\
\hline 11 & do & 5 & & keuzedag & $\mathrm{KP}$ & Wat we zo graag zouden willen, Sinterklaas \\
\hline 11 & $\mathrm{vr}$ & 6 & & keuzedag & & keuzedag \\
\hline 12 & $\mathrm{ma}$ & 9 & DD & De krekel en de mier & DD & De raaf, de geit, de schildpad en de muis \\
\hline 12 & di & 10 & $\mathrm{KP}$ & Het grote bed & $\mathrm{KP}$ & Ik ben lekker stout \\
\hline 12 & wo & 11 & NG & De ezel die kon lezen & NG & De boze heks is verkouden \\
\hline 12 & do & 12 & & keuzedag & NG & Het luipaard, de geit en de mand cassave \\
\hline 12 & $\mathrm{vr}$ & 13 & & keuzedag & & keuzedag \\
\hline 13 & $\mathrm{ma}$ & 16 & DD & Jezus wordt geboren & DD & De herders \\
\hline 13 & di & 17 & $\mathrm{KP}$ & Boom versieren & $\mathrm{KP}$ & Kersthond \\
\hline 13 & wo & 18 & NG & Kerstavond & NG & Kerstfeest in het bos \\
\hline 13 & do & 19 & & keuzedag & DD & De krekel en de mier \\
\hline 13 & $\mathrm{vr}$ & 20 & & keuzedag & & keuzedag \\
\hline \multicolumn{7}{|c|}{2014 JAN } \\
\hline 14 & $\mathrm{ma}$ & 6 & DD & Kikker in de kou & DD & De gast \\
\hline 14 & di & 7 & $\mathrm{KP}$ & Ik wens je al wat wenselijk is & $\mathrm{KP}$ & Ik wens je al wat wenselijk is \\
\hline 14 & wo & 8 & NG & De Gruffalo & NG & Dromenland \\
\hline 14 & do & 9 & & keuzedag & $\mathrm{KP}$ & Het poppenkopmannetje \\
\hline 14 & $\mathrm{vr}$ & 10 & & keuzedag & & keuzedag \\
\hline
\end{tabular}




\begin{tabular}{|c|c|c|c|c|c|c|}
\hline \multirow{2}{*}{\multicolumn{3}{|c|}{$\begin{array}{l}2013 \\
\text { Iv-week }\end{array}$}} & \multirow{2}{*}{\multicolumn{2}{|c|}{$\begin{array}{c}\text { GROEP } 2 \\
\text { Titel }\end{array}$}} & \multicolumn{2}{|c|}{ GROEP 4} \\
\hline & & & & & & Titel \\
\hline 15 & $\mathrm{ma}$ & 13 & $\mathrm{DD}$ & De mus met haar jongen & DD & $\begin{array}{l}\text { Over de arme sloeber die een rijk man had kunnen } \\
\text { worden }\end{array}$ \\
\hline 15 & di & 14 & $\mathrm{KP}$ & 12 januari & $\mathrm{KP}$ & Dubbel dubbel dit dit \\
\hline 15 & wo & 15 & NG & Rare bobbels & NG & Vrouw Holle \\
\hline 15 & do & 16 & & keuzedag & NG & Drie vrijdagen \\
\hline 15 & $\mathrm{vr}$ & 17 & & keuzedag & & keuzedag \\
\hline 16 & $\mathrm{ma}$ & 20 & $\mathrm{DD}$ & De kikker en de os & DD & De schaduw van de Ezel \\
\hline 16 & di & 21 & $\mathrm{KP}$ & Juffrouw Boggemog & $\mathrm{KP}$ & De heks van Sier-kon-fleks \\
\hline 16 & wo & 22 & NG & De drie biggetjes & NG & Hoe de Anansi-verhalen op aarde kwamen \\
\hline 16 & do & 23 & & keuzedag & DD & De vos en de geit in de put \\
\hline 16 & $\mathrm{vr}$ & 24 & & keuzedag & & keuzedag \\
\hline 17 & $\mathrm{ma}$ & 27 & DD & Een kusje voor Kleine Beer & DD & Alleen \\
\hline 17 & di & 28 & $\mathrm{KP}$ & Klap eens in je handen & $\mathrm{KP}$ & Tafelmanieren \\
\hline 17 & wo & 29 & NG & Max en de Maximonsters & NG & Het verhaal van het jaar in China \\
\hline 17 & do & 30 & & keuzedag & $\mathrm{KP}$ & $\begin{array}{l}\text { Tien dingen naar keus die je kunt doen met dingen } \\
\text { uit je neus }\end{array}$ \\
\hline \multirow[t]{2}{*}{17} & $\mathrm{vr}$ & 31 & & keuzedag & & keuzedag \\
\hline & FEl & & & & & \\
\hline 18 & $\mathrm{ma}$ & 3 & DD & De Samaritaan & DD & De barmhartige Samaritaan \\
\hline 18 & di & 4 & KP & Gong xi Gong xi & $\mathrm{KP}$ & Hongerige Harry \\
\hline 18 & wo & 5 & NG & Hodja op het feest & NG & Anansi rijdt op tijger \\
\hline 18 & do & 6 & & keuzedag & NG & $\begin{array}{l}\text { Hoe Tijl Uilenspiegel aan brood kwam voor zijn } \\
\text { moeder }\end{array}$ \\
\hline 18 & $\mathrm{vr}$ & 7 & & keuzedag & & keuzedag \\
\hline 19 & $\mathrm{ma}$ & 10 & $\mathrm{DD}$ & Kikker is verliefd & $\mathrm{DD}$ & Dokter De Soto \\
\hline 19 & di & 11 & $\mathrm{KP}$ & Rond of vierkant & $\mathrm{KP}$ & Wauwelwok \\
\hline 19 & wo & 12 & NG & Zazoe is verliefd & NG & De drie broers \\
\hline 19 & do & 13 & & keuzedag & $\mathrm{DD}$ & Wees mijn gast \\
\hline 19 & $\mathrm{vr}$ & 14 & & keuzedag & & keuzedag \\
\hline 20 & $\mathrm{ma}$ & 17 & $\mathrm{DD}$ & De wolf en het lam & $\mathrm{DD}$ & De beer en het varkentje \\
\hline 20 & di & 18 & $\mathrm{KP}$ & Fijne verjaardag voor jou & $\mathrm{KP}$ & Fijne verjaardag voor jou \\
\hline 20 & wo & 19 & NG & Moe & NG & Wintertje spelen \\
\hline 20 & do & 20 & & keuzedag & $\mathrm{KP}$ & De brug bij Breukelen \\
\hline 20 & vr & 21 & & keuzedag & & keuzedag \\
\hline 21 & $\mathrm{ma}$ & 24 & $\mathrm{DD}$ & Het suikerfeestcadeau & $\mathrm{DD}$ & Ramadan \\
\hline 21 & di & 25 & $\mathrm{KP}$ & Carnaval & $\mathrm{KP}$ & Dierencarnaval \\
\hline 21 & wo & 26 & NG & De nieuwe kleren van de keizer & NG & Een goede daad \\
\hline 21 & do & 27 & & keuzedag & NG & De gouden gans \\
\hline \multirow[t]{2}{*}{21} & & 28 & & keuzedag & & keuzedag \\
\hline & MR & & & & & \\
\hline 22 & $\mathrm{ma}$ & 10 & DD & Beer is op Vlinder & DD & De notenkraker \\
\hline 22 & di & 11 & $\mathrm{KP}$ & Tot tien tellen & $\mathrm{KP}$ & Een kikker en een karekiet \\
\hline
\end{tabular}




\begin{tabular}{|c|c|c|c|c|c|c|}
\hline 201 & & & GRO & OEP 2 & GRO & EP 4 \\
\hline Iv-u & eek & & & Titel & & Titel \\
\hline 22 & wo & 12 & NG & Een bos vol enge wilde beesten & NG & De nieuwe kleren van de keizer \\
\hline 22 & do & 13 & & keuzedag & DD & De Beer en de Reizigers \\
\hline 22 & $\mathrm{vr}$ & 14 & & keuzedag & & keuzedag \\
\hline 23 & $\mathrm{ma}$ & 17 & $\mathrm{DD}$ & Kikker is bang & DD & Trompet voor Olifant \\
\hline 23 & di & 18 & $\mathrm{KP}$ & Een kikker en een karekiet & $\mathrm{KP}$ & Verstoppertje \\
\hline 23 & wo & 19 & NG & Lente & NG & De drie wensen \\
\hline 23 & do & 20 & & keuzedag & $\mathrm{KP}$ & Chinese taalles \\
\hline 23 & $\mathrm{vr}$ & 21 & & keuzedag & & keuzedag \\
\hline 24 & $\mathrm{ma}$ & 24 & DD & De Koning bakt een huis & DD & Kees en Keetje \\
\hline 24 & di & 25 & $\mathrm{KP}$ & Epompee & $\mathrm{KP}$ & Vrolijk... \\
\hline 24 & wo & 26 & NG & De prinses op de erwt & NG & Briefjes in het bos \\
\hline 24 & do & 27 & & keuzedag & NG & De Bremer stadsmuzikanten \\
\hline 24 & $\mathrm{vr}$ & 28 & & keuzedag & & keuzedag \\
\hline 25 & $\mathrm{ma}$ & 31 & $\mathrm{DD}$ & De rijkaard en de schoenmaker & DD & Vergeet de mieren niet! \\
\hline & APR & & & & & \\
\hline 25 & di & 1 & $\mathrm{KP}$ & In de gekke-dingen-school & $\mathrm{KP}$ & De drie vliegen \\
\hline 25 & wo & 2 & NG & Komediant & NG & Appeltaart \\
\hline 25 & do & 3 & & keuzedag & DD & De eend en de vos \\
\hline 25 & $\mathrm{vr}$ & 4 & & keuzedag & & keuzedag \\
\hline 26 & $\mathrm{ma}$ & 7 & $\mathrm{DD}$ & Zwemmen & $\mathrm{DD}$ & De leeuw en de haas \\
\hline 26 & di & 8 & $\mathrm{KP}$ & $\begin{array}{l}\text { Ikkeltje, Tikkeltje, Spikkeltje } \\
\text { Boem }\end{array}$ & $\mathrm{KP}$ & De koning van Savoye \\
\hline 26 & wo & 9 & NG & Koekjes & NG & Het vrouwtje van Stavoren \\
\hline 26 & do & 10 & & keuzedag & $\mathrm{KP}$ & De vier koningen \\
\hline 26 & $\mathrm{vr}$ & 11 & & keuzedag & & keuzedag \\
\hline 27 & $\mathrm{ma}$ & 14 & DD & $\begin{array}{l}\text { Kleine Ezel en het zwarte } \\
\text { schaapje }\end{array}$ & DD & Een halve appel \\
\hline 27 & di & 15 & $\mathrm{KP}$ & Gele stippen op een ei & $\mathrm{KP}$ & Gekleurde eitjes en een haas \\
\hline 27 & wo & 16 & NG & Een hemelse maaltijd & NG & De weerwolf \\
\hline 27 & do & 17 & & keuzedag & & keuzedag \\
\hline 27 & $\mathrm{vr}$ & 18 & & keuzedag & & keuzedag \\
\hline 28 & di & 22 & $\mathrm{DD}$ & De leeuw en de muis & $\mathrm{DD}$ & De leeuw en de muis \\
\hline 28 & wo & 23 & $\mathrm{KP}$ & Een bof & $\mathrm{KP}$ & Dwaze droom \\
\hline 28 & do & 24 & NG & De koning en zijn schat & NG & Gierigheid gestraft \\
\hline 28 & $\mathrm{vr}$ & 25 & & keuzedag & & keuzedag \\
\hline 29 & di & 6 & DD & Kleine Beer is jarig & DD & Je moeder! Je moeder! Je moeder! \\
\hline 29 & wo & 7 & $\mathrm{KP}$ & Stekelvarkentjes Wiegelied & $\mathrm{KP}$ & Stekelvarkentjes wiegelied \\
\hline 29 & do & 8 & NG & Een grote ezel/Kleine Ezel & NG & Tijl Uilenspiegel als kunstschilder \\
\hline 29 & $\mathrm{vr}$ & 9 & & keuzedag & & keuzedag \\
\hline 30 & $\mathrm{ma}$ & 12 & $\mathrm{DD}$ & Kikker is Kikker & $\mathrm{DD}$ & De jonge die altijd te laat kwam \\
\hline 30 & di & 13 & $\mathrm{KP}$ & Een meestampertje & $\mathrm{KP}$ & Een meestampertje \\
\hline
\end{tabular}




\begin{tabular}{|c|c|c|c|c|}
\hline \multicolumn{2}{|c|}{2013} & GROEP 2 & \multicolumn{2}{|c|}{ GROEP 4} \\
\hline \multicolumn{2}{|c|}{ Iv-week } & Titel & & Titel \\
\hline 30 & wo 14 & $\begin{array}{l}\text { NG De muis die in een meisje } \\
\text { veranderde }\end{array}$ & NG & De bananenverdeling \\
\hline 30 & do 15 & keuzedag & NG & De steenhouwer \\
\hline 30 & vr 16 & De laatste Leeskalenderdag & & De laatste Leeskalenderdag \\
\hline
\end{tabular}




\section{Bijlage 3}

\section{Leeskalenderproject: overzicht van deelnemende scholen}

\begin{tabular}{ll}
\hline Basisschool & Deelnemende groepen \\
\hline HEERLEN & \\
Broederschool Molenberg & groep 4 \\
't Pannesjop & groep 2a, groep 2b; groep 4 \\
De Piramide & groep 2; groep 4 \\
De Wegwijzer & groep 2a, groep 2b; groep 4 \\
MAASTRICHT & \\
De Kring & groep 2a, groep 2b \\
De Lètterdoes (uitgevallen) & groep 2a, groep 2b, groep 2c; groep 4 \\
Markus & groep 2; groep 4 \\
NIJMEGEN & \\
Hidaya & groep 2a, groep 2b; groep 4 \\
SPRANG-CAPELLE & \\
De Prins Willem-Alexanderschool & groep 2a, groep 2b; groep 4a, groep 4b \\
TILBURG & \\
Aboe el-Chayr & groep 2a, groep 2b; groep 4 \\
Pendula & groep 2a, groep 2b, groep 2c, groep 2d \\
De Stelaertshoeve & groep 4a, groep 4b \\
De Vlashof & groep 2, groep 2-3; groep 4 \\
VENLO & \\
Montessorischool & groep 2a, groep 2b, groep 2c; groep 4a, groep 4b, groep 4c \\
Natuurlijk! & groep 2a, groep 2b; groep 4a, groep 4b \\
De Ontdekking & groep 2a, groep 2b; groep 4 \\
Sint-Jozef (Tegelen) & groep 2a, groep 2b, groep 2c; groep 4 \\
\hline
\end{tabular}




\section{Bijlage 4}

\section{Protocol voor afname Toets Ontluikende Culturele Geletterdheid}

\section{Toelicbting}

De Toets Ontluikende Culturele Geletterdheid wordt afgenomen in het kader van experimenteel onderzoek. Dit betekent dat de toets nauwkeurig moet worden afgenomen en vastgelegd en dat de antwoorden van de kinderen zo nauwkeurig mogelijk moeten worden genoteerd. Er zijn daarom enkele spelregels waaraan we ons moeten houden. Deze spelregels staan hieronder weergegeven. Lees ter voorbereiding onderstaande spelregels door, lees de specifieke instructies op de volgende pagina's en neem de toetsboekjes een paar keer door om bekend te raken met de vraagstellingen en soorten antwoordcategorieën. Uiteraard is de praktijk de beste leerschool, maar dit ter voorbereiding.

\section{Materialen}

Bij de toetsafnames worden de volgende materialen gebruikt:

1. Een voorleesexemplaar van het toetsboekje voor groep 2 of groep 4.

2. Scoreformulieren voor groep 2 of groep 4.

3. Een PowerPoint presentatie met plaatjes en geluidsfragmenten voor groep 2 of groep 4.

4. Een laptop waarop de PowerPoint presentatie kan worden getoond en waarop de geluidsfragmenten kunnen worden afgespeeld.

5. Een cd of USB-stick met daarop de PowerPoint presentaties met afbeeldingen en geluidsfragmenten voor groep 2 en voor groep 4.

6. Een (digitale) camera of webcam voor opname van de toetsafnames.

7. Een klassenlijst met de namen van de kinderen in de betreffende groep 2 of groep 4 .

NB: De onderzoekers en scholencoördinator zijn verantwoordelijk voor het aanleveren, verzamelen en verwerken van de materialen. Daar waar nodig maken zij hierover aparte afspraken met $u$.

Algemene spelregels

- De toets wordt altijd door twee personen afgenomen: een afnameleider en een scoorder (specifieke instructies voor beide rollen staan op pagina 3 en 4).

- De toets wordt alleen afgenomen bij kinderen die dit schooljaar in groep 2 en in groep 4 zitten (bij combinatieklassen worden kinderen uit groep 1, 3 of 5 dus niet getoetst).

- De toets wordt steeds bij één kind tegelijk afgenomen in een aparte en rustige ruimte op school en dit wordt per kind apart opgenomen met een (digitale) videocamera of webcam. 
- Kinderen worden opgehaald uit de klas en teruggebracht naar de klas: uit ervaring blijkt dat dit het makkelijkst door de afnameleider kan worden gedaan. Spreek in ieder geval onderling af wie dit doet en zorg dat er niet onnodig tijd mee verloren gaat.

- Bij ieder kind wordt een volledig toetsboekje afgenomen (hiervan mag worden afgeweken als het kind tijdens de toetsafname onwel wordt, overstuur raakt of herhaaldelijk aangeeft terug naar de klas te willen): de vragen worden altijd gesteld op de volgorde van het toetsboekje.

- Houd op een klassenlijst nauwkeurig bij welke kinderen zijn getoetst: zorg dat deze lijst door de leerkracht in de klas wordt bewaard zodat een volgend toetsteam de lijst kan raadplegen.

- Kinderen die op geen van de toetsdagen aanwezig zijn, of waarvan de ouders geen toestemming hebben gegeven voor deelname aan de toets, worden niet getoetst.

- Als zich tijdens de toetsafname iets voordoet waardoor deze onrustig, onvolledig of anderszins afwijkend verloopt, noteer dit dan duidelijk op het scoreformulier dat hoort bij de betreffende afname.

- De richtlijn is dat er 's ochtends van 8:30 tot 12:00 uur acht kinderen en 's middags tussen 13:00 en 15:00 uur vier kinderen getoetst worden ${ }^{206}$. De toetsafname kan dus per kind ongeveer 20 minuten duren. Omdat we een specifiek aantal kinderen moeten toetsen is het van belang dat $\mathrm{u}$ zich hier zoveel mogelijk aan probeert te houden. Houd er rekening mee dat het ook tijd kost om kinderen van en naar de klas te begeleiden.

- Als toetsafnemer of scoorder bent u een neutrale partij met als enig belang de toets op de juiste manier af te nemen: ga daarom niet met leerkrachten in gesprek over het project, maar verwijs hen bij vragen altijd door naar de scholencoördinator of, indien aanwezig, naar een van de onderzoekers.

- Daarnaast is uw taak ook niet om kinderen de toets zo goed mogelijk te laten maken: help ze dus niet en houd u aan de vragen zoals opgenomen in het toetsboekje.

- En natuurlijk: schrijf in een leesbaar handschrift, zorg altijd dat op de scoreformulieren de nodige gegevens over de afname zijn ingevuld en houd zorgvuldig bij welke kinderen getoetst zijn.

Instructies voor het afnemen van de toets door de afnameleider

De afnameleider stelt de toetsvragen uit het voorleesexemplaar van het toetsboekje en bedient daarbij de laptop voor het tonen van de afbeeldingen en het afspelen van de geluidsfragmenten. Bij gebruik van een webcam bedient de afnameleider ook de webcam. Stapsgewijze instructie:

\section{* Voor de afname:}

1. Zet de laptop klaar met de PowerPoint presentatie voor de juiste groep (2 of 4): controleer of het volume open staat en de geluidsfragmenten goed te verstaan zijn.

2. Bij het gebruik van een webcam: sluit deze aan op de laptop en/of zorg dat deze goed is afgesteld (focus, microfoon ingeschakeld).

3. Zorg dat $u$ het toetsboekje voor de juiste groep (2 of 4) voor u hebt.

${ }^{206}$ Houd u wel aan de officiële schooltijden, deze kunnen afwijken van genoemde tijden. 
4. Haal het kind op uit de klas, start de video-opname zodra het kind klaar zit en noem de starttijd zodat de scoorder deze kan noteren (en we de opnames later aan de juiste kinderen kunnen koppelen).

* Tijdens de afname:

5. Begin met de eerste vraag in het toetsboekje en werk de vragen één voor één af. In het toetsboekje staat aangegeven waar u een nieuwe dia (DIA) moet laten zien en waar u een geluidsfragment (\$)) moet starten (klik in PowerPoint op de )). NB: Laat geluidsfragmenten maar één keer horen, behalve als er een verstoring is.

6. Geef kinderen tijd om een antwoord te formuleren, maar laat stiltes niet te lang duren. Iedere vraag in de toets heeft een eerste formulering en een herformulering: als een kind niet direct een antwoord geeft, stel dan de herformulering. Geeft het kind weer geen antwoord? Ga dan door naar de volgende vraag. NB: 'weet ik niet' telt als een antwoord.

7. Sla geen vragen over en voeg geen vragen toe, ook niet als u denkt dat een kind net dat kleine zetje nodig heeft: het mag écht niet. Houd u aan het toetsboekje.

8. Als kinderen bij wijze van antwoord een plaatje aanwijzen op de laptop, benoem dan zelf welk plaatje het kind aanwijst zodat de scoorder dit kan noteren. Als kinderen onduidelijk spreken, herhaal dan hun antwoord of vraag het kind het antwoord nog eens te herhalen.

9. Stel kinderen wel gerust of moedig ze af en toe aan (bijvoorbeeld: "Wat doe jij goed je best, zeg" of, als ze iets niet weten te beantwoorden, "Dat is niet erg, dan gaan we toch gewoon naar het volgende verhaal luisteren"), maar vertel ze nooit of ze een vraag goed beantwoord hebben en geef ze nooit het goede antwoord (ook niet na afloop)207.

10. Beëindig de video-opname zodra de afname klaar is en benoem de eindtijd van de afname zodat de scoorder deze kan noteren.

Instructies voor het scoren van de antwoorden door de scoorder

De scoorder noteert de antwoorden van de kinderen op het scoreformulier. Als er gebruik wordt gemakkt van een losse (digitale) camera dan bedient u deze ook. Stapsgewijze instructie:

* Voor de afname:

1. Zorg dat u voldoende scoreformulieren voor de juiste groep (2 of 4) voor u heeft liggen.

2. Zorg, bij gebruik van een losse (digitale) camera, dat deze goed staat afgesteld (focus, microfoon ingeschakeld). Start de opname zodra het kind klaar zit en beëindig de opname zodra de toetsafname klaar is.

3. Noteer altijd de naam van de school, de groep, de voor- en achternaam van het kind, de datum, etc. van de betreffende toetsafname alvast op het scoreformulier.

\section{Tijdens de afname:}

4. Start, bij gebruik van een losse (digitale) camera, de video-opname zodra het kind klaar zit. NB: Noteer altijd de begintijd van de toetsafname op het scoreformulier! (zodat de onderzoekers de opnames later aan de juiste kinderen kunnen koppelen, ook bij gebruik van een webcam)

${ }^{207}$ Dit vanwege het feit dat de toets na de interventie opnieuw wordt afgenomen bij dezelfde kinderen. 
5. Streep bij een meerkeuzevraag altijd het antwoord aan dat het kind geeft. NB: Noteer bij een open vraag het letterlijke antwoord dat het kind geeft in de open ruimte bij de vraag op het scoreformulier. Probeer de antwoorden van de kinderen op open vragen daarna zoveel mogelijk te scoren op de weergegeven antwoordcategorieën. 'Weet ik niet' telt als antwoord: streep in dat geval de categorie '0:9 geen antwoord/weet ik niet' aan.

6. Vink op het scoreformulier aan of het kind antwoord geeft na de eerste of tweede vraagstelling.

7. Soms moet u ook noteren of het kind een bepaalde directe reactie geeft op een plaatje of een geluidsfragment: kijk naar het kind en kruis aan wat van toepassing is of noteer hoe het kind reageert.

8. Hebt $\mathrm{u}$ een antwoord gemist of twijfelt $\mathrm{u}$ of $\mathrm{u}$ het goed heeft verstaan? Maak hiervan dan een aantekening in de kantlijn (bijv.: 'antwoord gemist') van het betreffende scoreformulier zodat de onderzoekers weten dat ze dit later moeten controleren in de videoopname.

9. Stel geen vragen aan de kinderen tijdens de afname: de afnameleider stelt de vragen. Als $\mathrm{u}$ merkt dat de afnameleider een vraag overslaat of de afname gaat $\mathrm{u}$ te snel/te langzaam, geef dan even een seintje aan de afnameleider.

\section{* Na afloop van de afname:}

10. (Stop de videocamera en) noteer de eindtijd van de afname. Controleer of de nodige gegevens op het scoreformulier zijn ingevuld. Loop na of de antwoorden leesbaar zijn ingevuld. Schrijf de nodige gegevens alvast op het scoreformulier voor het volgende kind.

Algemene instructies na afloop van het toetsen

- Laat toetsmaterialen (toetsboekjes en scoreformulieren) niet achter op school: hou deze altijd bij u. Over het verzamelen van ingevulde scoreformulieren wordt u nader geïnformeerd, evenals over het verzamelen van video opnames.

- Voor het bijhouden van het toetsschema is het belangrijk dat de onderzoekers op de hoogte zijn van hoeveel kinderen er op een dag zijn getoetst en welke kinderen in welke groepen al aan de beurt zijn geweest. Stuur daarom op de dagen dat u niet samen met een van de onderzoekers of de scholencoördinator toetst, een mail met de volgende informatie naar Annette de Bruijn [mailadres]:

○ het aantal leerlingen dat u die dag getoetst heeft;

○ de school en de groep(en) waar u hebt getoetst;

o of $\mathrm{u}$ een groep heeft afgerond of niet.

- Als u onverhoopt toch niet kan toetsen op een dag waarop u bent ingepland, laat dit dan ook zo spoedig mogelijk weten aan uw contactpersoon. Zij kan dan proberen nog een vervanger te vinden. We hopen natuurlijk dat dit niet nodig zal zijn. Er is weinig ruimte om te schuiven. 


\section{Bijlage 5}

\section{Logboekgegevens}

\section{Logboekgegevens over de nitvoering van het Leeskalenderproject als geheel}

Leerkrachten die gedurende dertig weken in het schooljaar 2013-2014 met de Leeskalender hebben gewerkt, is gevraagd om voor iedere Leeskalenderdag een logboekblad in te vullen. De ingevulde logboekbladen zijn tijdens en na afloop van de interventie verzameld. De logboeken geven een schat van informatie over het gebruik van de Leeskalender in de klas. In dit verslag worden alleen die aspecten bekeken die gekwantificeerd kunnen worden voor de statistische analyses. In totaal zijn door 33 groepen logboeken ingevuld. Vier groepen (één school) zijn rond kerst 2013 met de Leeskalender gestopt. De logboeken van deze school zijn verder niet geanalyseerd. Dit betekent dat er voor de analyses logboeken van 29 groepen beschikbaar zijn: er zijn logboeken van 17 groepen 2 en 12 groepen 4 . Er is in de logboeken gekeken naar kwantificeerbare gegevens die iets zeggen over de mate waarin de Leeskalender daadwerkelijk gebruikt is in de klas en over de waardering die leerkrachten voor het Leeskalenderaanbod hebben. De volgende maten zijn geselecteerd: logboektrouw, kalendertrouw, bestede tijd (duur) en algemene waardering. Hieronder wordt elk van deze maten besproken, eerst voor het Leeskalenderproject als geheel en vervolgens voor het deelproject Kinderpoëzie. De logboekbladen op basis waarvan de gegevens verkregen zijn, zijn opgenomen aan het einde van deze bijlage.

\section{Logboektroum}

De leerkrachten hebben niet altijd de logboekbladen volledig ingevuld en soms helemaal niet. In totaal is voor $74 \%$ van de kalenderdagen iets ingevuld op een logboekblad. Regelmatig werden de logboekbladen uitgebreid ingevuld, inclusief uitgeschreven opmerkingen van de kinderen. Soms werd ook alleen aangekruist dat het betreffende kalenderblad niet was gedaan. Per groep verschilde de logboektrouw tussen $45 \%$ en $95 \%$.

\section{Kalendertroum}

De kalendertrouw is niet exact vast te stellen omdat de logboekbladen niet altijd zijn ingevuld. Er moet dus een schatting gemaakt worden. We gaan er hier van uit dat een kalenderdag niet gedaan is wanneer er geen logboekblad is ingevuld. Dat is een conservatieve maat, aangezien het mogelijk is dat een groep het kalenderblad wel degelijk heeft gedaan, maar dat de leerkracht niet meer aan het invullen van het logboek toekwam, ook niet op een later moment. Het lijkt echter problematischer om kalenderdagactiviteiten toe te kennen wanneer die mogelijk helemaal niet plaatsgevonden hebben, zodat we deze conservatieve maat toch zullen aanhouden.

De kalendertrouw is berekend door van het totaal van het aantal ingevulde logboekbladen het aantal af te trekken waarop was ingevuld dat de kalenderdag helemaal niet gedaan was, ook niet op een andere dag. Van de in totaal 150 kalenderdagen hebben de groepen er 
volgens deze maat naar schatting tussen de 42 en 121 gedaan, met een gemiddelde van 85,1 kalenderdagen (57\%). Het werkelijk gedane aantal kalender dagen ligt waarschijnlijk hoger.

\section{Aan de kalender bestede tijd}

Wanneer een kalenderactiviteit had plaatsgevonden kon er op het betreffende logboekblad aangegeven worden hoeveel tijd eraan besteed was. Dit is niet altijd ook daadwerkelijk ingevuld, ook niet wanneer er wel andere informatie over die kalenderdag in het logboek is ingevuld. In totaal is bij $89 \%$ van de gedane kalenderdagen wel ingevuld hoeveel tijd eraan besteed is. Dit verschilde tussen de $40 \%$ en 100\% per groep (gemiddeld $89 \%$ ).

De groepen besteedden tussen de gemiddeld 9,3 en gemiddeld 25,5 minuten aan de gedane kalenderdagen. Het gemiddelde van alle groepen was 15,6 minuten per gedane kalenderdag. In totaal, dus over de dertig interventieweken heen, is er door de groepen naar eigen zeggen tussen de 244 en 2.575 minuten aan de Leeskalender besteed, met een gemiddelde van 1.217 minuten per groep. Dat is ruim 20 uur. Het kwam af en toe voor dat groepen in het logboek aangaven een kalenderdag wel gedaan te hebben, maar de duur niet hadden opgeschreven. De totaal bestede duur kan nog iets nauwkeuriger berekend worden door voor deze dagen de duur te schatten op basis van de gemiddelde duur van de Leeskalender-activiteiten waar deze wel gerapporteerd was. De totale duur op basis van deze extrapolatie is gemiddeld 1.342,7 minuten (ruim 22 uur), variërend van 582,5 tot 2.694,2 minuten per groep.

\section{Waardering van de leeskalender}

Bij iedere kalenderdag konden de leerkrachten aangeven in hoeverre de leerlingen over het geheel genomen hadden genoten van de Leeskalender die dag. De waardering moest uitgedrukt worden op een vijfpunt-Likertschaal (1=helemaal niet, $2=$ onvoldoende, $3=$ voldoende, $4=$ ruim voldoende, $5=$ goed). De gemiddelde waardering was 4,0 en varieerde per groep van een overall waardering van 3,1 tot 4,7 voor het Leeskalenderaanbod.

\section{Verschillen tussen de groepen}

Er is gekeken of bovenstaande maten verschillen tussen de groepen 2 en de groepen 4. Soms zijn er wel verschillen, maar die zijn niet significant. Eveneens is gekeken of er verschillen zijn tussen de groepen die een volledige Leeskalender hadden en de groepen die een afgeslankte versie van de Leeskalender ${ }^{208}$ kregen. Ook die verschillen zijn niet significant. Verder is het doel van dit onderzoek niet om de deelprojecten te vergelijken, zodat er ook statistisch geen vergelijkende analyses zijn gedaan. Wel zijn de hierboven beschreven maten ook per deelproject geanalyseerd. Hieronder geef ik de resultaten voor het deelproject Kinderpoëzie weer.

\footnotetext{
${ }^{208}$ Zie Hoofdstuk 6, \$6.5. Er zijn vier verschillende versies van de Leeskalender ontwikkeld en geïmplementeerd: een volledige versie waarin het tekstaanbod van elk van de drie deelprojecten was opgenomen en drie 'afgeslankte' versies waarin steeds eens van de deelprojecten niet was opgenomen, dus een versie zonder Deugden \& Dilemma's, een versie zonder Kinderpoëzie en een versie zonder Narratieve Genres.
} 


\section{Logboekgegevens over het Leeskalenderproject met Kinderpoëzie}

\section{Logboektrouw op de kinderpoëziedagen}

In totaal hebben 22 groepen gewerkt met een Leeskalender met kinderpoëzie, waarvan 14 groepen (1-)2 en 8 groepen 4 . In totaal is binnen deze groepen voor $84 \%$ van de kinderpoeziedagen iets ingevuld op een logboekblad. Regelmatig werden de logboekbladen uitgebreid ingevuld, inclusief uitgeschreven opmerkingen van de kinderen. Soms werd ook alleen aangekruist dat het betreffende kalenderblad niet was gedaan. Per groep verschilde de logboektrouw op de kinderpoëziedagen tussen $60 \%$ en 100\%. De logboektrouw verschilde niet veel tussen groepen 2 en groepen 4 : in groepen 2 is voor $85 \%$ van de kinderpoeziedagen het logboekblad ingevuld en in groepen 4 voor $82 \%$ van de kinderpoëziedagen.

\section{Kalendertrouw op de kinderpoëziedagen}

De kalendertrouw op de kinderpoëziedagen is niet exact vast te stellen omdat de logboekbladen niet altijd zijn ingevuld. Er moet dus een schatting gemaakt worden. We gaan er hier van uit dat een kinderpoëziedag niet gedaan is wanneer er geen logboekblad is ingevuld. Dat is een conservatieve maat aangezien het mogelijk is dat een groep het kalenderblad wel degelijk heeft gedaan, maar dat de leerkracht niet meer aan het invullen van het logboek toekwam, ook niet op een later moment. Het lijkt echter problematischer om kalenderdagactiviteiten toe te kennen wanneer die mogelijk helemaal niet plaatsgevonden hebben, zodat we deze conservatieve maat toch zullen aanhouden.

De kalendertrouw is berekend door van het totaal van het aantal ingevulde logboekbladen op kinderpoëziedagen het aantal af te trekken waarop was ingevuld dat de kalenderdag helemaal niet gedaan was, ook niet op een andere dag. Volgens deze maat hebben de groepen over het geheel genomen naar schatting tussen de 17 en 53 dagen kinderpoëzie aangeboden, met een gemiddelde van 30,2 poëziedagen. Het werkelijk gedane aantal poëziedagen ligt waarschijnlijk hoger. In groep 2 waren in totaal 30 poëziedagen in de Leeskalender opgenomen, afhankelijk van de Leeskalenderversie en keuzes van de kinderen aangevuld met herhalingsdagen en keuzedagen. In groepen 2 is volgens deze maat naar schatting tussen de 17 en 53 dagen met kinderpoëzie gewerkt, met een gemiddelde van 31,1 dagen. In groep 4 waren in totaal 39 poëziedagen opgenomen, afhankelijk van de keuzes van de kinderen aangevuld met keuzedagen. In groepen 4 is volgens deze maat naar schatting tussen de 17 en 39 dagen met kinderpoëzie gewerkt, met een gemiddelde van 28,8 dagen.

\section{Aan kinderpoëzie bestede tijd}

In totaal is in groepen 2 bij 94\% van de gedane kinderpoëziedagen wel ingevuld hoeveel tijd eraan besteed is. Bij groepen 4 is in totaal bij $87 \%$ van de gedane kinderpoëziedagen ingevuld hoeveel tijd eraan besteed is. Als we alle groepen bij elkaar nemen, werd in de groepen tussen de gemiddeld 10,7 en gemiddeld 24,7 minuten aan de gedane kinderpoëziedagen besteed. Het gemiddelde van alle groepen was 15 minuten per gedane kinderpoëziedag. In totaal, dus over de dertig interventieweken heen, is er door de groepen naar eigen zeggen tussen de 115 en 1.235 minuten aan kinderpoëzie in de Leeskalender besteed, met een gemiddelde van 425 minuten per groep ( 7 uur). Het kwam af en toe voor dat groepen in het logboek aangaven een kinderpoëziedag wel gedaan te hebben, maar de duur niet 
hadden opgeschreven. De totaal bestede duur kan nog iets nauwkeuriger berekend worden door voor deze dagen de duur te schatten op basis van de gemiddelde duur van de kinderpoëzie-activiteiten waar deze wel gerapporteerd was. De totale duur op basis van deze extrapolatie is gemiddeld 464 minuten (7,7 uur), variërend van 217 minuten (3,6 uur) tot 1309 minuten (21,8 uur) per groep.

Kijken we alleen naar groepen 2 dan zien we dat in deze groepen tussen de gemiddeld 10,7 en gemiddeld 24,7 minuten aan de gedane kinderpoëziedagen besteed werd. Het gemiddelde van alle groepen 2 was 15,6 minuten per gedane kinderpoëziedag. In totaal, dus over de dertig interventieweken heen, is er door de groepen 2 naar eigen zeggen tussen de 247 en 1.235 minuten aan kinderpoëzie in de Leeskalender besteed, met een gemiddelde van 467,6 minuten per groep (7,8 uur). De totaal bestede duur per groep 2 kan nog iets nauwkeuriger berekend worden door voor de kinderpoëziedagen waarop wel met de Leeskalender is gewerkt, maar de bestede tijd niet is ingevuld, de duur te schatten op basis van de gemiddelde duur van de kinderpoëzie-activiteiten waar deze wel gerapporteerd was. De totale tijd die in de groepen 2 is besteed aan kinderpoëzie op basis van deze extrapolatie is gemiddeld 496,9 minuten (8,3 uur), variërend van 305 minuten (5 uur) tot 1309 minuten (21,8 uur) per groep.

Kijken we alleen naar groepen 4 dan zien we dat in deze groepen tussen de gemiddeld 11,3 en gemiddeld 17,9 minuten aan de gedane kinderpoëziedagen besteed werd. Het gemiddelde van alle groepen was 14 minuten per gedane poëziedag. Over de dertig interventieweken heen is er door de groepen 4 naar eigen zeggen tussen 115 en 590 minuten aan kinderpoëzie in de Leeskalender besteed, met een gemiddelde van 359 minuten per groep (6 uur). Ook voor groepen 4 kan de totaal bestede tijd nog iets nauwkeuriger berekend worden door voor de kinderpoëziedagen waarop wel met de Leeskalender is gewerkt, maar de bestede tijd niet is ingevuld, de duur te schatten op basis van de gemiddelde duur van de kinderpoëzie-activiteiten waar deze wel gerapporteerd was. De totale tijd die in de groepen 4 is besteed aan kinderpoëzie op basis van deze extrapolatie is gemiddeld 411,9 minuten (6,9 uur), variërend van 217,2 minuten (3,6 uur) tot 626 minuten (10,4 uur) per groep.

\section{Waardering van het aanbod kinderpoëzie in de Leeskalender}

Bij iedere kinderpoëziedag konden de leerkrachten in het logboek aangeven in hoeverre de leerlingen over het geheel genomen hadden genoten van de Leeskalender die dag. De waardering moest uitgedrukt worden op een vijfpunt-Likertschaal ( $1=$ helemaal niet, $2=$ onvoldoende, $3=$ voldoende, $4=$ ruim voldoende, $5=$ goed). De gemiddelde waardering over het geheel van de groepen die met een Leeskalender+Kinderpoëzie werkten, was 3,9 en varieerde per groep van een overall waardering van 3,1 tot 4,7 voor het kinderpoëzieaanbod.

In groepen 2 varieerde de gemiddelde waardering van kinderpoëzie tussen de groepen van 3,1 tot 4,6 met een gemiddelde waardering van 3,9. In groepen 4 varieerde de gemiddelde waardering van kinderpoëzie tussen de groepen van 3,2 tot 4,7 met een gemiddelde waardering van 4,1 . 


\section{Bijlage 6}

\section{Oudervragenlijsten: poëtische socialisatie in het gezin}

\section{De oudervragenlijst}

Om inzicht te krijgen in het (voor)leesklimaat (ook zingen van liedjes en opzeggen van rijmen) bij de kinderen thuis, is een oudervragenlijst ontwikkeld. Deze oudervragenlijst is ontwikkeld door dr. Elma Nap-Kolhoff ${ }^{209}$ in samenspraak met de onderzoekers binnen het Emergent Cultural Literacy onderzoeksproject. De oudervragenlijst is aan het begin van het schooljaar waarin de interventie heeft plaatsgevonden (2013-2014) via de leerkrachten verspreid onder de ouders van kinderen in de deelnemende groepen, zowel in de controleals experimentele conditie. In de oudervragenlijst zijn ten eerste vragen te vinden over onder andere het opleidingsniveau van de ouders, land van herkomst, de thuistaal of -talen, boekenbezit, voorlezen en bibliotheekbezoek. Een deel van deze vragen is ontleend aan de onderzoekspublicatie In de ogen van de ouders. Basisrapportage oudervragenlijst (Nap-Kolhoff, $\left.2011^{210}\right)$. Ten tweede zijn er vragen in opgenomen over de bekendheid met boekfiguren waarvan we verwachten dat die bekend zullen zijn in gezinnen waarin regelmatig wordt (voor-)gelezen. Het gaat dan om klassiek te noemen boekfiguren uit prentenboeken en verhalenbundels voor kinderen vanaf de peuterleeftijd tot en met de onderbouw, zoals Dribbel, Nijntje, Kikker, Jip en Janneke, Robin, Winnie de Poeh en Madelief. Een deel van deze boekfiguren is ook in de Leeskalender te vinden. De selectie van de boekfiguren is gebaseerd op de selectie op Leesplein (www.leesplein.nl), in de Boek en Jeugd Gids (tegenwoordig te vinden op www.boekenjeugd.nl) en in de onderzoekspublicatie Elke dag boekendag (Ghonem-Woets, 2009211). Daarnaast zijn er vragen opgenomen over specifieke boektitels die relevant zijn voor (een van) de drie deelprojecten. Die titels behoren tot de categorieën sprookjes en fabels, gedichten en liedjes en religieuze verhalen. Deze titels zijn ontleend aan het bestand met titels waaruit de teksten voor de Leeskalender zijn geselecteerd.

De ingevulde oudervragenlijsten die we, via de leerkrachten, hebben terugontvangen, leveren daarmee een schat van informatie over de achtergronden van de kinderen die betrokken waren in dit onderzoek. Specifiek geven ze inzicht in de mate waarin bepaalde genres en tekstsoorten uit de kinderliteratuur in gezinnen bekend zijn. Niet alleen zijn deze gegevens van belang voor het analyseren en interpreteren van de Toets Ontluikende Culturele Geletterdheid; de gegevens zijn op zichzelf ook interessant omdat ze een beeld schetsen van het geletterdheidsklimaat bij kinderen thuis en de rol die de binnen dit onder-

\footnotetext{
209 Als methodoloog betrokken bij dit onderzoeksproject.

${ }^{210}$ Nap-Kolhoff, Elma: In de ogen van de ouders. Basisrapportage oudervragenlijst. Centrum Onderwijskansen Kaans / Moelejaan Peuters / Maastricht University School of Business and Economics, 2011. Te downloaden via: www.kaans.nl (onder 'Publicaties').

211 Ghonem-Woets, Karen: Elke dag boekendag. Verslag van een onderzoek naar het voorlezen van prentenboeken in groep 1 en 2. Groningen: Rijksuniversiteit Groningen / Tilburg: Universiteit van Tilburg. M.m.v. Cubiss (Tilburg) en Stichting Lezen (Amsterdam), maart 2009. Te downloaden via: www.lezen.nl (http://www.lezen.nl/sites/default/files/ Elke\%20dag\%20boekendag\%21.pdf)
} 
zoeksproject onderzochte 'canonieke' (duurzaam geliefde en (trans)cultureel diepgewortelde) genres en tekstsoorten daarin spelen. Omdat in dit deelproject kinderpoëzie centraal staat en er nog minder bekend is over het gebruik van kinderpoëzie in hedendaagse gezinnen in Nederland dan over bijvoorbeeld het gebruik van prentenboeken, beperk ik me hier tot een bespreking van wat de oudervragenlijsten ons vertellen over bekendheid met en gebruik van poëzie en liedjes thuis. In totaal zijn 463 vragenlijsten ingevuld door ouders van kinderen op 17 scholen. Per school zijn er tussen de 11 en 50 vragenlijsten ingevuld, met een gemiddelde van 27,2 vragenlijsten. Er zijn 235 vragenlijsten voor groep 2 en 228 voor groep 4. We mogen er van uitgaan dat gezinnen waarin sprake is laaggeletterdheid en/of slechte (of geen) beheersing van de Nederlandse taal relatief ondervertegenwoordigd zijn in deze 'populatie', hoewel dit deels is opgevangen doordat op een van de twee deelnemende Islamitische scholen leerkrachten en tolken zijn ingezet om ouders te helpen de vragenlijst in te vullen.

\section{Poëtische socialisatie in het gezin}

Liedjes zingen en versjes opzeggen gebeurt, zo rapporteren de ouders, regelmatig bij de kinderen thuis. Bij $42 \%$ van de kinderen worden af en toe liedjes gezongen of versjes opgezegd, bij 31\% gebeurt dat één of meerdere keren per week en bij $27 \%$ dagelijks of meerdere keren per dag. De verschillen tussen groep 2 (34\% minimaal dagelijks) en groep 4 (19\% minimaal dagelijks) zijn aanzienlijk en statistisch significant $(\mathrm{t}(382)=3,524 ; \mathrm{p}<, 001)$. Ter vergelijking: de mate waarin kinderen thuis worden voorgelezen varieert van 'af en toe' $(33 \%)$ en 'één keer per week' (27\%) tot 'dagelijks' of 'meerdere keren per dag' (40\%). Er is een groot verschil tussen groep 2 (52\% minimaal dagelijks) en groep 4 (26\% minimaal dagelijks). Dit verschil is statistisch significant $(\mathrm{t}(415)=4,886 ; \mathrm{p}<, 001)$.

In de oudervragenlijst is ouders gevraagd of ze zelf kinderliedjes/-versjes kennen. Van de ouders van kinderen in groep 2 die op deze vraag een antwoord hebben ingevuld, zegt $6 \%$ geen liedjes of versjes te kennen en $90 \%$ wel; van de ouders van kinderen in groep 4 zegt $9 \%$ geen en $79 \%$ wel liedjes en versjes te kennen. Ook is gevraagd waar ouders die liedjes of versjes van kennen. Van de ouders die wel liedjes en versjes zeggen te kennen, zijn dit de bronnen op volgorde van meest naar minst vaak aangekruist (ouders konden meerdere opties aankruisen):

\begin{tabular}{lcc}
\hline Bron van liedjes/versjes & Ouders groep 2 (in \%) & Ouders groep 4 (in \%) \\
\hline Van eigen basisschooltijd & 79,1 & 75,0 \\
Van eigen ouders & 64,5 & 66,1 \\
Van televisie/Dvd & 54,0 & 43,3 \\
Van cd & 38,9 & 33,9 \\
Van internet/YouTube & 28,0 & 28,9 \\
Van liedjesbundels & 17,5 & 20,6 \\
\hline
\end{tabular}


Als we de bronnen samenvoegen tot drie categorieën, te weten 'mondeling', 'print' en 'audiovisueel', dan ontstaat het volgende beeld van de wijzen waarop hedendaagse ouders van kinderen in groep 2 en/of groep 4 aan hun kinderlied- en -rijmrepertoires zijn gekomen:

\begin{tabular}{lccc}
\hline & Mondeling & Audiovisueel & Print \\
\hline Ouders groep 2 (in \%) & 88,6 & 72,0 & 17,5 \\
Ouders groep 4 (in \%) & 85,6 & 58,9 & 20,6 \\
\hline
\end{tabular}

Mondelinge overdracht is dus ook voor de huidige generatie van ouders met kinderen aan het begin van het basisonderwijs nog de belangrijkste bron van hun kennis van kinderliedjes en -rijmen. Die mondelinge overdracht (uit de eigen basisschooltijd en door de eigen ouders) wordt op de voet gevolgd door verschillende audio en/of visuele media, met bovenaan televisie en/of Dvd's, gevolgd door cd's en ten slotte ook websites (waaronder YouTube).

Van de ouders die hebben aangegeven thuis liedjes met hun kind(eren) te zingen en/of versjes op te zeggen, wordt dat door ouders van kinderen in groep 2 door 33,5\% af en toe gedaan, door 2,4\% een keer in de week, door 27,7\% meerdere keren per week en door $24,8 \%$ dagelijks. Van ouders van kinderen in groep 4 doet $43,6 \%$ dat af en toe, $6,4 \%$ een keer in de week, $29,5 \%$ meerdere keren per week en 17,3\% nog dagelijks. Ook is gevraagd wanneer ouders dat doen, waaruit het volgende beeld naar voren komt:

\begin{tabular}{lcc}
\hline Wanneer liedje/versje? & Ouders groep 2 (in \%) & Ouders groep 4 (in \%) \\
\hline Net wanneer het uitkomt & 67,5 & 69,2 \\
Wanneer het kind daarom vraagt & 30,1 & 22,4 \\
Voor het slapen gaan & 14,6 & 4,5 \\
Ander vast moment op de dag & 6,8 & 5,8 \\
\hline
\end{tabular}

Het zingen van liedjes en/of opzeggen van versjes is dus in de dagelijkse tijd niet (meer) zo sterk verbonden aan vaste terugkerende momenten, maar wordt vooral 'net wanneer het uitkomt' gedaan of wanneer kinderen er zelf om vragen. Het is daarnaast duidelijk zichtbaar dat het 'zingen voor het slapen gaan' bij ouders van kinderen in groep 4 sterk is afgenomen ten opzichte van ouders van kinderen in groep 2.

Ouders is gevraagd of zij (of iemand anders in het gezin) met het kind naar de bibliotheek gaan en, zo ja, hoe vaak ze dat doen. Bijna een derde van de kinderen gaat nooit naar een bibliotheek. Een vijfde van de kinderen gaat meerdere keren per maand of wekelijks en de anderen maandelijks (32\%) of minder dan één keer per maand (19\%). Kinderen uit groep 4 gaan iets vaker naar de bibliotheek dan kinderen uit groep 2. Dit verschil is significant $(\mathrm{t}(428)=-3,164 ; \mathrm{p}<0,01)$. Ouders die wel met hun kind(eren) naar de bibliotheek gaan, hebben ook aangegeven wat voor soort materialen ze voor hun kind(eren) lenen. Van de ouders van kinderen in groep 2 die wel naar de bibliotheek gaan, zeggen 10 van de 133 ouders $(7,5 \%)$ wel eens gedichtenbundels te lenen; van de ouders van kinderen in groep 4 zeggen 4 van de 148 ouders (2,7\%) dit wel eens te doen. Aan het eind van de vragenlijst konden ouders op een boekenlijst aankruisen welke boeken hun kind gelezen had of voorgelezen had gekregen. De lijst bestond uit 56 titels en zeven keer de mogelijkheid om eigen 
titels op te schrijven. Indien ouders dat gedaan hebben, is dat bij iedere mogelijkheid als één titel gerekend. In totaal konden er dus 63 boeken aangekruist of opgegeven worden. De lijst was onderverdeeld in 24 titels van bekende prentenboeken en kinderboeken, 6 sprookjesboeken, 9 boeken met helden- of schelmenverhalen (of namen van de schelmen), 16 titels van boeken met gedichten en/of liedjes en versjes en 8 titels van kinderbijbels en islamitische en andere religieuze verhalen. Van de lijst met 24 bekende prenten- en kinderboeken kenden de kinderen gemiddeld 7,0 titels. Van de lijst met 6 sprookjesboeken kenden de kinderen er gemiddeld 1,1. Van de 9 schelmenverhalen kende $86 \%$ van de kinderen er geen. Gemiddeld kenden ze 0,2 van de 10 bundels met gedichten en van de 6 bundels met kinderliedjes en -versjes kenden de kinderen er gemiddeld 1,4. Van de 8 titels van religieuze kinderboeken/islamitische verhalen kende 63\% van de kinderen er geen; gemiddeld kenden ze er 0,5. Van de totale lijst met 63 titels kenden de kinderen er gemiddeld 10,1 met een maximum van 33. Als we inzoomen op de bundels met gedichten en liedjes dan is dit het beeld van de hoeveelheid titels die bij ouders/kinderen bekend is:

\begin{tabular}{lcc}
\hline $\begin{array}{l}\text { Aantal titels poëzie-/liedbundels bij } \\
\text { ouders/kinderen bekend }\end{array}$ & $\begin{array}{c}\text { Ouders groep 2 } \\
\text { (\% binnen ouders groep 2) }\end{array}$ & $\begin{array}{c}\text { Ouders groep 4 } \\
\text { (\% binnen ouders groep 4) }\end{array}$ \\
\hline 0 & 30,8 & 28,4 \\
1 & 30,8 & 24,3 \\
2 & 20,3 & 21,6 \\
3 & 6,0 & 10,1 \\
4 & 7,5 & 7,4 \\
5 & 2,3 & 3,4 \\
6 & 0,0 & 1,4 \\
\hline
\end{tabular}

De titels die ouders konden aankruisen, zijn hieronder weergegeven met daarbij de percentages ouders van kinderen in groep 2 en van kinderen groep 4 die de betreffende titel hebben aangekruist als titel die zijzelf of iemand anders in het gezin aan het kind heeft voorgelezen - ongeacht of ze het boek bezitten of ooit geleend hebben van de bibliotheek of van iemand anders -, of als het kind het boek zelf heeft gelezen.

\begin{tabular}{lcc}
\hline Titel gedichten-/liedjesbundel & $\begin{array}{c}\text { Ouders groep 2 } \\
(\% \text { binnen ouders groep 2) }\end{array}$ & $\begin{array}{c}\text { Ouders groep 4 } \\
(\% \text { binnen ouders groep 4) }\end{array}$ \\
\hline $\begin{array}{l}\text { Ziezo } \\
\text { (Annie M.G. Schmidt) }\end{array}$ & 9,0 & 9,5 \\
$\begin{array}{l}\text { Verzamelde liedjes en gedichten } \\
\text { (Willem Wilmink) }\end{array}$ & 4,5 & 5,4 \\
$\begin{array}{l}\text { Alsje goed om je heen kijkt, rie je dat alles gekleurd is (Tine van } \\
\text { Buul \& Bianca Stigter) }\end{array}$ & 1,5 & 2,7 \\
$\begin{array}{l}\text { Superguppie } \\
\text { (Edward van de Vendel) }\end{array}$ & 2,3 & 0,7 \\
$\begin{array}{l}\text { Spin op sokken } \\
\text { (Ted van Lieshout) }\end{array}$ & 1,5 & 2,0 \\
$\begin{array}{l}\text { Iij bent de liefste } \\
\text { (Hans \& Monique Hagen) }\end{array}$ & 2,3 & 8,1 \\
\hline
\end{tabular}




\begin{tabular}{|c|c|c|}
\hline Titel gedichten-/liedjesbundel & $\begin{array}{c}\text { Ouders groep } 2 \\
(\% \text { binnen ouders groep } 2)\end{array}$ & $\begin{array}{c}\text { Ouders groep } 4 \\
(\% \text { binnen ouders groep } 4)\end{array}$ \\
\hline $\begin{array}{l}\text { Oro heppie(jer) } \\
\text { (Joke van Leeuwen) }\end{array}$ & 0,0 & 1,4 \\
\hline $\begin{array}{l}\text { Wat je ziet zit in je hoofd } \\
\text { (Jan Van Coillie) }\end{array}$ & 1,5 & 2,0 \\
\hline $\begin{array}{l}\text { Klaproen } \\
\text { (Erik van Os \& Elle van Lieshout) }\end{array}$ & 2,3 & 1,4 \\
\hline $\begin{array}{l}\text { Daar buiten loopt een schaap/Op een grote paddestoel } \\
\text { (Mies van Hout) }\end{array}$ & 27,8 & 34,5 \\
\hline $\begin{array}{l}\text { Het grote versjesboek / Het grote liedjesboek } \\
\text { (Marianne Busser \& Ron Schröder) }\end{array}$ & 6,0 & 12,8 \\
\hline $\begin{array}{l}\text { Alle liedjes met een boepeljje erom } \\
\text { (Joke Linders) }\end{array}$ & 23,3 & 25,0 \\
\hline $\begin{array}{l}\text { Een mandje vol amandelen } \\
\text { (W.J. Stam-Van der Staay) }\end{array}$ & 0,0 & 1,4 \\
\hline $\begin{array}{l}\text { Rijmpjes en versjes uit de oude/ nieunve doos } \\
\text { (S. Abramsz OF Han G. Hoekstra) }\end{array}$ & 19,5 & 20,9 \\
\hline
\end{tabular}

Daarnaast konden ouders zowel titels opschrijven van andere bundels kinderpoëzie die ze kennen als van andere bundels met kinderliedjes of -versjes die ze kennen. Van de ouders van kinderen in groep 2 die dit deel van de oudervragenlijst hebben ingevuld, schreef $12,8 \%$ (17 ouders) zelf een titel van een gedichtenbundel op; van de ouders van kinderen in groep 4 deed 12,8\% (19 ouders) dat. Dit levert de volgende aanvullingen op de gegeven lijst van titels op (overgenomen uit de oudervragenlijsten zoals door ouders opgeschreven):

\begin{tabular}{|c|c|}
\hline Aanvullende poëzie-titels groep 2 & Aanvullende poëzie-titels groep 4 \\
\hline Annie MG Schmidt & 100 x Annie (M.G. Schmidt) / Leef! (M.J. Pas) \\
\hline $\begin{array}{l}\text { grappig verhaaltjes voor het slapengaan }+ \text { arm schaap en } \\
\text { nog veel meer boeken }\end{array}$ & Beertje Pippeloentje \\
\hline Cd Tita Tovenaar, Youtube & Beestenboel (Annie M.G. Schmidt) \\
\hline $\begin{array}{l}\text { Dialect gedichtenbundel van o.a. Truus Verbong, 'Er } \\
\text { was eens' (sprookjes op rijm) }\end{array}$ & Beestenboel, AMG Schmidt, stoute versjes \\
\hline Diversen & bosnische \\
\hline $\begin{array}{l}\text { Het fluitketeltje en andere gedichtenbundels van AMG } \\
\text { Schmidt en een boek van Joep vh Hek }\end{array}$ & Gedichtenbundel Tegels dialect \\
\hline $\mathrm{K} 3$ & Halal en Haram, Mijn kleine moslim Profeten \\
\hline $\begin{array}{l}\text { Knuffelboek. En versjes van school. Heb een boek met } \\
\text { verschillende schrijvers in een boek }\end{array}$ & Het fluitketeltje Annie MG Schmidt \\
\hline Liselotje & kerstliedjes \\
\hline Piggelmee & $\begin{array}{l}\text { Liedjes die ik zelf nog kan van vroeger en liedjes die de } \\
\text { kinderen kennen van school }\end{array}$ \\
\hline Soms van bibliotheek gedichten/ verhalenbundel & Liedjes van Vroeger \\
\hline Tegelse gedichtjes (dialect) & $\begin{array}{l}\text { Paddestoel met rood wit stippen. Kleine kleuter. In de } \\
\text { manenschijn }\end{array}$ \\
\hline $\begin{array}{l}\text { Verzamelbundel oude versjes, gemaakt door oma, div. } \\
\text { schrijvers }\end{array}$ & Sinterklaasgedichten \\
\hline Verzamelbundel versjes/liedjes & t Fluitketeltje en andere gedichten (Annie MG Schmidt) \\
\hline Weet niet hoe het boek heet & Visje bij de thee (Annie MG Schmidt) \\
\hline
\end{tabular}


Het is opvallend hoe overheersend Annie M.G. Schmidt aanwezig is in de door ouders genoemde titels, in het bijzonder bij ouders van kinderen in groep 4 . Nog eens 16,5\% van ouders van kinderen in groep 2 schreef eigen titels van kinderliedbundels op, evenals 12,2\% van ouders van kinderen in groep 4. De aanvullende titels die dit oplevert zijn (overgenomen uit de oudervragenlijsten zoals door ouders opgeschreven):

\begin{tabular}{|c|c|}
\hline Aanvullende kinderliedjes groep 2 & Aanvullende kinderliedjes groep 4 \\
\hline Allerlei kinderliedjes & Alle kinderliedjes die op school vaak worden gezongen \\
\hline Bijt ie in je bil & Allerlei Kinderliedjes \\
\hline $\begin{array}{l}\text { De } 100 \text { leukste kinderliedjes - Alle eendjes zwemmen i.h. } \\
\text { water }\end{array}$ & De beste kinderliedjes \\
\hline $\begin{array}{l}\text { Dirk Scheele, zingen zonder zijwieltjes, sesamstraat: } \\
\text { vriendjes voor altijd, K3 }\end{array}$ & Hiphop liedjes, K3 \\
\hline Echoput & Kinderliedjes voor groot en klein \\
\hline Elly en Rikkert & Liedjes van lang geleden (Raphael Winkel) \\
\hline K3, Kinderen voor kinderen & Liedjes van Lang geleden van Christl Vogl \\
\hline $\begin{array}{l}\text { Kinderversjes en verhaaltjes (Parragon Books), Op } \\
\text { Toonhoogte }\end{array}$ & $\begin{array}{l}\text { Liedjes van Vroeger, Raphael Winkel (Rebo } \\
\text { Productions) }\end{array}$ \\
\hline Liedjes van lang geleden Christl Vogl & Nijntje, Cd's met verschillende kinderliedjes \\
\hline Liedjes voor moeder \& kind $1(+2)$ & Ot en sien, lees/luistercd \\
\hline Liedjes voor moeder en kind & Veel van studio 100 Ernst en Bobbi \\
\hline $\begin{array}{l}\text { Liedjesboekjes van Mediadam, www.leuksteliedjes.nl, } \\
\text { een hele serie incl CD's (dansliedjes, dierenliedjes, } \\
\text { sinterklaasliedjes etc) }\end{array}$ & Vijver vol inkt, AMG Schmidt \\
\hline Lievelingsliedjes 1 en 2 & Woezel en Pip \\
\hline Middels cd diverse & zei gedichtenbundel \\
\hline \multicolumn{2}{|l|}{ Sesamstraat cd's, Efteling Liedjes (speeldoosjes) } \\
\hline \multicolumn{2}{|l|}{$\begin{array}{l}\text { Sinterklaas liedjesboek, Sinterklaas en kerst versjesboek } \\
\text { Marianne Busser }\end{array}$} \\
\hline Veel in het Turks zing hij, soms ook in nederlands & \\
\hline Veel van studio 100 Ernst en Bobbi & \\
\hline
\end{tabular}

Het beeld dat naar voren komt, is dat er thuis meer liedjes gezongen worden dan dat er poëzie uit bundels gelezen wordt. In die zin zijn liedjes meer 'de poëzie van dagelijks leven', van oude volksculturele kinderliedjes tot en met K3. 


\section{Bijlage 7}

\section{Een alternatieve benadering van 'effectiviteit'}

Een alternatieve benadering van 'effectiviteit' is om na te gaan of de implementatie van de ontwikkelde methode (hier: de Leeskalender) in het basisonderwijs niet ten koste gaat van voortgang op andere ontwikkelingsdomeinen bij kinderen, in het bijzonder de speerpuntdomeinen taal en rekenen. De beantwoording van deze alternatieve vraag kan een belangrijk fundament vormen voor de kwalitatieve effectiviteit en de door leerkrachten erkende intrinsieke waarde van het aangeboden materiaal (zie Hoofdstuk 9 en 10). De vraag kan beantwoord worden op basis van de binnen dit onderzoeksproject verzamelde CITOvaardigheidsscores ${ }^{212}$. Het blijkt dat het gebruik van de Leeskalender in de experimentele groepen geen zichtbare positieve bijdrage heeft geleverd aan de CITO-scores. Met name in groep 4 zijn er wel systematische verschillen tussen de controlegroep en de experimentele groep, maar die waren er al voorafgaand aan het gebruik van de Leeskalender. Een minstens zo belangrijke vraag is echter of het werken met de Leeskalender, wat toch de nodige onderwijstijd heeft gekost, een negatief effect heeft op de CITO-scores van kinderen in de experimentele conditie. Als de Leeskalender een negatief effect heeft gehad, verwachten we dat de leerlingen in de experimentele groep minder vooruitgang hebben geboekt dan de leerlingen in de controlegroep. Dit staat los van eventuele verschillen die er tijdens de voormeting al waren (buiten het mogelijke Mattheüseffect). We zien dat er een verschil is in vooruitgang op de Taaltoets in groep 2: de controlegroep is significant harder vooruit gegaan tussen het einde van groep 1 en het einde van groep 2 dan de experimentele groep. We zien dat er verder geen verschillen optreden: noch op de Rekentoets in groep 2, noch op de toetsen in groep 4 zijn de kinderen in de experimentele conditie significant minder vooruitgegaan. De afwezigheid van verschillen bij de andere toetsen wijst er op dat de Leeskalender over het algemeen geen negatief effect had op de CITO-scores, maar hoe zijn de verschillen op de Taaltoets in groep 2 dan te verklaren? Mogelijk is de tijd die aan de Leeskalender is besteed ten koste gegaan van aandacht voor woordenschat?213 Mogelijk komen er toch ook bij groep 4 verschillen boven water als we de variabele 'bestede tijd' controleren, want de aan de Leeskalender bestede tijd varieerde behoorlijk per groep ${ }^{214}$. Op

\footnotetext{
${ }^{212}$ Van het overgrote deel van de leerlingen zijn de resultaten van hun CITO-toetsen ontvangen. Het gaat om de toetsen Taal en Rekenen voor de leerlingen in groep 2, afgenomen op de momenten E1 (eind groep 1), M2 en E2 (medio en eind groep 2). Voor groep 4 zijn de gegevens van de toetsen Woordenschat, Begrijpend Lezen, Spelling en Rekenen en Wiskunde verzameld, op de momenten E3 (eind groep 3), M4 en E4 (midden en eind groep 4). Voor beide groepen is het eerste moment (E1 en E3) de laatste toetsing van het schooljaar voorafgaand aan het interventiejaar en het laatste moment (E2 en E4) de laatste toetsing van het interventiejaar.

${ }^{213}$ In de voorleesinstructies bij de Leeskalender werd leerkrachten expliciet gevraagd om het voorlezen zo min mogelijk te onderbreken: moeilijke woorden die mogelijk ten koste gingen van het tekstbegrip werden van te voren of na afloop van het voorlezen besproken. Verder was de instructie om zoveel mogelijk aaneengesloten voor te lezen.

214 Wanneer een kalenderactiviteit had plaatsgevonden kon er op het betreffende logboekblad aangegeven worden hoeveel tijd eraan besteed was. Dit is niet altijd ook daadwerkelijk ingevuld, ook niet wanneer er wel andere informatie over die kalenderdag in het logboek is ingevuld. In totaal is bij $89 \%$ van de gedane kalenderdagen wel ingevuld hoeveel tijd eraan besteed is. Dit verschilde tussen de $40 \%$ en $100 \%$ per groep (gemiddeld $89 \%$ ). De
} 
basis van de gegevens over bestede tijd uit de logboeken zijn drie groepen te onderscheiden: geen Leeskalender (controlegroep), Leeskalender, weinig tijd (minder dan 1250 minuten in totaal) en Leeskalender, veel tijd (1250 minuten of meer in totaal). In onderstaande tabel staan de uitkomsten van de analyses weergegeven voor groep 2 en groep 4.

Indien er een negatieve relatie bestaat tussen de aan de Leeskalender bestede tijd en de voortgang van kinderen op de CITO-toetsen, dan verwachten we te zien dat de groep die gemiddeld meer dan 1250 minuten (bijna 21 uur) aan de Leeskalender heeft besteed minder voortgang laat zien op de CITO-toetsen en dan vooral op het gebied van taal, want de Leeskalender zal eerder een deel van de 'taaltijd' hebben ingenomen dan een deel van de 'rekentijd'. De uitkomsten zijn niet eenvoudig te duiden. Bij groep 2 zien we dat de groep die relatief weinig tijd aan de Leeskalender heeft besteed, significant lager scoort op de Taaltoets dan de beide andere groepen (geen Leeskalender en veel tijd aan de Leeskalender besteed). In groep 2 scoort de groep die veel met de Leeskalender heeft gewerkt iets hoger op Taal, maar vooral ook hoger op Rekenen (niet verwacht).

\begin{tabular}{lcccc}
\hline & Geen Leeskalender & $\begin{array}{c}<1250 \text { minuten } \\
\text { Leeskalender }\end{array}$ & $\begin{array}{c}>1250 \text { minuten } \\
\text { Leeskalender }\end{array}$ & Significantie \\
\hline $\begin{array}{l}\text { GROEP 2 } \\
\text { Gem. verschilscore }\end{array}$ & 13,39 & 5,46 & 14,96 & $\mathrm{~F}(2,314)=19,72 ; \mathrm{p}<, 001$ \\
$\begin{array}{l}\text { TaalE1/TaalE2 } \\
\text { Gem. verschilscore }\end{array}$ & 14,91 & 15,59 & 17,02 & - \\
$\begin{array}{l}\text { RekenenE1/RekenenE2 } \\
\text { GROEP } 4\end{array}$ & & & & \\
$\begin{array}{l}\text { Gem. verschilscore } \\
\text { Begrijpend Lezen E3/E4 }\end{array}$ & 20,69 & 23,83 & 20,25 & \\
$\begin{array}{l}\text { Gem. verschilscore } \\
\text { Woordenschat E3/E4 }\end{array}$ & 10,66 & 4,20 & 8,78 & $\mathrm{~F}(2,204)=2,87 ; \mathrm{p}=, 059$ \\
$\begin{array}{l}\text { Gem. verschilscore } \\
\text { Spelling E3/E4 }\end{array}$ & 6,66 & 8,44 & 5,46 & $\mathrm{~F}(2,292)=4,74 ; \mathrm{p}=, 009$ \\
$\begin{array}{l}\text { Gem. verschilscore } \\
\text { Rekenen E3/E4 }\end{array}$ & 21,22 & 21,46 & 17,27 & $\mathrm{~F}(2,287)=3,76 ; \mathrm{p}=, 025$ \\
\hline
\end{tabular}

In groep 4 zijn er geen verschillen voor Begrijpend Lezen; de controlegroep is harder vooruit gegaan op Woordenschat; de groep 'weinig Leeskalender' heeft meer vooruitgang geboekt op Spelling; en de groep 'veel Leeskalender' heeft een lagere verschilscore op Rekenen. De mogelijk negatieve gevolgen van het werken met de Leeskalender voor de CITO-scores lijken vooral zichtbaar in de relatie met Woordenschat (de Taaltoets voor (peuters) en kleuters is in hoofdzaak een woordenschattoets). We zien in groep 2 een dip in de vooruitgang van de groep die relatief weinig met de Leeskalender heeft gewerkt ten opzichte

groepen besteedden tussen de gemiddeld 9,3 en gemiddeld 25,5 minuten aan de gedane kalenderdagen. Het gemiddelde van alle groepen was 15,6 minuten per gedane kalenderdag. In totaal is er door de groepen naar eigen zeggen tussen de 244 en 2.575 minuten aan de leeskalender besteed, met een gemiddelde van 1.217 minuten per groep. Dat is ruim 20 uur. Het kwam af en toe voor dat groepen in het logboek aangaven een kalenderdag wel gedaan te hebben, maar de duur niet hadden opgeschreven. De totaal bestede duur kan nog iets nauwkeuriger berekend worden door voor deze dagen de duur te schatten op basis van de gemiddelde duur van de Leeskalender-activiteiten waar deze wel gerapporteerd was. De totale duur op basis van deze extrapolatie is gemiddeld 1.342,7 minuten (ruim 22 uur), variërend van 582,5 tot 2.694,2 minuten per groep. 
van beide andere groepen, en in groep 4 zien we een soortgelijk verschijnsel. Geen van de uitkomsten vormt overtuigend bewijs van een negatief effect van het werken met de Leeskalender: wellicht alleen dat weinig met de Leeskalender werken nadelig is voor de ontwikkeling van woordenschat in vergelijking met zowel niet met de Leeskalender werken als veel met de Leeskalender werken. De duiding van de 'Woordenschat-dip' bij de groepen 2 en 4 die relatief weinig tijd aan de Leeskalender hebben besteed, moet waarschijnlijk gezocht worden in de vraag waarom bepaalde groepen minder of meer met de Leeskalender gewerkt hebben. Het kan bijvoorbeeld zijn dat de Leeskalender in deze groepen minder in de smaak viel omdat de kinderen een beperktere woordenschat hebben en het dus moeilijker vonden. Of het zijn groepen waar over het algemeen minder belang aan (voor)lezen en woordenschatontwikkeling wordt gehecht, of groepen die minder georganiseerd waren waardoor niet alleen bepaalde lesstof minder structureel is behandeld, maar ook minder tijd aan de Leeskalender is besteed. Met andere woorden: er was wellicht iets waardoor de leerlingen het minder goed deden op Woordenschat en ze ook de Leeskalender minder structureel of minder uitgebreid konden uitvoeren. Óf het is een vertekend resultaat omdat de logboeken niet in alle groepen even consequent zijn bijgehouden. 


\section{Bijlage 8}

\section{Zeilexpertise nodig bij onderzoek naar nonsens}

Bij de analyse van de nonsens in Annie M.G. Schmidts 'Drie apothekertjes' bleef me de vraag achtervolgen of het aspect van het 'drie nachten varen bij donkere maan' en vervolgens weer terugkomen op de plaats van vertrek (Goes) nu wel of niet mogelijk is. De specialistische kennis die nodig is om hier met enige zekerheid over te kunnen oordelen, had ik niet in huis. Om die reden besloot ik op een mooie vrijdag in juli 2014 om mijn vraag voor te leggen aan ervaren zeilers via een online forum (www.zeilersforum.nl). Daar opende ik een nieuw topic met als titel 'Zeilexpertise nodig bij onderzoek naar nonsens' en legde het geval van de drie apothekers voor:

Zeilexpertise nodig bij onderzoek naar nonsens

\begin{tabular}{|c|c|c|c|}
\hline Antwoord onderwerp Uitschrijen Favoriet & Nieuw onderwerp & \begin{tabular}{rr|}
- & Pagina: \\
- & $\frac{1}{2}$ \\
- & $\frac{3}{4}$ \\
&
\end{tabular} & \\
\hline \multicolumn{4}{|c|}{$\begin{array}{l}\text { Onderwerp: Zeilexpertise nodig bij onderzoek naar nonsens } \\
\text { Zeilexpertise nodig bij onderzoek naar nonsens } 04 \text { juli } 2014 \text { 09:25 \#530082 }\end{array}$} \\
\hline \multicolumn{3}{|c|}{$\begin{array}{l}\text { Ik heb een bijzonder verzoek waarbij ik de hulp van ervaren zeilers met kennis van getijden en stromingen goed kan } \\
\text { gebruiken, specifiek van getijden en stromingen in de Oosterschelde. Het volgende is het geval: momenteel ben ik aan } \\
\text { de Universiteit van Maastricht bezig met een promotie onderzoek waarin ik bepaalde kenmerken van kinderpoëzie } \\
\text { analyseer en in de praktijk van het basisonderwijs bekijk of jonge kinderen deze kenmerken waarderen en begrijpen. }\end{array}$} & $\begin{array}{l}\text { - UMonderzoeker } \\
\text { - } \text { Online } \\
\text { - } \quad 04 \text { juli } 2014\end{array}$ \\
\hline \multicolumn{3}{|c|}{$\begin{array}{l}\text { Een van de kenmerken die ik onderzoek is 'nonsens' en in mijn proefschrift (in wording) analyseer ik bijvoorbeeld het } \\
\text { gedicht 'Drie apothekertjes' van Annie M.G. Schmidt (Ziezo, p. 140) op de aanwezigheid van dit kenmerk. In dit gedicht } \\
\text { besluiten drie apothekers uit Goes op een dag dat ze willen gaan varen (naar Nieuw-Guinea). Ze gaan op zoek naar een } \\
\text { geschikt bottertje, maar kiezen uiteindelijk een hoed. Ze zijn er van overtuigd dat een hoed een zeer betrouwbaar en } \\
\text { geschikt vaartuig is, want hoeden vergaan maar zelden op de Schelde... De apothekers steken bij Goes van wal en } \\
\text { varen over de Schelde (dit zal de Oosterschelde zijn). Vervolgens staat er: 'Ze voeren drie nachten bij donkere maan,l } \\
\text { toen spoelden ze eindelijk aan." Wat blijkt: de apothekers zijn weer terug in Goes en gaan weer aan het werk in de } \\
\text { apotheek. }\end{array}$} & \\
\hline \multicolumn{3}{|c|}{$\begin{array}{l}\text { Op basis van mijn eigen kennis kan ik de nonsens in dit gedicht op verschillende niveaus aanwijzen (zoals het feit dat ze } \\
\text { een hoed nemen als vaartuig), maar het blijt voor mij een raadsel of het wel/niet mogelijk is dat de apothekers na drie } \\
\text { nachten varen bij donkere maan weer terug kunnen zijn op de plek waar ze zijn vertrokken. En zo ja, onder welke } \\
\text { omstandigheden? }\end{array}$} & \\
\hline \multicolumn{3}{|c|}{$\begin{array}{l}\text { Het gedicht is voor het eerst in } 1953 \text { verschenen, een veelzeggend jaar voor Zeeland, maar dus vóór de realisatie van de } \\
\text { Oosterscheldekering (als dat iets uitmaakt). Uiteraard is de hoed waarin ze varen niet voorzien van motor, roer of zeil. Ze } \\
\text { zijn volledig overgeleverd aan de elementen. Is wat Annie M.G. Schmidt hier heeft bedacht nonsens, of kan het (bij } \\
\text { bepaalde omstandigheden) wel? }\end{array}$} & \\
\hline \multicolumn{3}{|l|}{ Graag jullie reacties! } & \\
\hline \multicolumn{3}{|l|}{ Snel antwoord Antwoord Quote } & \\
\hline
\end{tabular}

Al snel kwamen de eerste reacties binnen en na vijf dagen waren het er welgeteld al negentig. Een aanzienlijk deel ervan ging over de (on)zin van wetenschappelijk onderzoek naar nonsens (Verspilling van Belastinggeld, uiteraard); een deel ging over het feit dat varen in een hoed niet mogelijk is (soms werd de mogelijkheid van varen in een hoed volledig verworpen; soms genuanceerd tot 'in een hoed kun je drijven, niet varen'); een deel van de reacties liet zien dat nonsens ook aanstekelijk kan zijn; en een deel van de reacties ging over 
jeugdherinneringen aan de poëzie van Annie M.G. Schmidt. Regelmatig werd er echter met een serieuze glimlach meegedacht over de (on)mogelijkheid van de voorgestelde situatie.

Er werd nagedacht over de vraag of donkere maan überhaupt wel drie nachten lang kan duren (hoewel 'ze voeren drie nachten bij donkere maan' ook kan betekenen dat de apothekers gedurende hun reis drie keer een nacht met donkere maan hebben gehad en ze dus ten minste drie maanden hebben gedreven in hun hoed). De conclusie was dat er op en rond nieuwe maan wel drie opeenvolgende nachten met donkere maan kunnen zijn. Moeilijker was het voor de forumleden om tot consensus te komen over het terugkomen op de plaats van vertrek: getijden in de Oosterschelde, winden, depressies, de situatie in 1953 (toen het gedicht voor het eerst gepubliceerd werd) spelen allemaal een rol. 'Sunday' (namen tussen aanhalingstekens zijn gebruikersnamen) stelt voor een stroomatlas uit 1953 te raadplegen en de situatie te recreëren in een routeringsprogramma (computersoftware).

\begin{tabular}{|l|l|}
\hline $\begin{array}{l}\text { Ik denk dat het ook relevant is de stroomatlas uit die tijd erbij te halen! } \\
\text { Als iemand daar dan een fijn gedetailleerde stroom grib van kan maken dan ikunnen we het naspelen in een } \\
\text { routeringsprogramma. }\end{array}$ & $\begin{array}{c}\text { Sunday. } \\
\text { Offline } \\
\text { Sunday; coarsvin 22; youtu.be/ExvDL1D1z18 }\end{array}$ \\
\hline Snel antwoord Antwoord Quote & Rapporteren aan moderator \\
\hline
\end{tabular}

Zo ver komt het uiteindelijk niet. 'Sea Force One' bedenkt dat de hoed in 1953 mogelijk via de Oosterschelde naar zee is gedreven en via het Veerse meer weer terug; 'La Mavare' legt uit dat het best mogelijk is dat de apothekers in drie dagen/nachten heen en weer zijn gedreven als de wind, die op die plek overwegend ZW is, op het juiste moment W of NW ging waaien. 'Selene' verwijst naar verhalen over daken (met mensen erop) die tijdens de watersnoodramp via de Schelde naar zee werden meegevoerd om met een volgend tij weer terug te drijven en dicht bij het vertrekpunt te eindigen. 'EelskeM' en 'ilCigno' denken vervolgens voor zeilersbegrippen 'out of the box' door de situatie voor te stellen dat de apothekers bij laagwater zijn vertrokken, wat volgens beide het verhaal een stuk aannemelijker makkt (hoewel zeilers nooit bij laagwater zouden vertrekken). Ondersteund met illustratief materiaal (de situatie van '53) geeft 'EelskeM', die vlak bij Goes blijkt te wonen, uiteindelijk de doorslag:

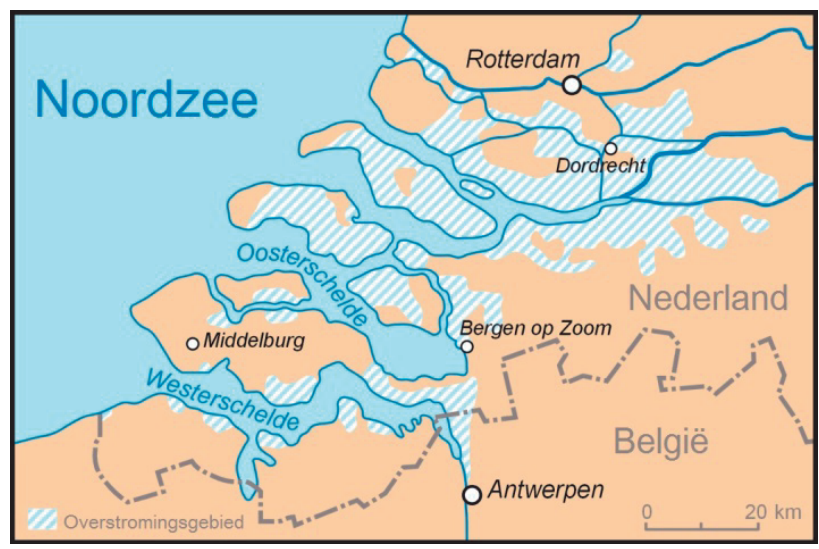


"Gelet op het bekken dat de Oosterschelde na Yerseke (bij de laatste "e") en voor Bergen op Zoom vormt, zal een voorwerp dat tenminste 3 dagen drijvend kan blijven (...), te water gelaten nabij het Goesche Sas (in de inham tussen de "l" en de "d" van "Oosterschelde") bij laagwater en een (stevige) wind van een paar dagen in de NW hoek

- nooit langs de westkant van Tholen naar boven gaan

- niet langs de Oostkant van Tholen kunnen 'ontsnappen'

aan de zuidkant van de Oosterschelde met vloed oostwaarts heen en met eb westwaarts weer zullen bewegen en mogelijkerwijs na 6 vloeden en 6 ebben bij het uitgangspunt (nabij het Goesche Sas) terug kunnen keren."

CONCLUSIE: het feit dat de drie protagonisten uit het gedicht 'Drie apothekertjes' van Annie M.G. Schmidt bij Goes van wal steken in een hoed en na drie nachten drijven bij donkere maan weer aanspoelen in Goes is niet per sé nonsensicaal, hoewel ook niet heel aannemelijk. 


\section{Summary}

Sensing Sound and Subverting Sense in Poetry

An interpretive and empirical study into the pragmatics of children's verse 
Currently little explicit and structural attention is paid to children's literature as a means to introduce children to (trans)culturally valued forms and to specific contents that help develop their emerging cultural literacy in Dutch primary education. Since its introduction, the concept of 'cultural literacy' itself has been subject to international critical debate, chiming in with ongoing debates on 'culture' and 'the canon' within culturally diverse societies and educational contexts. The diminishing influence and diversification of religious institutions, and the increasing volatility and transiency of 'culturally valued' knowledge within globalizing and digitalizing network societies have made cultural transmission less selfevident. Moreover, educational systems focused primarily on developing skills, individual competence and preference, and the growing importance of efficiency and measurable results in education have made the transmission of cultural knowledge increasingly problematic. Yet, these developments also invoke renewed pleas for broad societal, political and educational acknowledgement of the importance of introducing pupils to the different forms of expression and the values, norms, beliefs and practices that underlie the intricate cultural tapestry of the society they grow up in. Recently, the Dutch Council of Education stressed that the one-sided focus on literacy and numeracy has impoverished primary education at the cost of, amongst other things, cultural and civic education: "Measurable results have become the standard for educational quality. The Council calls for discussion about what Dutch education should pass on to pupils." (2013, pp. 4-5). In this discussion, we need to acknowledge that contemporary multicultural society on the one hand and school populations of young children on the other place specific demands on what we understand cultural literacy to be.

The research project 'Sensing Sound and Subverting Sense in Poetry', as part of the larger research program Emergent Cultural Literacy: Assimilating Children's Literature ${ }^{215}$, develops evidence-based criteria for the selection of children's poetry that effectively enhances the emergent cultural literacy of children in Kindergarten and Second Grade. These criteria contribute to the development of (trans-)cultural literacy programs as a crucially important supplement to the predominance of (measured results in) literacy and numeracy. With regard to children's literature, paying attention to its contribution to cultural literacy also supplements the scientific and educational focus on 'literary competence' - the skills needed to get access to, read, and appreciate literary texts. Instead of literary skills, we look into what kinds of texts effectively enhance children's emergent cultural literacy. 'Canonization' presents itself as a central issue to cultural literacy in education. Yet, deciding top-down what children should read cannot guarantee successful appropriation of texts by the intended audience. In order to effectively enhance children's emergent cultural literacy, texts not only need to represent widely acknowledged literary or cultural values; they also need to be attuned to the cultural competence - skills, knowledge, morals and world views, but also preferences - of their juvenile audience. From this perspective, selecting children's literature rooted in folklore presents itself as an obvious choice ${ }^{216}$. Text types such as the fable, the nursery song, the nonsense rhyme, the fairy tale, or trickster tale are deeply rooted in trans-

\footnotetext{
215 This project is part of the program Emergent Cultural Literacy: Assimilating Children's Literature, financed by the Netherlands Organization for Scientific Research (NWO).

216 The Emergent Cultural Literacy program contains three projects: Deugden \& Dilemma's (Virtues \& Dilemma's), Kinderpoëzie (Children's Poetry), and Narratieve Genres (Narrative Genres). Each of these project investigates different genres.
} 
cultural folkloric traditions. They have a proven longevity and vitality ('canonicity'), form important intertexts that are continually adapted, reverberated, and remediated in many different ways, while still speaking to today's children. If we understand what makes these trans-cultural 'classics' tick with young children, we can translate these insights into criteria for selecting works at the intersection between broad cultural value or relevance, and young children's emerging cultural competence. We define 'emergent cultural literacy' as knowledge and understanding of (specific features of) lastingly popular and trans-culturally deeply rooted ('canonical') genres and text types.

Children's poetry takes central stage in this thesis. The genre, however, is not to be taken for granted and poses additional difficulties in figuring out how poetry can effectively enhance young children's emergent cultural literacy. The theoretical question what children's poetry is and does for children leads to the conclusion that a new perspective is needed (Coats, 2013). Studies of how children's poetry is appraised by contemporary literary critics lead to the conclusion that "very many people fundamentally do not believe that children's poetry exists" (Hunt, 2010, p. 17). Commercially, children's poetry can be termed 'an endangered species' (Van Coillie, 2014, p. 247). And the position of children's poetry in education is just as volatile, since the threshold for doing poetry in primary education is high (SLO, online lexicon, 'Kinderpoëzie'). There is very limited understanding and appreciation of what poetry is and does for children as they are, in several ways, different from experienced (and trained) readers of poetry. This project aims to identify features that are rooted in transcultural folkloric tradition, and at the same time play a crucial role in the appreciation and appropriation of poetry by young children. To do so, it takes its cues from (studies of) folkloric nursery songs and children's rhymes and argues that for young children poetry and song derive their meaning, their 'sense', from their use, their performance, within specific pragmatic contexts. For five- to eight-year-olds, festivities as well as play are the most important contexts from which their primary understanding and appreciation of poetic forms sprouts. In these contexts, songs and rhymes have clearly demarcated uses and functions, like the lullaby, the counting-out rhyme, the birthday song, and the jumprope-rhyme. Looking at the (inter)textual features that may further enhance cultural literacy, folkloric nursery songs and children's rhymes are generally characterized as 'nonsensical', or 'meaningless' in the referential sense of the word. Seen within contexts of use, this 'nonsensicality' is divided into two broad categories. First, there is 'musical language play' in which the prosodic features of language are foregrounded for musical effect. Second, there is '(carnivalesque) nonsensicality' which plays with the referential function of language for humorous effect. Both the pragmatic and textual features of folkloric rhymes and songs point out that what makes poetry meaningful for young children, what constitutes a basic sense for poetry, is not its 'Abstract Literary Value' derived from textual analysis and interpretation within literary convention. What makes poetry and song meaningful for young children primarily derives from how it is used, when, where, by whom, and for what purpose. Of course, what children appreciate, want and need will at least partly depend on their developmental features and change with age. This thesis suggests that a pragmatic approach to poetry is needed to understand what poetry is and does for young children, and to identify and specify its crucial indicators of canonicity ensuring a close fit between 
broad cultural value or relevance of poetic forms and young children's emerging cultural competence.

From this pragmatic approach, expected contextual and textual indicators of canonicity' in children's poetry are identified, explored and specified in accordance with children's language and humor development. First, the relation between folkloric children's songs and rhymes and their most vital pragmatic contexts, festivities and play, is explored and analyzed based on folkloric and ethnographic sources, as well as different theories from developmental and evolutionary psychology. This leads to the characterization of that relation as the 'poetic ritualization of recurrent (physical and/or linguistic) behavioral patterns in contexts of ritual and play'. In relation to children's developmental features, it is expected that (i) the poetic ritualization of physical behavioral patterns is a crucial feature of poetry for children in Kindergarten, whereas (ii) the poetic ritualization of linguistic behavioral patterns is closer related to the preferences and cultural competence of Second Graders. Next, the first (inter)textual category of 'musical language play' is explored and analyzed in both folkloric and literary children's poetry in relation to pragmatic contexts and children's developmental features. This leads to the expectation that (i) forms of musical language play that evoke poetically ritualized physical action ensures a close fit between poetry and the skills and preferences of Kindergartners, whereas (ii) forms of musical language play that evoke poetically ritualized linguistic action, like tongue twisters, is a crucial indicator of canonicity in poetry for Second Graders. Finally, the second (inter)textual category of '(carnivalesque) nonsensicality' is also explored and analyzed in both folkloric and literary children's poetry in relation to pragmatic contexts and children's developmental features. Three different types are identified: (i) carnivalesque forms of nonsensicality that induce a physical/affective experience of 'incongruency', mediated by subversive physical acts related to the social context and the cultural categories (values and norms) that govern it, (ii) carnivalesque forms of nonsensicality that induce a physical/affective experience of 'incongruency', mediated by subversive linguistic acts related to the social context and the cultural categories that govern it, and (iii) forms of nonsensicality that induce a more intellectual experience of 'incongruency', mediated by representations of reality that subvert certain 'natural laws' or - on a more abstract level - mediated by a conceptual play with time, logic, numbers, or language itself. It is expected that poetry characterized by type (i) will be most appreciated by Kindergartners while children in Second Grade will especially take to poetry characterized by type (ii).

As the intersection between broad cultural value or relevance of poetic forms and young children's emerging cultural competence is governed by pragmatic, textual and developmental factors, it is not sufficient to only identify 'indicators of canonicity' based on the study of primary and secondary literature. After identifying, and specifying, expected 'indicators of canonicity' in children's poetry for Kindergarten and Second Grade, it is crucial to see if poetry with these indicators is indeed appreciated and appropriated by children and thus enhances their emergent cultural literacy. Hence, this program develops an innovative methodology for not only the identification, but also implementation and validation of crucial indicators of canonicity. Theoretical approaches and tools for hermeneutic specification to identify expected indicators are supplemented with empirical methods to check if these expectations 'hold up in court'. That is, whether real children and real 
teachers working with poetry selected on the basis of these indicators in real classrooms confirm or debunk them. An intervention program was developed and implemented to test the expected features of canonicity that have been identified. This intervention program unites this project on children's poetry with the two other projects in the Emergent Cultural Literacy program: Deugden \& Dilemma's (Virtues \& Dilemma's), and Narratieve Genres (Narrative Genres). The projects share the aims and design of the intervention program, called 'Leeskalenderproject' ('Reading Calendar Project'), and closely cooperate in the development of the intervention materials (the Reading Calendar with accompanying teacherguides), and the different instruments used for data collection. The intervention program implements selections of texts from each of the projects in the classroom in the form of a 'reading calendar', observes how teachers and pupils work with it over a period of thirty weeks and measures the effects of the implementation on children's emergent cultural literacy. A pretest-posttest control group design is used because it offers the best guarantees for the proper attribution of effects on children's emergent cultural literacy to the intervention program. To measure effects of the calendar on children's emergent cultural literacy, the Emergent Cultural Literacy Test is developed for Kindergarten (groep 2) and Second Grade (groep 4). The test is administered before (pre-test) and after (post-test) the implementation of the calendar to children in the experimental (with calendar) and in the control (without calendar) condition. Regular school test results on literacy and numeracy and parental questionnaires on reading in the home environment of the same children are collected to ensure the validity of the interpretation of the test results. Teachers' logs, semistructured interviews with teachers, and observations in the classroom are used to collect additional data for accurate attribution of the test results and for gaining qualitative insights into how teachers and children work with, react to, appreciate, and appropriate the selected texts, and to see whether or not the expected indicators of canonicity indeed play a crucial role in children's appreciation and appropriation of texts. Schools were recruited and seventeen schools were selected for the experiment. Schools were assigned to the experimental (eleven schools) or control (six schools) condition through cluster-randomization to ensure comparability of the experimental and control groups. Due to the fact that some schools withdrew from participation and had to be substituted, the comparability of the experimental and control condition of Second Grade groups could no longer be guaranteed. This is taken into account in the analyses and interpretation of results. In total, close to seven hundred children took part. The development of the selections of poetry that are implemented in Kindergartens and Second Grades ran through a process of two expert consultation rounds, a pilot study and several internal feedback rounds. The development of the poetry-items within the Emergent Cultural Literacy Test includes two pilot studies in which earlier versions of the test were administered to smaller groups of children at different schools. Several procedures are used to enhance the validity, reliability and objectivity of the analyses and interpretations of the qualitative data, such as 'triangulation' through the comparison of data collected from different sources using different instruments (observations, interviews and teachers' logs), linking insights to different theories that were also used in the identification of the expected crucial features of canonicity, comparing localized observations with overall findings from interviews and logs from all groups that worked 
with poetry in the Reading Calendar, the recording and archiving of observations, interviews and logs, and the specification of how data are analyzed.

Based on several procedures for testing validity and reliability, the Emergent Cultural Literacy Test as a whole is both a reliable and valid instrument for measuring effects of the Reading Calendar on children's emergent cultural literacy. The results from the Emergent Cultural Literacy Test show that the Reading Calendar has a positive effect on the emergent cultural literacy of Kindergartners (groep 2). After controlling for differences between the control and experimental condition, the results show that the Reading Calendar has also positively enhanced the emergent cultural literacy of the majority of children in Grade 2 (groep 4). However, looking only at the poetry-items in the test and effects from the Reading Calendars including poetry, a different picture emerges. The poetry-items turn out to be too difficult for the Kindergartners, not yielding valid results. Focusing on Grade 2, the items on poetry 'behave' differently towards measures of validity than the test as a whole, sometimes even in complete opposition to our expectations. Only one item shows a positive effect of the Reading Calendar including poetry on Second-Graders' knowledge and understanding of specific features of poetry. Although it is important that educational research objectively measures the effectivity of methods, the discussion of these findings raises questions about the possibility to measure effects of poetry with this type of instrument. Can effects of poetry be operationalized in this type of test if “... poetry bypasses concepts and interpretation and reaches directly into embodied experience to produce its effects, which exceed its linguistic meaning" (Coats, 2013, p. 133)? The qualitative findings reveal that external factors that play an important role in how teachers and children work with, react to, appreciate, and appropriate the selected poetry are: differences in the cultural competence of the youngest and oldest Kindergartners, teachers' skills, preferences and attitudes, issues of embedding the calendar in existing programs, and (lack of) time. The qualitative findings mostly confirm the expected crucial indicators of canonicity in poetry, with some specifications. Specifically, Kindergartners most appreciate poetry characterized by musical language play evoking poetically ritualized physical action like dancing, jumping and clapping. For them, sensing the patterned sounds of poetry is key to their appreciation. Second Graders most appreciate poetry characterized by carnivalesque nonsensicality inducing a physical/affective experience of 'incongruency', mediated by subversive performances (whether physical or linguistic) related to the social context, especially the classroom, and the cultural conventions that govern it. Subverting 'common sense' greatly contributes to seven- and eight-year-olds' appreciation of poetry. In Second Grade, explicit physical experience and physically mediated understanding of poetry through the performance of it and/or through the reactions it elicits are more crucial to children's appreciation of poetry than expected. Additionally, the findings show that Kindergartners rely on an explicit external pragmatic context to understand poetry as ritual form, as 'not real', while Second Graders have largely internalized the pragmatic context and rely on their recognition of formal aspects of poetry to identify it as a type of ritual speech act. This gradual internalization of poetic conventions is a key factor in children's appreciation and appropriation of poetry and clearly indicates the developmental aspect of 'poetic competence'. Moreover, it turns out that both Kindergartners and Second Graders show explicit appreciation of (for them) innovative features in poetry related to their specific competence and preferences. This is an 
important supplement to the idea that young children especially enjoy familiar features and repetition in texts (Ghesquière, 2009, p. 137).

To conclude, this thesis offers an important contribution to scientific, educational and societal debates on (the importance of) cultural transmission and canon formation in culturally diverse societies and schools. The methodology developed for the selection of children's literature is based on the identification and validation of 'indicators of canonicity' that are rooted in widely acknowledged trans-culturally valued genres while also closely fitting young children's cultural competence. The theoretical framework and methodology align educational approaches based on cultural transmission and approaches based on individual competence and preference, debunking the idea that these approaches are incompatible. It is shown that children's literature selected in this way can effectively enhance children's trans-cultural literacy. Moreover, the methodology developed in this research program contributes to scientific investigations of processes of canonization in children's literature by offering a highly innovative evidence-based bottom-up approach. The findings for children's poetry confirm the 'pragmatic approach' as useful for identifying crucial indicators of canonicity. They also raise questions about the usefulness of the standardized test as an instrument for observing effects of poetry on children's emergent cultural literacy. The qualitative insights into how children experience, understand and appreciate poetry in the classroom demand a radical shift in our conception of 'results' that are usually formulated in terms of intellectual effects - the gaining of knowledge, understanding, cognitive skills -, even in qualitative instruments for the evaluation of 'effectiveness'. Although instruments for evaluation are needed to ensure the quality of educational methods, further research on and theorization of what poetry is and does for children is needed to ascertain how its effects on children's cultural literacy can be evaluated. For the qualitative findings form a convincing validation of the - up to this point only theoretical - assumption that for children " $\ldots$ poetry bypasses concepts and interpretation and reaches directly into embodied experience to produce its effects, which exceed its linguistic meaning." (Coats, 2013, p. 133) 



\section{Valorisatie addendum}




\section{Maatschappelijke waarde : wetenschappelijke waarde}

Met kennisvalorisatie wordt bedoeld: "het proces van waarde-creatie uit kennis, door kennis geschikt en/of beschikbaar te maken voor maatschappelijke (en/ of economische) benutting en geschikt te maken voor vertaling in concurrerende producten, diensten, processen en nieuwe bedrijvigheid." (definitie op basis van Landelijke Commissie Valorisatie, 2011, p. 8) Een van de belangrijkste valoriserende aspecten van onderzoek dat expliciet gericht is op de (onderwijs)praktijk, gaat echter vooraf aan het vertalen van de kennis verkregen uit onderzoek naar de beoogde praktijk. In dit type onderzoek staat het erkennen en benutten van de waarde van kennis uit de praktijk in de ontwikkeling en uitvoering van wetenschappelijk onderzoek voorop. Idealiter wordt in de regulatieve cyclus van praktijkgericht onderzoek de beoogde praktijk al betrokken bij de formulering van het probleem (Hart et al, 1998, p. 127). Praktijkgericht onderzoek wil tenslotte bijdragen aan de oplossing van een praktijkprobleem. In het Emergent Cultural Literacy project is de probleemformulering gebaseerd op terugkerende vraagstukken in maatschappelijke, professionele én wetenschappelijke debatten rond cultuuroverdracht en literaire of culturele canonvorming in relatie tot het onderwijs. Daarmee is het een voorbeeld van wetenschappelijk praktijkgericht onderzoek dat zowel oplossingen beoogt te ontwikkelen en toetsen voor wetenschappelijke kennisproblemen als voor vraagstukken in de onderwijspraktijk. Enerzijds levert dit onderzoek daarbij een belangrijke wetenschappelijke bijdrage aan onze kennis van processen van tekst- en cultuurverwerving bij jonge kinderen. Anderzijds dienen de resultaten van dit onderzoek als basis voor de ontwikkeling van transculturele geletterdheidsprogramma's voor de onderwijspraktijk. De wetenschappelijke en maatschappelijke waarde van dit onderzoek zijn feitelijk niet strikt van elkaar te onderscheiden.

\section{Praktijkgericht onderzoek: de praktijk als partner}

Dit onderzoek richt zich expliciet op het basisonderwijs en heeft tot doel empirisch onderbouwde criteria te ontwikkelen voor de selectie van kinderliteratuur die effectief bijdraagt aan de ontluikende culturele geletterdheid van kinderen in groep 2 en in groep 4. Die criteria zijn eerst geformuleerd als theoretische verwachtingen. Vervolgens zijn die verwachte criteria op de proef gesteld in het basisonderwijs via een interventieprogramma, het Leeskalenderproject. De geldigheid van de criteria in de praktijk van het basisonderwijs is zowel kwantitatief als kwalitatief nagegaan. Voor zover ze geldig zijn, kunnen deze criteria gebruikt worden als basis voor de ontwikkeling van (trans)culturele geletterdheidsmethoden voor het onderwijs. Hoewel het onderzoek ook fundamentele - puur kennisgerichte - aspecten omvat, is het daarmee in hoge mate praktijkgericht. De expliciete gerichtheid op de praktijk van het basisonderwijs komt zowel tot uiting in de gekozen opzet en uitvoering van het onderzoek zelf, als in de beoogde toekomstige benutting van de uitkomsten. In verschillende fasen van het onderzoek hebben professionals met kennis van en rechtstreeks uit de onderwijspraktijk een belangrijke rol gespeeld. Omdat dit in detail beschreven staat in dit proefschrift, beperk ik me hier tot een beknopte samenvatting. 
Het Leeskalenderproject heeft een ontwikkelingstraject doorlopen waarin in iedere fase actoren uit het veld betrokken waren, in de vorm van twee expertraadplegingen en twee pilots op basisscholen. De eerste expertraadpleging bestond uit een gesprek met twee experts op het gebied van kinderliteratuur, leesbevordering en boekpromotie binnen en buiten het basisonderwijs. Deze experts zijn specifiek bij het ontwikkelingstraject betrokken om vanuit hun expertise de samenstelling van het tekstaanbod voor groep 2 en voor groep 4 te beoordelen. Daarnaast hebben beide experts ons geadviseerd over de wijze waarop teksten effectief kunnen worden aangeboden in de klas. In de tweede fase zijn op basis van de evaluatie van de eerste expertraadpleging aanpassingen gedaan in de tekstselecties, en zijn pilot-Leeskalenders en -handleidingen ontwikkeld ter voorbereiding op de eerste pilotstudie in de praktijk. Deze pilotmaterialen zijn echter eerst voorgelegd aan een panel in de tweede expertraadpleging. Het panel bestond uit een onderwijsadviseur, drie leesbevorderaars/methodeontwikkelaars, zes groep 1-2 leerkrachten, en drie groep 4 leerkrachten. Dit panel van experts is gevraagd feedback te geven op de pilot-Leeskalender en pilothandleidingen voor groep 1-2 en voor groep 4. Via beoordelingsformulieren werd de experts gevraagd verschillende onderdelen van de materialen op basis van concrete stellingen te scoren op een 5-punts Likertschaal, een schatting te doen van de tijd die de behandeling van elke tekst met aanbieding en verwerking in de klas in beslag zou nemen en te beoordelen of dit haalbaar is in de praktijk. Op basis van de uitkomsten van deze raadpleging zijn de materialen opnieuw aangepast. De derde fase van het ontwikkelingstraject van de Leeskalenders en handleidingen stond verder geheel in het teken van de voorbereiding, uitvoering, verwerking en evaluatie van de eerste pilotstudie. Drie weken lang werd op twee basisscholen in groepen 1-2 en in groepen (3-)4 gewerkt met proefversies van de Leeskalender. Gedurende de pilot is er regelmatig geobserveerd in de groepen om zoveel mogelijk inzicht te krijgen in de wijze waarop leerkrachten met de materialen werkten en in de wijze waarop de kinderen op de materialen reageerden. Ook hielden de leerkrachten een logboek bij om teksten, aanbiedings- en verwerkingsinstructies te beoordelen. $\mathrm{Na}$ afloop is er een gesprek met de leerkrachten gevoerd om hun ervaringen te inventariseren en te bespreken op welke punten aanpassing van het materiaal wenselijk of noodzakelijk was. Naast het werken met de Leeskalender werden op deze scholen ook de eerste versies van de Toets Ontluikende Culturele Geletterdheid voor groep 2 en groep 4 getest in pilot 1 en pilot 2 (alleen toets). De uitkomsten van de pilots zijn eveneens gebruikt om de interventiematerialen en de toets te verbeteren.

Dankzij de oordelen, adviezen en gedeelde ervaringen van alle betrokkenen uit de praktijk heeft het ontwikkelingstraject geleid tot een bruikbaar en aantrekkelijk interventieprogramma dat gedurende een heel schooljaar is ingevoerd in groepen 2 en groepen 4 van het basisonderwijs. Hoewel verschillende experts ons gaandeweg hadden gewaarschuwd dat het werven van voldoende scholen een grote uitdaging zou zijn, bleek het Leeskalenderproject - mede dankzij de enorme inzet van onze scholencoördinator - zo aantrekkelijk voor het onderwijs dat meer scholen dan strikt noodzakelijk zich aanmeldden. Een onderzoekspopulatie van 700 leerlingen is aanzienlijk, waar we uit af mogen leiden dat het programma en haar materialen aansluiten bij vragen en problemen die in het onderwijsveld leven. Dit wordt nog eens bevestigd door het feit dat verschillende scholen aangaven interesse te hebben in de Leeskalender als methode. De samenwerking tussen scholencoördinator, 
experimentele en controlescholen en de drie onderzoekers werd daarbij ondersteund door een Leeskalenderproject-blog (http://leeskalender.blogspot.com). Hierdoor kon de voortgang van het project direct worden teruggekoppeld naar de deelnemende scholen. Verder is de uitvoering van het interventieprogramma ondersteund door openbare bibliotheken die de scholen van de benodigde boeken hebben voorzien. Verschillende van de instrumenten die gebruikt zijn om onze theoretische verwachtingen te beproeven in de praktijk leveren daarbij niet alleen antwoorden op de geformuleerde onderzoeksvragen. Logboeken, observaties in de klas, en gesprekken met leerkrachten tijdens de interventie bieden ook een rijkdom aan inzichten in factoren die in het basisonderwijs van invloed zijn op de inbedding van een transculturele geletterdheidsmethode in de alledaagse praktijk. De resultaten van de interventie leren ons dat de Leeskalender op bepaalde punten moet worden bijgesteld om de aantrekkelijkheid en bruikbaarheid van de methode te verbeteren. Voor de doorontwikkeling beogen we een aanvraag in te dienen bij Alfa meerwaarde om dit, opnieuw in samenwerking met maatschappelijke partners, te kunnen realiseren.

\section{De maatschappelijke relevantie van culturele geletterdheid in het basisonderwijs}

Toen de Raad voor Cultuur in 2005 aandacht vroeg voor lezen als sleutel tot informatie en cultuur, als voorwaarde om volwaardig te kunnen deelnemen aan een geletterde samenleving, legde ze het primaat in het verwerven van kennis van onze cultuur bij het lezen van literatuur. Ze stelt dat het culturele lezen, het lezen van cultureel waardevolle en literaire teksten, bijdraagt aan de cognitieve ontwikkeling, de literaire competentie vergroot, leesplezier verschaft, en is te beschouwen als sociaal kapitaal. Het lezen van literaire en culturele teksten verschaft daarnaast toegang tot het culturele erfgoed, kweekt historisch besef aan en draagt bij aan cultureel relativisme en onderhoud van een collectief geheugen (2005b, p. 3). De Raad voor Cultuur wilde het belang van dit 'culturele lezen' opnieuw onder de aandacht brengen omdat de kennis en vaardigheden die nodig zijn voor het culturele lezen in de samenleving en in het onderwijs minder vanzelfsprekend zijn geworden: "Het accent is in de afgelopen periode verschoven van literatuur naar leesvaardigheid en leesplezier in het algemeen." (idem, p. 6) Tot op heden heeft vooral het begrip 'literaire competentie' veel aandacht gekregen, zowel voor het voortgezet onderwijs als ook voor het basisonderwijs (zie o.a. Coenen, 1992; Duijx, 2003; Dormolen et al, 2005; Witte, 2008; Ghonem-Woets, 2009; Pol, 2010). De aandacht voor het lezen van literatuur als toegang tot cultuur en het aanbieden van 'cultureel waardevolle' teksten als middel voor de ontwikkeling van culturele geletterdheid, het verwerven van kennis van 'onze cultuur' via literatuur, heeft tot op heden geen expliciete en structurele plaats in het Nederlandse basisonderwijs. Het belang van deze kant van lezen wordt tegelijkertijd steeds groter, getuige de terugkerende roep om aandacht voor brede cultuuroverdracht en culturele vorming in het onderwijs (Onderwijsraad, 2011; Onderwijsraad \& Raad voor Cultuur, 2012; Onderwijsraad, 2013). Juist vanwege de toegenomen complexiteit en de afgenomen vanzelfsprekendheid acht ook de Onderwijsraad het van belang dat in het onderwijs aandacht wordt besteed aan brede culturele vorming: 
"Kinderen en jongeren hebben behoefte aan brede cultuuroverdracht, waaronder kennis van tradities en moraal. Ze zullen deze kennis niet gauw meer op andere plekken kunnen opdoen. Scholen en leraren hebben de taak kinderen en jongeren in te leiden in de opgebouwde kennis en (morele) tradities, zowel door kennisoverdracht als door voorbeeldgedrag en regels." (2011, p. 12)

Zowel op het gebied van het lezen van 'cultureel waardevolle' teksten als toegang tot cultuur als op het gebied van brede cultuuroverdracht valt nog veel winst te boeken in het basisonderwijs. De eenzijdige aandacht voor de basisvaardigheden die in het (basis)onderwijs in de afgelopen decennia is gaan overheersen, heeft volgens de Onderwijsraad geleid tot een 'verschraling van het onderwijs' ten koste van (onder meer) cultuureducatie en burgerschapsvorming: "Meetbare doelen zijn de maatstaf geworden voor de kwaliteit van het onderwijs. De raad roept op discussie te voeren over wat het Nederlandse onderwijs leerlingen en studenten moet meegeven.” (2013, pp. 4-5)

Dit onderzoek stelt de rol die kinderliteratuur kan spelen in het ontwikkelen van de ontluikende culturele geletterdheid van kinderen in het basisonderwijs centraal. Echter, de vraag wat 'cultureel waardevolle teksten' zijn, is blijvend onderwerp van kritisch debat. "De canon-kritiek komt vooral voort uit de groeiende twijfel over het bestaansrecht van 'een canon van de samenleving', een lijst met boeken die ... 'functionele geldigheid heeft voor de maatschappij als geheel'," stellen Helma van Lierop-Debrauwer en Piet Mooren vast: "Pogingen om een dergelijke canon vast te leggen, leiden keer op keer tot verhitte discussies." (2004, p. 8) Cultuuroverdracht is complexer en minder vanzelfsprekend geworden onder invloed van tal van sociaal-culturele ontwikkelingen. Denk aan de afnemende invloed van traditionele levensbeschouwelijke instituties, toenemende culturele pluriformiteit in de samenleving, de toenemende dynamiek van de huidige netwerksamenleving, en het toegenomen belang dat aan economisch nut en rendement wordt gehecht, ook op het gebied van kennis, cultuur en wetenschap (Onderwijsraad, 2011; Onderwijsraad \& Raad voor Cultuur, 2012). Daarbij worden een leerlinggerichte en een cultuuroverdrachtgerichte onderwijsopvatting vaak recht tegenover elkaar geplaatst: "Dé canon op school moet het afleggen tegen persoonlijke voorkeur en competentie van leerlingen." (Schram, 2003, p. 6) Zeker wanneer we het over jonge kinderen hebben, is het van belang te realiseren dat debatteren over wat er aan cultuur zou moeten worden overgedragen weinig zin heeft als er niet ook gekeken wordt naar wat de beoogde doelgroep aan cultuur kan verwerven en hoe zij dat kan. De centrale vraag in dit onderzoeksproject is dan ook: waar liggen de raakvlakken tussen 'cultureel waardevolle' teksten en de culturele competentie van jonge kinderen met verschillende culturele achtergronden? Deze centrale vraag doet iets nieuws in relatie tot onderwijs- en canonvormingsdebatten: ze presenteert de culturele competentie van individuele leerlingen en de culturele waarde van teksten als twee zijden van dezelfde medaille. Daarmee komen leerlinggericht en cultuuroverdrachtgericht onderwijs in elkaars verlengde te liggen. Putten uit 'de canon van de volkscultuur' ligt daarbij voor de hand. Allereerst omdat we via die volkscultuur, "als aanduiding van de brede, alledaagse cultuur, waar iedereen, elite of volk, vreemd of eigen, in participeert" (Dekker et al, 2000b, p. 10), inzicht krijgen in de culturele praktijken die vorm geven aan de ontluikende culturele competentie van jonge kinderen. Ten tweede “... omdat rijmpjes en versjes, sprookjes en fabels, raad- 
sels en spreuken, moppen en grappen deel uitmaken van een internationale traditie." (Lierop-Debrauwer \& Mooren, 2004, p. 11) In groepen 2 en groepen 4 op basisscholen verspreid over Limburg en Noord-Brabant is dertig weken lang gewerkt met een aanbod van verhalen, gedichten en liedjes die op basis van specifieke verwachtingen over hun breed gedragen culturele 'canoniciteit' zijn geselecteerd. Zowel de inbedding van culturele pluriformiteit als de specifieke genres en tekstsoorten in het aanbod werden door leerkrachten gezien als belangrijke aanvulling op het type teksten waar ze doorgaans mee werken in het kader van taalmethoden en/of leesbevorderingsactiviteiten. De waardering van leerkrachten en kinderen voor het aanbod bevestigt ons uitgangspunt dat putten uit de orale volkscultuur een effectieve insteek is om kinderliteratuur te selecteren die enerzijds aansluit op de ontluikende culturele competentie en voorkeuren van de kinderen en anderzijds toegang biedt tot een brede waaier aan uitingsvormen die als 'cultureel waardevol' worden ervaren. Hiermee levert dit onderzoek een zeer waardevolle, en empirisch onderbouwde, bijdrage aan het maatschappelijk debat over cultuuroverdracht in het basisonderwijs.

\section{Praktijkgericht onderzoek en haar fundamentele waarde}

Over het algemeen wordt onderscheid gemaakt tussen fundamenteel en praktijkgericht wetenschappelijk onderzoek. Fundamenteel onderzoek richt zich op "het ontwikkelen en toetsen van theorieën voor de oplossing van kennisproblemen" die binnen of buiten de wetenschap kunnen bestaan (Hart et al, 1998, p. 109). Praktijkgericht onderzoek heeft tot doel "het ontwikkelen, uitproberen en evalueren van oplossingen voor praktijkproblemen" die buiten de wetenschap bestaan (ibidem). De twee typen onderzoek verschillen van elkaar op het niveau van de primaire onderzoeksdoelstelling. Echter, buiten die primaire doelstelling bestaat er geen volledig waterdichte scheiding tussen fundamenteel en praktijkgericht wetenschappelijk onderzoek: "Er bestaat nauwelijks fundamenteel onderzoek dat op termijn geen enkel praktisch nut heeft. Omgekeerd wordt in praktijkgericht onderzoek ook theorie ontwikkeld en gebruikt.” (idem, p. 133)

Waarom deze verhandeling over fundamenteel en praktijkgericht onderzoek in dit valorisatie addendum? Omdat de (relatief) recente expliciete nadruk op het belang van valorisatie in de wetenschap de suggestie wekt dat alle onderzoek een expliciet praktijkgerichte doelstelling moet hebben. Enerzijds bestaat er echter al een lange traditie van praktijkgericht onderzoek die zich over vele disciplines en maatschappelijke domeinen uitstrekt; anderzijds 'bestaat er nauwelijks fundamenteel onderzoek dat op termijn geen enkel praktisch nut heeft'. Tegelijk mag duidelijk zijn dat praktijkgericht onderzoek belangrijke bijdragen kan leveren aan fundamentele vraagstukken in de wetenschap. In het Emergent Cultural Literacy onderzoek blijkt de inbedding van kinderpoëzie in de praktijk van het basisonderwijs bijvoorbeeld een cruciale bijdrage te leveren aan de fundamentele vraag om een nieuw perspectief dat poëzie voor kinderen primair als zinvol of betekenisvol begrijpt in het gebruik ervan door kinderen in plaats van in de literaire interpretaties van haar formele en inhoudelijke eigenschappen door volwassen en ervaren lezers (zie ook Coats, 2013, p. 133). Dit helpt vervolgens bij het selecteren van poëzie die bij kinderen in de smaak valt waardoor het praktijkprobleem van de 'drempel voor het werken met poëzie in het basisonder- 
wijs' (SLO) verholpen kan worden. Een dergelijke nauwe relatie tussen fundamentele en praktische vraagstukken zien we ook met betrekking tot het toetsen van effecten van kinderliteratuur op ontluikende culturele geletterdheid. 'Rendementsdenken' in het onderwijs bemoeilijkt aandacht voor de bredere culturele ontwikkeling van kinderen, mede omdat de 'culturele ontwikkeling' van leerlingen zo moeilijk te vertalen is naar meetbare resultaten (Onderwijsraad \& Raad voor Cultuur, 2012, p. 15). Hoe een theoretisch construct geoperationaliseerd kan worden in objectief betrouwbare en valide meetinstrumenten is een fundamenteel probleem. Tegelijk is het een praktijkprobleem omdat scholen op basis van meetbare resultaten verantwoording moeten afleggen over de effectiviteit van het onderwijs dat ze aanbieden. Willen we dat kinderliteratuur als middel voor brede culturele ontwikkeling een structurele plaats krijgt in het basisonderwijs, dan vormt de fundamentele vraag over het meetbaar maken van culturele ontwikkeling een belangrijke voorwaarde. Vooral in groep 4 lieten leerkrachten hun definitieve oordeel over of ze de Leeskalender een aantrekkelijke methode vinden, afhangen van de toetsresultaten. Tegelijk kunnen fundamentele inzichten in culturele ontwikkeling en waarom het zich zo moeilijk laat vertalen naar meetbare resultaten een belangrijke bijdrage leveren aan het maatschappelijk debat over het 'rendementsdenken' in het onderwijs. Wetenschap en samenleving, maatschappelijke en wetenschappelijke relevantie, praktijkgericht en fundamenteel onderzoek: vaak zijn dit net zulke 'tegengestelde' domeinen als leerlinggericht en cultuuroverdrachtgerichte onderwijsopvattingen. Zowel fundamenteel als praktijkgericht onderzoek is van maatschappelijke waarde én van wetenschappelijke waarde. 



\section{Verantwoording}


Het onderzoek waar dit proefschrift verslag van doet, is onderdeel van het door NWO gesubsidieerde onderzoeksproject Emergent Cultural Literacy: Assimilating Children's Literature. Dit onderzoeksproject omvat in totaal drie deelprojecten. Naast het deelproject Kinderpoezie, dat in dit proefschrift centraal staat, is er het deelproject Narratieve Genres, uitgevoerd door drs. Inge Verouden aan de Universiteit Maastricht en het deelproject Deugden \& Dilemma's, uitgevoerd door dr. Karen Ghonem-Woets aan de Universiteit van Tilburg. De drie deelprojecten gaan uit van dezelfde centrale onderzoeksvragen binnen hetzelfde brede onderzoekskader en hebben nauw samengewerkt in de ontwikkeling, opzet en uitvoering van het empirisch deel van het onderzoek, het Leeskalenderproject. De interventiematerialen en het meetinstrument zijn in een gezamenlijk traject ontwikkeld. Daarbij zijn binnen het onderzoeksproject als geheel een scholencoördinator, Ingeborg Hendriks, en een methodoloog, dr. Elma Nap-Kolhoff, aangetrokken om de ontwikkeling, opzet en uitvoering van het Leeskalenderproject te ondersteunen. Ingeborg Hendriks was, in samenspraak met de methodoloog en de onderzoekers, verantwoordelijkheid voor de werving en selectie van scholen voor het experiment. $\mathrm{Zij}$ heeft daarnaast een belangrijke rol gespeeld in de organisatie van de expertraadplegingen en de pilots, de aanlevering van boeken door bibliotheken, ze heeft de externe communicatie rond het project en de organisatie en planning van de voor- en nameting verzorgd. Dr. Elma Nap-Kolhoff heeft, als methodoloog, een belangrijke rol gespeeld in de opzet en uitvoering van het experiment en de toewijzing van scholen aan onderzoekscondities. Zij heeft ons geadviseerd over en begeleid in de ontwikkeling, opzet en toepassing van het meetinstrument, de Toets Ontluikende Culturele Geletterdheid, en de logboeken. Alle statistische analyses waar in dit proefschrift de resultaten van worden besproken, zijn uitgevoerd door de methodoloog, op basis van de vragen die door de drie onderzoekers gezamenlijk (voor het project als geheel) en onafhankelijk (voor het eigen deelproject) aan haar zijn voorgelegd.

De nauwe samenwerking tussen de onderzoekers, maar ook met de scholencoördinator en methodoloog wordt weerspiegeld in bijdragen aan delen van dit proefschrift. Hoofdstuk 1 presenteert het brede onderzoekskader en is geschreven op basis van een eerdere 'beginselverklaring' opgesteld in samenwerking met Karen Ghonem-Woets. In Hoofdstuk 6, waarin de projectbrede opzet van het empirisch onderzoek beschreven staat, zijn in $\$ 6.6$ delen van de beschrijving van 'De Toets Ontluikende Culturele Geletterdheid', 'Oudervragenlijst' en 'Evaluatiegesprekken met leerkrachten' geschreven door Karen Ghonem-Woets en is het stuk 'Reguliere schooltoetsen' geschreven op basis van een rapportage van Elma Nap-Kolhoff. In $\$ 6.7$ is de beschrijving van 'De werving en selectie van scholen' gebaseerd op rapportages van Ingeborg Hendriks en is de beschrijving van 'De toewijzing van scholen aan onderzoekscondities' gebaseerd op rapportages van Elma Nap-Kolhoff. In Hoofdstuk 7 is een deel van $\$ 7.4$ over 'Het meten van ontluikende culturele geletterdheid' geschreven door Karen Ghonem-Woets. 
Over de auteur 
Annette de Bruijn (Lekkerkerk, 1981) studeerde Communicatie- en Informatiewetenschappen (BA, 2006, cum laude) en Algemene Cultuurwetenschappen (MA, 2007, cum laude) aan de Universiteit van Tilburg. Tijdens haar studie deed ze een onderzoeksstage bij het Meertens Instituut voor onderzoek en documentatie van de Nederlandse taal en cultuur (2005-2006). In haar Master thesis getiteld 'Twee maal twee is vijf' onderzocht ze de zin van de nonsens in de kinderpoëzie van Annie M.G. Schmidt op basis van een combinatie van hermeneutische en empirische onderzoeksmethoden (eervolle vermelding voor de L.M. Boerlage Scriptieprijs 2007). Vanaf 2007 is Annette (co-)auteur van verschillende professionele en wetenschappelijke publicaties in tijdschriften als Literatuur zonder Leeftijd, Leesgoed, en Bookbird. Ze heeft als co-redacteur en -auteur bijgedragen aan de bundel Helden, idolen en iconen in de jeugdliteratuur op basis van het gelijknamig Tilburgs symposium. Ze presenteert haar werk op verschillende (inter-)nationale conferenties en symposia. Annette deed haar promotieonderzoek aan de Faculty of Arts and Social Sciences (UM) binnen het onderzoeksprogramma Emergent Cultural Literacy: Assimilating Children's Literature (gefinancierd door NWO). Op dit moment werkt ze als docent aan dezelfde faculteit. 


\section{Bibliografie}


AARNOUTSE, Cor, e.a. (1985). De leesattitudeschaal. Nijmegen: Berkhout.

ALPHEN, Ernst van, DUYVENDAK, Lizet, MEIJER, Maaike \& PEPERKAMP, Ben (2010/1996). Op poëtische wijze: Handleiding voor het lezen van poëzie. Bussum: Uitgeverij Coutinho, $1^{\text {ste }} \mathrm{druk}$, $3^{\text {de }}$ oplage.

ANDERSON, Celia Catlett \& APSELOFF, Marilyn Fain (1989). Nonsense Literature for Children. Aesop to Seuss. Hamden CT: Library Professional Publications.

ANTENS, Marloes \& MOOREN, Piet (2002), 'De speelplaats als vrijplaats. Interculturele uitwisseling van kringspel-, klapspel- en touwspringliedjes’. In: Literatuur zonder Leeftijd, nr. 59 (najaar), pp. 411-423.

ARENDSEN, Annemieke (2011), 'Vraag van de maand: Ik ben op zoek naar het verhaal achter 'Holle Bolle Gijs'. Kunt u mij hieraan helpen?' In: Nieunsbrief Meertens Instituut, maart, zp. Geraadpleegd via: www.meertens.knaw.nl

ARLEO, Andy (1980), 'With a Dirty, Dirty Dishrag on Your Mother's Big Fat Toe: The Coda in the CountingOut Rhyme'. In: Western Folklore, Vol. 39, No. 3, Children’s Folklore (Jul.), pp. 211-222.

AVEGNO, T.S. (1956), 'Intermediate-grade choices of poetry'. In: Elementary English, no. 33, pp. 428-432.

AVEST, Ina ter (2010), 'Verhalen voor het leven. Culturele en religieuze geletterdheid'. In: Het jonge kind, juni, pp. 58-60.

BAKHTIN, Mikhail (vertaald door Hélène Iswolsky) (1984/1968). Rabelais and His World. Bloomington: Indiana University Press.

BARIAUD, Francoise (2013), 'Age Differences in Children's Humor.' In: McGhee, Paul E. (red.). Humor and children's development: a guide to practical applications. New York: Routledge, pp. $15-46$ (1 ${ }^{\text {ste }}$ uitgave: The Haworth Press, 1989).

BEAUVAIS, Clémentine (2013), 'The Problem of "Power": Metacritical Implications of Aetonormativity for Children's Literature Research'. In: Children's Literature in Education 44, pp. 74-86.

BEKKERING, Harry (1989), 'Van poesie tot poëzie - het kindervers'. In: Heimeriks, Nettie \& Toorn, Willem van (red.), De bele Bibelebontse berg. De geschiedenis van het kinderboek in Nederland \& Vlaanderen van de Middeleeunen tot heden. Amsterdam: Querido, pp. 341-390.

----- (2002), 'Gevonden voorwerpen in de literatuur. Redactionele inleiding.' In: Literatuur zonder leeftijd. Den Haag: Biblion Uitgeverij, 16 jaargang, nr. 59 (najaar), pp. 356-358.

BENNET, L.A., WOLIN, S.J. \& MCAVITY, K.J. (1988), 'Family Identity, Ritual, and Myth: A Cultural Perspective on Life Cycle Transitions'. In: Falicov, C.J. (red.) Family Transitions: Continuity and Change Over the Life Cycle. New York: The Guilford Press, pp. 211-234.

BOELENS, Tysger \& KOMRIJ, Gerrit (samenstelling) (2007). Perplexicon: Het abc van de nonsens. Amsterdam: Uitgeverij Nijgh \& Van Ditmar.

BOONSTRA, Bregje (1989), 'Ik was de zee en jij was de golven', In: Jan Campertprijzen. Den Haag: Bzztôh, pp. 127-134.

BORK, G.J. van, D. DELABASTITA, H. van GORP, P.J. VERKRUIJSSE \& G.J. VIS (2012). Algemeen letterkundig lexicon. DBNL online: http://www.dbnl.org/tekst/dela012alge01_01/dela012alge01_01_04978.php

BORNEMAN, Ernest (1973, 1974 en 1976). Studien zur Befreiung des Kindes; Deel I Unsere Kinder im Spiegel ibrer Lieder, Reime, Verse und Rätsel; Deel II Die Umwelt des Kindes im Spiegel seiner 'verbotenen' Lieder, Reime, Verse und Rätsel; Deel III Die Welt der Erwachsenen in der 'verbotenen' Reimen deutschsprachigen Stadtkinder. Olten: Walter-Verlag.

BOURDIEU, Pierre (1979). La Distinction. Critique sociale du jugement. Paris: Les Editions de Minuit.

BOURDIEU, Pierre \& PASSERON, Jean-Claude (1981/1970), 'Examen en uitsluiting zonder examen'. In: M. Du Bois-Reymond \& A. Wesselingh (red.). School en maatschappij. Sociologen over onderwijs en opvoeding. Groningen: Wolters-Noordhoff, pp. 120-134.

BRADSHAW, R.E. (1937), 'Children's choices in poetry in the first grade'. In: The Elementary English Review, no. 14, pp. 168-176.

BRONZWAER, W (1993). Lessen in lyriek. Nieuwe Nederlandse poëtica. Nijmegen: Uitgeverij SUN.

BRUIJN, Annette de \& MOOREN, Piet (2008), 'Kinderen van Pieter Hendrik Hagelslag. Over de zin van de onzin in de kinderpoëzie van Annie M.G. Schmidt.' In: Literatuur zonder Leeftijd. Leidschendam: Biblion Uitgeverij, zomer, 22ste jaargang, nr. 76, pp. 126-138.

----- (2013), 'Annies held(inn)en: van een spree met foeten tot drie apothekertjes in een hoed. Over de nonsensicaliteit in de kinderpoëzie van Annie M.G. Schmidt.' In: Bruijn, Annette de, Ghonem-Woets, Karen \& Verouden, Inge (red.). Helden, idolen en iconen in de jengdliteratuur. Tilburg: Tilburg University, pp.71-86.

BRYANT, P.E., BRADLEY, L.L. \& CROSSLAND, J. (1989). Nurse rbymes, phonological skills and reading. In: Journal of Child Language, 16, pp.407-428. 
BRYANT, P.E., MACLEAN, M., BRADLEY, L.L. \&CROSSLAND, J. (1990). Rhyme and Alliteration, Phoneme Detection, and Learning to Read. In: Developmental psychology, Vol. 26, No.3, pp.429-438.

BUCHEL, Jori (2010). Kindercultuur in Amsterdam. Een onderzoek naar interculturele nitwisseling, geschiedenis en overlevering van klapversjes, aftelrijmpjes en springtouwliedjes op twee schoolpleinen in de hoofdstad van Nederland. Universiteit van Amsterdam: Masterscriptie Muziekwetenschap, juni (niet gepubliceerd).

CHALL, J.S. (1983a). Stages of reading development. New York: McGraw-Hill.

CHALL, J.S., \& JACOBS, V.A. (1983b). 'Writing and reading in the elementary grades: Developmental trends among low-SES children'. In: Language Arts, vol. 60, no. 5, pp. 617-626.

CHALL, J. S., JACOBS, V.A., \& BALDWIN, L.E. (1990). The Reading Crisis: Why poor children fall behind. Cambridge, Mass.: Harvard University Press.

CHUKOVSKY, Kornei (1971/1925). From Two to Five. Translated and edited by Miriam Morton; foreword by Frances Clarke Sayers. Berkeley, Los Angeles/London: University of California Press, 2de druk.

CLARKE, A. (2008). The Pattern Recognition Theory of Humor: An Introduction. Cumbria: Pyrrhic House.

COATS, Karen (2010), 'If it rhymes, it's funny": Theories of Humour in Children's Poetry'. In: Styles, M., Joy, L. \& Whitley, D (red.). Poetry and Childhood. London: Institute of Education Press, A Trentham Book, pp. 121130.

(2013), 'The Meaning of Children's Poetry: A Cognitive Approach'. In: International Research in Children's Literature, 6.2, pp. 127-142.

COENEN, Lily (1992), 'Literaire competentie: werkbaar kader voor het literatuuronderwijs of nieuw containerbegrip?' In: Spiegel, 10, 2, pp. 55-78.

CUNNINGHAM, Jennifer (2005), 'Chapter 5. Children's Humor'. In: Scarlett, W. George, Sophie Naudeau, Dorothy Salonius-Pasternak, Iris Ponte (red.). Children's Play. California: Sage Publications, pp. 93-108.

DEKKER, T., ROODENBURG, H. \& ROOIJAKKERS, G. (red.) (2000a). Volkscultuur: Een inleiding in de Nederlandse etnologie. Nijmegen: Uitgeverij SUN.

(2000b), 'Ten geleide. Reflecties op de cultuur van het dagelijks leven'. In: idem (red.). Volkscultuur: Een inleiding in de Nederlandse etnologie. Nijmegen: SUN, pp. 7-12.

DICKINSON, David K. \& SMITH, Miriam W. (1994), 'Long-Term Effects of Preschool Teachers' Book Readings on Low-Income Children's Vocabulary and Story Comprehension'. In: Reading Research Quarterly, Vol. 29, No. 2 (Apr. - May - Jun.), pp. 104-122.

DICKSTEIN, Susan (2002), 'Family Routines and Rituals - The Importance of Family Functioning: Comment on the Special Section.' In: Journal of Family Psychology, Vol. 16, No. 4, pp. 441-444.

DIJK, Marie van (1999), 'Berend Botje in Lombok. Traditionele Nederlandse liedjes en versjes als bron van inspiratie voor kinderen van allochtone afkomst.' In: Volkskundig Bulletin 25.2/3, pp. 315-340 (Themanummer: 'De discipline van het dagelijks leven. Bijdragen voor Ton Dekker over orale cultuur, feestcultuur en de historiografie van de volkskunde', red. J. Helsloot, Th. Meder en C. Wijers).

----- (2004), 'Bedelliedjes en Sint Maarten'. In: Bulletin Vereniging van V rienden Martinikerk, volume 21 (maart), pp. $18-36$.

DIJK, Teun A. van (1980), ‘The Pragmatics of Literary Communication’. In: Forastieri-Braschi, E., Guiness, G. \& Lopez-Morales, H. (red.). On Text and Context. Rio Piedras, Puerto Rico: Editorial Universitaria, pp. 3-16.

DISSANAYAKE, E. (2007) 'What art is and what art does: An overview of contemporary evolutionary hypotheses'. In: Martindale, C., Locher, P. \& Petrov, V. M. (Eds.) Evolutionary and Neurocognitive Approaches to Aesthetics, Creativity, and the Arts. Amityville, NY: Baywood (in Foundations and Frontiers in Aesthetics series), pp. 1-14.

----- (2009), 'The Artification Hypothesis and Its Relevance to Cognitive Science, Evolutionary Aesthetics, and Neuroaesthetics'. In: Cognitive Semiotics, Issue 5 (Fall), pp. 148-173.

DONGELMANS, Berry, ROTTERDAM, Netty van, SALMAN, Jeroen \& VEER, Janneke van der (red.) (2000). Tot volle waschdom. Bijdragen aan de geschiedenis van de kinder-en jeugdliteratuur. Leidschendam: Biblion.

DORMOLEN, Marieke van, Agnes van MONTFOORT, Martijn NICOLAAS \& Anne-Mariken RAUKEMA (2005). De doorgaande leeslijn 0-18 jaar. Amsterdam: Stichting Lezen.

DROST, Ellen A. (2011), 'Validity and Reliability in Social Science Research'. In: Education Research and Perspectives, Vol.38, No.1, June, pp. 105-123.

DUIJX, Toin (red.) (2005). Leeskracht! Gids voor literaire competentie op school. Leidschendam: Uitgeverij Biblion, $3^{\mathrm{e}}$ druk (1e druk 2003).

EBBERS, Dirkje \& STEEGHS, Trees (2007). Ga met een blauw paard dwars door de hoogste Bergen. Een leerlijn poëzie schrijven en lezen voor het voortgezet onderwijs. Enschede: SLO. 
EISELIN, Judith (1996). Iene miene mutte: Over knikkeren, bokspringen en andere straatspelletjes. Amsterdam: Prometheus.

ENZENSBERGER, Hans Magnus (1962). Allerleiraub: Viele schöne Kinderreime. Frankfurt: Suhrkamp.

ERIKSON, E.H. (1966), 'Ontogeny of Ritualization in Man'. In: Philosophical Transactions of the Royal Society of London. Series B, Biological Sciences. The Royal Society, Vol. 251, No. 772, A Discussion on Ritualization of Behaviour in Animals and Man (Dec. 29), pp. 337-349.

FIESE, Barbara H., HOOKER, Karen A., KOTARY, Lisa \& SCHWAGLER, Janet (1993), 'Family Rituals in the Early Stages of Parenthood.' In: Journal of Marriage and Family, Vol. 55, No. 3 (Aug.), pp. 633-642.

FIESE, Barbara H., TOMCHO, Thomas J., DOUGLAS, Michael, JOSEPHS, Kimberley, POLTROCK, Scott \& BAKER, Tim (2002), 'A Review of 50 Years of Research on Naturally Occurring Family Routines and Rituals: Cause for Celebration?’ In: Journal of Family Psychology, Vol. 16, No. 4, pp. 381-390.

FINE, Gary Alan (1980), 'Children and Their Culture: Exploring Newell's Paradox'. In: Western Folklore, Vol. 39, No. 3, Children's Folklore (Jul.), pp. 170-183.

FISHER, C.J. \& NATARELLA, M.A. (1982), 'Young Children's Preferences in Poetry: A National Survey of First, Second and Third Graders'. In: Research in the Teaching of English, volume 16, nr. 4 (December), pp. 339354.

GELLER, Linda Gibson (1985). Wordplay and Language Learning for Children. USA: National Council of Teachers of English.

GHESQUIÈRE, Rita (2009a). Jeugdliteratuur in perspectief. Leuven: Acco (eerder uitgegeven onder de titel Het verschijnsel Jeugdliteratuur. Leuven: Acco, 1982).

----- (2009b), 'Wij zijn verhalen: Afscheidscollege Rita Ghesquière', gehouden aan de KU Leuven op 17 oktober 2009. Te raadplegen via: http://alum.kuleuven.be/germaanse/toespraken/ghesquiere09.htm

GHESQUIÈRE, R, JOOSEN, V. \& LIEROP-DEBRAUWER, H. van (2014), 'Inleiding: Geschiedenis van de jeugdliteratuur in vogelvlucht.' In: idem (red.). Een land van waan en wijs: Geschiedenis van de Nederlandse jeugdliteratuur. Amsterdam/Antwerpen: Uitgeverij Atlas Contact, pp. 11-55.

GHONEM-WOETS, Karen (1993). Taal van om de boek. Verslag van een exploratief onderzoek naar het leren en begrijpen van figuurlijk taalgebruik. Tilburg: Katholieke Universiteit Brabant, doctoraalscriptie (niet gepubliceerd).

----- (2009a). Elke dag boekendag! Verslag van een onderzoek naar het voorlezen van prentenboeken in groep 1 en 2. Amsterdam: Stichting Lezen.

----- (2009b). Literaire competentie in groep 3 tot en met 8. Amsterdam: Stichting Lezen.

----- (2010). Kennis van literaire conventies bij kinderen in de basisschoolleeftijd. Een inventarisatie en analyse van Engelstalig empirisch onderzoek naar de kennis van literaire conventies bij kinderen van 4 tot en met 12 jaar. Amsterdam: Stichting Lezen.

GORP, Hendrik van \& MUSARRA-SCHROEDER, Ulla (2000), 'Inleiding'. In: idem (red.): Genres as Repositories of Cultural Memory. Amsterdam/Atlanta: Rodopi, pp. i-ix (Studies in comparative literature 29).

GOSEN, M., BESSELSE, M., GLOPPER, K. de \& BERENST, J. (2009), 'De ontwikkeling van een instrument voor het meten van de voorleeservaring van kleuters'. In: Toegepaste Taalwetenschap in Artikelen, nr. 82, pp. 6979.

GRIJP, Louis P. (1991). Het Nederlandse lied in de Gouden Eeun: het mechanisme van de contrafactuur. Amsterdam: P.J. Meertens Instituut.

----- (2000a), 'Van Boekenoogen tot frater Remigius. Kinderliedverzamelingen in het Meertens Instituut'. In: Vries, A. de, Lierop-Debrauwer, H. van \& Mooren, P. Poëzie is kinderspel. Poëzie onder en boven de 18. Oisterwijk: Dutch University Press, pp. 86-98.

----- (2000b), 'Zangcultuur'. In: Dekker, T., Roodenburg, H. \& Rooijakkers, G. (red.). Volkscultuur: Een inleiding in de Nederlandse etnologie. Nijmegen: Uitgeverij SUN, pp. 337-380.

GRIJP, Louis Peter \& WILLAERT, Frank (2008). De fiere nachtegaal: Het Nederlandse lied in de middeleeuwen. Amsterdam: Amsterdam University Press.

HART, Harm 't, DIJK, Jan van, GOEDE, Martijn de, JANSEN, Wim \& TEUNISSEN, Joop (2001). Onderzoeksmethoden. Amsterdam: Boom, $5^{\text {de }}$ druk (1 ${ }^{\text {ste }}$ druk 1996; $3^{\text {de }}$, herziene druk 1998).

HEARNE, Betsy (2011). 'Folklore in Children's Literature. Contents and Discontents.' In: Wolf, Shelby A., Coats, Karen, Enciso, Patricia \& Jenkins, Christine A (red.). Handbook of Research on Children's and Young Adult Literature. New York/Abingdon: Routledge, pp. 209-222.

HEATH, Shirley Brice (1982), 'What No Bedtime Story Means: Narrative Skills at Home and at School.' In: Language in Society, Vol. 11, No. 1 (Apr.), pp. 49-76. 
HEIMERIKS, Nettie \& TOORN, Willem van (red.) (1989). De hele Bibelebontse berg. De geschiedenis van het kinderboek in Nederland \& Vlaanderen van de middeleeuwen tot heden. Amsterdam: Querido.

HEUSDEN, Barend van (2010), 'Cultuur in de Spiegel: naar een doorlopende leerlijn cultuuronderwijs'. Groningen: Rijksuniversiteit Groningen / Enschede: SLO.

----- (2011), 'Interpretatie en cognitie in de geesteswetenschappen'. In: Bernaerts, L. \& Pieters, J. (red.). CLW 3 Cabier voor Literatuurwetenschap. Hermeneutiek in veelvoud. Gent: Academia Press.

HIRSCH, Jr., E.D. (1983), 'Cultural Literacy’. In: The American Scholar, 52 (Spring), pp. 159-169.

----- (1987). Cultural Literacy: What Every American Needs to Know. [Appendix: What Literate Americans Know, E.D. Hirsch, Jr., Joseph Kett \& James Trefil], Boston: Houghton \& Mifflin.

----- (2003), 'Reading Comprehension Requires Knowledge - of Words and the World. Scientific Insights into the Fourth-Grade Slump and the Nation's Stagnant Comprehension Scores'. In: American Educator, vol. 27, nr. 1 (Spring), pp. 10-13, 16-22, 28-29, 48.

HIRSCH, Jr., E.D., Joseph E. Kett \& James Trefil (2002). The New Dictionary of Cultural Literacy (completely revised and updated). Boston/New York: Houghton Mifflin Company, 3de editie.

HOEFLAAK, Arie (2012), 'Hoe transparant zijn de examens leesvaardigheid? Een reactie op "Samenvatten in het vreemdetalenonderwijs”. In: Levende Talen Magazine, nr.3, pp. 18-22.

HOEVEN, M. van der, JACOBSE, A., LANSCHOT Hubrecht, V. van, RASS, A., ROOZEN, I., SLUIJSMANS, L., VORLE, R. van de (SLO); Hoofdstuk 3: COPINI, E., DORSTEN, T. van \& EKSTER, W. (RuG) (red.) (2014). Cultuur in de Spiegel in de praktijk: Een leerplankader voor cultuuronderwijs. Enschede: SLO.

HOVEN, Peter van den (1994), 'Kinderrijm zonder copyright: Over orale kinderpoëzie’. In: idem (red.). Grensverkeer: over jeugdliteratuur. Den Haag: NBLC Uitgeverij, pp. 151-161.

----- (1997), 'Uit de onderbuik. Over het scabreuze kindervers'. In: Literatuur zonder Leeftijd, jrg. 11, nr. 42, p. 213236.

HUIJER, Marli (2012). Ritme: Op zoek naar een terugkerende tijd. Zoetermeer: Klement, $2^{\text {de }}$ druk.

HUNT, Peter (2010), 'Confronting the Snark: the Non-Theory of Children's Poetry'. In: Styles, M., Joy, L. \& Whitley, D (red.). Poetry and Childhood. London: Institute of Education Press, A Trentham Book, pp. 17-24.

HUTCHEON, Linda (2013). A Theory of Adaptation (with Siobhan O'Flynn). Abingdon/New York: Routledge, 2de herziene editie (1ste editie 2006).

HUYSMANS, Frank (2013). Van woordjes naar wereldliteratuur: De leeswereld van kinderen van 7-15 jaar. Amsterdam/Den Haag: Stichting Lezen/SIOB. Geraadpleegd via: www.lezen.nl en www.siob.nl

ISER, Wolfgang (1978). The Act of Reading: A Theory of Aesthetic Response. Baltimore: Johns Hopkins University Press.

JAKOBSON, Roman (1987). Language in Literature. Cambridge: Harvard University Press.

JAKOBSON, Roman \& WAUGH, Linda R.; assisted by Martha Taylor (red.) (1987). The Sound Shape of Language. Berlijn: Mouton de Gruyter, 2de editie.

JANSEN, Frank \& AUKEMA, Saskia (2013), 'Lekker stout: Platte versies van populaire liedjes'. In: Onæ̧e taal, 82ste jaargang, nr. 10, pp. 270-273.

JUCHTMANS, Goedroen (2008), 'Rituelen thuis: van christelijk tot basaal sacraal. Een exploratieve studie naar huisrituelen in de Tilburgse nieuwbouwwijk De Reeshof.' In: Jaarboek voor liturgie-onderzoek. 24, pp. 225-230.

KALFF, G. (1972/1884). Het lied in de middeleeuwen. Arnhem: Gysbers \& Van Loon (facsimile-uitgave van druk 1884).

KAMBERELIS, George \& BOVINO, Thomas D. (1999), 'Cultural Artifacts as Scaffolds for Genre Development’. In: Reading Research Quarterly, Vol. 34, No. 2 (Apr. - Jun.), pp. 138-170.

KES, Dien, POLLMANN, Jop \& TIGGERS, Piet (1947). Kinderzang en Kinderspel (deel I $t / \mathrm{m}$ III). Honderdtwintig liedjes, canons en spelen voor jongens en meisjes van 6-11 jaar. Haarlem: Uitgeverij De Toorts.

KING, C.E. (1922), 'Favorite poems for children of elementary school age'. In: Teachers College Record, no. 33, pp. 255-273.

KOHNSTAMM, D. \& CASSEE, E. (samenst.) (1992). Het Cultureel Woordenboek: Encyclopedie van de algemene ontwikkeling. Amsterdam: Anthos.

Vanaf 2005 uitgegeven als Nieuw Cultureel Woordenboek en vanaf 2009 online beschikbaar via http://www.cultureelwoordenboek.nl.

KRAAYKAMP, Gerbert (2009). Culturele socialisatie: een zegen en een vloek. Verbreding en verdieping in het sociologisch onderzoek naar lange termijn effecten van culturele opvoeding (Oratie). Nijmegen: Radboud Universiteit Nijmegen, inaugurele rede uitgesproken op 4 december. 
KURVERS, Jeanne (2004), 'Waarom de olifant de straat overstak. Over de dubbele tong in raadsels.' In: Mooren, P., Kurvers, J. \& Lierop-Debrauwer, H. van (red.). De mondige jengdliteratuur. Over raakvlakeen van jeugdliteratuur en volkscultuur. Leidschendam: Biblion, pp. 183-198.

KUTIPER K. \& WILSON, P. (1993), 'Updating poetry preferences: A look at the poetry children really like'. In: The Reading Teacher, 47(1), September, pp. 28-35.

KYTE, G.C. (1947), ‘Children’s reactions to fifty selected poems’. In: Elementary School Journal, no. 47, pp. 331-339.

LAKOFF, Robin (1993), 'Lewis Carroll: Subversive Pragmatist'. In: Pragmatics, 3:4, pp. 367-385.

LAUTER, Paul (1991). Canons and Contexts. New York/Oxford: Oxford University Press.

LIEROP-DEBRAUWER, H., VRIES, A. de \& MOOREN, P. (red.) (2000). Poëzie is kinderspel. Poëzie onder en boven de 18. Oisterwijk: Dutch University Press.

LIEROP-DEBRAUWER, Helma van \& MOOREN, Piet (2004), 'Ter inleiding'. In: Lierop-Debrauwer, H. van, Mooren, P \& Bekkering, H. (red.). Dat moet je gelezen hebben: Literaire en educatieve canonvorming in de (jeugd)literatuur. Leidschendam: Biblion, pp. 7-17.

LIEROP-DEBRAUWER, Helma van (2004), 'De jeugdliteratuurkritiek als graadmeter'. In: Lierop-Debrauwer, H. van, Mooren, P. en Bekkering, H. (red.). Dat moet je gelezen bebben. Literaire en educatieve canonvorming in de (jeugd)literatuur. Leidschendam: Biblion Uitgeverij, pp. 30-38.

LIVINGSTON, Myra Cohn (1981), 'Nonsense verse: The complete escape.' In: Hearne, B. \& Kaye, M. (red.). Celebrating children's books: Essays on children's literature in honor of Zena Sutherland. New York: Lothrop, Lee \& Shepard, pp. 122-139.

LORBE, Ruth (1984), 'Kinderlyrik'. In: Haas, G. (red.). Kinder- und Jugendliteratur: Ein Handbuch. Stuttgart: Philipp Reclam, pp. 339-368.

LURIE, Alison (1990). Don't Tell the Grown-Ups: Subversive Children's Literature. London: Bloomsbury.

MACKINTOSH, H.K. (1924), 'A study of children's choices in poetry'. In: The Elementary English Review, no. 1, pp. 85-89.

MCCLURE, A.A. (1993), 'Children's responses to poetry in a supportive literary context'. In: Holland, K.E., Hungerford, R.A. \& Ernst, S.B. (red.). Journeying: Children responding to literature. Portsmouth (NH): Heinemann, pp. 151-172.

MCGHEE, Paul (1979). Humor: Its origin and development. San Francisco: W.H. Freeman and company.

MEDER, Theo, 'Van A tot Z Reeks'. Nijmegen: Uitgeverij SUN, lemma "Luilekkerland". Geraadpleegd via: http://www.vanatotzreeks.nl/

MEDER, Theo \& DIJK, Marie van (samenstelling) (2000). Doe open Zimzim. Verbalen en liedjes uit de Utrechtse wijk Lombok. Amsterdam: Stichting beheer IISG.

MEDER, Theo, KOMAN, Ruben A. \& ROOIJAKKERS, Gerard W.J. (2008). Canon met de kleine c: 50 verbalen en liederen bij de Canon van Nederland. Bedum: Profiel.

MEIJER, Maaike (1997), 'Poëzie en de cultuur van het innerlijk.' In: H. van Lierop-Debrauwer, H. Peters \& A. de Vries (red.), V an Nijntje tot Nabokov. Stadia in geletterdheid. Tilburg: Tilburg University Press, pp. 144-160.

MEIJER, Wilna A.J. (1996), 'Het boek en de school. Over geletterdheid en algemene vorming'. In: Soetaert, Ronald \& Luc Top (red.): Een beeld van belezenheid. Over culturele geletterdheid. Den Haag, Sdu Uitgevers / Stichting Bibliographia Neerlandica, pp. 17-30.

MILLER, Patricia H. (2002). Theories of Developmental Psychology. New York: Worth, 4de editie (1ste editie 1983).

MITHEN, Steven (2005), 'More than cheesecake? The similarities and differences between music and language'. In: idem. The Singing Neanderthals: The Origin of Music, Language, Mind and Body. London: Phoenix, pp. 11-27.

MOERBEEK, Jozien L.M. (1998). Canons in context. Canonvorming in bet literatuuronderwijs in Nederland en Vlaanderen. Proefschrift Universiteit Utrecht.

MOOREN, Piet (2000a). Het prentenboek als springplank: Cultuurspreiding en leesbevordering door prentenboeken. Nijmegen: SUN.

----- (2000b), 'Haring met ijs. Over de nonsensicale poëtica van en voor jonge kinderen.' In: Vries, A. de, LieropDebrauwer, H. van \& Mooren, P (red.). Poëzie is kinderspel: Poërie onder en boven de 18. Oisterwijk: Dutch University Press, pp. 19-36.

----- (2004), 'Toverstafjes en Zwavelstokken. Over literair-educatieve canonvorming.' In: Lierop-Debrauwer, Helma van, Mooren, Piet \& Bekkering, Harry (red.). Dat moet je gelezen hebben: Literaire en educatieve canonvorming in de (jengd) literatuur. Leidschendam: Biblion Uitgeverij, pp. 39-54.

MOOREN, P., KURVERS, J. \& LIEROP-DEBRAUWER, H. van (red.) (2004). De mondige jeugdliteratuur. Over raakvlakken van jeugdliteratuur en volkscultuur. Leidschendam: Biblion Uitgeverij. 
MOOREN, Piet \& KURVERS, Jeanne (2012), 'Ringel rangel ronde. Kinderrijmen, kinderverzen en gedichten met een kindperspectief’. In: Mooren, P., Ghonem-Woets, K., Koeven, E. van, Kurvers, J. \& Verschuren, H. (red.). Verborgen talenten. Jeugdliteratuur op school. Bussum: Coutinho, pp. 143-164.

NAP-KOLHOFF, Elma (2011). In de ogen van de ouders. Basisrapportage oudervragenlijst. Centrum Onderwijskansen Kaans / Moelejaan Peuters / Maastricht University School of Business and Economics, 2011. Te downloaden via: www.kaans.nl (onder 'Publicaties').

NELSON, R.C. (1966), 'Children's poetry preferences'. In: Elementary English, no. 43, pp. 247-251.

NICOLAAS, Martijn (2005), 'Wat gaat voor: literaire canon of leesplezier?’ In: Zicht op... literatuureducatie en leesbevordering: achtergronden, literatuur, lesmethoden, projecten en websites. Utrecht: Cultuurnetwerk Nederland, pp. 7-12.

NIKOLAJEVA, Maria (2010). Power, Voice and Subjectivity in Literature for Young Readers. London: Routledge.

NISPEN, Pieter van \& STRALEN, Anita van (2010). Culturele competentie: De verrijking door verschillen. Assen: Van Gorcum.

NISSEN, Peter (2000), 'Percepties van sacraliteit. Over religieuze volkscultuur.' In: Dekker, T., Roodenburg, H. \& Rooijakkers, G. (red.). Volkscultuur: Een inleiding in de Nederlandse etnologie. Nijmegen: Uitgeverij SUN, pp. 231281.

NOVAK, Julia (2011). Live Poetry. An Integrated Approach to Poetry in Performance. Serie: Internationale Forschungen zur Allgemeinen und Vergleichenden Literaturwissenschaft. Amsterdam/New York: Rodopi.

ONDERWIJSINSPECTIE (2014). Rapport van bevindingen onderzoek in het kader van voor en vroegschoolse educatie: openbare basisschool Het Palet, R.K. basisschool Markus, peuterspeelzaal SamSam. Ministerie van Onderwijs, Cultuur en Wetenschap. Geraadpleegd via: www.onderwijsinspectie.nl

ONDERWIJSRAAD (2006). Naar meer evidence based onderwijs. Den Haag: Onderwijsraad. Geraadpleegd via: https://www.onderwijsraad.nl/upload/documents/publicaties/volledig/naar_meer_evidence_based_onder wijs.pdf

----- (2011). Onderwijs vormt. Den Haag: Onderwijsraad. Geraadpleegd via: http://www.onderwijsraad.nl/ upload/documents/publicaties/volledig/onderwijs-vormt.pdf

----- (2013). De stand van educatief Nederland 2013. Een smalle kijk op onderwijskwaliteit. Den Haag: Onderwijsraad. Geraadpleegd via: https://www.onderwijsraad.nl/upload/documents/publicaties/links/Brochure-Standvan-educatief-Nederland.pdf

ONDERWIJSRAAD \& RAAD VOOR CULTUUR (2012). Cultuureducatie: leren, creëren, inspireren! Den Haag: Onderwijsraad. Geraadpleegd via: http://www.onderwijsraad.nl/upload/publicaties/688/documenten/cul tuureducatie.pdf

OOSTROM, Frits van (2006). Stemmen op schrift: Geschiedenis van de Nederlandse literatuur vanaf het begin tot 1300 . In de serie 'Geschiedenis van de Nederlandse literatuur' onder hoofdredactie van A.J. Gelderblom en A.M. Musschoot, Amsterdam: Uitgeverij Bert Bakker.

PATRICK, Lisa (2012), 'Creating Communities of Poetry Readers'. In: Nuances: estudos sobre Educação, Presidente Prudente, SP, volume 21, nr. 22 (jan./apr.), pp. 105-126.

PEER, Will van \& SOETAERT, Ronald (red.) (1993). Voorzetten 43. De literaire canon in bet onderwijs. Den Haag: Stichting Bibliographia Neerlandica.

PIAGET, Jean (1952). The Origins of Intelligence in Children. New York: International University Press.

----- (1977). The development of thought: Equilibration of cognitive structures (vertaling A. Rosin). Oxford, England: Viking.

PLEIJ, Herman (1997). Dromen van Cocagne. Middeleeuwse fantasieën over het volmaakte leven. Amsterdam: Prometheus.

PLOMP, Tjeerd (2010), 'Educational Design Research: an Introduction'. In: Plomp, T. \& Nieveen, N. An Introduction to Educational Design Research. Enschede: SLO - Netherlands institute for curriculum development, 3de druk, maart, pp. 9-35.

POL, Coosje van der (2010). Prentenboeken lezen als literatuur. Een structuralistische benadering van bet concept literaire competentie' voor kleuters. Delft: Eburon / Amsterdam: Stichting Lezen, Stichting Lezen Reeks 16.

POLDERS, Claire (1997), 'Verborgen Poetica's: Een lezing van poëzie zonder leeftijd.' In: Literatuur zonder leeftijd, Jaargang 11 (42), pp. 248-260.

POLLMANN, J. (1948). 'Inleiding'. In: Troelstra-Bokma de Boer, Sjoukje \& Pollmann, J. (samenstelling). Oude Kinderrijmen voor Jonge Ouders. Het spel van moeder en kind. Heemstede: Uitgeverij De Toorts, 4de druk, pp. VIIXVII.

RAAD VOOR CULTUUR (2005a), Brief bij de aanbieding van het advies Van zwarte lijnen en witte tussenruimte tot vaste, klinkende, zinvolle werkelijkheid aan de staatssecretaris van OC\&W, januari. Geraadpleegd via: http://www.cultuur.nl/upload/documents/adviezen/advies-leesbevordering.pdf 
----- (2005b). Van zwarte lijnen en witte tussenruimte tot vaste, klinkende, zinvolle werkelijkheid. Advies over het belang van het culturele lezen en leesbevordering. Den Haag: Raad voor Cultuur, januari. Geraadpleegd via: zie boven.

------(2008). Mediawijsheid in perspectief. Den Haag: Raad voor Cultuur, 29 februari. Geraadpleegd via: http://www.cultuur.nl/upload/documents/adviezen/advies-Mediawijsheid-in-Perspectief.pdf

REES, C.J. van (1983), 'How a literary work becomes a masterpiece: on the threefold selection practiced by literary criticism'. In: Poetics 12 , nr. 4/5, pp. 397-417.

----- (1985), 'Consensusvorming in de literatuurkritiek.' In: Verdaasdonk, H. (red.). De regels van de smaak. Amsterdam: Huis aan de drie grachten, pp. 59-85.

RENKEMA, Jan (1993). Discourse Studies: An Introductory Textbook. Amsterdam/Philadelphia: John Benjamins Publishing Company.

REYNOLDS, R.E., TAYLOR, M.A., STEFFENSEN, M.S., SHIREY, L.L. \& ANDERSON, R.C. (1982), 'Cultural Schemata and Reading Comprehension'. In: Reading Research Quarterly, Vol. 17, No. 3, pp. 353-366.

RODER, Jan de (2001), 'Het schandaal van de poëzie'. In: idem. Het onbehagen in de literatuur. Essays. Nijmegen: Uitgeverij Vantilt, pp. 23-46.

----- (2002), 'Poetry: The Missing Link?’ In: Frank Brisard \& Tanja Mortelmans (red.). Language and Evolution. Antwerp Papers in Linguistics, 101. Antwerpen: Universiteit Antwerpen, pp. 15-26. Geraadpleegd via: http://webhost.ua.ac.be/apil/apil101/deroder.pdf

ROEBBEN, Bert, 'Waarden: de moeite waard? Enkele gedachten bij een "nieuw" leergebied in het basisonderwijs'. Geraadpleegd via: www.waarden.org/studie/hoeken/2artikelen/roebben/

ROETHKE, Theodore (2001/1965). On Poetry and Craft: selected prose of Theodore Roethke / foreword by Carolyn Kaizer. Washington: Copper Canyon Press (1ste uitgave in 1965).

ROOIJAKKERS, Gerard (2000a), 'Mensen en dingen. Materiële cultuur'. In: Dekker, T., Roodenburg, H. \& Rooijakkers, G. (red.). Volkscultuur: Een inleiding in de Nederlandse etnologie. Nijmegen: Uitgeverij SUN, pp. 110172.

(2000b), 'Vieren en markeren. Feest en ritueel'. In: Dekker, T., Roodenburg, H. \& Rooijakkers, G. (red.). Volkscultuur: Een inleiding in de Nederlandse etnologie. Nijmegen: Uitgeverij SUN, pp. 173-230.

SASBRINK A. (2012). Onderzoek naar een methode voor kwalitatieve evaluatie van cultuuronderwijs. Groningen: Rijksuniversiteit Groningen.

SCHAERLAEKENS, A.M. (1977). De taalontwikkeling van het kind. Een oriëntatie in het Nederlandstalig onderzoek. Groningen: Wolters-Noordhoff. Geraadpleegd via: www.dbnl.org

SCHLIEBE-LIPPERT, Elisabeth (1950), 'Der Mensch als Leser. Entwicklungsverlauf der literaturästhetischen Erlebnisfähigkeit.، In: Else Schmücker (red.). Begegnung mit dem Buch. Ratingen, pp. 47-59.

SCHMIDT, Annie M.G. (1954). Van schuitje varen tot V an Schendel. Amsterdam: CPNB.

SCHRAM, Dick (2003), 'Canonisering als literair handelen en onderzoeksobject'. In: Tsjïp/Letteren, Jaargang 13, pp. 3-7.

SEWELL, Elizabeth (1952). The Field of Nonsense. London: Chatto and Windus.

SIPE, Laurence R. (2008). Storytime: Young Children's Literary Understanding in the Classroom. New York: Teachers College Press.

SLOAN, G. (2003). Give them poetry! A guide for sharing poetry with children K-8. New York: Teachers College Press.

SNOW, Catherine E. \& NINIO, Anat (1986), 'The Contracts of Literacy: What Children Learn from Learning to Read Books'. In: William H. Teale and Elizabeth Sulzby' (red.). Emergent Literacy. Writing and Reading. Norwood, New Jersey: Ablex Publishing Corporation, pp. 116-138.

SOETAERT, Ronald \& TOP, Luc (red.) (1996). Voorzetten 48. Een beeld van belezenheid. Over culturele geletterdheid. Den Haag: Sdu Uitgevers.

SOETAERT, Ronald (2006), 'De cultuur van het lezen'. In: Coussens, E. (red.). De cultuur van het lezen. Den Haag: Nederlandse Taalunie, pp. 7-74.

SPAGNOLA, Mary \& FIESE, Barbara H. (2007), 'Family Routines and Rituals: A Context for Development in the Lives of Young Children.' In: Infants \& Young Children, Vol. 20, No. 4, pp. 284-299.

STANOVICH, Keith E. (1986), 'Matthew effects in reading: Some consequences of individual differences in the acquisition of literacy'. In: Reading Research Quarterly XXI/4 (Fall), pp. 360-407.

STEPHENS, John (1992), 'Chapter 4: Ideology, carnival and interrogative texts'. In: Idem. Language and Ideology in Children's Fiction. London \& New York: Longman Group UK Limited, pp. 120-157.

STEWART, Susan (1989/1978). Nonsense: aspects of intertextuality in folklore and literature. Baltimore/London: The Johns Hopkins University Press, Johns Hopkins Paperbacks edition (1ste uitgave 1978). 
Stichting Leerplan Ontwikkeling (SLO), online lexicon. Geraadpleegd via: http://www.slo.nl/primair/leergebie $\mathrm{den} / \mathrm{ned} /$ taalsite/lexicon

STREET, A., YOUNG, S., TAFURI, J. \& ILARI, B. (2003), 'Mothers' attitudes to singing to their infants'. In: R. Kopiez, A.C. Lehmann, I. Wolther \& C. Wolf (red.). Proceedings of the $5^{\text {th }}$ Triennial ESCOM Conference. Germany: Hannover University of Music and Drama, September, pp. 628-631.

SUTTON-SMITH, Brian (1999), 'Introduction. What Is Children’s Folklore?’ In: Sutton-Smith, B., Mechling, J., Johnson, T.W. \& McMahon, F.R. (red.). Children's Folklore: a source book. Logan, Utah: Utah State University Press, pp. 3-10.

----- (2001). The Ambiguity of Play. Cambridge, Massachusetts: Harvard University Press, 2de druk (1ste druk 1997).

THIJS, Annette, FISSER, Petra \& HOEVEN, Monique van der (2014). Digitale geletterdheid en 21e eeuwse vaardigheden in het funderend onderwijs: een conceptueel kader (Concept). Enschede: SLO, januari. Geraadpleegd via: http://www.slo.nl/downloads/documenten/digitale-geletterdheid-en-21e-eeuwse-vaardigheden.pdf/

THOMAS, Joseph T. (2004), 'Child Poets and the Poetry of the Playground'. In: Children's Literature, 32, pp. 152177.

----- (2007). Poetry's Playground: The Culture of Contemporary American Children's Poetry. Detroit: Wayne State University Press.

TIGGES, Wim (1988). An Anatomy of Literary Nonsense. Amsterdam: Rodopi.

TREHUB, S.E. \& TRAINOR, L.J. (1998), 'Singing to infants: Lullabies and play songs'. In: Rovee-Collier, C. \& Lipsitt, L. (red.). Advances in Child Development and Behavior. Norwoord, NJ: Ablex, pp. 43-77.

TRONICK, Edward Z. (1989), 'Emotions and Emotional Communication in Infants.' In: American Psychologist, Vol. 44, No. 2 (February), pp. 112-119.

VAN COILLIE, J. (1982). V an lapjeskat tot liegbeest. Dertig jaar poëzie voor kinderen in Nederland en Vlaanderen (19501980). Lier / Den Haag: Van In / NBLC.

----- (1990), 'Geert de Kockere; Ssssst! niets verklappen'. In: Poëziekerant. Jaargang 14. 'Kinderpoëzie', Willy Tibergien, Gent 1990, pp. 44.

----- (2014), 'Van zedenspreuk tot levensvragen. Kinderpoëzie.' In: Ghesquière, R, Joosen, V. \& LieropDebrauwer, H. van (red.). Een land van waan en wijs. Geschiedenis van de Nederlandse jeugdliteratuur. Amsterdam/Antwerpen: Uitgeverij Atlas Contact, pp. 211-247.

VAN COILLIE, J., LINDERS, J., NIEWOLD, S. \& STAAL, J. (red.) (2004). Encyclopedie van de jeugdliteratuur. Baarn: Uitgeverij De Fontein/ Groningen: Wolters-Noordhoff.

VARGA, D. (2000), 'Hyperbole and Humor in Children's Language Play.' In: Journal of Research in Childhood Education, 14:2, pp. 142-151.

VEN, P.-H. van de (2006), 'Literaire competentie: een beschouwing'. In: Schram, Dick \& Raukema, AnneMariken (red.). Lezen in de lengte en lezen in de breedte. De doorgaande leeslijn in wetenschappelijk perspectief. Delft: Eburon / Amsterdam: Stichting Lezen, Stichting Lezen Reeks 7, pp. 185-205.

VENDLER, Helen (2002). Poems, Poets, Poetry: An Introduction and Anthology. Bedford: St. Martin's, 2e editie.

VERDAASDONK, Hugo (1985), 'Literatuursociologie.' In: R.T Segers (red.). Vormen van literatuurwetenschap. Moderne richtingen en bun mogelijkheden voor tekstinterpretatie. Groningen: Wolters-Noordhof, pp. 115-136.

VERHOEVEN, Ludo \& AARNOUTSE, Cor (red.) (2008). Tussendoelen beginnende geletterdheid. Een leerlijn voor groep 1 tot en met 3. Nijmegen: Expertisecentrum Nederlands, 9e druk (1e druk 1999).

VERHULST, Frank C. (2008). De ontwikekeling van het kind. Assen: Van Gorcum.

VRIEND, Gerard de (2004), 'Ingevoerd in de canon'. In: Lierop-Debrauwer, Helma van, Mooren, Piet \& Bekkering, Harry (red.). Dat moet je gelezen hebben. Literaire en educatieve canonvorming in de (jeugd)literatuur. Leidschendam: Biblion, pp. 18-29.

VRIES, A. de (1989). Wat beten goede kinderboeken? Opvattingen over kinderliteratuur in Nederland sinds 1880. Amsterdam: Em. Querido's Uitgeverij.

----- (1990), 'Het verdwijnende kinderboek. Opvattingen over jeugdliteratuur na 1980.' In: Leesgoed, jrg. 17 nr. 2 , pp. 64-68.

----- (2002), 'Iene miene mutte.' In: Literatuur zonder leeftijd. Jaargang 16. Den Haag: Biblion Uitgeverij, pp. 398-402.

----- (2003), 'Wat zegt de kinderjury? De stem van de kinderen bij de canonisering van kinderboeken'. In: Moore, Piet, Kurvers, Jeanne \& Lierop-Debrauwer, Helma van (red.). Bïna klassiek. Spraakmakende teksten uit de Tilburgse symposia. Leidschendam, Biblion, pp. 232-238.

VYGOTSKY, Lev S. (1978). Mind in society: The development of higher psychological processes. Cambridge, MA: Harvard University Press. 
WARNOCK, John (1987), 'Review of: Cultural Literacy: What Every American Needs to Know by E. D. Hirsch, Jr.'. In: College Composition and Communication, Vol. 38, Nr. 4 (Dec.), pp. 486-490.

WASSINK, Nina (2014). Poëzie en taal in het basisonderwijs. Rijksuniversiteit Groningen, Neerlandistiek, Masterscriptie begeleid door prof. dr. C.M. de Glopper en prof. dr. G.J. Dorleijn (niet gepubliceerd). Geraadpleegd via: http://www.lkca.nl/publicaties/informatiebank/poezie-en-taal-in-het-basisonderwijs-uo

WAUGH, Linda R. (1980), 'The Poetic Function in the Theory of Roman Jakobson'. In: Poetics Today, Vol. 2, No. 1a, Roman Jakobson: Language and Poetry (Autumn), pp. 57-82.

WETERINGS, Annet (2004), 'Torentje, torentje, bussekruit...' In: Moer. Tijdschrift voor bet onderwijs in het Nederlands, jrg. 36 (december), nr. 2004.3, pp. 78-86.

WHITMAN HERTZBERG, Hazel (1988), 'Review of: Cultural Literacy: What Every American Needs to Know by E. D. Hirsch, Jr.’. In: Teachers College Record, Vol. 90, Nr. 1, 1988, pp. 145-155.

WIJK, Carel van (2000). Toetsende statistiek: basistechnieken. Een praktijkgerichte inleiding voor ondervoekers van taal, gedrag en communicatie. Bussum: Uitgeverij Coutinho.

WITTE, Theo (2008). Het oog van de meester. Een onderzoek naar de literaire ontwikkeling van havo-en vwo-leerlingen in de tweede fase van het voortgezet onderwijs. Delft: Eburon / Amsterdam: Stichting Lezen, Stichting Lezen Reeks 12.

ZWAAGDIJK, M. (1947), 'Nieuwjaar'. In: De Speelwagen, 2e jaargang, nr.1, pp. 3-5. Uitgegeven door de Historische Genootschappen in Hollands Noorderkwartier van 1946 t/m 1955, geraadpleegd via: http://www.westfriesgenootschap.nl/archivering/speelwagen/ 